\title{
Extradition law
}

Citation for published version (APA):

de Almeida Costa, M. J. (2019). Extradition law: reviewing grounds for refusal from the classic paradigm to mutual recognition and beyond. [Doctoral Thesis, Maastricht University]. Maastricht University. https://doi.org/10.26481/dis.20190215mj

Document status and date:

Published: 01/01/2019

DOI:

10.26481/dis.20190215mj

Document Version:

Publisher's PDF, also known as Version of record

\section{Please check the document version of this publication:}

- A submitted manuscript is the version of the article upon submission and before peer-review. There can be important differences between the submitted version and the official published version of record.

People interested in the research are advised to contact the author for the final version of the publication, or visit the DOI to the publisher's website.

- The final author version and the galley proof are versions of the publication after peer review.

- The final published version features the final layout of the paper including the volume, issue and page numbers.

Link to publication

\footnotetext{
General rights rights.

- You may freely distribute the URL identifying the publication in the public portal. please follow below link for the End User Agreement:

www.umlib.nl/taverne-license

Take down policy

If you believe that this document breaches copyright please contact us at:

repository@maastrichtuniversity.nl

providing details and we will investigate your claim.
}

Copyright and moral rights for the publications made accessible in the public portal are retained by the authors and/or other copyright owners and it is a condition of accessing publications that users recognise and abide by the legal requirements associated with these

- Users may download and print one copy of any publication from the public portal for the purpose of private study or research.

- You may not further distribute the material or use it for any profit-making activity or commercial gain

If the publication is distributed under the terms of Article $25 \mathrm{fa}$ of the Dutch Copyright Act, indicated by the "Taverne" license above, 


\section{Extradition Law}

Reviewing Grounds for Refusal from the Classic Paradigm to Mutual Recognition and Beyond 



\title{
Extradition Law
}

Reviewing Grounds for Refusal from the Classic Paradigm to Mutual Recognition and Beyond

\author{
Miguel João Costa
}

Maastricht University

2019 



\section{EXTRADITION LAW}

Reviewing Grounds for Refusal from the Classic Paradigm to Mutual Recognition and Beyond

\section{Dissertation}

to obtain the degree of Doctor at Maastricht University, on the authority of the Rector Magnificus,

Prof.dr. Rianne M. Letschert

in accordance with the decision of the Board of Deans,

to be defended in public

on Friday, 15 February 2019, at 12:00 hours

by

Miguel João de Almeida Costa 
Supervisors:

Prof.dr. A. Klip

Co-supervisor

Dr. J. Keiler

Assessment Committee:

Prof.dr. T. Spronken (chair);

Prof.dr. P. Caeiro, University of Coimbra;

Prof.dr. M. Faure;

Prof.dr. V. Glerum, University of Groningen;

Prof.dr. D. Roef

Printed by: ProefschriftMaken | www.proefschriftmaken.nl

Funding: This research was funded by the Foundation for Science and Technology of the Portuguese Ministry for Science, Technology and Higher Education - Ph.D. scholarship with reference SFRH/BD/92979/2013 -, within the Operational Human Potential Programme / European Social Fund.

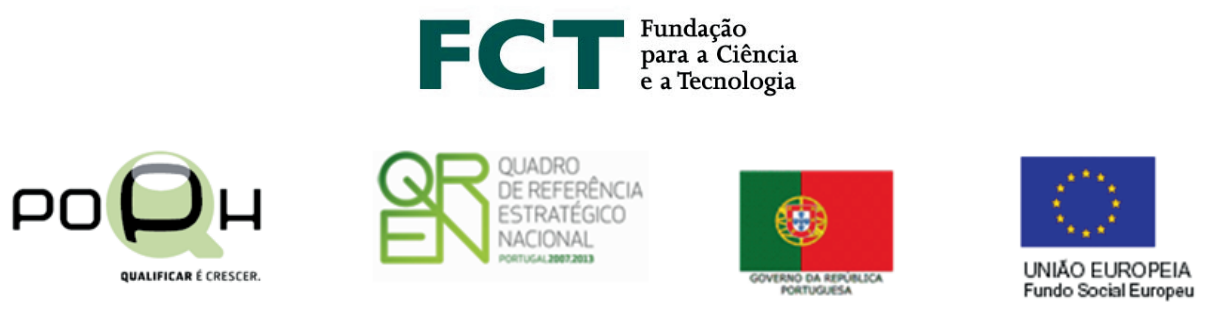


To José and Cris 

There is only a difference of degree between impunity and asylum

Cesare Beccaria 



\section{Acknowledgements}

First of all, I want to thank my family, including my family by affinity, for their support. I especially wish to thank Cristiana Milhão and our son José. José was born shortly after I started the Ph.D. By the time I reached the final stage of the study, in which I was to 'question' the status quo of my area of research, he was averaging several questions per hour, the answer to many of which I, of course, did not have. It is well-known that children have the talent of raising the most difficult questions, but I had never witnessed the spectacle so closely. One's eagerness for questioning seems prone to wane on the way to adulthood, and often not because one has found satisfactory answers. It is inevitable to think that growing up involves a lot of unlearning. Thank you very much for this lesson, José. But thank you especially for everything else. Cris and I have been side-by-side for over a decade through different adventures. Thank you for standing by me through this one more journey, whilst pursuing your own goals with that mighty drive and originality of someone who was born to create. It is a privilege to see the world together with you. I also want to say a special word to my father, Fernando Helena, whose support and faith in my life choices is a continuous source of stability.

At the top of my list of acknowledgments are also my supervisors, André Klip and Johannes Keiler, two outstanding scholars as well as persons, who provided me at once with their wide field of view and attention to detail; with their vast knowledge and readiness in applying it to new problems. With encouragement in the hard times and the necessary serenity in the more promising ones; with true guidance throughout them all. André received me with open arms in Maastricht, involved me in the environment and the activity of the Faculty, and saw to it that I would have all the conditions one might need for doing this work. But I am particularly thankful for his unwavering confidence in my project and in my ability to implement it. Johannes joined the supervision of my project not long after I started it and definitely in time to leave an indelible mark on it. His supervision too transcended academic aspects, and in him I also found the patience and the advice of a friend.

At Maastricht University I met remarkable people, insightful and thoughtful, who shaped greatly this experience and myself as a person. We shared both the joy of writing what seemed to be a fine couple of pages and the agony of the bad day where completing the thesis seemed impossible. We shared much more - thoughts of all kinds, experiences - and formed bonds. I especially want to acknowledge Constantijn van Aartsen and Hannah Brodersen - my superb paranymphs -, and Giulia Giardi. I also wish to acknowledge Juni Daalmans and Irene Hovers, for their fulfilling friendship and their discrete yet certain support - from my very first to my very last day in Maastricht. 
I also want to acknowledge my friends from Portugal, who form one of my broadest and strongest pillars. As proven once again, our friendship continues to evolve even when conditions are not too favourable. I wish to thank in particular, for supporting me in different ways, for visiting and/or being otherwise particularly present in key moments of this chapter of my life, António Vaz de Castro, Filipe Mota, Francisco Lopes, Gonçalo Tavares Gomes, João Aldeia, Micha, Miguel Felício, Nuno Albuquerque, Pedro Caeiro and Vítor Bruno Santos.

To António I am moreover thankful for his extreme availability and talent for discussing my topic and putting my ideas to the test. To João, for the illuminating conversations on sociological and philosophical themes which surface in some parts of this book. To Miguel, for the awesome design work put into all the images contained here. To Pedro, for the constant opportunity he provides for me to partake in research ventures with him, thereby enabling me keep learning closely from his incisive academic mind.

This research benefited from training and meaningful exchanges of ideas held in different fora and with different people whom I also want to acknowledge. In particular: the professors and colleagues who participated in the Courses of Empirical Research Methods and Methods of Human Rights Research at Maastricht University in 2013-2014; those who participated in the Graduate Program of the Netherlands Network for Human Rights Research held in Utrecht in 2014-2015; those who participated in the Ph.D. Seminar of the European Criminal Law Academic Network held in Copenhagen in 2015; and Maria João Antunes, for sharing with me her privileged insight into the interactions between constitutional and criminal law. I also want to thank Francisco Borges, and again Hannah and Constantijn, for their attentive read of major parts of the final version of my manuscript, as well as Afonso Patrão, of the parts involving private international law.

Furthermore, I wish to acknowledge the institutions whose support was pivotal for this research: the Portuguese Foundation for Science and Technology, which provided me with a Ph.D. grant; and the Faculty of Law of Maastricht University, where I encountered optimal conditions to develop my research. Within the latter, I want to mention the Department of Criminal Law and Criminology and its members, whose activity I had the chance to observe and learn from. Additionally, I wish to thank Queen Mary University of London, where I was received by Valsamis Mitsilegas for a brief but fruitful period of research on the extradition system of the United Kingdom, and the Portuguese Desk at Eurojust, where I completed a short but also very fruitful internship which allowed me to take a look at my topic of research in action.

Last but not least, I want to acknowledge the Assessment Committee - chaired by Taru Spronken (Maastricht University) and further composed of David Roef (Maastricht University), Michael Faure (Maastricht University), Pedro Caeiro (University of Coimbra), and Vincent Glerum (University of Groningen) -, for their meticulous evaluation of this thesis. 


\section{Abbreviations}

$\mathrm{AB}$ - Archbold Review

ACHR - American Convention on Human Rights

AG - Advocate General (ECJ)

AHDE - Anuario de Historia del Derecho Español

AIDP - Association Internationale de Droit Pénal

AJ - Acta Juridica

AJIL - American Journal of International Law

ALbLR - Albany Law Review

ALR - Adelaide Law Review

AR - Archbold Review

ASIL - American Society of International Law

AsJIL - Asian Journal of International Law

AUD - Acta Universitatis Danubius

AUJILP - American University Journal of International Law and Policy

AUNSLB - American University National Security Law Brief

BCICLR - Boston College International and Comparative Law Review

BFDUC - Boletim da Faculdade de Direito da Universidade de Coimbra

BFDUM - Boletim da Faculdade de Direito da Universidade de Macau

BJC - British Journal of Criminology

BJCL\&CJ - Bergen Journal of Criminal Law and Criminal Justice

BMJ - Boletim do Ministério da Justiça

BMSAES - British Museum Studies in Ancient Egypt and Sudan

BTLJ - Berkeley Technology Law Journal

BULR - Boston University Law Review

c. - circa

CalLR - California Law Review

CCHAIL - Collected Courses of The Hague Academy of International Law

CEBDI - Cursos Euromediterráneos Bancaja de Derecho Internacional

CEJ - Centro de Estudos Judiciários

CEJ - Centro de Estudos Judiciários

CES - Centro de Estudos Sociais

cf. - confer

Chap(s). - Chapter(s)

CISA - Convention Implementing Schengen Agreement

CJ - Crime and Justice

CJEL - Columbia Journal of European Law

CJTL - Columbia Journal of Transnational Law 
CL\&Ph - Criminal Law \& Philosophy

CLF - Criminal Law Forum

CLJ - Cambridge Law Journal

CLR - Criminal Law Review

CoE - Council of Europe

cont. - continuation

CorLR - Cornell Law Review

CovLJ - Coventry Law Journal

CPS - Crown Prosecution Service (UK)

CW - The Classical World

CWILJ - California Western International Law Journal

CWRJIL - Case Western Reserve Journal of International Law

D\&D - Desigualdade \& Diversidade - Revista de Ciências Sociais da PUC-Rio

DJ - Direito e Justiça

EA 2003 -Extradition Act of the United Kingdom

EAW - European Arrest Warrant

ECHR - European Convention on Human Rights

ECJ - Court of Justice of the EU

ECLAN - European Criminal Law Academic Network

ECompLR - European Competition Law Review

EConstLR - European Constitutional Law Review

ECrimLR - European Criminal Law Review

ECtHR - European Court of Human Rights

ed. - editor(s) / edition(s)

EILR - Emory International Law Review

EJCCL\&CJ - European Journal of Crime, Criminal Law and Criminal Justice

EJIL - European Journal of International Law

EJML - European Journal of Migration and Law

EJN - European Judicial Network

EJTN - European Judicial Training Network

ELF - The European Legal Forum

ELJ - European Law Journal

ELR - Edinburgh Law Review

EPL - European Public Law

esp. - especially

et al. - et alii / et aliae / et alia

EU - European Union

f. - following

FATF - Financial Action Task Force

FD - Framework Decision

FD-EAW - Framework Decision on the EAW

FDJ\&ISCJS - Fundação Direito e Justiça \& Instituto Superior de Ciências Jurídicas e Sociais 
FILJ - Fordham International Law Journal

fn. - footnote(s)

FYIL - The Finnish Yearbook of International Law

GC - Global Crime

GJI\&CL - Georgia Journal of International \& Comparative Law

GLJ - Georgetown Law Journal

HHRJ - Harvard Human Rights Journal

HILJ - Harvard International Law Journal

HK - Hong Kong Special Administrative Region of the PRC

HLR - Harvard Law Review

HRB - Human Rights Brief

HRLJ - Human Rights Law Journal

HRLR - Human Rights Law Review

HRR - Human Rights Review

I\&CLQ - International \& Comparative Law Quarterly

IACtHR - Inter-American Court of Human Rights

ibid. - ibidem

ICC - International Criminal Court

ICCPR - International Covenant on Civil and Political Rights

ICJ - International Court of Justice

ICTR - International Criminal Tribunal for Rwanda

ICTY - International Criminal Tribunal for the former Yugoslavia

id. - idem

IHLADI - Instituto Hispano-Luso-Americano de Derecho Internacional

II\&CLR - Indiana International \& Comparative Law Review

IJ - Instituto Jurídico da Faculdade de Direito da Universidade de Coimbra

IJConstL - International Journal of Constitutional Law

IJHR - International Journal of Human Rights

IJLCJ - International Journal of Law, Crime and Justice

IJRL - International Journal of Refugee Law

ILJ - Indiana Law Journal

ILR - Israel Law Review

IO - International Organization

JCL - Journal of Criminal Law

JCL\&C - Journal of Criminal Law \& Criminology

JCS - Journal of Cuneiform Studies

JEA - The Journal of Egyptian Archaeology

JECL - Journal of European Criminal Law

JECL\&P - Journal of European Competition Law \& Practice

JEPP - Journal of European Public Policy

JESHO - Journal of the Economic and Social History of the Orient

JICJ - Journal of International Criminal Justice 
JJ - JusJornal

JSAL - Journal of South African Law

JT - Journal des Tribunaux

L\&CP - Law \& Contemporary Problems

L\&SI - Law \& Social Inquiry

LJIL - Leiden Journal of International Law

LLAICLR - Loyola of Los Angeles International and Comparative Law Review

LLR - Liverpool Law Review

LouLR - Louisiana Law Review

LS - Legal Studies

MA - (UN) Model Agreement

MarLR - Marquette Law Review

MAW - Mercosur Arrest Warrant

MelbJIL - Melbourne Journal of International Law

MJE\&CL - Maastricht Journal of European and Comparative Law

MJIL - Michigan Journal of International Law

MLE - (UN) Model Law on Extradition

MLR - The Modern Law Review

MLRev. - Mercer Law Review

MT - (UN) Model Treaty

MTE - (UN) Model Treaty on Extradition

NATO - North Atlantic Treaty Organization

NAW - Nordic Arrest Warrant

NEP - Nouvelles Études Pénales

NILR - Netherlands International Law Review

NJECL - New Journal of European Criminal Law

NJIL - Nordic Journal of International Law

NYIL - Netherlands Yearbook of International Law

NYUJIL\&P - New York University Journal of International Law and Politics

OJ - Official Journal of the EU

OP - Optional Protocol (to the ECHR)

p. - page(s)

para(s). - paragraph / paragraphs

PCIJ - Permanent Court of International Justice

PRC - People's Republic of China

PT-EAW - Portuguese Law Implementing FD-EAW

PT-L - Portuguese Law on International Cooperation in Criminal Matters

QLJ - Queen's Law Journal

RBDI - Revue Belge de Droit International

RCEJ - Revista do Centro de Estudos Judiciários

RDES - Revista de Direito e de Estudos Sociais

RDIPP - Rivista di Diritto Internazionale Privato e Processuale 
REAdmL - Review of European Administrative Law

rep. - reporter(s) / report(s)

repr. - reprinted

rev. - revised

RIAA - Reports of International Arbitral Awards

RIDP - Revue Internationale de Droit Pénale

RJ - Revista Julgar

RLJ - Revista de Legislação e Jurisprudência

RMP - Revista do Ministério Público

RMS - Resource Material Series

ROA - Revista da Ordem dos Advogados

RPCC - Revista Portuguesa de Ciência Criminal

RPL - Research Papers in Law

SLR - Stanford Law Review

SLT - Scots Law Times

SRCL - Society for the Reform of Criminal Law

SSL - Scandinavian Studies in Law

STL - Special Tribunal for Lebanon

StLR - Statute Law Review

STLR - Suffolk Transnational Law Review

TC - Theoretical Criminology

TE\&CLF - Tulane European \& Civil Law Forum

TEC - Treaty establishing the European Community

TEU - Treaty on EU

TFEU - Treaty on the Functioning of the EU

TL\&CP - Transnational Law \& Contemporary Problems

TLT - Transnational Legal Theory

trans. - translator(s) / translation

UAE - United Arab Emirates

UCALL - Utrecht Centre for Accountability and Liability Law

UDHR - Universal Declaration of Human Rights

UDLJ - University of Detroit Law Journal

UK - United Kingdom of Great Britain and Northern Ireland

ULR - Utrecht Law Review

UN - United Nations Organization

UNALIL - UN Audiovisual Library of International Law

UNCAT - UN Convention against Torture and Other Cruel, Inhuman or Degrading Treatment or Punishment

UNCHR - UN Commission on Human Rights

UNHR Council - UN Human Rights Council

UNHRC - UN Human Rights Committee

UNODC - UN Office on Drugs and Crime 
UNSC - UN Security Council

UNWGAD - UN Working Group on Arbitrary Detention

UPLR - University of Pennsylvania Law Review

USA - United States of America

UWALR - The University of Western Australia Law Review

VJIL - Virginia Journal of International Law

VLJ - Virginia Law Journal

W\&LLR - Washington \& Lee Law Review

WFLR - Wake Forest Law Review

WULQ - Washington University Law Quarterly

YEL - Yearbook of European Law

YJIL - Yale Journal of International Law

YLJ - Yale Law Journal

ZIS - Zeitschrift für Internationale Strafrechtsdogmatik

ZRV - Zeitschrift für ausländisches öffentliches Recht und Völkerrecht

ZStW - Zeitschrift für die gesamte Strafrechtswissenschaft 


\section{Table of Contents}

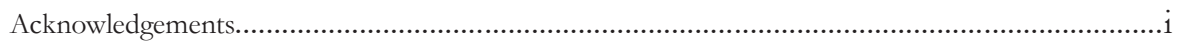

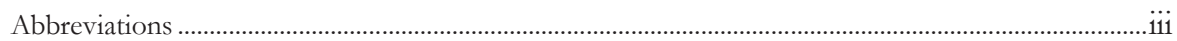

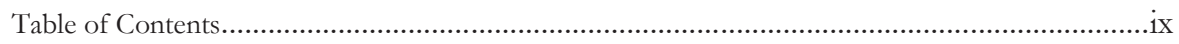

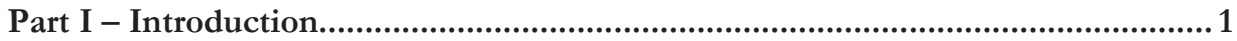

Chapter 1 - Fundamental Concepts.................................................................................

1. The purpose of this study ……………………………………………………………………... 3

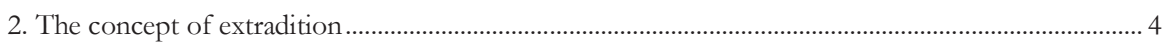

2.1. Definition and essential attributes........................................................................................... 4

2.2. Contrast with substantive criminal law and criminal procedure .................................................... 4

3. Why States need to obtain extradition.............................................................................................

3.1. Transfer of proceedings ................................................................................................. 8

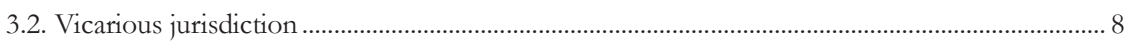

3.3. Common attributes ......................................................................................................... 9

3.4. Enforcement of foreign sentences ............................................................................................ 10

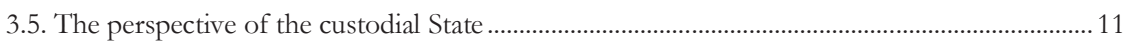

3.6. Standing trial by video-link .................................................................................................... 11

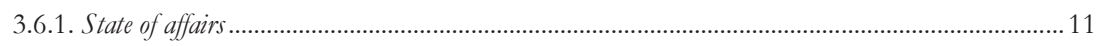

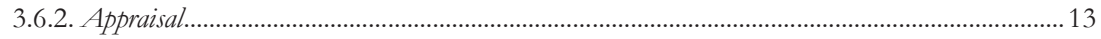

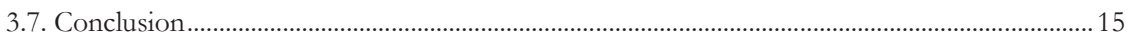

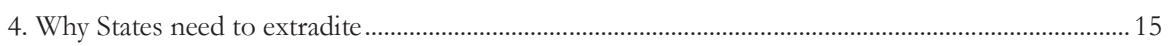

4.1. Avoiding the settling of criminals (the 'safe haven' argument)? ..................................................16

4.2. Solidarity towards other States (the 'moral' argument)? ................................................................. 16

4.3. Reciprocity (the 'self-interest' argument) .................................................................................... 18

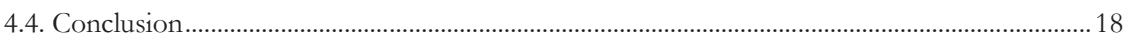

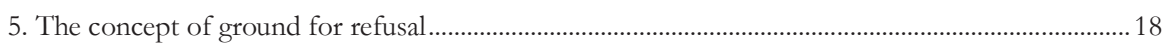

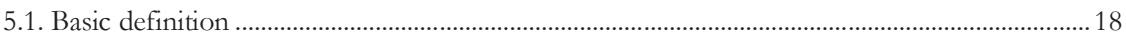

5.2. Grounds for refusal related to mere issues of interstate allocation of jurisdiction..................... 18

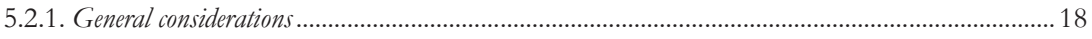

5.2.2. Specific considerations on international crimes ................................................................................ 19

5.3. Grounds for refusal that entail impunity..................................................................................... 20

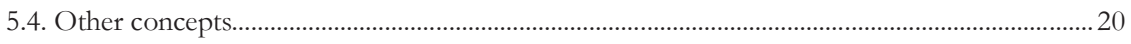

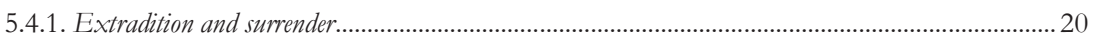

5.4.2. Extradition and rendition (witbin federal States)..................................................................... 21

5.4.3. Voluntary and mandatory grounds for refusal........................................................................2. 21

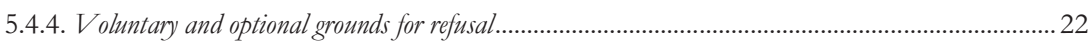




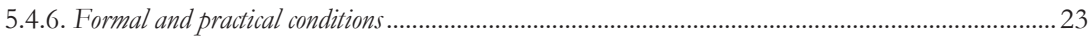

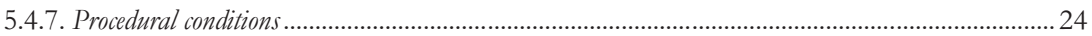

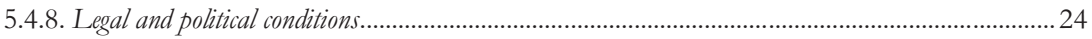

Chapter 2 - Research Design .............................................................................. 27

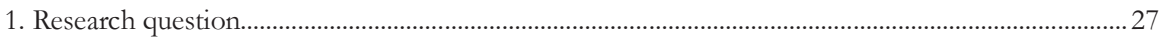

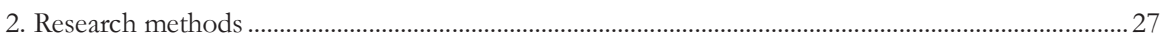

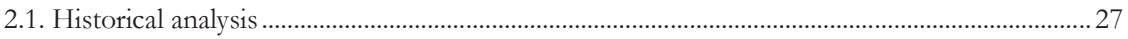

2.2. Grounds for refusal imposed upon States - Deductive analysis .................................................. 28

2.2.1. The imposed or mandatory character of these grounds for refusal......................................................2 28

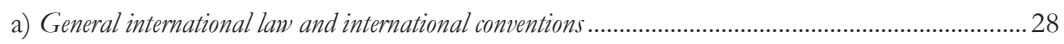

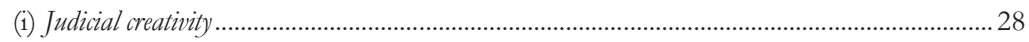

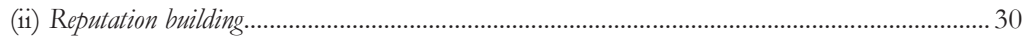

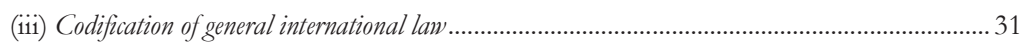

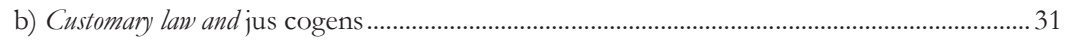

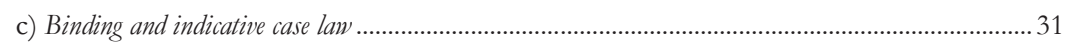

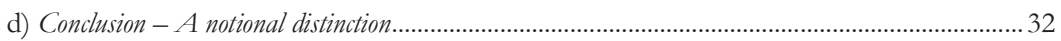

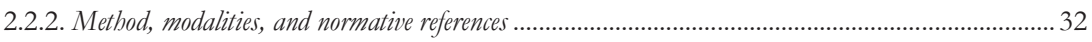

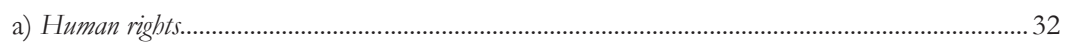

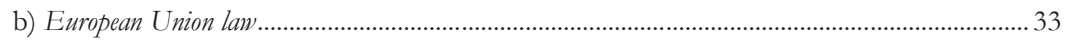

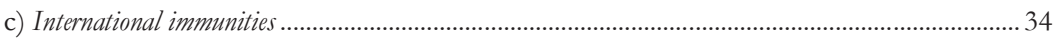

2.3. Grounds for refusal voluntarily enacted by States - Two-tiered approach ................................ 35

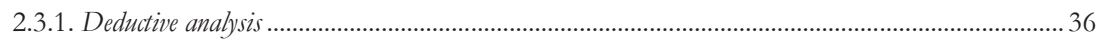

a) United Nations' model instruments on extradition ............................................................................... 36

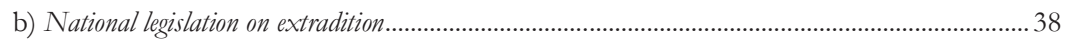

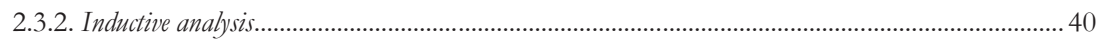

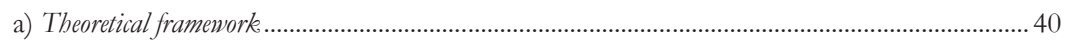

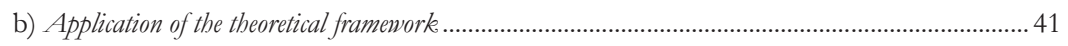

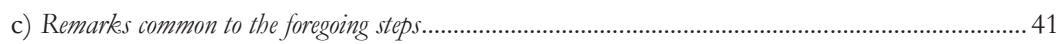

3. The dialogue between traditional cooperation and mutual recognition...............................................4 42

3.1. The European Arrest Warrant and other enhanced versions of extradition............................. 42

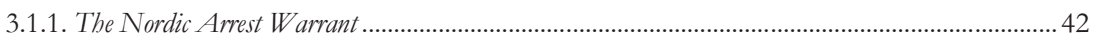

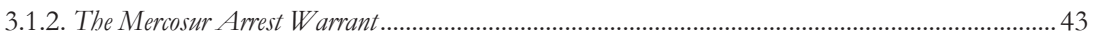

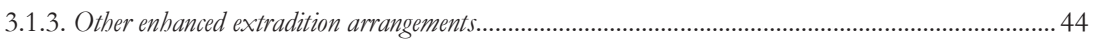

3.1.4. Brief digression - A symmetrical case: the formal inexistence of extradition within China................. 45

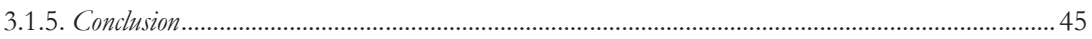

3.2. The European Arrest Warrant and classic extradition - Trust issues........................................... 45

3.2.1. The $\mathrm{E} A W$ as a paradigm shift? - From the original vision to Aranyosi \& Căldăraru................. 46

3.2.2. The $\mathrm{E} A W$ as a paradigm shift? - Non-automaticity and non-execution.......................................... 49

3.2.3. Harmonisation as a prerequisite to mutual recognition? ................................................................... 51

3.2.4. Specific political conditions as a prerequisite to mutual recognition? .................................................... 52 


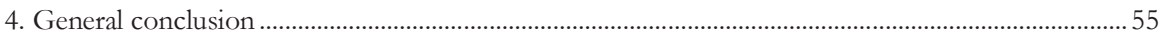

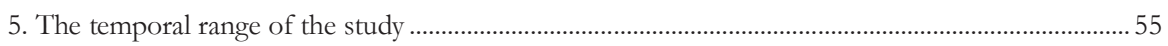

Part II - Grounds for Refusal Imposed upon States.........................................57

Chapter 3 - Human Rights....................................................................................... 59

1. The evolution of fundamental individual rights in extradition ..........................................................59

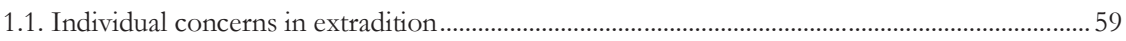

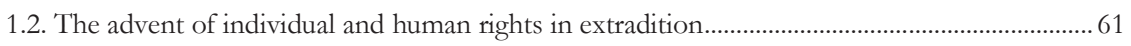

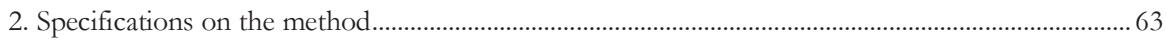

3. Criteria for defining 'grounds for refusal imposed by human rights' .................................................6 64

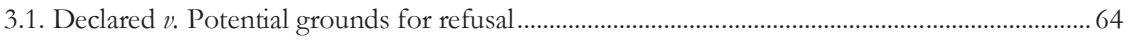

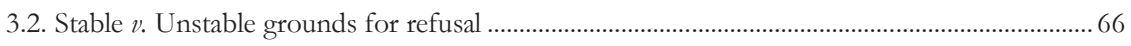

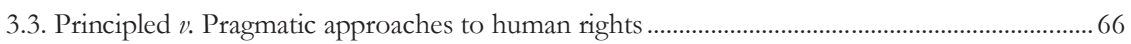

3.4. Grounds for refusal of extradition $v$. Prohibitions to deport ....................................................... 70

3.5. Conduct of the requesting State $v$. Other sources of harm.......................................................... 71

3.6. Human rights grounds for refusal $v$. Treaty-based obligations to extradite...............................73

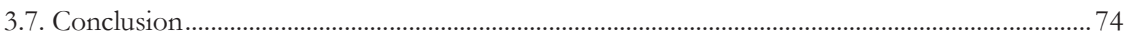

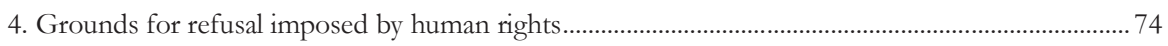

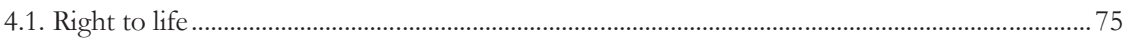

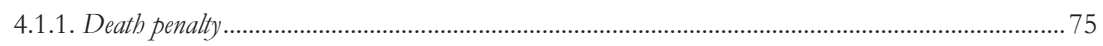

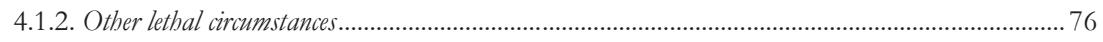

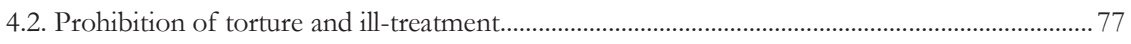

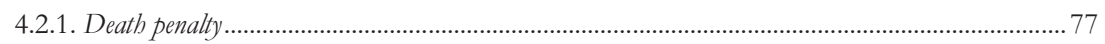

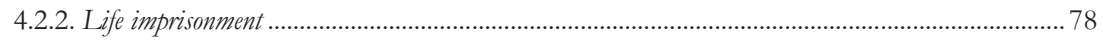

4.2.3. Other circumstances related to the criminal justice system of the requesting State ................................ 82

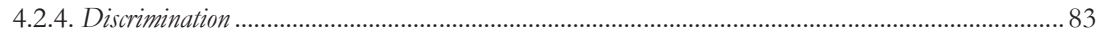

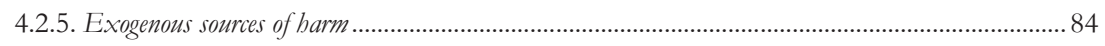

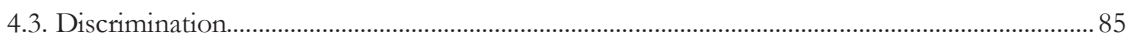

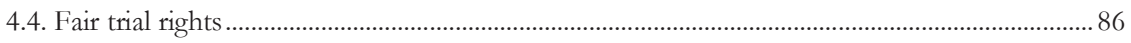

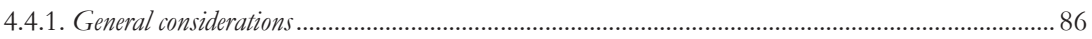

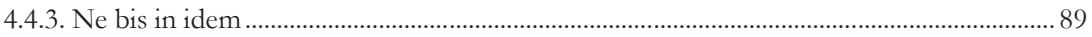

4.5. Rights that admit significant compression with a view to protecting other rights or public

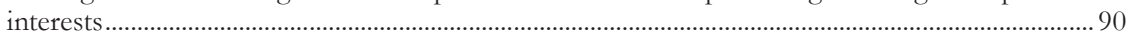

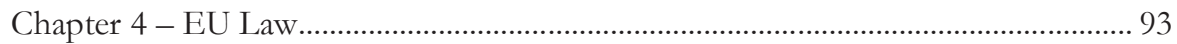

1. Introductory considerations - A trilogy of cases............................................................................... 93

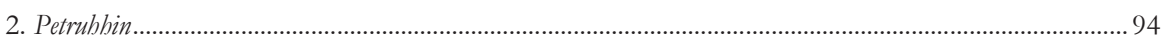

2.1. Main proceedings and request for a preliminary ruling ............................................................... 94

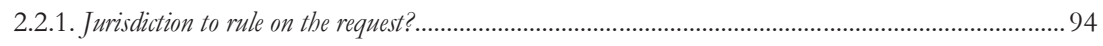

2.2.2. A EU citizenship obstacle to extradition?................................................................................... 95

2.3. The judgement of the Court.................................................................................................... 95

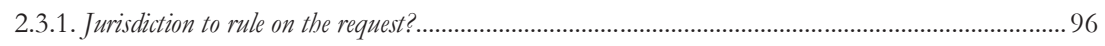


2.3.2. A EU citizenship obstacle to extradition?

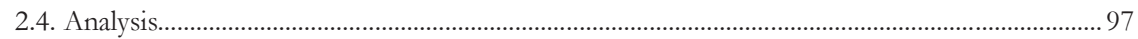

2.4.1. The ever-expanding jurisdiction of the Court ................................................................................... 97

2.4.2. The EU citizenship obstacle to extradition …................................................................................ 98

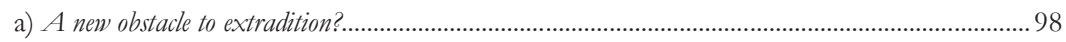

b) A probibition to extradite own nationals?....................................................................................... 99

c) Civis Europaeus sum'?

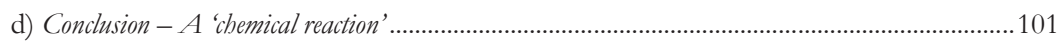

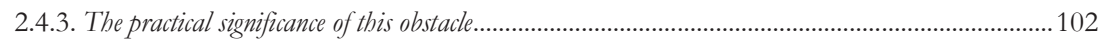

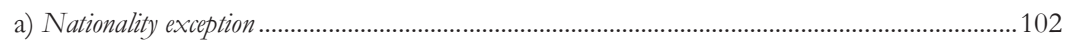

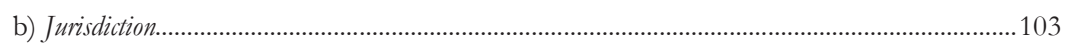

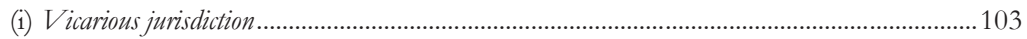

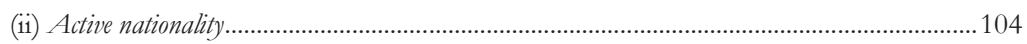

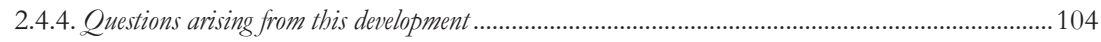

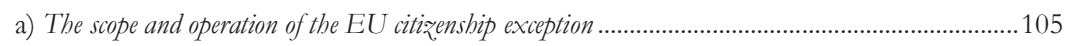

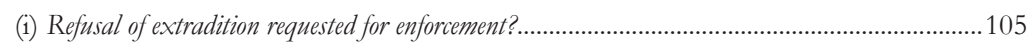

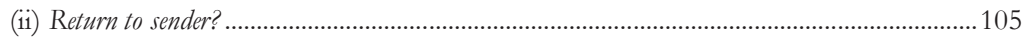

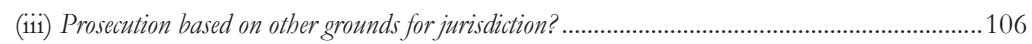

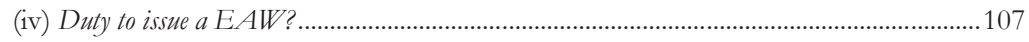

(v) EU citizenship exception without a nationality exception? .....................................................107

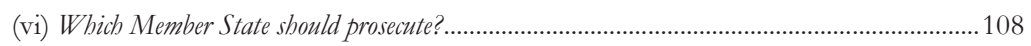

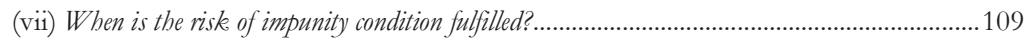

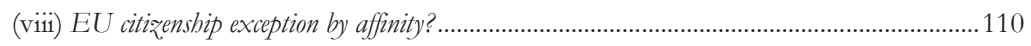

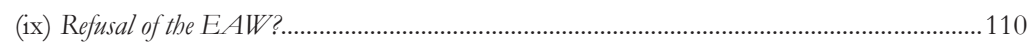

b) Impact upon the national laws of the Member States....................................................................110

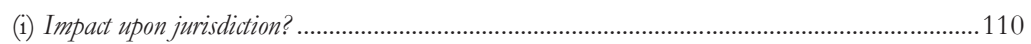

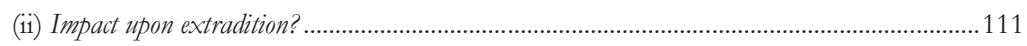

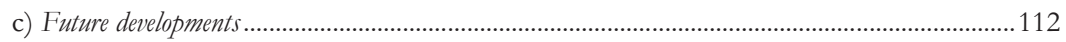

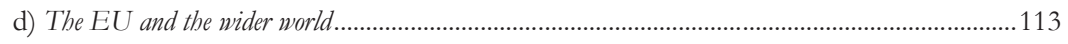

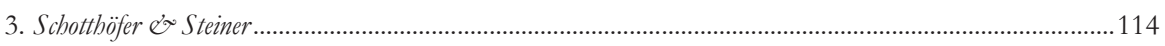

3.1. Main proceedings and request for a preliminary ruling .............................................................114

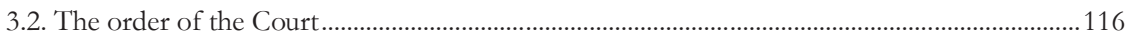

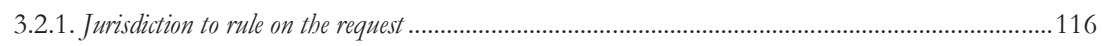

3.2.2. EU buman rights obstacles to extradition.........................................................................................116

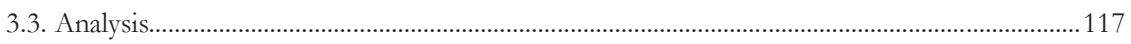

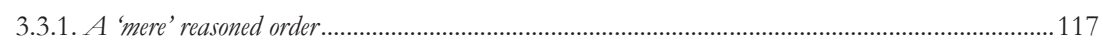

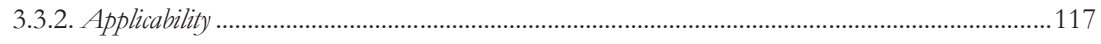

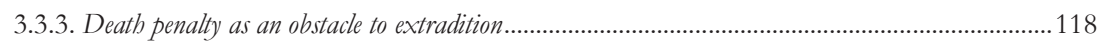

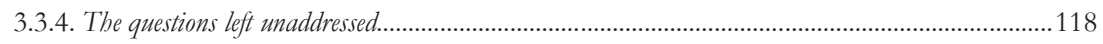

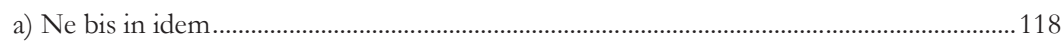

b) Effective remedy and fair trial .........................................................................................................119 


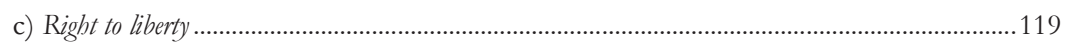

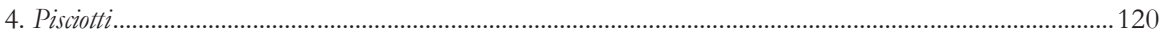

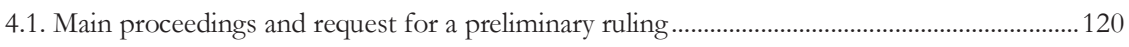

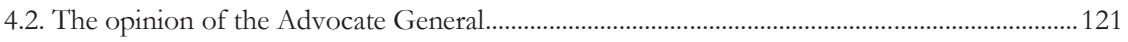

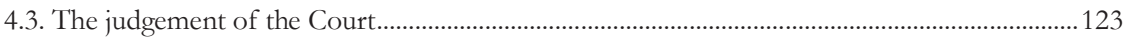

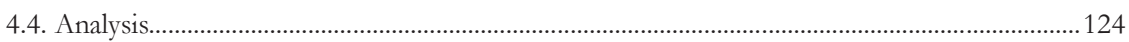

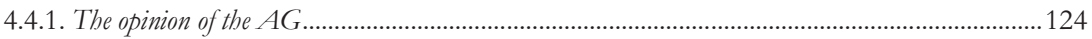

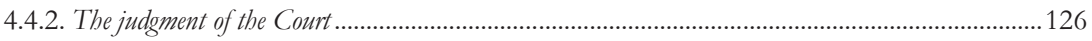

4.4.3. Brief digression on the extradition agreement between the EU and Norway \& Iceland....................127

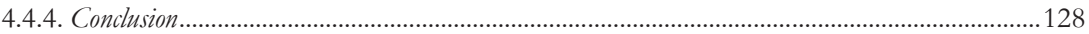

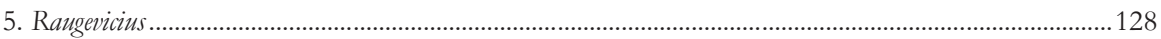

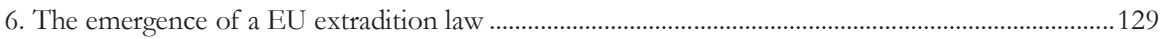

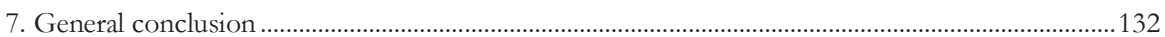

Part III - Grounds for Refusal Voluntarily Enacted by States ..........................133

Chapter 5 - Specifications and General Characterisation of the Normative Systems

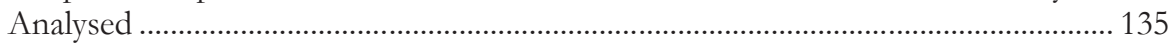

1. Specifications on the research methods, object and structure of this Part......................................135

1.1. Scope

1.1.1. National grounds for refusal absent from the UN model instruments............................................136

1.1.2. Voluntary grounds for refusal partly imposed upon States...........................................................136

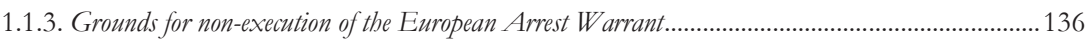

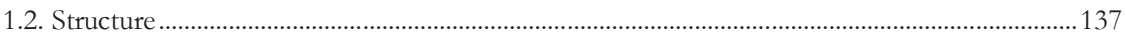

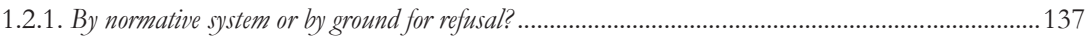

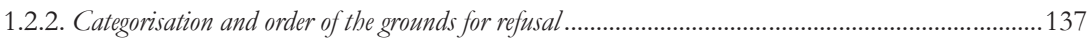

1.2.3. Order of the normative systems (within each ground for refusal) ...................................................139

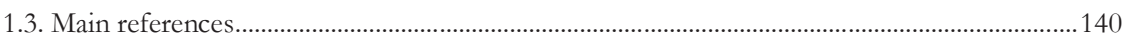

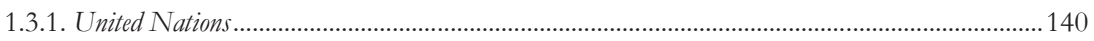

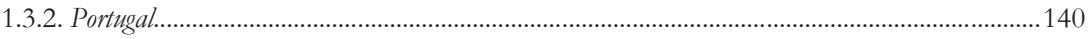

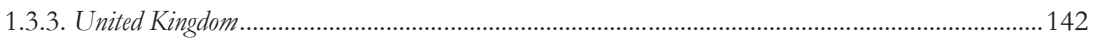

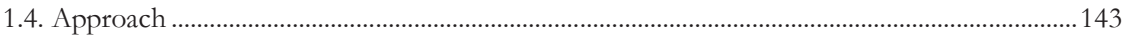

2. General characterisation of the normative systems assessed ........................................................143

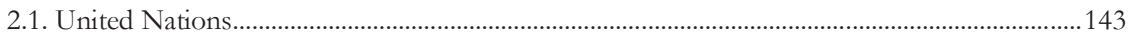

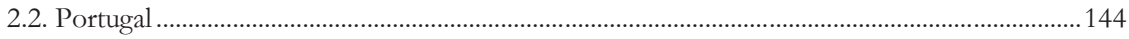

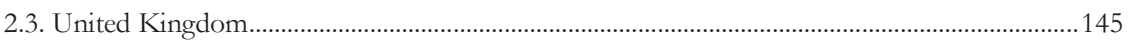

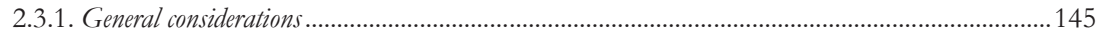

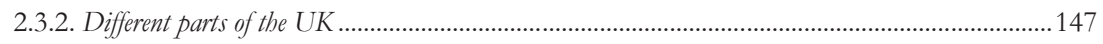

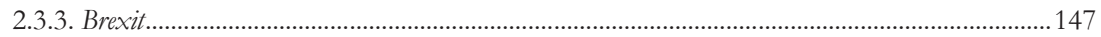

Chapter 6 - Analysis of Grounds for Refusal According to their Scope and Rationale151

1. Grounds for refusal related to the conditions in the requesting State..............................................151

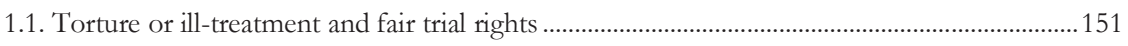

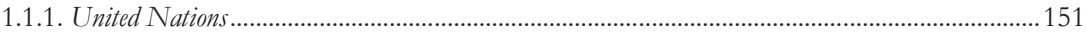




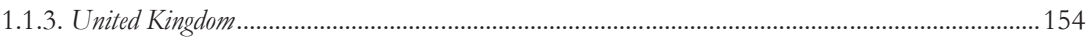

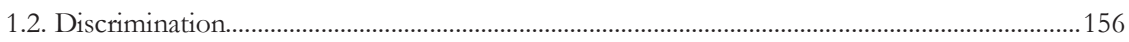

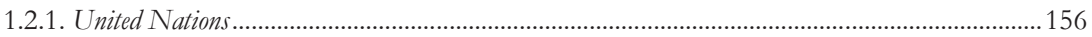

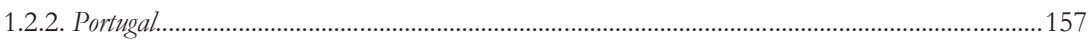

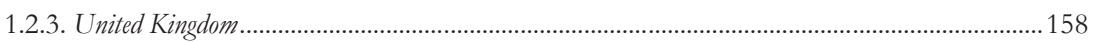

1.3. Death penalty and other penalties carrying irreversible damage ..............................................159

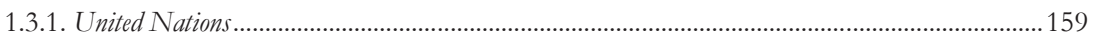

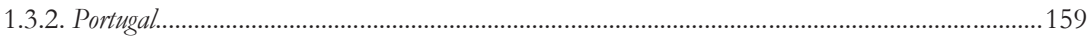

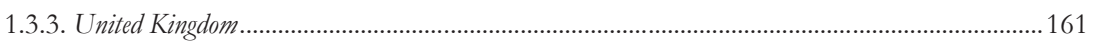

1.4. Imprisonment for life or for an undetermined period .................................................................163

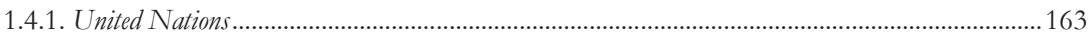

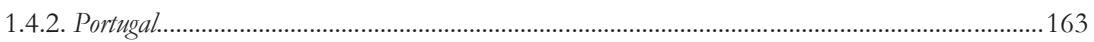

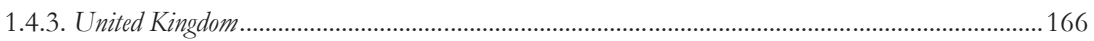

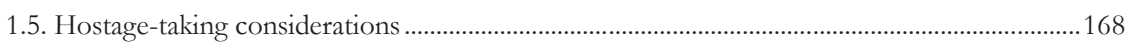

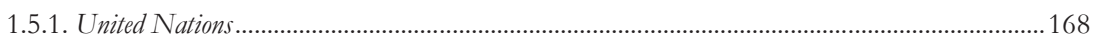

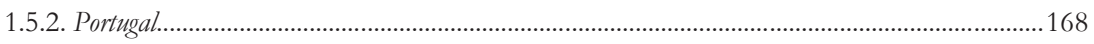

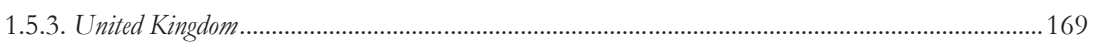

2. Grounds for refusal related to the nature or relevance of the acts ..................................................170

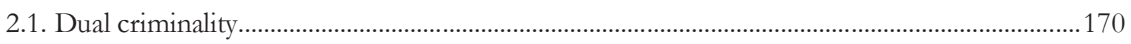

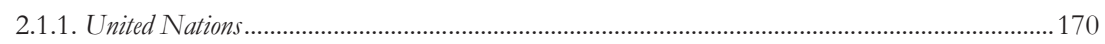

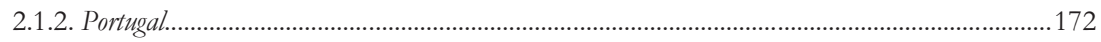

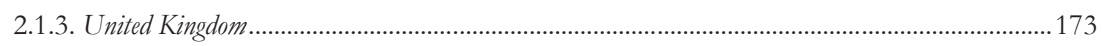

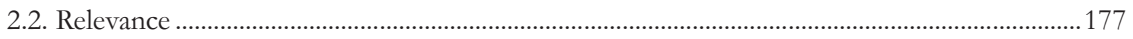

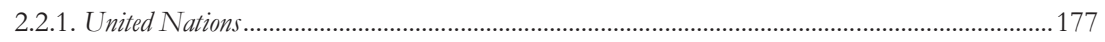

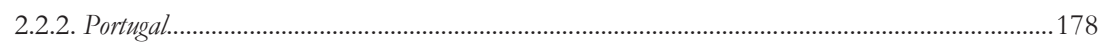

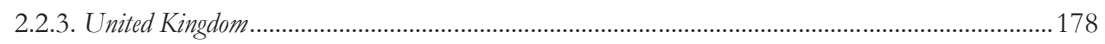

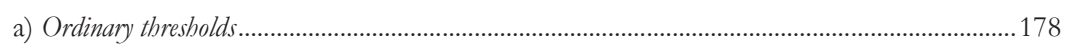

b) The proportionality bar and preliminary proportionality check ..........................................................179

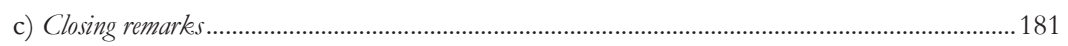

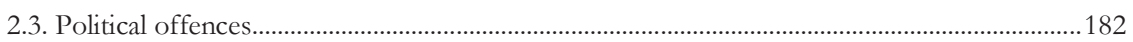

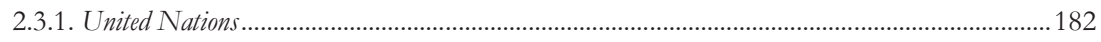

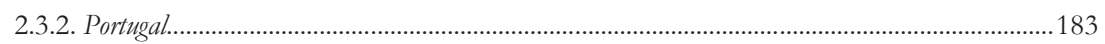

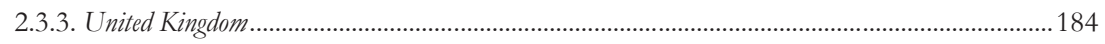

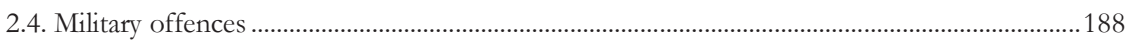

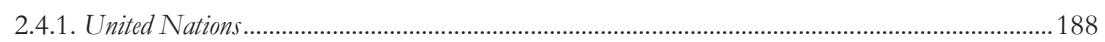

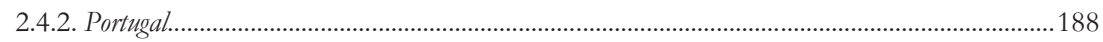

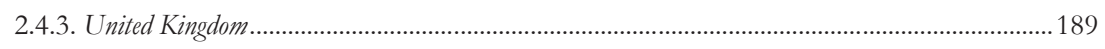

3. Grounds for refusal related to the punitive claim of the requesting State.......................................190

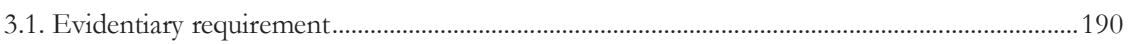

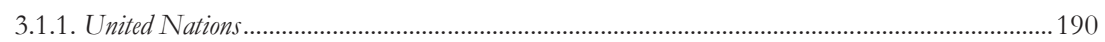




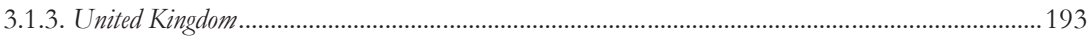

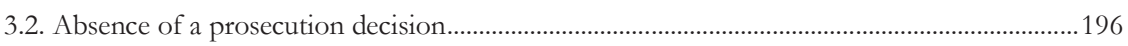

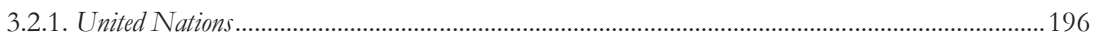

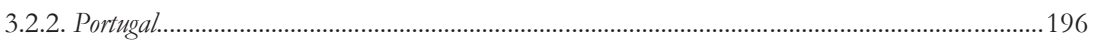

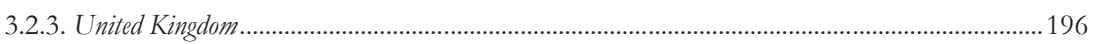

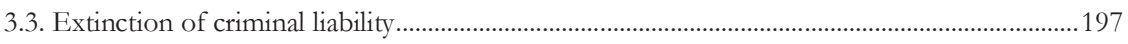

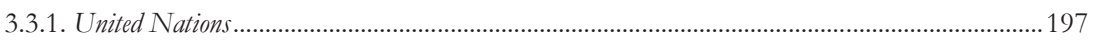

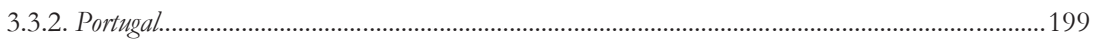

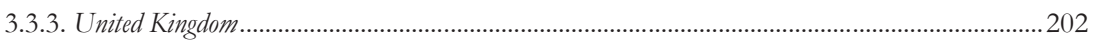

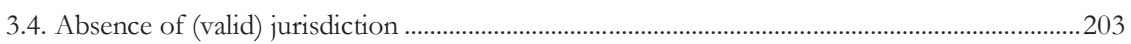

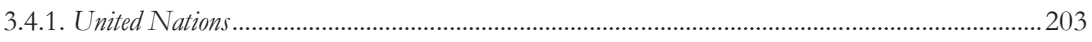

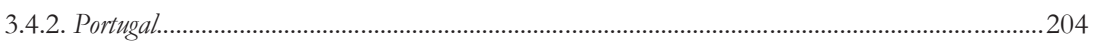

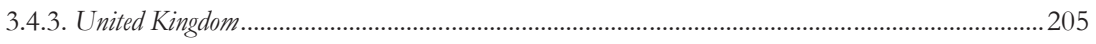

4. Grounds for refusal related to the status or condition of the person................................................205

4.1. Nationality / Rehabilitation.............................................................................................................220

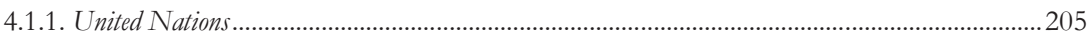

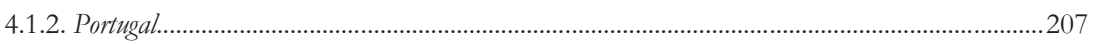

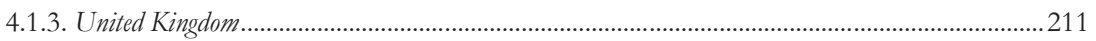

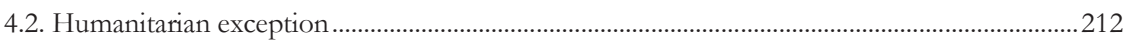

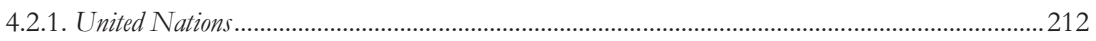

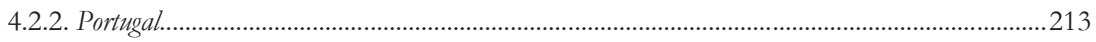

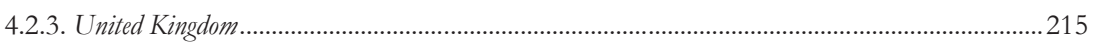

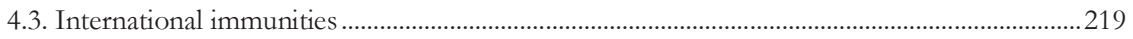

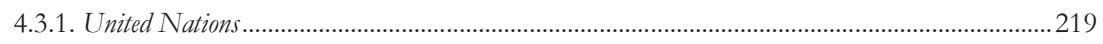

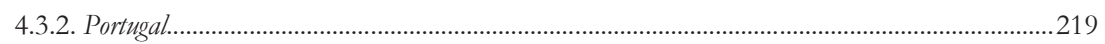

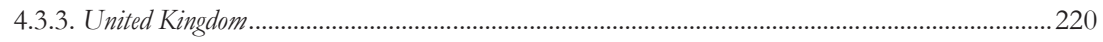

5. Grounds for refusal related to the misuse of extradition proceedings by the requesting State ......220

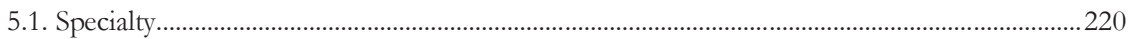

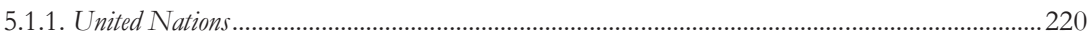

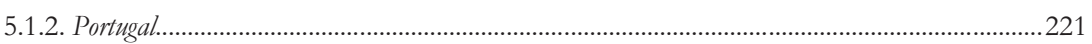

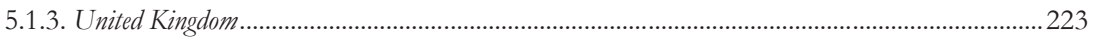

5.2. Earlier extradition (or limitation on re-extradition).........................................................................22 223

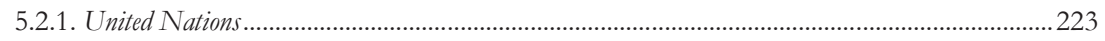

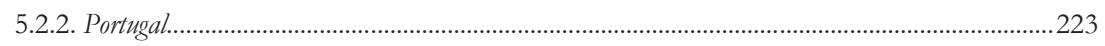

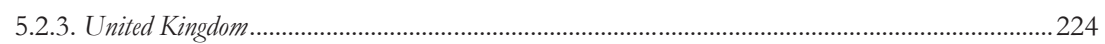

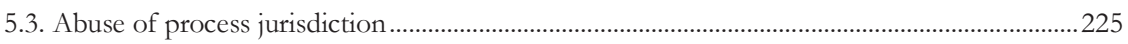

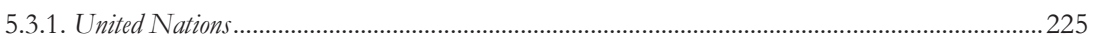

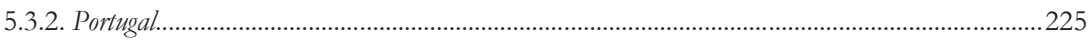

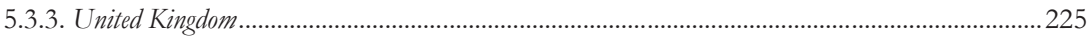

6. Grounds for refusal related to mere issues of interstate allocation of jurisdiction............................226 


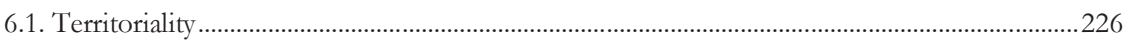

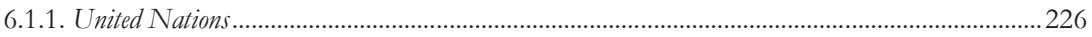

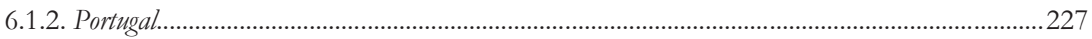

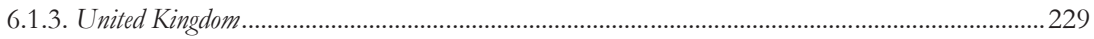

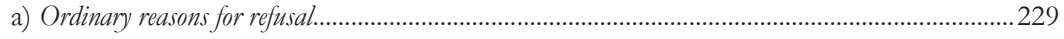

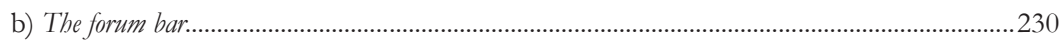

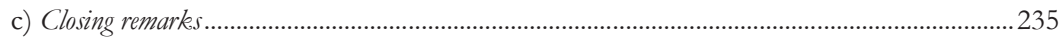

6.2. Pending proceedings or possibility or duty to initiate proceedings............................................226

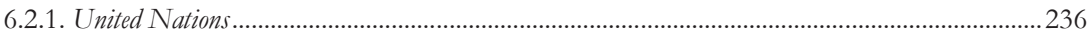

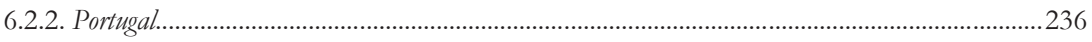

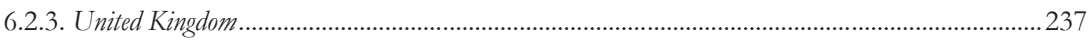

7. Grounds for refusal related to political concerns of the requested State.........................................239

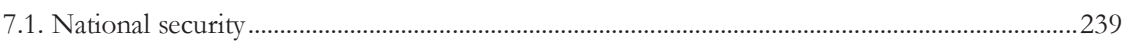

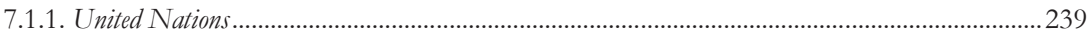

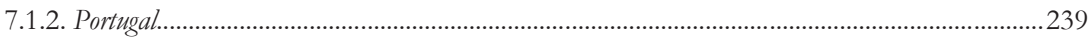

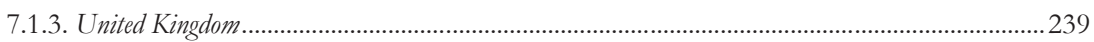

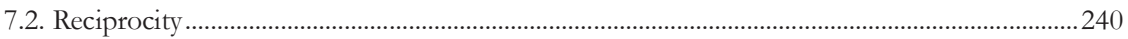

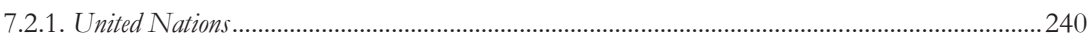

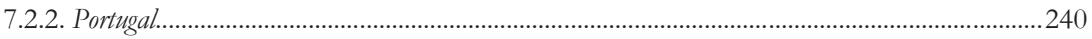

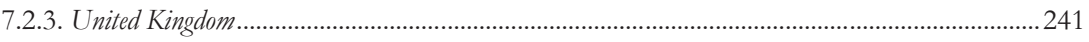

Part IV - Reviewing Grounds for Refusal................................................. 243

Chapter 7 - Questioning Grounds for Refusal: Theoretical Framework.................. 245

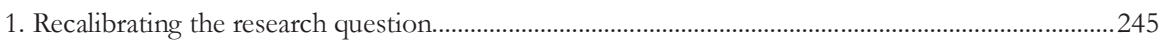

1.1. Specifications required by the concept of 'ground for refusal' adopted..................................245

1.1.1 Grounds for refusal related to mere issues of interstate allocation of jurisdiction.................................245

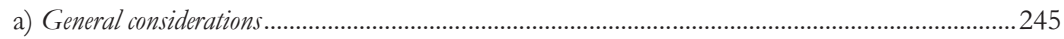

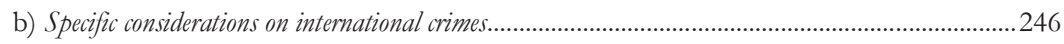

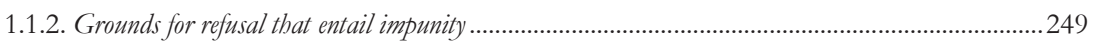

1.2. Specifications regarding grounds for refusal imposed upon States ..........................................251

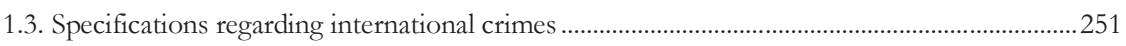

1.4. Specifications regarding the theoretical framework ..................................................................254

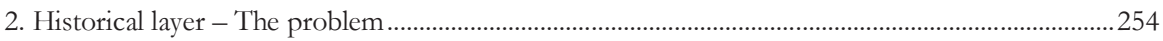

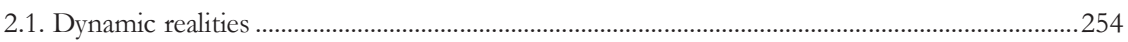

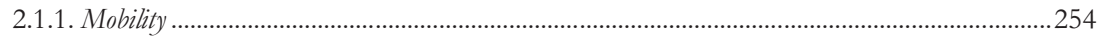

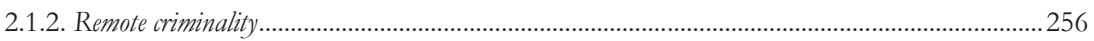

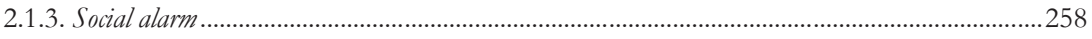

2.1.4. Conclusion - The need for a transnational approach to punishment .............................................259

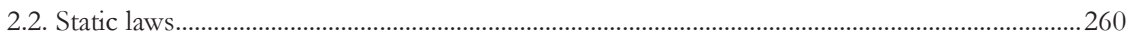

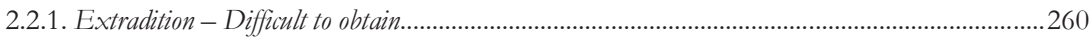

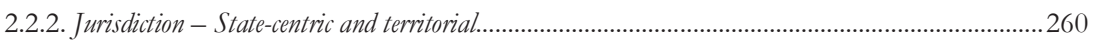

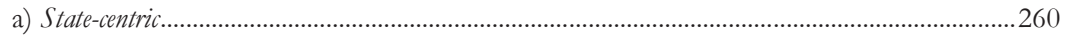


b) Territorial..

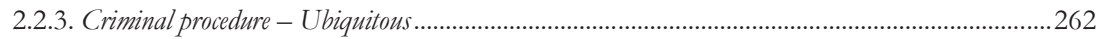

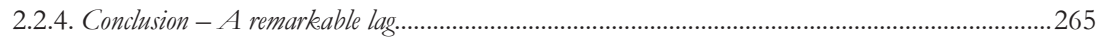

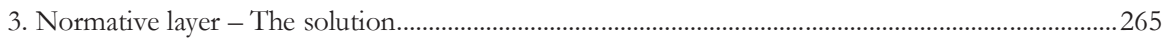

3.1. The rule - Furthering the principle of territoriality ...................................................................265

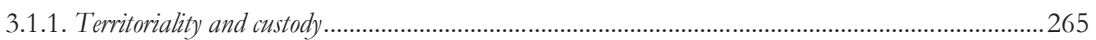

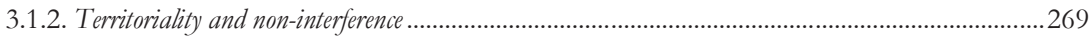

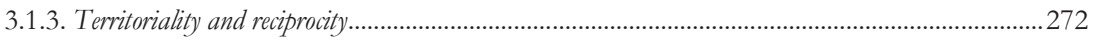

3.1.4. Conclusion - A rebuttable but robust presumption ……................................................................2 272

3.2. The exception - Preserving core national values.........................................................................273

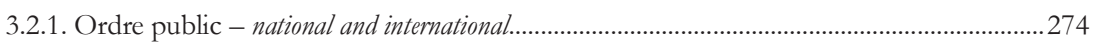

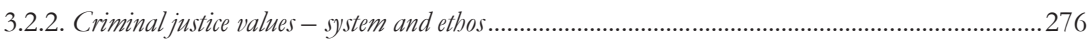

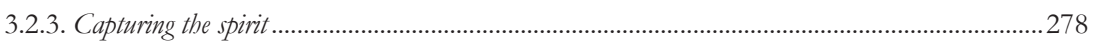

a) In private international law: indeterminacy, dynamism, contemporaneity and casuistry .....................278

b) In extradition law: same dynamism, contemporaneity and casuistry, less indeterminacy.....................279

c) The basic law of a State as the repository of its criminal justice ethos.................................................28

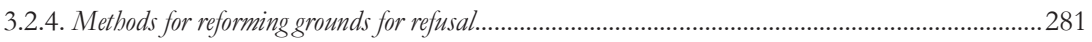

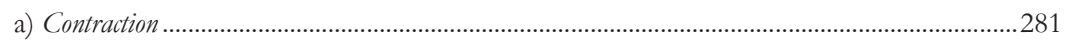

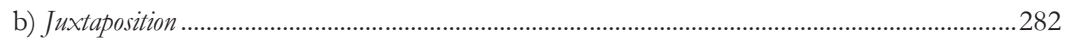

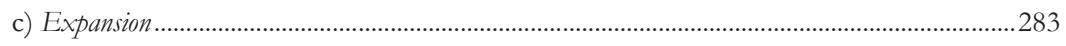

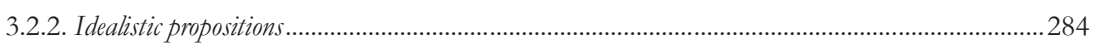

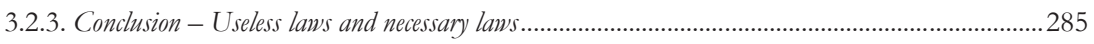

3.3. The balance - Weighing the interests of the subjects involved ..................................................286

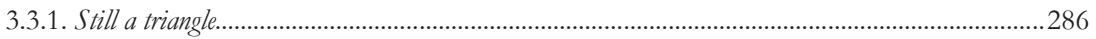

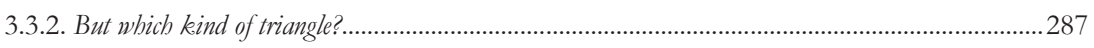

3.3.3. The imbalance of transnational criminal law ...................................................................................229

3.3.4. The immediate punitive effects of international arrest warrants .......................................................290

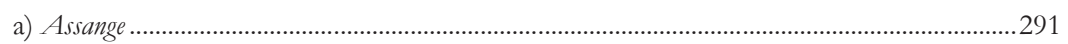

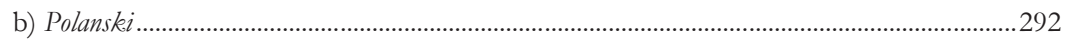

c) Sons of Iraqi ambassador to Portugal ...............................................................................................293

d) Conclusion - Limited freedom, limited persecution .............................................................................29

3.3.5. Individuals - Structural disadvantage, substantive advantage......................................................295

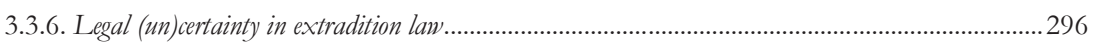

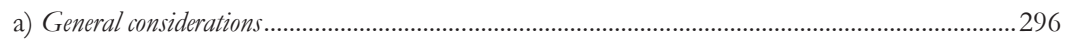

b) Advocaten voor de Wereld ..........................................................................................................298

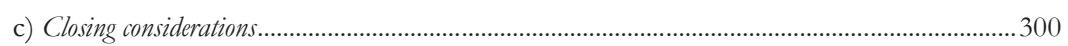

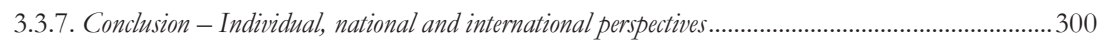

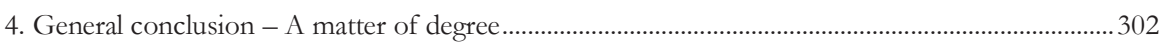

Chapter 8 - Reforming Grounds for Refusal: Theoretical Framework Applied..... 305

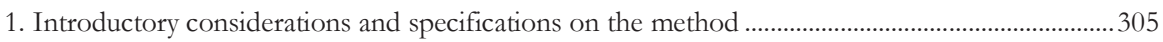

2. Grounds for refusal related to political concerns of the requesting State..........................................306 
2.1. The inexorability of political interference in extradition.

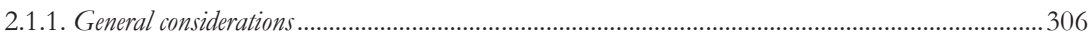

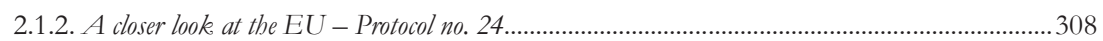

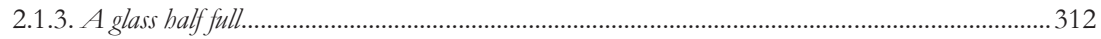

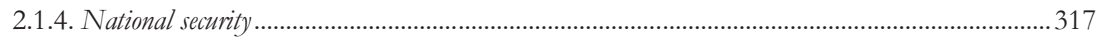

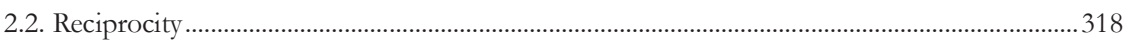

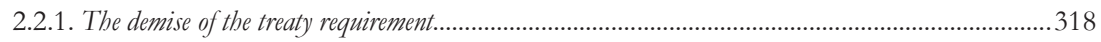

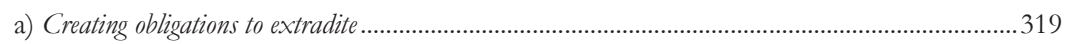

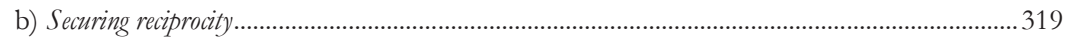

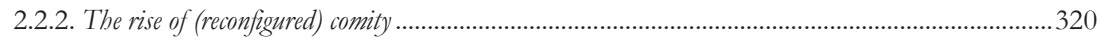

3. Grounds for refusal preserved in the EAW - Negative candidates to be reformed ........................322

3.1. Grounds for refusal related to the conditions in the requesting State .......................................322

3.2. Grounds for refusal related to the nature or relevance of the acts...............................................3 322

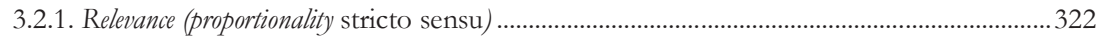

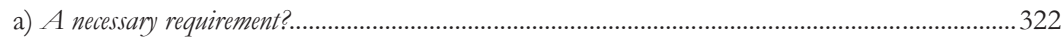

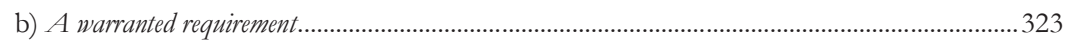

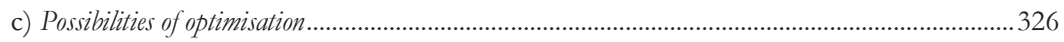

d) A further ground for refusal on disproportionality between acts and penalty?....................................327

3.3. Grounds for refusal related to the punitive claim of the requesting State ................................328

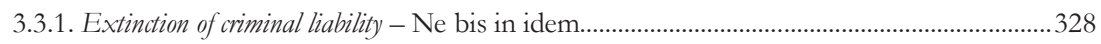

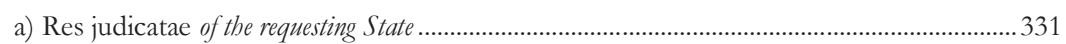

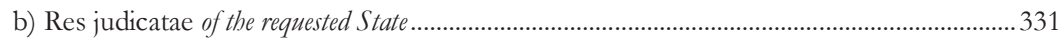

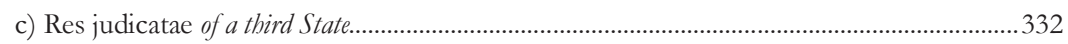

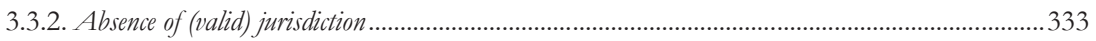

3.4. Grounds for refusal related to the status or condition of the person.........................................336

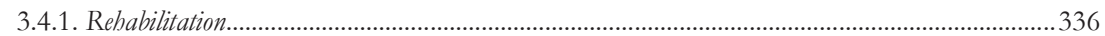

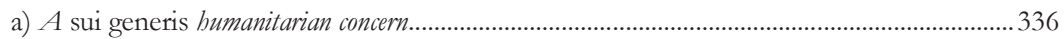

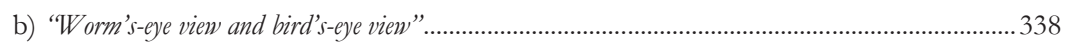

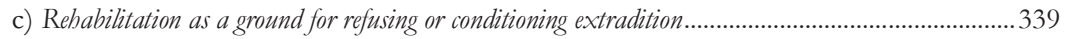

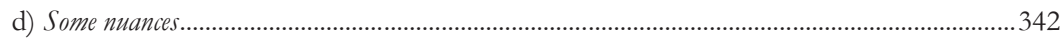

e) Articulation with relevance (proportionality stricto sensu)...............................................................343

3.5. Grounds for refusal related to the improper use of the extradition process by the requesting State

3.5.1. Specialty (or speciality).

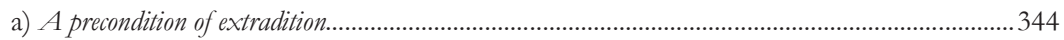

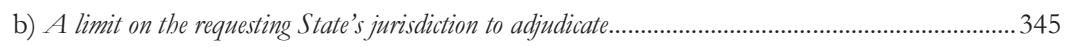

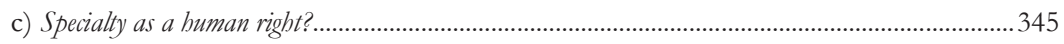

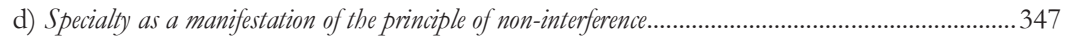

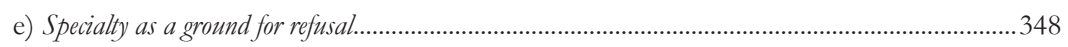

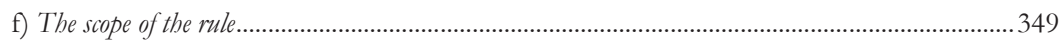

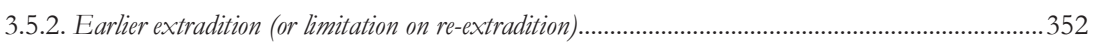


a) A manifold ground for refusal.

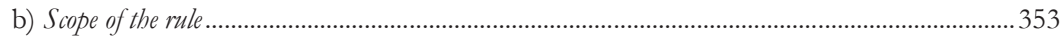

3.6. Grounds for refusal related to mere issues of interstate allocation of jurisdiction....................354

3.6.1. Territoriality.

3.6.2. Pending proceedings or possibility or duty to initiate proceedings.

4. Grounds for refusal abolished or mitigated in the EAW - Positive candidates to be reformed...357

4.1. Grounds for refusal related to the nature or relevance of the acts. .357

4.1.1. Dual criminality.

a) Rationale. .358

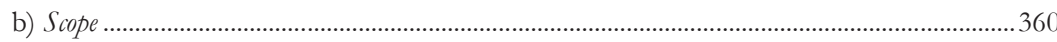

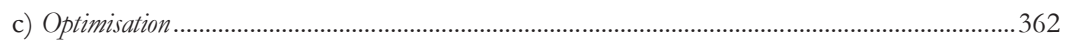

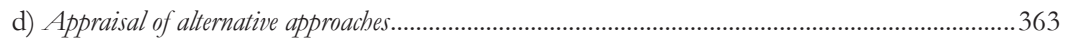

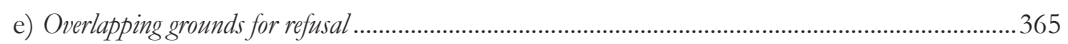

f) Approaching a solution - Ordinary law and constitutional law......................................................366

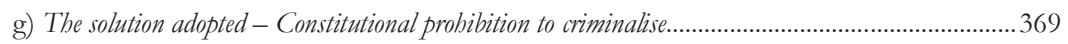

h) Illustrating the practical consequences of the proposed shift ...............................................................3 372

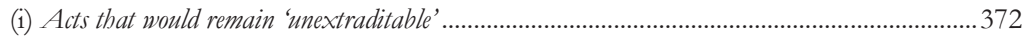

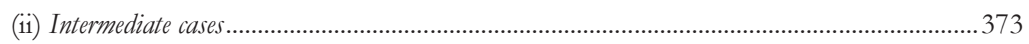

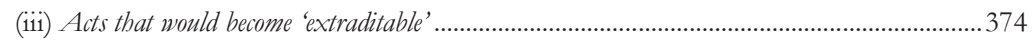

(iv) Special cases - Particularly money laundering (with a footnote also on confiscation of assets)......377

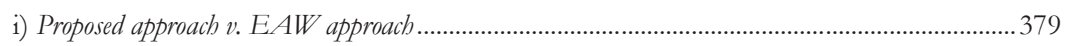

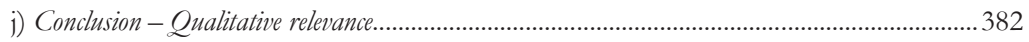

k) Collateral implications of the shift from dual criminality to qualitative relevance ................................383

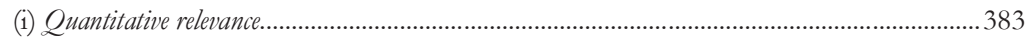

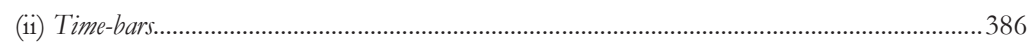

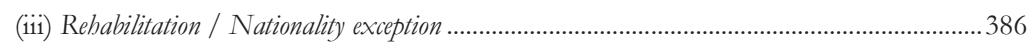

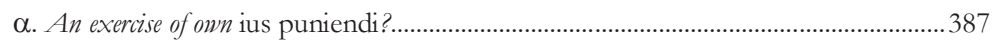

$\beta$. Offensive to the criminal justice ethos of the requested State? ....................................................38

$\chi$. Rehabilitating a person for acts that one does not criminalise - An impossible attempt? .........391

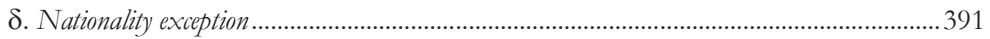

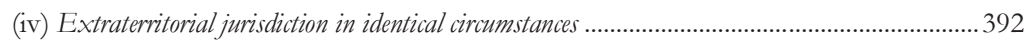

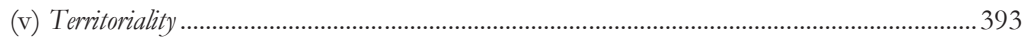

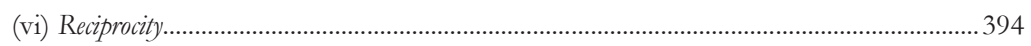

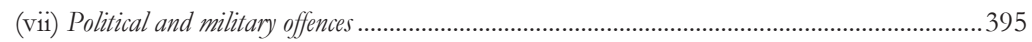

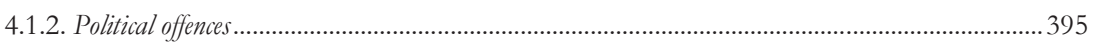

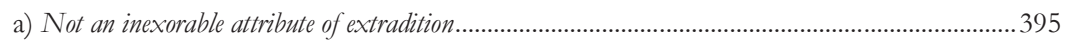

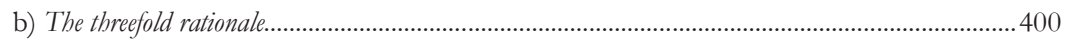

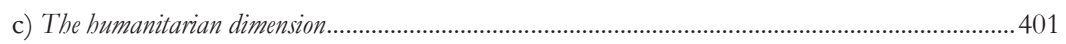

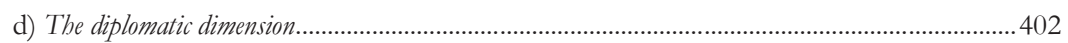

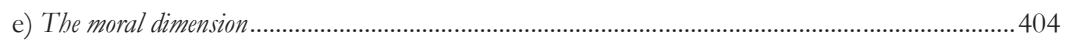

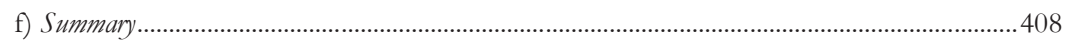




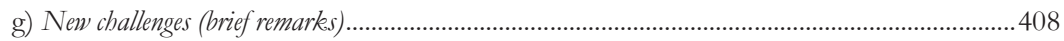

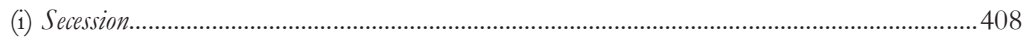

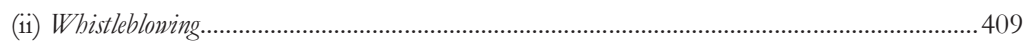

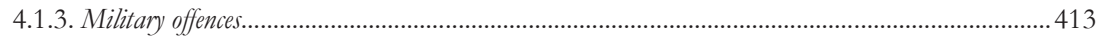

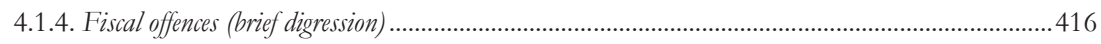

4.2. Grounds for refusal related to the punitive claim of the requesting State ................................418

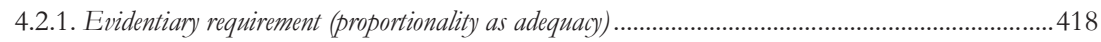

a) Revisiting the contrast between criminal proceedings and extradition proceedings.................................418

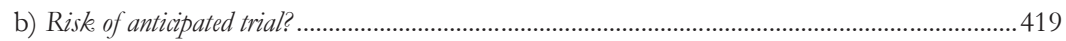

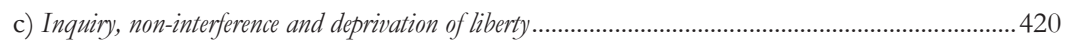

d) Presumption of innocence, guilt principle and proportionality (as adequacy) ......................................421

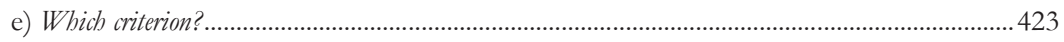

f) Interactions with other grounds for refusal ....................................................................................424

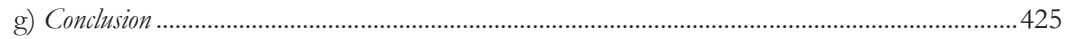

4.2.2. Extinction of liability (except ne bis in idem) according to the requested State ..............................425

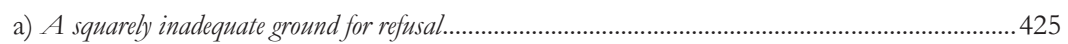

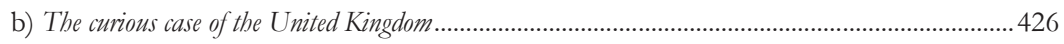

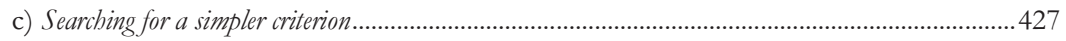

d) Why applying the time-bars of the requested State by reference to the penalty scale of the requesting State

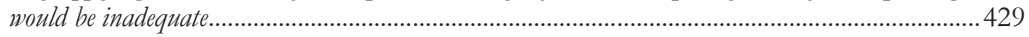

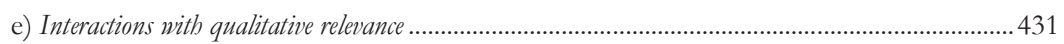

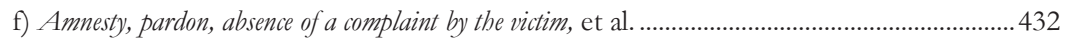

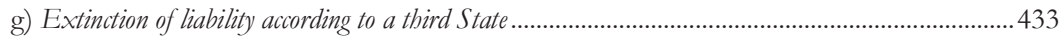

4.3. Obstacles related to the status or condition of the person .............................................................433

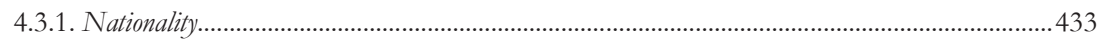

a) A glimpse into the perspectives of social sciences on nationality ...........................................................433

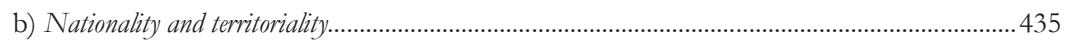

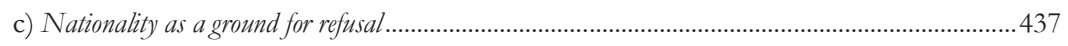

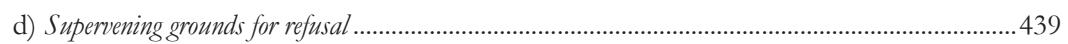

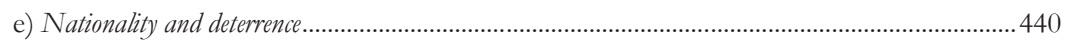

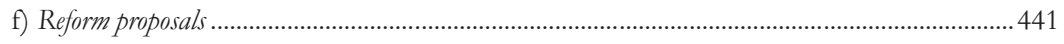

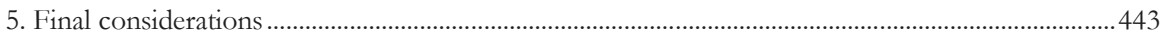

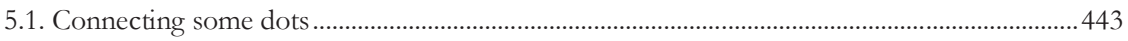

5.1.1. Supporting the rise of proportionality and of alternatives to extradition.............................................443

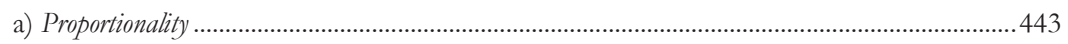

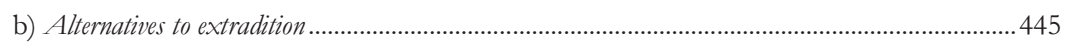

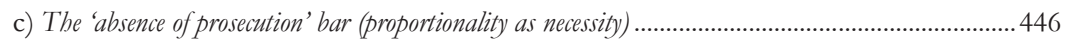

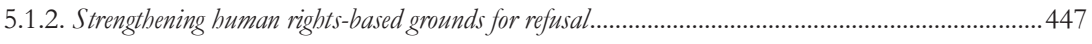

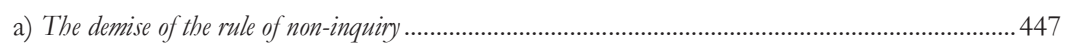

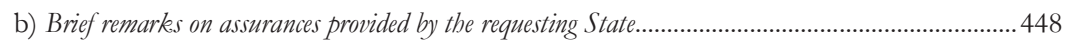

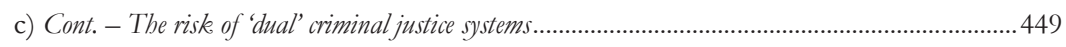


d) Aut dedere aut judicare 450

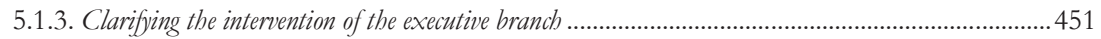

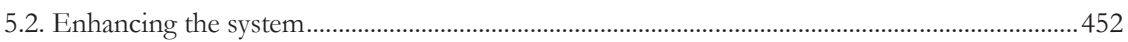

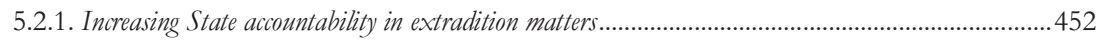

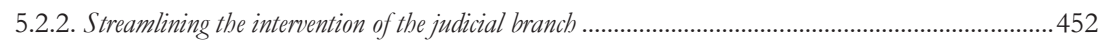

Chapter 9 - Conclusions: Reshaping the Extradition Triangle ................................ 455

ANNEX - Graphic Illustration of the Reform Defended ........................................................................465

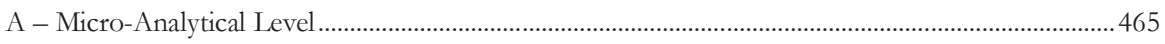

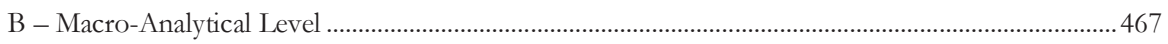

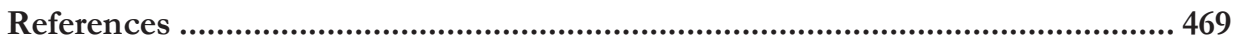

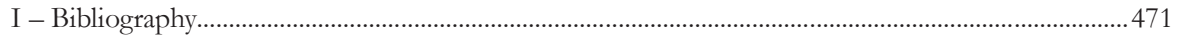

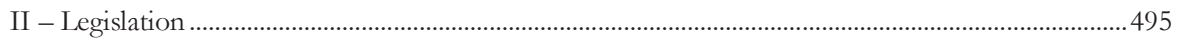

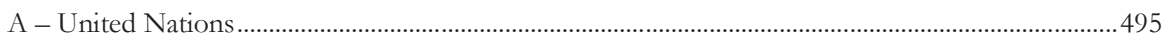

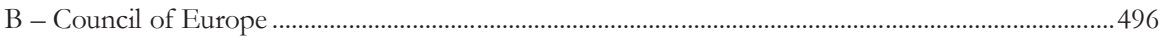

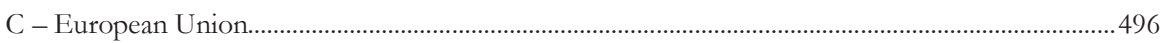

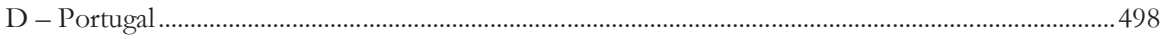

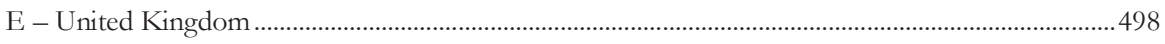

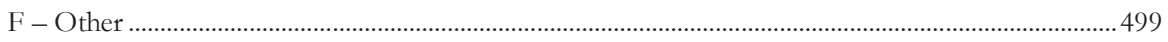

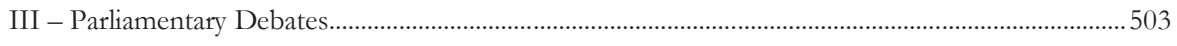

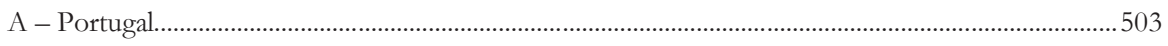

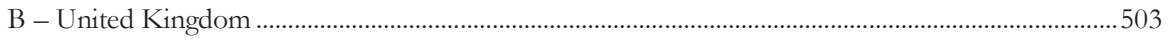

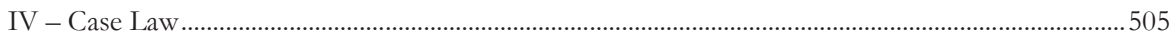

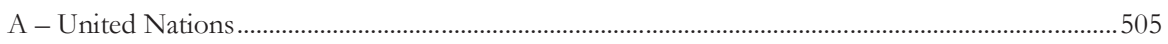

B - European Court of Human Rights ………....................................................................................506

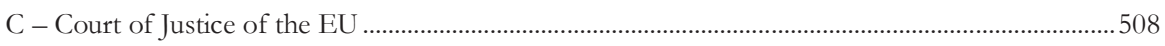

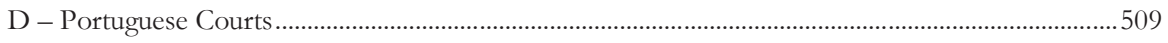

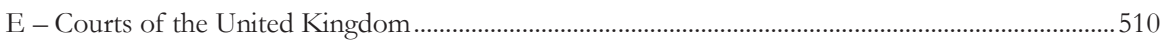

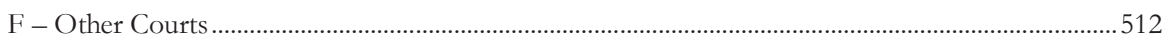

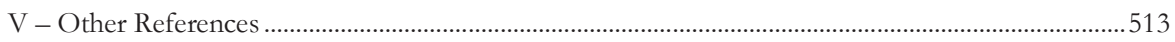

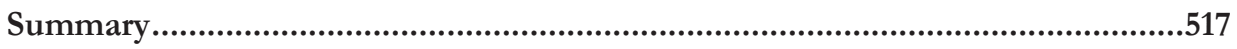

Valorisation Addendum .................................................................................. 527

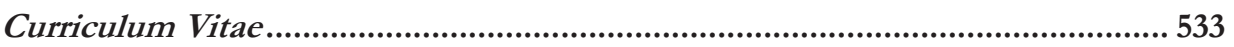


PART I

\section{INTRODUCTION}




\section{Chapter 1}

\section{Fundamental Concepts}

\section{The purpose of this study}

The purpose of this study is to assess whether extradition should be rendered more flexible by reducing the traditional grounds for its refusal. The reason for considering enhancing extradition in the present historical moment is intuitive. To quote from a prominent textbook on extradition: "In modern times the importance of the subject has vastly increased. The improved facilities of communication which modern invention has afforded, and the consequent ease with which malefactors can escape from the jurisdiction of the countries whose laws they have violated, have rendered it essential to the order of society that flight should not secure immunity from punishment." The statement is dated from $1891 .^{1}$

Since then, mobility of people has not only continued to increase, but has in effect reached exponential levels. It has also become easier to commit, from a distance, crimes that produce their effects preponderantly in other territories, ${ }^{2}$ which has led States to expand their extraterritorial jurisdiction. Some offences, notably those that are generally encompassed by protective jurisdiction, even tend to damage exclusively States and communities other than those within which they were committed, meaning that they are usually not punishable in the latter, ${ }^{3}$ and, consequently, that the only possibility to avoid impunity may be for the former to obtain the extradition of the offender.

Yet, several obstacles to an effective cooperation endure. Some of these have their origins in the distant and quite diverse world of the $18^{\text {th }}$ century, and others can be traced to even more ancient times. "If we look for reasons" - Eser holds - "we certainly find not only force of habit and strength of red tape, but also evidence of national egoism", as well as "mutual misunderstandings" owed to "different structural approaches and principles". Whether all such grounds for refusal are still required is the key issue to be addressed. In the following paragraphs, the concepts and notions that are essential to this study are reviewed and organised, its scope delimited, its precise research question formulated, and the method used in order to answer this question described.

\footnotetext{
${ }^{1}$ JohnBASSETMOORE, A Treatise on Extradition andInterstate Rendition, Boston:Book Company, 1891, p. 5 f.

2 SeeANDRÉKLIP, “Internationalcriminallaw.Informationsociety and penallaw”, RIDP85(2014),p.381 f.

3 SeeCHristineVAndenWyngaERT, “Double criminality as a requirement tojurisdiction”, in JohnDugard / Christine van den Wyngaert (ed.), International CriminalLaw and Procedure, Aldershot: Dartmouth, 1996, p. 135.

${ }^{4}$ Albin EsER, "Basic Issues Concerning Transnational Cooperation in Criminal Cases: A Problem in Outline", in Edward M. Wise (ed.), Criminal Science in a Global Society: Essays in Honor of Gerhard O. W. Mueller, Littleton: Fred B. Rothman \& Co., 1994, p. 4 f.
} 


\section{The concept of extradition}

\subsection{Definition and essential attributes}

Extradition can be defined as a coercible transfer of a person from one jurisdiction to another at the request of the latter, through a specified procedure and provided that certain conditions are satisfied, for the purpose of carrying out a criminal procedure or enforcing a penalty.

The person targeted by an extradition request has a legal standing enabling him/her to defend him/herself against extradition. The reason why one should speak of 'jurisdictions' rather than 'States' is that, currently, the term 'extradition', if understood in a broad sense, encompasses the transfer of persons from States to international tribunals, as well as the transfer of persons to and from political entities which do not qualify as States but which are nevertheless endowed with autonomous jurisdiction in criminal matters, such as the Special Administrative Regions of Hong Kong and Macau. ${ }^{5}$ The transfer is the material act which constitutes the immediate consequence of extradition. The circumstance that extradition is preordained to penal purposes - the completion of a criminal procedure or the enforcement of a penalty -, which constitute its ultimate consequences, separates it from other mechanisms such as deportation or expulsion; as does the circumstance that it presupposes a request. Extradition is not necessarily coercive, as the person may consent to being extradited, but it is coercible, as it can be imposed against his/her will.

Frequently regarded as an essentially procedural institute, extradition is in reality a rather complete or eclectic body of norms which cover procedural as well as substantive matters: the issuing of an extradition request (active extradition) triggers a procedure in the requested State (passive extradition) through which at least one judicial entity, and usually also a political one, determine whether the conditions necessary for extradition to be granted are fulfilled. These conditions may constitute simple formalities (such as the requirement that the request indicates the person sought), or truly substantive conditions (such as the requirement that the acts at issue be criminalised in the requested State). The latter are usually referred to as 'grounds for refusal' or 'obstacles' to extradition, ${ }^{6}$ and form the substantive element of this institute; they are the core object of this study.

\subsection{Contrast with substantive criminal law and criminal procedure}

The fact that extradition is ancillary to penal finalities, which are ultimately attained by the application of substantive penal norms through a penal procedure, does not mean that the structures underpinning extradition law constitute a mere extension or projection of the ones underpinning criminal law and criminal procedure. The circumstance that extradition involves an interaction of different States (with possibly very diverse penal conceptions and very diverse world-views), added to the fact that one of these States

\footnotetext{
5 These regions are integral parts of the PRC, but they have broad legal and judicial autonomy and treaty-making capacity, regulating autonomously their international cooperation relations: see the Fugitive Offenders Ordinance (Chap. 503 of the Laws of Hong Kong), and Law no. 6/2006, of 24 July (in Macau).

${ }^{6}$ This study uses the expression 'grounds for refusal' much more frequently than the term 'obstacles', because the former was thought to be more neutral and objective, in that it implies that there might exist sound reasons ('grounds') for extradition not to be effected in certain cases.
} 
was injured by the crime at issue while the other will often have no punitive interest whatsoever thereupon, already bestows extradition law with a specific rationality which is fairly independent from that of the criminal laws and the criminal procedures that it ultimately serves. It may be affirmed that extradition law is criminal law and criminal procedure put into perspective.

Certainly, the fundamental themes of criminal law and procedure are engrained in extradition law, or at least are always on its horizon. Extradition law concerns itself with such issues as the applicability of certain penalties, due process standards, and even the concept of crime. However, the angle from which such issues are observed is quite singular. This is why a State might extradite a person to another State that normally punishes the acts in question with a penalty that the former considers intolerable, or extradite a person to a State that offers fewer procedural guarantees, or even extradite a person for acts that it would itself be unable to punish; and why a State might deprive a person of liberty automatically upon receiving an extradition request even where it would be unable to order the pre-trial confinement of that person in the context of a domestic criminal procedure (e.g. because there was no risk of escape). Acknowledging the autonomy of extradition law in relation to criminal law and criminal procedure is crucial for reflecting on its evolution. The circumstance that such an autonomy tends to be insufficiently recognised is probably one of the main reasons why extradition law has remained so unchanged over the past centuries.

The fact that it involves the transfer of a person from one jurisdiction to another is another important specificity of extradition vis-à-vis criminal law and criminal procedure. Such a transfer carries a radical modification in the factual and legal circumstances involving a person, which calls into consideration specific questions which in national criminal cases are irrelevant or peripheral, such as that as to whether the transfer might endanger the health of the person concerned. This transfer also seems to be at the origin of an interesting phenomenon of reciprocal pressure of different criminal justice systems upon each other. The fact that a State which has been injured by a crime is in need of assistance by another State (sc. by the custodial State, where the suspect is located) to punish it, explains why, as exemplified briefly above, several principles that bear a nearly dogmatic strength in the realm of criminal law and procedure are relevant to extradition law only in a relative manner - i.e. only after they have been put into perspective, and only if and to the extent that they show relevant from such a perspective. However, the fact that, by extraditing, a State exposes a person to the factual and legal conditions in place in another jurisdiction confers upon that State a type of responsibility that is somewhat more stringent in view of certain international norms than its responsibility in the administration of its own criminal law and procedure. Thus, for instance, although States are bound to respect human rights in both their internal criminal cases and in extradition cases, and although the content of those rights is identical in both contexts (even if their assessment is structurally different, as in the latter case it is typically prospective in character), States are sometimes more demanding of other States (in extradition proceedings) than of themselves (in their own criminal proceedings). Vivid illustration of this is provided by Euro- 
pean cooperation following Aranyosi \& Căldăraru. ${ }^{7}$ In this case the ECJ held that deficient prison conditions in a Member State might prevent the transfer of a person to that State; but while Member States must now deny other Member States the surrender of persons if there is a real risk that they would be exposed to sub-standard prison conditions, it is clear that some Member States are unable to suddenly raise their penitentiary standards to the tolerable level, meaning that such Member States will continue, at least transitionally, to subject some convicts to such sub-standard conditions. ${ }^{8}$ On the other hand, the specificities of extradition law also carry that certain factors which are plainly immaterial in internal criminal cases be accredited great relevance in the context of extradition proceedings, the utmost example of which is the nationality of the person concerned.

The above remarks already imply another distinctive trait of extradition law, namely that it forms an intersection, a point of confluence of numerous sets of norms. As far as its sources are concerned, it involves: national norms, of both ordinary and constitutional rank, and of both the requested and the requesting States, since many conditions necessary for extradition to be granted relate to the latter's legal system; international norms, of both general (customary and imperative) and conventional (bilateral and multilateral) character; and, in States belonging to legally and politically integrated regional organisations such as the EU, peculiar normative instruments such as Framework Decisions may yet apply. Thematically, these norms may refer inter alia to: extradition law in a stricter sense, substantive criminal law (prescriptive and adjudicative), criminal procedure, rules on remand, human rights, diplomatic law, nationality law and private international law. At the organic level, such norms are applied by multiple judicial bodies (national, regional and international) whose jurisprudence also constitutes a source of law and in any case co-determines the real scope of other sources of law. On the other hand, extradition cases involve not only legal, but also political assessments, making them sensitive cases from the perspective of international relations. Many of these elements do also concur in criminal cases, such that presently it is questionable whether one may even accurately still speak of 'purely internal' cases. However, in criminal cases this confluence is usually much less profuse than in extradition cases, where the rule is the confluence of many of those elements.

Notwithstanding this intricacy, extradition law has a propensity for uniformity, because it involves an interaction between States. By definition States have different criminal laws and different criminal procedures. These differences can be minor, but also very substan-

\footnotetext{
${ }^{7}$ ECJ, Aranyosi \& Căldăraru (C-404/15 \& C-659/15), 5 April 2016.

8 A second request for a preliminary ruling concerning Aranyosi was lodged to the ECJ in 16 September 2016 (C-496/16), posing the following questions: (1) Are Arts. 1 (3), 5 and 6 (1) FD-EAW to be interpreted as meaning that an executing Member State, when taking a decision on extradition for prosecution purposes, must eliminate any real risk of ill-treatment attributable to the conditions of detention only in the first prison in which the person will be imprisoned following his surrender? (2) Must an executing State, instead, also eliminate any such real risk that may be attributable to the conditions of detention in the place where the person is subject to subsequent imprisonment in the event of conviction? (3) Must an executing State further eliminate such a risk also in the event of possible relocations to other prisons? Hungary subsequently withdrew its EAW for Aranyosi, and in consequence the ECJ declared, by an Order of 15 November 2017, that there was no need to proceed to judgment. However, the same court (Bremen) submitted similar questions to ECJ in Generalstaatsanwaltschaft (C-220/18), and another German court (Hamburg) is also seeking clarification on the implications of Aranyosi \& Căldăraru in Dorobantu (C-128/18) - adressed infra, Chap. 2, \ 3.2.1., and Chap. 8, \ 5.1.2.c).
} 
tial. To some extent, the same factors (cultural and other) that produce those differences also produce disparities in extradition matters. However, in the latter setting, as in international law more broadly, if States are to interact they must reach an understanding, agree upon common regulatory frameworks. This is why it is both possible and useful to reflect about extradition in global terms. As Bassiouni stated: "The ideal approach to extradition is to see it applied uniformly and fairly whether the case arises in Chicago or Cairo".?

\section{Why States need to obtain extradition}

With the exception of the cases where in absentia criminal proceedings are admissible, having custody of the offender is at some point necessary for conducting a penal procedure, and it is always necessary for enforcing a penalty involving deprivation of liberty, as this penalty cannot be served in absentia. Therefore, States need extradition to give effect to their substantive penal laws. This holds true regardless of whether a State follows a retributive or a preventative approach to criminal punishment. ${ }^{10}$

Forms of international cooperation other than extradition have later been developed which also contribute to narrowing the room for impunity, whilst being more considerate of individual interests. ${ }^{11}$ They include the transfer of proceedings, the execution of foreign sentences, and - although formally this is not a cooperation mechanism, but a basis for jurisdiction in criminal matters - vicarious administration of justice. ${ }^{12}$ In spite of these developments, extradition remains a priority because it continues to be the most effective mechanism of cooperation, in the following sense. Only extradition enables the State whose substantive law was breached ${ }^{13}$ to exert punishment on its own terms, and this is, from various angles, the preferable form of reaction to that breach: the requesting State, which is generally the place where the crime was committed and/or its harm materialised (hereinafter, 'injured State'), is the one where punishment is more necessary, as well as the one that is best placed to gather the evidence necessary to ascertain the liability of the suspect. ${ }^{14}$

\footnotetext{
${ }^{9}$ M. Cherif BASSIOUNI, International Extradition: United States Law and Practice, $6^{\text {th }}$ ed., Oxford: University Press, 2014, p. 60.

${ }^{10}$ See Cesare Beccaria, Crimes and Punishments, London: Chatto \& Windus, 1880, p. 192 f.; Albert BiLLOT, Traité de l'Extradition: suivi d'un recueil de documents étrangers et des conventions d'extradition conclues par la France et actuellement en vigueur, Paris: E. Plon et Cie, 1874, p. 11; PAUl BERnARD, Traité Théorique et Pratique de l'Extradition. Vol. II, Paris: Arthur Rosseau, Éditeur, 1883, p. 31; William EDWARD HalL, A Treatise on International Law, A. Pearce Higgins (ed.), Oxford: University Press, 7th ed., 1917, p. 59.

${ }^{11}$ See Christine VAn Den Wyngaert, "Double criminality...”, op. cit., p. 133.

12 On these concepts, see further infra. For an overview of the different modalities of international cooperation in criminal matters and the "indirect enforcement system" of criminal law they constitute, see M. CHERIF BASSIOUNI, Introduction to International Criminal Law, $2^{\text {nd }}$ ed., Leiden: Brill, 2013, p. 487 f.

${ }^{13}$ In this context, 'breach' means the perpetration (or, where punishable, an attempt or preparation) of a conduct described in a substantive penal norm (Tatbestand) and the concomitant verification of a relevant connection or link - territoriality, nationality of the offender or of the victim, etc. - between such a conduct and a given legal system (simnoller Anknüpfungspunkt).

${ }^{14}$ See e.g. CHARLES K. BURDiCK (rep.), "Harvard Research in International Law: Extradition”, AJIL (Sup.) 29 (1935), p. 38, and NeIL BOISTER, "The trend to 'universal extradition' over subsidiary universal jurisdiction in the suppression of transnational crime: transnational and organized crime", AJ (2003), p. $307 \mathrm{f}$.
} 
In addition, enabling the injured State to assert its own criminal law is the best option from a perspective of proportionality (and hence fairness) ${ }^{15}$ in sentencing: in principle proportionality cannot be attained if different penalty scales (from different legal systems) are applied; thus, if extradition is not granted, entirely similar crimes, harmful to one and the same State, will be treated differently, and possibly quite differently, owing to the sheer variable as to whether or not the offender has later escaped to another State. ${ }^{16}$ These reasons might help to explain why, despite the emergence of alternative mechanisms, extradition not only did not enter into decline, but is in fact in ascent - both normatively ${ }^{17}$ and empirically. ${ }^{18}$

In the following paragraphs, the greater effectiveness of extradition in comparison to other cooperation mechanisms is tested in further detail by reference to the UN model instruments where they are regulated: ${ }^{19}$ the Model Treaty on the Transfer of Proceedings in Criminal Matters and the Model Agreement on the Transfer of Foreign Prisoners.

\subsection{Transfer of proceedings}

That the transfer of proceedings is in the abstract a secondary option compared to extradition is reflected in the fact that its applicability tends to be limited to cases where extradition cannot be granted. Sometimes this condition is explicit and absolute, bearing no exception..$^{20}$ At other times it is only implicit and relative, but impactful nonetheless, as in the Model Treaty on the Transfer of Proceedings: this instrument limits the possibility of transferring proceedings to cases where "interests of the proper administration of justice so require", ${ }^{21}$ meaning "situations where the requested State would not be in a position to effect the extradition". ${ }^{2}$

\subsection{Vicarious jurisdiction}

Extradition also takes priority over initiating criminal proceedings based on vicarious or representational jurisdiction. The very definition of this type of jurisdiction is that a State will exert punitive action over acts for which it received an extradition request that it could not grant. The subsidiary character of vicarious jurisdiction in relation to extradition is recurrently emphasised.

\footnotetext{
15 See Andrew von Hirsch, Censure and Sanctions, Oxford: University Press, 2003 (rep.), p. 4, 6 f.; in further detail on proportionality, see further infra, Chap. 8, \$S 3.2.1., 4.2.1., and 5.1.1.

${ }_{16}$ On this particular topic, see yet further infra, Chap. 8, $\left.\int 5.1 .2 . c\right)$.

${ }^{17}$ Not always under its classic designation of 'extradition', but under variations of the same basic concept developed under the label of 'surrender', notably the EAW, the NAW and the MAW (on these, see further infra, and Chap. 2, $\int 3$.

18 As reported in M. CHERIF BASSIOUNI, International Extradition... op. cit., p. 58, "the volume of extradition has increased significantly in a number of countries".

${ }^{19}$ On the representativeness of these model instruments, see infra, Chap. 2, $\int$ 2.3.1.a).

20 As in the Portuguese legal system (assessed in Part III, infra): see Arts. 80 (1) (a) and 80 (2) (b) PT-L.

21 Art. 1 (1) and (2).

${ }^{22}$ Roger S. Clark, The United Nations Crime Prevention and Criminal Justice Program: Formulation of Standards and Efforts at Their Implementation, Philadelphia: University of Pennsylvania Press, 1994, p. 220 f., specifying that the typical case is that where the suspect is a national of the State that has his/her custody.
} 
For instance, Eser asserts that this basis of jurisdiction "should be limited to cases in which the State where the crime was committed intends to prosecute but is prevented from doing so only by a denial of extradition"; "how could the trial State call its assertion of justice 'representative" " - the author adds, conveying the scepticism of some States towards this type of jurisdiction (notably States of the common law tradition) - "when the 'represented' state would prefer to conduct its own trial?" Vicarious jurisdiction - the author unambiguously concludes - should be used "only as a substitute to extradition". 23

\subsection{Common attributes ${ }^{24}$}

It is true that, when conducting a criminal procedure on behalf of the injured State - whether pursuant to a request for a transfer of proceedings, or based on vicarious jurisdiction -, the State that has the custody of the suspect is often enabled to apply the law of that State (lex loci delicti) instead of its own (lex fori). ${ }^{25}$ To some extent, this does mitigate the shortcomings of representational proceedings. However, many disadvantages remain.

In the first place, the possibility to apply the lex loci delicti is generally limited to the cases where it is more favourable to the defendant than the lex for ${ }^{26}-$ which is quite sensible on the part of the custodial State, but again unsatisfying to the injured State, as in all other cases its punitive claim will not be entirely appeased. Secondly, applying the lex loci delicti does not eliminate the difficulties in assessing the blameworthiness of the offender or the harm caused to the (foreign) community of the injured State. These can only be adequately measured by this State. Their assessment by a different State is burdensome and prone to error. ${ }^{27}$ Finally, the procedural law applicable to the case is always that of the State conducting the proceedings, ${ }^{28}$ not that of the injured State, which concurs to spoiling the latter's interests: imagine a case where the available evidence consists largely of the content of telecommunications that have been intercepted in a manner which is fully legitimate in the injured State (where they were intercepted), but inadmissible, and thus incapable of being a basis for conviction, under the law of the custodial State.

\footnotetext{
${ }^{23}$ Albin ESER, "Common Goals and Different Ways in International Criminal Law: Reflections from a European Perspective”, HILJ 31 (1990), p. 120, 125; see also e.g. ChristOPHER L. BLAKESLEY / OTTO LAGODNY, "Competing National Laws: Network or Jungle?", in Albin Eser / Otto Lagodny (eds.), Principles and Procedures for a New Transnational Criminal Law, Freiburg: SRCL / Max-Planck-Institut, 1992, p. 66 f.

${ }^{24}$ Transfer of proceedings and vicarious jurisdiction are similar. The main difference is that the former presupposes an explicit request that proceedings be taken over, while the latter consists of a "fiction" that "in the end 'translates' a request to extradite into a request to take over criminal proceedings": RICHARD van Elst / Harmen van DER Wilt, "Netherlands", RIDP 79 (2008), p. 353; see also Marc HenZelin, Le principe de l'universalité en droit pénal international. Droit et obligation pour les états de poursuivre et juger selon le principe de l'université, Basel: Schulthess, 2001, p. 244. This is why the following considerations apply to both.

${ }^{25}$ See JÜRGEN MeYer, "The Vicarious Administration of Justice: An Overlooked Basis of Jurisdiction”, HILJ 31 (1990), p. 116; and again Albin ESER, "Common Goals and Different Ways...”, op. cit., p. 125.

${ }^{26}$ See Art. 11 (1) MT Transfer of Proceedings; and again JÜRgEN MEYER, $i d$.

${ }^{27}$ Stating that vicarious procedures raise "difficult questions, such as identification and interpretation of a foreign State's law", see once again ALBIN ESER, "Common Goals and Different Ways..." op. cit., p. 120. The assertion refers specifically to the assessment as to whether or not the acts are criminalised by the lex loci delicti, but it applies more generally.

${ }^{28}$ See again Art. 11 (1) MT Transfer of Proceedings.
} 


\subsection{Enforcement of foreign sentences}

Things are pointedly different with the execution of foreign sentences. When it comes to enforcing a penalty, extraditing the person to the sentencing (injured) State may not be so paramount anymore. The existence of an enforceable decision presupposes that, to a great extent, the concerns noted above have already been settled: a criminal procedure has been completed and a penalty determined, allowing for other interests - notably social rehabilitation - to be paid greater consideration. ${ }^{29}$ In fact, it may even be fully justified to transfer a convict from the sentencing State, after it has completed the penal procedure, to a State which has no connection whatsoever with the crime, if the latter is the most appropriate place to rehabilitate the person. ${ }^{30}$ Which a fortiori applies to the case where the person is already found in a State other than the injured State - due to an escape or a trial in absentia: $:^{31}$ here, extraditing might be less desirable than executing the foreign sentence.

However, for a foreign sentence to be enforced it is often necessary not only that the convict consents to that, ${ }^{32}$ but also that certain conditions be met which indicate that rehabilitation is more likely to be achieved in the custodial State - notably that the person is a national or a resident of this State, or that due to some other factor this is the best place for him/her to serve the sentence. ${ }^{33}$ If such conditions are not met, then the execution of the foreign sentence is usually dependent on the condition that extradition cannot be granted, ${ }^{34}$ reiterating its prominence among the several cooperation mechanisms.

Moreover, even if the custodial State does have the possibility to enforce the foreign sentence, extradition may still be preferable. Firstly, because although in executing a foreign sentence a State is "bound by the findings as to the facts insofar as they appear from the judgement imposed in the sentencing State", 35 it might still have to review it in order to render it compatible with its legal system. ${ }^{36}$ For instance, it is difficult to conceive that a State which does not apply life imprisonment would have such a penalty executed in its prison facilities on behalf of another State; or even that a State where the maximum penalty is 30 years of imprisonment would execute a penalty of 40 years. Secondly, because the concrete terms of the enforcement (e.g. the rules on early release) are governed by the

${ }^{29}$ See UNODC, Handbook on the International Transfer of Sentenced Persons, Vienna, 2012, p. 9 f.; and further infra, Chap. 3, \ 4.2.2., Chap. 4, \2.4.4.a)(i), Chap. 6, \4.1., and, especially, Chap. 8, \ 3.4.1.

30 As results clearly from Art. 1 MA Transfer of Prisoners.

31 There is no model treaty on the execution of foreign sentences. However, this form of cooperation is very similar to the transfer of prisoners (the only noteworthy difference in the latter case the person is originally in the sentencing State, whereas in the former he/she typically is in another jurisdiction), the MA Transfer of Prisoners serves as reference for the execution of foreign sentences.

32 See Arts. 4, 5 (esp.), 7 and 9 MA Transfer of Prisoners. Deviations to this principle do however occur in specific contexts where cooperation has been intensified, notably that of the CoE (see Arts. 2 and 31997 Additional Protocol to the 1983 Convention on the Transfer of Sentenced Persons), and that of the EU (see recitals 4 and 5, and Arts. 4 and 6 [esp.] of FD 2008/909/JHA).

33 See Art. 1 MA Transfer of Prisoners.

${ }^{34}$ As the MA Transfer of Prisoners does not cover execution of sentences in cases where the person is in a State other than the sentencing State, this condition is not to be found there; but see e.g. Art. 96 (3) PT-L.

35 Art. 17 MA Transfer of Prisoners.

36 See Arts. 14 f. MA Transfer of Prisoners. 
law of the executing State, ${ }^{37}$ which again increases the chances of a partial spoiling of the punitive interests of the injured State and raises proportionality and equality issues similar to those mentioned before regarding vicarious proceedings. ${ }^{38}$ In sum, in executing a foreign sentence much of the justice passed by the sentencing State can also be lost.

\subsection{The perspective of the custodial State}

It can be assumed that, in principle, the custodial State also prefers extraditing rather than conducting a criminal procedure or enforcing a penalty in the name of another State. Through extradition a State simply assists another in punishing a crime, whereas all the alternative mechanisms discussed above require a State to somehow deploy its own punitive apparatus, and as such they are considerably more cumbersome and costly. This pragmatic factor cannot be plainly overlooked, ${ }^{39}$ and in fact it may help to explain why, as noted before, such alternatives tend to be reserved to cases where there is a link (nationality, residence) between the person and the cooperating State, and why in the absence of such a link they can only be used if extradition cannot be granted. ${ }^{40}$

This line of reasoning was followed in the context of the already mentioned Aranyosi \& Căldăraru case, concerning the EAW. In his Opinion on this case, AG Bot held that the legal systems of the Member States rely essentially on the principle of territoriality, and that, even considering the duty of solidarity prescribed in Art. 4 (3) TEU, a Member State that has custody of a suspect but no jurisdictional link to the crime should not be burdened with the "difficulties and disproportionate means" typical of criminal proceedings carried out on behalf of other States. ${ }^{41}$

\subsection{Standing trial by video-link}

\subsubsection{State of affairs}

A trend is emerging which consists of allowing for the remote hearing of defendants instead of their physical presence in trial. Examples can be found in the context of cooperation with international criminal tribunals, and in the 2017 cooperation agreement between the Netherlands and Ukraine regarding crimes connected to the downing of Ma-

${ }^{37}$ See Art. 21 MA Transfer of Prisoners; see furthermore its Art. 22, conferring upon the administering State the competence to grant pardon and amnesty.

38 See Zsuzsanna Deen-Racsmány / Rob Blekxtoon, "The Decline of the Nationality Exception in European Extradition? The Impact of the Regulation of (Non-)Surrender of Nationals and Dual Criminality under the European Arrest Warrant', EJCCL \& CJ 13 (2005), p. 357, giving account of the frustration of the USA with the conversion by the Netherlands of sentences concerning Dutch nationals extradited to the USA for prosecution and returned to the Netherlands for enforcement.

39 As on occasion is even explicitly admitted by judicial entities, such as the Portuguese Supreme Court, in a ruling of 23 June 2010, no. 2113/09.4YRLSB.S1. On this issue, albeit from a somewhat different angle and with specific regard to EU cooperation, see EsTELLA BAKER, "What Price Criminal Justice in the EU?", EJCCL\&CJ 24 (2016), p. 95 f., and JANNEMIEKE OUWERKERK, “All 'bout the Money? On the Division of Costs in the Context of EU Criminal Justice Cooperation and the Potential Impact on the Safeguarding of EU Defence Rights", EJCCL\&CJ 25 (2017), p. 1 f.

40 See Art. 7 (a) MT Transfer of Proceedings and Art. 1 (1) MA Transfer of Prisoners.

41 Opinion of AG Yves Bot, 3 March 2016, JS 50, 58, $125 \mathrm{f}$. 
laysia Airlines flight MH17. ${ }^{42}$ These examples concern either international crimes or very high-profile politically significant crimes, tried by international judicial entities located in territories other than that where the acts at issue were committed, ${ }^{43}$ which makes it particularly serviceable to admit attendance of trial by video-link.

Even so, this is never considered ideal. The agreement between the Netherlands and Ukraine prescribes forthrightly the primacy of extradition over 'attendance' by videolink: "An accused person who is present in the territory of Ukraine and whose extradition to the Kingdom of the Netherlands has been refused, may stand trial in the Kingdom of the Netherlands via a videoconference link". ${ }^{44}$ In the ICC, attendance by video-link is possible only during part(s) of the trial, and subject to a case-by-case approval by the Trial Chamber. ${ }^{45}$ In the ICTY, such a possibility also requires a specific order by the Judge or Chamber attesting that it is not detrimental to the interests of justice. ${ }^{46}$ Similarly, in the Special Tribunal for Lebanon, use of video-link requires authorisation by the pre-trial Judge or the Trial Chamber, and that the counsel of the defendant attends the hearing in person. ${ }^{47}$

The use of video-link in international courts has reportedly been admitted "very sparingly", owing largely to the fact that its requirements are difficult to meet, and that other reasonable options, such as postponing the hearing, must first be exhausted. ${ }^{48}$ In terms of their typology, cases where video-link has been admitted include cases where the defendant would even be willing to undergo a pure in absentia trial (in which circumstances digital attendance presents itself as the lesser of two evils), and cases where the defendant would

42 Video-link is available in the EU in the context of other forms of cooperation in criminal matters, viz: supervision of measures (see Art. 19 (4) FD 2009/829), and supervision of probation measures and alternative sanctions (see Art. 17 (4) FD 2008/947), which are addressed again later, Chap. 8, \5.1.1.b).

${ }^{43}$ Strictly speaking, the MH17 case is running in the Netherlands: yet, it can hardly be considered a 'national' trial: the UN Security Council intervened in this case, having issued Resolution 2166 (2014), where it demanded that those responsible for this incident be held accountable, and that all States cooperate fully to that end; thereafter, Australia, Belgium, Malaysia, the Netherlands and Ukraine set up a joint investigation team to run this "international criminal investigation" (emphasis added), and agreed that it was in the interests of proper administration of justice to concentrate the proceedings in the Netherlands: see the Preamble of the Agreement between the Kingdom of the Netherlands and Ukraine on International Legal Cooperation regarding Crimes connected with the Downing of Malaysia Airlines Flight MH17 on 17 July 2014, signed in Tallinn on 7 July 2017, further informing that Ukraine also signed a cooperation agreement with Eurojust in Brussels on 27 June 2016 and an operational and strategic cooperation agreement with the European Police Office in The Hague on 14 December 2016. In fact, efforts were made to create an actual international court to try this case, but this option has reportedly been blocked by Russia: see TOBY STERLING, "Trials over downing of flight MH17 to be held in Netherlands", 5 July 2017, in www.reuters.com.

44 See Art. 8 MH17 Agreement between the Netherlands and Ukraine (emphasis added).

45 See Art. 134 bis ICC Rules of Procedure and Evidence.

46 See Art. 81 bis ICTY Rules of Procedure and Evidence.

47 See Art. 105 STL Rules of Procedure and Evidence. This legal instrument does provide that proceedings "shall not be in absentia if an accused appears before the Tribunal (...) by video-conference" (Art. 104, as amended in 30 October 2009 and 20 February 2013); however, the STL Draft Agreement on Legal Assistance denotes the priority of extradition over 'attendance' by video-link when it establishes that the State where the defendant is found shall enable attendance by video-link only where surrender to the Tribunal is impossible on constitutional grounds (Art. 22).

48 Gideon Boas / James L. Bischoff / Natalie L. Reid / B. Don TAYlor III, International Criminal Law Practitioner Library Series III: International Criminal Procedure, Cambridge: University Press, 2011, p. 273 f., also for what follows in this paragraph. 
be unwilling to waive his/her right to be physically present at trial, but where insisting on his/her physical presence would disrupt the trial or otherwise impair its celerity to an intolerable extent (considering e.g. the interests of other defendants).

Regarding international instruments on mutual legal assistance applicable to ordinary crimes, the hearing of defendants by video-link is even rarer. It is provided for in e.g. the 2000 EU Convention, ${ }^{49}$ and the 2001 Second Additional Protocol to the $1978 \mathrm{CoE}$ Convention, ${ }^{50}$ but again rather cagily, notably because the consent of the person concerned is required. Even the hearing by video-link of witnesses and experts - which is more readily acceptable than that of defendants ${ }^{51}$ (although it does also meddle with the principle audi alteram partem, as well as with the principles of orality and immediacy) $)^{52}-$ is subordinated to the condition that it is not desirable or possible for such subjects to attend in person.

At the national level, both States assessed later in this study can be said to be quite reluctant towards the use of video-link in procedural acts of evidentiary relevance. In Portugal, this is possible with regard to experts and witnesses, but not to defendants, at least in the phase of trial. ${ }^{53}$ In the UK the scenario is similar, except with regard to vulnerable defendants, who under certain conditions can be heard by video-link. ${ }^{54}$

\subsubsection{Appraisal}

It is very doubtful that the physical presence of defendants in trial should be meaningfully relinquished in favour of a 'presence' mediated by technological means. The view that defendants should attend their trials in person continues to reign supreme in many or indeed in most countries. It constitutes a human right and is instrumental to the effective exercise of several other basic defence rights. ${ }^{55}$ Moreover, it materialises the idea that the value of testimonial evidence "lies not only in what is said, but also in how it is said", such that it will be all the more reliable the closer is the "relation of communicational proximity" established between the judge and the deponents. ${ }^{56}$ In civil law systems this notion is

49 Art. 10.

50 Art. 9 (esp. $\iint 8$ and 9).

${ }^{51}$ See UNODC, "Manual on Mutual Legal Assistance and Extradition”, Vienna, 2012, p. 83 f.

52 On these principles, see shortly infra, $\ 3.6 .2$.

53 See notably Arts. 96, 158 (1) (b), 317 (1), 328-A, 332-334, 343, 350 (3), 355-357, and 360-361 Code of Criminal Procedure, Art. 145 (3) PT-L, Art. 5 Law no. 93/99 of 14 July, on the protection of witnesses; see also the Ruling of the Court of Appeal of Coimbra of 14 May 2014, no. 1721/11.8PBCBR-A.C1.

54 See notably ss. 51 f. and 116 Criminal Justice Act 2003, ss. 16(1), 17(1), 24, 27, and 33A Youth Justice and Criminal Evidence Act 1999. Thereon, see JoHn R. SPEnCER, Hearsay Evidence in Criminal Proceedings, Oxford: Hart, 2008, p. 105 f., 203, 219.

55 See Stefan Trechsel, Human Rights in Criminal Proceedings, Oxford: University Press, 2006, p. 252 f., $128 \mathrm{f}$., stating that this right has a "double function": it at once "enables the defendant to control the fairness of the proceedings in person", and secures the "effective implementation of the right to a public trial".

${ }^{56}$ Maria Joño Antunes, Direito Processual Penal, Coimbra: Almedina, 2017, p. 178. STEFAn TreCHSEL, op. cit., p. 253 also stresses that participation "is not only necessary for the purposes of the defence", but also "gives the court an opportunity to get a personal impression of the defendant". For an "ethnomethodological" analysis of the principle of orality, see THOMAS SCHEFFER / KATI HANNKEN-ILLJES / ALEXANDER KozIN, Criminal Defence and Procedure: Comparative Ethnographies in the United Kingdom, Germany, and the United States, Basingstoke: Palgrave Macmillan, 2010, p. 50 f., drawing inter alia on Luhmann's concepts of criminal procedure as a "meaning producing, self-referential frame", and of "legitimation by procedure": "In legal 
at the core of the principles of orality and immediacy, ${ }^{57}$ and in common law systems at the core of the prohibition of hearsay evidence and other exclusionary rules adjacent to it. ${ }^{58}$

Not that such principles are absolute or unrestricted. Trials in absentia are admissible in many legal systems, even if under demanding conditions and followed by such intense guarantees as the possibility of a retrial or at least of an appeal whereby the ad quem court has ample powers of cognition enabling it to reassess most of the evidence already produced. Moreover, some evidence produced before or outside of the trial hearing is often admitted, even if again under rather stern conditions. Finally, even if none of the above 'deviations' occurs, it would still be oversimplifying to assume that criminal proceedings (especially in inquisitorial systems) are conducted in fully immediate and oral terms: many evidentiary elements are assessed by the judges beforehand, or merely replicated at the hearing in order to secure formal compliance with the principles of orality and immediacy. ${ }^{59}$ On the other hand, in the light of these principles, a digital presence in trial is better than no presence at all. It is, as said, the lesser of two evils. ${ }^{60}$

procedures, according to Luhmann, 'every communication, even the unintended presentation that contributes to the proceeding, counts as information that opens, thickens and excludes opportunities that define the acting persons and their relevant history and reduces their options to decide. Every contribution enters the case and can be reinterpreted but not neglected' (...). 'Legitimization by procedure' means that the contestants can hardly gather solidarity against a verdict that derives from their own voluntary contributions". See also MARK KLAmberg, Evidence in International Criminal Trials: Confronting Legal Gaps and the Reconstruction of Disputed Events, Leiden: Martinus Nijhoff, 2013, p. 343, 363, offering examples of several legal systems where judgements can only be based on what has been said and debated in trial, and stating that "the ECtHR has expressed a clear preference in favour of direct and live testimony tested by cross-examination"; and again STEFAN TRECHSEL, op. cit., p. 305, mobilising profuse case law from Strasbourg amounting to a "standard reminder" that evidence should be examined at the trial, and reiterating: "It is of paramount importance. Here lies the nucleus of (...) the principle of immediacy." Nevertheless, as noted by STEFANO Ruggieri, Audi Alteram Partem in Criminal Proceedings: Towards a Participatory Understanding of Criminal Justice in Europe and Latin America, Cham: Springer, 2017, p. 325 f., the ECtHR has allowed defendants to follow the deposition of witnesses by video-link with the further possibility of raising questions (e.g. in A.S. v. Finland, 28 September 2010, no. 40156/07); in any case, the goal here was to protect vulnerable witnesses: allowing defendants to follow and react to their testimonies by video-link protects these witnesses whilst avoiding the complete relinquishment of the right of defendants to contradict them (audi alteram partem), which ultimately leads the author to praise the stance adopted by the Court: see ibid.

${ }^{57}$ See again the previous fn.

${ }^{58}$ See JoHn R. SPEnCER, Hearsay Evidence... op. cit., p. 22 f., passim, using also the expressions "directness principle" and "best evidence approach", elaborating on the historical roots of those principles, and assessing the differences between the civil and the common law approaches.

${ }^{59}$ See Stefan Trechsel, op. cit., p. 224 f.: "In the continental system with its inquisitorial preliminary phase, the investigation produces a file which will be an important element at the trial (...). We must keep in mind that that hearing itself does not always, and not to the extent which is essential to the common-law system, follow the rule which is referred to as the 'principle of immediacy' (...). [Said file] contains the transcripts of the interrogations of the defendant and witnesses by the police, the investigating authority, or the public prosecutor's office, expert opinions, [etc.]. The judges are familiar with all that material. The judgment will then be based on the contents of the file and the (repeated or complementary) evidence gathered during the hearing." Which incidentally is why, in such systems, having "advanced knowledge of the file is of essential importance for the defence".

${ }^{60}$ An alternative which offers more immediacy than digital presence, but also many disadvantages is for the trial judge to travel to the place where the defendant is located and conduct a hearing there. 
However, it is fated to be worse than physical presence. It is, so to speak, halfway between physical presence and pure absence. Therefore, while there are no objections to promoting the use of this method where physical presence is impossible or in other specific situations, it appears manifestly extravagant to argue that it is capable of replacing physical presence, at least for the time being and the foreseeable future.

A topic worthy of reflection is that of the evidentiary value of statements made by the defendant through video-link: should they have the same value as statements made in person? Since evidence produced in praesentia is more reliable, and the 'legitimacy ${ }^{91}$ of a conviction passed in such conditions consequently higher, it is sensible to credit less evidentiary weight to statements made through a video-link. ${ }^{62}$ Thus, even leaving on the side issues related to the enforcement of the penalty, ${ }^{63}$ it seems safe to conclude that extradition remains indispensable in spite of these technological and legal developments.

\subsection{Conclusion}

In synthesis, the primacy of extradition in relation to other forms of cooperation is in the interest of both the injured State and the custodial State. Hence, the progress of international cooperation in criminal matters should continue to consist largely of "perfecting and making general the practice of extradition". ${ }^{4}$ This also means that extradition will tend to be the benchmark of flexibility that can be aimed at in the field of cooperation, in the sense that, if it is the mechanism that deserves priority, then it will in principle also be the most flexible one (that is, the least difficult to grant) in terms of its substantive conditions. ${ }^{65}$

\section{Why States need to extradite}

The previous paragraphs sought to establish that States have an interest in obtaining extradition, and that - assuming that they are willing to cooperate - they will in principle prefer to extradite rather than to try a person or to enforce a sentence themselves. However, none of the elements assessed above entails that States have an interest in $e x$ traditing. Such an interest must be sought in a different set of considerations, namely the following. ${ }^{66}$

${ }^{61}$ In the very sense that the term bears in the construction of Niklas Luhmann: see supra, fn. 56.

${ }^{62}$ Namely by requiring the court - in the words of JOHN R. SPENCER, Hearsay Evidence... op. cit., p. 23, on the value of hearsay evidence in the German legal system - to handle such evidence "with caution", and to ensure that it is "corroborated by other evidence of a more reliable type".

${ }^{63}$ If the enforcement of a penalty of imprisonment cannot or should not be effected in the State where the person is found, extradition will at this point still be necessary, and in any case it is in line of principle preferable, in the terms mentioned supra, $₫ 3.4$.

${ }^{64}$ Charles K. Burdick (rep.), “Harvard Research...” op. cit., p. 39; also NeIL BOISTER, op. cit., p. 307 f.

${ }^{65}$ Naturally, this does not apply to the conditions that are by definition met in other forms of cooperation. For instance, in the transfer of proceedings there is no room for the custodial State to assess such factors as the due process standards of the other State, as it will itself be carrying out the criminal procedure.

${ }^{66}$ Drawn largely from the explanation provided in CHARLES K. BuRDICK (rep.), "Harvard Research..." op. cit., p. 32 f., with ulterior references. 


\subsection{Avoiding the settling of criminals (the 'safe haven' argument)?}

One argument is that it is highly inconvenient for States to allow for the settling of criminals in their territories. This well-established argument was articulated by Piggot in the following terms: "it is to the interest of the State into whose territory the criminal has come that he shall not remain at large therein, inasmuch as from his past conduct it may reasonably be anticipated that, if opportunity offers, he will again be guilty of crime. No State can desire that its territory should become a place of refuge for the malefactors of other countries. It is obviously its interest to get rid of them." ${ }^{\prime 67}$

This line of reasoning is hardly reconcilable with the principle of presumption of innocence: as pointed out by Caeiro, in the moment of taking a decision whether or not to extradite a person, this person may not have been convicted of the acts being imputed to $\mathrm{him} / \mathrm{her} ;{ }^{68}$ and, even if he/she has, such a sentence, as noted above, is generally not automatically valid in the custodial State. The settling of criminals may be countered through measures other than extradition, namely deportation or expulsion, and through immigration law more generally. These are the proper areas of the law to address such concerns.

Thus, however relevant the 'safe haven argument' may be at the political level, and without denying that it may have legitimate repercussions at the legal one, in the context of extradition it should be taken with strong reservations. Sight cannot be lost of the fact that the person in question may be innocent.

\subsection{Solidarity towards other States (the 'moral' argument)?}

Another argument is that there is a moral duty to extradite, a responsibility incumbent upon States to help each other tackle their local criminality. This doctrine arose in the $19^{\text {th }}$ century and is visible in the writings of several French authors of that period, such as Villefort, who separated modern extradition from earlier practices based fundamentally on the idea that the latter lacked an element of "moral solidarity". ${ }^{9}$ "

Although this view is consistent with the expansion (verified in that period) of extradition from political to common criminality, and with its consequent transformation into a mechanism of general use, the fact is that such a view has never acquired a legally binding character. As early as in 1917, Hall was writing that such an argument "goes too far": "It implies that international law commands human beings to combine for the repression of everything which is grossly injurious to the bases of social life. This evidently it does not do; and as a matter of fact (...) states have been far from acknowledging a duty of giving up criminals." 70

${ }^{67}$ Francis TAylor Piggot, Extradition - A treatise on the law relating to fugitive offenders, London: Butterworth \& Co., 1910, p. 16.

${ }^{68}$ See Pedro Caeiro, Fundamento, Conteúdo e Limites da Jurisdição Penal do Estado. O Caso Português, Coimbra: Coimbra Editora / Wolters Kluwer, 2010, p. 333 f., 342.

${ }^{69}$ Alfred Villefort, Des Traités d'extradition de la France avec les pays étrangers, Paris: A. Guyot et Scribe, 1851, p. 5, echoed in e.g. ALBERT BILlot, op. cit., p. 37, and FERNAND DE CARDAILLAC, De l'Extradition: Droit International, Tarbes: Émile Croharé, 1878, p. 5.

${ }^{70}$ William EDWARd Hall, op. cit., p. $58 \mathrm{f}$. 
In reality, to this date no duty to extradite has developed in international law as far as ordinary crimes are concerned, and some States do not even extradite in the absence of a treaty ${ }^{71}$ (although the concept of 'treaty' has been subject to some concessions for the purposes of extradition). Such a duty has been established only with regard to core international crimes, ${ }^{72}$ but, as far as these crimes are concerned, the idea of a moral imperative to prosecute is not even an idiosyncrasy of the late modern era. It was already advocated, long before that, by such authors as Grotius. ${ }^{73}$

The moral solidarity argument used by many of those French authors in fact seems to have played essentially the role of a theoretical coating for practical necessities brought about by the industrial age. ${ }^{74}$ It is not disputed that the rise in communication and mobility verified in that period may have been a seed for further solidarity among States. It does however seem that it was quite premature to construe it as a leading cause of the normative development of extradition effected in that very period, considering that a centuries-old status quo was being shaken by immediately impactful practical problems. In fact, even at present, with remarkably higher levels of communication and mobility, States remain fairly indifferent towards the idiosyncratic criminal justice concerns of oth-

${ }^{71}$ E.g. the UK: see infra, Chap. 6, S 7.2.c); and the Netherlands: see Arts. 2 (3) Constitution, Arts. 2 and 51a Extradition Act of 9 March 1967, and, thereon, BERT SwART, "Extradition", in Bert Swart / André Klip (eds.), International Criminal Law in the Netherlands, Freiburg: Edition Iuscrim, 1997, p. 93 f.; on the 'treaty requirement' see further infra, Chap. $8, \$ 2.2$.

72 Which to most authors carry a duty to either extradite or try (aut dedere aut judicare): see e.g. M. CHERIF BASsiounI, "International Crimes: jus cogens and obligatio erga omnes", L\&CP 59 (1996), p. 65 f.; LUIGI CONDORELLI, "Le Tribunal Pénal International pour l'ex-Yougoslavie et sa jurisprudence”, CEBDI 1 (1997), p. 251 f.; ANTONIO CASSESE, International Criminal Law, $2^{\text {nd }}$ ed., Oxford: University Press, 2008, p. 302 f.; OLIVIA SWAAK-GOLDMAN, "Recent Developments in International Criminal Law: Trying to Stay Afloat Between Scylla and Charybdis", I\&CLQ 54 (2005), p. 698; ROBERT CRYER, "Sudan, Resolution 1593, and International Criminal Justice”, LJIL 19 (2006), p. 219. But cf. Michael Plachta, “Aut Dedere Aut Judicare: An Overview of Modes of Implementation and Approaches", MJE 6 CL 6 (1999), p. $333 \mathrm{f}$. See yet the thorough reviews of M. Cherif BAssiouni / EDWARD M. Wise, Aut Dedere Aut Judicare: The Duty to Extradite or Prosecute in International Law, Dordrecht: Kluwer, 1995, p. 51 f., EDWARD M. WISE, "The Obligation to Extradite or Prosecute”, ILR 27 (1993), p. 280 f.; Claire MitChell, Aut Dedere, aut Judicare: The Extradite or Prosecute Clause in International Law, Genève: eCahiers de l'Institute, 2009, \$S 66 f. In case law, see notably - although by reference to a convention (the UNCAT), rather to general international law -, ICJ, Habré, 20 July 2012.

${ }^{73}$ Hugonis Grotil, De Jure Belli ac Pacis, Washington D.C.: Carnegie Institution, 1913, p. 365 f.; and before him probably by Baldo degli Ubaldi (in the $14^{\text {th }}$ century), as well as by Diego de Covarrubias y Leyva, Jean Bodin and Charles Dumoulin (in the 16 $6^{\text {th }}$ century): see M. CHERIF BAssiouni / EdwARD M. WisE, op. cit., p. 38, and Christine van Den Wyngaert, The Political Offence Exception: The Delicate Problem of Balancing the Rights of the Individual and the International Public Order, Deventer: Kluwer, 1980, p. 7.

74 This is implicit in the reasoning e.g. of Billot, that: "Nations no longer live in isolation as in preceding centuries. In result of the progress of civilisation and industry, such intimate relations have been established between them that nothing that happens in one of them is indifferent to the others. (...) It is of a general interest that impunity is not guaranteed to the culprit, and that the law triumphs everywhere: disorder and crime are contagious": Albert Billot, op. cit., p. 11 f. (emphasis added). Or of Fiore, to whom: "It is an almost universally accepted opinion in our era that mutual surrender of malefactors is something which is to the interest of the various states. (...) We should regard it not as being established to the advantage of any particular state, or motivated exclusively by considerations of reciprocal utility, or by the dead letter of the conventions deriving from the treaties, but rather as a wider application of the principle of penal justice": Pasquale Fiore, Traité de Droit Pénal International et de l'Extradition, Vol. II, Paris: A. Durand et PedoneLauriel Éditeurs, 1880, p. 453, 462 (emphasis added). 
er States. ${ }^{75}$ In sum, the 'moral solidarity' argument holds value as an ideal to be pursued in the regulation of this area of the law, but it lacks substance in actual law and practice.

\subsection{Reciprocity (the 'self-interest' argument)}

The decisive element propelling States to extradite is the reciprocity scheme underpinning international relations: States need to extradite if they wish to obtain extradition from other States in similar conditions in the future. In his 'rationalist' construction of international institutions, Keohane classifies reciprocity as one of the "principal guarantors of compliance with commitments", and divides it into two essential dimensions, namely "threats of retaliation" and "promises of reciprocal cooperation". ${ }^{76}$ It is primarily the latter that is manifesting itself here: States assuredly have an interest in extraditing because they have an interest in obtaining extradition.

\subsection{Conclusion}

In conclusion, the main force driving extradition relations among States is an interest in upholding their own penal systems. This interest manifests itself in a direct manner when a State requests extradition from another State, and in an indirect or forward-looking one when a State grants extradition to another State, but it manifests itself in both instances.

\section{The concept of ground for refusal}

\subsection{Basic definition}

If States have an interest in extraditing, then the norms which establish grounds for refusal of extradition cannot be conceived but as embodiments of other interests which conflict with, and supersede - or at least are deemed to supersede - the interest in ensuring the efficacy of national penal systems established in the former paragraphs. This definition carries the scope of this study to be delimited in the following terms.

\subsection{Grounds for refusal related to mere issues of interstate allocation of ju- risdiction}

\subsubsection{General considerations}

Some norms establishing grounds for refusal of extradition do not embody any interest which conflicts with the driving interest in upholding national penal systems, and which therefore do not meet the definition provided above. That is the case where: (1) a criminal procedure is pending in the requested State concerning the same acts for which extradition is requested, or this State has jurisdiction to initiate one such procedure; or (2) the crime was committed (in whole or in part) in the territory of the requested State. The

${ }^{75}$ See infra, Chap. 7, esp. \3.2. f.

${ }^{76}$ Robert O. Keohane, Power and Governance in a Partially Globalized World, London: Routledge, 2002, p. 3 and $27 \mathrm{f}$. The other 'principal guarantor of compliance' is reputation - an aspect that is also considered in this study in a different context: infra, Chap. 2, \$2.2.1.a)(ii). 
latter situation would already fall within the former, as States can generally prosecute any crime committed in their territory, ${ }^{77}$ but it is often provided for as an independent ground for refusal, because territorial jurisdiction raises a specific set of considerations.

Common to both of those situations - and absent in other grounds for refusal - is the circumstance that the offence in question injured not only the requesting State but also the requested State, given the existence of a jurisdictional link (territoriality, nationality of the victim and/or of the offender, etc.) between such an offence and its legal system. In such cases, the requested State too has a punitive interest which emerged with the perpetration of the crime, and which therefore precedes and is independent from any extradition request. ${ }^{78}$ This means that, although those situations are formally contained in norms establishing grounds for refusal of extradition, they do not translate any interest which conflicts with the goal of enforcing national criminal laws. Quite on the contrary, in such situations the requested and the requesting States both have an interest in punishing the offence; they co-hold this interest. A positive conflict of jurisdiction takes place, and impunity is not a possibility. The only point of contention is which of the two States should carry out the prosecution or enforcement. This requires the custodial State to take a specific decision on whether to extradite the person or to try him/her itself. ${ }^{79}$

In sum, substantially these situations do not constitute grounds for refusal of extradition, but mere clauses of allocation of jurisdiction. For that reason, they receive limited consideration in this study, where the focus is placed on situations which do conflict with the interest in avoiding impunity.

\subsubsection{Specific considerations on international crimes}

The foregoing also causes this study to be much more focused on common than on international criminality. Like common crimes, international crimes will in each specific case impact more directly on a given State or group of States: on the one(s) where the crimes were committed, of which the victims or perpetrators are nationals, etc. However, unlike what happens with ordinary crimes, the prevention and punishment of international crimes is a matter of shared interest and responsibility of the community of States as a whole (as far as core international crimes are concerned), or of a significant group of States (as far as concerns acts which do not constitute crimes under general international law but which are established in widely ratified multilateral conventions). Such crimes are subject to universal jurisdiction, which means that any State where the deemed perpetra-

\footnotetext{
77 True, the acts might not be criminalised in the requested State, and still the territoriality ground for refusal may apply, as a pure assertion of sovereignty. This aspect is addressed in this study, though not in the context of this ground for refusal (which in any case is further assessed infra, Chap. 6, $\$$ 6.1., and Chap. 8, $\$$ 3.6.1.): rather, in that of the dual criminality rule (infra, Chap. 6, \ 2.1., and esp. Chap. 8, \4.1.1.).

78 Although it is not entirely indifferent that extradition be requested, as some bases for jurisdiction can only be exerted if extradition is unavailable, and, thus, if a State does request extradition and no other ground for refusal is met, the grounds for refusal under consideration will not be applicable: see the following fn.

79 This decision, which is the only instance where States have an actual option - i.e. a decision the result of which is not predetermined by the law - between extraditing and trying (dedere aut judicare stricto sensu), is the core object of my previous research: Miguel Joño CostA, Dedere Aut Judicare? A decisão de extraditar on julgar à luz do direito português, europeu e internacional, Coimbra: IJ, 2014.
} 
tor is located has an immediate prerogative to prosecute him $/$ her, ${ }^{80}$ and, thus, that in theory impunity be out of the question. ${ }^{81}$ Insofar as concerns actual grounds for refusal of extradition - rather than the 'clauses of allocation of jurisdiction' in debate here -, there is nothing preventing the views upheld in this study from applying also to international crimes, with some specificities which will be identified at the appropriate moment. ${ }^{82}$

\subsection{Grounds for refusal that entail impunity}

It was noted above that there are forms of cooperation other than extradition which allow the custodial State to punish offences that have no link to its legal system, and it was argued that, although such alternatives do to an extent compensate the injured State for having been prevented from passing its own justice on the case, extradition should as a rule take priority. ${ }^{83}$

It is not, however, simply a matter of priority. In many cases, refusal of extradition still entails impunity, because some circumstances concomitantly prevent extradition and any form of punishment by the custodial State. The most apparent example of this is the case where the acts are not criminalised in the requested State: this State will often refuse extradition based on the classic rule of dual criminality, and it will be unable to deploy its own punitive apparatus on behalf of the unsatisfied requesting State, due to its principle of legality of substantive criminal law. This produces a scenario whereby the requested State can neither extradite nor punish the person, which can be labelled as a 'nec dedere nec judicare' scenario - the precise reverse of the ideal of ubiquitous criminal justice expressed in Grotius' aphorism 'aut dedere aut judicare. ${ }^{84}$ Since unwarranted punitive gaps constitute a key concern in this study, particular attention will be paid to these grounds for refusal.

\subsection{Other concepts}

The scope of the study is further delimited or informed by other concepts and conceptual options which are described and justified in the following paragraphs.

\subsubsection{Extradition and surrender}

Firstly, the central focus of this study is extradition proper, viz. the transfer of persons between States which are not necessarily linked by ties of political, legal, cultural or

80 See Pedro Caeiro, Fundamento... op. cit., p. 239 f., 385 f.; Cedric RYNGAERT, Jurisdiction in International Law. United States and European Perspectives, Leuven: Katholieke Universiteit, 2007, p. 131; M. CHERIF Bassiouni, “The 'Indirect Enforcement System'...” op. cit., p. 491.

${ }^{81}$ But see further infra, Chap. 7, $\left.\int 1.1 .1 . b\right)$.

82 See mainly infra, Chap. 7, $\int 1.3$.

83 See supra, $\int 3$.

84 The expression 'nec nedere nec judicare' is still directly inspired in HuGO GroTIUS, op. cit., p. 368, where the author, in accounting that the Eleans declared war on the Lacaedemonians because the latter had neither surrendered nor punished certain criminals who had inflicted severe injury upon Elis, uses the formula "nec animadverterent nec reos dederent". An effort to identify the cases where such a scenario occurs was effected in Miguel Joño Costa, Dedere Aut Judicare?... op. cit., p. $69 \mathrm{f}$. The circumstance that in certain cases the exercise of jus puniendi by the custodial State is precluded means that the scope of vicarious jurisdiction is not, in reality, each and every case where 'extradition is requested and cannot be granted'. 
historical affinity (hereafter referred to as 'unrelated States' or a similar expression). Over the past decades extradition arrangements between certain groups of States that are connected to each other by ties of that nature have been reviewed with a view to making extradition simpler and more flexible. This carried the emergence of a new term aimed at distinguishing those arrangements from traditional extradition, namely 'surrender', the ultimate specimen of which is the European Arrest Warrant.

The EAW is a concretisation (the first in criminal matters) of the principle of mutual recognition of judicial decisions among EU Member States, and departs from certain classic principles of international cooperation. Ample research has been conducted and literature produced on mutual recognition and the EAW. The swiftness of the instrument was welcomed, but the erosion of traditional principles that made it possible was met with substantial criticism. At present, the $\mathrm{EU}$ is promoting harmonisation of procedural rights so as to "improve the balance" " 85 that had been disturbed by the many measures adopted with the aim of "making it easier to fight crime" ${ }^{86}$ However, this approach does not consist of restoring the grounds for refusal that had been departed from, but of compensating such an erosion with new individual guarantees.

Meanwhile, classic extradition, the mechanism applicable in most interstate relations, has remained relatively unchanged, suggesting that such reform endeavours are only conceivable between specific States linked by specific ties. This study challenges this notion, and to that end it devotes attention, among other elements, to mechanisms that fall within the conceptual setting of mutual recognition (particularly the EAW), taking them as a reference for a possible reform of classic extradition. In so doing, the study should also shed new light on these very mechanisms, establishing a dialogue between classic cooperation and mutual recognition, between extradition and surrender. ${ }^{87}$

\subsubsection{Extradition and rendition (within federal States)}

Rendition between States of a federation is not considered in this study. While cooperation within federal States is fruitful in reflections about cooperation between legally and politically integrated sovereign States, such as EU Member States, the extreme level of integration binding federated States confers on their cooperation paradigm very narrow potential for informing cooperation between States which might be entirely unaffiliated.

\subsubsection{Voluntary and mandatory grounds for refusal}

Grounds for refusal were initially created by States in their autonomous law-making capacities. As international conventions were concluded and national statutes enacted with a view to developing extradition relations among States and to thereby strengthening their ability to tackle crime, certain interests were nevertheless deemed to be at risk in extradi-

85 "Roadmap for strengthening procedural rights of suspected or accused persons in criminal proceedings, 30 November 2009, esp. \10.

86 "Communication from the Commission making progress on the EU agenda on procedural safeguards for suspects or accused persons and strengthening the foundation of the European area of criminal justice", 27 November 2013, p. 4, presenting this agenda as a "shift of focus" in relation to the previous decade.

${ }^{87}$ In further detail on the role assigned to mutual recognition in this study, see infra, Chap. 2, \ 3. 
tion cases, which caused States to institute reservations to those goals. Such reservations, exceptions, grounds for refusal, obstacles, were included in those legal instruments, and many of them are still standing to this day. More recently, international and other supranational constellations of norms placed additional limits on States' prerogative to extradite. At present, those two sets of grounds for refusal coexist and, in part, overlap. However, for analytical purposes, it is convenient to understand and address them separately.

The first set of grounds for refusal is the product of the voluntary action (or interaction) of a particular and identifiable - however large - number of States, and thus their merits can be called into question. In contrast, the latter is dominated by restrictions arising from human rights and other international and regional norms which express a larger and more solid consensus in the international community as to the limits of State power in this realm, and which therefore apply regardless of the willingness of a particular State to apply them. Consequently, contemplating a reform of such grounds for refusal would not only be senseless, but also - at least regarding human rights - objectionable.

Nevertheless, the second set of grounds for refusal is still relevant for this study, as it is only possible to know which grounds for refusal are voluntary (and therefore open to reform), once those that are mandatory have been determined. By identifying the latter, the study will not only give an account of the 'obstructive' dimension of international norms (particularly of human rights) upon extradition, but also it will be drawing on their 'permissive' function: the fact that certain overriding grounds for refusal have been developed implies that the remaining could be reformed; it suggests that there are no cogent reasons not to reform the latter if they are proving more detrimental than useful to the interests involved in extradition. As Lagodny noted shortly after Soering, ${ }^{88}$ although those 'obstructive' (or, in his words, "negative") effects tend to garner most attention which is both understandable and laudable, considering the importance of human rights ,$-{ }^{89}$ their 'permissive' (or, in his words, "positive") dimension can also prove valuable, in that it points a way for international cooperation to be enhanced, a goal which ultimately also translates into benefits for individuals: "one should ask whether the traditional conditions of extradition (...) are really required by human rights. If they need not be maintained to protect human rights, it would merely be a question of legislative consideration as well as political evaluation and negotiation". 90

\subsubsection{Voluntary and optional grounds for refusal}

The preceding categorisation - separating grounds for refusal imposed upon States ('mandatory') and grounds for refusal adopted by States without any constraints ('volun-

${ }^{88}$ ECtHR, Soering $v$. UK, 7 July 1989. As is widely known in the field, this was the first time that a supranational human rights judicial body declared that human rights can block extradition.

${ }^{89}$ Indeed, from an axiological perspective these also constitute 'positive' effects of human rights upon extradition. This is why terms such as 'constraining' and 'permissive', or 'direct' and 'indirect', seem more adequate for illustrating the dichotomy in question than the terms 'positive' and 'negative'.

90 OTto Lagodny, "Human Rights in the Field of Extradition”, RIDP 62 (1991), p. 50 f. The text dates from 1991, but results from the debates taken place at the International Conference on Extradition held in Syracuse from 4 to 9 December 1989, shortly after Soering indeed. 
tary') - should not be mistaken for the distinction between: on the one hand, grounds for refusal that admit no discretion on the part of the judicial and/or the executive branch of the State when deciding whether to grant or refuse extradition, but rather always require extradition to be refused if the hypothesis provided for in the applicable norm is met (also often labelled as 'mandatory'); and, on the other hand, grounds for refusal that do admit such a discretion ${ }^{91}$ (usually designated as 'optional'). ${ }^{92}$

It is again underscored that, as used in the preceding section, the terms 'mandatory' and 'voluntary' seek instead to signify, respectively, grounds for refusal which have been 'State-generated' and grounds for refusal which came into being irrespectively of a decision on the part of a State or number of States in an autonomous capacity.

\subsubsection{State-oriented grounds for refusal and individual-oriented grounds for refusal}

The categorisation proposed above, separating grounds for refusal imposed upon States from grounds for refusal voluntarily adopted by States, should not be interpreted as a distinction between grounds for refusal protecting essentially individual interests and grounds for refusal protecting essentially State interests.

On the one hand, voluntary grounds for refusal, though originally aimed at protecting State interests, also guard individual interests. In fact, it can be said that each and every ground for refusal of extradition by definition protects both sets of interests concomitantly (albeit in varying proportions): grounds for refusal intended mainly to protect individuals inherently carry an upside for the requested State, because protection of individuals is also a State interest (both in itself and as a 'reputation builder'); similarly, grounds for refusal aimed mainly at protecting States inherently profit individuals targeted by extradition requests, because it is generally in their interest not to be extradited.

On the other hand, mandatory grounds for refusal, including those that derive from human rights, though primarily concerned with individuals, do also accommodate the notion (clearly expressed in the case law of human rights bodies) that extradition currently plays a key role in the prevention of crime, and that, therefore, it should not be hindered unless it is likely to cause serious damage to individual interests.

\subsubsection{Formal and practical conditions}

As noted earlier, extradition requires certain formal conditions which are important for assessing the request on its merits. These include e.g. an indication of the reasons basing the request, of the identity of the person sought and of the acts imputed to him/her; a declaration avowing that the specialty rule will be respected; the arrest warrant issued or the sentence applied (and in the latter case possibly also a document indicating the period of imprisonment remaining to be served); and a copy of the legal provisions applicable in the requesting State concerning statutory limitations of the criminal procedure and, if the person was tried in absentia, concerning the possibilities to appeal this conviction.

\footnotetext{
${ }^{91}$ For instance, the decision either to extradite or prosecute, mentioned supra, $\int 5.2 .1$.

92 This distinction is also widely used throughout this study, particularly in Chap. 6, but it should always be clear from the context in which sense the terms 'mandatory' and 'optional' are being used.
} 
While conditions of this character are certainly worthy of reflection from an angle of rationality of extradition proceedings, they do not block extradition, but only delay the decision. If such conditions are not met in the case, the request will not be ruined, but rather it may still be remedied by amending the faulty elements. Thus, these conditions are paid very limited attention in this study. ${ }^{93}$ The same applies to such practical issues as the 'overburdening, understaffing and underfunding' of national entities competent for processing extradition cases. ${ }^{94}$

\subsubsection{Procedural conditions}

Likewise, the procedural dimension of extradition law, which concerns such issues as the order in which the judicial and the political assessments of the request should take place and the conditions in which unfavourable decisions can be appealed, are not a central concern of this study, and are addressed only insofar as they show capable of informing substantive aspects. Again, this does not imply that procedural aspects are unimportant. On the contrary, the rationalisation of the extradition procedure increases its celerity and reduces the periods spent in deprivation of liberty by the targeted individuals; it unburdens the judicial system of the requested State and fosters the swift delivery of justice by the requesting State.

However, like the formal issues indicated above, procedural issues do not in themselves prevent extradition from being granted, but only influence its celerity. On the other hand, procedural simplification is more a matter of technical and administrative innovation than one of conceptual reform. Finally, a meaningful increase in the celerity of extradition proceedings is hardly conceivable without a reform of substantive conditions, as it is generally the assessment of these conditions that is laborious.

\subsubsection{Legal and political conditions}

Despite the strong legal and judicial dimension acquired over time, extradition remains a very peculiar institution infused with non-legal elements. Political intervention in the field of extradition is a research topic in its own right, related more to political science than to the law. ${ }^{95}$ In extradition systems that reserve some sort of intervention to the executive branch of the State (and most do), virtually any politically relevant factor - such as inimical relations between the requested and requesting States, public opinion within the requesting State, or even sheer economic interests $-{ }^{96}$ can influence decisions on ex-

\footnotetext{
${ }^{93}$ But see infra, Chap. 8, $\int 5.2 .2$.

${ }^{94}$ See M. CHERIF BASSIOUNI, International Extradition... op. cit., p. 58; also UNODC, "Manual on Mutual Legal Assistance and Extradition”, op. cit., p. 29 f.

${ }^{95}$ For approaches of this type, see ETHAN A. NADELMANN, "The Evolution of United States Involvement in the International Rendition of Fugitive Criminals", NYUJIL\&P 25 (1993), p. 813 f.; CHRISTOPHER H. Pyle, Extradition, Politics, and Human Rights, Philadelphia: Temple University Press, 2001; WiLliam Magnuson, “The Domestic Politics of International Extradition”, VJIL 52 (2012), p. 839 f.; AsIF EFRAT, "Resisting cooperation against crime: Britain’s extradition controversy 2003-2015”, IJLCJ 52 (2018), p. 118 f.

${ }^{9}$ See Manuel António Lopes Rocha / Teresa Alves Martins, Cooperação Judiciária Internacional em Matéria Penal: Comentários, Lisboa: Aequitas / Editorial Notícias, 1992, p. 24.
} 
tradition requests. ${ }^{97} \mathrm{On}$ the other hand, it is rather utopian to envisage the removal of political intervention in extradition outside of legally and politically integrated contexts such as the EU or Nordic States. It has not been removed even in some regional cooperation instruments that under certain variables fall within the concept of 'surrender', such as the Mercosur Arrest Warrant. For these reasons, this study focuses in an absolutely predominant manner on legally prescribed grounds for refusal, which are those where extradition is in the abstract deemed impossible to grant, and, thus, those that must be assessed by the competent authorities of the requested State when deciding on any extradition request.

Nevertheless, the political dimension of extradition is simply too relevant to be neglected altogether. Relevant not only at a pragmatic level, but also at the normative one, because there is an interaction between legal norms on extradition and the discretionary activity of the executive in this field, such that the functions assigned to any of them influence those assigned to the other. This means that even an analysis focused solely on the legal dimension of extradition must to some extent consider its political dimension. ${ }^{9}$

\footnotetext{
${ }^{97}$ A parallel theme is that of 'circumventing measures' such as international abduction, and even assassination: thereon see e.g. SAmANTHA K. DraKe, "Dangerous Precedents: Circumventing Extradition to Implement the Death Penalty", STLR 36 (2013), p. 333 f.; BRIgETTE BELTON Homrig, "Abduction as an Alternative to Extradition: A Dangerous Method to Obtain Jurisdiction over Criminal Defendants, WFLR 28 (1993), p. 671 f.; KRISTIN T. LANDIS, “The Seizure of Noriega: A Challenge to the Ker-Frisbie Doctrine”, AUJILP 6 (1991), p. 571 f.; YvonNe G. Grassi, "Federally Sponsored International Kidnapping: An Acceptable Alternative to Extradition?”, WULQ 64 (1986), p. 1205 f.; PAUL O’HIGgINS, “Disguised Extradition: The Soblen Case", MLR 27 (1964), p. $521 \mathrm{f}$.

98 As is essentially done infra, in Chap. 8, $\iint 5$ and 5.4.7.
} 


\section{Chapter 2}

\section{Research Design}

\section{Research question}

The research question of this study was already implied in the statement of its purpose, and it may now - informed by the conceptual specifications provided in the preceding chapter - be concisely formulated: which grounds for refusal of extradition voluntarily enacted by States are necessary to preserve the interests that are at stake in extradition law?

\section{Research methods}

That core question unfolds in a set of sub-questions which are articulated in the following paragraphs, together with an explanation of the methods employed with a view to answering them. The following paragraphs outline these methods in their essential traits. Further specifications are provided on a section-by-section basis, as this was thought to carry the reader more effectively through the different parts of the study and the respective substantial contents.

\subsection{Historical analysis}

As a preliminary step, a review of the history of extradition was carried out, in the conviction that this improves the understanding of this institution as it currently is, and the contemplation of what it might become. The view of Kopelman was followed that " $[t]$ he history of a subject will very often show its growing tendency and is therefore probably the proper method to be employed in proving what remedies or changes are to be made in order to meet the present demands and also, with some degree of certainty, the demands of the near future."

However, it was ultimately deemed unnecessary to provide the reader with an independent section, within the study, on the history of extradition. In its stead, the study mobilises selected historical information in the context of the specific topics regarding which it shows more useful. In any case, and although extradition is an old institution, dating back to at least the $13^{\text {th }}$ century BCE, ${ }^{2}$ this book should provide the reader with a satisfactory picture of the major breakthroughs recorded in its history. For as Pyle notes: "The law of extradition, like most bodies of law, has grown spasmodically. Its history, like that of sci-

${ }^{1}$ Frank Kopelman, "Extradition and Rendition: History - Law - Recommendations", BULR 14 (1934), p. 591.

2 More specifically to the Treaty between Hittite King Hattusili III and Pharaoh Ramesses II of Egypt, which is also the earliest known diplomatic document: see e.g. IVAN ANTHONY SHEARER, Extradition in International Law, Manchester: University Press, 1971, p. 5; CHRISTOPHER L. BLAKESLEY, "The Practice of Extradition from Antiquity to Modern France and the United States: A Brief History”, BCICLR 4 (1981), p. 41 f. 
ence, has consisted of long periods of administration marked by short bursts of innovation." ${ }^{\prime 3}$

\subsection{Grounds for refusal imposed upon States - Deductive analysis}

With the conceptual foundations and the methods adopted in the study established in Part I, Part II addresses 'mandatory grounds for refusal', or 'grounds for refusal imposed upon States'. As indicated before, these grounds for refusal produce not only (direct) obstructive effects, in that they block extradition even if the specific State at issue would not find it necessary to refuse it, but also (indirect) permissive effects, in that they suggest that the grounds for refusal that are in place strictly at the initiative of States are open to be reformed. ${ }^{4}$ Hence, such grounds for refusal play both an exclusionary and a babilitating role in this study. The purpose of analysing them is to establish an unyielding set of principles and guarantees below which extradition law should not under any circumstances fall, and above which it can be called into question.

\subsubsection{The imposed or mandatory character of these grounds for refusal}

Considering the twofold relevance of these grounds for refusal, it is convenient to reflect further on their 'mandatory' character. To which extent are such grounds for refusal indeed 'imposed' upon States?

\section{a) General international law and international conventions}

The term 'mandatory' obviously bears different meanings depending on whether it refers to general international law or to international treaties. Formally, adhesion to an international treaty is a voluntary act. And a malleable one too, in that it admits the formulation of reservations through which States can shape to a rather large extent the content of their obligations. It is, in a word, a "deliberate" act on the part of States. In contrast, the efficacy of general international law does not depend on its acceptance by States individually considered. As such, only the latter would seem to properly qualify as 'mandatory'. However, this divide is blurrier than it might seem, as expounded subsequently.

\section{(i) Judicial creativity}

Accession to multilateral treaties compliance with which is liable to assessment by international entities (as is the case with several human rights instruments) does not involve full awareness by States as to the duties being submitted to. The dynamism and creativity, ${ }^{6}$

${ }^{3}$ Christopher H. Pyle, op. cit., p. 141.

${ }^{4}$ See supra, Chap. 1, \5.4.3.

${ }^{5}$ Malcolm N. SHaw, International Law, 6 ${ }^{\text {th }}$ ed., Cambridge: University Press, 2008, p. 93.

${ }^{6}$ As noted by EIRIK BJORGE, The Evolutionary Interpretation of Treaties, Oxford: University Press, 2014, p. 9 f., the PCIJ already used "creative or dynamic methods of interpretation" as early as of 1925, in the British Claims in the Spanish Zone of Morocco, where it construed the applicable law "from the point of view of the conditions of our times". See also ALASTAIr MOWBray, “The Creativity of the European Court of Human Rights", HRLR 5 (2005), p. 57 f.; GEORGE LETSAS, "The Truth in Autonomous Concepts: How to Interpret the ECHR", EJIL 15 (2004), p. 279 f. 
or even activism, ${ }^{7}$ typical of these instances ${ }^{8}$ confers on these legal instruments a mutable character.

There is no consensus on the question as to whether the classic declaratory view of the judicial function, according to which judges should not make law but essentially apply existing law, has true application at the international level. Some authors hold that 'evolutionary interpretation' is perfectly compatible with traditional canons of treaty making, in that respecting the original will of the parties requires taking account of the significance obtained over time by the concepts used. ${ }^{9}$ Others hold that international case law has acquired the status of 'evidence of international law'. ${ }^{10}$ Either way, it is indisputable that international instances sometimes take particularly unpredictable views in respect of norms that had been intact since their inception, ${ }^{11}$ and that this is often met with resistance by State parties, especially when well-established legal institutions (as is the case of extradition) and/or serious types of criminality (notably terrorism) are concerned. Thus, for instance, in 2014 Belgium extradited alleged terrorist Nizar Trabelsi to the USA in breach of an interim measure issued by the ECtHR (which later, ruling on the merits, held that extradition was indeed inadmissible in that case). ${ }^{12}$ In the same line, in 2012 a ruling of the same Court blocking the deportation of alleged terrorist Abu Qatada from the UK to Jordan on human rights grounds ${ }^{13}$ was met with nothing less than opt-out threats by the UK. ${ }^{14}$

It is not incidental that human rights case law on extradition is regularly cited as an exemplary case of judicial creativity: ${ }^{15}$ neither the ECHR nor the ICCPR explicitly prefigure any of the rights provided therein as grounds for refusing extradition, ${ }^{16}$ and for a long while it was quite doubtful that such an interpretation could be made. ${ }^{17}$ Yet, States parties

\footnotetext{
${ }^{7}$ See e.g. Daria SARTORI, "Gap-Filling and Judicial Activism in the Case Law of the European Court of Human Rights", TE\&CLF 29 (2014), p. 1 f. This adjective has been used within the ECtHR itself, e.g. in the Partly Dissenting Opinion of Judge Kovler in Catan \& Others v. Moldova \& Russia, 19 October 2012.

${ }^{8}$ See e.g. BIRGIT SCHLÜTTER, "Aspects of human rights interpretation by UN treaty bodies", in Helen Keller / Geir Ulfstein (eds.), UN Human Rights Treaty Bodies: Law and Legitimacy, Cambridge: University Press, 2012, p. 296.

${ }^{9}$ See EIRIK BJORgE, op. cit., p. 9 f., passim.

${ }^{10}$ See Paul Mahoney, "Judicial Activism and Judicial Self-Restraint in the European Court of Human Tights: Two Sides of the Same Coin", HRLJ 11 (1990), p. 57.

${ }^{11}$ See David J. Bederman, The Spirit of International Law, London: University of Georgia Press, 2002, p. 64, stating: "It just cannot be doubted that judicial caution or creativity can exercise extraordinary influence over the outcome of disputes, the creation of doctrines, and even the entire direction and thrust of international legal regimes."

12 ECtHR, Trabelsi v. Belgium, 7 October 2014. Several other such cases are reported by the ECtHR Press Unit, "Terrorism and the European Convention on Human Rights", May 2018, p. 9 f.

${ }^{13}$ ECtHR, Othman (Abu Qatada) v. UK, 17 January 2012.

${ }^{14}$ See Cendric Ryngaert / Abdullahi Abdulrahman Abdalla, "Extradition of Terrorism Suspects: ECtHR Rules on the Compatibility of Life without Parole with the European Convention. The Case of Nizar Trabelsi v. Belgium", UCALL, 16 January 2015.

${ }^{15}$ See e.g. David J. Bederman, op. cit., p. 64 and 236, citing Soering. It is, in fact, the only example given by the author in that instance with regard to the human rights thematic.

${ }^{16}$ The sole reference made to extradition in those instruments is that found in Art. 5 (1) (f) ECHR, on the exceptions to the right to liberty: a person can be deprived of liberty in order, inter alia, to be extradited.

${ }^{17}$ See e.g. PAUl ARnell, "The European Human Rights Influence upon UK Extradition - Myth Debunked”, EJCCL\&CJ 21 (2013), p. 321.
} 
to those conventions are now bound to the innovative stance taken by the ECtHR in and since Soering, and by the UN Human Rights Committee in and since Ng. ${ }^{18}$ That such case law is creative is recognised by these very instances, although they do still seek to frame it within the first doctrine indicated above: since Tyrer that the ECtHR construes the ECHR as a "living instrument" requiring an "evolutionary interpretation" that "takes present-day standards in consideration without formally modifying the treaty"; ${ }^{19}$ in Judge, the UNHRC made an identical statement. ${ }^{20}$

Likewise, with few exceptions, EU primary law does not explicitly impose prohibitions to extradite upon Member States. Yet, in and since Petrubhin, the ECJ - also known for its innovative approach to the body of law falling within its competence ${ }^{21}$ - declared that EU primary law can under certain conditions block extradition from a EU Member State to third States. ${ }^{22}$ And, as in the cases indicated above, Member States were not particularly welcoming of such an interpretation: of all Governments that submitted observations to the Court in that case, only one (quite interestingly, that of the UK) did not express the view that EU law should not interfere with their extradition arrangements. ${ }^{23}$

\section{(ii) Reputation building}

Strategic reasons must also be considered when evaluating the meaning of accession to multilateral treaties, notably on human rights. Accession to such legal instruments may be necessary to join certain regional organisations (for instance, accession to the ECHR is necessary to join the $\mathrm{CoE}$ and the $\mathrm{EU}),{ }^{24}$ and at the very least it is highly convenient for the international outlook of a State (for instance, absence from the list of signatories of the ICCPR or of the UNCAT entails almost inexorably an aura of seclusion from the international community and its shared values).

Zartner and Ramos have addressed the use of human rights for "reputation building", and concluded that it typically takes place in the following settings: "when the State is facing regional pressures as the result of a desire to join a regional organization; when the State is facing regional pressures not to run afoul of a court within a regional organization; or when a State seeks foreign assistance from an entity with human rights requirements for the receipt of such assistance". ${ }^{25}$ Other researchers have exposed the "puzzling"

18 UNHRC, Ng v. Canada, 5 November 1993.

${ }^{19}$ ECtHR, Tyrer v. UK, 25 April 1978, \ 31.

20 UNHRC, Judge v. Canada, 20 October 2003.

${ }^{21}$ See Johannes Silvis, "Human Rights as a 'Living Concept”, EJTN, 29 April 2014, p. 1, submitting - albeit with specific regard to human rights issues - that the ECJ is inexplicitly but effectively also following a principle of "evolutive interpretation".

22 ECJ, Petrubhin (C-182/15), 6 September 2016 - analysed infra, Chap. 4, \$ 2.

${ }^{23}$ Lack of enthusiasm of Member States towards this ruling is visible for instance in a case ruled by the District Court of The Hague in 2 November 2017, process KG ZA 17-857 (still open to appeal), where the extradition of a EU citizen was requested by a third State (Russia), the Member State of which he was a national (Greece) refrained from issuing a EAW to the Member State where he was located (the Netherlands) aimed at avoiding his outward extradition, which led the Netherlands to accept this request.

${ }^{24}$ See Art. 66 ECHR, Arts. 3 and 4 Statute of the CoE, and Art. 6 TEU.

25 Dana Zartner / Jennifer Ramos, "Human Rights as Reputation Builder: Compliance with the Convention Against Torture”, HRR 12 (2012), p. 71 f. 
fact that dictatorships that practice torture are even more prone to acceding to the UNCAT than those that do not. ${ }^{26}$ This means that accession to treaties of this character does not necessarily presuppose genuine volition of their content.

\section{(iii) Codification of general international law}

Finally, to a large extent multilateral treaties simply codify international customary rules $^{27}$ - which otherwise would be practically ethereal. ${ }^{28}$ This means that many of the provisions included in those treaties are in fact but detailed reproductions of norms that were already in force with erga omnes effects.

\section{b) Customary law and jus cogens}

On the other hand, a narrow conception of 'mandatory grounds for refusal' would require a delimitation within general international law: only jus cogens norms would meet the concept, as only these are peremptory, admitting no derogation and being liable to modification only by other rules with the same parametric strength. ${ }^{29}$ Customary rules would be excluded. However, customary rules, as "evidence of a general practice accepted as law" - to use the definition of international custom provided for in the Statute of the ICJ ,$-{ }^{30}$ already constitute a firm indicator of the values that the international community finds worthy of being safeguarded. As Shaw abridges, although there are "disagreements as to the value of a customary system in international law", and "elements of truth" in different opinions, "custom does mirror the characteristics of the decentralised international system": "It is democratic in that all States may share in the formulation of new rules (...). It reflects the consensus approach to decision-making with the ability of the majority to create new law binding upon all, while the very participation of States encourages their compliance with customary rules." ${ }^{31}$ Thus, these norms are sufficiently representative and influential to satisfy the concept of 'mandatory' norms intended for this study.

\section{c) Binding and indicative case law}

A similar point can be raised in relation to the distinction between legal instruments that do and legal instruments that do not give rise to binding case law from international judicial instances, such that only the first would meet the concept of 'mandatory'. However, this distinction does not consider the norms themselves, in their content and efficacy, which are the factors of relevance in a study which is substantive in its focus. Rather,

\footnotetext{
${ }^{26}$ See Oona A. Hathaway, "Do Human Rights Treaties Make a Difference? YLJ 111 (2002), p. 1935 f.; id., "The Cost of Commitment", SLR 55 (2003), p. 1821 f.; and James RaYMOND VREELAND, "Political Institutions and Human Rights: Why Dictatorships Enter into the United Nations Convention Against Torture", IO 62 (2008), p. 65 f.

27 See Malcolm N. SHaw, op. cit., p. 95.

${ }^{28}$ See ibid., p. 74, noting the "imprecision" and "ambiguity" of international custom; see also KAI AMBOS, "Remarks on the General Part of International Criminal Law", JICJ 4 (2006), p. 660 f.

${ }^{29}$ See Arts. 53 and 64 Vienna Convention on the Law of Treaties; and Malcolm N. SHAw, op. cit., p. $123 \mathrm{f}$.

30 Art. 38.

31 Malcolm N. SHaw, op. cit., p. 73 f.
} 
it considers a procedural aspect which relates to the enforcement of those norms. Hence, no consequences are draw in this study from such a distinction.

\section{d) Conclusion - A notional distinction}

Admittedly, the distinction effected in this study between mandatory and voluntary grounds for refusal of extradition is no more than notional: different classes of international norms entail different modalities and degrees of compliance, such that splitting them into two meagre groups is inevitably simplistic. With this in mind, a twofold classification is nevertheless possible whereby: one group integrates grounds for refusal which are considered necessary by specific States to protect specific interests, and which they therefore deliberately set in place (voluntary); and the other group grounds for refusal which express a broader consensus around the paramount value of certain interests, and which therefore apply even if in concrete cases they are not desired by specific States (mandatory).

\subsubsection{Method, modalities, and normative references}

Considering again that the purpose of Part II is not to challenge the adequacy of grounds for refusal which are imposed upon States, but to establish their scope, in order precisely to exempt them from such a challenge, the method used there is a top-down analysis which consists of deducing from specified sources of law what that scope is. ${ }^{32}$

\section{a) Human rights}

As noted before, mandatory grounds for refusal derive largely from human rights law, which is analysed in Chapter 3. The main normative reference of analysis here is the ECHR. The option for a regional instrument in a study which strives for global reach requires justification. Analysing a fragment of reality with a view to drawing conclusions applicable to a broader span of reality is a common research method: such is the concept of 'sample' or 'case study', which by definition is narrower than the envisaged area of influence of the study it integrates. The effective area of influence of the study will be broader than its sample insofar as the sample is representative of the broader span of reality to which it purports to apply. ${ }^{33}$

The ECHR is not only - by far - the regional instrument on human rights that has given rise to more extensive case law on the subject matter of extradition, ${ }^{34}$ but also, and

\footnotetext{
32 In further detail on deductive analyses, see W. LAWrence Neuman, Social Research Methods: Qualitative and Quantitative Approaches, 7th ed., Harlow: Pearson, 2014, p. $69 \mathrm{f}$.

33 On the concepts of 'internal' and 'external' validity, although with regard to empirical legal research, see Frans L. LeEuw / HAns SCHMEET, Empirical Legal Research - A Guidance Book for Lanyers, Legislators and Regulators, Cheltenham: Edward Elgar, 2016, p. 119 f.

34 See Harmen van Der Wilt, "On the Hierarchy between Extradition and Human Rights", in Erika De Wet / Jure Vidmar (eds.), Hierarchy in International Law: The Place of Human Rights, Oxford: University Press, 2012, p. 150, stating that the only noteworthy case ruled under another such instrument is IAtCHR, Wong Ho Wing $v$. Peru, Order of 28 May 2010 - synopsised by Sarah Mazzochi / Jess Portmess / ALEXANDRA HANEY, "Special Coverage of the $140^{\text {th }}$ Period of Sessions of the Inter-American Commission on Human Rights", HRB 18 (2010), p. 29, and which later gave rise to IACtHR, Judgment of 30 June 2015.
} 
more importantly for the point being made, the ECtHR plays a "pace-setting role" in this matter, exerting extensive influence over other international judicial bodies, and even national courts which have no formal relation whatsoever with the ECHR. ${ }^{35}$ Thus, the UN Human Rights Committee acknowledged Strasbourg case law e.g. in Kindler, $\mathrm{Ng}$, and Cox ${ }^{36}$. As did the Supreme Court of Canada in the domestic proceedings in Kindler, ${ }^{37}$ and in Burns. ${ }^{38}$ In Burns - as Harrington notices -, the Canadian court did not even refer to case law of the UN Human Rights Committee based on the ICCPR, an instrument which is binding on Canada and which has been applied recurrently in proceedings against this State. ${ }^{39}$

On the other hand, in terms of their content, human rights have universal vocation, such that the assessment of any human rights instrument, whatever its scope of application is, is fated to have a broader area of influence. As Scheinin asserts, the fact that human rights are ultimately universal values requires any human rights instrument to "strive for a universalist view and allow itself to be informed by treaties and interpretative practices on the global (UN) level as well as within other regional human rights systems". ${ }^{40}$ This alone should prevent the approach followed here from rendering the study 'localised'. ${ }^{41}$

Finally, the purposes of this study are better served by taking as reference the most extensive body of law available imposing constraints on extradition. If the reason for addressing human rights in a study which contemplates a contraction of grounds for refusal of extradition is that human rights express paramount interests that must stay untouched, then it is not so significant that the selected sample should be representative as it is that it should be extensive, since this provides increased assurance that paramount interests are not put at risk in this theoretical exercise.

\section{b) European Union law}

Another set of mandatory grounds for refusal is that imposed by EU law upon EU Member States in their extradition relations with third States, which is assessed in Chapter 4. While these grounds for refusal are only binding on the Member States of that specific

35 Stephan Breitenmoser / Gunter E. Wilms, "Human Rights v. Extradition: The Soering Case", MJIL 11 (1990), p. 845; William A. Schabas, "Soering's Legacy: The Human Rights Committee and the Judicial Committee of the Privy Council Take a Walk Down Death Row”, I \& CLQ 43 (1994), p. 913 f.; and again HARMEN VAN DER WILT, op. cit., p. 153, $156 \mathrm{f}$.

${ }^{36}$ Kindler v. Canada, 11 November 1993; Ng v. Canada, 7 January 1994; Cox v. Canada, 9 December 1994.

${ }^{37}$ Kindler $v$. Canada (Minister of Justice), [1991] 2 SCR 779.

38 United States $v$. Burns [2001] 1 SCR 283.

39 See Johanna Harrington, "The Absent Dialogue: Extradition and the International Covenant on Civil and Political Rights”, QLJ 32 (2006), p. 91, 118. According to this author, implementation by Canada of its obligations under the ICCPR is effected through the Canadian Charter of Rights and Freedoms - a legal instrument which, according to STEPHAN BREITENMOSER / GUNTER E. WILMS, op. cit., p. 845, was also influenced by the ECHR.

40 MARTIN SCHEININ, "European human rights as universal rights: In defence of a holistic understanding of human rights", in Eva Brems / Janneke Gerards (eds.), Shaping Rights in the ECHR. The Role of the European Court of Human Rights in Determining the Scope of Human Rights, Cambridge: University Press, 2014, p. 260.

${ }^{41}$ Legal literature on extradition and human rights focusing on the ECHR while aiming for wider conclusions generally rebuffs convincingly the potential criticism that they are 'Eurocentric': see e.g. STEPHAN Breitenmoser / Gunter E. Wilms, op. cit., p. 847, Harmen VAN DER Wilt, op. cit., p. 150. 
organisation and are unique in their legal structure (given the uniqueness of EU law more generally), they are, nevertheless, representative of an approach that may be replicated in other constellations of States, and which as a matter of fact can already be found in other constellations of States, ${ }^{42}$ although not, as in the EU, owing to an imposition in the sense that this concept is assigned in this study.

The core elements of analysis here are the EU treaties, where the primary law of the Union is contained, but attention is also paid to extradition agreements concluded by the EU pursuant to its competence for external action, particularly to that concluded with the USA in 2003. Heavy focus is placed on the ground-breaking case law initiated by the ECJ in 2016 with Petrubbin.

\section{c) International immunities}

A third set of grounds for refusal could have been included in this study, namely that concerning the immunities recognised by international law to specific State agents (personal or ratione personae) or to any State agent regarding specific acts (functional or ratione materiae $).{ }^{43}$ Such immunities are a natural prolongation of certain prerogatives and interests accredited by international law to States themselves, and which would be undermined if States could be subordinated to the laws of other States through individuals who represent them or act on their behalf. Originally developed as limitations on States' prerogatives to exert criminal punishment, it is currently uncontroversial that these immunities extend to the field of international cooperation, carrying prohibitions on States to extradite individuals who are their beneficiaries. ${ }^{44}$ Authoritative jurisprudential evidence of this is offered by the rulings of the House of Lords of the UK in Pinochet (concerning a functional immunity), ${ }^{45}$ and by the ruling of the ICJ in Yerodia (concerning a personal immunity). ${ }^{46}$

42 E.g. among States forming part of the NAW system, and among Brazil and Portugal, based on the 2000 Treaty of Friendship, Cooperation and Consultation: see further infra, Chap. 4, S 2.4.4.b)(ii).

43 These immunities derive from customary international law, but have to a large extent been codified, notably in the 1961 UN Convention on Diplomatic Relations, widely regarded as the cornerstone of modern international relations: KAI BURns, A Cornerstone of Modern Diplomacy: Britain and the Negotiation of the 1961 Vienna Convention on Diplomatic Relations, London: Bloomsbury, 2014; JozEF BÁTORA / NiK HyNEK, Fringe Players and the Diplomatic Order: The New' Heteronomy, Basingstoke: Palgrave Macmillan, 2014, p. 7, 52 f., albeit noting that current diplomacy combines elements of different paradigms (mainly medieval and Westphalian), and that consequently its practical stability does not translate into perfect regulatory coherence. Other relevant sources are the 1963 UN Convention on Consular Relations, and the 1969 UN Convention on Special Missions. Quite different insofar as concerns the customary status of its rules and the balance it makes of the interests at issue, but also relevant on the subject of immunities, is the 1975 UN Convention on the Representation of States in their Relations with International Organisations of a Universal Character. Immunities of international organisations should also be considered in this setting, notably those contained in the 1946 General Convention on the Privileges and Immunities of the UN. Prominent case law on international immunities includes: Governor Collot (1797), Schooner Exchange v. McFaddon (1812); Caroline and MacLeod (1837), Powers (1960), Eichmann (1962), Rainbow Warrior (1986); Pinochet (1998-1999), and Yerodia (2002).

${ }^{44}$ See e.g. Marc Henzelin, op. cit., p. 179 f.; Paul Gully-Hart, "The Function of State and Diplomatic Privileges and Immunities in International Cooperation in Criminal Matters: The Position in Switzerland", FILJ 23 (2000), p. 1334 f.

45 Pinochet's extradition was ultimately rejected on humanitarian grounds (see infra, Chap. 6, § 4.2.3.), but the discussion in the UK as to whether or not a functional immunity applied presupposes that, if it did ap- 
However, in terms of their content, international immunities do not have noteworthy specificities regarding extradition: their scope as impediments to international cooperation in criminal matters is identical to their scope as impediments to the exercise of jurisdiction in criminal matters. ${ }^{47}$ Thus, although they have been carefully examined during the elaboration of this study, it was ultimately deemed superfluous to provide the reader with an independent chapter on this topic. For the purposes of this study, it should suffice to underline that international immunities do also constitute grounds for refusal imposed upon States, and that, consequently, they are not called into question in this study.

\subsection{Grounds for refusal voluntarily enacted by States - Two-tiered approach}

As follows from the research question, grounds for refusal voluntarily enacted by States are those that this study seeks to question. It is already established that States have an interest in maintaining extradition relations (so as to give effectiveness to their own

ply, then the UK would have been unable to extradite on that ground. In fact, one point of criticism on the UK's posture regarding Pinochet was that it took a formal request from a third State for him to be arrested, when it was known that he "had been visiting the UK regularly" and "could have been charged in a UK court": DAVID TURNS, "Pinochet's fallout: jurisdiction and immunity for criminal violations of international law", LS 20 (2000), p. 579 f. On the other hand, one of the aspects that UK lawyers find more remarkable in Pinochet is - in the words of HAzel Fox, "The First Pinochet Case: Immunity of a Former Head of State", I\&CLQ 48 (1999), p. 215 - the "surprising willingness" of the House of Lords "to apply, with municipal law effect, customary international law, with little regard to its source, status or date of coming into force". As DAVID TuRns, op. cit., p. 580, notes, such an approach was taken in spite of the fact that an applicable (if only "obliquely and imperfectly" so) municipal Statute - the State Immunity Act - was "unceremoniously discarded on the strength of developments in customary international law", in what constitutes a clear departure from the "very cautious" traditional approach of the UK to the incorporation of international law in its national law. This offers strong illustration of the concept that this study seeks to convey when it mentions 'grounds for refusal of extradition imposed by international law'.

46 ICJ, Arrest Warrant of 11 April 2000 (Democratic Republic of the Congo v. Belgium), 14 February 2002. To the extent that it concerns an arrest warrant, Yerodia inherently confirms that personal immunities paralyse not only national proceedings aimed at ascertaining criminal liability, but also international expedients aimed at obtaining custody. In her dissenting opinion on this case Judge van den Wyngaert noted that substantially the warrant issued by Belgium was neither international nor aimed at giving rise to an arrest. Together with other reasons, this led the Judge to hold that neither the issuance nor the circulation of the warrant were in violation of international law: see Dissenting Opinion of Judge van den Wyngaert, $\iint 68 \mathrm{f}$. However, the reasoning deployed in support of this conclusion implies that the action of extraditing does already fall within the concept of 'enforcement jurisdiction', which in principle is prohibited under the test set by the ICJ in Lotus: see id., $\iint 76 \mathrm{f}$.

${ }^{47}$ On the nature and scope of these immunities, see PEDro CAEIro, Fundamento... op. cit., p. 363 f.; HAZel Fox / Philippa WeBb, The Law of State Immunity, 3rd ed., Oxford: University Press, 2013; Hazel Fox, "Imputability and Immunity as Separate Concepts: The Removal of Immunity from Civil Proceedings Relating to the Commission of an International Crime”, in Kaiyan Homi Kaikobad / Michael Bohlander (eds.), International Law and Power: Perspectives on Legal Order and Justice - Essays in Honour of Colin Warbrick, Leiden: Nijhoff, 2009, p. 165 f.; MAтTHias KLOTH, Immunities and the Right of Access to Court Under Article 6 of the European Convention on Human Rights, Leiden: Brill, 2010, p. 107 f.; DAPO AKAndE / SANGEETA SHAH, "Immunities of State Officials, International Crimes, and Foreign Domestic Courts", EJIL 21 (2011), p. 825 f.; YORAM DinStEIn, "Diplomatic Immunity from Jurisdiction Ratione Materiae", I\&CLQ 15 (1966), p. 76 f; Antonio Cassese, "When May Senior State Officials Be Tried for International Crimes? Some Comments on the Congo v. Belgium Case", EJIL 13 (2002), p. 853 f.; STEFFEN WIRTH, "Immunity for core crimes? The ICJ's Judgment in the Congo v. Belgium case”, EJIL 13 (2002), p. $877 \mathrm{f}$. 
criminal laws), and that, consequently, the existence of norms that prevent such an interest from being more extensively attained must be due to other, conflicting interests. With grounds for refusal imposed upon States already identified in Part II, the research question then mainly requires two further operations: first, that those conflicting interests be ascertained; second, that they be weighed against that overarching interest in maintaining extradition relations. The former is effected in Part III (Chapters 5 and 6), again through deductive analysis; the latter in Part IV (Chapters 7 and 8), through inductive analysis.

\subsubsection{Deductive analysis}

Thus, in a first moment, a top-down analysis is carried out with a view to establishing the voluntary grounds for refusal currently in place, their scope and their rationales. This analysis - which is carried out in Chapters 5 and $6-$ is similar to that effected in respect of mandatory grounds for refusal, with the particularity that the sample here is more difficult to select, because 'voluntary grounds for refusal' are each and every such ground for refusal found in every existing international (bilateral and multilateral) and national legal instrument on extradition. Evidently, it would be impossible to assess all these normative elements, or even a decent fraction of them. The adopted solution consists of the composite sample described subsequently.

\section{a) United Nations' model instruments on extradition}

Providentially, and in evidence of its tendency for uniformity, ${ }^{48}$ extradition law has been the object of model normative instruments elaborated by the UN with a view to offering a "useful framework" for States "interested in negotiating and concluding bilateral or multilateral treaties": ${ }^{49}$ the Model Treaty on Extradition, and the Model Law on Extradition. Similar endeavours have been undertaken, but lack the significance that only an organisation like the UN could generate..$^{50}$ As instruments developed under the aegis of the UN, these model instruments possess virtually global reach, containing norms which reflect distinct "valuable contributions made by Governments, non-governmental organizations and individual experts". ${ }^{51}$ They offer a comprehensive view of existing grounds for refusal of extradition, while taking into consideration different legal traditions. They constitute an "attempt to capture the state of the art in international cooperative practice"; 52 a "distillation" of the international experience in this realm. ${ }^{53}$ Assessing these instruments therefore secures the representativeness of this part of the study.

\footnotetext{
${ }^{48}$ Signalled supra, Chap. 1, \\$2.2.

${ }^{49}$ The quote is taken from the Preamble of the MT Transfer of Proceedings, but it fits entirely the MT and the ML Extradition.

${ }^{50}$ Notably that provided in the "Harvard Research in International Law: Extradition" (cit.), which is extensively considered in this study, but has the further disadvantage that it is much more ancient (1935).

${ }^{51}$ See again the preamble of the Preamble of the MT Transfer of Proceedings.

52 Roger S. Clark, The United Nations Crime Prevention and Criminal Justice Program: Formulation of Standards and Efforts at Their Implementation, Philadelphia: University of Pennsylvania Press, 1994, p. 199.

${ }^{53}$ MATTI JOUTSEN, "International Instruments on Cooperation in Responding to International Crime", in Philip Reichel / Jay Albanese (eds.), The Handbook of Transnational Crime and Justice, Los Angeles: SAGE, $2^{\text {nd }}$ ed., 2014, p. 312, albeit referring to the MT on Mutual Assistance.
} 
According to Swart, the UN model instruments do more than to simply "codify cooperation at the level of the lowest common denominator": "they represent a thoroughgoing effort to create levels of co-operation in accordance with modern needs". ${ }^{4}$ On the MTE in particular, the author posits that its provisions "try to reduce the importance of traditional obstacles to extradition". ${ }^{55}$ However, as the author also notes, the MTE includes a "system of footnotes" which provides States with the option to adopt or not to adopt certain obstacles, as well as the option to confer a wider or narrower scope to certain obstacles. ${ }^{56}$ Therefore, without contesting that the model instruments pave ways for an increase in international cooperation, ${ }^{57}$ they still allow States to accommodate their traditional views, and ultimately do still mirror these views. In sum, the model instruments constitute much more a compendium of the existing paradigm than a venture to shift it.

The MTE, adopted by the UN General Assembly in 1990 and amended in 1997, is a document that carries legal implications: States are instructed to take its provisions into account when concluding or amending extradition treaties, and to periodically report to the Secretary-General the efforts made to that end; the Committee on Crime Prevention and Control is charged with reviewing periodically the progress attained in the matter, and, if so requested, with providing guidance and assistance to States in the development of legislation inspired by the MTE. The MTE has even been invoked before an international instance in support of the lawfulness of given provisions contained in a bilateral extradition treaty: in Kindler, already mentioned, Canada argued before the UNHRC that its extradition treaty with the USA was "in conformity with international standards as evidenced by the fact that the MTE included an optional, rather than mandatory clause on death penalty assurances". 58

In 2004, under a mandate given by the UN General Assembly with the goal of assisting States to give effect to the MTE, the UNODC drafted the MLE, ${ }^{59}$ informed inter alia by the provisions of the MTE, and by "new trends in extradition law". "The MLE also reflects "inputs and remarks" submitted by States, and thus it is representative in its own right. ${ }^{61}$ Consequently, although it was not adopted through a UN Resolution, the MLE is also assigned primary relevance in this part of the study, together with the MTE.

The model instruments, however, are not fully-fledged legal instruments. They are not binding in the sense either that they are applicable as such or that they must be im-

\footnotetext{
54 BERT SWART, "Refusal of Extradition and the United Nations Model Treaty on Extradition", NYIL 23 (1992), p. 178.

55 Ibid., p. 179.

${ }^{56}$ Ibid., p. 178.

57 The preamble of the Preamble of the MT Transfer of Proceedings, for instance, explicitly exhorts States to "strengthen international co-operation in criminal justice".

58 Apud JOHANNA HARrington, op. cit., p. 101 (emphasis added).

59 A brief review of the MLE can be found in DEMOSTENES CHRYssikos, "Commentary on the United Nations Model Law on Extradition”, in M. Cherif Bassiouni (ed.), International Criminal Law, Vol. II: Multilateral and Bilateral Enforcement Mechanisms, 3 ${ }^{\text {rd }}$ ed., Leiden: Brill, 2008, p. 377 f.

${ }^{60}$ Introduction to the MLE. The MLE took also into account several treaties containing provisions on extradition, such as the 2000 UN Convention Against Transnational Organized Crime and the 2003 UN Convention Against Corruption, as well as instruments against terrorism.

${ }^{61}$ See $i d$.
} 
plemented by States. ${ }^{62}$ Nor are they designed for that, given again the very wide flexibility they grant through said 'footnote system'. From all angles, the purpose of the model instruments is less to bind States than to stimulate them into pushing further the regulatory uniformity of extradition law. On the other hand, while much of their content mirrors international custom - which is applicable as such -, they somehow avoid compromises regarding the (few, but important) points on which States do have rather disparate views. Thus, for instance, such issues as the nationality exception, the applicability of the death penalty in the requesting State, and evidentiary requirements are addressed either through that footnote system or through their placement under a norm establishing merely optional grounds for refusal. Furthermore, the model instruments are not effectively in force or applied by any judicial instance. They are not applied in the decision of concrete cases and do not, therefore, give rise to case law. ${ }^{63}$ For these reasons, the UN model instruments on extradition would be insufficient for the purposes of this part of the study. They guarantee representativeness, but lack tangibility.

\section{b) National legislation on extradition}

Tangibility is ensured through the analysis of fully-fledged legal instruments, enacted in view of the interests of specific States and applicable in specific extradition cases. The legal instruments selected result from the following criteria.

In the first place, it was pivotal that, in combination, these legal instruments would contain all the grounds for refusal found in the UN model instruments. This would be the blend capable of producing a sample that is simultaneously representative and tangible. Within this approach, one possibility would be to select specific provisions from several legal instruments, such that all provisions selected would match the array of grounds for refusal contemplated by the model instruments. However, 'cherry-picking' is in general discouraged as a comparative law method, ${ }^{64}$ and there are particularly sound reasons not to use it in the context of extradition law: any given ground for refusal of extradition cannot be properly understood if taken out of its context, since its scope and function may be narrower or wider depending on the scope and function assigned to other grounds for refusal within the one and same legal instrument. ${ }^{65}$ It was therefore decided that the legal instruments selected would be assessed in their entirety.

\footnotetext{
${ }^{62}$ Reference to these instruments as 'soft law' is intentionally avoided in this study. As STEPHEN HALL, "Researching International Law", in Michael McConville / Wing Hong Chui (eds.), Research Methods for Law, Edinburgh: University Press, 2007, p. 202, construes, such a label is generally "an unfortunate one because the material is not really law at all", and it can "mislead the reader into ascribing to the materials a legal significance that they do not really possess".

${ }^{63}$ Which incidentally should help to explain why they have elicited such scarce literature as they have.

${ }^{64}$ See Thomas Kadner Graziano, "Is it Legitimate and Beneficial for Judges to Compare?", in Mads Andenas / Duncan Fairgrieve (eds.), Courts and Comparative Law, Oxford: University Press, 2015, p. 29 f.

${ }^{65}$ In this sense, the analysis carried out in this study qualifies as 'functionalist', which appears to remain the dominant approach to comparative law: see GEOFFREY SAMUEL, An Introduction to Comparative Law Theory and Method, Oxford: Hart, 2014, p. 65 f.; cf. with p. 79 f., on the drawbacks of this approach (and its alternatives, notably the 'structural' and 'hermeneutical' methods), which however were deemed not to affect this study, due, again, to the tendency of extradition law for uniformity: see supra, Chap. 1, \ 2.2.
} 
The decision was then made to assess national statutes, rather than international treaties on extradition. Whereas a treaty constitutes an agreement between specified States in view of specific conditions which can be assessed a priori, national legislation on extradition is conceived for regulating extradition relations of a certain State, in a capacity of requested State, with an undetermined group of requesting States. This means that the grounds for refusal contained in the latter legal instruments form a 'default' or 'worstcase scenario' parameter: they represent the set of interests that a certain State, in the abstract - i.e. without knowing the characteristics of the requesting State -, deems necessary to protect. ${ }^{66}$ These legal instruments therefore constitute the complete repositories of the legal traditions of States in extradition matters. In practice they have residual significance, because they are generally superseded by international treaties applicable in the case, and States between which there are significant fluxes of people tend to have extradition treaties in place. However, they are highly symbolic in their content, and thus constitute ideal units of analysis for a study intended to challenge traditional perspectives on extradition.

Within the above delimitations, the option was made to assess extradition statutes of States which are also parties to the EAW system - the legal instrument selected in this study to illustrate enhanced approaches to international cooperation - as this provides the basis to contrast those two cooperation paradigms ('default' and 'enhanced') within one and the same legal system. This approach has yet the advantage of inherently encompassing States that are parties to the ECHR and that as such are bound to all mandatory grounds for refusal assessed in Part II, enabling a complete view of specified extradition systems.

It was then decided that the sample should include as few national legal systems as necessary in order to fulfil the catalogue of grounds for refusal of the model instruments. Taking again into consideration the propensity of extradition law for uniformity, a wider sample was thought not to offer any substantial advantage, whilst presenting the disadvantage of consuming time that could be used in other parts of the study.

Thus, a sample was ultimately reached which consisted of the legal systems of Portugal and the UK. ${ }^{67}$ The combination of these two units of analysis alone matches in its entirety the catalogue of the model instruments. ${ }^{68}$ While most grounds for refusal found in the model instruments are shared by both of those States and several others (even if with natural particularities in each State), the following escape the tendency of extradition law for uniformity. Whereas Portugal is traditionally partial to the nationality exception,

\footnotetext{
${ }^{66}$ In a sense, these legal instruments are at the other end of the spectrum to those which contain facilitated versions of extradition such as the EAW.

${ }^{67}$ In regard of the legal system UK, the author of this study followed the recommendation of GEOFFREY SAMUEL, op. cit., p. 60 f., on "internal and external perspectives", to remain aware of his condition of "outsider" and cautious not to force his own epistemological mentality on the analysis of this legal system. This is the reason why additional methodological steps were taken to improve his ability to understand this legal system which was unfamiliar to him: see infra, Chap. $5, \$ 1.3 .3$.

${ }^{68}$ Not all possible units of analysis were evaluated, and it cannot be fully ruled out that other combinations of only two legal systems would produce similar results. However, as expounded subsequently, such a combination is quite improbable. Moreover, the selected sample showed favourable from a pragmatic angle, notably considering linguistic factors and prior acquaintance with one of the legal systems in question (that of Portugal).
} 
the UK - unlike most other States that could be selected based on the above criteria does not have a principled stance not to extradite its own nationals. On the other hand, the UK - again differently from most candidates - in some instances requires a prima facie case, whereas Portugal requires no evidence of criminal liability for the acts basing the extradition request. Moreover, the UK tends to extradite only pursuant to an international legal instrument (even if concluded on a mere ad hoc basis), whereas Portugal - unlike most candidates - extradites in the absence of a treaty, and in some circumstances even in the absence of reciprocity guarantees. Finally, Portugal - again differently from many or most candidates - traditionally rejects extradition in case of applicability of life imprisonment, which is not the case in the UK, where this penalty is applicable. Thus, these two extradition systems not only match the catalogue of grounds for refusal of the model instruments, but they also stand in open divergence on all contentious issues, conferring on this combination the additional advantage of enabling a contrast, already at this stage of the study, between opposing perspectives on traditional grounds for refusal. They also stand as representatives of two different legal traditions, common law and civil law. ${ }^{69}$

\subsubsection{Inductive analysis}

After establishing in Part III the interests protected by voluntary grounds for refusal of extradition, these grounds for refusal are subjected, in Part IV, to an essentially inductive exercise through which the research question is finally answered. ${ }^{70}$ Put in inductive terms, this question may at this point be worded as follows: in a hypothetical scenario where no grounds for refusal to extradition existed other than those which are imposed upon States, which ones would be necessary in order for those interests to be attained?

\section{a) Theoretical framework}

Within Part IV, Chapter 7 defines the core normative concept of the research question: 'necessary'. To that end, a theoretical framework is developed drawing on the findings and insights obtained in the previous parts of the study. This exercise is however not fully self-referential, but rather it also explores elements that only marginally or implicitly arose in earlier moments. ${ }^{71}$ Because it sets the parameters within which its research ques-

\footnotetext{
${ }^{69}$ For an overview of the differences between these legal traditions in the field of international cooperation in criminal matters, see UNODC, "Manual on Mutual Legal Assistance and Extradition", Vienna, 2012, p. $11 \mathrm{f}$., but concluding - quoting Bernard Rabatel - that in this field "the greater problem often is not differences in legal systems, but misunderstandings about those differences".

${ }^{70}$ In detail on inductive approaches in social research, see W. LAWRENCE NEUMAN, op. cit., p. 69 f.

71 In this regard the perspective was followed of JAN VRANKEN, "Methodology of Legal Doctrinal Research", in Mark van Hoecke (ed.), Methodologies of Legal Research: Which Kind of Method for What Kind of Discipline?, Oxford: Hart, 2011, p. 118 f., that the object of legal research need not and should not equate to its theoretical framework: "First, because there are hundreds of different systems (...) which are subject to constant change when old ones disappear and new ones arise. Second, because all systems are open and in a never-ending state of development (...). Third, because the researcher is more than someone who just translates and integrates new developments in law and society in one or more of the many systems. Researchers also have an independent position in furthering the law. (...) Fourth, because choosing consistency and coherence of the legal system as the only valid perspective is a normative choice, which without further substantiation is no better or worse than many other perspectives (...)."
} 
tion is answered, this exercise plays a key role within this study. So important is that concept, that ascribing a specific meaning to it already equates, in a sense, to answering the research question. This is also why the proper place to provide the reader with more detailed information on how that framework is constructed is the framework itself.

\section{b) Application of the theoretical framework}

With the research question already answered in its fundamental traits, Chapter 8 applies the theoretical framework to all voluntary grounds for refusal, so that a clear-cut picture is provided as to what could be the scope of those grounds for refusal if they were subject to such a reform. In the process of applying the theoretical framework to the object of analysis of the study, a dialogue was established between the two. Naturally, that process was essentially unidirectional, with the theoretical framework determining the 'new' scope to be assigned to the grounds for refusal. However, a process of reflux occurred, with the latter feeding back to the former: during the application of the framework to the grounds for refusal, new insights emerged which enabled an improvement of the framework. In result, the framework as presented in Chapter 7 is a fine-tuned version of a preliminary one which had been elaborated before the exercise carried out in Chapter 8.

\section{c) Remarks common to the foregoing steps}

Both the elaboration of the theoretical framework and its application to the several voluntary grounds for refusal are influenced by another dialogue. The interchange established in earlier moments of the study between classic cooperation and mutual recognition is maintained and in fact reinforced here. Ouwerkerk used cooperation between federated States - more precisely, within the USA and within the Helvetic Confederation as a "source of inspiration" for the possible furthering of cooperation between EU Member States. ${ }^{72}$ In turn, Willems evaluated cooperation within the USA as a possible "blueprint" for cooperation within the EU. ${ }^{73}$

This research uses cooperation between particularly integrated sets of States (notably EU Member States) as a reference for cooperation between unrelated States. This dialogue is again somewhat unidirectional, with mutual cooperation providing insight on the levels of cooperation that may be achieved in classic extradition. However, since the theoretical framework is inspired by other elements, the reflections on extradition developed here do to some extent revert to the instruments of mutual recognition, and thus this study may provide some insight on the very legal instruments it uses for inspiration. In any case, such a dialogue, as any dialogue, is only possible if the two interlocutors understand each other's language. In this case, it is necessary that those two cooperation paradigms have sufficient common denominators to enlighten one another based on a "genealogical" comparison. ${ }^{74}$ Which requires the following, autonomous section.

\footnotetext{
72 JANNEMIEKE OUWERKERK, Quid Pro Quo? A comparative law perspective on the mutual recognition of judicial decisions in criminal matters, Antwerp: Intersentia, 2011, p. 4, 129 f.

73 AukE Willems, "Extradition on the Two Sides of the Atlantic: The U.S. Model as Blueprint for the European Arrest Warrant?”, CLF 27 (2016), p. 443 f.

${ }^{74}$ On the concept, see GEOFFrey SAMUEL, op. cit., p. 57.
} 


\section{The dialogue between traditional cooperation and mutual recognition}

\subsection{The European Arrest Warrant and other enhanced versions of extradition}

The innovative character of the EAW is widely acknowledged. As already stated, it marked the first application of mutual recognition to criminal matters. Other mechanisms of mutual recognition were later developed, but the symbolism of the EAW is unparalleled. It marked a momentous advance in relation to earlier endeavours like the 1995 Convention, although this instrument already took meaningful steps towards facilitating extradition.

\subsubsection{The Nordic Arrest Warrant}

The only case comparable to the EAW in terms of how considerably it differs from classic extradition is the NAW, ${ }^{75}$ in force since $2012 .{ }^{76}$ Nordic extradition arrangements characterised by very high levels of cooperation have been in place since long before the EAW, and have in fact inspired this creation of EU law. ${ }^{77}$

However, only five States are involved (sc. Denmark, Finland, Iceland, Norway and Sweden), and the cultural, legal and linguistic affinity linking these States is overwhelming when compared to that linking EU States. Its depth is evidenced by the very antiquity of those arrangements (nearly five decades) ${ }^{78}$ which pointedly contrasts with the tender age of the EAW (2004). It is also evinced by the fact that such a cooperation system emerged spontaneously: it was not initially based on any treaty, but on national statutes made uniform through coordinated efforts. ${ }^{79}$ This again contrasts with the EAW, which, notwithstanding the existence of shared European values, ${ }^{80}$ was created somewhat 'by decree', prompted largely by the extraordinary event that was $9 / 11 .{ }^{81}$ Cooperation in civil matters - which is easier to establish, and thus tends to precede and pave the way for cooperation in criminal matters (which has greater impact on national sovereignty) ${ }^{82}$ - had been practised between Nordic States for over seven decades when said extradition arrangements emerged. ${ }^{83}$

75 Other arrangements providing for enhanced forms of extradition but which are longer in force, such as the Benelux Convention on Extradition of 1962, are not considered in this study.

76 See Annika SuOminen, "The Nordic Arrest Warrant finally in force", ECrimLR, 4 (2014), p. 41 f.

77 See GJermund Mathisen, "Nordic Cooperation and the European Arrest Warrant: Intra-Nordic Extradition, the Nordic Arrest Warrant and Beyond", NJIL 79 (2010), p. 1 f., adding that, in elaborating the NAW, Nordic States have in turn drawn inspiration from the EAW.

${ }^{78}$ See ibid., p. 5 f., on this "history of mutual trust"; see also JøRn VESTERGAARD / SilviA ADAMO, "Mutual Recognition in Criminal Matters: The Danish Experience”, SSL 54 (2009), p. 431 f.; ASBJøRNSTRANDBAKKEN, "Extradition between Nordic countries and the new Nordic Arrest Warrant", in Nico Keijzer / Elies van Sliedregt (eds.), The European Arrest Warrant in Practice, The Hague: T.M.C. Asser Press, 2009, p. 365 f.

${ }^{79}$ See GJERMUND MATHiSEn, op. cit., p. 6.

80 See Zygmunt Bauman, Europe (An Unfinished Adventure), Cambridge: Polity Press, 2004, p. 124 f.

81 The project for the creation of the EAW already existed, but met with the hesitancy of several Member States; it was 9/11 that triggered the necessary consensus: see e.g. ANNE WEYEMBERGH, "L'impact du 11 septembre sur l'équilibre sécurité / liberté dans l'espace pénal européen", Emmanuelle Bribosia / Anne Weyembergh (eds.), Lutte contre le terrorism et droits fondamentaux, Bruxelles: Bruylant, 2002, p. $153 \mathrm{f}$.

82 See Jannemieke Ouwerkerk, Quid Pro Quo?... op. cit., p. 73; SANDra LAVEnex, "Mutual recognition and the monopoly of force: limits of the single market analogy", JEPP 14 (2007), p. $762 \mathrm{f}$.

83 See GJermund Mathisen, op. cit., p. 8. 
It is true, as noted, that relevant efforts had been made before the EAW to facilitate extradition within the EU and the CoE. However, these by no means display the level of commitment visible in the Nordic arrangements, where several highly symbolical and practically important traditional obstacles to extradition had already been considerably mitigated, notably the dual criminality rule, the nationality exception and the political offence exception. ${ }^{84}$

\subsubsection{The Mercosur Arrest Warrant}

The MAW is closer to the EAW in terms of its regional breadth and cultural heterogeneity than the NAW. Its signatories are Argentina, Brazil, Paraguay and Uruguay, ${ }^{85}$ as well as Bolivia, Ecuador and Peru. ${ }^{86}$ The treaty creating this legal instrument was concluded in 2010, but has not yet entered into force.

Very symbolically, the MAW replaces the term 'extradition' for 'surrender'. In the image of the EAW, it streamlines contact between States through the designation of central authorities and the creation of standardised forms. ${ }^{87}$ At the substantive level, it also effects a partial (if very moderate) abolition of dual criminality, it requires a low threshold of relevance, and it mitigates (if also rather moderately) the nationality exception. ${ }^{88}$ Quite interestingly, the MAW, again like the EAW, contains no norm precluding extradition in the case of possible torture or ill-treatment. This may be due to the fact that this guarantee constitutes jus cogens, and that it is enshrined in several international legal instruments, including the ACHR, ${ }^{89}$ which all signatory States of the MAW have ratified.

However, the drafters of the MAW did find it necessary to provide explicitly for a non-refoulement clause, ${ }^{90}$ even though this guarantee is also found in the ACHR. ${ }^{91}$ Moreover, the MAW maintains several prominent traits of the classic paradigm, such as the political and military offence exceptions, which it provides for as mandatory grounds for refusal. ${ }^{92}$ Most meaningfully, it allows the executive branch of the requested State to refuse extradition on account of "special reasons of national sovereignty, security or public order, as well as of other fundamental interests". ${ }^{93}$ This 'Pandora's box' of extradition refusal separates decisively the MAW from the EAW, denoting acute differences in the levels of trust within the Mercosur and within the EU, let alone among Nordic States.

\footnotetext{
${ }^{84}$ See ibid., p. 9 f.

85 These are the Founding States and State Parties of the Mercosur. The only State Party that did not sign this agreement was Venezuela, which in any case saw its membership suspended in December 2016: see www.bbc.com/news/world-latin-america-38181198, last accessed 5 April 2017.

86 These are Associate States of the Mercosur; Bolivia is in the process of becoming a State Party: see www.mercosur.int. Some Associate States did not integrate this agreement, namely Chile, Colombia, Guyana and Surinam.

${ }^{87}$ See Arts. 2 (4), 6, and 7, as well as Annexes II and III.

${ }^{88}$ See Arts. 1, 3 (1), 3 (4), 4 (1) (a), and 5 (a), as well as Annex I.

89 See Art. 5.

${ }^{90}$ See Art. 5 (1) (h) and (i).

91 See Art. 22 (7) and (8).

92 See Art. 5 (d) and (e).

93 See Art. 4 (2).
} 
For that precise reason, the MAW could constitute an interesting reference for this study. It finds itself midway between the EAW and the classic paradigm of extradition. It represents an effort on the part of States which are not exceptionally integrated to nevertheless enhance their extradition relations in the name of shared interests. However, the MAW is not yet in force, and it therefore lacks the tangibility and analytical value that only practice could bestow upon it. This prevents it from being assigned more prominence in this study. It will nevertheless serve as a secondary source and be occasionally used to cross-check the analysis effected primarily on the basis of the EAW.

\subsubsection{Other enhanced extradition arrangements}

Apart from those indicated above, no legal instrument was identified which displays the attributes that would qualify it for consideration in this study. Some arrangements do exist that are characterised by high levels of cooperation, but these result from extraordinarily peculiar ties linking the jurisdictions involved, as is the case with the informal surrender procedure between the autonomous parts of the Kingdom of the Netherlands. ${ }^{94}$

Other arrangements exist between States that are historically connected, but whose current legal and political ties are much less specific than in the type of cases mentioned above. Such arrangements are somewhat more flexible than ordinary extradition, but not to such an extent as to fall within the conceptual framework of mutual recognition. Examples include extradition between Angola, Brazil, Cape Verde, East Timor, Guinea-Bissau, Mozambique, Portugal and São Tomé and Príncipe, ${ }^{95}$ and within the Commonwealth. ${ }^{96}$

Another hypothesis would have been the 1957 European Convention on Extradition, in force in all State parties of the CoE and even in some States that are not parties to this organisation, namely Israel, South Africa and South Korea. However, this Convention is also distant from the levels of cooperation associated with the concept of mutual recognition, ${ }^{97}$ and moreover it has been derogated by the FD-EAW insofar as concerns extradition between EU Member States, which form the larger share of its signatories.

Yet another hypothesis would have been the extradition agreements concluded by the EU and the USA, and Norway and Iceland. However, these are particular legal instruments involving certain States and an intergovernmental institution as a whole (the EU), rather than States only. ${ }^{98}$

${ }^{94}$ Enabled by Art. 40 of the Charter for the Kingdom of the Netherlands: "Judgments given and warrants issued by courts in the Netherlands, the Netherlands Antilles and Aruba (...) may be enforced throughout the Kingdom, with due observance of statutory provisions in the Country of enforcement."

95 These States are parties to an Extradition Treaty concluded in 23 November 2005, which is aimed at enhancing their extradition relations, but which for instance maintains the dual criminality rule (Art. 2) and the political and military offence exceptions (Art. 3 (1) (b) and (c)), as well as the nationality exception (although it does conceive it as a merely optional obstacle: Art. 4 (a)), and an ordre public clause (Art. 22).

96 Which, with few exceptions (e.g. s. 150 Extradition Act 2003, on the specialty rule), presently follows the same scheme as extradition from the UK (to take it as a reference, in the capacity of requested State) to any other category 2 country: see Clive NICHOLS et al., Nichols, Montgomery and Knowles on The Law of Extradition and Mutual Assistance, Oxford: University Press, 2013, p. 6 f. and 226 f.; see infra, Part III, passim.

${ }^{97}$ For instance, it also retains the dual criminality rule (Art. 2), the political and military offence exceptions (Arts. 3 and 4), and the nationality exception (although it also conceives it as merely optional: Art. 6).

${ }^{98}$ In any case, these instruments are addressed infra, Chap. 4, $\int 4$. 


\subsubsection{Brief digression - A symmetrical case: the formal inexistence of extradition within China}

It might be interesting to mention the case of cooperation within the PRC, which stands rather opposed to the models of reinforced cooperation mentioned above. Mainland China and the Special Administrative Regions of Macau and HK currently form a single State, but constitute separate jurisdictions with marked differences in their legal traditions. ${ }^{99}$ Each has its own extradition system and these display relevant differences in the conditions under which it is possible to extradite, e.g. insofar as regards the death penalty exception. ${ }^{100}$ Arguably owing to the depth of such differences, these jurisdictions, albeit now reintegrated under one single State for almost two decades, still lack a formal legal arrangement enabling them to extradite people among them. ${ }^{101}$

\subsubsection{Conclusion}

The EAW is not the only existing enhanced version of extradition, but it is the only device of that character in force (thus differing from the MAW) among a fairly heterogeneous group of States (thus differing from the NAW). Therefore, it is the only such device suitable as a primary reference for reforming traditional extradition, where interstate affinity cannot, in the abstract, be presumed to exist.

\subsection{The European Arrest Warrant and classic extradition - Trust issues}

As noted, in order for the EAW to serve as a reference for traditional extradition, a fundamental premise must be met. Specifically, it is necessary that solutions identical to those found in the EAW do not require the presence of a legal and institutional structure identical to that which is in place in the EU. ${ }^{102}$

${ }_{99}$ The legal system of Macau is highly influenced by Portuguese legal tradition, and that of HK by that of the UK. They differ significantly among them, and, together, they differ significantly from that of Mainland China. In this aspect, they form not 'one country, two systems', but 'one country, three systems'.

100 On extradition from Macau to outside the PRC, see MiguEL JOÃo COSTA, "Extradição e AdministraçãoSupletiva daJustiça Penal”, BFDUM34(2013),p.353f.; fromHK,JANICEBRABYN, “Inter-Jurisdictional Co-operation in Criminal Matters: Extradition, Mutual Legal Assistance, Prisoner Transfer to and from the HKSAR”, in Raymond Wacks (ed.), The NewLegalOrderinHongKong, Hong Kong: University Press, 1999, p. 133 f.

101 On the issue, see e.g. ZHAO GUOQIANG, "Cooperação judiciária inter-regional no âmbito penal da China, sob o princípio 'um país, dois sistemas' ”, in Leonel Alves / Paulo Cardinal (coord.), 1. as Jornadas de Direito e Cidadania da Assembleia Legislativa de Macau: Direito Processual Penal, Estado Presente e Perspectivas de Evolução, Coimbra: Coimbra Editora, 2009, p. 275 f.; Miguel Ângelo Lemos, "Direitos Fundamentais e Processo Penal: o Habeas Corpus, o Direito ao Recurso de Decisão Condenatória e as Funções de Tutela de Direitos Fundamentais do Tribunal de Instrução Criminal", in id., 2. ${ }^{a s}$ Jornadas de Direito e Cidadania da Assembleia Legislativa de Macau, Direitos Fundamentais: Consolidação e Perspectivas de Evolução, Macau: Assembleia Legislativa da RAEM, 2016, p. 257 f.; H. L. FU, “The Form and Substance of Legal Interaction Between HK and Mainland China: Towards HK's New Legal Sovereignty", in Raymond Wacks (ed.), op. cit., esp. p. 114 f. There is however a 2005 HK-Macau Agreement on Transfer of Prisoners, which augurs interregional cooperation.

102 Helmut SatzGer, "Is mutual recognition a viable general path for cooperation?", in Pedro Caeiro (org.), Proceedings of the Conference 'European Criminal Law in the Global Context: V alues, Principles and Policies' (Abstracts), Coimbra: IJ, 2018, p. 43 f., conceives mutual recognition as a "flexible" concept "adaptable" to very different conditions: it can be used either "in a nearly 'pure' form (as in federal states)", or "with very many exceptions". In this sense, it is not a specifically European concept, but a general one designating enhanced systems of cooperation. 


\subsubsection{The EAW as a paradigm shift? - From the original vision to Aranyosi \& Căldăraru}

From inception, mutual recognition in criminal matters is regarded as the seed of a new cooperation paradigm. ${ }^{103}$ The success obtained in the first pillar was promising, and the idea was marketed that a true revolution would occur in the field of criminal law, the FD-EAW being so bold as to proclaim in its preamble the 'abolition' of extradition between Member States. ${ }^{104}$ The context of this development - sc. the aftermath of a terrorist attack of exceptional impact ${ }^{105}$ - also hinted at deep changes. In fact, the initial sketch of the EAW scheme was in many regards more radical than the final product came to be. ${ }^{106}$ And indeed some of the features of the new instrument were impressive when compared to those of traditional extradition. The aspects that received greater consideration, often in the shape of criticism, were: (1) the (partial, but significant) abolition of dual criminality; (2) the drastic decline of nationality as a ground for refusal; (3) the outright suppression of any intervention from the political branch in the decision process; and (4) the absence of human rights safeguards, including the usual non-refoulement clause. ${ }^{107}$

Interestingly, the nearly complete absence of norms explicitly establishing grounds for refusal based on absolute human rights does not appear to have attracted the level of criticism that could be expected considering the importance of those rights. Instead, in a sense it appears to have been taken as a natural consequence of the existence of common EU standards in that regard. Advocaten voor de $\mathrm{Wereld}^{108}$ did raise doubts as to the compliance of the FD with certain fundamental rights, namely those deriving from the principles of legality, equality and non-discrimination, but they did so in strict connection to the dual criminality issue: the contention was that the mitigation of this specific rule violated those rights; not that their hypothetical violation (in whichever manner) by the issuing Member State was something that should be possible to assess by the executing Member State. ${ }^{109}$ The fact that such an extensive challenge on the legitimacy of the EAW as that posed by this case did not include an inquiry into the normative vacuum to which the prohibition of torture and ill-treatment was devoted, is symptomatic of the normality with which the situation was received. Such a vacuum was appeased by the proclamation in recital 13 of

103 See e.g. DANIEL FLORE, "Le mandat d'arrêt européen: première mise en œuvre d'un nouveau paradigme de la justice pénale européenne”, JT 121 (2002), p. 273 f.

104 See Recitals 1 and 5.

105 Regarded by some as a paradigm-shifting event in international law: see e.g. JÓNATAS MACHADO, Direito Internacional: Do Paradigma Clássico ao Pós-11 de Setembro, Coimbra: Coimbra Editora, 2003, p. 7, passim.

106 See e.g. STEVE PEERS, "Extradition to non-EU countries: the limits imposed by EU citizenship", EU Law Analysis, 7 September 2016, in regard of concurrent EAW and extradition requests; NuNO PIÇARRA, "A proibição constitucional de extraditar nacionais em face da União Europeia", RCEJ 7 (2007), p. 252, in regard of the nationality exception.

107 See e.g. GIAN LUIGI TOSATO, "Some remarks on the limits to mutual recognition of judicial decisions in civil and criminal matters within the European Union, RDIPP 38 (2002), p. 869 f.; JOHN VERVAELE, "European Criminal Law and General Principles of Union Law", RPL 5 (2005), p. 7 f.; ANABELA MirANDA Rodrigues, O Direito Penal Europeu Emergente, Coimbra: Coimbra Editora, 2008, p. 187 f.

108 ECJ (C-303/05), 3 May 2007.

109 See Christine Janssens, "Case C-303/05, Advocaten voor de Wereld VZW v. Leden van de Ministrraad", CJEL 14 (2007), p. 169 f.; Florian GEYER, "European Arrest Warrant: Advocaten voor de Wereld VZW v. Leden van de Ministerraad”, EConstLR 4 (2008), p. 149 f. 
the FD that no one should be removed, expelled or extradited in the face of a serious risk of being subjected to the death penalty, torture or ill-treatment. Human rights being considered secure in the EU (on the basis of both EU and CoE legal instruments), the FDEAW was not deserting them, but quite simply dispensing Member States from worrying unnecessarily about that issue, and making surrender swifter thereby.

As is well known, this is one aspect in which the EAW system suffered a retraction (even if it may be transitory in its practical implications), its defining point being Aranyosi \& Căldăraru, where the ECJ conceded that the execution of a EAW may have to be blocked if there is a real risk of ill-treatment in the issuing State. ${ }^{110}$ In his opinion on this case, AG Bot began by sustaining that Art. 1 (3) FD-EAW - according to which the FD does not modify the duty to respect fundamental rights and legal principles as enshrined in Art. 6 TEU - should not be construed as a ground for the non-execution of a EAW; the AG further argued that, even where, as was the case, detention conditions in the issuing State are systemically deficient, the executing State can (but, it appears, can only) ask the issuing State to provide information as to whether, in the specific case at hand, the execution of the EAW could expose the person to inhuman or degrading conditions. ${ }^{111}$ However, the ECJ took the protection of human rights in EAW proceedings one step further. In many regards the Court followed closely the AG: it agreed that the execution of a EAW cannot be automatically hindered by the existence of systemic problems in the issuing State, but rather there must be a serious risk that, in the case at hand, the person will be affected; furthermore, it stressed that the evidence substantiating such a risk must be "objective, reliable, specific and properly updated"; it moreover reiterated that the executing State must request supplementary information with a view to evaluating whether such risk can be "discounted", and that in the meantime the execution of the EAW shall simply be delayed, not refused. ${ }^{112}$ However, it went on to rule that if, after taking those steps, the executing State does conclude that a serious risk of ill-treatment exists, then it "must decide whether the surrender procedure should be brought to an end". ${ }^{113}$

110 Before the ruling, construing "the general statement of compliance with fundamental rights in Art. 1 (3) [FD-EAW] as constituting a de facto ground for refusal, at least as regards breach of fundamental rights resulting from deficiencies in detention conditions" - based on the Report from the Commission to the European Parliament and the Council on the implementation since 2007 of the Council FD of 13 June 2002 on the EAW and the surrender procedures between Member States, COM(2011) 175 final, Brussels, 11 April 2011, p. 7 -, see VALSAMIS Mitsilegas, "The Limits of Mutual Trust in Europe's Area of Freedom, Security and Justice: From Automatic Inter-State Cooperation to the Slow Emergence of the Individual”, YEL 31 (2012), p. 326.

$111 \mathrm{AG}, \int 183$.

112 ECJ, SS 93 f., 104, and 95 f.

113 Id., $\int 104$. This cautious wording, where terms like 'refusal' and 'obstacle' are avoided, does however allow some authors to construe this decision as instituting a new ground for "postponing" (rather than for 'refusing') the execution of a EAW: see SZILÁrd GÁspÁR-SZILÁGY, “Joined Cases Aranyosi and Căldăraru: Converging Human Rights Standards, Mutual Trust and a New Ground for Postponing a European Arrest Warrant”, EJCCLECJ 24 (2016), p. 197 f. The scope and implications of this ruling were further clarified by the ECJ, again at the request of the Bremen court, in Generalstaatsanwaltschaft (C-220/18 PPU), of 25 July 2018, also known as 'Aranyosi III' (although, unlike 'Aranyosi II', it does not in effect relate to the EAW for Pál Aranyosi, but to another EAW issued by Hungary). Further clarification has yet been requested by a court in Hamburg on 16 February 2018, in Dorobantu (C-128/18). 
Aranyosi \& Căldăraru departed from Radu, ${ }^{114}$ where the ECJ had implied that, even where fundamental rights are at risk, the EAW can only be refused on the grounds explicitly set out in the respective FD. ${ }^{115}$ Instead, Aranyosi \& Căldăraru trails the line of N.S. \& others, shortly subsequent to Radu, where the ECJ had ruled that the EU's asylum system cannot rely on a "conclusive presumption" that Member States observe fundamental rights in all events. ${ }^{116}$ Still, Aranyosi \& Căldăraru constitutes a landmark, as it was not settled that the EAW would be subject to the same principles as the transfer of asylum seekers. ${ }^{117}$ Not that the opposite was written in stone either; and thus, from a legal angle, this ruling constituted more a clarification than a retraction. A 'retraction' would presuppose that the situation was absolutely clear from the outset. It was not. Nevertheless, it is clear that the original political vision was that the EAW should be as swift a device as possible, and that this was feasible because of EU human rights standards. ${ }^{118}$ It is in this sense that Aranyosi \& Căldăraru can be qualified as a 'retraction'. ${ }^{119}$

In any case, thus far, human rights are the only aspect regarding which the EAW system has become less flexible than it was originally envisaged to be. In only one other aspect was that system 'stiffened' (in the sense of a widening of possibilities of refusal), namely in respect of the guarantees against trials in absentia, which were amplified by FD 2009/299/JHA. Still, this was more a harmonising measure than a reform of the EAW system, the ultimate goal of which was therefore, in fact, to reduce the room for refusals of EAW's. In time, such human rights case law may produce similar harmonising effects,

114 As well as from erstwhile case law such as ECJ, Kozlowski (C-66/08), 17 July 2008, \ 43; on this case, see LEANDro MANCANO, “The Place for Prisoners in European Union Law?”, EPL 22 (2016), p. 729 f.

115 ECJ (C-396/11), 29 January 2013. Referring to Radu - as well as Melloni, addressed further infra - as cases where the ECJ has paid rather limited consideration to human rights concerns, see VALSAMIS MITSILEGas / Niovi VAVOulA, "Criminal law: institutional rebalancing and judicialisation as drivers of policy change", in Florian Trauner / Ariadna Ripoll Servent (eds.), Policy Change in the Area of Freedom, Security and Justice: How EU institutions matter, London: Routledge, 2015, p. 141.

116 ECJ (C-411/10 \& C-493/10), 21 December 2011, \ 105. In turn, this ruling is aligned with ECtHR's M.S.S. v. Belgium \& Greece, no. 30696/09, January 2011.

117 The differences between the two had in fact been emphatically set out by AG Bot in his Opinion in

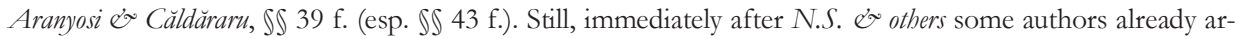
gued that such a principle would also apply to the EAW: see e.g. STEVE PEERS, EU Justice and Home Affairs Law, Oxford: University Press, 3rd ed., 2011, p. 709, propounding that, because human rights obstacles stem from primary EU law, they apply irrespectively of the content of secondary EU law in that respect; also Fenella Billing, "The Parallel Between Non-removal of Asylum Seekers and Non-execution of a EAW on Human Rights Grounds: The CJEU Case of N.S. v. Secretary of State for the Home Department', EC$\operatorname{rimLR} 2$ (2012), p. 77 f.

${ }^{118}$ It may be tempting to criticise the EU for having taken so long to enact measures promoting such improvements, the first bold effort of which took place only in 2010, with the agenda on procedural rights. However, it must be recalled that it was only with the Lisbon Treaty that criminal procedure was brought openly within its legislative competence, and that the road leading to the adoption of this Treaty was a long and winding one: see JeAn-Claude PIRIs, The Lisbon Treaty: A Legal and Political Analysis, Cambridge: University Press, 2010, p. 7 f.

119 A retraction which has later received powerful continuation in Celmer, labelled in ECJ proceedings as LM (C-216/18 PPU), of 25 July 2018. In this ruling the ECJ extended the principle set out in Aranyosi \& Căldăraru to the right to a fair trial, thereby outshining its ruling on 'Aranyosi III', delivered on the very same day. 
for what it ultimately entails is a command for Member States with lower human rights standards to elevate them. But changes of this nature can be quite difficult and lengthy to effect, making such a case law an unparalleled shortcoming for the EAW project.

As for all of the other progressive features of the EAW, they remain intact, having survived such stern challenges as Advocaten voor de Wereld, already mentioned, or Melloni, ${ }^{120}$ where the ECJ rebuffed the claim that national provisions of constitutional rank offering wider protection than the FD-EAW could supersede it. ${ }^{121}$ This ruling is all the more remarkable if one would take it for an axiom that " $[\mathrm{t}]$ he level of publicly guaranteed civil liberties at the national level should serve as a standard which European law must satisfy before it can be applied at the national level"; that is, as a minimum "level of taming and civilizing state power" below which the Union cannot fall. ${ }^{122}$

\subsubsection{The $\mathrm{E} A W$ as a paradigm shift? - Non-automaticity and non-execution}

Drawing closer to the question of whether such progressive features require an integrated setting such as that in place in the EU, it is necessary to assess whether there are structural differences between the EAW and extradition. There are not.

Mutual recognition never operates in a fully automatic manner: its non-automaticity is manifest in criminal law, especially in instruments on cooperation, but is visible even in civil law, its original field of application. ${ }^{123}$ Without plunging into the complex questions regarding the nature of mutual recognition and into the differences between its civil and criminal limbs, ${ }^{124}$ and bearing in mind that our goal is simply to use one of its concretisations (the EAW) as a reference for its classic international law counterpart (extradition), it should be uncontentious that the EAW would only be unfit for this role if it were characterised by a sizeably higher level of automaticity. And it should be uncontentious that it is not: the issuing of a EAW does not render its execution even nearly immediate or automatic; surely, in the absence of grounds for refusal, Member States should as a principle execute it, but this obligation is identical to that stemming from any extradition treaty. ${ }^{125}$

120 ECJ (C-399/11), 26 February 2013.

121 See John Vervaele, "The European Arrest Warrant and Applicable Standards of Fundamental Rights in the EU” - ECJ Judgment (Grand Chamber) C-399/11 of 26 February 2013”, REAdmL 2 (2013), p. 37 f.; Giulia Cavallone, "European arrest warrant and fundamental rights in decisions rendered in absentia: the extent of Union law in the case C-399/11 Melloni v. Ministerio Fiscal", ECrimLR 4 (2014), p. 19 f.; ANNE PIETER VAn DER MEI, "Flexibility and differentiation: A plea for allowing national differentiation in the fundamental rights domain", in Bruno De Witte / Andrea Ott / Ellen Vos (eds.), Between Flexibility and Disintegration The Trajectory of Differentiation in EU Law, Cheltenham: Edward Elgar, 2017, p. $179 \mathrm{f}$.

122 Jürgen Habermas, The Crisis of the European Union - A Response, Cambridge: Polity, 2012, p. $39 \mathrm{f}$.

${ }^{123}$ Holistic analyses of mutual recognition are effected in ANDRÉ KLIP, European Criminal Law. An Integrative Approach, Cambridge: Intersentia, 3 ${ }^{\text {rd }}$ ed., 2016, p. 409 f.; CHRISTINE JANSSENS, The Principle of Mutual Recognition in EU Law, Oxford: University Press, 2013, p. 126 f., et passim; and WouTER VAN BALLEGOOIJ, The Nature of Mutual Recognition in European Law - Re-examining the Notion from an Individual Rights Perspective With a view to Its Further Development in the Criminal Justice Area, Antwerp: Intersentia, 2015, p. 354, et passim.

124 See ibid., and also SANDrA LAVEnEx, "Mutual recognition and the monopoly of force..." op. cit., p. $762 \mathrm{f}$., construing the adaptation of mutual recognition to cooperation in criminal matters as "a typical case of institutional isomorphism where a policy concept that has proved useful in promoting integration in one area, the single market, has been borrowed to realize another area of integration".

125 See e.g. Art. 1 MTE. 
Not entirely identical, because their consequences are harsher within the EU. ${ }^{126}$ But identical in their structure and in their goal to establish cooperative relations between two or more States.

The only other meaningful difference - and which also does not relate to the structure of the obligation, but only to its scope - is that, in the classic paradigm, the political branch generally has a power to veto extradition. As we have seen, this is so even in the context of the MAW, which is an attempt to enhance extradition in a specific region. In contrast, the EAW has innovated by taking an exclusively judicial approach. This is by no means a minor difference. On the contrary, it is momentous, ${ }^{127}$ as political reasons are often the cause of failure to bring serious crimes to justice. The point is that in the EAW the efficacy of a decision taken by a Member State is still dependent on a favourable decision by another. ${ }^{128}$ This means that the first decision is in fact not so much a 'decision' as a 'request', which may or may not be granted. Exactly as in classic extradition.

Moreover, the set of grounds for refusal established in the EAW, whilst more moderate than in classic extradition, is not exactly residual either. It is closer to that typical of extradition than to that typical of interstate rendition ${ }^{129}$ - which is only consistent with the organic setting in which the EAW was generated: as is well known, Framework Decisions required unanimous voting in the Council, and thus their content was inherently infused with national sensibilities. In this sense, the grounds for refusal present in the FD-EAW constitute an acknowledgement that the criminal justice systems of the Member States are too discrepant in some aspects for cooperation between them to be conceivable as a tabula rasa where only rules favourable to European integration would be chalked. This indicates that mutual recognition is somewhat indexed to the level of proximity existing between Member States. ${ }^{130}$ Once more, as in traditional international cooperation. ${ }^{131}$

In sum, a close look at the EAW unveils (the somewhat underemphasised fact) that it does not differ from classic extradition in its basic structure. ${ }^{132}$ Apart from the judiciali-

126 In the classic international context it is possible to resort to the ICJ, but the jurisdiction of this instance is voluntary (see Art. 36 Statute of the ICJ), whereas in the EU the Commission can initiate infringement proceedings (see Arts. $258 \mathrm{f}$. TFEU). In any case, to the knowledge of this author no such proceedings have taken place thus far for breaches of FD-EAW, which only supports the point in making in the text.

127 Stating that it is "the most striking feature" of the FD-EAW, see also MiCHAEL PLACHTA, "European Arrest Warrant: Revolution in Extradition?”, EJCCL\&CJ 11 (2003), p. 187.

128 See Pedro Caeiro, "Reconhecimento Mútuo, Harmonização e Confiança Mútua (Primeiro Esboço de uma Revisão)", in Margarida Santos / Mário Ferreira Monte / Fernando Conde Monteiro (eds.), Os novos desafios da cooperação judiciária e policial na União Europeia e da implementação da Procuradoria Europeia, Braga: Centro Interdisciplinar em Direitos Humanos da Escola de Direito da Universidade do Minho, 2017, p. 35 f.

${ }^{129}$ See, by reference to US rendition, JENIA IONTCHEVA TURnER, "Interstate Conflict and Cooperation in Criminal Cases: An American Perspective”, ECrimLR 4 (2014), p. 127 f.; and again Michael PLACHTA, "European Arrest Warrant..." op. cit., p. 186.

130 See Christine Janssens, The Principle of Mutual Recognition in EU Law... op. cit., p. 190; and WOUTER VAN BALLEGOOIJ, op. cit., p. 325 f., 358 f. et passim.

131 See Helmut SATZGER, "Is mutual recognition a viable general path for cooperation?”, op. cit., p. 44, stating that "mutual recognition does not replace harmonisation", but does "rely on it insofar as it is necessary to create a sufficient and viable basis for 'mutual trust' ". But on this point see further infra, $\int \mathrm{c}$ ).

132 See again Michael PlachtA, "European Arrest Warrant..." op. cit., p. 190, asserting that the EAW is not "a qualitatively new form of international cooperation", but "extradition under a different name"; and 
sation of the decision process, ${ }^{133}$ the EAW is but a version of extradition harmonised at the procedural level and purged of some of its usual grounds for refusal at the substantive one.

\subsubsection{Harmonisation as a prerequisite to mutual recognition?}

Regarding the specific grounds for refusal that were purged, there is also no peculiarity in the EU context that prevents similar approaches from being implemented in other contexts. This is illustrated perfectly by dual criminality. The mitigation to which this rule was subjected in the EAW is, to a large extent, a consequence of the similarity of the substantive penal laws of the Member States. ${ }^{134}$ No doubt, this supports the idea that existing levels of harmony set parameters for what can be achieved by mutual recognition. In reality, assuming European integration as an objective to be continuously pursued, mutual recognition will always be a surrogate of harmonisation, a lesser means for attaining that one same objective: in eradicating the national idiosyncrasies which raise obstacles to mutual recognition, harmonisation uproots those obstacles, rather than compelling Member States to cooperate in spite of them. ${ }^{135}$ In some instances this causal nexus is even made explicit: notably, the Lisbon Treaty attributes the EU competence to harmonise the criminal procedure of the Member States " $[t]$ o the extent necessary to facilitate mutual recognition" (Art. 82 (2) TFEU). ${ }^{136}$

Reprising the train of thought: insofar as correlated to an already existing proximity of national criminal laws, the mitigation of dual criminality is but an act of pragmatism: it does not require Member States to make any concession at the axiological level (namely, that they collaborate towards the punishment of acts that they consider criminally innocuous); it simply exempts them from making an assessment whose result is from the outset known to be positive. In other words, it is simply an act of procedural simplification. In this sense, the reform of dual criminality effected in the EAW followed the same logic as

Pedro CAeIro, "Reconhecimento Mútuo...", op. cit., p. 38, stating that mutual recognition in criminal matters would be more accurately labelled as "intensified (classic) cooperation".

133 But even here the interference of the political branch is not absolutely excluded, due to Protocol no. 24 to the TFEU, on asylum for nationals of Member States of the EU - addressed infra, Chap. 8, $\int 2.1 .2$.

134 See ANDré KLIP, European Criminal Law... op. cit., p. 403 f.

135 On the interactions between mutual recognition and harmonisation, see ANNE WEYEMBERGH, "Le rapprochement des législations pénales au sein de l'Union européenne: les difficultés et leurs consequences", in Gilles de Kerchove et al., L'espace pénal européen: Enjeux et perspectives, Bruxelles: Ed. de l’Université, 2002, p. 139 f; Helmut SATZGER, "The Future of European Criminal Law Between Harmonization, Mutual Recognition and Alternative Solutions", JECL 1 (2006), p. 27 f; MASSIMO FICHERA, "The EAW and the Sovereign State: A Marriage of Convenience?”, ELJ 15 (2009), p. 76 f.; and, by reference to the 2010 EU agenda on procedural rights, Miguel Jỗo Costa, “Comentário à Proposta de Directiva relativa ao Apoio Judiciário Provisório para Suspeitos ou Arguidos Privados de Liberdade e ao Apoio Judiciário em Processos de Execução de MDE", in Pedro Caeiro (org.), A Agenda da União Europeia sobre os Direitos e Garantias da Defesa em Processo Penal: A 'Segunda Vaga' e o seu Previsível Impacto sobre o Direito Português, Coimbra: IJ, 2015, p. 61 f.

136 But precisely because harmonisation has an inherent aptitude to facilitate mutual recognition, that provision equates to saying that the EU can now freely harmonise criminal procedure. With this view, see ANDRÉ KLIP, European Criminal Law... op. cit., p. 226, to whom " $\mathrm{t}$ ] he legislative competences of the Union in the field of criminal procedure are shaped in a similar manner to substantive criminal law in Article 82 TFEU", such that currently "criminal procedure is fully within the competence of the EU". With a different view, cf. however MASSIMO FICHERA, op. cit., p. 77. 
the non-inclusion of traditional human rights grounds for refusal: both cases were less a signal that those matters were considered unimportant than a statement that they were solid integral parts of the European acquis.

However, relevant variations in the penal laws of the Member States do exist in respect of the classes of offences which were exempted from dual criminality. It suffices to mention euthanasia, abortion, the possession of low amounts of illegal drugs, or statutory rape ${ }^{137}$ Here, then, the exemption results from a political choice to enhance cooperation, confirming that the same could be effected in classic cooperation. It is 'simply' necessary that the States involved make the same choice. Naturally, one such choice will be all the easier to make the higher the pre-existing affinity linking those States is. Trust is relevant mainly in respect of prospective events: whether or not the suspect will be tortured in the requested State, whether or not this State will respect the specialty rule, whether or not it will refrain from applying a penalty deemed unacceptable by the requested State, etc. ${ }^{138}$ In turn, grounds for refusal which refer to past events can be evaluated by the requested State already when deciding on the request, requiring no leap of faith on its part as to the reliability of the requesting State: whether or not the acts at issue are criminalised in the requested State, whether or not the criminal procedure would be time-barred if it were to be carried out in this State, etc. Still, trust might be relevant even in respect of past events, as it increases the expectations of similarity on the part of the requested State towards the requesting State. Thus, for instance, a Member State may reasonably expect, without carrying out any specific assessment, that other Member States will not have criminalised acts that correspond to the exercise of such elemental individual rights as freedom of religion. That is, trust enables States to presume that, despite the possibility of differences, other States will not have exercised their competences (in the past) in such a way that this might (in the present) translate into insurmountable differences in perspective between them; it also enables them to presume that other States will not (in the foreseeable future) drift radically from their present conceptions, thereby opening such insurmountable differences between them. Thus, where mutual trust exists it will be easier to contemplate the removal of this type of obstacles to cooperation.

However, the fact is that it is possible, on the one hand, that States which are fairly like-minded have differences that cannot be overcome, and, on the other hand, that States which are rather different have, in respect of many issues, either common views or minor differences that can be overcome. Therefore, while affinity and mutual trust are propitious for strengthening cooperation, they are not indispensable. More importantly, they do not per se offer objective criteria for determining the range of cases in which, under given conditions, cooperation could take place with no sacrifice for either party.

\subsubsection{Specific political conditions as a prerequisite to mutual recognition?}

It is apparent that the more flexible profile of mutual recognition legal instruments (when compared to that of traditional legal instruments) is explainable by specific interests

137 See further infra, Chap. 6 S 2.1., and Chap. 8, \ 4.1.1.

138 See Pedro CaEiro, "Reconhecimento Mútuo...”, op. cit., p. 38, p. 35 f. 
which are shared by EU Member States and which may not be met in other international settings. A fundamental synallagma exists between the enhanced model of cooperation developed by the EU and the individual rights and freedoms sponsored by that same political project. These rights and freedoms, notably the freedom of movement, carried collateral damages to the integrity of the separate penal systems of the Member States, elevating significantly the degree to which cross-border criminality affects them.

However, such a flexible profile is not necessarily applicable to that setting only, but rather it might be justified in more general terms, in the name of a more global interest in preventing impunity. Using again dual criminality to illustrate the point of view: a process of gradual cession of sovereignty in criminal matters by EU Member States to the Union has undeniably taken place; however, the mitigation of that rule in the EAW is not related to such a process. The competence for defining criminal behaviour (viz jurisdiction to prescribe) remains largely in the hands of the Member States, which means that they are fated to criminalise different types of behaviour or to criminalise similar types of behaviour in slightly different terms (in which case surrender would in principle have to be refused under the classic dual criminality rule). As Klip observes, although most types of criminality for which dual criminality has been sidestepped in the EAW encompass acts that have been criminalised by EU legislation or other international obligations, ultimately it is Member States that define their own substantive penal law, which entails that even harmonised 'offences' are implemented in disparate terms. ${ }^{139}$ Conclusively, the mitigation of dual criminality within the EU was not so much a natural occurrence (sc. a case of obsolescence of a traditional rule caused by a verified homogeneity of the substantive penal laws of its Member States) as the result of political resolve. ${ }^{140}$

That no specific political infrastructure is indispensable for certain traditional features of extradition to be reformed is epitomised by Nordic cooperation, briefly reviewed above. Nordic States do not share a formalised legal or political edifice vaguely comparable to that of the EU, and for a long time they even lacked international legal instruments regulating their extradition relations. Yet, they have for decades had in place an extradition system whose agility is at the very least equivalent to that characterising the EAW. For what those States did have was a factual bond of trust arisen from their homogeneity at the cultural, linguistic, political, legal and socioeconomic levels. ${ }^{141}$ Hence the fact that an international legal basis regulating those relations was considered redundant. Incidentally, the point might in fact be made that, although the conclusion of an international legal instrument manifests trust between the States involved, in a sense it only hints that their initial posture was one of mistrust. One does not require a contract to help a friend. Surely things are more nuanced than this, as pacts offer guarantees to States against the volatility of factual circumstances and legal certainty to individuals against the action of States. How-

139 See ANDré KLIP, European Criminal Law... op. cit., p. 403 f.

${ }^{140}$ In the sense that there is no direct causal relation between mutual recognition and the mitigation of dual criminality, see DANIEL FLORE, "Reconnaissance mutuelle....", op. cit., p. 65 f.

141 On this tale of "genuine" trust, see yet KARri TOLTTILA, "The Nordic Arrest Warrant: What Makes for Even Higher Mutual Trust?, NJECL 2 (2011), p. 368 f., contrasted to the EAW at p. 376 f. 
ever, legal certainty can also be provided by national law, and supervening changes in essential circumstances may already carry the inapplicability of the pact (rebus sic stantibus).

Which brings us to the core issue: what is the nature of the mutual trust that supposedly sustains mutual recognition and the European project more broadly? Is it analogous to the factual mutual trust binding Nordic States? It appears conclusive - regardless of the current, rather tumultuous state of affairs of that project - that the answer is negative: the diversity verified within the EU with regard to all the variables indicated above is visibly greater. Moreover, there is a widespread social perception that the EU is highly heterogeneous, ${ }^{142}$ which in itself is a relevant factor. There are of course sizeable common standards and values, but they seem insufficient to sustain the intensive cooperation system that has been set in place. ${ }^{143}$ That is why, in the structure of the EU, mutual trust is not only a premise, a fact, a given, but also an obligation, a duty, a responsibility which is imposed on Member States by EU law. This is quite visible in Opinion 2/13, of 18 December 2014, where the ECJ declared that, in implementing EU law, Member States may be "required to presume" that fundamental rights are complied with throughout the EU. ${ }^{144}$ It is along this line that Klip classifies mutual trust as a "legal fiction": "It is presumed to be there, even in situations that in reality trust is lacking". ${ }^{145}$ By placing limits to this presumption, case law such as Aranyosi \& Căldăraru only confirmed that, in such a heterogeneous Union, mutual trust is simply insubstantial in certain circumstances.

\subsubsection{Conclusion}

The previous paragraphs addressed different enhanced models of cooperation, and contrasted them with classic extradition. The analysis carried out indicates that the EAW forms a suitable point of reference for contemplating the development of classic extradition, as they share the same foundation. By the same token, it also suggests that mutual recognition is less paradigm-shifting than is often argued, making it apposite to develop a conceptual framework that relies on deeper factors than political contingency, and that strives for more objective criteria than strategic choices.

142 See Zygmunt Bauman, Europe... op. cit., p. 11, 17; Alex Warleigh, Democracy and the European Union: Theory, Practice and Reform, London: Sage, 2003, p. 11, noting that, despite the fact that Europe has never been so politically integrated as today (some imperialistic ventures aside, one might add), their peoples tend to stress their differences much more than their affinities.

143 See Gisèle Vernimmen-VAn Tiggelen / Laura Surano, Analysis of the future of mutual recognition in criminal matters in the EU, ULB/ECLAN, 2008, p. 20, writing: "mutual recognition (...) was not a natural outcome of a process of evolution or the logical consequence of a high level of mutual trust"; "[i]n reality, this trust is still not spontaneously felt and is by no means always evident in practice", although it "appears to be growing". For very nuanced views on the relations between mutual trust and recognition, CHRISTINE Janssens, The Principle of Mutual Recognition... op. cit., p. 190; Wouter VAN BALLEGOOIJ, op. cit., p. 325 f., 358.

$144 \int 192$. Extensively on the assessment by the ECJ of the compatibility of the protection of fundamental rights in a cooperation system based on mutual trust, see VALSAMIS MiTSILEGAS, "The Limits of Mutual Trust..." op. cit., p. 335 f.

145 ANDRÉ KLIP, European Criminal Law... op. cit., p. 104. Quite symptomatically, writing on the Celmer case, SOFia Mirandola questions not 'where does mutual trust end?', but "where can mutual trust end?": "European arrest warrant and judicial independence in Poland: where can mutual trust end? (Opinion of the AG in C-216/18 PPU L.M.)”, in European Law Blog, 24 July 2018 (emphasis added). 


\section{Conclusion}

This study is normative. It uses deductive as well as inductive methods, and is composite also in its goals. This leads to a final result which features elements of different archetypes of legal research, namely: ${ }^{146}$ (i) doctrinal, in that it seeks to offer a systematic account of the rules governing a given legal area, and to expose their interactions; ${ }^{147}$ (ii) theoretical, in that it attempts to obtain a more comprehensive understanding of the conceptual bases of such a legal area; ${ }^{148}$ and (iii) reform-oriented, in that it evaluates the adequacy of existing rules, with a view ultimately to proposing solutions for them to be improved. ${ }^{149}$

\section{The temporal range of the study}

This study began in October 2013 and was submitted in June 2018. The purpose of the analysis of the national legal systems of Portugal and the UK contained in Part III was to collect solid indicators of the rationales underlying the several voluntary grounds for refusal. The topicality of the other parts of the study was more imperative, and hence they encompass all related developments taken place until the very end of May 2018. ${ }^{150}$

146 See Michael Pendleton, "Non-empirical Discovery in Legal Scholarship - Choosing, Researching and Writing a Traditional Scholarly Article”, in Michael McConville / Wing Hong Chui (eds.), op. cit., p. 159 f.

${ }^{147}$ Esp. in Parts II (Chaps. 3 and 4) and III (Chaps. 5 and 6), where, respectively, mandatory and voluntary grounds for refusal are analysed deductively.

148 Esp. in Part IV, Chap. 7, where the theoretical framework is developed.

149 Esp. in Part IV, Chap. 8, where voluntary grounds for refusal are analysed inductively.

${ }^{150}$ In highly exceptional cases, noteworthy developments taken place subsequently are briefly mentioned in the relevant places. 


\section{PART II}

\section{GROUNDS FOR REFUSAL IMPOSED UPON STATES}




\section{Chapter 3}

\section{Human Rights}

\section{The evolution of fundamental individual rights in extradition}

\subsection{Individual concerns in extradition}

Concern for fundamental individual rights in extradition proceedings is often said to be an exclusive product of the human rights movement that took place already in the mid- $20^{\text {th }}$ century. To a great extent this is a justified assessment. However, it is fair to affirm - with van den Wyngaert - that the issue "is not as new as it may seem": "From the outset, modern extradition law has expressed a clear concern for the protection of the requested person", as "can be seen from the exceptions allowing states to refuse extradition if it would subject the requested person to some kind of 'treatment' that, in one way or another, was unacceptable to the requested state".

In fact, such a concern is visible in even older practices. As Shearer notes: "That at least some institutional concepts, as distinct from mere crude machinery for surrender, may be found in the early history of extradition is indicated in the first treaty referred to above. In that treaty the Egyptian King and the Hittite prince expressly agreed that a person surrendered pursuant to the treaty might not be subjected to such severe punishments as mutilation and the destruction of his house and family". ${ }^{2}$ It would be utterly anachronistic to construe those provisions as an 'obstacle to extradition' in any sense faintly close to that which such a concept bears today. Nevertheless, if we accept that the breach of a treaty provision, then as today, would carry an erosion of the trust between the parties, producing a hindering effect, it might be argued that it does have some functional equiva-

\footnotetext{
${ }^{1}$ Christine van Den Wyngaert, "Applying the European Convention on Human Rights to Extradition: Opening Pandora’s Box?”, IECLQ 39 (1990), p. 757; also JoHn Dugard / Christine VAN DEN WyNGAERT, "Reconciling Extradition with Human Rights", AJIL 92 (1998), p. 188.

${ }^{2}$ Ivan ANthony SHEarer, Extradition... op. cit., p. 6. The Treaty of Qadesh provided in \$S 17-18: "as for the man who shall be brought to [Egypt or Hatti] let not his crime be charged against him, let not his house, his wives or his children be destroyed, let him not be killed, let no injury be done to his eyes, to his ears, to his mouth or to his legs, let not any crime be charged against him": see S. LANGDON / ALAN H. GARDINER, op. cit., p. 197 f., who construe these provisions as an "amnesty". The reasons for such an 'amnesty' cannot be established, but it should be interesting to note that the punitive system of the Hittites, in the period at issue (the 'New Kingdom'), is believed to have been more compensatory than punitive, to have extensively replaced corporal punishment by fines, and to have reserved capital punishment for rare occasions, in contrast with what happened in earlier periods of Hittite civilization, and with what still happened in most civilizations influenced by Hammurabic law: see HARRY ANGIER HOFFNER, JR., The Laws of the Hittites. A Critical Edition, Leiden: Brill, 1997, p. 7; Trevor BryCE, Life and Society in the Hittite World, Oxford: University Press, 2002, p. 42; DAVID LORTON, "The Treatment of Criminals in Ancient Egypt: Through the New Kingdom", JESHO 20 (1977), p. 50; JOHN A. WILSON, The Culture of Ancient Egypt, Chicago: University Press, 1951, p. $241 \mathrm{f}$.
} 
lence. ${ }^{3}$ In fact, some central contemporary rules protecting the individual also resemble more guarantees in the event of extradition than guarantees against extradition, producing their effects not so much during extradition proceedings as in a later moment, after and if extradition does take place. The rule of specialty is a clear example of this. ${ }^{4}$

Ancient Greece and Rome did not as a rule extradite their nationals, largely in consideration for the fact that extraditing was "tantamount to abandoning [them] to an unpleasant and probably permanent exile, if not death". The Bulle Brabantine of 1355 also reflected a "general feeling that the citizens of one State or region would be always at a grave disadvantage in securing justice from the courts of another". 6

Examples of individual protection are also found in legal instruments of the early modern era, such as the 1788 Consular Convention between France and the USA, which regulated the delivery of deserting sailors. The treaty established that deserters should be held captive and delivered at the first opportunity; however, quite interestingly, the provision also prescribed that: "if they be not sent back within three months, to be counted from the day of their arrest, they shall be set at Liberty and shall be no more arrested for the same cause" (Art. 9). It would again be speculative to provide an explanation for the provision, but the end result is again an individual guarantee - and a peculiar one too, in that it contains both habeas corpus and ne bis in idem notes.

Finally, it is undeniable that many of the grounds for refusal to extradition adopted in the late modern period had a clear dimension of individual protection. Such is the case of the nationality exception, which is aimed in part at protecting own citizens from other punitive systems (where it was assumed that they were likely to be discriminated against due to being foreigners), and which in this period was for the first time enshrined in a

\footnotetext{
${ }^{3}$ In a study covering this period, DAVID J. BEDERMAN, International Law in Antiquity, Cambridge: University Press, 2001, p. 6 f., argues that "doctrinal norms of international law, though small in number, were broad in importance and capable of eliciting certainty and security of expectation". This was reflected in "a range of restraints on State behaviour" that included "the sanctity given to treaties and alliances". The author concedes that there was not a "single, cohesive body of international law rules recognized by all States in antiquity": such a notion "would be folly, based (as it must be) on the same ruinous reasoning that compels some writers to suggest that modern doctrines of international law can trace their lineage directly back to ancient times". However, the author also rejects that international law is a "unique product of the modern, rational mind": the point is "not whether there was a common set of rules of State behaviour in antiquity, but whether there was a common idea or tradition that international relations were to be based on the rule of law". As for their enforcement, "for early Near Eastern polities (...) treaty-making was viewed as a unilateral act: the sovereign of one nation pledged his troth on the assumption (although without the certainty) that the treaty-partner was doing the same. (...) The idea that treaty-making was an inherently reciprocal exercise - indeed, that it had no meaning otherwise - appeared only later, with [precisely] the covenant between Rameses II and Hattusili III being exemplary". William MAgnuson, op. cit., p. 846, also notes that this treaty provided for "serious sanctions", with one provision stating that if any party would breach its terms, then the gods and the goddesses of both should exterminate its descendants.

${ }^{4}$ See further infra, Chap. 6, $\$ 5.1$, and 8, $\$ 3.5 .1$.

${ }^{5}$ Ivan ANthony SHEARER, "Non-Extradition of Nationals - A Review and Proposal", ALR 2 (1966), p. 274; see also HENRI DONNEDIEU DE VABRES, Supplément an Traité élémentaire de droit criminel et de législation pénale comparée: $2 e$ éd., Le Droit pénal du Gouvernement provisoire de la République française, Paris: Librairie du Recueil Sirey, 1946, p. 875; Micha£ PŁACHTA, “(Non-)Extradition of Nationals: A Neverending Story?”, EILR 13 (1999), p. 77.

${ }^{6}$ IVAN ANTHONY SHEARER, "Non-Extradition of Nationals..." op. cit., p. 274 f.
} 
written legal norm, namely in the 1834 Extradition Treaty between Belgium and France. It was also the case of the political offence exception, which is as well, in part, grounded in individual-oriented premises. The view that a person should not be extradited after the lapse of large periods of time was also widely accepted by the end of the $19^{\text {th }}$ century. The death penalty exception, whose protective dimension is clear, was also developed in this period, and can be found for instance in: ${ }^{8}$ the 1872 Extradition Treaty between Brazil and Spain (Art. 3), ${ }^{9}$ neither of which, most curiously, had yet abolished capital punishment domestically; ${ }^{10}$ the 1873 Extradition Treaty between the Helvetic Confederation and Portugal (Art. 3); ${ }^{11}$ the 1889 South American Treaty on International Penal Law (Art. 29); ${ }^{12}$ the 1892 Extradition Treaty between Great Britain and Portugal (Art. 2), ${ }^{13}$ and the 1908 Extradition Treaty between Portugal and the USA. ${ }^{14}$

\subsection{The advent of individual and human rights in extradition}

While the examples provided above reveal customs and rules which objectively protected individuals, these did not qualify as individual rights. Regarding ancient extradition, it must be noted that in Antiquity, despite occasional signals of benevolence, the "law of nations was conceived only as an instrument of State relations", with "virtually no regard for other values such as human rights or dignity". ${ }^{15}$ Similarly, at the outset of modern extradition, it was primordially State interests that shaped the institute. As Dugard and van den Wyngaert construe, even grounds for refusal with a clear facet of individual protection would always have State-oriented rationales: "The political offense exception excuses the requested state from having to take sides in a political dispute in the requesting state

7 According to AlBert Billot, op. cit., p. 226, of the 43 treaties concluded by France between 1828 and 1870, only 5 did not include this ground for refusal. See also CHARLES K. BurdiCK (rep.), "Harvard Research in International Law: Extradition", op. cit., p. 99 f.; and, vigorously defending this principle, FERNAND DE CARDAILLAC, op. cit., p. 25.

${ }^{8}$ The list combines the references provided in J. S. REEVES, "Extradition Treaties and the Death Penalty", AJIL 18 (1924), p. 288 f., and William A. Schabas, The Abolition of the Death Penalty in International Law, $3^{\text {rd }}$ ed., Cambridge: University Press, 2002, p. 270, n. 59.

${ }^{9}$ See Collecção de Leis do Império do Brasil de 1872 - Tomo XXXV, Parte II, Rio de Janeiro: Typographia Nacional, p. 473 f., in http://bd.camara.gov.br.

${ }^{10}$ Brazil would only abolish it in 1891 (see J. S. REEVES, op. cit., p. 299), although it is still possible during wartime (see Art. 5. ${ }^{\circ}$ (XLVII) (a) Federal Constitution); Spain only in 1932, and only briefly, as it was fully reinstated by the Junta Militar in 1938, lasting for common crimes until the Constitution of 1978 (see Pedro Oliver Olmo, La pena de muerte en España, Madrid: Editorial Sintesis, 2008, p. 13, 105, and 124).

11 Portugal had abolished this penalty in 1867, through an Act of 1 July.

12 Signed by Argentina, Bolivia, Chile, Costa Rica, Ecuador, Guatemala, Peru, Uruguay and Venezuela, under the aegis of the First South American Congress on Private International Law: see IsIDORO ZANOTTI, Extradition in Multilateral Treaties and Conventions, Leiden: Martinus Nijhoff, 2006, p. 97 f.

13 The UK had not yet abolished the death penalty; only in 1965 for common crimes (1973 in Northern Ireland), and in 1998 for military crimes: see ANDREW HAMMEL, Ending the Death Penalty -The European Experience in Global Perspective, Basingstoke: Palgrave Macmillan, 2010, p. 86 f.

${ }^{14}$ The norms of the treaty are silent on the issue, but it was explicitly agreed by an exchange of notes at the time of signature that Portugal would not extradite if the death penalty was applicable, and that such an agreement would, "in effect, form part of the treaty": AJIL 3 (1909), Supplement - Official Documents, p. 160 f., p. 168. As is well known, some States of the USA still apply the death penalty at present.

${ }^{15}$ David J. Bederman, "International law in the ancient world", op. cit. 
and protects it from the accusation that its failure to take sides implies support for either party. The double criminality requirement and the principle of speciality ensure that foreign states will not be allowed to punish fugitives for conduct considered contrary to the requested state's own - often chauvinistic - notions of criminal justice."16 As Shaw notes, more generally: "In the nineteenth century, the positivist doctrines of state sovereignty and domestic jurisdiction reigned supreme. Virtually all matters that today would be classified as human rights issues were at that stage universally regarded as within the internal sphere of national jurisdiction." ${ }^{\prime 17}$

It was not until the aftermath of WWII that it became possible to speak of 'individual rights' in extradition. ${ }^{18}$ As international cooperation continued to intensify in response to the changes brought by the industrial revolution, the position of individuals in cooperation proceedings started to raise concerns, ${ }^{19}$ resulting in a paradigm-shift that Eser summarises in the following terms: "Traditionally, the suspect was ignored or, at most, regarded as merely an object of bilateral proceedings between states. Recently, however, the question has been raised (...) as to whether the suspect to be extradited should not be given the status of a subject possessing rights of his own, with the consequence that the extradition relationship may be viewed as a three-way relationship - vir., between the two states involved and the person to be extradited"; more concisely, the individual "shifted from being a procedural object to being a legal subject". ${ }^{20}$

This shift presents three main facets. First, recognition that individuals have standing in extradition proceedings, enabling them to invoke any rules that may be to their benefit, notably those that establish grounds for refusal, ${ }^{21}$ a development which was accompanied by the judicialisation of these proceedings. ${ }^{22}$ Second, direct acknowledgement of individuals as procedural subjects, which prevented the requested State from arbitrarily waiving such rules as the specialty rule. ${ }^{23}$ Third, emergence of individual-oriented grounds for refusal, notably the non refoulement clause (which prevents extradition if the request is motivated by such reasons as race, religion or political opinion), ${ }^{24}$ and the humanitarian exception (which protects individuals from such serious consequences potentially arising from extradition as death or severe deterioration of health).

\footnotetext{
${ }^{16}$ John Dugard / Christine VAn Den WyngaerT, op. cit., p. 188; see further p. 189 f., on typical practices and procedures which "favor the requesting state and deny the individual an opportunity to invoke the treatment he is likely to be subjected to in that state as a bar to extradition".

${ }^{17}$ Malcolm N. SHaw, op. cit., p. 270.

${ }^{18}$ See e.g. BERT SWART, "Human Rights and the Abolition of Traditional Principles", in Albin Eser / Otto Lagodny (eds), Principles and Procedures for a New Transnational Criminal Law, Freiburg: Max Planck Institut, 1992, p. 508; M. CHERIF BASSIOUni, International Extradition... op. cit., p. 3.

${ }^{19}$ See e.g. Christine VAn Den WyngaerT, "Applying the European Convention on Human Rights to Extradition...", op. cit., p. 757.

${ }^{20}$ Albin EsER, "Basic Issues...", op. cit., 1994, p. 14 f., and 6, respectively.

${ }^{21}$ See John Dugard / Christine Van Den Wyngaert, op. cit., p. $188 \mathrm{f}$.

22 See further infra, Chap. 8, $\$ 2.1 .1$.

${ }^{23}$ See John Dugard / Christine Van Den Wyngaert, op. cit., p. 188 f.

${ }^{24}$ See Christine van Den Wyngaert, "Applying the European Convention on Human Rights to Extradition...", op. cit., p. 757.
} 
This shift, however, was effected mainly through legal instruments on extradition, whose fundamental goal not only was not to protect individuals, but in fact ran in a conflicting direction: the fundamental goal of extradition arrangements was to foster international cooperation. ${ }^{25}$ Therefore, the content of these legal instruments is still the outcome of a balance whereby State interests had an absolutely dominant influence. The case was different with the legal instruments on human rights that emerged in the post-war period. These were overwhelmingly focused on individuals; their function was to uphold fundamental individual rights. And while neither the UDHR, the ECHR or the ICCPR explicitly apply to extradition, deportation, which as well involves a coercive transfer of a person from one jurisdiction to another, and as such goes hand in hand with extradition in many regards, ${ }^{26}$ was, in certain circumstances, contemplated as a crime against humanity in the Charter of the International Military Tribunal of Nuremberg. ${ }^{27}$

Eventually, some of the rights enshrined in those instruments did obtain recognition as guarantees against extradition, the ground-breaking moment being marked by the ruling of the ECtHR in Soering, in 1989. It is true that human rights entities, such as the ECtHR, acknowledge that extradition is crucial to combat crime, and, consequently, that the scope of human rights is influenced by the necessity to maintain an international system of cooperation. ${ }^{28}$ However, the primary goal of human rights legal instruments is not to promote cooperation, and thus they are destined to uphold rights which are not contained in extradition arrangements. Particularly the legal instruments whose application is overseen by entities created with very the purpose of upholding human rights. ${ }^{29}$ These are the legal instruments that impose upon States human rights prohibitions to extradite..$^{30}$

\section{Specifications on the method}

Without detriment to the fact that the research method used in this chapter is deductive, ${ }^{31}$ the axiological orientation presiding over its application is expansive: since the ultimate goal of this study is to evaluate the necessity of grounds for refusal that are 'volun-

25 This conflict is widely recognised: see e.g. JOHN DUGARD / CHRISTINE VAN DEN WYNGAERT, op. cit., p. 187; PAUl ARNELL, “The European Human Rights Influence upon UK Extradition...”, op. cit., p. 336; VED P. NANDA, "Bases for Refusing International Extradition Requests - Capital Punishment and Torture", FILJ 23 (1999), p. 1369. See also CoE, "Explanatory Report to the European Convention on Extradition", European Treaty Series no. 24, Paris, 1957, informing: "During the drafting of the convention it became apparent that two different attitudes were being taken to certain principles which should govern extradition. (...) [O]ne follows the traditional view that the chief aim is to repress crime and that therefore extradition should be facilitated; the other introduces humanitarian considerations and so tends to restrict the application of extradition laws".

26 See Art. 13 ICCPR.

27 See Art. 6 (c), and in a sense also Art. 6 (b).

${ }^{28}$ In this sense, with respect to the ECHR, see JACQUES HARTMANN, "The European Convention on Human Rights and Extradition", in Kaiyan Homi Kaikobad / Michael Bohlander (eds.), International Law and Power Perspectives on Legal Order and Justice - Essays in Honour of Colin Warbrick, Leiden: Martinus Nijhoff, 2009 , p. 28. But see further infra, $\$ 3.3$.

${ }^{29}$ As is the case of the ECtHR (Arts. 19 f. ECHR) and of the UNHRC (Arts. $28 \mathrm{f}$. ICCPR).

${ }^{30}$ On the concept of 'imposition' regarding human rights legal instruments, recall supra, Chap. 2, $\int$ 2.2.1.

31 See supra, Chap. 2, \2.2.2. 
tarily set in place by States', with a view to their possible reform, grounds for refusal that are 'imposed by human rights' should be understood as a working concept encompassing any situation that has sufficient resonance in human rights law to be excluded from one such reform. In other words, this chapter takes an intentionally broad stance on the relevance of human rights as grounds for refusal of extradition, so that a high inviolable benchmark is established below which no reformist drive can fall.

The following paragraphs expound the criteria followed to establish which grounds for refusal are imposed by human rights. Based on such criteria, a section is then provided elaborating on the set of situations which for the purposes of this study are to be considered covered by grounds for refusal imposed by human rights.

\section{Criteria for defining 'grounds for refusal imposed by human rights'}

\subsection{Declared v. Potential grounds for refusal}

Firstly, the concept of 'grounds for refusal imposed by human rights' is construed widely insofar as regards its certainty. This aims at encompassing not only grounds for refusal that have unmistakeably been declared by the ECtHR, but also potential ones - i.e. grounds for refusal that can plausibly be deduced from that case law. Manifestly, there is some ambiguity to this approach. However, the steady practice of the living instrument doctrine' by the ECtHR renders it very probable that further situations will be recognised as grounds for refusal of extradition under the ECHR. ${ }^{32}$

Ground-breaking as it unquestionably was, Soering itself did not quite emerge adventitiously. There already was meaningful backing to the stance that human rights could bar extradition, particularly in situations subsumable in the prohibition of torture/ill-treatment. The peremptory character of this prohibition was already rather firm. ${ }^{33}$ As to its applica-

32 See JacQues HARTMANN, op. cit., p. 25 mentioning a "burgeoning" body of case law. See also PAUL ARNELL, "The European Human Rights Influence upon UK Extradition...”, op. cit., p. 322 f., referring to the application of the ECHR to extradition as a history of "substantive expansion" - i.e. of "acceptance of the applicability of further human rights to extradition" - although, in consequence, also one of "legal and practical limitation" of those rights through the "development of tests conditioning their applicability". See yet JANNEKE GERARDS, "The scope of ECHR rights and institutional concerns: The relationship between proliferation of rights and the case load of the ECtHR", in Eva Brems / Janneke Gerards (eds.), op. cit., p. 84,104 , noting more generally that "rights inflation" raises "institutional concerns" (notably, case overload) that entail a "danger" of "a lowering of standards of protection". This should not be underestimated when considering the likelihood of new breakthroughs in human rights case law on extradition.

33 As reflected in a 1986 report by the UN Commission on Human Rights at its 42nd session, "Torture and Other Cruel, Inhuman or Degrading Treatment or Punishment”, E/CN 4/1986/15, \ 3: “Torture is now absolutely and without any reservation prohibited under international law whether in time of peace or of war", and "belongs to the group of rights from which no derogation can be made"; "[i]f ever a phenomenon was outlawed unreservedly and unequivocally it is torture." The ECtHR had already held, in the seminal case Ireland v. UK, 18 January 1978, no. 5310/71, S 163, that this prohibition was "absolute". Questioning whether ECtHR case law does indeed "live up to the promise of such an absolute right", and concluding somewhat negatively, see in any case STIJN SMET, “The 'absolute' prohibition of torture and inhuman or degrading treatment in Article 3 ECHR: Truly a question of scope only?”, in Eva Brems / Janneke Gerards (eds.), Shaping Rights in the ECHR: The Role of the European Court of Human Rights in Determining the Scope of Human Rights, Cambridge: University Press, 2013, p. 273 f. 
bility in the context of extradition, the 1984 UNCAT had already explicitly adopted such a solution - innovatively in relation to the 1975 UN Declaration on the Protection of All Persons from Being Subjected to Torture and Other Cruel, Inhuman or Degrading Treatment or Punishment, which was silent on the issue -, by providing in its Art. 3 (1): "No State Party shall expel, return ('refouler') or extradite a person to another State where there are substantial grounds for believing that he would be in danger of being subjected to torture." 34 The notion was not new to the ECtHR and the European Commission on Human Rights either. They had addressed the question on several occasions since the 1960's, the latter in particular having produced "copious case law" favourable to the cause of applicability - though always dismissing the concrete applications at issue, giving rise to the criticism that those obiter dicta were "a sort of keg full of wet powder". 35

Following Soering, the ECtHR kept recognising more situations where a decision to extradite could entail a breach of the ECHR - and not only of Art. 3, but also of other provisions. The latest example of expansion has occurred already in the course of this study, with Trabelsi (2014), where for the first time the Court declared Art. 3 to prevent extradition to a State where an irreducible life-sentence would apply. ${ }^{36}$

A similar evolution is visible in the jurisprudence of the UNHRC. It was only in $\mathrm{Ng}$ $(1993)^{37}$ that the Committee in effect found an extradition decision to be in breach of the ICCPR, but such a prospect had been open since Torres (1990), ${ }^{38}$ the first case admitted by the Committee for a possible violation of the Covenant by an extraditing State, as such, for future actions of the requesting State. Ruling on the merits, it ultimately held that the applicant had failed to sufficiently substantiate his fear of being tortured in Spain, ${ }^{39}$ but it thereby implicitly rejected Finland's "absolutist position" that the ICCPR could not apply to extradition at all. ${ }^{40}$ In Kindler (1993), also before $\mathrm{Ng}$ (if only shortly), the UNHRC had reiterated its understanding that, where the "necessary and foreseeable consequence" of a State party's decision to extradite a person found within its jurisdiction is the violation of his/her rights in another jurisdiction, State party or not, that State itself could be in violation of the ICCPR, or otherwise the duty, provided in Art. 2, to protect all the individuals found within one's territory and subject to one's jurisdiction would be denied. The Committee further elaborated that, although in such cases the harm is prospective, its foreseeability makes it tantamount to a present violation of the Covenant. ${ }^{41}$

\footnotetext{
34 See also Art. 3 (2), concretisng: "For the purpose of determining whether there are such grounds, the competent authorities shall take into account all relevant considerations including, where applicable, the existence in the State concerned of a consistent pattern of gross, flagrant or mass violations of human rights."

35 Antonio Cassese, The Human Dimension of International Law. Selected Papers, Paola Gaeta / Salvatore Zappalà (eds.), Oxford: University Press, 2008, p. 299, 302, 318.

${ }^{36}$ ECtHR, Trabelsi v. Belgium, no. 140/10, 7 October 2014; see further infra, \$ 3.3. and esp. 4.2.2.

37 UNHRC, Ng v. Canada, 5 November 1993.

38 UNHRC, Torres $v$. Finland, 2 April 1990.

${ }^{39}$ See $i d .$, \ 6.

40 Johanna Harrington, op. cit., p. 96; see Torres, $\int 4.1$.

${ }^{41}$ UNHRC, Kindler v. Canada, \ 6.2., further clarifying at $\int 13.1$ that: "what is at issue is not whether Mr. Kindler's rights have been or are likely to be violated by the USA, which is not a party to the ICCPR-OP1, but whether by extraditing Mr. Kindler to the USA, Canada exposed him to a real risk of a violation of his rights under the Covenant”.
} 


\subsection{Stable $v$. Unstable grounds for refusal}

Even insofar as concerns situations that have been declared to constitute obstacles to extradition there is an inevitable margin of uncertainty, given that the evolutionary line of international case law is not straight, but rather marked by advances and retreats. This is especially so if one contrasts distinct jurisdictional instances. ${ }^{42}$ Naturally, major contradictions are unlikely to occur within the case law of the same instance, given that it has the responsibility to be coherent and to protect the expectations created by its own precedent. ${ }^{43}$ It is for instance unimaginable that the ECtHR would depart from its stance that a real risk of torture/ill-treatment in the requesting State is an obstacle to extradition under the ECHR. However, meaningful uncertainty does exist as to the situations that integrate each human right, and, especially, as to the thresholds that must be attained. This is perfectly illustrated by Hutchinson v. UK (2015), ${ }^{44}$ where the ECtHR narrowed the concept of 'irreducible life sentence' it had adopted in Vinter, influencing, in a reflex manner, the prohibition to extradite in case of applicability of one such sentence in the requesting State. $^{45}$

Nevertheless, the existence of a precedent, even where it has been reversed, casts a strong shadow of doubt as to the compatibility of the hypothesis in question with human rights. Thus, grounds for refusal that have been withdrawn or limited are still considered to be 'imposed by human rights' for the purposes of this study.

\subsection{Principled v. Pragmatic approaches to human rights}

Unlike individual rights enshrined in extradition treaties, which apply only to extradition between the States - however many - that are parties to the treaty at issue, human rights treaties apply also beyond or "outwith" 46 the set number of States parties. That is, to any third State that requests extradition from a State party. There is a debate as to whether breaches of Art. 3 ECHR (and 7 ICCPR) have a higher threshold when it depends on the conduct of a third State. ${ }^{47}$ The question appears to have been answered somewhat in-

${ }^{42}$ In the aftermath of Kindler, William A. SCHABAS, "Soering's Legacy: The Human Rights Committee and the Judicial Committee of the Privy Council Take a Walk Down Death Row", I\&CLQ 43 (1994), p. 913, was stating: "An inevitable feature of the proliferation of judicial and quasi-judicial human rights bodies is the danger of differing interpretations of fundamental norms. In domestic law, conflicting case law eventually makes its way to the ultimate appellate instance. But in international human rights law, with its parallel systems of implementation, there is no final arbiter." In Kindler the UNHRC came "perilously close to open conflict with the ECtHR", namely with Soering: ibid., p. $913 \mathrm{f}$.

43 See again William A. ScHABAS, "Soering's Legacy...", op. cit., p. 913, 922; and MARTIN SCHEININ, op. cit., p. 265.

${ }^{44}$ ECtHR, Hutchinson v. UK, no. 57592/08, 3 February 2015.

45 See Steve Harold Foster, "Whole Life Sentences and Article 3 of the European Convention on Human Rights: Time for Certainty and a Common Approach?”, LLR 36 (2015), p. 147 f.; NAOMI HART, "Case Comment: Whole-life sentences in the UK: volte-face at the European Court of Human Rights?", CLJ 74 (2015), p. 205 f.; CEDRIC RYNGAERT, "Does the European Court of Human Rights read the UCall blog? Court makes U-turn in life imprisonment cases", in UCALL, 24 February 2015. On Hutchinson, see further infra, $\int$ 4.2.2.

46 Paul ARnell, op. cit., p. 336 f.

${ }^{47}$ See ibid. 
consistently by the ECtHR. The restrictive position holds that such an application is 'extraterritorial' and imposes European standards on third States. The ruling generally quoted in its support is Al Skeini and Others $v$. UK, on the application of the ECHR to military operations outside the jurisdiction of State parties, ${ }^{48}$ which has been followed in an extradition setting by Harkins \& Edwards, ${ }^{49}$ Babar Abmad \& Others, ${ }^{50}$ and the Concurring Opinion of Judge Yudkivska in Trabelsi - which in turn has been largely echoed in legal commentary. ${ }^{51} \mathrm{~A}$ more expansive position advocates that the absolute nature of some rights, notably the prohibition of torture/ill-treatment, precludes any differentiation. Such a reasoning finds comfort in Chahal v. UK, ${ }^{52}$ reiterated e.g. in Saadi, ${ }^{53}$ Daoudi v. France ${ }^{54}$ and M.S. v. Belgium ${ }^{55}$ and it is aligned with the case law of other human rights instances. ${ }^{56}$

The latter stance relies strongly on the principle established in Soering ${ }^{57}$ and restated ever since ${ }^{58}$ that, in cases of removal of a person from the jurisdiction of the CoE, the responsibility for prospective torture/ill-treatment in a third State rests, not with that State, but with the sending State, for exposing the individual to such events. In Trabelsi it was stated that this principle by no means makes the ECHR an instrument governing the actions of third States or imposing European standards on such States. ${ }^{59}$ In fact, in extradition cases the ECHR is never quite applied extraterritorially, although it has indirect extraterritorial effects. ${ }^{60}$ What the Court is required to assess is not whether there is a real risk of breach of the Convention by a third State - which by definition cannot breach an instrument it has not subscribed to -, but whether the probable action of such State upon obtaining extradition would constitute a breach of the Convention if it were practised by

48 Al-Skeini \& Others $v$. UK, no. 55721/07, 7 July 2011, @ 141.

${ }^{49}$ Harkins \& Edwards v. UK, no. 9146/07 and no. 32650/07, 17 January 2012, \ 129, illustrating: "For example, a Contracting State's negligence in providing appropriate medical care within its jurisdiction has, on occasion, led the Court to find a violation of Article 3 but such violations have not been so readily established in the extra-territorial context (compare the denial of prompt and appropriate medical treatment for HIV/AIDS in Aleksanyan v. Russia, no. 46468/06, JS 145-158, 22 December 2008, with N. v. the United Kingdom [GC], no. 26565/05, 27 May 2008) (\$ 177)".

50 Babar Abmad \& Others, no. 24027/07, no. 11949/08, no. 36742/08, no. 66911/09 and no. 67354/09, 10 April 2012, \177, replicating \129 of Harkins \& Edwards, cit.

51 See e.g. LAURENS LAVRYSEN, "Belgium violated the ECHR by extraditing a terrorist to the USA despite an interim measure by the Strasbourg Court: Trabelsi v. Belgium”, in Strasbourg Observers, 12 September 2014, Cedric Ryngaert / Abdullahi Abdulrahman Abdalla, op. cit., Zoe Bedell, "European Court of Human Rights Takes on Extraditions to the U.S.: Trabelsi v. Belgium”, in Lawfare, 5 December 2014; Natasa Mavronicola, "Mavronicola on Trabelsi v Belgium”, in Human Rights in Ireland, 7 October 2014.

${ }^{52}$ Chabal v. UK, no. 22414/93, 15 November 1996, dS $80 \mathrm{f}$.

53 Saadi v. Italy, no. 37201/06, 28 February 2008, \ 138.

${ }_{54}$ Daoudi v. France, no. 19576/08, 3 December 2009, \ 64.

${ }_{55}$ M.S. v. Belgium, no. 50012/08, 31 January 2012, JS 126 and 127.

56 See Jacques Hartmann, op. cit., p. 26, exemplifying with UN-CAT, Alan v. Switzerland, 8 May 1996, Comm. no. 21/1995.

57 Cit., $\int 91$.

58 See e.g. Saadi, cit., \67, and Mamatkulov \& Askarov v. Turkey, no. 46827/99 and no. 46951/99, 4 February $2005, \int 126$.

${ }^{59}$ Cit, $\int 119$.

60 See Barbara Miltner, "Revisiting Extraterritoriality after Al-Skeini: The ECHR and its Lessons", MJIL 33 (2012), p. 731. 
a State party. It is a hypothetical assessment. Cases of actual extraterritorial application of the ECHR do exist, notably based on 'personal jurisdiction', regarding certain acts committed by agents of a State party in the territory of a third State; but extradition does not fall within the same category. ${ }^{61}$ Thus, McGoldrick asserts very clearly that measures such as deportation and extradition, which are taken within a State party but produce their effects upon an individual in another State, "are interesting but not that problematic": such human rights violations "only appear to occur in the territory of another state", but, "[i]n fact, the state parties obligations are clearly grounded in measures it has taken within its own territory". ${ }^{62}$

The restrictive stance seems to be anchored to pragmatic or tactical concerns. ${ }^{63}$ Let us consider the issue of irreducible life sentences. Before Trabelsi, and even Vinter, it was already observed in literature that the possible evolution of the case law of the ECHR into blocking extradition in case of irreducible life sentences could hinder significantly cooperation with States that are not parties to the CoE, because many States that apply capital punishment often replace this form of penalty for life without parole in order to enable extradition from States which have abolished the death penalty. ${ }^{64}$ Similarly, in the Wellington case before the courts of the UK (2008), Lord Hoffmann upheld that a "relativist" approach to Art. 3 ECHR is "essential if extradition is to continue to function", and that there is a "practical need to construe any human rights instrument in a way which does not make extradition dependent upon compliance by the receiving country with the full panoply of rights enjoyed in the extraditing country". ${ }^{65}$ When the Trabelsi ruling was delivered, it was considered "surprising" from a "strategic perspective", notably in the light of the UK's recent criticism of the Court's decision to block the deportation of alleged terrorist Abu Qatada - which, as noted earlier, went so far as to involve opt-out threats. ${ }^{66}$

${ }^{61}$ See, categorically, Marko Milanović, Extraterritorial Application of Human Rights Treaties: Law, Principles, and Policy, Oxford: University Press, 2011, p. 8 f., 120; the author goes on to dispel the "fallacy that the notion of state jurisdiction in human rights treaties reflects that notion of jurisdiction in general international law which delimits the municipal legal orders of states": p. 262.

${ }^{6}$ Dominic McGoldrick, "Extraterritorial Application of the International Covenant on Civil and Political Rights”, in Fons Coomans / Menno Kamminga (eds.), Extraterritorial Application of Human Rights Treaties, Antwerp: Intersentia, 2004, p. 52. Similarly, with respect to the ECHR, RiCK LAwsON, "Life After Bankovic: on the Extraterritorial Application of the European Convention on Human Rights", in ibid., p. 97 asserts that Soering does not provide authority for the statement that the concept of 'jurisdiction' is not restricted to the national territory of the contracting parties". This view is fully supported by MiCHAEL O’BOyLE, "The European Convention on Human Rights and Extraterritorial Jurisdiction: A Comment on 'Life After Bankovic", in ibid., p. $126 \mathrm{f}$.

${ }^{63}$ See e.g. JACQUES HARTMANN, op. cit., p. 26, referring to this position as a "pragmatic approach".

${ }^{64}$ See ibid.

${ }^{65}$ See $\mathrm{R}$ (On the Application of Wellington) (FC) (Appellant) v. Secretary of State for the Home Department [2008] UKHL 72 (Respondent) (Criminal Appeal from Her Majesty's High Court of Justice), esp. SS 27, 33.

${ }^{66}$ See supra, Chap. 1, \$ 2.2.1.a)(i). See CEDric RYNGAERT / AbDullahi AbDulrahman AbDalla, op. cit., stating: "Trabelsi only fans the flames and further complicates extradition proceedings with respect to presumed terrorists. It remains now to be seen how the interpretation of the ECHR in extradition cases will evolve after the Paris terrorist attacks of 7-9 January 2015 and the increased terrorist threat level. For surely it would affect the Court's credibility not to take seriously the legitimate security concerns of states and their interest in smooth international judicial cooperation in the fight against terrorism." See also NATASA MAVRONICOLA, op. cit. 
As also noted, in Hutchinson the ECtHR reviewed the concept of 'irreducible life sentences', compressing the scope it had set out in Vinter, which again has been understood by many as a strategic, rather than principled stance. Pettigrew, for instance, asserts that the ruling "appears to be more of a response to hard line domestic politics than a continuation of holistic legal principle which the ECtHR has outwardly supported in the past". ${ }^{67-68}$

If the principle that in extradition cases liability impends upon the extraditing State (party to the ECHR) is a well-founded one at the legal level, then, where the ECtHR rules that higher thresholds apply due simply to the fact that the requesting State is a third State, it will be conceding to pragmatic considerations. ${ }^{69}$ For the concrete person targeted by a specific extradition request - and human rights are innately centred on the person -, it is indifferent whether the requesting State is another State party or a third State. Such is the position defended by Swart, when he asserts: "It certainly makes no difference to the victims whether a Contracting State itself violates human rights or assists other States in doing so." ${ }^{70}$ If anything, the latter case is more unfavourable to the person, as upon being extradited he/she will cease to be protected by the ECHR, which in this instance is the instrument offering higher levels of protection. ${ }^{71}$ In this sense, there should in principle be only one threshold. ${ }^{72}$ The fact that the requesting State is a third State is immaterial from that perspective.

A similar reasoning, in fact, applies to the issue of the parametric strength of the rights in question: the distinction between absolute and relative rights may be relevant

${ }^{67}$ Mark PetTigrew, "A Tale of Two Cities: Whole of Life Prison Sentences in Strasbourg and Westminster", EJCCL\&CJ 23 (2015), p. 281 f. See also CEDRIC RYNGAERT, "Does the European Court of Human Rights read the UCall blog? Court makes U-turn in life imprisonment cases", op. cit.

${ }^{68}$ Note that Hutchinson, like Vinter, are purely 'internal' cases. The Court was ruling on the issue as to what should be considered an 'irreducible life sentence'; not on whether the threshold for 'outward extradition' should be higher than that for 'internal extradition', or on any extradition issue whatsoever. Indirectly, however, it influences the 'extraterritoriality' issue, as the concept of 'irreducible life sentences' valid at the 'internal level' is at least a starting point to establish that which is valid in an extradition setting.

${ }^{69}$ Even in Soering, the Court stated the importance of factors of this nature: "the beneficial purpose of extradition in preventing fugitive offenders from evading justice cannot be ignored in determining the scope of application of the Convention and of Art. 3 in particular": $\iint 86 \mathrm{f}$. It made a similar statement in Trabelsi, \117: "the Court does not lose sight of the fundamental aim of extradition, which is to prevent fugitive offenders from evading justice, nor the beneficial purpose which it pursues for all States in a context where crime is taking on a larger international dimension." See, finally, Elorza v. Spain, no. 30614/15, 12 December 2017, $\int 111$. This kind of reasoning is also found in the case law of the UNHRC, e.g. in Giry, no. 193/1985, 20 July 1990, \38, and by the IACtHR, e.g. in Wong Ho Wing, Order of the IACtHR of 28 May 2010, \ 16, and Order of the IACtHR of 29 January 2014, \ 13.

${ }^{70}$ BERT SwART, "Refusal of Extradition...", op. cit., p. $204 \mathrm{f}$.

71 The fact that upon extradition to another State party the protection of the ECHR endures has not, however, prevented the ECtHR from blocking extradition between State parties: see JACQUES HARTMANN, op. cit., p. $26 \mathrm{f}$.

72 As even the more sceptical opinions on Trabelsi admit: CEDRIC RYNGAERT / ABDULLAHI ABDULRAHman AbDalla, op. cit.; also NATASA MAvronicola, op. cit., who states, in regard of UK's current stance on the case law of Strasbourg: "Inconvenience is not a very good premise for criticising human rights doctrine, though it sometimes finds voice in more elaborate terms". Unreservedly welcoming that ruling for the effect it entails of "reinforcing prisoners' human rights", see JOSEPHA CLOSE, "Human rights outcasts: seriously-ill migrants as beyond the reach of European protective legal regimes", in International Law Blog, 20 April 2015. 
within the pragmatic line of reasoning, but it seems rather irrelevant from an individualoriented one. ${ }^{73}$ Accordingly, the approach followed in this study is expansive not only horizontally - in that the identity of the requesting State is irrelevant -, but also vertically - in that the parametric rank of the human right at issue is irrelevant.

This is not to advocate that judicial instances which apply human rights law should not take pragmatic factors into consideration. Merely that, when they do, they will not be doing so on behalf of any specific individual. The need to combat crime, especially serious crime (which is that where human rights based decisions to refuse extradition meet greater criticism), may have human rights connotations of its own, ${ }^{74}$ namely in view of the interests of the victims and of societies more broadly. ${ }^{75}$ However, these tend to be tenuous when contrasted to an imminent and definite human rights breach caused by the decision of a State to extradite an individual. Therefore, the recognition by a human rights judicial instance that extradition cannot be granted to another State party to the same instrument is sufficient to consider it as always applicable, for the purposes of this study. In sum, no differentiation is made here based on whether the requesting State is a State party or a third State, on whether the right in question is absolute or relative, or on any other pragmatic factor.

\subsection{Grounds for refusal of extradition $v$. Prohibitions to deport}

In the context of human rights, extradition and other forms of removal of a person from a given territory tend to be treated somewhat uniformly, allowing for the assumption that, where one of them is prohibited, so are the others. Naturally, the premises and the consequences of extradition are not fully identical to those of other forms of removal, and thus it is possible that certain situations are irrelevant to one but relevant to another. ${ }^{76}$ For instance, if a person is not targeted (de jure or de facto) by a criminal procedure

73 The recent ruling of the ECJ in Celmer might lend some strength to this view, in that it extended the case law delivered on an absolute human right to a relative human right. See the Opinion of AG Tanchev thereon, at $\iint 57 \mathrm{f}$., and the ruling of the Court, at $\iint 45 \mathrm{f}$. Still, this must be pondered in the light of the particularities of this case, for what was at stake here was the independence of a State's judicial system as a whole, which affects also as a whole the participation of that State in a fully judicialised cooperation system as is the EAW. This particularily, on the other hand, may justify a differentiation by the ECJ between the threshold of breach of the right to a fair trial in the context of the EAW and in that of extradition to third States: see further infra, Chap. 4, \$ 3.3.4.b).

${ }^{74}$ See JaCques Hartmann, op. cit., p. 28.

75 As the ECtHR noted in Trabelsi, \117: "the Court reiterates that it is acutely conscious of the difficulties faced by States in protecting their populations against terrorist violence, which constitutes, in itself, a grave threat to human rights. It is therefore careful not to underestimate the extent of the danger represented by terrorism and the threat it poses to society (...). It considers it legitimate, in the face of such a threat, for Contracting States to take a firm stand against those who contribute to terrorist acts (...). Lastly, the Court does not lose sight of the fundamental aim of extradition, which is to prevent fugitive offenders from evading justice, nor the beneficial purpose which it pursues for all States in a context where crime is taking on a larger international dimension".

76 See notably Stamose v. Bulgaria, no. 29713/05, 27 November 2012, decided in favour of the complainant on the basis of Art. 2 of OP4-ECHR, on freedom of movement. The complainant, a Bulgarian citizen who had entered the USA on a student visa, and later abandoned the studies to take on paid employment, was deported to Bulgaria. The Bulgarian border police imposed a two-year travel ban on him for breaching 
in the receiving State, fair trial issues are out of consideration. However, when a given situation is relevant to all forms of removal, the same threshold applies to all of them.

The ECtHR upheld this principle in relation to guarantees provided by the receiving State in cases of possible breach of Art. 3 (torture/ill-treatment) in Harkins \& Edwards, ${ }^{77}$ and Babar Abmad \& Others. ${ }^{78}$ In this respect the Court takes a stance which contrasts with that which it takes in the very same rulings in respect of the thresholds applicable to internal and outward extradition: regarding the latter issue, the Court implies that a higher threshold applies if the receiving State is a not a State party to the ECHR $;^{79}$ regarding the former issue, it emphasises the little practical difference between different legal bases of removal: "For example, extradition requests may be withdrawn and the Contracting State may nonetheless decide to proceed with removal from its territory. ${ }^{80}$ Equally, a State may decide to remove someone who faces criminal proceedings (or has already been convicted) in another State in the absence of an extradition request. ${ }^{81}$ Finally, there may be cases where someone has fled a State because he or she fears the implementation of a particular sentence that has already been passed upon him or her and is to be returned to that State, not under any extradition arrangement, but as a failed asylum seeker." ${ }^{\prime 2}$. The Court thus concludes: "it would not be appropriate for one test to be applied to each of these three cases but a different test to be applied to a case in which an extradition request is made and complied with." 83

The issue is not clearly defined in relation to relative rights, but the reasoning applies to them in identical terms: the patterns of State conduct selected by the Court to illustrate the similarity between extradition and other forms of removal are not exclusive of a scenario of potential ill-treatment. In sum, no distinction is made in this chapter based on the legal basis of the removal, whether in respect to absolute or to relative human rights.

\subsection{Conduct of the requesting State v. Other sources of harm}

Yet a different question is that as to whether a violation of the ECHR requires the prohibited harm to have been intentionally inflicted by the receiving State, or instead may be caused by exogenous sources such as civil war, absence of indispensable health care or food, and persecution from non-State agents. ${ }^{84}$ It has been argued that the Court should admit the second set of situations to fall within the scope of the Convention. This line of reasoning has acute similarities with the 'expansive approach' mentioned above in respect of the 'extraterritoriality' issue, in that it emphasises, on the one hand, that in extradition

USA immigration laws. He alleged that the ban had been unjustified and disproportionate, and that it had prevented him from travelling to the USA, where his mother and brother lived. He further complained that Bulgarian courts had not reviewed the proportionality of the measure.

${ }_{77}$ Cit., $\int 128$.

78 Cit., $\int 167 \mathrm{f}$.

${ }^{79}$ See supra, $\int 3.3$.

${ }^{80}$ See Muminov v. Russia, no. 42502/06, 11 December 2008, \ 14.

${ }^{81}$ See e.g. Saadi v. Italy, cit., and Bader \& Kanbor v. Sweden, no. 13284/04, 8 November 2005.

82 See D. \& Others v. Turkey, no. 24245/03, 22 June 2006.

83 Babar Ahmad \& Others, cit., \168 (case law cited by the Court itself)

84 See JaCQues Hartmann, op. cit., p. 31. 
cases liability rests with the requested State, rather than with the requesting State, and, on the other hand, that for the targeted person the consequences are identical irrespective of their source. Thus, Close, for instance, advocates that "it should not matter whether the suffering of an individual arises from an intentional act or a natural condition as long as it reaches a certain degree of gravity and can be prevented by the act of a Convention state", and that "even if a state's responsibility is not engaged on the basis of the deficiencies of its health system, the actions subject to scrutiny under the ECHR are not those of the receiving state but of the expelling state". ${ }^{5}$ The stance finds some backing in Mbunzu (1992), ${ }^{86}$ and in the dissenting opinion of Judge Power-Forde in S.J. v. Belgium (2014) ${ }^{87}$.

Nevertheless, this distinction is fundamentally different from that drawn above between 'internal' and 'outward' extradition. The human rights system set in place in the post-war has at its heart the realisation of the necessity to restrain State conduct which is harmful to individuals. If a State is willing and able to repress a certain crime in a manner which is compatible with human rights, and the only potential sources of harm verified in the case are of an exogenous nature, ${ }^{88}$ then blocking extradition in the exact same conditions as if the harm were produced by the receiving State is the one manner in which an imposition of standards on third States may be deemed to take place. Ultimately, States where, owing to most varying factors, living conditions are more precarious than in the State of custody, would have much narrower possibilities of pursuing the effectiveness of their sanctioning systems - something of a State capitis deminutio. Thus, in this aspect, the concept of 'ground for refusal imposed by human rights' adopted in this study is aligned with the dominant view in human rights case law that, in the case of exogenous sources of harm, higher thresholds must be met. This means, for instance, that the 'humanitarian clause', as such, does not rank as a human right - although the supreme importance of

\footnotetext{
85 JOSEPHA CLOSE, op. cit.

86 Mbunzu v. Netherlands, no. 17878/91, 10 May 1992, abridged by JACQUES HARTMANN, op. cit., p. 33 f.: "This was an admissibility case decided by the Commission before a restructuring of the Court took place and is thus possibly of limited precedent. (...) The case concerned expulsion from the Netherlands to Angola, a country at that time devastated by civil war. The applicant argued that in view of the continuing violence in Angola and its general shortage of food, he would, if returned, certainly die as a result either of starvation or forced conscription. The Commission considered that the general situation in Angola at the time of the applicant's requests was undoubtedly unstable but that the applicant had failed to substantiate as to how his personal situation was worse than that of the generality of other young Angolan men who were enlisted for active service. Consequently, the Commission held that Mbunzu had failed to disclose evidence sufficient to establish that he was personally at real risk of a violation. Notwithstanding the above, it did not find the claim to be unprotected by the Convention. It is uncertain (...) what may be inferred from this decision but it seemingly does not rule out that a lack of food in the receiving State or the threat of forced conscription therein may prevent removal, although the Commission did insist on the existence of an individualised threat." The author further emphasises his view that the indirect effect of the ECHR, first attributed to Art. 3, "may find analogous application in Article 2".

87 S.J. v. Belgium, no. 70055/10, 27 February 2014. As summarised by JOSEPHA ClOSE, op. cit., the dissenting magistrate emphasised: "the 'crucial fact' that will precipitate the suffering and death of the applicant is not the failure of the receiving country's health system but the implementation of the removal decision by the expelling state."

${ }^{88}$ Arguably, the concepts 'imputable to the receiving state' and its antonym 'exogenous' are very subjective. Some circumstances are neither strictly 'imputable' nor strictly 'exogenous', but instead 'partly imputable' or 'partly endogenous'.
} 
some of the values and rights it seeks to protect (life, health) justifies assigning it a 'parahuman rights' character.

\subsection{Human rights grounds for refusal $v$. Treaty-based obligations to extradite}

While human rights conventions may command refusal of extradition, decisions to refuse extradition may breach other treaties. In a thorough survey on the hierarchy between human rights and extradition, van der Wilt sets the terms of the problem clearly: "In order to extend their capacity to prosecute crimes, states engage in treaty relations, compelling them to surrender fugitives on a reciprocal basis. By the same token, contracting states expose the fugitive to foreign criminal justice which may fall short of human rights standards. (...) The requested state thus faces a real 'Catch-22' situation. Whichever way it chooses, it will flout treaty obligations." 89

The author notes that, in order to keep their international relations running smoothly, requested States seek as much as possible to escape the conflict, using, to that end, certain "avoidance techniques", such as: invoking the rule of non-inquiry; relying on assurances provided by the requesting State; requiring the targeted person to produce profuse evidence supporting the claim that a human rights breach is likely to occur; and arguing that local and international remedies will still be available after extradition is effected..$^{90}$ The common denominator is that extradition is favoured, to the detriment of human rights protection.

In any case, van der Wilt ultimately concludes that the norms provided for in international conventions on human rights "do not as a matter of principle prevail" over obligations to extradite based on pre-existing extradition treaties: Art. 30 of the Vienna Convention on the Law of Treaties, on the hierarchical relation between conflicting treaty obligations, refers to Art. 103 of the UN Charter, which confers primacy to the Charter over any other international agreement, and Art. 55 of the Charter commands the UN to promote universal respect for, and observance of, human rights and fundamental freedoms; however, "it is questionable (...) whether such a broadly phrased 'declaration of intent' could sustain the general hierarchical superiority of human rights, as it fails to mention which human rights should prevail and what level of infringement is required." "91 Swart had also already posited that the case law of the ECtHR on extradition in and since Soering "cannot be read as justifying a general principle to the effect that, notwithstanding its

${ }^{89}$ HaRmen VAN DER WILT, op. cit., p. 148 f., completing: "If it decides to refuse the extradition request out of concern for the prospective fate of the requested person, it will elicit the wrath of the requesting state that may choose to retaliate in kind by denying extradition in similar situations. If, on the other hand, [it] decides to take the risk and surrenders the fugitive, the state may turn out to be co-responsible for violating human rights, not only vis-à-vis the victimized individual but also towards its contracting partners of a human rights convention." At stake here is a clash between treaty obligations "in the narrow sense": "Different from the situation in which a state has to balance its right to grant or deny access to its territory with its obligation to observe the principle of 'non-refoulement' to refugees, in the case of extradition states have no option to circumvent the conflict of obligations by abstaining from exercising their rights."

${ }^{90}$ Ibid., p. 150 f., 172 f. In a similar sense, see also JOHN DUGARD / CHRISTINE VAN DEN WYNGAERT, op. cit., p. 87 f., CHRISTINE VAN DEN WYNGAERT, "Applying the European Convention on Human Rights to Extradition ...” op. cit., p. 757 f.; BERT SwART, “Human Rights...” op. cit., p. 505 f.

${ }^{91}$ Harmen VAN DER WILT, op. cit., p. 151 f., 172 f. 
extradition obligations, a Contracting State may not surrender an individual unless satisfied that the conditions awaiting him in the country of destination are in full accord with each of the safeguards of the Convention". ${ }^{92}$ Thus, the general rules of the Vienna Convention on hierarchy apply, which means that the human rights nature of a given norm does not per se determine its preponderance over a norm of a qualitatively different nature. ${ }^{93}$ The situation described is different only insofar as absolute human rights are concerned - which are basically limited to the prohibition of torture/ill-treatment. ${ }^{94}$ Therefore, the bulk of human rights case law upholding obstacles to extradition does not reflect perfectly the actual scope of prohibitions to extradite under current international law.

In practice, however, the fact that the human right that has broader application in human rights case law on extradition - sc. the prohibition of torture/ill-treatment - does assuredly have unconditional applicability vis-à-vis other international obligations pointedly mitigates that discrepancy. The hierarchical relation between the conflicting extradition and human rights instruments is decisive only insofar as relative human rights are concerned. Moreover, from the moment of accession to a human rights legal instrument, States undertake to at least henceforth comply with the corresponding human rights obligations, namely when concluding new extradition treaties or amending old ones. This in itself would already meet the forward-looking concept of 'grounds for refusal imposed by human rights' intended for the purposes of this study.

\subsection{Conclusion}

The foregoing criteria encompass situations where extradition is in fact prohibited by human rights law and situations where it is not, but which are adjacent to the former, and which as such may be labelled as 'para-human rights' prohibitions to extradite. Together, these two groups produce the intentionally broad concept of 'grounds for refusal imposed by human rights' intended for the purposes of this study.

\section{Grounds for refusal imposed by human rights}

Drawing on the foregoing criteria, this section provides a list of grounds for refusal deriving from the ECHR. The systematisation follows the order of the provisions of the ECHR, an objective criterion which, at the same time, to some extent, reflects the different relevance of different human rights in the field of extradition.

\footnotetext{
92 BERT SWART, "Refusal of Extradition...”, op. cit., p. 204.

${ }^{93}$ See ibid. Regarding this prohibition, HARMEN VAN DER WILT, op. cit., p. 173, notes that its hierarchical supremacy over extradition obligations "is not explicitly buttressed by a reference to its jus cogens character", but on its "special status within the realm of human rights as an absolute right, allowing no derogation", which is something that is "widely acknowledged".

94 See BERT SWART, "Refusal of Extradition...”, op. cit., 205, albeit remarking at p. 206: "Perhaps the priority of the human rights treaty derives from customary international law, in the sense that it is generally accepted in State practice that the requested State may refuse extradition if extraditing a person would be contrary to its obligations arising out of human treaties". The author concludes: "Whatever the case, conflicts between treaty obligations should be avoided and eliminated by revising extradition treaties to the effect that extradition may be refused whenever the person claimed is likely to suffer from a violation of his basic human rights in the requesting State.
} 


\subsection{Right to life}

\subsubsection{Death penalty}

As is well known, neither the ECHR nor the ICCPR preclude in absolute terms the death penalty, which is not proscribed by customary international law either. State inflicted death is prohibited only if certain conditions are not complied with. ${ }^{95}$ If a State which is requesting extradition does not comply with those conditions, a State which is requested to extradite and is a party to those instruments shall refuse the request in the name of the right to life - as was the case in Öcalan v. Turkey (2005), ${ }^{96}$ Bader \& Kanbor v. Sweden (2005), ${ }^{97}$ Al Nashiri v. Poland (2014), ${ }^{98}$ and A.L. (X.W.) v. Russia (2015). ${ }^{99}$ If, however, such conditions are met, extradition is not prohibited. In fact, in the original versions of neither the ECHR or the ICCPR was death penalty censored as such. As the ECtHR has noted, 60 years ago the death penalty did not violate international standards. ${ }^{100}$

An abolitionist movement would however ensue, leading a meaningful number of States to subscribe to international obligations to eradicate the death penalty. Eradication was effected in absolute terms in Optional Protocol no. 13 to the ECHR (2002), ${ }^{101}$ and in quasi-absolute terms in Optional Protocol no. 2 to the ICCPR (1989). ${ }^{102}$ The Charter of Fundamental Rights of the EU prohibits the death penalty in absolute terms in Art. 2 (2), and explicitly prescribes it as an obstacle to extradition, alongside torture/ill-treatment, in

95 See notably Art. 2 ECHR (and Art. 2 ICCPR).

96 Öcalan v. Turkey, no. 46221/99, 12 May 2005. The case concerned the former leader of the PKK, arrested in Kenya, taken to Turkey, and sentenced to death in 1999 for separatist acts. With the abolition of the death penalty in Turkish law in peacetime, in 2002, the sentence was commuted to life imprisonment. The Court held that there had been no violation of Art. 2 (right to life), 3 (prohibition of ill-treatment), or 14 (prohibition of discrimination) ECHR, because the death penalty had been abolished and the sentence commuted. However, the Court did assert it would be contrary to Art. 2 to implement a death penalty following an unfair trial.

${ }^{97}$ Cit. In this case, the applicants were a family of four Syrians whose asylum applications had been refused in Sweden and who were ordered to be deported back to Syria. They claimed that, since the father had been convicted in absentia of complicity to a murder, and sentenced to death, he ran a real risk of being executed. The Court found that there was a serious risk that the sentence would be executed. And, since executions were carried out with no public scrutiny or accountability whatsoever, he would inevitably experience considerable fear and anguish. Moreover, the criminal procedure had been summary in nature and carried out in flagrant disregard of fair trial rights, which generated further fear and anguish. The Court thus ruled that, in the case, deportation to Syria would carry a violation of Arts. 2 (right to life) and 3 (prohibition of ill-treatment).

${ }^{9}$ Al Nashiri v. Poland, no. 28761/11, 24 July 2014, concerning a Saudi Arabian of Yemeni descent detained in Guantanamo on terrorist charges. The Court found that there had been a breach by Poland of, inter alia, Arts. 2 and 3 ECHR, in conjunction with Art. 1 OP6, due to having enabled the CIA to transfer the applicant to its jurisdiction to face a probable death penalty. A similar verdict was reached in relation to the same applicant in AlNashiri v. Romania, no. 33234/12, 31 May 2018.

${ }_{99}$ A.L. (X.W.) v. Russia, no. 44095/14, 29 October 2015, concerning a Russian resident wanted in China, where he would run a risk of being sentenced to death.

100 Al-Saadoon and Mufdhi v. UK, no. 61498, 2 February 2010.

101 OP6-ECHR of 1983, had already taken large steps in that direction, but it did not exclude the death penalty for acts committed in time of war or of imminent threat of war.

102 The death penalty is still permitted, although it is permitted only in time of war pursuant to a conviction for a most serious crime of a military nature committed during wartime: Art. 2 (1). 
Art. 19 (2). The ratification record of OP13-ECHR is truly massive, counting 44 of the 47 members of the CoE. ${ }^{103}$ In view of this evolution, the ECtHR eventually held - in $\mathrm{Al}$ Saadoon \& Mufdhi (2010) ${ }^{104}$ - that the death penalty, as a "deliberate and premeditated destruction of a human being by the State authorities causing physical pain and intense psychological suffering as a result of the foreknowledge of death", could breach the Convention itself. Accordingly, the Court ruled the extradition of the applicants to amount to a violation of the Convention. However, it ultimately grounded the ruling on its Art. 3, rather than on its Art. $2 .{ }^{105}$ On the other hand, in Z. \& T. v. UK (2006), the Court remarked obiter dictum that the case law established in Soering "applies equally" to the risk of breach of the right to life of Art. $2{ }^{106}$ However, no ruling known to this author has held extradition to be inadmissible exclusively on that basis.

It follows that, currently, capital punishment, as an infringement of the right to life, is absolutely prohibited only for the States, however many, that have ratified the optional protocol(s).$^{107}$ Such instruments - it should moreover be noted -, do not rigorously meet the concept of 'imposition' adopted in this study. ${ }^{108}$ The specificity of their contents renders them 'deliberate', and the fact that they require an autonomous act of ratification reflects a limitation of the living instrument doctrine, in that not even an evolutionary interpretation would be able to extract such contents from the original text of the Convention. Also, although non-accession to this type of protocol can carry reputational implications, it tends not to be required for integration in any institutional framework.

Nevertheless, the optional protocols do constitute human rights instruments themselves, have been ratified by a considerable number of States, and have been accredited by the instance that applies them the potential to influence the scope of the original text of the respective conventions. While this prospect has not fully materialised so far, the growing consensus as to the proscription of the death penalty justifies bringing these grounds for refusal under the concept of 'imposed by human rights' for the purposes of this study.

\subsubsection{Other lethal circumstances}

It has been observed that it is the prevailing understanding that for a human rights violation to occur which is not directly imputable to the receiving State but to exogenous factors such as civil war or the lack of medical treatment, a higher threshold applies. This position has been subscribed to, and it is reinstated here: the existing human rights system seeks primarily to restrain harmful State conduct; only to a lesser extent can it be re-

${ }^{103}$ http://conventions.coe.int/Treaty/Commun/ChercheSig.asp?NT=187\&CM=\&DF=\&CL=ENG.

104 The case concerned two Iraqis, Sunny Muslims, accused of involvement in the murder of two British soldiers briefly after the invasion of Iraq in 2003. They complained that their transfer by British to Iraqi authorities carried a real risk of them being executed by hanging.

105 Al-Saadoon \& Mufdhi, cit., S 120, passim. To some extent this had already been implied in Öcalan, cit., where the court stated that the death penalty in peacetime had come to be regarded in Europe as unacceptable and no longer permissible under Art. 2 (irrespectively of whether the trial had been fair), but ultimately the court had also relied on Art. 3 in this ruling.

106 Z. \& T. v. UK, no. 27034/05, 28 February 2006, \ 4.

107 See Shamayev \& Others v. Georgia \& Russia, no. 36378/02, 12 April 2005, \ 333.

108 See supra, Chap. 2, S 2.2.1.a). 
lied upon to prevent harm arising from other sources. ${ }^{109}$ This does not mean that serious threats to paramount values such as life should not be taken into account, and be regarded as 'para-human rights' for these purposes.

In any case, there is potentially lethal conduct other than the application of a death penalty which may be imputable to a State. For instance, in the event - encompassed by the humanitarian exception found in several international treaties and national statutes on extradition - where, owing to some medical condition, a person runs serious risk of death as a consequence of the travel required to effect extradition, or of an absence of adequate medical treatment. In such an event, extradition should be considered as directly prohibited by human rights, and the 'regular' threshold of breach as being applicable. One case which illustrates this well is Aswat v. UK (2013), ${ }^{110}$ which however was not addressed under the right to life enshrined in Art. 2 ECHR either, but under its Art. 3, on the prohibition of ill-treatment.

\subsection{Prohibition of torture and ill-treatment}

As already noted, the prohibition of torture/ill-treatment ${ }^{111}$ enjoys a special position within the human rights system, as an absolute, insurmountable command. It is therefore natural that the first case where an extradition was held to breach a human rights legal instrument concerned this prohibition. For the same reason, it is also natural that most subsequent human rights case law on extradition was developed by reference to this prohibition - even inasmuch as it concerns certain situations that in extradition law are considered under very different parameters, such as the applicability of certain penalties in the requesting State. The following paragraphs address the most noteworthy elements forming this body of case law.

\subsubsection{Death penalty}

The death row phenomenon is the inaugural hypothesis of human rights case law on extradition, in Soering (1989). ${ }^{112}$ It forms one of the situations triggering ill-treatment contrary to Art. 3 ECHR (and Art. 7 ICCPR). ${ }^{113}$ However, the recognition of the death row phenomenon as a form of ill-treatment, even though it may be associated with abolitionist principles, ${ }^{114}$ is not grounded on the same considerations that underlie the death penalty exception found in States which do not apply such a penalty domestically: these States

109 See supra, $₫ 3.5$.

110 Aswat v. UK, 17299/12, 16 April 2013, addressed again infra, $\int 4.2 .5$.

${ }^{111}$ For a distinction between 'torture' and 'inhuman and degrading treatment', see WiLLIAM A. SCHABAS, The European Convention on Human Rights: A Commentary, Oxford: University Press, 2015, p. $174 \mathrm{f}$.

112 Also Einhorn v. France, no. 71555/01, 16 October 2001, although the application was ruled inadmissible.

113 Considering the great wealth of literature that has been produced on this issue, it would be superfluous to engage here in a description of the concept of 'death row phenomenon': see e.g. WiLLIAM A. SCHABAS, "Soering's Legacy..." op. cit., p. $913 \mathrm{f}$.

114 See William A. ScHabas, “Soering's Legacy...” op. cit., p. 915, reporting that, after Soering, "[a]round the world, inmates on death row hoped that the prestige of the European Court's judgment would have a persuasive effect upon their own domestic tribunals". See also JOHANNA HARRINGTON, op. cit., p. 102, classifying UNHRC's Kindler as a ruling “clearly favouring the eventual abolition of the death penalty". 
tend to refuse extradition, with no further condition, whenever such a penalty may apply in the requesting State. ${ }^{115}$ This serves to underscore that, conceptually, the risk of application of the death penalty in the requesting State only falls within the category of 'grounds for refusal imposed by human rights' due to the comprehensive approach defended above.

The same applies, mutatis mutandis, to the carrying out of the death penalty in other circumstances which in themselves infringe upon the prohibition of torture/ill-treatment, such as stoning or flogging, which has as its central case Jabari v. Turkey (2000). ${ }^{116}$ It also applies to life imprisonment and other hypotheses addressed throughout the subsequent paragraphs.

\subsubsection{Life imprisonment}

The consideration of irreducible life sentences within the prohibition of torture/illtreatment forms a clear example of the expansiveness of human rights in the field of extradition. Already during the elaboration of this study, in Trabelsi v. Belgium (2014), ${ }^{117}$ the ECtHR, assessing this situation on the merits for the first time, ${ }^{118}$ ruled that extraditing a person to a State where he/she runs a real risk of being sentenced to life imprisonment without the possibility of release violates Art. 3. Like Soering, this ruling was not fully unexpected, as it was consistent with the principle established in Soering, combined with the ECtHR's ruling in Vinter \& Others v. UK (2013), on the application of an irreducible life sentence by a State party itself. ${ }^{119}$

That a grossly disproportional or irreducible life sentence could raise issues under Art. 3 had already been admitted by the Court on several occasions. ${ }^{120}$ In Kafkaris v. Cyprus (2008), the Court had held that such a provision requires criminal sentences to be "de jure and de facto reducible". ${ }^{121}$ The concept of 'irreducible sentence', however, was quite difficult to meet. Too much so - some considered - for an issue with Art. 3 to ever arise in

115 Note in any case that not all abolitionist States have corresponding grounds for refusal of extradition. An example is precisely Canada, which extradited Kindler to the USA to face a death penalty: see JOHANNA HARRINGTON, op. cit., p. 99.

116 See Jabari v. Turkey, no. 40035/98, 11 July 2000. The applicant was an Iranian woman who had escaped from Iran, where she had been detained due to having had a relationship with a married man. She was arrested in Istanbul for using a forged Canadian passport, and complained that she ran a real risk of death by stoning if she were returned to Iran. The Office of the UN High Commissioner for Refugees found that she indeed risked inhuman punishment in Iran, particularly death by stoning, and granted her refugee status. The Court took this assessment into account, further noting that punishment of adultery by stoning was still prescribed by Iranian law and might be used. The Court thus ruled that, in the case, deportation to Iran would breach Art. 3. Similar facts were at issue in Razaghi v. Sweden, no. 64599/01, 25 January 2005, but since the Swedish expulsion order was revoked and a permanent residence permit granted, the case was struck out.

117 Cit.

118 Cedric Ryngaert / AbDullahi Abdulrahman AbDalla, op. cit.

119 Vinter \& Others $v$. UK, no. 66069/09, 130/10 and no. 3896/10, 9 July 2013.

120 E.g. in Weeks v. UK, no. 9787/82, 2 March 1987, V. v. UK, no. 294888/94, 16 December 1999, Nivette v. France, no. 44190/98, 14 December 2000 / 3 July 2001, Einhorn v. France, cit., Stanford v. UK, no. 73299/01, 12 December 2002, and Wynne v. UK, no. 67385/01, 22 May 2003.

121 Kafkearis v. Cyprus, no. 21906/04, 12 February 2008, \ 98. 
removal cases. ${ }^{122}$ In that case, after emphasising that a sentence could be considered reducible "even in the absence of a minimum term of unconditional imprisonment and even when the possibility of parole for prisoners serving a life sentence is limited", the Court concluded that, in the case, the sentence was not irreducible, because the Head of State of Cyprus had the power (purely discretionary in its character, but proven to have been used in the past) to suspend, remit or commute a sentence upon recommendation of the Attorney-General. ${ }^{123}$ A similar stance was followed in Iorgov v. Bulgaria (2010). ${ }^{124}$

Kordian v. Turkey (2006), on the admissibility of a case involving extradition, also did not augur an outcome as that later brought by Trabelsi: the ECtHR paid little attention to the issue of irreducible life sentences, declaring itself "unable to speculate whether the applicant would receive a life sentence without the possibility of parole, the conditions in which he might serve that sentence or the effect such a sentence might have on him". ${ }^{125}$ In this setting, Hartmann, although submitting that irreducible life sentences could "theoretically prevent extradition", concluded that "any such claim would be unlikely to succeed". ${ }^{26}$

This was plainly reflected in Harkins \& Edwards v. UK (2012). Here the Court added a further condition for a breach of Art. 3 to occur: that incarceration would prove not to be necessary anymore on "legitimate penological grounds". The Court thus ruled that neither this requirement nor that of 'irreducibility' could be met in a case where "the applicant has not yet been convicted, still less begun serving his sentence": "Indeed, if he is convicted and given a mandatory life sentence, it may well be that, as the Government have submitted, the point at which his continued incarceration would no longer serve any purpose may never arise. It is still less certain that, if that point were ever reached, the Governor of Florida and the Board of Executive Clemency would refuse to avail themselves of their power to commute the applicant's sentence". ${ }^{27}$ This view was in turn replicated almost ipsis verbis later the same year in Babar Abmad \& Others v. UK (2012). ${ }^{128}$

In Vinter the ECtHR undertook to "re-examine" "129 the concept of 'reducibility', in a purely 'internal' case, by reference to the legal system of the UK. The Crime (Sentences) Act 1997 provides in s. 30 (1) that "[t]he Secretary of State may at any time release a life prisoner on licence if he is satisfied that exceptional circumstances exist which justify the prisoner's release on compassionate grounds", while chapter 12 of the Indeterminate Sentence Manual, issued by the Home Secretary in 2010, limits compassionate release on medical grounds to convicts with a terminal illness likely to cause their death very shortly. ${ }^{130}$ The

122 See Josepha Close, op. cit.

123 Kafkaris, cit., \$S 98, $102 \mathrm{f}$.

124 Iorgov v. Bulgaria, no. 36295/02, 2 September 2010, JS 51-60.

125 Kordian v. Turkey, no. 6575/06, 4 July 2006, J 1.c.

${ }^{126}$ JaCQUes HARTMANn, op. cit., p. 36 f. (the text is posterior to Kafkaris, but does not yet cover it), recalling that in the moment of extraditing the person has not usually been sentenced or served the sentence or a significant part of it, and hence such a concept of 'irreducibility' could hardly be met in that moment.

127 Harkins \& Edwards v. UK, cit., \ 140.

128 Babar Ahmad \& Others, cit. The USA sought extradition on terrorism charges. The applicants claimed they risked serving in a super-max prison (on this, see infra, $\int 4.2 .3$ ) irreducible life sentences.

129 The expression is that used in Trabelsi, $₫ 115$.

130 See NAOMI HART, op. cit., p. 206. 
ECtHR found ${ }^{131}$ that the rules of the UK on life sentences review violated Art. 3, as the Manual's "restrictive and apparently exhaustive grounds for sentence reduction did not accommodate other legitimate penological grounds for a commutation", and it was "unclear how the Home Secretary would exercise his or her discretion to reduce a life sentence outside of the bases in the Manual". ${ }^{132}$ Drawing on its previous case law, the Court stated that in order for a life sentence to be reducible it must be open to a review that considers whether in the course of the sentence the prisoner has undergone such changes and made such progress towards rehabilitation that imprisonment may no longer be justified on legitimate penological grounds. ${ }^{133}$ Then it "explained for the first time" "134 that: "Although the requisite review is a prospective event necessarily subsequent to the passing of the sentence, a whole life prisoner should not be obliged to wait and serve an indeterminate number of years of his sentence before he can raise the complaint that the legal conditions attaching to his sentence fail to comply with the requirements of Article 3 in this regard. This would be contrary both to legal certainty and to the general principles on victim status within the meaning of that term in Article 34 of the Convention. (...) A whole life prisoner is entitled to know, at the outset of his sentence, what he must do to be considered for release and under what conditions, including when a review of his sentence will take place or may be sought." ${ }^{\text {"135 }}$ Such an expansion of the 'penological legitimacy' and 'reducibility' requirements made it possible to consider them in virtually any extradition case. If applied "lockstock-and-barrel" to the circumstances of Trablesi, it had almost inevitably to produce the verified outcome. ${ }^{136}$ In later cases, the Court rejected applications in cases similar to Trabelsi, namely in Findikoglu v. Germany (2016), ${ }^{137}$ and Harkins v. UK (2017), ${ }^{138}$ but these were admissibility decisions. ${ }^{139}$ As mentioned before, the verdict reached by the Court in Trabelsi has however been rendered unstable by the ECtHR's "withdrawal", ${ }^{140}$ in Hutchinson v. UK (2015), ${ }^{141}$ from the expansion it had operated in Vinter.

131 SS $125-130$.

132 NAOMI HART, op. cit., p. 206.

133 Vinter \& Others, $\int 119$.

134 To use again an expression found in Trabelsi, $\int 115$ (emphasis added).

135 Vinter \& Others, \122, adding: "Consequently, where domestic law does not provide any mechanism or possibility for review of a whole life sentence, the incompatibility with Article 3 on this ground already arises at the moment of the imposition of the whole life sentence and not at a later stage of incarceration."

136 Cedric Ryngaert / AbDullahi AbDulrahman ABDAlla, op. cit; see also Zoe Bedell, op. cit. See again the very ruling: Trabelsi, cit., SS 35, 128-130.

137 Findikoglu v. Germany (2016), no. 20672/15, 7 June 2016. The applicant was extradited to the USA on charges of an attack at the computer networks of certain financial service providers. He claimed he faced a maximum penalty of 247.5 years, meaning that, if convicted, he would have no prospect of being released.

138 Harkins v. UK(2017), no. 71537/14,15 June 2017, rejecting admissibility because the claim was "substantially the same" (see Art. 35 \2 (b) ECHR) as that already made by the applicant in Harkins \& Edwards, cit.

139 The similarity between Trabelsi and Harkins was established by the Court itself in Elorza, cit., \& 101.

140 MARK PETTIGREW, “A Vinter retreat in Europe: Returning to the issue of whole life sentences in Strasbourg”, NJECL 8 (2017), p. 132, et passim, assessing also the evolution of the domestic case law of the $\mathrm{UK}$ in the aftermath of ECtHR's Vinter.

${ }^{141}$ Hutchinson v. UK, no. 57592/08, 3 February 2015. 
Following Vinter, an important decision was taken in the UK by a specially constituted Court of Appeal. ${ }^{142}$ This Court held that, in Vinter, the ECtHR had "misconstrued" the review mechanism of the UK, by construing that the Home Secretary's power to review such sentences arises only where exceptional circumstances occur. ${ }^{143}$ It noted that the Indeterminate Sentence Manual offers guidance for sentence relief, but cannot and in effect does not "fetter" the Home Secretary's discretion, which, according to s. 6 Human Rights Act 1998, he/she must exercise in conformity with Art. 3 ECHR. ${ }^{144}$

Then came ECtHR's ruling in Hutchinson, on a situation that was nothing short of a "replica" of that at stake in Vinter, and in a context where "nothing had changed in England and Wales, legally, after the Vinter decision, except an increased amount of defiance to the Strasbourg court from the judiciary", as illustrated above. ${ }^{145}$ In Hutchinson, however, the ECtHR interpreted Vinter as establishing that "if section $30(\ldots)$ impos[es] a duty on the Secretary of State to exercise his power of release if it could be shown that the prisoner's continued detention was no longer justified on penological grounds, (...) this would, in principle, be consistent with the requirements of Art. 3". ${ }^{146}$ As abridged by Hart: "While Vinter had found that the UK's regime did not permit the review demanded by Art. 3, the subsequent Court of Appeal decision provided an 'unequivocal statement' that, under British law, the Home Secretary must consider all exceptional circumstances that could warrant a sentence reduction. The ECtHR considered itself bound to recognize the Court of Appeal's interpretation of national law as definitive. (...) For that reason, it accepted that the UK's system of reviewing whole-life sentences complied with Art. $3 "{ }^{147}$ In sum, Hutchinson does not appear to require anymore such a high degree of clarity as to the conditions under which a person may see a life sentence be reduced, which "severely dilutes the requirement that the rules regulating review, and possible release, allow the prisoner to foresee the eligibility and possibility of such review". ${ }^{148}$ In Matiošaitis \& Others v. Lithuania (2017), the Court did uphold that presidential pardon and other review measures available in Lithuania were insufficient for life sentences to be considered 'reducible' for the purposes of Art. 3 ECHR, and, therefore, that this provision had been breached. ${ }^{149}$ However, this ruling stays quite some way from 're-reversing' Hutchinson. ${ }^{150}$

142 R. v. Newell (Lee William) / R. v. McLoughlin (Ian) [2014] EWCA Crim 188; [2014] 1 W.L.R. 3964.

143 SS 14-22, 31-36; NAOMI HART, op. cit., p. 206.

144 See NAOMI HART, op. cit., p. 206.

145 MARK PETTIGREW, “A Vinter retreat...” op. cit., p. 132.

146 Hutchinson, cit., $\int 22$.

147 NAOMI HART, op. cit., p. 206. Criticising this development, see also MARK PETTIGREW, "A Vinter retreat..." op. cit., p. 128 f. It should be noted that the ruling counts two dissenting opinions, by Judge López Guerra and Judge Pinto de Albuquerque.

148 STEVE FOSTER, "Case Comment - The great review and release swindle: the European Court, whole life sentences and the possibility of review and release, CovLJ 20 (2015), p. 56.

149 Matiošaitis \& Others v. Lithuania, no. 22662/13, no. 51059/13, no. 58823/13, et al., 23 May 2017.

${ }^{150}$ Under Lithuanian law, only prisoners serving fixed-term sentences are eligible for early release. As for commutation owed to a terminal illness, the Court reiterated its established view that it cannot be regarded as a prospect of release. On the other hand, all previous amnesties passed by Parliament had not applied to prisoners convicted of the most serious crimes, and three of them had even excluded life prisoners from their scope; moreover, as general act, amnesties do not take into account the rehabilitation of each individual. As 
Hutchinson cooled the impetus of what Judge Power-Forde had labelled in his concurring opinion in Vinter as a "right to hope". Insofar as the topic of this research is concerned, it also means that the ruling of the ECtHR in Trabelsi may not have immediate sequence - as to some extent has already been suggested by Harkins, and, especially, by Findikoglu, although, as noted, these were mere admissibility decisions. ${ }^{151-152}$ Furthermore, in Elorza (2017) - also already mentioned -, concerning a possible extradition from Spain to the USA, the Court, ruling on the merits, held that Art. 3 ECHR would not be violated if extradition were granted. There were, however, pointed differences between this case and Trabelsi. To begin with, the fact that the prospect of a life sentence being applied was utterly "slight and hypothetical". ${ }^{153}$

At any rate, in spite of the significant instability by which it is currently surrounded, this ground for refusal should be considered, for the purposes of this study, as 'imposed by human rights', since the existence of a precedent, even if to a large extent 'withdrawn', already casts strong doubts as to the compatibility of this hypothesis ( $s c$. applicability of life sentences in a State that requests extradition) with human rights. Moreover, such a 'withdrawal' does not signify that this hypothesis is irrelevant under human rights law; it only narrows the relevance that had been transitionally conferred upon it by previous case law.

\subsubsection{Other circumstances related to the criminal justice system of the requesting State}

Among other hypotheses which may fall within the concept of torture/ill-treatment for the purposes of Art. 3 ECHR, we find other actions of, or conditions in place in the requesting State concerning its criminal justice system. These include the use of certain interrogation techniques, ${ }^{154}$ and prison conditions. ${ }^{155}$

for the eventual reclassification and commutation of a life sentence was a one-time possibility and all applicants who had already applied under that provision had been unsuccessful. Finally, presidential pardon is possible within a period substantially lower than the 25 years indicated as acceptable in e.g. Vinter and in Murray v. the Netherlands, no. 10511/10, 26 April 2016, the procedure was transparent, accessible and involved an assessment of whether imprisonment remained justified on 'legitimate penological grounds'. However, it did not render life sentences de facto reducible, because, inter alia, there was no duty to provide reasons for refusing a request for pardon. Moreover, based on a report by the European Committee for the Prevention of Torture, the Court held that conditions for life convicts in Lithuanian were not foreordained to rehabilitation.

${ }^{151}$ Harkins is subsequent to Hutchinson, but Findikoglu is not, and even so the Court stated that the existence of a risk of a prison sentence amounting to life imprisonment could not be assumed, and that the issue as to whether the applicant would have any chances of release was irrelevant. It thus held the application inadmissible as being manifestly ill-founded. This indicates that the Court may have started, already at this point, to entertain doubts as to the conclusions it had reached in Vinter and Trabelsi.

152 An application is currently pending in Romagnoli v. Montenegro, no. 11200/15 (extradition to the USA).

153 Cit., $\ 119$; but cf. $\int \Omega 114$ f., noting the "number of ways" in which this case differed from Trabelsi.

${ }^{154}$ See e.g. Ireland v. UK, no. 5310/71, 18 January 1978 and Al-Moayad v. Germany, no. 35868/03, 20 February 2007, \$ 69 .

155 See e.g. Denmark, Norway, Sweden \& the Netherlands v. Greece, no. 3321/67, 5 November 1969, Dougoz v. Greece, no. 40907/98, 6 March 2001; Peers v. Greece, no. 28524/95, 19 April 2001, Kalashnikov v. Russia, no. 47095/99, 15 July 2002, and Ilascu \& Others v. Moldova \& Russia, no. 48787/99, 8 July 2004. 
Deficient prison conditions are at the basis of the ruling of the ECJ in Aranyosi \& Căldăraru, mentioned before and again later in this study. ${ }^{156}$ An important peculiarity with such hypotheses - and which goes a long way to explain why they have given rise to that ground-breaking ruling - is that they may occur even if in the abstract the requested and the requesting States are bound together by significant ties of affinity and trust.

\subsubsection{Discrimination}

Discrimination is proscribed by Art. 14 ECHR, a prohibition which is further reinforced by OP12 of 2000. The ECHR does not explicitly prohibit refoulement, but this constitutes perhaps the primeval guarantee against removal under human rights law, developed within the context of asylum law as a protection for refugees. Such a prohibition justifies autonomous consideration. ${ }^{157}$ However, at this point it is necessary to note that discriminatory treatment can be so intense as to amount to a violation of the very prohibition of torture/ill-treatment, or pose a strong indicator that acts of torture or ill-treatment will be inflicted upon the person after his/her transfer to another jurisdiction. ${ }^{158}$

Discriminatory factors include religion - an example of which is provided by M.E. $v$. France (2013), ${ }^{159}$ concerning a Coptic Christian from Egypt -, ethnic group - as is illustrated by Makhmudzhan Ergashev v. Russia (2012), ${ }^{160}$ concerning a Kyrgyzstani national of Uzbek origin -, language - as illustrated by Shakurov v. Russia (2012), ${ }^{161}$ where the claim was made, albeit unsuccessfully, that the applicant would risk workplace discrimination in Uzbekistan because, inter alia, he did not master the Uzbek language -, and political ideas or activities. The latter category encompasses an array of cases including Chahal, Öcalan, Saadi, Othman, and Babar Abmad \& Others, ${ }^{162}$ as well as Abdolkhani \& Karimnia v. Turkey (2009), Baysakov \& Others v. Ukraine (2010), Klein v. Russia (2010), and Khaydarov v. Russia (2010). ${ }^{163}$

Politically significant circumstances include the fact that the person is an opponent of the requesting Government, a member of an illegal organisation, or accused of terrorism. Like the 'death row phenomenon' and 'irreducible life sentences', which should not be equated with traditional grounds for refusal of extradition (namely the death penalty and the life-imprisonment exceptions), these hypotheses should not be equated with the political offence exception: this exception is only in part explained by a risk of discrimi-

\footnotetext{
${ }^{156}$ See e.g. Chap. 8, \$ 5.1.2.c).

157 Shortly infra, $\$ 4.3$.

${ }^{158}$ See e.g. Poltoratskiy v. Ukraine, no. 38812/97, 29 April 2003; see also Wildiam A. SCHABAS, The European Convention... op. cit., p. 196, with several other references.

159 M.E. v. France, no. 50094/10, 6 June 2013.

160 Makhmudz̧han Ergashev v. Russia, no. 49747/11, 16 October 2012.

161 Shakurov v. Russia, no. 55822/10, 5 June 2012.

162 All of which were already mentioned.

163 Abdolkhani \& Karimnia v. Turkey, no. 30471/08, 22 September 2009, Baysakov \& Others v. Ukraine, no. 54131/08, 18 February 2010, Klein v. Russia, no. 24268/08, 1 April 2010, Khaydarov v. Russia, no. 21055/09, 20 May 2010. See further Violeta Moreno-Lax, Accessing Asylum in Europe: Extraterritorial Border Controls and Refugee Rights under EU Law, Oxford: University Press, 2017, see p. 266 f.; AOIFE DufFY, "Expulsion to Face Torture? Non-refoulement in International Law”, IJRL 20 (2008), p. 373 f.; KATHRYN GrEenMan, “A Castle Built on Sand? Article 3 ECHR and the Source of Risk in Non-Refoulement Obligations in International Law", IJRL 27 (2015), p. 264 f.
} 
nation, and it presumes the existence of such a risk from the nature of the offence, rather than from the concrete circumstances of the case. ${ }^{164}$ Furthermore, while the death penalty and life imprisonment can translate, in certain circumstances, into a violation of Art. 3 ECHR, political discrimination functions essentially as an indicator of the likelihood of such a violation taking place through other actions.

\subsubsection{Exogenous sources of harm}

In similar terms as those expounded in regard to the right to life, even though subject to a higher threshold, violations of the prohibition of torture or ill-treatment can be triggered by exogenous sources. Two main categories can be identified in this context: one involving harm deriving from non-State entities or factors, another involving serious health problems suffered by the individual concerned.

Regarding the first group, amidst several applications that were either declared inadmissible by the Court or held (on their merits) not to entail a violation of the ECHR, ${ }^{165}$ some rulings with the opposite outcome can be identified. One is N. v. Sweden (2010), ${ }^{166}$ where the applicant claimed that she ran a serious risk of being the victim of domestic violence if she were deported to Afghanistan. The Court found that around $80 \%$ of Afghani women were victims of domestic violence, acts which were regarded by local authorities as legitimate and which, accordingly, were not prosecuted. Another case is Sufi \& Elmi v. UK (2011), ${ }^{167}$ concerning an allegation by the applicants that, if returned to Somalia, they would run a real risk of ill-treatment: Sufi was a member of a minority clan (the Reer Hamar) and claimed that he had been persecuted and seriously injured by the Hawiye milita, who had also killed his father and sister; Elmi, who had arrived in the UK at the age of 19, alleged that he would be seen as 'westernised' and 'anti-Islamic', and that, moreover, since he was a drug addict with prior convictions for theft, he would be at a real risk of being amputated or publicly flogged or killed.

As for the other category, again amidst several unsuccessful applications, ${ }^{168}$ we find some cases where the Court ruled favourably to the applicants. One is D. v. UK (1997), ${ }^{169}$ where the ECtHR found that the UK would breach its obligations under Art. 3 ECHR if it were to deport a person in an advanced stage of a terminal illness to a place (in the instance, Saint-Kitts) where medical care and social support were blatantly inadequate. Another is Aswat v. UK (2013), ${ }^{170}$ initially inserted within Babar Abmad \& Others, and later extricated by the Court, in view of its particularities (including the special gravity of Aswat's health condition), to be autonomously ruled on. The applicant was found in the UK and

164 See infra, Chap. 6, \ 2.3., and Chap. 8, \ 4.1.2.

165 E.g. Mbunqu, cit. (supra, \$ 3.5), Collins \& Akaziebie v. Sweden, no. 23944/05, 8 March 2007, Izevbekhai \& Others v. Ireland, no. 43408/08, 17 May 2011, Omeredo v. Austria, no. 8969/10, 20 September 2011, A. A. and Others v. Sweden, no. 14499/09, 28 June 2012, D.N.M. v. Sweden and S.A. v. Sweden, no. 28379/11 and no. 66523/10, 27 June 2013.

166 N. v. Sweden, no. 23505/09, 20 July 2010.

167 Sufi and Elmi v. UK, no. 8319/07 and no. 11449/07, 28 June 2011.

168 E.g. Aoulmi v. France, 17 January 2006, and N. v. UK, no. 26565/05, 27 May 2008.

${ }^{169}$ D. v. UK, no. 30240/96, 2 May 1997.

170 Aswat v. UK, no. 17299/12, 16 April 2013. 
his extradition was requested by the USA. He claimed that he would be subjected to illtreatment in the USA, notably because the detention conditions to which he would possibly be exposed (a long period of pre-trial detention and placement in a 'supermax' prison) were likely to aggravate his condition of paranoid schizophrenia. The Court held that the severity of his mental illness would carry his extradition to breach Art. 3 ECHR.

\subsection{Discrimination}

The 1951 UN Convention relating to the Status of Refugees and its 1967 Additional Protocol provide for a principle of non-refoulement, which prohibits the expulsion or return of anyone whose life or freedoms would be threatened due to his/her race, religion, nationality, membership of a particular social group or political opinion, irrespectively of whether they had been granted refugee status, and of anyone concerning whom there are substantial grounds to believe that they would be in danger of being subjected to torture. The latter aspect has been covered above. This paragraph briefly addresses the former.

This principle originally appeared at the international level in Art. 3 of the 1933 Convention Relating to the International Status of Refugees, and gained impetus in the context of the massive fluxes of migrants produced by WWII, such that at present it is considered to possess the status of a rule of customary international law. ${ }^{171}$ It is regarded as the "keystone of the international system of refugee protection". ${ }^{172}$ It is present in several legal instruments, ${ }^{173}$ and has become a classic feature in extradition treaties, as exemplified by Art. 3 (2) 1957 CoE Convention on Extradition, which proscribes extradition if there are substantial grounds for believing that the request has been issued "for the purpose of prosecuting or punishing a person on account of his race, religion, nationality or political opinion, or that that person's position may be prejudiced for any of these reasons". Art. 3 ECHR, as construed by the ECtHR in the case law mentioned above, ${ }^{174}$ also contains a principle of non-refoulement. ${ }^{175}$ In fact, the principle of non-refoulement is inexorably linked to the prohibition of torture. ${ }^{176}$ However, taken in this sense, its scope is narrower than that of the cited provision of the CoE Convention (or of Art. 3 (b) UN Model Treaty on Extradition), as it requires discrimination to translate into a risk of torture or ill-treatment.

Meanwhile, as noted, Art. 14 ECHR prohibits discrimination more generally, by providing that: "The enjoyment of the rights and freedoms set forth in this Convention shall be secured without discrimination on any ground such as sex, race, colour, language, religion, political or other opinion, national or social origin, association with a national minority, property, birth or other status". The scope of that classic exception to extradition is therefore more consonant with the general repudiation of discrimination con-

${ }^{171}$ See Jahid Hossain Bhutyan, "Protection of Refugees through the Principle of Non-Refoulement", in Jahid Hossain Bhuiyan / M. Rafiqul Islam (eds.), An Introduction to International Refugee Law, Leiden: Brill Nijhoff. 2013, p. 101, 114 f., expanding on the scope of this principle at $106 \mathrm{f}$., and on the exceptions to which it is subject at p. $109 \mathrm{f}$.

172 See Violeta MORENO-LAX, op. cit., p. $282 \mathrm{f}$.

${ }^{173}$ For instance, under Art. 18 CFREU: thereon, see VIOLETA MORENO-LAX, op. cit., p. 249.

174 See supra, $\int 4.2 .4$.

175 See Jahid Hossain Bhuiyan, op. cit., p. 102.

176 See AOIFE DuFfy, op. cit., \5.4. 
tained in Art. 14 ECHR, and it is on this basis that such an exception must be considered as falling within the intentionally broad concept of 'grounds for refusal imposed by human rights' adopted in this study.

In fact, even a tighter understanding of the implications of the prohibition of discrimination upon extradition law might carry the same outcome, if we follow den Heijer's view that, although there is a prevalent assumption according to which, under the ECHR, only Art. 3 (and, to an extent, Art. 2) are relevant in cases of refoulement, it is possible to establish, by "unravelling the explicit and implicit principles applied by the ECtHR and elaborating upon earlier theoretical attempts to ascertain the impact of the Soering judgment on extradition and expulsion cases", that "there is no clear dichotomy of rights within the ECHR", and that the notion of a 'fundamental value' on which the application of the ECHR to extradition cases depend, albeit "somewhat nebulous", "is likely to encompass not only Articles 2 and 3, but also norms protected by other provisions, or at the least certain intrinsic components of those other provisions". ${ }^{177}$ Even if Art. 14 is not to be contemplated by this construction, the right to a fair trial enshrined in Art. 6 which arguably cannot be satisfied if criminal proceedings in the requesting State are motivated or rendered comparatively more detrimental to the person owing to discriminatory factors - in any case would, and this right has been explicitly referred to in ECtHR case law on extradition, as is depicted in the following paragraph.

\subsection{Fair trial rights}

\subsubsection{General considerations}

Failure by the requesting State to ensure a fair trial can prevent extradition on the basis of Art. 6 ECHR. The applicability of this right to extradition cases had been open, if quite cautiously, since the very beginning of the ECtHR's jurisprudence on extradition. In Soering, albeit rejecting the applicant's complaint under Art. 6, the Court asserted: “The right to a fair trial in criminal proceedings, as embodied in Art. 6, holds a prominent place in a democratic society. The Court does not exclude that an issue might exceptionally be raised under Art. 6 by an extradition decision in circumstances where the fugitive has suffered or risks suffering a flagrant denial of a fair trial in the requesting country."178

This statement reverberated in subsequent case law, including Drozd \& Janousek (1992), ${ }^{179}$ Einhorn (2001), ${ }^{180}$ and Tomic (2003). ${ }^{181}$ All of these rulings reinstated that Art. 6 could apply to extradition and all of them underscored how exceptional circumstances would have to be in order for such a prospect to materialise. In Drozd \& Janousek, the Court asserted quite clearly that "the Convention does not require the Contracting Parties to impose its standards on third States or territories", and hence "France was not obliged

177 MaArten Den Heijer, "Whose Rights and Which Rights? The Continuing Story of Non-Refoulement under the European Convention on Human Rights”, EJML 10 (2008), p. 277 f.

178 Soering cit., $\mathbb{\Omega} 113$.

179 Drozd \& Janousek. v. France \& Spain, no. 12747/87, 26 June 1992, \ 110.

180 Cit., \32.

181 Tomic v. UK, no. 17837/03, 14 October 2003, \ 3. 
to verify whether the proceedings which resulted in the conviction were compatible with all the requirements of Art. 6". Also: "To require such a review of the manner in which a court not bound by the Convention had applied the principles enshrined in Art. 6 would also thwart the current trend towards strengthening international cooperation in the administration of justice, a trend which is in principle in the interests of the persons concerned." Contracting States are, but are only, "obliged" to refuse co-operation in cases of "flagrant denial of justice". ${ }^{182}$

In their Joint Partly Dissenting Opinion in Mamatkulov \& Askarov v. Turkey, Judges Bratza, Bonello and Hedigan elaborated on the notion of 'flagrant denial of justice': "While the Court has not to date found that the expulsion or extradition of an individual violated, or would if carried out violate, Art. 6 of the Convention, it has on frequent occasions held that such a possibility cannot be excluded where the person being expelled has suffered or risks suffering a flagrant denial of a fair trial in the receiving country. What constitutes a 'flagrant' denial of justice has not been fully explained in the Court's jurisprudence but the use of the adjective is clearly intended to impose a stringent test of unfairness going beyond mere irregularities or lack of safeguards in the trial procedures such as might result in a breach of Art. 6 if occurring within the Contracting State itself. As the Court has emphasised, Art. 1 cannot be read as justifying a general principle to the effect that a Contracting State may not surrender an individual unless satisfied that the conditions awaiting him in the country of destination are in full accord with each of the safeguards of the Convention. In our view, what the word 'flagrant' is intended to convey is a breach of the principles of fair trial guaranteed by Art. 6 which is so fundamental as to amount to a nullification, or destruction of the very essence, of the right guaranteed by that Article." 183

That the test for an Art. 6 claim to succeed in a removal case is a 'stringent one' is clear from the fact that the first time in which the Court held that a deportation or extradition would breach that provision only came more than 20 years after Soering: after those cases indicated above and several other unsuccessful applications brought before it on Art. 6 grounds, ${ }^{184}$ the Court eventually held in Othman v. UK (2012) ${ }^{185}$ that the applicant's deportation to Jordan would breach Art. 6, given the existence of a serious risk that evidence previously obtained through torture would be admitted at his retrial (he had been convicted in absentia on terrorism charges). Such a breach of Art. 6 was closely related to past conduct that would infringe upon the prohibition of torture of Art. 3, and, as noted by the Press Unit of the ECtHR, this ruling "reflected the international consensus that the use of evidence obtained through torture made a fair trial impossible". ${ }^{186}$ However, a dominant note is the autonomous application of Art. 6 by the Court: the Court ruled out that the deportation would breach Art. 3, finding the diplomatic assurances of the Jorda-

182 Cit., \ 110.

183 Cit. (emphasis added). In Drozd \& Janousek, cit., \ 110, the Court had already, but very concisely referred that a flagrantly unfair trial would be one which is "manifestly contrary to the provisions of Article 6".

184 See further e.g. Peñafiel Salgado v. Spain, no. 65964/01, 16 April 2002, and Monedero Angora v. Spain, no. 41138/05, 7 October 2008; Ahorugeze v. Sweden, no. 37075/09, 27 October 2011.

185 Cit.

186 ECtHR Press Unit, “Expulsions and extraditions”, July 2013, p. 2. 
nian Government sufficient in that regard, and relied only on Art. 6. Similar findings have been reached by the Court in a number of cases concerning 'disguised extradition', namely Husayn v. Poland, ${ }^{187}$ Al Nashiri v. Poland, ${ }^{188}$ and AlNashiri v. Romania. ${ }^{189}$

The exact scope of application of Art. 6 to extradition cases may be considered to still be defining itself. Although the concept of 'flagrant denial of justice' remains somewhat unclear, the Court has hinted at a number of circumstances that can render a trial flagrantly unfair, including: $:^{190}$ conviction in absentia without subsequent possibility of fresh determination of the merits of the charge (Einhorn v. France, ${ }^{191}$ Sejdovic v. Italy, ${ }^{192}$ and Stoichkov v. Bulgari $\left.^{193}\right)$; a trial that is summary in nature and conducted with a total disregard for the rights of the defence (Bader \& Kanbor v. Sweden ${ }^{194}$ ); detention without any access to an independent and impartial tribunal to have the legality of the detention reviewed (Al-Moayad v. Germany ${ }^{195}$ ); deliberate and systematic refusal of access to a lawyer, especially for an individual detained in a foreign country (idem); use in criminal procedure of statements obtained as a result of a suspect's or another person's treatment in breach of Art. 3 (Othman v. UK, ${ }^{196}$ El Haski v. Belgium, ${ }^{197}$ Husayn v. Poland, ${ }^{198}$ Al Nashiri v. Poland, ${ }^{199}$ and Al Nashiri v. Romani ${ }^{200}$ ); lack of judicial independence and impartiality of an extraordinary court with jurisdiction on terrorism and formed exclusively of members of the armed forces (Husayn v. Poland, ${ }^{201}$ Al Nashiri v. Poland, ${ }^{202}$ and Al Nashiri v. Romania. $\left.{ }^{203}\right)$; lack of legitimacy of the court due to not having been 'established by law' (idem). In the light of this case law, provisions such as that contained in Art. 3 (f) UN Model Treaty, according to which extradition must be refused if the person has not enjoyed or would not enjoy minimum guarantees in criminal proceedings as contained in Art. 14 ICCPR (equivalent to Art. 6 ECHR), would to a great extent fall even within a narrower concept of 'grounds for refusal imposed by human rights' as that adopted in this study.

${ }^{187}$ Husayn (Abu Zubaydab) v. Poland, no. 7511/13, 24 July 2014, JS 552 f., 559.

188 Cit., \S 565 f.

189 Cit., SS $719 \mathrm{f}$.

190 Drawing in part on ECtHR Directorate of the Jurisconsult, "Guide on Article 6 of the European Convention on Human Rights Right to a fair trial (criminal limb)", 31 December 2013, p. 55 f.

191 Cit., \ 33.

192 Sejdovic v. Italy, no. 56581/00, 1 March 2006, \ 84.

193 Stoichkov v. Bulgaria, no. 9808/02, 24 March 2005, \ 56.

194 Cit., $\int 47$.

195 Cit., $\int 101$.

${ }^{196}$ Cit., $\int 267$.

197 El Haski v. Belgium, no. 649/08, 25 September 2012, \85.

198 Cit., \5 557.

199 Cit., \567.

${ }^{200}$ Cit., $\int 719$.

${ }^{201}$ Cit., $\int 557$.

${ }^{202}$ Cit., $\int 567$.

${ }^{203}$ Cit., $\int 719$. 


\subsection{3. $\mathrm{Ne}$ bis in idem}

No general rule can be derived from international law which entails a duty to comply with ne bis in idem, its main sources under international law being treaties, notably on human rights law and cooperation in criminal matters, as well as the ICC Statute; it is also enshrined in the Statutes of ad hoc international courts established by the UN-SC. ${ }^{204}$ However, in the image of many national legal systems, ${ }^{205}$ the main multilateral treaties on human rights recognise a most sparing, if any, transnational efficacy in the ne bis in idem principle.

The principle is not even provided for in any of its dimensions in the ECHR, and the former European Commission of Human Rights explicitly held that it could not be derived from Art. 6, notwithstanding the possibility that in certain extreme cases a second prosecution could display such characteristics as to breach fair trial rights. ${ }^{206}$ It has later been included in Art. 4 OP7, but many States (e.g. Germany and the Netherlands) have not ratified it, and the UK did not even sign it; many other States formulated reservations and limiting declarations when signing the Protocol. In its turn, the ICCPR does provide explicitly for a ne bis in idem guarantee in Art. 14 (7), but again some States formulated reservations to this norm, and, more importantly, the UN-HRC unambiguously ruled in 1987 that this provision does not apply to foreign res judicatae, but only within national legal systems, an understanding which it corroborated in equally assertive terms in its 2007 General Comment on Art. 14 ICCPR. ${ }^{207}$ The case is similar with other regional human rights judicial bodies: the ACHR provides for a ne bis in idem guarantee in Art. 8 (4), but the IACtHR has also construed it in very limited terms.

Finally, the approach to ne bis in idem followed by international criminal courts is that the ne bis in idem principle applies in national and international criminal courts in an articulated or 'trans-jurisdictional' manner, but such a prohibition will cease: for the ICC, if the proceedings in the court where the person has already tried (a) were aimed at shielding him/her from criminal responsibility for crimes within the jurisdiction of the Court, or (b) otherwise were not conducted independently or impartially, and were conducted in a manner inconsistent with an intent to bring him/her to justice; for the ICTY, if (a) the act for which the person was tried was characterised as an ordinary crime, or (b) the proceedings in the national court at issue were not impartial or independent, were designed

204 See John A. E. Vervaele, "Ne Bis In Idem: Towards a Transnational Constitutional Principle in the EU?”, ULR 9 (2013), p. 213 f., also for what follows in this paragraph.

205 See further infra, Chap. 8, $\$ 3.3 .1$.

206 See John A. E. Vervaele, “Ne Bis In Idem...” op. cit., p. 213, also for what follows in this paragraph; see European Commission of Human Rights, no. 4212/69, 13 July 1970; and, later, no. 9433/81, 12 December 1981.

207 See John A. E. Vervaele, “Ne Bis In Idem...” op. cit., p. 214; see UNHRC: (i) A.P. v. Italy, 2 November 1987, \ 7.3; (ii) A.R.J. v. Australia, 28 July 1997, \ 6.4; and (iii) "General Comment no. 32 - Article 14: Right to equality before courts and tribunals and to a fair trial”, 23 August 2007, \57: “This guarantee (...) does not guarantee ne bis in idem with respect to the national jurisdictions of two or more States. This understanding should not, however, undermine efforts by States to prevent retrial for the same criminal offence through international conventions." 
to shield the accused from international criminal responsibility, or the case was not diligently prosecuted. ${ }^{208}$ Arguably justified exceptions, but unquestionably broad ones.

Since it is mostly, indeed almost exclusively the transnational dimension of ne bis in idem that is relevant for this study, it is impossible, despite the profound significance of this principle from a fundamental rights perspective, to consider it as a ground for refusal of extradition imposed by human rights, even under the expansive criteria followed here. The only plausible exception to this is the case where the acts have been tried in the past in the requesting State itself, as this is the one situation that is precluded by international human rights instruments. This, however, is a very modest implication, for in most cases the acts will have been prosecuted or punished in a third State, making this the main issue involving ne bis in idem in the context of extradition. ${ }^{209}$

\subsection{Rights that admit significant compression with a view to protecting oth- er rights or public interests}

Within the dominant mentality according to which the hindering effects of human rights upon extradition are geometry which varies depending on the rights in question, the need to uphold effective and deterrent criminal justice systems, and several other factors, it is understandable that there is a complete absence of successful applications in extradition cases based on such provisions as Art. 8 (right to respect for private and family life) and Art. 9 (freedom of thought, conscience and religion) of the ECHR. ${ }^{210}$

This is one aspect in respect of which human rights case law on extradition differs remarkably from that on other mechanisms such as deportation and expulsion, in which the receiving State is not the holder of a legitimate punitive claim over the acts, and, accordingly, there is typically no concern that a decision to block removal will entail a situation of impunity. Insofar as those mechanisms are concerned, human rights case law not only exists, but is in fact rather profuse. ${ }^{211}$ The balance of conflicting interests is very different in respect of extradition also because it is ancillary to the possible application of a criminal sanction, and the compression of rights such as that to a family life is inherent to criminal sanctions.

In any case, however elevated the applicable threshold might be for an extradition case to trigger such a breach, the case law of the ECtHR on disguised extradition or international abduction denotes that it is possible for a claim to succeed under such provisions as Art. 8 even where the State of destination has criminal charges pending against the person concerned. ${ }^{212}$ Thus, the 'humanitarian exception' found in several instruments

208 See Art. 10 Statute of the ICTY, Art. 9 Statute of the ICTR, and Art. 20 Statute of the ICC.

${ }^{209}$ It will be addressed infra, Chap. 8, $\int 3.3 .1$.

210 See e.g. Chahal, cit., D. v. UK, cit., V.v. UK, cit., Saadi, cit., Charahili v. Turkey, no. 46605/07, 13 July 2010, and Cruz Varas \& Others v. Sweden, no. 46/1990/237/307, 20 March 1991.

211 See ECtHR Press Unit, "Expulsions and extraditions", cit., p. 11 f., and ECtHR Directorate of the Jurisconsult, "Guide on Article 8 of the European Convention on Human Rights: Right to respect for private and family life", 31 December 2016, as last updated on 30 April 2017, p. 53 f.

212 See El-Masri v. the former Yugoslav Republic of Macedonia, no. 39630/09, 13 December 2012, Al Nashiri $v$. Poland, cit., AlNashiriv. Romania, cit., Husayn (Abu Zubaydah) v. Poland, cit., and Abu Zubaydab [Husayn] v. Lithi- 
on extradition, such as the UN Model Treaty, the UN Model Law, and the national legislation of both States assessed in the forthcoming Part III of this study ${ }^{213}$ (an exception to extradition which covers, if also only in exceptional circumstances, the class of situations falling within the human rights now in consideration), should be considered at least as a para-human rights ground for refusal for the purposes of this study, with the consequence that it will be excluded from the reform later proposed in Part IV. ${ }^{214}$

ania, no. 46454/11, 31 May 2018, all similar. See WiLliAM A. SCHABAS, The European Convention... op. cit., p. $394 \mathrm{f}$.

213 See infra, Chap. 6, $\int 4.2$.

214 The same applies to one specific situation which arises in the context of the military offence exception (infra, Chap. 6, \ 2.4.), namely the case of conscientious objection - which falls within the scope of Arts. 9 ECHR and 18 ICCPR (on freedom of thought, conscience and religion), but on which no ECtHR case law on extradition could be found. 


\section{Chapter 4}

\section{EU Law ${ }^{*}$}

\section{Introductory considerations - A trilogy of cases}

The influence of EU law on extradition from EU Member States to third States hereafter referred to as 'outward extradition' or simply 'extradition' - is a vivid topic, as three cases have reached the ECJ for preliminary rulings. 'This chapter evaluates the nature, scope, impact and significance of these ground-breaking developments.

The first case is Petrubhin (C-182/15), involving an Estonian national requested by Russia on drug-related charges, and it constitutes the primary element of analysis of this Chapter. The ECJ delivered its ruling thereon on 6 September 2016, where it held that the circumstance that the sought person is a EU citizen may impose the refusal of extradition, in what may be called a 'EU citizenship exception'. However, to this date it remains somewhat unclear in which situations such an exception applies and how exactly it operates. This development raises yet other questions, ranging from its possible impact on the national laws of the Member States to its significance in terms of the relative position of the EU in the wider world insofar as international cooperation in criminal matters is concerned. Petrubhin is also noteworthy for settling the applicability of EU human rights to outward extradition, although this aspect is not emphasised in this Chapter, since on the one hand this was relatively foreseeable in the light of the CFREU, and on the other hand grounds for refusal imposed by human rights have already been addressed in this study based on other legal instruments, considered more adequate to the purposes of this study than the norms on human rights emanated from the EU.

The second case is Schotthöfer \& Steiner (C-473/15), involving an Austrian physician, Eugen Adelsmayr, tried in absentia in the United Arab Emirates on charges of murder and manslaughter, and who feared being extradited if he were to travel to another Member State. The ECJ delivered its ruling on this case on 6 September 2017, precisely one year after Petrubhin.

The third case is Pisciotti (C-191/16), in which an Italian national was extradited on cartel charges from Germany to the USA, where he was sentenced to imprisonment for two years after pleading guilty. This case reprised some of the issues already addressed in the above cases, but raised other relevant questions, notably that as to whether the principle established in Petrubhin could also apply to States with which the EU had an extradition agreement. The Court issued its ruling on this case on 10 April 2018.

* This Chapter draws largely on the article Miguel Joño CostA, "The Emerging EU Extradition Law: Petrubhin and Beyond", NJECL 8 (2017), p. 192 f., published during the elaboration of this study. Nevertheless, many parts were developed, adapted and/or updated to better serve the purposes of this study.

${ }^{1}$ A fourth request for a preliminary ruling was lodged after Petrubhin, and is also addressed here: infra, $\int 5$. 


\section{Petruhhin}

\subsection{Main proceedings and request for a preliminary ruling}

Aleksei Petruhhin is an Estonian who was arrested in Latvia and whose extradition was requested by Russia on charges of attempted large-scale drug trafficking in criminal association. The request was granted, but Petruhhin appealed arguing that under a 1992 Agreement between Latvia, Estonia and Lithuania he enjoyed the same rights in Latvia as a Latvian national and hence could not be extradited. The Latvian Supreme Court dismissed this claim, but conceded that extraditing the appellant could breach EU law principles of equal treatment and free movement. Accordingly, it annulled the detention, ${ }^{2}$ stayed the extradition proceedings, and referred to the ECJ for a preliminary ruling. ${ }^{3}$

The request was received by the ECJ on 22 April 2015, and contained, in essence, the following questions: (1) Do non-discrimination and free movement require that a citizen of any Member State whose extradition is requested by a third State, pursuant to a treaty binding a Member State and such third State, be accorded the same level of protection that is accorded to a citizen of the Member State in question? (2) If so, which conditions apply - those of the Member State of which the person is a national, or those of the Member State of which he/she is a resident? (3) Do the prohibitions to extradite in case of risk of torture/ill-treatment or of applicability of the death penalty apply? If so, how should the compliance of the third State with human rights be verified? ${ }^{4}$

The following paragraphs focus on the first two questions, which required from the Court an unprecedented assessment of the implications of EU law on extradition. The latter question also involves outward extradition, but - as noted above - its answer was fairly predictable, and therefore it is addressed only briefly.

\subsection{The opinion of the Advocate General}

On 10 May 2016, AG Bot delivered his Opinion on the case. In a nutshell, he concluded that difference in treatment between the nationals of a Member State and other EU citizens will, but will only constitute discrimination "if it is shown that those two categories of nationals are not in a comparable situation in the light of the objective of combating the impunity of persons suspected of having committed an offence in a third State. ${ }^{\circ 5}$

\subsubsection{Jurisdiction to rule on the request?}

The first question addressed by the AG was that as to whether the hypothesis at issue falls within EU law, particularly in the TFEU norms on citizenship. All Governments that submitted observations to the Court, except that of the UK, claimed that, where the EU has not concluded an extradition agreement with a third State, ${ }^{6}$ the matter remains in

2 Petruhhin later returned to Estonia, but this did not render inadmissible the proceedings before the ECJ: see Opinion of AG Bot, 10 May 2016, \$S 24-30, and Judgment, 6 September 2016, \S 18-24.

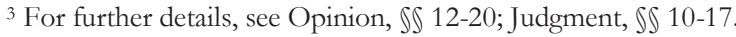

${ }^{4}$ See OJ C 205, 22 June 2015, p. 23 f.

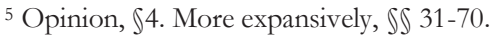

${ }^{6}$ As it has with the USA, and (albeit not yet ratified) with Norway and Iceland: see further infra, $\int$ 4.4.2. 
the hands of the Member States. The AG rejected this view. Instead, he held that EU law applies because Petruhhin had exercised his freedom of movement and residence. Without further elaboration, the AG stated that it constitutes settled jurisprudence of the ECJ that EU law applies to any situation involving such an exercise.

\subsubsection{A EU citizenship obstacle to extradition?}

It is apparent that refusing extradition of own nationals but not of other EU citizens constitutes a differentiation based on nationality. However, the AG noted that such a differentiation is illegitimate only where the situation of non-nationals is comparable to that of nationals. Conversely, it will be legitimate where it is justified by objective reasons and proportionate to the objectives pursued. In appraising whether non-Latvian EU citizens are in a position comparable to that of Latvians, the AG began by dissecting the rationale of the nationality exception, which in his view is threefold: State sovereignty over own nationals; mutual obligations between States and their nationals; and, particularly, distrust of the legal systems of other States, whose language and procedures are unfamiliar to foreigners. To the AG, this rationale is entirely compatible with the extension of protection required by the EU law principle of non-discrimination.

However, as noted, the AG identified a factor capable of justifying differentiation: the situation of those two types of offenders in the face of the goal of avoiding impunity. This goal is at the very core of the institute of extradition, which is aimed at allowing a State whose penal law was breached (generally the locus delicti) to punish the breach; and is "most certainly"7 a legitimate goal of EU law, as evidenced by such case law as Spasic. In this light, situations will only be comparable if, upon refusal of extradition, the requested Member State can prosecute non-nationals in similar terms as own nationals, pursuant to the principle aut dedere aut judicare, an expression of States" "mutual general commitment" to combat impunity. In the case, Latvian nationals and other EU citizens were not in equivalent conditions, because under Latvian law the offence at issue could only be prosecuted if it had been committed by a Latvian citizen, a Latvian non-citizen, ${ }^{10}$ or a foreigner with a Latvian permanent residence permit. Since Petruhhin was none of these, extraditing him would not violate EU law.

\subsection{The judgement of the Court}

On 6 September 2016, the ECJ delivered its ruling. ${ }^{11}$ In essence, the Court agreed with the AG, in that it maintained that differences in treatment will, but will only amount

7 Opinion, $\int 55$.

8 Judgment of 27 May 2014 (C-129/14) - see $\int S 58,72$.

${ }_{9}$ UN International Law Commission, "The obligation to extradite or prosecute (aut dedere aut judicare) Final Report", 2014, p. 14.

${ }^{10} \mathrm{Vi}$. former Soviet citizens who arrived in Latvia before independence; these individuals did not choose either Latvian or Russian nationality, and may become naturalised - see Opinion, $\int 7$.

${ }^{11}$ For a reader less familiar with EU law it might be worth conveying that the decisions of the ECJ are binding and enforceable: Arts. 280 and 299 TFEU, 91 RPCJ, 121 RPGC, and 98 RPCST - see RENÉ BARENTS (Helen E. Breese, ed.), Remedies and Procedures before the EU Courts, Alphen aan de Rijn: Wolters Kluwer, 2016, p. 81 f., 452 f., noting that the consequence of the binding nature of the ECJ's decisions for Member 
to discrimination if situations are comparable in view of the risk of impunity. However, it took a singular stance on the action to be carried out by the requested Member State. ${ }^{12}$

\subsubsection{Jurisdiction to rule on the request?}

Regarding this issue the ECJ followed the AG, asserting perhaps even more emphatically its jurisdiction over the case.

\subsubsection{A EU citizenship obstacle to extradition?}

The ECJ reiterated that objective considerations can justify differentiation, and that avoiding impunity is indeed a key concern, but it innovated regarding the proportionality condition: it ruled that prosecution by the host Member State is not the only available measure that is less detrimental to fundamental principles of EU law than extradition, as impunity can also be prevented if the Member State of which the offender is a national is offered the chance to issue a EAW with a view to prosecuting. This means that the scope ascribed by the ECJ to the 'EU citizenship exception to extradition' is broader than that which would result from the opinion of the AG.

To this end, the Court recalled that under Art. 3 (2) TEU the EU is bound to offer its citizens an area of freedom, security and justice without internal frontiers, where free movement is ensured in conjunction with measures of external border controls and crime prevention. The Court further invoked the principle of sincere cooperation, set out in the first subparagraph of Art. 4 (3) TEU, which commands the EU and Member States to, in full mutual respect, assist each other in carrying out the tasks established in the Treaties. The Court proceeded to note that the EAW is an expression of the principle of mutual recognition in criminal matters - the 'cornerstone' of judicial cooperation within the EU -, and held that nothing in the FD-EAW prevents the Member State of which an alleged offender is a national from issuing a EAW with a view to prosecuting him/her. Finally, the Court raised Art. 3 (5) TEU, which makes it incumbent upon the EU to uphold and promote its values and interests and contribute to the protection of its citizens in its relations with the wider world. This external dimension of EU action in criminal matters is being gradually developed through such legal instruments as extradition agreements between the EU and third States. In the absence of one such agreement binding the EU and Rus-

States is that they are obliged under Art. 260 TFEU to take the necessary measures to comply with those decisions. Regarding preliminary rulings in particular, the author submits that it follows from their very aim that the interpretation of EU law thereby adopted by the ECJ be binding on national courts, authorities and institutions. On the other hand, it is also worth noting that, although not all Member States have recognised the competence of Court, this does not affect the efficacy of its rulings: these settle the scope of EU norms and impact upon all Member States - which is why Member States that have not accepted that competence can still submit observations in these proceedings: see ibid., p. 454, and DANIEL FLORE (with the collaboration of Stéphanie Bosly), Droit Pénal Européen, Bruxelles: Larcier, 2014, p. 108 f. Finally, it should be noted that, although in answering references for preliminary rulings the ECJ does not exactly rule on the compatibility of national law with EU law, but only provides national courts with the elements necessary for them to assess such a compatibility, the interpretation made by the ECJ of a rule of EU law settles the meaning and scope of that rule as it must be or should have been understood as of the moment of its coming into force: see ANDRÉ KLIP, European Criminal Law... op. cit., p. 133 f., 146.

12 The reasoning of the Court (\$S 18-50) is described subsequently. 
sia - the Court closes -, protecting EU citizens from measures that deprive them of rights conferred by EU law, without thereby acquiescing to their impunity, requires the application of all mechanisms of cooperation in criminal matters available within the EU.

\subsection{Analysis}

\subsubsection{The ever-expanding jurisdiction of the Court}

It is possible to identify a steady, if not quite linear increase in the cognition powers of the ECJ in criminal matters throughout the years. This increase took "largely the same style of interpretation, diligence and consciousness as in the Community area", 13 such that it became justified to refer to a "complete merger of the internal market and the area of freedom, security and justice". ${ }^{14}$ To a great extent, the increase was directly correlated to the widening of the legislative competence of the EU - effected through explicit, if not always completely unambiguous amendments to the Treaties. However, in this process the Court seized jurisdiction over situations that were not plainly covered by those primary instruments, and not always in a manner appreciated by the Member States. ${ }^{15}$ The Court "has gone from ripples to shockwaves, taking this entire area of law to new levels". ${ }^{16} \mathrm{Ca}$ sati (1981) - where the Court ruled that, although in principle criminal law and procedure are matters for which Member States are still responsible, EU law sets certain limits necessary to protect freedom of movement - showed that any situation touching upon fundamental principles of EU law was liable to the jurisdiction of the Court. ${ }^{17}$

The applicability of EU law to the specific subject matter 'extradition' had been in the spotlight since the extradition of Pisciotti (even though this was the last of the three cases mentioned above to have made it to the ECJ for a preliminary ruling). ${ }^{18-19}$ The Ital-

${ }^{13}$ LARS BAY LARSEN, "Judicial control within the European penal area", in Stefan Braum / Anne Weyembergh (eds.), Le contrôle juridictionnel dans l'espace pénal européen, Bruxelles: Ed. de l’Université, 2009, p. 20.

14 ANDRÉ KLIP, European Criminal Law... op. cit., p. 21 f.

15 See Valsamis Mitsilegas, "The Transformation of Criminal Law in the 'Area of Freedom, Security and Justice", YEL 6 (2007), p. 1 f.; ADAM LAZOWSKI, "Towards the reform of the preliminary ruling procedure in JHA Area", in Stefan Braum / Anne Weyembergh (eds.), op. cit., p. 211 f.

16 ADAM ŁAZOWSKI, op. cit., p. 212.

17 (C-203/80), 11 November 1981, SS 26-29. The ruling states that this already constituted "consistent" case law at the time, but does not mention earlier cases. Noteworthy later cases include Cowan (C-186/87), 2 February 1989, \ 19, Bickel \& Fran₹ (C-274/96), 24 November 1998, \ 17, and Rottmann \& Bayern (C135/05), 2 March 2010, \41. On Casati and other cases where EU law placed limits on national criminal laws to secure free movement, see Niovi VAVOULA, "The interplay between EU immigration law and national criminal law: The case of the Return Directive", in Valsamis Mitsilegas / Maria Bergström / Theodore Konstadinides (eds.), Research Handbook on EU Criminal Law, Cheltenham: Edward Elgar, 2016, p. 296 f.

${ }^{18}$ See Christian Ritz / Bernardo Vasconcelos, "Extradition discrimination? Pisciotti's legal battle continues as Regional Court of Berlin refers questions of fundamental EU law principles to the CJEU", ECompLR 37 (2016), p. 278 f., noting that the theoretical debate on this question had in fact erupted even before Pisciotti, with several academics defending the applicability thesis.

19 There is another instance where the ECJ undoubtedly has jurisdiction on extradition: the case of asylum-seekers, whose extradition to the country of origin is limited by EU asylum law if it is established that such a State is persecuting them: see STEVE PEERS, EU Justice and Home Affairs Law - Vol. I: EU Immigration and Asylum Law, Oxford: University Press, 2016, p. 232 f. 
ian unsuccessfully challenged the conformity of his extradition with EU law before German Courts and at the European level. In an action before the Berlin Regional Court, he not only attempted to stop his impending extradition, but also claimed damages from the German State. The Berlin Court declared itself incompetent regarding the first issue, but competent regarding the latter, and it was in this regard that it lodged a request for a preliminary ruling, which added to Petrubhin and Schotthöfer \& Steiner, already pending at the time. A pattern emerged whereby courts of Member States denote the understanding that EU law does apply to extradition. ${ }^{20}$

In the light of case law such as Casati, of the opinions expressed in literature arguing for the applicability of EU law to extradition, and of the very proliferation of requests for preliminary rulings, the stance adopted by the ECJ in Petrubhin regarding its jurisdiction is far from astonishing. Nevertheless, it is worth recalling that during the proceedings the Governments of many Member States expressed the opposite view, and in the light of this reluctance, which is quite meaningful in the present state of affairs of the European project, that stance - however "correct" 21 - can still be considered bold. This is all the more true if we notice that there is one particularity in this case distinguishing it from other cases decided by the ECJ in the past: the matter at stake is the object of a treaty binding on a Member State, which produces a 'Catch-22' scenario ${ }^{22}$ whereby either of the available courses of action - to comply with EU law, or with the extradition treaty - entails the breach of an obligation by that Member State.

\subsubsection{The EU citizenship obstacle to extradition}

\section{a) A new obstacle to extradition?}

With the minor differences described above, both the AG and the ECJ recognise that EU citizenship can block extradition from Member States to third States. Yet, it appears rather exaggerated to see this as a 'new obstacle' to extradition, when its rationale is not autonomous, but is instead drawn from a pre-existing obstacle: the nationality exception. Thus, that obstacle will be more fittingly qualified as a derivation or extrapolation of the latter into a EU scale, caused by principles and interests of EU law. In this regard, it is worth observing that neither the AG nor the ECJ at any moment implied that Member States should refuse extradition of their own nationals to third States; only that, if they do, then they must dispense comparable treatment to other EU citizens.

\footnotetext{
${ }^{20}$ It may be worth recalling that it is the courts of the Member States, and not the ECJ, that determine whether a question shall give rise to a preliminary ruling: see ANDRÉ KLIP, European Criminal Law... op. cit., p. $139 \mathrm{f}$.

${ }^{21}$ STEVE PEERS, "Extradition to non-EU countries...", op. cit., albeit noting that the reasoning used by the Court was "rather abstract", and that it would have been more tangible to state that "Petruhhin would have been deterred from leaving Estonia for another Member State if he ran a risk of being extradited".

22 As noted earlier, this satirical scenario is evoked by HARMEN VAN DER WILT, op. cit., p. 148, to depict conflicts between treaty-based duties to extradite and treaty-based duties to uphold human rights.
} 


\section{b) A probibition to extradite own nationals?}

It has been suggested, based on the case law of the ECJ on EU citizenship (rather than on free movement and equal treatment), notably Zambrano, ${ }^{23}$ that EU law prohibits Member States from extraditing own nationals (and, consequently, other EU citizens), or else they would be deprived of their EU citizenship. ${ }^{24}$ However, in Petrubhin the ECJ did not draw support from that line of case law, and this is justified considering the following reasons.

From the case law initiated in Zambrano, and in a way already in Rottmann, ${ }^{25}$ it undoubtedly follows that EU law can cover purely internal situations (notably situations of so-called 'reverse discrimination') and that EU citizenship no longer requires, in order for an immanent set of rights to apply, that free movement has been exercised. ${ }^{26}$ However, extradition of own nationals involves no discriminatory element whatsoever, either direct or reverse, since the Member State also extradites other EU citizens. An argument might still be raised that the fact that some Member States have a nationality exception, while others extradite their own nationals, impairs the freedom of movement of the citizens of the former group, to the extent that they refrain from moving to the latter group in fear of extradition. It so happens that no Member State is as such responsible for the discrepancy. And the fact that the Member States of the former group are a minority surely does not render their position any less valid. Were Member States required to adhere to the most protective regime existing within the EU, that would mean that the national legal system offering the highest level of protection in regard of any given hypothesis would de facto govern that hypothesis in the whole EU. Or, at least, that the legal system of origin of a EU citizen moving to another Member State would prevail over the latter's whenever it offered a higher level of protection. That would amount to something of a 'mutual recognition of legal systems marked by a principle of most favourable treatment'. Such a concept does not exist even in matters covered by EU secondary law: ${ }^{27}$ if e.g. a national and resident of a given Member State is arrested in another Member State pursuant to a EAW, the rules that apply (notably, the set of grounds for non-execution) are, obviously, always those of the executing Member State.

On the other hand, a difference must be established between a plain refusal to recognise a EU citizen (whether actual or aspiring) the right to reside in a Member State

23 (C-34/09), \$S 36-45.

24 See STEve PeErs, "Extradition to non-EU countries...", op. cit., adding that at any rate the limits set in Petrubhin "apply by analogy: extradition of citizens can be justified on grounds of preventing immunity."

25 (C-135/08).

${ }^{26}$ See Koen Lenaerts, “Civis Europaeus Sum': From the Cross-border Link to the Status of Citizen of the Union", in Pascal Cardonnel / Allan Rosas / Pernilla Lindh (eds.), Constitutionalising the EU judicial system: Essays in honour of Pernilla Lindh, Oxford: Hart, 2012, p. 213 f.; but see also the (somewhat less definite) view of FRANÇOIS BILTGEN, "Citizenship of the Union and Purely Internal Situations - Discrimination of One's Own Citizens?”, NJECL 7 (2016), p. 151 f.

${ }^{27}$ Quite the opposite, the ECJ has on several occasions ruled that it is not contrary to the principle of non-discrimination to apply national law just because other Member States allegedly apply less severe rules: cf. e.g. van Dam \& Others (C-185 to 204/78), \10; Oebel (C-155/80), \ 9; Peralta (C-379/92), \ 48; earliest of all, although less explicit, Wilhelm \& Others (C-14/68), \ 13. 
(whether that of his/her nationality or a different one) - as was the case in Zambrano-, and the situation where a EU citizen is wanted in a third State on criminal charges, especially for offences committed there. Even in the context of human rights (and there does not exist a human right not to be extradited by one's own State) the function of extradition in a context of increasing transnational crime is regarded as crucial, such that even entities whose prime function is to uphold human rights concede that this affects their scope, compressing it. ${ }^{28}$ This jurisprudential orientation is in fact alluded to by the AG in Petrubbin. ${ }^{29}$ This intends to convey that, unlike mechanisms such as expulsion or deportation, extradition presupposes that one State be holder of a legitimate punitive claim fulfilment of which requires an action by another State. And if the latter has no objection to extraditing its own nationals, it is difficult to envisage why and how EU law should be capable of imposing otherwise, especially where, as is the case here, fundamental freedoms of EU law are not infringed upon.

Finally, extradition does not imply loss of citizenship. 'Only' a transfer to another jurisdiction.

c) 'Civis Europaeus sum'?

Both the AG and the Court held that the EU citizenship exception will only be met where it is shown to be necessary to prevent untenable discrimination and constraints on free movement. Whether it is justified to extradite is something to be determined in view of the purpose of avoiding impunity. It has been propounded that extradition of EU citizens should be refused regardless of a risk of impunity, in what would be an unreserved proclamation of the idea underlying the aphorism 'civis Europaeus sum'.${ }^{30}$ However, from the moment one establishes that the EU citizenship exception is derivative, that position - irrespective of one's opinion about the adequacy of the nationality exception to today's world - cannot be endorsed, for the subsequent reasons.

Jurisdiction and extradition cannot be fully disconnected. They are two sides of the same coin; two means for attaining the same basic end that is preventing impunity. This intrinsic relation is the very essence of the old aut dedere aut punire formula, currently materialised in such concepts as vicarious jurisdiction, addressed earlier. As far as specifically regards the relation between active nationality and the nationality exception, it is true that they are autonomous, rather than one being strictly a compensation for the other. ${ }^{31}$ Nevertheless, the fact that in practice they tend to concur - with active nationality enabling the prosecution of cases blocked by the nationality exception - is not purely casual

${ }^{28}$ See supra, Chap. $3, \S 3.3$.

29 See $\int 56$.

${ }^{30}$ Franz LeidenmÜHLER / SANDra GrafEnEdER, "Civis europaeus sum! - Current legal issues relating to the extradition of citizens of the Union to third States. Discussion of the Cases C-182/15, Petruhhin; C-473/15, Schotthöfer \& Steiner; C-191/16, Pisciotti”, ELF 3 (2016), p. 58 f., writing between the AG's opinion and the ECJ's ruling in Petrubin.

31 This is notably visible in the following factors: States can generally exert this type of jurisdiction even if they do not receive an extradition request from the locus delicti; some States have active nationality but do not even have a nationality exception (e.g. Denmark - see infra, $\int$ 2.4.3.); many States can even seek to obtain custody (i.e. issue an extradition request) of a national with a view to prosecuting. 
either. Indeed, it is quite doubtful that the nationality exception would have endured so long were it not usually offset by jurisdiction over nationals: the punitive gap that would have ensued seems intolerable from the standpoint of both the State injured by the crime and of that harbouring the offender. This is supported by such signals as: the presence in many normative instruments of provisions establishing that the refusal of extradition based on nationality must be followed by prosecution, ${ }^{32}$ and the development of cooperation forms consisting of the delegation of jurisdiction between States, ${ }^{33}$ as well as of unconventional types of extraterritorial (e.g. universal and vicarious) jurisdiction.

Moreover, and quite significantly, in cases such as Petrubhin, as noted, a 'Catch-22' situation occurs. This means that a refusal of extradition followed by a complete absence of punitive action compromises the goal of preventing impunity not just in an abstract, but indeed in its most concrete possible expression: that of an international obligation.

These reasons suffice to consider warranted the 'risk of impunity condition' required by the AG and the ECJ. On the other hand, the fact that such a condition has been required offers further proof of the derivative character of the EU citizenship exception: if this whole development were strictly inherent to EU citizenship, the ECJ would not have needed to subordinate it to any condition. Indeed, despite their intrinsic relation, jurisdiction and extradition retain a degree of autonomy that is visible at a normative level: States that accord their nationals protection against extradition generally do so unconditionally, often in their Constitutions; they do concomitantly tend to assert jurisdiction over these offenders, but the protection itself is not dependent on this prerogative, which typically stems from mere ordinary law. The picture is different with the EU citizenship exception: it does give rise to protection against extradition, but only if the offence can be prosecuted in the EU. It is an authentic aut dedere aut judicare obligation, where one of these two courses of action - extraditing or prosecuting - has to be followed. The main peculiarity in relation to other, more common versions of that obligation is that the 'judicare' option, where available, takes priority: primo judicare, secundo dedere. ${ }^{34}$ Another idiosyncrasy is that this option can be exercised not only by the custodial State, but also by a different State, through the use of the EAW system - which means, quite originally, that the fulfilment of the 'judicare' course of action may itself involve a 'deditio'.

\section{d) Conclusion - $A$ 'chemical reaction'}

In conclusion, this development of EU law is not primarily derived from EU citizenship, but from the nationality exception applied by some Member States. Its contact with the compound formed by free movement and equal treatment ${ }^{35}$ elicits, as if by chemical reaction, a EU citizenship exception which consequently applies only to the extent of

32 See e.g. Art. 6 (2) 1957 CoE Convention on Extradition, and Art. 4 (a) MTE.

33 See e.g. the MT Transfer of Proceedings.

34 The exact reversal of what happens in vicarious jurisdiction: see supra, Chap. 1, $\mathbb{\$} 3.2$.

35 This combination is classified by ANDRÉ KLIP, European Criminal Law... op. cit., p. 530 f., as a "fifth freedom", which is highly prone to "impact on the practice of all national criminal justice systems, as many differences in the application of national criminal law and criminal procedure indirectly relate to differences founded on nationality". The development under analysis corroborates this view. 
that contact. Thus, it is inadequate to construe this development as an additional layer in the evolution line of EU citizenship, ${ }^{36}$ as the signal of an impending fully-fledged citizenship status. ${ }^{37}$ This is not to deny that it is an extremely emblematic development. The protection against foreign punitive systems conferred by the nationality exception is still one of the iconic features of the bond linking many States and their nationals, and now it has acquired a EU dimension. The fact nevertheless remains that EU citizenship does not by itself generate such type of protection.

\subsubsection{The practical significance of this obstacle}

Since the EU citizenship exception requires the applicability of a nationality exception and the possibility of a subsequent prosecution in the EU, its practical significance is not instantly perceptible. A clearer picture would require ascertaining: a) Whether or not, and if so to what extent Member States apply a nationality exception; and b) Whether or not, and if so to what extent they have vicarious jurisdiction ${ }^{38}$ and/or active nationality.

It was impossible to collect information on the legal systems of all the EU Member States. However, a wide sample was gathered, with the invaluable help - for which gratitude is hereby stated - of National Desks at Eurojust ${ }^{39}$ and scholars with expertise in the criminal law of different Member States. ${ }^{40}$

\section{a) Nationality exception}

Most Member States have a nationality exception, often of general or quasi-general applicability (Austria, Belgium, Cyprus, Germany, Slovenia, Sweden), and also often with constitutional rank (idem, except Belgium). Sometimes it has constitutional rank, denoting a deep-rooted tradition, but exceptionally admits the extradition of nationals on the basis of a treaty (Estonia, Finland, Latvia, Lithuania, Italy, Portugal, Romania). Sometimes this possibility further requires that certain basic rights be guaranteed in the requesting State, and/or is - or can be - further limited to certain situations, namely: (i) to specific types of conduct such as terrorism or international organised crime (Portugal); (ii) to the specific purposes of prosecution (Finland, Portugal, Romania); or yet (iii) to other types of situations such as that in which the person concerned is also a national of the requesting State, or a resident of that State (Romania).

36 The history of EU citizenship prior to this development is outlined in THÉRÈSE BLANCHET, "From Workers to Citizens - The Evolution of European Citizenship", NJECL 7 (2016), p. 142 f., where five fundamental "layers" are identified.

37 But cf. with Christian Ritz / BERnARdo VASCONCELOS, op. cit., p. 281, stating, with respect to Pisciotti, that one such ruling would constitute a "milestone in the path to complete European Citizenship".

${ }_{38}$ But see infra, \4, construing that Pisciotti limited the possibility, which Petrubhin admitted, to fulfil the 'non-impunity' requirement by prosecuting based on vicarious jurisdiction.

${ }^{39}$ Contact with which was afforded by the Portuguese Desk, esp. José Guerra.

${ }^{40}$ Namely the following: Johannes Keiler (Austria); Auke Willems (Belgium); Alexandros Tsadiras (Cyprus); Jørn Vestergaard (Denmark), Hannah Brodersen (Germany), Samuli Miettinen (Finland), Giulia Giardi (Italy), Simona Žižienè (Lithuania), André Klip (the Netherlands), Florin Streteanu / Dan Morosan (Romania), Christoffer Wong (Sweden); other scholars preferred not to be mentioned. Responsibility for the contents provided rests entirely with the author of this study. 
Some Member States can always extradite their nationals for prosecution, but require their return for enforcement, and never extradite them for enforcement (the Netherlands). Some Member States which only exceptionally extradite nationals also require a 'return to sender' guarantee (Portugal, Romania).

In contrast, other Member States believe that the sheer fact of the offender being their national should not as a principle spoil a territorial claim (Denmark, UK). Nevertheless, even these Member States occasionally engage in a nationality exception in the context of specific treaties, ${ }^{41}$ possibly for reciprocity reasons.

Concluding, although to a highly variable extent - ranging from exceptional to certain -, all Member States might refuse extradition to third States on the basis of nationality. To the correlative extent, the EU citizenship exception might apply in all Member States.

\section{b) Jurisdiction}

\section{(i) Vicarious jurisdiction}

Vicarious jurisdiction was addressed earlier. ${ }^{42}$ To recall, this type of jurisdiction enables States to prosecute offences for which they received an extradition request that they could not grant. In vicarious jurisdiction no meaningful link exists whatsoever between the crime and the legal system of the requested State. The rationale of vicarious jurisdiction is to compensate the requesting State for the refusal of extradition, thereby contributing to the prevention of impunity.

According to the ECJ, Member States generally lack vicarious jurisdiction. ${ }^{43} \mathrm{How}-$ ever, several Member States do have a general power to prosecute offences whose perpetrators cannot be extradited (Austria, Denmark, Estonia, Finland, Germany, Portugal, Romania, Sweden). Besides, Member States lacking such a power can at least prosecute the most serious extraterritorial crimes, namely those of universal (e.g. genocide) or comparable (e.g. terrorism) ${ }^{44}$ character (Belgium, Cyprus, Italy, Latvia, Lithuania, the Netherlands) ${ }^{45}$ Thus, there seems to be wide room for vicarious procedures to be conducted in the EU, and, correlatively, for the EU nationality exception to be applied in practise.

${ }^{41}$ See e.g. Art. 5 of the 2005 Extradition Treaty between Denmark and the USA.

42 See again supra, Chap. $1, \mathbb{\Omega} 3.2$.

43 Petrubhin, cit. $\$ 39$.

${ }^{44} \mathrm{EU}$ (secondary) law itself provides for an aut dedere aut judicare duty in respect of some of these offences, namely in Art. 19 (4) Directive 2017/541 of 15 March 2017 on combating terrorism. On the status of terrorism under international law following the Interlocutory Decision of the Special Tribunal for Lebanon on the Applicable Law: Terrorism, Conspiracy, Homicide, Perpetration, Cumulative Charging, STL-11-01/I/AC/R176bis, 16 February 2011, see Miguel ÂNGELo Lemos, "As of today there is no doubt that terrorism is a crime under international law", 2016.

45 There are also cooperation mechanisms that serve the same goal as vicarious jurisdiction, notably the transfer of proceedings, but they entail an explicit request for the host Member State to prosecute. Therefore, if the third State does not make such an explicit request, the host Member State will be unable to fulfil the risk of impunity condition, and might grant extradition. In some Member States, vicarious jurisdiction itself requires an explicit request to prosecute (Czech Republic) - hence its exclusion from the list of examples provided in the text. 


\section{(ii) Active nationality}

All Member States assessed can prosecute the majority of offences committed by their nationals abroad. This prerogative is generally deemed necessary by States to secure peace and security within their communities, a goal which is still jeopardised by conduct carried out by the members of those communities outside of the respective territories. ${ }^{46}$

However, in order to respect the primacy of territoriality, active nationality tends to be subject to requirements that limit its scope, including that the acts be criminalised in the locus delicti, ${ }^{47}$ and that extradition be impossible to grant. ${ }^{48}$ Sometimes, and most importantly for our purposes, it is yet circumscribed to the hypothesis that the offender be found in the territory of the State: it is the view of some Member States (Italy, Portugal) that only the presence of the offender back within his/her community triggers the need to employ their penal apparatus. In principle, such States will be unable to issue a EAW with a view to prosecuting pursuant to active nationality. ${ }^{49}$

Apart from these cases, which do not appear to be too representative, EAW's can be issued on the basis of active nationality, and thus the conditions appear to be met also from this perspective - for the course of action indicated by the ECJ in Petrubhin to be set in motion by the Member States.

\subsubsection{Questions arising from this development}

In addition to those doubts regarding the practical significance of the EU citizenship exception, Petrubhin left some questions open, or at least not categorically closed, as to the situations that it may encompass and the manner in which it is to operate. Moreover, it appears capable of producing an impact on the national laws of the Member States and of shaking the axis of the relative position of the EU concerning international cooperation in criminal matters, which also raises questions. ${ }^{50}$

\footnotetext{
46 See Pedro Caeiro, Fundamento... op. cit., p. 203 f. Where the site of the crime is not subject to ius puniendi, active nationality also plays a function of international solidarity for the prevention of impunity - see Helmut SAtzger, International and European Criminal Law, München: Nomos, 2012, p. 20.

${ }^{47}$ Where such a limitation is absent, States will have a sort of prerogative of surveillance over their nationals, who are thereby bound to "carrying around [their] own national criminal legal order" - a trait generally associated with authoritarian concepts of State: HELMUT SATZGER, International and European Criminal Law... op. cit., p. 20. According to ANDRÉ KLIP, European Criminal Law... op. cit., p. 212, "somewhat surprisingly", most EU legal instruments providing for active nationality do not make it conditional on the criminalisation of the conduct in the State where it was committed. This requisite honours the territoriality principle in its 'negative dimension', in that it implies that conduct which is not punished in the locus delicti shall not be punished elsewhere: see INÊs FerreIRA LeITE, O Conflito de Leis Penais. Natureza e Função do Direito Penal Internacional, Coimbra: Coimbra Editora, 2008, p. 29. In the situation in analysis, this requirement will almost inevitably be met, as the requesting third State is in principle the State where the acts were committed, and it would not request extradition were the acts not criminalised under its law.

48 This requirement (which entails either that extradition was requested but an obstacle was met which prevented it from being granted, or that extradition was not requested at all) also pays tribute to the territoriality principle, as it marks a recognition of the primacy of the punitive claim locus delicti. This requirement is by definition met in the situation in analysis, as the EU citizenship of the offender precludes extradition.

${ }^{49}$ But see further infra, $\int \mathrm{b}$ )(i).

${ }^{50}$ Reflecting on the possible implications of Petrubhin, see also ANDRÉ KLIP, "Europeans First!: Petrubhin, an Unexpected Revolution in Extradition Law”, EJCCL\&CJ 25 (2017), p. 195 f.
} 
The developments analysed not only impact directly on the extradition relations of a broad agglomerate of States (EU Member States) with the rest of the world, but also they have the potential to be replicated or somehow reverberate in other such agglomerates. They constitute new ground in extradition law, and it is therefore justified to pay further attention to their characteristics and consider their possible implications.

a) The scope and operation of the EU citizenship exception

\section{(i) Refusal of extradition requested for enforcement?}

Petruhhin had not been tried, but instead was being sought for prosecution. Thus, the ECJ only refers to this circumstance. The question that arises is that as to whether the principles upheld in this ruling also apply to extradition requests aimed at enforcement.

So long as impunity is avoided, there is no apparent reason why they should not. From an axiological perspective, refusing extradition is probably even more warranted in this case, as it competes more intensely with a value that is increasingly prominent in current theory of punishment, namely the rehabilitation of the offender. ${ }^{51}$ In fact, the reason to refuse extradition of nationals for enforcement is fairly different from that underlying the classic nationality exception, such that in the EAW system (where it is possible to refuse the surrender of nationals for enforcement, and to demand their return in case they have been surrendered for prosecution ${ }^{52}$ the nationality exception has nevertheless been considered as completely abolished. ${ }^{53}$ What we now find in its stead is a 'rehabilitation exception, ${ }^{54}$ whose distinctiveness is patent in the fact that it applies to other classes of subjects who are as likely to be successfully rehabilitated in the executing Member State as its own nationals, notably its residents. ${ }^{55}$

The autonomy of the rehabilitation exception vis-à-vis the nationality exception by no means prevents the principle established in Petrubbin from applying. Provided, naturally, that the person concerned is a EU citizen: since that principle can only be sparked by the reagent labour of the principle of non-discrimination on the basis of nationality, it cannot apply to a person who, albeit a resident, is not a national of a Member State (however reasonable it might be, in the case, to pursue his/her rehabilitation within the EU).

\section{(ii) Return to sender?}

As indicated above, some Member States extradite their nationals for prosecution but require their return for enforcement. This does not constitute a ground for refusal of

\footnotetext{
51 See ECtHR, Vinter \& Others, \119, applied to an extradition context in Trabelsi. The FD-EAW itself, in regulating concurrence of EAW and extradition requests, bids host Member States to consider whether the requests are aimed for prosecution or enforcement: Art. 16 (3). See esp. infra, Chap. 8, \ 3.4.1.

52 See Arts. 4 (6) and 5 (3) FD-EAW. A similar regime is found in earlier normative instruments, notably the MTE: see the footnote to its Art. 4 (a). On the guarantee of devolution, see the following $\$$.

53 See e.g. AnNe Weyembergh, "L'espace pénal européen”, in Lucette Defalque (coord.), Actualités en droit européen et rappel de quelques principes, Bruxelles: Bruylant, 2006, p. 80.

${ }^{54}$ Similar, see NunO PIÇARRA, “A proibição constitucional de extraditar nacionais...”, op. cit., p. 252.

55 In Wolzenburg (C-123/08), the ECJ delimited the margin of discretion enjoyed by the Member States in determining the scope of 'residence' for these purposes.
} 
extradition in the typical sense of the expression, but rather (to use the terms of the FDEAW) a 'guarantee to be given by the requesting State in a particular case'. Still, there is again no seeming reason for the Petrubhin principle not to apply, as equal treatment and free movement are implicated in identical terms here. If so, Member States that require a 'return to sender' guarantee for their nationals should do the same for other EU citizens. ${ }^{56}$

\section{(iii) Prosecution based on other grounds for jurisdiction?}

Petrubhin suggests that Member States can prosecute the offence pursuant to vicarious jurisdiction ${ }^{57}$ or active nationality, but is silent regarding other bases for jurisdiction, such as active residence or passive nationality.

Peers (2016) posits that other grounds for jurisdiction are admissible. ${ }^{58}$ This view is to be supported. That in such cases (as in that of active nationality) a Member State can issue a EAW follows immediately from the fact that it has primary jurisdiction over the acts. ${ }^{59}$ It is recalled that grounds for jurisdiction involving a meaningful link between the offence and the legal system of a State are 'primary'. The presence of such a link leads to the perpetration of the offence breaching the substantive law of that State, triggering its punitive system instantly (although preference may yet have to be given to jurisdictional claims worthy of 'priority', notably territorial and protective). In contrast, vicarious jurisdiction is 'subsidiary', activating the punitive system of a State only where an extradition request is received but cannot be granted due to reasons other than a willingness on the part of such a State to prosecute. ${ }^{60}$ The question, therefore, is not whether a EAW can be issued, but whether, if it is issued, it must be given priority over the extradition request of the third State. For what Petrubhin does, normatively speaking, is to derogate from Art. 16 (3) FD-EAW, on the concurrence of EAW and extradition requests: this provision governs those conflicts in an open-ended manner, by establishing that priority may be given to either request, depending on the circumstances; Petrubbin makes this norm yield in favour of a principle of mandatory priority of EU prosecutions, anchored in the norms of EU primary law on equal treatment and free movement. ${ }^{61}$

${ }^{56}$ If rehabilitation is to be pursued in a Member State other than that which extradited (notably that of residence or nationality), the offender may be transferred to that Member State upon return, or, if possible, sent directly by the third State to that Member State.

${ }^{57}$ Differently from the AG, the ECJ does not explicitly state that vicarious proceedings shall be carried out, but rather it places the emphasis on the prosecution by the State of nationality. However, that may derive simply from its (erroneous) assumption that Member States generally lack vicarious jurisdiction.

58 See STEVE PEERs, "Extradition to non-EU countries...”, op. cit.

${ }^{59}$ See S. Z. FELLER, "Concurrent Criminal Jurisdiction in the International Sphere", ILR 16 (1981), p. 40 f.; ANdré KLIP, European Criminal Law... op. cit., p. 213; Pedro CAEIRO, Fundamento... op. cit., p. 231 f., 337 f.; INÊS FERREIRA LEITE, op. cit., p. 279 f., 380 f.

${ }^{60}$ See Miguel Jỗo COSTA, Dedere Aut Judicare?... op. cit., p. 129 f., 201 f.

${ }^{61}$ See Steve PeErs, "Extradition to non-EU countries...", op. cit., further informing that this goes even further than the original proposal for an FD-EAW, where priority was given to EAW's only vis-à-vis extradition requests made by non-Members of the Council of Europe, a solution that was abandoned "following intensive lobbying from the US government". The revised version of the "European handbook on how to issue a European arrest warrant", of 6 October 2017, p. 39, on "simultaneous EAW and extradition requests for the same person", already incorporates the implications of Petrubhin ruling. 
Still the answer is positive, and the reason for that lies again in the distinction between primary and subsidiary jurisdiction: if the ECJ concedes that extradition will yield in favour of prosecution by the host Member State based on vicarious jurisdiction (which involves no link at all between the offence and its legal system), then a fortiori it must envisage that priority be given to a Member State whose legal system does have a relevant jurisdictional link - whichever it might be - with the offence.

(iv) Duty to issue a $\mathrm{E} A W$ ?

The ECJ did not state that the Member State of which the person is a national has a duty to issue a EAW if it has jurisdiction to prosecute, ${ }^{62}$ but only that it must be given the "opportunity" to do so. ${ }^{63}$ This suggests that no such duty has been declared. It must however be noted that the ECJ was ruling on the course of action to be followed, not by the Member State of nationality, but by the custodial Member State, which is the one that is confronted with the decision whether or not to extradite. Hence, that expression has the force of a simple obiter dictum.

Considering the logic underlying Petrubhin, it can certainly be argued that the Member State of nationality should as a principle issue a EAW. At the very least where that is the only way to avoid extradition, as in this event, by refraining to act, that Member State will be co-producing an effect (i.e. a differentiation based on nationality) which under EU law is undesirable. Decisively, if to prevent such an effect the ECJ goes so far as to make it incumbent upon the host Member State, where that is possible and necessary, to prosecute an offence that has not breached its legal system, a fortiori again it should expect a Member State whose legal system did suffer a breach to take action if that is possible and necessary. The exceptions are the cases addressed in the following paragraph.

\section{(v) EU citizenship exception without a nationality exception?}

What if a Member State that has jurisdiction over its nationals but not a nationality exception (e.g. Denmark) issues a EAW in this context - i.e. in order to 'veto' extradition? Arguably, if a Member State does not have a nationality exception, in principle it will not be inclined to do that. Still the hypothesis must be discussed, because this is instrumental for determining whether those Member States are also liable to the duty to issue a EAW defended in the previous paragraph. It is evident that issuing a EAW in such circumstances would be discriminatory towards the nationals of that very Member State who are or have been extradited to third States. Therefore, to avoid such an effect, the hypothesis in question must be considered exempted from that duty.

That said, it is nevertheless still legitimate for such a Member State to issue a EAW based on active nationality for punitive reasons, when, after appraising the circumstances of the case, that Member State concludes that it should prosecute the crime even though it was committed in a third State. However, the fact that this Member State does not as a

${ }^{62}$ The considerations adduced in this $\int$ apply mutatis mutandis to the situation in which a Member State has jurisdiction based on any other type of primary jurisdiction: see the previous $\$.

63 Petrubhin, $\iint 48$ f., referring yet to the issuing of a EAW as "potential", or a "possibility". 
matter of principle refuse to extradite its nationals puts it in a fundamentally different position from that of a Member State that, having a nationality exception, issues a EAW in the same setting with a protective motivation. The situation is different also from the viewpoint of the individual concerned, whose expectations of being saved from extradition by his/her Member State of nationality are few or none, and would be few or none even if he/she were in its custody. It follows that if the Member State of nationality does issue a EAW, this EAW will be on the same footing as the extradition request of the third State, and should be decided by the host Member State in accordance with the general conflict rule of Art. 16 (3) FD-EAW, described earlier.

In fact, the circumstance that the Member State of nationality would not, in similar conditions, refuse to extradite its national appears to contaminate the mandatory priority of any other possibility of prosecution in the EU, even if based on primary jurisdiction. Not only because it would also generate discrimination, ${ }^{64}$ but also, and especially, because in such a circumstance free movement is not impaired: a person cannot feel deterred from moving to a Member State because of the fact that this Member State does not accord a protection that is not accorded by his/her Member State of origin either. ${ }^{65-66}$ In sum, the Petrubbin principle does not appear to apply if the Member State of which the person is a national would itself extradite him/her, since in that event one element is missing which is indispensable to elicit the EU citizenship exception: an impairment of free movement. ${ }^{67}$

\section{(vi) Which Member State should prosecute?}

If several Member States (including that which receives the extradition request) are entitled to prevail over the claim of the third State, which of them should take priority? This is yet another question the answer to which stems from the distinction between primary and subsidiary jurisdiction. If the host Member State has not been injured by the crime it should not be burdened with its prosecution (on the basis of vicarious jurisdiction), when a Member State that has been injured (due to a meaningful link between the crime and its legal system) is able to prosecute. A similar logic was employed by AG Bot in Aranyosi \& Căldăraru concerning the EAW, where he stressed the "difficulties and disproportionate means" typical of prosecutions in secondary fora. ${ }^{68}$

${ }^{64}$ If a Member State has primary jurisdiction other than active nationality but extradites its own nationals, then applying the Petrubbin principle will also in principle be reversely discriminatory to its own nationals.

${ }^{65}$ As above, if a Member State with primary jurisdiction nevertheless wishes to prosecute, it might still prevail in the regular terms of 16 (3) FD-EAW. If the sole basis for prosecuting is vicarious jurisdiction (by the host Member State), then extradition must be granted to the third State, since that type of jurisdiction cannot as a matter of principle prevail over any form of primary jurisdiction: see supra, (iii).

${ }^{66}$ It could yet be argued that it is unfounded to apply a protection derived from nationality when the Member State conferring this status would not itself accord such a protection. However, this argument is quite fragile, because it is the legal system of the host Member State - and not that of the Member State of nationality - the one whose conformity with EU law is in question.

${ }^{67}$ See also MARKus RÖHRIG, "Nowhere to Hide? Extradition in Antitrust Cases from a European Perspective”, JECL\&P 6 (2015), p. 173. But see further infra, \4.4.2, on Pisciotti.

${ }^{68}$ Cit., \S 50, 58, and 125 f., already quoted supra, Chap. 1, \3.5 - as was then noted, the AG was referring to the dichotomy between territorial and extraterritorial jurisdiction, but the reasoning applies even more plainly to that between primary (whether territorial or extraterritorial) and subsidiary jurisdiction. 
That a EAW issued pursuant to primary jurisdiction should prevail over the exercise of vicarious jurisdiction by the host Member State is unquestionable and will already result from the national law of this Member State. What moreover needs to be pointed out is that, in such an event, a Member State with primary jurisdiction should probably ${ }^{69}$ be required to issue a EAW, provided that this is necessary to release the host Member State from the burden of prosecuting. Normatively, such an obligation would follow from the duty of solidarity established in Art. 4 (3) TEU, also mentioned by AG Bot in his opinion on Aranyosi \& Căldăraru.

If more than one Member State with primary jurisdiction wishes to prosecute, then a regular conflict of jurisdiction occurs and it should be solved by the host Member State in view of the circumstances of the case, in the terms of Art. 16 (1) and (2) FD-EAW. Other normative or para-normative elements to be considered are FD 2009/948/JHA on prevention and settlement of conflicts of exercise of jurisdiction in criminal proceedings, and Eurojust's "Guidelines for Deciding 'Which Jurisdiction Should Prosecute?' ", which have been revised in $2016 .^{70}$

\section{(vii) When is the risk of impunity condition fulfilled?}

In line with the previous paragraphs, but on a slightly different note, the issue must also be raised as to which type of penal action on the part of a Member State is sufficient to fulfil the 'risk of impunity condition' required by the ECJ.

In respect of Schotthöfer \& Steiner, ${ }^{71}$ Leidenmühler and Grafeneder seem to suggest that any action capable of activating the EU law concept of ne bis in idem is sufficient to fulfil that condition. ${ }^{72}$ The position is endorsed. It could be objected that applying such a wide version of ne bis in idem would only be adequate within a setting of high mutual trust. However, third States are not being told to hold themselves bound to that EU law concept - especially regarding crimes committed in their territories. ${ }^{73}$ What is at stake here is only the minimum level of effort that Member States must attain in ascertaining the criminal liability of the person whose extradition was requested. And from this angle mutual trust not only is not detrimental to that criterion, but in fact only supports it: if Member States deny even each other (whom they are bound to trust), in such ample terms, leeway to prosecute the same acts twice, why should a more demanding - or just different - criterion be used when a punitive claim from a third State is involved?

${ }^{69}$ Exceptions must always be admitted: suppose e.g. that the third State that had requested extradition has all the evidence on the crime and for some reason is only willing to pass it to the host Member State.

${ }^{70}$ See also Katalin Ligeti / John Vervaele / André Klip (reps.), "Draft Legislative Proposals for the prevention and resolution of conflicts of jurisdiction in criminal matters in the European Union", European Law Institute: Vienna, 2017, in www.europeanlawinstitute.eu/, containing proposals for a Directive on the settlement of conflicts of exercise of jurisdiction in criminal proceedings and the prevention of violations of the principle of ne bis in idem ('horizontal mechanism'), a Regulation on the same subject ('vertical mechanism'), and a Regulation on the exercise of jurisdiction in the Area of Freedom, Security and Justice ('mechanism for the allocation of criminal jurisdiction').

${ }^{71}$ Which was expected to shed light on this issue, but ultimately did not: see infra, $\mathbb{} 3$.

72 See Franz LeidenMüHLER / SANDra GrafEnEDER, op. cit., p. 59.

73 Territoriality in fact constitutes an exception also to the ne bis in idem of EU law: Art. 55 (1) (a) CISA. 


\section{(viii) EU citizenship exception by affinity?}

From case law such as Zambrano and Carpenter it follows that non-EU citizens may in some cases rely on the fundamental freedoms enjoyed by the EU citizens to whom they are linked by, inter alia, family ties. ${ }^{74}$ The question thus arises as to whether the EU citizenship exception may apply to those persons.

It is recalled that extradition differs from other mechanisms such as deportation, in that it involves a State with a legitimate punitive claim over a crime, which moreover has typically been committed in its territory. Their potential to cause disruptive effects in the life of the person concerned is similar, but extradition is very different in its finality. Thus, while an application of the EU citizenship exception 'by affinity' cannot be ruled out, ${ }^{75}$ its threshold seems fated to be tougher to meet than in a direct application to a EU citizen.

\section{(ix) Refusal of the EAW?}

The fact that a EAW is issued with a view to preclude the extradition of a EU citizen cannot, obviously, render its execution automatic: the EAW request must still comply with the applicable grounds for non-execution. The person may consent to being surrendered - which in the cases in analysis is more likely than usual, since it might be necessary to avoid being extradited to a third State -, but the consent cannot remove certain norms, notably those protecting absolute human rights. It is therefore fairly probable, especially after Aranyosi \& Căldăraru, that cases occur in which the execution of the EAW must be refused - with the consequence that extradition might have to be granted to the third State, if no other Member State can prosecute.

Quite ironically, it might occur that the host Member State itself falls short of human rights standards (e.g. deficient prison conditions) and that it constitutes the only option within the EU to prosecute the crime; or that another Member State could also prosecute, but also falls short of those standards. Meanwhile, the third State may have decent or even optimal standards. Arguably, in such an event the person could consent to being extradited. But if for some reason he/she chooses not to do so (e.g. so as to remain closer to home), EU law may be causing an awkward situation, where in order to avoid discrimination based on nationality it increases the likelihood of a human rights breach.

\section{b) Impact upon the national laws of the Member States}

\section{(i) Impact upon jurisdiction?}

Does Petrubhin implicitly oblige Member States to expand their jurisdiction, so that they are always able to fulfil the risk of impunity condition, thereby rendering the EU citizenship exception applicable in all instances?

\footnotetext{
74 See ANDRÉ KLIP, European Criminal Law... op. cit., p. 95 f.

${ }^{75}$ Indeed, if a Member State offers such a protection to (persons linked to) its nationals - whether through a nationality exception, or via another obstacle (insofar as in correlation to nationality) -, then, in the light of Petrubhin, it can perfectly be argued that equal treatment must be accorded to (persons linked to) other EU citizens.
} 
Nothing in the ruling suggests so. As stated before, the ECJ in no way implies that EU citizens must not as a matter of principle be extradited to third States, but rather that sometimes that will be necessary for avoiding discrimination and an impairment of free movement. Therefore, Member States are not required to adopt measures aimed at optimising the applicability of the EU citizenship exception.

Nevertheless, Petrubhin seems destined to trigger some reactions by Member States in this respect. Member States that are unable to issue EAW's based on active nationality might feel encouraged to extend this ground for jurisdiction accordingly, so as to use the possibility opened by this ruling of having a 'long-armed nationality exception' within EU space. $^{76}$ In reality, such a possibility is probably already available to them, in the following terms. It is debatable whether the legal norms that establish jurisdiction are subject to the principle of legality: these norms do not define criminal behaviour, but form a "functional unity" ${ }^{\text {"77 }}$ with those that do, such that it is the conjugation of these two types of norms that determines who can be punished by whom for what. At any rate, the protection conferred by the legality principle operates only towards avoiding results that are detrimental to the individual (that is, in bonam partem), ${ }^{78}$ whereas in cases such as Petrubbin, as we saw, the issuing of the EAW - although it does express a formal compromise on the part of the issuing Member State to take some action aimed at satisfying the 'non-impunity condition' required by the ECJ - is fundamentally protective in character. In this sense, Member States that make active nationality dependent on the presence of the person in their territory may interpret that requirement in such a way as to consider that the term 'territory', to that effect, encompasses any EU territory. In fact, this is already the concept underlying the area of freedom, security and justice, which helps to substantiate the analogy.

This incidentally leads to another question concerning active nationality: might the fact that Member States have jurisdiction over their own nationals but not over other EU citizens entail reverse discrimination? The question has been addressed by the ECJ in the past, ${ }^{79}$ but is perhaps worthy of being revisited, because of the protective dimension assigned by Petrubhin to the very concept of jurisdiction in criminal matters.

Concomitantly, Petrubhin might prompt Member States to reduce the scope of their vicarious jurisdiction, for they have just learned - and might not appreciate - that if they have this basis for jurisdiction they might be required by EU law to prosecute more offences that are of no punitive interest to them.

\section{(ii) Impact upon extradition?}

The reaction of Member States to this development may take different forms and degrees, but a few ideas seem firm. One is that, in several Member States, the nationality

\footnotetext{
${ }^{76}$ In Portugal, this development of EU law only adds to already existing criticism according to which active nationality should allow prosecutorial authorities to seek custody of nationals on an opportunity basis: see Pedro CAeiro, Fundamento... op. cit., p. 339.

${ }_{77}$ Ibid., p. $226 \mathrm{f}$.

${ }^{78}$ See Jorge de Figueiredo Dias, Direito Penal... op. cit., p. 175; Christina Peristeridou, The principle of legality in European criminal law, Antwerp: Intersentia, 2015, p. 83.

${ }^{79}$ Notably in Peralta (C-379/92).
} 
exception is deep-rooted and has constitutional rank, rendering its abolition unlikely. If, as argued, the Petrubbin principle does not apply where the Member State of which the offender is a national would not apply a nationality exception, then this ruling might even put pressure on such Member States to create or extend such a protection, so as to avoid their nationals having - to phrase it roughly - 'fewer rights' than other EU citizens.

Nevertheless, the current trend is the moderation of the nationality exception, at least between States that consider each other trustworthy, ${ }^{80}$ a perfect example of which is no more no less than the EU and its EAW system. ${ }^{81}$ From this angle, Petrubhin is rather counter-cyclical. As such, and considering that Member States might not appreciate being forced to refuse to extradite offenders who are not even their nationals to established cooperation partners, Petrubbin might lead to some mitigation of the nationality exception. The reaction of third States to this development will also be relevant, as it is possible that it carries some repercussions in terms of reciprocity. ${ }^{82}$

\section{c) Future developments}

An important question raised by Petrubbin is that as to whether the ECJ will declare further grounds for refusal based on EU law. Considering its theoretical autonomy vis-àvis the nationality exception, the rehabilitation exception can already be regarded as an example of an additional ground for refusal to which the Petrubhin principle may apply.

As for other grounds for refusal found at national level, one of the elements necessary for eliciting the Petrubbin principle - viz. freedom of movement - is met in virtually all cases, given that a EU citizen can be deemed to be encumbered in the fruition of this freedom whenever any given ground for refusal exists in the Member State where he/she is located but not in another Member State. In contrast, discrimination on the basis of nationality - the other element necessary to elicit that 'chemical reaction' - is not very likely to occur in the context of grounds for refusal other than the nationality exception. Still, this is less implausible than may appear at first sight. By way of example: the UK lacks a nationality exception, but (or perhaps precisely because of that) it seems to give relevance to nationality in the context of other grounds for refusal, such as the forum bar, the human rights bar, humanitarian concerns, and the prima facie case requirement. ${ }^{83}$

In a somewhat different situation are the grounds for refusal arising from individual-oriented considerations, especially from human rights. As noted before, the applicability of EU law to some of these situations (sc. torture or ill-treatment, and death penalty) is explicit, and the answer to the third question of Petrubbin therefore unsurprising. ${ }^{84}$ In any

80 See UNODC, "Revised Manuals...", op. cit., p. 24.

81 Another is - as we have seen - extradition between Nordic States: see supra, Chap. 2, \3.1.1.

82 Notably, that third States start refusing to extradite nationals of other third States to whom they have particular links. To an extent this is done by the States forming part of the NAW system, and also e.g. by Brazil and Portugal, pursuant to the Treaty of Friendship, Cooperation and Consultation, of 22 April 2000.

${ }^{83}$ See respectively ss. 83A to 83F (esp. 83A (3) (g)), 87 (together with 8 ECHR), 91 (id.), and 206 EA 2003 - on these provisions, see further infra, Chap. 6, $\iint 5$ 3.1.3., 4.1.3., 4.2.3., and 6.1.3.

84 Although there do exist interesting aspects to it that merit further considerations, including the fact that it suggests (because it applies Aranyosi \& Căldăraru practically lock, stock and barrel to an external con- 
case, the question still holds in relation to other situations of the same character. In particular, it would be important to determine whether the agenda on procedural rights set recently in motion by the EU - which creates new rights in EAW proceedings - interferes, and, if so, in which manner, with outward extradition.

Irrespective of the possible advent of further obstacles stemming from fundamental individual rights, Petrubhin already raises an important question as to the operation of the grounds for refusal of Art. 19 (2) CFREU (whose applicability is certain): do refusals of extradition based on this provision also require that impunity be avoided in the EU? The Charter does not subordinate such grounds for refusal to an aut dedere aut judicare obligation, and at least the prohibition of torture or ill-treatment does not seem susceptible to restrictions, given its absolute character. However, then one may ask whether this is warranted, ${ }^{85}$ considering that the fact that a person risks being tortured or executed in a third State does not mean that he/she has not committed a crime worthy of being prosecuted, and possibly a very serious one, as in fact is often the case where the penalty applicable in the requesting State is capital punishment.

\section{d) The EU and the wider world}

In its current significance, the expression 'Fortress Europe' designates the buttressing of EU's external borders through a multitude of processes that include a firm control of the entrance and stay of foreigners, concomitantly with the furthering, within that area, of rights and benefits directed primarily at EU citizens ${ }^{86}$ It has been suggested that the phenomenon, more than guarding perceived European values, shapes European identity pursuant to an 'us'/ 'them' dichotomy where the first element obtains its meaning largely by contrast with the latter. ${ }^{87}$ The process is not specifically European, ${ }^{88}$ but thrived in this continent, which at least since the advent of the Nation State paradigm has arguably never been so politically integrated as presently (hence the need for a communitarian identity), but whose peoples still emphasise their differences much more than their affinities. ${ }^{89}$

The developments under scrutiny here do not display a segregating caracter. They do draw a line between EU citizens and other persons found in the EU, bestowing upon the former and upon them only an additional safeguard against extradition. However, they do not lessen the latter's rights, the most important of which are in fact imposed by EU law

text) that the ECJ may have a less relativistic view than the ECtHR about the thresholds of breach required in internal and in external cases. On this, see further infra, \$ 3.2.2. and 3.3, regarding Schotthöfer \& Steiner.

85 The aut dedere aut judicare as conceived in Petrubhin would be inadequate in these cases, because the human rights nature of these grounds for refusal means that extradition must always be refused, regardless of whether it is possible to prosecute in the EU. However, a duty to prosecute following the refusal of extradition could be attached to these grounds for refusal.

${ }^{86}$ See Zygmunt Bauman, Europe... op. cit., p. 20 f., passim; Peter Andreas, "Introduction: The wall after the wall", in Timothy Snyder / Peter Andreas (org.), The wall around the West: State borders and immigration controls in Northern America and Europe, Lanham: Rowman \& Littlefield, 2000, p. 1 f.; JOÃO ALDEIA, "An iron curtain around the continent. Produção e exclusão do 'outro' na 'Fortaleza Europa”, D\&D (12) 2013, p. 153 f.

87 Ibid.

88 "All societies produce strangers": Zygmunt Bauman, Postmodernity and its Discontents, Cambridge: Polity Press, 1997, p. 17 f.

${ }^{89}$ See Zygmunt Bauman, Europe... op. cit., p. 11, 17; Alex Warleigh, op. cit., p. 11. 
and apply to them to the exact same extent as to any EU citizen. ${ }^{90}$ Its specific application to EU citizens is inbuilt in that safeguard, since its very definition is the existence of a citizenship status, which inevitably is specific. ${ }^{91}$ More meaningful is the line which has been drawn between the EU as a criminal justice area (formed primordially by the jurisdictions of the Member States, but now clearly amounting to more than the bare sum of those parts) and all other jurisdictions, whereby the former seizes primacy in the prosecution of crimes committed in the territory of the latter, often against local victims.

It is beyond the reach of this study and of this author to establish whether any of that qualifies as 'another brick in the wall' of 'Fortress Europe'. Some thoughts are nevertheless presented. Regarding the first 'line' mentioned above, the remark is that, although it does separate EU citizens from other people insofar as external relations of cooperation are concerned, if one looks for comparatively wider rights or advantages for EU citizens within EU borders, one does not find them. On the contrary, as we saw, the internal extradition system of the EU - the EAW - is far less protective than classic extradition, including in respect of the nationality of the offender. ${ }^{92}$ As for the second 'line', it has not exactly been drawn by the EU, but by the Member States that in their sovereign capacity apply a nationality exception ${ }^{93}$ - which is where the EU citizenship exception originates. ${ }^{94}$ This means that, if this EU obstacle to extradition proves hurtful to international cooperation with third States, the response to that lies largely in the hands of the Member States themselves. They have been placed in an uncomfortable position: they may neutralise the new prohibition of extraditing EU citizens, but for that they have to let go of their old tradition of not extraditing their own nationals.

\section{Schotthöfer \& Steiner}

\subsection{Main proceedings and request for a preliminary ruling}

This case brought before the Court a situation very similar to that of Petrubhin, with the particularity that it had a 'preventive' character: the person concerned had not left the territory of the Member State of which he is a national (Austria), where he was protected by a nationality exception, because he was unsure as to whether in so doing he would be exposing himself to outward extradition. Another peculiarity of this case is that it reached the ECJ in the context of civil, rather than of criminal domestic proceedings. ${ }^{95}$

These proceedings concerned the payment of damages resulting from the cancellation of a contract involving, on the one side, Peter Schotthöfer \& Florian Steiner GbR, a

\footnotetext{
90 See Art. 19 (2) CFREU.

91 Which calls to mind, if in an admittedly improper sense, the notion of citizenship as "a right to have rights": HAnNAH AREndT, The Origins of Totalitarianism, New York: Meridian Books, 1962, p. 267, passim.

92 Notwithstanding the fact that this is the counterweight to a set of rights that was forged by this political project and that profits mainly its citizens - see further infra, $\int 6$.

${ }_{93}$ Which, on the other hand, does not separate them from most other States in the world either.

94 It is curious to note that the nationality exception was created basically to block extradition amongst European States, whereas now it is abolished between many of those States, and these must apply an extrapolated version of it on behalf of each other vis-à-vis third States.

95 See - also for what follows in this paragraph - ECJ, Order of 6 September 2017, $\iint 5$ 2-15.
} 
law firm based in Germany, and, on the other side, Eugen Adelsmayr, an Austrian physician residing in Austria. The law firm had invited Adelsmayr to speak at a conference to take place in January 2015, on working conditions and litigation in the UAE, where he had practised as an anaesthetist and intensive care physician for some years begining in 2004. Shortly prior to the conference, Adelsmeyr cancelled his participation on the reason that he feared being extradited to the UAE.

The underlying criminal case occurred in February 2009, when one of his patients in the UAE, who had suffered several heart attacks, died following an operation. A doctor of the hospital where Adelsmayr was practising lodged a complaint against him, and an investigation was carried out which concluded that his acts constituted murder and manslaughter. In 2011 criminal proceedings were initiated in Dubai, and in their course prosecution called for the application of the death penalty. Adelsmayr fled in 2012. Proceedings were completed in his absence. He was sentenced to life imprisonment, but the proceedings could be resumed at any time and the death penalty could still be applied.

Austria began criminal proceedings against him on the same charges, but on 5 May 2014 they were discontinued by the prosecution on the reason that he had been able to make a prima facie case showing that the proceedings in Dubai were motivated by a hate campaign against him'. Austrian authorities recommended that, if Adelsmayr intended to move to other States, he should inquire the respective authorities whether he could do so without risking extradition. In October 2014 he received the offer from Schotthöfer \& Steiner to speak at the conference, accepted it, and signed a contract, item 5.1 of which dealt with payment of damages in the event of cancellation: if the presentation were cancelled for reasons attributable to him within one month of the set date, he would have to pay the organiser a lump-sum reimbursement of expenses to the amount of $€ 150$.

In November 2014 Adelsmayr became hesitant to travel and asked German authorities to grant him safe-conduct. Having obtained no reply, he informed the law firm that he was cancelling. Based on point 5.1 of the contract, the firm sent him notice to pay the amount due, followed by an application for an order to pay. Uncertain as to whether the cancellation was 'attributable' to Adelsmayr, the Bezirkesgericht Linz referred to the ECJ requesting that the following questions be answered:

a) Is the principle of non-discrimination set in Art. 18 TFEU to be taken to mean that, if a Member State has laid down a provision in its legal system prohibiting extradition of its own citizens to third States, such a provision also applies to citizens of other Member States residing ${ }^{96}$ in the Member State at issue?

b) Do Arts. 19 (2) and 47 CFREU require a Member State to reject extradition to a third State concerning a EU citizen residing in that State, if criminal proceedings and the decision rendered in absentia in the third State did not respect the minimum standards of international law and the non-mandatory principles of EU's ordre public or the right to a fair trial?

${ }_{96}$ The specifications of 'resident' are rather odd, as this question does not appear to vary depending on whether the person concerned is a resident or a non-resident EU citizen, or even a non-EU citizen. 
c) Are Art. 50 CFREU or the principle ne bis in idem to be interpreted as precluding further prosecution by a third State in the case of a first conviction in this State followed by the discontinuation of proceedings in a Member State due to lack of real grounds justifying prosecution?

d) If any of the above questions is answered in the affirmative, does inter alia Art. 6 CFREU, on the right to liberty, carry that a EU citizen may not be held in custody due to an extradition request, where a third State makes such an application for extradition?

\subsection{The order of the Court}

On 6 September 2017 - one year to the day after its ground-breaking judgement in Petrubhin -, the ECJ (First Chamber) made known its stance on Schotthöfer \& Steiner. The Court addressed only one of the four questions referred, namely the one concerning the death penalty in the requesting State. Even the issue of admissibility of the case was addressed entirely by reference to that question. ${ }^{97}$ The ECJ, ruling through a reasoned order, reiterated that EU primary law imposes limitations on extradition from Member States to third States. Though brief and repetitive in relation to previous case law, as is typical of a reasoned order, this decision still presents some points of interest.

\subsubsection{Jurisdiction to rule on the request}

Regarding the applicability of EU primary law to extradition, the ECJ explicitly recalled that in Petrubbin it had established that the decision of a Member State to extradite a EU citizen in a situation where he/she has made use of his right to move freely across the EU falls within the scope of Arts. 18 (equal treatment) and 21 (free movement) TFEU, and, thus, of EU law for the purposes of Art. 51 (1) CFREU, with the consequence that Art. 19 CFREU is also applicable to such a situation. The Court then simply added that those considerations also held true for this case, which concerned the question of a EU citizen being able to enter a Member State other than that of his nationality, thereby exercising his freedom of movement without risk of being extradited.

\subsubsection{EU buman rights obstacles to extradition}

After recalling that Art. 19 (2) CFREU prohibits extradition to a State where there is a serious risk of application of the death penalty, torture or ill-treatment, the ECJ again invoked Petrubbin. It reiterated that, where a Member State receives a request from a third State for the extradition of a national of another Member State, it "must verify that the extradition will not prejudice the rights referred to in Art. 19 CFREU", and that, insofar as it is in possession of evidence of such a risk, "it is bound to assess the existence of that risk when it is called upon to decide on the extradition of a person to that State, on the basis of information that is objective, reliable, specific and properly updated". ${ }^{9}$

\footnotetext{
${ }_{97}$ The Court stated that the "appropriate" approach was to examine this question "first" (id., \ 18), but left the other three questions unaddressed.

${ }^{98} I d$., $\iint 22 \mathrm{f}$.
} 
Applying the law to the case at hand, and relying on the information provided by the referring court, the ECJ noted that the prosecution services of the UAE had requested the application of the death penalty, and that this penalty could still be applied. Consequently, Mr. Adelsmayr ran “a 'serious risk' within the meaning of Art. 19 (2) [CFREU] of being subjected to the death penalty." The Court thus ruled: "The answer to the second question, in so far as it concerns Art. 19 (2) of the Charter, is therefore that that provision must be interpreted as meaning that a request for extradition originating from a third country concerning a Union citizen who, in exercising his freedom of movement, leaves his Member State of origin in order to reside on the territory of another Member State, must be rejected by the latter Member State where that citizen runs a serious risk of being subjected to the death penalty in the event of extradition." 99

\subsection{Analysis}

\subsubsection{A 'mere' reasoned order}

The decision in Schotthöfer \& Steiner took the form of a reasoned order. The Court found that the case fell within Art. 99 of its Rules of Procedure. This norm allows the Court to rule by reasoned order (a more condensed type of decision than a judgment) where the question referred for preliminary ruling is identical to one on which the Court has already ruled, where the reply to such a question may be clearly deduced from existing case law, or where the answer to such a question admits of no reasonable doubt. ${ }^{100}$

The fact alone that the ECJ used this norm lends strength to the principle established in Petrubhin. It very strongly denoted that the applicability of EU primary law to outward extradition, inaugurated by that ruling, is a development that has come to stay.

\subsubsection{Applicability}

The applicability of the Charter to extradition from Member States to third States with whom the EU has not concluded extradition agreements had been settled in Petruhbin. Whereas the applicability of free movement and equal treatment to those matters was innovative, Art. 19 (2) CFREU explicitly refers to 'extradition', and thus its applicability was less doubtful. Still, according to its Art. 51 (1), the Charter is binding on Member States "only when they are implementing Union law"; and apart from the extradition agreements concluded by the EU pursuant to its competences for external action, ${ }^{101}$ extradition between Member States and third States is not regulated by instruments of, or implementing EU law, but by international conventions and 'strictly' national statutes on extradition. ${ }^{102}$

However, the very fact that fundamental principles and freedoms of EU law (equal treatment and free movement) are implicated in such matters brings them within the scope

${ }^{99} I d ., \$ S 26 \mathrm{f}$.

${ }^{100} I d ., \int S 16 \mathrm{f}$.

101 Art. 37 TEU.

102 As noted early in the study (Chap. $\left.1, \int 2.2.\right)$, at present there is hardly such a thing as 'strictly national legislation'. The expression as used here intends simply to distinguish national legislation implementing EU law from other national legislation. 
of EU law for the purposes of Art. 51 according to the approach taken by the ECJ in and since Akerberg Fransson. ${ }^{103}$ It may of course be argued that this ruling made an overly broad interpretation of that norm. But then this is an issue arising from, and more appropriately discussed by reference to Akerberg Fransson, ${ }^{104}$ not to Petrubbin or to Schotthöfer \& Steiner. In this respect, the latter simply applied a principle already established in the former. ${ }^{105}$

\subsubsection{Death penalty as an obstacle to extradition}

The prohibition to extradite in the case of applicability of the death penalty is enshrined in the same provision as the prohibition to extradite in the case of torture or illtreatment: Art. 19 (2) CFREU. In Petrubhin, a risk of ill-treatment was on the table. In Schotthöfer \& Steiner the Court asserted for the first time that EU law prohibits extradition if the death penalty is applicable in the requesting State. Another novelty is that, while in Petrubbin the Court simply pointed out the course of action that, in the abstract, the requested Member State should follow (to assess the existence of a risk of human rights violation based on objective, reliable, specific and properly updated information), in Schotthöfer \& Steiner it went so far as to pass an appraisal that in that concrete case there effectively existed a risk of violation. Indeed, the ECJ stated that "Adelsmayr runs a 'serious risk' (...) of being subjected to the death penalty in the event of extradition."

As we saw earlier, the prohibitions of torture or ill-treatment and of death penalty do not have the same status under international law: the first is absolute, the latter admits significant exceptions. ${ }^{106}$ Thus, there is some symbolic charge to this decision of the ECJ: under EU law, there is an absolute prohibition to extradite in both of those situations.

\subsubsection{The questions left unaddressed}

This reasoned order is arguably more noteworthy for the questions it did not answer than for the one it did. Since these questions might reach Luxembourg again in the future, they deserve to be addressed here, if only briefly.

a) $\mathrm{Ne}$ bis in idem

As noted, an issue involving ne bis in idem was on the table. Austria started criminal proceedings for the charges basing the extradition request and later discontinued them by prosecutorial decision, due to the lack of real grounds justifying prosecution. The refer-

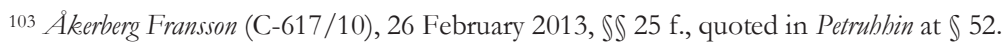

104 On the issue, see e.g. UlF BERNITZ, "The Scope of the Charter and its Impact on the Application of the ECHR: The Akerberg Fransson Case on Ne Bis in Idem in Perspective", in Sybe de Vries / Ulf Bernitz / Stephen Weatherill, The EU Charter of Fundamental Rights as a Binding Instrument: Five Years Old and Growing, Oxford: Hart, 2015, p. 196 f.; see also ANNE PiETER VAN DER Mei, "Flexibility and differentiation...”, op. cit., p. 199 f., noting that even this ruling already draws on pre-CFREU case law, such as Hubert Wachauf $v$. Bundesamt für Ernährung und Forstwirtschaft (C-5/88), 13 July 1989.

105 This does not mean that there are no particularities in respect of extradition matters, which evidently differ from the tax matters at issue in Akerberg Fransson, and from others at issue in later cases. However, it is clearly beyond the scope of this study to elaborate on the efficacy of human rights stemming from EU law, as the primary reference of this study regarding human rights is the ECHR: see supra, Chap. 2, $\int$ 2.2.2.

106 But on this see yet shortly infra, $\int \mathrm{c}$ ), on the right to a fair trial. 
ring court asked the ECJ whether this precluded further prosecution by the third State. ${ }^{107}$ The ECJ could have taken this opportunity to clarify the scope of the 'non-impunity condition' required in Petrubbin, namely to elucidate whether such a condition is to be considered satisfied (immediately enabling the refusal of extradition based on the EU citizenship exception, and rendering unnecessary any further penal action by any Member State) whenever the requested Member State has already taken some penal action (such as a prosecutorial decision) which is sufficient to trigger the EU law concept of ne bis in idem.

\section{b) Effective remedy and fair trial}

The Austrian court also asked whether Art. 47 CFREU, concerning effective remedy and fair trial, requires Member States to refuse extradition where the requesting State does not offer certain minimum standards of criminal procedure. So long as the 'Akerberg Fransson principle' is followed, the applicability of Art. 19 (2) CFREU to cases like Petruhhin and Schotthöfer \& Steiner is straightforward, as that provision explicitly refers to extradition. In contrast, Art. 47 does not; neither does it contain absolute human rights. Thus, it would have been interesting to learn whether the Court admits the interpretation that the Charter may contain implicit prohibitions to extradite - i.e. prohibitions to extradite derived from norms which do not directly apply to extradition -, in the image of the process verified in the context of the ECHR and of other human rights instruments. ${ }^{108}$

\section{c) Right to liberty}

Finally, the referring court questioned whether, in case any of the other questions submitted to the ECJ were answered in the affirmative, Art. 6 CFREU (inter alia), regarding the right to liberty, would prevent a EU citizen from being held in custody owing to an extradition request issued by a third State. Extradition requests can, and often do trigger in nearly automatic terms the arrest of the person concerned. It would have also been interesting to see the ECJ taking a stance on this question.

It is unclear why it was dodged, considering that it is cumulative, and not alternative in relation to the other three questions. The first three questions all involve the issue as to whether or not extradition is prohibited in certain situations, and therefore it is acceptable that the Court, having answered affirmatively to just one of them, consider itself dismissed from answering the remaining. In contrast, the final question involves the issue as to whether deprivation of liberty can be effected when extradition is foreseeably prohibited due to one of those situations being verified, and therefore it does appear that there was no reason for the Court not to answer it.

107 This question is somewhat odd, as by definition the EU law concept of ne bis in idem can only bind Member States. Its relevance thus appears to be limited to the question mentioned subsequently in the text.

108 As noted supra, Chap. 3, \ 4.4.2., Celmer might inform the future case law of the ECJ as to whether or not the breach of relative human rights imposes the refusal of extradition to third States based on Art. $47 \mathrm{CFREU}$, and, in the affirmative, as to what the required threshold of breach is. However, considering the specificities of EU cooperation in criminal matters, Celmer does not immediately allow to conclude that identical case law will be delivered in relation to outward extradition. 


\section{Pisciotti}

\subsection{Main proceedings and request for a preliminary ruling}

Pisciotti also brought before the ECJ an issue similar to that of Petrubbin, again with a temporal nuance: in this instance, extradition had already taken place. Suspected of engagement in concerted practices in the USA, Italian national Romano Pisciotti was sought by this State for prosecution. ${ }^{109}$ In August 2010, a warrant was issued on the charge that he had taken part in a group of manufacturer sales representatives who distorted competition by sharing out among themselves the market for the sale of marine hoses in Florida and elsewhere from 1999 to late 2006. In June 2013, as his flight from Nigeria to Italy stopped over in Frankfurt am Main, he was arrested. Before the District Court of Frankfurt am Main he opposed to being extradited by simplified procedure. He was provisionally detained pending extradition proceedings on the basis of an order of the Higher Regional Court of Frankfurt am Main of 24 June 2013, and on 7 August 2013 the USA sent a formal extradition request. On 16 August 2013, the same Court ordered the provisional detention to be extended by way of a formal detention for the purposes of extradition, and by an order of 22 January 2014 it ruled that extradition was permissible.

On 6 February 2014, Pisciotti made an application for interim measures to prevent execution of the order to the Federal Constitutional Court, which dismissed it by an order of 17 February 2014. In 26 February 2014, he submitted to the Federal Ministry of Justice of Germany a letter arguing that his extradition would be contrary to EU law, in that a literal application of Art. 16 (2) \ 1 of the German Basic Law would infringe upon the principle of non-discrimination. The expedient was fruitless. On 17 March 2014 Germany decided to extradite Pisciotti and the measure was effected on 3 April 2014. On the same day, Pisciotti brought an action before the Regional Court of Berlin - the referring court of this preliminary ruling - claiming that Germany was liable for having granted his extradition to the USA, and requesting that it compensate the corresponding damages.

Having pleaded guilty in the criminal proceedings brought against him in the USA, Pisciotti was sentenced to a term of imprisonment for two years, reduced by the period of his detention in Germany ( 9 months and 16 days), and fined USD 50.000. He served his sentence in the USA until his release on 14 April 2015. ${ }^{110}$

Departing from the view of the German Constitutional Court, the referring court implied that the case of Pisciotti might indeed fall within the scope of EU law, since the Italian had exercised his freedom of movement. It also stated that the EU-USA Extradition Agreement could on its own bring the case within the jurisdiction of the ECJ. The Court in Berlin stated its uncertainty as to whether Art. 17 (2) of that Agreement ${ }^{111}$ could

109 See Opinion of AG Bot, 21 November 2017, $\iint 10 \mathrm{f}$. On the circumstances of the case see also GIANNI De STEFAno, "Meet the First Extradited Businessman on Cartel Charges", JECL\&P 8 (2017), p. 281 f.

110 On the proceedings in the USA, see www.justice.gov/atr/case/us-v-romano-pisciotti.

111 Which provides: "Where the constitutional principles of, or final judicial decisions binding upon, the requested State may pose an impediment to fulfilment of its obligation to extradite, and resolution of the matter is not provided for in this Agreement or the applicable bilateral treaty, consultations shall take place between the requested and requesting States." 
justify discrimination based on nationality, but it denoted the view that it could not, since the norms at issue integrate primary EU law. Specifically, the Landgericht Berlin submitted the following questions to the ECJ on 5 April 2016:

1. a) Is extradition between a Member State and a third country a matter which, regardless of the facts of the individual case, never comes within the material scope of the Treaties, with the result that the prohibition of discrimination is not to be taken into account in the application of a (literally interpreted) rule of constitutional law that prohibits extradition only of the nationals of that Member State?

1. b) If the above question is to be answered in the affirmative, does it make a difference that the matter of extradition between a Member State and the USA is the object of an agreement concluded between this State and the EU?

2. If the applicability of the Treaties to extradition between EU Member States and the USA is not to be excluded from the outset, are Art 18 (1) TFEU and related case law to be construed as meaning that a Member State unjustifiably breaches the prohibition of discrimination enshrined in that norm in the case where, based on a constitutional rule, it treats its own nationals and other EU citizens differently by extraditing only the latter?

3. If such cases fall foul of the prohibition of discrimination, is the case law of the ECJ to be construed as meaning that, in a case such as the present, the breach may form a 'serious breach' capable of sparking a right to compensation, or would the breach have to be manifest?

4. If a manifest breach is not required, is the case law of the ECJ to be interpreted as meaning that there is a priori no sufficiently serious breach in a case such as that in the main proceedings, in which, in the absence of case law of the ECJ with regard to the particular type of factual situation at issue (in this case, the applicability of the prohibition of discrimination to extradition matters between EU Member States and the USA), the highest national executive authority can, in support of its decision, point to the fact that its decision is in line with previous decisions of national courts in the same matter?

\subsection{The opinion of the Advocate General}

On 21 November 2017, AG Bot delivered his opinion on the case. The AG stated that there was "no doubt" that the case fell within the scope of the Treaties, specifically of Art. 18 TFEU, for two reasons: due to its conjugation with the freedom of movement enshrined in Art. 21 TFEU (Petrubhin followed), and to the EU-USA Extradition Agreement (as the extradition request was made pursuant to that agreement after its entry into force, thereby fulfilling "squarely" the concept of 'act governed by EU law'). ${ }^{12}$

After reiterating the fundamental principles established in Petrubbin (and already reinforced in Schotthöfer \& Steiner), ${ }^{113}$ the AG addressed the specificities inherent in the applicability of an extradition agreement between the EU and the third State at issue. In this

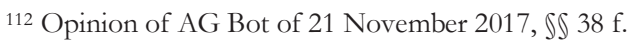

${ }^{113}$ Id., $\iint 32,36$ f., 43 f., passim. 
regard, he firstly noted that such an agreement does not contain any rule on whether extradition may or must be refused on the ground that the person sought is a national of the requested State, nor (as the Commission had also pointed out in its observations) any rule on extradition of own nationals or other EU citizens. The AG proceeded to indicate that "Art. 17 of agreement leaves it open to the States parties to that agreement to rely on grounds for refusal based, in particular, on a bilateral extradition treaty or on the constitutional principles of the requested State", and in this light he concluded that: "The existence of the EU-USA agreement does not therefore have the effect of entirely divesting the Member States of their competence in this field", and "Germany is therefore acting entirely within its competence in laying down, in its constitutional law, the rule that it will not extradite its own nationals". ${ }^{114}$

The AG then reiterated the principle established in Petrubbin that measures such as extradition, which restrict fundamental freedoms of EU law, must be considered in the light of "the objective of preventing the risk of impunity", and "may be justified by objective considerations only if they are necessary for the protection of the interests which they are intended to secure and only in so far as those objectives cannot be attained by less restrictive measures". ${ }^{115}$ Applying the criterion to the case at hand, the AG concluded that "there was no alternative measure to extradition which was less prejudicial to the exercise of the rights conferred by Art. 21 TFEU and which would have made it possible to attain equally effectively the objective of preventing the risk of impunity", given that: ${ }^{116}$

a) First, s. 7 (2) of the German Criminal Code did not allow Germany to prosecute Pisciotti for offences allegedly committed in a third State, since one of the conditions to which that provision subordinates the exercise of vicarious jurisdiction, namely the condition that extradition cannot be granted, was not met.

b) Second, the duty imposed by Petrubhin on the requested Member State to inform the Member State of which the person is a national that it may issue a EAW "was established by the Court in a situation, expressly highlighted by the Court, where there was no extradition agreement between the EU and the third State in question in that case."

c) A third set of remarks, which may be considered of a 'pragmatic' character, consisted of noting that several Member States that submitted observations in this case emphasised the "legal and practical difficulties associated with the approach adopted by the Court" in Petrubbin. Particularly, that "in most cases" the Member State of which the person is a national "is unlikely to be in possession of the information that would enable it to issue a EAW with a view to prosecution and then to prosecute the person", in which event "the objective of preventing the risk of impunity would be jeopardised". Moreover, it was stated that both Art. 16 (3) FD-EAW, and Art. 10 (2) and (3) EU-USA Agreement "run counter to the idea that a EAW should always be given priority over an extradition request.”

\footnotetext{
${ }^{114}$ Id., $\iint 34 \mathrm{f}$.

115 Id., $\iint 44 \mathrm{f}$.

116 Id., $\iint 47 \mathrm{f}$.
} 
The AG further noted that Italy had been informed by Germany of the extradition request made by the USA, and still it did not issue a EAW. He thus concluded that "the answer to be given to the referring court should be that (...) Arts. 18 and 23 TFEU must be interpreted as meaning that they do not preclude a Member State which has received from a third State, pursuant to an extradition agreement between the EU and that State, a request for the extradition of a Union citizen who is a national of another Member State and who has moved to the requested Member State, from granting that request."117

\subsection{The judgement of the Court}

On 10 April 2018 the ECJ delivered its ruling. After stating that the case fell within its competence (both on the basis of the principle established in Petrubhin and of the EUUSA agreement) ${ }^{118}$ the court addressed the case on the merits. ${ }^{119}$

The Court began by noting that the case should be dealt with "within the context" of that agreement, whose goal was to strengthen extradition relations between EU Member States and the USA. It then noted that the agreement does not address as such the issue of a difference in treatment by the requested Member State between its nationals and other EU citizens, and that in fact the agreement does not - save for Art. 13, on capital punishment - set out any grounds for refusing extradition. As for Art. 17, the Court noted that it does allow a EU Member State, on the basis either of provisions of the applicable bilateral treaty or of rules of its constitutional law, to provide for a particular outcome for its own nationals by prohibiting their extradition, but held that such discretion "must still be exercised in accordance with primary law and, in particular, with the rules of the TFEU on equal treatment and the freedom of movement". ${ }^{120}$

The ECJ then evoked Petrubhin to state that, in its light, a case like Pisciotti involves a restriction of free of movement, and that such a restriction would be admissible only if it were justified by objective considerations, proportionate to the legitimate objective pursued (namely to prevent impunity), and necessary due to the unavailability of less restrictive measures capable of attaining the same objective. The ECJ did not consider the option of Germany prosecuting based on vicarious jurisdiction (provided for in s. 7(2) of its Criminal Code), but only the question as to whether Germany could surrender Pisciotti to Italy (through the EAW system). In this regard the Court asserted clearly that: "Although that solution [i.e. the use of the EAW] was adopted [in Petrubhin] in a context characterised by the absence of an international agreement on extradition between the EU and the third State in question, it may be applied in a situation such as that at issue in the main proceedings, in which the EU-USA Agreement gives the requested Member State the option of not extraditing its own nationals". ${ }^{121}$

${ }^{117}$ Id., \} 5 5 .

118 ECJ, Pisciotti (C-191/16), Judgment of 10 April 2018, JS 31 f., further stressing: "The fact that, when [Pisciotti] was arrested, he was only in transit in Germany is not capable of casting doubt on that finding."

${ }^{119} I d ., \iint 36 \mathrm{f}$.

${ }^{120} I d ., \int 42$.

${ }^{121} I d ., \iint 52 \mathrm{f}$. 
In the concrete case at hand, the consular authorities of Italy had been informed of Pisciotti's situation before extradition was granted, and did not issue a EAW. For this reason, Germany's decision to extradite Pisciotti was not in breach of EU law. In conclusion, the Court ruled that the answer to the second question raised in this request for a preliminary ruling should be that: in a case in which a EU citizen who has been requested for extradition to the USA under the EU-USA Agreement is arrested on that ground in a Member State other than that of his/her nationality, Arts. 18 and 21 TFEU do not prevent the requested Member State from drawing a distinction based on its Constitution between its nationals and other EU citizens (refusing to extradite the former but not the latter), insofar as it has already put the competent authorities of the Member State of which the person is a national in a position enabling them to seek his/her surrender by issuing a EAW and this Member State has not taken any action thereon.

\subsection{Analysis}

Pisciotti has many similarities with Petrubhin and Schotthöfer \& Steiner, with the particularity that the discriminatory element was even more visible here than in those cases, as Germany had refused to extradite one of Pisciotti's co-authors due to his German nationality. ${ }^{122}$ Normatively, the most significant particularity was that an extradition agreement between the EU and the third State in question applied, which required an appraisal as to whether such an agreement compelled an outcome different from that of Petrubhin, and whether it was capable of superseding EU primary law. ${ }^{123}$ Since there are noteworthy differences between the Opinion of the AG and the Judgment of the Court, the two are analysed separately.

\subsubsection{The opinion of the $A G$}

Before the Opinion of the AG was delivered, the author of this study contended that an affirmative take on the issue as to whether the EU-USA agreement could supersede primary EU law would mean that, through its external action, the EU could thwart the fundamental principles and rights enshrined in the Treaties and in the Charter. ${ }^{124}$ The Opinion of AG Bot ran in the opposite direction.

122 See Christopher Thomas / Gianni DE Stefano, "Extradition \& antitrust: cautionary tales for global cartel compliance”, MLex Ab Extra, 30 September 2016, p. 2 and 6.

123 Christian Ritz / Bernardo VAsconcelos, op. cit., p. 277 f., inform that the view of the referring court was that such an agreement, as an international treaty, is part of the EU's legal order, but hierarchically inferior to EU primary law. The authors also note that other elements contemplated by the referring Court as potential justifications for differentiation on the basis of nationality were Art. 4 (2) TEU, requiring the EU to respect the national identities of the Member States, and a general unwritten principle entitling Member States to grant wider protection against extradition to their nationals than to other persons. However, these arguments appear to have been dispelled by Petrubhin, because they would also have been pertinent in this case, and yet the ECJ did not pay any consideration to them.

124 Miguel Jỗo COSTA, “The Emerging EU Extradition Law...”, op. cit., p. 212. For an organic analysis of the negotiation, signing and conclusion of international agreements by the EU under the single procedure established by the Lisbon Treaty, see ANNE PIETER VAN DER MEI, "EU external relations and interinstitutional conflicts: the battlefield of Article 218 TFEU”, MJECL 23 (2016), p. $1051 \mathrm{f}$. 
In his Opinion, AG Bot immediately states his view that in a situation such as that at issue EU law does not require the refusal of extradition. ${ }^{125}$ However, the arguments used by the AG in order to substantiate such a stance do not relate to the applicability of the EU-USA agreement, ${ }^{126}$ which as mentioned was the key variant in relation to Petrubbin and Schotthöfer \& Steiner. The sole reference made to the agreement in the reasoning of the AG is the remark that the obligation established in Petrubbin for the requested Member State to inform the Member State of which the person is a national with a view to the possible issuing of a EAW "was established by the Court in a situation, expressly highlighted by the Court, where there was no extradition agreement between the EU and the third State in question." 127 However, the fact that such an obligation had not been established in such a situation (in which it was simply not on the table) does not imply that it does not exist, and no argument is provided by the AG as to why it would not.

As for the other arguments - sc. vicarious jurisdiction, practical difficulties inherent to extraterritorial prosecutions, and concurring EAW and extradition requests -, not only do they not relate (even marginally) to the EU-USA agreement, but also they are entirely invariable from Petrubhin to Pisciotti. The first argument was that s. 7 (2) Strafgesetzbuch did not allow Germany to prosecute the offence, because one of its conditions is that the extradition request cannot be granted, and in the case at hand it could. As we saw earlier in this study, vicarious jurisdiction (Stellvertretende Strafrechtspflege) is a subsidiary type of jurisdiction that enables States to prosecute acts for which they received but could not grant an extradition request. ${ }^{128}$ It has a derivative nature: "The jurisdiction of the state that denied extradition is 'derived' from the jurisdiction of the requesting state", which is why it "only exists if extradition has been requested by a state having jurisdiction". ${ }^{129}$ Thus, up to the moment when it refuses extradition, the requested State does not have jurisdiction over the acts, but, as of that moment, it does. This is no different from jurisdiction based on active nationality, in the cases where it is subordinated to the condition that extradition cannot be granted. Whether active nationality is regarded as a strict compensation for the non-extradition of nationals ${ }^{130}$ or as something more than that, ${ }^{131}$ the fact is that it is often - albeit not in German law ${ }^{132}$ - subordinated to the condition that extradition cannot be granted. In any event, if there is a nationality exception, and the person concerned is an own national, extradition cannot be granted, and at least as of that moment the requested State will have jurisdiction to prosecute. Thus, this does not change the terms of the equal treatment issue as it was on the table in Petrubbin: the fact that the requested Member State does not extradite its own nationals and the fact that the person at issue is a EU citizen do entail an impossibility to grant extradition, since based on Petrubbin the nationality exception in place in a Member State extends to other EU citizens, forming a

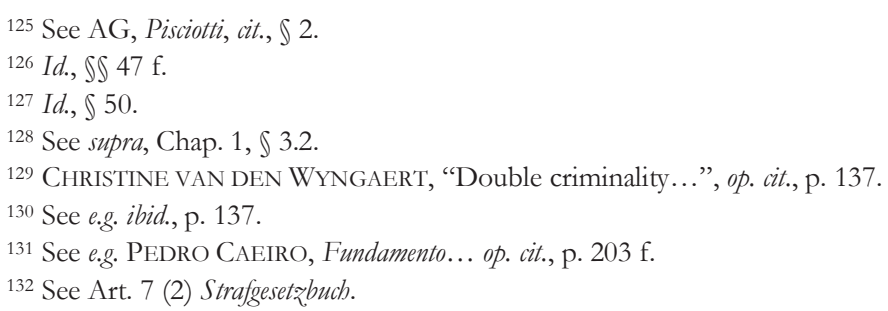


EU citizenship exception. It also does not change the terms of the non-impunity issue, since in both cases the requested Member State is equipped to avoid impunity.

It is probably not as equipped to do so as the State where the offence was committed, notably considering the shortage of evidence available to it - and this is the second argument of the AG. This author could not be more in agreement with this view, which in part is precisely why enhancing extradition is in general a goal that is worth pursuing. But, in this regard, the case at hand definitely does not differ from Petrubhin, Schotthöfer \& Steiner, or any other case in which a State must prosecute an extraterritorial offence, if the State where it was committed or which otherwise has most evidence thereon is unwilling to provide it. ${ }^{133}$

The final argument was that Art. 16 (3) FD-EAW and Art. 10 (2) and (3) EU-USA agreement "run counter to the idea that a EAW should always be given priority over an extradition request." These provisions of the EU-USA agreement do not have any relevant particularities in relation to that provision of the FD-EAW: both institute an openended mechanism for solving concurring extradition and EAW requests. And Art. 16 (3) FD-EAW was also applicable in Petrubhin. As contended above, what Petrubhin does, at the normative level, is simply to derogate from Art. 16 (3) FD-EAW, forcing it to yield in favour of EU prosecutions. ${ }^{134}$

\subsubsection{The judgment of the Court}

Like the AG, the ECJ ultimately found that Germany had not breached EU law by extraditing Pisciotti to the USA. However, the reason why the Court reached such a conclusion differs fundamentally from that which has been relied on by the AG in his opinion: the latter implied that, in the light of the EU-USA agreement, there could never be a breach of EU law if a Member State were to extradite a non-national EU citizen in a case where it would refuse to extradite an own national; in contrast, the Court stated that the principle established in Petrubhin also applied, but that in the light of this very principle it could not be said that extradition should have been refused in the specific case at hand, because Germany gave Italy the opportunity to issue a EAW and Italy remained idle. ${ }^{135}$ In other terms, while the AG held that the Petrubhin principle did not apply to Pisciotti, the ECJ held that it did, but that in this case it did not require Germany to have refused extradition. ${ }^{136}$ Thus, the great conclusion to be drawn from the ruling of the ECJ is that the momentous development brought by Petrubhin does extend to cases where there is an extradition agreement between the EU and the third State in question.

133 And if the third State requesting extradition does show unwilling to provide evidence, then arguably the situation of impunity that might arise therefrom becomes mostly imputable to that State.

134 See supra, \$2.4.4.a)(iii).

135 Which - it should be incidentally noted - may relate to the fact that Italy has limited jurisdiction on acts committed by its nationals abroad: see supra, $\$$ 2.4.3.b)(ii).

136 According to MARKUS RÖHRIG, op. cit., p. 172, Italy can extradite its nationals to the USA. If this is indeed so, then - according to the view presented supra, $\$$ 2.4.4.a)(v) - the ECJ should have ruled that this immediately enabled Germany to extradite, because it could not be said that Pisciotti's free movement had been impaired. In any case, this issue was not brought into discussion in these proceedings and the ECJ did not make any considerations in this regard. Therefore, this ruling does not dispel that view. 
There does however exist a relevant nuance in Pisciotti in relation to Petrubhin. The latter was somewhat ambiguous as to the course of action to be followed by the requested Member State in order to avoid impunity and to thereby enable refusal of extradition, since it appeared to admit either that the Member State of which the person is a national obtains his/her custody through a EAW, or that the requested Member State prosecutes the person itself based on vicarious jurisdiction. ${ }^{137}$ In turn, Pisciotti places full emphasis on the use of the EAW. ${ }^{138}$ In this manner, the ECJ suggests that all that is required from the requested Member State, even in a case like Petrubbin (where there is no extradition agreement between the EU and the third State), is that it gives the Member State of which the person is a national the possibility to issue a EAW. Otherwise, the ECJ would have had to rule that Germany breached EU law by extraditing Pisciotti, because it could have carried out a vicarious criminal procedure instead of granting extradition. That is, Pisciotti entails that the principle set out in Petrubhin does not impose a duty on any Member Stateneither on that which is requested to extradite, nor on that of which the person is a national - to take punitive action in order to satisfy the non-impunity condition and to thereby avoid the extradition of the EU citizen to a third State. ${ }^{139}$

This 'tactful' approach by the ECJ leads to a what may be seen as a paradoxical result: by extending the nationality exception applied in some Member States to possibly any EU citizen, the ECJ reveres and gives depth to the postulates of equal treatment and free movement; however, by stating that Member States are free not to put into practice this EU citizenship exception it has itself 'created', the Court is ultimately leaving the efficacy of those fundamental postulates of EU law at the disposal of entities which are not their primary addressees: Member States, rather than EU citizens. If this case law is indeed to be construed as allowing Member States not to strive in any manner to avoid the outward extradition of EU citizens, then it only creates a new prerogative for Member States; not a real safeguard for EU citizens. This, in any event, only reinforces the view defended above, that this case law is less a furthering of EU citizenship as such than a specific chemical reaction which has in the classic nationality exception to extradition its dominant element. ${ }^{140}$

\subsubsection{Brief digression on the extradition agreement between the EU and Norway \& Iceland}

By establishing that the Petrubhin principle applies to the EU-USA extradition agreement, Pisciotti indicates that this principle should apply to any such agreement, for, as the Court held: "discretion [to apply a nationality exception] must still be exercised in accordance with primary law and, in particular, with the rules of the TFEU on equal treatment and the freedom of movement". ${ }^{141}$ This includes the extradition agreement between the EU and Norway \& Iceland, not yet in force but already agreed upon.

\footnotetext{
${ }^{137}$ See supra, $\$ 2.4 .2$.

138 See also Bernardo Vasconcelos, “The Pisciotti Saga: A Duel in Karlsruhe as Finale?”, in Verfassungsblog, 15 April 2018.

${ }^{139}$ However, the ruling to be delivered in Rangevicius (infra, $\ 5$ ) might shed new light on this question.

${ }^{140}$ See $i d$.

${ }^{141}$ ECJ, Pisciotti, cit., $\ 42$.
} 
This agreement discourages the refusal of extradition based on the nationality of the individual, but ultimately still allows it. ${ }^{142}$ The agreement is moulded on the EAW, ${ }^{143}$ and, quite symbolically, it uses the term 'extradition' rather than 'surrender'. This implies the existence of legal and cultural ties similar to those linking EU Member States, and is yet justified by the fact that Norway and Iceland are integral parts of the Schengen area. Thus, there would be more arguments to defend that EU citizenship should not have blocking effects in this context than in that of EU-USA cooperation. However, as mentioned, the agreement does still provide Member States with leeway to make use of a nationality exception, and, if they do so, then the issue of equal treatment will be on the table.

Whether or not the EU may conclude extradition agreements with third States in which it precludes the applicability of a nationality exception is a different question. The point is that, if Member States do set in place such an exception, then the obligation to accord equal treatment to other EU citizens will as matter of principle have to hold. This means that, to a large extent, the analysis expounded earlier in respect of Petrubhin applies to any case of outward extradition, even if based on an agreement concluded by the EU and the third State in question.

\subsubsection{Conclusion}

The changes brought about by Petrubhin seem to be proving a bitter pill to swallow for all stakeholders involved - requested Member States, requesting third States, and apparently even Member States of which the persons concerned are nationals -, except for EU citizens themselves. In cases where the requesting third State is an established cooperation partner, the pill will be even more bitter. However, those changes do constitute a natural and in this sense inevitable development of EU primary law, and the existence of an extradition agreement between the EU and such a partner does not seem to make any meaningful difference.

\section{Raugevicius}

On 16 May 2017 the Finnish Korkein oikeus lodged a request for a preliminary of the ECJ in the context of a case involving Denis Raugevicius (Case C-247/17). The referring court raised the following questions:

a) Are national provisions on extradition to be assessed with respect to the freedom of movement of nationals of other Member States in the same way regardless of whether the extradition request of a third State on the basis of an extradition convention concerns the enforcement of a custodial sentence or a prosecution as in Petrubbin? Is it relevant that the person sought, as well as being a citizen of the Union, is a national of the requesting third State?

${ }^{142}$ See its Art. 7 (2), establishing a traditional nationality exception, and Arts. 5 (1) (f) and 8 (3), providing for a 'rehabilitation clause' identical to that of the FD-EAW.

143 See ANDrÉ KLIP, European Criminal Law... op. cit., p. 403. 
b) Does a national law establishing that only its own nationals are not extradited to outside the EU for enforcement of a penalty unjustifiably disadvantage nationals of other Member States? Are the mechanisms of EU law by means of which a legitimate objective may be achieved in a less prejudicial manner applicable also in an enforcement situation? How is an extradition request to be answered if, such mechanisms being applied, the request is notified to another Member State which, however, does not, for example due to legal obstacles, adopt measures concerning its nationals?

This is the fourth request for a preliminary ruling involving extradition between EU Member States and third States. It was not included in the original trilogy of cases presented at the opening of this chapter because it was already lodged after the first ruling of the ECJ on outward extradition was delivered and, therefore, after it became established that EU primary law interferes with this matter. It is, so to say, the first second-wave case on extradition. ${ }^{14}$ This explains why it does not contain any repetition in relation to Petrubhin (which it in fact explicitly quotes) or the later cases.

This request for a preliminary ruling comprises two main sets of questions that have already been explored above. One concerns the differences between extradition requested for prosecution and for enforcement purposes: the referring court seeks clarification as to whether the principle established in Petrubhin applies solely to extradition aimed at prosecuting a person (as was the case in that ruling), or also, and if so in which terms, to extradition aimed at enforcing a penalty. ${ }^{145}$ The other concerns the functioning of the mechanisms that can be used in the EU in order to avoid impunity and, thereby, the extradition of a EU citizen to outside the EU. ${ }^{146}$ While both sets of questions are relevant, the latter touches upon a truly crucial aspect of the developments in analysis in this chapter of the study, as the answer to the question as to what is the course of action that must be followed by Member States in these extradition cases is intertwined with the very questions as to what the legal nature and the significance of those developments is.

\section{The emergence of a EU extradition law}

Considering the range of issues involved, on the one hand, and their specificity, on the other hand, the developments introduced by Petrubbin, Schotthöfer \& Steiner and Pisciotti mark what can be considered the sprouting of yet another branch (perhaps a twig) within EU criminal law. The competence of the ECJ on outward extradition based on primary EU law being now certain, further cases are expected to reach Luxembourg, and Rangevicius already forms an example of this. As of the moment that several legal issues arise involving the same subject matter, coherence must be attained in the way they are handled. In this sense, those rulings constitute pillars upon and around which a new normative edifice may be built.

144 Which means that it stands in relation to Petrubbin as Aranyosi II, Aranyosi III (Generalstaatsanwaltschaft) and Dorobantu stand in relation to Aranyosi \& Căldăraru, in that it seeks clarification as to the scope of an already settled principle.

145 See supra, \$2.4.4.a)(i).

146 See supra, $\$ 2.4 .4 .$, esp. (v) and (vii). 
In addition to aiming for such an 'inner-coherence', subsequent developments are expected to be shaped also by reference (either by contrast or by equalisation) to the EAW system (inter-coherence), ${ }^{147}$ in what might institute a bi-directional process whereby the body of law to be developed on outward extradition also impacts upon the identity of EU's internal extradition device. In fact, these dynamics are already visible: (i) Assigning to a citizenship status the potential to block outward extradition accentuates the contrast with internal extradition (where nationality has limited relevance), suggesting that the weight of such a status in international cooperation varies according to the resolve of the parties. (ii) Acknowledging human rights to produce similar blocking effects in both outward and internal extradition brings the two closer together, evincing the transversal and cogent nature of these rights. ${ }^{148}$ (iii) Ascribing priority to EAW's based on extraterritorial jurisdiction and aimed primarily at blocking the extradition of EU citizens to third States over extradition requests based on territorial jurisdiction and aimed directly at exerting criminal punishment, reshapes the nature of the EAW, in that it can no longer be regarded simply as a repressive device, but must now in part also be seen as protective, ${ }^{149}$ and no longer as a device that operates simply in a EU cooperation setting, but now possibly also in a broader international setting, and which as such is itself an integral part of this emerging EU extradition law. In this manner, the area of freedom, security and justice moves one step closer to a model of criminal justice typical of a federal State, within which allocation of the custody of offenders is already quite malleable, and safeguards against extradition from any of the federated States to abroad quite homogeneous. ${ }^{150}$ Incidentally, but very significantly, this contributes to balancing an area that, during the first decades of existence, played almost exclusively a repressive function. ${ }^{151} \mathrm{EU}$ citizens are finally drawing (external) advantages from a criminal justice area which (internally) has had them ex-

147 The concept of 'coherence' as employed here should be taken in a more suggestive than stringent sense, since one must bear in mind that "coherence is an attribute of a system and there is no such thing as a European system of criminal law yet": PEDRO CAEIRO, "A coerência dos sistemas penais nacionais em face do direito europeu", in Constança Urbano de Sousa (coord.), The area of freedom, security and justice: recent developments, Lisboa: Universidade Autónoma, 2014, p. 242.

${ }^{148}$ In this case the equalisation between outward and internal extradition was effected not so much by Petrubhin as by Aranyosi \& Căldăraru, since the applicability of human rights to the former was already rather clear before Petrubhin, while its applicability to the latter was quite dubious before Aranyosi and Căldăraru. A new challenge concerning these dynamics was more recently raised by Celmer. As noted before, when confronted with the applicability of Art. 47 CFREU to outward extradition, the ECJ will be required to take position as to the 'density' of relative human rights, by deciding whether or not they do also apply to those cases, and, if so, whether they are subject to the same threshold of violation or require a higher one.

149 And the same can be said, inherently, of the exercise of jurisdiction in criminal matters, where aimed at avoiding outward extradition.

150 See Auke Willems, op. cit.; JANNEMIEke OUwERKERK, Quid pro Quo?... op. cit.; JenIA IONTCHEVA TURNER, op. cit., p. $114 \mathrm{f}$.

${ }^{151}$ In this sense, Petrubhin adds to the already mentioned EU agenda on procedural rights, although they are in several regards two very distinct developments: the latter is directly and explicitly aimed at tackling a perceived imbalance (see COM/2013/0820 final, 27 November 2013, p. 4), while the balancing effect produced by the former is incidental. This is simultaneously reflected in, and evidenced by the circumstance that the agenda profits any person found in the EU, while the EU citizenship exception is reserved to EU citizens and yet limited to specific cases (notably those involving an impairment of free movement). 
posed to such onerous and swift mechanisms as the EAW. Not that the legitimacy of these mechanisms depended on an increase of directly correlated individual rights, since those mechanisms are already the counterpart, or a response to the side effects of a set of rights that was created by the same political project. This basic synallagma remains unaffected. But this does not exclude that an imbalance did (or still does) exist.

Manifestly, these developments involve vertical interactions between EU law and national laws. ${ }^{152}$ These take place at a most substantive level, as they refer to the very hypotheses that might constitute grounds for refusal to extradition under EU law. As we saw, the new-born EU citizenship exception does not stem from the status of EU citizen as such (although it requires this element), but essentially from the classic nationality exception to extradition found at the national level. It is derivative in character, and that is why it exists only where and to the extent that the requested Member State applies a nationality exception or offers its nationals another type of protection from extradition. But this does not hinder the conceptualisation of these developments as an autonomous body of law: the fact alone that the ECJ has taken a rule of national law and assigned a EU dimension to it alters the scope and significance of that rule in such a manner that these variables cease to be fully controlled by the Member State where the rule originates. This, on the other hand, provides the conditions for another bidirectional process to establish itself: not only national rules on extradition may be derived into EU law, but also the fact that EU law is able to derive them might stimulate Member States into changing them, ${ }^{153}$ in which case the practical implications of EU law would again be redefined, and so on.

The developments in evaluation also involve horizontal interactions between EU law and separate areas of the law. As we saw, with few exceptions (e.g. extradition agreements concluded by the EU, human rights enshrined in the CFREU), EU law does not directly regulate extradition matters, and therefore the competence of the ECJ thereon is limited to cases implicating fundamental principles and rights of primary EU law. ${ }^{154}$ This renders the emerging EU extradition law largely subordinate in character, consisting to a great extent of an application of such principles and rights to those matters. However, this application is ultimately effected by reference to an axiological framework which is heteronomous in relation to EU law; to a specific rationality which is drawn from international law and international cooperation, and which consequently bestows uniqueness on that application. This is epitomised in the 'non-impunity condition' formulated by the ECJ, which incorporates into EU primary law (a unique form of) the principle aut dedere aut judicare. ${ }^{155}$

152 In this context 'national laws' include not only the constitutional and ordinary legislation of the Member States, but also the extradition treaties of which they are parties, since accession to these instruments expresses an informed and detailed volition of their content (in contrast with e.g. EU primary law or human rights instruments, which always bear some indeterminacy, and therefore, occasionally, even a note of imposition, given inter alia their 'living' character: see supra, Chap. 2, \$ 2.2.1.a)(i).

153 See supra, \2.4.4.b).

${ }^{154}$ Notably, the "fifth freedom" formed of the combination of free movement and equal treatment: see again ANDRÉ KLIP, European Criminal Law... op. cit., p. 530.

155 See supra, \2.4.2.c). 


\section{Conclusion}

The analysis carried out in this chapter suggests that a body of rules on extradition is surfacing within EU primary law. Petrubbin stands in that process as a functional equivalent to ECtHR's Soering, in that it has also subjected extradition - conventionally, a State prerogative free of exogenous interference - to compliance with a given, autonomous set of rights and principles. It takes a peculiar combination of factors for EU primary law to interfere with that prerogative, and for this reason too much interference is not to be expected. The novelty is that some interference is now certain.

Given their derivative character, these developments do not dispense with consideration of the traditional grounds for refusal of extradition on which they are based - notably the nationality exception. However, in deriving traditional grounds for refusal onto a much larger scale than that to which they were originally intended to apply, such developments shine an important light on those traditional grounds for refusal. They reiterate the pertinence of reassessing their foundations and of the reasons why they have been set in place. This in itself constitutes an invaluable contribution to this study. 


\section{PART III}

\section{GROUNDS FOR REFUSAL}

VOLUNTARILY ENACTED

BY STATES 


\section{Chapter 5}

\section{Specifications and General Characterisation of the Normative Systems Analysed}

\section{Specifications on the research methods, object and structure of this Part}

As expounded in the introduction, the essential goal of this study is to question the extent to which grounds for refusal of extradition voluntarily set in place by States retain a meaningful function. These grounds for refusal - it is recalled - result from the voluntary action or interaction of particular States, and therefore contrast with those which are derived from international law of general or wide regional character, which garner wider consensus in the international community and, accordingly, bear the character of an imposition upon States individually considered. The exercise ultimately to be effected in relation to these grounds for refusal is inductive, since the goal of this study is to determine which of them are necessary to protect the interests involved in extradition. That exercise requires as a preliminary step that those interests be identified through a deductive analysis of existing grounds for refusal. Such is the function of the present part of the study.

As also indicated before, the concept of grounds for refusal 'voluntarily enacted by States' encompasses grounds for refusal provided for in virtually all treaties and national statutes on extradition. Since it would be impossible to assess all such instruments, a sample was selected which blends the UN model instruments on extradition and the extradition systems of Portugal and the UK as regulated in their national legislation.

It should be made utterly clear that the national extradition systems analysed here have their own historical roots, and as such predate the UN model instruments by far. It is therefore very unlikely that they have been influenced by the latter. It is the latter that were influenced by national legal traditions, which, if with some progressive notes here and there, they basically codify. As was expounded in further detail in Chapter 2, on the methods used in this study, the crossed-reference established in the present chapter between national extradition systems and the UN model instruments is a theoretical structure aimed at guaranteeing that the analysis carried out is at once representative and tangible.

\subsection{Scope}

The analysis carried out in this part of the study covers all grounds for refusal provided for in the UN model instruments on extradition and in the national statutes on extradition of Portugal and the UK. This includes grounds for refusal that, in the light of the delimitations made in Chapter 2, could be expected to be omitted from this analysis. This is justified in the following paragraphs. 


\subsubsection{National grounds for refusal absent from the UN model instruments}

Although the primary normative reference of this part of the study is the UN legislation on extradition, the analysis of national legislation conducted here is not limited to grounds for refusal that have matching grounds for refusal in the UN model instruments. The reason for this was that in order to better understand any given obstacle it is important to discern its function within the system where it operates; and in order to better understand one such system it is important to look at the ensemble of its components. In Dinstein's words: “extradition law is like a tapestry. It takes countless threads to weave the embroidery. But, for the pictorial design to emerge, the tapestry must be looked at as a whole."1 Hence, to disregard the national grounds for refusal which do not have an equivalent in the UN legislation would impair the understanding of those which do. For instance: the UK does not have a classical nationality exception; nonetheless, the research conducted reveals that, to an extent, it compensates for this absence with some unconventional grounds for refusal that have no direct correspondence in the Model Treaty or the Model Law. ${ }^{2}$ Had these norms been overlooked, the understanding of nationality as a ground for refusing extradition would probably have been partly compromised.

\subsubsection{Voluntary grounds for refusal partly imposed upon States}

As noted repeatedly, this study distinguishes mandatory from voluntary grounds for refusal, and only the latter are ultimately questioned in their foundations. Nevertheless, the former are given a particular scope at the national level which may be wider than the correlative international prohibition, and if so they will be partly voluntary. On the other hand, some of the now mandatory grounds for refusal were already applied by States before their emergence as international norms. Finally, the argument that in order to better understand any ground for refusal it is important to discern its role within the respective system is again relevant here. Indeed, it may happen that in one State a certain voluntary ground for refusal has a narrower scope than in another State or in the UN legislation, in consequence of the width attributed in that system to a certain other ground for refusal which is mainly derived from international law. In consequence, in this part of the study grounds for refusal based on international law are not excluded from analysis.

\subsubsection{Grounds for non-execution of the European Arrest Warrant}

The main role of the EAW system in this study is to provide inspiration for a more flexible regulation of classic extradition. Nevertheless, national norms implementing the FD-EAW are also analysed in this part. Framework decisions and directives require implementation by Member States. This process is not neutral, but instead it entails some margin for shaping the rules as they will ultimately enter into force, and through this operation Member States can to some extent bring the European norms into harmony with their national norms, principles, interests. In the case of the EAW, considering the Member States assessed here, such a phenomenon is quite visible. For instance: originally, the

1 Yoram DinsteIn, “General Report”, RIDP 62 (1991), p. 32.

2 See supra, Chap. 4, \$2.4.4.c), and infra, \\3.1.3., 4.1.3., 4.2.3., and 6.1.3. 
Portuguese implementation act included constitutional grounds for refusal that were not present in the FD. The UK too enacted and still has in force several grounds for refusal which are not to be found in the FD; moreover, it made abundant use of concepts which have no backing whatsoever in the FD, but which are instead inspired in the classic paradigm of international cooperation, such as that of 'extradition offence'. ${ }^{3}$ Thus, while the FD-EAW is a supranational making, ${ }^{4}$ it is still infused with national sensitivities. Assessing the manifestations of these sensitivities should therefore contribute to understand the classic extradition systems of those Member States. It should also contribute to understand the EAW system itself - its shortcomings and differences to traditional extradition -, contributing to the dialogue established in this study between the classic paradigm of cooperation and mutual recognition.

\subsection{Structure}

\subsubsection{By normative system or by ground for refusal?}

Two main options were available for structuring this part of the study. One would consist of separating the three normative systems that constitute its object of analysis UN, Portugal, and the UK - into three different chapters, each of which would analyse continually the respective grounds for refusal. This approach would offer a clear picture of each of those systems as self-sufficient entities. In fact this is how the research was conducted. However, its results were reorganised into an obstacle-by-obstacle structure, in the belief that this would favour the comparison of different possible approaches to each ground for refusal.

\subsubsection{Categorisation and order of the grounds for refusal}

The question was then how to categorise and organise the several grounds for refusal. The most logical option was to group them based on common denominators, and again two main possibilities presented themselves. One was to group them based on the interests they protect. This approach showed itself promising for the inductive part of the study, in that it would help to assess the relative utility of adjacent grounds for refusal. However, the research conducted suggested that grounds for refusal tend to protect concomitantly interests of a different character, and that it is often difficult to determine which of them is the predominant one. ${ }^{5}$ Therefore, an alternative approach was followed which consisted of grouping the several grounds for refusal according to more objective factors, notably their 'physiognomies'. Categorisations of this character can be found in

\footnotetext{
3 On this "invention", see JOHN R. SPENCER, "Implementing the European Arrest Warrant: A Tale of How Not to Do it", StLR 30 (2009), p. 191. On the implementation of the FD-EAW in the UK, see also MARK MACKAREL, "'Surrendering' the fugitive - the European Arrest Warrant and the United Kingdom”, JCL 71 (2007), p. $374 \mathrm{f}$.

${ }^{4}$ But see further infra, $\int 1$ 1.3.3., on the peculiarity of the former third pillar's legislative procedure in relation to the procedure of adoption of directives and regulations.

${ }^{5}$ For this precise reason, the structure of Chap. 8 is similar to that of the present Chapter, with few adjustments justified in the proper moment: infra, Chap. $8, \int 1$.
} 
legal literature, ${ }^{6}$ and these were taken into account, but this study uses its own model, drafted in view of the specific universe of grounds for refusal that form its object of analysis. Grounds for refusal which could be included in more than one group were directed into the group to which they appeared to be have stronger links.

Regarding the order in which the several categories (and the several grounds for refusal within each category) are presented, one option would be to provide the sequence that would be more practical to be followed by a court in the requested State when confronted with an extradition request. ${ }^{8}$ However, the goal of this study is not to offer guidance for handling specific extradition cases, but to question grounds for refusal of extradition in their foundations, in a theoretical manner. 'Therefore, the study sought instead to address first the categories (and, within each category, the grounds for refusal) acquaintance with which proved useful or indeed necessary to understand more fully the function of grounds for refusal belonging to other categories (or of other grounds for refusal within one same category). ${ }^{10}$

\footnotetext{
${ }^{6}$ See e.g. M. Cherif Bassiouni, "Law and Practice of the United States", in M. Cherif Bassiouni (ed.), International Criminal Law, Vol. II, op. cit., p. 311 f.; PAUL GULlY-HART, "The European Approach to Extradition", in M. Cherif Bassiouni (ed.), International Criminal Law, Vol. II, op. cit., p. 354 f.; BERT SWART, "Refusal of Extradition...", op. cit., p. 180; UNODC, "Revised Manuals...", op. cit., \ 36; BERT SWART, Nederlands Uitleveringsrecht, Zwolle: W.E.J. Tjeenk Willink, 1986, p. 246 f.; see also the structure of the RIDP 62 (1991), an issue devoted entirely to extradition. Because each ground for refusal is a peculiar unit of analysis, some major studies on the topic prefer an uncategorised, if also logical approach: see notably VINCENT GLERUM, De weigeringsgronden bij uitlevering en overlevering - Een vergelijking en kritische evaluatie in het licht van bet beginsel van wederzijdse erkenning, Nijmegen: Wolf Legal Publishers, 2013, p. 290 f. The author of this study does not read Dutch, but sought to translate the indexes of the Dutch studies mentioned above so as to be able to use them as references for this purpose.

${ }^{7}$ For example: the humanitarian exception may relate to the conditions in the requesting State (e.g. risk of failure to provide indispensable medical treatment), but was inserted in the set of grounds for refusal related to the status or condition of the person, because it primarily and necessarily relates to such a status or condition (e.g. health, age); the political offence exception too might relate to the conditions in the requesting State (e.g. likelihood of a biased criminal procedure), but was inserted among the grounds for refusal related to the nature of the acts, since it is the political nature of the acts that triggers those conditions, and it triggers also other relevant considerations which do not concern the conditions in the requesting State.

${ }^{8}$ For example: if the person sought is a national of the requested State, and this State does not extradite own nationals, then it becomes immediately clear that extradition shall be refused, and there is no practical need to consider any other grounds for refusal, such as those that relate to the conditions in the requesting State, which are typically more difficult to appraise and sensitive to uphold.

${ }^{9}$ And in this light it would make no sense - to continue to the example provided in of the previous fn. - to address first the nationality of the person concerned (which to some extent, but to some extent only, seeks to protect that person from certain conditions he/she might face if extradited to the requested State), and only afterwards address the grounds for refusal related to the conditions in the requesting State (which are directly and exclusively concerned with the conditions that the person might face if extradited to the requested State).

${ }^{10}$ For example: although the rule of specialty is a guarantor of any extradition system as a whole, and as such could be presented before any other element, its importance appeared to be more forcefully conveyed if other grounds for refusal were presented first regarding which the specialty rule is absolutely instrumental (e.g. those related to the nature of the acts); on the other hand, it would not make sense to address limitation on re-extradition prior to the specialty rule, as the former is but a manifestation of the latter.
} 
The proposed categorisation and order are the following:

(1) Grounds for refusal related to the conditions in the requesting State

- Torture or ill-treatment and fair trial rights

- Discrimination

- Death penalty and other penalties carrying irreversible damage

- Imprisonment for life or for an undetermined period

- Hostage-taking considerations

(2) Grounds for refusal related to the nature or relevance of the acts

- Dual criminality

- Relevance

- Political offences

- Military offences

(3) Grounds for refusal related to the punitive claim of the requesting State

- Evidentiary requirement

- Absence of a prosecution decision

- Extinction of criminal liability

- Absence of (valid) jurisdiction

(4) Grounds for refusal related to the status or condition of the person

- Nationality / Rehabilitation

- Humanitarian concerns

- International immunities

(5) Grounds for refusal related to the misuse of extradition proceedings by the requesting State

- Specialty

- Earlier extradition (or limitation on re-extradition)

- Abuse of process jurisdiction

(6) Grounds for refusal related to mere issues of interstate allocation of jurisdiction

- Territoriality

- Pending proceedings or possibility or duty to initiate proceedings

(7) Grounds for refusal related to political concerns of the requested State

- National security

- Reciprocity

\subsubsection{Order of the normative systems (within each ground for refusal)}

Each ground for refusal is analysed as it is regulated in the normative systems of the UN, Portugal and the UK. The UN normative system includes the Model Treaty and the Model Law. The normative systems of Portugal and the UK comprise classic extradition and, where applicable, the EAW. Therefore, each ground for refusal is assessed in up to six different variants.

UN legislation is presented first, as it forms the backbone of this part of the study. Within that, the Model Treaty is analysed first, as it preceded historically, and influenced 
significantly the Model Law. Regarding national legislation, the Portuguese legal system is presented first, because in many respects it is representative of a broader group of States. Within each national system, classic extradition is addressed first, since it forms the paradigm of cooperation from which the EAW system was developed. ${ }^{11}$

The proposed order is the following:

(1) United Nations

- Model Treaty

- Model Law

(2) Portugal

- Classic extradition

- European Arrest Warrant

(3) United Kingdom

- Classic extradition

- European Arrest Warrant

\subsection{Main references}

\subsubsection{United Nations}

The fact that the model instruments are not fully-fledged legal instruments means that there is no related case law. Probably for the same reason, legal literature thereon is extremely scarce. The main exception is the study of Bert Swart: "Refusal of Extradition and the United Nations Model Treaty on Extradition". 12 The UNODC also offers an authoritative and extensive commentary in the "Revised Manuals on the Model Treaty on Extradition and on the Model Treaty on Mutual Assistance in Criminal Matters", ${ }^{13}$ as well as sharp annotations to the UN Model Law. ${ }^{14}$ The analysis of the UN Model Treaty and Model Law on Extradition contained in this study also benefited from authoritative clarifications provided in writing by $\mathrm{M}$. Cherif Bassiouni; ${ }^{15-16}$ while these are not immediately or directly mirrored in this study, they have most certainly contributed to the understanding by his author of the history and context of these normative instruments.

\subsubsection{Portugal}

The analysis of the Portuguese legal system focuses on the grounds for refusal contained in the internal act governing extradition - Law no. 144/99, of 31 August (PT-L) -, and in the act implementing the FD-EAW - Law no. 65/2003, of 23 August (PT-EAW). Provisions cited in this part without reference to their legal instrument belong to PT-L.

\footnotetext{
11 See supra, Chap. 2, \3.2.

12 NYIL 23 (1992), p. 175-219.

13 In https://www.unodc.org/pdf/model_treaty_extradition_revised_manual.pdf.

14 In https://www.unodc.org/pdf/model law extradition.pdf.

15 Whom, most sadly, this acknowledgment has meanwhile become impossible to reach.

16 Responsibility for the contents provided in this study rests, however, entirely with its author.
} 
In earlier research, the author of this study had the opportunity to analyse the Portuguese extradition system from a completely different angle and for completely different purposes. ${ }^{17}$ The analysis conducted in the present study builds on the elements gathered in that research, but covers a sizeable volume of additional references.

Concerning case law, the following guidelines were followed. Firstly, the decisions cited in the bibliographic elements mentioned above were considered. The fact that they are mentioned in doctrinal works on extradition allows for the presumption that they include some of the most relevant judicial decisions on the matter. Secondly, an 'organic' approach was followed whereby the decisions signalled as relevant by eminent entities of the Portuguese justice structure were considered. Regarding the case law of the Constitutional Court, the study followed the references provided in a 2012 report made under the auspices of this Court on the constitutionality checks performed in matters related to extradition and EAW. ${ }^{18}$ Decisions subsequent to the report were also considered. ${ }^{19}$ Regarding the jurisprudence of the Courts of Appeal (which in Portugal intervene as courts of first instance in extradition matters) and of the Supreme Court of Justice (which in these matters functions as an instance of ordinary appeal), the entity of reference was the Public Prosecution's Office of Lisbon, which runs a database where legislation on extradition and the EAW (inter alia), and a selection of related case law are provided and regularly updated. ${ }^{20}$ Concerning the EAW, consideration was also paid to the selected decisions indicated in the website of the Documentation and Comparative Law Office, ${ }^{21}$ an entity that functions in the dependence of the Attorney General's Office ${ }^{22}$ and has specialised competence on international cooperation in criminal matters (inter alia) ${ }^{23}$ Other decisions were considered which do not fall within the previous criteria - e.g. decisions mentioned in decisions which do fall within those criteria, and decisions searched spontaneously through the use of keywords in the official database where they are published. ${ }^{24}$

The review of literature and case law conducted was deemed insufficient to explain why some grounds for refusal, in certain moments, suffered major modifications in their constitutional regime. That was particularly the case with life-imprisonment and the nationality exception. To mend this shortcoming, parliamentary sessions leading to the constitutional amendments that brought about those modifications were consulted. ${ }^{25}$

\footnotetext{
${ }^{17}$ Miguel Jỗo CoSta, Dedere Aut Judicare?... op. cit.

18 MARIa José RANGEL DE MESQuita / CRISTINA SOUSA MACHADO Extradicãa e mandado de detenção europeu enquanto formas de cooperação internacional em matéria penal e fiscalização da constitucionalidade - Relatório do Tribunal Constitucional de Portugal - XIV Conferencia Trilateral dos Tribunais Constitucionais de Espanha, Itália e Portugal, Lisboa, November 2012.

${ }_{19}$ All the decisions of the Constitutional Court cited can be consulted in www.tribunalconstitucional.pt.

${ }^{20}$ See www.pgdlisboa.pt. The decisions can be found in www.dgsi.pt, unless indicated otherwise.

${ }_{21}$ Gabinete de Documentação e Direito Comparado.

22 Procuradoria Geral da República.

23 See www.gddc.pt.

24 The mentioned website www.dgsi.pt, managed by the Institute of Financial Management and Justice Equipment (Instituto de Gestão Financeira e Equipamentos da Justiça) - which, however, does not publish all decisions delivered by the courts.

${ }^{25}$ And these are available in http://debates.parlamento.pt/.
} 


\subsubsection{United Kingdom}

The analysis of the normative system of the UK is centred on the Extradition Act 2003 (EA 2003), which regulates both classic extradition and the EAW. ${ }^{26}$ Where a provision is cited without reference to its legal instrument, it belongs to the EA 2003.

Differently from what happens in Portugal, there is a great wealth of textbooks on the extradition system of the UK, many of which were consulted. Moreover, the extradition system of the UK was reformed in 2003, and later suffered yet other profound, if more concise amendments. This constituted an occasion for the publication of several documents assessing the current state of affairs of UK's extradition law, principally: (1) "Extradition: UK law and practice", ${ }^{27}$ elaborated by the House of Lords Select Committee on Extradition Law, ${ }^{28}$ established in 2014 to conduct post-legislative scrutiny into the law and practice relating to extradition; and (2) "A Review of the United Kingdom's Extradition Arrangements", 29 often referred to as the 'Baker Review', elaborated by Rt Hon Sir Scott Baker, David Perry QC and Anand Doobay, appointed by the Secretary of State in 2010 to assess mainly the following topics: a) The operation of the EAW, including the manner how its optional safeguards have been transposed into UK's law; b) Whether a forum bar should be brought into force; c) Whether the USA-UK Extradition Treaty is unbalanced; d) Whether requesting States should be required to make a prima facie case; and d) The breadth of the discretion of the Home Secretary in extradition matters. Both documents received responses from the Government, which shed additional light on the matters - respectively: (1) "The Government Response to the Second Report from the Select Committee on Extradition Law Session 2014-15 HL Paper 126: Extradition: UK law and practice"; 30 (2) "The Government Response to Sir Scott Baker's Review of the United Kingdom's Extradition Arrangements". ${ }^{31}$ The analysis carried out in this part relies significantly on the textbooks and documents mentioned above.

${ }^{26}$ The EA 2003 is structured into two main parts that differ depending on the identity of the requesting State: EU Member States are 'category 1 territories', and the rules applicable to their requests constitute an implementation of the norms of the FD-EAW; other States are 'category 2 territories', and their requests are regulated by generally more demanding rules, with extradition being more difficult to grant.

${ }^{27}$ House of Lords Select Committee on Extradition Law, "2nd Report of Session 2014-15 - Extradition: UK law and practice", ordered to be printed 25 February 2015 and published 10 March 2015, in www.publications.parliament.uk/pa/ld201415/ldselect/ldextradition/126/126.pdf.

${ }^{28}$ In elaborating the report, the Committee considered extensive oral and written evidence provided by a wide range of experts, practitioners, public entities and other institutions, which is also available online in www.parliament.uk/documents/lords-committees/extraditionlaw/SELECT\%20COMMITTEE\%20ON\%20EXTRADITION\%20LAW.pdf.

29 SCOTT BAKER / DAVID PERRY / ANAND DOOBAY, “A Review of the United Kingdom's Extradition Arrangements (Following Written Ministerial Statement by the Secretary of State for the Home Department of 8 September 2010) - Presented to the Home Secretary on 30 September 2011", in www.gov.uk/government/uploads/system/uploads/attachment data/file/117673/extradition-review.pdf.

30 Presented to Parliament by the Secretary of State for the Home Department by Command of Her Majesty, July 2015, Cm 9106, in www.parliament.uk/documents/lords-committees/extradition-law/201507-16\%20-Cm9106-ExtraditionEMBARGOED.PDF.

31 Presented to Parliament by the Secretary of State for the Home Department by Command of Her Majesty, October 2012, Cm 8458, in

https://www.gov.uk/government/uploads/system/uploads/attachment data/file/228566/8458.pdf. 
On the other hand, since the legal system of the UK is based on precedent, those elements contain profuse references to the most relevant case law on extradition and the EAW. Thus, the selection of case law to be analysed could rely essentially on the bulk of decisions indicated in those elements, without prejudice to the spontaneous search of further decisions through the use of keywords. ${ }^{32}$

As with the Portuguese system, the review of literature and case law of the UK was occasionally insufficient to grasp the reasons behind certain legislative amendments. For this reason, an assessment was also made of parliamentary debates held in the House of Lords and in the House of Commons. ${ }^{33}$

Finally, other research activities were carried out with a view to offsetting possible limitations resulting from the lack of familiarity of this researcher with this legal system. ${ }^{34}$ Such activities have no immediate or direct reflection in this text, but it is clear to this author that they improved greatly his understanding of this legal system.

\subsection{Approach}

This part of the study is quite descriptive, and in this sense it is perhaps more 'arid' than other parts. However, it is also very analytical, as the rationales of the several grounds for refusal were often not evident (which is what confers on this part its deductive nature). Because this part is concerned with grounds for refusal as they are concretely set in place by States, many elements begin to emerge here which possess great relevance for the inductive part to be carried out later.

\section{General characterisation of the normative systems assessed}

Before analysing the grounds for refusal found in the legislation of the UN, Portugal and the UK, it is important to depict the main characteristics of those normative systems, as 'ecosystems' within which those grounds for refusal operate.

\subsection{United Nations}

The UN model instruments have already been thoroughly characterised in Chapter 2 , on the methods used in this study. The central notions to keep in mind are that: they are not fully-fledged legal instruments, but points of reference for States wishing to conclude treaties or enact internal legislation on extradition; and that, content-wise, they

\footnotetext{
${ }^{32}$ In the Westlaw UK database: https://legalresearch.westlaw.co.uk/.

33 In http://www.publications.parliament.uk.

${ }^{34}$ Specifically, interviews were conducted in person to: Howard Riddle, Senior District Judge and Chief Magistrate at Westminster Magistrates' Court; Margot Coleman, District Judge at the same Court; Natalie Soule, Specialist Extradition Prosecutor at the CPS Extradition Unit in London; Edward Grange, Specialist Extradition Lawyer at Corker Binning and Vice-Chair of the Extradition Lawyers' Association; Valsamis Mitsilegas, Professor at Queen Mary University of London; Saskia Hufnagel, Senior Lecturer at the same University; and Mark Mackarel, Lecturer at St Mary's University. An interview was conducted in writing to David J. Dickson, Head of Extradition at the Crown Office in Edinburgh and EJN Contact Point. Court sessions in extradition and EAW cases were attended at the Westminster Magistrates' Court. Gratitude is hereby expressed to all the persons and institutions mentioned above. Responsibility for the contents provided rests entirely with the author of this study.
} 
constitute essentially an effort to codify global traditions on extradition, but in certain aspects also venture to promote above-average levels of cooperation.

\subsection{Portugal}

Portuguese extradition proceedings comprise two different, successive phases. ${ }^{35}$ The first is 'executive', and involves an assessment by the Minister of Justice as to whether, in view of the administrative or political circumstances of the case, the request should be refused outright or can instead proceed to the next phase. The ensuing phase is judicial and requires a court to assess whether all legally prescribed conditions necessary for extradition to be granted are satisfied. ${ }^{36}$ Although the law does not explicitly provide for such a possibility, a substantial part of legal literature holds that a second executive intervention may take place (with a view only to refusing extradition) ${ }^{37}$ in case of supervening changes in politically relevant circumstances.$^{38}$ In its intervention(s), the political branch is entitled to reject extradition based on virtually any reason it deems politically relevant, including of an economic character, as long as the interests at stake have constitutional rank. ${ }^{39}$

Portuguese courts do not generally feel compelled to pinpoint the rationales of the grounds for refusal they apply. Most decisions assessed focus on ascertaining whether or not the circumstances of the case at hand trigger a given ground for refusal. In a digest of the case law of the Supreme Court of Justice on the EAW, grounds for non-execution are wholesale condensed into a single notion: "reservations of sovereignty". "The exception to this shortage of information on the rationale of grounds for refusal is the body of case law produced by the Constitutional Court - which, however, naturally, only addresses the few grounds for refusal that have constitutional rank. This made it arduous to meet the goals of this part, and on occasion definite conclusions could not be drawn. Still, the fact that courts tend not to question or elaborate on the rationale of grounds for refusal has itself some hermeneutic relevance, in that it suggests that the existence of such grounds for refusal is regarded as a normal, well-established fact.

35 See Arts. 46 f.

36 The sole ground for refusal that appears to be an exclusive competence of the Minister of Justice is the general reciprocity clause regulated in Arts. 4 and 6 (4) (not to be mistaken for the specific reciprocity requirements attached to some specific grounds for refusal, such as the nationality exception): see the Preamble of the Decree-Law no. 43/91, of 22 January; the ruling of the Court of Appeal of Lisbon of 4 January 2004, process 3880/2003-3; MANuel António Lopes Rocha / TERESA Alves MARTins, op. cit., p. 29; Mário Mendes SERrano, “Extradição. Regime e praxis”, in José Manuel da Cruz Bucho et al., Cooperação Internacional Penal, Volume I, Lisboa: CEJ, 2000, p. 38; see yet infra, Chap. 6, SS 1.4.2., 4.1.2. and 7.2.2.

37 The decision to grant extradition rests entirely with the judiciary: see Art. 33 (7) Constitution, and J. J. Gomes Canotilho, Direito Constitucional e Teoria da Constituição, 5th ed., Coimbra: Almedina, 2001, p. 658, 662; see also the ruling of the Constitutional Court no. 360/2012, of 5 July 2012, \ II.7.

38 See Pedro CAEIRo, "O procedimento de entrega previsto no Estatuto de Roma e a sua incorporação no Direito Português”, Coimbra: Coimbra Editora, 2004, p. 124 f.; MÁRIo MENDES SERRANO, op. cit., p. 75 f.; CARLOS FernANDES, A extradição e o respectivo sistema português, Lisboa: IHLADI, 1996, p. 54 f.

39 See Manuel António Lopes Rocha / Teresa Alves Martins, op. cit., p. 24.

40 António PIRes HenriQues da GraçA, A Jurisprudência do Supremo Tribunal de Justiça na execução do regime relativo ao Mandado de Detenção Europeu, based on a communication made at the "Acção de Formação Permanente 'Cooperação Judiciária Internacional em Matéria Penal' ”, Centro de Estudos Judiciários (org.), 8 May 2008, p. 17, in http://www.stj.pt/ficheiros/estudos/piresdagraca-direitoeuropeu.pdf. 
In fact, the same may be said of the legislature: for example, the EAW statute implemented all the grounds for non-execution provided for in the FD-EAW - the mandatory ones as mandatory, the optional ones as discretionary. ${ }^{41}$ This suggests that no evaluation was carried out as to whether all the optional obstacles were really necessary or desirable in the light of Portuguese tradition in extradition matters. Not that judicial decisions refusing execution of EAW's are abundant. Quite the opposite, optional grounds for non-execution are applied quite exceptionally, and EAW's are usually executed in the name of mutual trust. ${ }^{42}$ What is symptomatic is the seemingly acritical implementation of each and every available ground for non-execution. ${ }^{43}$

The law provides that international cooperation in criminal matters is "subordinated to the protection of the interests of sovereignty, security, ordre public and other interests constitutionally defined". ${ }^{44}$ These concepts are highly abstract, and the law does not specify them. It appears safe to assume that the several grounds for refusal found in the law are concretisations of those interests, but the rapport is not always evident. The concept of ordre public - the set of peremptory values that the State is bound to uphold not only internally but also in its interactions with other States $-{ }^{45}$ offers a rationale for several of the grounds for refusal found in this extradition system, as does the concept of sovereignty. But security and other interests do not seem to materialise in any ground for refusal, and hence the only addressee of that general provision pinpointing the interests to which international cooperation is subordinated will be the political branch of the State.

\subsection{United Kingdom}

\subsubsection{General considerations}

The extradition system of the UK is also mixed: it includes a judicial and a political phase for which the Secretary of State for the Home Department is responsible. ${ }^{46}$ The sequence of the two phases is the opposite to that in Portugal: in the UK, the judiciary intervenes first. ${ }^{47}$ Another relevant difference concerns the allocation of competences between

\footnotetext{
41 See Pedro Caeiro / Sónia FidAlgo, "The Portuguese experience of mutual recognition in criminal matters: five years of European Arrest Warrant”, in Gisèle Vernimmen-Van Tiggelen / Laura Surano / Anne Weyembergh (eds.), The future of mutual recognition in criminal matters in the European Union / L'avenir de la reconnaissance mutuelle en matière pénale dans l'Union européenne. Bruxelles: Éditions de l'U.L.B., 2009, p. 455; see also Boaventura de Sousa Santos (coord.), The European Arrest W arrant in Law and in Pratice: A Comparative Study for the Consolidation of the European Law-Enforcement Area, Coimbra: CES, 2010, p. 355, noting that "most articles of the transposition law are a sheer translation" of the FD-EAW, and p. 357.

42 See Boaventura de Sousa Santos (coord.), op. cit., p. 373.

43 Which in any case is not as cooperation-unfriendly as the implementation of all optional grounds for non-execution as mandatory, as occurred in some Member States (at least in regard of their own nationals): see “Commission Staff Working Document”, SEC(2011) 430 final, Brussels, 11 April 2011, p. 3 and 37, in http://ec.europa.eu/justice/criminal/files/annex eaw implementation report 2011 en.pdf.

44 Art. 2 (1).

45 On the concept, which is central to this study, see further infra, Chap. $7, \int 3.2$.

46 See ss. $92 \mathrm{f}$.

${ }^{47}$ Both models can be imputed advantages and disadvantages. This issue is incidental to this study, but a brief note on this is yet provided infra, Chap. 8, $\$$ 2.1.1.
} 
the judiciary and the executive. Whereas in Portugal - as noted - courts must assess all grounds for refusal explicitly provided for in the law (save for reciprocity), in the UK, as far as regards classic extradition, the competence for applying certain grounds for refusal (namely death penalty, specialty and earlier extradition) belongs to the executive alone. ${ }^{48}$

In any case, according to Grange and Niblock, the evaluation to be made by courts in extradition cases is "essentially political", as is especially visible where human rights issues are raised: "Whilst [judges] must have regard to the human rights of requested persons, they are also acutely aware of the two things: first, that extradition arrangements are reciprocal, ie a refusal to extradite to a country may lead to an extradition request from this country being refused; and second, that blanket refusals to extradite (...) carry the possibility of creating a safe haven for fugitives". ${ }^{49}$ This echoes the notion, established earlier in this study, that States' interest in extraditing is largely based on their desire to secure reciprocity and to avoid the settling of 'criminals'. ${ }^{50}$ The tension between this interest and the protection of basic individual rights is clear in UK case law. A notable example is the Wellington case, ${ }^{51}$ still decided under the 1989 Act: Wellington was sought by the USA for two murders and other offences committed in that State; the House of Lords found that treatment deemed to be inhuman or degrading in domestic cases will not necessarily be deemed as such in the context of extradition, where a decision of refusal might enable a person to evade justice altogether. This means that even individual-oriented grounds for refusal are applied only in a "modified form which takes into account the desirability of arrangements for extradition". ${ }^{52}$ Similarly, in $H H$ \& thers $^{53}$ the view was held that there is "a constant and weighty public interest in extradition: that people accused of crimes should be brought to trial; that people convicted of crimes should serve their sentences; that the UK should honour its treaty obligations to other countries; and that there should be no 'safe havens' to which either can flee in the belief that they will not be sent back." Another example is Harkins, ${ }^{54}$ where the point was restated that there is an "overwhelming public interest in the functioning of extradition arrangements and in honouring extradition treaties." Thus, very much in line with the concept of ground for refusal adopted in this study, ${ }^{55}$ in the UK, grounds for refusal (or 'bars', as they are generally named in this legal system) are openly seen as conditions that conflict with interests that are immanent to the act of extraditing and that must be quite strong if they are to supersede them.

\footnotetext{
${ }^{48}$ See Edward Grange / RebecCa Niblock, op. cit., p. 148. Asylum claims are also decided by the Secretary of State: see Clive Nichols et al., op. cit., p. 157.

${ }^{49}$ Edward Grange / RebecCa Niblock, op. cit., p. 95 f.

${ }^{50}$ See supra, Chap. 1, $\mathbb{5} 4.1$.

${ }^{51} \mathrm{R}$ (on the application of Wellington) (FC) v. Secretary of State for the Home Department [2008] UKHL 72, SS 21, 38, 56; thereon, see MARKo Milanović, "Extradition and Life Imprisonment", CLJ 68 (2009), p. 248 f.

52 SCOTt BAKer / David Perry / ANAND Doobay, op. cit., p. 388.

${ }^{53}$ HH v. Deputy Prosecutor of the Italian Republic, Genoa, PH v. Deputy Prosecutor of the Italian Republic, Genoa, F-K (FC) v. Polish Judicial Authority, [2012] UKSC 25, 2012 WL 2191316, \8, drawing on Norris v. Government of United States of America, [2010] UKSC 9, 2010 WL 605760.

${ }^{54}$ Phillip Harkins v. The Secretary of State for the Home Department v. Government of the United States of America [2014] EWHC 3609 (Admin) 2014 WL 5599581, \ 66; see also Hamza v. Secretary of State for the Home Department [2012] EWHC 2736 (Admin).

${ }^{55}$ See supra, Chap. $1, \S 5$.
} 
The EA 2003 does not include a norm identifying in the abstract the interests to be safeguarded by the extradition law of the UK. However, the case law and other elements indicated above offer more plentiful indicators than what happens in Portugal as to what are the rationales of the different grounds for refusal.

\subsubsection{Different parts of the UK}

The extradition system of the UK involves some differentiations between England and Wales (which constitute the 'default' addressees of the norms of EA 2003), Scotland, and Northern Ireland. ${ }^{56}$ Although on occasion they are indicated, this study does not dissect those differences. In their main traits, the several bars are regulated rather uniformly, making those differences mere nuances whose scrutiny would present no advantages for the purposes of this study. The study therefore focuses on those default norms.

\subsubsection{Brexit}

On 23 June 2016, a few days after this author left the UK after a brief research period related to this study, $51.9 \%$ of UK's electorate voted to leave the EU through a referendum with a turnout of $71.8 \% .^{57}$ On 29 March 2017, the UK triggered Art. 50 TEU, setting the UK on course to leave the EU by 29 March 2019. ${ }^{58}$ Among the extensive effects of this event are probable consequences for UK's arrangements with EU countries in the field of international cooperation in criminal matters. ${ }^{59-60}$

56 Visible in such norms as ss. 30A, 107A, 112A, 141, 170, 183. 184, 192, and 199.

57 See www.bbc.com/news/uk-politics-32810887, last accessed 11 December 2017.

58 See www.theguardian.com/politics $/ 2017 / \mathrm{mar} / 29 /$ theresa-may-triggers-article-50-with-warning-ofconsequences-for-uk, last accessed 11 December 2017; see Art. 50 (3) TEU.

${ }^{59}$ See JoAnNa Dawson, "Brexit: implications for policing and criminal justice cooperation", House of Commons Briefing Paper no. 7650, 24 February 2017, with further references; STEVE PEers, "EU Referendum Brief 5: How would Brexit impact the UK's involvement in EU policing and criminal law?", 21 June 2017, in http://eulawanalysis.blogspot.com; VALSAMIS MitSILEGAS, "European criminal law without the United Kingdom? The triple paradox of Brexit", NJECL 8 (2017), p. 437 f.

${ }^{60}$ The activation of Art. 50 TEU by the UK may even carry immediate consequences for the EAW system insofar as the UK is involved. On 12 March 2018, the Supreme Court of Ireland, in Appeal no. 131 of 2017, Minister for Justice and Equality v. Thomas Joseph O'Connor, \3.16, lodged a preliminary ruling. Having regard to the uncertainty as to the arrangements that will be in place between the EU and the UK after UK's departure, and the consequential uncertainty as to the extent to which Mr. O'Connor would be able to enjoy rights under EU law if he were surrendered to the UK and remained incarcerated there after its departure, the Supreme Court of Ireland posed the following questions to the ECJ: (1) Is an executing Member State required by EU Law to decline the surrender to the UK, pursuant to a EAW, of a person whose surrender would otherwise be required by the national law of the Member State: (i) in all cases?, (ii) in some cases, having regard to the particular circumstances of the case?, or (iii) in no cases? (2) If the answer to question 1 is that set out at (ii), what are the relevant criteria or considerations? (3) In the context of question 2, is the court of the executing Member State required to postpone the final decision on the EAW to await greater clarity about the legal regime that will be in place after the withdrawal of the relevant issuing Member State from the EU: (i) in all cases?, (ii) in some cases, having regard to the particular circumstances of the case?, or (iii) in no cases? (4) If the answer to question 3 is that set out at (ii), what are the relevant criteria or considerations? 
On 2 February 2017, the Government of the UK released its White Paper on Brexit stating its intention to "continue to work with the EU to preserve UK and European security", to "fight terrorism and uphold justice across Europe", to "work more closely with our partners, including the EU and its Member States, sharing information and supporting each other in combating the threats posed by those who wish us harm", and to establish "a relationship that is capable of responding to the changing threats we face together"; the motto is "leaving the EU, not leaving Europe". ${ }^{61}$ It is also manifestly in the interest of the EU to maintain a close relation with the UK in the field of criminal justice, an aspect which does not seem to find itself among those regarding which the EU may want to take a very tough position vis-à-vis the UK in the Brexit negotiations. ${ }^{62-63}$

The future is uncertain, but it seems inevitable that the UK will cease to take part in the FD-EAW scheme. The three main alternatives for future extradition arrangements between the UK and EU Member States appear to be: (i) to rely on the 1957 CoE Extradition Convention; (ii) to conclude an agreement with the EU; and (iii) to conclude bilateral agreements with EU Member States. ${ }^{64}$ Whichever road is followed, it is reasonable to expect that the UK and at least several of its former EU fellows will seek to establish arrangements creating levels of cooperation that, while bound to be lower than those characterising the EAW, are still higher than those characterising classic extradition. Mitsilegas construes that one paradox brought about by Brexit is that, if the UK intends "to continue to reap the security benefits of EU cooperation", it might have to "accept more EU law than it currently does as an EU member state", because "only if [it] complies fully with the EU acquis, including the acquis on the protection of fundamental rights, part of

61 “The United Kingdom's exit from and new partnership with the European Union", Cm 9417, February 2017, www.gov.uk/government/publications, p. 61 f., last accessed 11 December 2017. Other such declarations of intention are conveyed in JOANNA DAWSON / SALLY LIPSCOMBE / SAMANTHA GODEC, “The European Arrest Warrant”, House of Commons Briefing Paper no. 07016, 18 April 2017.

62 See www.cer.eu/in-the-press/why-europe-wants-hard-brexit-hurt, last accessed 11 December 2017. On 8 December 2017, three documents were released reporting the advance of the Brexit negotiation process into a second phase, regarded by some as the possible 'beginning of the end' (see STEVE PEERS, "The Beginning of the End? Citizens' rights in the Brexit 'Sufficient Progress' deal', 9 December 2017 in http://eulawanalysis.blogspot.com: (1) "Joint Report from the Negotiators of the European Union and the United Kingdom Government on Progress During Phase 1 of Negotiations under Article 50 TEU on the United Kingdom's Orderly Withdrawal from the European Union”, TF50 (2017) 19 - Commission to EU 27; (2) European Commission, "Communication from the Commission to the European Council (Article 50) on the state of progress of the negotiations with the United Kingdom under Article 50 of the Treaty on European Union", COM(2017) 784 final; and (3) European Commission Task Force for the Preparation and Conduct of the Negotiations with the United Kingdom under Article 50 TEU and the UK, Joint Technical Note "Comparison of EU/UK Positions on Citizens' Rights, "Joint technical note expressing the detailed consensus of the UK and EU positions on Citizens' Rights" - all of them available at the TF50 website, in https://ec.europa.eu, last accessed 11 December 2017, where yet other documents on Art. 50 negotiations with the UK can be found.

${ }^{63}$ For an analysis of the possible implications of Brexit on EU-UK cooperation in criminal matters focused fundamentally on the perspective of the EU, see ANNE WEYEMBERGH, "Consequences of Brexit for European Union criminal law", NJECL 8 (2017), p. 284 f.

${ }^{64}$ See JoAnna Dawson, op. cit., p. 16 f.; JoAnnA Dawson / SAlly LipsCombe / SAmantha Godec, op. cit., p. 28 f.; VAlSAmis Mitsilegas, "European criminal law without the United Kingdom?...” op. cit., p. 437. 
which it currently is at liberty to disregard under its 'opt-outs' as an EU member state", will it be reasonable for it to partake in such an enhanced model of cooperation. ${ }^{65}$ That would probably require the UK to continue to submit, to a certain extent, to the jurisdiction of the ECJ, in terms identical to those provided for in Art. 37 of the Extradition Agreement between the EU and Iceland and Norway. ${ }^{66}$

Thus, while the analysis carried out in this part of the study on the law and practice of the UK as an element of the EAW scheme may soon become inapplicable, extradition relations between the UK and EU Member States can be expected to remain influenced by this system, under a model of cooperation that lies somewhere between the EAW and traditional extradition. This, in fact, is what to some extent already happens, since several UK norms on the EAW have been enacted unilaterally by this Member State to accommodate its particular views and needs.

65 VALSAMis MitSilegas, "European criminal law without the United Kingdom?...” op. cit., p. 437.

${ }^{66}$ According to which: "The Contracting Parties, in order to achieve the objective of arriving at as uniform an application and interpretation as possible of the provisions of this Agreement, shall keep under constant review the development of the case law of the Court of Justice of the European Communities, as well as the development of the case law of the competent courts of Iceland and Norway relating to these provisions and to those of similar surrender instruments. To this end a mechanism shall be set up to ensure regular mutual transmission of such case law." 


\section{Chapter 6}

\section{Analysis of Grounds for Refusal According to their Scope and Rationale}

\section{Grounds for refusal related to the conditions in the requesting State}

\subsection{Torture or ill-treatment and fair trial rights}

This paragraph includes several situations which do not have the same status under international law. The prohibition of torture or ill-treatment constitutes jus cogens, whereas fair trial rights stricto sensu constitute merely relative human rights. These differences were acknowledged in chapter 3, on human rights. The reason why at this moment those situations are addressed conjointly is a formal one and concerns the structure of the UN model instruments: the MTE includes 'torture or ill-treatment' and 'minimum guarantees in criminal proceedings' in the same norm (Art. 3 (f)), and in separate norms 'trials in absentia' (Art. $3(\mathrm{~g})$ ) and 'ad hoc courts' (Art. 4 (g)); the MLE separates 'torture or ill-treatment' (s. 6) from other cases, but condenses all of the latter into a single norm (s. 7), designated as 'fair trial standards - judgement in absentia - extraordinary or ad hoc court or tribunal'. The present paragraph brings all those situations together.

Regarding 'capital punishment' and 'life sentences', although, as noted earlier, they have connections with the prohibition of torture or ill-treatment, the model instruments regulate them separately. Such a structure is followed in this part, with some adjustments (indicated in the appropriate moments) required by the national legal systems analysed.

\subsubsection{United Nations}

The Model Treaty provides in Art. 3 (f) that extradition shall be refused if the person concerned has been or would be subjected in the requesting State to torture or cruel, inhuman or degrading treatment or punishment, or has not received or would not receive the minimum guarantees in criminal proceedings set in Art. 14 ICCPR. As the Revised Manuals note, this ground for refusal contains human rights exceptions to extradition, covering such situations as a real risk of mutilation or other corporal penalties, and the lack of fair trial rights. ${ }^{1}$ It admits, however, that extradition be granted if particular assurances given by the requesting State provide an acceptable degree of protection. ${ }^{2}$

The Model Law contains an identical provision in s. 6, as far as concerns torture or ill-treatment. The Model Law refers only to prospective actions by the requesting State, but past actions are covered by s. 7 (1), on minimum guarantees in criminal proceedings.

\footnotetext{
${ }^{1}$ See UNODC, "Revised Manuals...", op. cit., p. 20.

2 Ibid.
} 
The main difference between s. 7 (1) Model Law and Art. 3 (f) Model Treaty is that the former establishes merely optional grounds for refusal. Nevertheless, considering the absolute character of some of the situations that fall within its scope - notably the case where the evidence basing the charges has been obtained through torture -, an obligation to refuse will in some cases impose itself directly as from international law. Swart draws attention to the circumstance that the Model Treaty does not define 'torture or cruel, inhuman or degrading treatment or punishment' or 'minimum guarantees in criminal proceedings', which leaves the delimitation of the scope of this ground for refusal particularly dependent on the interpretation made of those concepts by national legislators - although international law does command a certain minimum content. ${ }^{3}$

On the other hand, Art. 3 (g) Model Treaty requires the refusal of extradition if the following, cumulative conditions are met: the person was tried in absentia, was not given sufficient notice of the trial or the opportunity to arrange for his/her defence, and did not have or will not have the chance of a retrial in his/her presence. ${ }^{4}$ The Model Law includes a similar provision in s. 7 (2), with the particularity, again, that it conceives refusal as merely optional. Swart notes that this ground for refusal is relatively new in the history of extradition, and that it is also clearly linked to human rights: the right to be present at one's trial is explicitly enshrined in Art. 14 ICCPR, and implicitly in Art. 6 ECHR, as the ECtHR ruled in Colozza that it constitutes an essential element of the right to a fair trial. ${ }^{5}$

Finally, Art. 4 (g) Model Treaty provides that extradition can be refused if the person has been sentenced or would be liable to be tried or sentenced by an extraordinary or ad hoc court or tribunal. The Model Law contains an identical ground for refusal and also bestows on it merely optional character (s. 7 (3)), with the particularity that it explicitly provides that it shall not be triggered if the requesting State offers sufficient assurances that the trial will be conducted by a court that is generally empowered in its judicial system to rule on criminal matters. The Revised Manuals affirm that this ground for refusal poses a supplementary safeguard against courts of "irregular and fundamentally unfair nature". ${ }^{6}$ Clearly, this provision it is not meant to apply to courts established by binding UN resolutions (e.g. the ICTY and the ICTR) or by a treaty binding on the State at issue (notably the ICC); it is not intended either to apply to regularly constituted martial courts adjudicating ordinary crimes committed by military personnel. ${ }^{7}$ Swart informs that this constitutes one of the oldest grounds for refusal concerned with the protection of the individual against an unfair trial, dating back to the $19^{\text {th }}$ century. ${ }^{8}$ Regarding its configuration in the Model Treaty, that author observes that, although it is not obvious why it has been given optional character, this may be due to the fact that this issue can be overcome through the offering of reliable guarantees by the requesting State. ${ }^{9}$

\footnotetext{
${ }^{3}$ See BERT SWART, "Refusal of Extradition...”, op. cit., p. 199.

${ }^{4}$ UNODC, "Revised Manuals...", op. cit., p. 20 f., offer guidance for interpreting these conditions.

${ }^{5}$ See BERT SWART, "Refusal of Extradition...”, op. cit., p. 197.

${ }^{6}$ See UNODC, "Revised Manuals...", op. cit., p. 28.

7 See ibid., p. 28.

8 See BERT SwART, "Refusal of Extradition...”, op. cit., p. 196.

${ }^{9}$ Ibid., p. 196.
} 


\subsubsection{Portugal}

According to Art. 6 (1) (a), extradition must be refused if the criminal procedure in the requesting State does not meet the requirements set in the ECHR or in any other international legal instrument binding on Portugal, such as the ICCPR and the CFREU. By refusing to cooperate with other States in criminal procedures which do not ensure levels of protection similar to those that it has itself internationally undertaken to respect, Portugal contributes indirectly to the respect of those human rights standards, and it preserves its own ordre public, which comprises human rights. ${ }^{10}$ Applicability in the requesting State of penalties carrying an irreversible damage to the person may trigger the prohibition of torture and ill-treatment, but in Portuguese law such situations are regulated together with the death penalty issue, and thus will be better assessed in that setting.

Art. 6 (1) (d) provides that extradition must be refused if the trial in the requested State is to be conducted before an ad hoc court, or, where extradition is requested for enforcement purposes, if the sentence at issue has been proffered by a court of that nature. The reason for refusing extradition in these cases lies in the fact that courts of exceptional jurisdiction, created subsequently to the acts, constitute a deviation from the principle of natural justice, and often also of the legality principle, in that they have the power to apply penalties which are higher than those admitted by ordinary law. ${ }^{11}$ The prohibition of ad hoc courts has constitutional rank, ${ }^{12}$ but the Constitution does not contain a correlative prohibition to extradite. Ad hoc courts are to be distinguished from courts of special jurisdiction competent for specific classes of offences or offenders. Apart from military courts (which are allowed in times of war), special penal courts are not allowed by the Portuguese Constitution either. ${ }^{13}$ However, ordinary law does not preclude extradition if the requesting State intends to try the offence in one such special court. As Moreira informs, in Portugal, the repudiation of these special courts is historically related to the dictatorship that governed the country from 1926 to 1974, where crimes against the security of the State were tried in courts with those characteristics (so-called 'plenary courts'). ${ }^{14}$ In any case, the special nature of the court may pose an indicator of discriminatory persecution (e.g. based on political reasons).$^{15}$ Excluded from the concept of ad hoc courts are also international tribunals, such as those created by UN Security Council resolutions, and the ICC. Cooperation with the ICC has been embraced in full in the Portuguese legal system through a constitutional amendment in $2001 .{ }^{16}$ Cooperation with former tribunals had already been regulated in Law no. 102/2001, of 25 August.

\footnotetext{
${ }^{10}$ See Arts. 20 (4) and 32 Constitution.

${ }^{11}$ See Robert Zimmermann, La Coopération Judiciaire Internationale en Matière Pénale, Bruxelles: Staempfli Editions / Bruylant, 2004, p. 485.

12 See Arts. 29 (3), 32 (9) and 209 (4) Constitution.

${ }^{13}$ See Arts. 209 (4) and 213 Constitution.

14 Vital Moreira, "O Tribunal Penal Internacional e a Constituição", in O Tribunal Penal Internacional e a Ordem Juridica Portuguesa, Coimbra: Coimbra Editora, 2004, p. 22; see the ruling of the Court of Appeal of Lisbon of 9 April 2008, no. 4076/2005-3, qualifying these courts as "a bad memory from the recent past".

${ }^{15}$ See the Ruling of the Court of Appeal of Lisbon mentioned in the previous fn.

${ }^{16}$ Which introduced current Art. 7 (7).
} 
As was already discussed in a different regard, in the FD-EAW there does not exist an explicit ground for non-execution on torture or ill-treatment and fair trial rights. Still, Portugal implemented one grounds for non-execution related to the applicability of penalties carrying irreversible damages. ${ }^{17}$ The only ground for non-execution concerned with procedural rights is the provision on in absentia trials, which gives rise to mandatory nonexecution under Art. 12-A PT-EAW. ${ }^{18}$

\subsubsection{United Kingdom}

According to s. 87, extradition shall be refused if it would be incompatible with the rights of the ECHR within the meaning of the Human Rights Act 1998. According to s. 2 (1) Human Rights Act, in deciding on an extradition request, courts must take into account, inter alia, any existing judgment, decision, declaration or advisory opinion of the ECtHR, insofar as in their opinion it proves relevant in the case. This does not entail that the judgments of the ECtHR be binding as such. ${ }^{19}$ It also does not mean that UK courts cannot apply levels of protection that are higher than those offered by ECtHR case law: in some cases, courts in the UK have applied the rights of the ECHR more liberally than the Strasbourg court itself. ${ }^{20}$ Under s. 87, extradition has been contested on the basis of the following provisions of the ECHR: Art. 2 (right to life), Art. 3 (prohibition of torture or ill-treatment), Art. 5 (right to liberty and security of person), Art. 6 (right to a fair trial), and Art. 8 (right to respect for private life and family life), ${ }^{21}$ the most frequently invoked provisions being Arts. 3 and 8. ${ }^{22}$ Art. 3 requires a 'real risk' of breach, while Arts. 5 and 6 will only be successful in the event of a 'flagrant' breach. ${ }^{23}$ Art. 2 initially required a 'near certainty' of breach, but the threshold has been lowered to a 'real risk' test akin to that of Art. $3 .^{24}$ Some of these provisions require the refusal of extradition in cases covered by autonomous grounds for refusal, and are revisited in the respective sections. That is notably the case of Art. 8, which is assessed under the humanitarian exception. ${ }^{25}$

${ }^{17}$ See further infra, $₫ 1.3 .2$.

18 PT-EAW also implemented the FD 2009/299/JHA, of 26 February 2009, enhancing the procedural rights of persons and fosters the application of the principle of mutual recognition to decisions rendered in the absence of the person concerned at the trial.

${ }^{19}$ See Badre v. Court of Florence, Italy [2014] EWHC 614 (Admin), S 44; also Phillip Harkins v. The Secretary of State for the Home Department v. Government of the United States of America, [2014] EWHC 3609 (Admin), 2014 WL 5599581, \ऽ $120 \mathrm{f}$.

${ }^{20}$ In this sense, on Art. $8 \mathrm{ECHR}$, and writing even prior to the $H H$ case (see further infra, $\ 4$ 4.2.3.), see Antje DU-Bois PEDAin, "The Right to Family Life in Extradition Cases: More Defendant-Friendly than Strasbourg Requires", CLJ 69 (2010), p. 223 f.

${ }^{21}$ See House of Lords Select Committee on Extradition Law, op. cit., p. 18 f.; EDWARD GRANGE / REBeCCA Niblock, op. cit., p. 96 f.; Julian B. KnOwles, Blackstone's Guide to the Extradition Act, Oxford: University Press, 2004, p. 93 f.; Alun Jones, Jones on Extradition and Mutual Assistance, London: Sweet \& Maxwell, 2001, p. $136 \mathrm{f}$.

22 See House of Lords Select Committee on Extradition Law, op. cit., p. 19.

${ }^{23}$ Ibid., p. 23.

${ }^{24}$ See Clive Nichols et al., op. cit., p. 127, supported by Maclean v. High Court, Dublin [2008] EWCA 547 (Admin), $\int 10$.

25 See infra, $₫ 4.2 .3$. 
Within the scope of due process, one guarantee has been established autonomously provision: conviction in absentia. According to ss. 20 and 85, applicable respectively to category 1 and category 2 States, extradition is barred if the person was convicted in his/ her absence and is entitled to a retrial. However, this bar does not apply if the person absented him/herself from trial deliberately. ${ }^{26}$ Imprisoning a person convicted in absentia at a trial that he/she could not have attended and without offering the possibility to reopen the case has been declared by the ECtHR - in a case involving the UK - to be one of the exceptional cases where extradition could be barred ex vi Art. 6 ECHR. ${ }^{27}$ In any case, in common law systems, with typically adversarial criminal proceedings, protection against a trial in absentia is very well-established, those trials being regarded as "obviously unjust". 28 Thus, this bar protects human rights as well as a deep-rooted principle of justice of the UK.

There does not exist an explicit 'ad hoc court' bar to extradition in the UK, but extradition must be refused on the basis of the human rights' clause - more specifically of Art. 6 ECHR - if there is a real risk that the person will not be tried in an independent or impartial tribunal. ${ }^{29}$ But there do exist discrepancies in relation to the classic ad hoc court ground for refusal: on the one hand, not each and every ad hoc court triggers the human rights clause, since the lack of impartiality or independence of the court must be established in each case and attain a certain threshold; on the other hand, a court which is not an ad hoc court may in a specific case be found not to be impartial or independent.

Although the FD-EAW does not contain a general human rights ground for nonexecution, the UK enacted a provision of this character in s. 21 EA 2003. Based on this provision - which is entirely similar to that applicable to classic extradition - the execution of a EAW shall be refused if it would be incompatible with the rights of the ECHR within the meaning of the Human Rights Act 1998. According to the Baker Review, UK courts construe the human rights bar in harmony with the principles developed by the ECHR in the field of extradition, ${ }^{30}$ but EU Member States are presumed to comply with their obligations under the ECHR, and this presumption is difficult to rebut. ${ }^{31}$ Category 2 States are also presumed to comply with human rights (in what should constitute a manifestation of the classic rule of non-inquiry), but the presumption is less robust here. ${ }^{32}$ Still - the Review emphasises -, in both cases the presumption can be displaced, and the per-

${ }^{26}$ On the concept, see Clive Nichols et al., op. cit., p. 90 f., EDWARd Grange / REBECCA NiblOCK, op. cit., p. 77 f., and indicated case law.

${ }^{27}$ ECtHR, Othman v. UK, cit., \259; see Clive NiCHOLS et al., op. cit., p. 90.

${ }^{28}$ Clive Nichols et al., op. cit., p. 90.

${ }^{29}$ See House of Lords Select Committee on Extradition Law, op. cit., p. 24; Vincent Brown aka Vincent Bajinja, Charles Munyaneza, Emmanuel Nteziryayo, Celestin Ugirashebuja v. The Government of Rwanda, The Secretary of State for the Home Department [2009] EWHC 770 (Admin).

30 See SCOTtT BAKER / David PERry / ANAND DoObay, op. cit., p. 318 f.

${ }^{31}$ See ibid., p. 319; EDWARd GRANGE / REBECCA Niblock, op. cit., p. 92; Dabas v. High Court of Justice in Madrid, Spain [2007] UKHL 6, $\int 4$.

32 The presumption of compliance is similar with regard to non-EU Member States that are parties to the ECHR, to the exception of the Russian Federation; as for States that are not parties to the ECHR, the solidity of the presumption depends essentially on the relations of trust between the State in question and the UK, and on the compliance record of such State: see House of Lords Select Committee on Extradition Law, op. cit., p. 18 f. and 20 f.; EDWARD GrangE / REBECCA NibLOCK, op. cit., p. 94 f., and case law cited. 
son concerned is entitled to adduce evidence to that end. ${ }^{33}$ While "clear and cogent evidence" is necessary for a EAW to be refused on these grounds, this is possible: ${ }^{34}$ initially, the presumption of compliance with human rights by the issuing Member State was in several cases implied to be irrebuttable, but a shift appears to have taken place following the ECtHR's ruling in M.S.S. v. Belgium, ${ }^{35}$ such that, in Agius, the view was held that "the burden of displacing the assumption will be a heavy one, and it may well be the case that as a matter of fact successful reliance on s. 21 (1) will be the exception rather than the rule, but that does not mean that there is a legal obligation on an appellant (...) to demonstrate 'exceptional circumstances' ". 36

The human rights bar provided for in the law of the UK departed manifestly from the FD-EAW. In its prominent ruling in Aranyosi \& Căldăraru, the ECJ did rule that serious risk of ill-treatment in the issuing Member State may carry EAW proceedings to be "brought to an end", ${ }^{37}$ but the conditions in which this may occur and the manner in which the executing Member State is to proceed differ from those in place in the UK. Not least of all because Aranyosi \& Căldăraru appears to apply only to absolute human rights (notably the prohibition of torture or ill-treatment enshrined in Arts. 4 CFREU and 3 ECHR), ${ }^{38}$ whereas the human rights bar enacted by the UK admits the refusal of cooperation on the basis of any right enshrined in the ECHR.

\subsection{Discrimination}

\subsubsection{United Nations}

Art. 3 (b) Model Treaty provides that extradition must be refused if there are substantial grounds to believe that the request was made with a view to prosecuting or punishing a person on account of race, religion, nationality, ethnic origin, political opinions, sex or status, or that that person's position may be prejudiced for any of those reasons. The Model Law contains an identical provision in s. 5, but uses the concept of 'membership of a particular social group', which will encompass virtually any imaginable discriminatory factor, standing in contrast with the less generous formulation used in the Model Treaty. The width of the formulation used in the Model Law is entirely justified in light of the spirit of this ground for refusal, as the focal point is the risk of discrimination, regardless of the particular nature of the factor which triggers it. In fact, this is the formulation of Art. 33 (1) of the 1951 Convention Relating to the Status of Refugees. ${ }^{39}$

\footnotetext{
33 See SCott Baker / David Perry / ANAND Doobay, op. cit., p. 319, adding that evidence adduced "may include reports prepared by respected organisations or bodies concerning the risk of human rights violations occurring in the category 1 territory".

${ }^{34}$ See ibid., p. 319.

${ }^{35}$ See Dabkowski v. Poland [2010] EWHC 1712 (Admin); R. (Rot) v. District Court of Lublin, Poland [2010] EWHC 1820 (Admin) and Klimas v. Prosecutors General Office of Lithuania [2010] EWHC 2076 (Admin).

36 Agius v. Court of Magistrates, Malta [2011] EWHC 759 (Admin), \19; EDWARd Grange / Rebecca NiBLOCK, op. cit., p. $92 \mathrm{f}$.

${ }^{37}$ Cit. $\$ 104$.

${ }^{38}$ See ibid., esp. \86. As argued supra, Chap. 3, \3.3., the Celmer ruling alone does not seem to change this.

${ }^{30}$ See UN-MLE, s. 5 , fn. to option 2.
} 
As the Revised Manuals declare, this is a "non-controversial" ground for refusal, used in extradition treaties throughout the world and inspired by the non-refoulment principle enshrined in the aforementioned Convention. ${ }^{40}$ Swart (1992) notes that, irrespective of the question as to whether it applies to extradition, the Refugee Convention has unquestionably influenced extradition law greatly, such that nearly all treaties and national statutes adopted after 1951 contain a similar provision, unless it was deemed superfluous due to the high levels of trust binding the States in question - as was the case in the 1962 Benelux Convention on Extradition and the Extradition Treaty between the Netherlands and the USA [and, more recently, the FD-EAW]. ${ }^{41}$ The author further reports that it has become a usual understanding in legal literature that this ground for refusal acquired status of international custom. ${ }^{42}$

\subsubsection{Portugal}

According to Art. 6 (1) (b), extradition shall be refused where there is well-founded reason to believe that cooperation is being requested for the purpose of persecuting or punishing a person on account of that person's race, religion, sex, nationality, language, political or ideological beliefs, or belonging to a given social group. As in the Model Law, this ground for refusal is formulated in an open manner, such that in the concept of 'belonging to a given social group' virtually any discriminatory circumstance may be encompassed, including those that are mentioned in the CFREU. This norm concretises constitutional law, specifically Art. 33 (6) of the Constitution. While the latter provision explicitly prohibits extradition for political motives only, it should be construed as encompassing any type of discrimination of an analogous character. Additionally, Art. 6 (1) (c) PT-L requires the refusal of extradition where the risk exists that the person's procedural situation might be impaired on account of any of those discriminatory factors.

The primary and direct rationale of this ground for refusal is the intent to protect human rights. The prohibition of discrimination is provided for in Arts. 13 and 26 (1) of the Constitution, and therefore Portugal will also be tending its own ordre public by refusing to cooperate in such cases. In the case of Art. 6 (1) (b), one further reason exists to refuse cooperation: if the persecution is due exclusively to discriminatory factors, then the most basic premise of extradition - sc. the existence of a crime requiring punishment - is absent. $^{43}$

\footnotetext{
${ }^{40}$ See UNODC, "Revised Manuals...", op. cit., p. 17. Other UN treaties where this ground for refusal is found include the: 1988 Convention against Illicit Traffic in Narcotic Drugs and Psychotropic Substances: Art. 6 (6); 1997 Convention for the Suppression of Terrorist Bombings: Art. 12; 1999 Convention for the Suppression of the Financing of Terrorism: Art. 15; 2000 Convention against Transnational Organized Crime ('Palermo Convention'): Art. 16 (14); 2003 Convention against Corruption ('Merida Convention'): Art. 44 (15); 2005 Convention for the Suppression of Acts of Nuclear Terrorism: Art. 16. The "Revised Manuals", also offer guidance on how to properly regulate this ground for refusal, weighing the seriousness of discriminatory persecutions against the risk of proliferation of unfounded claims of discrimination.

${ }^{41}$ See BERT SWART, "Refusal of Extradition...", op. cit., p. 194, adding that, nevertheless, there will always be "no harm in including the provision".

${ }^{42}$ See ibid.

${ }^{43}$ See Art. 31 (1).
} 
The FD-EAW does not contain a ground for non-execution on the risk of discrimination. As with other human rights, there is an assumption that EU Member States do not carry out discriminatory persecutions. The preamble of the FD-EAW does declare in Recital 12 that "[n]othing in this FD may be interpreted as prohibiting refusal to surrender a person for whom a EAW has been issued when there are reasons to believe, on the basis of objective elements, that the said arrest warrant has been issued for" discriminatory reasons, but this was not established as an actual ground for non-execution. The Portuguese implementation act initially contained a unilateral ground for non-execution on politically motivated requests in Art. 11 (e). This provision aimed to concretise the constitutional provision which prohibits extradition for political reasons, indicated above. ${ }^{44}$ The provision was criticised by the Council of the EU in $2007,{ }^{45}$ prompting the Portuguese legislator $^{46}$ to remove it through an amendment effected in $2015 .^{47}$

\subsubsection{United Kingdom}

Under the title 'extraneous considerations', s. 81 precludes extradition if it appears that the request, though purporting to be made on account of an extradition offence, is in fact made for the purpose of prosecuting or punishing a person on account of his/her race, religion, nationality, gender, sexual orientation or political opinions, or if, once extradited, the person might be prejudiced at the trial, or punished, detained or restricted in his/her personal liberty due to one such reason. Human rights considerations are on the basis of this ground for refusal, which as a matter of fact is frequently invoked in parallel with the human rights clause assessed previously - although different tests apply. ${ }^{48}$

Like the human rights clause, extraneous considerations are also provided for as a bar to the execution of the EAW, in s. 13. The Baker Review acknowledges that this bar has "no direct equivalent" in the FD-EAW, but stresses that it is "consistent with Recital 12 " and "reflects the basis upon which a person may claim refugee status" under the Refugee Convention. ${ }^{49}$ The same remarks adduced before regarding the human rights clause apply here: it is inevitable to conclude that this ground for non-execution stands in conflict with the FD-EAW, even when construed in the light of Aranyosi \& Căldăraru, because the principle of non refoulement does not constitute an absolute human right.

${ }^{44}$ As mentioned before, this norm includes other discriminatory factors, such as race or religion, but only implicitly, and that is probably why the provision inserted into PT-EAW only mentioned political reasons, raising the criticism of INÊS GODINHO, "O mandado de detenção europeu e a 'Nova Criminalidade': a definição da definição ou o pleonasmo do sentido”, Politeia 2 (2005), p. 133.

${ }^{45}$ See Council of the EU, "Evaluation Report on the Fourth Round of Mutual Evaluations 'The Practical Application of the European Arrest Warrant and Corresponding Surrender Procedures Between Member States' - Report on Portugal” - Doc. 7593/2/07 REV 2, Brussels, 27 July 2007, p. 39, stating that such a provision was "contrary to the FD-EAW", and in any case "unnecessary in light of Art. 6 TEU".

46 See the Opinion of the Attorney-General's Office on the Law Proposal no. 271/XII, which lead to the mentioned Law no. 35/2015, Annex II, p. 17.

47 Through Law no. 35/2015, of 4 May.

48 See Edward Grange / Rebecca Niblock, op. cit., p. 60; Nikolics v. The City Court of Szekszard (A Judicial Authority in Hungary) [2013] EWHC 2377 (Admin), \ 14, indicating that the ground for refusal 'extraneous considerations' has a "different and longer history".

49 SCOTt BAKER / DAVId PERry / ANAND DoObay, op. cit., p. 377. 


\subsection{Death penalty and other penalties carrying irreversible damage}

\subsubsection{United Nations}

According to Art. 4 (d) Model Treaty, extradition can be refused if the offence carries the applicability of the death penalty under the law of the requesting State, unless this State provides such assurance as the requested Sate deems sufficient, that this penalty will not be applied or, if applied, will not be enforced. The equivalent norm in the Model Law is s. 12, which is identical, apart from the detail that it gives States the option to configure this obstacle as mandatory. The Revised Manuals underline that this provision, as drafted in the Model Treaty, requires the executive of the requesting State to exert its prerogatives of pardon or commutation if the death penalty is applied, and that extradition will not be granted unless it can guarantee that such a prerogative will be exerted as a matter of standing practice of that State or upon the request of the requested State. ${ }^{50}$ Yet according to the Manuals, one way to provide assurance that the death penalty, if applied, will not be enforced, is for States to incorporate into their domestic law a norm assigning legal authority (and, hence, binding effect upon the judiciary) to the conditions set by the requested State and agreed to by the executive of the requesting State in the context of the extradition proceedings. ${ }^{51}$ As was possible to discern in the human rights chapter of this study, and as is also stressed by Swart, a prohibition to extradite in case of applicability of the death penalty is not indisputably imposed by human rights, but rather it derives essentially from the ordre public of the requested State. ${ }^{52}$

\subsubsection{Portugal}

Concretising Art. 33 (6) Constitution, Art. 6 (1) (e) bars extradition if the offence is punishable by death or with a penalty carrying irreversible damage (e.g. mutilation), unless the requesting State has commuted the penalty by an irreversible decision binding on its judiciary or another authority competent for its enforcement (Art. 6 (2) (a)), or accepts its conversion by Portugal (Art. 6 (2) (c))..$^{33}$ The following analysis is structured by reference to the death penalty exception, but it applies mutatis mutandis to any penalty carrying irreversible bodily harm, as these abide by the exact same constitutional provisions.

Rather singularly, the rationale of grounds for refusal concerning the penalty applicable in the requesting State has been long debated in Portuguese case law, legal literature and political circles. In the 1990's two cases in particular fueled the debate after the rulings of the Constitutional Court in Leung, concerning death penalty (with the PRC as the requesting State), and Varizo, ${ }^{54}$ concerning life imprisonment (with the USA as the request-

50 See UNODC, “Revised Manuals...”, op. cit., p. 27.

51 See ibid., p. 27.

52 See BerT SWART, “Refusal of Extradition...”, op. cit., p. 197; HARMEN VAN DER WILT, op. cit., p. 153.

${ }^{53}$ It is interesting to note that the first ordinary act governing extradition - the already mentioned Decree-Law no. 437/75, enacted shortly before the 1976 Constitution, provided that the applicability of death penalty in the requesting State constituted a merely optional ground for refusal: see Art. 4 (1) (a) - a provision that would shortly after be rendered unconstitutional.

54 See infra, $₫ 1.4 .2$. 
ing State). Leung was a Chinese citizen found in Macau (at the time, a territory under Portuguese administration), who had allegedly committed a homicide in China and faced the death penalty. Through its Minister of Public Security, China pledged not to apply either capital punishment or life imprisonment. Relying on those assurances, the highest judicial instance in Macau granted the request through a plenary ruling dated from 14 April 1994, confirming a decision of the same court dated from 1 March 1994. The decision to grant extradition was however blocked by the Constitutional Court through ruling no. 417/95, of 4 July. This Court held that political guarantees of non-execution were immaterial and that extradition would only be possible if the law internally binding on the requesting State precluded the applicability of the death penalty in the case, namely by virtue of commutation or an amnesty law.

Portugal abolished the death penalty as far back as in $1867,{ }^{55}$ making this a deeplyrooted element of Portuguese legal culture. From the constitutional prohibition to apply the death penalty, several authors have drawn the conclusion that refusing to extradite in the face of a possible application of this penalty is necessary to uphold the constitutional values protected by that prohibition, namely the right to life (directly) and human dignity (in that it entails that any person be given the chance to be rehabilitated if convicted of a criminal offence). ${ }^{56}$ This was, in essence, the reasoning of Constitutional Court in Leung and in similar subsequent cases. ${ }^{57}$ The Court later gave erga omnes effects to this interpretation through ruling no. 1146/96, of 12 November; ${ }^{58}$ and in ruling no. $1 / 2001$, of 10 January, prompted by a clarification request lodged by the Ombudsman, it affirmed that the Constitutional amendment that had been effected in 1997 had not changed the situation.

Another position pointed out that such an interpretation conflicted with the duty of mutual respect to which Portugal is bound under international law, in that it entails an imposition on other States of the Portuguese sanctioning system, which naturally is binding only within its legal system. ${ }^{59}$ Such a prohibition to extradite could only be grounded on the necessity of the Portuguese State to uphold its ordre public in its relations with other States: repudiation of this penalty in Portugal is so intense that it projects itself upon those relations, preventing Portugal from cooperating towards its possible application. ${ }^{60}$ The very ruling of the Constitutional Court in Leung implictly carried this view: the Court

55 See supra, Chap. 3, \1.1.

56 Along these lines, see J. J. Gomes Canotilho, "Caso Varizo - Extradição no caso de prisão perpétua”, RLJ 128 (1995), p. 250 f., J. J. Gomes Canotilho / Vital Moreira, Constituição da República Portuguesa Anotada, Vol. I, 4. ${ }^{a}$ ed. revista, Coimbra: Coimbra Editora, 2007, p. 533; JORGE DE FIGUEIREDO DiAS / Manuel da Costa Andrade, Direito Penal. Questões Fundamentais, A Doutrina Geral do Crime (fascículos), 1996, p. 210; Mário Mendes Serrano, op. cit., p. 51; Maria José Rangel de Mesquita / Cristina SOUSA MACHADO, op. cit., p. 7.

${ }^{57}$ See the rulings of the Constitutional Court no. 430/95, of 6 July 1995, and no. 449/95, of the same date, indorsing in totum the stance adopted in Leung.

58 The same stance was also upheld in the ruling no. 384/2005, of 13-07-2005.

59 See Pedro Caeiro, "Proibições Constitucionais de Extraditar em Função da Pena Aplicável”, RPCC 8 (1998), p. 12, 20, et passim; see also CARlos FERnANDES, op. cit., p. 56 f.; NunO PIÇARRA, "As revisões constitucionais em matéria de extradição. A influência da União Europeia”, in Themis: Edicão Especial (2006), p. 228.

60 Pedro Caeiro, "Proibições Constitucionais...” op. cit., p. 12. 
elaborated on the "benign penal culture" characterising the Portuguese legal system, noting that the conformity of the request with the ordre public of the requested State is a general principle of extradition law and that the Portuguese prohibition to extradite in view of a possible application of the death penalty relates to that principle. Following this line, however, one would have to concede that extradition can be granted not only where the application of that penalty is impossible under the 'law internally binding' on the requesting State, but also when this State provides reliable and internationally binding guarantees that such a penalty will not be applied or, if applied, will not be carried out. ${ }^{61}$

In fact, this had been the view of Portuguese courts until Leung. ${ }^{62}$ It is not however the case anymore. Unlike what happens regarding life imprisonment, ${ }^{63}$ in case of applicability of death penalty political guarantees are insufficient under the Portuguese Constitution and ordinary law. This means that, as it stands, Portuguese extradition law does to an extent impose principles of its sanctioning system on other States, going further than would be required to protect its ordre public, and seeking instead to protect in rather symbolical terms the right to life and the principle of human dignity which preclude the applicability of the death penalty at the internal level.

The FD-EAW asserts in its Recital 13 that nobody should be extradited to a State where he/she would run a serious risk of being subjected to the death penalty. However, this is again not reflected in any actual ground for non-execution. Given its constitutional status in the Portuguese legal system, the prohibition to extradite in case of possible application of the death penalty or a penalty carrying irreversible injury was incorporated in the original version of the implementation act (Art. 11 (d)). However, this norm was removed together with that on politically motivated requests, in $2015 .{ }^{64}$ Insofar as concerns the death penalty this norm was indeed superfluous, since that penalty is proscribed in all EU Member States. ${ }^{65}$

\subsubsection{United Kingdom}

According to s. 94, the Home Secretary must refuse extradition if the person could be, will be or has been sentenced to death, unless a written assurance is received which is considered adequate that a sentence of death will not be applied, or, if applied, will not be enforced. The EA 1989 assigned full discretion to the Home Secretary to decide on this matter in s. 12 (2) (b): the Secretary could "decide to make no order for the return of a person" accused or convicted of an offence not punishable with death in Great Britain, ${ }^{66}$ if that person could be or had been sentenced to death. This solution was adopted

61 Pedro Caeiro, "Proibições Constitucionais...", op. cit., p. 12.

62 See ibid.; and MÁrIo MENDES SERrANO, op. cit., p. 80, mentioning that the prohibition of extradition would only occur if there were a "concrete and effective" possibility of application of the death penalty.

${ }^{63}$ See infra, the following $\mathbb{S}$.

64 Through Law no. 35/2015 of 4 May.

65 See Miguel Beltrán de Felipe / Adán Nieto Martín, "Post9/11 Trends in International Judicial Cooperation: Human Rights as a Constraint on Extradition in Death Penalty Cases”, JICJ 10 (2012), p. 581.

${ }^{66}$ The death penalty had been abolished in Northern Ireland for all offences, but remained in place in the rest of the UK for some offences: IVOR STANBroOK / Clive STANBROOK, Extradition: Law and Practice, $2^{\text {nd }}$ ed., Oxford: University Press, 2000, p. 154; see further infra in the text. 
in spite of pressure in Parliament either for an absolute prohibition to extradite, or a limitation of the possibility to extradite through a system of guarantees of non-application. ${ }^{67}$

When the EA 1989 was enacted the death penalty was still applied in the UK for treason and piracy with violence; complete abolition took place in 1998, and in 1999 the UK acceded to OP6-ECHR. This accession entailed not only a full abolition of the death penalty for peacetime offences in the UK (which, as mentioned, had already been effected), ${ }^{68}$ but also a duty not to subject anyone in its jurisdiction to a risk of execution of the death penalty. ${ }^{69}$ As of that moment the UK would no longer be able to extradite a person where the execution of that penalty was a real possibility, which meant the elimination of the discretion that had been conferred on the Home Secretary by the EA $1989 .{ }^{70}$

The EA 2003 reflects those developments in s. 94, mentioned above. According to Alastair, this provision "reflects the same deeply rooted opposition to the death penalty which has led the UK to accede to Protocol 6 ECHR". ${ }^{71}$ That provision only prevents the UK from cooperating in procedures which entail an actual risk of application of the death penalty. Unlike what happens in Portugal, the UK can extradite if the death penalty, though applicable in the abstract, is guaranteed by any reliable means not to be applied or carried out. Still, the level of assurance necessary for extradition to be granted is higher than it has been in the past. In Soering, for instance, the sole assurance offered to the UK was that the prosecutor in charge of the case would inform the court that it was the wish of the UK that the death penalty were not applied. ${ }^{72}$ To Knowles, in the light of Art. 1 OP6-ECHR, which prohibits sentencing any person to death, "it is difficult to see how the Secretary of State would be acting compatibly (...) if he were to accept the undertaking that a person would be sentenced to death but not executed". ${ }^{74}$ The author submits that, "in order for extradition to be compatible with [OP6], the Secretary of State must receive a written assurance that the death penalty will not be imposed ${ }^{75}$ However, courts in the UK have held that a violation may occur if assurances are not received that the death penalty will not be "carried out" ${ }^{76}$ which implies that the prohibition to 'impose' that penalty is directed only at signatory States of OP6, not at third States which request extradition to a signatory.

${ }^{67}$ See ibid., p. 154.

${ }^{68}$ The UK in fact had gone further than the OP6-ECHR required, as it abolished the death penalty also in wartime: see Alun Jones, op. cit., p. 137; Julian B. KNOwles, op. cit., p. 105.

${ }^{69}$ See Alun Jones, op. cit., p. 137 f.; Julian B. KNOwles, op. cit., p. 105 f.

70 See Alun Jones, op. cit., p. 154.

71 Alastair Brown, Extradition and International Co-operation Act 2003 - A Current Law Statute Guide, London: Sweet \& Maxwell, 2004, p. 94; see also Ivor STANBrooK / Clive STANBrook, op. cit., p. 153.

72 See e.g. Alastair Brown, op. cit., p. 95.

73 "The death penalty shall be abolished. No-one shall be condemned to such penalty or executed".

${ }^{74}$ JULian B. KNOWLES, op. cit., p. 106.

75 Ibid., p. 106 (emphasis added).

${ }^{76} \mathrm{R}$ (St John) v. Governor of Brixton Prison [2002] QB 613, S 49. This was the first extradition case possibly leading to death penalty after the Human Rights Act 1998. The USA had requested extradition for several offences, including murder. Under the law of Pennsylvania, first degree murder carries either death or a life sentence, the choice belonging to a jury. By the time of the committal proceedings before the district judge in the UK, the Home Secretary had not obtained any assurance from the USA that, if extradited and found guilty of murder of the first degree, the applicant would not be subjected to the death penalty. 
According to the same ruling, if the Home Secretary grants extradition absent adequate assurances that the death penalty will not be applied or enforced, the person concerned can apply for judicial review. ${ }^{77}$ At any rate, the competence of the Home Secretary in these matters does appear to be uncontroversial: according to the Baker Review, the Secretary "is much better placed to deal with these matters than the courts". ${ }^{78}$

\subsection{Imprisonment for life or for an undetermined period}

\subsubsection{United Nations}

The Model Treaty gives States the option to establish a ground for refusal concerning the applicability of imprisonment for life or an undetermined period. This ground for refusal is considered "more controversial and not as widely accepted" as that concerning the death penalty. ${ }^{79}$ Accordingly, the Model Treaty confines it to a footnote to the provision on the death penalty. In the Model Law, life imprisonment is altogether absent. ${ }^{80}$

\subsubsection{Portugal}

In line with Art. 33 (4) Constitution, Art. 6 (1) (f) forbids extradition if the offence at issue is punishable with imprisonment for life or an indefinite term, unless the requesting State: (a) has withdrawn the life-long character of the sentence through an irreversible decision binding on its courts or on any other authority competent for its enforcement; (b) accepts its conversion by a Portuguese court according to Portuguese law; or (c) provides assurances that such a penalty will not be applied or enforced, and the requesting State is a party to a treaty that is also binding on Portugal. ${ }^{81-82}$ According to Art. 6 (3), the assessment as to whether assurances are sufficient should take into account - in the light of the law and practice of the requesting State - such factors as the possibilities that the sentence will not be carried out, that the situation of the person will be reconsidered, and that the person will be conditionally released, as well as the possibilities of a pardon, amnesty or commutation.

As is visible, the prohibition to extradite in the event of life imprisonment is not as strict as the prohibition to extradite in the event of death penalty, as it admits guarantees of non-execution. Before the constitutional amendment of 1997, explicit provision was made for the admissibility of guarantees in the event of applicability of the death penalty.

${ }^{77}$ Id., $\int 49$.

78 SCOTtT BAKER / DAVId PERry / ANAND DOOBAy, op. cit., p. 15 f.

79 UNODC, "Revised Manuals...", op. cit., p. 26.

80 BERT SWART, "Refusal of Extradition...", op. cit., p. 198, informs that a life imprisonment ground for refusal - moreover, of mandatory character - was provided for in the 1981 Inter-American Convention on Extradition: Art. 4 (d). In any case, this instrument has a very low ratification record: JOHANNA HARRINGTON, "Extradition of Transnational Criminals", in Neil Boister / Robert J. Currie (eds.), Routledge Handbook of Transnational Criminal Law, New York: Routledge, 2015, p. 162.

81 This 'treaty requirement' is not to be found in Art. 6 (2), but imposes itself directly on the strength of Art. 33 (4) Constitution.

${ }^{82}$ As with the death penalty, the first ordinary act on extradition - the Decree-Law no. 437/75 - configured this as a merely optional ground for refusal, in Art. 4 (1) (a). 
This amendment was also the first time the prohibition to extradite in case of life imprisonment was explicitly enshrined in the Constitution. Before that moment, this prohibition already had constitutional status, but it was implicit. That the Constitution already forbade extradition in the event of applicability of life imprisonment was unequivocally held by the Constitutional Court in Varizo. ${ }^{83}$ In this case, the Constitutional Court also ruled that only law which is internally binding on the requesting State could displace the prohibition to extradite, a position supported by several authors. ${ }^{84}$

Varizo was a Brazilian found in Portugal and requested by the USA on drug related charges carrying a life sentence. The prosecutor and the judge in charge of the case gave guarantees of non-execution, and these were found sufficient by the Supreme Court, but the Constitutional Court blocked extradition through ruling no. 474/95, of 17 November 1995. In essence, the Court held that the same rules governing the case of applicability of the death penalty, as construed in Leung, applied to life imprisonment, meaning that the prohibition to extradite could not be displaced by mere guarantees of non-execution, but rather it was necessary that the non-application or non-execution of the penalty resulted from internal norms binding on the requesting State.

At once, the 1997 constitutional amendment gave explicit existence to the prohibition to extradite in the event of applicability of life imprisonment, like the death penalty, but subjected it to less demanding conditions than the latter, such that at present it is clear that the Constitution admits extradition in the event of life imprisonment, as long as guarantees of non-application or non-execution are offered. ${ }^{85}$ The main arguments for the differentiation vis-à-vis the death penalty are: on the one hand, that the right to life has higher parametric rank than the right to liberty; and, on the other hand, that life imprisonment can be rescinded, unlike the death penalty and other penalties carrying irreversible damage. ${ }^{86}$

On the other hand, Art. 33 (5) Constitution, introduced in 2001 in order to render constitutional the rules to be enacted in implementing FD-EAW, ${ }^{87}$ created a momentous exception to that prohibition in the context of cooperation between Portugal and other EU Member States: execution of a EAW by Portugal in the event of life imprisonment is fully admissible in the light of the Constitution as amended in 2001. In the implementation act, Portugal made used of the option given by Art. 5 (2) FD-EAW. According to

${ }^{83}$ Some authors already defended this interpretation (e.g. MANUEL ANTÓnIO LOPEs Rocha / TERESA Alves MARTins, op. cit., p. 33), but it was not unanimous (see e.g. JORGE DE FigueIREDo DiAs / MANUEL DA Costa Andrade, op. cit., p. 210). Debates held in Parliament in the context of the 1989 constitutional amendment involved a discussion on this issue. Some parties argued that the Constitution already implicitly barred extradition in case of applicability of life imprisonment, but that this should be made explicit: see Diário da Assembleia da República, II Série: Número 11-RC, 12 May 1988, p. 306; Diário da Assembleia da República, II Série: Número 65-RC, 10 January 1989, p. 2005 f.; Diário da Assembleia da República, II Série: Número 68RC, 25 January 1989, p. 2080 f. However, at the time, the change was not effected.

84 See e.g. Jorge DE Figueiredo Dias, "Extradição e non bis in idem [parecer]”, DJ 9 (1995), p. 213 f.; Jorge Miranda / Miguel Pedrosa Machado, "Processo de extradição e recurso para o Tribunal Constitucional: admissibilidade e tema do recurso - Parecer”, DJ 9 (1995), p. 223 f.

85 See the rulings of the Constitutional Court no. 1/2001, of 10 January, and no. 384/2005, of 13 July.

${ }^{86}$ See again the ruling of the Constitutional Court no. 1/2001, cit., esp. $\int 11$.

${ }^{87}$ See the intervention of the Minister of Justice in this regard in Diário da Assembleia da República, II Série-RC: Número 11, 4 July 2001, p. 170 f. 
this norm (reportedly motivated by Portugal), ${ }^{88}$ if the acts for which the EAW has been issued carry life imprisonment, execution of the warrant may be subject to the condition that the legal system of the issuing Member State has provisions enabling the review of the penalty upon request or at the latest after 20 years, or the application of measures of clemency to which the person is entitled to apply according to the law or practice of the issuing Member State. PT-EAW makes it mandatory, in Art. 13 (1) (a), that such a condition is met if it is to surrender a person in case of applicability of this penalty. This condition, however, does not in effect guarantee that the person will not be imprisoned for life. It only creates an obligation on the part of the issuing Member State to assess, after a certain period, whether the penalty may cease. ${ }^{89}$ Which manifestly departs from Art. 33 (4) Constitution (applicable to extradition from Portugal to any State that is not a Member State of the EU), according to which life imprisonment must be effectively impossible to be applied or enforced. ${ }^{90}$ The 2001 constitutional amendment made a similar exception for the surrender to the ICC, ${ }^{91}$ in this instance by means of a clause of "global acceptance of the terms of the Rome Statue", ${ }^{22}$ inserted in Art. 7 (7) Constitution.

The prohibition to extradite in the event of imprisonment for life or for an undetermined period is necessary to preserve the ordre public of the Portuguese State, as is held explicitly in legal literature ${ }^{93}$ as well as in case law: in a ruling of 18 March 1999, the Supreme Court, while evaluating the sufficiency of guarantees of non-execution of a life sentence, stated that these satisfied the "requirements of the ordre public of the Portuguese State", and that extradition could therefore be granted. ${ }^{94}$ The Constitutional Court itself conveyed this view in Varizo, by asserting that this penalty, abolished as long ago as in 1884, is "repugnant to the legal conscience of the Portuguese legal system". The ruling of the Constitutional Court no. 1/2001, of 10 January 2001, also acknowledged explicitly

88 See Luís Silva Pereira, “Alguns aspectos da implementação do regime relativo ao mandado de detenção europeu”, RMP 96 (2003), p. 43 f.; ANTÓNIO DELICADO, op. cit., p. 4; NunO PiÇARRA, “As revisões constitucionais...”, op. cit., p. 218, 220.

${ }^{89}$ See Damião Da Cunha, “Artigo 33.””, in Jorge Miranda / Rui Medeiros, Constituição da República Portuguesa Anotada, Vol. I, 2nd ed. revista, Lisboa: Universidade Católica Editora, 2017, p. 544; ANTÓNIO DELICADO, op. cit., p. 4; see also the rulings of the Court of Appeal of Porto of 18 January 2006, no. 0516310, and of the Supreme Court of 25 February 2010, no. 42/10.8YFLSB, emphasising that an obligation to reassess the sentence or to consider the application of clemency measures suffices for Portugal to execute a EAW. The Constitutional Court was called upon to evaluate the constitutionality of Art. 13 (1) (a) PT-EAW, but the appeal was deemed inadmissible by the Constitutional Court: ruling no. 501/07, of 9 October.

90 See Pedro CaEiro, "Ut Puras Servaret Manus - Alegações contra a assunção, pelo Estado Português, da obrigação de entrega ao Tribunal Penal Internacional de um cidadão que possa ter de cumprir uma pena de prisão perpétua", RPCC 11 (2001), p. 49, fn. 34, referring to Art. 5 of the agreement on the accession of Portugal to the CISA, through which Portugal had already subscribed to a similar obligation. Such agreement was concluded before the 2001 constitutional amendment, and, therefore, was unconstitutional. Portuguese courts did however grant extradition based on that agreement before the constitutional amendment of 2001: see e.g. the ruling of the Court of Appeal of Évora of 5 January 1999, confirmed by a Ruling of the Supreme Court of Justice of 18 March 1999 (apud MÁrIO MENDES SERRANO, op. cit., p. 91).

91 Which may apply life sentences: see Arts. 77 (1) (b) and 110 (3) ICC Statute.

92 See Vital MOREIRA, op. cit., p. 17.

93 See Pedro CaeIro, "Proibições Constitucionais...", op. cit., p. 12 f.; NunO PIÇARRA, "As revisões constitucionais...”, op. cit., p. 228.

94 Apud Mário Mendes SERrano, op. cit., p. 91. 
that the rationale of this prohibition to extradite is the preservation of the Portuguese ordre public. This view is validated by the fact that the Constitution admits extradition in the event of life-imprisonment if guarantees of non-execution are provided by the requesting State: this separates conceptually this prohibition from that concerning the death penalty, which relies on a more abstract and symbolical rationale.

Still, as Caeiro notes, this does not justify the exceptions admitted for EU Member States and the ICC. ${ }^{95}$ While the mitigation of some classic grounds for refusal in the cooperation with those entities can be plausibly explained based on increased security concerns, mutual trust, or other factors, the life imprisonment exception cannot, precisely because it integrates the Portuguese ordre public and, as such, constitutes a matter of principle. ${ }^{96}$ The damage of ordre public caused by the application of a life sentence does not vary meaningfully depending on those factors, making Art. 33 (5) of the Constitution - in the suggestive words of Pereira - an "unconstitutional constitutional provision". ${ }^{97}$ Thus, this norm only seems possible to be construed as a pure concession by Portugal to the project of EU integration, and, in the case of the ICC, as a manifestation of its commitment to international justice. ${ }^{9}$ Debates in Parliament before the 1997 constitutional amendment already mirrored this fact, with the Minister of Justice arguing that the 'Varizo doctrine' made it virtually impossible for Portugal to comply with its obligations under the CISA. ${ }^{99}$

\subsubsection{United Kingdom}

There is no such ground for refusal in the legal system of the UK, since the UK itself applies life imprisonment. As we saw in Chapter 3, in Vinter the ECtHR ruled that the penal system of the UK breached the ECHR because it did not provide for the possibility to reduce life sentences after a set period of time. ${ }^{100}$ As we also saw, in Trabelsi the

95 See Pedro Caeiro, “Ut Puras Servaret Manus...”, p. 50 f.

${ }^{6}$ See ibid. Case law also denotes mixed feelings in this regard. Thus, for instance, in a ruling of 9 August 2013, no. 750/13.1YRLSB.S1, the Supreme Court emphasised that in the case at hand there did not exist sufficient guarantees that life imprisonment, if applied and subject to review within 20 years, would be "mandatorily altered" (which, as we saw, is no longer required). Eventually, the EAW was executed, but the person was a Portuguese resident and therefore would be returned for enforcement (with the consequence that the sentence would be reviewed and, if necessary, adapted).

${ }^{97}$ Luís Silva Pereira, “Alguns aspectos...” op. cit., p. $44 \mathrm{f}$.

98 See again the explanations of the Minister of Justice in the context of the 2001 amendment and subsequent discussion, in Diário da Assembleia da República, II Série-RC: Número 11, 4 July 2001, p. 170 f. Apparently agreeing with this line of reasoning, see NUNO PIÇARRA, "As revisões constitucionais...", op. cit., p. 233; also DAmiño DA Cunha, op. cit., p. 544, and MAnuel Monteiro Guedes VAlente, Do mandado de detenção europeu, Coimbra: Almedina, 2006, p. 319.

${ }^{99}$ See ruling of the Constitutional Court no. 1/2001, of 10 January; see Diário da Assembleia da República, II Série - RC - Número 82, 30 April 1997, p. 2348 f.; also NunO PIÇARRA, "As revisões constitucionais...”, op. cit., p. 233, stating that, in "several cases", extradition under the CISA was blocked due to that ruling of the Constitutional Court, creating impunity, making it clear that a constitutional amendment was necessary to secure European cooperation; see yet the ruling of the Constitutional Court no. 403/2015, of 27 August.

${ }^{100}$ In Hutchinson, as also noted before, the ECtHR retracted from the stance taken in Vinter, conceding that life sentences in the UK are not 'irreversible'. The decision took into account Attorney General's Reference (no. 69 of 2013) [2014] EWCA Crim 188, [2014] 1 W.L.R. 3964, also known as R. v. Newell (Lee William) / R. v. McLoughlin (Ian): see supra, Chap. 3, S 4.2.2.; and again STEvE Harold Foster, "Whole Life Sentenc- 
Soering principle was applied to that ruling, so that irreducible life sentences can now give rise to the refusal to extradition under the ECHR. The EA 2003 does not have an explicit ground for refusal on irreducible life sentences, but, in the light of Trabelsi, the human rights clause assessed earlier will encompasses that situation as a bar to extradition.

In Harkins, ${ }^{101}$ the Administrative Court had an opportunity to confirm this, but ultimately did not do so, due to what may be considered a technicality. Harkins had been indicted in the USA for murder and attempted robbery with a firearm and escaped to the UK; his extradition was ordered by the UK, following which he submitted two unsuccessful challenges by way of judicial review; in the second of them he alleged that his extradition would violate Art. 3 ECHR, because, if convicted in the USA, he would be sentenced to mandatory life imprisonment without the possibility of parole. In 2012 Harkins appealed to the ECtHR, and the Court ruled that the sentence was not grossly disproportionate in his case, and that there was no serious risk of ill-treatment meeting the threshold of Art. 3; however, as just mentioned, in Vinter, in 2013, the ECtHR ruled that a sentence such as that which Harkins would face did constitute a breach of Art. 3. In this setting, the Administrative Court had to consider: (i) the circumstances in which it was required to reopen a challenge to an extradition order, in a case where a previous challenge had already been dismissed by the Divisional Court and the ECtHR; and (ii) whether the Vinter ruling indeed had changed Harkins' rights under the ECHR in such a manner as to render his extradition incompatible with Art. 3. With some concessions, ${ }^{102}$ the court found that: (i) Vinter did not change the fact that only 'grossly disproportionate' prison sentences breach Art. 3 ECHR; (ii) in Vinter, the ECtHR reiterated that only on 'rare and unique' occasions would this test be met; (iii) in dealing with life sentences in particular, the ECtHR maintained the view that had been held in Kafkaris, that even if the sentence is considered 'irreducible', it may, but will not necessarily give rise to an issue under Art. 3; (iv) in determining whether a life sentence is 'irreducible', the ECtHR again reiterated its stance in Kafkaris, that, "where national law affords the possibility of review (...) with a view to its commutation, remission, termination or the conditional release of the prisoner", Art. 3 will be satisfied. ${ }^{103}$ In sum, to that Court, Vinter did not bring new principles of law beyond those that had been applied in Harkins, but only made some clarifications. As such, the test for reopening Harkins had not been satisfied. ${ }^{104}$

Regarding Trabelsi, the court also found that it had not advanced beyond the principles laid down in Vinter, "save in the obvious sense that it purports to lift the Vinter principles and apply them wholesale in the extradition context". ${ }^{105}$ The court did admit that the statement in Trabelsi at $\int 115$ (sc. "for the first time") denotes that the ECtHR be-

es...”, op. cit., p. 147 f.; NAOMI HART, op. cit., p. 205 f.; MARK PETTIGREW, op. cit., p. 281 f. However, as was also established, this retraction left unaffected the principle established in Trabelsi, that a life sentence, if considered 'irreversible', will preclude extradition pursuant to Art. 3 ECHR.

101 Phillip Harkins v. The Secretary of State for the Home Department v. Government of the United States of America [2014] EWHC 3609 (Admin) 2014 WL 5599581.

102 See id., $\int 68$.

103 See $i d ., \S 66 \mathrm{f}$.

104 See id. JS $92 \mathrm{f}$.

${ }^{105}$ Id. 
lieves Vinter to have developed the principles established in Kafkaris and in subsequent cases up to and including Harkins. "If so" - the court of the UK, however, remarked "we must respectfully decline to agree". ${ }^{06}$ The court further recalled that s. 2 (1) Human Rights Act commands that consideration be given to ECtHR case law, but not that it be followed. Therefore, even if Trabelsi did extend previous principles, that still did not prevent the court from "declin[ing] to decide this case on the basis of what we regard as new and untried ECtHR jurisprudence in this area." 107 In this light, it may be concluded that the position of the courts in the UK regarding extradition in case of an irreducible life sentence is not fully clear yet.

Nevertheless, in Shaw ${ }^{108}$ the High Court seems to have embraced the principle set in Trabelsi. Lord Justice Aikens declared that such a principle "is not in dispute": "If a life sentence is imposed that is de jure and de facto 'irreducible', then this may raise an Art. 3 issue". ${ }^{109}$ He noted that Trabelsi had relevant differences in relation to the case at hand, but did not rule out that the same regime might apply; however, yet again the ruling was not categorical: "for present purposes I am going to assume that (...) I should follow what is stated by the ECtHR in Trabelsi"; "I will assume, therefore, that (...) it has to be demonstrated that there is a form of 'dedicated review mechanism' available." 110 Ultimately, the court found that, in the case, the requirements set out in Trabelsi were met, and, thus, that extradition could be granted. Shaw does in any case provide solid bases to argue that currently the UK cannot extradite if an irreducible life sentence applies. This ground for refusal is contiguous but conceptually different from that found in States (such as Portugal) where a life sentence - whether irreducible or not - cannot be applied.

\subsection{Hostage-taking considerations}

\subsubsection{United Nations}

The 1979 UN Convention against the Taking of Hostages provides in its Art. 9 (1) (b) (ii) that extradition shall not be granted if the requested State has substantial grounds to believe that the person's position may be impaired for the reason that communication with him/her by the appropriate authorities of the State entitled to exercise rights of protection cannot be effected. ${ }^{111}$ However, this obstacle has not been reproduced in any of the UN model instruments on extradition.

\subsubsection{Portugal}

This obstacle is not found in the Portuguese legal system.

${ }^{106} I d$. As we saw supra, Chap. 3, \ 4.2.2., the ECtHR itself declared Harkins' second application inadmissible, as his complaints were "substantially the same" (within the meaning of Art. 35 \ 2 (b) ECHR).

107 Id.

108 Domminich Shaw v. Government of the United States of America [2014] EWHC 4654 (Admin).

109 Id., \ 31.

${ }^{110} I d$., $₫ 32$ (emphases added).

111 On this Convention and the extradition aspects covered therein, but without elaborating on the one under analysis here, see BEN SAUL, "International Convention against the Taking of Hostages", UNALIL, in http://legal.un.org/avl/pdf/ha/icath/icath e.pdf. 


\subsubsection{United Kingdom}

Based on s. 83 , extradition is barred due to 'hostage-taking considerations' if the requesting State is a party to the UN Convention on hostage-taking and "it appears that", if extradited, the person might be prejudiced at the trial because communication between him/her and the appropriate authorities would be impossible, and the act or omission constituting the extradition offence also constitutes an offence under s. 1 Taking of Hostages Act 1982, ${ }^{112}$ or an attempt to commit such an offence. 'Appropriate authorities' are the relevant consular authorities. ${ }^{113}$ This ground for refusal was instituted by the EA 2003, ${ }^{114}$ and is derived from Art. 9 (1) (b) (ii) of said UN Hostage-taking Convention. ${ }^{115}$

This bar can be understood as a prolongation of those on fair trial and extraneous considerations. Possibility of communication between the individual and his/her consular authorities is taken as an indicator that the he/she will not be prejudiced at trial, and the absence of such a possibility as an indicator that he/she will be in a position akin to that of an 'hostage'. This bar is reported to be of very limited practical importance. ${ }^{116}$

This bar was initially provided also for the EAW, in s. 16. The FD-EAW does not feature such a ground for non-execution, and it could not be regarded as a 'prevailing obligation', since the UN Convention whence it has been derived came into being after the entry into force of the TCE, on 1 January $1958 .{ }^{117}$ This bar was repealed in respect of the EAW by the Anti-social Behaviour, Crime and Policing Act 2014, s.158 (1). ${ }^{118}$ This revocation is entirely justified in the light not only of its absence in the FD-EAW, but also of the fact that is has never been raised in practice. ${ }^{119}$ On the other hand, it had become redundant in view of the harmonisation of procedural rights taking place in the EU: communication between defendants and their consular authorities is one of the rights provided for in the Directive 2013/48/EU of 22 October 2013, on the right of access to a lawyer in criminal and EAW proceedings, and on the right to have a third party informed upon deprivation of liberty and to communicate with third persons and with consular authorities when deprived of liberty. ${ }^{120}$ The UK did not opt-in on this instrument, but benefits, as an executing Member State, from the fact that other Member States are bound to its provisions.

112 According to this provision: “(1) A person, whatever his nationality, who, in the United Kingdom or elsewhere, - (a) detains any other person ('the hostage'), and (b) in order to compel a State, international governmental organisation or person to do or abstain from doing any act, threatens to kill, injure or continue to detain the hostage, commits an offence. (2) A person guilty of an offence under this Act shall be liable, on conviction on indictment, to imprisonment for life."

113 See Clive Nichols et al., op. cit., p. 85; SCOTt BAKer / DAvid Perry / ANAND Doobay, op. cit., p. 379, 426 f.; see also the 1963 Vienna Convention on Consular Relations, Art. 36.

114 See SCOTT BAKer / David Perry / ANAND DoObay, op. cit., p. 200.

115 See Clive NiCHOLS et al., op. cit., p. 84.

116 See Katherine Tyler / Kingsley NApley / Daniel Sternberg, "Extradition: bars to extradition (Insight)", Westlaw, last updated 22 December 2014, \ 16.

117 See ANDRÉ KLIP, European Criminal Law... op. cit., p. 424 f.

118 SeeKatherineTyler / Kingsley Napley / DanielSternberg, “Extradition:bars”...op.cit., 16.

119 See Katherine Tyler / Kingsley NAPley / Daniel Sternberg, "Extradition: special cases”, Westlaw, last updated 20 February 2015, \ 14.

120 See Arts. 1 and 7 of this Directive. 


\section{Grounds for refusal related to the nature or relevance of the acts}

\subsection{Dual criminality}

\subsubsection{United Nations}

Art. 2 (1) MTE considers "extraditable" acts punishable under the laws of both the requesting and the requested State. In Art. 2 (2) it specifies the scope of this requirement by establishing that in order to determine whether an offence is punishable in both States it shall not matter whether: (a) Those laws place the acts or omissions at issue within the same category or offence, or denominate the offence by the same terminology; (b) Under those laws the constituent elements of the offence differ, it being understood that the totality of the acts or omissions as presented by the requesting State shall be taken into account. Finally, it suggests that, if the request concerns a tax or similar offence, extradition shall not be refused on the ground that the requested State does not contain a tax, customs duty or exchange regulation of the same kind. ${ }^{121}$ The MLE contains identical provisions in s. 3 .

The model instruments therefore use dual criminality, a consolidated feature of extradition law which according to some authors constitutes customary international law. ${ }^{122}$ This rule replaced the old-fashioned 'list of offences' system as a method for determining extraditable acts. Such an enumerative method showed itself prone to obsolescence due to the constant emergence of new offences, as well as fallible in the light of the risk of inadvertent failure to include in the list important offences criminalised in both States; it consequently required States to keep renegotiating or supplementing treaties. ${ }^{123}$

While the model instruments acknowledge dual criminality to be a "deeply ingrained principle of extradition law", ${ }^{124}$ they clearly assert that an "excessively formalistic application" of this rule, based on the "semantic description of an offence (which will obviously differ depending on the legal systems and languages concerned) rather than its practical nature" is to be avoided. ${ }^{125}$ Thus, in line with what was already a general trend in extradition law, ${ }^{126}$ the model instruments do not require the offence to have the same nomen juris or the acts to fall within the same offence or category of offences: it suffices that the acts constitute any offence in both States. ${ }^{127}$ This creates what the Revised Manuals designate

121 The MTE admits, on a footnote to this provision, that States derogate from this approach and instead adopt an optional ground for refusal.

122 See M. Cherif BAssiouni, "Law and Practice of the United States...”, op. cit., p. 313.

123 See UNODC, "Revised Manuals...", op. cit., p. 8.

124 UNODC, "Revised Manuals...”, op. cit., p. 10. Qualifying dual criminality as probably the most important rule in extradition law, see BERT SWART, "Human Rights...”, op. cit., p. 250.

125 See UNODC, "Revised Manuals...”, op. cit., p. 10. Some of the complex issues where such a formalistic approach would be problematic are addressed in MiCHAEL E. TiGAR, "The extradition requirement of double criminality in complex cases: illustrating the rationale of extradition”, RIDP 62 (1991), p. 164 f.; GIUSTO SCIACCHITANO, "Doppia incriminazione nelle maxi-istruttorie relative a casi di criminalità organizzata", id., p. 193 f.; Gregory B. RiCHARDSOn, "Double criminality and complex criminal offences", id., p. 79 f.; and RiCHARD A. MARTIN, "Dual criminality in organized crime cases", $i d$., p. 175 f.

126 See Jean Pradel / Geert Cortens, Droit Pénal Européen, Paris: Dalloz, 2. nd ed., 2002, p. 60 f., 226.

127 See UNODC, "Revised Manuals...”, op. cit., p. 10 f. 
as a "generic double criminality standard" which "explicitly minimizes the significance of the particular legislative language used to penalize certain conduct and encourages a more pragmatic focus on whether the underlying factual conduct is punishable by both contracting States". 128

Regarding tax offences, the Revised Manuals inform that extradition was historically precluded for this type of acts out of deference for State sovereignty, but the situation began to change in reaction to such phenomena as money laundering, corruption and the infiltration of criminal proceeds into national economies. ${ }^{129}$ The UN model instruments mirror this evolution, and suggest that dual criminality be configured as "sufficiently flexible" to allow extradition even where the types of taxation vary between the two States. ${ }^{130}$ This expresses the same view mentioned above regarding common offences: formal differences between penal systems are immaterial; what matters is the existence of a 'generic' communion of perspectives between States as to the criminal character of given conduct. States wishing to maintain the fiscal offence exception are given that possibility, but are advised to take into consideration the approach made to this issue in recent international instruments. ${ }^{131}$ In the light of the existing consensus not to exempt fiscal offences from extradition (which is perfectly mirrored both in the Portuguese and UK's legal systems), this ground for refusal is not covered in this study.

The Revised Manuals do not expand or provide hints as to the rationale of the dual criminality rule. ${ }^{132}$ In legal literature unrelated to the model instruments, several different positions are advocated, ranging from the necessity to ensure the lawfulness of any form of deprivation of liberty in the requested State (on the basis that no person can be arrested or detained for acts which do not constitute a crime in that legal system), to the intent to preserve reciprocity; ${ }^{133}$ other arguments are that this is required by the principle of legality (nullum crimen sine lege), ${ }^{134}$ by the principle of proportionality, ${ }^{135}$ or - in what is arguably the predominant stance - by the ordre public of the requested State. ${ }^{136}$

128 Ibid., p. 10

${ }^{129}$ Ibid., p. 11; see also BERT SWART, "Human rights...", op. cit., p. 256 f.; and id., "Refusal of Extradition...", op. cit., p. 188, in open agreement with this trend.

${ }^{130}$ UNODC, "Revised Manuals...", op. cit., p. 11. According to BERT SwART, "Refusal of Extradition...", op. cit., p. 188, this provision has been copied from Art. 2 of the Second Protocol to the European Convention on Extradition, which also abolished the fiscal offence exception.

131 Ibid., p. 11, mentioning particularly the 1988 Vienna Convention, the 2000 Palermo Convention, and the 2003 Merida Convention.

132 BERT SWART, "Refusal of Extradition...", op. cit., also does not address the issue of dual criminality.

133 The contention is that, if the acts are not criminalised in the requested State, this State will never be in a position, in the future, to request extradition for similar acts: see e.g. PAUL GULLY-HART, op. cit., p. 356 f.; Sharon A. Williams, “The Double Criminality Rule Revisited”, ILR 27 (1993), p. 298.

134 See e.g. S. Z. FELLER, "The Significance of the Requirement of Double Criminality in the Law of Extradition - Steven Ivan Ross v. State of Israel (1973) (II) 27 P.D. 365”, ILR 10 (1975), p. 78 f., CHRISTINE VAN DEN WYNGAERT, "Rethinking the law of international cooperation: the restrictive function of international human rights through individual-oriented bars", in Albin Eser / Otto Lagodny (eds.), op. cit., p. 493; Id., "Double criminality as a requirement to jurisdiction", op. cit., p. 141 f.; CHristOPHER L. BLAKESLEY, "The law of international extradition: a comparative study", in John Dugard / Christine van den Wyngaert (eds.), op. cit., p. 156; LECH GARDICKI, "Double Criminality in Extradition Law", ILR 27 (1993), p. 289; SHARON A. Williams, op. cit., p. 298. 


\subsubsection{Portugal}

The dual criminality rule is provided for in Art. 31 (2). Consummation is not necessary: attempted offences explicitly satisfy the rule. It is not necessary that the person be a principal either: complicity suffices to satisfy the rule. ${ }^{137}$ Finally, the rule will be satisfied if the acts constitute an offence: an identity of terminology or a categorisation is not necessary - in this sense the rule is assessed in concreto. ${ }^{138}$ Blameworthiness, in turn, is not called into consideration: it suffices that the acts are possible to be subsumed in a substantive penal norm (Tatbestand) and are unlawful - and in this sense the rule is assessed in abstracto.

The purpose of dual criminality is to protect the ordre public of the Portuguese State. In Serrano's words: “it would not make sense for a requested State to collaborate in the punishment of a person if it does not censor him/her in the light of its own legal system". ${ }^{139}$ The Court of Appeal of Porto has also explicitly held that this rule seeks to avoid Portugal being "obliged" to cooperate for acts that in its view are innocuous. ${ }^{140}$ The rationale of the rule can also be assessed through an exclusionary approach, viz. by dismissing other possibilities. Thus, in the first place, it cannot be related to the principle of legality. ${ }^{141}$ Such a position would entail that dual criminality have constitutional rank. That this is not the case is clear from the circumstance that Art. 2 (2) of the act implementing FD-EAW - which partially abolishes this rule in the cooperation between EU Member States -, has not raised any issues of constitutionality. On the other hand, it also appears to be unrelated to reciprocity, since this issue is already regulated in a specific and autonomous ground for refusal. As for the proportionality argument, the Constitution explicitly admits deprivation of liberty of individuals whose extradition is requested to the Portuguese State: Art. 27 (3) (c). ${ }^{142}$

Although dual criminality does not have constitutional rank, it is worth noting that it elicited debate in Parliament at the time of the drafting of the 1976 Constitution: in the context of a discussion on the death penalty as a ground for refusal (which gathered consensus), the question was raised as to whether the Constitution to be drafted should also bar extradition in relation to offences which are intrinsically unfair or discriminatory. The

135 See e.g. THEO VOGLER, “The rule of speciality in extradition Law”, RIDP 62 (1991), p. 233. This position is quite close to that according to which the rationale of the rule is to ensure the lawfulness of any form of deprivation of liberty in the requested State.

136 See e.g. ROBERT ZIMMERMANN, op. cit., p. 393, with more references; JEAN PRADEL / GEERT CORTENS, op. cit., p. 120.

137 See Manuel António Lopes Rocha / Teresa Alves Martins, op. cit., p. 66.

138 Ibid., p. 66; MÁrio Mendes SERrano, op. cit., p. 47. On the range of elements covered by the dual criminality rule in Portugal, see Miguel Jỗo COSTA, "O princípio da dupla incriminação na extradição", in Pedro Caeiro (org.), Temas de Extradição e Entrega, Coimbra: Almedina, 2015, p. 43 f.

139 Mário Mendes Serrano, op. cit., p. 47.

140 Ruling of the Court of Appeal of Porto of 7 March 2012, process 32/12.6YRPRT.

${ }^{141}$ In this sense, see also Jorge De Figueiredo Dias / PEDro CAEIRO, "Comentário ao Acórdão do Tribunal de Justiça de 3 de Maio de 2007, proc. C-303/05, Advocaten voor de Wereld VZW contra Leden van de Ministerraad', in Eduardo Paz Ferreira / Maria Luísa Duarte / Miguel Sousa Ferro (orgs.), Jurisprudência Cunha Rodrigues - Comentários, Lisboa: Associação Académica da Faculdade de Direito de Lisboa, 2013, p. 24 f.

${ }^{142}$ In further detail on the dual criminality rule in the Portuguese extradition system, see MigUEL JOÃO Costa, "O princípio da dupla incriminação...”, op. cit., p. 62 f. 
example used was a hypothetical extradition request issued by South Africa in respect of a South African person for acts violating apartheid laws. The intervening deputies stated that extraditing in such cases would be as unacceptable and shocking to the worldview of the newly democratic Portuguese Republic as exposing a person to capital punishment; in the end, however, they held that, considering the problems that a specification of such cases in the Constitution could raise, they would be better tended by ordinary law. ${ }^{143}$

As is well-known, the mitigation of the dual criminality rule is one of the main features of the FD-EAW. As in other Member States, this feature was received in Portugal with some disapproval, the main claim being the excessive focus on the repressive profile of European criminal law. ${ }^{144}$ However, Portuguese policymakers saw it as justified based on two main reasons: the seriousness of the offences concerning which dual criminality was abolished, and the fact that they were already more or less harmonised by EU law. ${ }^{145}$ On the other hand, the FD-EAW gave Member States the option to retain dual criminality in respect of offences not included in Art. 2 (2), and the Portuguese legislator chose to retain it (Arts. 2 (3) and 12 (1) (a) PT-EAW).

\subsubsection{United Kingdom}

Dual criminality is also a traditional principle of UK's extradition law. In determining whether the rule is satisfied, the acts for which extradition is requested are transposed into the UK and an assessment is made as to whether they would constitute an offence in this legal system. ${ }^{146}$ It is therefore not necessary that there be an identity of terminology or categorization - and in this sense the rule requires an assessment in concreto.

Stanbrook and Stanbrook hold that this rule is "founded on common sense", more specifically: in part, on reciprocity (in that the requested State would never be able make a request for similar acts); in another part, on the legality principle (in that it prevents a person from being restricted in his/her liberty on account of acts that are not established to be criminal); and, finally, on the defence of the "social consciousness" of the UK - i.e. its ordre public (which could be "embarrassed" by extraditing a person who is not deserving of criminal punishment under its own standards). ${ }^{147}$ As far as reciprocity is concerned, it is subject to autonomous consideration in another moment of the EA 2003, and as such it appears to have limited relevance in the context of dual criminality. The remaining arguments are the principle of legality and ordre public, discussed below.

143 See Diário da Assembleia Constituinte, n. ${ }^{\circ}$ 36, 23-08-1975, p. 988 f.

144 See Anabela Miranda Rodrigues, “O Mandado de Detenção Europeu - Na Via da Construção de um Sistema Penal Europeu: Um Passo ou um Salto?”, RPCC 13 (2003), p. 31 f., RiCARdo JorgE BRAGANÇA DE MATOS, "O princípio do reconhecimento mútuo e o Mandado de Detenção Europeu”, RPCC 14 (2004), p. 351 f.; MANuel MonteIro Guedes VALENTE, op. cit., p. 61; InÊs GOdinHo, op. cit., p. 122.

145 See Pedro Caeiro / Sónia Fidalgo, op. cit., p. 452.

146 See Rosemary Davidson, "Extradition Offences", in John R. W. D. Jones (general ed.) / Rosemary Davidson (assistant ed.) / Arvinder Sambei (contributor) / Brian Gibbins (contributor), Extradition and Mutual Legal Assistance Handbook, 2nd ed., Oxford: University Press, 2010, p. 29 f.

${ }^{147}$ Ivor Stanbrook / Clive STANBrook, op. cit., p. 20, supported on IVAN ANTHONy SHEARER, op. cit., p. 137 f. 
The case that sheds brighter light on this issue is Pinochet. One of the many issues addressed in this case was that as to whether the rule of dual criminality should be established by reference to the date of the acts, or rather to that of the extradition request. Although there was no precedent on the matter, it had generally been assumed that the relevant moment was the date of the request. ${ }^{148}$ This belief was dispelled by the judgment of Lord Browne-Wilkinson in R. v. Bow Street Metropolitan Magistrate and others, ex parte Pinochet Ugarte (No. 3). ${ }^{149}$ The ruling did not elaborate on the rationale of dual criminality. It simply noted that it was 'clear' from the EA 1870 that the criterion was the conduct date, and that it seemed "impossible that the legislature [when enacting the EA 1989, applicable to the case] can have intended to change that date from the one which had applied for over a hundred years (...) by a side wind and without investigation." Some elaboration on the rationale of dual criminality was put forward by Montgomery QC on behalf of the applicant: "The magistrate must exercise the extradition jurisdiction in the same way as the domestic criminal jurisdiction (...). The objective is to give the defendant the same rights as a defendant under English law." This reasoning was disputed by Alun Jones QC on behalf of the appellants: "It is impossible to say that extradition for the crimes alleged against the applicant is unfair. If a statute allowing for retrospective extradition infringes no rights, is not penal and does not impose disabilities, it is difficult to see that such extradition is inherently unfair (...). The rationale behind the double criminality principle is that a country does not send a person under compulsion from its jurisdiction to be tried or punished abroad for crimes alien to its own system of law. There is no need to write into a statute a further artificial safeguard which that rationale does not call for." While the latter stance has been considered "more persuasive" and its consequences more "palatable", ${ }^{150}$ the conduct date criterion prevailed by unanimity and it is the one that remains valid under the EA 2003. ${ }^{151}$ Such a criterion points towards the notion that, in the UK, dual criminality does have close ties to the principle of legality: the 'social consciousness' of a State would not be disturbed if the acts were criminalised in the moment of extraditing; only criminal punishment itself requires criminalisation in the moment of acting. It is arguably unequivocal that extraditing Pinochet for acts of torture committed before the entry into force of the statute criminalising those acts in the UK (sc. the Criminal Justice Act 1988, s. 134) would have been incapable of 'embarrassing' its 'social consciousness'. An interesting question is that as to whether, in the UK, offences created in response to shifting public perception (e.g. computer hacking, marital rape), to which common law can be applied retroactively (insofar as the criminal nature of such acts were reasonably foreseeable), ${ }^{152}$ meet the 'offence date' test in force for extradition.

148 See IVOr Stanbrook / Clive StanbroOK, op. cit., p. 23.

149 [1999] 2 WLR 827, \ 837.

150 IVOr StANBrook / Clive StANBroOK, op. cit., p. 23.

151 See Julian B. KNOwles, op. cit., p. 21 f.; see Dabas v. High Court of Justice in Madrid, Spain [2007] 2 AC 31, $\int 46$.

152 Ivor Stanbrook / Clive Stanbrook, op. cit., p. 20, citing Regina (Respondent) v. R. (Appellant) [1992] 1 AC 599. 
At any rate, the notion that dual criminality stems from the principle of legality has been destabilised by the partial abolition of that rule in the context of the EAW. Indeed, if, as Montgomery QC held on behalf of Pinochet, "[ $t$ ] he objective is to give the defendant the same rights as a defendant under English law", then it is difficult to explain why the situation would be any different simply because the requesting State is an EU Member State. While the mitigation of dual criminality within the EU can to an extent be justified by the high similarity of Member States' criminal laws, ${ }^{153}$ it is clear that significant differences exist between those criminal laws which reflect very different worldviews, clear-cut examples of this being abortion, euthanasia, assisted suicide and certain drugrelated offences. ${ }^{154}$ And, where the acts for which a EAW is requested are not criminalised in the UK, legality concerns would still arise. ${ }^{155}$ The only argument capable of reasonably justifying the dispensation of dual criminality, in the UK, for EAW purposes is that, in the Schengen Area, where it is extremely easy to circulate, the social consciousness of the requested State is not affected - or at least not as affected - if the requesting State is a part of that area and the acts have been committed within that area. ${ }^{156}$ This argument, however, would presuppose that the rationale of dual criminality is to preserve that social consciousness.

${ }^{153}$ See Office of the King's Prosecutor, Brussels v. Cando Armas [2006] 2 AC 9, \$9: "Underlying the list [of offences regarding which dual criminality check is abolished] is an unstated assumption that offences of this character will feature in the criminal codes of all member states. (...) The assumption is that double criminality need not be established in relation to these offences because it can, in effect, be taken for granted."

154 As is acknowledged in the Baker Report: see SCOTT BAKER / DAVID PERRY / ANAND DOOBAY, op. cit., p. 185 f.

155 See ibid., p. 188, stating that the partial abolition of the double criminality rule was one of the most controversial aspects of the FD-EAW and that "the essential point made by the critics is that a person present in the UK is at risk of being surrendered (...) to face prosecution for conduct which Parliament has not considered it necessary to criminalise (such as holocaust denial which is an offence in Germany and Austria but not an offence in the UK), or which Parliament has legalised such as abortion under strictly defined conditions".

156 It is in this very line that SCOTT BAKer / DAvid PerRy / ANAND DoObaY, op. cit., p. 189, speak in favour of the mitigation of dual criminality in the EU: "While we accept that harmonisation of the criminal law within the EU has not taken place, and that significant differences exist in the Member States' substantive criminal law, the trend should be towards even greater cooperation in the suppression of crime. This is in the public interest and reinforces the rule of law: it is not in the interests of good order both within a State and internationally for crime to go unpunished as a result of movement across borders. Where foreign criminal law has been violated, and an overseas territory has suffered harm to its interests and citizens, it is no longer possible to view this with indifference on the basis that no interest of the executing territory has been affected. Wherever serious crime is committed it should not go unpunished. (...) [A]s the need for cooperation becomes greater in an area of freedom, security and justice made up of like-minded Member States, we envisage that the double criminality requirement may be relaxed to an even greater extent where the conduct takes place wholly in the requesting territory." The authors further at p. 190: "Also relevant in this connection is the obligation on Member States to take into account the interests of the victims of criminal offending. Council FD 2001/220/JHA on the status of victims in criminal proceedings is part of a wider programme designed to enhance the protection of the victim of crimes by improving their access to justice and right to compensation. Member States are exhorted to attain the objective of affording victims a high level of protection, irrespective of the Member State in which they are present. The surrender of accused and convicted persons between Member States is an important aspect of this programme." 
The mitigation of dual criminality within the EU was even presented by the Home Office, in the review published in preparation of the Bill that would lead to EA 2003, as something of a 'natural' consequence of the EU criminal justice project: 'We considered that it was not necessary to retain the requirement for the offence to be an offence in both the requesting and requested country (dual criminality). This was thought to be an inappropriate judgement on the criminal justice systems of our European partners. If an offence is a crime on the statute book of our European partners then the UK should respect that." 157 This denotes openness on the part of the Home Office to even consider a complete abolition of dual criminality within the EU. This stance is also consistent with the UK's strong tradition of respect for territorial jurisdiction. It is in this very line that ran the views of Mr. Ainsworth in a debate held in the House of Commons in 2003: "We expect people who come to our country to abide by our laws and not their own, and the reverse must also be true". ${ }^{158}$ In any case, ultimately the EA 2003 only abolished the control of dual criminality in respect of the 'list of offences' of the FD-EAW.

Regarding dual criminality in the EAW context, the following should yet be noted. In ss. 64 and 65, the EA 2003 uses the concept of 'extradition offence' typical of classic extradition, but the concept is unknown to the FD-EAW. ${ }^{159}$ As Spencer apprises: "The definition of an extradition offence is a multi-partite one that combines, in various permutations and combinations, requirements as to how severely the offence is punishable in the executing State, the presence or absence of the offence from the FD list, requirements as to how severely the offence is punishable in the UK, and elements derived from the 'optional grounds for refusal' listed in Art. 4 of the FD."160 Under this complex scheme, at a first glance, offences listed in the FD as being exempted from the control of dual criminality would only be 'extraditable' if, among other conditions, the conduct took place in the issuing Member State, and no part of it took place in the UK: s. 65 (2). This would manifestly depart from the discipline envisaged by the FD-EAW. Like several other difficulties arising from the "unnecessarily complicated" implementation made in the UK of the FD-EAW, this difficulty was solved in practice by construing the EA 2003 in such a manner as to render it compatible with the FD, drawing on Pupino. ${ }^{161}$ This was the approach followed for instance in Cando Armas: Belgium issued a EAW against Armas for smuggling of illegal immigrants from Ecuador to Europe. According to the warrant, he was operating from London, and the UK was one of the countries of destination

157 Home Office, “The Law on Extradition: A Review”, March 2001, p. 21. The Review did question, however, "whether this should extend to cases where a state requests an individual's extradition on the basis of that state's extra-territorial jurisdiction over an offence, which did not occur in the requesting state and where the conduct is not an offence in the requested state", as "[t]his could lead to the UK being in the position of having to extradite someone for conduct committed in the UK which is not even an offence in the UK and for which a prosecution could not be pursued here" - ibid., p. 21.

158 House of Commons, 25 March 2003, column 181.

159 See JOHn R. SPEnCER, "Implementing...”, op. cit., p. 191, calling it an 'invention' on the part of the UK legislator.

160 Ibid., p. 191, adding: "This confusing piece of handiwork is executed twice, once in s. 64, which applies in cases where the wanted person has not yet been sentenced, and once again, with minor variations, in 65, which applies in cases where he has."

161 See ibid., p. 185, 190 f., et passim; see ECJ, Pupino (C-105/03), Judgment of 16 June. 
of the immigrants. His surrender was refused in first instance, because, as noted, according to s. 65 (2) (the only provision that in a literal interpretation would apply to the case), a EAW can only be executed for smuggling of people (an offence included in the list of offences of the FD-EAW) if no part of it occurred in the UK, which manifestly was not the case, as the operation had been run from London. This ruling construed the different types of 'extradition offences' defined in the EA 2003 as "watertight compartments". ${ }^{162}$ It was overturned by the Divisional Court, and by the House of Lords on further appeal, which held that listed offences could still be regarded as 'extradition offences' under s. 65 (3), encompassing offences that are also punishable in the UK without requiring that no part of them occurred in the UK. ${ }^{163}$ The case would have been even more interesting if the acts in question were not criminalised in the UK, although the outcome would probably have been similar, as the House of Lords followed a very comprehensive approach whereby, "while Parliament might properly provide for a greater measure of cooperation by the UK than the [FD-EAW] required, it did not intend to provide for less."164

\subsection{Relevance}

\subsubsection{United Nations}

It is a deep-rooted rule that offences of low importance do not give rise to extradition. This rule is established in Art. 2 (1) Model Treaty, according to which 'extraditable offences' are only those that are punished in both the requesting and the requested States with deprivation of liberty for at least one/two years, ${ }^{165}$ or with a more severe penalty. ${ }^{166}$ The Model Law practically replicates this provision in s. 3 (1) (a) and (b). If the request is aimed at the enforcement, extradition can be granted only if at least four/six months ${ }^{167}$ remain to be served. ${ }^{168}$ Finally, Art. 2 (4) Model Treaty provides that, where the request includes several offences (punishable in both States) and some of them do not satisfy the above thresholds, the requested State may still grant extradition for such offences if extradition is possible for at least one offence that does satisfy those thresholds.

According to the Revised Manuals, thresholds should be set at such levels as to ensure that "extradition is not invoked in de minimis cases", but is "available for a wide range of more serious conduct." 169 They should also beware of covering offences established in multilateral treaties binding on the requested State. ${ }^{170}$ Regarding extradition requested for

162 Ibid., p. 192.

163 Office of the King's Prosecutor, Brussels v. Cando Armas [2004] EWHC 2019 (Admin), [2005] 1 WLR 1389, and [2005] UKHL 67, [2006] 2 AC 1.

164 Ibid., $\int 8$.

165 States can choose either, or a different threshold: see UNODC, "Revised Manuals...”, op. cit., p. 8.

166 Notably, the death penalty: see ibid., p. 9.

167 Again, States can choose either of these, or a different threshold: see ibid., p. $8 \mathrm{f}$.

168 See Art. 2 (1) Model Treaty and s. 3 (2) Model Law.

169 UNODC, "Revised Manuals...", op. cit., p. 8.

${ }^{170}$ Especially those giving rise to an aut dedere aut judicare obligation or requiring that their offences qualify as 'extraditable offences', such as the UN conventions on terrorism, drug trafficking and transnational organised crime: see ibid., p. 9. 
enforcement, the rationale is similar: thresholds should be such as to inhibit the "intrusive and resource intensive extradition process" for unimportant cases, but "realistic" in view of such factors as geographic distances between the States at issue, transportation facilities, and resulting cost implications. ${ }^{171}$ With regard to extradition for enforcement, however, the Revised Manuals indicate that a threshold might not be established at all, if States desire to secure enforcement of short imprisonment sentences, house arrests or supervised conditional releases. ${ }^{172}$ This suggests that the arguments in favour of refusing extradition in minor cases are weaker if a penalty has already been applied. This is consistent with the fact that upon conviction presumption of innocence ceases.

\subsubsection{Portugal}

Art. 31 (2) and (4) prescribes that extradition is possible only for offences punishable with deprivation of liberty for at least 1 year or, where extradition is requested for enforcement purposes, if the penalty remaining to be served amounts to at least 4 months. Art. 31 (3) then establishes that, where the request concerns several offences, and one or more of them do not reach that threshold, extradition is still possible for the latter. This requirement is regarded as a manifestation of proportionality in the restriction of fundamental rights, required by Art. 18 (2) of the Constitution, as well as a pragmatic option intended to avoid the proliferation of extradition requests for minor cases. ${ }^{173}$

Art. 2 (1) PT-EAW also requires, in order for a EAW to be executed, that the acts be punishable, according to the law of the issuing Member State, with imprisonment or a detention order for at least twelve months or, where a sentence has been passed or a detention order has been made, for sentences of at least four months. ${ }^{174}$

\subsubsection{United Kingdom}

\section{a) Ordinary thresholds}

According to ss. 137 and 138, an offence is an extradition offence, according to its seriousness, if it is punishable in the requesting State and in the UK with imprisonment or another form of detention for a term of 12 months or greater punishment. If the person has already been convicted, a sentence of imprisonment or another type of detention for a term of 4 months or greater punishment is required, as long as the conduct is punishable in the UK with imprisonment or another form of detention for 12 months or greater punishment. The law does not provide for an 'economy clause' allowing extradition to be granted for offences punished below those thresholds if extradition is possible for several offences and at least one of them meets the stated thresholds. In the UK, this

171 Ibid., p. 9.

172 Ibid., p. 9, adding that in any case the offence must still satisfy the respective relevance threshold.

173 See António Lopes Rocha / Teresa Alves Martins, op. cit., p. 39; see also the ruling of the Supreme Court of 21 May 2015, no. 16/13.7YREVR.E1.S3, \ II.B.4.

174 The expression "sentences of at least four months" is construed as 'period of imprisonment remaining to be served', and not as 'period of imprisonment applied in the sentence': see the ruling of the Court of Appeal of Évora of 31 January 2012, no. 179/11.6YREVR, in a case where 72 days of imprisonment remained to be served from a sentence of 3 years and 1 day. 
condition is also deemed essential to secure proportionality, based on the notion that a device as severe as extradition should not be used in unimportant cases. ${ }^{175}$

Provisions similar to ss. 137 and 138 are found in ss. 64 and 65, on the EAW. The only difference is, again, that in the latter case relevance is assessed in the light only of the law of the issuing Member State. However, other proportionality conditions were enacted in the UK which depart from the FD-EAW. These are addressed subsequently.

\section{b) The proportionality bar and preliminary proportionality check}

The Anti-social Behaviour, Crime and Policing Act 2014 further limited the execution of EAW's through a proportionality bar, such that the EA 2003 now requires in s. 21 A that the court assess whether extradition would be disproportionate in the light of: a) the seriousness of the conduct alleged to constitute the extradition offence; b) the likely penalty that would be imposed if the person were found guilty of the extradition offence; and c) the possibility of the relevant foreign authorities taking measures that would be less coercive than extradition. ${ }^{176}$ If the judge concludes that extradition would be disproportionate, the person must be discharged. Moreover, an additional preliminary proportionality check was introduced in s. 2 (7A). According to this provision, at the very start of the proceedings, a designated certifying authority ${ }^{177}$ must "filter out" the "most obviously disproportionate cases" $" 178$ - i.e. those where it is clear that at a later procedural stage the judge would be required to discharge the person pursuant to s. $21 \mathrm{~A}$, described above. ${ }^{179}$

As the House of Lords Select Committee on Extradition Law informs, these additional proportionality requirements sought to tackle the large-scale use of the EAW system by some Member States whose prosecutorial authorities are bound to a legality principle that leaves practically no room for opportunity even in minor cases. ${ }^{180}$ The view was

175 See RoSEMARY DAVIDSON, "A sledgehammer to crack a nut? Should there be a bar of triviality in European arrest warrant cases?”, CLR (1) 2009, p. 33. Under previous legislation courts could discharge the person if they were satisfied that, owing to the trivial character of the offence, extradition would be unjust or oppressive, but such a discretion has been removed in EA 2003: see ALASTAIR BROWN, op. cit., p. 51; see s. 10 Fugitive Offenders Act 1881, s. 8 (3) Fugitive Offenders Act 1967, and ss. 11 (3) and 12 (3) EA 1989.

176 According to Rosemary Davidson / Ben Lloyd / ADAm PAYTER, "Recent developments in extradition law - some practical implications”, CLR 7 (2015), p. 508, such alternative measures include mainly cases where it is possible to use the European Supervision Order, introduced by FD 2009/829/JHA of 23 October 2009. Other possibilities include temporary transfers, and investigative measures carried out in the UK (e.g. Swedish prosecution in the Assange case interviewed him and took his DNA in London): ibid.

177 The National Crime Agency (NCA), in England, Wales and Northern Ireland; the Crown Office and Procurator Fiscal Service, in Scotland: House of Lords Select Committee on Extradition Law, op. cit., p. 35.

178 Ibid., p. 35.

179 According to EDWARD GRANGE, "Amendments to the Extradition Act 2003: new opportunities (and new pitfalls) for those defending extradition requests", 7 July 2015, in Corker Binning Blog, \ 2, in http://www.corkerbinning.com/amendments-to-the-extradition-act-2003-new-opportunities-and-newpitfalls-for-those-defending-extradition-requests- $2 /$, in determining whether a judge should be expected to find extradition disproportionate, the NCA may rely on the guidance provided for by Lord Chief Justice in the Criminal Practice Direction Amendment No. 2 [2014] EWCA Crim 1569.

180 See House of Lords Select Committee on Extradition Law, op. cit., p. 34 f. Statistics show that in the 2013-2014 period alone the UK received 7.881 EAW requests, which "provides an indication of the problem”: ibid., p. 35. See also SCOTT BAKer / DAVID PERry / ANAND DOOBAY, op. cit., p. 162. 
that some offences which meet the relevance thresholds of the FD-EAW are still trivial cases of their type, notable examples including drunk cycling, theft of groceries worth less than $f, 50$, and theft of a pigeon. ${ }^{181}$ Using the EAW in such cases has been compared to using "a sledgehammer to crack a nut". ${ }^{82}$ In any case, the effectiveness of these new requirements has been doubted. Among other things, they have been criticised for: ${ }^{183}$ being overly prescriptive (limiting courts to specified factors), adding little to the protection already resulting from other bars (e.g. from Art. 8 ECHR, applicable via the human rights bar), ${ }^{184}$ and applying only to prosecution (not enforcement) cases. ${ }^{185}$ Others have voiced a different opinion, namely that the proportionality check can lessen the burden on courts and the impact on individuals. ${ }^{186}$ According to the Government, only from July 2014 (the date when those requirements entered into force) to September 2014, the NCA refused certification of 14 EAW's, carrying estimated savings of more than $£ 180.000$ to the public purse, ${ }^{187}$ as each EAW costs on average $£, 13.000$ to execute. ${ }^{188}$ And these numbers are likely to increase following the Miraszewski case, where the view was taken that any of the specified matters related to proportionality can, alone, lead to a refusal of extradition. ${ }^{189}$

The use of the EAW to tackle petty crime had been the main problem identified by the Baker Review. ${ }^{190}$ In its reaction to the Review, the Government pledged to "take the opportunity of the 2014 [Justice and Home Affairs] opt-out decision to work with the European Commission, and with other Member States, to reform the [EAW]". ${ }^{191}$ How-

181 See House of Lords Select Committee on Extradition Law, op. cit., p. 34, 37; ROSEMARY DAVIDSON, "A sledgehammer to crack a nut?...", op. cit., p. 33. SCOTT BAKER / DAVID PERry / ANAND DOOBAY, op. cit., p. 164, do however warn that a State "should be careful of judging the seriousness of offences committed in other jurisdictions by [its] own standards", as was, yet according to the authors, "forcefully" illustrated in Sandru v. Government of Romania [2009] EWHC 2879 (Admin). RosEMARY DAvidSOn, "A sledgehammer to crack a nut?...", op. cit., p. 34 also takes this view, as does Lord Chief Justice in the Criminal Practice Directions Amendment No. 2, cit.

182 Rosemary Davidson, “A sledgehammer to crack a nut?...”, op. cit., p. $31 \mathrm{f}$.

183 See House of Lords Select Committee on Extradition Law, op. cit., p. 36 f.

${ }^{184}$ However, as noted by Rosemary Davidson / Ben Lloyd / AdAm PAYTER, op. cit., p. 507 f., the proportionality bar is wider, as it does not require that the person have a settled life or a family in the UK.

185 See ibid., p. 509, noting that one reason for this limitation could be that "legitimate concerns about a relativist approach that imposes UK judges' views on other countries and trespasses on the role of their courts are likely to be more acute in circumstances in which a person has been convicted and sentenced."

186 See House of Lords Select Committee on Extradition Law, op. cit., p. 36 f., conveying the statements of Nick Vamos, Head of Extradition at the CPS, that: "If somebody is discharged at court on the basis of proportionality, they have already been arrested; they have been detained in custody; they have been taken to court. Cost resource has been used. That person's human rights have already been interfered with, one might say. It is much better if those cases can be filtered out by the NCA."

187 See ibid., p. 36.

188 See Home Office, “The Government Response to the Second Report...”, op. cit., p. 2.

189 See Miraszenski v. Poland [2014] EWHC 4261 (Admin), \ 31; Rosemary Davidson / Ben Lloyd / ADAM PAYTER, op. cit., p. 506.

190 See ScotT BAKer / David Perry / ANAND Doobay, op. cit., p. 317, passim; House of Lords Select Committee on Extradition Law, op. cit., p. 35. Proportionality issues were raised in Assange v. The Swedish Prosecution Authority [2012] UKSC 22, 2012 WL 1854507, \ 90: "The scheme of the EAW needs to be reconsidered in order to make express provision for consideration of proportionality".

191 See House of Lords Select Committee on Extradition Law, op. cit., p. 35; Home Office, "The Government Response to Sir Scott Baker's Review...”, op. cit., p. 3. 
ever, the Home Secretary later declared that in the course of those discussions it became clear that, while other Member States had similar concerns as the UK on proportionality issues, "there was no appetite for opening up the whole [FD-EAW]." 192 Thus, the Government of the UK chose to unilaterally approve domestic legislation introducing a proportionality bar for EAW cases. ${ }^{193}$

Indeed, the new requirements notoriously lack support in the FD-EAW. The "European handbook on how to issue a EAW" ${ }^{194}$ bids Member States to run a proportionality test before issuing a warrant, but this is not mandatory under the FD. Some interviewees of the House of Lords Select Committee on Extradition Law questioned the compatibility of this bar with EU law. The Law Society said that unilateral action risked "inconsistent approaches", and Spencer argued that "it could eventually result in the [ECJ] having to make a ruling on the matter." ${ }^{\prime 195}$ However, others propounded that, if EU legislation was not forthcoming, then it was "understandable that individual Member States are having to take action to try to deal with it themselves" (Doobay). In the end, the Select Committee followed the latter road: "The UK's role is to ensure the human rights of the people it extradites are properly protected. That said, the operation of the EAW, in particular the absence of an effective proportionality check by the Issuing State, means the Government was right to introduce the proportionality bar into domestic legislation." ${ }^{196}$

\section{c) Closing remarks}

The above analysis indicates that pragmatic reasons concerning costs and the overload of the judicial system weighed heavily on the introduction of these new proportionality requirements. These requirements do also guard individuals against exaggerated persecutions, but, considering the protection already conferred by other bars specifically focused on individuals and the general minimum relevance threshold already provided for in the FD-EAW, individual concerns do not appear to have been the main force driving the enactment of such requirements. Otherwise, they should also - and in fact even more so - have been enacted for traditional extradition to category 2 States. ${ }^{197}$ Quite simply the volume of classic extradition requests is drastically lower than the volume of EAW re-

192 House of Lords Select Committee on Extradition Law, op. cit., p. 35.

193 Ibid., p. 35.

194 Council of the EU, "Revised version of the European handbook on how to issue a European Arrest Warrant”, 17195/1/10, REV 1, Brussels, 17 December 2010, p. 14 f.

195 House of Lords Select Committee on Extradition Law, op. cit., p. 40.

${ }^{196}$ Ibid., p. 40 f., further reporting: "Home Secretary told us that it was unrealistic to expect the Commission to give 'blanket guarantees' that the UK would not be subject to infraction proceedings. However, she said: (...) These are areas where other Member States have, through various means, applied similar arrangements within their own domestic decision-making processes as well.' "

197 This incoherence has not gone unnoticed: some witnesses interviewed by the House of Lords Select Committee on Extradition Law argued that although fewer extradition requests were received from category 2 States this did not "justify fewer protections". Grange and Niblock, for instance, stated that it was "inappropriate and illogical to limit the bar to Part 1 cases, particularly given that requested persons are likely to be sent further away from the UK if extradition is granted in Part 2 cases": ibid., p. 34, 38. Moreover, in this case the UK was not constrained by exogenous obligation as it was in the case of the EAW system. 
quests, ${ }^{198}$ meaning that introducing additional proportionality bars for classic extradition would be a "solution to a problem that does not exist." 199 By justifying the incongruity on the ground that in extradition there is no "similar systemic risk", ${ }^{200}$ the Committee only confirms that the introduction of those requirements was not a matter of principle.

\subsection{Political offences}

\subsubsection{United Nations}

The Model Treaty contains a political offence exception in Art. 3 (a), requiring extradition to be refused for offences considered by the requested State as having a political character. The Model Treaty excludes therefrom offences regarding which the States involved have assumed an aut dedere aut judicare obligation pursuant to a multilateral convention, and any other offences they have agreed not to consider as political offences for extradition purposes. ${ }^{201}$ As a footnote to the provision the Model Treaty confers on States the option to exclude further acts from that concept, notably violent acts.

A political offence exception is also contained in s. 4 (1) Model Law, but as optional only. Subsection (2) provides that the requested and the requesting States should consult if extradition is to be refused on this ground, namely to discuss the application of the principle aut dedere aut judicare. Subsection (3), in turn, states that extradition shall not be refused for offences that the requested State has undertaken by a multilateral or bilateral treaty either not to consider political extradition purpose or to prosecute action in lieu of extraditing. Additionally, a footnote is included giving States the option to exclude terrorist acts. ${ }^{202}$ Subsection (4) further invites States to exclude other (mainly, violent) acts.

In sum, both the Model Treaty and the Model Law encourage States to narrow the scope of this ground for refusal, and the latter goes so far as to conceive it as optional. However, neither instrument proposes a paradigm-shifting approach to this ground for refusal. $^{203}$

The rationale and the evolution of the political offence exception are outlined in the Revised Manuals: its central purpose is to prevent the requested State from meddling in the domestic politics of the requesting State, where "today's dissidents may be tomorrow's governing class". ${ }^{204}$ It is deemed to be a corollary of the duty of non-interference, and an acknowledgement of the relativity of political regimes. Insofar as concerns nonviolent, 'purely' political offences, such as the slandering of a Head of State, this ground

198 In 2012 and 2013, in contrast with 6.263 EAW's, the UK received only 84 extradition requests: see House of Lords Select Committee on Extradition Law, op. cit., p. 34, 38.

199 Ibid., p. 37 f.

200 Ibid., p. 41.

201 This was added in the 1997 revision of the Model Treaty with a view mainly to cover the 1948 UN Genocide Convention (Art. 7), the 2002 Inter-American Convention against Terrorism (Art. 11), the 1999 UN Convention for the Suppression of the Financing of Terrorism (Art. 14), and the 1997 Convention for the Suppression of Terrorist Bombing (Art. 11): see UNODC, "Revised Manuals...", op. cit., p. 16.

202 According to the Model Law, a useful reference in this regard is the 2002 FD against terrorism.

203 See BERT SwART, "Refusal of Extradition...", op. cit., p. 186, classifying it as "timid” approach.

204 UNODC, "Revised Manuals...”, op. cit., p. 16. 
for refusal constitutes also a tribute to values of political tolerance and free speech, and, hence, in these cases, refusal of extradition remains quite uncontroversial. The situation, however, is quite different in respect of violent offences. Historically, this ground for refusal sought to promote reaction against authoritarian political regimes that could only be overthrown by armed resistance. The rise of democracy brought the intolerance of international law and public opinion at the use of violence in such regimes, such that "justifications that may once have excused political violence no longer exist between treaty partners with democratic systems in which political change can be achieved by peaceful means". ${ }^{205}$ This development materialised in the trend to exclude violent conduct from the scope of the grounds for refusal. It adds that political offenders incur in a greater risk of unfair trials and other violations of basic rights than ordinary offenders. ${ }^{206}$

\subsubsection{Portugal}

Art. 7 (1) (a) provides that extradition must be refused if it concerns any acts that, under Portuguese law, constitute a political offence or a connected offence. In line with the international tendency to 'empty' the concept of political offence extradition purposes, Art. 7 (2) excludes therefrom: genocide, crimes against humanity, war crimes and serious offences under the 1949 Geneva Conventions; the acts mentioned in Art. 1 of the 1977 European Convention on the Suppression of Terrorism; the acts mentioned in the 1984 UN Convention against Torture and other Cruel, Inhuman or Degrading Treatment or Punishment; and any other acts that should not to be considered political due to any international legal instrument binding on Portugal.

While this exception is one of the aspects of extradition law that raise greater interest worldwide, its rationale is not particularly debated in Portugal, which might be due to the scarcity of cases. It must be stressed that the political offence exception does not have explicit constitutional backing, unlike the prohibition to extradite in case of a persecution motivated by political reasons (where no offence whatsoever has been committed, or has been committed but the fundamental force driving the persecution are political reasons), addressed earlier. ${ }^{207}$ During the drafting of the 1976 Constitution proposals were made to include reference to 'political offences', ${ }^{208}$ but only the expression 'political reasons' made its way to the constitutional text. Nevertheless, some authors still posit that the provision forbidding extradition requested for political reasons, though "not of an evident meaning", "appears to include" also requests for political offences, ${ }^{209}$ an understanding that has found some corroboration in case law, namely in a ruling of the Court of Appeal of Lisbon of 9 August $2008 .^{210}$

205 Ibid., p. $16 \mathrm{f}$.

206 See e.g. Christine van Den Wyngaert, “The Political Offense Exception...”, op. cit., p. 753; BERT SWART, "Refusal of Extradition...”, op. cit., p. $182 \mathrm{f}$.

207 Art. 33 (6) Constitution; see supra, $\int 1.2 .3$.

208 See Diário da Assembleia Constituinte, n. ${ }^{\circ}$ 14, p. 296-6.

209 J. J. Gomes Canotilho / Vital Moreira, op. cit., p. 533; see also DAmião Da CunHA, op. cit., p. 545, Margarida Frias, "Portugal e a Convenção Europeia sobre Extradição de 13 de Dezembro de 1957”, RMP 11 (1990), p. 101; NuNO PIÇARRA, “As revisões constitucionais...”, op. cit., p. 234.

210 No. 4076/2005-3. 
In any case, Art. 33 (8) of the Constitution pledges asylum to, and only to, foreigners or stateless individuals who are persecuted or seriously threatened with persecution "in consequence of their activity in favour of democracy, social and national liberation, peace between the peoples, freedom and human rights". In turn, Art. 48 (1) Law no. 27/ 2008, of 30 June, makes it clear that granting asylum entails refusing extradition (so long as the request concerns circumstances based on which asylum has been granted). ${ }^{211}$ The distinction between 'political reasons' and 'political offences' was again discussed in the context of the constitutional amendment of 1982. Some deputies proposed that the reference in the Constitution be changed to 'political offences', since terrorist acts could not be considered 'political offences' for extradition purposes according to several legal instruments binding on Portugal but might be considered as 'politically motivated', and if so the Constitution would be preventing the extradition of terrorists. ${ }^{212}$ The reasoning is inconsistent, since the reference to 'political reasons' refers not to the acts, but rather to the extradition request - as was noted by other deputies, who underscored that the rationale of that rule is to prevent a person from being extradited due to his/her political practice, rather than to a crime. ${ }^{213}$ The constitutional amendment would not change the wording of the rule.

In view of the above, the Portuguese Constitution can be said to establish a binary approach whereby: extradition must be refused whenever it is requested for political reasons; and must only be refused for political offences when the person at issue was pursuing causes and values shared by Portugal (e.g. democracy, self-determination). This means that the political offence exception found in ordinary law - which is general and abstract, not axiologically bounded and casuistic - is a pure option of the ordinary legislator.

In the FD-EAW, the political nature of the acts is not an obstacle to cooperation. As noted before, the PT-EAW initially included a ground for non-execution on persecution for political reasons, but the provision was later revoked. In a ruling of 5 July 2012, where Germany was requesting the surrender of a person for acts involving denial of the Holocaust, the Supreme Court limited itself to appraising whether the acts were criminalised in Portugal (so as to establish whether dual criminality was met), refraining from any consideration as to the hypothetical political motivation of the request. ${ }^{214}$

\subsubsection{United Kingdom}

The EA 2003 appears to have fully abolished the political offence exception, ${ }^{215}$ departing from what was a long-established tradition in the UK. Indeed, the EA 1870 pro-

211 One of the conditions for granting asylum is that there are no founded reasons to believe that the person committed intentional crimes of an ordinary character punishable with imprisonment for over three years (Art. 9 (1) (c) (ii) of the same Law), but the political finality of the crime may supersede its ordinary nature and trigger the protection of asylum: see ANDREIA SOFIA PINTO Oliveira, O Direito de Asilo na Constituição Portuguesa - Ambito de Proteção de um Direito Fundamental, Coimbra: Coimbra Editora, 2009, p. 351 f.

212 See Diário da Assembleia da República: II Série, Suplemento ao n. ${ }^{\circ}$ 6, 20 October 1981, p. 70-43 f.

213 See $i d$.

214 No. 48/12.2YREVR.S1.

215 See Arvinder SAmbei, “The Political Offence Exception”, in John R. W. D. Jones (general ed.) / Rosemary Davidson (assistant ed.) / Arvinder Sambei (contributor) / Brian Gibbins (contributor), op. cit., p. 137; JULIAN B. KNOWLES, op. cit., p. 56. 
vided that extradition could not be granted for offences "of a political character" or if the request "ha[d] in fact been made with a view to try or punish [the person] for an offence of a political character." ${ }^{\prime 216}$ The Fugitive Offenders Act 1881 did not contain a political offence exception, but this instrument applied only to "Her Majesty's Dominions" - which explains why dual criminality and the specialty rule were also absent. A political offence exception is however already found in the Fugitive Offenders Act 1967, enacted following the independence of those Dominions, ${ }^{217}$ and also in the EA $1989 .{ }^{218}$

According to the Baker Review, the idea behind this exception is that "the requested person is at odds with the State that applies for his extradition on some issue connected with the political control or government of the country and that extradition is sought for reasons other than the enforcement of the ordinary criminal law". ${ }^{219}$ Stanbrook and Stanbrook note that, in the $19^{\text {th }}$ century, sheltering fugitives from oppressive regimes was "part of the Western democratic tradition": "Those who fought for political liberty against oppressive regimes were regarded by public opinion as heroes. Their resistance to tyranny inevitably involved them in breaches of local law. It was unthinkable that, having escaped to the west, they should be handed back to their oppressors". ${ }^{220}$ This understanding was voiced by the House of Lords Select Committee charged with reviewing the extradition law of the UK in 1868, who claimed: "the British Parliament and people would not tolerate any infringement of the tradition of political asylum". ${ }^{221}$ However, the prominence of the political offence exception faded with the rise of modern international terrorism (a phenomenon "very different in scale and character from anything known in the nineteenth century"), and especially with the terrorist activity verified in the second half of the $20^{\text {th }}$ century. ${ }^{222}$ This shift translated into the expansion of extraterritorial jurisdiction over these offences, ${ }^{223}$ the exclusion of several acts from the concept of political offence for extradition purposes, ${ }^{224}$ and changes in the attitude of courts towards individuals seeking refugee status after having committed violent acts. ${ }^{225}$

The review of the extradition system of the UK conducted in 2001 did not envisage the abolition of the political offence exception. The Home Office noted that it forms "an increasingly rare consideration in extradition", and that derogations from the principle not to extradite political offenders "appear to have recently become standard features of international conventions which deal with terrorism"; but, nonetheless, it "should be

216 See ss. 3 (1) and 7.

217 See ScotT Baker / David Perry / AnAnd Doobay, op. cit., p. 42 f.

218 See s. 6 (1) (a).

219 See Scott Baker / David Perry / AnAnd Doobay, op. cit., p. 37 f., supported on R. v. Governor of Brixton Prison, Exparte Schtraks [1964] AC 556, and Cheng v. Governor of Pentonville Prison [1973] AC 931.

220 IVOr STANBROOK / Clive STANBROOK, op. cit., p. 66.

221 Apudibid.

222 SCOTT BAKER / DAvid PERry / ANAND DOOBAY, op. cit., p. 71, noting that in the UK the tendency to limit the concept of political offence for extradition purposes was effected mainly by the Suppression of Terrorism Act 1978, enacted to accommodate the 1977 CoE Convention on the Suppression of Terrorism.

223 See s. 4 of the Suppression of Terrorism Act 1978.

224 See 2 fn. above; see Ivor Stanbrook / Clive STANBrook, op. cit., p. 67.

225 See Julian B. KNOWles, op. cit., p. 56. 
retained for non-terrorist offences." 226 The Draft Extradition Bill published on 27 June $2002,{ }^{227}$ and the Bill presented to the House of Commons on 14 November 2002, already lacked the exception, providing only for a bar on extraneous considerations, and only for category 2 cases. The Select Committee on Home Affairs, in line with the Joint Committee on Human Rights, voiced its concern at the situation: "if s. 6 (1) [EA 1989] were to be repealed, this would create a serious risk that, in relation to category 1 and category 2 territories, people could be extradited for political offences and, in relation to category 1 territories, subject to extradition requests that are motivated by (...) political opinions. (...) We asked the Home Office what its intentions are in relation to the future repeal or amendment of s. 6 (1)." 228 The Home Office later did extend the protection provided to category 2 States by Clause 61 (3) of the Draft Bill to category 1 States. However, a political offence exception in the classical sense of the expression, like that which was provided for in s. 6 (1) (a) EA 1989, was not enacted.

As far as it was possible to establish, the removal of the political offence exception in the EA 2003 did not raise outstanding controversy. ${ }^{229}$ Instead, it appears to have been regarded as a natural adjustment of UK extradition law to the escalation of terrorism. As argued by Knowles, the EA 2003 has simply "taken this trend to its conclusion". ${ }^{230}$ On the other hand, such a removal reinstated the importance of the extraneous considerations bar, which prevents extradition for political reasons. This bar is almost unanimously deemed to compensate sufficiently for the abolition of the classic political offence exception. The Baker Review, for instance, argues that: "Although (...) the 2003 Act does not contain an express political offence exception, s. 13 [and s. 81, for category 2 States] is wide enough to permit a consideration of the political motivation of the offence."231 That was also the view of the Joint Human Rights Committee, to whom the extraneous considerations bar "might be sufficiently wide to bar extradition (...) for political offences". ${ }^{232}$ The Baker Review further notes that, in certain cases, abuse of process jurisdiction

${ }^{226}$ Home Office, "The Law on Extradition: A Review”, op. cit., p. 28 f.

227 In http://www.publications.parliament.uk/pa/cm200203/cmbills/002/en/0300002x--.htm, last accessed 18 February 2018.

228 Select Committee on Home Affairs, "First Report: ordered by the House of Commons to be printed 28-11-2002, http://www.publications.parliament.uk/pa/cm200203/cmselect/cmhaff/138/13802.htm, $\int 129$, last accessed 18 February 2018. Liberty, an organisation dealing with civil liberties and human rights in the UK, expressed the view that the political offence exception should not be abolished, because even within the EU "circumstances could always change (states of emergency, rise of right-wing extremists etc) which might make this a necessary exception": "The Law On Extradition: A Review - Submissions of Liberty in response to the Home Office Consultation Document of March 2001", in https://www.libertyhuman-rights.org.uk/sites/default/files/jun-extradition.pdf, last accessed 18 February 2018, p. 3.

${ }^{229}$ See Select Committee on Home Affairs, op. cit., S 129; Joint Human Rights Committee, "Draft Extradition Bill - Twentieth Report of Session 2001-02 - Report and Proceedings of the Committee", 22 July 2002.

230 Julian B. KNOWles, op. cit., p. 56; also SCOTT BAKER / DAVID PERry / ANAND DoObay, op. cit., p. 40 f., 101; Arvinder SAmbei, "The Political Offence Exception”, in John R. W. D. Jones (general ed.) / Rosemary Davidson (assistant ed.) / Arvinder Sambei (contributor) / Brian Gibbins (contributor), op. cit., p. 137.

231 SCOTT BAKER / DAVID PERry / ANAND DOOBAy, op. cit., p. 377.

${ }^{232}$ Joint Human Rights Committee, op. cit., p. 13; also Liberty, "Liberty's response to the Home Office review of extradition legislation”, December 2010, p. 9. 
may also be used to avoid political persecutions. ${ }^{233}$ The same views have been expressed in Parliament, ${ }^{234}$ and echoed in case law. ${ }^{235}$

As for the absence of a political offence exception in the EAW system, the Baker Review notes it is only natural in the light of the elevated levels of trust between Member States. The Review further notes that it is very unlikely that any Member State would carry out criminal proceedings for offences of a political nature, ${ }^{236}$ although this contention is more dubious today than it has been in the recent past, as recently evidenced by the prosecution of Puigdemont and other politicians by the Spanish State for acts which include political offences. ${ }^{237}$

On the other hand, it is necessary to consider the asylum law of the UK. ${ }^{238}$ The bases for claiming asylum in the UK are contained in the 1951 Refugee Convention and its 1967 Protocol. Again, this regime is closer to the extraneous considerations bar than to a classic political offence exception. ${ }^{239}$ However, according to Art. 1F, the protection conferred by the Convention shall not apply to individuals in respect of whom there is serious reason to consider that they have: (a) committed a crime against peace, a war crime, or a crime against humanity, as defined in the relevant international norms; (b) committed a serious non-political crime outside the country of refuge prior to admission to that country as a refugee; or (c) been found guilty of acts contrary to the purposes and principles of the UN. ${ }^{240}$ Item (b) suggests that a person who has committed a political offence, or even a non-political offence insofar as it is not a serious offence, can be given the status of refugee in the UK. However, this still does not qualify as a political offence exception, and therefore, in conclusion, this classic exception to extradition can be considered to have been abolished in the UK.

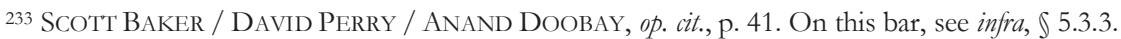

234 See the parliamentary debates in the House of Commons, 9 December 2002, columns 64, 67, 114 118, http://www.publications.parliament.uk/pa/cm200203/cmhansrd/vo021209/debtext/21209-17.htm, last accessed 18 February 2018; see also the parliamentary debates in the House of Lords, 10 July 2003, column GC108, in http://www.publications.parliament.uk/pa/ld200203/ldhansrd/vo030710/text/3071032.htm\#column GC105, last accessed 18 February 2018.

235 See VB, CU, CM, EN v. Westminster Magistrates' Court, The Government of Rwanda, The Crown Prosecution Service v. CMK, [2014] UKSC 59: "the previous legislation also gave courts a significant substantive role in relation to the extraneous considerations now covered by s. 81 of the 2003 Act: see s. 6 (1) of the Extradition Act 1989; prior to that, it had a similar role, as regards any request made with a view to trial or punishment for an offence of a political character: see s. 3 (1) of the Extradition Act 1870". The norms quoted by the court correspond to the classic political offence exception, which implies that the court construes that the 'extraneous considerations' bar basically absorbed the function formerly played by that exception.

236 See SCOTT BAKer / David PERry / ANAND DoObay, op. cit., p. 101.

237 See further infra, Chap. 8, $\$$ 2.1.2.

238 See ss. 39, 40 and 121; see also the Nationality, Immigration and Asylum Act 2002.

239 See Clive NiCHOLs et al., op. cit., p. 157 f.

240 Similar conditions are provided for in Directive 2011/95/EU, of 13 December 2011, on standards for the qualification of third-country nationals or stateless persons as beneficiaries of international protection, for a uniform status for refugees or for persons eligible for subsidiary protection, and for the content of the protection granted: Art. 12 . 


\subsection{Military offences}

\subsubsection{United Nations}

Art. 3 (c) Model Treaty provides that extradition shall be refused if the offence at issue is an offence under military law but is not simultaneously an offence under ordinary criminal law. The Model Law contains an identical provision in s. 10, with the single particularity that (in line with the approach taken regarding the political offence exception) it allows States to configure this refusal ground as optional.

According to the Revised Manuals, it is a "recognized principle" that extradition is not possible for military crimes that are not otherwise criminally relevant, such as desertion and insubordination, ${ }^{241}$ and Bassiouni claims that it is recognised in customary international law. ${ }^{242}$ Swart notes that this is "one of the oldest exceptions" to extradition, and that its rationale "is clearly that it is not in the interest of states to assist each other in enforcing military laws"; to the author, there is no reason to conclude, from an angle of individual protection, that extradition for military offences is in itself "objectionable", but, if it is admitted, an exception should be made for the refusal to perform military service for reasons of conscience: it would be "hard to accept that persons who under the law of the requested State would qualify as conscientious objectors would be extradited to a State that offers no or lesser possibilities to follow one's own conscience". ${ }^{243}$ As noted earlier, in this specific aspect, this ground for refusal stems from an individual right to freedom of thought in military matters, and is mandatory for States. ${ }^{244}$

\subsubsection{Portugal}

The military nature of the offence is also a ground for refusal of extradition under Portuguese law - Art. 7 (1) (b) -, so long as the offence is strictly military, vir. not simultaneously provided for as a crime under ordinary criminal law. ${ }^{245}$ Nevertheless, Art. 32 (7) opens a momentous exception to that ground for refusal: extradition is possible based on special arrangements concluded within the framework of military or other strategic alliances, notably status of forces agreements, such as the NATO-SOFA. ${ }^{246}$

While this ground for refusal is often linked with an individual right to freedom of thought in military matters, in Portugal military service is currently not mandatory, which means that offences such as desertion are configured, not as a refusal to comply with an

241 UNODC, “Revised Manuals...”, op. cit., p. 18.

242 M. CHERIF BASSIOUNI, International Extradition... op. cit., p. 739.

243 BERT SWART, "Refusal of Extradition...", op. cit., p. 187.

244 See e.g. GEOFF GILBERT, op. cit., p. 184; ROBERT ZimMERMANN, op. cit., p. 440; MATTHEW LipPMAN, "The Recognition of Conscientious Objection to Military Service as an International Human Right", CWILJ 21 (1990), p. 31 f. See supra, Chap. 3, \ 4.5, and esp. infra, Chap. 8, \ 4.1.3.

245 In Portugal, these offences are mainly established in the Code of Military Justice: Law no. 100/2003, of 15 November.

2461951 Agreement between the Parties to the North Atlantic Treaty regarding the Status of their Forces. This type of agreement tends to allow extradition almost unconditionally, although the advent of human rights in extradition did bring some limitations: see BERT SWART, "Extradition”... op. cit., p. 114, on the case of Short, an American soldier deemed to have murdered his wife in the Netherlands. 
order to serve in the military, but as a breach of a duty assumed voluntarily. ${ }^{247}$ On the other hand, it covers all strictly military offences; not just those that can somehow be seen to curtail such a freedom. Thus, its rationale lies in a rupture by the offender of a duty that bound him/her to a specific State and to it only. ${ }^{248}$ Only this explains why extradition can take place without restrictions between States that are military allies: here, the duty of fidelity to a specific State extends to the organisation as a whole.

However, some strictly military offences do not presuppose such a duty of fidelity, but consist of acts committed by any person against Portugal. An example is the offence of Art. 28 Code of Military Justice: intelligence with foreign States or with any group in order to promote or provoke war or an armed action against Portugal. In such cases, the prohibition to extradite will only be possible to justify on a different ground, such as the duty not to interfere with the affairs of other States, ${ }^{249}$ and in these cases the military offence exception will be indeed fully identical to the political offence exception.

There is no military offence exception in FD-EAW nor, therefore, in PT-EAW.

\subsubsection{United Kingdom}

Based on ss. 137 (7) and 138 (7), if extradition is requested for acts that constitute an offence under the military law of the requesting State but not under the general criminal law of the relevant part of the UK, extradition will be refused. Very limited attention is paid to this ground for refusal in the UK. According to the Baker Review, it "had little or no practical impact on extradition", and in the EAW system it is simply "unnecessary". 250

Nevertheless, a noteworthy case took place in the UK during WWI, namely that of Duke of Chatean de Thierry, a French national who had defected to England to evade serving in the French military. The case is assessed in detail by Bassiouni, both in the context of the military offence exception and as an instance whereby an alternative expedient was functionalised to achieve what in substance was an extradition. In the author's synopsis: "The English lower court held for the relator in agreeing that the Home Secretary had no power to order an alien deported to a particular country, which had been ordered as an alternative to extradition. On appeal, the decision was reversed on the grounds that, although the Home Secretary had no power to order deportation to a particular country, he could select the particular ship upon which the offender must sail. Even if such ship should happen to sail for the requesting state, it would be of no concern. The court concluded that the duke was not a political refugee, and as French authorities had assured the British government that the offender would be tried solely as a military absentee for desertion, the court, in effect, condoned disguised extradition between allies for the return of those accused of such offenses as the military crime of desertion." ${ }^{251}$ That this is an actual ex-

247 See Arts. 72 f. Code of Military Justice.

248 See Pedro Caeiro, Fundamento..., op. cit., p. 271.

249 See BERT SWART, op. cit., p. 256.

250 See SCOTT BAKer / David PERry / ANAND DoObay, op. cit., p. 101.

251 M. Cherif BASSIOUNI, International Extradition... op. cit., p. 739. The principle that deportation could be used to secure the return of military deserters to France was reiterated in Regina v. Superintendent of Chiswick Police State, ex parte Sacksteder, in 1918: see ibid., p. 219. 
tradition results not from speculation, but from the fact that France and England themselves admitted that the principles of specialty and non-extradition of political offenders applied. ${ }^{252}$ The case is noteworthy in that it is rather prescient of a tendency which would later become more visible, namely that of the erosion of the military offence exception among States that are military allies. ${ }^{253}$

\section{Grounds for refusal related to the punitive claim of the requesting State}

\subsection{Evidentiary requirement}

\subsubsection{United Nations}

One of the most divisive questions of extradition law is whether evidence should be required from the requesting State in order for extradition to be admissible. And it is one of the questions that the Model Treaty does not address assertively: it does not recognise such importance to evidentiary requirements as to include them in the body of the provisions establishing grounds for refusal, but does not simply neglect it either, attaching a footnote to Art. 3, on mandatory grounds for refusal, 'allowing' States to refuse extradition where "there is insufficient proof, according to the evidentiary standards of the requested State, that the person whose extradition is requested is a party to the offence." 254

The Model Law took a similarly uncompromised approach, by providing, between parentheses, ${ }^{255}$ in s. 16, that, when extradition is sought for prosecution purposes, the requesting State may be required to submit documents and information with evidence considered sufficient to either "establish a prima facie case that the person sought had committed the offence for which extradition is requested", "justify the committal of the person sought for trial for the offence in respect of which extradition is requested, if that offence had been committed", or "evidence that would constitute reasonable and probable grounds to believe that the offence had been committed". ${ }^{256}$ In a footnote to this norm ${ }^{257}$ the Model Law provides an abridgement of the different State approaches to the issue of evidence: ${ }^{258}$ "Common law and civil law often differ as to the nature of extradition and, therefore, as to the documents required to be presented to the requested State. For example, in most European States, extradition is considered an act of international legal cooperation, the purpose of which is to further criminal investigations conducted abroad. Courts dealing with extradition cases abstain from examining the evidence of guilt against the person wanted, as they feel this examination is incumbent exclusively upon the judicial au-

252 Ibid., p. 219, noting: "The states themselves treated the surrender as a special form of extradition to which the general rules governing extradition should be applied.”

253 See infra, Chap. 8, \ 4.1.3.

254 A footnote to Art. 5, on the content of extradition requests, adds that States that do require evidence "may wish to define the evidentiary requirements necessary to satisfy the test for extradition and in doing so should take into account the need to facilitate effective international cooperation."

255 The functional equivalent to the footnote system of the Model Treaty.

256 See also s. 24 (1) (c).

${ }^{257}$ In the Model Law, footnotes serve basically to provide comments on the content of the provisions.

258 An excerpt which replicates verbatim UNODC, "Revised Manuals...", op. cit., p. 32 f. 
thorities of the requesting State. For extradition to be authorized, it suffices that the formal and material requirements provided for by the treaty be present. Some common law States have recently changed their law and practice in this regard and have followed the approach of civil law States. In other States influenced by common law the magistrate will examine whether the request contains reasonable grounds to believe (...) that the person wanted committed the crime charged, or whether the request provides prima facie evidence of guilt as if the accused were charged with the same alleged offences in that State. In such States, if the magistrate holds that the evidence produced by the requesting State is sufficient to justify committal for trial should the facts be prosecuted in that State, extradition will be granted, assuming that the other legal requirements are met." The footnote closes with the following assertive statement: "In view of the need for simplification of the evidentiary requirements in extradition proceedings (...), it is recommended that States not insist on the establishment of a 'prima facie evidence of guilt' for granting an extradition request." 259

The UNODC Manual on Mutual Legal Assistance and Extradition states that evidentiary requirements are sometimes "a challenge for civil law countries, as they are not familiar with this burden and therefore do not draft their extradition requests with it in mind". ${ }^{260}$ It also notes that the concept of "prima facie' should not be mistaken for the "beyond reasonable doubt' standard necessary for convicting someone in a criminal trial in a common law country, the latter being much more demanding than the former. ${ }^{261}$ On the other hand, the document observes that evidentiary requirements are not monolithic, but concepts that vary depending, inter alia, on the legal tradition of the requested State. ${ }^{262} \mathrm{It}$ proceeds to describe the three major approaches used in extradition regarding evidence: (1) the 'no evidence test', which will be satisfied with the mere "statement of the offence, the applicable penalty, the warrant of arrest for the person and a statement setting out the alleged criminal conduct" - the normal approach in the continental tradition; (2) the 'probable cause evidence test', which requires "sufficient evidence to create reasonable grounds to suspect that the person sought has committed the alleged offence"; and (3) the 'prima facie evidence test', which requires "actual evidence that must be presented to the authorities that would allow them to form the opinion that the person sought would have been required to stand trial had the alleged conduct of the criminal offence occurred in the requested State" - usual in common law States. ${ }^{263}$ Yet according to the UNODC, the essential challenge when issuing an extradition request to a State with a different legal tradition is "the process of discerning what is required in each requested State, along with the actual preparation of the documentation". ${ }^{264}$

${ }^{259}$ In support of this argument the model law quotes Art. 16 (8) UN Convention against Transnational Organized Crime, and Art. 44 (9) UN Convention against Corruption.

260 UNODC, "Manual on Mutual Legal Assistance and Extradition”, op. cit., p. 15.

261 Ibid.

262 Ibid, p. 47.

263 Ibid.

${ }^{264}$ Ibid., adding: "As with mutual legal assistance requests, prior research into the requirements of the requested State, along with ongoing communication with the requested State's central authority, will be key to moving an extradition request forward." 


\subsubsection{Portugal}

Portuguese extradition law follows what the UNODC would call a simple 'no evidence test', ${ }^{265}$ making the Portuguese extradition system what Correia classifies as a merely "formal judicial system of extradition." ${ }^{266}$ However, the argument has pertinently been made that, in cases where it is manifest that the person is innocent, the court is bound to reject extradition. Dias uses the following example in support of this contention: imagine that on a given Sunday a renowned football player partakes in a match in Lisbon watched by thousands of spectators and millions of TV viewers, and that sometime later the State of which he/she is a national issues an extradition request to Portugal alleging that on the date and time of the match he/she had committed a theft in its territory; would it be tolerable to grant such a request? ${ }^{267}$ To the author, the answer is "obviously negative": there is a minimum threshold below which the very notion that extradition is a 'judicial' procedure of the competence of a 'court' in the sense assigned to the concept by the Constitution would be jeopardised; instead, given that extradition proceedings have a punitive nature, some of the guarantees of criminal procedure apply there as well, even if with some adaptations, and that is the case of the principle of presumption of innocence enshrined in Art. 32 (2) Constitution. ${ }^{268}$ Nevertheless, the author generally finds it a positive feature of the Portuguese extradition system that as a rule evidence is not required, in that this avoids extradition proceedings being converted into anticipatory trials; according to the author, only in blatant cases should this principle be departed from. ${ }^{269}$ In any event, it is clear that only very seldom will blatant cases occur, and, therefore, even if that position is followed, this system will still be more fittingly classified as a system that does not require evidence as a pre-condition to extradite.

There is no evidentiary requirement in the FD-EAW either - nor, consequently, in PT-EAW. The sole possibility explicitly allowed for by the law of opposing the execution of a EAW is the case where there is an error concerning the identity of the person, ${ }^{270}$ but this hardly qualifies as an 'evidentiary' requirement. The stance has been made in legal literature that Portugal, as an executing State, has the prerogative or indeed a duty to allow for the presentation of evidence of the acts on which the execution of the EAW depends (e.g., the place where they were committed), ${ }^{271}$ but this is also still different from requiring evidence that the individual is criminally liable: evidence necessary to establish whether a given ground for non-execution is met might simultaneously constitute evidence of criminal liability, but the link between the two things is incidental, and the lack of evidence of criminal liability does not by itself allow for refusing the execution of the EAW.

${ }^{265}$ See Art. 46 (3), in fine.

266 See Eduardo Correia, op. cit., p. 187; see further infra, Chap. 8, \ 4.2.1.

${ }^{267}$ Jorge DE Figueiredo Dias, “Algumas questões em tema de extradição e de sede do crime...” op. cit., p. $14 \mathrm{f}$.

268 Ibid.

${ }^{269}$ Ibid.

270 See Art. 21 (2).

271 See Pedro Caeiro / Sónia Fidalgo, op. cit., p. 459 f. 


\subsubsection{United Kingdom}

In the UK, serious consequences are drawn from the hardship inherent to extradition proceedings. ${ }^{272}$ According to s. 206, where a question arises as to burden or standard of proof, it must be decided by applying any enactment or rule of law that would apply if the proceedings were for an offence (i.e. if they were criminal proceedings), the extraditee being the defendant, and the requesting State the prosecution. Aware that evidentiary requirements can raise serious difficulties for cooperation, the UK recently undertook to reassess their necessity: this was one of the main questions commissioned to be researched by the Baker Review, where the issue is addressed in great depth.

The Review provides detailed account of the history of this requirement. ${ }^{273}$ A prima facie requirement was found in Art. 27 of the Jay Treaty of 1794, ${ }^{274}$ and was first included as a requirement in extradition to and from the British Dominions in the Act for the Better Apprehension of Certain Offenders 1843, where a strong or probable presumption of guilt test was required. The 1868 Select Committee on Extradition suggested that the requesting State should always supply evidence sufficient to establish a prima facie case, and the Royal Commission of 1878 noted that "[i]t is and always must be necessary that a prima facie case shall be made out before a magistrate in order to support the application for extradition." The main forces behind the prima facie rule were: (1) to enable the magistrate to determine whether or not the dual criminality rule was met; (2) to ensure that no one would be "put to the trouble and vexation of being sent to an overseas territory" if there were no case against him/her; and (3) to ensure coherence between two procedural acts regarded as identical, namely extradition hearings and committal proceedings in domestic criminal cases. The EA 1870 included a prima facie requirement as well, in s. 10. As for the Fugitive Offenders Act 1881, which repealed the 1843 Act indicated above, it contained a simplified system of surrender between groups of British possessions, and no prima facie case was required.

In 1974, the Report of a Government Working Party contracted to establish which changes should be introduced in UK extradition law considered that prima facie requirements were preventing the extradition of many individuals who were probably guilty, and deterring many States from even issuing extradition requests; it also concluded that they were amplifying the length, complexity and cost of extradition proceedings. ${ }^{275}$ In the end, the Working Party concluded that the prima facie case requirement should be maintained, but in more relaxed terms. The decision to keep the requirement was based on the desire

272 Rosemary Davidson, "The Extradition Hearing”, in John R. W. D. Jones (general ed.) / Rosemary Davidson (assistant ed.) / Arvinder Sambei (contributor) / Brian Gibbins (contributor), op. cit., p. 41, goes so far as to assert that "[e]xtradition proceedings are a special type of criminal proceedings." See also ADAM CARLSON, "The Case of Richard O’Dwyer: Extradition as a Means to the International Enforcement of Copyright Protections”, TL\&CP 23 (2014), p. 453 f.

273 See SCOTT BAKer / David PERry / ANAND DoObay, op. cit., p. 39 f., followed closely along this $\rrbracket$.

274 An evidentiary test was also provided for in the Webster-Ashburton Treaty (1842), between Great Britain and the USA, which required "such evidence of criminality as, according to the laws of the place where the fugitive or person so charged, shall be found, would justify his apprehension and commitment for trial, if the crime or offense had there been committed", in http://avalon.law.yale.edu/.

275 See ibid., p. 259 f. 
to secure that British nationals would have the same rights as in domestic committal proceedings; and, since it would be "invidious" to provide this safeguard to British nationals only, the requirement was maintained in relation to any requested individual. The Working Party also found that the requirement was "the only real safeguard" against "trumped up" cases. Other reasons deployed in favour of the requirement concerned the necessity to have sufficient information to determine whether other bars were met, particularly dual criminality and the political offence exception.

The prima facie requirement was again questioned by an Interdepartmental Working Party established in 1982, which, reporting in 1984, asserted that one of the main reasons to maintain the requirement was that it was central to "ensure equal treatment with those subject to domestic committal proceedings". ${ }^{276}$ The Working Party posited that the prima facie requirement "provided a safeguard in setting a standard for the quality of extradition request which the UK was prepared to accept". Again, its disadvantages were also recognised: together with the rules on admissibility of evidence, it "presented a serious obstacle to successful extradition requests, even where the Requesting State had sufficient evidence to obtain a conviction"; and it made extradition proceedings longer and costlier. Ultimately, a majority of the Working Party found that the dual criminality rule, the speciality rule, and the political offence exception offered "sufficient protection from manifestly unjust or oppressive extradition", and advocated the abolition of the prima facie requirement. A Government Green Paper published in 1985 reiterated the arguments of the Working Party, noting that, if the UK considered the standards of justice of a certain State sufficiently solid to conclude an extradition treaty with that State, then it should allow this State to judge whether there is sufficient evidence to prosecute.

In 1986 a White Paper was published stating that the UK was "widely regarded as one of the most difficult countries from which to secure extradition", the "principal obstacle" being the requirement that the requesting State establish a prima facie case according to UK rules of evidence. ${ }^{277}$ The Paper proposed that the requirement be abolished. It found that it did not pose a necessary individual safeguard, but was a "formidable impediment to entirely proper and legitimate extradition requests". The EA 1989 did not abolish the requirement entirely, but reformed it. One of the objectives of this statute was to facilitate adhesion to the 1957 European Convention on Extradition, which the UK ratified only in 1991. The Convention was based on a "spirit of mutual confidence" between "like-minded" States, and did not contain any such requirement (although it was permitted under Art. 26). ${ }^{278}$

${ }^{276}$ Ibid. p. 260, further noting that the working party did however recognise that this justification did not apply to Scotland, where the test for committal was different: "In Scotland, a petition with a relevant charge simply had to be signed by the procurator fiscal and presented to the Sheriff; there was no evidence presented and the Sheriff made no assessment of whether a prima facie case was made out. This distinction continues to exist. (...) Therefore, it remains the case in Scotland that the court is not provided with any evidence to make a determination of whether evidence has been provided to make out a prima facie case."

277 See ibid., p. 54 f., informing e.g. that in 1978, Spain denounced its extradition treaty with the UK in consequence of difficulties experienced in satisfying evidentiary requirements.

278 See ibid., p. 58; also Clive NiCHOLs et al., op. cit., p. 111. 
The prima facie requirement was reassessed yet again in a 2001 Extradition Review, which found strong reasons for it not apply to UK's closest extradition partners. ${ }^{279}$ It also appraised that its abolition in the 1957 Convention had not deteriorated the protection of requested individuals. That Review raised two main objections to the requirement: (1) the UK applies domestic standards to evidence which is ultimately to be weighed in the requesting State under its own criteria; (2) the ability of the requesting State to meet the requirement may be affected not only by the lack of evidence, but also by simple difficulties in presenting its case in terms that are satisfactory to the UK. The Review did however hold that, in regard of States with which the UK does not have an extradition treaty, the requirement should continue to serve "as an additional safeguard for the fugitive".

The prima facie requirement endures. ${ }^{280}$ It constitutes one of the main differences between extradition to category 1 States, where it does not apply, and to category 2 States, where it applies unless the State in question has been dispensed by the Home Secretary ${ }^{281}$ from this requirement. ${ }^{282}$ The requirement is laid down in ss. 84 and 86 , which are identical. ${ }^{283}$ According to these provisions, where extradition is requested for prosecution, the judge must ascertain whether there is evidence which would be sufficient to make a case requiring an answer by the person if the proceedings were the summary trial of an information against him. These conditions are significantly easier to satisfy than those which were prescribed in the 1989 Act: s. 84 (2) gives the court wide discretion to admit hearsay evidence, which for instance means that it is possible to take into account a summary of witness statements reported by a prosecutor or a police officer. This marked a significant reform of this requirement, as one of the main reasons why it formerly blocked so many extradition requests was the "comparative rigidity of English rules against hearsay". ${ }^{284}$

The prima facie requirement was assessed by the Baker Review in its current configuration. ${ }^{285}$ The Review begins by noting that Lord Justice Auld's "Review of the Criminal Courts of England and Wales", in 2001, having assessed the desirability of maintaining committal proceedings in criminal proceedings, found that they were no longer justified, and recommended their abolition, a recommendation that was later given statutory effect in Schedule 3 of the Criminal Justice Act 2003. The Baker Review noted that, if committal proceedings were indeed to be abolished in domestic criminal proceedings, then "one of the historical justifications for the prima facie evidence requirement in extradition proceedings disappears". In any case - the Review added -, committal proceedings have al-

279 See SCOTT BAKer / DAVId Perry / ANAND DOOBAy, op. cit., p. 266 f.

${ }^{280}$ Extensively, see ibid., p. 273 f.; Julian B. KNOWLes, op. cit., p. 81 f.; Julian B. KNOWLes / ANAND DoObay / MARK Summers, op. cit., p. 111 f.; EdwARD Grange / REBECCA Niblock, op. cit., p. 145 f., and cited case law.

281 Under ss. 84 (7) or 86 (7).

282 See Clive NiCHOLS et al., op. cit., p. 111. Category 2 States that must not satisfy this requirement include Australia, Canada, New Zealand and the USA, regarded as "democratic states and trusted extradition partners”: SCOTT BAKER / DAVID PERRY / ANAND DOOBAY, op. cit., p. 270; see yet EDWARD GRANGE / REBECCA NIBLOCK, op. cit., p. 145.

283 See Edward Grange / REBECCA Niblock, op. cit., p. 145.

284 IVOr StANBrook / Clive STANBroOK, op. cit., p. 428.

285 See SCOtT Baker / David Perry / AnANd DoObay, op. cit., p. 273 f. 
ready been limited and are no longer available for indictable offences (which can only be tried in the Crown Court), creating some incoherence between extradition and domestic proceedings. Secondly, the Review considered that the bar on abuse of process jurisdic$\operatorname{tion}^{286}$ is already "broad enough" to prevent requests grounded on "improper motive[s]", and that under this bar the court can already request that evidence or information be offered. ${ }^{287}$ Thirdly, the Review claimed that the prima facie requirement is unable to prevent error on the identity of the individual. Ultimately, however, it conceded that evidentiary requirements are important because some States "routinely violate human rights or abuse the system of international cooperation for extradition". 288

In conclusion, despite the erosion suffered over time by the prima facie requirement, and the increasing awareness of the necessity to maintain fluent extradition relations, the UK still has mixed feelings in relation to that requirement. While it is considered dispensable in the cooperation with trusted partners, it is still deemed valuable in the cooperation with States regarding which no such trust can be presumed. The main reasons for its preservation are, in sum: a desire to establish coherence between extradition and domestic criminal proceedings, and a view according to which such a repressive device as extradition should only be employed where there is reason to believe that the criminal proceedings it ultimately serves are truthful and solid.

\subsection{Absence of a prosecution decision}

\subsubsection{United Nations}

No similar requirement is found in the UN model instruments.

\subsubsection{Portugal}

A similar requirement is not to be found in Portuguese extradition law either.

\subsubsection{United Kingdom}

In addition to the relevance bar assessed earlier, and also linked to the principle of proportionality, the Anti-Social Behaviour, Crime and Policing Act 2014 introduced yet another bar to the execution of the EAW. The EA 2003 now provides in s. 12A that the request shall be refused if the person satisfies the judge that there are reasonable grounds to believe that no decision to charge or to try him/her has been taken in the requesting State, and that his/her absence from that State is not the exclusive reason for those decisions not to have been taken. This bar has also been called "trial readiness bar". 289

The Explanatory Notes to the Anti-Social Behaviour, Crime and Policing Act 2014 inform that this bar "intended to ensure that a case is sufficiently advanced in the issuing State (that is, there is a clear intention to bring the person to trial) before extradition can occur, so that people do not spend potentially long periods in pre-trial detention follow-

286 See infra, $\int 5.3 .3$.

287 See SCOTT BAKER / DAVID PERry / ANAND DOOBAy, op. cit., p. 276, 282.

288 Ibid., p. 283.

289 Rosemary Davidson / Ben Lloyd / AdAm PAYTER, op. cit., p. 509, passim. 
ing their extradition, whilst the issuing State continues to investigate the offence" ${ }^{290}$ This amendment was reportedly sparked by the case of Andrew Symeou, who after the execution of a EAW by the UK spent more than 10 months in pre-trial custody in Greece, and further time on bail without the possibility of leaving Greece whilst awaiting trial, at which he was eventually acquitted. ${ }^{291}$

As the Explanatory Notes also convey, this provision is expected to be applied in a "cosmopolitan way", "mindful of the differences in criminal procedure in other Member States", particularly in respect of the concepts 'decision to charge' and 'decision to try'. ${ }^{292}$ In Kandola and Others this bar was successfully raised by some of the requested persons. ${ }^{293}$ The ruling acknowledges that the newly created s. 12A is not based directly on anything in the FD-EAW, nor in the FD 2009/948/JHA of 30 November 2009 on conflicts of jurisdiction: "It is purely domestic in origin". ${ }^{294}$

\subsection{Extinction of criminal liability}

\subsubsection{United Nations}

The model instruments contain provisions on both ne bis in idem and other forms of extinction of criminal liability. The Model Treaty provides in Art. 3 (d) that extradition shall be rejected if there has been a final judgment for the acts in question in the requested State; and in Art. 4 (b) it provides that extradition may be refused if the competent authorities of the requested State have decided either not to institute or to terminate proceedings for the same offence. In Art. 3 (e), the Model Treaty provides that extradition shall be refused if the person has become immune from prosecution or punishment for any other reason, such as lapse of time or amnesty, under the law of either the requesting or the requested State. However, a footnote to this provision indicates that this ground for refusal may be configured as optional, that the issue of lapse of time may be limited to

\footnotetext{
${ }^{290}$ In http://www.legislation.gov.uk/ukpga/2014/12/pdfs/ukpgaen_20140012_en.pdf, \462.

${ }^{291}$ See www.fairtrials.org/fair-trials-chairs-extradition-panel/. On the case and the "barrage of criticism" it raised, see JoHn R. SPENCER, "Fair trial rights and the European Arrest Warrant", CLJ 69 (2010), p. 225 f.

292 \463, illustrating with Asztaslos v. Szeekszard City Court Hungary [2010] EWHC 237 (Admin). This approach was followed in Kandola and Others, mentioned immediately infra in the text.

${ }^{293}$ See Kandola, Droma, Ijaz v. Generalstaatwaltschaft Frankfurt, Germany, State Prosecutor Nürnberg-Fürth, Bavaria, Germany, The Court of Milan (An Italian Judicial Authority) [2015] EWHC 619 (Admin).

${ }^{294} I d ., \$ 21$. The ruling further remarks that by introducing s. 12A the UK did "no more than following the example of Ireland, which had insisted at the time the FD was being negotiated that its domestic legislation implementing the FD would provide that an EAW could only be executed for the purpose of 'bringing that person to trial' in the case of an 'accusation' EAW', and which did effectively introduce such a bar in s. 21A (1) of the Irish EAW Act 2003. The decision informs that a similar bar is yet contained in s. 7 (3) (b) of the Gibraltar EAW Act 2004. Rosemary Davidson / Ben Lloyd / ADAM PAYter, op. cit., p. 510, also submit that this bar is not based directly on the FD-EAW, but argue that Art. 1 (1) FD-EAW, as implemented in s. 2 (3) (b) and (5) (b) EA 2003, make it "clear" that "EAWs are only available "for the purpose of conducting a criminal prosecution or executing a custodial sentence or detention order', and, thus, that "for an EAW to be a valid warrant it must have been issued for the surrender of an 'accused' person (rather than a suspect) and their surrender must be sought for 'for the purpose of being prosecuted for the offence' (rather than for an investigation) (...). Extradition for any other purpose, such as obtaining evidence, is not a 'legitimate purpose of an arrest warrant'."
} 
the law of the requesting State, and that the factors which interrupt the running of timebars in the requesting State can be recognised in the requested one. The Model Law contains a similar provision on ne bis in idem in s. 8, with the particularity that it is wider than the Model Treaty, in that it also encompasses decisions proffered in a third State. ${ }^{295}$ As for other causes of extinction of criminal liability, they are regulated with no noteworthy differences in s. 9 of the Model Law.

The Revised Manuals appear to take for granted the fundamental character of the protection conferred by the principle ne bis in idem, and do not elaborate on the rationale of this ground for refusal, but instead they focus on some practical aspects to consider in complex cases. ${ }^{296}$ Regarding amnesty, the Manuals posit that "States should consider whether the unilateral granting of amnesty by a requested State, which may often be based on purely domestic legal and policy considerations, should always operate to bar extradition to a requesting State which may have significant prosecutive interests quite independent from those of the requested State." ${ }^{297}$ Lapse of time was one of the issues revised in the 1997 amendment of the Model Treaty, so as to reflect the "increasing awareness that domestic legal frameworks governing lapse of time often vary widely, with various formulae for calculating the expiration of the statutory period, and that application of the laws of both requesting and requested States may lead to unintended consequences". ${ }^{298}$ Again the rationale of these grounds for refusal is not elaborated on.

Regarding Art. 3 (d) Model Treaty, concerning decisions rendered by the requested State itself, Swart argues that it serves a "dual purpose": "Firstly, the requested State thus gives priority to its own system of criminal justice", in that extraditing a person for acts it has already tried would be "irreconcilable with [its] sovereignty"; secondly, "the individual is given protection against double jeopardy". ${ }^{299}$ Regarding decisions proffered in third States, the author notes that the case is different, and that "[p]rovisions excluding extradition in such cases are relatively rare": these do not directly impinge upon the sovereignty of the requested State, and "[c]onsequently" the person concerned will not benefit from the protection conferred by the ne bis in idem principle. The author remarks that this is an "unsatisfactory situation", and approves the tendency of expansion of this ground for re-

295 The UNODC, "Revised Manuals on the Model Treaty..." op. cit., p. 18, do mention that decisions of third States may be taken into account under this provision, but this does not find support in the wording of the Model Treaty: see e.g. BERT SWART, "Refusal of Extradition...", op. cit., p. 200, assuming that this is not covered by the Model Treaty.

296 See ibid., p. 18 f.: "States may wish to consider what criteria and evidentiary information are appropriate and necessary to measure whether a second prosecution is for the same offence, particularly in complex and continuing group crimes. Where a criminal group may be carrying out activities in more than one State simultaneously, as part of an overall enterprise (...) it can be beneficial for States to consult in advance of prosecution so that the charges brought by one State do not unnecessarily increase the likelihood that a subsequent extradition request will be precluded (...)”.

297 Ibid., p. 19.

${ }^{298}$ Ibid., p. 19 f., adding: "it may be difficult for (...) a State that is searching for a person wanted to anticipate which actions they should take to stop expiration of the statute of limitations of other countries to which the person wanted may flee, in order to guard against potential expiration of the statute of limitations in another State."

299 BERT SwART, "Refusal of Extradition...”, op. cit., p. 200 f. - also the other quotes in this paragraph. 
fusal to decisions of third States, visible for instance in Additional Protocol no. 1 to the European Convention in Extradition. The blocking effects of ne bis in idem in the field of extradition indeed seem to have expanded subsequently. This should help to explain why the Revised Manuals affirm, without any literal support in the Model Treaty, that, in implementing it, States can expand those effects to decisions of third States. Quite significantly, and as already discussed earlier in this study with respect to human rights, Swart notes that human rights instruments offer no protection against punishment in two or more States, and, as it stands, refusal of extradition in such cases is based only on the ordre public of the requested State.

As for the other causes of extinction of penal liability, Swart notes that, although they do not correspond to any human right, they are "almost universally accepted". ${ }^{300}$ After drawing attention to the technical difficulties that this ground for refusal can raise, the author elaborates on its manifold rationale: (i) if the offence falls within the jurisdiction of the requested State, then, again, refusing extradition is immediately a matter of sovereignty; (ii) on the other hand, it secures reciprocity between requested and requesting States; (iii) finally, it is a matter of ordre public of the requested State, in that it may find no "valid reason for prosecuting or punishing an offender".

\subsubsection{Portugal}

Art. 8 establishes that extradition shall be refused if, either in Portugal or in another state where criminal proceedings concerning the same acts have been initiated, one of the following circumstances occurs: a) proceedings ended with a final sentence of acquittal or were otherwise definitively discontinued; ${ }^{301}$ b) the sentence was served or cannot be served according to the law of the sentencing State (e.g. due to presidential pardon or because they became time-barred); and c) proceedings became extinct on any other ground (e.g. time-bars), unless a treaty establishes that their discontinuation on those grounds does not prevent the requested State from extraditing. ${ }^{302}$ This provision should be read in conjunction with Art. 12, according to which Portugal recognises and gives effect to any circumstances that interrupt or suspend the running of time-bar terms according to the law of the requesting State, as well as to any complaint submitted in due time to a foreign authority in cases where a complaint is required under Portuguese law to initiate a criminal procedure.

\footnotetext{
${ }^{300} \mathrm{Ibid}, \mathrm{p} .201$ - also the other quotes in this paragraph.

301 The second segment of the norm covers only decisions that entail a definitive extinction of criminal liability, such as decisions of public prosecutors to file the procedure due to the existence of sufficient evidence that the defendant did not commit the crime, and not those that constitute merely formal res judicatae, such as decisions of public prosecutors to file the procedure due to lack of evidence of the crime, and court decisions to close the procedure due to lack of jurisdiction - according to PEDRO CAEIRO, Lessons of the LLM in Criminal Law (unpublished), FDUC, 2008.

302 The exception 'unless a treaty provides otherwise' was intended particularly to accommodate Art. 8 (1) of the 1997 Convention on Extradition between EU Member States - according to HENRIQUE GUERRA TAVARES GOMES, "A prescrição do procedimento criminal na extradição e no mandado de detenção europeu em Portugal”, LLM paper: FDUC, 2012 (unpublished), p. 17.
} 
This ground for refusal "refers to several aspects of the principle ne bis in idem", 303 but not only: it includes virtually any circumstances that entail an impossibility to exercise the ius puniendi. Besides, it bestows relevance not only on the law of the requesting State and of other States that have jurisdiction over the acts, but also of Portugal in its simple condition of requested State. It is important to remark that, although the event that the 'sentence cannot be served' is to be assessed under the law of the State that proffered it, there is case law asserting that the passage of very long periods of time causes extradition to be refused based on the Constitution: ${ }^{304}$ the argument is that "the right to a fair trial requires that sentences be served within a reasonable period of time"; punishment after long spans of time "offends the legal appeasement inherent to the passage of time and the guarantees of the defence". ${ }^{305}$ This sheds light on the rationale underpinning this ground for refusal: applying this ground for refusal to cases where a penalty has not been extinguished under the law of the sentencing State denotes that it is regarded as necessary to protect certain criminal justice values of Portugal as a requested State.

The same occurs even more plainly regarding time-bars and other causes of extinction of the criminal procedure: extradition shall be refused if the procedure would have become time-barred under Portuguese law. While acknowledging that Art. 12 recognises the factors for the interruption or suspension of time-bars as prescribed in the law of the requesting State, the Supreme Court has ruled that this does not preclude the application of the Portuguese criteria on time-bars. ${ }^{306}$ To the Supreme Court, this ground for refusal forms a "reserve of sovereignty", 307 and its rationale is intertwined with the fundamental concepts of the Portuguese legal system on the goals of criminal punishment (mainly deterrence and rehabilitation).

Regarding the ne bis in idem principle, this ground for refusal appears to constitute a projection on foreign States of the fundamental character assigned to this principle in the Portuguese Constitution. ${ }^{308}$ In the cases where a procedure was initiated or carried out in Portugal, this is added by considerations of sovereignty: it is also a matter of guaranteeing the efficacy of Portuguese decisions that form res judicata.

303 See JORGE DE Figueiredo DiAs, "Extradição e non bis in idem [parecer]”, op. cit., p. 218; MANUEL António lopes Rocha / Teresa Alves martins, op. cit., p. 37; Teresa Alves Martins / Mónica Quintas Roma, “Cooperação internacional no processo penal”, RPCC 5 (1995), p. 459; Luís SiLVA PEREIRA / TERESA Alves MARTINS, "O princípio ne bis in idem e os conflitos internacionais de jurisdição", RCEJ 7 (2007), p. $321 \mathrm{f}$.

304 As well as on the ECHR. However, this analysis is limited to the Portuguese legal instrument.

305 Ruling of the Court of Appeal of Lisbon of 17 November 2011, no. 759/11.0YRLSB-3, in a case where 41 years had lapsed over the crime, more than twice the time required under Portuguese law to consider the procedure time-barred for the acts in question.

306 Regulated in Arts. 118 f. Penal Code.

307 Ruling of the Supreme Court of 30 May 2012, no. 290/11.3YRCBR1.S1.

308 Art. 29 (5). JORGE DE FIgueIREDo DiAs, "Extradição e non bis in idem [parecer]”, op. cit., p. 218, 220, uphold that extraditing in such cases would breach this constitutional provision. However, in terms similar to those discussed supra, $\iint$ 1.3.2. and 1.4.2., regarding the applicability of certain penalties in the requesting State, that provision is only binding within the Portuguese legal order. Its application to extradition can only be explained by an intent to protect the ordre public of this State. The difference in relation to the applicability of certain penalties in the requesting State is that there is no constitutional provision preventing extradition in case of a breach of ne bis in idem, meaning that it is a pure option of the ordinary legislator. 
This ground for refusal has correspondence in several norms of PT-EAW. ${ }^{309}$ According to Art. 11 (a), surrender shall be refused if the offence is covered by amnesty in Portugal, provided that Portugal has jurisdiction over the acts. The Supreme Court has ruled that this norm is connected to amnesty as a "fundamental principle" with "peremptory" character, ${ }^{310}$ although the notion is not further elaborated on, and the ruling is not directly concerned with this hypothesis. Based on Art. 11 (b), surrender shall also be refused if the person concerned has been tried in a Member State for the same acts, provided that, in case of conviction, the sentence has been served, is currently being served, or can no longer be served under the law of the Member State where the decision was proffered. The Supreme Court has also ruled that this obstacle is linked to ne bis in idem as a "fundamental principle" with "peremptory" character. ${ }^{311}$ In another decision this Court referred to ne bis in idem again as a fundamental principle, stating that it is related to "reasons of material justice and respect for the human being", as well as to a "necessity of legal certainty" and to the "principle of proportionality". ${ }^{312}$ Related to the principle ne bis in idem is also Art. 12 (1) (d), ${ }^{313}$ according to which surrender may be refused if a final decision has been passed in another Member State in respect of the same acts that prevents further proceedings, in cases other than those regulated in Art. 11 (b). Moreover, Art. 12 (1) (f) provides that surrender may be refused if the person has been tried in a third State for the same acts, provided that, in case of conviction, the sentence has been served, is currently being served, or can no longer be served under the law of the sentencing State. This ground for refusal also concretises the ne bis in idem principle, in this case regarding decisions of States that are not Member States. ${ }^{314}$ Yet related to the ne bis in idem principle is Art. 12 (1) (c), ${ }^{315}$ which provides that surrender may be refused if Portugal has jurisdiction over the acts and Public Prosecution decides either not to prosecute or to halt proceedings. ${ }^{316}$ On the other hand, Art. 12 (1) (e) provides that surrender may be refused if prosecution or punishment is statute-barred according to Portuguese law, so long as Portugal has jurisdiction over the acts. This ground for non-execution has been invoked repeatedly before Portuguese courts, but in all cases assessed its application was dismissed due to the fact that Portugal did not have jurisdiction over the acts. ${ }^{317}$

In EU law, the principle ne bis in idem is provided for in Art. 54 CISA, mirrored in Arts. 3 (2), 4 (3) and 4 (5) FD-EAW, and enshrined in Art. 50 CFREU. It has been inter-

309 See Luís Silva Pereira / Teresa Alves Martins, op. cit., p. 325 f.

310 Ruling of the Supreme Court of 21 November 2013, no. 753/13.6YRLSB.S1.

${ }^{311} \mathrm{Id}$.

312 Ruling of the Supreme Court of 25 June 2009, no. 1087/09.6YRLSB.S.

313 See António Pires HenriQues Da GraÇA, op. cit., p. 17.

314 See VÂnia Costa Ramos, "Ne bis in idem e Mandado de Detenção Europeu. Comentário ao Caso Gaetano Mantello (Acórdão do Tribunal de Justiça, de 16.11.2010, Processo n. ${ }^{\circ}$ C-261/09)", RMP 127 (2011), p. 282.

315 See ibid., p. 282.

${ }^{316}$ In the selection of case law offered by the Documentation and Comparative Law Office no decision exists on this provision.

317 See the rulings of the Supreme Court of 9 January 2008, no. 07P4855, of 24 April 2008, no. 08P1422, of 21 July 2010, no. 586/10.1YRLSB.S1, and of 29 September 2010, no. 143/10.2YRCBR.S1, and the ruling of Court of Appeal of Oporto of 31 October 2007, no. 0715689. 
preted and developed by the ECJ in several cases beginning with Gözü̈tok \& Brügge. ${ }^{318}$ In an area that has in free movement one of its most fundamental characteristics, a strong ne bis in idem is not only a fundamental guarantee in the narrowest sense of the concept, but also a key condition for the effectiveness of that freedom. ${ }^{319}$

\subsubsection{United Kingdom}

According to ss. 12 and 80 (applicable to category 1 and 2 States, respectively), extradition is barred by reason of the rule against double jeopardy if it appears that the person would be entitled to be discharged under any rule of law relating to previous acquittal or conviction if he/she were charged with those acts in the UK. As the Baker Review informs, double jeopardy (ne bis in idem, in the continental lexicon) was not explicitly provided for in the EA 1870, but in Atkinson v. United States Government ${ }^{320}$ Lord Reid held that the extradition magistrate had the same jurisdiction and powers as if the defendant had been brought before him/her charged with an indictable offence, and thus had the prerogative to deal with a plea in bar of prosecution: autrefois acquit or autrefois convict. ${ }^{321-322} \mathrm{In}$ the UK as in most States, ne bis in idem is regarded as a fundamental principle of justice with deep historical roots. ${ }^{323}$ It is regarded as particularly important in the context of the EU, given its close and direct impact upon freedom of movement, but is bears the same fundamental rationale in any instance. ${ }^{324}$

On the other hand, under ss. 14 and 82 - applicable to category 1 and category 2 States, respectively -, extradition is barred if it would be "unjust or oppressive" to extradite the person, considering the "passage of time" since the acts were allegedly committed or the suspect become unlawfully at large. The leading case generally quoted for establishing the scope of the concepts "unjust and oppressive" is Kakis, ${ }^{325}$ decided under the equivalent provision of the former Fugitive Offenders Act 1967. Here, Lord Diplock stated: “'Unjust' I regard as directed primarily to the risk of prejudice to the accused in the conduct of the trial itself, 'oppressive' as directed to hardship to the accused resulting from changes in his circumstances that have occurred during the period to be taken into consideration." As Knowles summarises: "A refusal to return the defendant must be based on injustice or oppression caused by the passage of time as it operated in the circumstances of the particular case to give to that particular passage of time a quality or significance which leads to the conclusion that return would be unjust or oppressive. (...) In other words, delay must have operated as the 'cradle of events' giving rise to injustice or oppression". ${ }^{326}$ Hence, the rationale of this ground for refusal is twofold: on the one hand,

318 Cases C-187/01 and C-385/01; thereon, see ANDRÉ KLIP, European Criminal Law..., op. cit., p. 285 f.

319 SCOTT BAKER / DAVID PERry / ANAND DOOBAy, op. cit., p. 89.

320 Atkinson v. United States Government [1971] AC 197.

321 Or, in Scotland, 'tholed assize'.

322 SCOtT BAKer / David Perry / AnAnd DoObay, op. cit., p. 50, fn. 103, and p. 376, fn. 40.

323 See Clive Nichols / Clare Montgomery / Julian B. Knowles / Anand Doobay / Mark SUMMERS, op. cit., p. 76.

324 See Edward Grange / REBECCA Niblock, op. cit., p. 57.

325 Kakis v. Government of the Republic of Cyprus [1978] 1 WLR 779.

326 Julian B. KNOWLes, op. cit., p. 58. 
it seeks to prevent trials which might be rendered unfair due to such factors as erosion of evidence (e.g. fading of the memory of witnesses); ${ }^{327}$ on the other hand, it recognises that the events that have taken place during the lapse of time (e.g. that the person lived a honourable life free of crime, built a family) should be relevant when the question is raised as to whether he/she should answer for acts committed in a remote past. ${ }^{328}$ In other terms, it is necessary to establish whether, considering the time lapsed, it would still be possible to conduct a fair trial, and, in any case, whether it would still be proportional to do so taking into consideration the subsequent behaviour of the person. This also means that there is a partial overlap between this bar and the human rights bar, more specifically with the hypotheses of 'undue process' and 'disproportionality'.

A very relevant point to be learned from Kakis is that delays caused by the person having fled the requesting State will make it very difficult to rely on this bar. This is so even where the requesting State itself has contributed significantly to the delay, as was the case in Gomes, where the requesting State lost the file. ${ }^{32}$ The gravity of the acts also plays an important role in the assessment as to whether or not it would be unjust or oppressive to extradite: the more severe the crime, the less likely the refusal of extradition. The importance attached to these factors underscores the public interest in honouring extradition agreements. ${ }^{330}$

\subsection{Absence of (valid) jurisdiction}

\subsubsection{United Nations}

Art. 4 (e) Model Treaty provides that extradition may be refused if the offence was committed outside the territory of the requesting and the requested States, and the latter would not have jurisdiction over the offence in comparable circumstances. Similarly, s. 13 Model Law states that extradition may be refused if the offence was committed outside the territory of the requesting State and the law of requested State would not allow prosecution for the same offence if committed outside its territory. As a footnote to this provision, the Model Law clarifies that the extraterritorial jurisdiction of the requesting State should be exercised in accordance with international law and its domestic legislation.

The Revised Manuals posit that the purpose of this norm is to enable States to refuse extradition where the exercise of jurisdiction by the requesting State is deemed "overly broad", notably where it is "clearly excessive under generally accepted standards of international law". ${ }^{331}$ The reason why refusal is optional is the concern for the tradition of civil law States to assert extraterritorial jurisdiction over their nationals, which most common law States tend not to follow, but sometimes "find acceptable".

327 See ibid.

328 See House of Lords Select Committee on Extradition Law, op. cit., p. 22, 39, 132; see Matuszenskei v. Regional Court in Radom [2014] EWHC 357 (Admin).

329 See Edward Grange / Rebecca Niblock, op. cit., p. 63; see Gomes v. Government of the Republic of Trinidad and Tobago [2009] 1 WLR 1038.

330 See Edward Grange / REBECCA Niblock, op. cit., p. 64.

331 UNODC, "Revised Manuals on the Model Treaty..." op. cit., p. 27. 
Swart begins by construing this ground for refusal as an expression of the principle of reciprocity: according to the author, it is in fact probably "the only exception in the Model based solely on the wish to maintain reciprocity". ${ }^{332}$ After claiming that reciprocity should be given fewer relevance in the context of other obstacles to prosecution or to the execution of a sentence, ${ }^{333}$ the author concludes that the same may not apply to jurisdictional issues: "It seems an exaggeration to the principle of reciprocity to refuse extradition if, for example, the competence of the requesting State is based on the passive nationality principle (...). But this example raises a question of a different nature, even more so where the universality principle is concerned. In certain circumstances, the requested State may be of the opinion that the requesting State is meddling in the internal affairs of a third State". ${ }^{334}$ The author hence closes: "after all, there may be valid reasons to refuse extradition on the ground that the requested State would not be competent to try the offence in the same situation, although these reasons have little to do with reciprocity". ${ }^{335}$

\subsubsection{Portugal}

Art. 31 (1) makes it explicit that extradition can only be granted if the offence falls within the jurisdiction of the requesting State. ${ }^{336}$ This condition requires Portugal not only to look into the internal law of the requesting State, but also to assess whether in the particular case it complies with international law, and thereby it also covers situations where e.g. the requesting State intends to exert territorial jurisdiction over acts committed in a territory which under international law is subject to the sovereignty of another State, or universal jurisdiction without the offender present in its territory. ${ }^{337}$ The rationale of this condition is to prevent mistakes or abuses by the requesting State. ${ }^{338}$

That provision is complemented by Art. 33, on extradition requests submitted by States with extraterritorial jurisdiction, which prescribes that, if the offence was committed in the territory of a State other than the requesting State, extradition can be granted only if Portugal would have jurisdiction in identical circumstances, or the requesting State is able to prove that the State where the acts were committed is not seeking to obtain extradition. As is apparent, this provision seeks to protect the territoriality principle.

This obstacle has correspondence in Art. 12 (1) (h) (ii) PT-EAW, which prescribes that a EAW may be refused if the acts in question were committed outside the territory of the issuing Member State, provided that Portuguese law is inapplicable to the same offences when committed outside national territory. This provision does not mention the

332 BERT SWART, "Refusal of Extradition...”, op. cit., p. 213.

333 See ibid., p. 213 f., and further infra, \ 7.2.1, and Chap. 8, \2.2.

334 See ibid., p. 214.

335 See ibid., p. 214.

336 The concern of the legislator with this situation is reiterated in Art 44 (1) (a), where it requires the requesting state to "show, in the concrete case, that the person sought is subject to its jurisdiction".

337 See Pedro Caeiro, Fundamento..., op. cit., p. 228, 366; MAnuel António Lopes Rocha, "Aplicação da lei criminal no tempo e no espaço", in Jornadas de Direito Criminal. O Novo Código Penal Português e Legislação Complementar. Lisboa: CEJ, 1983, p. 122 f. But on the limits of universal jurisdiction see further infra, Chap. 7, \$2.2.2.b).

338 See Pedro Caeiro, Fundamento..., op. cit., p. 228, fn. 615. 
possibility of proving that the State where the acts were committed is not requesting the person. However, since in this case refusal is simply optional, that fact can always be taken into account.

\subsubsection{United Kingdom}

Pursuant to ss. 64-66 and 137-138, as a rule the UK only grants extradition for acts committed in the territory of the requesting State. If the acts were committed elsewhere, then it is necessary that in corresponding circumstances they would constitute an extraterritorial offence under the law of the UK. These conditions are as well intended to protect the territoriality principle. They are similar to those found in the UN model instruments and in Portuguese law, but: unlike what happens in the former, they are mandatory; and, unlike what happens in the latter, they do not offer the requesting State the alternative of proving that the State where the acts were committed is not seeking extradition. Thus, the blocking effects of these conditions are much broader in the UK than any of the above arrangements, especially when one considers in the UK extraterritorial jurisdiction is exceptional, and consequently the basis of jurisdiction held by the requesting State will often have no parallel there. ${ }^{339}$

Furthermore, it is possible that the requesting State considers that the offence was partly committed in its territory, but that the territorial element is so tenuous that the UK considers that extraditing in such a case would be disproportionate under Art. 8 ECHR (via the human rights bar). This doctrine, known as 'exorbitant jurisdiction', ${ }^{340}$ has been applied by the High Court ${ }^{341}$ even in EAW proceedings, which again seems to be at odds with EU law, since the FD does not provide a basis for such a refusal. ${ }^{342}$

This denotes that, in the UK, this grounds for refusal is considered not only from the angle of the territoriality principle, but also from that of the individual concerned: if a territorial link between the acts and the requesting State exists but is very weak, exposing that individual to a foreign punitive system is seen as a disproportionately harsh measure.

\section{Grounds for refusal related to the status or condition of the person}

\subsection{Nationality / Rehabilitation}

\subsubsection{United Nations}

Art. 4 (a) of the Model Treaty provides for a nationality exception, but assigns it an optional, rather than a mandatory character. Like the territoriality exception, the national-

339 See infra, \6.1.3.

340 See SCOTT BAKer / David Perry / ANAND DOOBAy, op. cit., p. 218 f.

341 See e.g. Hashmi v. Government of the United States of America [2007] EWHC 564 (Admin), S 26, also cited ibid., p. $219 \mathrm{f}$.

${ }^{342}$ In regard of a EAW issued by Spain, the High Court held: "it is possible that a request might range so widely and have so tenuous a connection with the requesting state as to amount to the exercise of exorbitant jurisdiction. It might then be appropriate for the court to consider the situation under the rubric of s. 21 [human rights bar]": Boudhiba v. Central Examining Court No 5 of the National Court of Justice Madrid [2006] EWHC 167 (Admin), S 44, also cited in the Baker Report at p. 219. 
ity exception is accompanied by an aut dedere aut judicare injunction: if extradition is refused on this ground, the requested State shall, if the other State so requests, submit the case to its competent authorities with a view to taking appropriate penal action. The Model Treaty further invites States to contemplate the possibility of at least admitting extradition of their own nationals for serious offences or their temporary extradition for prosecution, under a guarantee of return for enforcement in case of conviction.

The Model Law is slightly more assertive in bidding States to consider abandoning the nationality exception, but acknowledges that this will meet with resistance in several States. Thus, it offers two main alternatives - not as a footnote (hence the added assertiveness in comparison to the Model Treaty), but in the actual body of the text: option 1 is that extradition of nationals must or may be refused; ${ }^{343}$ option 2 is that it must not be refused. As a footnote to this section the Model Law notes that the two alternatives are offered "in view of the divergent national approaches on this issue", namely from common to civil law States. The possibility within option 1 to make this a discretionary ground for refusal would lie midway between pure refusal and pure acceptance to extradite nationals, an approach which has spread even to some civil law States through such arrangements as the $1957 \mathrm{CoE}$ Convention (Art. 6), and the 1996 EU Convention (Art. 7), albeit under wide possibilities of reservations. The Model Law refers explicitly to the FD-EAW, stressing that it did "not include nationality as either a mandatory or optional ground for nonexecution", but rather it provides for an option to make execution conditional on a guarantee that upon conviction the person is returned to his/her State of nationality to serve the sentence (Art. 5 (3)) and for an optional ground for non-execution where the EAW is issued already for enforcement purposes, in which event the Member State must in any case undertake to execute the sentence. The Model Law construes that this trend may be explained "by the complexity and resource implications of conducting domestic prosecutions in lieu of extradition based on foreign gathered evidence, and the concern that dangerous criminals may be able to remain at large in their societies". It then closes by recommending "that States prefer the second option offered". ${ }^{344}$

Regarding the nationality exception contained in the Model Treaty, Swart begins by noting that there does not exist a human right or any rule under general international law prohibiting extradition of nationals, although this is "one of the most important classical obstacles to extradition" which in many States even enjoys constitutional rank. ${ }^{345}$ The author posits that the "majority" of States does not embrace the idea of extraditing nationals, and concludes that, in such a context, the approach taken in the Model Treaty forms "an important breakthrough", in that it makes refusals of extradition on this ground optional only, and explicitly attaches to them a duty to prosecute the acts subsequently. ${ }^{346}$

343 That is, within option 1 States may provide for either a mandatory or an optional ground for refusal. In this regard the Model Law is less stringent than the Model Treaty, which simply includes the nationality exception among the optional grounds for refusal.

344 This elaboration, provided for in the Model Law, practically replicates the remarks already contained in the UNODC, "Revised Manuals.." op. cit., p. $23 \mathrm{f}$.

345 See BERT SwART, "Refusal of Extradition...”, op. cit., p. 189, 191 f.

346 Ibid., p. 191. 


\subsubsection{Portugal}

Art. 5 (1) (e) Penal Code provides that Portugal has jurisdiction over acts committed by Portuguese citizens, as long as: they are found in Portuguese territory; the acts are also punishable in the locus delicti (except where this State does not exercise ius puniendi); and the acts constitute offences for which extradition could in the abstract be granted but, for some reason, this was impossible in the particular case. Most authors explain this basis for jurisdiction as a means to compensate for the non-extradition of nationals. In other words, as a means to enable the Portuguese State to preserve this traditional exception to extradition without acquiescing to the impunity of the person. ${ }^{347}$ However, this understanding is rather difficult to reconcile with the law currently in force in Portugal. Firstly, because Portugal has vicarious jurisdiction, which allows it to prosecute virtually any acts for which extradition has been requested and could not be granted. ${ }^{348}$ It is true that this basis for jurisdiction was adopted only in 1998, but, if the rationale of active nationality were simply to compensate for the non-extradition of nationals, then the introduction of vicarious jurisdiction should have led to its revocation. Secondly, and more importantly, because active nationality, as conceived in the Penal Code, allows Portugal to prosecute acts committed by its nationals abroad regardless of any extradition request. ${ }^{349}$ Thus, this rule can only be justified independently from extradition. ${ }^{350}$

In turn, Art. 32 (1) (b) PT-L, drawing on Art. 33 (3) of the Constitution, lays down the rule of non-extradition of nationals. ${ }^{351}$ Since the constitutional amendment of 1997 , this rule is no longer absolute. It then became possible to extradite Portuguese citizens if the following (if "very restrictive") ${ }^{352}$ conditions are satisfied: reciprocity is secured based on an international treaty; the acts refer to terrorism or international organised crime; the legal system of the requesting State ensures due process; and, unless the person explicitly

347 In this sense (and, thus, regarding this basis of jurisdiction as a concretisation of the principle aut dedere aut judicare specific for nationals), see Jorge DE FIGUEIREDo Dias, Direito Penal I... op. cit., p. 216; id., "Compétence...", op. cit., p. 125; MANuel António Lopes Rocha / Teresa Alves Martins, op. cit., p. 75; Teresa Alves Martins / Mónica Quintas Roma, op. cit., p. 463; Germano Marques Da Silva, Direito Penal Português I, Parte Geral: Introdução e Teoria da Lei Penal, Lisboa: Editorial Verbo, 2001, p. 299, 313 f.; in case law, see the ruling of the Court of Appeal of Oporto of 14 February 1990, no. 0123625.

348 See Art. 5 (1) (f) Penal Code.

${ }^{349}$ In the case of active nationality, the condition that 'extradition cannot be granted' does not require than an extradition request be received and refused: see Jorge DE FIGUEIREDo Dias, Direito Penal I... op. cit., p. 216.

350 See e.g. Pedro Caeiro, Fundamento... op. cit., p. 203 f., and Julian J. E. SchutTe, "O Direito Internacional Público...", op. cit., p. 19, positing that the repression of acts committed by nationals abroad is still justified on the basis of direct punitive interests of the State.

351 Like the cases where death penalty and life imprisonment are applicable in the requesting State, it is interesting to note that the first ordinary statute governing extradition (Decree-Law no. 437/75 of $16 \mathrm{Au}-$ gust) conceived the nationality exception as merely optional in Art. 4 (1) (b), a norm that would shortly later be rendered unconstitutional by the enactment of the 1976 Constitution. It is also interesting to know that this was the first Portuguese Constitution that prohibited extradition of nationals, although many treaties to which Portugal was a party did already contain such an exception: see NuNO PIÇARRA, "A proibição constitucional de extraditar nacionais...”, op. cit., p. 250.

352 NUNO PIÇARRA, “A proibição constitucional de extraditar nacionais...”, op. cit., p. 251; DAMIÃO DA CUNHA, op. cit., p. 544, also stress the exceptionality of the extradition of nationals. 
waives this condition, extradition is requested for prosecution purposes and the requesting State guarantees his/her return for enforcement, which requires the foreign sentence to be reviewed and confirmed, so as to be rendered compatible with Portuguese law: Art. 32 (2) and (3). ${ }^{353-354}$ According to Art. 32 (4), due process guarantees are to be assessed in the light of the ECHR and other relevant international instruments ratified by Portugal, as well as of the same conditions applicable to the protection against discrimination. ${ }^{355} \mathrm{It}$ is worth noting that this provision limits itself to repeating the protection that the grounds for refusal on 'due process' and 'discriminatory persecution' already confer upon each and every requested person. If this analysis is correct, this means that a higher level of protection was not established for Portuguese citizens, and, thus, that the 'due process' requirement found in the exception to the rule of non-extradition of nationals is redundant.

In ruling no. 403/2015, of 27 August 2015, the Constitutional Court stated that the constitutional amendment which broke the then absolute character of the nationality exception is a consequence of enhanced imperatives of security and reaction against serious criminality that call for "new normative balances between conflicting values". 356 One of the proposals that was on the table during the 1997 constitutional amendment narrowed the possibility to extradite nationals to the cases where, in addition to the requirements indicated above, the requesting State is a EU Member State. The view that prevailed was, instead, that, since terrorism and organised criminality have no borders, extradition should not have them either. ${ }^{357}$ Another argument used in support of this view was that it would be preferable from a perspective of reciprocity. ${ }^{358}$ Piçarra claims that the 1997 amendment marked the beginning of the recognition, in Portugal, that refusing extradition of own nationals is not an unchallengeable idea, but one which should be understood "with critical detachment", in a spirit of communion of interests among States and of respect for the primacy of territorial jurisdiction. ${ }^{359}$ Still, extradition of nationals remains quite exceptional.

One possible manner of justifying the Portuguese nationality exception is to regard it as a consequence of an interest of the Portuguese State in punishing acts committed by its nationals abroad. That is, Portugal would refuse to extradite its nationals in order to punish their crimes - a reasoning symmetrical to that, mentioned above, according to which Portugal would punish acts committed by its nationals because it cannot extradite them. In this line of thought, it is alleged that there exists an "umbilical" 360 relationship between

353 The last condition is not required by the Constitution, but only by the extradition statute.

354 Originally, the sole practical implication of the amendment was the possibility to extradite based on the 1996 EU Extradition Convention, as no other international instrument ratified by Portugal, at the time, met those constitutional requirements: see Luís SILVA PEREIRA, "Contributo para uma Interpretação dos Artigos 12 n. 1 al. g) e 13. ${ }^{\circ}$ al. c) da Lei n. ${ }^{\circ}$ 65/2003, de 23 de Agosto”, RCEJ 7 (2007), p. 267.

355 Described supra, $\int 1.2 .2$.

356 This is the same decision that was mentioned previously in relation to the ground for refusal on life imprisonment.

357 See Diário da Assembleia da República, II Série - RC - Número 20, 12 September 1996, p. 547 f.

358 See ibid., p. 552 f.; and Diário da Assembleia da República, II Série-RC-Número 84, 6 May 1997, p. 2404.

${ }^{359}$ NunO PIÇARra, “As revisões constitucionais...”, op. cit., p. 236.

360 MARC Henzelin, op. cit., p. 133. 
the State and its nationals which extends beyond borders, and that such relationship entails a duty of loyalty of the latter towards the former. ${ }^{361}$ Thus, the State would be entitled to something of a right of surveillance over its nationals. ${ }^{362}$ This view assumes that active nationality is such a strong ground for jurisdiction that the State seeks, as much as possible, to exert it. However, this reasoning is also inconsistent with Portuguese law currently in force: if the primary intention of the Portuguese State were to punish the acts committed by its nationals abroad, it would not have limited jurisdiction based on active nationality to the conditions that the offender is found in Portugal, that extradition is impossible to grant, and that the acts also constitute a crime in the locus delicti.

In this light, the only plausible justification for the Portuguese nationality exception is the will of the Portuguese State to protect its nationals from foreign punitive systems. This view too acknowledges the existence of an 'umbilical' connection between the State and its nationals, but from that connection it draws, not a right of the State to survey its citizens, but a duty (or at least a prerogative) ${ }^{363}$ to protect them. ${ }^{364}$ Only this view can explain why non-extradition of nationals is enshrined as a fundamental individual right in the Portuguese Constitution, ${ }^{365}$ and why it can only be departed from in cases where trust in the foreign legal system is either presupposed in the abstract (as in EU cooperation) ${ }^{366}$ or in the case at hand (after it is established that the requesting State affords a due process). ${ }^{367}$ It is also the only view that is capable of explaining why the concept of 'national' relevant for the purposes of the nationality exception is determined by reference to the moment of extraditing, rather than to the moment when the acts were committed, which is the relevant moment for the purposes of jurisdiction based on active nationality: ${ }^{368}$ if a person obtains Portuguese nationality after committing a crime, he/she will still benefit

361 Apparently leaning toward this position, although acknowledging that the ius puniendi of the State of nationality should, in these cases, be subject to "serious limitations", EDUARDO CORREIA, op. cit., p. 166.

362 See Julian J. E. SCHUTTE, “O Direito Internacional Público...”, op. cit., p. 19.

363 See Marc Henzelin, op. cit., p. 133, adding that it is a historical right rooted on the clan system.

364 Julian J. E. SCHuTTE, “O Direito Internacional Público...”, op. cit., p. 18. Reporting - and criticising - that it remains a common understanding that extraditing nationals equates to exposing them to the "punishing impetus" of other legal systems, JosÉ VERA JARDIM, "Por fim, podemos extraditar portugueses! Explicações de um Ministro", in António José Avelãs Nunes et al., A Inclusão do Outro: BFUDC9 (2002), p. 97. Also Nuno PiÇARrA, "A proibição constitucional de extraditar nacionais...” op. cit., p. 245, informing that this standpoint is tied to the consolidation of the Nation-state paradigm, which carried an "obligation" on States to harbour their citizens, to allow them to live permanently in their territories and always to grant them legal protection, in the name of the "special bond" that binds them; this author too criticises the mistrust implied by the nationality exception, claiming that it is based on "predominantly emotional reasons", and that it is unsustainable under any "criteria of strict legal rationality": ibid., p. 243, 248, et passim.

365 In any case, while some authors understood the formerly absolute constitutional prohibition to extradite nationals as entailing an absolute right of Portuguese citizens to reside in Portugal, others emphasised that such a provision should not be construed as a fundamental right to be actively protected by the State, but rather as a self-restraint on the Portuguese State concerning its power to coactively remove from its ambit of protection citizens found in its territory: on the issue, see NuNO PIÇARRA, "As Revisões Constitucionais...” op. cit., p. 220.

366 See Ricardo Jorge BraganÇA de Matos, op. cit., p. 357.

367 Even though, as mentioned above, every requested person is entitled to be protected from an undue process.

368 See, unequivocally, Art. 32 (6) of the extradition statute. 
from the nationality exception, ${ }^{369}$ but all the while Portugal will lack jurisdiction based on active nationality. In sum, in Portugal, the rationale of the nationality exception is a desire of the Portuguese State to protect its citizens from the punitive systems of other States. This principle is not absolute anymore, but the exceptions are narrow.

The one momentous exception to that principle is found, not in classic extradition, but in the EAW system: the execution of EAW's by Portugal concerning its nationals is constitutionally possible under Art. 33 (5) of the Constitution, enacted in $2001 .{ }^{370}$ Here, the view that the legal systems of EU partners are generally deserving of trust is added by another set of arguments: as is reflected in the debates held in Parliament on occasion of the 1997 constitutional amendment, it would be hypocritical to support the furthering of EU integration, EU citizenship and free movement, whilst all along allowing criminals to rely on their nationality to dodge the criminal justice of the partners to that project. ${ }^{371}$ Still, the Portuguese statute implementing the FD-EAW used all the margin left available by the FD to protect nationals. The relevant provisions are Arts. 12 (1) (g) and 13 (1) (b) PT-EAW. According to the latter, Portugal can only execute EAW's issued for prosecution purposes if guarantees are provided that the person will be returned for enforcement. According to the former, if the EAW is already requested for enforcement, then Portugal can refuse it if it undertakes to execute the foreign sentence. However, as noted earlier in a different regard, these norms do not apply only to nationals, but also to other persons who receive no specific protection from the Portuguese State against classic extradition, such as residents. This means that these norms do not express anymore a nationality exception in the sense established above (i.e. as a protection against trial in a foreign legal system), or otherwise it would not be possible to surrender an own national for prosecution purposes. They constitute instead what may be called a 'rehabilitation exception', whereby Portugal presumes itself to be the best place for its nationals and residents to be rehabilitated in the event of a conviction. The reason why refusal is optional is that the issuing Member State may be the most suitable place to attain rehabilitation in some specific cases. In sum, it is fair to say that, in its cooperation with EU partners, Portugal has abolished the nationality exception entirely. ${ }^{372}$ At the same time another exception to

369 See e.g. the Ruling of the Court of Appeal of Lisbon of 17 November 2011, no. 759/11.0YRLSB-3.

370 Already mentioned in $\int 1.4 .2 .:$ it is the same norm which allows for the execution of EAW's in case of applicability of life sentences.

371 See Diário da Assembleia da República, II Série - RC - Número 20, 12 September 1996, p. 547 f. See also Anabela Miranda Rodrigues, “O Mandado de Detenção Europeu...”, op. cit., p. 54; RiCARdo Jorge BRAGANÇA DE MATOS, op. cit., p. 357 f.

372 NUNO PiÇARRA, "A proibição constitucional de extraditar nacionais...” op. cit., p. 252, notes that the Commission's proposal leading to the FD-EAW replaced completely the classic nationality exception by a "principle of rehabilitation", as it did not mention nationality at all (Arts. 33 and 36). Still, in line with STEVE PEERs, EU Justice and Home Affairs Law, $2^{\text {nd }}$ ed., Oxford: University Press, 2006, p. 469, the author posits that the FD-EAW ultimately still did maintain vestiges of the classic nationality exception in Arts. 5 (3), 6 (4), and 25. Claiming that the nationality exception has in essence been abolished, see RICARDO JORGE Bragança de Matos, op. cit., p. 358, Carlota Pizarro de Almeida, “A Cooperação Judiciária Internacional", in Maria Fernanda Palma (coord.), Jornadas de Direito Processual Penal e Direitos Fundamentais, Coimbra: Almedina, 2004, p. 405. The rulings of the Supreme Court of 12 November 2008, no. 08P3709, and of 9 February 2011, no. 1215-10.9YRLSB.S1, mention "abolition" and "disappearance" of this classic rule. 
surrender emerged which does also profit national citizens, but only party (because it does not concern prosecution, but only enforcement), and only incidentally (because it is not rooted in a mistrust of foreign systems, but only in an objectively founded belief that the requested State will often be the place that offers the best prospects of rehabilitation, and this is why residents are placed on the same footing as nationals for these purposes). This is the understanding transpiring from the ruling of the Supreme Court of 27 April 2006, declaring that the ground for refusal contained in Art. 12 (1) (g) PT-EAW is to be construed in the light of the goals of criminal punishment, chiefly of the principle of rehabilitation enshrined in Art. 40 (1) of the Penal Code. ${ }^{373}$ As noted before, Art. 12 (1) (g) PT EAW is an optional ground for non-execution, meaning that Portugal may still choose to surrender the person. ${ }^{374}$

\subsubsection{United Kingdom}

Unlike most civil law States, the UK does not take a principled stance not to extradite its citizens. This is a deeply rooted Anglo-American tradition. As early as in 1877, in an extradition case to Switzerland, the requested person was able to resist extradition because the applicable treaty barred extradition of British nationals; but in this very judgment Lord Chief Justice Sir Alexander Cockburn stated: "I am chairman of the commission on the subject of extradition, and I will take care that, if possible, this blot upon the law shall be removed, so as to prevent an Englishman who commits an offence in a foreign country from escaping with impunity." 375 By 1891 Moore was commenting that "refusal to surrender citizens must $(. .$.$) be regarded as resting upon sentimental considerations and an$ exaggerated notion of the protection which is due by a state to its subjects (...). [T] here appears to be no valid reason why the system of extradition, which is intended to avert a failure of justice should not be extended to citizens or subjects. As long as the citizens of a country are accorded justice abroad, no right of intervention of their government on their behalf accrues and there is no occasion for the assertion of its protective power." ${ }^{\prime 376}$ This passage was evoked in 2015 by the House of Lords Select Committee on Extradition to emphasise that it "has even greater force in the age of the jet aeroplane". 377

The absence of a nationality exception is perfectly aligned with the absolute subsidiarity assigned by the UK to extraterritorial jurisdiction. ${ }^{378}$ In the UK, the principle is that territorial acts and only them should be prosecuted. Thus, refusing to extradite nationals who committed crimes abroad would mean, at once, to deny justice to the forum which by UK's own standards deserves full primacy, and to invite the settling of 'criminals', because the UK would generally be unable to try them based on territorial jurisdiction.

373 And reciprocity need not (unlike what happens in classic extradition) be secured: see the ruling of the Supreme Court of 13 January 2005, no. 06P1429; reiterated by the same court in rulings of 10 September 2009, no. 134/09.6YREVR, and of 21 November 2013, no. 753/13.6YRLSB.S1.

374 No. 04P4738.

${ }^{375} \mathrm{R} v$. Wilson [1877] 3 QBD 42, cited also in SCOTT BAKER / DAVID PERRY / ANAND DoOBAy, op. cit., p. 222.

376 JOHN BASSET MOORE, op. cit., p. 157.

377 House of Lords Select Committee on Extradition Law, op. cit., p. 51.

378 See supra, \ 3.4.3., and infra, \ 6.1.3. 
However, the connections of the requested person with the UK - which naturally include citizenship - are not entirely disregarded. As noted earlier these are taken into account in the context of forum, human rights and humanitarian concerns. ${ }^{379}$ Some of these bars were in fact reportedly enacted owing to public outcry at the possible extradition of UK nationals. In any event, this is still fundamentally different from establishing that citizenship, in and of itself, bars extradition: on the one hand, those bars apply to individuals who are not nationals of the UK; on the other hand, nationality is simply one among several factors influencing the decision of whether or not to extradite, in terms similar to those assigned to nationality and residence in the FD-EAW.

Coherently with its tradition not to block the extradition of nationals, the UK did not make use of the 'return to sender' option given by the FD-EAW, or of the option to refuse EAW's issued for enforcement (although similar results can be achieved through FD 2008/909/JHA on the transfer of sentenced persons, to which the UK has adhered).

\subsection{Humanitarian exception}

\subsubsection{United Nations}

Art. 4 (h) UN Model Treaty provides for a humanitarian clause: extradition may be refused if the requested State, while also taking into account the nature of the offence and the interests of the requesting State, finds that, in the case, extraditing the person would be incompatible with humanitarian considerations in view of age, health or other personal circumstances. A similar norm is found in ss. 26 and 29 Model Law, with one main particularity: the humanitarian clause is not included in the regular catalogue of grounds for refusal, but either in a provision specifically dedicated to laying down the prerogatives of the executive branch in the extradition procedure, or in a provision which refers to the postponement of extradition (and in this case too competence belongs to the executive branch). This option to vest the executive with the competence for evaluating humanitarian issues seems to be somewhat incompatible with the importance of the values at stake, such as health and even life. ${ }^{380}$ States may choose between making this a general prerogative of refusal (s. 26) or a ground for postponement. The latter approach corresponds to that adopted in FD-EAW, where humanitarian concerns also only bar extradition insofar as they persist. However, if those concerns have a permanent character, then this provision will function as any 'regular' ground for refusal. ${ }^{381}$ Conversely, some grounds for refusal may be met at the time of deciding on an extradition request but cease to be met at a later moment (e.g. due to an improvement of prison conditions), and from this moment onwards extradition will be possible. This means that 'regular' grounds for refusal may also have temporary applicability.

The Revised Manuals refer only sparingly and somewhat reluctantly to this ground for refusal. They simply underline that it should not be confused with the human rights

\footnotetext{
${ }^{379}$ See supra, Chap. $5, \$ 1.1 .1$.

380 See further infra, $\iint$ 4.2.2., and, esp., 4.2.3.

381 And, as the Revised Manuals note, the factors giving rise to humanitarian concerns are often permanent, as is the case with advanced age or severe illness: see UNODC, "Revised Manuals", op. cit., p. 28.
} 
grounds for refusal provided for in other provisions of the Model Treaty; and that States should evaluate whether they indeed need to provide for such a ground for refusal, considering that a similar protection may be ensured through measures other than refusal of extradition, "such as appropriate arrangements for medical care" in the requesting State". ${ }^{82}$ Swart explains that the inclusion of humanitarian clauses in extradition arrangements is a relatively recent development, with the first examples appearing after 1950 in the form of reservations made by several States to the $1957 \mathrm{CoE}$ Convention. ${ }^{383}$ The author stresses that extradition can cause consequence of "exceptional gravity" to individuals, and therefore welcomes openly the approach taken by the Model Treaty to adopt one such ground for refusal; not without conceding, however, that refusals on this ground should be carefully considered in the light of the interests of the requesting State, based on such factors as the gravity of the acts and the possibility to make use of cooperation mechanisms other than extradition. ${ }^{384}$

\subsubsection{Portugal}

Art. 18 (2) entitles Portugal to refuse extradition where it may carry severe consequences for the person, considering his/her age, health condition or other reasons of personal nature. The law explicitly conceives this ground for refusal as "optional". ${ }^{385} \mathrm{Howev-}$ er, one may question whether the situations at issue are compatible with a discretionary decision. In view of the principle of equality enshrined in Art. 13 of the Constitution, it appears impossible to admit discretion with regard to such paramount values as life and health. For instance, if there is a demonstrated risk that extradition may entail the death of the person, it should not be possible to choose between refusing extradition (due to that risk) and granting it (in spite of that risk): in both cases refusal should be mandatory. In this sense, this ground for refusal simply requires the ascertainment of whether one such risk is met in the case. This is, no doubt, a difficult operation. ${ }^{386}$ But difficulty in determining the scope of a rule does not mean its application is optional. In reality, courts implicitly seem to follow this view, in that, although repeatedly referring to this ground for refusal as optional, they ultimately often limit themselves to assessing whether or not its scope is met, i.e. whether or not, in the case at hand, extraditing could carry severe consequences for the person. ${ }^{387}$

382 Ibid., p. 28 f., adding: "States should be extremely precise with respect to the factors that would justify refusal of extradition, in order to preserve predictability and reciprocal trust in their treaty relationships".

383 See BERT SWART, “Refusal of Extradition...”, op. cit., p. 195.

384 Ibid.

385 Art. 18 (2); see also Manuel António Lopes Rocha / Teresa Alves Martins, op. cit., p. 49 f.

386 Which almost inevitably involves a "probabilistic assessment": ibid., p. 51. Courts have been cautious in construing the concept 'other reasons of personal nature'. It certainly does not encompass consequences that result naturally from the condition of being imprisoned (such as being separated from one's family), or otherwise nobody could ever be extradited: see the rulings of the Supreme Court of 30 October 2013, no. 86/13.8YREVR.S1, and of 29 April 2003, no. 03P1646. Consequences for persons other than the requested person (namely children and spouse) also tend to be seen as irrelevant: see the rulings of same court of 5 May 2011, no. 22/11.6YREVR.S1, and of 7 January 2009, no. 08P4144; but see further infra in the text.

387 See the rulings of the Supreme Court mentioned in the previous fn., and also that of 30 September 1999, no. 99P885. 
Sometimes this ground for refusal is linked to the notion of 'unfitness to stand trial'. ${ }^{388}$ However, with the exception of the young age of the person (in Portugal, minors under 16 years old are presumed incapable of guilt, ${ }^{389}$ and this may be encompassed by this ground for refusal), ${ }^{390}$ such a concept has no resonance in Portuguese law. Instead, as the wording of this ground for refusal suggests, its rationale is to protect the person from the risks emerging from the very circumstances of an extradition, such as the absence of indispensable medical treatment in the country of destiny. ${ }^{391}$ In a ruling of 21 May 2015 the Supreme Court held that this ground for refusal can also be triggered in cases of disproportionate interference with the right to private and family life of the requested person. To that end the court invoked - as far as it was possible to determine, for the first time Art. 8 ECHR. ${ }^{392}$ In this case, the court ruled not only that in the requesting State the person was likely to be exposed to severe damage to her physical and mental integrity, inflicted by her former husband and his family - a risk which, according to the court, the authorities of the requesting State could not obviate -, but also that she would have "no family support whatsoever" in that State (although her minor son lived in that State under the guardianship of the father, whereas in Portugal she would have the support of several family members well integrated in the Portuguese community. ${ }^{393}$ Very importantly, extradition was being requested for prosecution, not for enforcement, which makes the stance of the court even more ground-breaking.

By protecting the requested person from severe personal damage, this ground for refusal inherently protects the ordre public of the Portuguese State, which assuredly encompasses the values at risk here (life, health). Here surfaces again what has earlier been designated as the 'para-human rights character' of this ground for refusal. Nevertheless, case law takes into account the gravity of the acts when determining the scope of this ground for refusal: a proportionality assessment is carried out between the gravity of the acts and the possible impact of extradition on the person, such that the more serious the acts are the less likely it is that extradition will be refused. ${ }^{394}$ Even this trend, however, appears to be in decline, as in the mentioned ruling of 21 May 2015 the Supreme Court held that the gravity of the acts is a matter to be considered strictly under the relevancy thresholds regulated in a separate ground for refusal, and is immaterial when humanitarian concerns are at stake. ${ }^{395}$

In the image of FD-EAW, the PT-EAW contains two provisions concerned with humanitarian issues. On the one hand, the EAW must be refused if the person could not

388 This line of reasoning is visible in the Pinochet case in the UK: see infra, $\$ 4.2.3.

389 See Art. 19 Penal Code.

390 See Manuel António Lopes Rocha / Teresa Alves Martins, op. cit., p. 53.

391 See ibid.

392 No. 16/13.7YREVR.E1.S3, esp. S II.B.5. The ruling confirmed a ruling of the Court of Appeal of Évora of 3 March 2015, which could not be accessed.

393 See $i d$.

394 See the rulings of the Supreme Court of 6 February 2008, no. 369/06, and of 30 October 2013, cit.

395 The ruling does in any case pay consideration to the risk of impunity inherent to a refusal of extradition, such that refusal of extradition on humanitarian grounds will be narrower where Portugal is thereafter unable to conduct a criminal procedure in representation of the requesting State: cit., $\int \mathbb{I I I . 2 .}$ 
be held criminally liable for the acts at issue under Portuguese law owing to his/her age, (as stated, 16 years old). ${ }^{396}$ Age refers to the moment of perpetration, not to the moment of the request. ${ }^{397}$ It has been posited in Portuguese legal literature that this provision also encompasses cases of incapability of guilt owing to mental illness, ${ }^{398}$ but this would arguably have no backing in the FD-EAW, and no ruling could be found where a EAW was refused on this basis. It is quite noteworthy that the young age of the requested person is one of few aspects where the FD gave preponderance to the concepts of the executing Member State rather than to those of the issuing Member State. This denotes the impact that the extradition of a very young person can have on the sense of justice of a community. ${ }^{399}$

On the other hand, Art. 29 (4) PT-EAW establishes that the execution of a EAW may be temporarily postponed for serious humanitarian reasons, for instance where there are substantial reasons to believe that it would manifestly endanger the life or health of the person. While this is not exactly configured as a ground for non-execution, it appears clear that, if the humanitarian reasons endure, this will cause the postponement to be converted into a permanent impossibility of executing the EAW. ${ }^{400}$

\subsubsection{United Kingdom}

According to s. 91, if it appears to the judge that the physical or mental condition of the person is such that it would be "unjust or oppressive" to extradite him, the judge must order the person's discharge, or adjourn the extradition hearing until it appears to $\mathrm{him} /$ her that such a condition is no longer met. This ground for refusal was first introduced in the EA 2003, in reaction to issues which emerged during the Pinochet case: after his extradition was ordered in October 1999, Pinochet suffered a series of strokes, raising the issue as to whether he had become "unfit to stand trial". ${ }^{401}$ The issue was answered in the affirmative by Home Secretary Jack Straw based on "contested medical evidence", 402 and extradition was eventually refused, carrying frustration to the requesting State and to several other parties. During the legislative process leading to the EA 2003, Parliament decided that matters of health should not be left to the discretion of the political branch, but instead should be possible to assess by the courts. ${ }^{403}$

396 Art. 3 (3) FD-EAW and Art. 11 (c) PT-EAW.

397 See the ruling of the Supreme Court of 4 March 2009, no. 09P0685, where the EAW was nevertheless executed, following a clarification that the person was already 16 years old at the time of the first of the several crimes at issue.

398 See INÊs GODINHO, op. cit., p. 135.

399 On the scope of this ground for non-execution of the EAW, see ECJ, Piotrowski (C-367/16), Judgment of 23 January 2018.

400 See further infra, the following $\$$.

401 See Frank Sullivan, JR., “A Separation of Powers perspective on Pinochet”, II\&CLR 14 (2004), p. 438; Christopher L. Blakesley, "The Autumn of the Patriarch: The Pinochet Extradition Debacle and Beyond - Human Rights Clauses Compared to Traditional Derivative Protections Such as Double Criminality", JCL \& 91 (2000), p. 15.

402 Clive Nichols et. al., op. cit., p. 93.

403 See Clive Nichols et. al., op. cit., p. 93; Shrien Dewani v. Government of the Republic of South Africa [2012] EWHC 842 (Admin), \66. 
The fact alone of a person having an illness is insufficient to activate this bar; it is necessary that such an illness renders extradition "unjust or oppressive". ${ }^{404}$ The meaning of this expression in this context is similar to that of passage of time: ${ }^{405}$ "unjust" refers primarily to the risk of an unfair trial; "oppressive" to the hardship possibly endured by the person. ${ }^{406}$ The High Court has held that a high threshold must be attained if an argument under this section is to succeed, the stress and hardship inherent in any extradition being insufficient to that effect. ${ }^{407}$ Risk of suicide, however, may justify refusal. ${ }^{408}$ On the other hand, extraditing a person who is unfit to stand trial - a concept regulated in the Criminal Procedure (Insanity and Unfitness to Plead) Act $1991-{ }^{409}$ will almost inevitably be considered oppressive. ${ }^{410}$ Similarly to what happens in Portugal, but even more clearly so in the UK, the view is that the more serious the acts are, the greater will be the public interest in extraditing the person, and, consequently, the harder it will be for a claim on the basis of this bar to succeed. ${ }^{411}$

An identical ground for refusal is found in s. 25, applicable in cooperation relations with EU Member States. The threshold is even higher here. In $H^{412}$ the High Court refused to discharge the appellant under s. 25. This was due in part to the fact that she was not found to have any illness, but the court noted that in any case it would have assumed that adequate medical care would be provided in Italy, a fellow signatory of the ECHR. Claims can nevertheless succeed, as is illustrated by Jansons, ${ }^{413}$ where the High Court refused to execute a EAW because the person was mentally unfit and the risk of suicide was real; the court did not express any doubts as to the ability of Latvian authorities to provide medical care, but considered that the risk of suicide would increase significantly whichever measures were taken. This provision of the EA complies with Art. 23 (4) FD-EAW. As already noted, the latter provision refers only to the temporary postponement of the exe-

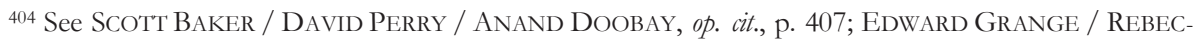
CA Niblock, op. cit., p. 84; Boudhiba v. Central Examining Court No. 5 of the National Court of Justice, Madrid, Spain [2007]1 WLR 124; Prancs v. Rezekne Court of Latvia [2006] All ER (D) 28 (Oct.).

405 See Shrien Dewani, cit., SS 67, 74; see supra, \$ 3.3.3.

406 See ScotT Baker / David Perry / AnAnd Doobay, op. cit., p. 406 f.; Shrien Dewani, cit., $\int 67$.

407 See Clive NiCHOLS et. al., op. cit., p. 94; Shrien Dewani, cit., $\int 73$.

408 See Edward Grange / REbeCCA Niblock, op. cit., p. 84 f. and case law cited therein.

${ }^{409}$ See R. D. MACKAY, “Unfitness to plead - some observations of the Law Commission's consultation paper", CLR 6 (2011), p. 443 f., stating that this institution is "designed to protect those defendants whose mental or physical conditions prevent them from being able to participate and engage effectively in the criminal trial process"; see further LAURA MCDAVITT, "Unfitness to plead: the Law Commission's report", $A B 2$ (2016), p. $5 \mathrm{f}$.

410 See Clive Nichols et. al., op. cit., p. 94; Julian B. KNOwles, op. cit., p. 65; R (Warren) v. Secretary of State for the Home Department [2003] EWHC 1177 (Admin), SS 26 f. Nevertheless, if the requesting State disputes that the person is unfit to plead, it should in principle be for that State to assess the issue in the course of the respective criminal proceedings, provided that it has a proper and fair procedure to carry out such an assessment: see ROSEMARY DAVIDSON, "Bars to Extradition”, op. cit., p. 57.

411 See SCOTt BAKer / David Perry / AnAnd Doobay, op. cit., p. 407; Clive Nichols et. al., op. cit., p. 94; $R$ (Ahsan) v. Government of the United States [2008] EWHC 66 (Admin), \ 68; Spanovic v. Government of Croatia and another [2009] EWHC 723 (Admin), S 39.

${ }^{412}$ HH v. Deputy Prosecutor of the Italian Republic, Genoa, [2011] EWHC 1145 (Admin).

413 Jansons v. Riga District Court, Latvia [2009] EWHC 1845 (Admin). 
cution of a EAW, but, insofar as humanitarian concerns endure, that may equate to a refusal. ${ }^{414}$

There is a significant overlap between this bar and the human rights bar addressed previously. Although the threshold is also quite high in the latter case, ${ }^{415}$ UK courts have ruled that Arts. 2 and/or 3 ECHR may be breached by extraditing someone who is physically or mentally ill, ${ }^{416}$ or shows a high risk of suicide. ${ }^{417-}$ The bars are not identical: ss. 25 and 91 are wider, in that they may cover any situation where extradition would be "harsh, wrong or unfair" ${ }^{\prime 418}$ due to an illness. ${ }^{419}$ The overlap does in any case suggest that their rationales are identical, which again evinces the 'para-human rights character' of the ground for refusal analysed here. The paramount importance of life and health should mean that this ground of refusal is also necessary to preserve the ordre public of the UK.

To be more specific, the humanitarian bar is closely linked to the refusal of extradition via the human rights bar on the basis of Art. 8 ECHR (sc. right to respect for private and family life). Art. 8 ECHR provides that everyone has the right to respect for his/her private and family life, his/her home and his/her correspondence. Unlike Art. 3 ECHR, Art. 8 is a merely relative human right. Interference by public authority in the exercise of this right is possible (although it is possible only) in accordance with the law and if it is necessary in a democratic society in the interests of national security, public safety or the economic wellbeing of the country, the prevention of disorder or crime, the protection of health or morals, or the protection of the rights and freedoms of others. One case that is particularly noteworthy in this regard is $H H$ \& others, ${ }^{420}$ described by the House of Lords Select Committee on Extradition Law. ${ }^{421}$ The case involved three appeals. Two of the appellants $(\mathrm{HH}$ and $\mathrm{PH})$ were married with three young children $(\mathrm{HH}$ being the mother and $\mathrm{PH}$ the father), and were wanted in Italy. The other appellant (F-K) had five children,

414 Such is the position defended in Clive NiCHOLS et. al., op. cit., p. 93, supported on the Commission proposal which lead to the FD-EAW, which mentioned that this provision was concerned with "concrete situations in which the EAW should not be executed on account of the practical situation of the person, and in particular his health" (emphasis added).

415 In her speech before Parliament announcing her decision to block the extradition of Gary Mckinnon, then Home Secretary Theresa May stressed that extradition "is a vital tool in a world where criminals and crime can easily cross borders" and that Mckinnon was "an exceptional case" (cit., starting at 01:29). It is not fully clear to this author whether the refusal was based on the human rights bar or on the humanitarian bar, but the assumption is being made that it was based on the latter, because intervention by the executive branch in regard of the former had been fully entrusted to the judicial branch by EA 2003 (s. 91), following the Pinochet case: see supra, in the text. In any case, after the refusal of the request for Gary Mckinnon, the Home Secretary promoted a similar change in respect of the human rights bar, although in this instance political intervention has not been completely proscribed (s. 83 (3) EA 2003).

416 See McKinnon v. Secretary of State for the Home Department [2009] EWHC 2021 (Admin), SS 67-71. In the case law of the ECtHR, see Pretty v. UK, no. 2346/02, 29 April 2002, \ 52, although it refers to deportation rather to extradition.

417 See Clive NiCHOLS et. al., op. cit., p. 131; Shrien Dewani, cit., \87; Wrobel v. Judicial Authority of Poland [2011] EWHC 374 (Admin); Sbar v. The Court of Bologna [2010] EWHC 1184 (Admin); Jansons, cit.

418 Ibid., p. 94.

419 See Shrien Dewani, cit., \S 37 f., $70,87$.

${ }^{420}$ See HH v. Deputy Prosecutor of the Italian Republic, Genoa (Official Solicitor intervening), PH v. Deputy Prosecutor of the Italian Republic, Genoa, F-Kv. Polish Judicial Authority [2012] UKSC 25, [2012] 3 WLR 90.

421 Op. cit., p. $131 \mathrm{f}$. 
and was sought by Poland. Regarding F-K, Baroness Hale held that: "During that lapse of time, the appellant and her family have made a new, useful and blameless life for themselves in this country. Two more children have been born (...). At neither time did the parents have any reason to believe that the Polish authorities were seeking the mother's return." 422 The Court held unanimously that extradition would be disproportional in view of F-K's Art. 8 rights. Regarding $\mathrm{HH}$ and $\mathrm{PH}$, the Baroness held: "The circumstances in this case can properly be described as exceptional. The effect upon the children (...) of extraditing both their parents will be exceptionally severe." In her view, HH's extradition, however, could not be discharged, because, on the one hand, HH's mental capacity made her unsuitable to look after the children alone, and, on the other hand, Italian authorities regarded her offences to be more serious than those of $\mathrm{PH}$. Consequently, together with all other members of the Court, she dismissed the appeal. However, she dissented in regard of PH, the father. In her view, his appeal should have been allowed, because his offences were less serious, and, as indicated, the effect of extraditing both parents would be "exceptionally severe". However, the other six members of the Court concluded that the strong public interest in extradition outweighed the painful and damaging effects of separation for the children, and dismissed his appeal as well. Baroness Hale summarised the conclusions to be drawn from case law on Art. 8 in these terms: "(1) There may be a closer analogy between extradition and the domestic criminal process than between extradition and deportation or expulsion, but the court has still to examine carefully the way in which it will interfere with family life. (2) There is no test of exceptionality in either context. (3) The question is always whether the interference with the private and family lives of the extraditee and other members of his family is outweighed by the public interest in extradition. (4) There is a constant and weighty public interest in extradition: that people accused of crimes should be brought to trial; that people convicted of crimes should serve their sentences; that the UK should honour its treaty obligations to other countries; and that there should be no 'safe havens' to which either can flee in the belief that they will not be sent back. (5) That public interest will always carry great weight, but the weight to be attached to it in the particular case does vary according to the nature and seriousness of the crime or crimes involved. (6) The delay since the crimes were committed may both diminish the weight to be attached to the public interest and increase the impact upon private and family life. (7) Hence it is likely that the public interest in extradition will outweigh the Art. 8 rights of the family unless the consequences of the interference with family life will be exceptionally severe." 423

The House of Lords Select Committee on Extradition Law also provide an account of the current situation. ${ }^{424}$ To some, the impact of $H H$ is still to be seen; somewhat "like watching a lake into which a very large rock has been thrown. Ripples are still reaching the edges but the surface of the water is starting to settle." 425 Most people however agree that

$422 \int 47$.

${ }^{423}$ House of Lords Select Committee on Extradition Law, op. cit., p. 8.

${ }^{424}$ Idem, p. $21 \mathrm{f}$.

${ }^{425}$ Ibid., p. 23, paraphrasing Daniel Sternberg; only one interviewee (Liberty) seems to consider the bar in relation to Art. 8 to be too high: ibid, p. 23 . 
the blocking effects of Art. 8 increased significantly. This is notably the perspective of the Crown Prosecution Service, which stated: "It seems to us that it has become much easier to avoid extradition on the basis of Art. 8 or because of delay in seeking surrender where the offence might not be thought of as particularly serious. Any suggestion that there is a test of 'exceptionality' has been swept away". ${ }^{426}$ Indeed, since $H H$ Art. 8 has been used more and more often, including - in the view of Sternberg - "by persons who may have committed very minor offences, such as shoplifting or minor road traffic offences. Although they may not have children in this jurisdiction, the fact that they have established themselves here is a basis on which extradition is being refused." ${ }^{9427}$ Kaim Todner Ltd., a firm of solicitors, went so far as to claim that in all cases extradition could now to an extent be regarded as a breach of the requested person's Art. 8 rights. ${ }^{428}$

Also peripherally related to humanitarian concerns is the bar contained in s. 15, on the age of the requested person. Based on this norm - which applies only in the context of the EAW -, extradition shall be refused if the person, owing to his/her age, could not be guilty of the offence if it had been committed in the UK. The age of liability in England and Wales is 10 years old (s. 50 Children and Young Persons Act 1933), in Northern Ireland as well (Art. 3 Criminal Justice Order 1998), and in Scotland 8 years old (s. 41 Criminal Procedure Act 1995). ${ }^{429}$ This makes this bar virtually inapplicable, as there currently is no country in the EU where criminal liability starts at a lower age. ${ }^{430}$

\subsection{International immunities}

\subsubsection{United Nations}

Neither the Model Treaty or the Model Law contain grounds for refusal concerning international immunities. Art. 3 (e) MTE provides as a mandatory ground for refusal the circumstance that the person concerned has "become immune from prosecution or punishment for any reason, under the law of either Party", but the norm refers to such situations as amnesty and lapse of time. The fact that the norm mentions "the law of either Party" is symptomatic that it is not concerned with immunities stemming from international law. ${ }^{431}$

\subsubsection{Portugal}

No such grounds for refusal are to be found in the PT-L, the FD-EAW or the PTEAW either. Its applicability in Portugal derives strictly from international law.

\footnotetext{
426 Ibid, p. 22.

${ }^{427}$ Ibid, p. 23.

428 Ibid.

429 See SCOTt BAKer / DAvid PERry / ANAND DOObay, op. cit., p. 347, 378.

430 See Edward Grange / REBECCA Niblock, op. cit., p. 68.

431 The Revised Manuals do not address international immunities in the paragraphs on this norm: cit., p.
} $19 \mathrm{f}$. 


\subsubsection{United Kingdom}

UK law does contain its own norms on international immunities: the Diplomatic Privileges Act 1964 (s. 1 and sch. 1), implementing the 1961 Vienna Convention on Diplomatic Relations, confers absolute immunity from arrest on diplomats, members of their families and their immediate households, which extends to extradition; ${ }^{432}$ in turn, s. 20 (1) (a) State Immunity Act 1978 confers identical immunity on foreign heads of State while visiting the UK. ${ }^{433}$ Other figures, such as members of special missions and certain foreign ministers, are immune from extradition on the basis of international law 'only'. ${ }^{434}$

\section{Grounds for refusal related to the misuse of extradition proceedings by the requesting State}

\subsection{Specialty}

\subsubsection{United Nations}

Art. 14 (1) (a) Model Treaty enshrines the specialty rule, a "widely recognized international principle (...) which limits the power that the requesting State has over the person surrendered" ${ }^{435}$ According to that provision, a person who has been extradited "shall not be proceeded against, sentenced, detained, re-extradited to a third State, or subjected to any other restriction of personal liberty in the territory of the requesting State for any offence committed before surrender (...)" other than that for which extradition has been granted. The Model Law uses a similar wording in s. 34 (1), and in s. 34 (4) it contains a specification which in the Model Treaty is provided only as a footnote and in somewhat less detailed and definite terms: "When the description of the offence charged is altered in the course of proceedings in [the requested State], the extradited person may only be proceeded against [etc.] in so far as the offence is based on the same facts and under its new description is shown to be offence which would allow extradition carrying out the same or lesser penalty as the original offence for which extradition (...) was granted".

Neither of the model instruments configures the specialty rule in such a manner as to allow for extradition to be refused if the requested State lacks a guarantee that the rule will be fulfilled by the requesting State. The Revised Manuals imply that legislation adopted on the basis of the Model Treaty should establish as a condition for granting extradition that the requesting State give an undertaking or assurance that it will respect the rule; however, they also mention that a State may "be taken to have given such an assurance" if it is bound to apply the rule of specialty on the basis of a provision of its own law or of an applicable treaty where the rule is enshrined. ${ }^{436}$

\footnotetext{
432 Clive NiCHOLS et al., op. cit., p. 99.

433 Ibid.

434 Ibid.

435 UNODC, "Revised Manuals on the Model Treaty..." op. cit., p. 52.

436 Ibid., p. 54.
} 
The model instruments admit that the rule be dispensed with in certain cases, particularly if the requested State so consents. The Model Treaty provides in Art. 14 (1) (b) that such a consent "shall be given if the offence for which it is requested is itself subject to extradition in accordance with the present Treaty". This condition is not present in the Model Law, and this difference does not appear to be innocuous: by requiring that authorisation be given to the requesting State to proceed against the person for acts that were not covered in the request whenever the conditions set in the Model Treaty are met, the Model Treaty suggests that in such cases there will exist no margin for political discretion on the part of the requested State, even if it did exist in respect of the original request. In any case, the fact that the extraditing State must still, if only formally give its consent conveys the ancillary character of the specialty rule for preserving the integrity of the extradition process: it "ensures that the requested State is aware of what it consented to when it ordered the extradition of a person in its jurisdiction to the requesting State". ${ }^{437}$ Thereby, it also ensures that "the suspect was aware, both during his extradition hearing and afterwards, what the allegations against him are". 438

According to the Model Law the specialty rule will also be derogated from if extradition was granted through a simplified procedure (i.e. with the consent of the person), ${ }^{439}$ and the person renounced his/her entitlement to the rule: s. 34 (1) (c). The Model Treaty admits similar results through a footnote to Art. 6, on simplified extradition. However, neither of the model instruments makes it clear whether waiver of the specialty rule by the person dispenses with the authorisation of the requested State. A positive answer would mean that a person may consent to being extradited even if grounds for refusal are met which protect interests of the requested State.

Both instruments establish, with minor variations, that the protection conferred by the specialty rule will also cease if the person had an opportunity to voluntarily leave the territory of the State to which he/she was extradited and has not done so within a given period of time (30/45 days) of his/her final discharge in respect of the offence for which he/she was extradited or if he/she has voluntarily returned to that territory after leaving it. $^{440}$

\subsubsection{Portugal}

Pursuant to Art. 16 (2), a person who is extradited from Portugal - either as a suspect, as an accused, or as a convict - shall not be proceeded against, sentenced, detained, or in any way limited in his/her personal freedom for any act committed or sentence passed prior to his/her departure from Portuguese territory other than those indicated in the extradition request. In turn, Art. 16 (3) provides that Portugal must refuse extradition if the requesting State does not guarantee that it will comply with those conditions.

Specialty is regarded as pivotal for ensuring the efficacy of other requirements, particularly dual criminality. In the words of the Supreme Court, it functions as a "reaction

437 UNODC, "Manual on Mutual Legal Assistance and Extradition”, op. cit., p. 48.

438 Ibid.

439 See s. 27 MLE.

440 Art. 14 (3) MTE, and s. 34 (1) (b) MLE. 
against 'deceitful requests', where extradition is requested for certain acts but in the end the person is tried for other acts that were not mentioned." 441 The Court adds that breaching the rule of specialty denotes "disregard for the conditions imposed by the requested State and, in this sense, for that State itself'. This is why it was traditionally considered an affront to "sovereignty". Over time, like other extradition rules, speciality developed an important function of individual protection. In that same ruling the Supreme Court notes this evolution, and construes specialty as something of a 'right to a fair extradition process', more precisely as a manifestation of the principle audi alteram partem: a breach of the rule of specialty means that the individual was denied the chance to defend him/herself (against extradition) for the unmentioned acts.

The mixed character of the specialty rule in terms of its beneficiaries (sc. requested State and concerned person) is reflected in the conditions in which it can be dispelled. The views of the person concerned must always be considered, but it is necessary (unless otherwise provided for in an applicable treaty) that the State agrees to the non-application of the rule. ${ }^{442}$ The relevance assigned to the person's opinion shows the eminent function of individual safeguard of the rule; the fact that such an opinion is insufficient to dispel it shows its importance to the requested State. This arrangement is consistent with the general rules on consent to being extradited: according to Art. 40 (3), if a person consents to his/her extradition, the "conditions necessary for extradition to be granted" must still be met, which equates to requiring that no interests of the requested State expressed in applicable grounds for refusal be thwarted. ${ }^{443}$ For example: if a State to which a person had been extradited intended to prosecute him/her for acts unmentioned in the extradition request and punishable with a life-long sentence, ${ }^{444}$ and if for some farfetched reason the person wished to waive the protection conferred on him/her by the specialty rule, then such a waiver would be immaterial, since Portugal would have a duty to uphold its prohibition to extradite concerning the applicability of life imprisonment. ${ }^{445-446}$

The specialty rule will also cease if the person had the opportunity to leave the territory of the State to which he/she was extradited and did not do so, or did do it but later returned voluntarily to that territory: Arts. 16 (4) (a).

${ }^{441}$ Ruling of the Portuguese Supreme Court of Justice of 11 January 2012, process 111/11.7YFLSB also the other quotes in this paragraph.

442 See Arts. 16 (4) (b), 17 (2) and 54 (1), (3) and (4).

443 See António Miguel Veiga, "Da Relevância da Vontade do Visado na Extradição Passiva e na Execução do Mandado de Detenção Europeu”, RPCC 22 (2012), p. 600 f.

444 The same example is provided by MANUEL ANTÓnIO Lopes Rocha / TERESA Alves MARTINS, op. cit., p. 87, though not specifically in relation to the rule of specialty.

${ }^{445}$ In the notorious Abu Salem case, Portugal granted extradition to India for certain offences, and India later prosecuted for further offences which carried a life sentence. Portugal revoked its decision to grant extradition, thereby rendering unlawful India's custody over Salem: see the ruling of the Constitutional Court no. 360/12, of 5 July 2012, with reference to the relevant rulings of the Court of Appeal of Lisbon and of the Supreme Court. In this case, as is more common, the requested person had not consented to being tried for the acts unmentioned in the extradition request.

${ }^{446}$ In this sense, case law on consent to extradition and waiver of the specialty rule could form a superb setting for developing clearer constructions on the rationales of grounds for refusal of extradition. Unfortunately (to that effect), specialty is seldom waived and extradition seldom consented to. 
The principle of specialty is also enshrined in the FD-EAW, and is implemented in Art. 7 PT-EAW. Unlike what happens in classic extradition, in the case of the EAW it is not configured in such a manner as to enable refusal, but quite simply enunciated as a rule that is supposed be complied with by the issuing Member State.

\subsubsection{United Kingdom}

According to ss. 17 and 95 - applicable to category 1 and category 2 States, respectively -, extradition cannot be granted if there are no speciality arrangements with the requesting State. In category 1 cases this bar is assessed by the court at the extradition hearing, and in category 2 cases by the Home Secretary, after the extradition hearing. ${ }^{447}$ In the UK, the specialty rule is also seen as a "long-standing protection" of extradition law. ${ }^{448} \mathrm{It}$ is considered necessary to "avoid abuse of the extradition process" by the requesting State - for instance, by requesting extradition for an offence which is not time-barred and then prosecuting for one which is. ${ }^{449}$

The applicability of a specialty bar to EAW's issued by other EU Member States apparently stands in conflict with the FD-EAW, which as noted above concerns the issuing Member as the proper forum for addressing a possible breach of the specialty principle. In practice, however, it is virtually impossible to establish that no speciality arrangements are in place, as all Member States are parties to the 1957 Extradition Convention, and this instrument contains a provision on specialty. ${ }^{450}$

According to \S 53 and 278 of the Explanatory Notes of the EA 2003, the speciality rule ceases to apply if the agreement of the UK is obtained, or the person has had an opportunity to leave the territory of the State to which he/she was extradited but did not do so. ${ }^{451}$ Arguably, the agreement of the UK may be dispensed with if a treaty concluded by the UK provides that the specialty rule may be dispelled in more flexible conditions.

\subsection{Earlier extradition (or limitation on re-extradition)}

\subsubsection{United Nations}

The model instruments place limitations on the prerogative of States to re-extradite individuals who have been extradited to them by other States. However, they regulate this issue within the provisions on the specialty rule, assessed above, without meaningful particularities.

\subsubsection{Portugal}

Art. 34 limits re-extradition. According to this provision, a State that has obtained custody of a person in result of extradition cannot re-extradite him/her to a third State. Such a prohibition will cease if: (a) authorisation for re-extradition is requested and grant-

${ }^{447}$ See Edward Grange / RebecCA Niblock, op. cit., p. 69.

448 See the Explanatory Notes of the Extradition Act 2003, cit.

${ }^{449}$ See Alastair Brown, op. cit., p. 23.

450 See ibid.; Hilali v. National Court of Madrid [2006] EWHC 1239 (Admin), \52.

451 In http://www.legislation.gov.uk/ukpga/2003/41/notes. 
ed in the same terms as those established for an extradition request, after the person concerned has been heard, or (b) the extradited person, having been given the possibility to leave the territory of the requesting State, did not avail him / herself of that possibility within a period of 45 days or, having left the country, has voluntarily returned to it. The prohibition will also cease if, by virtue of a treaty binding on Portugal, the consent of the requested State is not required.

As can be observed, although this issue is regulated separately from that of specialty, the two have little conceptual autonomy. Limitations of the power to re-extradite are a "necessary consequence" of the speciality principle. ${ }^{452}$ Both translate the notion that the validity of extradition is limited to the specific ends for which it is granted, and the notion that the extradited person retains a connection with the State that extradited him/her until those ends have been met. ${ }^{453}$ The only significant difference appears to be that, in the case of re-extradition, Portuguese law does not explicitly establish that extradition must be refused in the absence of guarantees from the requesting State that it will not reextradite the person. In any event, this situation may always be tended by the executive branch, in its political assessment of the request.

Art. 8 PT-EAW contains a provision limiting the possibility to grant extradition or execute a EAW of a person whose custody was obtained by Portugal owing to a EAW. This is consistent with Art. 28 FD-EAW, which ultimately also regards this issue as an implicit ground for non-execution, although it is not included in Arts. 3 and 4, or even 5, which supposedly are the only provisions that could establish grounds for non-execution.

There seems to be a significant difference in this regard between the UN model instruments and the Portuguese legal system: in the latter case, limitations of re-extradition apply to any acts that occurred before (the first) extradition was granted, whereas in the former (which assimilate re-extradition and specialty completely) those limitations appear to apply only to $\operatorname{acts}^{454}$ other than those for which (the first) extradition had been obtained. This difference will be addressed later in the study. ${ }^{455}$

\subsubsection{United Kingdom}

The situation is quite similar in the UK: the same reasons that justify the existence of the speciality rule also prevent the UK from re-extraditing a person whose custody it had obtained after an extradition granted by another State. ${ }^{456}$ This bar is provided for in ss. 18 and 19 (insofar as it concerns EU Member States), and in s. 96 (insofar as it concerns other States).

As noted above, in its Art. 28 the FD-EAW limits extradition or surrender of individuals whose custody has been obtained through the EAW system, and this regime can

452 MANuel António Lopes Rocha / Teresa Alves MARTins, op. cit., p. 78 f., arguing that the main reason why re-extradition is regulated in a separate norm is that it applies only to extradition, while specialty also applies to other cooperation mechanisms, such as the transfer of sentenced prisoners.

453 See ibid.

454 Also committed prior to the first extradition.

455 Namely in Chap. 8, \3.5.2.

456 See Clive NiCHOLS et al., op. cit., p. 88. 
be considered a ground for refusal (of the EAW or of extradition, depending on the case). Thus, unlike other aspects in which the EA 2003 is at odds with the FD-EAW (including the specialty rule), it is entirely consistent with the FD-EAW when it explicitly conceives 'earlier extradition' as a bar to the execution of a EAW or of an extradition request.

As with the specialty rule, the norms on 'earlier extradition' do not create an absolute prohibition: re-extradition may take place if the State that had granted extradition to the UK consents to it, as well as if this consent is unnecessary in the light of a treaty applicable to the case or, in the case of the FD-EAW, allowed under its Art. 28. ${ }^{457}$

The difference between the UN model instruments and the Portuguese legal system, mentioned at the end of the previous paragraph, applies also to the legal system of the UK. Here too the limitations on re-extradition apply to any acts which took place before (the first) extradition, rather than only to $\operatorname{acts}^{458}$ other than those for which (the first) extradition had been obtained.

\subsection{Abuse of process jurisdiction}

\subsubsection{United Nations}

There is no such ground for refusal in the UN model instruments.

\subsubsection{Portugal}

There is no such ground for refusal in the Portuguese legal system.

\subsubsection{United Kingdom}

Although the EA 2003 does not explicitly provide so, courts in England, Wales and Northern Ireland ${ }^{459}$ have developed the rule that abuses of the court's process by the requesting State bar extradition, in what is generally known as 'abuse of process jurisdiction'. ${ }^{460}$ This bar to extradition applies to both category 1 and category 2 States. ${ }^{461}$ Its applicability in the context of the EAW stands in blatant conflict with the FD-EAW, which does not provide for any ground for refusal that might barely resemble this one.

This is a residual jurisdiction that can be exerted only where all other bars to extradition have failed, ${ }^{462}$ and it covers essentially cases where: (a) the request is made for collateral purposes (maxime political); (b) criminal proceedings in the requesting State breach

\footnotetext{
457 See R. v. Secretary of State for the Home Department exp Johnson [1999] QB 1174, decided under the 1957 European Convention on Extradition.

458 Also committed prior to the first extradition.

459 According to ScOTT BAKer / David PERry / AnAND DoObay, op. cit., p. 276, in Scotland there is no abuse of process jurisdiction as such.

460 See ScotT BAKer / David Perry / AnAnd Doobay, op. cit., p. 275; House of Lords Select Committee on Extradition Law, op. cit., p. 14; EDWARD GRANGE / REBECCA NiBLOCK, op. cit., p. 86; R. (Kashamu) v. Governor of Brixton Prison (No 2) [2002] QB 887, esp. \$S 27 f.; R. (Bermingham and other) v. Government of the USA and another [2006] EWHC 200 (Admin).

461 Clive Nichols et. al., op. cit., p. 96 f.

462 See Edward Grange / Rebecca Niblock, op. cit., p. 86; Loncar v. County Court in Vukovar Croatia [2015] EWHC 548 (Admin), esp. \ 22.
} 
fundamental principles of justice and rule of law; (c) the acts for which extradition is requested relate very closely to an offence for which the person has already been prosecuted; and (d) the requesting State knows that the criminal proceedings that it is carrying out are fated to fail. ${ }^{463}$ These are instances where extradition proceedings are used to "oppress or unfairly prejudice a defendant", ${ }^{664}$ where the request is made "for improper reasons or pursued in a vexatious or oppressive manner" ${ }^{465}$ where there is something "so unfair and wrong with the prosecution that the court should not allow the case to proceed"; 466 in sum, where it would be an "affront to justice" to extradite the person. ${ }^{467}$

This will not necessarily be due to bad faith on the part of the authorities of the requesting State that submit the request (e.g. a Minister of Justice). It may result from corrupt or dishonest conduct by the parties intervening in the underlying criminal procedure taking place in the requesting State (e.g. judges, prosecutors, the police, witnesses). ${ }^{468}$ The court must assume that the requesting State is acting in good faith, but such an assumption can be rebutted on the basis of cogent evidence. ${ }^{469}$

Considering its scope, this bar can be regarded as a prolongation of other grounds for refusal provided for in EA 2003 - namely extraneous considerations, undue process and double jeopardy $-{ }^{470}$, and a compensation for the inapplicability of the prima facie case requirement, in cases where it does not apply. ${ }^{41}$

\section{Grounds for refusal related to mere issues of interstate allocation of jurisdiction}

\subsection{Territoriality}

\subsubsection{United Nations}

The fact that the acts were committed in the territory of the requested State constitutes a ground for refusal under the Model Treaty: Art. 4 (f). According to Swart it is "one of the oldest concerning concurrent jurisdiction". ${ }^{472}$ The Model Law confers discretion on the executive branch of the requested State to refuse extradition if the acts are regarded under its law as having been committed, in whole or in part, within its territory: s. 26 (4) and (b). In both cases refusal is optional.

463 See House of Lords Select Committee on Extradition Law, op. cit., p. 90 f.; EDward GranGE / REBeCCA Niblock, op. cit., p. 86 f.; Clive NiCHOls et. al., op. cit., p. 96 f.; Symeou v. Public Prosecutor's Office Patras Greece [2009] EWHC 897 (Admin), and other case law mentioned in the previous and subsequent fn.

464 Scott Baker / David Perry / AnAnd Doobay, op. cit., p. 275; R. (Bermingham) and others v. Director of the Serious Fraud Office [2007] QB 727; R. (Government of the United States of America v. Bow Street Magistrates' Court [2007] 1 WLR 1157; Re Campbell's Applicant [2009] NIQB 82.

465 Clive NiCHOLS et. al., op. cit., p. 94.

${ }^{466}$ House of Lords Select Committee on Extradition Law, op. cit., p. 124.

467 Clive Nichols et. al., op. cit., p. 95.

468 Ibid.

469 See Edward Grange / REBECCA Niblock, op. cit., p. 86 f.

${ }^{470} \mathrm{Cf}$., respectively, with items a), b) and c) above.

471 Cf. item d) above.

472 BERT SWART, "Refusal of Extradition...”, op. cit., p. 212. 
The Model Treaty further provides that if extradition is refused on this ground the requested State must, should the other State so request, submit the case to its competent authorities with a view to taking appropriate action against the person for the acts at issue. The Model Law also prescribes that the applicability of this ground for refusal could be limited to cases where those authorities actually proceed to prosecute the acts.

\subsubsection{Portugal}

In Portugal as in most States, territoriality is the essential principle of jurisdiction in criminal matters. This is unequivocally stated in Art. 4 of the Penal Code, and has been the rule since the first autonomous codification of Portuguese criminal law: the Penal Code of $1852 .{ }^{473}$ The preponderance of territoriality is due mainly to the fact that the locus delicti is the place where punishment is deemed more necessary. As Caeiro articulates: on the one hand, territorial crimes are the ones that raise greater preventative concerns; on the other hand, all territorial crimes raise such concerns. ${ }^{474}$ Moreover, at the procedural level the locus delicti is the most adequate forum to investigate the crime (forum conveniens), and, thus, that where expectations of reaching a fair decision are more justified. ${ }^{475}$ To these reasons it is also usually added that the widespread adoption of territoriality as the primary basis of jurisdiction is the best manner to avoid conflicts of jurisdiction between States. ${ }^{476}$

Portugal extends its concept of 'territory', understood strictly, to crimes committed aboard vessels and planes with Portuguese flag. ${ }^{477}$ It also assigns the concept of 'locus delicti a very broad scope: offences are deemed to have been committed in Portugal if that is the place where, in whole or in part, and whether in the capacity of author or in that of accomplice, the person acted or (in the case of liability for omissions) should have acted, as well as if that is the place where the result materialises; attempted offences are moreover deemed to have been committed in Portugal if that is the place where the person intended the result to materialise. ${ }^{478}$ Furthermore, Portugal has two grounds for extraterritorial jurisdiction $-s c$. the protective principle (which encompasses offences harmful to specific interests of the Portuguese State), and 'dual nationality' (viz: the case where both the perpetrator and the victim are Portuguese nationals) which are not subsidiary to extradition, but which instead allow Portugal to assert jurisdiction even if the State where the offence was committed is itself interested in prosecuting it and requests the extradition of the suspect. ${ }^{479}$

473 See Jorge de Figueiredo Dias, “Compétence...”, op. cit., p. 118.

474 Pedro CaEiro, Fundamento..., op. cit., p. 321, adding that, in this sense, territoriality is rooted more in anthropological factors than in legal and political concepts of sovereignty and State authority. Construing that there is a certain precedence of the anthropological notion of space in relation to its legal and political determination into a territory, the latter being but an acknowledgment by the law of the "cognitive and volitional structure of the concrete person”, see JOSÉ DE FARIA COSTA, Globalização e Direito: Reflexões não locais e pouco globais, Coimbra: Coimbra Editora, 2010, p. 71.

475 See Jorge de Figueiredo Dias, Direito Penal I, op. cit., p. 210.

476 Ibid., p. 209.

477 See essentially Art. 4 (b) Penal Code.

478 Art. 7 Penal Code.

${ }^{479}$ See Art. 5 (1) (a) and (b) Penal Code. 
Coherently with the primacy ascribed to territoriality as a basis for jurisdiction, Portuguese law establishes as a ground for refusal of extradition the circumstance that the crime was committed in Portuguese territory: Art. 32 (1) (a). This ground for refusal admits no exceptions: if the crime is deemed to have been committed in Portuguese territory according to the (very broad) concept of locus delicti described above, extradition must be refused; even if the requesting State also has (as it typically does) territorial jurisdiction, and even if the most significant part of the criminal activity took place in its territory. ${ }^{480}$ In order to protect its sovereignty over acts committed in its territory, Portugal refuses to extradite in each and every case where Portuguese law is territorially applicable. ${ }^{481}$

The fact that the crime was committed wholly or partly in Portugal or aboard Portuguese ships or aircrafts may prevent the execution of a EAW pursuant to Art. 12 (1) (h) (ii) PT-EAW. A significant difference in relation to classic extradition is that, here, refusal is optional, which allows Portugal to execute a EAW if, for instance, the most significant part of the criminal activity was committed in the issuing Member State. ${ }^{482}$ Hence, this grounds for refusal consists of weighing the punitive claim of Portugal against that of the issuing Member State, so as to establish which of them is the most appropriate forum to carry out the criminal procedure or enforce the penalty. ${ }^{483}$ Sometimes, a criminal procedure is carried out in Portugal, and the EAW - which is still necessary for another Member State to prosecute a broader set of correlated criminal acts - is postponed. The person will be protected by the principle ne bis in idem insofar as concerns the acts prosecuted in Portugal, and prosecuted in the issuing Member State for the remaining acts. ${ }^{484}$

480 Portuguese law is aware of the possibility of positive conflicts of territorial jurisdiction when it regulates concurrent extradition requests. Here, it gives preference to the State "where the main act was carried out": Art. 37 (1) (a). In contrast, it does not adopt a similar solution for the cases where Portugal is one of the concurring States. Therefore, in such cases, there appears to be no alternative, de iure dato, to refuse extradition. If this were not the intention of the law, it would not have been necessary for it to provide a specific ground for refusal on territoriality, as the cases where Portugal has a duty or possibility to prosecute (which naturally include the case where the offence was committed in Portugal) are already covered by the general ground for refusal established in Art. 18 (1), analysed infra, \ 6.2.2.

481 Basing this ground for refusal on sovereignty, and stating that its function is to prevent "irremediable alienations" of such sovereignty, see JORGE DE FIGUEIREDO DiAs, "Algumas questões em tema de extradição e de sede do crime [anotação]”, RLJ 118 (1985), p. 18, apparently indorsing the rule.

482 Apparently criticising the optional character of this ground for refusal, and regarding it as a "clear concession" of the jurisdiction of Portuguese courts, see INÊS GODINHO, op. cit., p. $135 \mathrm{f}$.

483 See the rulings of the Supreme Court of 15 March 2006, no. 06P782, 2 January 2008, no. 07P4850, 12 November 2008, no. 08P3709, 25 March 2010, no. 76/10.2YRLSB.S1, and 15 September 2011, no. 92/11.7YRPRT.S1. In the ruling of 12 November 2008, the EAW was refused because Portugal was prosecuting other acts closely related to those giving rise to the EAW and which could activate the rules on concurring offences. What is more interesting, however, is that the Court seems to have weighed this ground for refusal conjointly with that of Art. 12 (1) (g) PT-EAW, on nationality/residence. The Court stated that acts committed in Portugal by a Portuguese national residing in Portugal shall in principle be prosecuted in Portugal. Arguably, such a line of reasoning denies the autonomy which (justifiably) exists between the two grounds for refusal: it is possible that the issuing Member State be the best forum to carry out the procedure (e.g. because most criminal activity occurred there), but Portugal be the best place for rehabilitation, in which case the EAW can be granted and made dependant on the return of the person upon conviction.

${ }^{484}$ See e.g. the ruling of the Supreme Court of 22 June 2006, no. 06P2326. 
It has become a rather stable understanding that the norm of the FD-EAW which establishes this ground for refusal - Art. 4 (7) (a) - was intended, at least in part, to counterbalance or compensate the partial abolition of dual criminality: if the acts were committed in a Member State where they are not criminalised, and are exempt from control of dual criminality due to falling within one of the categories mentioned in Art. 2 (2) FDEAW, that Member State can refuse to execute the EAW based on territoriality. ${ }^{485} \mathrm{How}$ ever, Portuguese case law does not appear to mirror this understanding. Instead, as noted, this ground for refusal is used for deciding which of two competing fora is the most appropriate one for prosecuting the acts in question.

\subsubsection{United Kingdom}

As in virtually all States, the fundamental principle of jurisdiction in the UK is also territoriality. ${ }^{486}$ The primacy assigned to this ground for jurisdiction is particularly strong in the common law tradition, known for its reluctance to prosecute extraterritorial acts. ${ }^{487}$

\section{a) Ordinary reasons for refusal}

If the requested individual is already being prosecuted or serving a sentence in the UK, domestic proceedings take precedence. ${ }^{488}$ According to ss. $8 \mathrm{~A}, 8 \mathrm{~B}, 22,23,36 \mathrm{~A}, 36 \mathrm{~B}$, $76 \mathrm{~A}, 76 \mathrm{~B}, 88,89,118 \mathrm{C}$ and $118 \mathrm{D}$, if the requested person is charged in the UK with an offence - which might be the same one for which extradition is requested $-{ }^{489}$ or is serving a sentence, extradition must be adjourned until one of the following events occurs: (1) the charge is disposed of; (2) the charge is withdrawn; (3) proceedings in respect of the charge are discontinued; (4) an order is made for the charge to lie on the file (or, in Scotland, the diet is deserted pro loco et tempore). It is possible, if unusual, that during the course of an extradition procedure a domestic prosecutor ${ }^{490}$ decides to prosecute for the same offence motivating the extradition request. ${ }^{491}$ This will force the extradition judge to ad-

485 See DANIEL FLORE, "Reconnaissance mutuelle, double incrimination et territorialité", in Gilles de Kerchove / Anne Weyembergh (eds.) La reconnaissance mutuelle des décisions judiciaires pénales dans l'Union européenne, Bruxelles: Ed. de l'Université, 2001, p. 65 f., and "Le mandat d'arrêt européen...”, op. cit., p. 227 f.; Nico KeIJZER, "The Double Criminality Requirement”, op. cit., p. 161; see also SCOTT BAKER / DAVID Perry / AnAND Doobay, op. cit., p. 225, noting that this was how the Proposal of the Commission which gave rise to FD-EAW envisaged that Art. 4 (7) (a) would operate; the authors however add that Art. 4 (7) (a) FD-EAW "is used by some Member States to cater for the situation where the prosecuting authorities in the executing Member State assume responsibility for prosecuting the conduct".

486 See e.g. SCOTt BAKER / DAVID PERry / ANAND DoOBAy, op. cit., p. 218.

487 See e.g. David Ormerod / David Perry (general eds.), Blackstone's Criminal Practice 2016, Oxford: University Press, 26 th ed., 2015, p. 164; ANNE-SoPHIE MASSA, "Jurisdiction in England and Wales and the Netherlands: A comparative appraisal with a European touch”, in André Klip (ed.), Substantive Criminal Law of the European Union, Antwerp: Maklu, 2011, p. $104 \mathrm{f}$.

488 See e.g. SCOTt BAKER / David Perry / AnAND DoObay, op. cit., p. 223; Alastair Brown, op. cit., p. 27.

489 See Clive NiCHOLS et al., op. cit., p. 102.

${ }^{490}$ On the differences between a domestic prosecutor and a prosecutor from the CPS Extradition Unit, see Domminich Shaw v. Government of the USA [2014] EWHC 4654 (Admin), \ 48; see yet s. 83E (2).

491 See ss. 8A-8B, 22-23, 36A-36B, 76A-76B, 88-89, and 118C-118D. 
journ the extradition procedure and give precedence to the domestic criminal procedure, based on the provisions mentioned above. Generally, decisions whether or not to prosecute abide by the Code for Crown Prosecutors, ${ }^{492}$ and, in the case of positive conflicts of jurisdiction (the case at issue here) - assuming that the domestic prosecutor is aware of the transnational character of the offence -, by the Director's Guidance on the Handling of Cases where Jurisdiction to Prosecute is Shared with Prosecuting Authorities Overseas. ${ }^{493}$

The principles enshrined in the latter instrument are the following: (1) First, insofar as charges can properly be brought that reflect the seriousness and extent of the offence supported by admissible evidence, prosecution should ordinarily be brought in the jurisdiction where most of the criminality or most of the loss/harm occurred. (2) Where potentially relevant material may be held in another jurisdiction, the prospects of the material being identified and provided to prosecutors for review in accordance with disclosure obligations in this jurisdiction will also be an important consideration. (3) So long as this is practicable and consistent with the foregoing principles, where the crime is committed in more than one jurisdiction, all relevant prosecutions should be concentrated in one jurisdiction. (4) Other relevant factors include: (i) location of witnesses, their ability to give evidence in another jurisdiction and, where relevant, their right to be protected; (ii) location of the accused and his/her connections with the UK; (iii) location of co-defendants and/or other suspects; and (iv) availability of extradition or transfer of proceedings, and prospects of success of such proceedings. (5) Where all other factors are finely balanced, delays inherent to prosecution in one jurisdiction rather than another and the respective cost and resources may be relevant. (6) The relative sentencing powers and/or powers to recover the proceeds of the crime should not be a primary factor in determining where a case should be prosecuted, but CPS prosecutors should always ensure that sentences and powers of recovery are available which reflect the seriousness and extent of the offence. (7) In cases of concurrent jurisdiction, decisions can be reviewed if circumstances change; however, circumstances will rarely change to such an extent that a compelling case could be made for proceedings already underway in one jurisdiction to be discontinued and commenced instead in another jurisdiction. (8) Unless a crime for which extradition is requested is already being investigated with a view to prosecution, receipt of such a request and any orders made pursuant to such a request do not, without more, require CPS prosecutors to (re)consider whether prosecution should be brought in the UK.

\section{b) The forum bar}

On the other hand, the Crime and Courts Act 2013 introduced a fresh 'forum bar' into ss. $19 \mathrm{~B}-9 \mathrm{~F}$ and $83 \mathrm{~A}-83 \mathrm{E}$, applicable to cases where the person has not yet been, but could be charged with the offence in the UK. ${ }^{494}$ This bar requires the court to refuse extradition if a substantial measure of the person's relevant activity was performed in the UK and extradition would not be in the 'interests of justice'. The latter concept is to be

492 See $\iint$ 3.1. f. On this decision, see DAVID OrMEROD / DAVID PERRY (general eds.), op. cit., p. 1301 f.; Malcolm Davies, Davies, Croall and Tyrer's Criminal Justice, Harlow: Pearson, 2015, p. 249 f.

493 See $\int 8$ (1).

494 See Piotronicz v. Regional Court in Gdansk Poland [2014] EWHC 3884 (Admin), \ 10. 
assessed in the light of the following 'specified matters', which to a large extent resemble the prosecutorial guidelines summarised before: (1) The place where most of the loss or harm resulting from the extradition offence occurred or was intended to occur. (2) The interests of any victims. (3) Any belief of a prosecutor that the UK, or a particular part of it, is not the most appropriate jurisdiction in which to prosecute the person. ${ }^{495}$ (4) Were the person to be prosecuted in the UK, whether evidence necessary to prove the offence is or could be made available there. (5) Any delay that may result from prosecuting in one jurisdiction rather than another. (6) The desirability and practicability of all prosecutions taking place in one jurisdiction, having regard (particularly) to the jurisdictions in which witnesses, co-defendants and other suspects are located, and the practicability of the evidence of such persons being given in the UK or in jurisdictions outside the UK. (8) The person's connections with the UK. The relative weight to be assigned to each of those factors varies on a case-by-case basis. ${ }^{496}$ It is important to mention ss. $19 \mathrm{C}-19 \mathrm{D}$ and 83B83C, which establish that, if a domestic prosecutor issues a certificate stating that an assessment was made as to whether a prosecution should be brought in the UK and it was decided that it should not, because of insufficient evidence, because it would not be in the public interest, or because there are concerns on the disclosure of sensitive material, the court is prevented from considering the issue of forum as a possible bar to extradition. ${ }^{497}$ Such a decision by the prosecutor is also guided by the Code for Crown Prosecutors and the principles enshrined in the mentioned Director's Guidance on the Handling of Cases where Jurisdiction to Prosecute is Shared with Prosecuting Authorities Overseas.

Under previous legislation the issue of forum was a matter for the discretion of the Home Secretary, ${ }^{498}$ subject to judicial review. ${ }^{499}$ However, according to the Baker Review, there is no notice of any instance where such discretion was used. ${ }^{500}$ With the enactment of the EA 2003 this discretion ceased to exist and extradition became possible to challenge on forum grounds only indirectly, via the human rights bar. ${ }^{501}$ Forum issues were always discussed "behind closed doors", ${ }^{02}$ between the UK prosecutor in charge of the case and his/her foreign counterpart, who would evaluate given criteria and try to agree upon where the case should be tried. ${ }^{503}$

495 On this specific item, see Domminich Shaw, cit., $\int S 48 \mathrm{f}$.

496 See again Piotrowicz, cit., $\ 10$, drawing on Dibden (see infra, that following fn.), stating that this constitutes a "fact specific exercise".

${ }^{497}$ See Katherine Tyler / Kingsley Napley / Daniel Sternberg, op. cit., \22; see Dibden $v$. Tribunal de Grande Instance de Lille France [2014] EWHC 3074 (Admin), and Piotrowicr, cit.

498 See Rosemary Davidson, "Bars to Extradition", op. cit., p. 56.

499 See SCOTT BAKer / David PERry / ANAND DoObay, op. cit., p. 206.

500 Ibid., p. 206.

501 See Rosemary Davidson, "Bars to Extradition”, op. cit., p. 56; SCOTT BAKer / David Perry / ANAND DOOBAY, op. cit., p. 206; COLIN WARBriCK, "Recent developments in UK extradition law", I\& CLQ 56 (2007), p. 199 f.; CHRIS STEPHEN, "We want you: extradition in the UK Supreme Court", EdLR 15 (2011), p. 133 f.; see R (Bermingham) v. Director of the Serious Frand Office [2007] QB 727 (the 'NatWest Three' case), \121; Boudhiba v. Central Examining Court No. 5 of the National Court of Justice Madrid Spain [2006] 3 All ER 547 (DC), $\int 43$.

502 See House of Lords Select Committee on Extradition Law, op. cit., p. 44.

503 See ScotT Baker / David Perry / AnAnd Doobay, op. cit., p. 213. 
The question as to whether a forum bar should be introduced was one of the main issues addressed in the Baker Review. ${ }^{504}$ After a thorough analysis, the Review concluded unfavourably to introduction. ${ }^{505}$ It found no evidence that any injustice was being caused by its absence and noted that the extradition judges at City of Westminster Magistrates' Court could not think of any case already decided under the EA 2003 in which it would have been in the 'interests of justice' to prosecute the offence in the UK. ${ }^{506}$ According to the Review, the main problems with the forum bar were that it would "create delay" and "generate satellite litigation" (which would "slow down the extradition process, add to the costs of the proceedings and provide no corresponding benefit"), and that "[p] rosecutors are far better equipped to deal with the factors that go into making a decision on forum than the courts". The forum bar was however introduced by the Crimes and Courts Act 2013, and brought into force in October 2013 in England, Wales and Northern Ireland (but not in Scotland). ${ }^{507}$ The political atmosphere in which the forum bar was enacted was one of public disapproval at the possible extradition of Gary Mckinnon to the USA for cyber-attacks carried out strictly in UK soil. ${ }^{508}$ Mackinnon was diagnosed with Asperger's syndrome and his extradition was eventually barred by the Home Secretary on human rights grounds, ${ }^{509}$ but the case added to an ongoing debate as to the reasonability of extraditing in cases that have a significant link to the UK, an issue the assessment of which had been commissioned by the Home Secretary herself. ${ }^{510}$ The Mckinnon case touched upon other aspects covered by the Baker Review, namely a perceived imbalance in the extradition relations of the UK with the USA (in favour of the latter), and the issue as to whether UK nationality should indeed be irrelevant in extradition decisions taken by the UK. The circumstance of Gary Mckinnon being a UK national reportedly contributed to the public commotion at his possible extradition to the USA. ${ }^{511}$

504 The Review considered a forum bar envisaged in the Police and Justice Act 2006 but never brought into force, and whose main difference in relation to the forum bar presently in force was that it did not allow UK prosecutors to veto consideration of forum by the extradition judge by producing a certificate to the effect that they would not prosecute in the UK: see House of Lords Select Committee on Extradition Law, op. cit., p. $46 \mathrm{f}$. Another difference was that the specified matters that the court must consider are now explicitly and exhaustively indicated in the law, which has been regarded as an improvement: see PAUL ARNELL, “The forum bar to extradition", SLT 24 (2013), p. 169.

505 See ScotT BAKer / David Perry / ANAnd DOOBAy, op. cit., p. 204 f.

506 See ibid., p. 230.

507 See House of Lords Select Committee on Extradition Law, op. cit., p. 46. The reasons for the forum bar not to have been adopted in Scotland are explained in PAUL ARNELL, "Extradition and the right to a fair trial - Case Comment", SLT 36 (2013), p. 247 f.: "the operation of the forum bar may entail a review of prosecutorial discretion - something inimical to the well established position of the Lord Advocate as master of the instance."

508 See e.g. AsIF EFRAT, op. cit., p. $122 \mathrm{f}$.

509 The speech (16 October 2012) where then Home Secretary Theresa May informed Parliament of her decision on Mckinnon is the same where she announced her plans to enact a forum bar and other new bars to extradition: in www.youtube.com/watch?v=5MEQVo8ENC8, last accessed 11 February 2018.

510 The Review, as just mentioned, did not endorse the enactment of a forum bar. In the same speech, the Secretary acknowledged this and stated that the design to be given to the future forum bar would take into account the concerns expressed in the Baker Review: see ibid, starting at 04:46.

511 See ASIF EFRAT, op. cit., p. 122; see further infra, in the text, shortly below. 
As stated before, domestic proceedings in the UK take precedence. Thus, a forum bar was not absolutely necessary to protect the exercise of territorial jurisdiction by the UK. In fact, the requirement that a substantial measure of the criminal activity has taken place in the UK is to be regarded as a mere "threshold or qualifying condition": $: 512$ if it is met, then it entitles the court to assess whether extradition would be in the interests of justice'; but the latter is the concept that constitutes the "ultimate test". ${ }^{513}$ The forum bar appears instead to have been aimed at allowing for a process whereby prosecutors' decisions not to charge the person in the UK (thereby allowing for him/her to be extradited) could be "directly scrutinised in open court", rendering this part of the proceedings "more transparent". ${ }^{514}$ In this sense, the forum bar sought to bring the interests of the individual to the forefront in the context of decisions on allocation of jurisdiction. It is in this line that the Baker Review notes that the rationale underlying this bar "is that where a person has committed an offence largely or partly in the UK, indeed perhaps without ever having left these shores, the extradition judge should have the power to prevent extradition and that the requested person should be prosecuted in the UK rather than in the requesting overseas territory, particularly if his extradition would cause disruption to his life, his work or his family." ${ }^{515}$ In fact, from the submissions assessed, the Review detected a sentiment that UK citizens or permanent residents should be tried in the UK whenever possible. ${ }^{516}$ The same transpires from the Report of the House of Lords Select Committee on Extradition Law. ${ }^{517}$ This view has no doubt been instilled into the law, as one of the specified matters that the judge must consider when applying the forum bar are the "person's connections with the UK" - a factor which in any case was already present in the prosecutorial guidelines described above. ${ }^{518}$ There is also an overlap here with the human rights bar (on the basis of Art. 8 ECHR), where the impact of extradition upon the person's life and relationships in the UK is weighed against the public interest in extraditing. ${ }^{519}$

Another concern related to the forum bar is the exercise by some States of 'exorbitant jurisdiction', i.e. jurisdiction which is extraterritorial or has a very tenuous territorial element. ${ }^{520}$ A typical example is the jurisdiction of the USA over wire and mail frauds, offences that can be prosecuted even if only marginally connected to the USA, e.g. because a simple email was sent through a server located there. ${ }^{521}$ In the past, this could give rise to a decision to refuse extradition on several grounds: first, it could be mobilised by the Home Secretary in the exercise of his/her discretion; second, it could trigger Art. 8 ECHR via the human rights bar (proportionality); third, the very concept of 'extradition offence'

512 See Piotrowicz, cit., $\ 10$.

513 Id.

514 See House of Lords Select Committee on Extradition Law, op. cit., p. 52.

515 See SCOTT BAKer / David Perry / AnANd DoObay, op. cit., p. 208.

516 See ibid., p. 222.

517 See House of Lords Select Committee on Extradition Law, op. cit., p. 50 f.

518 See, however, infra, $\ 3$ 3.4.1.c), elaborating on why this does not amount to a nationality exception.

519 See House of Lords Select Committee on Extradition Law, op. cit., p. 51; PAUL ArNELL, "The forum bar to extradition", op. cit., p. 170.

520 See SCOTt BAKer / DAvid Perry / ANAND DOOBAy, op. cit., p. 218; see supra, S 3.4.3.

521 See ibid., p. $218 \mathrm{f}$. 
entails that the UK can extradite for offences committed outside of the territory of the requesting State only if the UK would be able to exert extraterritorial jurisdiction in similar conditions. ${ }^{522}$ However, those grounds for refusal have autonomous rationales and, as such, do not cover many of the situations that are now encompassed by the forum bar.

It is very important to stress that, unlike what happens in other States, such as Portugal, the fact alone that part of the criminal activity (even a 'substantial' part of it) took place in the UK does not necessarily carry extradition to be refused. Dibden, the first case to make substantive arguments on the forum provisions of EA 2003 as bases for an appeal against extradition, illustrates this well. ${ }^{523}$ It was a EAW case, but the forum bar operates identically with regard to category 2 States. The case is described by the House of Lords Select Committee on Extradition Law (2015): Dibden faced charges in France of drug smuggling from the Netherlands to the UK through France. Two other co-accused were arrested in France with more than $60 \mathrm{~kg}$ of amphetamines and $6 \mathrm{~kg}$ of cocaine, which they planned to carry into the UK in a microlight airplane. Dibden was based in the UK the whole time, but was charged in France with importing, acquiring and transporting illegal substances as part of an organised gang. Initially extradition was granted, and later appealed. Both the UK and France recognised that a substantial measure of the criminal activity was carried out in the UK; the question raised by Dibden concerned the manner how the UK had balanced the 'specified matters' relating to the 'interests of justice. ${ }^{524}$ The arguments in favour of extradition prevailed and the appeal was refused, with the UK waiving territorial jurisdiction in favour of extradition to an overall better forum. A similar reasoning was followed in such cases as Williams, ${ }^{525}$ Piotrowicz, ${ }^{526}$ Shaw, ${ }^{527}$ and Atraskevic. ${ }^{528}$ In fact, the first refusal of extradition based on the forum bar only occurred very close to completion of this study, in the Lauri Love case, ${ }^{529}$ a case with pointed factual similarities to that of Gar Mckinnon, mentioned above. ${ }^{530}$

522 See ibid., p. 220 f.

523 Dibden v. Tribunal de Grande Instance de Lille France [2014] EWHC 3074 (Admin).

524 According to the House of Lords Select Committee on Extradition Law, op. cit., p. 128 f.: "The defence argued that extradition would go against the interests of justice as: the drugs were intended for use in the UK; the defendant resided in the UK; much of the evidence in this case was based in the UK; prosecution in France would cause unnecessary delay in the transfer and translation of evidence; and Mr Dibden had a 13-week-old son. The Issuing State, France, argued that although the offence was intended to cause harm in the UK, it was a trans-national offence with significant harm occurring in France and the Netherlands. With regard to trial proceedings, the strength of the UK-based evidence was unclear and it was not yet known whether it would be sufficient to prove the offences. It was also argued that the trial for these offences should occur in France because, as a general principle, all prosecutions for related crimes should happen in one jurisdiction and proceedings in France were already well advanced for linked offences".

525 The Queen on the Application of Stephen Williams, Geoffrey Williams v. Public Prosecutor of Lille Court of First Instance, France [2012] EWHC 2128 (Admin).

526 Piotrowič, cit.

527 Domminich Shaw, cit.

${ }^{528}$ Jaroslav Atraskevic v. Prosecutor General's Office, Republic of Lithuania [2015] EWHC 131 (Admin).

${ }^{529}$ Love v. US A [2018] EWHC 172 (Admin).

530 See BRunO Min, "The Forum Bar: it does exist", UK Human Rights Blog, 9 February 2018, available in www.ukhumanrightsblog.com, last accessed 11 February 2018. 


\section{c) Closing remarks}

In sum, a forum bar would not be necessary to protect the exercise of territorial jurisdiction by the UK, since the UK can prosecute any offence over which it has jurisdiction (notably territorial), thereby causing extradition to be adjourned and eventually denied (on double jeopardy grounds). Prosecutorial authorities exercise such a power in accordance with the Code for Crown Prosecutors and, in the case (at issue here) of concurrent jurisdiction, with the Guidelines outlined above, which practically equate to the 'specified matters relating to the interests of justice' provided for in the forum bar. Considering this correspondence, as well as the power of veto or "trump card" 531 conferred upon prosecutors in the context of the forum bar, ${ }^{532}$ it is indeed quite doubtful that this bar can produce results which are significantly different from those that were reached under the previous legal framework. In any case, where prosecutorial authorities decide not to prosecute, a substantial measure of the criminal activity took place in the UK, and a certificate is not issued vetoing the application of the forum bar, then this bar will require a transparent assessment by the court as to whether or not the UK is the most appropriate forum to prosecute. Such an assessment takes into account a number of elements related to the 'interests of justice'. Primacy should be given to the State where most of the loss or harm resulting from the offence occurred or was meant to occur, and in this sense this bar protects not only the specific territorial jurisdiction of the UK, but also the territoriality principle more broadly. However, precisely because the concept of 'interests of justice' includes a variety of elements, extradition can be granted even if the UK has a stronger territorial claim than the requesting State, so long as, all elements considered, 'interests of justice' so advise. And in this sense this bar is a fully-fledged instrument of interstate administration of justice, through which a decision can be made as to which of two competing fora is the most adequate to punish certain acts.

Insofar as concerns the EAW, in the context of which the UK may be required to extradite for acts that it would not be able to punish, the grounds for refusal analysed in this paragraph might also constitute a means for avoiding what would be perceived as an exorbitant punitive action by another State. This is implied in the words of then Home Secretary Theresa May before Parliament in 2012 announcing plans for the enactment of a forum bar, where she expressed concerns at the "disproportionate use of the EAW for trivial offences and for actions that are not considered to be crimes in the UK". ${ }^{333}$ One clarification must be made in this regard: the forum bar later enacted in 2013 applies to all extradition cases (not to EAW cases only), and in classic extradition cases dual crimi-

531 Rosemary Davidson / Ben Lloyd / ADAM PAYTER, op. cit., p. 514, adding: "No doubt the purpose of the prosecutor's certificate is to ensure that the prosecutor retains the ultimate decision as to the appropriate forum for a prosecution", and that "this provision appears to have the potential to dramatically reduce the scope and effectiveness of the forum bar: whatever arguments a defendant may feel he or she has to support a forum argument, they can ultimately be trumped by a prosecutor". However, as the authors also underline, "the issuance of a certificate can be challenged by way of a statutory appeal to the High Court pursuant to the 2003 Act. The Court, on such an appeal, is required to apply the procedures and principles that would be applied on an application for judicial review."

$532 \mathrm{Sc}$. the power to issue a certificate on the basis of ss. 19C, 19D, 83B and 83D.

533 Cit., starting at 03:27. 
nality will always have to be met, as was in fact the case with the request for Mckinnon. ${ }^{534}$ Therefore, when the Home Secretary referred to "actions that are not considered to be crimes in the UK", she was indeed referring to the EAW only. ${ }^{535}$

\subsection{Pending proceedings or possibility or duty to initiate proceedings}

\subsubsection{United Nations}

According to Art. 4 (c) Model Treaty, extradition requests can be refused if a prosecution in respect of the same offence is pending in the requested State against the person whose extradition is requested. Similarly, s. 26 (4) (a) Model Law confers on the executive authority of the requested State discretion to refuse extradition if a prosecution is pending in that State against that person in respect of the same offence.

As Swart notes: "It is logical that extradition may be refused if prosecution for the same offence is pending in the requested State. If the requested State is also competent to try the offence its right to give priority over extradition cannot of course be denied." 536 It is clear that this ground for refusal raises few concerns because it does not in principle entail impunity. "Whether it is always wise to give priority to prosecution over extradition is a different matter". 537

\subsubsection{Portugal}

According to Art. 18 (1), extradition may be refused if the offence(s) giving rise to the request are being, should or could be prosecuted in Portugal. Through this ground for refusal, Portugal guarantees that it will not be bound to extradite if the crime at issue is subject to its jurisdiction - namely on the basis of active nationality (in the exceptional case where extradition is not already mandatorily barred by the nationality exception), active and passive nationality (idem), passive nationality, protective principle or universality. ${ }^{538}$ As noted shortly above, crimes committed in Portuguese territory require refusal of extradition, meaning that these cases are in no instance dealt with under this ground for refusal, which is of an optional character. ${ }^{539}$ It should also be noted that, as a matter of principle, it is not possible to refuse extradition with a view to trying the acts on the basis of vicarious or representational jurisdiction: since this type of jurisdiction presupposes the absence of a relevant link between the acts and the Portuguese legal system, and considering that its rationale lies only in the compensation of the requesting State, whose interests have actually been jeopardised by the crime, for not being able to obtain extradition, it would be a paradox that the request could be refused with the sole purpose of prose-

534 See Art. 2 of the UK-USA Extradition Treaty of 2003.

535 On the interplay between dual criminality and the quantitative seriousness of the acts, see in any case infra, Chap. 8, \ 4.1.1.d)(i).

536 BERT SWART, "Refusal of Extradition...”, op. cit., p. 209.

537 Ibid., p. 209 f.

538 See Miguel Jỗo Costa, Dedere Aut Judicare?... op. cit., p. 124 f.; MAnuel António Lopes Rocha / Teresa Alves Martins, op. cit., p. 74.

539 Ibid. 
cuting. ${ }^{540}$ In sum, this ground for refusal can be used in cases where Portugal has original jurisdiction over the crime (given the presence of a relevant connection linking it with the Portuguese legal system), and refusal of extradition is not compulsory (given the absence of grounds for refusal of a mandatory character).

The rationale of this ground for refusal, as results clearly from its scope, is the goal to avoid Portugal being prevented from exercising its penal jurisdiction simply because it receives an extradition request. Like the ground for refusal concerning territoriality, it is a matter of sovereignty. The reason why it is optional is that extradition may nevertheless be preferable. The decision either to extradite or prosecute that this ground for refusal requires abides essentially by two sets of criteria: one relates primarily to the notion of proper administration of justice, and it encompasses such factors as the predominant location of the evidence and the deterrent effectiveness of prosecuting in one forum rather than in another (elements which typically point towards the State where the crime was committed); the other is oriented towards favouring the procedural position of the individual and his/her rehabilitation in the event of conviction, considering such aspects as the predominant location of his/her family and social circles. ${ }^{541}$

The PT-EAW also contains a ground for refusal on pending proceedings: according to Art. 12 (1) (b), requests may be refused if the person is being prosecuted in Portugal for the same acts. Arguably, there is a partial overlap between this provision and that on territoriality (Art. 12 (1) (h) (i)), but the former is wider, as it covers criminal procedures based on any jurisdictional title. At any rate, the rationale of both grounds for refusal is to enable an evaluation of the competing punitive interests of the executing and issuing Member States, so that the criminal procedure is carried out in the most appropriate forum. ${ }^{542}$ The reason why refusal is optional is that in the case of lis pendens, unlike what happens in that of actual res judicatae, continuation of the procedure in another State does not yet carry a breach of the principle ne bis in idem, but only a danger of violation. ${ }^{543}$

\subsubsection{United Kingdom}

As noted, jurisdiction in the UK relies heavily on the territoriality principle. Extraterritorial jurisdiction can be exerted only where that is provided for by statute in relation to specific places, individuals or offences in clear and unequivocal terms ${ }^{544}$ Additionally, the actual number of prosecutions of extraterritorial offences is significantly lower than in other countries, because the UK exerts this type of jurisdiction only if extradition is impossible to grant, either because it is barred or because it has not been requested. ${ }^{545}$ Hence, the UK will virtually never initiate criminal proceedings based on extraterritorial jurisdiction when extradition proceedings are pending. ${ }^{546}$

\footnotetext{
540 See Miguel Jỗo Costa, Dedere Aut Judicare?... op. cit., p. 129 f., 201 f.

541 See ibid., p. 134 f., 202; Manuel António Lopes Rocha / Teresa Alves Martins, op. cit., p. 74.

542 See e.g. the ruling of the Court of Appeal of Lisbon of 14 December 2004, no. 6293/04.

543 See e.g. the ruling of the Court of Appeal of Évora of 3 May 2005, no. 29/05-1.

544 See AnNe-Sophie MASsA, op. cit., p. 105 f.; David Ormerod / David Perry (eds.), op. cit., p. 171.

545 See ANNE-SOPHIE MASSA, op. cit., p. 109 f.

546 The case is different regarding territoriality, given the forum bar assessed in the previous paragraph.
} 
The situation is different where the person has already been charged or is serving a sentence in the UK. In this case, as noted earlier, domestic proceedings take precedence over the extradition request, regardless of the type of jurisdiction (territorial or extraterritorial) supporting them. ${ }^{547}$ This does not necessarily mean that extradition must be refused whenever criminal proceedings are pending, as the charge might still be withdrawn or the proceedings terminated otherwise. ${ }^{548}$ In such an event, so long as double jeopardy issues do not arise, extradition may eventually be granted. The EA 2003 does not offer criteria on which to base the decision whether or not to withdraw or discontinue criminal proceedings. This is a prosecutorial decision, and must comply with the general rules on termination of proceedings. ${ }^{549}$ In the case (of interest here) of concurrent jurisdiction, the principles set in the Director's Guidance on the Handling of Cases Where Jurisdiction to Prosecute is Shared with Prosecuting Authorities Overseas must also be observed. While the latter document is drafted chiefly in view of decisions whether or not to prosecute, it implicitly applies also to cases where a decision to prosecute has already been issued: $\int 9$ of this document states that decisions in cases of concurrent jurisdiction may need to be reviewed where circumstances change, and that circumstances will rarely change to such an extent that a compelling case could be made for proceedings already underway in one jurisdiction to be discontinued and commenced in another instead. That is, once prosecution is ordered, proceedings become very unlikely to be discontinued. The Guidance further states that specific public policy considerations apply to the (few) cases where the courts in England and Wales can try UK nationals for offences committed fully abroad. It was impossible to determine which considerations those might be. However, it is conceivable that they relate to the specificities inherent in the offences over which the UK has extraterritorial jurisdiction, such as murder or manslaughter, sexual offences against children under 18 years old, bribery, and certain acts relating to terrorism, hijacking and piracy. ${ }^{50}$

On the other hand, as also noted already, during the extradition proceedings prosecutors are still able to issue a decision to prosecute the same offence, forcing the extradition judge to adjourn those proceedings and give preference to the domestic ones. ${ }^{551}$ Such a decision to prosecute should also abide by the Director's Guidance and by the general rules set in the Code for Crown Prosecutors. If no charge has been made before extradition proceedings, or is made during their course but a substantial fraction of the acts took place in the UK, then the forum bar may be invoked, in which case the remarks adduced earlier thereon apply in full. ${ }^{552}$

The forum bar and the provisions that require extradition to be adjourned if criminal proceedings for the same acts are pending in the UK protect domestic proceedings. They enable the UK to prosecute or complete the prosecution of offences falling within

547 See supra, \ 6.1.3.a); see ss. 8A-8B, 22-23, 36A-36B, 76A-76B, 88-89, and 118C-118D.

548 See the same provisions as in the previous fn.

${ }^{549}$ Notably with ss. 23 and 23A of the Prosecution of Offences Act 1985 (see the guidance offered in http://www.cps.gov.uk/legal/s to u/termination of proceedings/\#a10), as well as in the Code for Crown Prosecutors; see Malcolm Davies, op. cit., p. 251, 551.

550 See David Ormerod / David Perry (general eds.), op. cit., p. $171 \mathrm{f}$.

551 See again ss. 8A-8B, 22-23, 36A-36B, 76A-76B, 88-89, and 118C-118D.

552 See supra, $\$ 6.1$. 
its jurisdiction, even if it receives an extradition request for the same offences. Since extradition may nevertheless be given preference over prosecution, those norms qualify as clauses of interstate administration of justice, instances in the context of which a decision is taken as to which of two competing fora serves the 'interests of justice' better.

\section{Grounds for refusal related to political concerns of the requested State}

\subsection{National security}

\subsubsection{United Nations}

There is no such ground for refusal in the UN model instruments.

\subsubsection{Portugal}

No such ground for refusal is explicitly provided for in the Portuguese legal system either, although similar results can be achieved through the general prerogative of the executive branch to interfere with extradition matters, in the terms described earlier. ${ }^{53}$

\subsubsection{United Kingdom}

Based on s. 208, the Home Secretary has the power to block extradition in order to protect the national security of the UK. Specifically, extradition will be blocked if: (1) (a) In engaging in the conduct constituting (or alleged to constitute) the offence, the person was acting for the purpose of assisting in the exercise of a function conferred or imposed by or under an enactment, or (b) as a result of an authorisation given by the Secretary the person is not liable under the criminal law of any part of the UK for the conduct constituting (or alleged to constitute) the offence; and (2) The person's extradition in respect of the offence would be against the interests of national security.

The rationale of this norm, which applies to both category 1 and category 2 States, is to prevent the extradition of members of the intelligence services - including the Security Service (MI5), the Secret Intelligence Service (MI6) and the Government Communications Headquarters (GCHQ) - for acts committed in the exercise of their functions. ${ }^{554}$ To a certain extent, this provision constitutes an extension of the concept of international immunities ratione materiae: it appears to rely on the (same) assumption that the exercise of specific functions on behalf of the State can only be effectively developed if the agents in question have a guarantee that they will not be subject to the criminal apparatus of the State where they are acting. At the same time, such agents will normally be in possession of sensitive information relating to their home State, which in itself would already justify reluctance to extradite. In any case, both conditions are necessary to trigger this ground for refusal. They are cumulative, and hence it is not sufficient that the acts were committed by agents of the State in the course of their functions, nor that extraditing these individuals would jeopardise national security.

\footnotetext{
553 See supra, Chap. 5, \ 2.2.

554 See Clive Nichols et. al., op. cit., p. 65.
} 


\subsection{Reciprocity}

\subsubsection{United Nations}

As an instrument intended to provide guidance to States in concluding extradition treaties, reciprocity is inherent in the Model Treaty, and is in any case reiterated in its Art. 1 , where the 'obligation to extradite' typical of extradition treaties is provided for. As for the Model Law, the key provision is s. 2. According to s. 2 (1) extradition may be ordered on the basis of such law or of a relevant extradition treaty or agreement, and s. 2 (2) establishes a principle of subsidiarity of national law in relation to international law. Thus, if a treaty or agreement is applicable, its provisions will govern the case, while those of the Model Law will apply only to certain procedural issues and only if that is not precluded by the treaty or agreement in question. In the absence of one such treaty or agreement, extradition may be governed by the provisions of the Model Law. Finally, according to s. 2 (3), extradition may still be granted: (a) by virtue of comity; (b) where, based on assurances given by the competent authorities of the requesting State, it can be anticipated that this State would comply with a comparable request of the requested State; or (3) where it is otherwise deemed in the interests of justice to do so.

\subsubsection{Portugal}

Portugal does not require a treaty to extradite. Internal law is a sufficient normative basis to extradite, but does not bind Portugal to do so. ${ }^{555}$ That is, a treaty is not necessary to extradite, but there is no obligation to extradite in the absence of a treaty.

As a counterweight to the absence of a treaty requirement, Art. 6 (4) imposes the refusal of extradition if reciprocity is not secured in the case. Thus, by relinquishing the treaty requirement Portugal did not quite renounce reciprocity as a condition for cooperating. In fact, Art. 4 (1) symbolically declares reciprocity to be the foundation of international cooperation. Quite simply it has been converted into a condition possible to assess on a case-by-case basis: Art. 4 (2). ${ }^{556}$ But even this condition is not absolute: in certain situations Portugal can extradite in the absence of reciprocity, notably if extradition is desirable in view of the nature of the acts or the need to combat certain types of serious criminality. In this manner, Portugal preserves to a large extent its prerogative to secure extradition from the requesting State in comparable future circumstances, but does give away part of that prerogative in favour of wider possibilities of cooperation. According to Rocha and Martins, this option is a signal of predisposition on the part of the Portuguese State for increased cooperation. ${ }^{557}$

555 Arts. 3 (1) and 2 (2).

556 In an absolutely singular manner, only the executive branch, in the figure of the Minister of Justice, can raise this ground for refusal; judicial refusals on this basis are excluded: see the Preamble of the Decree-Law no. 43/91, which preceded PT-L, currently in force; in case law, see the Ruling of the Court of Appeal of Lisbon of 4 February 2004, no. 3880/2003-3; in legal literature, see MANUEL ANTÓNIO LOPES Rocha / Teresa Alves Martins, op. cit., p. 29, and MÁrio MEndes SERrano, op. cit., p. 37.

557 See Manuel António Lopes Rocha / Teresa Alves Martins, op. cit., p. 29; António BerNARDO COLAÇO, “O Procedimento Extradicional na Óptica do Operador Judiciário”, RPCC 7 (1997), p. 648. 
There are, nevertheless, two exceptions to the possibility of extraditing on the basis of ad hoc reciprocity: the case where the person sought is a Portuguese national, and that where imprisonment for life or an undetermined period is applicable in the abstract. ${ }^{558}$ In these two cases it is necessary that the requesting State and Portugal be linked through an international legal instrument. ${ }^{559}$ In the past, extradition had without exceptions to be refused in those cases. In this sense, this 'selective treaty requirement' can be understood as compensation for the partial abolition of those formerly absolute grounds for refusal.

\subsubsection{United Kingdom}

The UK used to require a treaty, in the formal sense of the term, in order to extradite. The EA 1989 modified this state of affairs, making room for ad hoc extradition arrangements. Driving the change was the realisation that many States are not linked by a treaty, and that in such cases that requirement was making it overly easy for criminals to stay unpunished by 'shopping' a country of refuge. ${ }^{560}$ According to a 1982 Report by the Home Office, the goal was to widen the room for cooperation whilst sparing time and resources in arranging for extradition with States with which the expected extradition traffic would hardly justify the effort of negotiating a treaty, as well as to reduce "inhibitions" to issue requests to States with which no treaty was in place. ${ }^{561}$ The modification materialised the long expressed view of the 1878 Royal Commission that "[i]t is as much to our advantage that such criminals should be punished and that we should get rid of them, as it is to that of the foreign state that they should be brought within the reach of its law". ${ }^{562}$

Special extradition arrangements made their way to the EA 2003, in s. 194, whose conditions can be reduced, but not widened. ${ }^{563}$ Reciprocity is inherent in such arrangements. ${ }^{564}$ If one such arrangement is concluded, the request is decided under the rules for category 2 States, with some adjustments, including that a prima facie case must be made. ${ }^{565}$ In any case, very few special arrangements have been concluded thus far. There is record of one with Brazil (but it was not even implemented), ${ }^{566}$ added only, as far as was possible to determine, by arrangements with Rwanda regarding allegations of involvement in genocide (but here the request was eventually rejected on human rights grounds). ${ }^{567}$

558 Arts. 33 (3) and (4) Constitution, and Art. 32 (2) (a) PT-L.

559 Of interest to this topic is the ruling of the Constitutional Court no. 384/2005, of 13 July 2005.

560 See Ivor Stanbrook / Clive STANBroOK, op. cit., p. $231 \mathrm{f}$.

${ }^{561}$ Home Office Working Party Report, A Review of the Law and Practice of Extradition in the UK-Report of an Interdepartmental Working Party, 1982, apud IvOr StANBroOK / Clive STANBroOK, op. cit., p. 232.

562 Apud Scott Baker / DAvid Perry / ANAND DoObay, op. cit., p. 1896.

563 See Alun Jones, op. cit., p. 229.

564 See Alastair Brown, op. cit., p. 125.

565 S. 194 (4); see thereon SCOTT BAKer / DAvid PERry / ANAND DoObAY, op. cit., p. 272, Julian B. Knowles, op. cit., p. 25, Ivor StAnbrook / Clive STANBrook, op. cit., p. 232, Alun Jones, op. cit., p. 229.

566 See Ivor Stanbrook / Clive STANBrook, op. cit., p. 232; Alun Jones, op. cit., p. 228.

567 See SCOTT BAKer / DAVID PERry / ANAND DoOBAy, op. cit., p. 272; see Vincent Brown aka Vincent Bajinja, Charles Munyaneza, Emmanuel Nteziryayo, Celestin Ugirashebuja v. The Government of Rwanda, The Secretary of State for the Home Department [2009] EWHC 770 (Admin), and, thereon, MARK A. DrumBL, "Prosecution of Genocide v. the Fair Trial Principle Comments on Brown and others v. The Government of Rwanda and the UK Secretary of State for the Home Department', JICJ 8 (2010), p. 289 f. 
While mostly favourable to special extradition arrangements, the 1982 Report mentioned above called for some caution in the use of this possibility: "if there were to be a power to extradite without a treaty, the legislation should require the Secretary of State to be satisfied, before issuing an Order to proceed and before surrendering a fugitive, that the standards of justice and penal administration in the requesting State were such that it would be in the interests of justice to surrender the fugitive". ${ }^{568}$ Stanbrook and Stanbrook agree that special extradition arrangements require "continuous monitoring of regimes in all countries outside the present nexus of formal extradition arrangements, since decisions are likely to be taken at a moment's notice"; however - the authors note - this "is already the normal practice of UK diplomatic missions abroad". ${ }^{569}$

Those concerns appear to be duly accommodated in the EA 2003. If an extradition request is received from a State with which no treaty is in force, the Home Secretary has no duty to enter into a special arrangement. ${ }^{570}$ If the Home Secretary does decide to enter into one such arrangement, the UK and the requesting State will sign a Memorandum of Understanding, which will cover the matters that would usually be included in a formal extradition treaty. ${ }^{571}$ This Memorandum forms something of a "mini-extradition treaty" with a "different and less formal status than a treaty in international law", as it relates only to a specific request; it is signed by a representative of the UK and a representative of the requesting State. ${ }^{572}$

568 Apud IVOr StAnbrook / Clive StAnbrook, op. cit., p. 232 f.

569 IVOr STANBROOK / Clive STANBROOK, op. cit., p. 232 f.

570 See SCOTt Baker / David Perry / ANANd DoObay, op. cit., p. 272.

571 Ibid.

572 Ibid., p. 455. 


\section{PART IV}

\section{REVIEWING}

\section{GROUNDS FOR REFUSAL}




\section{Chapter 7}

\section{Questioning Grounds for Refusal: Theoretical Framework}

\section{Recalibrating the research question}

As mandatory grounds for refusal have been identified and the rationale of voluntary grounds for refusal evaluated, the moment is reached to reflect on whether the latter are warranted in an increasingly transnational world. As indicated earlier, the exercise to be conducted here is inductive, with the research question boiling down to the following terms: which voluntary grounds for refusal of extradition remain necessary?

For this question to be answered, the concept 'necessary' must be defined. Inevitably its definition will be somewhat subjective, as purely neutral definitions are hardly conceivable in normative research. Because it sets the parameters within which the research question is to be answered, the theoretical exercise developed in order to define this concept plays a key role in this study. Such is the exercise effected in the present chapter.

Before engaging in this exercise, the present section recalibrates the research question of the study in the light of the insights already obtained from the foregoing chapters. It also revisits the thematic delimitations effected at an early stage of the study, and, finally, it recollects and elaborates on some of the fundamental concepts of this study, as well as on the reasons why some problems receive more attention than others.

\subsection{Specifications required by the concept of 'ground for refusal' adopted}

Earlier in the study grounds for refusal were defined as interests that conflict with the interest of ensuring the efficiency of national criminal law systems, and supersede it. This definition carried as immediate consequences that the study would pay limited attention to grounds for refusal related to issues of mere allocation of jurisdiction between the requested and the requesting State, and place added emphasis on those that entail impunity. The following paragraphs review and develop the definition of 'ground for refusal' adopted in this study and expand on its implications.

\subsubsection{Grounds for refusal related to mere issues of interstate allocation of jurisdiction}

\section{a) General considerations}

This group of grounds for refusal includes the following cases: (1) that where criminal proceedings are pending in the requested State for the offence motivating the extradition request (lis pendens), or this State has the possibility or duty to initiate such proceedings; and (2) that where that offence was committed (at least partly) in the territory of the 
requested State. The latter hypothesis would already fall within the scope of the former, but it involves specific considerations and hence it is often regulated in a separate ground for refusal. ${ }^{1}$

As noted before, these grounds for refusal have as a common denominator the fact that both the requesting State and the requested State have been directly injured by the offence, due to a meaningful link (territoriality, nationality of the victim and/or of the offender, etc.) between that offence and their legal systems. In such a setting, the requesting State is not the only subject involved in the extradition proceedings that has a punitive claim. The requested State too has an interest in punishing the offence, an interest which emerged immediately upon its perpetration and which therefore can (and often must) give rise to a criminal procedure in this State regardless of any extradition request. Thus, albeit formally contained in legal norms that establish grounds for refusal of extradition, these hypotheses do not conflict with the interest in ensuring the efficiency of national penal systems. On the contrary, they presuppose that the requested State is a co-holder of the interest in punishing the offence. A positive conflict of jurisdiction occurs, which means that impunity is not a possibility. The point of controversy is mainly that as to which of the two competing States should take priority in exacting punishment.

In sum, these are not 'obstacles' to extradition in the sense relevant for this study, but clauses of allocation of jurisdiction designed to regulate situations where one of the States involved has custody of the suspect, and the other seeks to obtain it. Nevertheless, the manner in which such conflicts of jurisdiction interfere with the fulfilment of the interest in ensuring the efficiency of national penal systems requires these clauses to still be appraised in this study, if more briefly than actual grounds for refusal.

\section{b) Specific considerations on international crimes}

The remarks submitted above apply a fortiori to international crimes. Like ordinary crimes, in each particular case international crimes will impact more directly on a given State or set of States: the locus delicti, the State of nationality of the victims or perpetrators, etc. However, unlike what happens with ordinary crimes, the prevention and punishment of international crimes is not so much a matter of preservation of national penal systems as a matter of shared responsibility of the community of States as a whole (in the case of core international crimes), or at least of a broad group of States (in the case of crimes established in multilateral treaties). ${ }^{2}$ These crimes are subject to universal jurisdiction, which means that any State where the suspect is located has an immediate prerogative to prosecute. ${ }^{3}$ Thus, regarding international crimes, impunity is not a concern.

In theory, that is; because not seldom the State where the suspects are located is reluctant to bringing them to justice. An example is the prominent Yerodia case, where the Democratic Republic of Congo shielded its then Foreign Minister from an arrest warrant issued by Belgium charging him with crimes against humanity and serious breaches of

\footnotetext{
1 These grounds for refusal have been analysed in Chap. 7, \ 6 .

2 In this case, the following applies only to the States that are parties to the treaty in question.

3 See supra, Chap. 1, \5.2.2.
} 
the 1949 Geneva Conventions and Additional Protocols; the acts consisted essentially of hate speeches inciting racial hatred and eventually leading to violent attacks on Tutsi residents in Kinshasa. ${ }^{4}$ Congo not only refused to assist Belgium, but also waged a (successful) case before the ICJ. ${ }^{5}$

Reluctance to cooperate manifests itself even in cases involving international criminal courts, to whom States have an obligation to provide extensive assistance. ${ }^{6}$ This is illustrated by Serbia's attitude towards the ICTY. Serbia was required to cooperate with this court not 'only' by the UN Security Council, but also by the EU, as a precondition for membership. And even though most Serbs desired accession to the EU, cooperating with the ICTY, whose activity "touches directly upon the Serbian national identity", was "politically difficult to sell to the population", large segments of which still see most Serb indictees as "national heroes". ${ }^{7}$ Moreover, it met with resistance from such crucial national institutions as the police and the army, which had remained basically unchanged since Milošević's days, and from the Government itself, eager to secure its share of nationalist supporters. $^{8}$

As for protective behaviour by a State requesting extradition, a prominent example is the request for Pinochet issued by Chile to the UK, following an arrest warrant issued by Spain on charges of genocide (inter alia), pursuant to jurisdiction based on passive nationality. While Spain sought to try the former dictator, Chile apparently intended to use extradition (based on territorial jurisdiction) as a means for frustrating Spain's effort.'

It is true that reluctance to cooperate can also be detected in cases involving acts which do not constitute international crimes, notably in the context of politically relevant cases. Ongoing examples of this are the exile of Edward Snowden in Russia and the refuge of Julian Assange in the embassy of Ecuador in London. However, in these cases the State according protection is not that where the offence was committed or whose interests were elsehow breached. This differs profoundly from the cases under consideration here, where the State which is obstructing justice is that where the offence was committed, and, hence, that which in normal conditions should take priority in prosecuting.

${ }^{4}$ ICJ, Case Concerning the Arrest Warrant of 11 April 2000 (Democratic Republic of Congo v. Belgium), 14 February 2002 .

${ }^{5}$ See supra, Chap. 2, $\left.\int 2.2 .2 . c\right)$.

${ }^{6}$ See $\int 4$ of the UN-SC Resolution 827 (1993), establishing the ICTY, and Art. 29 of its Statute; \ 2 of the UN-SC Resolution 955 (1994), establishing the ICTR, and Art. 28 of its Statute; and Arts. 86 and 89 (1) of the Rome Statute of the ICC.

7 Kei Hannah Brodersen, “The ICTY's Conditionality Dilemma: On the Interaction of Influences of the European Union's Conditionality Policy and the International Criminal Tribunal for the Former Yugoslavia on the Development of Rule of Law in Serbia", EJCCL\&CJ 22 (2014), p. 230 f.; see also MiLICA Kostić, "Public Opinion Survey in Serbia Sheds Light on ICTY Legacy", in EJIL: Talk!, 22 January 2018, analysing a survey published in December 2017 which suggests that "revisionism and denialism are prevalent, and ethnic bias is entrenched".

8 See Kei Hannah Brodersen, op. cit., p. 230 f.

${ }_{9}$ Pinochet returned to Chile after UK's refusal to extradite him to Spain, and Chile did take some judicial measures aimed at establishing his criminal liability: see CHRISTOPHER L. BLAKESLEY, "The Autumn of the Patriarch ...", op. cit., p. 23 f. Still, he died in 2006 without ever having been convicted of the crimes he was imputed: see CATH Collins, Post-transitional Justice: Human Rights Trials in Chile and El Salvador, Pennsylvania State: University Press, 2010, p. 96 f., passim. 
In fact, it is a rather typical feature of international crimes that the State where the acts were committed seeks to protect their perpetrators. It is true that prosecution by the territorial State does sometimes occur (usually, if structural changes take place in the local power structure). An example of this would be the case of Gonzalo Sánchez de Lozada, former President of Bolivia charged by this State with genocide and crimes against humanity, and currently exiled in the USA. ${ }^{10}$ However, acquiescence by the State where the acts were committed is recurrent in international crimes, because these are typically engineered by high-ranking officials or other influential actors of that State (and either these remain in power, or the State engaged in a transitional process but its institutions are still exceptionally unstable), and co-authored, aided or abetted by large fringes of the population, rendering those crimes truly collective deeds. ${ }^{11}$ To an extent this is what explains the development of such imputation theories as joint criminal enterprise, concerned with the difficulties in establishing the accountability of the masterminds of such deeds. ${ }^{12}$ And it is in part what explains the very creation of international criminal courts, as is mirrored in their priority over national courts in the prosecution of international crimes: in the case of the ad hoc tribunals, established by UN Security Council Resolutions, such a priority is nothing short of absolute; ${ }^{13}$ the ICC, established by treaty, follows instead a complementarity model that concedes primacy to States, ${ }^{14}$ but even so it reserves the prerogative to take over a case if the State in question shows itself unwilling or unable genuinely to carry out the investigation or prosecution. ${ }^{15}$

In conclusion, important specificities exist in relation to international crimes. Since these crimes can always be prosecuted (either by States or international courts), in theory they involve no risk of impunity, but simply require that the issue be solved as to who is to carry out their adjudication, which is similar to the situation of interstate conflicts of

10 See www.theguardian.com/commentisfree/2012/sep/09/america-refusal-extradite-bolivia, last accessed 29 April 2017. Ironically, the extradition request issued by Bolivia to the USA in 2008 was possible due to an extradition treaty concluded by Lozada's Administration with the US as an expression of his "intensely pro-US" positioning - which is arguably what earned him the refusal of that request by the US Department of State in 2012: ibid., and the 2005 documentary film "Our Brand is Crisis", by Rachel Boynton.

11 See Elies van Sliedregt, Individual Criminal Responsibility in International Law, Oxford: University Press, 2012, p. 17 f., passim.

12 This doctrine was developed by the ICTY and later used by other international courts, such that presently it may be considered a "consolidated concept of international criminal law" (although the imputation model adopted by the ICC is much stricter): see JoANA COSTA, Joint Criminal Enterprise: O Problema da Imputação Individual do Facto Colectivo na Jurisprudência dos Tribunais Penais Internacionais, Coimbra: Coimbra Editora, 2014, p. 9 f., 55 f., 309 f. As for common criminality, several national legal systems adopt imputation models that have been linked to the concept of joint criminal enterprise. An example is UK's 'joint enterprise liability', examined in JOHANNES KEILER, Actus reus and participation in European criminal law, Antwerp: Intersentia, 2012, p. 258 f. However, these models appear to be much narrower in their reach than that developed by the ICTY: see again JOANA COSTA, op. cit., p. 222. Moreover, as far as the UK is concerned, the trend in recent case law is one of retraction: see R. v. Jogee [2016] UKSC 8.

13 See Art. 9 Statute of the ICTY, and Art. 8 Statute of the ICTR.

${ }^{14}$ For a contrast between the two approaches, see BARTRAM S. BROWN, "Primacy or Complementarity: Reconciling the Jurisdiction of National Courts and International Criminal Tribunals", YJIL 23 (1998), p. $383 \mathrm{f}$.

15 See Art. 17 Rome Statute of the ICC. 
jurisdiction regarding ordinary crimes. However, in the case of international crimes this 'mere' jurisdictional issue is particularly sensitive, because here the real risk of impunity is considerable, ${ }^{16}$ and this type of impunity particularly dramatic in its effects, given its aptitude for compromising such vital goals as securing peace and (re)instating the rule of law in the affected territories. ${ }^{17}$

\subsubsection{Grounds for refusal that entail impunity}

In the introduction to this study it was noted that forms of cooperation other than extradition exist which allow the State where the suspect is located to prevent impunity. More specifically, this can be achieved through the transfer of criminal proceedings, the exercise of vicarious jurisdiction, and the execution of foreign criminal sentences. When modern extradition law was founded, at the turn of the $18^{\text {th }}$ century, refusal of extradition was almost inevitably tantamount to impunity, whereas now it can be supplanted by those alternative tools. This is because the situations where extradition is blocked do not necessarily also preclude other forms of cooperation. Thus, for instance, if the requested State does not extradite where there is a real risk of application of the death penalty in the requested State, and if there is such a risk in a given case, then this will block extradition, but it will not prevent the requested State from carrying out a criminal procedure, where only its own penalties can be applied, on behalf of the requesting State. On the other hand, sometimes extradition is possible, but other cooperation mechanisms are preferable in the specific case in view of the interests of the person.

In a sense, the emergence of alternative cooperation mechanisms has reconfigured the very concept of grounds for refusal of extradition. Grounds for refusal of extradition are no longer a situation the verification of which inherently entails impunity, but which may instead (albeit preventing punishment by the State where the crime was committed) spark a different sort of cooperation from the State where the person is found. By preventing the cases where extradition is impossible from escaping justice altogether, those alternatives certainly marked an advance in the reaction against impunity. ${ }^{18}$ However, as was also argued quite early in this study, extradition should in principle take priority, because it continues to have solid comparative advantages: it is the only mechanism that enables the State where the crime was committed or materialised to carry out its own

${ }^{16}$ Which confers appositeness on critical reflections on how the issue is regulated, such as that developed (in relation to the ICC) by ANDRÉ KLIP, "Complementarity and concurrent jurisdiction", NEP 19 Special no. 'International Criminal Law: Quo Vadis?' (2004), p. 173 f.

${ }_{17}$ See e.g. RUTi G. TEITEL, “Transitional Justice Genealogy”, HHRJ 16 (2003), p. 69 f., 89 f.; ALLISON Marston Danner / Jenny S. Martinez, "Guilty Associations: Joint Criminal Enterprise, Command Responsibility and the Development of International Criminal Law”, CalLR 93 (2005), op. cit., p. 90 f.; specifically on the Serbian case, again Kei Hannah Brodersen, op. cit., p. 226 f. But cf. with Eric A. PosNER / AdRIAN VERMEUle, "Transitional Justice as Ordinary Justice”, HLR 117 (2004), p. 762 f., who vehemently refuse the notion that transitional justice and common justice are fundamentally distinct.

18 That prevention of impunity is a key principle of international cooperation was strongly reaffirmed in the context of the EU in the recent Petrubhin case, where the ECJ, having 'created' a new ground for refusal of extradition from Member States to third States (the 'EU citizenship exception' extensively discussed supra, Chap. 4), was nevertheless quite demanding, conditioning its operability to the possibility of prosecuting the crime at issue within the EU. 
criminal procedure, and this is the State where a criminal procedure is more necessary and adequate to be carried out. ${ }^{19}$

But the fact that extradition is in line of principle preferable is not the only reason why its improvement should be pursued. Refusal of extradition still does entail impunity in many cases. This is because certain circumstances, in addition to blocking extradition, inherently prevent the requested State from providing any other type of international cooperation, namely from carrying out a criminal procedure or enforcing a penalty in representation of the requesting State. Such situations produce a scenario where the requested State can neither extradite the person nor punish him/her ('nec dedere nec judicare'). Leading examples of this concern dual criminality and statutory limitations of the criminal procedure: if the acts are not criminalised, or are time-barred in the requested State, and this State refuses to extradite in those circumstances, then it will also be unable to employ its own legal system to punish the acts, owing to its principle of legality and its rules on time-bars, respectively.

Other grounds for refusal likely to create such a scenario are: ${ }^{20}$ (1) lack of reciprocity (if the requested State refuses to extradite because the requesting State would not cooperate in similar circumstances, a fortiori it also will be unavailable to carry out a vicarious procedure in the name of this State); (2) low relevance of the acts (if the acts in question are not sufficiently serious for the requested State to extradite a person, a fortior they will not be sufficiently serious for this State to employ its own punitive system thereupon; (3) political or military character of the offence (as offences committed against a specific State, these offences have an intrinsically limited scope of application, such that the acts at issue can only be subsumed in the Tatbestand of that specific State, and thus do not satisfy the principle of legality of any other State that might contemplate punishing them; ${ }^{21}$ (4) absence of valid jurisdiction on the part of the requesting State (if the requested State rejects the type of jurisdiction claimed by the requesting State, it will be paradoxical for it to carry out a criminal procedure on its behalf); and (5) applicability of an international immunity to an individual who is an agent of a State other than the requesting and the requested States. ${ }^{22}$

\footnotetext{
${ }^{19}$ See supra, Chap. 1, $\ 3$ See again JoHn BASSET MOORE, op. cit., p. 154, stating: “The practice of extradition is in itself a recognition not only of the principle that crime should be punished, but also of the fact that it can best be punished at the place of its commission."

${ }^{20}$ See Miguel JoÃo Costa, Dedere Aut Judicare?... op. cit., p. 70-113.

${ }^{21}$ This is not a jurisdictional issue, but a matter of wrongfulness or illicitness of the acts: these acts are wrongful only under the legal system of the State against whom they are directed, as this specific State is an integral element of the Tatbestand where they are criminalised.

${ }^{22}$ It is recalled that, in any case, as these immunities stem from international law, they are not considered in this Part of the study. On the other hand, it is stressed that only immunities that benefit individuals who are agents of third States give rise to nec dedere nec judicare situations: if the person is an agent of the requested State, this State can prosecute without constraints (sic et simpliciter judicare); if the person is an agent of the requesting State, the extradition request contains an implicit waiver of the immunity, enabling both extradition, and, if the requested State does not oppose to that, a vicarious prosecution (aut dedere aut judicare). This is because the rationale of these immunities is to protect the regular development of certain State functions, rather than the concrete persons who exercise them. Protection enjoyed by these persons is but incidental, and will cease if the State in view of whose interests the immunity exists intends to exert criminal punishment.
} 
Since impunity is the key concern of this study, added attention is given to these grounds for refusal. Utmost attention is given to dual criminality, a rule which truly puts to the test the conceptual difference between punishing and assisting in punishing.

\subsection{Specifications regarding grounds for refusal imposed upon States}

In a previous moment, grounds for refusal which are imposed upon States were identified. They were grouped into three categories - viz: (i) grounds for refusal imposed by human rights (according to intentionally expansive criteria aimed at encompassing any situation with a minimum level of significance under human rights law and case law); (ii) grounds for refusal derived from general international law (which mainly boil down to international immunities, because most other grounds for refusal stemming from general international law were already covered by the former category); ${ }^{23}$ and (iii) grounds for refusal imposed by EU law (used here as an illustration of how some traditional grounds for refusal, notably the nationality exception, can be expanded onto a range of situations that was not originally covered by their scope, as a result of political arrangements of the requested State with other States). This brief paragraph serves to recollect this categorisation and to reiterate that a possible reform of these grounds for refusal is excluded from consideration in this part of the study. ${ }^{24}$

\subsection{Specifications regarding international crimes}

Without prejudice to the importance of the jurisdictional issues addressed above, ${ }^{25}$ the particularity of core international crimes which has greater interest to this study lies in the fact that many of the traditional grounds for refusal of extradition are inapplicable to them. Indeed, many such grounds for refusal are irreconcilable with the nature of these crimes, branded by the Rome Statute of the ICC as "the most serious crimes of concern to the international community as a whole". ${ }^{26}$ This is for example the case of dual criminality (which by definition is met, as these are crimes under general international law and, thus, under the laws even of States that do not criminalise them), of the political offence exception (which, however pertinent in some cases, cannot possibly protect the authors of such atrocities), and of the nationality exception (which is immaterial across the board when considered against the gravity of such acts). ${ }^{27}$ It is also the case of international immunities ratione materiae (since international crimes cannot qualify as acts of State) ${ }^{28}$

${ }^{23}$ Although ultimately these were not analysed in detail, given their lack of conceptual autonomy in the context of criminal law and international cooperation in criminal matters: see supra, Chap. 2, S 2.2.2.c).

${ }^{24}$ Although some brief remarks will be adduced later in relation to grounds for refusal based on human rights: notably infra, Chap. $8, \mathbb{\$} 5.1 .2$.

25 Supra, 1.1.1.b).

26 Art. 1.

${ }^{27}$ See KaI Ambos, "The International Criminal Court and the traditional principles of international cooperation in criminal matters", FYIL 9 (1998), p. 413 f.; PEDRO CAEIRO, "O procedimento de entrega...", op. cit., p. 75, 81, $135 \mathrm{f}$.

${ }^{28}$ As follows from the Statutes of international criminal tribunals (see Art. 7(2) Statute of the ICTY, Art. 6(2) Statute of the ICTR, and Art. 27 Rome Statute of the ICC), and as was ruled in the Pinochet case in the UK (see DAVID TURns, op. cit., p. 574 f.). 
It is not, however, the case of immunities ratione personae (as these are vital for the steady development of international relations, and consequently apply even in respect of such dreadful acts, insofar as the official capacity remains). ${ }^{29}$ It is not the case, either, of the grounds for refusal deriving from human rights or other basic individual rights, such as the applicability of capital punishment, the lack of procedural safeguards (notably the risk of torture or ill-treatment), or humanitarian concerns (e.g. where extradition shows likely to entail such severe consequences as death). These situations are either excluded or very unlikely to be met in the context of the surrender to international tribunals, ${ }^{30}$ but possible in that of interstate extradition, where they will apply in similar terms as they do in respect of common crimes. Indeed, the eradication of such grounds for refusal, which are pivotal for protecting fundamental individual rights, cannot be justified even by the extreme gravity of the crimes at issue. Firstly, at the axiological level, because that would be similar to the behaviour which is being censored. As Blakesley put it, on the subject of the UK's refusal to extradite Pinochet on humanitarian grounds: "It is ironic, of course, that a person charged with having violated the most basic human rights of so many may be the beneficiary of those human rights protections he mocked in a most heinous way. Nevertheless, we must remain worthy of our human rights principles." ${ }^{11}$ That it is vital to maintain an "ethical difference between the persecution of the crime and the crime itself" 32 is, after all, also one of the many valid reasons for rejecting e.g. the use of abusive means for obtaining inculpatory evidence, ${ }^{33}$ the application of criminal law in deviation from the commandments of the principle of legality, ${ }^{34}$ or the application of the death penalty. Secondly, at the normative level, because fundamental rights - at least, but most certainly those that constitute jus cogens - do not admit such a sacrifice. Finally, at the pragmatic level, since punishing atrocities at the expense of fundamental rights is detrimental to the very goals that international criminal justice purports to attain, notably the restoration of the rule of law, in that breaching fundamental rights stands obviously opposed to any conception of the rule of law.

Undeniably, the benefits of respecting fundamental individual rights are less apparent when other goals of international criminal justice are considered. That is the case of social reconciliation: infringing upon the basic rights of the offenders denotes bias, and may therefore foster partisanship among segments of people sympathetic towards those offenders and their deeds; but honouring those rights tends to decrease the prospects of conviction or at least the severity of the punishment to be applied, and acquittals or lenient penalties for international crimes tend to be marketed by the defendants as complete

29 As ruled by the ICC in Yerodia, cit.

30 An exception is the ne bis in idem principle, enshrined in Art. 10 Statute of the ICTY, Art. 9 Statute of the ICTR, and Arts. 20 and 89 Rome Statute of the ICC.

${ }^{31}$ Christopher L. Blakesley, "The Autumn of the Patriarch: The Pinochet Extradition Debacle...", op. cit., p. 15.

32 Winfreid Hassemer (1988), apud MANuel Da Costa Andrade, Sobre as Proibições de Prova em Processo Penal, Coimbra: Coimbra Editora, 1991, p. 120.

33 See again Manuel da COSTA ANDrade, Sobre as Proibições... op. cit., p. $117 \mathrm{f}$.

34 See António Castanheira Neves, Digesta: Escritos Acerca do Direito, do Pensamento Jurídico, da sua Metodologia e Outros - Volume 1. , Coimbra: Coimbra Editora, 1995, p. 362. 
validations of their deeds, which ultimately also bolsters partisanship and instils feelings of injustice among other segments of the population. ${ }^{35}$ The same applies to the objective of deterring future atrocities, to the extent that such leniency is perceived as punitive inefficacy. However, none of this legitimises departing from the principle that even the authors of despicable acts are entitled to fundamental rights. Since the goals of international criminal justice are manifold, it is inevitable that they will at times pull in contrary directions. ${ }^{36}$ Accepting that certain values are uninfringeable requires enduring results that are unpleasant.

In sum, many of the traditional grounds for refusal of extradition are excluded in relation to international crimes, as a consequence of their extreme gravity. The gravity of the crime does not exclude the applicability of international immunities ratione personae, given their key role in upholding international relations. It is also incapable of excluding the applicability of grounds for refusal that protect fundamental individual rights, since these cannot be made dependent on the nature or gravity of the acts imputed to the individual. For this very reason, these grounds for refusal possess basically the same scope irrespectively of whether the acts in question constitute common crimes or international crimes.

As for the surrender of individuals from States to international criminal courts, no further considerations appear to be necessary either, as the fundamental structures of this "supra-state" model of cooperation were already charted: ${ }^{37}$ while the assumption in interstate cooperation (albeit debatable) is that States bear similar standing, and therefore are legitimised to impose on each other a number of grounds for refusal designed in view of their own interests, the view basing cooperation between States and international courts is that the latter hold a position of full superiority, and therefore the former shall assist them almost unreservedly, which results in the virtual non-existence of grounds for refusal.

35 See Allison Marston Danner / Jenny S. Martinez, op. cit., p. 90 f. For example, Rwanda claimed before the UN Security Council that the exclusion of the death penalty in the ICTR put at risk national peace (although the argument consisted largely on the contrast with the treatment given to the offenders tried in its domestic courts, many of whom were being convicted to capital punishment in spite of the fact that they were not among the chief culprits of the genocide): see William A. SCHABAS, "International Law and Abolition of the Death Penalty", W\&LLR 55 (1998), p. 836 f.

36 See Allison Marston Danner / Jenny S. Martinez, op. cit., p. 91; see also Milica Kostić, op. cit., observing, in respect of the ICTY experience, that: "Despite the vast factual legacy of the ICTY which should lay the foundation for reconciliation in the region, the people in the former Yugoslavia are in fact further away from each other than ever. In the ICTY's defense though, the survey [indicated supra, $\$ 1.1.2.] doesn't support the hypothesis that had the ICTY been perceived as impartial it would have persuaded the public in its findings. (...) Leaving aside the issue of whether reconciliation was in the ICTY's mandate [in this regard, see in any case the statements of the president of the Court, Carmel Agius: "We are closing the door, but we are giving you a large collection of determined facts. We are giving you the truth about what happened. We are not offering reconciliation, because it has not been the mandate of this court to do it." in www.balkaninsight.com, 21 June 2017, last accessed 23 January 2018], the court was doubtlessly a tool for restoring and maintaining peace in the Western Balkans. We know that this goal wasn't achieved in the short-term as the Srebrenica genocide and the Kosovo conflict took place after its establishment. Unless we define peace as the mere absence of war, these latest public survey results question whether this goal has been achieved even in the long-run considering the rampant and worsening revisionism, denialism, ethnic nationalism and warnings of new conflicts."

37 Antonio Cassese, The Human Dimension of International Law. . o op. cit., p. 520; see supra, Chap. 1, S 5.2.2. 


\subsection{Specifications regarding the theoretical framework}

As indicated earlier, this chapter aims to establish a theoretical framework enabling the demarcation between the grounds for refusal that have become obsolete, inadequate, redundant, and those that remain useful, adequate, necessary. Admittedly, these terms are not perfectly synonymous, but they express adjacent concepts the combination of which should convey the polygonal character of the object of analysis of this study. Therefore, they are used interchangeably, such that any of them should be understood in a comprehensive sense.

The framework is formed of two fundamental layers. The first constitutes a historical analysis aimed at establishing factual or objective premises that have necessary implications for extradition law. This analysis is then translated into normative propositions which pinpoint the fundamental aspects of extradition law requiring a reform.

\section{Historical layer - The problem}

\subsection{Dynamic realities}

\subsubsection{Mobility}

The juxtaposition carried out at a very early moment of this study between extradition and the EAW, traditional cooperation and mutual recognition, revealed that they do not constitute two conflicting or incompatible paradigms ${ }^{38}$ While they do display a few meaningful differences, they are not so distant from each other as it might seem at a first glance. The EAW constitutes but a step forward on the same pathway, a stage further in the same evolutionary line. Note that these expressions ('forward' and 'further') are used neutrally. They are not necessarily to be understood as meaning that the EAW marked an improvement. Only that it marked a change in relation to a pre-existing state of affairs. And in any case not a very profound one at the conceptual level. The diversity existing within the EU - which contrasts with the uniformity of other constellations of States, such as the Nordic States - prevented the EAW from being the revolution it purported to be. As noted earlier, this is precisely why it constitutes such an adequate point of reference for re-evaluating traditional extradition. It is because of this that the suppression of certain grounds for refusal in the EAW system suggests that they may have become unnecessary in a more universal manner. Thus, the EAW system constitutes a signal of something larger than an adaptation of one paradigm to fit the specific needs of a given region: it constitutes a symptom of the conversion of such a paradigm (considered as a whole) into an object of reflection; and, therefore, a symptom of its possible demise. ${ }^{39}$

Naturally, the fact that the Schengen Area is characterised by a very high level of mobility raises considerations which concern not so much the question of whether certain

\footnotetext{
38 See supra, Chap. 2, $₫ 3$.

${ }^{39}$ See Byung-Chul Han, A Sociedade do Cansaço, Lisboa: Relógio d’Água, 2014, p. 10, et passim, who affirms more broadly that the explicit conversion of a paradigm into an object of reflection is often a signal of its demise.
} 
grounds for refusal have become unnecessary, as the question of whether it is legitimate to abolish them even though they remain relatively necessary. In other words: it is possible that some grounds for refusal remain as 'necessary' in the EU as in the wider world, but that removing them is only legitimate in a setting such as the EU, because here their removal can be conceived as a counterweight to a set of individual rights and freedoms which have been offered or highly magnified by this very political project. This is the aspect of the EU criminal justice area's synallagma ${ }^{40}$ that has not been explored yet. It is apparent that mobility is a key element when reflecting about extradition, since extradition is typically called into play when a person commits an offence in a given territory and later flees to a different one. It is also known that it is much easier to cross the internal borders of the EU (even for non-EU citizens) than most other borders in the world. Mobility is variable, and it is higher in the EU than in most other contexts. However, there are other regional contexts characterised by a generous freedom of movement, and where nevertheless cooperation in criminal matters has not been subjected to reforms even barely comparable to those effected by the EAW system. ${ }^{41}$

At any rate, there is a 'global' minimum level of mobility, which is that given by the objective possibilities of transportation and communication available to human beings. Such a minimum level is relatively uniform. It oscillates rather universally, though not quite simultaneously in all places. It appears to be mainly at the maximum level of the 'mobility scale' - i.e. the level of ease of movement given by such factors as legal, political, and cultural conditions - that we see meaningful variations from some regions to others, from some sets of States to others.

The most drastic oscillation ever recorded in the mentioned minimum level of the mobility scale was probably the one brought by the industrial age. So acute was the rise in the ease of transportation and communication recorded in this period that, practically on its own, it carried extradition to be profoundly reformed, re-founded even, in the late $18^{\text {th }}$ century. ${ }^{42}$ Indeed, while perhaps not so revolutionary as some authors classify it, such a reform was arguably the most profound one ever effected. Very importantly, the industrial revolution was not chronologically confined in its effects, but rather it reverberates to this date. Most theories - notably, those pioneered by Kondratiev and developed by Schumpeter and other subsequent scholars - which construe modern economy as a sequence of super-cycles or waves prompted by technological outbursts, begin in the invention of the steam engine. ${ }^{43}$ Through surges of innovation that took place at relatively regular intervals, ease of movement has increased and become more affordable ever since. Travelling shifted from rare to normal on a quasi-universal scale. This allows for the postulation that - with-

${ }^{40}$ See supra, Chap. 2, \3.2.4., and Chap. 4, \6.

41 An example is the Economic Community of West African States: see "Quadro Jurídico sobre o Branqueamento de Capitais, Combate à Corrupção e ao Tráfico de Droga nos PALOP”, Cidade da Praia: Imprensa Nacional de Cabo Verde, July 2015, p. 203, in http://www.legis-palop.org/bd. The Member States of this Organisation are Benin, Burkina Faso, Cape Verde, Ivory Coast, Gambia, Ghana, Guinea, Guinea Bissau, Liberia, Mali, Niger, Nigeria, Senegal, Sierra Leone and Togo: see http://www.ecowas.int/.

${ }^{42}$ But see further infra, $\int 2.3 .3$.

43 See Chris Freeman / Francisco Louçã, As Time Goes By: From the Industrial Revolutions to the Information Revolution, Oxford: University Press, 2001, p. 153 f. 
out prejudice to the development of peculiar versions of extradition adapted to the specific levels of mobility verified within given regions or sets of States - traditional extradition, as a device to be used in the context of any given interstate relations, should evolve continuously in adjustment to the fluctuations of the 'minimum global level of mobility' mentioned above. At the very least, it should avoid falling excessively below par in relation to such fluctuations.

\subsubsection{Remote criminality}

Another conspicuous development followed the industrial revolution and intensified steadily to the rhythm of technological advances and globalisation processes: the increase in human capacity to produce effects in places geographically distant from the one where the conduct is carried out. This resulted from an unremitting evolution in the means of communication, which probably recorded its most spectacular upsurge in the invention of the Internet and the World Wide Web, ${ }^{44}$ and which more recently was yet further magnified by the eruption of social media. ${ }^{45}$ Like the rise in mobility and so many other impactful technological developments, this raised new challenges for criminal law. ${ }^{46}$

Notably, it carried a severe increase in human capacity to harm the interests of distant jurisdictions and of the individuals located therein, in what may be labelled as 'remote criminal capacity'. Extradition is central for addressing this phenomenon, as it empowers States where the harm materialised to reach out to States where the acts were committed in pursuit of its authors. ${ }^{47}$ In a sense, extradition constitutes the nemesis of remote criminality, as it is itself remote: a remote criminal law tool through which national legal systems outreach their ordinary (territorial) area of influence; a long-armed tool against longarmed criminality. Its only, yet colossal, debility is that it does not operate automatically or spontaneously, but instead requires the collaboration of other legal systems. The real nemeses of remote criminality are, therefore, such measures as international abduction and certain military or quasi-military actions, which however fall basically outside of the realm of the law ${ }^{48}$ (which incidentally allows for the proposition that the easier it is to obtain extradition, the less incentive there will be for States to use such questionable expedients).

Cybercrime is a paradigmatic instance of remote criminality. It raises overwhelming challenges to traditional concepts of jurisdiction in criminal matters, including, and espe-

44 See ibid., p. $301 \mathrm{f}$.

45 See Catherine D. Marcum / George E. Higgins (eds.), Social Networking as a Criminal Enterprise, New York: CRC Press, 2014, p. 49 f.

46 See M. Cherif BAssiouni, International Extradition... op. cit., p. 49 f.

${ }^{47}$ This, however, needs to be understood in the light of the fact that not only States, but also individuals have been faced with serious difficulties arising from technological developments, notably because their actions now have a nearly uncontrollable aptitude for activating at once the punitive apparatuses of several States - on this aspect, see further infra, 3.3.3. One type of activity which is particularly problematic in this regard is copyright infringement, as discussed in ADAM CARLSON, "The Case of Richard O'Dwyer: Extradition as a Means to the International Enforcement of Copyright Protections”, TL\&CP 23 (2014), p. 453 f.

48 Thereon, see e.g. Christine van Den Wyngaert, The Political Offence Exception... op. cit., p. 50 f.; DAVID A. SADOFF, Bringing International Fugitives to Justice: Extradition and its Alternatives, Cambridge: University Press, 2016, p. 345 f. 
cially to the principle of territoriality, calling for the question as to whether it is even possible to say that there is a 'there' in this type of criminality. ${ }^{49}$ But while in its 'digital' facet this phenomenon is relatively recent, in its essence it is not. Before the Internet and mobile phones, criminal activities already existed that were run from certain jurisdictions while aimed mainly at producing their effects elsewhere. And extradition was a key issue already then. This is vividly illustrated by the war waged in the 80's by the USA on South-American narcotic kingpins, particularly on Pablo Escobar and his fellow, thus self-designated 'extraditables', whose motto was that it was 'better a grave in Colombia than a prison in the USA ${ }^{50}$ None of whom was ever extradited, due (legally speaking) to the absence of an extradition treaty. ${ }^{51}$ In fact, it can be assumed as a general principle that the leading figures of certain criminal organisations (notably of those dedicated to trafficking activities) have the capacity to completely avoid territorial contact with the jurisdictions at whose expense they profit.

As with personal mobility, the trend since the creation of modern extradition law is the increase in the capacity to commit crimes remotely. And, as with personal mobility, this factor does not vary meaningfully from region to region or from State to State. The damages caused remotely might or might not be territorial in the classic, physical sense of the term, but the common denominator is that perpetrators often do not set foot on the territory of the States that suffer most of the damage - which means that these States do not at any point have the possibility to detain the perpetrators, and that extradition is the sole unequivocally lawful means at their disposal to obtain custody of these individuals. ${ }^{52}$

49 MiChael A. GEIST, "Is there a there there? Toward Greater Certainty for Internet Jurisdiction", BTLJ 16 (2001), p. 1345 f., and ANDRÉ KLIP, "International criminal law. Information society and penal law", op. cit., p. $381 \mathrm{f}$, where the challenges raised by cyber criminality are extensively discussed.

50 See Ron CHePesiuk, The W ar on Drugs: An International Encyclopedia, Santa Barbara: ABC-CLIO, 1999, p. 71.

51 A more recent tale of this type is that of Joaquín 'El Chapo' Guzmán, imprisoned in Mexico twice (the first of which following an extradition from Guatemala), and twice escaped, but eventually extradited to the USA in 2017, for - and this is the focal point - criminal activities ran mainly from Mexico: see www.theguardian.com/world/2017/jan/19/el-chapo-extradited-to-the-us, last accessed 8 January 2018.

52 Investigative journalist specialised in Colombian narcotic kingpins, William C. REMPEL, "How Colombia is busting drug cartels", 19 January 2012, in www.edition.cnn.com/2012/01/18/opinion/rempelcolombia-extradite-cartels/, argues that in "Colombia, once home to the world's biggest cocaine cartels, new crime organizations are being picked apart with silent efficiency - aided by Bogota's enthusiastic embrace of extradition": "in recent years, more than 1.300 of Colombia's top crime bosses and their most dangerous enforcers have been sent north to face trafficking charges". The author notes that there is "scant evidence" that extradition can "stop drug smuggling". Arguably, some activities are simply too lucrative to be possible to deter by punitive means. To the author, "[t] he beauty of extradition as practiced by Colombia" is that "it continues to splinter the leadership of trafficking gangs, keeping them in a perpetual state of rebuilding", which releases political institutions from the sway of criminal organisations of which in the past they "too often seemed to be a hostage": "In short, extradition disorganizes organized crime." The author notes that some neighbouring countries are already drawing inspiration from this approach, namely Mexico, which - despite some "lingering reluctance", owed partly to "national pride" and "the conviction that Mexico should and can take care of its own crime problems" - has slowly been reassessing its "historic reluctance to extradite its citizens". The author further claims that, in comparison to other alternatives consisting of a direct involvement of foreign personnel and funds in the local criminal justice system, extradition is a "bargain"; it is "also the most potent weapon against organized crime available in the region". 


\subsubsection{Social alarm}

In connection with the factual developments mentioned above, another important phenomenon arguably took place which is of a more subjective character: the increase in the degree of social alarm triggered by evasion from justice. Ancient communities were so insulated that being displaced was a very hostile idea for a member of one such community. It meant serious adversity and a menace to survival itself. It should not be incidental that banishment used to be conceived as a criminal penalty: it was arduous enough for the person and appeasing enough for the community. ${ }^{53}$ In fact, offenders themselves would often refrain from escaping: "voluntary exile in itself constituted one of the harshest penalties", as "[f]oreigners abroad were usually not well-treated as they did not enjoy the rights and freedoms which were accorded to citizens." 54

These views began to change some centuries ago. By the mid- $18^{\text {th }}$ century Montesquieu was submitting that, "while banishment is always considered among us as a penalty, we are able to separate the idea of ostracism from that of punishment". ${ }^{55}$ In the same period Beccaria was construing banishment as a consequence to be inflicted upon "whosoever disturbs the public peace, or obeys not the laws", but not upon proven criminals: it "should be employed in the case of those against whom, when accused of an atrocious crime, there is a great probability but not a certainty of guilt". ${ }^{66}$ It was, in Beccaria's view, a consequence to be applied in the cases where the State would find itself in the "fatal dilemma" of having either to fear or unjustly convict an individual. ${ }^{57}$ This suggests a phase of transition of the perception as to the function of banishment: it was not regarded anymore as an appropriate sanction for a crime, since it would still entitle the person to liberty and to prove his innocence and was even regarded as a softer legal consequence than loss of property, but it was still linked to the perpetration of a crime and conceived as a "condemnation" or "punishment" in and of itself. ${ }^{58}$

Current circumstances are very different. Information on other places is abundant and easy to obtain. Being compelled to live abroad may carry difficulties, but is not nearly as hostile a thought as it may be assumed to have been in the past. The range of options for an escape is broader, unhindered by limitations in mobility; integration in a foreign community more viable, smoothed by the spread of a lingua franca. Concomitantly, contact with the people and the reality left behind can remain largely unbroken, enabled by a wide array of digital and telematic platforms.

While these factors have already removed much of the stigma formerly associated with exile, they are yet added by the fact that the exiled person may now keep visibility in

\footnotetext{
${ }^{53}$ See Christopher L. Blakesley, “The Practice of Extradition from Antiquity...”, op. cit., p. 46, stating that "in ancient social cells, such as the family, clan or tribe, expulsion was the ultimate penalty for internal crime"; see also Homer, The Iliad, New York: Signet Classics, 2007, p. 219, the passage on the death of Lycophron (fighter on the Greek side), who had been "banished from Cythera after killing a man".

${ }^{54}$ Christine van Den Wyngaert, The Political Offence Exception... op. cit., p. 5.

55 Montesquieu, The Spirit of Laws (1748), Kitchener: Batoche Books, 2001, p. 515.

56 Cesare Beccaria, op. cit., p. $180 \mathrm{f}$.

57 Ibid.

58 Ibid.
} 
the offended polity, and the wound of his/her crime remain open thereby. For instance, in a notorious case which ocurred in 2017, a convict of Portuguese and Israeli nationality escaped from a prison facility in Portugal, where he was awaiting trial on charges of multiple violent assaults on casino gamblers. Following the escape he repeatedly ridiculed Portuguese authorities through a social network, writing scornful messages and uploading pictures of himself en route to fleeing the country. The escape took place in February 2017; by July he was still scot-free, reportedly exiled in Israel, which does not generally extradite its own nationals, and which moreover does not have an extradition treaty in force with Portugal. ${ }^{59}$ Arguably very different in their contours, but also useful to illustrate the point in making, are the cases of Edward Snowden, who regularly delivers conferences which are streamed worldwide, of Julian Assange, who also maintains visibility, and of Roman Polanski, who continues to make prominent movies.

Lastly, while in the past a fugitive or banished person would typically be a member of the very society that was injured by his/her crime, with the rise in mobility described earlier it became more normal that the author of a crime be a member of another community; someone with tenuous or indeed no relation to the society within which he/she commits the crime. Often, the escape of such an individual will raise even greater social concerns: on the one hand, because in these cases exile tends to involve less hardship than when a person is displaced from his/her own community, which may affect significantly the sense of justice of the injured community; on the other hand, because these cases render even more visible the (already higher than in the past) vulnerability of national criminal justice systems, which jeopardises their preventative efficacy.

\subsubsection{Conclusion: The need for a transnational approach to punishment}

Habermas characterises the past few decades as "decades of unprecedented creativity and destructiveness of a politically intended globalization", where "functional systems of world society whose influence permeates national borders" have given rise to "problems that individual states, or coalitions of states, are no longer able to master". In this context, the author proclaims, "the relation between politics and society as such is up for discussion." ${ }^{\prime 00}$ In the light of current levels of mobility, remote criminality, and social alarm at the escape of criminals, crime prevention is clearly among the concerns that can no longer be addressed on a national scale, in a hermetical manner. A transnational angle is required, and to a great extent that means reconsidering extradition law.

The contention is not that criminality has increased overall during the period at issue. Such a claim would be highly questionable from different angles, empirical as well as nor-

\footnotetext{
59 See http://expresso.sapo.pt/sociedade/2017-05-28-Fugitivo-de-Caxias-esta-escondido-em-Israel and http://expresso.sapo.pt/revista-de-imprensa/2017-07-07-Portugal-pede-a-extradicao-de-fugitivo-deCaxias-a-Israel-passados-cinco-meses, last accessed 21 January 2018.

${ }^{60}$ JÜrgen Habermas, The Crisis of the European Union: A Response, Cambridge: Polity, 2013, p. xi, 55 f., specifying: "The global political agenda is no longer dominated in the first instance by conflicts between states but by a new theme, namely, whether the international potential for conflict can be brought under control to such an extent that globally effective norms and procedures, and correspondingly extensive political capacities for joint action, can develop out of an - until now improbable - cooperation among the major powers."
} 
mative: it would be virtually impossible to measure, and in any case the concept of crime is an ever-evolving one, such that to an extent one would inevitably be computing different types of human conduct indistinctly. The contention is simply that criminality of transnational character has increased; ${ }^{61}$ or, at the very least but most certainly, ${ }^{62}$ that conditions are more propitious than ever before for criminality of this character to occur. ${ }^{63}$

\subsection{Static laws}

\subsubsection{Extradition: Difficult to obtain}

While the current global minimum levels of mobility, remote criminal capacity, and social alarm inherent in situations of evasion from criminal justice are significantly higher than when modern extradition law was designed, this area of the law remains very similar to its original design, particularly insofar as it concerns grounds for refusal. ${ }^{64} \mathrm{With}$ the reform effected at the end of the $18^{\text {th }}$ century, extradition no doubt became much easier to obtain than in antiquity; but today, in many regards, it remains almost as difficult to obtain as at the end of the $18^{\text {th }}$ century.

The apathy of extradition law before impending hazards calls to mind the image of an ostrich with its head buried in the sand. Such an apathy is especially striking if one observes that, as factual circumstances continued to change, the theoretical and legal bases underpinning the reform of the $18^{\text {th }}$ century persisted in time, as reviewed subsequently.

\subsubsection{Jurisdiction: State-centric and territorial}

\section{a) State-centric}

Despite the increase in the transnational reach of human conduct, the paradigm of criminal punishment remains pointedly State-centric: as in the early days of the Westphalian paradigm, it is still essentially States that prescribe and enforce criminal offences, and few or no signals exist which allow us to anticipate significant changes in this respect. Ash-

${ }^{61}$ See e.g. REgINE SCHÖNEnBERG / ANNETTE VON SCHÖNFELD (orgs.), Transnational Organized Crime: Analyses of a Global Challenge to Democracy, Bielefeld: Transcript, 2013, p. 295, passim, stating that transnational organised crime has become an 'intrinsic' or 'inherent' feature of an economically globalised world. See also MARK FINDLAY, The Globalisation of Crime: Understanding Transitional Relationships in Context, Cambridge: University Press, 1999, p. 9, 18, 187 f., et passim, making the interesting claim that not only globalisation is a force for crime, but also crime is a force for globalisation.

62 According to UNODC, "The Globalization of Crime: A Transnational Organized Crime Threat Assessment", Vienna, 2010, p. 276, of the 16 transnational organised crime problems gauged, only 4 are clearly increasing. However, "this may be because only the largest and best established flows were included": some of those problems "have been around for decades, and may already be declining due to interventions and other factors"; others "are rapidly emerging, and it may be possible to take action before the problem spirals out of control". In any case, the time-span covered in the report is extremely limited compared to that in debate in this study, and it seems indisputable that transnational crime increased during the latter.

${ }^{63}$ Mark GALEOTTI, "Introduction: Global Crime Today", GC 6 (2004), p. 4 f., affirms that "the global underworld is evolving every bit as rapidly as its legal, 'upperworld' counterpart - and to a large extent in response to the same pressures and opportunities", which the author categorises into five main groups of 'drivers': (1) technological; (2) political; (3) economic; (4) enforcement-related; and (5) internal.

${ }^{64}$ See e.g. supra, Chap. 3, \1.1. 
worth posits that, in many States, the model according to which responsibility for the security of individuals belongs to the State is "not sustainable", and "is being devolved to private entrepreneurs and local authorities". ${ }^{65}$ However, this phenomenon refers to failed States, which are unable to 'fulfil their side of an agreement' (generally derived from social contract theories) which, according to the author, had correctly bestowed that responsibility upon them. ${ }^{66}$

The few developments that in effect depart from this pattern concern international crimes - acts which affect the international community as a whole. Currently, criminalisation of these acts does transcend the perspectives of any given State individually considered, and their enforcement might be effected by international judicial entities. ${ }^{67}$ But even here States have retained considerable standing: as noted before, in the case of the ICC (created by treaty) this is unequivocal, since its intervention is limited to situations where States cannot or will not exert their ius puniendi; other courts, such as the ICTR and the ICTY (created by UN resolutions), have more unreserved jurisdictional powers, but the assumption is still that they should only exert them if the State in question cannot or will not exert its ius puniendi. This implies that even these international judicial bodies are not so much the result of a consensus in the international community on the notion that international crimes should be tackled conjointly, in an authentically supranational manner, as a precaution against the proven incapacity or unwillingness of some States, in certain moments, to fulfil responsibilities of which they remain the main bearers.

As for transnational common criminality, no comparable initiatives have ever been taken. Intervention of supranational human rights judicial entities with a view to defending fundamental individual rights is possible, but the intervention of other supranational judicial entities with a view to assessing whether these proceedings are balanced is very limited. ${ }^{68}$ Cooperation proceedings remain essentially interstate proceedings, subordinated above all to the interests of requested States. ${ }^{69}$

\section{b) Territorial}

The scope of application of criminal offences remains fundamentally territorial. Extraterritorial jurisdiction was expanded over time in order to eliminate untenable punitive gaps, but territoriality retained undisputed primacy. This is clear from the fact that extraterritorial jurisdiction is generally subsidiary to territorial jurisdiction (and therefore to extradition).$^{70}$ It is also visible in the fact that - regardless of whether one takes a 'statist' or instead an 'internationalist' stance on the issue of the source of the power to adjudicate -

${ }^{65}$ Andrew Ashworth, Sentencing and Criminal Justice, 4th ed., Cambridge: University Press, 2005, p. 72; see also PEDro CAEIro, Fundamento..., op. cit., p. 47 f.

66 See ibid. (both references).

${ }^{67}$ For an account of this process, see PHILIPPE SANDS (ed.), From Nuremberg to The Hague: The Future of International Criminal Justice, Cambridge: University Press, 2003; ROBERT CrYER / HÅKAN FRIMAN / DARRyl Robinson / Elizabeth Wilmshurst, An Introduction to International Criminal Law and Procedure, Cambridge: University Press, 2014, p. 115 f.

${ }^{68}$ See supra, Chap. 2, $\$$ 3.2.2., and infra, Chap. 8, \5.2.1., on the ICJ.

${ }^{69}$ See esp. further infra, $\$$ 3.3.2. f.

${ }^{70}$ See supra, Chap. 1, \3.2., and Chap. 4, \ 2.4.3. 
${ }^{71}$ international law places limits on States' extraterritorial tentacles, e.g. by inhibiting the exercise of universal jurisdiction in absentia, ${ }^{72}$ or of a principle of jurisdiction based on such discriminatory factors as the ethnic origin of the suspect. International law also sets limits to the exercise of territorial jurisdiction, namely regarding acts committed in a territory that a State claims to be under its domain but that according to international law is being illegitimately occupied. ${ }^{73}$ However, the question there is not the prerogative to punish crimes committed in one's territory, but the prerogative to claim domain over a certain territory.

\subsubsection{Criminal procedure: Ubiquitous}

Another key premise that has remained unchanged is the conception that criminal punishment should seek to be ubiquitous, rather than symbolic. One of the characteristics of earlier extradition practices was their focus on political, rather than on ordinary criminality, ${ }^{74}$ in contrast with modern extradition, used primarily for ordinary crimes. ${ }^{75}$ This metamorphosis of extradition from a mainly political phenomenon into an essentially legal one has been labelled as a "striking occurrence", a "flip-flop" in its evolutionary line. ${ }^{76}$ However, the expansion of extradition to ordinary crimes and its exclusion for po-

71 That is, of whether one considers that this power originates in States themselves, or in international law instead; and, consequently, whether States can exert jurisdiction wherever international law does not so prohibit, or only where international law so permits: on the issue see e.g. PEDRO CAEIRO, Fundamento... op. cit., p. 294 f.; DAN HeLENIUS, "The If, How, and When of Criminal Jurisdiction - What is Criminal Jurisdiction Anyway?”, BJCL\&CJ 3 (2015), p. 31 f.; PCIJ, Lotus, 7 September 1927, and related literature.

72 As is well known this assertion is debatable. The ICJ approached this issue in the Yerodia case, but ultimately it did not take a stance thereon. The separate and dissenting opinions delivered by different judges of the ICJ in this case reflect the controversy and complexity involving the issue. This study is not required to take a stance thereon either. The goal is simply to acknowledge that elements do exist which allow to defend that universal jurisdiction can only be exerted if the perpetrator is found in one's territory, a position sustained e.g. by Pedro Caeiro, Fundamento... op. cit., p. 385 f., and admitted e.g. by Claus Kreß, "Universal Jurisdiction over International Crimes and the Institut de Droit International', JICJ 4 (2006), p. $578 \mathrm{f}$.

${ }^{73}$ See Pedro Caeiro, Fundamento... op. cit., p. 228.

74 See e.g. Edward Clarke, A Treatise upon the Law of Extradition, London: Stevens \& Haynes, $3^{\text {rd }}$ ed., 1888, p. 17 f.; Arthur Nussbaum, A Concise History of The Law of Nations, New York: McMillan, 8 th $^{\text {ed., }}$ 1954, p. 214; M. CHERIF BASSIOUNI, International Extradition... op. cit., p. 6; JOHN T. PARRY, "The Lost History of International Extradition Litigation", VJIL 43 (2002), p. 98, 102.

75 A remarkable exception is a 1376 Treaty between France and Savoy, which sought to combat ordinary criminals more than political enemies. This treaty contrasted acutely with the political, at times even vengeful, character of earlier treaties - perfectly mirrored in that concluded by Pedro I of Portugal with Spain in 1360, aimed at seizing the assassins of Inês de Castro, his lover, and those concluded by Charles II of England with Denmark in 1661 and with the Netherlands in 1662, with a view to capturing the persons implicated in the murder of Charles I, his father: see CHRISTOPHER L. BLAKESLEY, "The Practice of Extradition from Antiquity...”, op. cit., p. 48 f.; MANUEL AdOLFO VIEIRA, "L'évolution récente de l'extradition dans le continent américain”, CCHAIL 185 (1984), p. 168; and MÁRIO MENDES SERRANO, op. cit., p. 20 f.

76 William Magnuson, op. cit., p. 851. IVAN ANTHONy SHEARER, op. cit., p. 166, goes so far as to link the two tendencies: "The coterminous movement in policy towards the prohibition of the surrender of political offenders with the beginning of the large-scale conclusion of extradition treaties prompts the conclusion that the recognition of the interdependence of nations and the motives of international cooperation which inspired extradition necessarily precluded the idea of surrendering political offenders". Identical, see CHARLES K. Burdick (rep.), "Harvard Research in International Law: Extradition”, op. cit., p. 108 f. 
litical ones, despite their temporal proximity, do not appear to be opposite sides of the same coin, but rather independent effects deriving from different causes. ${ }^{77}$

It is commonly advocated that the 'generalisation' of extradition was an adjustment to the revolutionary developments in the means of transportation and communication that took place in the early $19^{\text {th }}$ century, which made it remarkably easier both for criminals to escape and for national authorities to assist each other in bringing them to justice. ${ }^{78}$ The notion is not disputed, and was in fact already endorsed above. However, the causal processes in question do not appear to be so simple as they are sometimes depicted. The inventions immediately responsible for the industrial shock (notably George Stephenson's first steam engine, in 1814) took decades to be implemented in such a way as to become of widespread use. ${ }^{79}$ Extradition treaties for common crimes began to appear still in the $18^{\text {th }}$ century, but with very few exceptions only between nearby States, where the flux of people was already relatively easy. ${ }^{80}$ Again, this undoubtedly supports the view that pragmatic reasons ( $s c$. the necessity to adjust to these changes) are among the leading factors prompting the verified increase in cooperation. However, it does not explain, on the one hand, why it is that between distant States the process of concluding extradition treaties began, if rather sparsely, before the new means of transportation and communication became accessible; or, on the other hand, why it is that between neighbouring States such a process did not begin even earlier than it did.

The missing element seems to be that in this period another revolution was taking place: a revolution in criminal law and political economy. One that had started already in the mid- $18^{\text {th }}$ century, with such thinkers as Beccaria and politicians as Le Peletier, and which entailed deep changes in the theoretical foundations of criminal punishment. This period was thoroughly analysed by Foucault, who construes it as "a time when, in Europe and in the United States, the entire economy of punishment was redistributed": punishment "leaves the domain of more or less everyday perception and enters that of abstract consciousness; its effectiveness is seen as resulting from its inevitability, not from its visible intensity; it is the certainty of being punished and not the horrifying spectacle of public

\footnotetext{
77 As is recognised by William Magnuson, op. cit., p. 851, and Charles K. Burdick (rep.), "Harvard Research in International Law: Extradition", op. cit., p. 108. That there is no necessary incompatibility between extraditing for political and ordinary offences is denoted by the existence of an eclectic phase in the early modern era. In this phase a clear trend began to emerge of using extradition used against ordinary criminality, but it remained in use also for political and military offences, notably as a reaction against desertion of troops and sailors, a major problem in a Europe "riven by dynastic rivalries and interminable conflicts": William Magnuson, op. cit., p. 848; see also M. Cherif BASsiouni, International Extradition... op. cit., p. 5 f. An example is the 1765 Treaty between Spain and France, which provided for the extradition of rebels and deserters, on the one hand, but also of assassins, thieves, poisoners, raiders, arsonists, blasphemers, rapists and forgers, on the other hand: see MÁrIO MENDES SERRANO, op. cit., p. 19.

78 See again, e.g., IVAN ANTHONy SHEARER, op. cit., p. 7.

${ }^{79}$ See Charles K. Burdick (rep.), "Harvard Research in International Law: Extradition”, op. cit., p. 35 f.

${ }^{80}$ See IVAN ANTHONY SHEARER, op. cit., p. 8 f., construing this as one reason for England and the USA to have barely concluded any extradition treaty during this period: they "were naturally protected by geography until the more sophisticated means of transport enabled criminals to move farther afield."
} 
punishment that must discourage crime". ${ }^{81}$ The generalisation of extradition is extremely consistent with the generalisation of punishment. Beccaria phrased most clearly the inextricable link between the new paradigm of penal intervention and the rise of extradition as a means to repress ordinary crimes: "as the effective influence of punishment consists more in its inevitability than in its violence, asylums do more to invite to crimes than punishments do to deter from them"; thus, "the conviction of finding nowhere a span of earth where real crimes were pardoned might be the most efficacious way of preventing their occurrence". ${ }^{82}$ In this light, it is plausible to assume that the modern paradigm of extradition law should not be understood strictly as an inevitable and immediate product of a world where it is easy to communicate and travel, but also as an indirect product of deeper and relatively independent changes in the manner how the function of criminal punishment is perceived.

The paradigm of omnipresent punishment endures. One of its most visible expressions is the procedural principle of legality followed by many States, obliging them to prosecute virtually all crimes of which they obtain notice. It is true that many States confer significant discretion on their prosecutors, as is illustrated by the UK (one of the case studies of this research); but the principle of opportunity is not tantamount to arbitrariness, as its exercise is usually constricted by criteria defined beforehand in general and abstract terms by the legislator. ${ }^{83}$ It is also true that even many of those States that at a certain point embraced wholeheartedly the legality principle eventually conceded to deviations. This is the case of Portugal (the other case study of this research), where such concessions symbolise a recognition both that minor crimes can be handled by means softer than a regular criminal procedure, and that in any case it is unrealistic to assume that all crimes can be prosecuted, with the consequence that the system would do well to focus on the most serious ones ${ }^{84}$ Either way - and this is the point -, any penal system that aims to be at the same time effective and egalitarian must strive to ensure that at least most of the more serious crimes are sanctioned. ${ }^{85}$ Extradition is pivotal for attaining that goal.

${ }^{81}$ Michel Foucault, Discipline and Punish - The Birth of the Prison, Alan Sheridan (trans.), New York: Vintage Books, 1977, p. 7 f., framing this period between c. 1760-1840 (although arguing that some of the traits of the preceding paradigm are still visible contemporarily: p. 15 f., et passim). For a critical analysis of this period (its underlying processes, the reform effected, and its consequences), see esp. p. $73 \mathrm{f}$. This is not a context to engage in these topics, but it would be inappropriate not to remark that it was the understanding of the author that the conjuncture that saw the reform was not that of a "new sensibility", but simply of "another policy with regard to illegalities": p. 74.

82 Cesare Beccaria, op. cit., p. $192 \mathrm{f}$.

${ }^{83}$ See e.g. Tricia Howse, "England", in Katalin Ligeti (ed.), Toward a Prosecutor for the European Union Volume 1: A Comparative Analysis, Oxford: Hart Pub., 2012, p. 137.

84 See MANUEl DA COSTA ANDRADE, "Consenso e oportunidade (reflexões a propósito da suspensão provisória do processo e do processo sumaríssimo)", in CEJ (ed), Jornadas de Direito Processual Penal: O Novo Código de Processo Penal, Coimbra: Almedina, 1988, p. 317 f.; Pedro CaEIro, "Legalidade e oportunidade: a perseguição penal entre o mito da 'justiça absoluta' e o fetiche da 'gestão eficiente' do sistema”, RMP 21 (2000), p. $31 \mathrm{f}$.

85 As for the postulate that minor crimes justify softer punitive approaches, it is duly considered in the context of extradition, notably through the ground for refusal that reserves the use of this device to crimes that present a minimum level of seriousness: see infra, Chap. 8, $\int 3.2 .1$. 


\subsubsection{Conclusion: A remarkable lag}

For understandable reasons, the State-centric, territorial and ubiquitous paradigm of punishment in emergence when modern extradition law was devised remains fundamentally unchanged, and in consequence extradition continues to be an indispensable criminal justice mechanism. Meanwhile, factual conditions have changed drastically: distances became easier to travel and human conduct wider in reach; taking refuge abroad became less intimidating and social alarm at the escape of criminals more intense. Today's world is a smaller one, where States and their communities are in several regards closer to each other.

Yet, extradition law still conceives them as isolated entities. It still displays many of the features it was bestowed with upon inception at the end of the $18^{\text {th }}$ century, and as such it contributes to distancing those communities. It did not accompany reality, and is therefore lagging behind it. The following paragraphs seek to translate this diagnosis into normative propositions susceptible of being used for determining how such a lag can be rectified.

\section{Normative layer - The solution}

\subsection{The rule: Furthering the principle of territoriality}

The foregoing historical analysis relates intrinsically to the principle of territoriality. It has become common knowledge that globalisation carried the erosion of sovereignty, and particularly - territory being the fundamental area of efficacy of sovereignty - of territorial jurisdiction: a reduction has taken place in the capacity of States to perform unaided their function of controlling ordinary domestic criminality. ${ }^{86}$ Translated into a basic normative proposition, and considering the narrow prospects of development of supranational approaches to ordinary criminality, this can only mean that even greater preponderance must be attributed to the State where the crime was committed or where most of its harm materialised. ${ }^{87}$ Paradoxical as it might seem, globalisation requires 'more' territoriality. This proposition is dissected in its several dimensions throughout the following paragraphs.

\subsubsection{Territoriality and custody}

In the context of extradition law, assigning greater preponderance to territorial jurisdiction equates to recognising greater preponderance to the requesting State, as this is typically the State where the crime was committed or most of its harm materialised. This proposition has very tangible consequences. It causes the relevance currently attached by extradition law to the legal system of the State where the possible offender is located - a State whose involvement in the case may derive from the sheer event that after the crime

\footnotetext{
86 See supra, Chap. 1, $\int 3 \mathrm{f}$.

${ }^{87}$ Even in the EU, with its high level of integration, the primacy of territoriality is still quite modest, as is denoted by such elements as the Eurojust Guidelines for Deciding Which Jurisdiction Should Prosecute? (revised in 2016), p. $3 \mathrm{f}$.
} 
it provided shelter to its possible author - to be compressed in favour of the punitive necessities of the State that was injured by the crime. That is, the higher the levels of mobility, remote criminal capacity and social alarm are, the more imperative it will be to assist other States in enforcing their laws territorially, regardless of how one's own law might regulate the same situation had it been committed in one's own territory. In more graphic terms: the energy emanating from the legal system of the requested State fades, and that emanating from the legal system of the requesting State intensifies in an inversely proportional manner.

This perspective finds support in the evolution verified in the area of private international law. As expounded by Kuipers, ${ }^{88}$ this area of the law comes into play when two or more States are involved, differences exist between their laws, and there is some level of contact between them. Private international law is usually deemed to have started with the post-glossators, especially Bartolus ( $14^{\text {th }}$ century), who deduced a conflict of laws rule from the Corpus Juris Civilis: "To answer the question whether a law could be applied to a citizen residing outside the relevant territory and whether a law could be applied to foreigners residing in the relevant territory, he divided laws as to groups (contracts, torts, goods etc.) and nature (permissive v. prohibitive rules and rules that were advantageous or disadvantageous to the individual concerned). For example, a prohibitive rule could be applied extraterritorially when it was advantageous for the individual concerned, but not when it was disadvantageous." This approach, generally known as 'statute' or 'statutist' theory, according to which the sphere of application of a given rule is determined by its object, lingered throughout the medieval period, was refined by French authors of the $16^{\text {th }}$ century, and was yet further developed by Dutch scholars of the $17^{\text {th }}$ century. These authors argued that, if the sovereignty of a State does not extend beyond its borders, then the same should apply to personal statutes; however, they did not take the view that States would have a duty to give effect to the laws of other States in their territories: this could - and, in a world of blooming international commerce, should increasingly - be done voluntarily (out of comity), but no such obligation existed.

This state of affairs changed radically in the $19^{\text {th }}$ century, owing to the work of Savigny, whose ideas, despite the natural adaptations required by the times, remain vivid in this area of the law and in legal theory more generally. ${ }^{89}$ Savigny considered the statutist approach both "incomplete and ambiguous", and developed a different theory based on a clear-cut division between public and private law, whereby conflict rules would be used solely to determine the applicable private law. ${ }^{90}$ This shifted the terms of the problem entirely: "The scope of application of private laws should not be deduced from the rule at stake, but rather from the legal relationship. The law of the jurisdiction where the legal situation had its 'Heimat' (home) or natural seat should be applied. The object, content and purpose of the rule thus became irrelevant. (...) [It] was as a matter of principle not inter-

88 JAN-JaAp Kuipers, EU Law and Private International Law: The Interrelationship in Contractual Obligations, Leiden: Brill, 2012, p. 35 f.; also the subsequent quotes in this paragraph.

${ }^{89}$ See e.g. Geert van CAlster, European private international law, 2nd ed., Oxford: Hart, 2016, p. 4; A. Ferrer Correia, Lições de Direito Internacional Privado I, Coimbra: Almedina, 2000, p. 116 f., 128 f.

90 See JAN-JAAP KUIPERS, op. cit., p. 38 f. 
ested in the outcome of the application of the substantive rule it held applicable. Rather it was only concerned with the establishment of the spatially most appropriate law." ${ }^{\prime 91}$ In the words of Savigny himself: "Most writers on this subject beginning with the question of conflicts or collisions, deal with these as the only problems requiring solution. No satisfactory results can arise from this method of procedure. The natural sequence of thought is rather the following. As to the rules of law, the question is, what legal relations do they affect? As to legal relations, to what rules of law are they subject? Within what limits certain rules of law operate, - how far the province of each extends, - and when they come into collision, are, in their very nature, secondary and subordinate questions." 92

Private international law hence became "rule blind, value free, or neutral"; "93 "blindfolded". ${ }^{94}$ The determination of the sphere of application of a given rule would no longer be unilateral, but multilateral. The comity doctrine was criticised, and the possible application of foreign laws grounded instead upon a more universalist concept - namely that of "völkerrechtliche Gemeinschaft der miteinder verkehrenden Nationen" -, pursuant to which "every legal dispute had to be decided in the same way regardless where the proceeding was brought". ${ }^{95}$ In other words, a concept of "international harmony of decisions", ${ }^{96}$ where "the focus is on the Sitz or 'seat' of a relationship in law: which legal order has the closest connection to the specific facts at issue, where lies the nexus of the case, which legal order connects predominantly to the case". ${ }^{97}$

This brief survey does not mean to imply that the rules which establish States' jurisdiction in criminal matters compare to the conflict of laws rules of private international law. Such an understanding is highly debatable, ${ }^{98}$ considering the profound differences existing between those two types of norms and the areas of the law (private and public) to which they refer. The notion of 'conflict of jurisdiction' in criminal matters can hardly be compared to that of 'conflict of laws' in the sense borne by this expression in the field of private international law, as in the former case what is at stake is but a delimitation of the spatial scope of application of given legal systems, without an inherent determination of the competence of any other (foreign) legal system..$^{99}$ In fact, in the situations we are addressing at this point of the study a conflict of jurisdiction does not exist at all: issues of allocation of jurisdiction have already been duly contextualised, and it is now assumed that the requesting State is the one that holds the title of jurisdiction which deserves to

91 Ibid., p. 38.

${ }^{92}$ Friedrich Carl von Savigny, Private International Law: A Treatise on the Conflict of Laws, and the Limits of Their Operation in Respect of Place and Time (transl. William Guthrie), Edinburgh: T. \& T. Clark, 1869, p. 6. The book is the eighth and final volume of the author's work on Roman private law.

93 JAN-JAAP KUIPERS, op. cit., p. 38.

94 GEERT VAN CALSTER, op. cit., p. 4.

${ }^{95}$ JAN-JAAP KUIPERS, op. cit., p. 38.

96 Ibid.

${ }^{97}$ Geert van Calster, op. cit., p. 4; see also IsABel de MagalHães Collaço, Direito Internacional Privado: Vol. II, Lisboa: AAFDL, p. 228 f., 334 f.

${ }_{98}$ With diverging views, see e.g. PEDro CAEIRO, Fundamento... op. cit., p. 215 f., and INÊS FERrEIRA LEITE, op. cit., passim.

${ }^{99}$ See Rui Manuel Moura Ramos, Da Lei Aplicável ao Contrato de Trabalho Internacional, Coimbra: Almedina, 1991, p. $271 \mathrm{f}$., adding that the same applies to civil procedure and to administrative and fiscal law. 
be satisfied. The 'natural seat' of the legal situation is, therefore, settled. The issue that is now in debate is the fact that the decision of whether or not to grant extradition - which from that jurisdictional perspective should be answered in the affirmative -, is dependent on grounds for refusal that are infused with considerations springing from the legal system of the requested State. As if such situations had a link to this legal system other than the sheer contingency, which is fully unrelated to the crime itself, that at a certain moment (subsequent to its perpetration) its author moved into the respective territory. That is, under current extradition law, the requested State in a sense 'internalises' acts that have no contact with its legal system. It applies its own rules of criminal law to those acts (not in the same terms as these rules are applied in criminal proceedings, of course, but for the specific purposes of extradition proceedings), and it is in this sense that 'conflicts of laws' arise which may be compared to those that take place in the field of private international law. And, to the extent that such conflicts are solved by reference to those rules, more specifically to their content (as is always the case here, because as noted above they do not intervene here as mechanisms for determining which of several competing laws is applicable to a case, but instantly as criteria for determining how such a case shall be decided), that resolution not only is not neutral (in the same way as the conflict of laws rules of private international law were not neutral before the displacement of the statutist theory), but also it is subjective, in that it is predetermined by reference to a subject (the requested State), rather to an object.

This is all the more inconsistent when one observes that, whereas private international law involves intersubjective relationships (marriage, trade, e.g.) that might persist in time and continue to produce their effects (or that are indeed yet to produce their effects) in the legal system where the individuals in question are based, criminal law is retrospective. It concerns acts that have taken place in a certain (even if prolonged) moment in the past and whose results will generally have materialised within a more confined timeframe. On the other hand, precisely because the legal system of the requested State has no contact with the legal situation other than the custody of the suspect, if and when this State transfers this person to another State it breaks all contact with that legal situation. ${ }^{100}$ That is, extradition too is relatively confined. This constitutes another reason to strive for further neutrality in its regulation.

But the impact caused by the increase in mobility, remote criminal capacity and social alarm upon extradition law was not just that it made it more desirable, from a rational policymaking perspective, to constrict the influence of the legal system of the custodial State over that of the injured State. The allegation that is being made here is that such an increase effectively diminished the influence of the legal system of the custodial State, irrespective of any voluntary process of adaptation on its part: the easier it is for individuals to flee the territory of States where they commit crimes and to thereafter take harbour in the territory of other States, the more preponderant the legal systems of the former become. The situation has therefore become unsustainable, even considering that in crimi-

100 Save for the right to have the requesting State comply with the specialty rule - analysed infra, Chap. 8, $\int 3.5 .1$. - , or with other guarantees or conditions that have been agreed upon. 
nal matters, unlike what happens in private matters, the State is inherently an intervening or interested party to the legal situation being regulated. ${ }^{101}$

\subsubsection{Territoriality and non-interference}

In view of the observed changes in factual conditions, the only alternative available to constricting the influence of the requested State's legal system would be austere border controls and other isolationist measures. It is highly doubtful that such an approach could have any efficacy in an increasingly integrated world. It would represent an effort to swim against the tide of history, and could only succeed at the expense of an extraordinary sacrifice of individual liberties.

In any case, at the ideological level, this study could not possibly endorse such an approach. It relies instead on the understanding that the world not only probably will, but also that it should become a progressively more integrated place, because, among other factors, this has become the only manner to tackle the main problems it is faced with. ${ }^{102}$ If the world is to continue its integration process, some regulatory adjustments are necessary, and it is within this mind-set that the proposition is made for a transnational criminal justice model characterised by an increased respect for the legal system of the State where the crime is committed or its consequences materialise.

The alternative approach would likely prove detrimental not only to that aspiration, but also to the functioning of democratic principles. Legitimacy to establish prohibitions of conduct (jurisdiction to prescribe) has a fundamentally territorial foundation: as already noted, territorial crimes are the ones that trigger greater preventative concerns (and, thus, greater need for penal intervention), and all territorial crimes raise such concerns, due to their intrinsic proximity to the respective community - and in this sense the principle of territoriality stems more from anthropological factors than from developed constructs of political sovereignty and State authority. ${ }^{103}$ Consequently, the territorial efficacy of a legal

101 On this issue, see further infra, $\int$ 3.2.2. Even in private international law, when a State has a particular interest in the regulation of certain private relations, it sets in place substantive norms that apply 'necessarily and immediately' to those relations even if according to neutral criteria the applicable norm would be a foreign one (lois d'application immédiate): see e.g. Rui MANUEL Moura RAMOS, Estudos de Direito Internacional Privado e de Direito Processual Civil Internacional - II, Coimbra: Coimbra Editora, 2007, p. 312 f. However, these are specific norms based on specific considerations (e.g. political) and which do not carry the application in totum of the law of the forum: the aspects of the relation at issue that are not covered by the 'norm of necessary and immediate application' will still abide by the foreign law, unless this carries intolerable results to the legal system of the forum and triggers its ordre public - and on this issue see further infra, $\int 3.2 .3$.a). This is quite different from using the ensemble of concepts of this legal system to regulate a relation which from a neutral perspective should be regulated by a foreign law.

102 In this line, see e.g. Jürgen Habermas, op. cit., passim; John Rawls, The Law of Peoples; with The Idea of Public Reason Revisited, Harvard: University Press, 1999, p. 112 f., et passim; see further infra, \ 3.2.3.

103 See Pedro Caeiro, Fundamento... op. cit., p. 321; JosÉ DE FARIA CosTA, Globalização e Direito: Reflexões não locais e pouco globais, Coimbra: Coimbra Editora, 2010, p. $182 \mathrm{f}$. See also, albeit with regard to private law, Friedrich CARL vON SAVIGNY, op. cit., p. 15 f.: "In order to discover the connection by which a person is attached to a particular positive law by subjection to it, we must remember that the positive law itself has its seat in the people as a great natural whole", such that "[i]t is only another expression of the same truth, when we say that law has its seat in the state (...), because, as it is only in the state that the will of individuals is developed into a common will, it is there only that the nation has a realized existence." 
system is not disturbed by the fact that other legal systems regulate the same situation differently. On the contrary, in an international community where non-interference in the affairs of other States is almost a creed, the default premise in interstate relations should be that States do assist other States in enforcing their law territorially regardless of how their own laws govern the same situation, as occurs in private international law, with its neutral model of determination of the applicable law. It is worth evoking the 1970 UN Declaration on Principles of International Law concerning Friendly Relations and Cooperation among States in accordance with the UN Charter, which postulates that the principle of sovereign equality of States entails that each State has "the right freely to choose and develop its political, social, economic and cultural systems" - which includes its criminal policy,$-{ }^{104}$ and "the duty to respect the personality of other States". ${ }^{105}$

The principle of non-interference is "the mirror image of the sovereignty of States", 106 "an antithesis of the right of intervention that was, from time to time, exercised by powerful states against weaker states in many different forms". ${ }^{107}$ It emerged as a solid practice in the $19^{\text {th }}$ century, although it was already "inherent in the new world order ushered in by the Peace of Westphalia", ${ }^{108}$ and it remains a solid principle of international law, even if its once absolute status has been somewhat mitigated by the advent of human rights and other developments. ${ }^{109}$ As Grotius expounded even before the 1648 Treaties of Münster and Osnabrück, the reason why States request extradition is that they cannot legitimately cross the borders of other States with a view to getting hold of individuals suspected of having committed crimes in their own territories or against their own interests. ${ }^{110}$ Therefore, to issue an extradition request is to put in practice the principle of non-interference.

But this duty has ulterior, less obvious implications in the realm of extradition. As Grotius also posited, in the same manner as individuals who order or aid other individuals in committing crimes bear some responsibility for those crimes, States and communi-

The author attaches relevance also to factors of a more "personal nature" (notably nationality), rather than only to territoriality, but notes that in territoriality, which "is connected with something outwardly cognisable, namely, the visible geographical frontiers", "the influence of human choice on its application is more extensive and immediate than in nationality, where this influence is merely exceptional". The author further notes that in the course of time territoriality "supplanted nationality," and that this is all the more irreversible "the more varied and more active [the] intercourse between different nations, by which the rougher contrasts of nationalities were necessarily removed."

104 See Dan Helenius, op. cit., p. 33.

105 See, respectively, e) and c) of said Declaration, under the 'principle of sovereign equality of States'.

106 Michael WoOD, “The Principle of Non-intervention in Contemporary International Law: Noninterference in a State's Internal Affairs used to be a Rule of International Law: Is it still?”, Summary of the Chatham House International Law discussion group meeting held on 28 February 2007, p. 2. See also LASSA Oppenheim, International Law: A Treatise - Vol. I. Peace, New York: Longmans, Green and Co., 1905, p. 428 , stating that this principle "is a corollary of every state's right to sovereignty, territorial integrity and political independence".

${ }^{107}$ Hitoshi Nasu, "Revisiting the Principle of Non-Intervention: A Structural Principle of International Law or a Political Obstacle to Regional Security in Asia?”, AsJIL 3 (2013), p. 33.

108 Maziar Jamnejad / Michael WoOd, “The Principle of Non-intervention”, LJIL 22 (2009), p. 349; see also Hitoshi NASU, op. cit., p. 33.

109 See Michael WoOd, op. cit., p. 6 f.

110 See Hugo Grotius, De Jure Belli ac Pacis... op. cit., p. 368. 
ties that support individuals who commit crimes in other States and against other communities, notably by granting them asylum, also share some responsibility for such crimes - hence his famous proposition that an international duty impends upon States where criminls abscond to either surrender or punish them. ${ }^{111}$ The author attached such a duty only to 'crimes which affect mankind as a whole' and to 'crimes which are particularly harmful to another State'. ${ }^{112}$ The former group corresponds to what is currently known as 'core international crimes'; the latter to the offences that nowadays tend to be covered by protective jurisdiction, as well as to the most serious ordinary offences covered by territorial jurisdiction - which in today's standards can be extended to all territorial offences, ${ }^{113}$ given the transition effected in the Enlightenment from a paradigm of symbolic into one of ubiquitous criminal justice. ${ }^{114}$ Regarding the first group of offences, a duty did emerge in international law requiring States not to allow them to stay unpunished; as for the latter, however, no similar duty has emerged to this date. ${ }^{115}$

And yet, considering States' increasing difficulties in controlling domestic criminality by themselves, the philosophy underlying Grotius' argument is probably more pertinent and up-to-date than ever before. If territory is the fundamental space of sovereignty, and territoriality the quintessential basis for jurisdiction thereby, then refusing to help other States in applying their laws to acts committed in their territories may be regarded as a form of interference in their affairs. One that will not take the more usual form of an action, but that of an omission. This omission can be considered censurable because the principle of territoriality places States in what in the conceptual framework of substantive criminal law would be called a 'position of care', i.e. a position carrying a duty to take the positive actions that prove necessary to avoid an unlawful result. ${ }^{116}$ Similarly to individuals - the basic and concrete entities forming the complex and abstract entities that States are -, States can be held accountable not only for doing things that they should not have done, but also for failing to do things that they should have done. ${ }^{117}$ In this case, that would mean a positive dimension in the (mostly negative, even in its wording) duty of non-interference.

This is not to claim that refusals to extradite are necessarily in breach of the principle of non-interference. Only that this principle, in articulation with the principle of territoriality, provides a solid normative reference for understanding the significance of refusals to cooperate with other States towards the enforcement of their territorial laws.

111 Ibid., p. 366 f.: " aut ut ipsa interpellata pro merito puniat nocentem, aut ut eum permittat arbitrio interpellantis: hoc enim illud est dedere” (p. 368), most known as 'aut dedere aut punire'.

112 Ibid:: "delictis quae ad societatem bumanam aliquo modo pertinent", and "delictis quibus alia civitas aut ejus rector peculiariter laesus est'.

113 Except again for those of reduced seriousness, which trigger specific proportionally considerations.

114 See supra, $\$ 2.2 .3$.

115 See supra, \3.1.2., and further supra, Chap. 1, \ 4.2.

116 On the concept, see JOHANNEs KeILER, "Commission versus Omission”, in Johannes Keiler / David Roef (eds.), Comparative Concepts of Criminal Law, Antwerp: Intersentia, 2015, p. 47 f., 58 f.

117 See Art. 2 Draft Articles on Responsibility of States for Internationally Wrongful Acts (2001); and the accompanying commentaries of the International Law Commission, stating, supported on ICJ case law, at p. 35 f.: "Conduct attributable to the State can consist of actions or omissions. Cases in which the international responsibility of a State has been invoked on the basis of an omission are at least as numerous as those based on positive acts, and no difference in principle exists between the two." 


\subsubsection{Territoriality and reciprocity}

At which point another important element comes into play, namely that which may be called the 'ground-levelling' role performed by the reciprocity principle. As established quite early in this study, altruism is largely immaterial in interstate cooperation, but, since the paradigm of criminal justice remains fundamentally State-centric, States are bound to keep intensifying their cooperation relations, because these relations rely heavily on the notion of reciprocity: increasing cooperation with other States means obtaining more cooperation from them. ${ }^{118}$ The international community may be somewhat closer to the ideal of a civitas maxima today than it has been in the past, but there is sound cause to claim that it remains a largely Hobbesian one. ${ }^{119}$

Selfishness may be regrettable, but it also forms a powerful warranty of cooperation. It functions as cement keeping together even the most polarised elements of the international community; it introduces a certain type of rationality into their behaviour towards each other. ${ }^{120}$ Relying on this ground-levelling role of reciprocity, the decision that States need to make regarding their extradition relations boils down to the following question: is it more important for them to punish acts that are harmful to them, or to refrain from partaking in the punishment of acts that, albeit harmful to other States, are innocuous in their eyes? This resembles strikingly the classic 'crime control $v$. due process' query as to whether it is more imperative to avoid that criminals escape or that innocents be convicted. Blackstone's response is well-known and conserves all its authority: "it is better that ten guilty persons escape, than that one innocent suffer". ${ }^{121}$ The author of this study too could not be more reverent towards the principle of presumption of innocence and other fundamental principles aimed at guarding individuals from States as potentially abusive entities. However, in the problem that occupies this study, choosing to enhance crime control - within certain limits, notably the observance of human rights, which constitutes a matter of principle that cannot be foregone owing to sheer public policy considerations (the intrinsic role of such rights being precisely to protect individuals from the might of States) - does not by definition entail any risk to any such principles. ${ }^{122}$

\subsubsection{Conclusion: A rebuttable but robust presumption}

This section sought to establish that, as a matter of principle, extradition should be granted to the State with territorial or protective jurisdiction. This does not entail that the jurisdictional title held by the requesting State should prevail over all other factors. Only that it constitutes a factor worthy of even greater preponderance or priority than that which it already, justly garners. It is the factor that is assigned the most overarching sway

\footnotetext{
118 See supra, Chap. 1, $\int 4.3$.

${ }^{119}$ For a review of "different constellations of thought" on the nature of international relations (including the "civitas maxima hypothesis" and the "anarchical" or "Hobbesian" approach), with criminal justice as background, see M. Cherif Bassiouni / Edward M. Wise, op. cit., p. 26 f.; Edward M. WisE, "Extradition: The Hypothesis of a Civitas Maxima and the Maxim Aut Dedere Aut Judicare", RIDP 62 (1991), p. $109 \mathrm{f}$.

120 See again Robert O. KEOHANE, op. cit., p. 3, 27 f.

121 See William Blackstone, op. cit., p. 352.

122 On this, see yet infra, Chap. 8, $\$$ 2.1.3.
} 
within the theoretical framework in development; the principle against which all other factors are to be tested; a presumption rebuttal of which requires compelling reasons. The ensuing paragraphs elaborate on what such reasons might be.

\subsection{The exception: Preserving core national values}

As was established earlier, States are bound to comply with certain prohibitions on extradition. Such prohibitions result mainly from human rights, added by international immunities, and, for States belonging to certain regional organisations, by some norms of a correlatively regional character. ${ }^{123}$ As was also established, States also set voluntarily in place many other grounds for refusal in the name of values that integrate their particular legal traditions, ${ }^{124}$ and it is this set of grounds for refusal that is open to be reformed. If these grounds for refusal are created and shaped by States on their own, unconstrained initiative, then it is primarily within their national legal systems that the rationales of such grounds for refusal lie, and, therefore, that their reform must be contemplated. National legal traditions constitute the source from which spring the factors capable of derogating the presumption that extradition should be granted to the State where the crime was committed or its effects materialised.

As we could observe in Part III, the reason for States to refrain from extraditing to other States consists, in many instances, of a necessity felt by such States not to damage the sense of justice of their communities, which is expressed in the norms in force in their own legal systems. As established shortly above, the relevance assigned to the legal system of the custodial State vis-à-vis the legal system of the injured State must be unequivocally understood as exceptional, given the latter's absolute - neutrally determined - preponderance at the jurisdictional level. However, considering the repressive character of extradition, it is also clear that the absolute preponderance of the requesting State at the jurisdictional level cannot be expected to translate into an absolute entitlement to obtain extradition. Let us discount the fact that, by extraditing, a State is contributing to the possible application of an extreme legal consequence to a person (a criminal penalty) - a factor which might still be considered offset by that jurisdictional preponderance. Even so, the fact that, by extraditing, a State immediately subjects a person to a repressive measure (a deprivation of liberty coupled with a coercive transfer to another jurisdiction) inevitably confers some relevance on its own notions of criminal justice, triggering "law and public policy considerations" ${ }^{125}$ which are often associated with the concept of ordre public. ${ }^{126}$

123 See supra, Part II.

124 See supra, Part III.

125 M. CHERIF BASSIOUNI, International Extradition... op. cit., p. 55.

126 See e.g. BERT SWART, "Human Rights...”, op. cit., p. 250 f.; HANS-HEINRICH JESCHECK, "Die internationale Rechtshilfe in Strafsachen in Europa”, ZStW 66 (1954), p. 531 f.; PETTER ASP / ANDREW VON Hirsch / DAN FrÄNDE, "Double Criminality and Transnational Investigative Measures in EU Criminal Proceedings: Some Issues of Principle”, ZIS 11 (2006), p. 512 f. 


\subsubsection{Ordre public - national and international}

The concept of ordre public also originates in private international law. Despite the shift to a neutral approach according to which conflicts of laws should be solved, not on the basis of the content of these laws, but rather on their connection with the acts at issue, this area of the law never ceased to concede that such a neutral approach could occasionally carry problematic results.

A necessary and central consequence of the shift to the neutral approach was that the substance or content of the foreign norms possibly to be given effect by a given State would only acquire relevance a posteriori - that is, after it was established, and provided that it was indeed established that those foreign norms are the ones that should be given effect. ${ }^{127}$ This gave rise to the concept of ordre public as we presently know it: an "exceptional mechanism" ${ }^{128}$ destined to operate exclusively in negative or exclusionary terms. ${ }^{129}$ Accordingly, the sequence is the following: in line of principle, respect is paid to the neutral operation which led to the conclusion that a foreign law is the law applicable to the case; this application is, but is only limited or excluded where it would entail certain substantive effects. ${ }^{130}$ The only issue remaining is that as to which effects trigger such a limitation or exclusion.

As Brotóns observes, ordre public is an "iconographic notion", generally "better described than defined": "for those who practise dangerous sports, it will be an emergency parachute that permits the jump into the void, while those versed in ballistics will see it as a time bomb." 131 It has been depicted as a defence against the "frontal collision" of legal systems enabled by the neutral system of determination of the applicable law; ${ }^{132}$ as a "massage" technique through which the courts of the State that is required by such a system to apply foreign law is enabled to alleviate its unwanted results. ${ }^{133}$ One might yet add the image of a shock-absorbing device. Looking now at the concept from the angle of its object of protection, ordre public is portrayed as a means for safeguarding the "spirit", the "legal consciousness", ${ }^{134}$ the "incompressible domain" 135 of a legal system against the possible negative impacts produced upon it by the application, within its own environment, of rules that express values of other legal systems.

Whichever terms are chosen to describe ordre public, it is clear that it constitutes an exclusive concept which covers but a select cluster of values and which purports to avoid but a particular type of results. It is not aimed at blocking the application of foreign rules whenever they would carry results that are different from those that would follow from the

\footnotetext{
127 See Isabel de Magalhães Collaço, op. cit., p. 325; Rui Manuel Moura Ramos, “L'ordre public international en droit portugais", in BFDUC 74 (1998), p. 45 f., 49 f.

128 Ibid., p. 50.

${ }^{129}$ See A. Ferrer Correia, op. cit., p. 407 f.

${ }^{130}$ Rui Manuel Moura Ramos, “L’Ordre Public International...”, op. cit., p. 50.

131 Antonio Remiro Brotóns, "La Reconnaissance et l'exécution des sentences arbitrales étrangères”, CCHAIL 184 (1984), p. 245.

132 SusAnA CHABERT, op. cit., p. 157.

133 GeERT VAN CALSTER, op. cit., p. 4.

134 Rui Manuel Moura Ramos, “L’Ordre Public International...”, op. cit., p. 53, 54.

135 IsABEl de MAgalHães COLlaÇO, op. cit., p. 324.
} 
application of national rules, even where these are imperative rules that, in purely national cases, individuals would not be allowed to derogate from in the exercise of their freedom to contract or to elsehow shape their private relations. ${ }^{136}$ Ordre public is aimed strictly - or otherwise the neutral system of determination of the applicable law would be entirely deprived of significance - to prevent results that are "unacceptable in the light of the essential legal values" of the State. ${ }^{137}$

This constitutes the basis of the distinction between 'national' and 'international' ordre public: while the former encompasses the entirety of national rules (or at least of national rules of imperative character), the latter is concerned only with those among them which are essential. The latter is therefore narrower. This poses no paradox: the geographic terms employed to distinguish them refer, not to their source (which is always national), but to their ambit of efficacy: national ordre public is only valid locally; international ordre public is so essential at the local level that it projects itself externally, in the interactions of that polity with other polities. This can be illustrated through concentric circles:

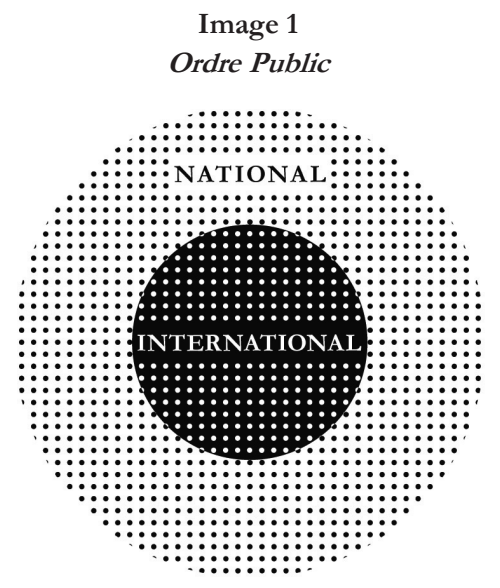

As Collaço puts it, 'international' ordre public is as 'national' as it gets. ${ }^{138}$ It is the line past which differing foreign laws become locally intolerable, and, thus, meet with rejection. ${ }^{139}$ A rejection made in such terms and for such reasons - vir. motivated by concrete negative effects that the application of a foreign law would produce upon one's own social consciousness, rather than by an abstract repudiation of that law as such ${ }^{140}-$ cannot be resented. It can only be understood as a rightful act of self-preservation on the part of a State that was being compelled to give effect to a foreign law by a neutral system of resolution of conflicts of laws. Since this system is as a matter of principle warranted, that rejection can still be considered prima facie 'unlawful'. However, such a rejection is - one might say, again in analogy with substantive criminal law - 'justified by necessity'.

\footnotetext{
136 Rui Manuel Moura Ramos, “L’Ordre Public International...”, op. cit., p. 53 f.

137 Ibid., p. 50.

138 IsABEL DE MAgalHães Collaço, op. cit., p. 324, 332.

139 See ibid.

140 See Rui Manuel Moura Ramos, “L’Ordre Public International...”, op. cit., p. 54.
} 


\subsubsection{Criminal justice values - system and ethos}

It appears to be an established understanding in private international law that the weaker the connection of the situation with the legal system of a State is, the less intense the effects of its international ordre public will be; that is, the less justified will it be for that State to refuse to give effect to a foreign law owing to its incompatibility with values emanating from its own. ${ }^{141}$ This notion is condensed in the expressions 'Inlandsbeziehung' or 'Binnenbeziehung'. The inexistence or frailty of such a 'domestic connection' may ultimately carry the complete inoperability of international ordre public. It should be stressed that this is no longer an issue concerning the determination of the applicable law: such an issue is settled through the neutral operation indicated above. ${ }^{142}$ The issue as to the existence and intensity of an 'Inlandsberiehung' is methodologically subsequent: it comes into play already within the assumption that the law that shall be applied to the case is a foreign law. The issue at this point is whether the case has sufficient resonance in one's own legal system to trigger a protective mechanism (international ordre public) which displaces the application of the law that had been established to possess the strongest connection with the case.

In the context of extradition law, as noted shortly before, the requested State has custody of the suspect, and transferring such a custody requires this State to carry out an act that is repressive in and of itself. In this light, it can be assumed that there is an inherent connection of the case with its legal system that is sufficiently strong to bestow some relevance to its own conceptions of criminal justice: an intrinsic 'Inlandsberiebung'. It should again be underlined that such a connection does not concern the crime itself. It is not jurisdictional in character and it must therefore not be mistaken with the concept of 'sinnvoller Anknüpfungspunkt. ${ }^{143}$ At the jurisdictional level, primacy belongs unreservedly to the State whose legal system has the strongest link - typically, territorial or protective - with the crime, and consequently extradition should in line of principle be granted to this State. Custody and the repressive nature of extradition do nevertheless constitute sufficient bases for assuming that the values professed by the requested State have intrinsic relevance in extradition proceedings. In sum, extraditing being a repressive act, in extradition law it would also be unreasonable to require States to conform uncritically with the views of other States.

For the reasons deployed throughout the preceding paragraphs, extradition should not be hindered by the existence of unessential variations in perspective between States. However, States cannot be expected to extradite in disregard of their core values, as that would put in crisis the sense of justice of their communities. This is not only an unrealistic prospect, in an international community formed of States which remain quite selfcentred (particularly insofar as concerns criminal matters), ${ }^{144}$ but also one that could not possibly be endorsed in this study: as has been unambiguously acknowledged, the reform

141 See Paul Lagarde, "Public Policy", in Kurt Lipstein (chief ed.), International Encyclopedia of Comparative Law - Vol. 3, Chap. 11, Tübingen: J.C.B. Mohr, 1994, p. 21 f.

142 Although the autonomy between the issues is not clear-cut: see ibid., p. $22 \mathrm{f}$.

143 See supra, Chap. 1, $\$ 3$.

144 See shortly supra, $\int 3.1 .3$, and ulterior references. 
pursued here is guided by the ideal of a more cooperative and integrated world, ${ }^{145}$ but it also assumes that this ideal should not be attained at the expense of national identities, ${ }^{146}$ and that in any case it probably could not, as this would form an artificial and, thus, fragile platform of understanding. Therefore, a distinction analogous to that developed in private international law between national and international ordre public must be drawn in extradition law which separates States' essential and unessential values.

Since the types of situations and, consequently, of values at stake in one area of the law and the other are different, alternative terms are henceforth used to refer to criminal justice, namely 'system' and 'ethos'. The first comprises the entirety of principles, values and norms that integrate States' criminal justice systems; the latter is limited to the part of those elements in respect of which no concessions can be made to other States without thereby jeopardising one's own cultural identity. The two concepts relate to each other in terms similar to those in which the concepts of national and international ordre public do, and therefore they can be represented through the same image:

\section{Image 2}

Criminal Justice Values

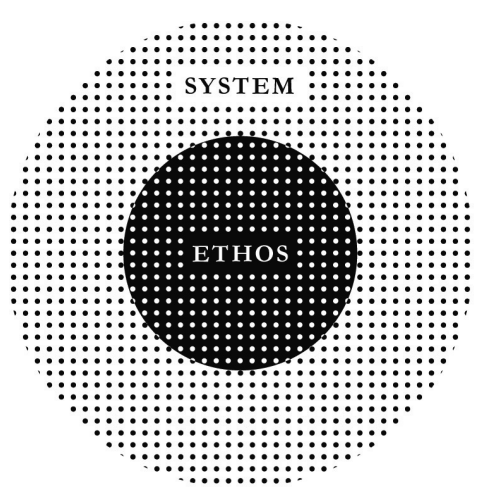

Under current extradition law, what requested States are doing when they use their own concepts indiscriminately as a criterion for deciding whether or not to extradite is to project their criminal justice systems upon other States, rather than to limit the externalisation of such systems to their core elements (i.e. their ethos). Dual criminality provides an exceptional basis for illustration: the higher the levels of mobility, remote criminal ability and social alarm become, the less justified it will be to reject other States' concepts of crime in the name of one's own; and, as posited above, the less relevant one's concepts of crime will effectively be, ${ }^{147}$ because the easier it becomes for individuals to flee the territory of a State where they committed a crime onto that of another State, the less shocking it will be for the community of the latter to expose such individuals to the criminal justice

145 See e.g. supra, \ 3.1.2.

146 On the "interest in preserving culturally influential ways of living", see JÜRGEN HABERMAS, op. cit., p. 42,53 , defending (by reference to European integration specifically) that, while some uniformity of standards is worthy to be pursued, by no means does it require a "levelling of cultural differences".

147 See supra, \3.1.1. 
system of the former for acts that in purely internal situations could not give rise to criminal punishment. Again the image presented above comes to mind, that the energy radiating from the concepts of crime of the custodial State fades, and that emanating from the concepts of crime of the injured State intensifies in an inversely proportional manner.

\subsubsection{Capturing the spirit}

The question that follows is: how can the ethos of a criminal justice system be identified? This question will again be approached from the angle of private international law, which has matured the concept of ordre public for centuries.

\section{a) In private international law: Indeterminacy, dynamism, contemporaneity and casuistry}

From the 'iconographic' character of international ordre public it follows that it cannot be precisely delimited. Instead, it is an indeterminate concept "which resists any attempt of densification". ${ }^{148}$ As noted, its function can be defined somewhat palpably (as a parachute, a shock absorber, etc.), but the concept itself is as indeterminate as any of the expressions (spirit, consciousness, etc.) that are used to describe its object of protection.

On the other hand, from its object of protection it follows that international ordre public constitutes a dynamic concept, although not exactly volatile: as Savigny observed, the "common consciousness of the nation", in which the "law has its root", is "entirely different from the easily and quickly changing, the accidental and momentary consciousness of the individual man", but is "subject to the law of progressive development, and cannot therefore be conceived as fixed and immoveable."149 An example used by the author to support the assertion, and which is relevant also in the realm of criminal law, is that of slavery: "Throughout all antiquity the status of slavery was regarded as a kind of natural necessity, and no one imagined the possibility of a civilised people living without slaves. In modern Christian Europe (...), this status is regarded as totally impossible, and utterly contrary to all sense of right". ${ }^{150}$ The author adds that this type of modification tends to be "very gradual", taking place "so slowly and imperceptibly" that it is impossible to "fix with certainty the epoch of history at which the former state of things ceased". Nevertheless - the author claims -, even where such transitions occur "within a brief space of time, in consequence, perhaps, of a powerful spiritual shock to the national conscience", still "we could not possibly refuse to such a new age the right of giving way to the present universal conviction, and repudiating all further recognition of [the erstwhile institution, in the example slavery] as a legal institution." This view, expressed in the $19^{\text {th }}$ century, has wide room for application in the much more rapidly changing world of the $21^{\text {st }}$.

From the circumstance that the function of international ordre public is to protect a dynamic object, it necessarily follows (as is already implied in the words of Savigny quoted shortly above) that it is contemporaneous in character. It applies as its stands at a certain

\footnotetext{
148 Rui Manuel Moura Ramos, “L’Ordre Public International...”, op. cit., p. 53.

149 Friedrich CARL VON SAVIGNY, op. cit., p. 370.

150 Ibid., p. 371 - also the following quotes in this paragraph.
} 
point in time, quite independently from erstwhile perceptions. ${ }^{151}$ It is topical, in that it refers to current circumstances and perspectives.

From the foregoing it necessarily follows yet another characteristic, namely that international ordre public can only be ascertained on a case-by-case basis. ${ }^{152}$ As an indeterminate, dynamic and contemporaneous institution aimed at preventing the negative effects which the application of a foreign law might produce in a concrete case, it is inevitably dependent on the concrete effects of that case and their significance in the concrete moment in which such a case occurs. This ascertainment lies in the hands of a decision-making entity, typically judicial, and is not susceptible to predetermination in a legal norm.

\section{b) In extradition law: Same dynamism, contemporaneity and casuistry, less indeterminacy}

The former considerations apply almost squarely in the context of criminal justice. Here too the values of a State are dynamic, since they are also an expression of the 'common consciousness of the nation'. In consequence, the concept of 'criminal justice ethos' (the distillation of those values) is also contemporaneous: insofar as the acts at issue in an extradition procedure have no connection with the criminal justice system of the requested State, there is no reason to refer the appraisal of their significance - as perceived by the community of this State - to the moment when they were committed. Present is the key tense in extradition law. ${ }^{153}$ The moment of perpetration is key only in substantive criminal law: only here is it paramount that individuals know at all times which conduct they can adopt without incurring in a penalty. ${ }^{154}$ In sum, possible infringements of the social consciousness of the requested State can only be determined in the moment when the act of extraditing is to take place.

The criminal justice ethos of a State is also indeterminate. This is again an unescapable consequence of the intangible and dynamic character of its object. This indeterminacy is not problematic, because, again, extradition law is fundamentally different from criminal law, and therefore it is not subject to the same demanding principles and requirements. ${ }^{155}$ Nonetheless, since extradition does constitute a repressive measure, the concept of 'criminal justice ethos', if it is to serve as a criterion for deciding whether or not such a measure is going to be deployed, should as much as possible be bestowed with greater levels of definition than the concept of international ordre public used in private international law with regard to private law issues. That is, the level of indeterminacy of extradition law should rank somewhere between that admissible in private international law and that required in criminal law. This does not necessarily mean that the content of a State's criminal

151 See Isabel de Magalhães Collaço, op. cit., p. 333; Rui Manuel Moura Ramos, “L’Ordre Public International...”, op. cit., p. 54.

152 See Rui Manuel Moura Ramos, “L’Ordre Public International...”, op. cit., p. 54.

153 As we could see supra, Chap. 6, \ 4.1.2., Art. 32 (6) PT-L explicitly provides that, for the purposes of the nationality exception, the quality of national is ascertained in the moment of extraditing, which forms a a sound example of the contemporaneity of grounds for refusal of extradition.

154 See further infra, $\int$ 3.3.6.a).

155 See supra, Chap. 1, \2.2.; and, by all means, further infra, $\$$ 3.3.6., more extensively on the differences between extradition law and criminal law in respect of the issue of determinacy. 
justice ethos is broader than that of its international ordre public (this is a different issue). It simply means that it should be more defined.

\section{c) The basic law of a State as the repository of its criminal justice ethos}

Criminal justice ethos being the set of core values regarding which States cannot make concessions without jeopardising their identity, the fundamental reference to consider when endeavouring to reform grounds for refusal must be their constitutional laws which is the normative level where those values are typically enshrined, and which supersedes the ordinary laws of the requesting State. ${ }^{156}$ National constitutional norms are joined (if they do not already encompass them) by human rights, ${ }^{157}$ the set of 'universal' core values respect for which is demanded by international law, which form what in the conceptual edifice of private international law would correspond to 'truly international ordre public ${ }^{158}$ - which in this context one might call 'international criminal justice ethos'.

Since each State has its own set of core values, it would be inadequate to approach the concept of criminal justice ethos by reference to a specific set of constitutional rules. Portugal and the UK are used in this study as references in respect of grounds for refusal of extradition voluntarily adopted by States (and occasionally of other aspects of national extradition systems), because in that respect they stand as representatives of a wider reality, namely the world tradition in extradition matters as abridged in the model instruments of the UN. For the present purposes, however, such a method would be overly limited, because constitutional rules are more varied than extradition rules, which as noted before are prone to uniformity. ${ }^{159}$ Therefore, any set of States that might be selected as a sample would be unable to mirror the multitude of existing constitutional traditions. Instead, the fact that these traditions are variable will be assumed as a constant for the present analytical purposes. Accordingly, 'criminal justice ethos' is taken as an abstract concept encompassing an unspecified set of essential values enshrined in norms of supreme parametric rank within a legal system. On this basis, it seems possible to draft principles for a reform of extradition law which are applicable in the presence of any specific set of essential values. $^{160}$

156 The concept shall be construed broadly, so as to encompass core principles that are substantially constitutional, and that as such have clear vocation to supersede ordinary norms. This accommodates in this construction legal systems which have no Constitution in a formal sense (e.g. the UK), or which do, but one which is sparse insofar as concerns criminal law (e.g. Sweden: see PETTER ASP / ANDREW VON HiRSCH / DAN FRÄNDE, op. cit., p. 516). On this issue, see further infra, Chap. 8, \ 4.1.1.c)(i).

157 National constitutions and international human rights can thus coexist within this construction in perfect harmony (or, as constitutional pluralism theories might call it, 'heterarchy': see e.g. ANNE PIETER VAN DER MEI, "Flexibility and differentiation...", op. cit., p. 182), without a risk (which those theories ultimately seem to struggle with: ibid., p. 184) of a conflict whereby one normative system must yield before another.

158 This expression is generally attributed to Niboyet (1928), and its first extensive doctrinal elaboration to Rolin (1960): see SUSANA CHABERT, op. cit., p. $261 \mathrm{f}$.

${ }^{159}$ See supra, Chap. 1, $\mathbb{\delta} 2.2$.

160 This also seems to be a good method to avoid epistemological biases, reaching for wider "peripheral vision and a more sensitive geopolitical imagination", in the awareness that, "[r]ather than envisaging the world as a flat, generic entity, which can be zoomed in and out at will, the complex nature of the contemporary world order presents us with a patchwork of unequal geographies, frictions and spaces of difference" which 


\subsubsection{Methods for reforming grounds for refusal}

Since the reform envisaged in this study assumes that States cannot and should not sacrifice their systems of values, but rather adapt them to interact with other States in terms more compatible with current conditions, complete abolition of grounds for refusal is not a plausible prospect, as they generally perform functions that relate to States' systems of values and that, as such, States would not and should not be willing to waive completely. Consequently, the focus should lie not on pinpointing grounds for refusal to be removed and grounds for refusal to be retained, but on optimising existing grounds for refusal as much as possible. Such an optimisation can be effected through the following methods.

\section{a) Contraction}

It has been sustained that, by attaching undue relevance to the criminal justice concepts of a State whose legal system (which is the natural ambit of efficacy of those concepts) is contacted owing to the simple contingency that at a given point in time a person entered its territory, current extradition law hinders the neutrally justified and universally agreed principle that the State with stronger connections with the crime shall as much as possible be entitled to pass justice upon it. What is quite interesting to note is that States, to an extent, already acknowledge that in many instances the only valid reason for them to refuse to cooperate with other States is that such an action would damage the sense of justice of their communities - their criminal justice ethos. ${ }^{161}$ It is also apparent that, if States were to make an obstacle out of each and every idiosyncrasy of their legal systems, extradition would as a rule be extremely difficult to grant, because there are no perfectly identical legal systems. However, all the while, States have maintained in place grounds for refusal whose scope is demarcated mainly by reference, not to their ethos, but to their criminal justice system as a whole, with all its specificities. The distinction between ethos and system, essential and unessential values, has not trickled down sufficiently to the norms that determine whether or not cooperation can be granted, which produces a discrepancy between their scope (i.e. the range of situations that they encompass) and their rationale (i.e. the set of reasons that actually justify encompassing certain situations).

It is debatable whether such a discrepancy should be regarded as a design flaw. The reigning paradigm when modern extradition law was developed rested very heavily upon the notions of national identity and sovereignty. Moreover, the necessity of international cooperation was not nearly as acute as it is today; the world had been shaken by momentous technological developments, but the magnitude of their effects was yet to present itself. On the other hand, the primary concern of the emerging criminal law of the Enlightenment was to safeguard individuals from the might of States, as is epitomised in the advent of the legality principle. ${ }^{162}$ In this light, it is reasonable to assume that, in that histor-

requires "systematic forms of humility and de-parochialization": KATJA FRANKO AAS, "The Earth is one but the world is not': Criminological theory and its geopolitical divisions”, TC 16 (2012), p. $16 \mathrm{f}$.

161 This is visible in the analysis conducted earlier, in Chap. 6: see e.g. $\iiint_{2} .1$.

162 Enshrined e.g. in the 1813 Bavarian Penal Code. The conception of this Code is generally credited to Feuerbach, as is the phrasing of the legality principle as 'nullum crimen, nulla poena sine lege': see GEORG RUsche / OtTo KIRCHHEImer, Punishment and Social Structure, Columbia: University Press, 1939, p. 99 f. 
ical moment, nearly all values (essential and unessential) given positive expression in the criminal justice system of a State were believed to require some type of projection in the context of its interactions with other States.

In any case, subsequent developments changed the terms of the problem: national identity and sovereignty eroded; necessity to cooperate intensified; criminal law, without detriment to its unremitting responsibility to promote individual guarantees, grew the function of devising, in a manner that is compatible with those guarantees, punitive approaches to contain rapidly-evolving types of criminality. At once, these developments compressed the criminal justice ethos of the requested State, and broke with the notion that grounds for refusal of extradition should mirror the entirety of its criminal justice values. This had become an insubstantial reason not to cooperate with, and obtain further cooperation from other States. Both of which concur to the current mismatch between the rationale and the scope of several grounds for refusal, which can be represented through the same concentric circles as those representing the difference between national and international ordre public, and between criminal justice system and ethos:

Image 3

Discrepant Ground for Refusal

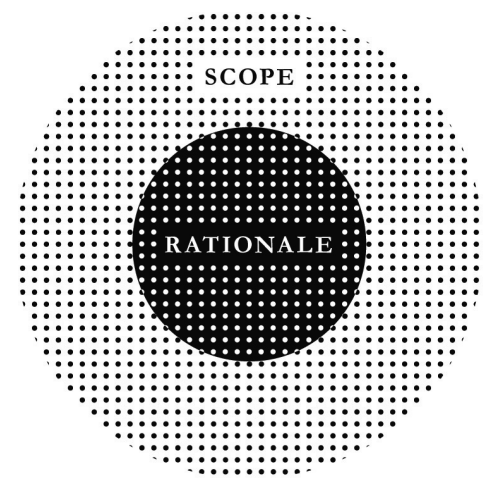

The goal is to reduce the scope of such discrepant grounds for refusal, so that it covers but does not exceed the situations that, according to its rationale, require protection.

\section{b) Juxtaposition}

On the other hand, we saw that many traditional grounds for refusal of extradition remained in place following the advent of individual and human rights in extradition, and that this movement carried the emergence of new grounds for refusal. ${ }^{163}$ In consequence, some grounds for refusal currently in place have overlapping scopes and rationales, such that they are at least partially redundant vis-à-vis each other. ${ }^{164}$ This phenomenon is particularly noticeable in the case of grounds for refusal with composite rationales, which at once are intended to perform several functions.

\footnotetext{
163 See supra, Chap. 3, \ 1.2.

164 As we also saw supra, Chap. 4, e.g. SS 4.1. and 2.3.3.
} 
For instance, both the nationality exception and the political offence exception are in part aimed at ensuring that the individual is not discriminated against or subject to an unfair criminal procedure in the requesting State. Such functions are presently performed by human rights-based grounds for refusal the rationale of which is specifically to perform such functions, and the scope of which is narrower than that of the grounds for refusal that they partly overlap.

The phenomenon can be expressed through the following image:

Image 4

Overlapping Grounds for Refusal

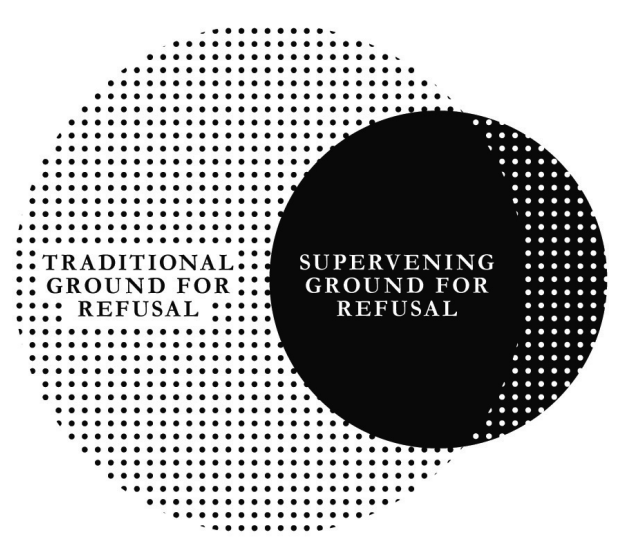

The question that arises is that as to whether the segment of the classic ground for refusal that has not been absorbed is self-standing, vi\%. capable of surviving autonomously. In other words: whether the classic ground for refusal, if stripped of integral elements of its rationale, still has any vital function to perform, any core value to protect; whether it remains necessary. If it does not, then it has become redundant, and should be abolished. If it does, then the question still needs to be answered as to whether there is a mismatch between the subsisting rationale (the core value or function deserving of protection) and the respective scope. If there is a mismatch, there is room for optimisation in accordance with the previous paragraph, on discrepant grounds for refusal.

\section{c) Expansion}

In a different direction, the possibility must be admitted that there are core values which are lacking protection, requiring an expansion of the scope of existing grounds for refusal. This possibility is symmetrical to that (which in the light of the analysis conducted above is more plausible) ${ }^{165}$ where the scope of the ground for refusal is broader than the values it purports to safeguard. Whereas in the latter case there is a protection surplus, in the case that is now in consideration there is a protection deficit. Accordingly, the reflection required by the two situations is symmetrical: in both cases there is room for optimisation (viz. for adjusting the scope of the ground for refusal to the values that are tru-

165 See supra, \a). 
ly lacking protection), with the difference that, in the case of protection deficit, optimisation should take the form of an expansion, rather than that of a contraction.

This runs counter to the general goal of this study (to promote more flexible cooperation arrangements), but otherwise its integrity would be compromised. In any event, the enactment of missing safeguards may contribute to the removal of superfluous ones. The following image seeks to illustrate the case where protection against extradition is necessary and is not being accompanied by a ground for refusal with a corresponding scope:

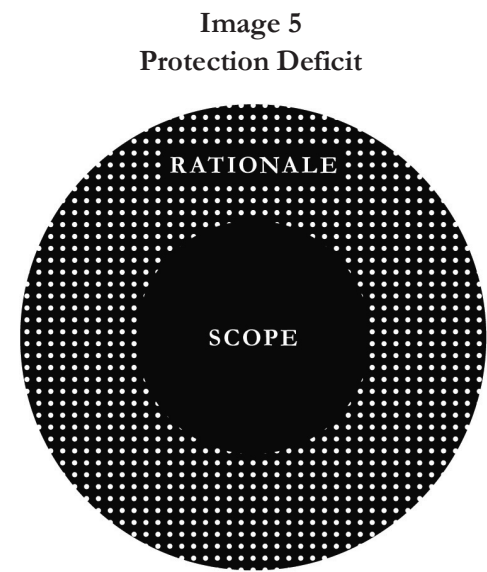

\subsubsection{Idealistic propositions}

Utopia is a place that does not exist. Argentinian director Fernando Birri portrayed it as something which is unremittingly on the horizon: if one moves ten steps towards it, it distances itself those same steps; but, whilst impossible to reach, it offers a direction to follow, and that is its function. ${ }^{166}$ Since extradition law allowed itself to lag so acutely behind reality, it is in the direction of reality that the next steps need to be taken.

As long ago as in 1968, Bassiouni was calling for improvements of extradition law that would at once raise the levels of cooperation and of respect for fundamental individual rights; "but then again" - the author notes -, the same ideas had been on the table at least since de Vattel, in the 1870's. ${ }^{167}$ That increasing cooperation levels is imperative is now a long-standing diagnosis. The work currently required of the "concerned jurist"168 is essentially that of reviewing that diagnosis, gathering and testing the factors and arguments that substantiate it, articulating them into an intelligible account of the specific aspects that ought to be improved, and devising concrete propositions that would allow these ends to be met. This is what this study primarily attempts to do. This, however, does not prevent it from occasionally conjecturing what a more idealistic version of extradition might look like, a direction to consider following. ${ }^{169}$

166 ApudEduardo GaLEANO, "El Derecho al Delirio", in www.youtube.com/watch?v=Z3A9NybYZj8, last accessed 22 January 2018.

167 M. CHERIF BASSIOUNI, International Extradition... op. cit., p. 60.

168 Ibid.

${ }^{169}$ Examples of this may be found infra, $\iint 53.3$, and Chap. 8, $\int 5.2 .1$. 


\subsubsection{Conclusion: Useless laws and necessary laws}

This study relies on its own diagnosis of the state of affairs in international cooperation. The reform proposals contained here, which consist essentially of the rectification of a discrepancy that has been identified between extradition law and reality, between the scope and the rationale of grounds for refusal, are a direct result of that diagnosis. They do not track externally defined criminal policy objectives, even if they do show consistent with a widely supported position according to which strengthening international cooperation is a pressing concern. They constitute, above all, an effort to rationalise extradition law on the basis of criteria that strive for objectivity. The fact that the study contemplates the expansion of certain grounds for refusal - which runs counter to that criminal policy agenda - should constitute evidence of this objectivity.

This approach finds support in the classic principle condensed by Montesquieu in the aphorism 'useless laws weaken necessary laws'. ${ }^{170}$ Bringing the scope of the law back into harmony with its rationale is salubrious in and of itself. We saw that grounds for refusal currently encompass States' essential and unessential values alike. By equating them, extradition law strengthens the latter at the expense of the former, making them converge onto an intermediate degree of importance, in a process which could be compared to the second law of thermodynamics, according to which differences (especially in temperature) between two systems that are in contact with one another tend to become uniform. For example: a State that applies the dual criminality rule is requested to extradite a person on charges of heresy, a conduct which it does not criminalise in any form, because it considers freedom of religion an essential value; in another case, the same State is asked to extradite a person charged with an environmental offence (e.g. the disposal of a certain substance found to be extremely harmful), an act that it also does not criminalise but which is analogous in its configuration and effects to other acts that it does criminalise, protection of the environment being considered by its community as very important. It is apparent that the two cases are fundamentally distinct: in the former case, extraditing would entail a blatant conflict with a core value of the requested State; in the latter case, there is but a slight disparity in the manner how it regulates a type of behaviour which in essence it also repudiates. However, since neither conduct is criminalised - in the case of the environmental offence, perhaps simply because the substance at issue had not yet been identified as hazardous -, both cases will have the exact same outcome (refusal of extradition), based on the exact same extradition rule (dual criminality). This misrepresents the sense of justice of the community of the requested State, and is hardly understandable in the eyes of the community of the requesting State, distancing them pointlessly.

Conversely, to extricate from the scope of grounds for refusal the cases that relate to secondary values of the community of the requested State is to bolster its consensus as to what is essential. It does not sacrifice its identity and idiosyncrasies, but in a way only

170 See MONTESQuieu, op. cit., p. 606 f. It shall be noted that, although the principle underpinning this aphorism has a broader applicability, the passage whence it has been drawn ("useless laws debilitate such as are necessary") has a rather specific significance, namely that the laws which "may be easily eluded weaken the legislation": see ibid., p. 617. 
reiterates them. At the same time, it expresses deference towards the necessities of other communities and respect for their conceptions, and through this process it may carry them to esteem each other more. In Rawls' words: “as cooperation between peoples proceeds apace they may come to care about each other, and affinity between them becomes stronger. Hence, they are no longer moved simply by self-interest but by mutual concern for each other's way of life and culture, and they become willing to make sacrifices for each other." ${ }^{\prime 11}$ It is also consistent with the views of Habermas: "When it comes to the constitutional definition of the boundaries of a political community (...) there are no 'givens'; loyalties evolve and traditions change. Nations, too, just like all other comparable referents, are not natural facts, even if they are generally not merely fictions either (as was the case with many colonial state creations). Many loyalties overlap in the political life of a citizen, loyalties to which individuals attach quite different weights. Among them are politically relevant ties with one's region of origin, with the state or province of one's domicile, with country or nation, etc. Only in cases of conflict do the weights attached to these loyalties acquire relevance because they have to be balanced against each other. A measure of the strength of an identification with one social unit rather than another is the willingness to make sacrifices based on longer-term relations of reciprocity. (...) But the long shadow cast by nationalism continues to obscure the present. The supranational expansion of civic solidarity depends on learning processes (...) [and] can take on concrete form only as the national public spheres gradually open themselves up to each other" ${ }^{172}$

\subsection{The balance: Weighing the interests of the subjects involved}

\subsubsection{Still a triangle}

It is now a consolidated idea that extradition is not a bilateral procedure where the only subjects deserving of consideration are the two States involved, but a triangular procedure which devotes substantial attention to the interests of the person targeted by the request. ${ }^{173}$ It could be questioned whether other classes of individuals - notably victims should also receive specific consideration in extradition proceedings, which would then assume the form of a polygon of four or more vertexes. Since these other potentially relevant subjects tend to be located in the territory of the State where the crime was committed (which in part is exactly why the principle of territoriality deserves primacy), their interests tend to be aligned with those of the requesting State. Nevertheless, it is not certain that such an alignment occurs, and therefore the question still holds.

However, considering the intensity of the interests of the subjects which form the triangle, it appears that the only situations in which it might be pertinent to pay any consideration to the interests of other subjects, such as victims or witnesses, would be those where the requested State also has primary jurisdiction over the acts, and those where extradition is requested by more than one State. Both involve a positive conflict of jurisdiction, and the interests of subjects like victims and witnesses are definitely among the fac-

171 JOHN RAWLS, op. cit., p. $112 \mathrm{f}$.

172 JÜRGEN HABERMAS, op. cit., p. 47 f.

173 See supra, Chap. 3, \ 1.2.; and again Albin EsER, "Basic Issues..." op. cit., p. 6, 14 f. 
tors to be considered when deciding which State should prosecute. ${ }^{174}$ At any rate, both are of very limited relevance in a study focusing on the importance of extradition for avoiding impunity, as they do not hinder this goal, but simply seek to regulate allocation of jurisdiction between two or more States which are willing to prosecute a crime. ${ }^{175}$

Therefore, without detriment to the possibility of paying greater attention to other subjects interested in the outcome of extradition proceedings, especially the victims of the crimes that give rise to such proceedings, the fact remains that those subjects are not involved in such proceedings. For this reason, extradition proceedings should continue to be conceived as triangular proceedings, where the subjects involved are the requesting State, the requested State, and the individual whose extradition is being sought.

\subsubsection{But which kind of triangle?}

The analysis carried out above allowed us to establish that, in spite of the huge increase in mobility, remote criminal capacity and social alarm at impunity verified over the past centuries, grounds for refusal of extradition remained quite similar in their scope. In the context of extradition, the duty of non-interference governing international relations operates almost exclusively in its classic negative dimension, as a command on States not to unilaterally seize individuals located in the territory of other States. Conversely, it is not considered to encompass a duty of States to extradite individuals to other States where this is necessary for these to assert their sovereignty in respect of acts committed in their territories. This produces an imbalance between the requested State and the requesting State, the former enjoying unequivocal preponderance over the latter. Their bilateral relationship is therefore not horizontal (as is commonly presented), but oblique instead, with the requested State holding the upper standing.

\section{Image 6}

Extradition Currently

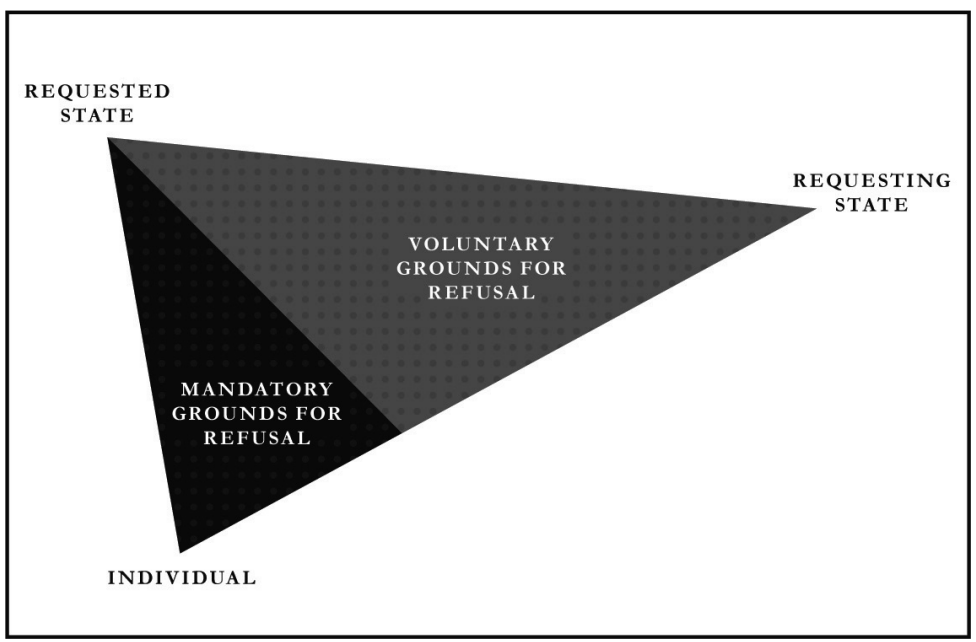

174 See e.g. Eurojust Guidelines... cit., p. 3; Miguel Joño Costa, Dedere Aut Judicare?... op. cit., p. 134 f.

175 As expounded supra, Chap. 1, S 5.2., Chap. 6, \ 6, Chap. 7, \1.1.1., and further infra, Chap. 8, \$ 3.6. 
Accordingly, the subjects involved in extradition proceedings should be represented in a triangle where the vertex corresponding to the requested State is higher up than that corresponding to the requesting State, and the vertex corresponding to the person is farther away from the vertex corresponding to the requesting State than to that corresponding to the requested State. This conveys the notion that the individual being extradited or not is an event which depends fundamentally on the interests of the requested State and lies fundamentally within its potestas. The triangle may be either scalene or, as in the image below, isosceles, so long as the individual is represented closer to the requested State than to the requesting State (because of the preponderance of the former over the latter), and not farther away from the requesting State than the requested State from the requesting State (because, despite its preponderance, the requested State does also have an interest in extraditing which stems from the principle of reciprocity). The latter is the reason for the choice of an isosceles acute triangle, which necessarily places the individual at the same distance from the requesting State as the requested State from the requesting State (insofar as the side linking the person to the requested State is the smaller side of the triangle). It would have been possible to customise how much closer the individual is to the requested State than to the requesting State, and this possibility could be used to express a specific measure of preponderance of the requested State over the requesting State. However, this would not only transcend the point at issue here - which is simply to express that preponderance, not its degree -, but also it would be overly subjective.

The individual is represented as the inferior vertex of the triangle because, despite the advent of individual and human rights, extradition proceedings still present the same basic structure as they did at their origin, when its only subjects were States. In an alternative reality in which, from inception, the individual had been recognised as a subject of these proceedings, extradition might consist e.g. of a procedure where an individual could defend him/herself simultaneously before the requested and the requesting States, ${ }^{176}$ disputing aspects related to his/her transfer to another jurisdiction as well as to his/her criminal liability, in what would be a blend of extradition and criminal proceedings; or where a precondition for a State to issue an extradition request would be a certification by a supranational human rights body that, in the case, a risk of human rights breach is excluded. These are speculative scenarios which seek only to emphasise that extradition remains procedurally anchored in the requested State, with the consequence that it is only before this State that individuals can resist their extradition, even though the aspects of more concern to them, notably human rights violations, relate to possible actions of the requesting State upon obtaining extradition. ${ }^{177}$

176 An approximation to this type of conception has been brought forward by the recent EU agenda on procedural rights, which confers on individuals targeted by EAW's such guarantees as a right to dual legal representation and to dual legal aid - that is, to have a lawyer and financial support necessary for his/her defence in both the executing and the issuing Member States: see the Directive 2013/48/EU, of 22 October 2013, and the Directive 2016/1919/EU, of 26 October 2016.

177 The requesting State itself usually also does not have a standing in the judicial proceedings in the requested State, which for instance prevents it from appealing unfavourable decisions. This might be intended to avoid these proceedings becoming a stage of interstate quarrels, but it constitutes another signal of the preponderance of the requested State. The lack of standing of the requested State in the judicial phase of 
This holds true even where supranational human rights bodies are called upon to intercede, since the decisions delivered by such bodies do not exactly oblige the challenged State to act in the prescribed manner, ${ }^{178}$ although the intervention (in fact, the sheer existence) of such entities does represent a meaningful constraint on State discretion in extradition matters. ${ }^{179}$ Thus, and to conclude, the standing that in time was afforded to individuals in extradition proceedings is better understood as an appendix to a fundamentally unchanged bilateral arrangement. ${ }^{180}$

This is also why the two inner triangles into which the outer triangle is divided ( $s c$. the one representing grounds for refusal imposed upon States, and the one representing grounds for refusal voluntarily set in place by States) have as their common vertex the requested State: it is the requested State that applies both sets of grounds for refusal, even though one of them is exogenous in its source. Grounds for refusal voluntarily adopted by States are represented by the triangle with the larger area because the analysis carried out in Parts II and III suggests that these are more extensive, in both number and scope, than those which are imposed upon States. In any case, the inner triangles are again not intended to express specific measures.

\subsubsection{The imbalance of transnational criminal law}

The State-oriented structure of extradition law is symptomatic of a wider reality. In consequence of accrediting excessive weight to State interests - in view mainly of which it was developed, and whose theoretical bases it therefore largely replicates ${ }^{181}-$, transnational criminal law is generally quite imbalanced. It cares insufficiently for individual interests, in spite of the fact that individuals too are faced with serious difficulties arising from the erosion of State sovereignty, because their actions now have a propensity to trigger at once the punitive power of multiple States. ${ }^{182}$

extradition proceedings is illustrated again by one of the case studies of this reserach (Portugal) particularly by the notorious Abu Salem case (whose extradition was however eventually granted to India, and followed by a violation of the specialty rule): see the rulings of the Supreme Court of 21 October 2011 and 13 December 2011, no. 130/11.3YFLSB, and the ruling of the Constitutional Court no. 360/12, of 5 July 2012. Indirectly, however, the subject who ultimately is affected the most is the individual, as this prevents him/ her from challenging the requesting State within the very extradition proceedings.

178 As illustrated by the Trabelsi case before the ECtHR: see supra, Chap. 2, S 2.2.1.a)(i). The Draft Copenhagen Declaration issued on 5 February 2018 apparently limits even further the sway of the ECtHR on State parties: see e.g. ANTOINE BUYSE, “The Draft Copenhagen Declaration - What About Civil Society?”, Strasbourg Observers, 1 March 2018; Alice DonAld / PHILIP LEACH, “A Wolf in Sheep's Clothing: Why the Draft Copenhagen Declaration Must be Rewritten”, EJIL: Talk!, 21 February 2018; see also the stance of the ECtHR itself: "Opinion on the draft Copenhagen Declaration", adopted by the Bureau in light of the discussion in the Plenary Court on 19 February 2018.

179 See supra, Chap. 2, \2.2.1., and infra, \ 3.3.5., and Chap. 8, \ 2.3.1.

180 M. CHERIF BASSIOUNI, International Extradition... op. cit., p. 50, argues as well that, "[n]otwithstanding the qualified recognition of the individual as a subject of international law, he/she is not yet part of its legal constitutive framework", but more of a "third-party beneficiary": p. 52.

181 On this topic, see KATJA FranKO AAS, "Analysing a world in motion: Global flows meet "criminology of the other'", TC 11 (2007), p. $283 \mathrm{f}$.

182 Extensively on this topic, see SABINE GLESS, "Bird's-Eye View and Worm's-Eye View: Towards a Defendant-Based Approach in Transnational Criminal Law”, TLT 6 (2015), p. 117 f. 
Shortly above it was argued that certain principles conceived for individual liability (e.g. commission by omission) can be extrapolated into the State level because the individual is the basic and concrete unit forming the complex and abstract construction that is the State. This might seem incoherent with the claim now submitted that transnational criminal law is imbalanced because it extrapolates into the international level structures that have been developed mainly in the image of States. The problem with extrapolating the latter kind of structures into the international level is that in this case the entity that is being extrapolated is already an extrapolation. That is, the process here is an extrapolation of an extrapolation, or an extrapolation of an abstraction, and in such a process the link between the final result and the original unit is more likely to wane. In the context of extradition, an individual perspective - a "worm's-eye view", in Gless' metaphor - seems to be lacking in relation mainly to one aspect, which for practical reasons is addressed in the separate paragraph that follows.

\subsubsection{The immediate punitive effects of international arrest warrants}

The fact that refusing extradition denies the injured State the possibility to prosecute the crime, and that being a fugitive is not so arduous today as it was in the past, does not allow for the conclusion that evading justice carries no consequences whatsoever for the person. When an arrest warrant is issued, the person is immediately affected in his/ her freedom of movement, an interest which increases in importance the more integrated the world becomes. Even if the person is not subjected to a criminal sanction whatsoever, it would be oblivious to assume that his/her life stays unaffected.

The impact upon the person varies greatly depending on many factors, objective as well as subjective, including: whether the State of refuge is that of which the person is a national or resident, or instead one with which he/she has no connection; whether it is a State where the person has or can easily build a social and professional life; whether the person has the possibility to move to other State(s) that would not extradite him/her either, or is instead confined to a single jurisdiction; whether the person cherishes the possibility to move to other States, or instead finds it unimportant; etc.

Unquestionably, these constraints are generally a fair price to pay for evading justice. Not for the act of escape in itself - which corresponds to the exercise of a basic instinct, and as such can hardly be reproached,$-{ }^{183}$ but because it spoils communitarian expectations that justice be done on a crime that harmed such a community. However, cases exist where hardship is so substantial as to cast legitimate doubts about its proportionality. Some examples are presented to substantiate this perspective.

183 This is a time-honoured notion dating back to as least FrAnCESCO CARRARA, Programma del Corso di Diritto Criminale - Parte Speciale, Vol. V, 2 ${ }^{\text {nd }}$ ed., Lucca: Tipografia Giusti, 1870, p. 372. It was also defended by Eduardo Correia, Actas das sessões da comissão revisora do Código Penal: Parte Especial, Separata BMJ (1979), p. 442, to whom: "it is prison guards that have the duty to prevent prisoners from evading; hence, only the former, and not the first, can be held liable for an evasion. Freedom is eminently personal, such that only exceptionally and moderately can criminal law impose its self-limitation." More extensively, and conveying the above references, see Cristina Líbano Monteiro, "Art. 349. (Tirada de presos)" and "Art. 352. (Evasão)", in Jorge de Figueiredo Dias (dir.), Comentário Conimbricense do Código Penal: Parte Especial, Tomo III, Artigos 308. a 386. ${ }^{\circ}$, Coimbra: Coimbra Editora, 2001, p. 360 f., 393 f. 


\section{a) Assange}

The case of Julian Assange epitomises that perspective. Sweden issued a EAW to the UK in November 2010, on charges of sexual assault and rape. In June 2012 Assange took refuge in Ecuador's embassy in London. The Swedish investigation was dropped in May 2017, but he remains in the embassy, as he is still facing criminal charges in the UK for breaching bail conditions, as well as a hypothetical extradition to the USA for his activity at WikiLeaks, in particular the publishing of materials leaked by Chelsea Manning (convicted to 35 years of imprisonment, but released in May 2017 following commutation of the sentence by former USA President Barack Obama). The USA did not reveal any indictment of Assange, its standard practice reportedly being never to disclose whether an extradition request has been issued or received until the person at issue has been arrested, but admitted that an FBI investigation is still ongoing concerning the Manning leaks, and in April 2017 USA Attorney General declared that Assange's arrest was a "priority", after CIA director branded WikiLeaks as a threat to national security. At the time of writing, Assange has spent nearly 6 years inside an embassy. ${ }^{184}$

The view that exile may entail significant hardship does not require that it be perfectly comparable to authentic deprivation of liberty. However, such a comparison is now not pure theoretical recreation either, after the UN Working Group on Arbitrary Detention $^{185}$ adopted Opinion 54/2015, of 4 December. ${ }^{186}$ It is a non-binding but official ruling by a UN body, which therefore demands consideration. Among other aspects, the Working Group looked at the several phases of deprivation of liberty as a whole, and held that the stay at the embassy "should be considered as a prolongation of the already continued deprivation of liberty [in Wandsworth Prison and house arrest] that had been conducted in breach of the principles of reasonableness, necessity and proportionality"; the Group held that "what matters in the expression 'arbitrary detention' is essentially the word 'arbitrary' (...). Placing individuals in temporary custody in stations, ports and airports or any other facilities where they remain under constant surveillance may not only amount to restrictions to personal freedom of movement, but also constitute a de facto deprivation of liberty". ${ }^{187}$ The Group found that the UDHR and the ICCPR had been breached, and bid Sweden and the UK to "ensure the right of free movement" to Assange.

\footnotetext{
${ }^{184}$ He reportedly obtained Ecuadorian nationality in December 2017 and was appointed as a diplomatic agent of Ecuador to the UK in January 2018, raising the question as to whether this entails a duty for the UK to allow him to leave the embassy without arresting him: see DAPO AKANDE, "Ecuador Seeks to Confer Diplomatic Status on Julian Assange: Does this Oblige the UK to Allow Him to Leave the Embassy \& Is the Matter Headed to the ICJ?”, EJIL: Talk!, 25 January 2018. However, the Foreign and Commonwealth Office's declared that it did not grant Ecuador's request to confer him diplomatic status, and in February 2018 Westminster's Magistrates' Court upheld his arrest warrant: see MiLES JACKSON / DAPO AKANDE, "Foreign Office Certificates and Diplomatic Immunity in the Assange Affair", EJIL: Talk!, 2 March 2018.

185 A body created by UNCHR Resolution 1991/42, whose mandate has been clarified and extended by UNCHR Resolution 1997/50, and further extended by UNHR Resolution 24/7 of 26 September 2013.

186 In www.ohchr.org/EN/NewsEvents/Pages/DisplayNews.aspx?NewsID=17012, last accessed 24 January 2018.

${ }^{187}$ Id., $\iint 90$ f.; other concerns of the Working Group on the stay at the embassy are provided at $\int 97$.
} 
Opinion 54/2015 is far from undisputed. Sweden and the UK had argued that the stay at the embassy was "voluntary", and that Assange was and had always been "free to leave". ${ }^{188}$ As it was delivered, the Opinion was vehemently criticised by authorities in both States, with the spokesman of then UK Prime Minister James Cameron branding it as no less than "ridicule"; news was later released implying that this Working Group is systemically inclined to favour applicants, as only 4 out of 1.325 claims between 2009 and 2014 were found not to constitute arbitrary detention. ${ }^{189}$ The Working Group itself was divided: Vladimir Tochilovsky (its longest-serving member) ${ }^{190}$ dissented, arguing that the opinion "raises serious questions as to the scope of the mandate" of the Group, since the case does not involve a detention whatsoever, but a "self-confinement" in a "safe haven". ${ }^{191}$

It is most contentious that the stay of Julian Assange at Ecuador's embassy constitutes 'deprivation of liberty' under solid legal criteria. However, the UNWGAD's Opinion cannot be simply overlooked, and does mark an influential recognition of the adversity that may accompany the status of fugitive. Particularly noteworthy is its recurrent reference to 'freedom of movement'. By ruling that Sweden and the UK, in a lawful attempt to bring a person to justice, eventually subjected him to an unlawful detention, the UNWGAD devised a doctrine symmetrical to that of male captus, bene detentus: ${ }^{192}$ something of a bene captus, male detentus doctrine. However, this case is quite atypical and in no way representative of the standard case whereby a fugitive flees to the actual territory of another State. Thus, two arguably less impressive, but more common cases are further presented.

\section{b) Polanski}

One is that of Roman Polanski, wanted in the USA for a sexual offence committed in 1977 against a 13 -year-old victim, ${ }^{193}$ to which he pleaded guilty in $1978 .{ }^{194}$ Polanski has faced several extradition requests, namely in France, Switzerland and, latest of all, in Poland in 2016. The case in Poland reached the Supreme Court, after an appeal by the Polish

${ }^{188}$ Id., $\int 70$, et passim.

189 The then Minister for Human Rights also stated: "The ruling is factually upside down. (...) [Assange] holed himself up in the Ecuadorean embassy, and he is facing a serious allegation of rape. Sweden is not some tin pot banana republic. It's a country with a well-respected justice system. He can forget about compensation, and frankly many people here will think this kind of nonsense undermines the credibility of the UN, which is not what we want": see www.telegraph.co.uk/news/uknews/12141755/Julian-Assangeshould-receive-compensation-UN-says.html, last accessed 24 January 2018.

${ }^{190} I d$., further informing that another member of the Working Group, Leigh Toomey, did not take part in the discussion (meaning that voting was 3 versus 1), because he had the same nationality as Assange: see $\int 5$ of the Methods of the UNWGAD, in https://documents.un.org.

${ }^{191}$ Dissenting Opinion, $\int 3$. He further regretted: the case could have been ruled by UN human rights bodies or the ECtHR, which "do have mandate to examine such complaints", and that any further application may now be declared inadmissible due to having been considered by the Working Group: id., $\iint \mathrm{f}_{\mathrm{f}}$.

192 A doctrine applied by some States and profusely debated in respect of Eichmann: see e.g. WILLIAM A. SCHABAS, "The Contribution of the Eichmann Trial to International Law", LJIL 26 (2013), p. 683 f.

${ }^{193}$ Who in June 2017 unsuccessfully asked a court in California to drop the case, so as to put an end to the exposure it brings: www.edition.cnn.com/2017/06/09/us/roman-polanski-victim-court/index.html, last accessed 7 May 2018.

194 See www.telegraph.co.uk/culture/film/6240914/The-hunt-for-Roman-Polanski.html, last accessed 7 May 2018. More claims against Polanski for akin offences continue to be made, but that is a different issue. 
Minister of Justice against a decision by a Krakow court refusing extradition. The noteworthy element in the Supreme Court's decision is the argument - which is aligned with UNWGAD's Opinion 54/2015 - that the time spent in deprivation of liberty by Polanski on account of those charges (between jail, house arrest and custody) already exceeded that of his original sentence. ${ }^{195}$

\section{c) Sons of Iraqi ambassador to Portugal}

In August 2016, the 17-year-old twin sons of Iraqi ambassador to Portugal allegedly committed a brutal assault on a 15 -year-old victim after a row in a bar, leaving him in a coma. ${ }^{196}$ The twins were arrested and then released due to enjoying diplomatic immunity. They publicly claimed that they acted in self-defence, and that they were not planning to 'make use' of the immunity. Portugal asked Iraq to waive the immunity, but this request was not fulfilled. Portugal did not declare the ambassador persona non grata, but Iraq recalled him from duties. The immunity at issue is a personal immunity, meaning that their beneficiaries were only protected from prosecution insofar as the status generating it persisted (i.e. until the functions as ambassador ceased). Meanwhile, an out-of-court settlement was reportedly reached with the victim, already recovered from the coma, concerning civil issues, namely compensation. Since the procedural principle of legality requires the Public Prosecution to initiate a criminal procedure for this offence regardless of the agreement of the victim, an investigation must still be carried out in Portugal, and if during its course 'sufficient evidence' is gathered that the crime was committed by the suspects it is mandatory to prosecute them. ${ }^{197}$

Considering the nature of the offence and the applicable penalty scale, and the fact that the status giving rise to the immunity ceased, it is mandatory for Portugal to issue an international arrest warrant if the accused do not attend willingly and their custody is necessary to carry out the criminal procedure or enforce a penalty possibly applied in absentia. ${ }^{198}$ In Iraq they likely benefit from a nationality exception; no other ground for refusal seems to be met that would guard them from a hypothetical Portuguese extradition request. In such cases, until the procedure becomes time-barred, the only option to preserve freedom may be to stay in a single jurisdiction at all times (assuming also that the custodial State will not take any penal action against the person). In this case, one of the

195 See www.telegraph.co.uk/news/2016/12/06/roman-polanski-no-longer-faces-extradition-polandsupreme-court/, last accessed 7 May 2018.

196 See www.euronews.com/2016/08/22/portugal-braces-itself-for-diplomatic-row-with-iraq-overbrutal-attack, last accessed 7 May 2018.

197 Arts. 262 (2) and 283 (1) CCP. Confirmation that an investigation was conducted came in early 2018 in the form of a prosecution for attempted murder: www.lusa.pt/article/23558659/desconhece-se-paradeirode-filhos-de-ex-embaixador-mp-pede-ajuda-\%C3\%A0s-autoridades-do-iraque, last accessed 7 May 2018.

198 Shortly after the news that a decision to prosecute had been issued, it was reported that the public prosecutor in charge of the procedure called upon the General Attorney's Office to intervene next to the Iraqi authorities so that they assist in notifying the suspects - whose whereabouts are at the time unknown - of their prosecution; it was also reported that the Minister of Foreign Affairs stated that he would immediately forward through diplomatic channels any request that the General Attorney's Office deemed necessary: see www.observador.pt/2018/01/18/governo-realizara-imediatamente-diligencia-pedida-pela-justicasobre-filhos-de-ex-embaixador-do-iraque/, last accessed 7 May 2018. 
twins was training to become a pilot. The acts reportedly took place precisely near an airbase where he was taking flying lessons. Even if he does dodge criminal justice, his professional expectations may have been irreversibly compromised.

\section{d) Conclusion - Limited freedom, limited persecution}

The preceding paragraphs appraised the immediate effects of being targeted by an international arrest warrant, and concluded that, although they are a fair price to pay for avoiding criminal justice, they can be quite stern. ${ }^{199}$ In its effects, the condition of fugitive may be compared to that of refugee: fugitives might be free in the sense that they are not deprived of liberty in a classic form, but this constitutes a limited kind of freedom, and in extreme cases it can even be convincingly compared to the former. It will be especially so when the person has not been convicted, and as such deserves to be presumed innocent.

It might appear paradoxical to argue that the hardship inherent to the condition of fugitive should be given greater attention, when earlier in this very chapter it was argued that being a fugitive is not as gruelling a condition today as it was in the past and that this is one of the reasons why extradition law should be reformed. However, the two claims will not be incompatible if each is understood in its proper scale: the fact that being a fugitive is not as arduous as before does concur to the obsolescence of a legal area that was conceived on the assumption that the absence of the offender from the injured community was often sufficiently appeasing; ${ }^{200}$ but this does not mean that the condition of fugitive equates to genuine freedom, or that on occasion it does not strikingly resemble traditional deprivation of liberty. ${ }^{201}$ And if the hardship imposed on the person is indeed so intense as to be comparable to actual deprivation of liberty, it would seem that some ef-

199 From a patrimonial angle, the fact that a person evades justice and cannot be extradited or otherwise held liable does not currently prevent the deployment of certain mechanisms aimed at lessening his/her financial capacity, such as enlarged confiscation (see e.g. KATALIN LiGETi / MiCHELE SimonAto (eds.), Chasing Criminal Money: Challenges and Perspectives on Asset Recovery in the EU, Oxford: Hart, 2017, JON PETTER RUI / Ulrich SIEBER (eds.), Non-Conviction-Based Confiscation in Europe: Possibilities and Limitations on Rules Enabling Confiscation without a Criminal Conviction, Berlin: Max-Planck-Institut, 2015), and, on a different level, targeted or smart sanctions (see e.g. GORDON FrIEDRICHS, Smart Security Council? Analyzing the Effectiveness of Targeted Sanctions, Hamburg: Anchor, 2013; JoAna Amaral Rodrigues, “As Sanções (ou Medidas Restritivas) Internacionais: Enquadramento e Questões Jurídicas Fundamentais”, Themis 24/25 (2013), p. 201 f.).

200 To Zygmunt BAuman, "Social Issues of Law and Order”, BJC 40 (2000), p. 208, spatial separation (including, but not only confinement in a cell or comparably limited space) has as its "deepest meaning" the "banning or suspension of communication, and so the forcible perpetuation of estrangement".

201 See e.g. Katherine Beckett / Steve Herbert, "Penal Boundaries: Banishment and the Expansion of Punishment", L\&SI 35 (2010), p. 1 f., reviewing social control theories and noting that they identify two main modalities of 'spatial control' ( $s c$. sets of strategies applied to "respond to the threats of disease, migration, disorder, and crime"): expulsion and containment. Similar considerations are on the basis of the concept of 'crimmigration': see Juliet P. STUMPF, "The Process is the Punishment in Crimmigration Law", in Katja Franko Aas / Mary Bosworth (eds.), The Borders of Punishment: Migration, Citizenship, and Social Exclusion, Oxford: University Press, 2013, p. 58, 74, and KATJA FrANKO AAS, “'Crimmigrant' bodies and bona fide travellers: Surveillance, citizenship and global governance”, TC 15 (2011), p. 343, passim, positing that borders and surveillance are not only physical but also social, but noting that individuals from different social groups are in "highly unequal positions" in terms of their subjection to crimmigration processes, "ranging from extreme deprivation to great social privilege": ibid. Such variations should be taken into account if one is to draw lenient consequences from the condition of fugitive in the context of actual criminal law. 
fects should be drawn from this fact also in the context of substantive criminal law, and in that of extradition law, regarding aspects other than grounds for refusal. ${ }^{202}$

\subsubsection{Individuals: Structural disadvantage, substantive advantage}

Although extradition proceedings do not incorporate the individual in their structure so unreservedly as would be justified, ${ }^{203}$ and without prejudice to the claim that even impunity may come at a high price, ${ }^{204}$ at the substantive level (i.e. as far as the scope of protection conferred by existing grounds for refusal is concerned) extradition law is far less imbalanced than other aspects of transnational criminal law. ${ }^{205} \mathrm{~A}$ reason for this may be that extradition is not a new mechanism whose impact upon individuals is still unclear; quite the contrary. It is recalled that the very first known international legal norms on extradition, found in the Treaty of Qadesh $\left(13^{\text {th }}\right.$ century BCE), already revealed some consideration for the fate of extradited individuals. ${ }^{206}$ In the field of extradition, individuals have benefited very clearly from the broader movement of the advent of individual rights in international law that took place following WWII. Their sphere of guarantees grew visibly, and the most fundamental of such guarantees are not even in the hands of States anymore, but have rather become compulsory under international law. Although human rights praxis is far from homogeneous, and in this sense human rights are not universal, their theoretical underpinnings are, and as such these rights must feature as insurmountable obstacles in any study on extradition law. ${ }^{207}$

But there is another (arguably more powerful, and certainly less philanthropic) reason why extradition law is not particularly detrimental to individuals at the substantive level. Namely that most of its grounds for refusal, while developed primarily in view of the interests of the requested State, ultimately also profit individuals, who in principle will benefit from not being extradited, as this marks the first and often decisive step towards impunity. The protection of the interests of the requested State through grounds for refusal translates into protection of the individual. The interests of these two subjects are, in this respect, almost perfectly aligned. This is noticeable in numerous modern and premodern extradition treaties concluded long before the advent of individual rights in international law. ${ }^{208}$ This is why, unlike other aspects of transnational criminal law, extradi-

202 It lies beyond the scope of this study to discuss what those effects should be, but they could include, for instance: (i) limiting the issuing of multiple extradition requests for the same individual owing to the same offence; (ii) making clear provision for the fact that periods spent in deprivation of liberty on account of the same acts be discounted in a sentence possibly to be served (based on the principle nemo debet bis vexari pro una et eadem mentioned in UNWGAD's Opinion 54/2015, \19); (iii) establishing lower (if only moderately so) time-bars for situations where the crime and its author were detected and the latter sought refuge in another State, away from the community that was injured by his/her crime); and (iv) developing a transnational system of punishment of concurrent offences.

203 See supra, \3.3.3.

204 See supra, $\int 3.3 .4$.

205 In the incisive depiction of the imbalance characterising transnational criminal law provided in SABINE GLESS, "Bird's-Eye View...” op. cit., extradition law is not mentioned as a particularly worrying area.

206 See supra, Chap. 3, \1.1.

207 See, more generally, JÜRgEn HABERMAS, op. cit., p. xi f., 71 f., et passim.

208 See again supra, Chap. 3, $\int 1.1$. 
tion law not only does not offer deficient protection to individuals, but in fact offers them excessive protection in many regards: they benefit from a wide range of grounds for refusal that were not developed out of consideration for them and that, therefore, do not necessarily protect individual interests worthy of protection. Thus, reducing the scope of such grounds for refusal certainly does narrow the chances of an individual avoiding extradition, but it does not necessarily sacrifice individual rights. Again, this does not mean that some grounds for refusal do not protect individual rights. The claim is simply that, historically and structurally, grounds for refusal protect individuals in an incidental manner, as a side effect of an intention to protect (State) interests which, according to the analysis carried out in this chapter, have excessive hindering effects on international cooperation.

This excess manifests itself in one aspect which affects in a rather transversal manner the regulation of grounds for refusal: the degree of certainty to which individuals are entitled vis-à-vis the requested State. That is, the level of assurance which is provided to them that they will be protected from extradition should they flee to the territory of a certain State. The following paragraph addresses this pivotal aspect.

\subsubsection{Legal (un) certainty in extradition law}

\section{a) General considerations}

Grounds for refusal of extradition are regulated in a rather stringent manner, comparable to that which is characteristic of substantive criminal law. In many instances their scope is even determined, ultimately, by reference to norms of substantive criminal law. For instance, the dual criminality rule prevents a State from extraditing for acts which are not described as a criminal offence in its own substantive criminal law; similarly, the time bars exception often prevents States from extraditing for acts whose prosecution would be time-barred according to the criteria of that State. This hinders the enactment of rules capable of separating the essential from the superfluous for extradition purposes.

What is submitted here is that, in extradition law, a decrease in legal certainty is not only acceptable but also desirable. Unquestionably, all law should strive to be predictable, reliable, certain as much as possible. However, there is a profound difference between punishing and assisting in punishing. Although extradition is a severe measure, it is not the same as imprisonment. The requested State must see to it that the person in question will enjoy due guarantees in the process to be carried out abroad, and failure to do so is imputable to that State - as human rights case law now so unmistakably asserts. However, extradition law is not required to offer the same guarantees as substantive criminal law - particularly those arising from the principle of legality and its corollaries that the law be previous, written, strict and certain.

In substantive criminal law certainty is sacred, even if for criminals it represents, in the famous expression of von Liszt, a magna carta. ${ }^{209}$ What people can and cannot do is something that must be made utterly clear, so that they can determine their behaviour ac-

${ }^{209}$ FRANZ VON LISZT, “Die deterministischen Gegner der Zweckstrafe”, ZStW13 (1893), p. 357, partly translated into English in JICJ 5 (2007), p. 1009 f. 
cordingly. As Montesquieu had already posited: "Philosophic liberty consists in the free exercise of the will; or at least, if we must speak agreeably to all systems, in an opinion that we have the free exercise of our will. Political liberty consists in security, or, at least, in the opinion that we enjoy security. This security is never more dangerously attacked than in public or private accusations. It is, therefore, on the goodness of criminal laws that the liberty of the subject principally depends. (...) The knowledge already acquired in some countries, or that may be hereafter attained in others, concerning the surest rules to be observed in criminal judgments, is more interesting to mankind than any other thing in the world." ${ }^{210}$

This is vital not only for safeguarding personal liberty, but also for legitimising the exercise of the ius puniendi, for a person cannot be subjected to such a severe consequence as a criminal penalty on account of acts that were not prohibited. ${ }^{211}$ But as of the moment that someone, being fully aware or enabled to being aware that certain acts are criminally censured, even so undertakes to commit those acts, why should he/ she be entitled to a comparable level of certainty in respect to whether or not he/she will obtain protection from prosecution? In the name of which value must such a level of certainty be provided? It appears to be conclusive that the level of uncertainty (whichever it might exactly be) that would have to be reached in order for extradition proceedings to be unfair is higher than in the case of actual criminal proceedings.

Current extradition law displays markedly positivistic - or, rather, formalistic - attributes, ${ }^{212}$ in that it is compelled to cover all conceivable situations - including the abnormal, extraordinary, exceptional ones -, narrowing down to a marginal span the co-constitutive role that the entities that apply the law to concrete cases may play in the determination of the "just, wise, efficient, or prudent" 113 solution for each and every such case. It seeks as much as possible to settle the discipline of all those situations already at the prescriptive level, leaving scant room for their case-by-case appraisal. Such an approach does not seem apt for a legal field such as extradition, where, as noted, the meaning of human behaviour must be appraised as it is perceived at each given point in time. It is perhaps in this sense that Bueno Arus, after criticising the indeterminacy of the extradition law concept of 'political offence' and claiming that legal certainty is an essential goal of the Law,

210 MONTESQUieu, op. cit., p. $206 \mathrm{f}$.

211 As is well know this is not so black and white, as the principle has suffered some erosion and admits some deviations and adaptations - on the issue, see CHristinA PERISTERIDOU, op. cit., p. 103 f.; MigueL ÂNGELO LEMOS, Nullum crimen nulla poena sine lege $e$ o direito internacional-Em defesa de como os tribunais de guerra deram vida ao direito penal internacional, Ph.D Thesis, Coimbra: FDUC, 2017, p. 403 f.

212 Substantive criminal law as we currently know it, starting with the nullum crimen principle, is to a large extent a specific product of legal positivism: see HANS KELSEN, General Theory of Law and State, Cambridge: Harvard University Press, 1949, p. 52 f.: "human behavior can be considered a delict only if a positive legal norm attaches a sanction as a consequence to this behaviour as a condition". And: "Certainly, the legislator must first consider a certain kind of behaviour harmful, a malum, in order to attach it a sanction. Before the sanction is provided, however, the behavior is no malum in a legal sense, no delict. There are no mala in se, only mala probibita, for a behaviour is a malum only if it is probibitum (...): nulla poena sine lege, nullum crimen sine lege", which is "the expression of legal positivism in the field of criminal law."

${ }^{213}$ Leslie Green, "Legal Positivism”, in Edward N. Zalta (ed.), The Stanford Encyclopedia of Philosophy, , in https://plato.stanford.edu/archives/spr2018/entries/legal-positivism/, Spring 2018 ed.. 
ultimately posits that the concepts used in this legal area should probably be indeterminate. ${ }^{214}$ Using formalistic structures in a legal area to which they are unsuitable is the technical facet of the mismatch between the scope and the rationale of grounds for refusal, indicated before. It could be changed through the use of more indeterminate concepts in the rules establishing grounds for refusal, and the correlative expansion of the competence of the entities charged with the decision whether or not to extradite.

\section{b) Advocaten voor de Wereld}

The above considerations find clear support in the ruling of the ECJ in Advocaten voor de Wereld, where the issue was addressed as to whether the list of offences of the FDEAW for which control of dual criminality is dispensed contravened fundamental principles of EU law due to its indeterminacy.

In approaching the argument that "there is a risk that Art. 2 (2) FD may be interpreted incorrectly owing to a lack of precision in the definitions it contains", thereby infringing upon the principle of equality enshrined in Arts. 6 (2) TEU and 20 CFREU, AG Colomer immediately notes that there is an "underlying confusion here between equality in the law itself and the equality which operates when the law is applied": "The former, which is substantive in nature and aimed at ensuring that comparable situations are treated in the same way, is not respected when a provision makes similar situations subject to different rules without reasonable justification, whereas the latter, which is procedural in nature, is breached when an authority which is required to apply the provision in a particular instance construes that provision differently from on previous occasions with regard to similar situations. Accordingly, there is no inequality in the application of the law where conflicting judgments are handed down by courts which are acting in the legitimate exercise of their jurisdiction to determine a case, because the principle of equality does not require separate courts to reach identical conclusions. It would be ludicrous to class a law as discriminatory because it may be open to different interpretations which it may be possible to consolidate via the appropriate remedies". ${ }^{215}$

This brings the AG to the other argument concerning the indeterminacy of Art. 2 (2) FD, namely that it would infringe upon the principle of legality, enshrined in Art. 49 (1) CFREU, in its facet of legal certainty (lex certa). In this regard the AG, after reinstating the extreme importance of this principle, notes that it applies only to substantive criminal law "as a requirement which is addressed to the legislature when it defines offences and sentences, and which is addressed to the courts when they analyse and apply those definitions in criminal proceedings. In other words, it comes into play during the exercise of the States' right to punish and during the application of acts which may be strictly construed as imposing a penalty" - which manifestly entails that the FD-EAW does not contravene such a principle, "because it does not provide for any punishments or even seek

214 Francisco Bueno Arus, "L'Infraction Politique et L'Extradition dans la Legislation Espagnole”, RIDP 62 (1991), p. 311, 322: “Les concepts juridiques indéterminés ne favorisent pas la sécurité juridique, mais peut-être, dans le domain envisagé, les concepts juridiques doivent-ils êtres indéterminés en raison de la nature des choses, comme disait Montesquieu”.

215 Opinion of Advocate General Ruiz-Jarabo Colomer, 12 September 2006 (C-303/05), \$S 96 f. 
to harmonise the criminal laws of the Member States", but is instead "confined to creating a mechanism for assistance between the courts of different States during the course of proceedings to establish who is guilty of committing an offence or to execute a sentence." Thus - the AG conclusively asserts -, "the certainty required by that principle must be demanded from the substantive criminal law of the issuing Member State and, therefore, from the legislature and the courts of that State for the purposes of commencing criminal proceedings and resolving them, where appropriate, with a sentence". In addition, the AG noted that the arrest and surrender procedure presupposed by the execution of a EAW "is not punitive in nature", as it simply requires the court of the executing Member State "to establish that the conditions for handing over an individual" are met, and not to look into "the substance of the case", except insofar as this is necessary for the purposes of the surrender procedure itself. In support of this view the AG mobilised the case law on extradition of the ECtHR, which, ruling by reference to the $1957 \mathrm{CoE}$ Extradition Convention, rejected that it has the character of a punishment. ${ }^{216}$ In conclusion, the AG submitted that the questions raised in this case "relate little to the principle of legality in criminal proceedings and a great deal to the fear that the concepts referred to in Art. 2 (2) FD-EAW may be interpreted differently in each Member State, with the risk of nonuniform application, which however "is inherent in the nature of all legislative provisions", in that they are "both abstract and general".

Insofar as regards these specific issues, the Court begins by noting that Advocaten voor de Wereld stood alone among all parties who submitted observations in these proceedings in contending that, by dispensing with the verification of dual criminality, Art. 2 (2) FD-EAW contravened the principles of equality and legality. It elaborated on the two principles in the reverse order from the AG, but corroborated his opinion with no noteworthy nuances. ${ }^{217}$ Regarding the legality principle, the Court also reinstated its paramount relevance: this principle requires legislation to "define clearly offences and the penalties which they attract", such that "the individual concerned is in a position, on the basis of the wording of the relevant provision and with the help of the interpretative assistance given by the courts, to know which acts or omissions will make him criminally liable"; however, a person targeted by a EAW "does not benefit from the guarantee that criminal legislation must satisfy conditions as to precision, clarity and predictability allowing each person to know, at the time when an act is committed, whether that act does or does not constitute an offence". The Court then noted as well that the FD "does not seek to harmonise the criminal offences in question in respect of their constituent elements or of the penalties which they attract", and that, even if this were the case, "the actual definition of those offences and the penalties applicable are those which follow from the law of 'the issuing Member State' ". The Court then addressed the inequality issue. ${ }^{218}$ In most

216 The rulings invoked are $X v$. Netherlands, no. 7512/76, 6 July 1976; Polley v. Belgium, no. 12192/86, 6 March 1991; and Bakhtiar v. Switzerland, no. 27292/95, 18 January 1996: see further infra, Chap. 8, \ 4.2.1.a).

217 ECJ, Judgement of 3 May 2007 (C-303/05), JS $44 \mathrm{f}$.

218 This issue also concerned the circumstance of the FD-EAW exempting certain acts from dual criminality whilst allowing Member States to still subject the remaining acts to this rule: see ibid., $\iint 55 \mathrm{f}$. However, this aspect does not relate to the issue of indeterminacy in consideration here, or, for that matter, to 
definite terms, it asserted that, in this regard, "suffice it to point out that (...) nothing in Title VI [TEU], Arts. 34 and 31 of which were indicated as forming the legal basis of the FD, makes the application of the EAW conditional on harmonisation of the criminal laws of the Member States within the area of the offences in question."

\section{c) Closing considerations}

Indeterminacy in extradition law will be intolerable only where it concerns grounds for refusal that protect fundamental individual rights, because individuals are the primary beneficiaries of both these rights and of the imperative that the law be certain. Insofar as regards grounds for refusal whose function is to safeguard the 'criminal justice ethos' of the requested State, there is ample room for indeterminacy, as the individual protection emanating from such grounds for refusal is but incidental. Indeed, from the perspective of the individual concerned, a refusal based on such grounds takes the shape of a 'bonus' - a favourable side effect of a norm set in place for altogether different reasons. That is why it can even be argued that these grounds for refusal could simply be replaced by a general ordre public clause, an approach which would entail as much indeterminacy as one can possibly conceive. Such an approach is not endorsed in this study, but not because it would entail an intolerable level of indeterminacy; rather, because it would dodge entirely the challenge of determining the fundamental criteria that may allow us to discern which national values are worthy of protection in the context of extradition. ${ }^{219}$

If at the theoretical level it is acceptable and indeed warranted to increase the level of uncertainty of extradition law, at the pragmatic level it is most serviceable, because not knowing whether asylum is assured is a factor with an evident preventative potential. To evoke again the time-honoured words of Beccaria: "the conviction of finding nowhere a span of earth where real crimes were pardoned might be the most efficacious way of preventing their occurrence". ${ }^{220}$ To conclude, it is preferable that extradition law be reasonably uncertain than certainly unreasonable.

\subsubsection{Conclusion - Individual, national and international perspectives}

In the past, extradition proceedings were bilateral, and as such could be graphically expressed through a straight line linking the requesting and the requested States. With the advent of individual rights in international law, the person targeted by an extradition request was recognised legal standing, rendering those proceedings triangular, which is the shape that they still display currently. Individuals occupy the lower vertex of this triangle. They constitute an appendix to the original straight line, because in their basic structure

the approach adopted in this study in relation to dual criminality, because the approach propounded here is applicable to any class of acts, unlike the 'list approach' of the FD-EAW: see infra, Chap. 8, \ 4.1.1.c)(v).

219 See notably infra, id.

${ }^{220}$ Cesare BecCARIA, op. cit., p. 192 f. In order to put the sentence into context, it should be noted that Beccaria refused to advocate an increased use of extradition "until laws more in conformity with the needs of humanity, until milder penalties, and until the emancipation of law from the caprice of mere opinion, shall have given security to oppressed innocence and hated virtue (...)": ibid., p. 192. Nevertheless, the author does establish a link between the use of extradition and the prevention of crime. 
these proceedings remained fundamentally unchanged: a State requests the extradition of a person to another State, and the latter decides whether or not to grant it; the only difference is that that person can actively attempt to influence this decision. Not that this is an insignificant difference - in fact it is nothing short of paradigm-shifting, such was the "omnipotence" of States under pre-WWII international law,$-{ }^{221}$ but it does not change the fact that the fate of individuals whose acts have transnational implications remains essentially in the hands of States as sovereign entities. Aside from (important, but) relatively few exogenous constraints, it is still States, as holders of authority over acts committed in their territories, that decide whether or not, and if so to what extent, they will persecute an individual; and it is still States, as holders of some authority over individuals located in their territories that decide whether or not, and if so in which conditions they will contribute to such a persecution. This carries adverse consequences for individuals and States alike.

As far as individuals are concerned, the lack of a "worm's-eye view"222 is preventing the acknowledgement that the condition of fugitive, albeit unlawful, involves potentially arduous consequences. As far as concerns States, the State-centeredness of extradition law leads to an unreasonably extensive set of grounds for refusal which is preventing cooperation relations between States from attaining the levels of intensity required by a globalised world. In this respect, it seems that States' 'bird's-eye view' is itself insufficiently far-sighted, and that certain issues should be looked at from an even more elevated position, with detail giving way to wider field of view. Accordingly, a truly international perspective should be adopted that would focus on the community of States as a whole. The individual perspective should draw further consequences from the fact that individuals targeted by extradition proceedings are in a position of vulnerability. As for the national perspective, which focuses on States in their separate, idiosyncratic existence, it should be subjected to the adjustments required by the two preceding premises. Such adjustments should take essentially the form of a contraction, since those premises require States, on the one hand, to waive part of their punitive might in favour of individuals, and, on the other hand, to waive part of their national values in favour of other States and of the whole international community thereby.

To effect those changes, a set of normative propositions was posited which can be outlined as follows: (1) The requesting State should as a principle be assisted in tackling its domestic criminality (in the name of the principles of territoriality and non-interference).

(2) The requested State should as a principle provide such an assistance (in the name of the same principles, and with the further incentive of reciprocity). (3) The exception to the above principles are the cases in which cooperating would put at risk the core values

221 To use the expression of Hersch LaUterpacht, An International Bill of the Rights of Man, Columbia: University Press, 1945, p. $v$ (and already of FRANZ VON LISZT, op. cit., p. 356, although in regard of national criminal law, more specifically of the principle of legality: “the citizen’s bulwark against the State's omnipotence", "against the ruthless power of the majority, against Leviathan"). On the pre-war paradigm of international law and the role of Hersch Lauterpacht (as well as of Rafael Lemkin) in subsequent developments, see Philippe SAnds, East West Street: On the Origins of 'Genocide' and 'Crimes Against Humanity', London: Weidenfeld \& Nicolson, 2016.

222 To use again the metaphor of SABINE GLESS, "Bird’s-Eye View..." op. cit. 
of the requested State (i.e. its criminal justice ethos). (4) Individuals targeted by extradition should be acknowledged to find themselves in a vulnerable position. (5) Nevertheless, it must be made utterly clear that these individuals benefit from excessive guarantees deriving from grounds for refusal set in place in the interest of the requested State, and which as such do not necessarily translate into relevant individual rights.

\section{General conclusion: A matter of degree}

This chapter sought to identify and articulate the variables for a reform of extradition law. It was observed that the key factual conditions underpinning modern extradition have changed: mobility, remote criminality, and social alarm at impunity all have increased significantly, reducing States' capacity to tackle domestic criminality singlehandedly. Meanwhile, the paradigm of criminal justice remained basically unaltered: jurisdiction is still fundamentally State-centric and territorial, and criminal procedure ubiquitous. Extradition thus remains the main tool at the disposal of the international community to counter those phenomena. In turn, grounds for refusal have a similar scope as that which was bestowed upon them at the end of the $18^{\text {th }}$ century. They were not subject to conceptual review, which produced a lag between the reality and the law.

With this diagnosis in mind, a set of normative propositions was submitted and a reassessment made of the interests that are at play in extradition proceedings. The theoretical framework assembled in this chapter is somewhat intricate, but there is one thread linking its components, one theme resounding throughout this entire chapter: the reform of extradition law pursued in this study is not a 'black and white', but rather a 'grey' undertaking; not a matter of 'yes or no', but one of 'degree'. The following lines abridge to the sound of this leitmotif the propositions that were submitted.

This study is markedly pragmatic, in that it addresses an existing problem and seeks primarily to devise solutions that may be immediately applicable. This does not necessarily render the study short-termist or short-sighted. Focusing primarily on long-termed goals might not only be ineffective but also counter-productive, as is arguably illustrated by the EAW experience. Underpinning the enactment of the FD-EAW was a vision of the EU as a cohesive criminal justice area with solid common standards and principles where mutual trust was fundamentally conceived as a fact - as a reality that naturally and inherently enabled Member States to cooperate in nearly unconditional terms. In time, signals began to emerge and eventually it did become clear that mutual trust also entails a duty on Member States to trust each other even where they see no solid reason to do so. However, this also entailed that they would not have to cooperate where such a duty would be absolutely untenable, notably in view of a risk of human rights breaches, such that, today, in some regards, the EAW is less swift a mechanism than it was at its inception. ${ }^{223}$

223 Which only reflects the broader crisis in which the European project has immersed notwithstanding all measures of continuous integration adopted over the decades, with 'excessive integration' being precisely one of the main arguments raised by sceptics of that project. For those who trust integration to be the right path, it seems to be the moment to reflect whether slower, more sustainable integration would not be a wiser, more effective approach A similar understanding appears to underlie the remark by ANNE PIETER VAN DER MEI, "Flexibility and differentiation...", op. cit., p. 203, that giving Member States "sufficient space 
The transformations envisaged in this study follow the ideal of a more cooperative world, which, normatively speaking, means bestowing upon the principle of territoriality even greater preponderance than that which it already, justifiably enjoys. Notwithstanding, this study also assumes that such an ideal cannot be attained in disregard of national 'cultural biotopes'. States cannot be expected to cooperate in betrayal of their essential values, and in any case, in the long term, that would be both undesirable and, again, probably counter-productive. The approach taken in this study renders implausible the complete abolition of any grounds for refusal of extradition, as these generally perform some function that the requesting State would (and, in that light, should) be unwilling to waive completely. This is why the fundamental exercise to be developed here is not to pinpoint grounds for refusal to be removed and grounds for refusal to be maintained, but instead to optimise grounds for refusal to the extent necessary to bring to an end the identified discrepancy between extradition law and current factual conditions. That is, to adjust the scope of grounds for refusal to a certain degree. Such a degree is given by the core values of the requested State, which are the only national values capable of superseding the punitive interests of the requesting State, rebutting the presumed priority of territorial jurisdiction.

Transnational criminal law is imbalanced in many aspects, generally to the benefit of States and the detriment of individuals. This is visible in particular traits of extradition law: albeit less arduous than in the past, the condition of fugitive does not equate to fully-fledged freedom; it is a limited kind of freedom; freedom to a degree. However, as far as regards its substantive conditions - the aspect in focus in this study -, extradition law is by no means disadvantageous to individuals, as they benefit from extensive grounds for refusal set in place in view of the interests of the requested State, with whom their interests are, in this respect, almost perfectly aligned. Individuals moreover benefit from the fact that extradition law remains a highly formalistic body of norms which affords them great certainty as to whether they are entitled to impunity. Such an ample protection is excessive, because it does not fully correlate to individual rights or interests worthy of protection, and it is problematic, because it compromises the preventative efficacy of criminal justice systems. Consequently, it is both legitimate and sensible to reduce such a protection to a certain degree.

Although they admit different interpretations - considering the historical context in which they were written and the discourse in which they are incorporated -, the following words of Beccaria condense perfectly the views defended above: "There is only a difference of degree between impunity and asylum". 224

to enforce the additional protection (...) as compared to that available under the [CFREU] (...) would be welcome, not in the least because doing so may positively contribute to the political and sociallegitimacy of the ongoing integration process".

${ }^{224}$ Cesare Beccaria, On Crimes and Punishments (trans. David Young), Indiana: Hackett, 1986, p. 67. 


\section{Chapter 8}

\section{Reforming Grounds for Refusal: Theoretical Framework Applied}

\section{Introductory considerations and specifications on the method}

Drawing on the theoretical framework developed above, the present chapter offers proposals for a reform of extradition law. In applying that framework to the several grounds for refusal, mutual recognition - particularly the EAW, but occasionally also the MAW is assigned a relevant role: the 'genealogical' comparison between mutual recognition and classic cooperation maintained throughout the study is continued here. ${ }^{1}$ The traditional grounds for refusal that were removed or mitigated in the EAW are seen as 'positive candidates' to be reformed in classic extradition; those that were basically maintained are regarded as 'negative candidates' to be reformed.

This does not predetermine the answer to the question as to which grounds for refusal should in effect be reformed in classic extradition. This answer follows mainly from the theoretical framework, which is why that comparison, albeit primarily focused on improving traditional cooperation, might also shed critical light on mutual recognition. The binary reference to the EAW used here serves mainly systematisation purposes: it constitutes a means for structuring this chapter according to a criterion of 'plausibility of reform'.

Section 3 addresses the negative (or implausible) candidates for reform, and section 4 the positive (or plausible) ones. Both sets of grounds for refusal are organised according to the same systematisation used in Part III, since the reasons then invoked are also valid here. Positive candidates are addressed later, so that at that moment a picture has already begun to take shape as to which grounds for refusal should be conserved.

In respect of only one type of grounds for refusal are those criteria not followed namely, of those that concern the political interests of the requesting State. There is scant room for political interference in the EAW system. ${ }^{2}$ This would qualify those grounds for refusal as positive candidates to be reformed. However, as established early in the study, a similar approach is extremely ulikely to be transplanted into the realm of cooperation between States that are not integrated in such a robust common legal and institutional organisation as the EU. On the other hand, the executive branch intervening in extradition proceedings or not is a difference that can have quite an impact on the scope of grounds for refusal as a whole, and, therefore, it should be dealt with beforehand. Thus, the role of the political branch in extradition matters is addressed even before the (other) negative

\footnotetext{
${ }^{1}$ See supra, Chap. $2, \S 3$, more generally on the dialogue between classic cooperation and mutual recognition.

${ }^{2}$ But see further infra, $₫ 2$, shortly below.
} 
candidates. The same applies to the reciprocity requirement, which is not only a political concern of the requesting State, but in fact constitutes the cement holding together the cooperation building as a whole, legal and political aspects included.

Of the grounds for refusal analysed in chapter 6 , only three will remain unaddressed here, namely 'hostage-taking considerations', 'abuse of process jurisdiction', and 'absence of a prosecution decision'. These grounds for refusal are absolutely specific to the UK's legal system and find no expression in the UN model instruments. The only reason why they were analysed in Part III is methodological, namely the conviction that the 'tapestry' of an extradition system requires looking at all its 'threads' in an integrated manner. ${ }^{3}$ In any case, ultimately those grounds for refusal turned out to be complementary in relation to other, more common ones, ${ }^{4}$ which are covered in the present chapter, meaning that the absence of the former carries no meaningful loss to this chapter.

The proposals submitted in this chapter should not be taken to constitute the only conceivable concretisation of the theoretical framework developed earlier. That theoretical framework is intended to be self-standing. It certainly points towards relatively welldefined directions - such is its function, and that is why it can be deemed to already answer the research question of this study in its main traits -, but its concrete application is malleable in several points. It therefore admits different - even if, one does expect, not radically different - specific reform proposals. What follows is therefore more an exemplification of the possibilities opened by the theoretical framework than a crystallisation of this framework into exclusive propositions.

\section{Grounds for refusal related to political concerns of the requesting State}

As noted repeatedly, full judicialisation is extremely unlikely to be implemented in classic extradition. The following paragraphs elaborate further on this fact and attempt to reposition the interchange between law and politics in extradition matters.

\subsection{The inexorability of political interference in extradition}

\subsubsection{General considerations}

Until quite recently extradition was regarded as a purely political prerogative, competence for which was reserved to the executive branch of the State. It was only with the advent of individual rights in international law, after WWII, that it acquired a legal, and hence judicial dimension. ${ }^{5}$ Observed through post-war lenses, extradition was clearly lacking a reform that would pay due attention to the fact that it is an oppressive measure. ${ }^{6}$ The

${ }^{3}$ See supra, Chap. 5, \$1.1.1, and again YORAm DinsteIn, “General Report”, op. cit., p. 32.

${ }^{4}$ See supra, Chap. 6, $\iint 1.5$, and 5.3; but see yet infra, $\ 4$ 4.2.1.e), on absence of a prosecution decision, which has some autonomy and therefore justifies some specific considerations.

${ }_{5}^{5}$ On this evolution, see JacQues Lemontey, Du Rôle de l'Autorité Judiciaire dans la Procédure d'Extradition Passive, Paris: R. Pichon et R. Durant-Auzias, 1966, p. 5 f.

${ }^{6}$ On the subject of extradition's harshness it is worth recalling that deportation, its 'non-identical twin', was listed as a crime against humanity, under certain conditions, in the Charter of the Nuremberg Tribunal: see supra, Chap. 3, \$ 1.2. 
judicialisation of extradition constitutes one example of the erosion of the "omnipotence of the State" characteristic of the pre-war era. ${ }^{7}$ In Portugal, which was under an authoritarian rule until 1974, it was only more recently that such a shift took place. ${ }^{8}$ That bringing extradition under the umbrella of the judiciary was a priority is visible in the fact that such a modification was effected immediately in $1975,{ }^{9}$ even before the adoption of the 1976 Constitution (which would then require extraditions to be approved by a court). ${ }^{10}$

It is ironic that the full judicialisation of extradition, effected in subsequent projects aimed at modernising this mechanism (notably the EAW), was basically intended to narrow the room for refusal of extradition, carrying a disadvantage to individuals. This is not to imply that full judicialisation of extradition is problematic in any sense similar to what its full politicisation used to be: judicial decisions on matters involving individual rights offer a specific type of protection that no political entity is supposed to, or could ever offer. The observation was simply that, from an objective angle, full judicialisation did carry disadvantages for individuals.

In any case, with rare exceptions, the organic shift that took place following WWII did not fully eradicate politics from extradition. Most States maintained in the hands of their governments wide prerogatives to intervene in these matters, and presently most extradition systems are mixed or hybrid: approval by a court is indispensable for extradition to be granted, but the political branch has a power of veto. That is the case of both extradition systems assessed earlier in this study - Portugal and the UK -, and it is also the solution envisioned in the UN Model Law. ${ }^{11}$

As mentioned above, the nature of the entities which decide on the extradition request affects the scope of the grounds for refusal provided for in the applicable statute or treaty. The judiciary ascertains their legal substance, through interpretation of their wording, history and telos. In contrast, the executive evaluates their political significance. For a fictional example involving the nationality exception: two States conclude a treaty that allows them, under certain conditions, to reciprocally extradite own nationals; the treaty confers on their governments the power to block extradition on the basis of 'any reason of political convenience'; a change in government befalls in one of the States; the new administration is a far-right nationalist party whose motto is to 'return the Nation to its nationals'; shortly afterwards, this State receives a request to extradite a national pursuant

7 To use again the expression of HersCH LAUTERPACHT, An International Bill... op. cit., p. $v$.

8 The same applies to other States, and in some States the shift has never even taken place yet.

${ }_{9}$ See the Preamble, and Art. 24 (3) Decree-Law no. 437/75, equivalent to current Art. 46 (3) PT-L. In legal literature it had been advocated for long that extradition proceedings lacked individual guarantees: see José Caeiro da MatTa, Direito Criminal Português - vol. II, Coimbra: F. França Amado Ed., 1911, p. 97 f.; José Magalhães Godinho, "O asilo político e o direito de extradição", ROA 33 (1973), p. 427 f.

${ }^{10}$ See Art. 23 (4) of the original version, and current Art. 33 (2).

11 See supra, Chap. $5, \sqrt{ } 2$. The range of competences allocated to each branch varies, as does the order in which they intervene. This is also illustrated by the extradition systems of Portugal and the UK. Different approaches have advantages and disadvantages. For instance, if the judiciary intervenes first this may release the executive to a more purely political analysis of the case, unconstrained by the parameters set by legal norms on extradition; but it might also be more compromising for international relations, because if the executive branch intends to refuse extradition, it will have to do so after the judiciary has declared that, from a legal perspective, extraditing would pose no problem. 
to that treaty; its courts may rule that the request is admissible under that treaty, but the new administration will probably hold it to be politically inadmissible.

That was only regarding circumstances covered by legal norms establishing grounds for refusal. Even more important, though, is that evaluating an extradition request from a political angle increases massively the array of circumstances that can lead to refusal. As was acknowledged at the very beginning of this study, where the political branch has (as it usually does) the power to veto extradition, it will be able to raise virtually any argument to deny a request, even if this argument has no tangible expression in any legal norm establishing a ground for refusal. ${ }^{12}$ As Bassiouni appraises, in essence "[p]olitical considerations have no direct relationship with the practice of extradition or its rationale, but derive from purely political factors and national political determinations"; they rely on "a value-oriented judgement frequently grounded in subjective and self-serving political interests". ${ }^{13}$ Examples include the fact that the requested person is a spy who had been operating in its territory and is thought to be in possession of sensitive information; ${ }^{14}$ the fact that the requesting State is taking part in a war which is illegitimate under international law, or which is being waged against, or is somehow affecting the requested State or an ally of its; even sheer economic considerations.

The variety of circumstances that may come into play in an extradition case in such a way as to render it politically sensitive is so vast that it would be naïve to imagine that States will light-heartedly waive a power that enables them to manage this type of contingency. However predisposed States might in the abstract be to cooperate, that is a scene that can only be pictured in a very specific political and cultural landscape in which States have firm guarantees that their counterparts are reliable with regard to this type of issues. This is what happens in the EU, with its common political institutions and foreign and security policy, and in the Nordic States, where mutual trust is so deep that formal guarantees are not even necessary. It is not, however, what happens in most interstate relations. Even the MAW, which to some extent qualifies as an expression of the concept of 'mutual recognition in criminal matters', admits political refusals. ${ }^{15}$

\subsubsection{A closer look at the EU: Protocol no. 24}

In fact, one may question whether, within the EU, political interference has been eradicated so categorically as is usually vented. The 1997 Protocol no. 24 to the TFEU / TEU $^{16}$ allows Member States to grant asylum to citizens of other Member States. ${ }^{17}$ The

12 See supra, Chap. 1, \5.4.8., and ulterior references.

13 M. Cherif Bassiouni, International Extradition... op. cit., p. 56, further emphasising the difference between "law and policy concerns considered valid on the basis of objective value-oriented goals", on the one hand, and "purely national political considerations", on the other hand.

14 This circumstance is sometimes encompassed by an explicit ground for refusal, as is the case in the UK: see supra, Chap. 6, $\left.\int 7.1 . c\right)$. That is not the case in Portugal, but the law does state that national security is one of the general interests to be taken into consideration in the regulation of extradition: see supra, Chap. 5, \ 4.2, and Chap. 6, \ 7.1.c).

${ }^{15}$ See supra, Chap. 2, $\int 3.1 .2$., and again Art. 4 (2) MAW.

${ }^{16}$ Initially attached by the Amsterdam Treaty as Protocol no. 29 to the TEC; later by the Lisbon Treaty as Protocol no. 24 to both the TFEU and the TEU: see STEVE PEERS, EU Justice... op. cit. (2016), p. 255. 
Protocol begins by proclaiming that, in view of the solid human rights standards verified throughout the EU, its "Member States shall be regarded as constituting safe countries of origin in respect of each other for all legal and practical purposes in relation to asylum matters". However, it eventually concedes that applications for asylum made by a national of a Member State can be considered by another Member State in certain cases, namely: a) if the Member State of which the applicant is a national proceeds to take measures derogating in its territory from its obligations under the ECHR, due to war or other public emergency threatening the life of the nation; ${ }^{18}$ b) if Art. 7 (1) TEU (which enables the Council, ruling by a majority of four fifths and pursuant to a certain procedure, to establish that there is a clear risk of a serious breach by a Member State of the fundamental values of the $\mathrm{EU})^{19}$ has been triggered with regard to the Member State of which the applicant is a national, and a final decision has not been reached; c) if the Council has adopted a final decision based on Art. 7 (1) TEU in respect of the Member State of which the applicant is a national, or if the European Council has adopted a decision in accordance with Art. 7 (2) TEU ${ }^{20}$ in respect of that Member State; and, finally, d) if a Member State should so decide unilaterally in respect of the application of a national of another Member State. In the last case, however, the Council must be immediately informed, and the application presumed to be manifestly unfounded.

Protocol no. 24 is widely reported to have been adopted with the goal of reducing the room for political interference by Member States in the criminal justice affairs of other Member States, and in particular to prevent Belgium from granting asylum to persons charged in Spain with terrorist acts - a goal which had already been central for the conclusion of the 1996 EU Extradition Convention. ${ }^{21}$ Considering its background - Peers submits -, the Protocol can be qualified as "an extradition measure in disguise". ${ }^{22}$

${ }^{17}$ As for asylum granted in the EU to citizens of third States, it has already been mentioned in passing in Chap. 4. This type of asylum is widely admissible, and the decision of a Member State to grant asylum to one such person extends to other Member States, preventing them from extraditing as well. A case involving the two States covered in this study illustrates this quite well: in 2000 the UK granted asylum to Sikh activist Paramjeet Singh, and issued a travel document enabling him to move within EU space; Singh was arrested in Portugal in December 2015, on the basis of an international arrest warrant issued by India on charges of financing a terrorist organisation; in February 2016 Portugal refused his extradition to India; the request did not even reach the judicial phase, but was rejected outright by the Minister of Justice; in her decision she reportedly invoked the 1951 Refugee Convention, and the common asylum policy enshrined in the TFEU: see www.expresso.sapo.pt/sociedade/2016-02-12-Portugal-nao-vai-extraditar-nacionalista-sikh.

18 See Art. 15 ECHR.

19 These are listed in Art. 2 TEU: "The Union is founded on the values of respect for human dignity, freedom, democracy, equality, the rule of law and respect for human rights, including the rights of persons belonging to minorities. These values are common to the Member States in a society in which pluralism, non-discrimination, tolerance, justice, solidarity and equality between women and men prevail."

20 According to which: "The European Council, acting by unanimity on a proposal by one third of the Member States or by the Commission and after obtaining the consent of the European Parliament, may determine the existence of a serious and persistent breach by a Member State of the values referred to in Article 2, after inviting the Member State in question to submit its observations."

21 See Emmanuelle Bribosia / Anne Weyembergh, "Extradition et Asile: Vers un Espace Judiciaire Européen?”, RBDI 30 (1997), p. 71 f., scrutinising the Garcia-Moreno case. SiBEL ToP, “The European Arrest Warrant against Puigdemont: A feeling of déjà vu?”, EJIL: Talk!, 3 November 2017, refers to the Protocol as the 'Aznar Protocol', in reference to then Prime Minister of Spain. See yet STEVE PEERS, EU Jus- 
In the light of the 1951 Refugee Convention - particularly of its Art. 3, which establishes that the Convention must be applied without discrimination as to (inter alia) the country of origin of the refugee -, the Protocol arguably restrains to an illegitimate extent Member States' prerogatives (and responsibilities) to grant asylum. ${ }^{23}$ Indeed, the Protocol practically neutralises the right of EU citizens to seek asylum within the EU: situations where asylum is admissible are absolutely exceptional, save for the 'unilateral' hypothesis, which however is subordinated to such demanding conditions that it can hardly ever be applied. ${ }^{24}$ Still - and this is the point of relevance for this study -, the Protocol does admit asylum, and asylum has effectively been granted by Member States to citizens of other Member States after adoption of the Protocol. ${ }^{25}$

That political asylum within the EU is not deceased was emphatically confirmed by the statements of Belgian State Secretary for Asylum and Migration on 28 October 2017 with reference to Carles Puigdemont: ${ }^{26}$ "Catalan people who feel politically threatened can ask for asylum in Belgium". ${ }^{27}$ Charged in Spain for sedition, rebellion and misuse of public funds, Puigdemont and four other Catalan politicians moved to Belgium shortly after those statements, and Spain issued a EAW on 3 November 2017. The case could be approached from the angle of fair trial and other fundamental procedural rights, and in fact the lawyer of Puigdemont in Belgium reportedly stated that he would "fight extradition without seeking political asylum". ${ }^{28}$ However, the political dimension of the case was not only evident, but also profound and potentially far-reaching. ${ }^{29}$

tice... op. cit. (2016), p. 256, further informing that Belgium submitted a declaration to the Amsterdam Treaty stating that it would make use of the final option of the Protocol and "carry out an individual examination of any asylum request made by a national of another Member State". On the other hand, the author notes, despite its very specific background, the Protocol is attached to the Treaties generally, and not specifically to Title $\mathrm{V}$ of the TFEU, and therefore applies to all Member States.

22 Steve Peers, EU Justice... op. cit. (2016), p. 256, adding that, in any case, "the Protocol is couched in more general terms and it might have broader effect, particularly for a period after enlargement of the EU, when citizens of the newer Member States might still wish to make asylum claims in the old Member States because they will not have the right of free movement of workers for a transition period of up to seven years."

${ }^{23}$ See ibid.

${ }^{24}$ See SiBEL TOP, op. cit., stating that asylum for EU citizens has become "almost impossible", and CECilia RizCallah, "The EU and the Spanish Constitutional Crisis”, EU Law Analysis, 6 November 2017, stating it has been "practically remove[d]".

${ }^{25}$ See Immigration and Refugee Board of Canada, "EU: Application of the Protocol on Asylum for Nationals of Member States of the European Union (2013 - June 2015)", 9 July 2015, ZZZ105193.E, in www.refworld.org/docid/55bf55094.html, last accessed 13 May 2017, cited in CECILIA RizCALLAH, op. cit.

${ }^{26}$ It should be borne in mind that the concept of refugee of the 1951 Geneva Convention encompasses individuals persecuted on account of their political opinions: see Art. 1 (A) (2).

27 See www.politico.eu/article/belgian-minister-puigdemont-can-apply-for-asylum-here/, last accessed 13 May 2018.

28 See www.theguardian.com/world/2017/nov/03/european-arrest-warrant-issued-for-ex-catalanleader-carles-puigdemont, last accessed 13 May 2018.

29 Allowing for the claim that a Belgian decision to refuse the Spanish EAW could have caused a "political tsunami”: SIBEL TOP, op. cit. On the underlying issue (vi\%. Catalan secession efforts), see JURE VIDMAR, "Catalonia: The Way Forward is Comparative Constitutional Rather than International Legal Argument", EJIL: Talk!! 24 October 2017, with further references. 
In $I . B .{ }^{30}$ the ECJ noted that the grounds for non-execution of the EAW listed in Arts. 3 and 4 of the respective FD do not include an application for asylum or for the grant of refugee status or subsidiary protection, and that Protocol no. 24 is very restrictive, suggesting that EAW's cannot be refused on such a basis. These remarks were mere obiter dicta, but were quite revelatory of the principles that the Court would later uphold in Radu and Melloni, that EAW's can only be refused on grounds explicitly provided for in the FD, and that a EAW may have to be granted even if that conflicts with the constitutional law of the executing Member State. As discussed earlier, Aranyosi \& Căldăraru later brought a momentous exception to those principles, but one that is conditioned to stern requirements, and that in any case concerns absolute human rights only. It is therefore implausible that the same principle could have been used in a case such as that of the Catalan politicians. ${ }^{31}$ More importantly, there is a key difference between this case and Melloni. In Melloni the issue was a conflict between rules of EU law and rules of national law construed in a narrow sense ( $s c$. as rules that neither implement nor are explicitly allowed for by EU law). In contrast, in the Catalan case it was EU law itself that admitted asylum. In very strict conditions, certainly, but it admitted it. Therefore, the conflict here was a conflict between certain rules of EU law (Protocol no. 24) and other rules of EU law (FDEAW). With the detail that Protocol no. 24, as an integral part of the Treaties, is parametrically stronger than the FD-EAW, which constitutes mere secondary EU law. If the Protocol admits asylum, and extradition is one of the archetypical forms of persecution justifying the very existence of the institution of asylum, ${ }^{32}$ it appears inevitable that one of them would have to yield in favour of the other. Most likely, such a conflict would never have materialised, because asylum is admitted in very strict conditions; but if asylum were admitted a conflict of EU rules would have taken place.

In conclusion: Considering that Protocol no. 24 is very restrictive on the granting of asylum and that the FD-EAW does not provide for any correlative ground for refusal, a Belgian decision not to execute a EAW from Spain would have been twice unlikely. But the simple fact that it was possible was already momentous, having cast upon the EU a cloud of political polarisation and cooperative rupture which was not fully dispersed by the decision of the Spanish Supreme Court of 5 December 2017 withdrawing the EAW's for Puigdemont and the other Catalan politicians on grounds of procedural inopportunity. ${ }^{33}$ In fact, his "unhindered" passage through Finland, Sweden and Denmark, taken place

${ }^{30}$ ECJ (C-306/09), 21 October 2010, DS 43 f.

31 As reported in Cecilia RizcallaH, op. cit., "the lawyer of the other Catalan ministers who are already in jail has lodged a complaint for mistreatment of them, but more elements will be required to refuse the execution on the EAW on this basis."

32 On the interactions between extradition and asylum, see EMmanuELLE BRIBOSIA / ANNE WEYEMBERGH, op. cit., p. 69 f.; STEVE PEERS, EU Justice... op. cit. (2016), esp. p. 288 f.

${ }_{33}$ Namely on the consideration that the possible refusal of Belgium to execute the warrant in respect of at least some of the offences, due to lack of dual criminality, could hinder severely (due to the specialty rule, one may infer) the court's capacity to give the "homogeneous response" required by offences, such as those at stake, which form an "inseparable legal unity": see Spanish Supreme Court, ruling of 5 December 2017, appeal no. 20907/2017, in www.poderjudicial.es/, last accessed 2 February 2018, SS 3-4, paying also some consideration to the fact that the persons concerned "seem to have shown the intention of returning to Spain". 
subsequently, only dimmed that cloud, ${ }^{34}$ even though Puigdemont was shortly afterwards arrested in Germany, where at the time of writing a second Spanish EAW is pending. ${ }^{35}$ In the abstract, EU Member States constitute safe countries of origin and predisposed cooperation partners, which is more than can be said of most interstate relations. Still, as any other States, Member States are at different moments represented by specific governments with specific political agendas, and these may diverge from the goals of EU integration. Politics will only be truly absent from interstate cooperation where no politically sensitive issues exist among the States involved, which in itself is a political condition. It is in this sense that political interference is an inexorable attribute of extradition.

\subsubsection{A glass half full}

The inexorability of political interference in extradition is a fact which can be quite exasperating when studying this subject matter from a fundamentally legal angle. However, at a second glance it reveals a valuable upside: it may release the legal dimension of extradition from minding the 'abnormal' cases, allowing it to focus on, and develop balanced solutions for the 'normal' ones. ${ }^{36}$ In one word: it may unfetter extradition law.

Like all legal norms, extradition norms are general and abstract, applying to all individuals and situations falling within their scope. If extradition law is relied upon to look after the abnormal cases, then their scope is fated to be very wide. In the preoccupation to tend all situations where extraditing could be problematic from the perspective of the requested State - a goal which could hardly ever be attained anyway -, it ends up encompassing situations where in normal conditions extraditing would carry marginal or indeed no undesirable consequences whatsoever. Let us again consider an example involving nationality. As established earlier, the rationale of the nationality exception is, to a large extent, the desire of States to protect their citizens from criminal justice systems which are unfamiliar to them, language issues included. ${ }^{37}$ What if - to introduce just one variation the person concerned is also a national or a long-time resident of the requesting State and is perfectly familiar with its criminal law and its language ${ }^{38}$ In the name of which values should, then, the nationality exception still apply in such a situation? ${ }^{39}$

\footnotetext{
${ }^{34}$ See http://www.spiegel.de/international/europe/puigdemont-arrest-puts-germany-in-a-predicamenta-1201096.html, last accessed 14 May 2018.

${ }^{35}$ Germany has given no sign of predisposition to grant political asylum to Puigdemont based on Protocol no. 24. It did already rule that it could not surrender him for what in Spain constitutes the offence of 'rebellion', but this decision was based on an evaluation by the German court that the acts at issue were not criminalised in Germany and, hence, that the dual criminality rule was not met in the case. But even so the decision has been received by many as having political bearing: see (focusing on the legal aspects of the ruling) Daniel Sarmiento, "The Strange (German) Case of Mr. Puigdemont's European Arrest Warrant", in Verfassungsblog, 11 April 2018. On the other hand, it must be noticed that, although at the legal level the situation is identical to what it might have been in Belgium - in that in both cases the Spanish EAW could not be granted in respect of all offences -, Spain has not withdrawn its second EAW, issued to Germany.

${ }^{36}$ See supra, Chap. 7, $\$ 3.3 .6$.

${ }^{37}$ See supra, Chap. 4, $\$ 2.2 .2$., and Chap. 6, $\$ 4.1$.

38 A hypothesis which is explicitly contemplated in Romanian law: see supra, Chap. 4, $\$ 2.4 .3 . a)$.

${ }^{39}$ One might question whether there would have been an Aranyosi \& Căldăraru ruling if the political branch of Member States had an active role in the EAW system. Perhaps those requests would have been
} 
Why not, then, openly disentangle the political dimension of extradition from its legal regulation, reducing the latter to the situations which are typically problematic and entrusting the atypical ones to the former? Why not release the law, which is general and abstract, from its fixation with the exceptional cases, if these can always be looked after by politics, whose very function is to cope with specific and concrete problems? ?0-41 $^{40}$

It is undeniable that this approach carries two consequences which may be imputed faults, namely: enhancing the discretionary power of the executive branch, and increasing the uncertainty as to the outcome of extradition proceedings. However, as argued in the theoretical framework, uncertainty (up to a certain extent) is not only legitimate, but also, from a preventative perspective, desirable. ${ }^{42}$ As for enhanced discretion, it should be noted that discretionary power does not equate to arbitrariness. ${ }^{43}$ The actions and omissions of the executive limb of a State are liable to scrutiny by other branches of that State, notably its administrative courts, ${ }^{44}$ as well as by its constituency, at the polls; and yet by other States, at the diplomatic stage. It is also worth recalling, however obvious this might be, that it is always a political entity, even if of a fully legislative character, that enacts extradition statutes and ratifies extradition treaties, and, thus, that is ultimately responsible for the extradition norms that the judiciary is charged with applying. Whichever angle is taken, it is clear that developing a criminal justice civitas maxima requires political will. Like politics in general, the political dimension of extradition must therefore be embraced for what it is: an inexorable constituent of all Law, which can only, but can, be influenced by an increased scrutiny of the performance of political entities in these matters.

That government behaviour in the field of extradition is capable of sparking public reaction is visible for instance in some of the cases mentioned earlier in respect of inter-

politically blocked all along. This is admittedly an improper example, as it concerns human rights: the judiciary is the appropriate branch of the State to assess issues of this character, and therefore it would always, one way or the other, have to be recognised competence to refuse such requests - which, then again, only confirms that, before that ruling, the EAW system was somewhat out of touch with reality as far as human rights are concerned: see supra, Chap. 2, \$ 3.2.1. Still, the example might help to illustrate how political involvement in extradition can have positive effects. Noting that on occasion political considerations also reflect concern for individuals, see M. CHERIF BASSIOUNI, International Extradition... op. cit., p. 56.

40 This is structurally similar to what OTTO LAGODNY, "Human Rights...", op. cit., p. 50 f., proposed in relation to human rights, namely that "positive" consequences could be drawn from their hindering effects: see supra, Chap. 1, \5.4.3.

${ }_{41}$ This guideline will be put into practice during this chapter, e.g. in $\iint$ 2.1.4., 3.2.1.d), 3.5.1.e), 4.1.2.g)(i), 4.2.1.d), and 4.2.2.c).

42 See supra, Chap. 8, \3.3.6.

43 See Rogério Ehrhardt Soares, “Administração Pública e Controlo Judicial”, RLJ 127 (1994-5), p. $226 \mathrm{f}$.

44 Whether the executive's decision is considered an administrative act (and as such is liable to challenge before administrative courts), or rather a political act (and as such cannot be judicially challenged) may vary from State to State, as the borders between those two types of acts can be quite blurry: see AFONSO QUEIRÓ, "A função administrativa”, RDES 24 (1977), p. $1 \mathrm{f}$. Should the intervention of administrative courts be admissible, it will in principle be limited to cases where extradition is granted, since as a rule only these are detrimental to individuals, and also as a rule only individuals can appeal before the courts of the requested State: see, in the Portuguese experience, the Ruling of the Constitutional Court no. 360/12, of 5 May 2012, on the high-profile case of $\mathrm{Abu}$ Salem. Recognising a similar prerogative to the requesting State would render the extradition proceedings running in the requested State an arena for international disputes. 
national crimes. ${ }^{45} \mathrm{It}$ is also visible in recent developments that occurred in the UK, where the public clamour sparked by some cases - notably, 'NatWest Three', Symeou, and Mckinnon - led to the enactment of several unconventional grounds for refusal. ${ }^{46}$ Illustrative of the political branch's awareness of the impact that its performance in extradition cases can have on public opinion is precisely the speech of then Home Secretary Theresa May before Parliament announcing her decision to block the extradition of Gary Mckinnon, and, at the same time, plans to enact a range of new bars and modifications to the extradition system of the UK. In this speech the Home Secretary stated: "I believe extradition decisions must not only be fair; they must be seen to be fair". ${ }^{47}$ To be accurate, the statement was made in support of the argument that some aspects of extradition (in the case, forum issues) should be decided in an open court; not in support of more involvement of the executive branch in extradition matters. However, this is only a different manner of denoting awareness of the political impact of certain extradition decisions. In fact, the changes to the EA 2003 enacted shortly later, in 2013, curtailed the Home Secretary's intervention in human rights issues, which would probably ${ }^{48}$ have prevented her from barring extradition in a case such as Mckinnon. ${ }^{49}$ This leads Efrat to construe that "it is likely that the Home Secretary decided to reduce her involvement" precisely due to "the intense pressure that she faced to block Gary McKinnon's extradition". ${ }^{50}$

In a survey on UK's domestic politics in extradition matters - including the interactions between law enforcement entities, politicians and the public - Efrat concludes that there are "contrasts" between "the law-enforcement view" and the "popular view", with the latter being generally "sceptical and apprehensive" about the "removal of protections and safeguards", a perception which is echoed by "politicians (especially from the right), the media, members of the public, as well as NGO's concerned with human rights". ${ }^{1}$ To the author, it is "precisely this emphasis that leads members of the law-enforcement community to support swift, efficient extradition, even in the face of varying standards of justice across countries": "After all, the mission of judges, prosecutors, and the police is to enforce the law and to secure compliance with legal rules and decisions. These actors naturally see much value in extradition, which aims to improve the enforcement of laws across borders and strengthen the rule of law." 52 Turning again to the 'popular view', the author posits: "A large body of literature suggests that trade and immigration - two key expressions of globalization - could meet resistance inspired by xenophobic or ethnocentric sentiments (...). Extradition is a manifestation of global integration that might elicit similar objections. Members of the public holding ethnocentric attitudes might view foreign legal systems as inferior and, therefore, as inappropriate partners (...). The public's attitude may also reflect nationalist tendencies, which would lead to the rejection of extradition as

\footnotetext{
45 See supra, Chap. 7, \ 1.1.2.

46 See supra, Chap. 6, e.g. $\iint$ 4.2.3. and 6.1.3.b).

${ }^{47}$ In www.youtube.com/watch?v=5MEQVo8ENC8, last accessed 11 February 2018, starting at 04:23.

${ }^{48}$ Not 'certainly', because this intervention was not completely removed: see s. 87 (3) EA 2003.

49 As is in fact acknowledged in the speech, cit., starting at 06:33.

50 AsIF EFRAT, op. cit., p. 124.

51 Ibid., p. 121.

52 Ibid.
} 
undermining national legal sovereignty. Ethnocentric and nationalist sentiments might therefore drive public resistance to extradition as unfair and unjust - a threatening encroachment by foreign judicial systems. The implication of such view is that the state's nationals should not come under the authority of foreign judicial systems, which have lower standards of justice. (...) Politicians who seek public support might follow the public sentiment by arguing against easy extradition and by demanding protections for citizens. NGO's are also likely to subscribe to the popular view. Such a view emphasizes fairness, justice, and the protection of individual rights, and it is closer to the values typically promoted by NGO's than the law-enforcement view's emphasis on apprehending and prosecuting offenders". 53

Populism and rising nationalism call for legislative rationality. Their influence upon the executive power may undermine this rationality to an extent, but, as the UK case indicates, it can backfire: as was just mentioned, Mckinnon and the other high-profile cases where extradition would have met with opposition from the majority of the public - and this is not to say that in those specific cases the prevailing public opinion was xenophobic or ethnocentric, for it does appear that there were solid reasons to disapprove of extradition in those cases - ultimately only led to less political intervention in extradition matters, namely to the curtailing of the Home Secretary's prerogatives in human rights issues, which in turn caused that possible xenophobic and ethnocentric opinions would thereafter have lesser sway upon the outcome of extradition requests.

In any case, in legal systems where extradition must be approved by a judicial entity, one certainty remains: political intervention, as a prerogative of veto, can only operate to the benefit of the person concerned; it cannot impose extradition if a court decides that it has to be refused pursuant to legal norms establishing grounds for refusal, notably to those which protect human rights. Thus, while it may be frustrating to see the author of a serious crime be spared from extradition owing to sheer political convenience, the assurance remains that the contrary cannot befall, i.e. the author of whichever crime be extradited in breach of fundamental values. Here, Blackstone's formula applies rather square$l y:^{54}$ it is preferable to save from extradition ten people who should be extradited, than to extradite one single person who should be spared to extradition. As does apply apply the principle that States should uphold fundamental values even where that is to the benefit of individuals who have affronted those very values. ${ }^{55}$ In sum, insofar as political discretion remains limited to vetoing extradition, increasing such discretion as a means for narrowing down the scope of more rationally designed legal grounds for refusal allows cooperation to be fostered without compromising either the safeguard of individuals against the potential abusiveness of States, or the relative capacity of governments to resist the punitive thirst often exhibited by some segments of their constituencies.

Of course, having wide-ranging legally prescribed grounds for refusal affords great political malleability in the handling of concrete cases, such that even the judiciary is enabled to perform what might be qualified as a 'politically informed' or 'selective' applica-

53 Ibid.

${ }^{54}$ See supra, Chap. 7, \3.1.3.

55 See supra, Chap. $7, \mathbb{\Omega} 1.3$. 
tion of the law. This is most noticeable in the political offence exception. As Gilbert noted: "whilst hiding behind the court's decision that the offence was of a political character, the requested state in fact has always passed judgement on the requesting state, cast aspersions on the impartiality of its judiciary and effectively sided with the fugitive. (...) Indeed, the judges' decisions often seem to owe more to foreign policy than to legal reasoning. In the past, political offence decisions have been based upon whether the fugitive was from the former Soviet bloc, whether the requesting state was an ally, support for the fugitive or his group in the requested state, encouraging a peace process, the usefulness of the transnational fugitive offenders to the intelligence services, even economic interests. ${ }^{, 56}$ Such a malleability is very handy also in respect of human rights issues: it is understandably much less damaging to a State's international relations to refuse extradition for instance on the ground that the offence at issue has a political character (in the name of a supposedly general and abstract principle according to which extradition should never be granted for offences of that character), or that the individual sought is a national of that State (in the name of a purportedly sacrosanct bond between States and their nationals), than to cause the requesting State to lose face by being flagged to disrespect human rights. Some grounds for refusal do constitute excellent excuses. ${ }^{57}$

They also constitute missed opportunities for encouraging States to improve their criminal justice standards, and for addressing the true problems that prevent international cooperation from developing further. Indeed, if a State with a problematic human rights record is denied extradition on such grounds as the fact that the individual in question is a national of the requested State (a factor which is completely external to the requesting State and regarding which it can therefore do nothing), rather than because its human rights standards raise legitimate doubts, this surely does not stimulate this State into improving these standards. Thus, the predicament that States are faced with is whether they are willing to toughen up their diplomatic relations in order to progress as a global community which is a less unrealistic prospect than it may seem at first sight, and certainly less unrealistic than it was until a not too distant past, if we consider that the gradual internationalisation of certain aspects of extradition law (notably of those that concern human rights) has to a large extent relieved the diplomatic implications of refusals of extradition based on such grounds, in what may be interpreted as an additional 'permissive' effect of human rights in the field of extradition. ${ }^{58}$ Currently, a requested State, even where it is applying what is formally its own law, is in fact also giving practical expression to values that have garnered broader international consensus. Sometimes, its decisions will even be based on information and assessments supplied by international (judicial and non-judicial) entities whose function is to oversee and uphold respect for such values. ${ }^{59}$ This makes the re-

\footnotetext{
${ }^{56}$ Geoff Gilbert, Responding to International Crime, Leiden: Martinus Nijhoff Publishers, 2006, p. 194 f., with supporting references; see especially the thorough analysis of this phenomenon by CHRISTINE VAN DEN Wyngaert, The Political Offence Exception... op. cit.., p. 95 f., et passim.

57 Or "avoidance techniques", in the expression of HARMEN VAN DER WILT, op. cit., p. 150 f., already quoted supra, Chap. 3, $\mathbb{\Omega}$ 3.6.

58 See supra, Chap. 1, $\int 5.2 .4$.

${ }^{59}$ As was presciently proposed by CHRISTINE VAN DEN WYNGAERT, The Political Offence Exception... op. cit.., p. $215 \mathrm{f}$.
} 
quested State less a judge of the law and practice of the requesting State, than a messenger of a higher command. In a sense, the requested State becomes reduced, like a judge in an $18^{\text {th }}$ century positivistic construction, to a "mouth that pronounces the words of the law"; 60 in this instance, the words of international law.

\subsubsection{National security}

We saw earlier that the legal system of the UK contains an explicit ground for refusal concerned with national security. ${ }^{61}$ According to s. 208 EA 2003, the Home Secretary shall bar the extradition of agents of the State (notably, members of the intelligence services) for certain acts committed in the exercise of their functions, if extraditing them would put national security at risk. As was noted in that moment, this bar displays characteristics that are typical of international immunities ratione materiae, in that it constitutes an indirect protection of specific functions of the State. This protection is projected upon the individuals who exercise such functions. However, the fact that the person was acting on behalf of the State is insufficient to trigger this protection, as this ground for refusal is subordinated to the further condition that extradition would jeopardise national security.

It is understandable that the fact alone of an individual acting on behalf of a State be deemed insufficient to trigger an actual international immunity. Otherwise, the principle of non-interference would be overly exposed: States whose affairs had been meddled in through acts which they see as criminal would be fully prevented from reacting against such acts through their criminal justice systems. That is why international immunities are limited to certain classes of agents. However, it also appears rather unfair to State agents that the line between extradition and refusal be drawn based on whether or not extraditing would entail a risk for national security: in both cases the agent was acting on behalf of his/her State, frequently in implementation of specified orders.

Thus, it would seem more sensible to extend this protection to any agent who exerts specific functions on behalf of the State. This is different from an actual international immunity, as the latter would entail that the person could not be extradited by any State (rather than only by the State he/she was representing). Alternatively, such a protection could be removed altogether, which would be all the more plausible the closer the political ties are between the States at issue. In such an event, States would still be able to rely on the general prerogative of their political branch to veto extradition, in the exceptional cases where national security would be jeopardised by a decision to extradite.

That is, the fact that the person was acting on behalf of the requested State, and the fact that extraditing the person might entail risks for national security, both constitute sufficiently strong reasons to refuse extradition. Considering the exceptional and political nature of these cases, they would probably be better handled by the executive branch of the State, which is already equipped to do so pursuant to the discretion it enjoys in most extradition systems.

\footnotetext{
${ }^{60}$ Montesquieu, op. cit.., p. 180.

${ }^{61}$ See supra, Chap. 6, \ 7.1.3.
} 


\subsection{Reciprocity}

As a 'guarantor of compliance with commitments ${ }^{62}$ between States whose relations rely heavily on a principle of non-intervention which is 'the mirror image of their sovereignty, ${ }^{63}$ reciprocity should be expected to conserve an undisputed place among the requirements for extraditing. This does not exclude that some concessions be made in favour of broader possibilities of cooperation.

\subsubsection{The demise of the treaty requirement}

Once a dominant principle of extradition law, the treaty requirement is in decay. At least, but certainly, if the term 'treaty' is understood in its most formal, traditional significance. Some States do retain this requirement, but this frequently gives rise to criticism, with arguments revolving mainly around the 'cumbersome' character of the treaty-making process - which normally depends on 'advice and approval' by a paramount legislative body of the State (Parliament, Senate) -, and the 'problem of treaty obsolescence'. ${ }^{64}$

These 'weaknesses' are also the main strengths of the treaty requirement. It is the fact that concluding a treaty is lengthy, cumbersome, bureaucratic, that bestows the treaty requirement its matchless aura of a guarantee against extraditions to States with doubtful (not necessarily bad, just not aprioristically assessed) criminal justice standards. It is therefore understandable that, in many States, the abolition of this requirement be difficult to consider and unpopular to defend.

However, the treaty requirement was conceived in view of a very different state of affairs, in a historical period where individual rights had virtually no relevance in extradition matters and in international law more generally. Accordingly, that was also a period where the rule of non-inquiry was widely observed. ${ }^{65}$ With the advent of individual and human rights, this function of individual guarantee ceased to be a nearly exclusive attribute of the treaty requirement. It was absorbed by supervening grounds for refusal specifically designed to perform that function, and more apt to perform it - in that they no longer consider the issue in the abstract, but on a case-by-case basis -, making this a paradigmatic example of how the obstructive effects brought by human rights into the realm of extradition led to the decline of traditional requirements. ${ }^{66}$ The treaty requirement thus seems to have preserved two main functions only: to establish an obligation to extradite (as opposed to leaving States dependent on each other's comity), and to secure reciprocity among States in comparable circumstances.

${ }^{62}$ See supra, Chap. $1, \mathbb{1}$ 4.3, and Chap. 7, \$ 3.1.3.

${ }^{63}$ See supra, Chap. 7, \$3.1.2.

${ }^{64}$ See e.g. M. Cherif BAssiounI, "Reforming International Extradition: Lessons of the Past for a Radical New Approach", LLAICLR 25 (2003), p. 403 f., urging for "the cumbersome process of basing extradition on treaties" to be abandoned, and based instead on "national legislation, supplemented by executive agreements establishing reciprocity", and even on simple "comity". Similar, see UNODC, "Manual on Mutual Legal Assistance and Extradition", op. cit., p. 21 f.

${ }^{65} \mathrm{On}$ the (correlative) demise of the rule of non-inquiry, see infra, $\left.\$ 3.1 . \mathrm{b}\right)$.

${ }^{66}$ See supra, Chap. 1, \$ 5.4.3., and Chap. 7, \$ 3.2.4.b). 


\section{a) Creating obligations to extradite}

Regarding the first function, it should be noted that the proliferation of extradition treaties in the late $18^{\text {th }}$ and in the $19^{\text {th }}$ centuries undoubtedly marked an advance towards a more cooperative international community. As we could observe earlier, no duty to extradite has emerged to this date in general international law regarding most crimes, which means that, without treaties generating such a duty, States would have to rely on the good will of other States to obtain extradition. ${ }^{67}$ However, that must also be understood in the light of the conditions of that era, where the legacy of Westphalia was still very vivid and inflexibly construed. In today's world, where criminal justice systems are much more interdependent, the absence of a treaty might still mean the non-existence of a formal duty to extradite, but is counterbalanced by the awareness of such an interdependence, ${ }^{6}{ }^{6}$ which translates into an increased predisposition to cooperate.

On the other hand, the duty to extradite inherent to treaties, and often (redundantly) reiterated in their opening provisions, should not be overestimated. By concluding a treaty, theoretically States become bound to extradite if no grounds for refusal provided for in that treaty are met. However, most extradition treaties contemplate a discretionary intervention of the political branch of the requested State in the decision process, and/or an explicit, generally quite vague ordre public clause, which means that extradition can be lawfully refused on grounds broader than those which at first sight are admitted by the treaty. This is not the same as a complete absence of treaty, but it does render very fragile the duty to extradite supposedly following from treaties. If a State that is bound to an extradition treaty is not predisposed to cooperate in a given case, a treaty alone will not secure its cooperation; if it is predisposed to cooperate, a treaty is not necessary.

This is not to say that States should no longer conclude extradition treaties. Treaties most certainly remain useful, particularly among States which are linked by particular ties and among States between which there are significant fluxes of personal mobility. Treaties enable States to tailor their cooperation arrangements to fit the specificities of their relations. But this is utterly different from making the possibility of extraditing dependent on the existence of a treaty.

\section{b) Securing reciprocity}

As for the second function (securing reciprocity), it also does not require and does not seem to be significantly better served by such a demanding condition as the existence of a treaty. It could be replaced by a simple requirement that the requesting State provide ad hoc guarantees that it will extradite in future cases with similar characteristics. This is the approach that is advised by the UN Model Law, ${ }^{69}$ and provided for in some States. ${ }^{70}$

${ }^{67}$ See supra, Chap. 1, \ 4.2., and Chap. 7, \ 3.1.2.

${ }^{68}$ Stating that over the $20^{\text {th }}$ century "the peoples of the world have become more conscious than ever of the need to ensure their collective security", see M. CHERIF BASSIOUNI, International Extradition... op. cit., p. 49.

${ }^{69}$ See supra, Chap. 6, $\int$ 7.2.a).

${ }^{70}$ E.g. Portugal (see supra, Chap. 6, \$ 7.2.b), and Japan (see Art. 3 (2) of its 1953 Extradition Act, available in www.oecd.org: UNODC, "Manual on Mutual Legal Assistance and Extradition”, op. cit., p. 23). 
Even the special extradition arrangements presently admitted in the $\mathrm{UK},{ }^{71}$ although much more flexible than the treaty requirement that was in force until 1989, appear to be overly laborious compared to that simple alternative. Special arrangements have the merit of balancing the two other approaches, but in so doing they fail to secure the core advantages of them both: they offer neither the readiness of ad hoc reciprocity guarantees (because a 'mini-treaty' must still be drafted), nor the political legitimacy of the treaty requirement (because such a 'mini-treaty' is drafted by a single political representative, who moreover is the very same person who would be competent for appraising the reliability of ad hoc guarantees of reciprocity if this were the chosen approach). And if political legitimacy is not secured, then why not embrace readiness? $?^{72}$

\subsubsection{The rise of (reconfigured) comity}

In one sense, 'comity' (from the Latin 'comitas') signifies "courtesy and considerate behaviour towards others". ${ }^{73}$ Taken in this sense, it seems to be somewhat incompatible with such notions as 'reciprocity', 'duty to cooperate', or any other upon which a reliable cooperation model could be based. But 'comity' can also mean "an association of nations for their mutual benefit", "mutual recognition by nations of the laws and customs of others". ${ }^{74}$ And, taken in this sense, it can coexist with those notions. In fact this is what happens in EU cooperation, ${ }^{75}$ and it is most interesting to see the term 'comity' (in the latter sense indicated) defined precisely through the expression 'mutual recognition'.

Whether taken in the former or the latter sense, and whether bestowed a mandatory character or not, cooperation based on comity rests upon premises that are fundamentally different from those underpinning cooperation based on reciprocity. It accepts that cooperating might be justified even if it brings no immediate recompense. This does not necessarily mean that it is altruistic, for it is also in the interest of the requested State to avoid becoming a safe haven for criminals. ${ }^{76}$ The essential difference is the absence of the 'retaliatory' element that characterises reciprocity as traditionally understood. ${ }^{77}$

Of course, the fact that in specific cases this 'retaliatory' element is detrimental to the interests of both States involved (in the sense that extraditing would be in the interest of both, but the requested State refuses to extradite only to uphold its entitlement to reciprocity) does not mean that in the broader context such negative effects are not outdone by its positive ones. We saw earlier that reciprocity did and does play a pivotal role in the development and operation of international law, given its capacity to induce States to comply with their commitments. ${ }^{78}$ It is, as Bassiouni phrases it, 'the underpinning of extradi-

${ }^{71}$ See supra, Chap. 6, \$ 7.2.c).

${ }^{72}$ Particularly considering that during the process the person concerned is either deprived of liberty or, at least, subject to constraints in his/her freedom of movement.

${ }^{73}$ See Oxford Dictionary online, in https://en.oxforddictionaries.com, last accessed 23 November 2017.

${ }^{74} \mathrm{Id}$.

75 See supra, Chap. 2, $₫ 3$.

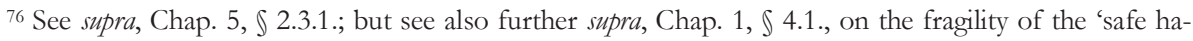
ven' line of reasoning.

${ }_{77}^{7}$ See supra, Chap. 1, \4.3., and Chap. 3, \3.6.

${ }^{78}$ See supra, Chap. 1, \4.3., and Chap. 7, \3.1.3. 
tion's substantive requirements'. ${ }^{79}$ Thus, some 'retaliation' is desirable, and, as noted, this can be achieved through the requirement of ad hoc guarantees of reciprocity, if a treaty is not in force between the States at issue. Nevertheless, there most certainly remains some room for comity, as defended subsequently.

First of all, it must be noted that reciprocity need not necessarily entail that a State seeking extradition from another State guarantees that in the future it will cooperate with that State in perfectly symmetrical terms. To conceive reciprocity in such stringent terms fails to acknowledge that differences between legal systems are both inevitable and legitimate. ${ }^{80}$ Thus, for instance: if a State agrees to extradite for acts ' $x$ ' in spite of the fact that it does not criminalise them, it cannot expect to obtain extradition in the future for those very same acts, since they cannot even give rise to an extradition request on its part; but reciprocity could be considered satisfied if the now requesting State undertakes to extradite in the future for acts ' $y$ ', which it does not criminalise but the now requested State does.

The same applies to the catalogue of grounds for refusal considered as a whole. Let us imagine that a State does not apply the nationality exception and another State does. The first State may agree to extradite a national citizen in spite of the fact that in the future the latter State will not do the same, so long as this State agrees to extradite in the future in circumstances that in the other State would constitute a ground to refuse extradition. Ultimately this still amounts to a principle of reciprocity, but nuanced with an element of comity. If States would agree to cooperate in such terms, then one could speak of 'reciprocal comity': 'comity' because there is no direct recompense; 'reciprocal' because cooperating would still be indirectly advantageous to the requested State.

If such a model were given mandatory character, then one could speak of 'mandatory comity', which is a manner of phrasing in more traditional terms what in the EU and other settings came to be known as 'mutual recognition': Member States must cooperate whenever grounds for refusal are not met, and the set of grounds for refusal that Member States can apply is delimited by EU law; but within the boundaries delimited by EU law, Member States can and did establish different catalogues of grounds for refusal, because each Member State has particular concerns that may not be so important in other Member States. Thus, Member States can execute EAW's that cannot be perfectly reciprocated, as well as obtain EAW's that they cannot perfectly reciprocate. Within the limits stemming from their core values, and with the adaptations required by the absence of an institutional and normative structure such as that in place in the EU, States could implement such a model of cooperation in the realm of traditional cooperation, either through (bilateral or multilateral) treaties, or on the basis of ad hoc reciprocity.

Finally, as the UN Model Law also suggests ${ }^{81}$ and some States provide for, ${ }^{82}$ there is yet another approach - which may be called 'pure comity' - according to which States will agree to extradite without any guarantee whatsoever of securing future cooperation from the now requesting State. Considering the importance that many States still attach

\footnotetext{
${ }^{79}$ See M. Cherif BAssiouni, International Extradition... op. cit., p. 496.

${ }^{80}$ In a similar sense, see BERT SWART, "Refusal of Extradition...” op. cit., p. $213 \mathrm{f}$.

${ }^{81}$ See supra, Chap. 6, $\int 7.2 .1$.

82 That is again the case of Portugal: see again supra, Chap. 6, $\mathbb{S}$ 7.2.2.
} 
to the concept of reciprocity in its most traditional significances, this approach is at present rather unlikely to be very extensively adopted. Nevertheless, it deserves serious consideration (at least regarding serious types of criminality and other specific cases), as a complement to the more 'reciprocity-friendly' approaches addressed above.

\section{Grounds for refusal preserved in the EAW: negative candidates to be reformed}

\subsection{Grounds for refusal related to the conditions in the requesting State}

These grounds for refusal are almost fully encompassed by the concept of 'grounds for refusal imposed by human rights', whose reform is proscribed in this study. They include: the prohibition of torture or ill-treatment (the first provision of the ECHR and of the ICCPR to have been ascribed a blocking effect in extradition matters by the ECtHR and the UNHRC); fair trial rights, among which the one not to be tried by an ad hoc court (aside from international criminal courts, given their specificities) or in absentia; the prohibition of discrimination (which lies at the heart of the non-refoulement principle and of asylum law more generally, notably as regulated in the 1951 Refugee Convention and respective 1967 Protocol); the prohibition to apply such penalties as capital punishment or lifelong imprisonment; and the humanitarian clause.

As is clear at this moment, the fact that the EAW does not contain most of these grounds for refusal does not mean that they were disregarded, but only that they were believed to be safeguarded across the EU. As was observed in detail, such an assumption proved erroneous, giving rise to ECJ's ruling in Aranyosi \& Căldăraru, but this ruling only confirmed that human rights are highly important and consequential in the EU.

Nevertheless, the analysis made of the extradition systems of Portugal and the UK indicates that some of those grounds for refusal are ascribed a scope that is wider than that which would be required by the human rights they seek to protect (even considering that the concept of 'grounds for refusal imposed by human rights' adopted in this study is quite expansive). As such, some of the propositions developed in the theoretical framework may also be useful with regard to such grounds for refusal. Because, however, these grounds for refusal are fundamentally exempt from the reformist drive of this chapter, they are addressed only at a later stage, once that theoretical framework has been applied to the other grounds for refusal and a clearer picture has emerged as to what extradition might look like if such a framework were applied. ${ }^{83}$

\subsection{Grounds for refusal related to the nature or relevance of the acts}

\subsubsection{Relevance (proportionality stricto sensu)}

a) A necessary requirement?

If extradition is requested for enforcement, in which case the individual concerned has been convicted and is therefore, in principle, no longer presumed innocent, abandon-

\footnotetext{
${ }^{83}$ See infra, $\ 5.1 .2$
} 
ing relevance thresholds would not necessarily cause disproportionality. ${ }^{84}$ Criminal law and procedure themselves are generally not limited by such a requirement.

In contrast, in the case of extradition for prosecution purposes, the person has not been convicted and is presumed innocent. ${ }^{85}$ Extraditing for petty cases would render extradition broader in scope than such criminal procedural measures as pre-trial custodial detention. However, whereas in internal cases a criminal procedure can still be conducted if no pre-trial measure involving deprivation of liberty is applied, refusal of extradition may entail the impossibility of conducting a criminal procedure tout court. Thus, excluding extradition for trivial cases is not absolutely indispensable for a reasonable nexus of proportionality to be established between the harshness of extradition and its function within the criminal justice system. ${ }^{86}$

\section{b) A warranted requirement}

It is, nevertheless, one of the most undisputed principles of extradition law that extradition should not be used in cases of very little importance. So deeply entrenched is this principle that extradition is barely even requested in such cases. ${ }^{87}$ In fact, relevance thresholds tend not to be regarded as actual 'grounds for refusal', but more as an inbuilt feature of extradition law. ${ }^{88}$

The introduction of additional proportionality bars to the EAW system in the UK (arguably in breach of EU law) provided an outstanding opportunity to verify that such a requirement is largely explained by pragmatic reasons, notably by the fact that extradition is costly and time consuming for the requested State. ${ }^{89}$ In fact, the EU itself is sympathetic towards these concerns - although, of course, the legal and conceptual underpinnings of the EAW scheme are much better served by sensitising Member States to perform proportionality controls before issuing EAW's, ${ }^{90}$ than by conferring on them such an additional prerogative to refuse executing EAW's issued by other Member States. ${ }^{11}$ These concerns are shared by the UN, ${ }^{92}$ and acknowledged in legal literature. ${ }^{93}$ Somewhat para-

${ }^{84}$ This is why the UNODC, "Revised Manuals...", op. cit., p. 9, propose that, in the case of extradition for enforcement purposes, States may refrain from establishing a relevance threshold: see supra, Chap. 6, I 2.2.1. On the concept of proportionality lato sensu and its three dimensions, see further infra, $\int 4$ 4.2.1.d).

${ }^{85}$ Linking relevance thresholds to presumption of innocence, ANDRÉ KLIP, European Criminal Law... op. cit., p. 415.

${ }^{86}$ But please do see infra, $\left.\int 4.2 .1 . \mathrm{d}\right)$, on the principle of proportionality lato sensu.

87 See Robert Zimmermann, op. cit., p. 459.

88 See Art. 31 (2) (3) (4) PT-L, and ss. 137 and 138 EA 2003; see ANDrÉ KLIP, European Criminal Law... op. cit., p. 413 f., construing proportionality (in the EAW context) as an element inobservance of which undermines mutual trust, and proposing that such a 'clear shortcoming' be accepted as general exception to the duty to recognise emanating from mutual recognition. Similar remarks apply to dual criminality (see e.g. M. Cherif BASSIOUNI, International Extradition... op. cit., p. 500 f., 509 f.), but not to the same extent, given its 'qualitative' nature, as opposed to the 'quantitative' nature of relevance thresholds.

${ }^{89}$ See supra, Chap. 1, \3.5., and esp. Chap. 6, \ 2.2.3.b).

${ }^{90}$ It is noteworthy that Poland undertook to limit the issuing of EAW's to cases where it is in the 'interests of justice' to do so: see JOANNA DAWSOn / SALly LipsCOMBE / SAMANTHA GODEC, op. cit., p. 13.

${ }^{91}$ See the 'Handbook on how to issue and execute a European arrest warrant', cit., p. 14.

92 See UNODC, "Revised Manuals...", op. cit., p. 9.

93 See e.g. Rosemary Davidson, "A sledgehammer to crack a nut?...”, op. cit., p. 34. 
doxically, the more frequent (and in this sense the more necessary) cooperation is between given States, the higher relevance thresholds will tend to be, because the costs and resources spent will also be higher.

In any case, the view taken here is that there are also principled reasons for maintaining such thresholds. The fact that excluding extradition for petty cases is not indispensable for sustaining a proportionality nexus between its harshness and its preventative function does not mean that extraditing for petty cases is optimal from a proportionality perspective. As noted earlier, the Enlightenment brought a vision of criminal justice as a ubiquitous system, and this was an important factor for the expansion of extradition to ordinary criminality. ${ }^{94}$ As also noted, this paradigm remains basically unchanged. ${ }^{95}$ However, as was moreover noted, over time criminal justice systems made concessions to such an ambition of 'omnipresence', such that this ambition is currently construed less literally than as a guideline not to be excessively departed from. ${ }^{96}$ The reasons that explain those concessions are various, but among them is arguably the fact that the rise of certain types of criminality (international, organised) has reduced even further the relative importance of minor crimes within the whole 'economy of punishment'. Accordingly, criminal justice systems increased the room for prosecutorial opportunity, introduced 'diversionary measures' (which allow certain cases to be settled without even reaching trial) and fully extrajudicial mechanisms for resolving penal conflicts, promoted the substitution of imprisonment for penalties carrying no deprivation of liberty, etc. Such expedients are applicable to cases of low gravity, the concept of 'low gravity' being often indicated by the law in objective terms, by reference to the applicable penalty.

Moreover, the concept of 'low gravity' has in itself often been broadened. For instance, within only the past few decades, Portugal expanded its concept of 'minor or intermediate criminality' from 3 to 5 years based on criminological considerations, ${ }^{97}$ giving much wider applicability to several expedients such as those mentioned above. For a procedural example: if the offence is punished with imprisonment up to 5 years, the case may under certain conditions be provisionally suspended and not reach trial. ${ }^{98}$ For a substantive example: if at the end of the trial the court finds that a penalty of imprisonment not higher than 5 years should be applied (which means that the offence may be punished in the abstract with imprisonment for up to even some 10 years), it may under certain conditions suspend its execution and impose that the convict simply comply with a number of rules of behaviour, instead of serving actual imprisonment time. ${ }^{99}$ Of course, these are not examples of cases that escape altogether the criminal justice system, but examples of criminal justice approaches that are less stigmatising to the individual and less burdensome to

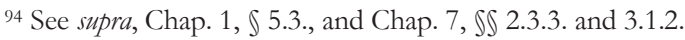

95 See supra, Chap. 7, \2.3.3.

96 See $i d$.

${ }^{97}$ See Maria Jỗo Antunes, Consequências Jurídicas do Crime... op. cit. p. 24 f.

98 This suspension has a maximum normal term of 2 years, during which the suspect shall comply with certain rules of behaviour; if on expiry of this term he/she has satisfied those rule and did not commit any crime of the same nature, the criminal procedure is definitely closed and cannot be reopened: see Arts. 281 f. Code of Criminal Procedure.

${ }^{99}$ See Arts. 50 f. Criminal Code. 
the judicial system than other, more traditional, approaches. Therefore, they do not compare perfectly to minimum thresholds for extraditing. Relevance thresholds for extraditing do not fully compare either to the wide prosecutorial discretion existing in some States, such as the UK, since the decision as to whether or not certain cases should be brought into the criminal justice system is taken by an entity which belongs to the very State that was injured by the crime: it is not an exogenous constraint. These examples do however illustrate that, at one point, a trend emerged in substantive and procedural criminal law to mitigate punitive reaction against an increasing fraction of criminal acts.

In contrast, extradition stood static also in the face of these transformations, with most treaties and statutes allowing extradition for offences punished with as little as imprisonment for 1 year, or unserved prison sentences for periods as short as 4 months. In these cases, the simple fact that the person concerned cannot set foot on the territory of the requesting State without risking a criminal procedure seems sufficient to compensate for his/her impunity. On the other hand, such cases do not raise 'safe haven' type of concerns in the requested State either, ${ }^{100}$ precisely because the gravity of the acts is quite low: the very notion of a 'safe haven for petty criminals' is absurd.

Thus, and in sum, requiring a minimum relevance threshold for extraditing is justified in the light of several reasons. First, although as noted these thresholds are not absolutely indispensable to secure a nexus of proportionality between the harshness of extradition and the acts, they do improve such a nexus. Second, they protect pragmatic concerns of the requested State, a factor that is not decisive but which also cannot be simply overlooked. Third, they entail no risk for the requested State of becoming a safe haven for criminals. Fourth, they promote coherence between extradition and criminal law and procedure. Fifth, the margin for impunity opened by these thresholds is fairly offset by the immediate punitive effects inherent in the existence of a criminal claim against the individual, as this limits his/her freedom of movement. These constitute sufficient reasons to defend the idea that, as matter of principle, a minimum level of relevance should be maintained in extradition law, and possibly even elevated - if only moderately and only in careful observance of the obligations stemming from relevant multilateral treaties. ${ }^{101}$ Deviations from this principle should be limited to cases where the person has been convicted, as in this case presumption of innocence fades. ${ }^{102}$

This is also a suitable moment to emphasise that acts which another State intends to punish and fulfil the minimum threshold for extraditing, but which are still relatively unimportant - that is, acts of mid-low gravity -, will often be strong candidates to be dealt with through delegation of proceedings, rather than through extradition, if the per-

100 See supra, Chap. 1, \4.1.

101 See supra, Chap. 6, $\$ 2.2 .1$.

${ }^{102}$ In this sense, the approach followed in the MAW - which practically eliminates these thresholds, by simply requiring that the acts be punishable with imprisonment (see Arts. 1 (1) and 3 (4)) - cannot be endorsed. According to the latter provision, apart from the acts that the parties have criminalised pursuant to treaties to which they have subscribed, dual criminality and relevance thresholds are governed by the bilateral arrangements applicable to the case at hand, and these will usually carry a minimum threshold. However, the point is that, according to the former provision, extradition would be possible under the MAW in any case where a penalty involving deprivation of liberty is applicable, regardless of its length. 
son concerned is a national, resident or another person who is well integrated in the State that has his/her custody. Delegation of proceedings avoids the displacement of this person during both criminal proceedings and enforcement of the penalty. Since the acts have but a mid-low relevance to the requesting State, in many of these cases wider consideration can be paid to the interests of the individual than in other cases.

The proportionally bar and the proportionality check introduced by the UK into the EA 2003 for EAW requests could also be implemented in classic extradition, either in complement or in replacement of traditional relevance thresholds, allowing the requested State to refuse extradition in cases that meet these thresholds but are still insignificant in the light of other factors, such as those itemised in the EA 2003. ${ }^{103}$ If so, requested States should mind not to project their own concepts upon requesting States when evaluating whether certain acts are sufficiently serious. An abusive application of these proportionality bars can be avoided through a 'preclusive threshold' according to which extradition may not be refused on grounds of irrelevance if the acts at issue are punished with imprisonment for ' $\chi$ ' or more years, or the penalty remaining to be served exceeds ' $y$ '.

\section{c) Possibilities of optimisation}

In any case, some room remains for rationalising the classic relevance thresholds, narrowing their scope in certain aspects. First, unlike what currently appears to happen in the UK, if extradition is requested for several offences and not all of them meet the required threshold, there is no reason not to extend extradition to all of them if at least one does meet the threshold. Second, unlike what appears to happen in all normative systems assessed earlier (the UN, Portugal and the UK), if extradition is requested for several offences and none of them meets the threshold, there is also no reason not to grant extradition for all of them when, according to the rules on concurring offences, they may entail the application of a penalty which does meet the threshold. The justification for both propositions is the same: the overall penalty in which the person incurs in the requesting State is the measure which expresses the harm caused to such a State, and the measure in view of which an assessment can be made as to whether extraditing that person would be disproportionally harsh to him/her. The multiple or reiterated, possibly even professional perpetration of offences that in themselves are minor may raise sufficiently elevated levels of unlawfulness and, consequently, preventative concerns.

Even more important is to reflect about the question as to whether the relevance of the acts should be assessed on the basis of the criteria of the requested State or, instead, of those of the requesting State. The theoretical framework developed above points a clear path to answering this question: if the requesting State is that where the crime was committed and/or its damage materialised, the presumption should be followed that its concepts of criminal justice, rather than those of the requested State, are the ones that should apply to the acts. ${ }^{104}$ This principle should be subject to some nuances, but these can only (and will) be properly addressed in articulation with the dual criminality rule.

103 See again supra, Chap. 6, \ 2.2.3.b).

104 This is the view enshrined in the FD-EAW: see Art. 2 (1), (2) and (4) FD-EAW. 


\section{d) A further ground for refusal on disproportionality between acts and penalty?}

Yet a different question is that as to whether the requested State should be entitled to refuse extradition if, in its view, the requesting State punishes the acts with a penalty which is disproportionate to their gravity. It is interesting to verify that there is a ground for refusal which requires the applicability of certain minima penalties in order for extradition to be granted (relevance thresholds), as well as grounds for refusal which prevent extradition in the event of applicability of certain maxima penalties (death, life imprisonment), but no ground for refusal whatsoever concerned with the possible disproportionality - within those minima and maxima scenarios - between the acts and the penalty. ${ }^{105}$

The theoretical framework also points out ways to answer the question as to whether such a ground for refusal should exist. The starting point is again that this is an issue for the requesting State to assess, as it is its penal law that applies to the acts. However, proportionality between acts and penalties will often constitute a core criminal justice principle of the requested State with constitutional rank. That is, it will be an integral part of its 'criminal justice ethos'. The possibility must therefore be admitted that the requested State's own concepts supersede those of the requesting State if this is necessary to avoid a damage to its sense of justice.

This is similar to what will be expounded much more extensively on dual criminality, but there is one difference: it is much more subjective for the requested State to assess whether extraditing would be disproportional due to the quantum of penalty that could come to be applied in the requesting State (the issue at stake here) than due to the nature of the acts (the issue at stake in dual criminality). Not least of all because in attaching a given penalty to a given conduct a State will not only be taking into account the supposed absolute seriousness of that conduct (cardinal proportionality), but also the relative seriousness of that conduct in the context of its criminal justice system as a whole, by reference to other types of conduct and the penalties that have been attached to them (ordinal proportionality). ${ }^{106}$ In assessing ordinal proportionality, the requested State would have to compare the acts and the penalty to acts and penalties established in its own legal system, or with other acts and penalties in the legal system of the requesting State. In the first case it would be making a double projection of its own concepts of criminal justice upon the requesting State: it would not only be casting a proportionality judgement in relation to a penalty prescribed by this State, but also it would be doing so by reference to its own sanctioning system. In the second case it would be casting a proportionality judgment in relation to another State's sanctioning system as a whole, an exercise which at best is on the edge of (active) interference in the internal affairs of that State. Regarding cardinal

105 The view that such a disproportion might justify refusing extradition was detected in only one text: LECH GARDOCKI, op. cit., p. 291, in what the author calls "double penal policy standard, in other words, the double possibility of a similar sentence in a given case", "comparing sanctions provided for this offence in both penal codes or even comparing judicial practices in both countries".

106 See ANDrew VON Hirsch, Censure and Sanctions... op. cit., p. 18 f., and already in e.g. "Proportionality in the Philosophy of Punishment", CJ 16 (1992), p. 55 f.; ANDREW AsHWORTH, Sentencing and Criminal Justice... op. cit., p. 102 f., PETTER ASP, The Substantive Criminal Law Competence of the EU, Stockholm: Juridiska Fakulteten vid Stockholms Universitet, 2012, p. 199 f. 
proportionality, it must be noted, with von Hirsch, that "no quantum of punishment suggests itself as the uniquely appropriate penalty" for a crime, as the "amount of disapproval conveyed by penal sanctions is a convention". ${ }^{107}$ It is a very delicate concept indeed, and as such the requested State should as much as possible refrain from wielding it, in deference for the presumed primacy of the criminal justice concepts of the requesting State.

Still, the possibility must be admitted that in some cases the penalty applicable in the requesting State is so strikingly excessive in the light of the sense of cardinal proportionality of the requested State that extraditing would be intolerable. Indeed, while highly subjective, cardinal proportionality is not an ethereal concept either, but one that can be "anchored" to certain factors and bound by certain limits. ${ }^{108}$ Suppose that a State requests the extradition of a person for the theft of a worthless item, and that in that State this act is punished with imprisonment for up to 20 years. The idea of collaborating towards such a punishment will be offensive to the most basic notions of criminal justice of many States.

In any case, considering again the great subjectivity of cardinal proportionality, and the fact that consequently it should only be invoked by the requested State in blatant cases, this should probably be regarded as one of those abnormal hypotheses to be entrusted to its executive branch, ${ }^{109}$ rather than allowed to be raised in court by any individual, generating extensive and often meritless litigation. This is especially so if we consider the following. Cardinal proportionality is an assessment of the relation between two elements: an act and a penalty. Therefore, in the eyes of the requested State, a blatant case of cardinal disproportionality will presuppose the existence of a deeper - not 'quantitative', but 'qualitative' - divergence of perspective between the requested and the requesting States. The acts may be criminalised in both States but the underpinnings and purposes of criminalisation completely different in one State and the other. And this is already another issue, which will be better addressed in articulation with dual criminality. ${ }^{110}$

\subsection{Grounds for refusal related to the punitive claim of the requesting State}

\subsubsection{Extinction of criminal liability: ne bis in idem}

As we saw in Chapter 3, there is no international customary rule entailing a duty to comply with the ne bis in idem principle, and one such duty also does not follow from the ECHR. In its transnational dimension this principle has indeed but tenuous resonance in human rights conventions. ${ }^{111}$

At the national level, ne bis in idem is regarded as a fundamental principle of criminal law in many States and often has constitutional rank, as is illustrated by the Fifth Amendment of the USA Constitution or Art. 103 of the German Basic Law. It has been rooted in multiple rationales, including sovereignty, efficacy of a State's own res judicatae, proper administration of justice, legal certainty, fair trial, proportionality, and even the principle

\footnotetext{
107 ANDREW VON HiRSCH, Censure and Sanctions... op. cit., p. 19.

108 See ibid., p. 19 f., 29 f., 36 f.

109 See supra, $\$ 2.1 .3$.

110 See infra, S 4.1.1.d)(i).

111 See supra, Chap. 3, \ 4.4.2.
} 
of legality. ${ }^{112}$ However, in the image of international human rights treaties, few States assign a transnational dimension to this principle. States tend generally not to recognise any validity to foreign decisions in their legal systems, especially where the acts at issue are territorially linked to their legal systems. Common law systems such as the UK have a more internationalist approach to ne bis in idem (or 'double jeopardy'), ${ }^{113}$ but this is by no means usual in civil law systems, the Netherlands being probably the main exception among European States. ${ }^{114}$ Portugal does not apply its criminal law to acts committed outside of its territory unless the person has not been tried in the locus delicti or has evaded enforcement; however, as in most civil law States, this does not apply to acts committed in its own territory. $^{115}$

Transnational ne bis in idem has its privileged field of application in international legal instruments on international cooperation. This is somewhat peculiar, since the normal situation is the opposite: i.e. that principles which are considered fundamental at the national and/or at the more substantive international (e.g. under human rights law) levels be reflected into international cooperation. Vervaele ${ }^{116}$ provides an account of European extradition arrangements, where, albeit with variations, ne bis in idem has been present since the 1957 CoE Extradition Convention. ${ }^{117}$ It is also provided for as a ground for nonexecution in the FD-EAW, namely in its Art. 3 (2), concerning decisions of other Member States (in which case refusal is mandatory), and in Art. 4 (5), concerning decisions of third States (in which case refusal is just optional). ${ }^{118}$ As we saw, transnational ne bis in idem is also present in the UN model instruments on extradition. ${ }^{119}$

112 See, in combination, John A. E. Vervaele, “Ne Bis In Idem...” op. cit., p. 213, and Bas VAn BockEL, “The 'European' Ne Bis in Idem Principle: Substance, Sources, and Scope”, in Bas van Bockel (ed.), Ne Bis in Idem in EU LAW, Cambridge: University Press, 2016, p. $13 \mathrm{f}$.

113 See Martin Friedland, Double Jeopardy, Oxford: University Press, 1969, passim; Law Commission (LAW COM no. 267), "Double Jeopardy and Prosecution Appeals: Report on two references under section 3 (1) (e) of the Law Commissions Act 1965", Presented to the Parliament of the UK by the Lord High Chancellor by Command of Her Majesty, Cm 5048, March 2001, p. 76 f.

114 See John A. E. Vervaele, “Ne Bis In Idem...” op. cit., p. 214; and ANDrÉ KLIP / HARMEN VAN DER WiLT, "Non bis in idem: Report for the Netherlands", RIDP 73 (2002), p. $1100 \mathrm{f}$.

115 See Art. 6 (1) Penal Code. Naturally, this is without prejudice to international obligations subscribed to by this State, notably at the European level.

116 See John A. E. Vervaele, “Ne Bis In Idem...” op. cit., p. 215 f.

117 See Arts. 8 and 9, as supplemented by $\iint 2$ and 3 Additional Protocol of 15 October 1975, which extended the scope of the principle from the requested and the requesting State to other Contracting Parties. The principle is also present in legal instruments concerning forms of cooperation other than extradition, such as the CoE 1970 Convention on the International Validity of Criminal Judgements (Arts. 53-57) and the 1972 Convention on the Transfer of Proceedings in Criminal Matters (Arts. 35-37), both of which, however, have a low ratification rate and in any case contain wide exceptions to the principle. The principle is also found in the 1990 Convention on Laundering, Search, Seizure and Confiscation of the Proceeds from Crime (Art. 18 (1) (e)), which has a larger ratification record, but not in the 1959 CoE Convention on Mutual Assistance in Criminal Matters (nor in the Additional Protocol of 1978 and in that of 2001), nor in the 2000 Convention on Mutual Assistance in Criminal Matters between the Member States of the EU and its Additional Protocol of 2001.

118 The principle was also included in the European Evidence Warrant (Art. 13 (1) (a)), and maintained in the European Investigation Order (Art. 10 (1) (d)).

119 See supra, Chap. 6, \3.3.1. 
At a second glance, there is a good reason for the privileged seat of transnational ne bis in idem to be legal instruments of international cooperation. When States regulate this issue in legal arrangements on cooperation, they are not binding themselves not to prosecute acts that have already been tried in another State (which is the duty that they are reluctant to subscribe to, at least regarding acts committed in their territory or against their interests). What States are doing when they provide for a ne bis in idem ground for refusal in an extradition treaty is to narrow the possibilities of obtaining extradition for such acts - which, from a perspective of self-interest, is already a concession on their part, but is still very different from holding themselves prevented from prosecuting such acts if the offender is found in their territory. This, in turn, leads to a more important topic.

When States provide for a ne bis in idem ground for refusal in an extradition treaty, they are usually only narrowing significantly their possibilities of obtaining extradition in respect of acts that have been tried in another contracting party. Only here is refusal usually mandatory, because by engaging in one such instrument States concomitantly evaluate the reliability of sentences passed in the other contracting States. As for sentences passed in third States (which may be any State), refusal is usually not mandatory. This denotes that cooperation instruments in fact contain what could be called a 'proto-substantive' regulation of transnational ne bis in idem between the contracting States vis-à-vis any other States: by defining the circumstances in which ne bis in idem shall block extradition, contracting States are in fact stating what they believe is, in the abstract, the reliability of the sentences passed by each other. That is, transnational ne bis in idem as a ground for refusal of extradition is, like other grounds for refusal, geometry that varies depending on existing levels of trust, but trust, here, refers to the State whence the relevant sentence emanates, rather than to that which requests extradition. Such that, even if the requested State has the utmost trust in the State which requests extradition, it will nevertheless reject extradition if the sentence in question emanates from another State in which it also has trust, to the extent of this trust. Symmetrically, a requesting State which is not linked to the requested State by any particular ties of trust has the same possibility of obtaining extradition (as far as this specific issue is concerned) as any State which does have close ties with the requested State and has its trust. The only relevant variable in this context is the source of the sentence triggering the protection conferred by ne bis in idem. The level of trust between the requested State and the requesting State is immaterial here.

It is therefore only natural that, for instance, in the EU, transnational ne bis in idem has been developed concomitantly as a 'constitutional' guarantee and as a ground for refusal of extradition, rather than in a sequence whereby it would first establish itself as a constitutional guarantee and only then as a guarantee of extradition law. In fact, in the EU, the latter element has probably been more preponderant than the former: as is well known, the CISA (1985) contains what can be considered an almost fully-fledged regulation of regional ne bis in idem; ${ }^{120}$ however, the essential goal of the Schengen agreements was to establish free movement within the EU, and the transnational ne bis in idem principle there-

120 See André Klip, European Criminal Law... op. cit., p. 285 f.; JoHn A. E. Vervaele, "Ne Bis In Idem..." op. cit., p. $218 \mathrm{f}$. 
by created is somewhat functionalised to that goal. As Bockel notes: "it is clear from the context of the Schengen Agreements that the wording of Art. 54 CISA does not necessarily reflect any particular supranational human rights ambitions on the part of the drafters. The CISA is closely linked to extradition and was in many ways drawn up in a spirit of intergovernmental, rather than supranational enforcement cooperation between states."121 Also: "The need for a clearly worded and broad ne bis in idem rule such as Art. 54 CISA is clear, given the aim of the extradition provisions in the Schengen-agreements (...) to simplify and expedite extradition procedures between the Member States, much in the same way as the European Arrest Warrant that later replaced them". ${ }^{122}$ The 'constitutionalisation' of the transnational ne bis in idem in the EU only arrived with Art. 50 CFREU, which does already express 'supranational human rights ambitions'. It is therefore also only natural - although not yet certain - that the principle will now also block extradition (on the basis of primary EU law) from a Member State to a third State if the sentence in question emanates from a fellow Member State. ${ }^{123}$

What all of this means is that the question as to what should be the scope of transnational ne bis in idem as a ground for refusal of extradition is, to a great extent, the question as to what should be the scope of transnational ne bis in idem itself. And this question is one that could not possibly be addressed in detail in this study. Still, some propositions can be drawn from the above considerations.

\section{a) Res judicatae of the requesting State}

When the acts have already been tried in the requesting State itself, then refusal of extradition shall in line of principle be refused. As we saw, the event that the same State prosecutes or punishes the same acts twice is the one dimension of the ne bis in idem principle that is widely accepted, and that can be considered as a ground for refusal of extradition imposed by human rights law.

\section{b) Res judicatae of the requested State}

The case is also quite simple where the acts have already been tried in the requested State, even if based on extraterritorial jurisdiction, and even if the sentence is not gen-

121 BAS VAN BOCKEL, op. cit., p. 23 f., elaborating: "Inter alia, this may be evidenced by the way in which the Schengen-agreements were adopted outside of the EU framework, by the scope of application of Art. 54 CISA (applying between the Schengen states), by the exception possibilities laid down in Art. 55 CISA, and by the requirement that the previous penalty must have 'been enforced, or can no longer be enforced' from Art. 54 CISA. In jurisdictions in which foreign res indicata is legally recognized and accepted this enforcement requirement applies only in relation to foreign judgments."

122 Ibid., p. 23 f., adding: "At the same time however, the majority of national ne bis in idem rules emphasize the objective, historical facts over their legal qualification, also in domestic situations. On the one hand, the specific context of the Schengen-agreements could therefore justify some interpretative differences in case law of the CJEU. In national systems of law, extradition is procedurally distinct from the actual trial in which the full bill of national procedural and constitutional rights protects the subject, so that different standards of protection may be deemed acceptable. On the other hand, however, a transnational fundamental right like Art. 54 CISA does not exist in interpretative isolation from other ne bis in idem provisions in different legal orders once it has come about."

123 See supra, Chap. 4, \§ 2.4.4.a)(vii), and 3 (esp. 3.4.); but see further infra, \ c). 
uine. One may of course contest that this State has exerted exorbitant extraterritorial jurisdiction and/or that it has fabricated a sentence to spare a person from punishment, but it is unreasonable to expect that State not to draw to itself all the consequences immanent to its own res judicatae: this is necessary to uphold its sovereignty and assert its credibility. Where prosecution has been genuine, then refusing extradition will moreover correspond to the protection of a fundamental right of the person concerned. In such a case, refusal of extradition is a natural emanation of this State's internal ne bis in idem (possibly of constitutional rank), and is therefore fully justified at every level.

\section{c) Res judicatae of a third State}

The real questions arise when the acts have already been tried in a State other than the requested or the requesting State. It appears unquestionable that this situation should in line of principle lead to the refusal of extradition. One conclusion that can be drawn from the foregoing analysis, as well as from that carried out earlier in the human rights chapter of the study, is that, roughly speaking, all States agree with the principle ne bis in idem, including its transnational dimension. The very fact that ne bis in idem is generally referred to as a principle rather than as a rule is a symptom of its elevated bearing, because technically it appears that there is more reason to see it as a rule than as a principle. ${ }^{124}$

The reason why most States do not provide for a general protection of this character appears to be that they cannot anticipate, in the abstract, what is the State whence the sentence sparking the protection emanates, nor, consequently, what the credibility of this sentence is. And if this sentence is not credible, that protection becomes devoid of any rationale; it falls apart. As a ground for refusal of extradition, ne bis in idem oscillates between two poles: (i) it seeks to avoid an unjustifiable consequence to a person and an affront to the credibility of the State that passed the sentence; but (ii) it risks contributing to the impunity of a person and denying a legitimate punitive claim by the State that requests extradition. This should help to explain why most States recognise ne bis in idem as a fundamental guarantee at the internal level, and often even assign it constitutional rank, but do not - even when the punitive claim at stake is not their own - embrace it more unreservedly at the transnational level by always refusing to extradite.

However, if the factor preventing such an unreserved embracing of ne bis in idem as a ground for refusal is the uncertainty as to the truthfulness of the sentence that triggers the guarantee, then it may be posited that extradition should be refused (at least) up to the extent to which the requested State has undertaken - through normative instruments altogether independent from those governing the extradition request at issue - not to punish or to extradite for acts that have been tried in the State whence, in the specific extradition case at hand, the sentence emanates. To use the EU as an example: a Member State should for instance refuse extradition (to whichever State) if, in the case at hand, the acts have been tried in another Member State in conditions which meet the ne bis in idem in force between those two States, based on the CFREU, the CISA and the FD-EAW. This is not anymore to discuss whether such instruments, notably the CFREU, apply to extra-

124 See BAS VAN BOCKEL, op. cit., p. 14. 
dition requests issued by third States. The contention is simply that Member States, in their separate sovereign capacity as parties to extradition relations with third States, should use this as a criterion. Such is the natural consequence of the near sameness of ne bis in idem as a ground for refusal and as a substantive criminal law principle. This applies to any legal instrument through which the requested State has undertaken to respect the res judicatae of other States. In these terms, the minimum scope of ne bis in idem as a ground for refusal in each given extradition case is the extent (if any) to which the requested State has undertaken to recognise the res judicatae of the sentencing State. The exception is the situation where the requesting State itself has ne bis in idem arrangements in place with the State that proffered the relevant sentence, and according to such arrangements it is entitled to prosecute or punish the acts.

Of course, this solves the problem only in part, because it is only useful if extradition is requested for acts tried in a State with which the requested State has ne bis in idem agreements in place. Each State must therefore have a default criterion to use when this is not the case. And here we go back again to the scope of ne bis in idem itself, and the most sensible approach seems to be to provide for an optional ground for refusal in these cases which enables consideration of all the factors which may be relevant, including the connection of the acts with the legal system of the requesting State and with that of the sentencing State, as well as the reliability of the sentence.

\subsubsection{Absence of (valid) jurisdiction}

As we saw earlier, refusing extradition to States exerting an extraterritorial basis for jurisdiction which is not recognised by the requested State might pursue different goals. One is to pay tribute to the territoriality principle, in that it reflects that this is the normal basis for jurisdiction. Another is to deter the exercise of bases for jurisdiction which are not in accordance with international law. Yet another, intertwined with the previous two, is to deter interference in the internal affairs of other States. In the UK it is also regarded as an individual entitlement not to be displaced to a State whose connection with the acts is tenuous. Finally, reciprocity might also be deemed to play a role, if taken in the sense that a State cannot expect to see such requests reciprocated if it would not have a jurisdictional claim over such acts in comparable circumstances.

Starting with the last rationale, it should be excluded from consideration, as it is already contemplated by the remarks adduced above on reciprocity in general: it is anachronistic to consider that reciprocity requires perfect equivalence of conditions. ${ }^{125}$ As for the idea that extradition should not be granted if the jurisdictional basis held by the requesting State infringes upon international law, it is indisputable. In fact, if narrowed down to this rationale, this ground for refusal would be imposed by general international law, in parallel with international immunities. ${ }^{126}$

\footnotetext{
125 See supra, \ 2.2.2.

126 See supra, Chap. 2, S 2.2.2.c).
} 
That the territoriality principle should be given absolute primacy is also unquestionable. ${ }^{127}$ The only question in this respect is whether the criterion 'jurisdiction of the requested State in identical circumstances' is warranted. At a first glance, such a criterion entails an imposition by the requested State of its model of extraterritorial jurisdiction upon the requesting State. Why should this jurisdictional model constitute the parameter? However, it is difficult to envisage a better criterion. The jurisdictional model of the requesting State would be useless, because the extradition request already implies that this State has jurisdiction according to its own legal system. One might contemplate using as reference the jurisdictional model of the State where the crime was committed. However, protecting the principle of territoriality does not equate to protecting the concrete jurisdictional model of the State where the acts at issue were committed. Theoretically, it is even possible that such a State does not regard territoriality as its main basis of jurisdiction (but instead, for instance, active nationality), and still it would be precisely as protected by the ground for refusal in debate as if it did elect territoriality as its paramount principle of jurisdiction. The latter criterion would also offer no guarantee against overlyreaching exercises of extraterritorial jurisdiction (which is exactly the event that this ground for refusal mainly seeks to avoid), because the State where the crime was committed might itself have an overly-reaching model of extraterritorial jurisdiction.

In this light, the criterion of 'jurisdiction of the requested State in identical circumstances' represents no imposition, but rather it emerges as the sole possible criterion of its kind which could be used. However, one must question whether a criterion of this kind is indeed necessary. If the goal is to protect territorial jurisdiction, why not simply require the requesting State to offer proof that the State with territorial jurisdiction does not intend to take any action, or does intend to do so but cannot obtain extradition due to some ground for refusal? ${ }^{128-129}$ Considering that abusive grounds for jurisdiction will already be prohibited by international law - and these should always give rise to refusal -, why then subordinate the possibility of extraditing to the opinion of the requested State as to what should be the proper scope of States' extraterritorial jurisdiction in criminal matters? We must bear in mind that States have different traditions in this regard, and that the ground for refusal in analysis is so wide as to cover not only what in the eyes of a requested State might look like a bizarre jurisdictional principle, but also (and in fact predominantly) jurisdictional principles that are very well-established, such as active nationality, passive nationality, or residence. It will even cover instances where the requested and the request-

127 See supra, Chap. 7, $\int 3.1$. and all ulterior references.

128 One might conceive of a differentiation between the case where the State with territorial jurisdiction does not intend to, and that where it cannot prosecute, such that in the latter case, in order not to hinder a territorial claim by triggering the ne bis in idem principle, the requesting State would still be prevented from obtaining extradition. However, there appears to exist no solid reason to make such a differentiation, because usually the State with territorial jurisdiction is not prevented by its ne bis in idem principle (whether or not this is warranted is a different issue) to pass its own justice upon acts committed in its territory: see supra, $\$$ 3.3.1.

${ }^{129}$ If the State with territorial jurisdiction would intend to take action and extradition could be granted to that State, then there would be a case of concurring extradition requests and that State would already, in principle, prevail. 
ing States agree that a given factor should trigger jurisdiction but subordinate its exercise to different requirements: for instance, where they agree that acts committed by nationals abroad should entitle their States to prosecute them (active nationality), but disagree as to whether prosecution should be admissible if the national does not return to its territory; ${ }^{130}$ or where they agree that certain acts aimed at injuring a State should entitle such a State to prosecute them even if they were committed fully abroad and are not punishable in the locus delicti (protective jurisdiction), but disagree as to the exact set of acts that should be covered by such a basis for jurisdiction. The latter example is particularly illustrative of the prejudiced implications of using the requested State's (or, for that matter, any State's) jurisdictional concepts as a reference for extradition decisions: different States have different characteristics and are affected by different circumstances, and some may legitimately feel the necessity to guard against certain types of criminal conduct more extensively than others.

The function expected from this ground for refusal would be adequately attained if extradition were prohibited only where the jurisdictional basis held by the requesting State is prohibited by international law, or the State with territorial jurisdiction intends and is able to prosecute the acts. This departs openly from the legal system of the UK, and combines elements of the other approaches assessed. ${ }^{131}$ It follows the UN model instruments, the Portuguese extradition statute, and the FD-EAW in that it permits extradition even where the requested State would not have jurisdiction in identical circumstances. ${ }^{132} \mathrm{It}$ departs from the UN model instruments and the FD-EAW in that it is configured as mandatory (so as to allow no room for extradition where this may carry an infringement of international law or the spoiling of a territorial claim). And it departs from the Portuguese extradition statute in that it takes as a focal point the condition that the State with territorial jurisdiction does not intend to or cannot prosecute the acts, with the consequence that this condition must be satisfied even where the basis for jurisdiction held by the requesting State has correspondence in the legal system of the requested State. ${ }^{133}$ The condition

130 A difference which became visible in the analysis made in Chap. $4, \$ 2.4 .3 . b)(i i)$, on Petrubhin.

131 See supra, Chap. 6, $\int 3.4$.

${ }^{132}$ In the UN model instruments and in the FD-EAW, this is so because they configure this ground for refusal as merely optional. In the Portuguese legal system, this is so because, although this ground for refusal is configured as mandatory, the requesting State is given the alternative of proving that the State with territorial jurisdiction does not intend to prosecute.

133 In any case, the suggestions of UNODC, "Revised Manuals..." op. cit., p. 27 f., still merit consideration: "Between countries that have a clear understanding and acceptance of each other's jurisdictional approaches, such a clause may not always be necessary. States will also want to have regard to the recognition of, and in some instances requirements for, the extension of jurisdiction, through international conventions, such as the 1988 Drug Convention [Art. 4 (1) (b)], the Palermo Convention [Art. 15 (2)], the Merida Convention [Art. 42 (2)] and several counter terrorism conventions, as well as the Security Council resolution 1373(2001) with respect to some of the mandated offences. The parties will want to ensure that the treaty is sufficiently flexible to allow for extradition in cases where jurisdiction has been extended in accordance with such conventions or resolution. One possible approach would be to draft the provision in a way that expressly bestows discretion on the requested State to grant extradition even in cases in which the basis of jurisdiction relied upon by the requesting State is not available under the requested State's law. This would provide the necessary flexibility and still ensure sufficient protection to the requested State to guard against excessive claims of extraterritorial jurisdiction." 
that the State with territorial jurisdiction does not intend to or cannot prosecute the acts should probably be set aside if the basis for jurisdictional held by the requesting State is protective jurisdiction, which is the only basis for extraterritorial jurisdiction that can still be regarded as inherent in State sovereignty. ${ }^{134}$

If understood in these terms, this condition will not really amount to a 'ground for refusal', because its consequence is not 'impunity': ${ }^{135}$ where the jurisdictional basis held by the requesting State conflicts with international law, then there is quite simply no legitimate punitive claim worthy of being fulfilled; where the State with territorial jurisdiction intends and is able to prosecute, then this condition translates into a mere clause for solving concurring extradition requests, with the particularity that one of them has not been received yet. $^{136}$

Only one issue remains: the requested State might be concerned that the individual sought will be prosecuted for acts that he/she could not reasonably be expected to know would trigger the jurisdiction of the requesting State. Such an issue can also be raised in regard to the criterion of 'jurisdiction in comparable circumstances'. The sole difference is that the requested State considers that, if its own jurisdictional model confers it power to prosecute in such a case, then this means that it is warranted for other States to do so. It is a subjective, endogenous criterion which secures the ordre public of the requested State, but which does not necessarily satisfy objective, individual-oriented criteria. The latter issue, however, can be tended through a condition requiring the acts to be criminalised in the locus delicti (unless no punitive power is exerted in that place, e.g. because it is a failed State), or - then again - that the acts have been aimed at injuring the requesting State.

\subsection{Grounds for refusal related to the status or condition of the person}

\subsubsection{Rehabilitation}

a) $A$ sui generis humanitarian concern

The notion that a person who has meaningful links to the requested State (notably because he/she is a national or a resident of that State) deserves particular consideration when deciding on an extradition request is uncontested even in States of the common law tradition, which do not have a principled stance not to extradite their own nationals. ${ }^{137}$ The

\footnotetext{
134 See Christine van Den Wyngaert, "Double criminality...”, op. cit., p. 135, $141 \mathrm{f}$. Nevertheless, the author posits that even this basis for jurisdiction may have to comply with the condition that the acts be criminalised in the State where they were committed, as the legality principle prevents prosecution for acts that were not punishable "not only tempore delicti but also loco delicti": p. 142. On the other hand, States (such as the USA) which follow an 'effects doctrine' according to which virtually any acts affecting their interests are deemed 'territorial', there does not even exist a clear distinction between territorial and protective jurisdiction, since that doctrine " 'territorializes' extraterritorial behaviour": ibid., p. 143, arguing that such doctrine does not overcome, but rather "circumvent[s] the problem", and is a "potential for abuse".

135 See supra, Chap. 1, \ 5.2 .

136 Which in turn would carry the general norm on concurring extradition to solve only: (i) conflicts of territorial, or between territorial and protective jurisdiction; and (ii) conflicts of extraterritorial jurisdiction.

137 The forum bar enacted in the UK in 2013 has again illustrative value here. One of the conditions for this bar to be triggered is the 'requested person's connections with the UK': see further infra.
} 
reason why this can hardly be contested is that what is at stake here is no longer, as in the classic nationality exception, a symbolical, largely irrational and somewhat discriminatory approach to the formal connections of a person with a given State, but tangible arguments supported by solid and rational criminal policy factors which indicate that the most suitable place for individuals to be rehabilitated is that where they have their family, their social and professional roots, etc.; and that this is also the most humane thing to do. ${ }^{138}$ That is, in this case one is no longer discussing the meaning of nationality or domicile in their formal, but rather in their substantial dimension; not as abstract symbols of the bond linking an individual to a certain State, but as concrete indicators of the bond linking that individual to a certain place and to other people who live in this place.

This is why recognising relevance to these factors in the context of extradition has much less to do with nationality as such than with humanitarian considerations. ${ }^{139}$ In this sense, this ground for refusal might have been brought within the humanitarian exception, which covers human and 'para-human' rights. ${ }^{140}$ Indeed, as we saw earlier, rehabilitation is an increasingly prominent principle in human rights law. ${ }^{141}$ However, the rehabilitation exception does not inherently entail a type of hardship comparable to certain situations that

\footnotetext{
138 See BERT SWART, "Refusal of Extradition...”, op. cit., p. 190; UNODC, Handbook on the International Transfer of Sentenced Persons, Vienna, 2012, p. 11, raising three sets of considerations: (i) "Differences in language, culture and religion and distance from family and friends may increase the difficulties of imprisonment and aggravate the impact of the sentence imposed"; (ii) "There is also a strong humanitarian argument for transfer if the prison conditions and regimes in the sentencing State are particularly poor or are not in line with international minimum standards"; and (iii) "the humanitarian argument is also applicable to the needs of the family and dependants of a sentenced person who is held in a foreign prison while they remain in their country of origin. Research suggests that prisoners' families face an array of challenges as a consequence of their family member's imprisonment that include marital difficulties, financial and housing problems, social stigma and victimization, loneliness, anxiety and emotional hardship. Prisoners' children may experience psychological harm and develop behavioural problems. Such indirect consequences of imprisonment are highly likely to be exacerbated by the imprisonment of a family member abroad."

139 See ibid., p. 194; M. Cherif Bassiouni, "United States Policies and Practices on the Execution of Foreign Sentences", in M. Cherif Bassiouni (ed.), International Criminal Law, Vol. II... op. cit., p. 552 f; Michą PŁachta, "Human Rights Aspects of the Prisoner Transfer in a Comparative Perspective", LouLR 53 (1993), p. 1043 f.; UNODC, Handbook on the International Transfer of Sentenced Persons, op. cit., p. 9 f.

140 See supra, Chap. 3, So 3.5, 4.1.2., and 4.5.

141 See supra, e.g. Chap. 4, \$4.2.2.; see again ECtHR's Trabelsi and Vinter, see yet Dickson $v$. UK, 4 December 2007, \ 28, where the ECtHR stated: "In recent years there has been a trend towards placing more emphasis on rehabilitation, as demonstrated notably by the CoE's legal instruments. While rehabilitation was recognized as a means of preventing recidivism, more recently and more positively, it constitutes rather the idea of resocialization through the fostering of personal responsibility. This objective is reinforced by the development of the 'progression principle': in the course of serving a sentence, a prisoner should move progressively through the prison system thereby moving from the early days of a sentence, when the emphasis may be on punishment and retribution, to the latter stages, when the emphasis should be on preparation for release." And yet, at $\int 10$ : “The argument for encouraging the transfer of sentenced persons has a strong basis in international human rights law", for instance: in the ICCPR, Art. 10 (3) of which specifies that the "essential aim" of a penitentiary system is the "reformation and social rehabilitation" of prisoners; in the Standard Minimum Rules for the Treatment of Prisoners, which are used as a guide for interpreting that provision of the ICCPR; and in the European Prison Rules on Managing Detention, rule 6 of which has influenced the interpretation of the ECHR. See, moreover, the preamble to the ACHR, stating its goal to "cooperate to ensure improved administration of justice through the social rehabilitation of the sentenced persons"; and, in the EU, \& 9 of the Preamble to FD 2008/909/JHA.
} 
fall within the humanitarian exception (e.g. acute mental illnesses or risk of death), on the one hand, and is inherently more intense than others that also fall within that exception (e.g. impairment of family life). Thus, if considered within that setting, probably, rehabilitation would constitute a relevant factor only in extreme circumstances. Its relevance as a ground for refusing or conditioning extradition, however, is autonomous, and, as such, it will be better grasped if considered also from the perspective of the requesting State.

\section{b) 'Worm's-eye view and bird's-eye view"142}

Considered in their substantive, rather than in their formal character, nationality and residence are no longer relevant - as in the classic nationality exception - regarding each and every penal action by another State, but only regarding the enforcement of a penalty. Indeed, although extraditing a person for prosecution purposes also uproots such a person from his/her habitat, it is not comparable to extraditing a person for enforcement purposes. For two reasons: on the one hand, and looking at the issue from the 'worm's-eye view, ${ }^{143}$ because in the latter case the displacement of the person is usually more permanent, ${ }^{144}$ on the other hand, and looking at the issue from the 'bird's-eye view', because the preponderance attributed to the requesting State in this study refers much more to the prerogative to prosecute the acts than to the prerogative to enforce a sentence.

There is no doubt that the enforcement of a sentence is an integral part of the process whereby a criminal justice system reinstates its efficacy, which had been challenged by the commission of a crime linked to that legal system by a strong jurisdictional connection. However, there should also be few doubts that such a process finds its defining moment in the assessment by a State of the criminal liability of the suspect according to its own criminal law, in a court open to its community. This is the view held by the UNODC: "When implementing sentences of imprisonment, considerable attention is paid to the rehabilitation of offenders to ensure that they are resocialized and eventually reintegrated into the community. In other words, the objective of rehabilitation may become more significant than it was at the time when the sentence was initially imposed. At the imposition of the sentence, the primary objective of sentencing may have been to ensure that offenders received retributive punishment". ${ }^{145}$

As for the requested State, enforcing a foreign sentence imposed on one of its nationals or residents is also strategically wise, as this is likely to be the State where in any case that person will be living after serving the sentence. ${ }^{146}$ Therefore, receiving this person immediately at the enforcement stage allows that State to orient the execution of the penalty towards his/her reintegration in the specific society of which he/she will later be again an active element. ${ }^{147}$

142 This is again a reference to the metaphor of SABINE GLESS, op. cit., p. $117 \mathrm{f}$.

143 See supra, Chap. 7, \3.3.3.

$144 \mathrm{On}$ this isse, see further infra, $\iiint_{4.2 .1 . a)}$ and 4.3.1.c).

145 UNODC, Handbook on the International Transfer of Sentenced Persons, op. cit., p. 9 f.

146 Often in result of deportation or expulsion by the sentencing State: see ibid., p. 13.

147 See Michael ABbelL, International Prisoner Transfer 2010, Leiden: Brill, 2010, p. 6, adding that foreign convicts moreover tend to experience great difficulties in obtaining consular assistance. 
All angles considered, refusing extradition for enforcement purposes whilst undertaking to enforce the foreign sentence, and allowing extradition for prosecution purposes whilst requiring the return of the person to serve the sentence, ensures a fairly optimal balance between the conflicting interests. In fact, the state of affairs in interstate cooperation in the modality of transfer of prisoners suggests that steering the execution of sentences towards the States with which individuals have closer personal ties not only is not significantly detrimental to the interests of sentencing States, but often is even beneficial according to other variables, notably financial. As is apparent, these transfers allow sentencing States to spare resources: not only does the enforcement of any sentence carry costs, but also these costs are reportedly higher when the convict is a foreigner or a nonresident, as this raises specific administrative challenges, such as the necessity to hire or train staff who speak the languages of these inmates, and to adapt certain prison procedures to their cultural idiosyncrasies. ${ }^{148}$ But the issue is not financial only. The issue is not the money spent in the enforcement, but the fact that it does not constitute an investment' later to be returned to that society, because as noted above this society is often not the one where the convict will later be reintegrated. Furthermore, transferring such convicts reduces the chance that upon release they will return to, and reoffend in, the sentencing State. ${ }^{149}$

Therefore, to promote the execution of sentences in the State of nationality and/or residence of the offender is a 'win-win-win' situation from which all three vertexes of the 'extradition triangle' can draw benefits. This may help to explain why transferring prisoners has become arguably the most popular of all the 'new' forms of cooperation, as evidenced by an outstanding proliferation of related legal instruments. ${ }^{150}$

\section{c) Rebabilitation as a ground for refusing or conditioning extradition}

Refusing extradition for enforcement whilst undertaking to execute the foreign sentence, and allowing extradition for prosecution whilst requiring a guarantee that the individual will be returned to serve the sentence, is but to infuse extradition proceedings with principles typical of the cooperation mechanisms 'transfer of prisoners' and 'execution of foreign sentences'. In the first case this translates into an actual ground for refusal, since the proceedings in the requesting State are already at the enforcement stage and therefore

148 See UNODC, Handbook on the International Transfer of Sentenced Persons, op. cit., p. 15; M. CHERIF BASSIOUNI, "United States Policies and Practices on the Execution of Foreign Sentences", op. cit., p. 589, et passim; MiCHAEL ABBell, International Prisoner Transfer..., op. cit., 5 f.

149 See UNODC, Handbook on the International Transfer of Sentenced Persons, op. cit., p. 13.

150 See ibid., p. 17 f.; Michael ABBell, International Prisoner Transfer..., op. cit., 5 f. This trend is reflected in UN's activity of embodying international cooperative practice in model instruments, namely the already mentioned Model Agreement on the Transfer of Foreign Prisoners, which is so assertive as to bid States to "afford each other the widest measure of cooperation" (see \1), as well as the Model Treaty on the Transfer of Supervision of Offenders Conditionally Sentenced or Conditionally Released, and the Standard Minimum Rules for the Treatment of Prisoners. Quite symptomatic of the circumstance that this cooperation mechanism can be as much to the interest of the sentencing as to that of the other subjects concerned is the fact that, in the EU, the consent of the person to being transferred is no longer even indispensable: see Art. 6 (2) FD 2008/909/JHA, and compare e.g. with \$S 5 and (7) UN Model Agreement on the Transfer of Foreign Prisoners. 
the foreign sentence is immediately open for execution in the requested State. In the second case it takes the form of a temporary extradition followed (in the event of conviction) by an execution of foreign sentence, in what constitutes an authentic merger between extradition and execution of foreign sentences.

Such a 'return to sender' approach is not a novelty in extradition law. It was already used in the context of: (i) the temporary extradition of a person whose extradition is unconditionally admissible but the requested State is itself conducting a criminal procedure or enforcing a sentence against that person for acts other than those for which extradition is requested; ${ }^{151}$ (ii) and, in the end, of all other cases where the requested State grants extradition but requires the requesting State to comply with certain conditions, such as that not to inflict a given penalty (notably death), or that not to prosecute acts other than those for which extradition has been granted (specialty). ${ }^{152}$

The first manifestation of this idea may have appeared in the Netherlands, through an amendment of its Extradition Act in $1986 .{ }^{153}$ It is also present in the UN Model Treaty on Extradition as updated in $1997 .{ }^{154}$ It can also be found in such legal instruments as the 2000 UN Convention on Transnational Organised Crime ${ }^{155}$ and the 2003 UN Convention Against Corruption. ${ }^{156}$ However, in all these instruments the approach was limited to nationals. It did not apply to other types of subjects such as residents, making it more of a spinoff of the classic nationality exception - vi\% a counterbalance for the rupture of the absolute character of a traditionally much cherished principle not to extradite nationals -, than a fully-grown rehabilitation exception. ${ }^{157}$ Effecting a clear axiological division between the classic nationality exception and rehabilitation concerns seems to be an innovation to

151 See e.g. Art. 12 UN Model Treaty on Extradition.

152 See shortly below, $\int 3.5 .1$. On the use of guarantees in extradition law more generally, see further infra, $\left.\int 5.1 .2 . \mathrm{b}\right)$.

153 See D. J. M. W. PARIDAens, "The Extradition of Nationals According to Dutch Law", RIDP 62 (1991), p. 515 f., informing that this amendment was effected in the aftermath of the 1983 revision of the Constitution, where the absolute prohibition to extradite nationals was eliminated. The mentioned amendment of the Extradition Act (Art. 4 (2)) was effected in 10 September 1986 and entered into force in 1 January 1988: see http://wetten.overheid.nl/BWBR0002559/2017-03-01/0/HoofdstukII/Artikel4/informatie, last accessed 13 February 2018.

154 See footnote to Art. 4 (a).

155 See Art. 16 (11) and (12).

156 See Art. 44 (12) and (13).

157 Evidence of this is found e.g. in BERT SWART, "Extradition", in Bert Swart / André Klip (eds.), op. cit., p. 107 f., where, regarding Art. 4 (2) Dutch Extradition Act introduced in the mentioned 1986 amendment, the author posits that: "In linking extradition of nationals for the purpose of facing trial elsewhere to transfer of enforcement of criminal judgements the Extradition Act aims to eliminate one of the main objections which traditionally existed in the Netherlands to extraditing nationals: the belief that sanctions consisting of deprivation of liberty are normally best executed in the state where the offender has his social roots" (emphases added). And: "the Act represents an attempt to take an intermediate position between common law systems and civil law systems" (id.). On a more empirical note, which appears interesting to share, the author (writing in 1997, around a decade after the amendment) adds: "On the whole" the system "seems to function well". Another example is ZsuZSANnA DEEN-RACSMÁNY, "Modernizing the Nationality Exception: Is the Non-extradition of Residents a Better Rule?", NJIL 75 (2006), p. 29 f. On the other hand, according to the author, in legal literature, the idea of extraditing for prosecution under a guarantee of return for enforcement can be traced back at least to H. F. van Panhuys (1961), also in the Netherlands. 
be credited to the FD-EAW, where on the one hand a classic nationality exception is not provided for, and on the other hand refusal or conditioning of extradition due to rehabilitation considerations applies to nationals and residents alike. ${ }^{158}$ The 'rehabilitation exception', however, has not become widespread. Both national legal systems assessed in Part III illustrate this, as none of them has adopted a similar approach, except insofar as concerns the FD-EAW scheme itself, and some occasional manifestations of that concept in the context of classic extradition. ${ }^{159}$

But even where it takes the form of a spinoff of the classic nationality exception, this approach already marks a meaningful development: it denotes that States have begun to re-evaluate the nationality exception in its foundations and have acknowledged that, at least to a certain extent, it has become insufficient to justify refusing cooperation to the State with the strongest jurisdictional link with the acts. And in this sense the rehabilitation exception does constitute a distillation of the traditional nationality exception: a process whereby the formal elements of the nationality bond evaporate and only its substantive ones remain, in a condensed state which amounts to a qualitatively new substance. This carries two ulterior consequences at once: on the one hand, it adds enormous load to the already existing doubts as to the justification for maintaining the classic nationality exception (an issue that will be addressed later); ${ }^{160}$ on the other hand, it commands that analogous bonds be treated equally. In turn, the latter consequence unfolds into two further consequences: the more immediate one is that extradition should be refused or conditioned regarding any person who has such ties with the requested State as to allow for the presumption that this is the best place for his/her rehabilitation; the other, less immediate, is that only persons linked to the requested State by such ties should benefit from this protection, which ultimately may even exclude national citizens, if this bond only exists in its formal dimension. One example would be the case where the person had never even set foot before in the territory of the requested State and is its national only because his/her grandparents were too, and at the same time is also a national of the requesting State, plus he/she resides in this State, the only reason for him/her to seek protection by a rehabilitation exception being an intent to benefit from more advantageous conditions of execution of the penalty.

The following conclusions can be derived from the foregoing analysis: (i) a rehabilitation exception is in line of principle justified; (ii) such an exception not only is not detrimental to, but is in fact generally advantageous to all parties involved, including the re-

158 As was already observed supra, Chap. 4, \ 2.4.4.a)(i), and Chap. 6, \ 4.1.

${ }^{159}$ Regarding the UK, the forum bar is again an example, but the person's connections with the UK are only one among several factors to be pondered; other examples are the humanitarian clause and the human rights clause, but here too rehabilitation concerns do not have conceptual autonomy and thus will only be relevant in specific circumstances. As for Portugal, rehabilitation concerns might surface in context of the humanitarian clause, but only rarely and in any case not autonomously either, as well as in the context of exceptional deviations from the rule of non-extradition of nationals, which must be conditioned to the return of the person for enforcement of the sentence, but in this case they function as a mere counterbalance for the mitigation of an until recently absolute prohibition to extradite nationals, in the image of the UN Model Treaty on Extradition and further examples mentioned above in the text.

160 See infra, \4.3.1. 
questing State; (iii) such an exception should apply to any person who has strong factual connections with the requested State which indicate that this is the best place for his/her rehabilitation; (iv) such an exception is justified even if a classic nationality exception is in place, precisely because it covers persons other than nationals; (v) but such an exception does add weight to the argument that the classic nationality exception has fragile foundations in today's world; (vi) if the classic nationality exception were abolished, a national might even, in certain cases, not benefit from the protection of the rehabilitation exception, if the bond of nationality does not translate into a substantial connection with the requested State and/or the requesting State is an adequate place to pursue rehabilitation; (vii) thus, the rehabilitation exception should be configured through the use of undetermined concepts expressing substantial, rather than formal, ties of the person with the requested State, so that this State can evaluate in each case whether there are indeed rehabilitation considerations that justify enforcing the penalty there rather than in the requesting State.

\section{d) Some nuances}

Naturally, there are differences between transfer of prisoners as an autonomous cooperation mechanism, and a transfer of prisoners required by the requested State as a precondition for granting extradition or a plain refusal of extradition requested for enforcement. In an actual transfer of prisoners the sentencing State must explicitly agree to transfer the person. That is, even if, for the reasons observed above, the sentencing State itself has in the abstract an interest in forwarding the enforcement of the sentence to another State, in certain concrete cases this may not hold true. And whereas in an actual transfer of prisoners the sentencing State can uphold its interests, in the rehabilitation exception to extradition it is another State (sc. the requested State) that will be making the call. The very fact that another State is requesting the extradition of that person already indicates that the case bears an above-minimum interest to the requesting State, because as we also saw States already usually refrain from requesting extradition for low-relevance cases, and in any case this is in itself a ground for refusing extradition. ${ }^{161}$

On the other hand, the execution of a foreign sentence tends not to be automatic, but instead is generally subject to adaptation by the administering State, through a procedure known as 'exequatur', which is a unilateral procedure. ${ }^{162}$ Thus, as noted earlier, in the execution of a foreign sentence much can still be lost in terms of justice as conceived by the sentencing State. This is in fact one of the reasons adduced earlier in support of the claim that extradition remains the primary cooperation mechanism. ${ }^{163}$ Admitting a rehabilitation exception is, therefore, a deviation from that principle. A warranted deviation, and one that, all things considered, can still be considered a low price to pay by the requesting State for being enabled to pass its own justice on the acts and have its own sentence applied by another State. But it is a deviation, and therefore it must be addressed.

161 See supra, \3.2.1., and further supra, Chap. 6, \2.2.1.

162 See Michat PŁachta, "Human Rights Aspects of the Prisoner Transfer...” op. cit., p. 1075 f.

163 See supra, Chap. 1, \$ 3.4 . 
The proper context to address that issue is the exequatur procedure indicated above, which could only be done properly in a study specifically dedicated to the transfer of foreign sentences. In any case, it is hereby posited that the principles defended in the theoretical framework of this study, although developed in view of extradition, can be applied with few adaptations to that cooperation mechanism, as well as to others. Here too there seems to exist an imbalance between the requested and the requesting State, whereby the latter is not credited the primacy it would deserve according to a neutral evaluation that takes into account the link between the acts and the legal systems at issue. Consequently, the conditions to which those cooperation mechanisms are subordinated also seem to be set by reference to the entire legal system of the requested State, rather than limited to the part of it which expresses core values of this State (its criminal justice ethos). Thus, for instance, a State that does not apply life imprisonment would certainly not apply such a penalty on behalf of another State. ${ }^{164}$ In the same way as the conditions for extraditing could be reformed in favour of the requesting State up to the point where that becomes intolerable to the requested State, the conditions for executing a foreign sentence could be reformed along the same lines. The notion of extradition as the 'primary' cooperation mechanism means not only that it will often take precedence over other mechanisms, but also that in certain aspects it will set standards applicable to them: as already noted, if extradition is the mechanism that tends to have a greater impact on individuals, other mechanisms can be safely adjusted up to the point which is deemed acceptable for extradition.

However, extradition does not require the cooperating State to exert its own ius puniendi, and therefore it may admit certain adjustments which would not be acceptable for other mechanisms. It is therefore understandable that the execution of a foreign sentence should abide essentially by the concepts of the State carrying out such an execution, based on the principle locus regit actum (which in the end is still a manifestation of the principle of territoriality, only procedural rather than substantive). Another reason to enforce the sentence according to the concepts of the executing State is the fact that it is in its community that the convict will in principle be later reintegrated. Still, it should be possible to create further room for respecting the concepts of the sentencing State, rather than, as is currently done, applying one's own lock, stock, and barrel. ${ }^{165}$

\section{e) Articulation with relevance (proportionality stricto sensu)}

Finally, it is recalled that, if the person whose extradition is requested is a national, a resident or another person who is well-integrated in the requested State, and the acts in question, albeit fulfilling the minimum threshold for extraditing, are still relatively unim-

\footnotetext{
${ }^{164}$ In fact, in this case there does not even exist a possibility of rehabilitation, because that penalty denies the very idea of rehabilitation (which is precisely the core argument of the ECtHR in Vinter and Trabelsi, and the basis of its 'right to hope doctrine'), and therefore that State would probably only accept to extradite the person, even temporarily, already under a guarantee of non-application of that penalty. It does nevertheless serve as an example.

165 The question as to whether it is possible to carry out the enforcement of a foreign sentence for acts that a State does not criminalise will be specifically addressed infra, $\int$ 4.1.1.d)(iii), since discussing this specific issue is a necessary implication of the proposals made in this study in respect of the dual criminality rule.
} 
portant, the case will often be better dealt with through a delegation of proceedings than through extradition. As already noted in the section on the ground for refusal 'relevance', delegation of proceedings prevents the displacement of the person even during the criminal procedure (rather than only during enforcement), and, since the acts have but a midlow relevance to the requesting State, extradition may be unnecessary to satisfy the criminal justice concerns of this State. ${ }^{166}$

\subsection{Grounds for refusal related to the improper use of the extradition pro- cess by the requesting State}

\subsubsection{Specialty (or speciality)}

\section{a) Aprecondition of extradition}

So long as there are grounds for refusal of extradition, the rule of specialty will exist. Without it, grounds for refusal would become completely deprived of efficacy, since the requesting State could act without any constraints after obtaining extradition, as if the person had always been in its custody. Quite simply, the function of the specialty rule is to protect the function of other rules, and therefore it is as important as those rules are. Or, in a reverse phrasing, grounds for refusal of extradition "are only as strong as the extent to which the principle of specialty is observed". ${ }^{167}$

The constraining effects of the specialty rule are not indispensable for each and every ground for refusal, but they are extensive, covering such grounds for refusal as dual criminality, lapse of time, ne bis in idem, political offence exception, applicability of certain penalties and ill-treatment. ${ }^{168}$ Even the efficacy of grounds for refusal more immediately related to the status of the person than to the character of the acts or to the penalty, such as the nationality exception and international immunities, may depend on the proper functioning of the specialty rule, as these might not apply in relation to certain acts but apply in relation to others. The influence of specialty is so wide-ranging that this rule emerges as a true guarantor of the extradition procedure as a whole, and of the concept of extradition itself. This is clear when one considers the event that the requesting State prosecutes acts that are not mentioned in the extradition request at all, and even more blatantly so when one considers acts that were mentioned in the request and for which extradition has been explicitly refused. Without the specialty rule, it would be superfluous for a requested State to even carry out a procedure aimed at assessing whether the conditions (whichever they might be) are met for extradition to be granted. The specialty rule, therefore, is not only a fundamental principle of extradition law, but the condition of all other extradition conditions - a precondition of extradition.

166 See supra, \3.2.1.b).

167 Gavan Griffith / Claire Harris, "Recent Developments in the Law of Extradition", MelbJIL 6 (2005), p. 51.

168 Suppose e.g. that the offence unmentioned in the extradition request, or mentioned but in respect of which extradition is rejected, carries the probable confinement of the person in a high-security facility that does not satisfy human rights standards on prison conditions. 


\section{b) A limit on the requesting State's jurisdiction to adjudicate}

The natural addressee of the specialty rule is the State that obtains extradition; not that which grants it. As noted, the very concept of extradition presupposes that only the adjudication of the acts indicated in the request, which are the ones in view of which the decision to extradite was taken, be permitted to the recipient State. Extradition transfers in full the custody of the person (jurisdiction in personam), since evidently the person cannot be split, but only to the extent specified in the extradition request does it enable the adjudication of acts committed by that person. It constrains the jurisdiction to adjudicate of the recipient State, and it is this State that has the responsibility not to use exorbitantly its thus delimited jurisdiction. In this sense, specialty is less an extradition rule than a rule of substantive criminal law. That is why it is often not configured in such terms as to enable the requested State to refuse extradition (based on a risk assessment of breach), but is always configured as a command to be observed by the State that obtains extradition. ${ }^{169}$

\section{c) Specialty as a buman right?}

There would be credible reasons to address the specialty rule from a human rights angle - in the context of fair trial rights, more specifically of the right to be informed of the charges and of the principle audi alteram partem, both enshrined in the ECHR. ${ }^{170}$ As far as regards the matters at issue in this study, human rights, like the specialty rule, also have as their primary addressees States conducting criminal, rather than extradition proceedings. However, since Soering that the principle has been settled that the efficacy of human rights can be anticipated immediately to the moment of granting extradition. ${ }^{171}$ As far as concerns acts or offences ${ }^{172}$ unmentioned in the extradition request, a breach of specialty carries - and it carries necessarily - a posthumous frustration of the right to a fair extradition procedure, in that it means that the extradited person was denied the chance to defend him/herself against extradition for those acts. Hence, although it is not fully clear which (and the extent to which) human rights conceived originally for criminal proceedings are applicable to extradition proceedings, the human rights 'resonance' of the specialty rule could be sufficiently intense to bring it within the artificial, intentionally wide concept of 'grounds for refusal imposed by human rights' adopted in this study, which would dismiss it from further reflection in the present chapter.

However, even limiting the analysis to the right to a fair trial, and also leaving aside the circumstance that it constitutes a merely relative human right, there is a fundamental difference between a breach of that right within the very criminal procedure taking place in the State which obtained extradition, and a retrospective breach of that right in the extradition procedure that took place in the State which granted extradition: the latter breach also results from that criminal procedure, namely from the fact that it covers acts that had

169 But see further infra, \e), on specialty as an actual ground for refusal to extradition.

170 See ANNA ZaÏrI, Le principe de la spécialite de l'extradition au regard des droits de l'homme, Paris: Librairie Générale de Droit et de Jurisprudence, 1992, p. 26 f., 43 f.

171 See supra, Chap. 3, e.g. $\$ 3.3$.

172 The acts may be the same but be subject to a reclassification in the requesting State after obtaining extradition, and this can be as problematic as a prosecution for additional, entirely 'new' acts. 
not been on the table in the extradition procedure, but it does not affect the criminal procedure itself, as the right to be informed of the charges and the principle audi alteram partem can still be respected in that criminal procedure. It is 'only' the extradition procedure that is posthumously affected. To be sure: when in Soering the ECtHR established that the extraditing State may in certain circumstances be held responsible for a prospective breach of a human right in the requesting State, the effects of such a breach are envisaged by the Court to materialise in the latter State. This is structurally different from upholding that the extraditing State may be held responsible for a breach which (is also carried out by the requesting State, but) materialises back in the extraditing State. Especially when in essence the human rights at issue can still be respected in the requesting State, within the criminal procedure to which the extradition procedure was but ancillary. In yet other terms: it would already be 'by proxy' that the right to be informed of the charges and the audi alteram partem principle may apply to extradition based on human rights law, and it would already be indirectly that human rights conceived for criminal proceedings may be anticipated to the moment of extraditing; thus, to conceive a possible breach of the specialty rule by the requesting State as a ground for refusal imposed by human rights law upon the requested State would be thrice derivative.

More importantly, such an understanding would not grasp the spirit of the specialty rule. While endowing it with human rights status via the right to a fair trial, it would ultimately narrow its significance (and consequently its scope) to this specific right, whereas extradition law is necessary to safeguard several other human rights as well as values of a wholly different nature, namely those forming the criminal justice ethos of the requested State. None of these is necessarily hampered in consequence of a breach of specialty: the 'new' acts might also be criminalised in the requested State, the corresponding penalty might still be acceptable in the eyes of the requested State, etc. However, theoretically, all of them can be hampered in consequence of a breach of the specialty rule. A breach of specialty carries a potential damage to virtually all the interests at stake in extradition proceedings. Thus, another line of thinking is necessary to accommodate the transversal safekeeping function of the specialty rule. ${ }^{173}$

That such a perspective would fail to grasp the essence of the specialty rule is evidenced by the fact that the most blatant modality of breach of this rule (sc. that where the requested State did mention in the request all acts and offences that it intended to prosecute, and was explicitly denied authorisation to do so by the requested State in relation to some of them) is precisely the modality in which the right to fair extradition proceedings and the audi alteram partem principle were fully respected. The core reasons justifying the specialty rule lie elsewhere entirely.

${ }^{173}$ Naturally, if the requesting State breaches human rights after obtaining extradition, that is an autonomous problem, to be addressed as such and independently of whether or not the specialty rule was complied with. A human rights breach following extradition might of course befall even though the specialty rule was fully complied with. The event that the specialty rule was not complied with arguably makes the human rights breach more outrageous in the eyes of the requested State, but does not fundamentally shift the axes of either of the problems at issue here: neither of that which concerns the breach of human rights, nor of that which concerns the breach of the specialty rule. 


\section{d) Specialty as a manifestation of the principle of non-interference}

Extradition is necessary to fulfil the duty of non-interference, as this principle prevents States from unilaterally seizing custody of individuals found in the territory of other States. ${ }^{174}$ Upon obtaining extradition of a person, States cannot exercise their adjudicative jurisdiction over acts other than those for which extradition was granted, since that would shatter the very concept of extradition. ${ }^{175}$ If the principle of non-interference requires extradition, and if without the specialty rule extradition will be deprived of any significance, then the conclusion seems to syllogistically impose itself that a breach of the specialty rule equates to a breach of the principle of non-interference. ${ }^{176}$ As such, the specialty rule has the same status under international law as the principle of non-interference. The principle of non-interference is sometimes qualified as a rule of customary international law, ${ }^{177}$ others as a general principle of international law giving rise to more specific rules of international law (also customary, or even jus cogens, as the prohibition of aggression). ${ }^{178}$ Either way, it must be complied with unless otherwise provided for in an applicable treaty provision. $^{179}$

174 See supra, Chap. 7, \3.1.2. It is not incidental that legal literature and case law often address breaches of specialty within the same conceptual framework as cases of sheer international abduction - without prejudice to the recognition that there are relevant differences between them: in the USA, for instance, criminal proceedings are in fact more likely to be ruled admissible in case of abduction than in case of breach of the specialty rule. In the synopsis of JACQUES SEMMELMAN, "The Doctrine of Specialty in the Federal Courts: Making Sense of United States v. Rauscher", VJIL 34 (1993), p. 113: "a defendant brought to the USA from abroad for prosecution, may not be prosecuted for crimes for which he has not been surrendered - except when he has not been surrendered for any crime, in which case he may be prosecuted for every crime!" The male captus bene detentus doctrine is practised only by some States, and remains very contentious. When Mossad agents abducted Eichmann from Argentina, the UN Security Council was unhesitant to uphold (by 8 votes to none, with 2 abstentions) that Israel had thereby violated the sovereignty of Argentina (Resolution 138 (1960), of 23 June); and while the approach of Israeli courts in Eichmann has served as support for case law of international criminal tribunals (notably of the ICTY in Nikolic), these have always underscored that such a doctrine is only tolerable in very specific conditions, including that the acts at issue constitute core international crimes: see WILliAm A. SCHABAS, “The Contribution of the Eichmann Trial...” op. cit., p. 683 f. This doctrine does not therefore annul the principle that non-interference prevents States from unilaterally seizing custody of individuals found in the territory of other States.

175 See supra, DS a) and b).

176 This is entirely without prejudice to the argument (made earlier, Chap. 7, \3.1.2) that a State that has custody of a person suspected of, or convicted for criminal acts committed in the territory of another State should presumably grant extradition to this State owing to the very same principle of non-interference: the fact that a State with a territorial claim should in line of principle be entitled to obtain custody of the offender by no means entails that extradition can be sidestepped.

177 See MALCOLm N. SHAw, op. cit., p. 1147, with further references.

178 See Maziar Jamnejad / Michael WoOD, op. cit., p. 358, with further references. Where those specific rules rank as jus cogens, it does however appear that this is owed more to the (concurring) breach of the principle of non-use of force in international relations: see again MALCOLM N. SHAW, op. cit., p. 1148.

${ }^{179}$ This is substantially different from the stance according to which specialty has become a customary rule on its own. Such a stance - defended chiefly by M. CHERIF BASSIOUNI, International Extradition... op. cit., p. 538, and somewhat endorsed by GAVAN GRIFFITH / CLAIRE HARRIS, op. cit., p. 50 - has been convincingly disputed by CAROLYN FORSTEIN, "Challenging Extradition: The Doctrine of Specialty in Customary International Law”, CJTL 53 (2015), p 363 f., and is, at best, very debatable. 
The 'internal affair' of the requested State which is interfered with is its extradition procedure as a whole. This encompasses all the conditions to which such a State subordinates extradition, whether established primarily in its own interest or rather in that of the person concerned, as this State has the duty or at least the prerogative to safeguard both.

\section{e) Specialty as a ground for refusal}

The possible status of specialty as a rule of customary international law entails that a State that obtains extradition must respect it even if no treaty applies which commands its applicability, but it does not necessarily entail that a State that is requested to extradite must refuse the request whenever it lacks guarantees that the requesting State will comply with this rule. That is, the possible status of specialty as a rule of customary international law does not necessarily entail that there is a correlative duty for a requested State to assess whether there is a serious risk that it will be breached by the requesting State. This is why it cannot be classified as a ground for refusal imposed upon States. ${ }^{180}$

That does not mean that States should not reserve themselves the power to refuse extradition where there is a real risk of breach, verifiable in the moment of deciding whether or not to extradite in the light of such indicators as a record of prior breaches, particularly vis-à-vis the requested State. Griffith and Harris go so far as to uphold that, if a State has not complied with the requirements of specialty, "foreign states should decline to cooperate on extradition matters with that state in the future". ${ }^{181}$ Considering the centrality of specialty to extradition law, such an intransigent attitude towards transgressing States is not entirely indefensible. However, it might be more sensible to ponder the issue on a case-by-case basis, save perhaps in the case of completely reiterated or systemic breaches. Prior breaches might not translate into an actual risk of breach in a concrete case. Refusing extradition due to that reason would bear something of a moralising tone, and have less to do with specialty than with reciprocity - although in the abstract, then again, such a classic retaliatory use of reciprocity will induce compliance with specialty. In contrast, it will constitute a tangible symptom that there is a risk of breach e.g. the event that a prosecutorial authority of the requesting State issues a public statement denoting an intentions to move proceedings for acts mentioned in the extradition request but in respect of which extradition is likely to be refused, or to be authorised but in such conditions as the non-application of certain penalties.

In contexts like the EU, where upon being extradited the person remains under an overarching, common normative setting which provides solid guarantees of enforceability of the specialty rule, there is no compelling reason for this rule to be configured as a ground for refusal. ${ }^{182}$ Even the UN model instruments do not configure it as a ground for

180 Please bear in mind that this concept - and indeed the whole concept of 'grounds for refusal imposed by international law' - is a working concept designed for the specific purposes of this reserach, and it does not equate the term 'imposition’ to jus cogens rules: see supra, Chap. 2, \$ 2.2.1., and Chap. 3, \3.

181 GaVAn GrifFith / Claire Harris, op. cit., p. 53.

182 See Art. 27 FD-EAW. In the context of the EAW, moreover, the ECJ has construed specialty in a rather flexible sense in Leymann \&Pustovarov (C-388/08 PPU), 1 December 2008. In this case the ECJ ruled that an offence is not to be considered an 'offence other than that for which the person was surrendered' if 
refusal, but simply enunciate it as a command to be observed by requesting States. ${ }^{183}$ Considering its centrality to the whole extradition system, the specialty rule should always have some influence on the decision whether or not to extradite: it simply does not make sense to extradite if already at that moment it is clear that a breach is impending. The stronger the trust between the involved States, the higher the threshold for refusing extradition on such a ground, and the more warranted to fully entrust such a risk assessment to the executive branch, rather than add it to the burden of the judicial system. ${ }^{184}$

Another important issue to consider is that as to whether extradition is being governed by a treaty that contains a provision commanding respect for the specialty rule, or rather by a treaty that does not, ${ }^{185}$ or yet to the internal law of the requested State (even if the law of the requesting State requires it to respect the specialty rule). Since the customary status of specialty is uncertain, caution advises that in the two latter cases the requested State should subordinate the possibility of extraditing to an internationally binding guarantee by the requesting State that it will comply with specialty. Even if its customary status does come to be firmly established, requiring ad hoc guarantees of compliance will still be useful to ascribe a precise scope to the rule (which as a customary rule it by definition could not have), and for truly tailoring its scope, since customary rules can be derogated or tailored interpartes. But this is already another issue, addressed subsequently.

\section{f) The scope of the rule}

While cultural and legal differences among States make the idea of a global extradition treaty a mirage, the rule of specialty has sufficient importance and appears to garner sufficient consensus in the international community for an effort to be made for agreeing upon its minimum content through a wide multilateral convention. In its basic traits specialty is quite simple: a State cannot take penal action for acts other than those regarding which extradition has been authorised. However, different approaches can be taken as to the conditions in which the rule can be waived (by the person as well as by the requesting State), the conditions in which the requested State can otherwise lawfully take penal action for those acts, and the legitimacy to raise a breach of the rule before a court. ${ }^{186}$

its constituting elements, as defined in the EAW, are later maintained in the criminal procedure in the issuing Member State (in the case, the 'new' offence would continue to be punishable with imprisonment for up to at least three years and, thus, to fall within the list of Art. 2 (2) FD). To require the consent of the executing Member State in such cases would run counter to the goal of the FD of facilitating extradition.

183 See supra, Chap. 6, \5.1.1.

184 This is another factor regarding which the political branch of the requested State can be relied upon to intercede in abnormal cases: see supra, $\int 2.3 .1$. In the UK, specialty is already a matter for the exclusive concern of the Home Secretary: see supra, Chap. 6, \$ 5.1.c). Naturally, if the likely breach of specialty is accompanied by a risk of breach of other conditions (e.g. guarantees of non-execution of death penalty), then the request can or shall also be refused on that basis; and if the judiciary is competent for the assessment of such conditions, then naturally that competence will still hold.

185 And many treaties do not, especially when they are not extradition treaties, but treaties that are wider in scope and only incidentally contain extradition provisions: see CAROLYN FORSTEIN, op. cit., p 366.

186 The latter is one of the most problematic issues arising from the undefined legal regime of this rule: see M. Cherif Bassiouni, International Extradition... op. cit., p. 579 f; CAROLYN FOrSTEIn, op. cit., p 367 f. 
In this regard, it is first of all submitted that it is reasonable for the specialty rule to cease its effects if the person has had an opportunity to leave the territory of the State at issue and did not do so within a certain time frame, or did do so but later returned voluntarily. These situations are analogous to that where a person moves to the territory of a State in a completely voluntary manner without there being any extradition request or another constraint whatsoever. In all such cases the person spontaneously submits to the punitive apparatus of that State. In fact, the latter cases may even be comparatively more unfavourable to the person, as he/she might not know that a criminal charge is impending upon him/her. In the former cases, arguably, the person should be entitled to know that there is an ulterior criminal charge against him/her, or otherwise the act of staying in, or returning to the territory of that State cannot be presumed to signify a waiver of the right to which that person was entitled not to be punished for further acts. ${ }^{187}$ On the other hand, the concept of 'voluntary stay or return' should be understood in accordance with fundamental individual rights. Suppose for instance that from a legal perspective the person is subject to no constraints whatsoever to leaving the State, but his/her health or life would be seriously jeopardised if he/she were to do so, in what would form something of a 'protracted or posthumous humanitarian exception'. This is consistent with the view of Bassiouni on the specialty rule more broadly, that through this rule the requested State "exercises a long-arm residual jurisdiction over the relator."188

The willingness of the person to submit to the punitive power of the State may also express itself through a waiver of the specialty rule. As we saw earlier, consenting to being extradited and waiving the specialty rule may not be unconditional prerogatives of its individual beneficiary, since the requested State might still find it imperative to uphold grounds for refusal protecting interests of which it is a holder. ${ }^{189}$ However, the situation where the person consents to being extradited and/or waives such a protection may also be regarded as a voluntary submission to the punitive system of the other State, and the agreement of the requested State, consequently, as a somewhat paternalistic requirement. The fact nevertheless remains that in these cases there has been an extradition procedure, and this places the requested State in a position of responsibility not only towards the individual concerned, but also towards its own community. It is a shared responsibility (with that individual, who is him/herself relinquishing a protection to which he/she was entitled), but a responsibility nonetheless. Therefore, it is not entirely superfluous to require the agreement of the requested State. Should the person indeed desire to submit unconditionally to the punitive system of the other State, then he/she may do so by refraining to leave its territory within the set time frame, if and when such a possibility presents itself. ${ }^{190}$

\footnotetext{
${ }^{187}$ Such a right naturally does not exist in the other cases mentioned, since obviously States do not have a duty to disclose their criminal procedural strategies to suspects.

188 M. CHERIF BASSIOUNI, International Extradition ... op. cit., p. 596.

189 Supra, Chap. 6, \$ 5.1.b).

190 This may entail some procedural entropy, notably a duplication of criminal proceedings, but it seems to be the only possibility to optimise the different interests at stake.
} 
Apart from the situations (which are probably quite exceptional in practice) where the person consciously exposes him/herself to the punitive system of the other State, the agreement of the requested State will be a condition sine qua non for the derogation of the specialty rule. This follows from the absolutely pivotal character of this rule to whole extradition system. Ultimately, such an agreement compares to a posthumous decision to grant extradition for the 'new' acts or offences, with the peculiarity that the person concerned is not in the custody of the requesting State anymore. ${ }^{191}$ New extradition proceedings need to be carried out, even if they do not receive that label and are somewhat swifter than ordinary extradition proceedings. ${ }^{192} \mathrm{~A}$ decision not to authorise the new 'request' not only will prevent penal action for the respective acts or offences, but also it may entail the revocation of the first extradition decision, if the reconfigured prosecution inexorably entails the verification of a mandatory ground for refusal (e.g. death penalty).

Another issue worth addressing is that as to whether, in the event of a legal reclassification of the acts (e.g. from simple homicide into aggravated homicide), the fact alone that a higher level of (the same) penalty will become applicable is enough to trigger specialty. According to the UN Model Law on Extradition, it is. ${ }^{193}$ However, it appears that such a situation already lies beyond the spirit of the specialty rule - provided, as noted, that the reclassification does not carry the applicability of a penalty (life imprisonment, death penalty) or another type of modification that would trigger a ground for refusal in the requested State. In this regard, the stance of the ECJ in Leymann \& Pustovarov may well serve as a reference for classic extradition.

By the same token, inspiration can be drawn from the FD-EAW in respect of other cases where the agreement of the requested State need not be secured, notably where the 'new' acts or offences are not punishable by a custodial sentence or detention order. ${ }^{194}$ Although formally this would also breach the principle of specialty, such a breach can be considered sufficiently moderate in its intensity to dispel the protection conferred by that principle to both the individual concerned and the requested State. Proportionality oper-

191 On the differences between the terms in which the consent of the requested State is conceived in the UN Model Treaty and in the UN Model Law on Extradition, and appraising those differences, see supra, Chap. 8, \5.1.a).

192 This is so even in the FD-EAW, which, notwithstanding other possibilities of derogation of specialty (see further infra in the text), provides, in Art. 27 (4) S 1 , that: "A request for consent shall be submitted to the executing judicial authority, accompanied by the information mentioned in Art. 8 (1) ['Content and form of the EAW'] and a translation as referred to in Art. 8 (2)." The provision goes on to prescribe (in the image of the MTE) that: "Consent shall be given when the offence for which it is requested is itself subject to surrender in accordance with the provisions of this Framework Decision". The phrase may imply that consent operates ipso jure; but then the provision adds: "Consent shall be refused on the grounds referred to in Art. 3 [Grounds for mandatory non-execution of the EAW] and otherwise may be refused only on the grounds referred to in Art. 4 [Grounds for optional non-execution of the EAW]." Is this not in essence the same as a new EAW?

193 See supra, Chap. 6, \5.1.c), and again s. 34 (4) MLE. The MTE is less definite in this respect: as a footnote to Art. 14 (1) (a), it gives States the possibility to embrace this option, but it does not suggest that they should embrace it. The MTE is, in this aspect, more 'cooperation-friendly' than the MLE, despite the latter being more recent; and in this case the fact that the former is a blueprint for a treaty, rather than for an internal statute, does not appear to make any difference capable of explaining the divergence.

194 See Art. 27 (3) (b) FD-EAW. 
ates here to the disadvantage of the individual, somewhat reversely to what happens within the relevancy ground for refusal: ${ }^{195}$ whereas the irrelevance of the acts or of the penalty remaining to be served prevents an otherwise acceptable extradition request, the same irrelevance legitimises an otherwise unacceptable criminal procedure.

\subsubsection{Earlier extradition (or limitation on re-extradition)}

As we saw, limitations on the power to re-extradite are immanent to the specialty principle. They are an extension of this principle, in that they also express the notion that the validity of extradition is limited to the specific finalities for which it has been granted. ${ }^{196}$ Consequently, the remarks adduced above on the specialty rule apply in their essential lines to the limitations on re-extradition. Some issues do in any case require consideration.

\section{a) A manifold ground for refusal}

First of all, it is useful to clarify the functioning of limitations on re-extradition: its addressee is also the State that has obtained extradition (as in the specialty rule), but (unlike what happens in the specialty rule) the State which is ultimately encumbered by such limitations is a third State intending to take penal action against the person. A State that obtains extradition has limited powers to grant extradition to a third State, and, therefore, a limitation on re-extradition is, inherently, a limitation on (i.e. a ground for refusing) extradition. ${ }^{197}$

But a risk of re-extradition may exist already in the moment of deciding on the original extradition request. An example is the Assange case: the only publicly expressed penal claim was Sweden's (based on sexual charges), but the rumour of a possible re-extradition to the USA (based on Wikileaks' activity) hovered like a dense cloud: ${ }^{198}$ as mentioned before, although the USA never announced an indictment of Assange (its standard practice reportedly being never to confirm whether an extradition request has been issued or received until and if the person concerned is arrested), it has acknowledged that an FBI investigation is ongoing concerning the Manning leak, and in April 2017 the AttorneyGeneral stated that arresting Assange was a priority, after CIA director described WikiLeaks as a threat to USA's national security. ${ }^{199}$ Where a founded risk of re-extradition is verifiable already in the moment of granting the first extradition request, then the same

195 Assessed supra, \3.2.1.

196 See supra, Chap. 6, \5.2.

197 Which is why the UK was right to have assertively labelled this limitation as a 'bar' to the execution of a EAW. This is indeed a ground for non-execution under the FD-EAW, even though it is not included in the provisions where those grounds are contained in a supposedly exclusive manner.

${ }^{198}$ In any case, the FD-EAW limits not only the re-execution of a EAW, but also the extradition to a third State following the execution of a EAW: according to Art. 28 (4), a person who has been surrendered pursuant to a EAW "shall not be extradited to a third State without the consent of the competent authority of the Member State which surrendered the person", and such a consent shall abide by "the Conventions by which that Member State is bound, as well as [by] its domestic law" - which, then again, would require a (new) extradition decision by the Member State that initially had custody of the person.

199 See supra, Chap. 7, \3.3.3.a) 
reasons which justify the refusal of extradition in case of a likely, prospective breach of the specialty rule will apply in perfectly identical terms.

An interesting question is that as to whether the 'intermediary' State must also authorise extradition, such that re-extradition would only be possible if neither the grounds for refusal in force in the first State nor those in force in the intermediary State apply in the case. That is, that the State intending to obtain re-extradition must satisfy the substantive extradition requirements of more than one State. If the essence of the specialty rule is the idea that extradition does not transfer in full the prerogative to punish the extradited person, then requiring that the conditions in place in the intermediary State be met might be considered dispensable. However, the transfer of custody seems sufficient to trigger the responsibility of the intermediary State for the fate of the person, and therefore reextradition seems best conceived as a co-responsibility of the two States which held custody of the person.

\section{b) Scope of the rule}

Another issue concerns the scope of limitations on re-extradition. While the same remarks adduced above in respect of the specialty rule also apply here with practically no adaptations, the UN model instruments contain an eye-catching nuance in relation to the national legal systems assessed: whereas the latter limit re-extradition for any acts committed before the first extradition was effected, the former only limit re-extradition for acts other than those for which the first extradition was granted. ${ }^{200}$

It is difficult to envisage any reason why re-extradition for the same acts should be admitted without limitations. The potential for abusive and deceit is (at least) the same in both cases, as in both of them grounds for refusal might apply vis-à-vis the third State which did not apply vis-à-vis the State that obtained the first extradition. In practice, reextradition for the same acts will be a rare event, since extradition is usually granted to the State with the strongest jurisdictional claim, ${ }^{201}$ and usually this State will not relinquish such a claim in favour of another State (which only makes re-extradition for the same acts more likely to be abusive or deceitful). The fact is that the situation is theoretically possible, and as such it must be contemplated by the relevant norms.

In reality, the UN model instruments probably did not intend to make such a differentiation. Most likely, it was an inadvertent consequence of the option to regulate specialty and re-extradition in the same norm. Such an option stems from the correct premise that they are conceptually affiliated, and is laudable yet from a perspective of normative simplification. However, it seems to have neglected that the functioning of limitations on re-extradition is slightly different from that of the specialty rule, since the former ultimately projects itself upon a third State. Obviously, specialty does not prevent the State

\footnotetext{
200 See supra, Chap. 6, $\$$ 5.2. It is recalled that Art. 14 (1) MTE provides: "A person extradited under the present Treaty shall not be proceeded against, sentenced, detained, re-extradited to a third State, or subjected to any other restriction of personal liberty in the territory of the requesting State for any offence committed before surrender other than: (a) An offence for which extradition was granted." The wording of s. 34 MLE is identical.

${ }^{201}$ See supra, Chap. 6, \3.4.
} 
that obtained extradition from prosecuting or enforcing a penalty for the acts for which extradition was authorised. This is precisely what is expected from this State. However, in the case of re-extradition, in order for the same principle (sc. that according to which the validity of extradition is limited to the specific finalities for which it has been granted) to be respected, the acts for which the first extradition was granted must also be covered, as the ultimate recipient is always a State other than that in view of which the first extradition was deemed admissible. That is to say: re-extradition necessarily exceeds the scope of the authorisation contained in the first extradition.

\subsection{Grounds for refusal related to mere issues of interstate allocation of ju- risdiction}

As noted early, these norms do not fall within the concept of 'ground for refusal' or 'obstacle' to extradition adopted in this study, as they tend not to entail impunity, but rather they mainly seek to solve conflicts of jurisdiction between the requested State and the requesting State, both of which have punitive interests over the acts. For this reason, these norms were assigned secondary importance in this study, which focuses mainly on grounds for refusal that entail impunity. Nevertheless, the analysis carried out in Part III suggested that this type of norms is sometimes used for purposes other than allocating jurisdiction among competing fora, namely in the context of the EAW, where it is regarded as a mechanism of compensation for the partial abolition of dual criminality. Moreover, in an increasingly integrated world, positive conflicts of jurisdiction (including of territorial jurisdiction) become more and more normal, which in itself requires that some attention be paid to these 'grounds for refusal'.

\subsubsection{Territoriality}

As is well known, in most States the fundamental principle of jurisdiction in criminal matters is territoriality. The preponderance of this ground for jurisdiction is explained, at the substantive level, by the fact that the locus delicti is the place where punishment is more pressing, and, at the procedural level, by the fact that it is the most adequate forum for investigating and prosecuting the crime, as well as that where the probability of reaching a fair decision is higher.

In addition to those reasons, it is often argued that territoriality constitutes the basis for jurisdiction which is best suited for avoiding conflicts of jurisdiction. This notion raises no objections of principle - insofar as the modern paradigm of State sovereignty (based on territory) is concerned -, but ultimately it will be the concrete extent assigned to the rule that will determine its potential for avoiding such conflicts. As we could see in the deductive part of this study, the Portuguese legal system illustrates vividly how territoriality is at times configured much more broadly than a strict understanding of 'territory' would allow for: ${ }^{202}$ (1) In addition to extending this type of jurisdiction to offences committed aboard vessels or airplanes of Portuguese flag, on the basis of the (very common) 'territoire flottant' doctrine, it (2) adopts a very wide concept of locus delicti, whereby the of-

202 See supra, Chap. 6, \ 6.1.3. 
fence is deemed to have been committed in Portugal if that is the place where, in whole or in part, and whether in the capacity of author or of accomplice, the person acted or, in case of liability by omission, should have acted, as well as if that is the place where the result materialises; moreover, attempted offences are deemed to have been committed in Portugal if that is the place where, according to the prognostication of the offender, the result was supposed to have materialised. Furthermore, (3) the Penal Code establishes two bases of extraterritorial jurisdiction - sc. the protective principle (which encompasses offences that are harmful to specific interests of the Portuguese State), and dual nationality (i.e. the case where both the offender and the victim are Portuguese nationals) - that are not subsidiary to extradition, but instead allow Portugal to prosecute even if it receives an extradition request from the State where the offence was committed. ${ }^{203}$ Such broad configuration of territorial jurisdiction promotes positive conflicts of jurisdiction, departing significantly from the classic understanding of territoriality, which in its purest form would preclude the efficacy of foreign law over any offence committed in national territory, and of national law over any offence committed abroad. ${ }^{204}$

Meanwhile, unlike what happens in the UK, extradition norms in place in Portugal require that extradition be refused in each and every case where, according to any of the very broad criteria described above, the offence is to be considered as committed in Portugal. This ground for refusal admits no exception. Not even if the requesting State also has and it typically does - territorial jurisdiction, and not even if the most significant part of the criminal activity in question took place in the territory of this State. ${ }^{205}$

This constitutes a paradox. The reasons why a State should refuse extradition for offences committed in its specific territory are the same why territoriality in general should receive full primacy as a basis for jurisdiction. Thus, where, in the light of those very reasons, the requesting State is the one deserving of primacy (due to being the one in which most of the criminal activity occurred and/or most of the harm materialised), there is no justification for denying that State the possibility to prosecute. The conclusion must therefore be drawn that territoriality should never be conceived as a ground for refusal which admits no exceptions, because such a configuration is contradictory to the very rationale of this ground for refusal. To ensure prosecution of territorial crimes it is sufficient to have a discretionary ground for refusal enabling a case-by-case evaluation of the comparative strength of the punitive claims of the requested and requesting States. This means that this ground for refusal can simply be abolished, as territorial jurisdiction can be encompassed by a single ground for refusal concerned with concurrent jurisdiction (territorial or otherwise) between the requested and the requesting States. ${ }^{206}$ Such is the approach followed in the UN instruments on Extradition ${ }^{207}$ and in the FD-EAW, ${ }^{208}$ which conceive territoriality as an optional ground for refusal.

\footnotetext{
${ }^{203}$ In many States, this applies also to active nationality: see supra Chap. 4, § 2.4.3.b)(ii).

204 See Pedro Caeiro, Fundamento..., op. cit., p. 294 f.; INÊS FErreira LeITE, op. cit., p. 29.

205 See supra, Chap. 6, \ 6.1.2.

206 See, with regard to the UN Model Treaty, BERT SwART, "Refusal of Extradition...”, op. cit., p. 213.

207 See Art. 4 (f) Model Treaty and s. 26 (4) (b) Model Law; emphatically praising the optional character conferred to this ground for refusal in the Model Treaty, see ibid.
} 
But while this configuration is warranted in the light of the above reasons, it seems that it will become flawed if this ground for refusal is to be construed as a mechanism of compensation for the abolition of dual criminality, i.e. as a means for ensuring that a person will not be punished for acts which are criminalised in the issuing Member State but not regarded as criminal in the executing Member State. In this case, it would appear that the law should impose in absolute terms that extradition is either always or never possible to grant. Otherwise there is a risk of inequality, as it is hardly possible to justify that, the acts in question being innocuous to the executing Member State, some individuals should be spared from extradition because of that fact, and others extradited in spite of it. Thus, the EAW should probably separate those two very different types of cases. A solution could be to provide for an autonomous ground for refusal (of an optional character) concerned with allocation of jurisdiction, whilst eliminating the compensation mechanism for the absence of dual criminality, ${ }^{209}$ or maintaining such a mechanism but bestowing on it a mandatory character. In the latter case, it might be sensible to provide - as an exception to the exception - that extradition will however be possible if the perpetrator and the victim are habitual residents of the issuing Member State. This would allow to avoid 'fraudulent' situations whereby offenders take advantage of a temporary presence in a foreign jurisdictions to commit acts which are considered criminal in the community where they are normally integrated. ${ }^{210}$

Issues of inequality might also emerge if, the acts being criminalised in the requested State and this State having refused extradition due to the fact that they were committed (in whole or in part) in its territory, this State subsequently does not take any punitive action thereon. In procedural systems, such as the Portuguese, which follow a principle of mandatory prosecution, ${ }^{211}$ there is little risk that this will happen. The situation might be different in procedural systems such as that of the UK, where prosecutorial authorities enjoy broader discretion. ${ }^{212}$ These concerns are given due attention in the UN model instruments. ${ }^{213}$ The Model Treaty establishes that, where extradition is refused on the ground that the acts were committed in the requested State, this State should, if the other State so requests, take appropriate action against the person for the offence at issue. The Model Law too suggests that the refusal of extradition on this ground be limited to cases where national authorities of the requested State actually proceed with the prosecution of the offence.

208 See Art. 4 (7).

${ }^{209}$ But see the autonomous analysis of this rule carried out infra, $\int 4.1 .1$.

210 The requirement that there is a victim and that such a victim is also a habitual resident of the issuing Member State would allow to spare from extradition offenders who, albeit habitual residents of that State, commit so-called 'victimless crimes' abroad. In such cases, punishment in the State of origin could only be explained on the basis of an authoritarian notion according to which one's legal system of origin must at all times be paid reverence: on this issue, see the considerations on jurisdiction based on active nationality adduced supra, Chap. 4, \$2.4.3.b)(ii).

211 See Art. 262 (2) Code of Criminal Procedure.

212 See $\int S$ 3.1. f. Code for Crown Prosecutors.

213 See supra, Chap. 6, \$ 6.1.1. 


\subsubsection{Pending proceedings or possibility or duty to initiate proceedings}

In the light of the considerations adduced above on territorial jurisdiction, few additional remarks are necessary regarding allocation of jurisdiction more generally. If both the requested and the requesting States have jurisdiction over the acts, and both have an actual interest in prosecuting, all that remains to be settled is which of them should carry out the task. Such a decision may be complex, as it requires consideration of various factors, including the type of jurisdiction held by each State and the prospects of reaching a fair decision in each of them. Identifying these factors is a relevant exercise, but one that does not fit within the scope of this study. For our purposes it should suffice to stress that this 'ground for refusal' should be configured as optional, rather than mandatory, and that refusal of extradition on such a ground should be followed by an actual effort on the part of the requested State (at least if this is requested by the State seeking to obtain extradition) to prevent the acts in question from remaining unpunished. So long as these guidelines are observed, the ground for refusal assessed above (territoriality) can be fully absorbed by the present one. This would help to rationalise extradition systems, condensing into one single norm all the issues concerning allocation of jurisdiction between competing fora involved in the extradition procedure.

\section{Grounds for refusal abolished or mitigated in the EAW: positive candidates to be reformed}

\subsection{Grounds for refusal related to the nature or relevance of the acts}

\subsubsection{Dual criminality}

Perhaps the most emblematic ground for refusal of extradition, the dual criminality rule embodies the idea that the State where a person is found should not expose him/her to the punitive power of another State for acts that it does not criminalise, even if these were committed in the jurisdiction of the latter State. This paragraph does not address the hypothesis that the acts are not criminalised in the requesting State itself. This is a residual event in practice, because as a rule States will only request extradition for acts that constitute a crime in their legal systems, and it is a straightforward problem in theory, because if a State does request extradition for acts that it does not criminalise, then this carries a plain refusal of extradition based on the absence of its most basic premise: the existence of a crime requiring punishment. The challenging dimension of the dual criminality rule is the case where the acts constitute an offence in the requesting State and are not criminalised in the requested State.

On the other hand, except where specifically stated otherwise, this section assumes that the acts were committed or produced their effects in the requesting State, and that no part (at least no significant part) of them was committed in the requested State, as this is the archetypical extradition scenario. Nevertheless, the hypothesis where the acts were committed in the requested State is theoretically important, and therefore it is addressed in an autonomous item later in this section. 


\section{a) Rationale}

As we saw earlier, the preponderant rationale of dual criminality is to avoid the betrayal of the requested State's worldview, sense of justice, social consciousness, core values, 'criminal justice ethos'. ${ }^{214}$ In some States - of which the UK constitutes an excellent example -, this notion is blurred by the fact that the relevant date for the purpose of establishing whether the dual criminality requirement is satisfied is the date of the conduct, rather than that of the request or of the extradition decision. ${ }^{215}$ Such an approach might suggest a close link between dual criminality and the legality principle, since only this principle, in its function of magna charta liberatum, would require previous knowledge by the person of the criminal nature of his/her acts. However, this approach has proved to be quite insubstantial in the light of later developments. Thus, the UK partly relinquished dual criminality by entering the EAW scheme, which would have been virtually impossible if the rule were indeed tied to its legality principle. At the time of the implementation of the FD-EAW into the legal system of the UK, high-ranking political representatives of this State even expressed openness to the idea of a complete abolition of the rule. Quite importantly, the argumentation was based on a principle which is even more deeply engrained in that legal culture than in other legal cultures where dual criminality is not associated with nullum crimen, namely that crime is fundamentally, indeed almost entirely, a territorial issue. ${ }^{216}$

That crime is essentially a territorial issue is a notion that is embraced wholeheartedly in the theoretical framework developed above. ${ }^{217}$ As is the notion that extradition is autonomous in relation to substantive and procedural criminal law, and that consequently the principles that apply to it are not necessarily applicable to the latter. ${ }^{218}$ As was defended in that moment of the study and is now reiterated, this is manifestly the case with the legality principle. As far as the requested State is concerned, this principle has no bearing whatsoever for extradition purposes, because - and so long as - the acts in question were criminalised in the requesting State and it was in this State that they were committed or materialised. It is again stressed that what people can and cannot do is something that must be as clear as possible - defined in a previous, written, strict and certain manner -, so that they can determine their behaviour accordingly and be held liable for it. However, as of the moment that someone, being conscious or enabled to being conscious that certain acts constitute a crime in the place where they are being committed or will produce their effects, even so undertakes to commit them, there is no solid reason to confer on this person a correlative guarantee of impunity elsewhere. This means that extraditing for acts that were not criminalised in one's legal system in the moment when they were committed but were later criminalised and are criminalised at present does not

${ }^{214}$ See supra, Chap. 6, \2.1., and Chap. 7, \3.2.2.

${ }^{215}$ See supra, Chap. 6, $\$ 2.3$. The alternative approach is followed in Portugal, the other extradition system assessed in Chap. 6 (see $\ 2.2$ ), and in many other States, such as the USA or Switzerland: see M. CHERIF BASSIOUNI, International Extradition ... op. cit., p. 502.

${ }^{216}$ See supra, Chap. 6, \4 4.1.3., and Chap. 7, \3.1.

217 See supra, Chap. 7, \$3.1.

${ }^{218}$ See supra, Chap. 7, $₫$ 3.3.6. and ulterior references, and already Chap. 1, $\$ 2.2 . ;$ see yet infra, 4.2.1.a). 
constitute a retroactive application of extradition law to the acts, but an acknowledgment that extradition law is concerned only with the meaning that those acts bear in the present moment. In other words, the criminal nature of the acts in the requested State serves but as an indicator that extraditing for such acts might injure the sense of justice of its community - something of an irrebuttable ordre public norm. Thus, it is hereinafter clearly assumed that dual criminality is not required by, or grounded on the principle of legality of substantive criminal law, a view which is strongly supported by the authoritative interpretation upheld by the ECJ on this topic in Advocaten voor de Wereld. ${ }^{219}$

On the other hand, from the moment one establishes that dual criminality does not find its roots in the legality principle, the proportionality argument also deteriorates. The reason why the requested State applies such a severe measure as extradition is not a punitive claim of its own, but a punitive claim of another State. It is in the name and in the interest of this State (even though, ultimately, it also serves the interests of the requested State, given the reciprocity principle $)^{220}$ that extradition is carried out. The harshness of extradition most certainly raises proportionality concerns, namely: whether such measures as provisional arrest are indeed necessary for preventing the person from absconding or fleeing before an assessment is even made as to whether extradition should be granted; ${ }^{221}$ and - already regarding the merits of the case - whether the acts at issue are objectively relevant, ${ }^{222}$ whether the penal claim of the requesting State is adequate, ${ }^{223}$ and whether extradition is indeed necessary for the requesting State to carry out a criminal procedure. ${ }^{224}$ These are all important proportionality issues. Their focus, however, lies not on the nature of the acts.

As for reciprocity, in the light of the remarks adduced above on this concept, it can also be forthrightly dismissed that it plays a relevant role in justifying the dual criminality rule. ${ }^{225}$ The argument in favour of reciprocity - it is recalled - is that, if the acts for which extradition is requested are not criminalised in the requested State, then this State will never be in a position to request extradition for similar acts in the future, and for this reason it would refuse to cooperate in regard to such acts. The idea that reciprocity requires perfect symmetry has never credited proper weight to the fact that differences between States' criminal laws are inevitable, legitimate, normal indeed. ${ }^{226}$ The increase verified over the last decades in the necessity for States to cooperate in criminal matters only rendered this more visible. Currently, few would raise reservations to the notion that reciprocity can be fulfilled if the now requesting State undertakes to extradite in the future for acts that it does not criminalise but the now requested State does. This is still a clear form of reciprocity.

${ }^{219}$ See supra, Chap. 7, \3.3.6.b)

220 See supra, Chap. 1, \4.3., and Chap. 7, \3.1.3.

221 An aspect which is not particularly focused in this study, but on which some remarks and references are provided infra, $₫ 4.2 \cdot 1 . \mathrm{g})$.

${ }^{222}$ See supra, $\$ 3.2 .1$.

${ }^{223}$ See infra, $\ 4.2 .1$.

224 See infra, $\ 4.2 \cdot 1 . \mathrm{g})$.

225 See supra, $\$ 2.2 .2$.

226 See $i d$., and further supra, Chap. 6, $\$ 7.2 .1$. 
In sum, the following considerations assume that dual criminality is not rooted either in the legality principle, in proportionality concerns or in reciprocity issues, but in an intent to preserve the requested State's sense of justice - its criminal justice ethos.

\section{b) Scope}

One question that immediately arises when one establishes that dual criminality has no connection to the principle of legality is that as to why, then, States limit extradition to acts which they undertook to criminalise (in compliance with the requirements of that principle). ${ }^{227}$ The proposed answer is that the legality principle serves only as a criterion one among others that could perform a similar function - for determining the acts regarding which it is not harmful for the sense of justice of the requested State to deliver a person found within its community to the criminal justice system of another State.

We saw earlier that the dual criminality or formula system was developed to replace the list-of-offences or enumerative system as a method for determining the acts for which States are willing to cooperate with each other $^{228}-i$.e. for determining the concept of 'extraditable acts'. The enumerative system revealed major deficiencies, namely a tendency for becoming outdated and for omitting acts regarding which States would have been willing to cooperate but neglected to include in the list. The dual criminality system allowed such problems to be overcome, by forwarding their solution to the ever-updated internal law of the States involved, and, concomitantly, by inducing and bestowing a general and abstract character on the criterion that was implicit in the list-of-offences system - i.e. that acts which are criminalised in both States constitute acts regarding which States are willing to cooperate. The shift was therefore practical, more than conceptual. Still, it did carry in it a significant reconfiguration of States' attitude towards international cooperation: whereas the enumerative system assumed that extraditing was something of an exceptional event admissible only for acts explicitly agreed upon, the formula system presupposed that extraditing is the normal event and that it should only be departed from if the acts do not meet a certain abstract standard or criterion. This shift thus marks what can be considered the first great reform of the concept of 'extraditable acts" ${ }^{229}$ in the modern era. ${ }^{230}$

227 Whether before or after the concrete acts in question were committed is no longer relevant here. It is assumed that it suffices that they were criminalised in the moment of extraditing.

228 See again supra, Chap. 6, \$ 2.1.1. It must however be noted that not all States have effected a complete shift: "Some States require dual criminality independently of what they deem extraditable offences, while others deem the dual criminality formula sufficient without needing to add a list of extraditable offences" - M. CHERIF BASSIOUNI, International Extradition... op. cit., p. 500, and 508 f., advocating that the former is the "desirable" approach. See also, SHARON A. Williams, op. cit., p. $299 \mathrm{f}$.

229 The transition (recommended by the $10^{\text {th }}$ International Congress of Penal Law of the AIDP, held in Rome in 1969: see M. CHERIF BASSIOUNI, International Extradition... op. cit., p. 501) from the in abstracto approach to dual criminality (which required semantic identity of offences) to the in concreto approach (which considered sufficient that the acts, however labelled, constitute an offence in both States) marks what can be considered the second great reform of the concept of 'extraditable acts'; or the first great reform of the concept of 'dual criminality'.

${ }^{230}$ Aside, of course, the shift from political to ordinary criminality, which is one of the most symbolic changes of the transition from the pre-modern to the modern era: see supra, Chap. $7, \int 2.2 .3$. 
The criterion that was elected was the criminal nature of the acts. As stated, such a criterion was already implicit in the list-of-offences system. However, it is interesting to note that the list-of-offences system did not necessarily entail that the acts would constitute an offence in both States. It can be assumed that this was the guideline presiding the enumeration of acts (hence the label 'list-of-offences'), but nothing intrinsic to this method guaranteed that this would be so. Even if the political entities responsible for negotiating a treaty would abide scrupulously by a policy only to include in extradition treaties acts that constituted offences in their legal systems, those acts might later be decriminalised, while the obligation to extradite stemming from the treaty would remain. That is, in theory, and unless the clause rebus sic stantibus could be raised, ${ }^{231}$ the enumerative system could entail an international duty to extradite for acts that were not criminalised in the requested State. Moreover, the 'offences' listed in the treaties were in fact often not even actual offences (in the sense of Tatbestände), but general references to certain types of acts (resembling the technique used in the FD-EAW), ${ }^{232}$ and up to a certain moment did not even refer to acts, but to classes of offenders. ${ }^{233}$ Thus, in a sense, the enumerative system can be assumed to have been more flexible than the dual criminality system. ${ }^{234}$

In any case, what is more relevant to note is this: the fact that in dual criminality States found a formula to cooperate with respect to all acts that they criminalise, ${ }^{235}$ and to these only, does not necessarily mean that they were thereby rejecting downrightly the idea of cooperating with respect to all other acts. The shift from the enumerative system to the formula system was driven by an 'expansionist' mentality, rather than by a 'protective' or 'defensive' one. It was, as we saw, more committed to overcoming the obstacles to cooperation arising from the enumerative system than to creating obstacles to cooperation. In a word, the fact that States acknowledged that all the acts that they criminalise constitute acts in respect of which they are willing to cooperate does not entail that they would only be willing to cooperate in respect of such acts. Evidence of this arrived with the partial abolition of dual criminality in such contexts as Nordic and EU cooperation, as well as, although far more moderately, in the Mercosur. ${ }^{236}$ This suggests that, as far as the dual

231 On this exception to the principle pacta sunt servanda, see e.g. HERSCH LAUTERPACHT, The Function of Law in the International Community, Oxford: University Press, 1933 (ed. 2011), p. 280 f.; EMMANUEL DECAUX, La Réciprocité en Droit International, Paris: R. Pichon et R. Durant-Auzias, 1980, p. 207 f.

232 See e.g. the 1853 Extradition Treaty between Bavaria and the USA, which contemplated "murder, or assault with intent to commit murder, or piracy, or arson, or robbery, or forgery, or the utterance of forged papers, or the fabrication or circulation of counterfeit money, whether coin or paper money, or the embezzlement of public moneys" (Art. I), in http://avalon.law.yale.edu/.

233 See e.g. the 1765 Extradition Treaty between the Duchy of Württemberg and France, which contemplated "robbers, wrongdoers, thieves, arsonists, murderers, assassins, vagabonds" and "deserters" (Art. I), in Georg Friedrich Martens, Recueil des Principaux Traités d'Alliance, de Paix, de Trêve, de Neutralité, de commerce, de limites, d'échange etc. conclus par les Puissances de l'Europe tant entre elles qu'avec les Puissances et États dans d'autres parties du Monde : Depuis 1761 jusqu'à présent, Tome VI, Suplémments et continuation jusqu'aux préliminaires de Leoben 1797, Gottingen: Dieterich, 1800, p. 43.

234 Naturally, this must be understood in the light of the stage of development of criminal law, and particularly of legality principle.

235 This is excluding specific exceptions to extradition concerned with the (political, military, fiscal) nature of the acts, which have specific and autonomous rationales.

236 See supra, Chap. 2, \$ 3.1.1. and 3.1.2. 
criminality rule is concerned, the mismatch between scope and rationale is perhaps indeed a design flaw, and not just a supervening event resulting from the changes in factual conditions occurred over the past centuries.

The question that still requires an answer is: in respect of which of the acts that are not criminalised in the requested State is extraditing damaging to its sense of justice? Neither in the NAW nor in the EAW is it clear what the criterion is. In the NAW, dual criminality has been abolished in practically absolute terms, such that no line is drawn at all between different categories of acts. In the EAW, the set of acts regarding which dual criminality has been abolished ranges from acts whose criminal nature gathers virtually absolute consensus to acts that spark very disparate sentiments among Member States (suffice to recall euthanasia), and all the while it has been maintained regarding an indeterminate set of acts that may fall within either of those two, or in yet other categories. As for the MAW, it modestly exempts from dual criminality the acts that have been criminalised pursuant to international legal instruments ratified by the States in question, which does constitute an intelligible criterion, but not a self-standing one, in that it forwards the solution of the problem to exogenous sources which moreover are applicable only to specific types of criminality. ${ }^{237}$

\section{c) Optimisation}

The theoretical framework developed above provides a basis to draw a line between acts regarding which the requested State may be willing to cooperate even though it does not criminalise them, and acts regarding which that would be intolerable. To recapitulate, the propositions posited in that theoretical framework apply to this ground for refusal in the following terms. In view of increased levels of mobility and remote criminal capacity, the concepts of crime in force in the State where the acts were committed deserve further primacy over those in force in the State where the person is located. Even assuming that, in the historical moment when the dual criminality formula was developed, its scope was as broad as it needed to be in order to protect the 'criminal justice ethos' of the requested State, the drastic change in circumstances verified later ineluctably compressed that ethos. This is because the easier it is for a person to commit a crime in one State and flee to another State, the more imperative it will be to assist the former State in upholding its concepts of crime, and the less shocking it will be for the community of the latter State to extradite that person for acts that it does not itself deem criminal. ${ }^{238}$ To provide assistance in such cases is also the course of action which is most consistent with non-interference,

237 The UNODC, "Revised Manuals..", op. cit., p. 8 f., exhorts States to pay attention to their international obligations when concluding treaties or enacting legislation on extradition, particularly wide multilateral treaties that establish minimum common standards of the international community. This approach already indicated by BERT SWART, "Human Rights...”, op. cit., p. 251, drawing inspiration on the $1970 \mathrm{CoE}$ Convention on the International Validity of Criminal Judgments (Art. 6 [(d)]), and by LECH GARDOCKI, op. cit., p. 293 - does have the potential to serve as a baseline among contracting States, but the discretion enjoyed by States in their implementation at national level will inevitably produce differences - as BERT SWART, "Human Rights...", op. cit., p. 253 also notes -, and these may be sufficient to hinder the fulfillment of dual criminality.

238 See supra, Chap. 7, ss 3.1.1. and 3.2.2. 
understood as a principle which not only prevents States from acting in a certain manner, but also requires them to act in a certain manner. ${ }^{239-240}$ However, the primacy of the locus delicti is not unconditional, because it is unreasonable to expect and require States to cooperate to such an extent as to jeopardise their core values. ${ }^{241}$ Thus, a perspective according to which dual criminality should simply be abolished is rejected. The path to be pursued is instead that of its optimisation. Before applying the optimisation methods indicated in the theoretical framework, some alternative propositions are critically analysed.

\section{d) Appraisal of alternative approaches}

The idea that dual criminality could and should be reformed is far from new. Several authors have argued that its scope is excessive and should be condensed. The following lines present some of the main possibilities of reform available.

First of all, it has been suggested that dual criminality (together with other grounds for refusal) could be replaced by one single ordre public clause. Underlying this position are principles fundamentally identical to those defended in this study - sc. that dual criminality is aimed, first and foremost, at protecting the sense of justice of the requested State, and that, accordingly, its scope can be narrowed down to the extent of that concept. Bassiouni concedes that dual criminality and/or lists-of-offences could be replaced by refusals to extradite based on "public policy grounds", but contends that such a policy issue "should not be left to the determination of individual states, because its conflict-creating potential is sufficient to make it a question of international concern". ${ }^{242}$ In this regard, the position already upheld above is reiterated here, that, while the existence of wide-ranging legally prescribed grounds for refusal certainly offers great political and diplomatic malleability in handling concrete cases, it also represents a missed opportunity to develop international cooperation. ${ }^{243}$ An inelastic point seems to have been reached whereby States need to become tougher in their bilateral relations if international cooperation is to progress. And if international cooperation does not progress, national criminal justice systems may be unable to combat criminality, which is increasingly transnational. Therefore, the reservation posited by Bassiouni is not followed here, although it is believed to be duly accommodated by the criterion proposed here for reforming dual criminality.

One possibility of reform that is immediately dismissed is that according to which dual criminality could be considered satisfied whenever the 'legal good' or 'legal interest' at issue receives protection in the criminal law of the requested State - in what Gardocki calls "dual criminality in genere". ${ }^{244}$ According to this approach, dual criminality would be satisfied whenever the acts at issue affected human life, physical integrity, honour, property, etc. However, it is apparent that this criterion is unable to capture disparities in the

239 See supra, Chap. $7, \int 3.1 .2$.

240 These factors are then bound together by the aggregating role played by the principle of reciprocity: see supra, Chap. 7, \3.1.3, and further supra, Chap. 1, \4.3.

241 See supra, Chap. 7, Js 3.2 .

242 M. CHERIF BASSIOUNI, International Extradition... op. cit., p. 513.

243 See supra, $₫ 2.1 .3$.

244 LECH GARDOCKI, op. cit., p. 291. 
sense of justice of different communities. Indeed, those concepts can bear very diverse meanings in different legal systems, ${ }^{245}$ and express very different worldviews. In fact, it is in the details that such differences typically lie: for instance, all States will have offences aimed at protecting human life, but some States and some States only do not criminalise such acts as euthanasia; similarly, all States will have offences concerned with the protection of intrauterine life, but in some States and in some States only is voluntary abortion not criminalised.

Another idea - mentioned by Lagodny - is to 'demote' or 'downgrade' dual criminality into 'dual prohibition': the disapproval of the acts by the requested State needs not be criminal in nature, but instead that State would still be able to extradite if the acts are unlawful under its administrative law. ${ }^{246}$ Sometimes, the frontier separating administrative and criminal offences is so tenuous that the difference between them seems to lie on the single circumstance that the latter can lead to deprivation of liberty and the former cannot. ${ }^{247}$ Good examples are the cases where that frontier is set on the basis of quantitative elements, such as a pecuniary sum (e.g. in tax offences) or percentage of a given substance in the blood by weight (e.g. in road traffic offences). In this light, the concept of administrative unlawfulness would appear to constitute a good indicator of the social consciousness of a community. All the more so if - as Swart posits - one were to restrict, for these purposes, the concept of administrative offence to acts that are sanctioned with 'deterrent and punitive' legal consequences that are nearly comparable to those typical of criminal law. ${ }^{248}$ However, administrative and criminal offences are very different at the axiological level. Even where their frontier is somewhat superficial, the underpinning distinction is profound. ${ }^{249}$ This manifests itself in numerous ways. Thus, administrative law does establish as unlawful some acts which would be appalling for a given community to punish with deprivation of liberty. For instance, and to use as examples the fields of activity mentioned above: it is likely to be incomprehensible for a community to punish criminally a parking violation, or a tax fraud amounting to a derisory pecuniary sum. On the other hand, the law (criminal or administrative) of the requested State might not prescribe certain acts as unlawful due only to certain factual particularities, such as its geographical or economic characteristics, ${ }^{250}$ but nevertheless be understanding as to why they are criminalised in another State with different characteristics. For instance, a State with no coast-

245 As LECH GARDOCKI, op. cit., p. 291, also argues.

246 See OTTO Lagodny, "Possible ways to reduce the double criminality requirement: From double criminality to double prohibition", Report of the CoE Committee of Experts on Transnational Criminal Justice, PC-TJ/Docs 2005/PC-TJ, 2005, in www.coe.int/tcj/.

247 See Nuno Brandão, Crimes e Contra-Ordenações: da Cisão à Convergência Material - Ensaio para uma Recompreensão da Relação entre o Direito Penal e o Direito Contra-Ordenacional, Coimbra: Coimbra Editora, 2016, p. 401 f., 565 f. and, esp., p. 809 f.

248 See BERT SWART, “Human Rights...”, op. cit., p. 254 f., supported on ECtHR, Öztürk, no. 8544/79, 21 February 1984, on the 1970 CoE Convention on the International Validity of Criminal Judgments, and on bilateral supplementary agreements concluded by Germany with other then State parties to the European Convention on Extradition concerning extradition for Ordnungswidrigkeiten.

${ }^{249}$ See Nuno Brandão, op. cit., p. 70 f., 259 f.; Jorge de Figueiredo Dias, Direito Penal. Parte Geral. Tomo I... op. cit., p. $144 \mathrm{f}$.

${ }^{250}$ Factors also mentioned by BERT SwART, “Human Rights...”, op. cit., p. 252. 
line and no tradition in fishing activities might never have felt the need to threaten with a sanction of any kind acts which are damaging to fishing resources; similarly, certain types of economic activity might be extremely damaging when conducted in a given economic setting, but rather unremarkable when conducted in a different one; also, a State where military service is not mandatory will have no associated sanction of any kind, whereas a refusal to serve in the military will tend to be highly disapproved of in States inserted in delicate geopolitical contexts. Moreover, regarding certain types of conduct, criminal law tends to draw a line past which the acts will constitute a criminal offence, but up to which they have no unlawful character at all. ${ }^{251}$ An example would be consensual sexual practices with individuals who have not reached a certain age: below such an age the acts will be criminally punishable, but above it they will trigger no liability of any kind, because then they will even correspond to the legitimate exercise of a personal right (to sexual selfdetermination) by the otherwise victim of a crime. Thus, administrative law is inept to capture the essence of the dual criminality problem. The same applies even more clearly to other areas of the law, such as torts, which do not even seek primarily to perform punitive functions concerned with the welfare of a community as a whole, but to compensate damages caused by one private subject to another private subject.

Decidedly, only a concept emerging from the axiological setting of criminal law can provide a yardstick for determining the cases in which international cooperation in criminal matters is justified. For reasons abundantly expounded in this study, such a concept is that of ordre public - or, as was suggested in order to distinguish the sets of values at issue in private international law and in criminal law, of 'criminal justice ethos'.

\section{e) Overlapping grounds for refusal}

Dual criminality is one of those grounds for refusal that has been partly absorbed by supervening grounds for refusal brought about by the advent of individual and human rights in international law. Not that there be a human right according to which States can only grant extradition for acts they criminalise. ${ }^{252}$ That a deprivation of liberty effected in the context and for the purposes of an extradition request does not require the acts at issue to constitute a crime in the requested State results immediately from the distinction between extradition and substantive and procedural criminal law, and is historically supported by the enactment of extradition arrangements which dispense with dual criminality in whole or in part. ${ }^{253}$

An "altogether different matter" - as Swart notes - "is that penal provisions in the law of the requesting state, or their application in specific cases, may conflict with internationally protected basic individual rights", namely where they "unduly restrict the right to private life or freedom of expression, contain presumptions of fact or of law incompatible with the presumption of innocence, violate the nullum crimen principle by being ret-

\footnotetext{
251 Save the possibility of torts liability, which is concerned with compensation and does not inherently involve the type and level of social reproach that is relevant for the purposes in discussion.

252 Openly in this sense, see also BERT SWART, "Human Rights...", op. cit., p. $250 \mathrm{f}$.

253 See supra, Chap. 2, \$ 3.1., Chap. 6, \$ 4.1.; and again Jorge DE Figueiredo Dias / Pedro CaEIRO, op. cit., p. 33.
} 
roactive, or [are] irreconcilable in other respects with human rights conventions to which the requested state is a party". These are indeed very different issues, which relate to the criminalisation of the acts in the requesting State itself. In this study, such issues are duly accommodated by the insurmountable role assigned to human rights, ${ }^{254}$ which in this case function as a 'truly international ordre public', or an 'international criminal justice ethos'. ${ }^{25}$ Thus, if a State requests extradition for an offence that criminalises only the behaviour of individuals of a certain ethnic or social origin, then the refusal of extradition is imposed immediately by the prohibition of discrimination that stems from human rights, and it is not even necessary to bring into consideration the issue as to whether or not such acts are criminalised in the requested State. In theory, it is even conceivable that such a State does criminalise the acts (when committed by any individual), and still extradition should be refused due to the discriminatory character of the offence as regulated in the legal system of the requesting State.

Therefore, some overlap does exist between dual criminality and certain basic individual rights whose protection is commanded by international law. It is, however, an incidental overlap, and, consequently, the part of the dual criminality rule that is not overlapped - which is its most essential part, because it is the one that concerns the meaning of the acts in the light of the national criminal justice values of the requested State - conserves all its autonomy and reason to exist. We can therefore now focus on the meaning of the acts in the eyes of the requested State.

\section{f) Approaching a solution: Ordinary law and constitutional law}

Swart and other authors have argued that the protection offered by dual criminality (as well as that conferred by other grounds for refusal) can be attained through the use of the concept of ordre public. ${ }^{256}$ However, the author eventually discards this approach, based on the argument that such a concept is too vague to be operative. ${ }^{257}$ Private international law shows that the concept can be put into practice despite its indeterminacy. However, it is true that in the context of extradition law, given its repressive character, a higher level of certainty is called for. As argued earlier, in this context, the level of determinacy of the concept of ordre public - or criminal justice ethos - should lie between that allowed in private international law and that required by substantive criminal law. ${ }^{258}$

Criminal justice ethos constitutes a starting point for understanding and amending the inadequacy of several extradition rules, but requires a specific exercise of adaptation to each such rule. If the application of that concept to extradition is not clearly anchored to the principle that the territorial forum deserves primacy, and that failure to respect this primacy can be conceptualised as a breach of the duty of non-interference governing in-

254 In Chap. 3, supra.

255 See supra, Chap. 7 S 3.2.3.c).

256 See ibid., p. 251 f., and already HANS-HEINRICH JESCHECK, "Die internationale Rechtshilfe in Strafsachen in Europa”, ZStW 66 (1954), p. 531 f., quoted there and also in LECH GARDOCKI, op. cit., p. 293.

257 See BERT SWART, “Human Rights...”, op. cit., p. 254. The author defends instead the 'administrative offences' approach mentioned above.

258 See supra, Chap. 7, \ 3.3.6. 
ternational law, it is indeed difficult to bestow on the concept of ordre public sufficient determinacy to render it functional. More importantly, leaving the concept excessively undetermined dodges the challenge of optimising extradition law.

The theoretical framework provided above posits assertively that: based on a neutral assessment, the (ordinary) criminal law that should apply to the acts is that of the State where they were committed or their effects materialised, which typically is the requesting State; and that, according to the principle of non-interference, assistance should be provided towards the enforcement of that law unless this is absolutely intolerable to the requested State. In consequence, the values in the light of which cooperation can be considered intolerable by the requested State must be enshrined in norms that are parametrically superior to those that form its (ordinary) criminal law, as it has already been neutrally determined that these should yield before norms of the requesting State which have the same parametric rank. Therefore, the concretisation of the concept of criminal justice ethos must be made through a constitutional criterion. ${ }^{259}$

Although Swart ultimately rejects ordre public as a substitute for dual criminality, he provides valuable insight into the reasons why States criminalise different acts, a reasoning which touches implicitly upon the argument that the concept must be constitutionally grounded. He distinguishes three types of cases: (i) those where "the requested state radically disagrees with the requesting state on the desirability of criminalisation, even to the extent that what is prescribed by one state is proscribed by the other", making it "impossible for the individual to obey the laws of both countries at the same time"; (ii) those where "absence of criminalisation is due to the fact that a more liberal attitude towards such basic rights as the right to private life or freedom of speech prevails in the requested State"; ${ }^{260}$ and (iii) those where the requested State has decided not to criminalise "because disadvantages would outweigh advantages or because the law would be too difficult to enforce". The author then posits: (i) Regarding "conflicts of legislations", "individuals should not be the victims if they cannot obey the legislation of different states at the same time", and thus there is "no room for extradition here"; (ii) As for differences in 'liberalism' towards basic rights, the same applies: "Interwoven as such differences are with different national conceptions of liberty, it makes no sense to ignore them for the sake of international cooperation", as international cooperation "is not an instrument for reducing that liberty to the lowest common denominator among states": it "must serve an end legitimate in the eyes of both states concerned", which "cannot be the case if the requested state has rejected criminalisation out of respect for basic individual rights"; (iii) Concerning inconvenience', the author finds that "refusal to lend assistance is less convincing": "Of course, to criminalise certain acts always is a matter a principle and always, in one way or another, interferes with human liberty. But it is not obvious that the requested state should

259 On the meaning of the term 'constitutional' as used in this context, see supra, Chap. 7, $₫$ 3.2.3.c).

${ }^{260}$ Differences which - the author notes - may exist "even among closely related states": "For instance, there are no equivalents in the law of the United States and The Netherlands to the $\iint 90 \mathrm{a}$ and $90 \mathrm{~b}$ of the German Criminal Code, making it a crime to insult the German state or its organs, and it is not likely that there will ever be. (...) In matters of sex and morals, legislation in the United States is, generally speaking, less liberal than in Germany or The Netherlands": BERT SWART, "Human Rights...”, op. cit., p. $252 \mathrm{f}$. 
absolutely refuse co-operation if lack of criminalisation is primarily due to factual circumstances and pragmatic considerations that may vary from state to state". ${ }^{261}$

It is submitted that this still does not grasp the essence of the problem as to which acts should give rise to cooperation. Regarding the first set of situations (i), it is necessary to exclude from consideration the hypothesis where, by committing what in the eyes of the requesting State is a crime, the individual was exercising a legitimate right pursuant to the law of the requested State. This hypothesis assumes that the acts were at least in part committed in the territory of the requested State itself. Only this would enable the contention that there was a 'conflict of legislations', since otherwise the only law applicable to the acts would be that of the requesting State. Such a hypothesis is most certainly relevant, but - as already noted - it must be considered autonomously, because it is not strictly an issue of lack of dual criminality. ${ }^{262}$ Regarding the final set of situations (iii), the idea that they should not preclude cooperation merits no opposition. This is perfectly in line with the theoretical framework proposed in this study, for factual circumstances and pragmatic considerations do not express core values of the requested State. As for the intermediary class of situations (ii), the view that international cooperation should not aim at reducing individual liberty to "the lowest common denominator among states" is also subscribed to. What is disputed is the notion that cooperating in such situations would necessarily equate to a reduction of individual liberty to its lowest common denominator. There are weighty reasons for States to give different scopes to the same basic individual rights, or - which is to say the same from the perspective of criminalisation - to criminalise to different extents conduct which potentially corresponds to an exercise of one same basic individual right. To use examples provided by Swart himself, there will be historical, cultural and legal reasons for Germany to have criminalised a given range of acts involving statements about the German State or its organs, or for the USA to have criminalised a given range of acts of a sexual nature. The question is: how fundamental is the right to practice such acts in the requested State? This question is one that such a reasoning is not capable of answering, because the criminalisation of those classes of acts is not equivalent to the core content of those fundamental rights. Criminalisation is ultimately effected by the ordinary legislator of that State, based on an assessment which takes into account other factors - even if this assessment is itself bound to certain constitutional limits like the ultima ratio principle. The core content of fundamental rights does draw a line that the ordinary legislator cannot cross, but, up to that line and in respect of certain requirements, the ordinary legislator has discretion to define criminal behaviour. Therefore, that reasoning is still ultimately attached to concepts of ordinary criminal law of the requested State, rather than to its constitutional concepts, which are the only ones that have the parametric and/or axiological strength necessary to supersede the presumed primacy of the ordinary criminal law concepts of the requesting State.

261 Ibid., p. 253 f.

262 See supra, \ Chap. 6, 2.1.1., and further infra, \ 4.1.1.d)(v). 
The same problem taints an approach that the author of this study had contemplated at an early stage of its elaboration. ${ }^{263}$ The approach would consist of allowing extradition for acts that, albeit not criminalised in the requested State, this State could plausibly be expected to criminalise if its factual circumstances (social, economic, geographical, etc.) were identical to those existing in the requesting State. Leaving aside the considerations on the limited practicability of this approach, it incurs the same fault as above: it makes use of a concept which intervenes at the mere ordinary level of the normative edifice of the requested State, since the plausibility of criminalising certain acts in the light of given factual conditions depends on an assessment which constitutes a competence of the ordinary penal legislator of that State. ${ }^{264}$

The same reason precludes also the idea of subordinating the appraisal of the acts to a legislative body of the requested State (e.g. to a parliamentary commission). The decision whether or not to extradite could still remain in the hands of the judiciary and executive bodies that intervene in extradition proceedings, but the legislative power would be called upon to issue an opinion (in principle non-binding, so as to avoid meddling in other functions of the State) as to whether certain acts which are not criminalised nevertheless justify cooperating with a foreign State. ${ }^{265}$ Leaving again aside considerations on the practical viability of such an approach, as well as considerations on the complications it might raise in terms of international relations, this approach would again fail to capture the essence of the problem in debate, which is to draw a differentiation between essential and unessential criminal justice values of the requested State. ${ }^{266}$ To rely on an intervention by the ordinary legislator itself - the organ of the State competent for criminalising conduct - as a means for establishing whether extradition can be granted would constitute but a manifestation of the same basic assumption underlying dual criminality, namely that extradition should only be granted for acts that in one's own view are criminal - or, one should say in this case, 'quasi-criminal', because they are not actually criminalised. It is hereby submitted that this is not the question.

\section{g) The solution adopted: Constitutional probibition to criminalise}

The position which is adopted here is that States can extradite without jeopardising their core values up to the point where the acts in question are acts that, from a constitutional standpoint, their ordinary legislators could not criminalise. In other words, extradition

${ }^{263}$ See Miguel JoÃo COSTA, “O princípio da dupla incriminação...”, op. cit., p. 78 f.

${ }^{264}$ Evidence that this type of criterion misses the point is that, in theory, it is even possible that the acts at issue are criminalised in the requested State (thus satisfying the dual criminality principle), but would not plausibly be criminalised in this State (according to its ultima ratio principle) if its factual circumstances were identical to those existing in the requesting State.

${ }^{265}$ In general on the exercise of legislative functions by judicial entities and vice-versa (but primarily on the former), see, extensively, ANTÓNIO CASTANHEIRA Neves, O Instituto dos Assentos e a Função Jurídica dos Supremos Tribunais, Coimbra: Coimbra Editora, 1983, p. 315 f., et passim.

${ }^{266}$ Elaborating on the differences and interactions between the "political will of the governing majority" and the "constitutional majority incorporated in the Fundamental Law", see VitAL Moreira, "Princípio da maioria e princípio da constitucionalidade", in Legitimidade e Legitimação da Justiça Constitucional: Colóquio no 10. Aniversário do Tribunal Constitucional, Coimbra: Coimbra Editora, 1995, p. 179 f. 
is inadmissible, but is inadmissible only where the compression of individual rights that would result from a hypothetical criminalisation of the acts in the requested State ${ }^{267}$ could not be justified in the name of any right or interest of supra-ordinary rank in that State. ${ }^{268}$ The precise way in which the criterion may be concretised will vary from State to State, but shall revolve around such principles as the 'legal good' (Rechtsgut) or the 'harm' principles. ${ }^{269}$

Identical in its result is the approach posited by Asp, von Hirsch and Frände. ${ }^{270}$ The underpinning premises are not provided, save for the classic view that territoriality is the primary basis for jurisdiction. ${ }^{271}$ However, the authors - referring to the EAW, not to traditional extradition - ultimately hold that reintroducing the dual criminality rule would be preferable to implementing such an ordre public approach. This appears to result from the fact that the authors rely on a view according to which the concept of 'extraditable acts', although unrelated to the principle of legality, has close resonance in human rights considerations. This is denoted by their reference, in this context, to ECtHR's case law, more specifically to Soering. ${ }^{272}$ In this respect, the remarks adduced above in relation to the views of Swart apply. Underpinning the use of ordre public as proposed in this study is not a sense of "responsibility" 273 for prospective actions of the requesting State, since according to the construction used here extradition should already be barred where such actions show themselves capable - and, where that is so, because they show themselves capable - of hindering human rights. Rather, once extradition is excluded in such cases, ordre public will intervene only towards the protection of the requested State as such, i.e. of the core values of its community. On the other hand, this study posits that, in the light of the principle of non-intervention governing international law, the default normative prem-

\footnotetext{
267 Some of these rights are compressed as a direct effect of a penalty (notably, the right to liberty is inherently compressed by imprisonment), and some offences only compress these rights, since the acts at issue do not correspond to the exercise of any right, constitutional or otherwise (as is notably the case with homicide). Other offences do correspond to the exercise of certain right(s) (sometimes, of constitutional rank, such as freedom of expression) and here the criminalisation of the acts (e.g. defamation) entails, in and of itself, the compression of rights other than those which follow directly from the application of a criminal penalty.

268 Such rights or interests can be divided in each legal system into different categories, according e.g. to their aptitude to justify the compression of other rights. Thus e.g. JorgE DE FigueIredo Dias, Temas Básicos da Doutrina Penal, Coimbra: Coimbra Editora, 2001, p. $48 \mathrm{f}$. argues that, at least insofar as concerns the Portuguese legal system, a difference can be established between legal goods of personal character (generally protected by classic criminal offences found in the Criminal Code), which seek to protect the activity of human beings "as such"; and those of social or economic character (generally protected by offences found in extravagant legislation developed in a historically subsequent moment), which seek to protect the activity of human beings "as members of a community".

${ }^{269}$ On the concepts, see e.g. Claus Roxin, Derecho Penal. Parte General. Tomo I: Fundamentos. La Estructura de la Teoria del Delito, Madrid: Civitas, 1997, p. 51 f., esp. 55 f.; Jorge DE FigueIREdo Dias, Temas Básicos... p. 46 f.; NinA PERŠK, Criminalising Harmful Conduct: The Harm Principle, its Limits and Continental Counterparts, London: Springer, 2007, passim; KAI AMBOS, "The Overall Function of International Criminal Law: Striking the Right Balance Between the Rechtsgut and the Harm Principles - A Second Contribution Towards a Consistent Theory of ICL”, CL\&F 9 (2015), p. $301 \mathrm{f}$.

270 See PetTer Asp / ANDreW VOn Hirsch / DAN Frände, op. cit., p. 515 f.

271 See ibid., p. 517.

272 See ibid., p. 514.

273 Ibid.
} 
ise should be that extradition will be granted unless refusal is necessary for the requested State to ensure such a self-protection. Together, these premises entail that the classic dual criminality rule, even if is more 'practical', ${ }^{274}$ could never outweigh a well-defined ordre public approach to the concept of 'extraditable acts'.

At the organic level, the approach proposed does not entail meddling by the entities competent for deciding on extradition requests in the competences of other organs of the State. Nor does it involve casting judgement on the views of other States. ${ }^{275}$ Moreover, it must be especially stressed that it does not constitute any form of constitutionality control. It does not constitute an evaluation of the conformity of any norm with a constitution, as obviously could never be the case here, because the constitution and the relevant norms at issue here do not even belong in the same legal system. Rather, it constitutes an evaluation as to whether extraditing for certain acts would infringe certain State values (its criminal justice ethos) which happen to be enshrined in its constitution. The function assigned to the constitution in this construction is ancillary: interpretation of the constitution serves only as a point of support for the specific extradition law question of whether extradition should be granted. As such, this approach is applicable not only in the context of constitutional systems where all courts are at all times bound not to apply infra-constitutional norms that in their view infringe upon the constitution, ${ }^{276}$ but indeed in constitutional environments of all types, including those where a formal constitution and /or constitutional court does not even exist. ${ }^{277}$ The approach may fit less naturally in constitutional systems where constitutionality control is heavily concentrated in a constitutional court, but even here it is practicable, because - it is underlined one last time - what is at stake here is not an evaluation of the constitutionality of any norms, but an evaluation as to whether or not, in the light of the values enshrined in one's constitution, certain acts should or should not give rise to extradition. This means, for instance, that it would in principle be impossible, in any constitutional system, to request an intervention by a constitutional court to rule on such an issue. It also means that interpretations thus made of the constitution for extradition law purposes by the entities that decide on extradition matters would not conflict with or compromise the interpretations made by the constitutional court or another court of the same State when ruling on the same or adjacent classes of acts for national criminal law purposes. They would not conflict with or compromise the activity of that State's ordinary penal legislator either. This does not exclude that such extradition decisions spark some synergetic processes between these organs, because, in this man-

\footnotetext{
${ }^{274}$ See ibid., p. 516 f.

275 As also noted by PetTer Asp / ANDREW vON Hirsch / DAN Frände, op. cit., p. 515.

${ }^{276}$ Such is the Portuguese system, where all courts are "organs of constitutional justice": JOSÉ JOAQUIM Gomes Canotilho, Direito Constitucional... op. cit., p. 909 f.

277 And sometimes even more clearly so in such environments, as is arguably the case in the UK, where as a result of the principle of parliamentary sovereignty all norms (constitutional or otherwise) are inherently open to interpretation by all courts, and where common law as interpreted by courts can itself be "an independent locus of authority" and a source of constitutional law: MiChael Gordon, Parliamentary Sovereignty in the UK Constitution: Process, Politics and Democracy, Oxford: Hart, 2015, p. 23 f., et passim; see also MARK V. Tushnet, Weak Courts, Strong Rights: Judicial Review and Social Welfare Rights in Comparative Constitutional Law, Princeton: University Press, 2008, esp. p. 28 f.
} 
ner, case law on extradition would become another cause for the requested State to reflect on its own concepts of crime. This, however, is not tantamount to meddling.

At the pragmatic level, the application by the entities competent in extradition matters of the approach proposed here can be very challenging, ${ }^{278}$ particularly until a body of case law begins to accumulate and basic jurisprudential orientations begin to take shape. However, in implementing that approach, those entities can find abundant support in the case law of the respective constitutional court or other court invested with similar competence: either directly (when extradition is requested for acts whose criminalisation has been promoted by the ordinary legislator and ruled unconstitutional), or indirectly (since principles can be drawn from the former type of case law and applied mutatis mutandis to other types of acts). Support can moreover be found in case law, legal literature and other secondary sources concerning the scope of the criminal offences in place in that State, more specifically on the constitutional interests that they protect and the precise acts that, in that light, they can and cannot be deemed to encompass. ${ }^{279}$

\section{h) Illustrating the practical consequences of the proposed shift}

An exhaustive illustration of the acts that do not satisfy the current dual criminality rule but which would become 'extraditable' if the approach proposed here were adopted and of the acts that would remain 'unextraditable', as well as a systematisation of all those acts into different categories according to appropriate criteria, is an exercise which would not be possible to perform in this study. A fairly comprehensive set of examples is nevertheless provided below.

It is necessary to bear in mind that, in its final contours, the approach adopted here is supposed to vary from State to State in accordance with the natural differences of their legal traditions. The following illustration assumes that the requested State is a State based on the rule of law ('Rechtsstaat') and individual liberty.

\section{(i) Acts that would remain 'unextraditable'}

Starting with acts that would still not admit extradition, and using the non-exhaustive categorisation of Roxin, ${ }^{280}$ we have: (1) acts which contravene arbitrary requirements of a public authority (which the author illustrates with the tale of Wilhelm Tell and his refusal to bow before Gessler's hat); (2) acts whose criminalisation serves strictly ideological finalities (which the author illustrates with the Nazi prohibition of compromising the purity of Aryan blood ['Rassenschande'], but which encompass many other strictly ideological offences based on less reprehensible systems of thought); (3) acts which at most constitute immoralities (where the author includes certain sexual practices between adults in a consensual manner and in private); (4) acts which create or maintain inequality among hu-

${ }^{278}$ Focusing on the practical challenges raised by an approach of this character, see PETTER ASP / ANDREW VON HIRSCH / DAN FRÄNDE, op. cit., p. 516 f., convincingly downplaying some of those difficulties, but - as noted above - ultimately concluding in favour of traditional dual criminality.

${ }^{279}$ But see further infra, $\int 5.2 .2$., on pragmatic approaches that can be implemented in the field of extradition, and that would render smoother the adoption of approaches such as that proposed here.

280 See Claus Roxin, Derecho Penal... op. cit., p. 56 f. 
man beings (which the author does not illustrate, but where one may include such acts as the entrance of individuals of a certain ethnic group into given public spaces or any other offences entailing discrimination based on belief [e.g. heresy], gender [e.g. adultery, where committed by women only], etc.); and (5) an unspecified category which the author illustrates with the bare action of expressing one's opinion. ${ }^{281}$

Regarding the acts indicated in (4), in some States their criminalisation will be proscribed even if they do not display a discriminatory character (e.g. criminalisation of adultery practised by any of the elements of the conjugal relationship), since they do not protect any constitutional right or interest to begin with. In these legal systems, absence of a paramount value deemed worthy of protection will prevent criminalisation of numerous acts. An instructive example is provided by Antunes: ${ }^{282}$ the Penal and Disciplinary Code of the Portuguese Merchant Navy criminalised the act of a crew member who, without a reason, let the ship sail without embarking; ${ }^{283}$ the Constitutional Court ruled that this offence could not encompass such an act when committed by a crew member who did not have any function related to the ship's maintenance, security or equipment, since it would not even put at risk (let alone damage) any right or interest essential to life in society, namely to the 'safety of human life at sea'; the Court held that the protection of the economic activity developed by the ship, alone, was insufficient to sustain criminalisation. ${ }^{284}$

\section{(ii) Intermediate cases}

Regarding the cases indicated in item (5), we are dealing with constitutional rights that do admit compression in order to safeguard other constitutional rights or interests. Thus, freedom of speech, for instance, is generally subject to limitations as of the point where it becomes offensive e.g. to the honour of another person, or where it is used for the purpose of denying events deemed to be historically irrefutable, thereby causing harm to certain groups of people. In such cases, whether or not extradition is possible will not be as straightforward as in the above cases, but will instead require more thorough consideration of conflicting constitutional values, in accordance with the coordinates outlined above. The same applies to the compression of other rights, such as freedom of association.

Intermediate cases also include such acts as euthanasia, abortion or minor drug offences, such as the consumption of prohibited substances. Within the hypothesis that the requested State does not criminalise the acts, there will be States where absence of criminalisation is a matter of principle justified immediately at the constitutional level by the prevalence of other constitutional rights - e.g. the freedom to dispose of one's own life -,

${ }^{281}$ In some of these cases extradition would also be imposed by international law, as they hamper upon 'truly international ordre public, or 'international criminal justice ethos': see supra, $\int$ (ii).

282 MARIA Jỗo ANTUNES, “A problemática penal e o Tribunal Constitucional”, in Estudos em homenagem ao Professor Doutor José Joaquim Gomes Canotilho. Vol. I: Responsabilidade entre passado e futuro, BFDUC: Stvdia Ivridica 102 (2013), p. 102, with abundant information on further cases where the Portuguese Constitutional Court was called upon to ascertain whether certain acts could be criminalised or not.

283 See Art. 132 Decree-Law no. 33252/43, of 20 November.

284 Ruling no. 527/95, of 4 October. 
whereas in other States absence of criminalisation does not result from a recognition of the axiological preponderance of other constitutional rights, but from pragmatic considerations which intervene at the mere ordinary level - e.g. from an assessment according to which the criminalisation of those acts was being widely disregarded by the population, and generating more social harm than if the acts were decriminalised and the problem addressed through other public measures instead. In the first case, under the approach proposed, extradition would be refused (because the acts correspond to the exercise of what in the requested State would constitute an overriding constitutional right); in the second case extradition could still be granted (because the acts do not resonate in any core value of the requested State, but are simply acts that, in the light of its factual and social conditions, were deemed preferable not to criminalise).

Other intermediate cases include plane-spotting when carried out inside a military zone. ${ }^{285}$ Cases such as the Merchant Navy case, mentioned above, might also, in a slightly different constitutional environment where greater weight is ascribed to the economic interests of the State, receive a different evaluation at the constitutional level, rendering extradition possible to grant.

Finally, where no political offence exception is in place between the States at issue, political offences will also often fall within this category of cases where extradition may or may not be granted depending on the constitutional significance of the acts to the requested State. Consider for instance the recent EAW case of Puigdemont and other Catalonian politicians. According to the approach proposed in this study, in a case such as this - political considerations aside -, extradition would probably be possible despite minor differences between the criminal laws of the States involved. ${ }^{286}$

\section{(iii) Acts that would become 'extraditable'}

We shall now consider the acts that currently tend not to satisfy the dual criminality rule, but for which extradition could in principle be granted if the approach proposed in this study were followed.

To pick up where the last paragraph left off, the first group of offences that should be mentioned is that which covers offences enacted by a State to protect its interests as a State. The fact that the acts are harmful to this specific State is an integral part of the Tatbestände of these offences, and therefore the acts will only constitute an offence under its criminal law when they are harmful to this State. That is by definition the case of political and military offences, but it is also the case of any other offences (e.g. electoral fraud) that carry injury to a specific State, which are in general the offences covered by the so-called

285 This activity came to the attention of the press in 2001, when British and Dutch plane-spotters were arrested and convicted in Greece on spy charges. See TheOdore Konstadinides, "The Perils of the 'Europeanisation' of Extradition Procedures in the EU Mutuality, Fundamental Rights and Constitutional Guarantees", MJECL 14 (2017), p. 198, addressing the topic by reference to the partial abolition of dual criminality in the EAW.

286 This issue is quite different from that as to whether or not a State is, as a matter of principle, willing to cooperate with another State for political acts: this is the topic addressed in the subsequent $\int(4.1 .2)$. It is also different from the issue mentioned immediately infra, $\int \chi$, concerning offences where a damage of the specific State which enacts them is an element of the offence. 
'protective principle' of jurisdiction. ${ }^{287}$ Consequently, dual criminality will not be satisfied if the acts for which extradition is requested were not directed against the requested State, but against the requesting State (which is the normal situation). As noted before, although dual criminality does not find its roots in the principle of legality, it is conceived by reference to the principle of legality (of the requested State), and hence it will prevent extradition even in cases like these, where the offence is entirely identical to an offence that also exists in the requested State, the only variant being the identity of the subject against whom the acts are committed. Such is the view taken by Dias and Caeiro, who note that Germany, in order to make these acts 'extraditable', enacted a norm ${ }^{288}$ enabling it to grant extradition for acts committed against other States if they would constitute an offence in Germany had they been committed against the German State. ${ }^{289}$ A norm of this character lends strength to some ideas defended in this study: one is that the rationale of dual criminality indeed lies not in the nullum crimen principle, or else such a norm could not even exist, because extradition would be impossible to grant in relation to any acts that would not satisfy that principle in the requested State ${ }^{290}$ the other is that dual criminality indeed misses (even if not completely) the essence of the question as to which acts should admit extradition, or else Germany would not have adopted a rule enabling it to cooperate in such cases. The fact that Germany has adopted such a rule only concurs to demonstrate that States themselves already recognise, here and there, that dual criminality carries consequences that they do not intend it to carry. In any case, and to conclude, the approach proposed in this study would manifestly allow requested States to grant extradition for acts that are fully criminalised in their substantive criminal laws save for the detail that the addressee of the acts must be themselves. ${ }^{291}$

This rather specific issue being settled, we shall consider other cases that would be brought into the realm of extradition if the approach proposed here were adopted. These include all the cases where there are but minor differences in the manner in which an es-

287 See e.g. Christine VAN DEN WyngaERT, "Double criminality as a requirement to jurisdiction", op. cit., p. 135; PEDRO CAEIRO, Fundamento... op. cit., p. 265; LECH GARDOCKI, op. cit., p. 291.

288 See $\int 3$ (1) Gesetz über die internationale Rechtshilfe in Strafsachen.

289 See JORGE DE Figueiredo Dias / Pedro CAEIRO, op. cit., p. 28, arguing, accordingly, that, in legal systems where one such norm does not exist, extradition will be impossible to grant for this type of acts. The position merits no objection: this does seem to be a necessary consequence of the fact that dual criminality is conceived by reference to the own concepts of crime of the requested State. However, tax offences also fall within that category of acts (see LECH GARDOCKI, op. cit., p. 291), and yet extradition for these offences appears to be an acquired feature of extradition law even in the absence of a norm (in a treaty or in a national statute) explicitly enabling States to extradite in such conditions. Moreover, the debate on dual criminality with regard to the Puigdemont case, both in Spain and in Germany, revolved only around the disparities between the Spanish and Belgian/German criminal laws in the description of the acts themselves, no argument having been raised on the fact that the acts at issue were directed specifically against the Spanish State. In any case, the admissibility of extradition for tax offences only concurs to demonstrate that States already recognise implicitly, here and there, that dual criminality covers cases that they would not intend it to cover: but see further immediately below, in the text.

290 As is also affirmed by Jorge DE Figueiredo Dias / PEdro CAEIRo, op. cit., p. 28.

291 Again it is underlined: whether or not there are other reasons for a State not to cooperate with another State regarding such offences (notably if they have a political character) is an altogether autonomous problem, to be pondered autonomously infra, $\int 4.1 .2$. 
sentially similar conduct is criminalised in the two States: from offences against physical and moral integrity to offences against property; from offences against personal liberty to offences against privacy. Differences that would become irrelevant include any small variations in the relevant acts, and, even more blatantly, variations in quantitative or otherwise formal elements of the Tatbestände. For instance: offences related to the age of consent, which generally vary from one legal system to another depending on the age to which they associate personal maturity and attach a number of legal effects such as the possibility to be held criminally liable or consume certain products; or offences such as driving under the influence, which are triggered only if there is a certain percentage of a given substance (e.g. alcohol) in the blood by weight. Perhaps even more blatant are those cases where the very same act is criminally relevant only where it reaches a certain pecuniary threshold: a pecuniary sum does not have the same economic significance everywhere, ${ }^{292}$ and while the requested State might consider that such an act should only be criminalised if it does have a certain economic significance, the act for which extradition is requested may not reach the nominal sum established in its Tatbestand, but be even more economically significant in the requesting State than that sum is in the requested State. ${ }^{293}$ Another category of examples concerns the cases where the offences are also in essence identical, and differ only in the description of e.g. substances or goods that must be involved in order for the Tatbestand to be fulfilled, and factual elements exist that show that those substances or goods, albeit not contemplated in the criminal law of the requested State, are analogous in their effects, function or significance to other substances or goods that are. The paradigmatic example of this are drug-related offences, which require that the substance at issue be included in a list provided for by a criminalising statute: perhaps not all substances listed in one State will be considered criminally relevant in another State, but under the approach proposed in this study such an evaluation could be made case-by-case; this is especially relevant considering the dynamic 'industry' of development of so-called 'designer drugs', which have similar effects to traditional drugs that are criminalised, but which, owing to minor molecular variations, do not fall within the scope of criminal law until they are specifically inserted in the relevant list. The proposed notion of extraditable acts would yet encompass all those cases, already mentioned above, where the only reason for a State not to criminalise certain acts is the fact that such acts are not problematic in the light of its factual conditions, such as geographic or economic.

The proposed approach may enable interstate cooperation also in relation to those types of acts pertaining to 'neo-criminalisation movements', the major example of which would be acts that are harmful to the environment. One State may be particularly active in tackling the threat posed by environmental problems and have enacted criminal legislation aimed at preventing them. Other States may be less sensitive towards these issues and lack comparable legislation, but all the while be perfectly identified with the requesting State's concerns and available to cooperate with it in tackling such threats. In such

292 As also noted by Eugenio SelvagGI, "Dual criminality in abstracto or in concreto?", CoE Committee of Experts on the Operation of European Conventions on Co-operation in Criminal Matters, 2011, p. 2.

${ }^{293}$ Indexes of the price of reference of certain basic goods and services could be of help to the requested State in its evaluation. 
cases, not only may there be no clash of perspectives whatsoever between the requesting and the requested States, but also there may be a manifest alignment, such that international cooperation might even have the ulterior effect of inspiring the requested State to adopt similar measures at the internal level. ${ }^{294}$

On the other hand, attention should be paid to the eventuality of a criminalisation drift - i.e. a tendency for requested States to start criminalising acts for which they would now, with the approach proposed, be able to extradite. However, this risk should not be overestimated either, because, unlike extradition, criminalisation must still comply with the principle of ultima ratio of substantive criminal law. That is, the criminalisation of the acts in the requested State must still have to be justified in the light of all relevant conditions, including factual conditions, existing in this State.

\section{(iv) Special cases - particularly money laundering (with a footnote also on confiscation of assets)}

The scope of some criminal offences is ultimately determined by reference to other criminal offences. Exemplary cases are money laundering and terrorist financing, which presuppose the existence of other offences. Let us discard from consideration terrorism financing, because, one way or another, most States will have criminalised terrorist acts. Different definitions of 'terrorism' certainly exist in different States, which may raise dual criminality issues; but money laundering is a more interesting object of analysis, because in theory it is possible to launder the proceeds of any crime.

The FATF Recommendations bid States to criminalise money laundering based on the 1988 UN (Vienna) Convention against Illicit Traffic in Narcotic Drugs and Psychotropic Substances and the 2000 UN (Palermo) Convention against Transnational Organized Crime, and to "apply the crime of money laundering to all serious offences, with a view to including the widest range of predicate offences". ${ }^{295}$ States can follow a broader approach in defining the set of predicate offences, ${ }^{296}$ but they often limit it to such serious offences as trafficking in drugs or weapons, paedophilia and connected activities, corruption and influence peddling. ${ }^{297}$ It is possible that two States criminalise money laundering in perfectly similar terms as far as the modalities of conduct that constitute laundering are concerned, but establish different sets of predicate offences. Consequently, it is possible that one State requests extradition of a person who laundered the proceeds of an activity that the requested State does not criminalise, raising the question as to whether this will carry the impossibility of extraditing due to the non-fulfilment of the dual criminality rule.

294 The ICC Office of the Prosecutor "Policy Paper on Case Selection and Prioritatisation", of 15 September 2016, p. 3, 13 f., explicitly assigns great gravity to environmental crimes. Analysing the significance of that paper, see Luigi Prosperi / JACOPO TERrosi, "Embracing the 'Human Factor': Is There New Impetus at the ICC for Conceiving and Prioritizing Intentional Environmental Harms as Crimes Against Humanity?”, JICJ 15 (2017), p. 509 f.

${ }^{295}$ FATF, "International Standards on Combating Money Laundering and the Financing of Terrorism \& Proliferation", adopted by the FAFT Plenary in February 2012, as updated in November 2017, in www.fatf-gafi.org/, last accessed 2 November 2018, p. 10. This recommendation draws on what was already prescribed in Art. 6 (2) (a) and (b) of the Palermo Convention.

296 As is the case with the UK: see Art. 340 Proceeds of Crime Act 2002.

297 As is the case with Portugal: see Art. 368-A Criminal Code. 
It is unclear whether this is the question that the FATF Recommendations are addressing when they state: "Where dual criminality is required for extradition, that requirement should be deemed to be satisfied regardless of whether both countries place the offence [of money laundering] within the same category of offence, or denominate the offence by the same terminology, provided that both countries criminalise the conduct underlying the offence." ${ }^{298}$ The Recommendations generally use the expression 'predicate offences', rather than 'underlying offences', to refer to the acts whose proceeds can give rise to money laundering. The Palermo Convention does not either explicitly limit extradition for money laundering to the situations where the predicate offence is also criminalised in the requested State. ${ }^{299}$ However, it appears to be an inevitability that the dual criminality rule will not be satisfied if both States do not criminalise the predicate offence at issue, because, although predicate offences are ultimately described in separate Tatbestände, the money laundering Tatbestand - for which extradition is requested - still requires the proceeds at issue to result from those offences.

According to the approach proposed in this study, this does not have to be so, because criminalisation of the acts in the requested State ceases to be the focal point, giving way to an evaluation of whether extraditing for those acts would be harmful to the ethos of this State. Money laundering is unlawful in its own terms. What the legal good is that this offence seeks to protect, or the harm that it seeks to prevent, is a very debated issue, but, whatever view is taken, the reasons why money laundering is criminalised are not the same why its predicate offences are criminalised. Two States may have very different perspectives on the criminal relevance of a certain activity, but still agree that, if a State does criminalise such an activity, laundering the money which proceeds from it justifies the intervention of criminal law.

Let us for instance suppose, for an extreme example, that a State prohibits the sale (which thereby becomes 'traffic') of chewing gum. The fact alone that the sale of a certain product is criminally prohibited allows for the point to be raised that selling that product is more censurable than if the prohibition did not exist. Not in the sense that disobeying a criminal norm is reason enough to legitimise the penal intervention of the State. Rather, in the sense that it disrupts some societal balances, notably in that it puts the disobedient in a better position for profiting than the rule-abiding. Of course, if there is no substantial reason, a priori, for a given activity to be criminalised, the legitimacy of that prohibition should be discussed. But this is a question for the requesting State, and we are looking at the problem from the perspective of the requested State. And from this angle what we may conclude is: the fact that a certain predicate offence conflicts blatantly with one's criminal justice ethos, and that one would therefore certainly refuse extradition for such acts, does not necessarily mean that the laundering of their proceeds will cause the same type and level of distress to one's ethos. Naturally, in the extreme example presented above, the predicate offence (chewing gum) is so absurd that even the laundering of its proceeds would most probably justify refusing extradition. The point is simply that, in less extreme

${ }^{298}$ FATF Recommendations, cit., p. 27 (emphasis added).

299 See Art. 16 (1). 
cases, according to the approach proposed in this study, a requested State might consider extradition for money laundering admissible even if it would not consider extradition admissible for the acts whence the money proceeded.

The reason of this incursion into money laundering was that this offence, due to its 'composite' structure, offers yet another angle from which the inadequacy of dual criminality can be observed. The remarks adduced here may apply or be useful also for other offences of a similar structure, and also for cooperation forms other than extradition. ${ }^{300}$

\section{i) Proposed approach v. EAW approach}

The approach proposed here is based on a notion, not of mutual trust, but of mutual respect; not of mutual recognition, but of mutual understanding. The differences in relation to an approach such as that followed in the EAW - which exempts certain classes of acts from any kind of control (other than simple secretarial verification that a box has been ticked), and maintains the possibility of a classic dual criminality control regarding all other acts - are clear.

EAW-type lists have the obvious practical advantage of unburdening the requested State from appraising in each concrete case whether the warrant can be executed. ${ }^{301}$ This also means that they take away any possibility on the part of the requested State of refusing extradition in order to preserve its own sense of justice. Therefore, such lists can only have any axiological consistency if they are based on an aprioristic assessment that there is a communion of perspectives among the States involved in respect of the acts covered. However, such assessments have intrinsic limitations, since profound differences of perspective often manifest themselves in small details, and within categories of acts which in the abstract can be considered to garner consensus. The European Criminal Policy Initiative's "Manifesto on European Criminal Procedure Law" emphatically pinpoints that the EAW scheme leaves unaddressed the "national identity and the ordre public" of executing Member States, by requiring them to extradite for "behaviour which is by no means considered criminal in all Member States", such as euthanasia, abortion and the circumcision

300 To give only one example (closely related to the issue considered in this paragraph): cooperation towards the execution of a confiscation order, in the $\mathrm{EU}$, is admissible in perfectly similar conditions as those in which a EAW is admitted: Art. 6 (3) FD 2006/783/JHA, of 6 October 2006 prescribes that, apart from the cases falling within the list of Art. 6 (1), "the executing State may make the recognition and execution of a confiscation order subject to the condition that the acts giving rise to the confiscation order constitute an offence which permits confiscation under the law of the executing State". This is maintained in the Commission's "Proposal for a Regulation of the European Parliament and of the Council on the mutual recognition of freezing and confiscation orders", COM(2016) 819 final - 2016/0412 (COD), 21 December 2016, p. 4,12 . Besides the fact that dual criminality could be subjected here to a reform similar to that proposed for extradition, the same considerations adduced in this paragraph with respect to money laundering apply mutatis mutandis: the fact that a State disagrees, even if very intensely, with the criminalisation of given acts in another State does not mean that it may not have a supplementary margin of sympathy towards the intention of that State to confiscate the financial gains resulting from that activity, which in its legal system is criminal.

301 As mentioned supra, Chap. 1, \5.3.1.b), the MAW also effects a partial abolition of dual criminality (Arts. 3 (1) and 5 (a), and Annex I), but this is a most moderate attempt, as it only exempts from control acts the criminalisation of which is imposed by international conventions to which these States are parties. 
of boys. ${ }^{302}$ Asp, von Hirsch and Frände also uphold that there is "a need for a possibility of refusing a request for assistance with reference to the content of [the executing Member State's own] criminal law". ${ }^{303}$ The Manifesto goes so far as to hold that a general ordre public clause should be adopted in order to mitigate the most blatantly unwanted results made possible by an unreserved application of the principle of mutual recognition. ${ }^{304}$ The perspectives defended in this study are consistent with those views, according to which cooperation in criminal matters within the EU neglects the national identities of Member States: in the same way as classic cooperation should be narrowed down to the limits set by the criminal justice ethos of the requested State, EU cooperation should be broadened up to those limits. However, the combination of these two propositions does not result in perfect convergence: cooperation among EU Member States (as well as among any other States with particular ties of affinity) could always be more flexible than among unrelated States, because in part the conditions for international cooperation do vary in accordance with pre-existing levels of proximity and trust, and the very scope of States' criminal justice ethos varies in accordance with existing factual and legal conditions (notably ease of movement and associated individual rights applicable between the involved States owing to a common political project). ${ }^{305-306}$

In dual criminality, the key issue is not trust. ${ }^{307}$ For instance, Belgium may, at the same time, trust wholeheartedly the criminal justice system of another Member State and despise profoundly the idea of collaborating with such a State towards the punishment of a person who assisted another person who was in profound suffering to commit suicide. In fact, the Belgian act implementing the FD-EAW explicitly provides that abortion and euthanasia are not covered by the item 'murder or grievous bodily harm' listed in the FDEAW, which the European Commission has held to be "contrary" to the FD, "since it is the law of the issuing state and not the executing state which determines whether an offence is within the list". ${ }^{308}$ Whether the competence to subsume acts in the list belongs to the executing or to the issuing Member State is an issue which already lies somewhat be-

302 ECPI, A Manifesto on European Criminal Procedure Law, ZIS 8 (2013), p. 436 f.

303 PetTer Asp / ANDREW vON Hirsch / DAN FrÄnde, op. cit., p. 514.

304 See ECPI, A Manifesto... op. cit., p. 437.

305 See supra, esp. Chap. 7, \2.1.1.

306 On the other hand, the idea of a general ordre public clause would probably jeopardise the very idea of mutual recognition underpinning the EAW system. The approach followed in this study in relation to classic cooperation, and which might also apply in the context of mutual recognition, is instead to ascertain, in more specified terms and within the context of each ground for refusal, the extent to which the ordre public of a requested State needs to be protected. This presupposes defining beforehand (even if also on the basis of relatively undetermined concepts) the concept 'ordre public'. This difference in approach carries meaningful practical consequences, such as those indicated shortly below in respect of the execution of foreign sentences following a refusal to extradite, or of an extradition granted under a 'return to sender' guarantee.

307 As transpires from ECPI, A Manifesto... op. cit., as well as from PETTER AsP / ANDREW VON HiRSCH / DAN FRÄNDE, op. cit. On 'trust issues' more generally (and already drawing heavily on the angle provided by the dual criminality rule), see supra, Chap. $2, \$ 3.2$.

${ }^{308}$ European Commission, "Commission Staff Working Document Annex to the Report from the Commission based on Article 34 of the Council Framework Decision of 13 June 2002 on the European arrest warrant and the surrender procedures between Member States", (revised version) COM(2006)8 final, SEC (2006)79, Brussels, 24 January 2006, p. 6. 
yond the point in debate here, i.e. that as to which acts should be 'extraditable': assigning such a competence exclusively to the issuing Member State aims primarily at reducing the margin for frictions between Member States, and at smoothing the procedure. Of course, the operation of subsuming acts to the list is co-determinant of the real scope of that list, and, thus, of the concept of 'extraditable acts'. However, the underlying assumption is that the issuing Member State will essentially be performing that operation within the boundaries set by the FD itself. ${ }^{309}$ Few doubts should exist that the FD and the Commission do not envisage, for instance, that under the item 'grievous bodily harm' a Member State will issue a EAW for a slap in the face made in public, possibly carrying great harm to the honour, but not to the physical integrity of another person; or that under the item 'grievous bodily harm' a Member State will issue a EAW for a tattoo-maker who made a tattoo in the face of another person with this person's consent. ${ }^{310}$ As the normative instrument that disciplines extradition between Member States, it is naturally the FD that draws the fundamental line separating the acts which are from the acts which are not exempt from dual criminality control. Hence, when the Commission asserts that the exclusion of abortion and euthanasia by Belgium contravenes the FD because it is the law of the issuing State that determines whether an offence falls within the list, what the Commission is also asserting is that, in its view, abortion and euthanasia do fall within (or, at the very minimum, do not manifestly fall outside) the list, and that this is so regardless of the fact that Belgium may find it unacceptable to extradite for such acts.

Agreeing upon a carefully drafted list of acts to be exempted from any type of control in the requested State may be a valid technique, but it will always have the problem that by definition it is not contemporary, in the sense that it is drafted at one point in time and does not capture subsequent changes in perspective by States, unless updated (in the end, the same problem that affected the enumerative system that preceded the dual criminality or formula model that we have today). If the principle is that States indeed should not compromise their core criminal justice values, then those lists will moreover always have to be relatively narrow (in the case of the FD-EAW list, it would certainly have to be narrower than it currently is). If the idea is primarily and openly to capitalise on the practical benefits offered by such an approach, even knowing that this comes at the price of a sacrifice for those values, then the lists may be broader. Either way, and unless one contemplates a plain abolition of the concept of 'extraditable acts' - a position which, for reasons abundantly expounded, is rejected in this study -, it will always be necessary to have a criterion to solve the cases that do not fall within the list. And here we come back again to the classic dual criminality rule and its discontents.

Dual criminality is the criterion followed in the FD-EAW regarding acts that do not fall within the list. And, where dual criminality does apply, all problems discussed thus far apply as well. To refer again to the Puigdemont case, Spain withdrew the EAW it had issued

309 And this is one aspect that does already trigger trust issues.

310 The example is less farfetched than it may seem at first sight, since acts which are objectively grievous to the physical integrity of another person are usually subject to limitations based on 'public' considerations that cannot be sidestepped by the consent of the person; and while most States will not deem the acts described in the example to fall within such a hypothesis, this is theoretically possible. 
to Belgium based precisely on the argument that it would be unable to meet the Belgian dual criminality rule, and it was on the basis of this rule that Germany ruled the Spanish EAW partly inadmissible. ${ }^{311}$ Perhaps in this concrete case, at least insofar as Belgium is concerned, dual criminality came in handy for some politicians in office - and, for that matter, for Spain itself and for the EU, which in this way dodged the risk of a politicallybased refusal decision -, playing the role of an 'avoidance technique'. ${ }^{312}$ But it does show how the dual criminality rule can block an extradition which, in different circumstances, and considering strictly what a proper concept of 'extraditable acts' could be, might have been acceptable for all States involved.

In sum, a mixed approach to the concept of 'extraditable acts' such as that adopted in the EAW is a valid idea, but the specific approach adopted in the EAW has problems in both of its limbs: it encompasses in its list acts for which extradition may put in crisis the sense of justice of the executing Member State, and it allows dual criminality to remain in place in regard of all other acts, even if they do not collide with that sense of justice. As such, the FD-EAW forces Member States to extradite in cases where they should not, and allows them not to extradite in cases where they should. ${ }^{313}$

\section{j) Conclusion: Qualitative relevance}

In sum, according the approach proposed in this study, extradition would be possible for acts which constitute a crime in the requested State and for acts that this State, in the light of its supreme law, would be able to criminalise. The question may legitimately be raised as to whether, if such an approach were adopted, one could still say that the requested State would be cooperating in criminal matters. ${ }^{314}$ From the standpoint of the requesting State it certainly would - and, according to this study, this is the standpoint that matters, because the requesting State is the State that was injured by the crime. This being the case, the matter will also be inherently 'criminal' for the requested State, because this State agrees that criminal law is fundamentally immanent to the legal system to which the acts are more closely linked. And it is a 'criminal' matter for the requested State even in a more internal perspective, and in more than one sense: on the one hand, because by amplifying its conditions to cooperate this State will be improving its conditions to give efficacy to its own criminal law, based on reciprocity; on the other hand, and more important-

311 See supra, \2.1.2.

312 On this topic see again supra, $\ 2.1 .3$, and ulterior references.

313 To be precise, the FD-EAW does not impose that Member States subject to the dual criminality rule the acts that do not fall within the list of offences for which control of dual criminality is dispensed with; it merely gives them that option - an option which many Member States will have activated, as is illustrated by the two States studied in Part III of this study: see supra, Chap. 6, $\iint \sqrt{2.1 .1}$. and 2.1.2. This means that, as it stands, Member States could already adopt, in relation to those acts, an approach other than the traditional dual criminality rule (so long as more 'cooperation-friendly' than this rule, or else it would contravene the FD, by falling below the minimum levels of cooperation that it sets), such as the approach proposed in this study - which is itself also a mixed approach, in that it combines dual criminality and a complementary criterion for the cases where the acts are not criminalised in the requested State: see the summary provided in the next paragraph: j).

314 See Jorge de Figueiredo Dias / Pedro Caeiro, op. cit., p. 28; and in a sense also Bert Swart, "Human Rights...", op. cit., p. 253. 
ly at the conceptual level, because the scope of its cooperation with other States is still being defined by reference to its own criminal justice values - just not anymore to all such values, but only to the core ones.

In any case, it is admitted that, understood in these terms, the issue of determining the acts for which extradition is admissible has more to do with proportionality than with criminality. This is, in fact, the intention. If the approach proposed in this study were followed, the concept of 'extraditable acts' would stand - not only formally (as already happens), but also substantially - shoulder to shoulder with the minimum measure of penalty necessary to grant extradition: the latter expresses the quantitative, the former the qualitative relevance (or proportionality stricto sensu) of the acts.

To close, it is recalled that the fact that the acts are not criminalised in the requested State means that, if extradition is not granted, the requested State will be unable to carry out a criminal procedure on behalf of the other State, because, although vicarious procedures are more an act of cooperation than an exercise of own ius puniendi, a criminal procedure based solely on foreign criminal law is hardly conceivable. ${ }^{315}$ Therefore, to reform dual criminality in the terms proposed in this study would lead to effectively reducing the room for impunity, avoiding the verification of 'nec dedere nec judicare' situations. ${ }^{316}$

\section{k) Collateral implications of the shift from dual criminality to qualitative relevance}

So fundamental is the concept of 'extraditable acts' to the infrastructure of extradition law, that reforming it would have collateral implications on several other extradition norms and grounds for refusal. The following paragraphs address this issue.

\section{(i) Quantitative relevance}

Implications would fall immediately upon quantitative proportionality stricto sensuthat is, relevance thresholds. From the moment one accepts to extradite for acts that one does not criminalise, one will have no penalty scale expressing the quantitative relevance that one attributes to these acts. That is, a State might consider that certain acts, although not criminalised in its legal system, have sufficient qualitative relevance to justify extraditing their perpetrator to another State, but it will not have an own penalty scale against which to weigh whether they have sufficient quantitative relevance. The only point of reference for assessing quantitative relevance would therefore be the penalty scale of the requesting State. And it would be incoherent to require a minimum threshold of quantitative relevance for acts that constitute a crime in the requested State, but not for acts that

315 Although in theory the same principles defended for the reform of the dual criminality rule could be applied to vicarious procedures, it would appear that in this case it would be going too far to mobilise one's own criminal justice system to punish acts that do not satisfy one's own principle of legality. Still, this conclusion should not be regarded as absolute, but rather as a tentative perspective open to reflection. This author does not consider himself bound to solve this specific problem conclusively, because, although vicarious procedures take place following extradition procedures, they do not quite constitute an extradition problem anymore. On the other hand, carrying out a criminal procedure for acts that one does not criminalise is slightly different from enforcing a penalty applied in another State for acts that one does not criminalise: on this, see shortly below, $\int \mathrm{k}$ )(iii).

316 To recall the concept, see supra, Chap. $1, \int 5.3$. 
do not. Thus, the reform proposed here for the concept of 'extraditable acts' can only be effected together with a reform of the concept of 'quantitative relevance' such as that also proposed in this study, whereby this relevance should as a principle be assessed by reference to the penalty scale of the requesting, rather than to that of the requested State. ${ }^{317}$

Still, the concept of quantitative relevance defended earlier needs to be specifically pondered in the light of the hypothesis that the acts are not criminalised in the requested State. For an example: in 2001, Portugal decriminalised drug use and possession of low amounts of drugs for personal use, which thereafter became administrative offences triggering specific sanctions designed mainly to dissuade further drug use by the offender; ${ }^{318}$ before decriminalisation, those acts were punished with imprisonment for up to only 3 months, ${ }^{319}$ the underpinning view, even before decriminalisation, was already that the unlawfulness of such acts was very reduced, drug addiction being regarded more as an illness than as a crime. Let us assume that, although these acts are no longer criminalised in Portugal, they fall, at least in some cases, within the group of acts for which extradition, according to the concept of qualitative relevance proposed in this study, would be admissible. Something rather paradoxical might follow: before decriminalisation the acts satisfied even the dual criminality rule, but did not meet the classic relevance threshold for extraditing, set at one year of imprisonment (that is, the acts were qualitatively extraditable, but Portugal could not extradite given their quantitative irrelevance); after decriminalisation the acts would still be qualitatively extraditable (according to the criteria proposed here, and assuming that they would indeed be met), but extradition would no longer be blocked due to their quantitative irrelevance (assuming that in the requesting State they would meet the quantitative threshold, and that this would suffice for the requested State to agree to extradite without making any evaluation of its own on quantitative relevance). ${ }^{320}$

As defended above, the criterion for quantitative relevance should be primarily, in line of principle, the level of penalty applicable in the requesting State. The perspectives of the requested State in relation to this issue only acquire significance in blatant cases which, in practice, since the level of classic relevance threshold is already quite low, translates into a nearly complete proscription of any assessment by the requested State. These general propositions are still valid in respect of cases where the acts are not criminalised but are considered qualitatively relevant in the requested State, because the fact does not change that the requesting State is the one that was injured by the crime and whose criminal justice concepts should therefore be presumed to set the discipline of the case. However, a process of mutual co-determination appears to establish itself between qualitative

317 See supra, $\int 3.2 .1$.

318 The decriminalising statute, which entered into force on 1 July 2001, had been approved the year before by Law no. 30/2000, of 29 November. On this decriminalisation experience, see e.g. GLENN GREENWALD, Drug Decriminalisation in Portugal: Lessons for Creating Fair and Successful Drug Policies, Washington: Cato Institute, 2009.

319 See Art. 40 (1) Decree-Law no. 15/93, of 22 January, until the version conferred to it by the DecreeLaw no. 214/2000, of 2 September.

320 And cases like these, where until a relatively recent moment the acts were criminalised, are not even the most challenging ones, because the repealed legislation would provide a historical element of hermeneutical value upon which to support an evaluation of the current quantitative relevance of those acts. 
and quantitative relevance that shifts to an extent the axis of those propositions, as outlined subsequently.

On the one hand, if the acts are not criminalised in the requested State and extradition is only possible (from a qualitative perspective) because this State is already amplifying its availability to cooperate beyond its ordinary concepts of criminal justice and up to the limit set by its core values, it appears sensible for this State to limit that availability to acts which have an above-par quantitative relevance for the requesting State. ${ }^{321}$ That is, to require, in such cases, that the acts are more important for the requesting State than the minimum importance expressed in the regular threshold. Therefore, there should probably be a regular threshold for acts that the requested State criminalises, and a higher one for acts that it does not criminalise but for which it is still willing to extradite. This is in fact what already happens in the EAW system, ${ }^{322}$ although in this case this is an inevitability (rather than an additional safeguard against disproportionality), since the partial abolition of dual criminality, as carried out in that system, does not even require that the acts have any qualitative relevance whatsoever to the requested State. ${ }^{323}$

On the other hand, the higher the penalty applicable in the requesting State is, the more likely it will be that it is deemed disproportional to the acts by the requested State. ${ }^{324}$ Let us go back to the possession of low amounts of drugs for personal use. Suppose that: a State criminalises such a possession only if the quantity of drugs is higher than a certain threshold (e.g. 5 grams), and punishes it with imprisonment for up to only 6 months (or even, let us assume, 1 year, so as to satisfy the classic threshold generally in place); another State criminalises the possession of any amount of drugs; and the latter State requests the extradition of a person to the former State for possession of 3 grams of drugs; suppose also that, from a qualitative perspective, the former State would be willing to extradite. Now let us consider two different scenarios: in hypothesis A, the requesting State punishes the acts with imprisonment for up to 3 years; in hypothesis $\mathrm{B}$, with imprisonment for up to 25 years. In hypothesis B, the level of penalty in the requesting State is so much higher than that which would apply in the requested State for the possession of an even higher quantity of drugs, that this suggests the existence of differences in perspective not of a quantitative nature only, but also of a qualitative nature. More specifically, it suggests that the offence in the requesting State does not seek to protect the same interests as the offence of the requested State, but instead probably constitutes what above has been classified as a 'moralistic' or 'arbitrary' offence. ${ }^{325}$ This example is akin to that mentioned earlier of theft of a worthless item, with the further particularity that here the acts assuredly do not even constitute a crime in the requested State.

321 Without detriment to the notion that such an amplification is justified in and of itself.

322 See Art. 2 (1) and (2) FD-EAW.

323 The articulation of these two factors (lack of dual criminality and very low relevance thresholds) are at the origin for instance of the proportionality bar and preliminary check introduced by the UK in the EA 2013 in breach of the FD-EAW: see again the speech of then Home Secretary Theresa May before Parliament, cit., starting at 03:27.

324 Which, in blatant cases, as defended supra, $\left.\int 3.2 .1 . \mathrm{d}\right)$, can justify a refusal of extradition.

325 See supra, $\int 4.1 .1 . h$ ) (although the issue there concerned the meaning of the criminalisation in the $r e-$ quested State). 
Interactions between qualitative and quantitative relevance in extradition law certainly deserve further reflection. This is so even if extradition law remains based on the dual criminality rule and on the quantitative thresholds currently in place. In any case, and to conclude, some basic coordinates of the topic seem to be that, if the acts are qualitatively relevant but not criminalised in the requested State, the segment of acts for which extradition could be granted will be formed of acts that are punishable in the requesting State with a level of penalty which is: (i) higher than that expressed in the traditional thresholds (since this denotes an added importance for the requesting State in obtaining extradition, and thereby lends impetus to the availability of the requested State to cooperate beyond its ordinary qualitative concepts of criminal justice); but (ii) not so high as to render punishment manifestly disproportionate to the acts (in a cardinal sense) in the eyes of the requested State; such a disproportionality can be established by the requested State even in regard to acts that it criminalises, ${ }^{326}$ but this will be more likely to occur in regard to acts that it does not criminalise.

\section{(ii) Time-bars}

A similar situation occurs in respect of time-bars: from the moment one admits the hypothesis of extraditing for acts that one does not criminalise, one will lack own criteria to assess the periods of time past which the criminal procedure or the penalty would be proscribed. This ground for refusal and its interactions with qualitative relevance are addressed later. ${ }^{327}$

\section{(iii) Rehabilitation / Nationality exception}

Likewise, from the moment one admits extraditing for acts that one does not criminalise, one must contemplate the idea of enforcing in one's own prisons a foreign penalty for those acts. This is because, if the requested State is the one where the rehabilitation of the person is more likely to be attained, extradition may only be possible for prosecution purposes (under a guarantee of devolution of the person for enforcement purposes), or it may simply have to be refused, if it is already being requested for enforcement purposes. ${ }^{328}$ And it would make no sense to refuse or condition extradition for rehabilitation reasons if the acts are criminalised in one's own State, but not if they are not. This raises the question as to whether the execution of a foreign sentence must be subject to a dual criminality requirement, or, instead, if it may be adjusted into a concept of qualitative relevance such as that propounded in this study for extradition.

As noted with regard to the rehabilitation exception, the execution of foreign sentences does not necessarily abide by the same principles as extradition. The terms of the problem have already been set out in that moment, and are briefly recollected here: the conditions on which the execution of foreign sentences should depend can only be more definitively determined in a study specifically devoted to that form of cooperation; how-

\footnotetext{
326 See again supra, $\left.\int 3.2 .1 . \mathrm{d}\right)$.

327 See supra, \ 4.2.2.e).

328 See supra, $\ 3.4 .1$. and ulterior references.
} 
ever, the principles defended in the theoretical framework of this study seem possible to apply with some adaptations, so that further preponderance is accredited to the sentencing State, which is the State whose penal concepts should in principle set the discipline of the case. Accordingly, in the abstract, in the same way as the conditions for extraditing can be compressed in favour of the requesting State up to the point where that becomes intolerable to the requested State, so the conditions for executing a foreign sentence can be adjusted. However, extradition does not require the cooperating State to exert its own ius puniendi, and therefore it may admit certain adjustments which are inadmissible for other cooperation mechanisms, namely the execution of foreign sentences, which does involve an exercise of one's own ius puniendi.

One position would be to plainly refuse the idea of a State executing in its prison facilities a penalty applied for acts that such a State does not criminalise. ${ }^{32}$ The core arguments, as far as is possible to see, would be that: on the one hand, the requested State cannot exert ius puniendi in such cases, due to the principle of legality (nulla poena sine lege); on the other hand, even if it could, that would necessarily be offensive to its criminal justice ethos, and it would defeat the very notion of rehabilitation, because if that State does not even consider the acts criminal there is nothing to rehabilitate the person from. It is important to note that this position would not disqualify the approach propounded in this study regarding the possibility of extraditing for acts that a State does not criminalise. It would simply carry one of the following effects: (i) a limitation of that possibility to cases where the person concerned is not a national, a resident and/or another person who, from a rehabilitation perspective, should serve the sentence in the requested State, in which case this State would neither extradite temporarily nor execute the foreign sentence, but simply refrain to cooperate in any manner with the State that was injured by the crime; or (ii) the inapplicability of the rehabilitation exception itself, in which case the requested State could extradite unreservedly even for enforcement purposes. ${ }^{330}$ In any case, it is submitted that neither of the foregoing (black and white) approaches is ideal. Rather, the rehabilitation exception should still be applied, and the foreign sentence should still be enforced, as articulated subsequently.

\section{$\alpha$. An exercise of own ius puniendi?}

The first argument can be contested in its own terms: to execute a foreign sentence does not correspond to a fully-fledged exercise of one's own ius puniendi. If the person in question is a national or a resident of the requested State, it is possible that this State had primary jurisdiction over the acts. However, this is an incidental factor, since the reason to refuse or condition the extradition of this person based on a rehabilitation exception is the likelihood of rehabilitation of that person in that State, rather than a primary connection of the acts with its legal system. In fact, as mentioned earlier, it may even be that the person was not a national or a resident of that State at the time of the acts, in which case he/she cannot be prosecuted in that State based on those grounds for jurisdiction if the

329 This seems to be the position upheld in ECPI, $A$ Manifesto..., op. cit., p. 437.

330 On these two alternatives, see further infra, $\int \chi$. 
acts were criminalised there, but nevertheless could be protected by the rehabilitation exception and/or a classic nationality exception. ${ }^{331}$

Secondly, and more importantly, even if such a connection between the person and the requested State did already exist at the time of acts, the connection between the acts and the State where and/or against which the crime was committed would still in line of principle deserve priority, because those connections, albeit 'primary', in the sense that they are met at the time of the acts, are nevertheless 'subsidiary', in the sense that they yield before stronger (notably territorial and protective) bases for jurisdiction. Thus, the latter are not only 'primary', but also 'prioritary' bases for jurisdiction. ${ }^{332}$ In the case under consideration, 'priority' does not refer to preponderance in the context of a conflict of jurisdiction, as the acts are not even criminalised in one of the States (sc. the requested State); but since the connection between the acts and this State is weaker, the evaluation it makes of those acts should yield all the same before that made by the State with a stronger connection. This is the necessary consequence of introducing 'neutrality', in the Savignyian sense of the term, to the process of determination of the law applicable to given acts. ${ }^{333}$ And it is, thus, the very same reason why, even if the acts also constitute a crime in the requested State, the criminal justice concepts of the requesting State deserve priority over those of the requested State regarding other grounds for refusal: time-bars, relevance, etc. This equates to saying something as fundamental for the principle of territoriality as the following: the circumstance that a person is a national or a resident of a certain State does not exempt him/her from complying with the criminal law of the State where he/she is carrying out his/her conduct or against which he/she is aiming its effects. A clash does not exist here between a duty (not to breach the criminal law of one State) and a right (to behave in whatever manner that is not unlawful in another State), because from that neutral perspective only the norm establishing the duty is applicable. If the acts at issue are of such a quality that extraditing would damage the ethos of the State of which the person is a national or a resident, then this State should refuse extradition, but only because this is necessary to avoid that damage; not because its criminal law (or, in the case, the absence of it) prevails over the criminal law of the requesting State. A person is not entitled to choose to abide by the law of his/her homeland rather than by that of the State where he /she is acting or against which he/she intends the acts to materialise.

That is also why, even if the acts are criminalised in the requested State and such a State has primary but subsidiary jurisdiction thereon (active nationality or residence, passive nationality, universal jurisdiction, etc.), another State has primary and prioritary jurisdiction (notably territorial or protective), and the latter transfers criminal proceedings to the former (e.g. because for some reason extradition was impossible), the former will still not be exerting its own (subsidiary) jurisdiction, but instead the (prioritary) jurisdiction of the other State, on its behalf. The same happens even more clearly when the latter State has already delivered a sentence and transfers its enforcement to another State. This even happens when a State also has prioritary jurisdiction (e.g. territorial) but accepts a transfer

331 See supra, Chap. 4, \ 2.4.4.a)(i), Chap. 6, \ 4.1., and Chap. 8, \ 3.4.1.

332 See ibid.

333 See supra, Chap. 7, \ 3.1.1. 
of proceedings made by another State where such proceedings had already been initiated or completed; and even - one must yet admit - if the latter State had primary but merely subsidiary jurisdiction (e.g. active nationality). For this is what 'delegating' means. ${ }^{334}$

In sum, from the neutral perspective that should guide the determination of the law applicable to the acts, it is not only possible, but also, as a principle, warranted for the requested State to execute a foreign penalty concerning acts that it does not criminalise. This is what already happens in the EU, based on the FD 2008/909 on the mutual recognition of sentences carrying deprivation of liberty - which, in the image of the FD-EAW, dispenses certain acts from dual criminality. ${ }^{335}$ Whether or not that is possible and warranted from other perspectives is, as we know, ${ }^{336}$ a methodologically subsequent question.

\section{B. Offensive to the criminal justice ethos of the requested State?}

The question as to whether executing a foreign sentence for acts that one does not criminalise would be offensive to one's criminal justice ethos can also be answered based on principles of the theoretical framework developed in this study. It is recalled that the issue in debate will not emerge in relation to acts that, albeit not criminalised, are qualitatively relevant in the eyes of the requested State - i.e. acts that have sufficient resonance in the concepts of criminal justice of the requested State for this State to be willing to extradite for such acts -, or else extradition would simply be refused and the question as to whether the requested State should undertake to enforce a sentence concerning those acts would not even arise.

Considering that transfer of prisoners is a cooperation mechanism driven to a large extent by altruistic concerns for the convict, ${ }^{337}$ it is plausible to claim that States should be willing to receive prisoners who are their nationals or residents in an even broader number of cases than those in which they would accept to extradite them. By refusing to take in prisoners who are their nationals or residents for acts which they do not criminalise, States are denying those individuals a possibility that would be manifestly to the advantage of both those individuals and these States themselves, because as we saw these are the States to which such individuals will often return upon being released.

It is, of course, understandable that States refuse to partake in any way in the punishment of acts that are lawful in their eyes. It is a principled stance. But the person will still be serving a sentence in another State. States should probably still refuse to receive

334 See supra, Chap. 1, \3.1; and again MARC HENZELIN, op. cit., p. 244. For the same reason, that is not quite what happens when a State exerts vicarious jurisdiction, which is not even a primary (let alone prioritary) basis for jurisdiction, but a unilateral undertaking by one State. Surely, such an undertaking is derived from the primary jurisdiction of another State (which is why it is much more a cooperation act than an exercise of own ius puniendi); but it is an undertaking that is not explicitly delegated by another State.

335 See Art. 7. This FD therefore suffers from the same problems, mutatis mutandis, as the FD-EAW, inasmuch as concerns the notion of 'acts for which cooperation is admissible': see supra, $\int 4$ 4.1.1.i).

336 See supra, Chap. 7, \$S 3.1.1. f.

337 In addition to the very fact that it enables prisoners to serve their sentences in the place where their family and social circles are located, the transfer as a principle cannot entail the aggravation of their situation, and often will even carry its improvement: see respectively $\iint 19$ and 16 UN Model Agreement on the Transfer of Foreign Prisoners. 
individuals sentenced in other States if the acts at issue are manifestly irrelevant according to their own criminal justice concepts. This may bring no immediate advantage to anyone, but be necessary, in a more indirect manner, to preserve the integrity of a criminal justice system. However, it does seem clear that States could receive prisoners where this is not shocking to their community, and that the cases where doing so would be shocking are fewer than those where extraditing would be shocking, because these communities understand that the alternative would be for those individuals to still serve a sentence elsewhere, possibly in much worse conditions. ${ }^{338}$

This is not quite the same as in the case under consideration, because here the State which has custody of the person is already that of his/her nationality or residence, and it therefore holds in its hands the power simply not to cooperate with the other State. However, the contention of this study is that such a power should not be construed as unreserved anymore: refusing to cooperate without justification is also a form of meddling in the internal affairs of the State that was injured by the acts, denying territorial or protective efficacy to its law, and therefore such a refusal will be justified only where it is necessary to avoid damaging one's own sense of justice. Thus, if, as happens in the cases under consideration, the acts have sufficient relevance in one's eyes to justify extradition, refusing to enforce a foreign sentence will be difficult to justify on that basis. Especially if one considers that the requested State, despite the differences between its substantive criminal prohibitions and those in place in the requesting State, shares with this State the respect for the territorial and protective enforcement of criminal law. That is, it agrees with the notion that a State's criminal law is supposed to be complied with by individuals acting in its territory or against its interests, and recognises that the individual whose extradition is being requested did not do so - which in itself already triggers common rehabilitative concerns.

Therefore, rejecting the idea that such sentences could be enforced, and refusing to extradite because of that, will only be possible to justify in the light of other factors related to certain specificities of the cooperation mechanism 'execution of foreign sentences', and of the concept of 'execution of penalties' itself. And here we enter again hostile territory: ${ }^{339}$ the factors that have direct interrelations with the object of this study are deemed to be fully addressed in the foregoing lines; taking a more definitive stance on other factors would require a specific evaluation of that cooperation mechanism. In any case, some tentative remarks are adduced subsequently.

338 This is not what currently happens, as the transfer of prisoners/execution of foreign sentences, and even the supervision of offenders conditionally sentenced or conditionally released, are - like extradition generally subject to the dual criminality rule: see respectively $\$ 3$ UN Model Agreement on the Transfer of Foreign Prisoners, and Art. 6 UN Model Treaty on the Supervision of Offenders Conditionally Sentenced or Conditionally Released. In the EU, as we saw, this is possible (based on Art. 7 FD 2008/909), but the list of acts for which dual criminality is dispensed with is the exact same one as that of the FD-EAW, rather than broader.

339 As in $\$ \mathrm{j}$ ), supra (see the footnote on vicarious criminal proceedings). 


\section{$\chi$. Rehabilitating a person for acts that one does not criminalise - an impossible attempt?}

From the moment one emphasises that the acts at issue here are acts that are still qualitatively relevant in the light of the criminal justice concepts of the requested State, the argument that this State would be unable rehabilitate the person becomes rather feeble. Certainly, imprisonment conditions and the rehabilitation plan to be imposed on an individual who is imprisoned for this type of acts will require some variations (possibly quite significant) in relation to those to be imposed on an individual who is considered a criminal in that very legal system. ${ }^{340}$ However, the qualitative distance between acts that are criminalised and acts that are not but could have been criminalised (for this is, roughly speaking, what is meant by 'acts with sufficient qualitative relevance'), does not appear to be so large and fundamental as to preclude the possibility to effect rehabilitation.

If, on the other hand, rehabilitation in the requested State indeed was impossible in such situations, then the logical conclusion to draw from this is that the rehabilitation exception should not even apply and the person could simply be extradited unconditionally. But here we would go back again to the consideration that it would still probably be better to undertake to enforce the foreign sentence than to send the person for imprisonment in the sentencing State, as otherwise the person would be serving a sentence anyway, and in comparably less favourable personal conditions: that is, the humanitarian rationale of the rehabilitation exception would probably still suffice to refuse extradition for enforcement purposes or to extradite for prosecution purposes under a return to sender guarantee, even though its rehabilitative rationale stricto sensu would not be met. ${ }^{341}$

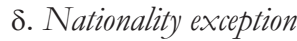

The remarks adduced in the previous paragraphs apply mutatis mutandis to the case where the requested State has in place a traditional nationality exception. The main variation is that, here, extradition is refused even for prosecution purposes, and a delegation of criminal proceedings is in principle precluded. Naturally, the requested State moreover cannot exercise its own jurisdiction based on active nationality, as in the cases in consideration the acts are not criminalised in that State. If the requesting State did already deliver a sentence, such a sentence may be possible to enforce, in the same terms as above.

340 At this point a bifurcation seems to open between the execution of foreign sentences and the transfer of criminal proceedings. It is true that the concept of applying foreign law in one's own criminal procedure already exists, for instance if the foreign law is more favourable to the defendant than one's own law (see e.g. Art. 11 (1), in fine, UN Model Treaty on the Transfer of Proceedings in Criminal Matters). However, it already appears unrealistic (however equally warranted in the abstract) to require magistrates to conduct a criminal procedure and apply a penalty for acts that are not criminalised in their legal system, with all that this entails. Not only due to the technical difficulties as such, but also because these seem to carry substantially untenable consequences: it should suffice to image the application, by a judge in whose eyes the acts are not censurable, of a criminal law concept such as that of 'censurability'. This, on the other hand, only reinforces the notion that the defining moment for the requesting State is the criminal procedure (and more particularly the judgment), and that the terms of the problem change significantly when it comes to the enforcement stage.

341 As mentioned in respect of the rehabilitation exception, such an exception is based not only on rehabilitative concerns, but also, in part, on broader humanitarian considerations: recall supra, \3.4.1.a). 


\section{(iv) Extraterritorial jurisdiction in identical circumstances}

It is utterly clear at this point that the perspectives defended in the preceding paragraphs and in this chapter more generally presuppose that the requesting State is the State with the strongest connection to the acts; otherwise there would be no reason to confer primacy on its concepts of criminal justice. In any case, it may happen that the requesting State has a connection to the acts and the requested one does not (or also does, but is a weaker one), and that a third State has a stronger connection than the requesting State. If the latter State also requests extradition, its request should in principle prevail; however, if it does not request extradition, and assuming that extradition could be granted to that other State despite the fact that its connection to the acts is not the strongest one, ${ }^{342}$ it is necessary to determine which conditions apply to its extradition request. For instance: if for some reason the State with territorial jurisdiction does not wish to prosecute the acts, and the State of which the person is a national issues an extradition request based on active nationality, should this request be dealt with according to the reformed concept of 'extraditable acts' defended here? ${ }^{343}$

This study has addressed jurisdictional issues at several points, but was built largely on the assumption that the requesting State has territorial or protective jurisdiction, since this is the archetypical scenario by reference to which any effort to review the suitability of existing grounds for refusal should be carried out. Therefore, nuances such as the one presented here can be explored only tentatively in this study. Still, an answer is attempted. From a narrow perspective focused on the comparative connection of acts to the requested and the requesting States, the answer would still be affirmative. Indeed, if the requested State has no connection whatsoever with the acts, and the requesting State has a connection based on nationality, then - and to use an image already used earlier in the theoretical framework - the 'energy' emanating from its legal system is more intense than that emanating from the legal system of the requested State, and its concepts of criminal justice should still supersede those of the requesting State.

However, the primacy assigned in this study to the requesting State is fundamentally anchored to the territoriality and the protective principles. No other jurisdictional principles bear comparable significance: the preventive concerns elicited by the acts encompassed by those principles are unparalleled; the whole criminal justice system of a State is primarily designed to tackle the threat posed by such acts; the arguments are many and are strong. ${ }^{344}$ This translates into differences in terms of impact upon the criminal justice ethos of the requested State: within the hypothesis that the acts are not criminalised in this State, there is arguably greater potential of damage for the sense of justice of its community in exposing a person to punishment in a State which is not even the one where the acts were committed or against which they were directed. Territoriality has anthropological resonance $^{345}$ also in this sense. This alone would already justify a lower level of availabil-

342 On this, see supra, \3.3.2. and ulterior references.

343 As noted, the same question applies, mutatis mutandis, to other grounds for refusal whose reform is proposed here under the assumption that the requesting State is the State with territorial jurisdiction.

344 See supra, Chap. 4, \$3.1. and ulterior references.

345 See supra, Chap. 6, \$ 6.1.2. 
ity to cooperate, meaning that a proper reform of extradition probably consists of having two-tiered grounds for refusal, these being narrower in scope where the requesting State has a territorial or protective link with the acts, and wider where its link is weaker.

But there is an additional factor leading to the same conclusion: the eminently territorial and protective character of criminal law also manifests itself in the level of predictability of its rules to the individuals to whom they are addressed: individuals can generally be held responsible for complying with the rules in force in the place where they are acting or (perhaps already to a lower degree) in the State against which their acts are directed; but those levels will be lower in the case of other jurisdictional connections. Thus, to argue that the level of availability to cooperate should be lower if the connection of the requesting State with the acts is not particularly strong is to recognise and give substance to the (undisputed, but not yet fully consequential) understanding that extradition is no longer a straight line linking two States, but a triangle which has the individual concerned as one of its vertexes. ${ }^{346}$

\section{(v) Territoriality}

The conclusion posited at the end of the previous paragraph already points the way for reflecting about a different situation, namely that in which the acts were committed, at least in part, in the territory of the requested State itself, and they are not criminalised there. It is a situation that the FD-EAW is considered to implicitly accommodate in Art. 4 (7) (a). According to this provision, the execution of EAW's can be refused if it relates to "offences" that "are regarded by the law of the executing Member State as having been committed in whole or in part in the territory of the executing Member State or in a place treated as such". As already noted earlier, ${ }^{347}$ it is not fully clear to this author that this constitutes a compensation for the partial abolition of dual criminality: that provision does not neutrally refer to 'acts', but to "offences"; this suggests that the acts envisaged by the provision are acts that constitute offences also in the requested State. This would make this provision more a classic territoriality exception aimed at enabling the requested State to prosecute the acts itself, ${ }^{348}$ than a device aimed at exempting the person from criminal liability. Whatever the case may be, the fact that the person acted in the territory of the requested State, and that in this State the acts were not criminalised, is certainly a relevant element to consider in articulation with the dual criminality issue.

As in the hypothesis dealt with in the previous point, so too in this situation the 'energy' emanating from the criminal justice system of the requesting State is lower than in the archetypical hypothesis where this State is the one with the strongest connection to the acts. On the other hand, the energy emanating from the criminal justice system of the requested State is higher, because (at least a part of) the conduct was carried out in its territory. Even if the requesting State has territorial jurisdiction, the presumption that its criminal justice concepts should prevail will cease, because it is matched by an equally territo-

\footnotetext{
346 See supra, Chap. 3, \ 1.2., and Chap. 7, \ 3.3.

347 See supra, Chap. 6, \$ 6.1.3.

348 As addressed supra, Chap. 6, \ 6.1., and Chap. 7, \ 1.1.1.
} 
rial link of the acts with the legal system of the requested State. Consequently, in this case, extraditing would also have a larger impact on the sense of justice of the requested State than what happens in the archetypical hypothesis: in the hypothesis now in debate extradition is more difficult to justify in the eyes of its community, and not only due to 'altruistic' reasons, but also to 'egoistic' ones, because the members of this community would then be placed in a situation of uncertainty as to whether they could be exposed to a foreign criminal justice system even when they acted in full compliance with their own. As already mentioned, in such cases it is impossible for individuals to fully abide by the laws of multiple States simultaneously, and evidently they are not to blame for this predicament, ${ }^{349}$ which moreover has increased intensity in a globalised world. ${ }^{350}$ And here is one instance where taking the 'worm's-eye view' might contribute to improve the balance of transnational criminal law. ${ }^{351}$

That said, nuances must nevertheless be considered, notably the hypothesis where most (or the most significant part) of the acts were committed in the requesting State. The exercise to be carried out here will have many similarities with that which must already be carried out when a positive conflict of jurisdiction occurs between the requested and the requesting States: in both instances the exercise will consist largely of an evaluation as to which of the two States has a stronger connection with the acts. ${ }^{352}$ The peculiarity is that in one case the goal is to establish which of the two States should exert punishment, and in the other to establish whether the acts should be punished (as will be the case if the State that prevails in that exercise is the requesting State, where the acts are criminalised), or not (as will be the case if the State that prevails in that exercise is the requested State, where the acts are not criminalised). If the acts were fully committed and materialised in the territory of the requested State, then they manifestly should not be punished: in such a case, what is a stake is not even simply ensuring an adequate regulation of the concept of dual criminality (or of 'extraditable acts', at any rate) as a requirement to extradition, but in fact of ensuring an adequate regulation of the concept of dual criminality as a requirement to the exercise of extraterritorial jurisdiction, since this exercise generally presupposes save, possibly, in the case of protective jurisdiction - that the acts are criminalised in the locus delicti. ${ }^{353}$

\section{(vi) Reciprocity}

As far as concerns reciprocity, it suffices to reiterate the idea established above that reciprocity does not require perfect symmetry. Thus, if the concept of 'extraditable acts' proposed here were followed and a State were to extradite for acts that it does not crimi-

349 See again BERT SWART, "Human Rights...", op. cit., p. 252 f.

350 As noted supra, Chap. 7, \3.3.3, globalisation brought challenges not only for States, but also for individuals, one of which relates to the fact that human conduct has developed much greater propensity to trigger at once the punitive systems of several States.

351 See supra, id., and again SABINE GLESS, op. cit., p. 117 f.

352 On this, see supra, Chap. 1, \5.2., Chap. 6, \ 6, and Chap. 7, \ 1.1.1. This specific type of conflict, which may be labelled a 'dedere aut judicare stricto sensu' case, has been the object of previous research by this author: Miguel JoÃo Costa, Dedere Aut Judicare?... op. cit., esp. p. 119 f.

353 See supra, Chap. 4, \$ 2.4.3. 
nalise, naturally it could not later obtain extradition for the same acts, because it will not even issue such a request; but this State could be fully reciprocated if the now requesting State later extradites for acts that it does not criminalise but the now requested State does, as already happens in the EAW scheme. ${ }^{354}$

\section{(vii) Political and military offences}

Regarding political and military offences, it is also sufficient to recall two ideas that have already been established. One is that these offences fall within that class of offences which are directed against a specific State, and which therefore only fulfil the principle of legality of that specific State, its punishment by other States being excluded. We saw that the consequence of this peculiarity for extradition law is that the dual criminality rule will not be satisfied if that specific State requests the extradition of the offender to another State, because the acts do not constitute a crime under the law of the latter State. In such cases, within the current dual criminality model, extradition will only be possible if the requested State provides for a norm explicitly enabling it to grant it. This would change with the alternative model proposed here, because if the only difference between the criminal laws of the requested and the requesting States is the addressee of the acts, then these acts will normally be qualitatively relevant in the requested State, and extradition can be granted. ${ }^{355}$

The other idea is that this issue is independent from the question as to whether or not the requested State is willing to extradite for acts that have political or military nature. This is the question addressed in the following section of this study immediately below.

\subsubsection{Political offences}

The political offence exception is one of those institutions of extradition law which is a research topic in its own right. Its problematic nodules are many, its theoretical interest vast, its symbolical charge immense. With this in mind, it nevertheless seems possible to address satisfactorily all the facets of this polyhedral ground for refusal.

\section{a) Not an inexorable attribute of extradition}

The first step to be taken should be to establish that the political offence exception is not an indispensable feature of extradition law. In antiquity extradition was used mostly in the context of politically relevant cases, while modern extradition has in the political offence exception one of its defining traits. ${ }^{356}$ The axiological framework of liberal revolutions encompassed the view that resistance against unrepresentative political regimes was legitimate; thus, the new liberal States were willing to protect fellow revolutionaries, ${ }^{357}$ and

354 See supra, $\$ 2.2 .2$.

355 See supra, \c)(iv).

356 See supra, Chap. 7, \ 2.2.3.

357 See e.g. LorA L. DEERE, "Political Offenses in the Law and Practice of Extradition", AJIL 27 (1933), p. 250 f.; Gregory Chadwick Perry, “Comment - The Four Major Western Approaches to the Political Offense Exception to Extradition: From Inception to Modern Terrorism”, MLRev. 40 (1989), p. 716; WILLIAM MAgNUSON, op. cit., p. 851; CHARLES K. BURDicK (rep.), "Harvard Research in International Law: Extradition", op. cit., p. $108 \mathrm{f}$. 
despite some resistance this doctrine prevailed, supported on the rise of liberal democracy. ${ }^{358}$ However, in antiquity as in the present day, extradition would not always be granted: the polity granting asylum would sometimes support or acquiesce to the acts and, accordingly, refuse to cooperate. ${ }^{359}$ Indeed, from the fact that before the late $18^{\text {th }}$ century extradition was practically limited to political cases it does not follow that in all such cases it would be granted, given the prominence held by the institution of asylum. ${ }^{360}$ As van den Wyngaert construes, asylum would only, but it would be, granted "insofar as it could serve the interests" of the requested polity: for instance if it were useful "as a tool to attract rebels from enemy countries to thereby exploit them". ${ }^{361}$ Furthermore, it is plausible to assume that the offended polity would often refrain from making any request. As Blakesley posits: "The territorial and national ruler during those epochs considered it a duty of his honor to protect fugitives entering his territory. This duty to protect fugitives became linked to the very prepollence and integrity of the ruler. Any act or demand emanating from a foreign power to obtain jurisdiction over any person within another power's territory represented at least a potential threat to the sovereignty of the requested ruler". ${ }^{362}$

This allows for the proposition that the political offence exception born in the late $18^{\text {th }}$ century constitutes but an institutionalised version of the same principle. ${ }^{363}$ In reality, at its inception, ${ }^{364}$ the modern concept of 'political asylum' was not general in scope, but

358 See e.g. LASSA OPPENHEIM, op. cit., p. 514; CHRISTINE VAN DEN WyNGAERT, The political offence exception to extradition... op. cit., p. 9 f.; M. CHERIF BASSIOUNI, International Extradition... op. cit., p. 669 f.; CHRISTOPHER H. PYLE, op. cit., p. 82.

359 For accounts of rejected extradition requests related to politically relevant cases, see e.g.: on the ancient near east, Trevor Bryce, The Kingdom of the Hittites, Oxford: University Press, 2nd ed., 2005, p. 127 f.; id., "The 'Eternal Treaty' from the Hittite perspective", op. cit., p. 4, 6; Id., Letters of the Great Kings of the Ancient Near East: The Royal Correspondence of the Late Bronze Age, London: Routledge, 2003, p. 29, 107, 206 f.; William J. Murnane, The Road to Kadesh: A Historical Interpretation of the Battle Reliefs of King Sety I at Karnak, $2^{\text {nd }}$ ed., Chicago: Oriental Institute, 1990, p. 56 f., WERnER WOUTERS, "Urhi-Tešub and the Ramses-Letters from Boghazköy", JCS 41 (1989), p. 226 f.; Judges 20:12 f. On classical antiquity and the middle ages, HuGo Grotius, op. cit., p. 368; Christine van Den Wyngaert, The Political Offence Exception... op. cit., p. 6.

360 See Paul Bernard, op. cit., p. 11, 27; Evariste Blondel, Monographie Alphabétique de l'Extradition, Paris: Cosse, Marchal et Cie, 1866, p. $88 \mathrm{f}$. That asylum was key to the scarcity of extradition in antiquity is implied even by those who upheld that ancient practices were 'non-analogous' to modern extradition, such as Fernand de Cardaillac, op. cit., p. $6 \mathrm{f}$., who mentions Justinian's Novel XVII only to stress that it was an exception and that the principle of asylum would later remain intact for a long time.

361 Christine VAn Den Wyngaert, The Political Offence Exception... op. cit., p. 6.

362 Christopher L. Blakesley, "The Practice of Extradition from Antiquity to Modern France and the United States: A Brief History”, BCICLR 4 (1981), op. cit., p. 45.

363 See M. CHERIF BASsiouni, International Extradition... op. cit., p. 182 f.

364 There are earlier examples of exclusion of extradition for political offences. In 30 September 1833, the day before the enactment of the Belgian Act, France and the States of the Helvetic Confederation had abrogated through an exchange of notes a provision from their 1828 Treaty allowing extradition for offences against the security of the State, which equated to a complete exclusion of extradition between those States for political offences: see ALBERT Billot, op. cit., p. 109 f.; IVAN ANTHONY SHEARER, op. cit., p. 18; LORA L. DEERE, op. cit., p. 250 f. More than two decades before that, the 1802 Peace Treaty of Amiens, between Spain, France and England, was already limited to common crimes: see WiLLIAM MAGNUSON, op. cit., p. 848 f.; ANTONIO QuintAno RiPOLÉs, Tratado de Derecho Penal Internacional e Internacional Penal: vol. II, Madrid: Instituto Francisco de Vitoria, 1955, p. 162. The 1376 Treaty between France and Savoy (as already noted supra, Chap. $7, \$ 2.2 .3)$, was also less concerned with political than with common criminality. 
selective or biased: the French Constitution of 1793 did not reject the extradition of each and every political offender or politically persecuted person, but only of those who were exiled "on account of liberty"; it did not refuse extradition to each and every requesting State, but only to "tyrants." ${ }^{\text {" }} 65$ It was, therefore, in and of itself, a political weapon.

The exception would soon evolve and crystallise into an instance of general scope, applicable in the relations not only between States with disparate political regimes, but also between States with similar ones, and it is already with this shape that we find it in the Belgian Act of 1 October 1833. ${ }^{366}$ Perhaps neutrality in relation to the political problems of all States served to legitimise the original intentionality of the rule. On the other hand, this development was consistent with the accentuation of the concept of territorial sovereignty verified in the $18^{\text {th }}$ century. ${ }^{367}$ Moreover, it can be hypothesised that the opponents of a given political regime would often not seek refuge in a State governed by a regime of the same kind. In any case, as van den Wyngaert observes, in practice, "even in the new liberal democracies, the principle was not immediately accepted, or was accepted only to a limited extent": "The new rulers often vehemently protested when asylum was violated by other states, but did not hesitate to infringe it themselves whenever they wanted to get hold of their political opponents. For example, when, in 1801, the Senate of Hamburg extradited three Irish rebels to England, Napoleon Bonaparte wrote a letter to the authorities of Hamburg, in which he strongly condemned the surrender. (...) This, however, did not prevent Napoleon, as far as his own adversaries were concerned, from exhausting all available means to obtain their extradition, including the use of threats against other states. Immediately after the signature of the Peace Treaty of Amiens in 1802, he requested the English to expel the French immigrants. The refusal of the English to do so was one of the causes of the long wars which followed." 368 As far as specifically concerns the Belgian 1833 act, the author gives account of strong contextual reasons for the inclusion of such a general, abstract, and very broad (as it covered also faits connexes, and not purely political acts only) political offence exception: "It was hoped that through this provision the intervention of the mighty neighbour states concerning the extradition of political refugees could be avoided. The pressure exerted by the Holy Alliance against the Swiss Confederation was still fresh in mind and, at the time of the discussion of the law in Parliament, the Members gave particular consideration to the Polish refugees, who, after the

However, none of these yet conceived the political offence exception as a principle of extradition law, as would later do the French 1793 Constitution or the Belgian 1833 Act. In any case, while liberal revolutions and the Enlightenment produced the concept of political asylum as currently understood, its seed had been planted during the preceding phase of religious wars in Europe. To CHRISTINE VAN DEN WYNGAERT, The Political Offence Exception... op. cit., p. 6 f., the religious refugees which those wars produced "can be likened to political refugees because their only crime consisted of their noncompliance with religious dogmas".

365 See \120: “[La France] donne asile aux étrangers bannis de leur patrie pour la cause de la liberté. - Il le refuse aux tyrans".

366 See Art. 6: “(...) l'étranger ne pourra être poursuivi ou puni pour aucun délit politique antérieur à l'extradition, ni pour aucun fait connexe à un semblable délit (...)”.

367 See M. Cherif Bassiouni, International Extradition... op. cit., p. 182; Gregory CHADWICK PERRY, op. cit., p. 713.

368 Christine VAN DEN WyngaerT, The political offence exception to extradition... op. cit., p. $10 \mathrm{f}$. 
unsuccessful rebellion of Warsaw, had come to Belgium to seek asylum". ${ }^{369}$ More generally, yet according to the author: "The first provisions concerning the political offence exception were drafted in an atmosphere of romanticism and glorification of political offenders, starting from an almost naïve identification of the political offender with the liberal revolutionary, without, however, taking into account the possibility that other political offenders would in turn oppose the new liberal legal order itself'. ${ }^{370}$

Even so, in time the rule carried what was perceived by States as momentous shortcomings. It was again by impulse of Belgium and France that was adopted what came to be known as the 'attentat clause', following the famed Jacquin case, where French citizens residing in Belgium made an attempt on the life of French Emperor Napoleon III. ${ }^{371}$ After this case, Belgium enacted an 'exception to the exception', so that extradition could be granted if the acts, although political, consisted of an attempt on the life of a foreign sovereign. Thus began the erosion of the political offence exception, through a "legal fiction of depolitization", which expanded almost instantly to other classes of acts and, later, to international crimes and terrorism, and which was further accompanied by doctrinal and jurisprudential efforts to interpret restrictively the concept of political offence. ${ }^{372}$ The political offence exception entered a deflation drift, with a significant number of acts that in the abstract could be deemed political being excluded from its scope. Quite interesting was the approach taken by the Institut de Droit International at a session held in Geneva in 1892 and later replicated in many extradition instruments. This approach entailed the exclusion in totum of acts committed in the name of specific political ideologies, notably anarchism, by excluding from the political offence exception any acts directed at the bases of social organisation as a whole, rather than against a specific State or form of government. ${ }^{373}$

The history of the political offence exception reveals that its selective or biased nature never disappeared. As Gilbert - already quoted above regarding the intervention of political entities in extradition proceedings - appraised, judicial decisions "often seem to owe more to foreign policy than to legal reasoning. In the past, political offence decisions have been based upon whether the fugitive was from the former Soviet bloc, whether the requesting state was an ally, support for the fugitive or his group in the requested state, encouraging a peace process, the usefulness of the transnational fugitive offenders to the intelligence services, even economic interests." ${ }^{374}$

${ }^{369}$ Ibid., p. 13, further informing: "The Belgian Revolution had destroyed a state which by the Congress of Vienna (1815) had been erected as a barrier against France. The Great Powers were very upset about this event. In November 1830, Prussia and Austria wanted to intervene. The Polish uprising of the same year (1830), however, mobilized the Holy Alliance's armed forces and as such contributed to the successful outcome of the Belgian Revolution"; and yet: "The simultaneousness of both revolutions and the failure of the Polish Revolution had created enormous sympathy in Belgium for the Polish refugees. It was in fact especially for them that the 1833 Extradition Act was introduced and that the 'faits connexes' (related facts) were added to the originally proposed formulation of the political offence exception."

${ }^{370}$ Ibid., p. 14.

371 See Christine VAN DEN WyngaERT, The political offence exception to extradition... op. cit., p. $14 \mathrm{f}$.

372 See ibid., p. 15 f.; and $i d$. ., "The political offence exception to extradition: How to plug the 'terrorists' loophole' without departing from fundamental human rights”, RIDP 62 (1991), p. $291 \mathrm{f}$.

373 See Christine VAN DEN WyngaerT, The political offence exception to extradition... op. cit., p. 16.

374 GEOFF GILBERT, Responding to International Crime... op. cit., p. 194 f.; see further supra, \ 2.1.3. 
In sum, while the political offence exception was an iconic feature in extradition arrangements at the turn of the $18^{\text {th }}$ and into the $20^{\text {th }}$ century, it never constituted an element that modern extradition law could structurally not do without: (i) it is not a necessary result of the expansion of extradition into ordinary criminality (which is the true distinctive trait of modern extradition); (ii) although concomitant, the two effects in fact result from different causes; (iii) from inception the political offence exception was all along a selective or biased rule (as is visible in the 1793 French Constitution) and, although in theory it would shortly later evolve into a rule of a general nature (e.g. in the 1833 Belgian act), in practice its application has always remained rather selective or biased, oscillating notoriously according to the political ties binding the requested State and the requesting State.

If any doubts existed that the political offence was not an indispensable element of extradition law, they have been emphatically displaced throughout the second half of the $20^{\text {th }}$ century, when several extradition arrangements emerged where this ground for refusal was subject to substantial mitigation, with several violent acts (particularly terrorist) being stripped of political character for extradition purposes. To mention only a few examples, this is the case of the $1957 \mathrm{CoE}$ Convention, ${ }^{375}$ the 1996 EU Convention, ${ }^{376}$ the $1998 \mathrm{Ar}-$ ab Convention for the Suppression of Terrorism, ${ }^{377}$ and the 1999 Convention of the Organization of the Islamic Conference on Combating International Terrorism. ${ }^{378}$ By the 1990 's it had become a rather uncontroversial understanding that the political offence exception did not cover most violent acts, ${ }^{379}$ which to a large extent settled, if only at the pragmatic level, the 'problem' of the political offence exception, in that it removed from beneath its umbrella the acts whose impunity sparked greater social disapproval and concern.

Most meaningfully, the deterioration of the political offence exception has been taken to another level in the context of cooperation between States with extremely close political ties, which eventually developed extradition arrangements that excluded completely the possibility of refusing extradition due to the political character of the acts, regardless of their violent character. This was the case of Nordic extradition arrangements, ${ }^{380}$ and, later, EU arrangements: the 1996 Convention had already made an approximation to this solution, if relatively timid, ${ }^{381}$ and the EAW embraced it conclusively. ${ }^{382}$ This is conceptu-

375 See Art. 3 (3) and (4).

376 See Art. 5.

377 See Arts. 2 (b) and 5 f.

378 See Arts. 2 (b) and 5 f.

379 See e.g. VincEnt DeFABO, “Terrorist or Revolutionary: The Development of the Political Offender Exception and Its Effects on Defining Terrorism in International Law”, AUNSLB 2 (2012), p. $74 \mathrm{f}$.

380 See supra, Chap. 2, \3.1.1.

381 Indeed, whereas most contemporary arrangements maintained the political offence exception in line of principle, and then exempted some offences from such a principle, in the $1996 \mathrm{EU}$ Convention the principle was abolition (Art. 5 (1)), and some reservations were then admitted (Art. 5 (2) f.). On the political offence exception in the context of this convention, see EMMANUELLE Bribosia / ANNE WEYEMBERGH, op. cit., p. $77 \mathrm{f}$.

382 See e.g. Vincent Glerum / KLAas Rozemond / EliES VAn SliEdregt, "Lessons of the European Arrest Warrant", in Larissa van den Herik / Nico Schrijver (eds.), Counter-Terrorism Strategies in a Fragmented International Legal Order: Meeting the Challenges, Cambridge: University Press, 2013, p. 195; but see supra, S 2.1.2, on Protocol no. 24 to the TFEU. 
ally very different from denying political character to certain classes of acts for extradition purposes. Similarly to what happened in the transition from the enumerative or listof-offences system of determination of extraditable acts to the dual criminality or formula system, ${ }^{383}$ the depolitisation system still assumes that, as a principle, extradition should not be granted for political acts; it simply concedes that the violent nature of certain acts supersedes the reasons which underpin that principle. ${ }^{384}$ In contrast, excluding altogether the political offence exception means that States no longer see any reason not to cooperate with each other due to the political character of the acts. Therefore, and to conclude, when we currently address the issue of political offences in the context of extradition, we know for a fact that it is not an inexorable rule of extradition law. ${ }^{385}$

\section{b) The threefold rationale}

Although in the wealth of literature on the political offence exception there may be some variations as to what the rationale of this ground for refusal is, the analysis of van den Wyngaert has been widely endorsed and remains an essential reference. ${ }^{386}$ The author posits that this rationale unfolds into three main sets of considerations: (i) Humanitarian, in that it presumes that political offenders are very likely not to receive a fair trial in the State at which their acts were aimed. (ii) Diplomatic, in that it guards the requested State from meddling in the affairs of other States, allowing it to remain neutral. Such a neutrality, on the other hand, will often serve the interests of the requested State, since individuals who are at one point considered offenders in a given State may later emerge as its rulers, such that the criminal character of their acts "is in the end only dependent upon the outcome of the political struggle". ${ }^{387}$ (iii) Moral, in that it presumes that political crimes are harmful only to the interests of the specific State at which they are aimed, and that therefore there does not exist a common interest in punishing them. By the same token, political offenders are deemed generally not to pose a danger to the polity granting them asylum. Inherent in this argument is also the view that resistance to political oppression is legitimate and may justify acts that, albeit criminal, seek to bring about political changes.

It is by reference to this threefold categorisation that the following paragraphs address the question as to whether the political offence exception remains 'necessary' in the sense assigned to this term in this study. The reader should be forewarned that, to a large extent, this question has already been answered in legal literature and State practice.

383 See supra, \4 4.1.1.b), and further supra, \Chap. 6, \ 2.1.1.

384 This is the notion implied in CHRISTINE VAN DEN WYNGAERT, "The Political Offence Exception to Extradition: Defining the Issues and Searching a Feasible Alternative”, RBDI 17 (1983)”, op. cit., p. 752, when the author asserts: "Rather than questioning the rule itself, practical solutions are sought to avoid the rule (depolitization)".

385 Even if political contingency is: see supra, $\int 2.1$.

386 Christine van DEN Wyngaert, The Political Offence Exception... op. cit.., p. 2 f.; also, with some variations, "The Political Offense Exception to Extradition: How to Plug the 'Terrorist's Loophole'...", op. cit., p. 298. The categorisation of the author, however, is perhaps not as clear-cut as presented in this study, this being a responsibility of this author. The same applies to the labels attached to each category.

387 Christine van Den Wyngaert, The Political Offence Exception... op. cit.., p. 3 f., evoking Balzac's remark that "Les conspirateurs vaincus sont des brigands, vainqueurs, ils sont des héros". 


\section{c) The bumanitarian dimension}

As far as concerns its humanitarian dimension, the political offence exception constitutes a clear-cut example of how supervening grounds for refusal brought about by the advent of individual and human rights in extradition have rendered redundant some preexisting grounds for refusal. ${ }^{388}$ Indeed, in this specific dimension the political offence exception has been absorbed by grounds for refusal concerned with fair trial rights, namely the right to a due process and the right not to be discriminated against for political reasons (non refoulement). Pursuant to these grounds for refusal, extradition should already be refused if there is a real risk that the person will not be entitled to sufficient procedural guarantees in the requesting State - which in turn unfolds into an array of circumstances, such as the possible partiality of the court where the acts will be tried, the lack of guarantees of defence, the risk of torture or ill-treatment, etc. -, or that he/she will be discriminated against owing to his/her political activity or beliefs. The person will moreover be protected by certain grounds for refusal related to the applicable penalty, if the political character of the offence translates into inadmissible forms of punishment in the requesting State.

As far as the guarantee against discrimination is concerned - a principle originated in asylum law and enshrined in Art. 33 (1) of the 1951 Refugee Convention -, it enjoys constitutional rank in some States (as in Portugal), and in others (as in the UK) it is even deemed to have functionally replaced in full the political offence exception. ${ }^{389}$ This might seem evident today, but in the 1980's the role of individual rights in extradition was far from unequivocal. The partial overlap of the classic political offence exception by grounds for refusal concerned with unfair and discriminatory procedures was precisely one of the propositions made by van den Wyngaert in her study on the political offence exception. ${ }^{390}$ According to the author, the political offence exception failed to capture the essential individual guarantees that required protection: on the one hand it was excessively narrow, in that it only protected political offenders, and no other individuals facing real prospects of discrimination or unfairness in the requesting State; ${ }^{391}$ on the other hand it was excessively broad, in that it offered such a protection even in the absence of a concrete risk of discrimination or unfairness. ${ }^{392}$

388 See supra, Chap. 3, § 2.1., and Chap. 7, \ 3.2.4.b).

389 See supra, Chap. 6, \$ 2.3.3.

390 See Christine van Den Wyngaert, The Political Offence Exception... op. cit.., p. 207 f. M. CHeriF BASSIOUNI, International Extradition... op. cit., p. 676, also argues that preventing discrimination is "in a large part" the purpose of the political offence exception.

391 Excessively narrow also in the sense that political offenders generally tend to be the most persecuted offenders and, thus, those who are more exposed to alternative devices of doubtful lawfulness, such as international abduction: see ibid. p. 51 f.; see also Antje C. PETERSEN, "Extradition and the Political Offense Exception in the Suppression of Terrorism”, ILJ 67 (1992), p. $767 \mathrm{f}$.

392 Excessively broad also in the sense that refusal of extradition is generally be ensued by sheer impunity, however atrocious the acts at issue might have been. And in this regard the author propounds the application of the principle aut dedere aut judicare: CHRISTINE VAN DEN WyngaERT, The Political Offence Exception... op. cit.., p. 207 f.; in a similar sense, see M. CHERIF BASSIOUNI, International Extradition... op. cit., p. 737. This question will re-emerge further below, in $\left.\int \mathrm{e}\right)$. 
It cannot be denied that such guarantees, particularly fair trial rights, must generally meet very demanding thresholds in order to give rise to a prohibition to extradite under human rights law (sc. under Art. 14 ICCPR or Art. 6 ECHR). ${ }^{393}$ Moreover, the fact that the offence has a political character does in the abstract enable the presumption that the likelihood of an unfair or discriminatory trial is higher than usual. This still transpires from the writings of van den Wyngaert, when she observes that political offenders tend to be "the more wanted offenders", 394 as well as of Bassiouni, when he contends that political offences affect "the most sensitive interests" of the requesting State and, in consequence, "inspire a passionately hostile atmosphere"; 395 or of García-Mora, when he refers to a risk of being tried by courts "colored by political passion". ${ }^{396}$ This concern must be taken into consideration. However, it does not require a traditional, blind-folded political offence exception that presumes in irrebuttable terms that a fair trial is impossible. Instead, such a concern may be accommodated by lowering the threshold at which the risk of an unfair trial becomes sufficient to refuse extradition on human rights grounds. That is, the fact that the offence is political need not give rise to a ground for refusal of extradition if it can be taken as an indicator that the criminal procedure in the requesting State may be unfair or discriminatory, this being the true reason for refusing extradition. ${ }^{397}$

\section{d) The diplomatic dimension}

Turning to the diplomatic aspect, the claim is that extraditing for political offences may "embroil" the requested State in the domestic politics of the requesting State. ${ }^{398}$ As a starting point to this question, the view is reiterated that positive actions are not the only manner through which the principle of non-interference may be hindered. The same effect may be caused by omissions, and this is what happens when an extradition request is unfulfilled without justification. ${ }^{399}$ That the 'neutrality argument' used in favour of the political offence exception is quite fragile is clearly pointed out by van den Wyngaert, who asserts that, while by extraditing a deemed political offender the requested State may be seen to be siding with the forces in power in the requesting State, one may "as well argue that the impunity granted to political offenders whose extradition has been denied factually amounts to effectively supporting foreign dissidents", which is also "very far from 'neutrality" ". 400

Nevertheless, the neutrality argument appears to play out differently depending on certain variables, such as whether or not the requesting State is immersed in a civil crisis or war. If this is the case, then granting extradition to this State does inevitably appear to entail taking the side of the forces in power, which are the ones that are requesting extra-

393 See supra, Chap. 3, esp. \4.4. and 4.5.

394 Christine VAn DEN Wyngaert, “The Political Offence Exception...”, op. cit., p. 753.

395 M. CHERIF BASSIOUNI, International Extradition... op. cit., p. 735.

396 Manuel R. García-Mora, “The Nature of Political Offences: A Knotty Problem of Extradition Law", VLR 48 (1962), p. 1226.

397 In this line, see AG, Celmer, $\$ 113$.

398 UNODC, "Revised Manuals...”, op. cit., p. 16.

399 See supra, Chap. 7, \3.1.2.

400 Christine van Den Wyngaert, “The Political Offence Exception...”, op. cit., p. 752. 
dition. At the same time, however, this is also the case where refusing to extradite can more readily be understood as a gesture of support for the other faction in the conflict. This suggests that, if the political situation in the requesting State is such that either an action or an omission by the requested State may carry interference in its internal affairs, then both (action and omission) will be acceptable courses of action in the light of the duty of non-interference. ${ }^{401}$ But the case will already be different if the requesting State is not visibly embroiled in an internal conflict. In this case, if one agrees that, in normal circumstances, the requesting State should be entitled to obtain extradition so that it can assert its prioritary jurisdiction over the acts, it will be difficult to justify how granting extradition would count as interference in its affairs, when it is this very State, functioning normally, that is requesting such an action from another State.

The problem, of course, is that establishing whether or not the political environment in the requesting State is such as to allow for the conclusion that there is an internal conflict constitutes a pointedly subjective assessment. More importantly, such an assessment - like the concept of 'political offence' itself - is inevitably conditioned by the variable of whether the requested State has greater empathy for the intention of the requesting State to punish the acts, or for the rebels who committed them. It is impregnated by concomitant assessments of a more ideological character, such as that as to whether the requesting State has an authoritarian form of government (in which case its political stability can be read as apparent and artificial), or instead a democracy functioning normally (in which case an extradition request may be assumed to represent the interests of its community).

Even if one seeks as much as possible to avoid the dichotomy between democracy and other forms of government in the light of international law $-{ }^{402}$ let alone the discussion as to the core meaning of those concepts and the myriad of variations existing within each of them -, it is a historically uncontroversial fact that the political offence exception is a creation of liberal democracies, a product of $18^{\text {th }}$-century theories of freedom, democracy and resistance against oppression. ${ }^{403}$ The point here is that the question of whether or not the requesting State is a democracy has little to do with the duty of noninterference. ${ }^{404}$ Naturally, the fact that the requesting State is a dictatorship will constitute a weighty indicator that extradition of political offenders should be rejected on humanitarian grounds. It will also constitute a relevant factor from the diplomatic and the strate-

401 The situation calls to mind the classic problem of the unstoppable trolley-car on course either to kill a person / group of people, or, if steered onto another direction (this being the only choice available to the driver), kill another person or group of people. Answers to this problem differ depending on the philosophical standpoint adopted (consequential, categorical), but generally the driver will not be held liable in either scenario: the conduct either will not be blameworthy, or will not be unlawful to begin with. A recent review of this quandary by reference to the subject of self-driving vehicles can be found in IVÓ COCA-VILA, "Self-driving Cars in Dilemmatic Situations: An Approach Based on the Theory of Justification in Criminal Law”, CL\&Ph. 12 (2018), p. 59 f.

402 But see Jure VIDMAR, Democratic Statehood in International Law: The Emergence of New States in Post-Cold War Practice, Oxford: Hart, 2013, p. 20 f. et passim.

403 See Christine van Den Wyngaert, The Political Offence Exception... op. cit.., p. 8 f.; M. CHeRIF BASSIOUNI, International Extradition... op. cit., p. 673 f.

404 The UN Charter provides in Art. 2 (1) that the UN "is based on the principle of the sovereign equality of all its Members". 
gic angles, as well as from the 'moral' one yet to be discussed here. If that State is committing severe human rights violations against its people, then this may even constitute a justification for external intervention. However, in and of itself, the political system of the requesting State does not shift the terms of the 'neutrality issue' now in debate, or otherwise one would be admitting that only certain types of States are entitled not to be interfered with. ${ }^{405}$

That the diplomatic and moral dimensions of the political offence exception are interwoven is denoted by the fact, recurrently noted, that in practice the political offence exception has always been selective: drawing again on the research of van den Wyngaert, while the presence of this ground for refusal in nearly all extradition arrangements of the modern era might invite the conclusion that it forms a general principle of extradition law, in reality this would be "but a prima facie conclusion": "a further look at the practical application of the principle shows a relatively chaotic situation, in which extradition of political offenders is, indeed, in theory refused but in practice very often granted" ${ }^{406}$ This also means that the key dimension of the political offence exception is its moral one, and, therefore, that - humanitarian aspects aside - this ground for refusal can only be rationally discussed in that dimension, as is done subsequently.

\section{e) The moral dimension}

In turn, this discussion relates less to legal factors than to political factors stricto sensu, such as political affinity between the requested and the requesting States, and the strategic interests of the requested State - factors which can only be properly assessed from the standpoint of political science. Hence the proposition of van den Wyngaert that "diplomatic" reasons might justify maintaining the political offence exception (although only as an optional, rather than as a mandatory ground for refusal). ${ }^{407}$ Nevertheless, several issues can be addressed from a legal perspective, notably the following: (i) Is it coherent to conceive of political regimes - whichever their characteristics are - as relative, and in consequence sustain that each and every political regime is liable to be challenged from within, or is it not more logical to uphold, instead, that political regimes which are similar to one's own are deserving of one's solidarity? (ii) What constitutes a 'challenge' to a political regime - that is to ask: what is a political offence anyway?

Starting with the second question, it should be noted that the concept of 'political offence' is also a creation of modern extradition law: before the $18^{\text {th }}$ century there was no such concept in either theory or practice of 'international law', ${ }^{408}$ although as already not-

405 See Christine van Den Wyngaert, The Political Offence Exception ... op. cit.., p. 201 f.

406 Ibid., p. 191; see also, again, GEOFF GILBERT, Responding to International Crime... op. cit., p. 194 f.

407 See Christine van DEN Wyngaert, The Political Offence Exception... op. cit.., p. 205 f.; the same solution was also proposed in CHARLES K. BURDICK (rep.), "Harvard Research in International Law: Extradition", op. cit., p. 22, 107 f. (although at p. 31 the possibility is admitted that States may wish to formulate a reservation according to which extradition is mandatorily refused if it concerns political offences). At the time when the Harvard Research in Extradition was conducted the political offence exception had been included as merely optional in some legal instruments, but this was "decidedly the exception rather than the rule": ibid., p. 109, providing examples.

${ }^{408}$ See ibid., p. 4 f. 
ed there is record of earlier cases which do fall within what may be construed as a manifestation of principle of 'political asylum'. ${ }^{409}$ The fact that the concept of political offence was born within extradition law, concomitantly with a corresponding ground for refusal (the political offence exception), rather than derived from pre-existing theoretical structures (notably from substantive criminal law), is a most significant fact, in that it entails a 'circularity problem' which pierces this whole topic. The difficulty - which is similar to that, mentioned above, of intrinsic intertwinement between the diplomatic and the moral dimensions of the political offence exception $-{ }^{410}$ can be articulated as follows: 'a political offence is an offence for which extradition cannot be granted because it is political'. This problem is labelled by van den Wyngaert as a "definitional problem": "the decision [as to whether or not extradition should be granted] is based upon the characterization of the facts as common or political offences, and the [different rationales of the political offence exception, viz: humanitarian, political, moral], insofar as they are explicit, are advanced in the framework of characterization. For example, the seriousness of an offence is often advanced as an argument to demonstrate that it is not a political crime, whereas this characteristic in se does not affect the nature of the offence. What is actually meant is that the crime concerned should be liable to extradition. This way of reasoning results from the fact that, in cases where the political offence exception is raised, characterization of the crimes for which extradition is requested directly determines their liability to extradition, i.e., if they are characterized as political crimes, extradition will be denied; if, on the contrary, they are considered as common offences, extradition will be granted." The result of this approach - the author claims - is that "attention has often first been focused on the conceptual aspect of the problem rather than on the problem itself." More specifically: "Since characterization is the decisive criterion, the whole problem of the political offence exception has often been viewed as a definitional problem. Rather than taking a critical stand with respect to the political offence exception itself, efforts have been concentrated on the identification of criteria in order to give a more appropriate definition to the term 'political offence' and to delineate it, both in a positive and a negative manner". ${ }^{41}$

Accordingly, the present study refrains from addressing the 'characterisation issue' and the numerous theories that have been developed with the aim of drawing frontiers between political and ordinary offences, pure and relative political offences, political of-

\footnotetext{
${ }^{409}$ See supra, \a).

${ }^{410}$ See supra, \d).

411 Christine van Den Wyngaert, The Political Offence Exception... op. cit., p. 196 f.; adding: "the widely shared conviction that the political offence exception is a democratic axiom of which no departure should be made provoked a fundamental reluctance": "Rather than explicitly derogating from the exception, legal techniques were devised so as to obtain the same result, (albeit, in an implicit manner) leading to the chaotic situation wherein, without explicit departure from the rule, offences were 'politicized' and 'depoliticized' only in view of the extraditability of a given offender. Theory and practice (...) have so narrowly focused on the drawing of the line between political and common offences that the core of the problem has often been reduced to a conceptual issue. The conceptual issue should, however, only be a secondary aspect of what, in this writer's opinion, constitutes the heart of the problem: the extraditability of the requested person and the extraditability of the offence. The extraditability of the requested person should depend on the treatment to which he is likely to be subjected in the requesting state; the extraditability of the offence should be dependent upon its inherent seriousness in the light of international public order."
} 
fences and délits connexes, among other categorisations. ${ }^{412}$ For our purposes, the one truly relevant question is that as to whether or not there is something intrinsic to political offences which justifies their principled exemption from extradition. To this end, the concept of political offence can be analytically reduced to a highly abstract concept, such as that found in Bassiouni: a substantive criminal norm which "embodies the protection of sociopolitical structures". ${ }^{413}$ If a State is willing to extradite for such acts, a fortiori it will be willing to extradite for those among them that are violent or terrorist in character or that constitute core international crimes (the classes of acts which have already been 'depoliticised'), while the opposite is not true.

Within this setting, we can then address the issue which is at the heart of the moral dimension of the political offence exception: is it coherent not to assist any State towards upholding its 'sociopolitical structures'? As a preliminary step to answering this question, it is necessary to distinguish two groups of acts, namely acts that are and acts that are not criminally reproached in the requested State. Some States have a more liberal attitude than others regarding certain fundamental individual rights, such as freedom of speech. ${ }^{414}$ Thus, what in a given State may constitute e.g. slander of the head of State, vituperation of State symbols or insult to collective memory, may in another State constitute an unequivocal exercise of a constitutional right. ${ }^{415}$ In many constitutional traditions, freedom to criticise political figures or the State itself has broader boundaries than where the addressee is another individual in his/her private capacity. ${ }^{416}$ This issue, however, can and shall be completely solved through the general rules on 'extraditable acts': according to the approach proposed in this study, the acts will be extraditable if they are criminalised in the requested State or have sufficient qualitative relevance within its criminal justice concepts to justify cooperation on its part. ${ }^{417}$ The fact that the acts have a political character might shift the terms of that problem slightly, but the problem will simply and always be whether the requested State criminalises or recognises the acts to have sufficient criminal resonance; not whether or not the acts have a political character. Only if the acts do meet the concept of 'extraditable acts' (thus ensuring that the requested State will not offend its criminal justice ethos) will the moral question of the political offence exception truly arise.

412 On this issue, which will preserve utmost relevance insofar as the 'definitional' aspect of the political offence exception remains important, do however see e.g.: ibid., p. 27 f., 95 f.; M. CHERIF BASSIOUNI, International Extradition... op. cit., p. 674 f.; GREGORY CHADWICK PERRY, op. cit., p. 718 f.; LORA L. DeERE, op. cit., p. 247 f.; STEVEn Lubet / MORRIS CzACKes, "The Role of the American Judiciary in the Extradition of Political Terrorists", JCL\&C 71 (1980), p. 193 f.; Charles L. CANTrell, "The Political Offense Exemption in International Extradition: A Comparison of the United States, Great Britain and the Republic of Ireland”, MarLR 60 (1977), p. 777 f.; MANuel R. García-Mora, op. cit., p. 1231 f.; CharLes K. BurDICK (rep.), "Harvard Research in International Law: Extradition”, op. cit., p. 113 f.

413 M. Cherif BASSIOUNI, International Extradition... op. cit., p. 675.

414 See supra, and \$ 4.1.1.c), and further supra, Chap. 6, \$ 2.1.

${ }^{415}$ For a recent discussion on some aspects of this topic, see AlinA CHERVIATSOVA, "Gravity of the Past: Polish-Ukrainian Memory War and Freedom of Speech”, EJIL: Talk!, 22 February 2018.

416 See MANuel Da Costa AndRADE, Liberdade de Imprensa e Inviolabilidade Pessoal: Uma perspectiva juridico-criminal, Coimbra: Coimbra Editora, 1996, p. 259 f., et passim.

417 See supra, \ 4.1.1. 
As for this question, it is impossible not to notice the incoherence of denying help to States which share the same basic political values and have similar political institutions. In such a context, even the argument that political offenders are harmless to the requested State erodes, since attacks against similar institutions of foreign States inherently challenge and menace those of the requested State. For many decades now the view has been defended that there is no universally and abstractly applicable reason for a State not to extradite political offenders. Thus, for instance, as early as in 1935 the Harvard Research in Extradition was unmistakeably asserting that: "There is no reason why a State should be precluded from surrendering, if it so chooses, a person sought for a political offense. It may well be that some States, because of close association or because of the close similarity of their political institutions, would find the extradition of political offenders desirable. And there seems to be no reason why they should not be allowed to do so (...). There is no generally recognized rule of international law holding that extradition for a political offense is never permissible irrespective of whatever be the point of view of the requested State in this respect." ${ }^{\text {418 }}$ Similarly, in 1980 van den Wyngaert was also clearly positing that, as long as fundamental individual rights are safeguarded, "there is no reason why extradition should be precluded": "Why, for example, should a country like the Netherlands be compelled to grant asylum to a person who has attempted to introduce a fascist state system in Sweden?"419

At present, these views bear the strength of a fact, as the political offence exception has been practically eradicated between certain States that are linked by particular ties of political affinity. The EAW is paradigmatic of the solidity of this trend, because the political realities of the EU Member States are not even exceptionally homogeneous, and still this ground for refusal is absent from the FD-EAW. On the other hand, the fact that EU Member States are integrated under a common political and institutional structure can be dismissed to constitute a condition for the political offence exception to be abolished, as the same approach had already been implemented among Nordic States. This denotes that it is political affinity - in and of itself, and regardless of a common political structure -, that provides the bases for such an approach. Quite symptomatic of this is also the silence of the EU-USA Extradition Agreement on the subject of political crimes.

Turning back to the diplomatic dimension of the political offence exception, and to complete the circle of its intertwinement with the moral dimension, it is then possible to claim that in situations such as these there will inherently exist no diplomatic reason not to grant extradition for political offences. That is: where there is moral affinity between the requested and the requesting States, there will be no convincing diplomatic justification for them not to cooperate with each other, and refusing extradition thus becomes conceptually much closer to an infringement of the duty of non-interference (by omission), than (the action of) extraditing could ever be.

418 ChARLES K. Burdick (rep.), "Harvard Research in International Law: Extradition”, op. cit., p. 110.

419 Christine van Den Wyngaert, The Political Offence Exception... op. cit., p. 204 f. See also FranCISCO BuENO ARUs, op. cit., p. 322, stating that refusing extradition due to the political nature of the acts when the exact same acts would be punished under the own law of the requested State contravenes the "principle of contradiction", in what seems to be a reference to the prohibition of venire contra factum proprium. 
On the other hand, it is also the moral dimension of the political offence exception that determines whether the principle aut dedere aut judicare can be put into practice. Indeed, if the requested State has moral empathy towards the requesting State, and the only reason why it cannot extradite a political offender to this State is that this State cannot ensure a fair trial in that specific case or that another ground for refusal is met, the possibility can be contemplated of conducting a criminal procedure on behalf of that State, in the name of its sociopolitical proximity. In contrast, if moral affinity is lacking, then not only will extradition not be granted, ${ }^{420}$ but also, a fortiori, the requested State will not take any further action on behalf of the requesting State - which only reinforces the view that the moral dimension of the political offence exception is its key dimension.

\section{f) Summary}

The preceding paragraphs can be summarised as follows: (i) The existence of a real risk of an unfair or discriminatory trial in the requesting State should cause extradition to be refused, and in fact this is now imposed by human rights. The fact that the acts have a political nature does not justify an irrebuttable presumption that the trial will be unfair or discriminatory, but it does increase that risk, which justifies lowering the threshold at which extradition becomes inadmissible on human rights grounds. (ii) The diplomatic dimension of the political offence exception may justify maintaining this ground for refusal, but the argument that extraditing for political offences hinders the principle of non-interference is immaterial. In addition to other variables, the diplomatic implications of the decision whether or not to extradite for political offences depends intrinsically on the moral affinity between the requested and the requesting States. (iii) If there does exist moral empathy, and provided that fundamental individual rights are safeguarded, then there does not exist a universal reason for States not to cooperate with respect to political offences. In fact, if such an empathy exists, refusing extradition will come much closer to breaching the duty of non-interference that granting extradition would.

\section{g) New challenges (brief remarks)}

With the dogma of non-extradition for political offences broken, the time seems to have arrived to start uncovering the challenges that this development brings. The following paragraphs attempt to outline what seem to be the key issues.

\section{(i) Secession}

One emerging challenge for extradition law is secession, which is precisely the core issue underlying the EAW issued by Spain to Belgium and Germany for Puigdemont and other politicians. ${ }^{421}$ The reason why this constitutes a challenge for extradition law is that secession may correspond to an expression of self-determination, and is often unilateral.

420 Assuming, naturally, that we are talking about acts that have not been 'depoliticised', since otherwise - as noted - the problem is no longer establishing whether extradition can be granted for political offences (which is the 'real issue'), but one of determining whether or not given acts have a political character for extradition purposes (which is the merely 'definitional issue' mentioned above).

421 See supra, \2.1.2. 
Consequently, even if a State has extensive moral empathy towards another State and as a principle would cooperate with this State for political offences, the fact that these offences are committed with a view to upholding values that stand at the heart of that very moral empathy (as self-determination stands in relation to democracy), such an affinity may not extend to those acts, especially if they have been committed in an entirely peaceful manner. This is regardless of whether a segment of the population of the requested State has secessionist inclinations itself, although if this is the case the question will naturally assume more vivid contours.

While this represents a new challenge for extradition law, for general public international law it represents a classic one. ${ }^{422}$ And it is primarily in the realm of the latter that it should be addressed, for if the secessionist claim is patently unfounded the moral bond necessary for extraditing will still hold. As for the cases where there is a strong claim for secession, or at least a debatable argument, then it appears that the inexorability of diplomacy and politics upon extradition matters will surface, and that some margin for refusal has to be admitted.

Such a refusal may be determined either through the intervention of the executive branch in the extradition procedure itself, ${ }^{423}$ or through the asylum system (in the light of which that claim might qualify as an act of democracy and self-determination justifying a principled act of protection of the deemed offender on the part of the requested State). ${ }^{424}$ The two options are somewhat different at the conceptual level: through an executive intervention in the extradition procedure, the requested State will simply be stating that its generic moral empathy towards the requesting State does not apply to those specific acts; in turn, granting asylum implies not only the same, but also that the requested State even has moral empathy for those specific acts.

It should be emphasised that none of this intends to convey that a classic political offence exception should be set in place. Only that its abolition - which in line of principle is defended in this study - can, and on occasion should be compensated through expedients other than classic grounds for refusal. ${ }^{425}$

\section{(ii) Whistleblowing}

Another prominent challenge is that posed by cases where the deemed offender was not seeking to attack the sociopolitical foundations of the State, but to uphold those very foundations. That is, cases where the offence is not aimed at bringing about changes to the political organisation or axiology of the State, but to react against the fact that the con-

422 See e.g. Jure Vidmar, Democratic Statehood... op. cit., p. 39 f., 139 f.; see the 1933 Montevideo Convention on the Rights and Duties of States, adopted at the International Conference of American States, which codifies international customary norms, but which raises as many difficulties and interrogations as it provides answers: see ibid, p. $39 \mathrm{f}$.

423 See supra, \2.1., and further supra, Chap. 7, \3.3.6.

424 See e.g. supra, Chap. 6, SS 1.2. and 2.3.

${ }^{425}$ Here one must depart from the stance of CHRISTINE VAN DEN WYNGAERT, The Political Offence Exception... op. cit., p. 210, that, by abolishing the political offence exception among likeminded States, "political asylum is reduced to its most basic rationale and also restricted to it, i.e. the protection of the requested person against an unfair and partial trial in the country requesting his extradition". 
duct of the State is contravening its moral underpinnings. The paradigmatic example of this is 'whistleblowing', a term which immediately conveys a positive significance, by suggesting an action of alerting to an ongoing problem - rather than an action of producing a problem -, intentionally distancing its author from such stigmatising labels as 'fink', 'informer', 'squealer', 'rat'. ${ }^{426}$

One particularly noteworthy case is that of Edward Snowden, who disclosed secret government documents in breach of USA secrecy laws. Snowden initially fled to Hong Kong, and the US sought his extradition from this Special Administrative Region of the PRC; a political offence exception applied, although refusal was justified by Hong Kong on the basis that insufficient information had been received for the provisional arrest to be possible to process; Snowden fled to Russia shortly later, staying at the airport pending his application for a visa, and was eventually granted temporary asylum on 1 August 2013; on 23 January 2014, USA's Attorney General declared that it was very unlikely that the USA would consider a clemency measure. ${ }^{427}$

Bassiouni claims that in this case there is sound reason not to grant extradition. The author argues that no "human harm" or "general social harm" has been caused, and that "harm to the 'national security' is not only subjective, but it is also dependent upon who decides what is and what is not part of "national security" ". "To the author, not only has no relevant harm been caused, but in fact Snowden's action “constituted a positive benefit as it revealed abuses of secretive practices that violate the constitutional right of privacy and other individual rights", as well as the sovereignty of other States, as it revealed that the National Security Agency was "targeting (...) foreign governments and foreign leaders". After conveying Snowden's claim that he was not acting on behalf or in the interest of any foreign State, Bassiouni notes the similarities of this case to that of Daniel Ellsberg and the disclosure of the 'Pentagon Papers' back in 1967. Ellsberg was prosecuted based on the very same statute as Snowden: the Espionage Act of 1917. As is well known, that case gave rise to a landmark ruling by the US Supreme Court allowing the New York Times to continue to publish the leaked information. As for Ellsberg and Anthony Russo (who had assisted him in the leak), as is also known, charges against them were dismissed in 1973, following, and in direct correlation with the Watergate scandal. While acknowledging that "[c]ertainly, every state has something equivalent to a state's secrets law", and that "Snowden committed a crime under US law", Bassiouni posits that

426 See RoBert TOWnSEnd, “The Whistle Blower as Entrepreneur”, in Ralph Nader / Peter J. Petkas / Kate Blackwell (eds.), Whistle blowing: the report of the Conference on Professional Responsibility, New York: Grossman Publishers, 1972, p. 26. This book, and particularly Nader's activity, are generally considered the triggers for the dissemination of the use of the expression 'whistleblowing': see WIM VANDEKERCKHOVE / Tina Uys / Michael T. ReHG / A.J. Brown, "Understandings of whistleblowing: Dilemmas of societal culture", in A. J. Brown / David Lewis / Richard E. Moberly / Wim Vandekerckhove (eds.), International Handbook on Whistleblowing Research, Cheltenham: Edward Elgar, 2014, p. 39 f., elaborating on different perceptions of whistleblowing worldwide.

427 See M. Cherif BAssiouni, "Two Hypothetical Prospective Extradition Cause Célebre: the Snowden and Knox cases", in Pia Acconci (ed.), International law and the protection of humanity: Essays in honor of Flavia Lattan₹i, Leiden: Brill, 2017, p. 297 f.

${ }^{428}$ Ibid., also the subsequent quotes in this paragraph. 
the issue with his hypothetical extradition is "basically simple", namely that of determining whether "his action was politically motivated or based on a crime that constitutes the criminalization of conduct that would otherwise be lawful because it is peaceful and in the exercise of freedom of expression". After noting that the political offence exception "has a longstanding history in most of the world's legal practices", based on equally longstanding political theories inherited from the Enlightenment, and that the purely political offence exception is "well established in customary international law", the author concludes that Snowden's acts qualify as a purely political offence, because the law that he breached "does not look into his motives", and "protects what is essentially a political interest as opposed to a social interest" - which may not be relevant for national criminal law, but is certainly relevant for extradition law, where "both the nature of the crime and the motive of the requesting state are taken into account". Bassiouni further noted that this would even "exten[d] to what is called the 'relative political offence' exception when, as incident to a purely political offence exception, an unintended social harm results".

In the text described above, Bassiouni is fundamentally reiterating the reasons why the political character of the offence (especially if it is 'purely' political) is in many cases a reasonable ground for refusing extradition. The reasoning manifestly applies to this case, in the light of the diplomatic and moral considerations expounded above, since it is clear that the US and Russia are not linked by ties of close political affinity which would make it sensible on either part to abolish the classic political offence exception in their bilateral relations. However, the interesting hypothesis to explore is that where the requested and the requesting States are linked by such ties, as would be the case if for instance the States involved were EU Member States. The challenge is to determine whether it would be reasonable to extradite an offender like Snowden in a setting of generic moral affinity between the involved States. Two facts must be underscored beforehand with respect to the Pentagon Papers: one is that the US Supreme Court's ruling on the New York Times case relates to the First Amendment (i.e. freedom of expression), rather to Ellsberg and Russo's possible criminal liability; the second is that the proceedings which did concern the criminal liability of Ellsberg and Russo were discontinued not on the merits, but because gross misconduct by the government and illegal gathering of evidence had "incurably infected the prosecution of this case". ${ }^{229}$ This is not the place to consider whether or not, and if so in which cases and why whistleblowing should exclude criminal liability, or constitute a particularly strong candidate for clemency measures to be applied. The existence of criminal offences aimed at deterring the disclosure of State secrets is a fact, and it matters here only insofar as extradition is concerned.

What is more interesting in the Pentagon Papers case, insofar as our topic is concerned, is the wide public support with which the disclosure of information was met within the very State whose criminal law was breached, as well as in other, politically similar, States. ${ }^{430}$ Another case (already mentioned earlier) that triggered identical reaction was that

${ }^{429}$ US v. Anthony Joseph Russo and Daniel Ellsberg, C.D. California, no. 9373-CD (1973), apud M. CHERIF Bassiouni, "Two Hypothetical Prospective Extradition Cause Célébre...” op. cit., p. 300.

${ }^{430}$ Daniel Ellsberg has been awarded e.g. the Gandhi Peace Award (USA) in 1976, aimed at "promoting enduring peace" (see www.gandhipeaceaward.org/), the inaugural Ridenhour Courage Prize (USA) in 2004, 
of Chelsea Manning, convicted in 2013 by a US court-martial to 35 years of imprisonment (also based, inter alia, on the Espionage Act of 1917), for the disclosure of secret military and diplomatic information to WikiLeaks. ${ }^{431}$ After 7 years in deprivation of liberty, Manning had her sentence commuted down to 4 months of imprisonment in January 2017 by former US President Barack Obama. It is noteworthy that a commutation, rather than a pardon was granted to Manning, with Obama having stressed that her punishment, harsh as it might have been (and her sentence was by far the longest ever applied in the US for this type of acts), had been a fair consequence for those acts. In fact, during that presidency, approximately 10 cases were prosecuted involving the leak of government secrets, more than under all previous US administrations combined. In any case, like Ellsberg (to whom she has often been compared), Manning has also received sizeable support within the US and abroad. There are, of course, large segments of the population that regard this type of acts as high treason. The point is simply that these acts can, even within the State that was affected by them the most, receive significant support.

Extraditing an individual for such acts will often not translate adequately the political sensibility of the requested State. Even if this State has a generic moral rapport with the requesting State, this rapport will often not extend to this class of acts. The mismatch between 'generic' and 'specific' moral affinity is much more visible here than in the case of acts such as secession, mentioned above. The latter still presuppose an attack on the political structure of a State, even if carried out in the name of values that are at the core of its axiological identity, such that what ultimately determines whether that generic moral affinity will hold or cease is the strength of the political claim underpinning the acts (i.e. whether or not there is sound claim for statehood under general public international law). In contrast, in cases such as whistleblowing, as noted at the opening of this section, the distinctive trait is that the offender does not attack the sociopolitical foundations of the State in any manner, but in fact acts towards upholding those very foundations, by reacting against State action which is jeopardising them. As such, these cases disrupt even more clearly than cases such as secession the moral empathy of the requested State towards the requesting State, and therefore are even stronger candidates for the refusal of extradition.

As for the contours that this refusal might take, the same options presented above in respect of secession apply: direct refusal by the executive branch within the extradition proceedings, or indirect refusal via the asylum system. However, as in these cases the disruption of moral empathy is even more blatant, these cases could perhaps justify the creation of a 'whistleblowing exception to extradition', applicable between States that have a generic moral rapport which enables them to cooperate for virtually all other political offences. Such an exception would not require that the motivation of the offender be estab-

aimed at "fostering the spirit of courage and truth" (see www.ridenhour.org/); and the Right Livelihood Award (Sweden) in 2006, intended to "honour and support those offering practical and exemplary answers to the most urgent challenges facing us today" (see www.rightlivelihoodaward.org/).

431 See www.cbc.ca/news/world/obama-commutes-chelsea-manning-s-prison-sentence-1.3939966, www.nytimes.com/2017/01/17/us/politics/obama-commutes-bulk-of-chelsea-mannings-sentence.html, and www.theguardian.com/us-news/2017/jan/18/barack-obama-final-press-conference-chelsea-manning, also for the remaining factual information provided in this paragraph. 
lished, but might focus on factual criteria instead, namely on the fact that the acts imputed to the offender consisted of exposing actions of the requesting State which objectively amount to breaches of its own constitutional law or of international law. ${ }^{432}$ Cases such as that of Manning and Snowden would fit within this criterion more clearly than cases such as that of Ellsberg, because, in the latter case, unethical, but not necessarily unlawful State action has been exposed, whereas the former cases strongly suggest a breach of national constitutional law and international law by the State.

Naturally, a 'whistleblowing exception' exposes itself to the criticism that it constitutes an open invitation to the breach of national secrecy laws, which would place democratic States at a disadvantage vis-à-vis States ruled by other types of governments. However, a whistleblowing exception: (i) is theoretically vindicated, because in such cases there is a disruption of the moral rapport which is necessary in the first place for the traditional political offence exception to be abolished; (ii) would still be much narrower than the traditional political offence exception which remains in force between States bound by ties of moral empathy; and (iii) from a strategic and symbolic perspective, it is quite doubtful that having individuals such as Snowden flee to States with whom the breached State has no generic moral rapport is more sensible than permitting them to remain within the pool of States with which it does have such a rapport. Finally, (iv) to defend a whistleblowing exception is not to defend the decriminalisation of the breach of State secrets.

\subsubsection{Military offences}

The principles adduced above in relation to political offences apply almost squarely to military offences. In fact, many of the difficulties that arise in the context of the political offence exception do not arise in that of the military offence exception, since the latter has been traditionally limited to acts that do not simultaneously constitute an offence under common criminal law - i.e. purely military offences. That it is incoherent to refuse extradition for such offences among States that are parties to a common military and defence allegiance is even more evident than in relation to political offences, ${ }^{433}$ which prob-

${ }^{432}$ It should be interesting to note that, on 8 February 2018, UK's Supreme Court unanimously held a WikiLeaks document to be admissible in court: see ROBERT MCCORQUODALE, "Wikileaks Documents are Admissible in a Domestic Court", EJIL: Talk!, 21 February 2018: “The Wikileaks document in issue purported to be a copy of a diplomatic cable from the US Embassy in London summarising a meeting between US and British officials. In reaching their decision, the Court had to interpret the Vienna Convention on Diplomatic Relations 1961, which provides that a document and archive of a diplomatic mission is 'inviolable'. The importance of this case, the lack of any strong precedent anywhere in the world, and its broad ramifications, led the Court, unusually, to sit as a 7 member panel". Note also that the ECtHR has ruled that whistle-blowers may rely on the protection offered by Art. $10 \mathrm{ECHR}$, on freedom of expression, and it has developed - notably in Guja v. Moldova, no. 1427724, 12 February 2008,- criteria for determining in which cases such a protection can be relied on. Note also that the European Commission has put forward, in April 2018, a set of measures aimed at strengthening whistle-blower protection as a means for unveiling unlawful activities (including environmental) and helping to enforce EU law. This includes a proposal for a Directive on the protection of persons reporting on breaches of Union law: European Commission, Brussels, 23 April 2018, COM(2018) 218 final, 2018/0106 (COD).

433 See Charles K. BurdicK (rep.), "Harvard Research in International Law: Extradition”, op. cit., p. 122 , applying plainly to military offences the same principle defended for political offences ("every State is 
ably lies among the reasons for the military offence exception to have entered an erosion process earlier than the political offence exception, with many international instruments on military matters - notably, status of forces agreements (SOFA's) - excluding the possibility to refuse extradition for purely military offences. ${ }^{434}$

Many States conceive the surrender of persons pursuant to SOFA's as an alternative to extradition, rather than as an actual extradition, which carries some differences. These differences are mostly procedural in character, but some of them have indirect effects on the scope of substantive requirements of extradition, such as the exclusion of the executive's power of veto, or the derogations of otherwise applicable requirements such as the nationality exception (if the citizen of the requested State was serving in the armed forces of the requesting State). ${ }^{435}$ This only confirms that the predisposition of likeminded States to cooperate for military offences is an even more solid tendency in extradition law than the erosion of the political offence exception. The WWI France-UK case Duke of Chatean de Thierry, mentioned earlier, ${ }^{436}$ is quite illustrative of this predisposition: it took place in a time where non-extradition of military offenders still enjoyed an aura of a principle, and all the same extradition was granted - albeit in a 'disguised' manner (which, of course, is not commendable, but may be deemed understandable in view of that historical atmosphere). Openly admitting that extradition for purely military offences among militarily aligned States could also contribute to discourage the use of such shady alternatives to extradition.

free to extradite for military offenses and there is no reason why it should not be allowed to do so if it so chooses"), although again allowing for States to make a reservation providing for the refusal of extradition. See as well Christine VAN DEN WyngAeRT, The Political Offence Exception... op. cit., p. 204, extending her analysis on political offences to military offences: "It could also be argued that it would be illogical on the one hand to conclude military alliances for the defence of the common external safety, but on the other hand to grant asylum to persons who jeopardize that same safety." See as well MicHAEL D. WiMs, "Reexamining the Traditional Exceptions to Extradition", RIDP 62 (1991), p. 328, already propounding that "it [was] time to renegotiate treaties amongst free and democratic governments to include provisions for extradition for purely military offences".

434 See CHARLES K. BuRdicK (rep.), "Harvard Research in International Law: Extradition”, op. cit., p. $119 \mathrm{f}$., observing: "The practice of non-extradition for military offenses has not gained such a universal acceptance - or at least has not been so universally incorporated in treaty and statute law - as the practice of non-extradition for political offenses." In fact, the majority of treaties appended to that research work more specifically, 52 against 36 - "do not contain any provision relating to military offenses". This is partly due to the fact that many of those treaties still followed the traditional enumerative method of determination of extraditable acts, rather than the dual criminality formula, and "in a large number of these treaties (43 out of 52) extradition for military offenses is excluded by implication, namely, by the use of lists of extraditable offenses which do not include acts constituting military offenses". Of the 36 treaties that did exclude extradition for military offences, 29 followed the dual criminality method. Nevertheless, this would also apply to political offences, and all the same a political offence exception was virtually always explicitly provided for, denoting that it borne an aura of principle which was not paralleled in the military offence exception. One of the States assessed in Part III of this study provides an example of this: see supra, Chap. 6, $\iint$ 2.3.2. and 2.4.2.

435 See M. Cherif Bassiouni, International Extradition... op. cit., p. 105 f.; WiLliam J. Norton, "United States Obligations under Status of Forces Agreements: A New Method of Extradition?”, GJI\& CL 5 (1975), p. $1 \mathrm{f}$.

436 See supra, Chap. 6, \ 2.4.3. 
An exception should however be made for conscientious objection or draft evasion more generally. Wims, for instance, defends the abolition of the military offence exception between allies, but is equally assertive in defending an exception for conscientious objectors: extradition for purely military offences should be limited to cases where the "person sought is voluntarily a member of the armed forces, not a conscript. The introduction of the conscription issue into a discussion of the topic of purely military offences unnecessarily complicates the discussion, and politicized responses might blur an otherwise straight forward proposal". ${ }^{437}$ As noted in the chapter of this study dedicated to human rights, conscientious objection is closely linked to the freedom of thought, conscience and religion provided for in international human rights legal instruments such as the ICCPR (Art. 18) and the ECHR (Art. 9), which justifies regarding this case as a 'prohibition to extradite imposed by human rights', under the intentionally broad scope attributed to that concept in this study. ${ }^{438}$

However, the reasons to refuse extradition will be less compelling if a State imposes on conscientious objectors a duty to provide certain public services in compensation for their refusal to serve in the military, failure to comply with this duty constitutes a criminal offence, and the person does not comply with this duty. If an allied State ${ }^{439}$ requires mandatory military service from its citizens, the moral empathy of its allies justifies a presumption that such a State has good reasons to do so - e.g. because it is inserted in a delicate geopolitical context. Such a moral empathy may be broken if that State forces its citizens to serve in the military by directly criminalising their refusal to do so, but the same may not occur if that State allows them to desert military service by providing a different contribution to that society. In fact, although some States take pride in having abolished mandatory military service, the fact is that, at least in States that are quite active at the military level, mandatory military service may be considered to instil an ingredient of democracy and governmental restraint in military decision-making, as statistics demonstrate that it is generally youngsters from less privileged social strata that volunteer to serve in the military, while decisions to go to war are generally taken by the parents and grandparents of youngsters from more privileged strata. ${ }^{440}$ It should be stressed that those very instruments on human rights explicitly provide that imposing that type of duties on conscientious objectors is legitimate and does not qualify as forced labour: Arts. 8 (3) (c) (ii) IC-

${ }^{437}$ MiChaEL D. Wims, op. cit., p. 328. As we saw in Chap. 8, \2.4.a), this was also the position defended by BERT SwART, "Refusal of Extradition...”, op. cit., p. 187; see also, again, ROBERT ZimMERMANN, op. cit., p. 440, GEOFF GILBERT, Responding to International Crime... op. cit., p. 184, MATTHEW LIPPMAN, “The Recognition of Conscientious Objection to Military Service as an International Human Right”, op. cit., p. 31 f.; see, finally, writing during the Vietnam war, with the asylum of large numbers of US draft evaders in Canada and Sweden as a background, DAvid A. TATE, "Draft Evasion and the Problem of Extradition", AlbLR 32 (1968), p. 337 f., although grounding the refusal of extradition for these acts more in their political character than in their human rights resonance.

438 See supra, Chap. $3, \sqrt{\Omega} 3$.

439 The concept of 'allies' here need not presuppose that the States in question are parties to a common military framework, but could be met if the States are likeminded in a sense similar to the concept of 'moral empathy' used above in the context of the political offence exception.

440 See the debate between KEN TAYLOR and JOHn PERry (featuring DAvid KENNEDy) "The Military: What is it Good For?”, in Philosophy Talk, 26 November 2011, esp. at 20m:27s f. 
CPR and 4 (3) (b) ECHR. ${ }^{441}$ In fact, failure to comply with such a duty will often not even constitute a purely military offence anymore, but an ordinary offence against public authority (e.g. disobedience), and therefore extraditing 'only' requires that the acts meet the general criteria of determination of 'extraditable acts'. ${ }^{442}$

A different problem is the case where a State directly criminalises refusals to serve in the military (leaving its citizens no alternative course of action but either to do so or to desert), but treats this offence as an ordinary, rather than as a military offence - which is reportedly the case in many States. ${ }^{443}$ In this event, the formal classification of the offence as an ordinary offence does not conceal the fact that, substantially, these acts amount to a military offence. As such, the requested State should - and can, for the determination of the nature of the acts is a prerogative of this State - treat it as such. On the other hand, it should again be emphasised that conscientious objection is different from desertion taken in the sense, not of a refusal to comply with a command to serve in the military, but as a breach of a military obligation undertaken voluntarily, "after sober reflection". ${ }^{44}$ The abandonment of freely assumed military duties is conceptually different from a refusal to assume military duties in the first place, and has an immanent potential of damage to the lives of other individuals and to other legal goods or interests. This confers it an incomparable type and level of unlawfulness, and justifies extradition from allied States. ${ }^{445}$

\subsubsection{Fiscal offences (brief digression)}

Tax offences used to be exempted from extradition together with political and military offences, but for some decades now a consensus has been reached that they should be extraditable. This is why they fall out of the focus of this study. The UN Model Treaty still contains a reference to fiscal offences, but an irrelevant one; ${ }^{446}$ the Model Law does not contain a reference whatsoever to these offences. Moreover, both model instruments go so far as to establish that acts which infringe the law of the requesting State relating to taxes, duties, customs and exchange shall or at least may be considered extraditable (pro-

441 Although these provisions also imply that States might not recognise the concept of 'conscientious objection', which is why a less extensive approach to the concept of 'grounds for refusal imposed by international law' than that followed in this study would probably not allow to recognise the former concept as being encompassed by the latter.

${ }^{442}$ See supra, $\int 4.1 .1$. Offences such as disobedience will fall within the same group as money laundering (see $\int$ supra, $\int 4.1 .1 . c$ (iv)), in that virtually every State will have an offence that consists of requiring a certain positive action from individuals subject to their jurisdiction, but there may be relevant differences in relation to the positive actions that States deem legitimate for a State to require.

443 See Michael D. Wims, op. cit., p. 328.

444 Ibid, p. 329.

445 Another issue concerning conscientious objection, which cannot be properly addressed here due to its specificity and complexity, is that as to whether extreme events (e.g. state of emergency) change the terms of the problem, in the sense that they legitimise the criminalisation of refusals to serve in the military and justify extradition between ally States. Note that Art. 4 (2) ICCPR does not admit the derogation of Art. 18 in case of emergence, but Art. 9 ECHR admits derogation of Art. 15. See also Art. 4 (3) (c) ECHR, establishing that the concept of 'forced labour', for the purposes of that provision, does not include "any service exacted in case of an emergency or calamity threatening the life or well-being of the community".

$446 S_{c}$. as a mere footnote - and not even to the provisions on grounds for refusal, but rather to Art. 15, on the authorisation for the transit of a person being extradited to another State. 
vided that they correspond to offences of the same nature in the requested State) even if the requested State does not impose the same kind of tax or duty or does not have a tax, duty, customs or exchange regulation of the same kind as the requesting State. ${ }^{447}$ This is nothing less than an exception to the dual criminality rule. In fact, in its purest form, dual criminality could never be fulfilled in the case of fiscal offences, since acts committed specifically against foreign States do not constitute a crime in the requested State. ${ }^{48}$

Tax offences have much more in common with political and military offences than with ordinary offences, in that they do not co-involve private wrongs, but affect only organisational aspects of the State. ${ }^{449}$ The Revised Manuals on the Model Treaty claim that the "clear trend" of abolition of the tax offence exception is explained by the emergence of the "phenomena of money laundering, corruption and the infiltration of criminal proceeds into national economies". ${ }^{450}$ However, this argument does not seem particularly robust, as a usual feature of money laundering is precisely the taxation of the proceeds of the predicate offence: it is often through taxation than money is washed. Criminalisation of the laundering of those proceeds is much more a reaction against the frustration of the capacity of States to confiscate them than of their capacity to tax them. ${ }^{451}$ In fact, at a strictly fiscal level, money laundering can be positive: it is not through tax offences that States avoid the laundering or infiltration of dirty money into the economy. Sometimes, tax offences provide the only way for punishing individuals who cannot be proven to be engaged in other criminal activities, but this is a different issue. If the problem were indeed money laundering, corruption and adjacent offences, then the focus should lie on increasing cooperation for those offences ${ }^{452}$ - which do not have a fiscal character. ${ }^{453}$

The compelling justification for the eradication of the tax offence exception is the increasing economic and fiscal interdependence of States in a globalised world. ${ }^{454}$ States need to enforce their tax laws, and other States are sensitive to this necessity, as they are very interested in having it reciprocated. It is most interesting to observe that, if a fiscal offence exception is not in place, a State will be able to extradite a person for acts of this nature to States for which it has no moral sympathy, possibly to States where the money whose taxation that person evaded barely reverts to its population. It is indeed remarkable that the tax offence exception has nearly vanished from the arsenal of grounds for refusing extradition, while the political and the military offence exceptions, which are equally

447 See Art. 2 (3) UN Model Treaty and s. 3 (4) UN Model Law.

448 See supra, $\left.\iint 4.1 .1 . c\right)(i v)$, in respect of political offences.

${ }^{449}$ M. Cherif BAssiouni, International Extradition... op. cit., p. 740 also mentions that the reason for excluding these offenses from extradition is "the same as in cases of offenses of a military character".

450 UNODC, "Revised Manuals...”, op. cit., p. 11.

451 See Pedro CAEIRO, "A Decisão-Quadro do Conselho, de 26 de Junho de 2001, e a relação entre a punição do branqueamento e o facto precedente: necessidade e oportunidade de uma reforma legislativa", in Manuel da Costa Andrade / José de Faria Costa / Anabela Miranda Rodrigues / Maria João Antunes (eds.), Liber Discipulorum para Jorge de Figueiredo Dias, Coimbra: Coimbra Editora, 2003, p. 1067 f.

452 As in fact (but not for this reason) was propounded supra, $\int \mathbb{S} 4.1 .1 . c$ )(iv).

453 On the relative intertwinement between fiscal and economic offences for the purposes of the fiscal offence exception, see in any case M. CHERIF BASSIOUNI, International Extradition ... op. cit., p. $740 \mathrm{f}$.

${ }^{454}$ It its along these lines that the decay of the tax offence exception is explained by BERT SwART, "Refusal of Extradition..." op. cit., p. 188, and M. CHERIF BASsIOUnI, International Extradition... op. cit., p. $741 \mathrm{f}$. 
unsuitable to an interdependent world, have been mitigated much more warily. ${ }^{455}$ The decay of the fiscal offence exception supports the view that the political and the military offence exceptions do not have a raison d'etre between States linked by ties of moral affinity.

\subsection{Grounds for refusal related to the punitive claim of the requesting State}

\subsubsection{Evidentiary requirement (proportionality as adequacy)}

\section{a) Revisiting the contrast between criminal proceedings and extradition proceedings}

Extradition proceedings are considered by many as a "special type of criminal proceedings". ${ }^{456}$ 'Special' in the sense that they are nearly, but not fully criminal. The difficulty, of course, lies in determining how special they are. Are they so special as to do away with most principles applicable in criminal proceedings, or are they so similar to criminal proceedings as to require that all, or at least most principles apply similarly in both? Wherever the line is drawn, it is unquestionable that extradition proceedings differ from criminal proceedings, but have in common with the latter the fact that they typically also involve deprivation of liberty. ${ }^{457}$ Not for a period as lengthy as that to which a penalty can correspond, but a period of deprivation of liberty nonetheless, and one which can plausibly be compared to that applied in domestic criminal proceedings pursuant to certain pre-trial measures. Extradition proceedings moreover have in common with pre-trial measures of criminal procedure - even with some which do not entail deprivation of liberty, but are instead aimed at filtering the cases where it is reasonable for the procedure to advance to a further stage where a criminal penalty may come to be applied ${ }^{458}$ - the fact that they are ancillary to the criminal trial. Trial is, in both cases, the ulterior finality. As summarised by Bentley: "Extradition (...) exists to enable the primary instruments of criminal justice (trial and punishment) to operate properly. The extradition process is merely a preliminary to this operation. Its safeguards and procedures should always reflect that." 459

Extradition proceedings moreover necessarily involve something that internal criminal proceedings do not - an extra element of potential hardship: the transfer of the person to another jurisdiction (possibly on the other side of the world), and thereby the exposure of this person to a factual and legal framework which may be entirely different from that in which he/she somehow found him/herself at a given point in time. Not that some simplistic proportion should be established according to which extradition proceed-

455 The MAW is quite symptomatic in this respect: it contains no exception concerning tax offences but maintains the classic political offence exception (although it 'depoliticises' several classes of acts, as is now in itself already 'classic') - and the classic military offence exception, and even configures these grounds for refusal as mandatory: see Art. 5 (d) and (e).

456 Rosemary Davidson, "The Extradition Hearing”, in John R. W. D. Jones (general ed.) / Rosemary Davidson (assistant ed.) / Arvinder Sambei (contributor) / Brian Gibbins (contributor), op. cit., p. 41.

457 See supra, Chap. 1, \2.2. Note moreover that, to the ECtHR, extradition proceedings are predominantly administrative in character: in detail on this issue, see PETER LANGFORD, "Extradition and fundamental rights: the perspective of the European Court of Human Rights", IJHR 13 (2009), p. 522 f.

458 Such as committal proceedings in the UK, mentioned supra, Chap. 6, J 3.1.c).

${ }^{459}$ David J. Bentley, "Procedural Safeguards and Evidentiary Requirements: The Common Law Approach”, RIDP 62 (1991), p. 350. 
ings, due to involving a period of deprivation of liberty plus a transfer of jurisdiction, would be 'more repressive' than criminal proceedings themselves. The latter involve 'only' (and only in the worst scenario) deprivation of liberty, but an incomparably more stable and consequential modality of deprivation of liberty.

\section{b) Risk of anticipated trial?}

One argument often used against the idea of a prima facie requirement in extradition proceedings is that it might constitute an anticipated trial. As the UNODC informs, 'prima facie' derives from the Latin expression 'on its first appearance', bearing the significance of "evidence that, unless rebutted, would be sufficient to prove a particular proposition or fact." ${ }^{\prime 60}$ When used in criminal proceedings, this presumption is not the definitive test for such a 'proposition or fact' to be established as truthful and to give rise to the consequences that the law ultimately attaches to it. It constitutes simply a provisional test, preordained to transitory purposes within those proceedings. Hence, the use of that type of concept in intermediary stages of criminal proceedings is functionally similar to its use in extradition proceedings, which are also ancillary to an ulterior purpose.

It is not true either that continental criminal justice systems are unfamiliar with such evidentiary tests. Taking as a reference the Portuguese legal system - the civil law system covered in Part III of this study -, evidentiary tests of that nature are used in several intermediary moments of the criminal procedure. This is notably the case with: (i) the decision to prosecute a person, which requires 'sufficient evidence' that this person committed a crime (evidence being considered 'sufficient' when it is such as to carry a fair probability of substantiating the application of a criminal sanction later in trial); ${ }^{461}$ and (ii) the decision to subject a person to certain pre-trial measures, such as custodial detention, which requires 'strong evidence' that this person deliberately committed a crime. ${ }^{462}$ It is utterly clear within these criminal justice systems that such decisions are autonomous in relation to the ulterior decision as whether or not a person is indeed guilty of a crime and deserving of a penalty. The fact alone that these types of tests constitute a well-established feature in virtually every national criminal justice system constitutes a firm guarantee that using them in extradition proceedings entails no risk of an anticipated trial.

As for States that already tend to require evidence also in extradition proceedings, there is no signal of such a conceptual confusion. This could be observed earlier with respect to the UK, and can be further illustrated with the USA system, where it constitutes long-standing case law that the extradition hearing "is not designed as a full trial", and that its purposes are only "to inquire into the presence of probable cause to believe that there has been a violation of one or more of the criminal laws of the extraditing country, that the alleged conduct, if committed in the United States, would have been a violation

${ }^{460}$ UNODC, "Manual on Mutual Legal Assistance and Extradition, op. cit., p. 15.

461 See Arts. 277 and 283 CCP; Jorge De Figueiredo Dias, Direito Processual Penal: Vol. 1, Coimbra: Coimbra Editora, 1974, p. 133, noting that 'sufficient evidence' is therefore conceived as a 'realistic prospect of conviction', i.e. as a quantum of evidence which renders 'conviction more probable than acquittal'.

462 See Arts. 191 f. CCP; on the concept, and relating it to the (constitutional) principle of proportionality, see Maria Joño Antunes, Direito Processual Penal, op. cit., p. 134 f. 
of [its] criminal law, and that the extradited individual is the one sought by the foreign nation for trial on the charge of violation of its criminal laws". ${ }^{463}$

\section{c) Inquiry, non-interference and deprivation of liberty}

It is very intriguing that most extradition systems, while characterised by a wide array of grounds for refusal, exceptions and defences, do not require a shred of evidence to consider extradition admissible. Why do States traditionally mistrust each other in relation to so many aspects, but not in relation to the claim that a person is probably guilty of a crime - a claim which, if inconsistent, casts a strong shadow of doubt upon the very pertinence of making use of extradition?

One answer to this question is tied to the duty of non-interference: from the fact that extradition is ancillary to a criminal procedure to be effected in another State, States would have drawn an imperative not to meddle in the merits of the case. Taken in these terms, the no-evidence rule would have conspicuous similarities with the non-inquiry rule traditionally more associated with human rights issues, or would indeed constitute a modality of the latter rule. However, the two rules are conceptually autonomous. This is clear in the extradition systems of some States, such as, again, the USA. This State has a deeply-rooted tradition not to inquire into how other States conduct their criminal proceedings, but at the same time it also has a strong tradition to require a 'probable cause' in order to extradite: it is only the means through which the requested State secures its 'cause' that are not 'inquired' into. ${ }^{464}$

The idea that evidentiary requirements can be explained based on the duty of noninterference is fragile in many other regards. First of all, it is clear that States do not have the same understanding of this duty as that defended in this study: ${ }^{465}$ the fact that the person in question is found within their borders is generally regarded as a preponderant element in extradition matters; it legitimises any decision to refuse extradition. Only this explains that States do not draw consequences from the duty of non-interference in regard of most grounds for refusal, even of the most important ones - i.e. those that protect human rights. In fact, the former were precisely those regarding which an inquiry was traditionally proscribed. As we saw, the advent of individual and human rights in international law carried the erosion of the rule of non-inquiry. From the moment that requested States began to be regarded as co-liable for the fate of extradited individuals, this rule could not retain its former vigour. ${ }^{466}$ And even so evidence of criminal liability is required only by a small number States, and even in these States the tendency has been the dilution of such requirements. ${ }^{467}$

463 Peroff v. Hylton (1976, 1977), apud JACQues Semmelman, "Federal Courts, the Constitution, and the Rule of Non-Inquiry in International Extradition Proceedings”, CorLR 76 (1991), p. 1202.

464 See M. Cherif Bassiouni, International Extradition... op. cit., p. 632 f.; JACQUES SEMmelman, "Federal Courts...”, op. cit., p. $1203 \mathrm{f}$.

465 See supra, Chap. 7, \ 3.1.2.

466 See supra, \Chap. 7, \3.1.2, and further infra, \5.1.2.a).

467 On the UK, see supra, Chap. 6, \$3.1.3. This example may again be added by that of the USA: see LIS WieHL, "Extradition Law at the Crossroads: The Trend toward Extending Greater Constitutional Proce- 
Rather, the rationale of evidentiary requirements in some States seems to lie in concerns immanent to their very criminal justice systems. Not because they regard extradition proceedings as analogous to criminal proceedings: as we just saw, to a narrower or wider extent these States also draw this distinction. The concern appears to lie fundamentally on the act of deprivation of liberty, in and of itself, which the execution of an extradition request requires them to carry out. Thus, and to maintain the USA as a reference, the 'probable cause' required for extraditing is grounded on the fourth amendment ${ }^{468}$ - that is, on the exact same norm which protects individuals from a multitude of other "unreasonable" actions by the American State.

Thus, the problem is neither the rule of non-inquiry nor the duty of non-interference. The problem is the immediate accountability of the requested State for subjecting a person to a measure which involves deprivation of liberty.

\section{d) Presumption of innocence, guilt principle and proportionality (as adequacy)}

According to the theoretical framework developed in this study, that is not a suitable starting point for determining whether or not evidence should be required from another State in order to extradite a person. The fundamental element of that framework is that the criminal justice concepts that as a matter of principle should govern the case are those of the requesting State, which includes evidentiary issues. The concepts of the requested State can displace that presumption, but only if, in a methodologically subsequent moment, this shows necessary to safeguard the core values of this State. As will be stated shortly below, there are plenty of fundamental criminal justice values that are jeopardised if the requested State extradites a person without a minimum degree of evidence of his/ her criminal liability. However, this degree cannot be anchored to the same concepts that the requested State uses in its own criminal proceedings: this is what could amount to an interference (by omission) in the affairs of the requesting State. In the same way as every State has its own conception of what constitutes criminal conduct, every State has its own conception of how to "build up a case", making it absolutely normal that evidence deemed consistent in a given criminal justice system may be deemed insufficient in another. ${ }^{469}$

There is no human right not to be extradited without evidence of criminal liability. Nevertheless, evidentiary requirements are umbilically related to rights that in the context of criminal proceedings do constitute human rights and core constitutional guarantees, namely presumption of innocence, guilt principle (Schuldprin₹ip) and proportionality. This is why, even in States that follow a supposedly strict 'no evidence' approach, some authors advocate that such an approach must be relinquished where it would lead to blatantly unfair results (as is illustrated by Portugal); ${ }^{470}$ and why the erosion of evidentiary require-

dural Protections to Fugitives Fighting Extradition from the United States", MJIL 19 (1998), p. 733; REMY

Z. LEVIN / PAUL CHEN, "Rethinking the Constitution-treaty relationship", IJConstL 10 (2012), p. $251 \mathrm{f}$.

468 See John G. KeSter, "Some Myths of United States Extradition Law”, GLJ 76 (1988), p. 1464 f.

${ }^{469}$ See again DAVID J. BENTLEY, op. cit., p. 355, informing that one of the complaints of other States on UK's evidentiary requirement was that "their process of building up a case was so different from ours that to attempt extradition from the United Kingdom was seen as a frustrating and even pointless exercise".

${ }^{470}$ See supra, Chap. 6, \$3.1.b). 
ments in extradition systems where they used to play a more dominant role still receives significant objection (as is illustrated by the UK). ${ }^{471}$ Even in the EU, where the existence of a common normative framework offers relative certainty that those rights are observed, the necessity was felt by the Commission, after complaints by several Member States, to instruct that proportionality assessments be carried out before the issuing of a EAW. ${ }^{472}$ The instruction did not contemplate the case where evidence of criminal liability is inconsistent, and it focuses on the issuing rather than on the execution of EAW's, but the underlying concern is the same, leading Klip to question whether " $i t$ is still proportional to use [the EAW system] if a Member State issues it for cases where the accused are released soon after the surrender and the cases are never brought to court". ${ }^{473}$

Most extradition systems have some manifestations of proportionality, but they accommodate this principle only in a fragmented manner. ${ }^{474}$ In order to pass a full proportionality test, extradition would have to be (i) suitable to attain the public interest at issue (proportionality as 'adequacy': Geeignetheit), and (ii) capable of attaining it with less harm to the person than any other available measure (proportionality as 'necessity': Erforderlichkeit); if it shows adequate and necessary in these terms, it must yet (iii) be proportional to the harm it will cause to the person (proportionality stricto sensu: Verbältnismässigkeit). ${ }^{475}$ Virtually all extradition systems agree that extradition would be disproportional if the acts at issue do not reach a given quantitative and qualitative threshold according to the requested State's own sense of justice. ${ }^{476}$ This can only concern proportionality in its strictest sense, because extradition is adequate to enable the requesting State to do criminal justice upon crimes which do not meet those concepts, and it is often the only means available for accomplishing that end. ${ }^{477}$ However, the 'seriousness' of a case is not mirrored only in the

${ }^{471}$ See supra, Chap. 6, \ 3.1.c). Indeed, the evolution of the prima facie requirement in the UK still sparks mixed feelings: while it has become rather unanimous that such a requirement probably creates more harm than good in the context of cooperation with trusted partners, the Baker Review (the latest of several studies to have thoroughly addressed this requirement in the UK) ultimately concedes that it remains important in view of States that "routinely violate human rights or abuse the system of international cooperation for extradition": SCOTT BAKER / DAVID PERRY / ANAND DOOBAy, op. cit., p. 283.

472 See the "Report from the Commission to the European Parliament and the Council on the implementation since 2007 of the Council Framework Decision of 13 June 2002 on the European arrest warrant and the surrender procedures between Member States", COM(2011)175 final, Brussels, 11 April 2011, p. 8. This instruction was later incorporated into the Handbook on ow to issue and execute a EAW, cit., p. 19.

473 ANDrÉ KLIP, European Criminal Law... op. cit., p. 535 f.

474 The several manifestations of the principle of proportionality in extradition law are articulated below in this study: $\int 5.1 .1$.

475 See José Johquim Gomes Canotilho, Direito Constitucional... op. cit., p. 269 f.

476 See supra, Chap. 6, sS 2.1., and 2.2.

477 Proportionality stricto sensu is also the type of test underlying the consideration of certain fundamental rights against the interest in extraditing. As we saw earlier, even judicial instances charged with upholding human rights perform this type of assessment: see supra, Chap. 3, \3.3. As posited by JOHN R. SPENCER, "Extradition, the European Arrest Warrant and Human Rights", CLJ 72 (2013), p. 253, in relation to the EAW system and the protection of human rights: "In a Europe of free movement - which regrettably means free movement for criminals as well as honest citizens - the EAW is a necessary instrument. But if necessary, it is also one which is capable of heavy-handed use. Although invented with serious trans-border crime in mind, it is capable of being used in many cases which are not particularly serious. And in the cur- 
'quality' of the acts and in the 'quantum' of penalty with which they are punished, but also in the level of suspicion that substantiates it. ${ }^{478}$ Without a minimum level of evidence suggesting that a crime may indeed have been committed by the person in question, it is arguably impossible to even establish that extradition is adequate (geeignet) to begin with.

It may be conceded that, among States which consider each other's criminal justice systems very reliable, it will not in principle be necessary to explicitly provide for one such requirement, since an extradition request issued by such a State can be presumed to be founded on a sufficient probability of criminal liability. ${ }^{479}$ However, as a default approach, it is difficult to conceive that extradition is admissible without requiring a humble shred of evidence that the person has indeed committed a crime. Obviously, an evidentiary requirement cannot guarantee that no innocent person will be extradited. ${ }^{480}$ Even in criminal proceedings, a fully-fledged application of the principles of presumption of innocence and in dubio pro reo cannot ensure that no innocent person will be convicted. Miscarriages of criminal justice are virtually inevitable. But one can and should seek to avoid them.

\section{e) Which criterion?}

If an evidentiary requirement is enacted, then the question arises as to what its scope should be. The evolution verified in the UK in respect of the prima facie requirement reflects an increase in the concern for the conceptions of other States on evidentiary issues. Initially the requirement was quite stark, practically replicating rules that had been developed in view of domestic criminal proceedings, and gradually it became more elastic, notably with respect to the hearsay rule. However, in the light of the theoretical framework adopted in this study, even this approach falls rather short of the ideal that the legal system of the requesting State is the one that deserves primacy.

Furthermore, in this case, the issue with evidentiary requirements is not only a matter of giving primacy to the requesting State. It is a matter of ensuring the operability of extradition. The specificity of extradition proceedings vis-à-vis domestic criminal proceedings is patent in the mechanism of 'provisional arrest', typical of extradition proceedings, aimed at 'immobilising' the fugitive pending exchanges of information between States.

rent absence of any parallel system for enabling less serious trans-border crime to be dealt with by less drastic means, prosecutors are tempted to use it in such cases."

478 See ANDrÉ KLIP, European Criminal Law... op. cit., p. 433, construing the 'degree of suspicion' as an integral part of the principle of proportionality in the use of legal instruments based on mutual recognition.

${ }^{479}$ This is yet another instance where the executive branch can be relied upon to block abnormal cases.

${ }^{480}$ Jens Soering was extradited by the UK to the USA with the latter fulfilling an evidentiary requirement (see Arts. VII and IX USA-UK Extradition Treaty of 1972, and STEPHAN BREITENMOSER / GUNTER E. WiLMS, op. cit., p. 853), but always claimed his innocence: see SuSANNE ZÜHLKE / JENS-CHRISTIAN PASTILLE, "Extradition and the European Convention: Soering revisited", ZRV 59 (1999), p. 749; see also the 2016 documentary-film "Killing for Love", by Marcus Vetter / Karin Steinberger. See also the 2017 episodes "True East", part of the documentary series "The Confession Tapes", by Kelly Loudenberg, on the Rafay \& Burns case (also mentioned supra, Chap. 2, \$ 2.2.2.a)), where Sebastian Burns and Atif Rafay - who also always claimed their innocence - were extradited by Canada to the USA with the latter fulfilling an evidentiary requirement (see Arts. 9 and 10 Canada-USA Extradition Treaty of 1971). Both Soering and Rafay \& Burns were based on self-incriminatory elements, and their innocence claims have been supported by different innocence projects. 
As Vien notes: "The concepts of flight and urgency are closely associated with that of extradition" ${ }^{481}$ The author informs that, at one end of the spectrum, we find States that are often used as points of transit and where it is therefore nearly "impossible (...) to follow a policy of location without arrest", while at the other end we find States that require "extensive evidence" that makes it nearly "impossible to arrest a person for a crime committed abroad". ${ }^{482}$

A balanced approach could be to require the requesting State to give information as to what the criteria is in its legal system for prosecuting a person, and to then provide evidence which, in that system, suffices to commit that person to trial. The evidence thus provided would not have to be admissible in criminal proceedings in the requested State, so long as it would satisfy the limits imposed by human rights or other 'mandatory' sets of norms, and the core values of this State on admissibility of evidence.

\section{f) Interactions with other grounds for refusal}

Requiring evidence to extradite carries systemic effects. One argument in favour of requiring such evidence is precisely that it bestows certainty upon the assessment of other requirements, such as specialty: it provides additional security against fabricated charges preordained to trying the person for acts unmentioned in the request. Other grounds for refusal that may benefit collaterally from evidentiary requirements are qualitative relevance (or dual criminality), the political offence exception and, very importantly, grounds for refusal based on human rights, such as discriminatory persecution. Naturally, even in extradition systems that require no evidence of criminal liability, it is possible to produce evidence which shows necessary for ascertaining whether or not the requirements for extraditing are met in the case - e.g. whether the acts were committed in the territory of the requested State. However, this evidence must generally be produced by the person him/ herself, whereas, by requiring evidence of the acts as such, the requesting State is bound to contribute to the pool of information available to the requested State for an informed decision.

On the other hand, evidentiary requirements may also contribute to loosen or even dispense with other grounds for refusal. We saw earlier that in the UK there is a significant area of overlap between the prima facie requirement and the 'abuse of process' bar. ${ }^{483}$ It is also perhaps not accidental that States which require some evidence of the acts in order to extradite (any person) are States which do not as a matter of principle refuse to extradite their own nationals: because of the evidentiary requirement, they know that the probability of extraditing one of their own citizens who is innocent is low. From the cos-

481 MiCHAel Vien, "Provisional Arrest, Release and the Role of Interpol”, RIDP 62 (1991), p. 63 f., see also MiChaEl ABbell, "Controlling the Abusive Use of Provisional Arrest", RIDP 62 (1991), p. 369 f., acknowledging that provisional arrest in necessary to "prevent the further flight" or "hiding" of fugitives.

482 See Michael Vien, op. cit., p. 66, 73. In any case, State power to arrest provisionally for extradition purposes should be subject to some constraints: ibid., p. 69 f.; also MiCHAEL ABBELL, op. cit., p. 369, 375, arguing that "it is critical to the integrity of the extradition process that the courts exercise vigilance in objectively reviewing the adequacy of information supporting the provisional arrest of persons requested for extradition before depriving such persons of their liberty".

483 See supra, Chap. 6, \$ 3.1.b). 
mopolitan standpoint defended in this study, between an egalitarian requirement which strengthens fundamental rights (presumption of innocence, guilt principle, and proportionality in its dimension of adequacy) and a selective one which protects just the formal bond of citizenship between a person and a State, the choice is easy.

\section{g) Conclusion}

The conclusions following from the preceding lines are that: (i) refusing extradition due to insufficient evidence is justified, but (ii) the criteria on the type and amount of evidence to be required from the requesting State should be defined by the concepts of the requesting State itself, up to the limits set by international law and the requested State's own sense of justice. (iii) If trust between the requested State and the requesting State is strong, such a requirement can be left for the executive branch of the requested State to use in abnormal cases. (iv) Evidentiary requirements do not necessarily block, but might simply delay extradition. This will be especially so if, as defended, this ground for refusal is constructed by reference to the concepts of the requested State itself. In this sense, evidentiary requirements are not even grounds for refusal in a peremptory sense. (v) These requirements have the supplementary advantage of facilitating the assessment of other requirements, such as specialty, and moreover (vi) they might to create room for mitigating the scope of other grounds for refusal, such as the nationality exception.

\subsubsection{Extinction of liability (except ne bis in idem) according to the requested State}

\section{a) A squarely inadequate ground for refusal}

The perspectives defended in relation to dual criminality, based on the theoretical framework developed earlier, apply squarely to the ground for refusal now in debate: the criminal justice concepts that should in principle be applied are those of the requesting State; there is no justification to apply directly the concepts of the requested State to acts that have no connection whatsoever with its legal system or a weaker connection (e.g. active nationality) than that linking the acts to the legal system of the requesting State ( $s c$. territoriality or protective jurisdiction). ${ }^{484}$

On the other hand, the principle still holds that the core concepts of the requested State cannot be neglected. ${ }^{485}$ And, in several legal systems, time-bars do constitute an ex-

\footnotetext{
${ }^{484}$ Noting that refusal of extradition due to lapse of time according to the criteria of the requested State is "inappropriate to modern conditions" and should rather be limited to cases where the crime has become time-barred in the requesting State, and defending the view that "[u]fortunately" the latter approach "cannot yet claim general validity", see PETER WILKITSKI, "Defences, Exceptions and Exemption in the Extradition Law and Practice and the Criminal Policy of the Federal Republic of Germany: (Excluding the 'Political Offence' Defence)", RIDP 62 (1991), p. 283 f. Similar, see also BERT SWART, "Refusal of Extradition..." op. cit., p. 201, although defending that the own concepts of the requested State should apply whenever this State has jurisdiction over the acts, even if much weaker than that of the requesting State.

485 And for this reason the position of BERT SWART, "Refusal of Extradition..." op. cit., p. 201, that the concepts of the requested State should never apply to the case if this State has no jurisdiction over the acts, is again refused. As is, consequently, the solution contained in Art. 4 (4) FD-EAW, which never allows refusal if the acts do not fall within the competence of the executing Member State.
} 
pression of core principles, such as the principle that criminal punishment must envisage the rehabilitation of the offender, which in turn is linked to such principles as proportionality (hence the fact that, in many States, time-bars can, but can only, be set aside with respect to core international crimes (and even here there is room for disagreement). ${ }^{486}$ Timebars may yet be based on due process principles, in that a fair assessment of criminal liability is hardly possible if long periods of time have elapsed since the crime. ${ }^{487}$ This does not hold true for every State, as is exemplified by the UK, where prosecution of most serious offences is not subject to statutory limitations ${ }^{488}$ - a long-standing principle condensed in the axiom 'no lapse of time bars the King' (nullum tempus occurrit regi). ${ }^{489}$ Such a stance finds some comfort in the fact that human rights case law tends to consider timebars as procedural, rather than substantive instances, meaning that they will not be subject to the principles of substantive criminal law. ${ }^{490}$ However, the view that crime should not be punished after the passage of a set period of time is an entrenched feature of civil law States, traceable to Roman Law, and even of some common law States, such as the USA. $^{491}$

\section{b) The curious case of the United Kingdom}

That extraditing for acts which have been committed in a relatively distant past can be offensive to the sense of justice of the requested State is most curiously shown by the legal system of the UK. In what appears to be a paradox, this State does not generally establish time-bars for internal cases, but provides a ground for refusal of extradition concerned with 'passage of time', through which it seeks to protect the very same type of values that time-bars seek to protect in States that apply them in their own criminal cases. ${ }^{492}$

\footnotetext{
486 See e.g. José Luis GUZMÁn DALBORA, “Crímenes internacionales y prescripción”, in Kai Ambos / Ezequiel Malarino / Jan Woischnik (eds.), Temas Actuales del Derecho Penal Internacional: Contribuciones de América Latina, Alemania y España, Montevideo: Fundación Konrad-Adenauer, 2005, p. 76, et passim. See also ECtHR, Kononov v. Latvia, no. 36376/04, 17 May 2010, JS 229 f.; Kolk and Kislyiy v. Estonia, no. 23052/04 and no. 24018/04, 17 January 2006; Penart v. Estonia, no. 14685/04, 24 January 2006. As is noted in the UN Model Law on Extradition, no statutory limitation applies to war crimes, crimes against humanity, and the crimes of genocide and apartheid: see Art. I of the 1968 UN Convention on the Non-Applicability of Statutory Limitations to War Crimes and Crimes against Humanity.

487 See supra, Chap. 6, \3.1.2.; see further JoyCElyn M. Pollock, Criminal Law, 11th ed., New York: Routlegde, 2016, \3 - 3.9.

488 As Ivor Stanbrook / Clive STAnbrook, op. cit., p. 273, inform, by reference to the $1957 \mathrm{CoE}$ Extradition Convention: " 'Lapse of time' according to Continental usage in extradition matters is akin to prescription and means a fixed period following the commission of a crime after which a prosecution for the crime is barred by law. The UK does not generally practice such a rule except in regard to certain, mostly summary, offences". The UK made a reservation to that Convention defining 'lapse of time' as an event whereby, due to the passage of time and having regard to all circumstances, it would be unjust or oppressive to extradite the person, which is the wording of a "long-standing bar to extradition under UK law".

489 See Bruce L. Castor (ed.), "The Statute of Limitations in Criminal Law: A Penetrable Barrier to Prosecution”, UPLR 102 (1954), p. 630.

490 See e.g. Previti v. Italy, no. 1845/08, 12 February 2013, \S 80 f.; Borcea v. Romania, no. 55959/14, 22 September 2015, \64.

491 See Bruce L. CASTOR (ed.), op. cit., p. 631.

492 See supra, Chap. 6, \3.3.3.
} 
This ground for refusal, it is recalled, prevents extradition if it appears that it would be "unjust or oppressive" to extradite the person due to passage of time, considering, on the one hand, the associated risk of unfair trials (e.g. due to erosion of evidence), and, on the other hand, the fact that during that time the offender may have proved to be rehabilitated (as indicated e.g. by an honourable life free of crime).

By providing a ground for refusal that does not have a direct equivalent in its own criminal law and procedure, the UK not only validates the idea that this constitutes an issue which resonates in a State's sense of justice, but also it incidentally points a way for States that apply time-bars internally to develop an autonomous concept conceived specifically for extradition, adjusted to fit its specificities. ${ }^{493}$ The 'passage of time' bar constitutes an approach which is very much in line with some ideas defended in the theoretical framework of this study, namely in that it uses indeterminate concepts ('unjustness', 'oppressiveness') developed specifically for extradition, rather than applying to extradition the much more detailed (and rightly so) concept of 'time-bars' developed for internal criminal law. This enables an evaluation of what, in each specific case, passage of time represents for the UK as a requested State. In this sense, this approach satisfies the principles defended in this study and it could be contemplated by States that have time-bars for internal cases and that project them directly upon requested States in extradition cases.

However, when States establish time-bars for internal cases, they are already pouring into those rules, with the advantages inherent to more abstract criteria, many or most of the considerations that a concept such as 'passage of time' requires a court to evaluate in each concrete case. Thus, an alternative and more practical approach is proposed subsequently for those States (which appear to constitute the majority).

\section{c) Searching for a simpler criterion}

The problem with applying one's own time-bars squarely to extradition is that they do not, and are not supposed to express a measure of time past which punitive action by any State becomes offensive to one's core values as enshrined in one's constitution. It is the ordinary legislator that sets the specific periods of time past which punitive action becomes barred, in an exercise which is carried out in view of its own factual and legal reality, and which is addressed at its own public authorities. To presume that the time-bars set by an ordinary legislator are stretched up to the limit past which the core values of its legal system no longer admit punitive action would be a most implausible diagnosis. It would mean to assume, at once, that the ordinary legislator: (i) interpreted to perfection the limits set by its constitution; (ii) that it chose to take the most punitive approach admitted by that constitution; and, given that the constitution is dynamic, (iii) that it is at all times doing so. More importantly, it would disregard that the rules at issue use arithmetic elements, and, as such, constitute mere indicators of a deeper, underlying value of a substantive nature. Considering that, as defended in the theoretical framework, in an extradition setting,

493 'Incidentally' because this approach does not appear to express a coherent and overarching view of extradition law as an area of the law with profound differences in relation to criminal law and procedure, as is visible in several instances of UK's extradition system, of which a sufficient example is the prima facie requirement, modelled from the committal proceedings of UK's internal criminal procedure. 
the State which has been neutrally identified as being the rightful bearer of primacy in relation to the acts in question is another State, it is virtually impossible to admit that the scope of one's ordinary rules contains an insurmountable axiological limit past which cooperating with that other State would require betraying one's criminal justice ethos. The more plausible diagnosis, especially when formal or arithmetic criteria are involved, is that such a limit lies significantly beyond one's own ordinary criteria.

Naturally, for the very same reasons, the exact point to which it is possible to go without disrupting one's core values is virtually impossible to determine. In this regard, the challenge with the 'time-bars' ground for refusal is comparable to that of quantitative relevance (rather than to that of qualitative relevance), more specifically of the concept of cardinal proportionality and its intrinsic subjectivity. It is virtually unthinkable, for instance, that, by raising a time-bar from 4 to 5 years, an ordinary legislator will be incurring in unconstitutionality. If a clear-cut ordinal nexus of proportionality has been developed in that constitutional system (whereby, for instance, a given offence could not be subject to timebars longer than the maximum limit of its penalty scale), then this may constitute a strong indicator that we are in the presence of a core value of that legal system. However, even here, it appears that the justified primacy of the requesting State would still be sufficient to break that nexus and render extradition admissible. If no point even exists where such an assessment could be anchored, then States can, without risk to their core values, extradite beyond the limit set by their ordinary law for internal cases. An utterly simple criterion could then be adopted, namely: to use the time-bars of the requested State as a starting point - they are, after all, the only tangible indicator of what the insurmountable limits of that State's ethos might be -, and then raise them in a certain proportion to be defined by each State $\left(\right.$ e.g. $\left.{ }^{1} / 3\right) .{ }^{494}$

This criterion would have the advantages and disadvantages typical of any arithmetic criterion. On the side of the advantages, it is clear that it would be extremely simple to calculate by the courts in each concrete case. On the side of the disadvantages, it might still exclude extradition in cases that would not offend the sense of justice of the requested State. However, to the extent that each State makes a careful evaluation of the proportion they wish to use, this disadvantage should manifest itself just marginally. On the oth-

494 A similar approach could have been proposed for quantitative relevance: see supra, $\int 3.2 .1$. However, in this case the minimum threshold is already quite low, which entails that one will be operating within a contained span of possibilities ranging from nothing (when the acts are not even criminalised in the requested State but extradition can nevertheless be granted because they have sufficient qualitative relevance: see supra, $\int 4.1 .1$.) or almost nothing to very low. That is why it seemed more practical and deferential to the penal concepts of the requesting State, whilst fully capable of safeguarding the core values of the requested State, to plainly and simply defend the use of the penalty scale of the requesting State, and trust the executive branch of the requested State to intervene where that is necessary to correct abnormal cases which might trickle through that criterion and offend the sense of justice of its community. The case is different as far as time-bars are concerned, because here one will be operating within the entire range of time-bars of different criminal justice systems - and indirectly also with an entire range of penalty scales (as the former are generally indexed to the latter). Therefore, in order to ensure that the sense of justice of the requested State is not offended - a goal which could not be attained by simply taking into consideration the criteria of the requesting State -, in the case of time-bars it does seem inevitable to invert the method, and use as the starting point the concepts of the requested State, rather than those of the requesting State. 
er hand, should the criterion encompass cases where extraditing would offend the sense of justice of the requested State, the executive branch can be relied on to intervene.

A final note concerns the recognition by the requested State of the factors that, in the requesting State, cause the calculation of the time-bars terms to be interrupted or suspended. Considering again that the concepts of the requesting State are the ones that deserve primacy, the requested State should in principle take those factors into account, as already occurs in some States, such as Portugal. ${ }^{495}$ However, the possibility must be considered that the requesting State will provide for such ample factors of interruption or suspension that, in practice, they render the very concept of 'time-bar', as understood in the requested State, completely void. This could be accommodated in any extradition arrangement through an indeterminate concept to be triggered only in manifest cases.

d) Why applying the time-bars of the requested State by reference to the penalty scale of the requesting State would be inadequate

Time-bars are generally scaled into different levels, each such level being applicable to offences punishable with a penalty up to a certain quantum. One could then contemplate taking as a reference the quantum of penalty applicable to the acts in the requesting State, and apply the matching time-bar established in the requested State. ${ }^{496}$ The problem is that this would only be more 'cooperation-friendly' where the penalty applicable in the requesting State is higher than that applicable in the requested State. This can be illustrated through the two tables presented shortly below.

In both tables, and in every case, the maximum period of time up to which a person can be persecuted is set at 20 years, as this is reportedly the traditional maximum period that was applied in Roman Law. ${ }^{497}$ It is also assumed that, in all cases, time-bars are defined by reference to the upper level of the penalty scale applicable to the offence. It is moreover always assumed that the period of time lapsed since the acts were committed is 12 years, and that no causes occurred for suspending or interrupting the calculation of the time-bar. Note that the time-bars of the requesting State never apply (this is what the grey background seeks to denote): they are only included in order to provide a picture of how they might be regulated in this State, which will be relevant for reflection later. They are also constant in all cases, because this will also be useful for that reflection. It is assumed that the maximum penalty applicable in the requesting State is 15 years of imprisonment, because, again, this will be helpful later. Note furthermore that, in all scenarios, the requesting State could prosecute the acts according to its own time-bar criteria. The timebar criteria that apply are always those of the requested State, for the reasons already expounded. These are also constant in all cases, serving as the 'control group'.

\footnotetext{
495 See supra, Chap. 6, $₫$ 3.3.2.

496 This would still only be a starting point: the criterion proposed above could still apply cumulatively.

497 See BruCE L. CASTOR (ed.), op. cit., p. 631.
} 
Table 1

Time-bars (first scenario)

\begin{tabular}{|c|c|c|c|c|}
\hline \multicolumn{2}{|c|}{$\begin{array}{l}\text { Upper level of the penalty } \\
\text { applicable to the acts }\end{array}$} & \multirow{2}{*}{$\begin{array}{c}\text { Upper level of penalty scales } \\
\text { for time-bar purposes }\end{array}$} & \multicolumn{2}{|c|}{ Time-bars } \\
\hline Requested State & Requesting State & & Requested State & Requesting State \\
\hline \multirow{5}{*}{9 years* } & \multirow{5}{*}{11 years $^{+}$} & More than 15 years & 20 years & - \\
\hline & & More than 10 years ${ }^{+}$ & 15 years $^{+}$ & 20 years \\
\hline & & More than 5 years* & 10 years* & 15 years \\
\hline & & More than 1 year & 5 years & 8 years \\
\hline & & Less than 1 year & 2 years & 5 year \\
\hline
\end{tabular}

* Calculation of time-bar according to penalty applicable in the requested State;

+ Calculation of time-bar according to penalty applicable in the requesting State

If the requested State takes into consideration the penalty applicable to the acts according to its own law (9 years), the criminal procedure will be time-barred after 10 years; if, instead, it considers the penalty applicable in the requesting State (11 years), then the criminal procedure will only be time-barred after 15 years. Since the hypothesis is that 12 years have lapsed since the acts were committed, in the first case extradition would have to be refused, whereas in the latter it could be granted. Let us now compare this outcome with that verified in the second scenario, below.

Table 2

Time-bars (second scenario)

\begin{tabular}{|c|c|c|c|c|}
\hline \multicolumn{2}{|c|}{$\begin{array}{l}\text { Upper level of the penalty } \\
\text { applicable to the acts }\end{array}$} & \multirow{2}{*}{$\begin{array}{c}\text { Upper level of penalty scales } \\
\text { for time-bar purposes }\end{array}$} & \multicolumn{2}{|c|}{ Time-bars } \\
\hline Requested State & Requesting State & & Requested State & Requesting State \\
\hline \multirow{5}{*}{11 years* } & \multirow{5}{*}{9 years $^{+}$} & More than 15 years & 20 years & - \\
\hline & & More than 10 years* & 15 years* & 20 years \\
\hline & & More than 5 years ${ }^{+}$ & 10 years $^{+}$ & 15 years \\
\hline & & More than 1 year & 5 years & 8 years \\
\hline & & Less than 1 year & 2 years & 5 year \\
\hline
\end{tabular}

* Calculation of time-bar according to penalty applicable in the requested State;

+ Calculation of time-bar according to penalty applicable in the requesting State

The only difference from table 1 to table 2 is that, in the latter, the penalty applicable in the requesting State is lower than that which would apply in the requested State for the same acts. In this case, if the requested State considers the penalty applicable under its own law (11 years), the procedure will be time-barred after 15 years; if, instead, it considers the one applicable in the requesting State (9 years), the procedure will be time-barred after 10 years. In the hypothesis, again, that 12 years have lapsed since the acts, in the first case extradition could be granted, and in the latter it would be refused. Thus, using the penalty applicable in the requesting State does not necessarily increase cooperation.

We might then contemplate using this approach, but limited to the cases where the penalty applicable in the requesting State is higher - i.e. to the cases where this approach would carry more cooperation. However, what the above exercise shows is that the crite- 
rion is essentially inadequate. Using it only in cases where it would be convenient would be absurd, and would be a missed opportunity to reflect about why it is inadequate. It would miss the point.

The reason why it is inadequate is that the reasons why States attach given penalties to the acts that they criminalise are independent from the reasons why they establish given time-limits for prosecuting those acts. A State may follow the view that criminal punishment should not be heavy, but should be certain - which is, in rough terms, the criminal policy programme of the Enlightenment. Such a State will tend to have 'lower' penalties 'than' time-bars. Another State, however, might instead believe that crime should be punished somewhat severely (or feel the practical need to do so, due e.g. to an incapacity to otherwise tackle its levels of criminality), but at the same time attach great importance to the passage of time over the perpetration of the acts. And this State will generally have 'higher' penalties 'than' time-bars. ${ }^{498}$ Differences in the length of time-bars may also be a natural consequence of differences in the importance assigned in different States to the presence of the defendant in trial: States where this requirement knows nearly no exceptions will tend to have longer time-bars.

The above tables do not even express a significant contrast between the requested and the requesting States in their approach to these issues; the difference between the penalty applicable in the two States was also intentionally made very close ( 9 years $v .11$ years); moreover, the maximum period of time after which prosecution becomes impossible was set at the same level for both States (20 years). And still the outcomes were different.

\section{e) Interactions with qualitative relevance}

As noted earlier, from the moment one admits extraditing for acts that one does not criminalise (as was proposed), one will be unable to assess by reference to one's own concepts, the periods of time lapsed which the criminal procedure or the penalty would be barred. ${ }^{499}$ This is similar to what happens with quantitative relevance (i.e. minimum thresholds of penalty to extradite).

The approach of the UK to the issue of lapse of time shows that it is not necessary to have statutory limitations of criminal proceeding to be able to appraise the meaning of passage of time in the context of extradition proceedings. This extradition system is based on dual criminality, and therefore it presupposes that the acts for which extradition is requested do constitute a crime in the UK, but this does not, in essence, change the terms of this problem. Whether the approach followed in relation to lapse of time is that of the UK or that proposed in this study, if the requested State agrees to extradite for acts that it does not criminalise, it should in principle regard them, from a quantitative perspective, as acts of low gravity. Thus the criteria proposed here for time-bars could be adapted to these cases by establishing that, for the purposes of such acts, the applicable time-bar periods should be the lower ones that are available in the legal system of the requested State. These could still be increased in the defined proportion, or in a different one.

498 See BERT SWART, “Refusal of Extradition...” op. cit., p. 201.

${ }^{499}$ See supra, \ 4.1.1.d)(ii). 
However, as we saw, the interactions between qualitative and quantitative relevance are not straightforward. Regarding certain acts, it may be that it only makes sense either not to criminalise them or, if they are criminalised, to assign them a level of penalty which is not particularly low: this may be necessary from an angle of ordinal proportionality (i.e. of coherence with other penalties applicable to acts that offend the same or adjacent legal interests, or that have some elements in common with those acts). Euthanasia would be one such case: it will make little sense to criminalise euthanasia and punish it with imprisonment for up to some 6 months only. Thus, if a State is empathetic enough towards the fact that another State criminalises one such conduct, it is inherently conceding that it will probably not be punished with the lowest penalty in the catalogue. Another example are environmental crimes, also mentioned before.

Hence, for acts that are not criminalised in the requested State, an approach to the lapse of time issue may be to: (i) always admit extradition if the acts were not time-barred according to the lowest time-bar provided for in the requested State (increased to the set proportion); and, (ii) if the acts were time-barred according to the lowest time-bar provided for in the requested State (increased to the set proportion), allow the entities that decide on extradition requests to evaluate whether the request should indeed be refused, in the light of such factors as the qualitative relevance of the acts in the eyes of the requesting State, and the meaning of passage of time for the person in the light of such concepts as 'unjustness' and 'oppressiveness'. (iii) A preclusive threshold could also be established, whereby those entities would be prevented from granting extradition if the acts were timebarred according to, for example, the highest or second higher time-bar provided for in the law of the requested State.

\section{f) Amnesty, pardon, absence of a complaint by the victim, et al.}

The perspectives defended above apply mutatis mutandis to other causes of exclusion of criminal liability. The criteria of the requesting State should also as a matter of principle prevail, and in this case there seems to be no room for disruption of the sense of justice of the requested State, because, unlike the passage of time, events such as an amnesty, a pardon, or the absence of a complaint by the victim have barely any resonance with fundamental individual rights. This is also noted by Swart while assessing the UN Model Treaty. The Model Treaty encompasses all these factors as grounds for refusal, sparking the comment by the author: "how tenacious old traditions can be". 500

The main exception will be the case where the requested State itself has jurisdiction over the acts, and the cause of extinction of criminal liability emanates from its own legal system - e.g. because it was the State that granted amnesty or pardon. Even here, though, the requesting State will deserve primacy if its connection with the acts is clearly stronger (territorial, protective) than that of the requesting State. Not least of all, because to admit otherwise would open the door to fabricated amnesties or pardons (a problem that these factors have in common with the ne bis in idem principle). The point might be made that not recognising the effect of an amnesty or a pardon would infringe upon legal certainty,

500 BERT SWART, "Refusal of Extradition...” op. cit., p. 201. 
but this can be refuted, again and always, with the fundamentally territorial character of criminal law: a person cannot reasonably expect to become immune from prosecution owing to an amnesty or a pardon issued by a State which is not the one where his/her crime was committed or against which it was aimed.

\section{g) Extinction of liability according to a third State}

Finally, the perspectives defended throughout this section also apply mutatis mutandis to the extinction of liability according to the criteria of a State other than the requested or the requesting State. Where the requesting State is the State with the strongest connection with the acts, the criteria of a third State are even less relevant than those of the requested State: whereas the requested State still needs to project its own concepts upon the requesting State to a certain extent, in order to avoid damaging its own sense of justice, the concepts and the sense of justice of a third State are absolutely immaterial here.

In contrast, where the third State is the one with a stronger link to the acts, then the fact that liability has become extinct according to its criteria becomes relevant. Here, the remarks made earlier in this chapter on ne bis in idem stemming from a sentence passed by a State other than the requested and the requesting States apply, mutatis mutandis.

\subsection{Obstacles related to the status or condition of the person}

\subsubsection{Nationality}

\section{a) A glimpse into the perspectives of social sciences on nationality}

Nationality is not a topic, but a theme. It can be looked at from many angles, within and outside the legal field. ${ }^{501}$ Social sciences have produced ample and provocative literature on nationality, nationalism, citizenship. To take only the line of thought that offers the more interesting contrast with the one underpinning a concept such as that according to which a State should not extradite its citizens, one can mention Anderson and his concept of 'nation' as an 'imagined political community': “It is imagined because the members of even the smallest nation will never know most of their fellow-members, meet them, or even hear of them, yet in the minds of each lives the image of their communion". 502 The concept "was born in an age in which Enlightenment and Revolution were destroying the legitimacy of the divinely-ordained, hierarchical dynastic realm", which is why it is "imagined as sovereign": "Coming to maturity at a stage of human history where even the most devout adherents of any universal religion were inescapably confronted with the living $p l u$ ralism of such religions, and the allomorphism between each faith's ontological claims and territorial stretch, nations dream of being free (...). The gage and emblem of this freedom is the sovereign State."

501 See Margaret R. Somers, Genealogies of Citizenship: Markets, Statelessness, and the Right to Have Rights, Cambridge: University Press, 2008, p. 147.

502 Benedict Anderson, Imagined Communities: Reflections on the Origin and Spread of Nationalism, $3^{\text {rd }}$ ed., London: Verso, 2006, p. 6.

503 Ibid., p. 7. 
On the subject of 'nationalism', Gellner marks its birth in the transition from the agrarian into the industrial age (the same where extradition as we currently know it was developed): "The old worlds were, on the one hand, each of them, a cosmos: purposive, hierarchical, 'meaningful'; and on the other hand, not quite unified, consisting of subworlds each with its own idiom and logic, not subsumable under a single overall orderliness. The new world was on the one hand morally inert, and on the other, unitary." "504 "But nationalism" - he argues - "is not the awakening of an old, latent, dormant force, though that is how it does indeed present itself. It is in reality the consequence of a new form of social organization, based on deeply internalized, education-dependent high cultures, each protected by its own state. (...) Nations as a natural, God-given way of classifying men, as an inherent though long-delayed political destiny, are a myth; nationalism, which sometimes takes pre-existing cultures and turns them into nations, sometimes invents them, and often obliterates pre-existing cultures: that is a reality, for better or worse, and in general an inescapable one. Those who are its historic agents know not what they do, but that is another matter. ${ }^{" 505}$

Gellner stresses that this does not mean that nationalism is unimportant: "To reach such a conclusion would, ironically, come close to a tacit, oblique acceptance of the nationalist ideologue's most misguided claim: namely, that the 'nations' are there, in the very nature of things, only waiting to be 'awakened' ". ${ }^{006}$ Anderson argues that Gellner's view still carries that drawback: in its eagerness "to show that nationalism masquerades under false pretences", it “assimilates 'invention' to 'fabrication' and 'falsity', rather than to 'imagining' and 'creation'", which "implies that 'true' communities exist which can be advantageously juxtaposed to nations." To Anderson, this is not so: "In fact, all communities larger than primordial villages of face-to-face contact (and perhaps even these) are imagined." 507

In any case, the authors converge in construing nations as fictional or artificial entities; and they converge - even if this is more vivid in Anderson and follows more naturally from the dichotomy upon which he operates - in acknowledging that this artificiality does not mean that nations do not exist. 'artificial' does not equate to 'inexistent'. Nations can be considered fictional entities; genealogies can be drawn to uncover how such fictions came to be; and, if one goes back in time far enough (and not necessarily very far), one can discern a point up to which they can be deemed not to have existed. ${ }^{508}$ However, from the moment that polities of a certain territorial breadth come to be which seek to establish a correspondence between 'power' and 'culture, ${ }^{509}$ a chain of reactions is triggered

504 ERnest GelLner, Nations and Nationalism, Oxford: Basil Blackwell, 1983, p. 34.

505 Ibid., p. $48 \mathrm{f}$.

506 Ibid., p. 47 f.

507 BENEDICT ANDERSON, op. cit., p. 7.

508 An evocative anecdote, conveyed by José MATToso, A Identidade Nacional, Lisboa: Gradiva, 1998, p. 14, goes as follows: already well into the $19^{\text {th }}$ century, Portuguese king Luís I, while cruising in his yacht past a group of fishermen near the Portuguese coast, asked them whether they were Portuguese; to which they replied 'us?; no, good Sir, we are from Póvoa do Varzim' (which is, and already was, a Portuguese town). This all the more interesting if one notes that Portugal is a relatively small State, in size as well as in population, and that its territory is considered to have had very stable borders for centuries.

${ }^{509}$ To use terminology of ERNEST GELLNER, op. cit., passim. 
which indeed contributes to establishing such a correspondence. Whether or not the individuals falling within the territorial span of a given such polity could be deemed to constitute something that would already amount to the concept of 'nation', they thenceforth engage in a process of psychological identification with each other that does steer them onto that direction - through common education, military ventures, political experiences, etc. ${ }^{510}$ In sum, whereas a nation often does not pre-exist a State, a State often contributes to create a nation. Its members become objectively linked by common languages, usages, morals; laws, rights.

As Sommers expounds: "Modern ideas of rights derive from natural law and are attached to people not as citizens of any particular political entity but as abstract Men with natural rights. As Locke first conceived them in the state of nature, these ethereal individuals exist independently and prior to any political or social body. Today's human rights movement finds its roots in this understanding of indefeasible natural, universal rights. But history has shown us that the normative idea of the rights-bearing subject is tragically abstract, for this is a subject whose very identity is rooted in the 'state of nature', where no political power can actually enforce these rights and protect the bearer. On the basis of the sovereign power of nation-states to control their own borders and population movements, untold numbers of stateless people - Jews, 'Gypsies', and other ethnic minorities expelled and denaturalized by their own governments - have been served up to genocidal regimes while sovereign liberal nations have stood by and refused asylum. These stateless peoples, as Arendt (...) so brilliantly reminds us, were in full possession of their natural rights as they entered the gas chambers in Nazi Germany. Citizenship, by contrast, is available only to those with the privilege, not the right, of membership in a specific political body existing prior to and independent of any particular human beings. Looking from the outside in, citizenship is discriminatory and exclusive; but once inside, it is a force for equality and inclusion". ${ }^{511}$ This is, in a superficial analysis, the state of affairs we inherit when we currently consider nationality as a relevant institution in several areas within the law.

\section{b) Nationality and territoriality}

In the field of criminal law, to the individuals who are bound by nationality to a given State, this bond comes not only as a benefit, but also as a duty. Thus, States which reserve themselves the power to punish individuals based on the fact that they are their nationals (which from the perspective of these individuals constitutes a duty to comply with the law of that State) are generally the same which refuse to cooperate with other States towards the punishment of those individuals (which for these individuals is beneficial). In a symmetric manner, where nationality does not entail a duty to comply with the law of a State (which in itself is not a benefit, but in comparison to the above case does entail wider freedom of action) are generally the same States which tend not to refuse to cooperate

510 See Benedict Anderson, op. cit., p. 7 f.; José MATtoso, op. cit., p. 14 f.; José Gil, Em Busca da Identidade - o desnorte, Lisboa: Relógio D’Água, 2009, p. 23 f.

511 Margaret R. Somers, op. cit., p. $161 \mathrm{f}$, adding that this contributes significantly to explaining the "silence of serious sociological engagement with citizenship" before the 1950's, and its scarcity until the 1980’s (see also p. 147). 
with other States towards the punishment of those individuals (which in itself is not a duty vis-à-vis the State of their nationality, but does in a sense reinforce the duty to comply with the law of other States).

In the light of the model of ubiquitous criminal justice brought by the Enlightenment, ${ }^{512}$ both approaches are suitable, as in both of them individuals can be either prosecuted by their own State or extradited to other States. From this perspective, none of them is imbalanced, although the latter requires some adjustments, since it may be impossible to extradite a person owing to reasons (e.g. lack of due process guarantees in the requesting State) that do not entail that the person should not be brought to justice altogether, in which case the exercise of ius puniendi by the State of which he/she is a national may be the only option. Intermediary approaches also satisfy that ideal of ubiquity, so long as the person can in most cases be either extradited or prosecuted, and regardless of which of the two paths should take priority.

However, all States - the former and the latter - agree that criminal justice is fundamentally territorial, and the reasons for this are different from those which confer on nationality its current significance. Territory and nation are the two central elements of the Westephalian paradigm. However, as we saw, nationality is to a large extent a product of that paradigm, whereas the territorial foundations of criminal law pre-exist it: such a paradigm changed their scope of efficacy, but did not change them qualitatively. Therefore, whereas it can be presumed in the abstract, on the basis of sound anthropological factors, that a crime committed in a certain place will trigger the need for punitive intervention by the polity that governs such a place, the fact that a person bears a bond of citizenship with a given polity does not so immediately translate into a reason for this polity either to protect or to punish this person. Many ancient communities, way into the medieval ages, relied mainly on a principle of personal jurisdiction. ${ }^{513}$ However, citizenship was almost necessarily a factual link, which presupposed that the person indeed lived among that community, shared its usages and principles, knew its law. The organisation of several such communities into larger polities demarcated mainly by reference to a given territorial span, and the concentration of their punitive power into a single such polity, changed the nexus between community and polity to such an extent as to have qualitatively changed the concept of community, but that is not what conferred on territoriality its essence as a principle of jurisdiction in criminal matters. ${ }^{514}$

As things stand, it seems clear that most States that refuse to extradite nationals to other States for crimes committed in the latter do not do so because they believe they have strong reasons to punish them, but in spite of the fact that they recognise that other States have stronger reasons to do it. That is, the reasons why some States do not extradite their own nationals stem from their link with these individuals, not from their link with the acts committed by them. This means that nationality has few or no influence upon the neutral

512 Cesare Beccaria, op. cit., p. 180, although in reference to banishment rather than to extradition, denotes consideration for the bond of nationality when he states: "The reasons ought to be stronger for banishing a citizen than a stranger".

513 See e.g. ZSUZSANNA DEEN-RACSMÁNY, op. cit., p. 35.

514 See supra, Chap. 7, \ 3.1.2., and Chap. 8, \ 4.1.1.k)(iv) and (v). 
determination of which of several States is more closely linked to given acts. Like ordre public, its influence is felt only subsequently, as a factor that may justify that a State unilaterally depart from the results that such an operation would dictate. It is therefore natural that the phenomenon of transnationalisation of criminality - which did not shift significantly the neutral principles by which that operation abides, but which did significantly narrow the factors capable of justifying a departure from the results it dictates - led many States that traditionally did not extradite nationals in any event to open at least some exceptions to that principle. ${ }^{515}$

The fact that nationality intervenes here in the quality of a link between a person and a State, rather than between this State and certain acts, is also what explains that even the States which do not traditionally refuse to extradite their own nationals eventually began to make some concessions to this principle. To such States, even more than to other States, criminal justice is a territorial issue. That is, there is indeed no doubt in the mind of these States that the prevailing law is that of the State where or against which the crime was committed. They follow this principle irrespectively of whether it is to their advantage or not, i.e. of whether or not it points toward the conclusion that theirs is the applicable law. They reject the view that their legal systems are linked to any acts committed by their nationals abroad. Even so, as any other nation-States, they have links with their nationals as subjects. As any other nation-States, they underwent the processes of psychological identification that bind together their members and instil in them a sense of community, however 'artificial' it might have been until a not very distant past. Consequently, they are not immune to those forces - 'discriminatory and exclusive' when looked at from the outside, 'equalitarian and inclusive' when looked at from the inside - that drive States to protecting their nationals, and to protecting them more than other subjects. It is therefore noteworthy, but not astonishing, that for instance the UK has over recent years attached some weight to nationality as a factor for refusing extradition, even though not to such an extent as to introduce a classic nationality exception. ${ }^{516}$

\section{c) Nationality as a ground for refusal}

In the light of the above, the question as to whether the nationality of the requested person should prevent extradition must be addressed within the clear assumption that the 'burden of proof impends upon the affirmative position. As is well known, in many States the prohibition to extradite nationals even constitutes a constitutional guarantee. However - unlike what happens with respect to other grounds for refusal addressed before - , in this case, constitutions are incapable of providing an axiological reference on which to anchor an answer to that question. The fact that a State bestows constitutional rank to the principle of non-extradition of nationals denotes the importance of this rule to its community, but it does not necessarily translate into the protection of any value which reflects its sense of what is essential - its ethos.

515 In this regard the MAW is closer to the EAW than in most other regards, although the mitigation of the nationality exception that it operates is, once again, quite timid: see Art. 4 (1) (a) MAW.

516 See supra, $\$$ 2.1.1, and further supra, Chap. 5, $\int 1.1 .1$, and ulterior references. 
Even when the nationality exception is enshrined in a constitutional catalogue of fundamental individual 'rights', ${ }^{517}$ it does not directly protect a right in a natural law sense of the term: not only in the sense that it would be unenforceable in the absence of a State, but also in the sense that it could not exist in the absence of that State. Such a provision will therefore honour just the abstract link between that State and its nationals, making it - in the image of nationality itself - a "privilege, not a right". 518 This is why the nationality exception can be "relativised" to accommodate "security concerns", in a what constitutes a symptom that "today's constitutional law is, more and more, internationally and communally dependent". ${ }^{519}$ Thus, the fact that the nationality exception has constitutional rank in a certain State does not constitute a justification - but at best an excuse $-{ }^{520}$ for that State to deny to the State that was injured by a crime its neutrally accredited prerogative to assert jurisdiction thereon.

In order to address our question, it is therefore necessary to look directly into the elements which integrate the rationale of the nationality exception, and evaluate whether they can be redirected into any actual value or right of constitutional character. As a necessary consequence of the qualification of the abstract bond of nationality as a 'privilege', the part of that rationale which consists of the sheer existence of such an abstract bond must be discarded from consideration. Not that such an abstraction (and here we are no longer referring to the bonds binding together the members of the 'nation', but to those binding each such member and the State) be completely "irrational". ${ }^{521}$ In fact, it can to some extent be construed as an expression of the social contract logic, namely as an "allegiance with a synallagmatic quality" whereby State protection against foreign justice constitutes one of the rewards for the loyalty and contribution provided to it by its citizens, for instance through the payment of taxes. ${ }^{522}$

However, and tempting as it might be to engage in this topic, such a line of reasoning only evinces the note of privilege mentioned above: ${ }^{523}$ the synallagmatic explanation of the bond of nationality confers some rationality on the rapport between nationals and their State, but not to the relations between those individuals and any other State, from whose point of view those individuals benefit from an authentic exemption. Once again Somers' observation resounds, that citizenship constitutes a "force for equality and inclusion" to those who possess it, but is "discriminatory and exclusive" if looked at from the outside. ${ }^{524}$ For the same reason, the argument that the nationality exception ensures pro-

517 As is the case in Portugal: see supra, Chap. 6, \ 4.1.2.

518 See supra, \a), and again MARGARET R. SOMERS, op. cit., p. 161.

519 José JoAquim Gomes Canotilho, Direito Constitucional... op. cit., p. 212.

520 On the sense in which the terms 'justification' and 'excuse' are used here, see supra, Chap. 7, $\mathbb{\S}$ 3.2.1.

521 But see BERT SwART, "Refusal of Extradition...” op. cit., p. 190.

522 STEFAN OETER, "Effect of Nationality and Dual Nationality on Judicial Cooperation, including Treaty Regimes such as Extradition”, David A. Martin / Kay Hailbronner (eds.), Rights and Duties of Dual Nationals: Evolution and Prospects, The Hague: Kluwer Law International, 2003, p. 58; see as well ZSUZSANNA DEEN-RACSMÁNY, op. cit., p. 35.

${ }^{523}$ For instance, it would legitimise rather unreservedly the idea of conferring protection on individuals who obtain so-called 'golden visas' owing basically to their investment of large sums of money in a State.

524 MARgaret R. SOMERS, op. cit., p. 161. 
tection of the ordre public of the requested State ${ }^{525}$ is also discarded, since the concept of ordre public is, as we saw, axiological in character.

If we exclude the abstract element of the bond, we are left with the following arguments: ${ }^{526}$ (i) There is a risk that the national will be discriminated against in the foreign State due to being a foreigner. (ii) In any case, he/she will objectively be at a disadvantage due to being unfamiliar with that criminal procedure and the language used therein, as well as to the unavailability, in that State, of character witnesses who can vouch for him/her. And (iii) the State of nationality is the best place for him/her to be rehabilitated.

All these factors are quite fragile in their own terms: (i) To presume discrimination is to presume that the requesting State is xenophobic, which not only is unfounded, but also - for that very reason - somewhat xenophobic on the part of the requested State itself. (ii) To argue that the person will be at a disadvantage presupposes that the criminal procedure in the requesting State is not equipped to deal with defendants who have specific personal characteristics, notably linguistic, which may not be the case. If the disadvantage refers to such factors as evidentiary issues, a procedure in the requesting State will not necessarily put the person at a disadvantage. Most of the evidence, inculpatory as well as exculpatory, will in principle be found in the requesting State, and therefore the person will only be at a disadvantage in this State if he/she is indeed guilty, in which case a criminal procedure in the State of nationality might put him/her in a position of unjustified advantage (because here one is no longer referring to factors concerning the person as such, but his/her acts, and, insofar as these are concerned, primacy is owed to the requested State). (iii) The rehabilitation argument, as we already saw, applies to the enforcement of the penalty, but has very limited validity at the prosecution stage, which on the other hand precisely happens to be the most important stage for the requesting State. ${ }^{527}$

\section{d) Supervening grounds for refusal}

It is always possible that in a concrete case any of those factors will be verified, and if so refusal of extradition would indeed be justified. The point is that the nationality exception presumes that they will be verified in every case. This not only is unfounded, but also has become redundant in the light of the emergence of other grounds for refusal that are specifically concerned with the possible verification of those factors. Indeed, the nationality exception is a paradigmatic example of a ground for refusal fallen into obsolescence owing to supervening grounds for refusal that have overlapped and fully absorbed the elements of its rationale that had any consistency.

Thus: (i) Risk of discrimination is a ground for refusal in its own right and it allows for a verification in each concrete case of whether such a risk is real. (ii) The same applies to minima procedural rights in the requesting State. Very symptomatic with regard to both of those factors is the Portuguese system, assessed earlier: Portugal opened some exceptions to its formerly absolute rule of non-extradition of nationals, subordinating the pos-

525 See e.g. ZSUZSANNA DEEN-RACSMÁNY, op. cit., p. 35.

526 See e.g. BERT SWART, "Refusal of Extradition...” op. cit., p. 190; ZSUZSANNA DEEN-RACSMÁNY, op. cit., p. 35; AG, Petrubbin, Opinion, cit. in Chap. 4, \$ 2.2.2.

527 See supra, $\left.\int 3.4 .1 . \mathrm{b}\right)$ and ulterior references. 
sibility to extradite to a set of conditions which include the requirement that the criminal procedure in the requesting State satisfies the standards of the ECHR and other relevant international legal instruments. These conditions are at least as demanding as those that Portugal was already bound to require from the requesting State in regard of any requested person, whether national or foreign. ${ }^{52}$ This is not a technical redundancy, but a symptom of something more profound: the propensity of human and fundamental individual rights for universalism, and their attachment to natural law conceptions of 'rights', is irreconcilable with formalistic conceptions of 'rights' grounded on the sheer political status of a person. These conceptions can and do coexist, but where that occurs the former will only expose the insubstantial and prejudiced nature of the latter. If even so the requested State is compelled to be more zealous towards its nationals than towards other subjects, this still does not require it to refuse extradition in all cases, based on presumptions, but can be attained by requiring broader guarantees from the requested State that the person will be entitled to a due process, for instance by requiring specific information that an interpreter and contact with consular authorities will be made available. ${ }^{529}$ (iii) The rehabilitation argument is entirely offset by the enactment of a 'rehabilitation exception' with the characteristics mentioned above. Precisely because such an exception is concerned with substantial factors only (such as the real links of the person to the requested State), it necessarily extends to classes of subjects other than nationals, in what constitutes an unprejudiced ground for refusal which is qualitatively very different from the nationality exception. ${ }^{530}$

\section{e) Nationality and deterrence}

A further argument against the nationality exception is that, from a perspective of deterrence, it is probably the most unsustainable of all traditional grounds for refusal of extradition. States that do not extradite their nationals wave the flag of active nationality to state that impunity is not a risk. However, while theoretically this is a sound argument, in practice it bears in it all risks inherent to a prosecution in a secondary forum: it will frequently carry unjustified acquittals, ${ }^{531}$ and moreover it may spark an unjustified ne bis in idem protection. At the jurisdictional level, the nationality of the offender is a primary link of the acts to the legal system of the requested State, and, while it is weaker than a territorial or protective link, it is stronger than no link at all. In this sense, the requested State is in a better position to prosecute than if the only means to compensate for the refusal of extradition were a vicarious procedure. However, at the procedural level, active nationality is on the very same footing as vicarious jurisdiction, since in principle the evi-

528 See supra, Chap. 6, IS 1.2.2. and 4.1.2.

${ }^{529}$ In this regard, the recent Agenda of the EU on procedural rights provides a reference of how the problems potentially arising from increased levels of cooperation need not be addressed through further obstacles to such cooperation, but instead through further individual guarantees in criminal proceedings, or in cooperation proceedings themselves but without directly entailing their refusal: supra, Chap. 1, $\mathbb{S}$ 5.4.1., Chap. 2, \$ 3.2.2. and 3.2.3., and Chap. 4, \$ 6).

530 See supra, $\$$ 3.4.1. and ulterior references.

531 See BERT SwART, "Refusal of Extradition...” op. cit., p. 190. 
dence and the victims are found in the requesting State. This is why, even if the requested State has primary jurisdiction, the prospects of a successful prosecution will be higher if the requesting State delegates the proceedings on that State along with evidence and other elements that such a State is lacking. This causes that the requested State will in fact not be exerting its own jurisdiction, but that of the delegating State, in a surrogate manner. ${ }^{532}$ This puts again in evidence the deep differences in nature and in strength between active nationality and territoriality as bases for jurisdiction.

Meanwhile, the State of which a person is a national or a resident is the most comfortable place for him/her to be integrated (which is why a rehabilitation exception is justified). It is difficult to imagine a less deterrent factor than for an individual to know that the State where he/she is more comfortable will be sheltering him/her from prosecution - moreover, with good prospects of impunity - for any acts they might commit abroad. Beccaria stated that "the conviction of finding nowhere a span of earth where real crimes were pardoned might be the most efficacious way of preventing their occurrence". 533 The nationality exception provides offenders with the most privileged such span of earth conceivable.

\section{f) Reform proposals}

None of the above is new or contested in impartial academic research. As noted by Swart: "Flexible approaches [such as the rehabilitation exception] along the lines suggested here are not really controversial in academic circles. It is State practice that is conservative and resistant to change." 534 Thus, it is worth addressing the nationality exception within States' own mind-set. And, if this exception is to endure, then at least some proposals can be made with a view to its improvement.

We have seen that States themselves admit to the 'relativity' of the nationality exception and that this exception constitutes geometry which can vary depending on 'security concerns' ${ }^{535}$ It certainly varies according to specific levels of political integration and ease of movement. This is evidenced by EU integration, where many States completely relinquished their classic nationality exceptions (which, in many cases, required constitutional amendments) in exchange for security advantages that had started to be perceived as indispensable in such an integrated area.

But the nationality exception already adapted to global oscillations too: ${ }^{536}$ some States where the nationality exception is deeply-rooted and has constitutional rank have already made room for extraditing nationals to whichever State if certain conditions are met, such as the fact that the acts at issue amount to certain types of serious criminality. Portugal provided us with a clear example of this. ${ }^{537}$ This separates the nationality exception from

532 See again supra, \4.1.1.k)(iii), and ulterior references.

533 Cesare Beccaria, op. cit., p. 192.

534 BERT SwART, "Refusal of Extradition..." op. cit., p. 191; see also M. ChERIF BAssiouni, "Reforming International Extradition...”, op. cit., p. 406.

535 See supra, Chap. 6, \4 4.1.

536 On 'regional oscillations' and 'global oscillations', recall supra, Chap. 7, \ 2.1.1.

537 See supra, Chap. 6, \$ 4.1.2. 
grounds for refusal that have an axiological substrate, such as the life-imprisonment exception - to which that very State also made some concessions in the specific context of its cooperation within the EU and with the ICC, but not in global terms. ${ }^{538}$ And even so those concessions received stern criticism, ${ }^{539}$ such a criticism being most well-founded, because this ground for refusal protects core values of the Portuguese legal system. And it matters not here whether such values are 'right' or 'wrong', 'better' or 'worse' than other perspectives, but only that, to that legal system, they are essential, and, as such, the respective ground for refusal imposes itself as a matter of principle.

But if States themselves already admit the inadequacy of the nationality exception in global terms, and if the criterion - guarantees of reciprocity and of due process aside, which in any case could (and in the case of the latter should) already be required in respect of any person, national or foreign - is the type and gravity of the crime at issue, then it would seem that the catalogue of offences that can give rise to the extradition of nationals should extend to further offences. At least, to those that are analogous or more serious than the ones for which extradition has already been admitted. What is the material justification for extraditing nationals for international organised crimes (e.g. a corruption scheme operating in one State, followed by money laundering in another), but not e.g. for genocidal acts committed entirely within the confines of one State in a disorganised manner!?

If a State concedes that it should extradite its nationals for prosecution, but only for certain acts, it may then establish a set of categories of offences where that will be possible, or simply establish a minimum threshold of quantitative relevance higher than the default one. Even if this threshold were to be relatively high, this approach would be more aligned with the imperative to respect the preponderance of the requesting State: cooperation would still be limited, but at least the criteria would not consist of an (inevitably more subjective) qualitative determination of admissible types of cases, but rather it would apply to any acts that have an overall high relevance to the requesting State: from a cardinal perspective, and to use again the corruption example, what is the material justification for extraditing in such a case (and this is not to deny its significance), punishable for instance with imprisonment for up to 10 years, but not, for instance, for a multiple homicide carrying the maximum level of imprisonment admissible in the requesting State (e.g. 30 years)? Below this special threshold, the requested State would carry out a criminal procedure on behalf of the requesting State, in the general terms (although the material justification to do so is, again, a consideration for the personal conditions of the individual in question, rather than his/her quality of national as such).

On a different note, but still attempting to address the problem within the mindset of States that do not as a rule extradite their own nationals, it is interesting to observe the silence of most extradition arrangements on the hypothesis of multiple nationality. If a person is a national not only of the requested State but also of the requesting State, and if the bond of nationality, in and of itself, is the reason for a State not to extradite its own nationals, how does this argument play out when the person is a national of the request-

538 See supra, Chap. 6, \1.4.2.

539 See again Pedro CAeIro, “Ut Puras Servaret Manus...”, op. cit., p. 50 f. 
ing State too? By refusing extradition in such an event, the requested State will not only be denying the requesting State its justified preponderance at the jurisdictional level, but also it will be doing so in the name of a bond that the other State also has with that person. Thus, if even so a requested State in all cases refuses to extradite - as is generally the case,$-{ }^{540}$ it will be stating that the bond of nationality in the name of which it refuses to cooperate with all other States is not only a privilege, but a privilege which is only consequential when it is conferred by itself, in what will form an epitome of self-centeredness. Always refusing extradition in such cases also precludes the possibility of explaining the symbolic dimension of nationality through a synallagmatic logic drawn from social contract theories - a logic which in itself was already quite weak, as residents usually also pay taxes and provide other contributions to the State where they live -, because the person in question is linked to the requesting State by the very same synallagma.

\section{Final considerations}

\subsection{Connecting some dots}

\subsubsection{Supporting the rise of proportionality and of alternatives to extradition}

\section{a) Proportionality}

One message that can be drawn from the EAW experience is that the more flexible cooperation mechanisms which entail significant hardship to the person become, the more careful States should be not to use them disproportionately to the seriousness of the case. This is visible in the fact that, with FD-EAW, the EU not only did not abandon the relevance thresholds typical of classic extradition, ${ }^{541}$ but also it attached to them a further instruction for Member States to conduct a proportionality assessment before issuing a request. The same message follows from the manner how the issue of 'extraditable acts' has been regulated in the FD-EAW: control of dual criminality is dispensed with only in respect of acts listed in Art. 2 (2) - acts which tend to be serious -, ${ }^{542}$ and only if they are punished in the issuing Member State by a custodial sentence or a detention order for a maximum period of at least 3 years - a relevance threshold which is superior to the regular threshold of Art. 2 (1), applicable to acts in regard of which dual criminality can still

\footnotetext{
540 One exception only could be identified during the elaboration of this study in this regard - namely the extradition system of Romania: Chap. 4, \$ 2.4.3.a).

541 See supra, $\int 3.2 .1$.

542 As was already the case with the 1996 EU Convention on Extradition, which abolished dual criminality for conspiracy or association to commit offences in the field of terrorism, drug trafficking, and other organised crime or other acts of violence against the life, physical integrity or liberty of a person, or creating a collective danger for persons: Art. 3 (1). It is true that Art. 3 (3) allowed Member States to reserve the right not to apply this derogation, or to apply it only under certain conditions, but according to Art. 3 (4) any Member State that had made such a reservation should still "make extraditable" the conduct of any person who contributed to the commission by a group of persons acting with a common purpose of one or more of the offences mentioned above, even if that person did not take part in the actual execution of the offence(s), so long as that contribution was intentional and made with knowledge either of the purpose and the general criminal activity of the group, or of the intention of the group to commit the offence(s).
} 
be controlled. The same is also visible or at least implied in most measures that the EU began to adopt some time elapsed over the enactment of the FD-EAW with the purpose of rebalancing the synallagma upon which rests its Area of Freedom Security and Justice, notably: (i) the agenda on procedural rights of suspects and individuals targeted by EAW's; and (ii) cooperation mechanisms that seek to avoid as much as possible the use of preconviction custodial detention. ${ }^{543}$ And it is moreover visible at the national level, with several Member States complaining about the disproportionate use being made of the EAW system by other Member States, the most visible example of dissatisfaction being probably that verified in the UK. As we could see, the UK unilaterally enacted two grounds for non-execution concerned with proportionality: (i) the 'proportionality bar' and a concomitant 'preliminary check', which impede the execution of a EAW at a very early procedural stage, if such an execution would be manifestly disproportionate in the light of certain specified factors; ${ }^{544}$ and, moreover, (ii) an 'absence of prosecution bar', which blocks the execution of a EAW if the person concerned has not been prosecuted in the issuing Member State. ${ }^{545}$ These bars do not even have an equivalent in that legal system for classic extradition, where in the abstract the trustworthiness of the requesting State is lower.

In extradition as in all public law based on democracy and the rule of law, proportionality is a key principle. ${ }^{546}$ However, most extradition systems pay attention to only one of its dimensions. As noted in the context of evidentiary requirements, in order to pass a complete proportionality test, extradition would have to be: (i) suitable to attain the public interest in question (adequacy); (ii) capable of doing so with less harm to the person than any other measure available (necessity); and (iii) proportional to the harm it causes to the individual (proportionality stricto sensu). ${ }^{547}$ Currently, virtually all extradition systems agree that extraditing would be disproportional if the acts at issue do not attain a certain quantitative and qualitative relevance according to their own sense of justice, as expressed in relevance thresholds and in the dual criminality rule, respectively. This study proposes the reform of both of these grounds for refusal, but in respect of neither is the notion of proportionality abandoned: only reformulated into an optimal degree. ${ }^{548}$ Quantitative and qualitative relevance both concern proportionality stricto sensu, since extradition is still adequate for allowing justice to be done upon acts that do not satisfy those notions, and it is often the only means available for doing so. However, the 'seriousness' of a case is not reflected only in the quality of the acts and in the penalty that they attract, but also in the degree of suspicion that substantiates them. Without a minimum level of proof suggesting that a crime may indeed have been committed by the person in question, it is arguably impossible to even establish that extradition is adequate to begin with.

${ }^{543}$ See supra, Chap. 1, \5.4.1., Chap. 2, \3.2.2. and 3.2.3., and Chap. 4, \6); and further infra, $\ 5.1 .1$.

${ }^{544}$ See supra, $\ 3.2 .1$, and Chap. 6, \2.2.3.

${ }^{545}$ See supra, Chap. 6, \3.2.3; see further infra, \e).

546 See e.g. Aharon Barak, Proportionality: Constitutional Rights and their Limitations, Cambridge: University Press, 2012, passim.

547 See José Johquim Gomes Canotilho, Direito Constitucional... op. cit., p. 269 f.

548 See supra, $\$ \$$ 3.2.1. and 4.1.1., and further supra, Chap. 6, \\ 2.1. and 2.2. 
Qualitative and quantitative relevance express what may be called the 'objective seriousness' of a case; evidentiary requirements what could be called its 'subjective seriousness'. In consequence of their different nature, there is a key difference between the two: the former is 'peremptory' or 'static', in that an offence either meets the applicable criteria and extradition can be granted, or it does not and extradition must be refused; the latter is 'conditional' or 'dynamic' instead, in that extradition must be refused if, but only insofar as, the requesting State does not satisfy the applicable threshold. If a request is refused due to evidentiary insufficiency, the requesting State can still take action to overcome such an insufficiency, a process in which the requested State itself can provide legal assistance e.g. by taking or enabling the requesting State to take statements from the suspect, and by supervising the suspect in order to prevent him/her from absconding or fleeing to another State.

\section{b) Alternatives to extradition}

This type of measure is available within the EU pursuant to FD 2009/829, on the supervision of measures as an alternative to provisional detention, generally referred to as 'European Supervision Order'. ${ }^{549}$ This mechanism "stimulates respect for the right to liberty and the presumption of innocence of the accused whilst, at the same time, protecting victims and the general public". ${ }^{550}$ It is, ultimately, a specific modality of the broader cooperation mechanism that is mutual legal assistance. As an alternative to pre-trial detention in cross-border cases, this mechanism is, inherently, an alternative to extradition - in the case, to the EAW. Such an alternative may be definitive, if the evolution of the underlying criminal proceedings eventually renders the use of the EAW unnecessary (e.g. if these proceedings are filed), or temporary, if they advance and the EAW still proves necessary at that later stage. But in either scenario the supervision order will accomplish its finality of bringing pre-conviction custody to levels closer to the minima necessary for delivering criminal justice. One is dealing here with the second dimension of proportionality - necessity: extradition might be adequate and potentially proportional stricto sensu, but be necessary only at a certain point and if such a point does arrive, before which the person's rights to freedom and presumption of innocence can be more broadly ensured. It is a manifestly positive effort to optimise the many interests at stake in transnational criminal cases, and it therefore deserves consideration also in the realm of classic extradition. This is irrespective of whether an evidentiary requirement, or any other bar relating to the concept of 'subjective seriousness ${ }^{551}$ is in place: naturally, a mechanism such as the European Supervision Order will be all the more useful the fewer grounds for refusal are in place which are concerned with the necessity of extradition.

It goes without saying that other, now themselves already 'classic' forms of cooperation, such as the delegation of criminal proceedings and the execution of foreign sentences conserve their utility and should be used as an alternative to extradition when this

549 See also FD 2008/947 on the supervision of probation measures and alternative sanctions. On these two instruments of EU law, see ANDRÉ KLIP, European Criminal Law... op. cit., p. 448 f., 462 f.

550 Ibid., p. 448.

551 See infra, $\int \mathrm{e}$ ), addressing a ground for refusal to which these considerations apply even more plainly. 
is sufficient to satisfy the interests of the injured State and less detrimental to the person concerned. The fact that such mechanisms have only sporadically surfaced throughout this chapter should be understood as a consequence of the presumption (justified at an early stage in the study) ${ }^{552}$ that extradition is the mechanism that has greater potential not only for satisfying the interests of the State that was injured by the crime, but also for determining the truth of the facts (whether ultimately favourable or unfavourable to the person).

\section{c) The 'absence of prosecution' bar (proportionality as necessity)}

The 'absence of prosecution' bar, which precludes extradition if the person has not been prosecuted in the requesting State, was excluded from consideration in the foregoing paragraphs, because it is a unilateral making of the UK which has no equivalent either in the UN model instruments or in the FD-EAW. ${ }^{553}$ However, it also constitutes a manifestation of the principle of proportionality, and therefore it is justified to address it briefly at this moment.

Like evidentiary requirements, that bar also reflects a notion of 'subjective seriousness' of the case. It is akin to evidentiary requirements, but its focus is somewhat different, in that it is more 'procedural' than 'substantive' in character. It seeks to avoid that a person - being suspected of a crime which (objectively) is sufficiently serious to give rise to extradition, and regardless of the level of suspicion falling upon him/her - will be held in custody (or at any rate in a jurisdiction other than that where his/her life is based) for a long period of time, waiting for criminal proceedings to evolve to the trial phase, which is the phase where his/her presence indeed becomes indispensable or highly desirable.

Like quantitative and qualitative relevance and evidentiary requirements, and in the image of cooperation mechanisms aimed at reducing pre-conviction deprivation of liberty, such as the European Supervision Order, it constitutes an expression of proportionality as necessity: even if extradition is adequate and potentially proportionate stricto sensu, it might be unnecessary before a certain procedural moment. An evaluation as to whether such a moment has or has not arrived will often have been carried out by the requesting State before issuing an extradition request, but this might not always occur, in which case the requested State will find itself in a position where it is expected to subject an individual located in its jurisdiction to an unnecessarily (if only temporarily so) harsh measure. Therefore, this bar undoubtedly carries a benevolent motivation, and it shows particularly warranted in the light of the possibility - which, considering again the principle of presumption of innocence, should be assumed by default - that the individual does not even have to attend a trial owing to the lack of a case against him/her, or does have to attend a trial but is ultimately acquitted. It was precisely one such case (Symeou) which reportedly triggered the enactment of this bar in the UK.

On the other hand, again in parallel with evidentiary requirements, this ground for refusal does not constitute a peremptory, but simply a transitional impediment to extradi-

552 See e.g. supra, Chap. 1, \3, Chap. 6, \ 6.1., and Chap. 7, $₫ 3.1$.

${ }_{553}$ See supra, Chap. 6, \3.2.3; see also supra, \1. 
tion. Likewise, its blocking effects can be counterbalanced through cooperation mechanisms alternative to the immediate extradition of the suspect.

Nevertheless, such a ground for refusal can also create difficulties for the investigation and prosecution of some cases. Notably where there is a large number of suspects and the trial can only commence once the presence of all or most of them is secured; or where custody of some suspects is crucial for preventing evidence from being destroyed, a finality that in a fully domestic case would typically justify pre-trial custodial detention. Therefore, if a ground for refusal with these characteristics is adopted, it would be sensible to configure it as optional, so as to enable a case-by-case basis appraisal on the part of the entities competent for deciding on extradition; or to configure it in any other manner that duly accommodates the conflicting interests, such as configuring it as mandatory but making exception for such cases as organised crime or criminal procedures with a large number of defendants.

\subsubsection{Strengthening human rights-based grounds for refusal}

\section{a) The demise of the rule of non-inquiry}

The advent of fundamental individual rights in the field of extradition carried as a necessary consequence the obsolescence of the principle according to which the requested State should refrain from looking into the praxis of the requesting State. The idea that such an inquiry on the part of the requested State could breach its duty not to interfere in the affairs of the requested State became unfounded on two different grounds: first, human rights issues are precisely among the few issues regarding which the principle of nonintervention does admit deviations (if still quite moderately); ${ }^{554}$ second, the principle set in Soering is that responsibility for a hypothetical human rights breach in the requesting State upon obtaining extradition lies immediately with the requested State for extraditing in spite of a real risk of breach. ${ }^{555}$ Thus, blurry as this construction might be, the requested State will not be casting judgment on the practice of the requesting State, but assessing, by reference to objective elements concerning such practice, whether by extraditing it would itself be breaching the human rights of a person found within its jurisdiction and in its custody.

That is, even if such an inquiry did involve an intrusion into the affairs of the requesting State, such an intrusion would always be 'justified ${ }^{556}$ by the necessity of the requested State to comply with its own human rights obligations. ${ }^{557}$ While requested States should certainly be cautious and as much as possible objective in their assessments, it appears unquestionable that upholding human rights in such transnational settings requires the proscription, or at least a strong mitigation of the rule of non-inquiry.

554 See Malclom N. SHAw, op. cit., p. 1147, esp. p. 1155 f.

555 See again supra, Chap. $3, \sqrt{\int} 3.3$.

556 The term is again being used within the meaning it was ascribed supra, Chap. 7, $\int$ 3.2.1.

557 The causal link between the rise of human rights and the demise of non-inquiry is acknowledged e.g. in Johanna Harrington, “The Absent Dialogue...”, op. cit., p. 84 f., and JaCques SEmmelman, "Federal Courts, the Constitution, and the Rule of Non-Inquiry...”, op. cit., p. $1198 \mathrm{f}$. 


\section{b) Brief remarks on assurances provided by the requesting State}

As far as certain human rights are concerned, assurances provided by the requesting State are immaterial. In his report to the UN General Assembly, the Special Rapporteur on torture and other cruel, inhuman or degrading treatment or punishment posited that: "States cannot resort to diplomatic assurances as a safeguard against torture and illtreatment where there are substantial grounds for believing that a person would be in danger of being subjected to torture or ill-treatment upon return". ${ }^{558}$ According to the UNODC, "several arguments tend to demonstrate that such diplomatic assurances are imperfect: for example, concerns that requiring a diplomatic assurance from a requesting State is equivalent to an implicit acknowledgement that torture is used generally and systematically in the requesting State. In addition, post-return monitoring mechanisms have proven to be no guarantee against torture: diplomatic assurances are not legally binding and therefore carry no legal weight and no sanctions if breached; and the person whom the assurances are aimed at protecting has no recourse if the assurances are violated." 559

However, other grounds for refusal do not involve similar risks, since they do not concern the practices of the requesting State, but certain consequences that result openly from its law. The most evident examples are the grounds for refusal that concern the applicability of life-imprisonment or the death penalty. If the requesting State is capable of providing a solid guarantee that the penalty will not be applied, there is no reason capable of justifying why the requested State should refuse cooperation. International cooperation, by its very definition, is not the place to take purely dogmatic, symbolic positions towards other States. ${ }^{560}$ However ingrained the abolitionist tradition might be in a given State and its community, the scope of efficacy of such a worldview is that State and that community. The theoretical framework developed earlier can be applied to these cases in terms similar to those in which it was applied to other grounds for refusal throughout this chapter: if the requesting State is the one whose law is applicable to the acts, it is its penalty system and its punitive conceptions that deserve primacy. Extraditing to such a jurisdiction in a case where a penalty that is repudiated by the requested State could apply would certainly offend its sense of justice; but where such a penalty cannot be applied few or no reasons remain to refuse extradition other than a repudiation of the requesting State's law as such. ${ }^{561}$

Quite interesting to note is that democratic States, where there is a clear separation of powers, are those that will have more difficulties in providing reliable assurances that a certain penalty will not be applied or, if applied, enforced. This is because assurances are provided by the executive power, penalties are applied by the judicial power, and the former cannot bind the latter. ${ }^{562}$ A solution to this predicament is to call upon the third power to intervene: the legislator may enact a provision according to which, if the State obtains

558 Apud UNODC, "Manual on Mutual Legal Assistance and Extradition”, op. cit., p. 51.

559 Ibid.

560 As currently occurs in Portugal: see supra, Chap. 6, \ 1.4.2., and ulterior references.

561 If the penalty that is repudiated in the requested State cannot be applied in the requesting State, extradition can certainly not be refused in the name of a protection of the person concerned, because he/she will not be facing such a penalty.

562 Moreover, the executive branch of authoritarian regimes also tends to be less fluctuant. 
extradition of a person by providing assurances that it will not apply a given penalty, then the maximum penalty applicable in that case will automatically - ipso jure - be a different penalty; or the 'forbidden' penalty may still be applicable, but if it is applied it is automatically converted into a different one (e.g. from capital punishment into life-imprisonment, and/or from life-imprisonment into imprisonment for a set period). One such type of approach is followed for instance by India (from capital punishment into life-imprisonment only). ${ }^{563}$ The same may be provided for in extradition treaties.

But even regarding absolute human rights, such as the prohibition of ill-treatment, there is some room to contemplate extradition under certain assurances. A clear example, which is probably also the most relevant in practice, concerns prison conditions: it is quite possible that the penitentiary system of the requesting State has serious systemic deficiencies, but that a specific prison facility complies fully with human rights requirements. ${ }^{564}$

\section{c) Cont. - the risk of 'dual' criminal justice systems}

The main problem with 'assurances systems' - and, more generally, with limiting to the specific circumstances of each case the assessment to be made by the requested State of the prospective actions of the requesting State - manifests itself not in the context of international cooperation (assuming, of course, that the assurances are complied with), but within the legal system of the requesting State. The problem is that this may create dualisation, producing ordinal inequality between individuals who committed similar acts: e.g., where a person arrested and tried within a State would be sentenced to life-imprisonment and/or serve a sentence in sub-par prison conditions, a person who had fled after committing the crime and who had later been extradited could only be sentenced to 25 years of imprisonment and/or serve the sentence in a prison facility which fully complies with the human rights standards required by the requested State. ${ }^{565}$

563 See s. 34C Extradition Act 1962.

564 As noted supra, Chap. 1, \ 2.2., requests for preliminary rulings have been lodged to the ECJ seeking clarification of the scope and implications of the principle established in Aranyosi \& Căldăraru. In Generalstaatsanwaltschaft ('Aranyosi III) the Court set out a number of important ideas in this respect. As far as concerns the topic in debate here, it ruled that, in assessing whether prison conditions in the issuing Member State preclude the execution of a EAW, the executing Member State may take into account information provided by authorities other than its issuing judicial authority (although the latter must at least endorse such an information), such as, in particular, an assurance that the individual concerned will not be subjected to inhuman or degrading treatment: see ECJ, Generalstaatsanwaltschaft (C-220/18), cit., \$S $106 \mathrm{f}$.

565 To take again as a reference ECJ's Generalstaatsanwaltschaft, in deciding whether or not to extradite the requested State must assess "only the conditions of detention in the prisons in which, according to the information available to it, it is likely that that person will be detained", and, to that end, it must assess "solely the actual and precise conditions of detention of the person concerned that are relevant for determining whether that person will be exposed to a real risk of inhuman or degrading treatment": $\iint 117$ (emphases added); see also $\int S 77 \mathrm{f}$. Likewise, in Celmer, concerning fair trial rights, the ECJ ruled that the execution of a EAW may only be refused if a violation is likely to occur in the specific case of the person concerned: see supra, Chap. 2, \$ 3.2.1., and Chap. 3, \ 4.4.2. At once, this case law reinforces two important notions: on the one hand, that the co-responsibility of requested States for future human rights violations by requesting States does not include each and every possible such violation, but only those that were reasonably foreseeable (in that obviously only these can somehow be imputed to the requested State itself); on the other hand, that, even where there are systemic or generalised human rights violations in the requesting State, 
That such a differentiation exists is unquestionable. In fact, one of the arguments used at an early stage of this study in order to justify why extradition should as a principle be preferred to alternative mechanisms whereby the acts are prosecuted and/or sentenced in the requested State, rather than in the requesting State, was precisely that such mechanisms produce ordinal inequality. ${ }^{566}$ However, while an assurance system may surely carry double standards in the requesting State, the disparity between one group of cases and the other will necessarily be wider if extradition is altogether refused. All the while, by obtaining extradition the requesting State is enabled to enjoy all other advantages inherent to the prosecution of the case in its own forum.

On other hand, it is important to note that this inequality is not created by the requested State or by the requesting State. Neither of them is - to borrow again from the conceptual framework of substantive criminal law - a 'participant' (whether primary or secondary $)^{567}$ to that result. Such an inequality results from the sheer contingency that an offender escaped or committed a crime remotely. Faced with such a contingency, the requested State must uphold its criminal justice ethos, and the requesting State, if it wishes to uphold its substantive criminal law, may have to comply with certain conditions set by the former. Neither State, therefore, is behaving in a discriminatory manner. That is, such a dualisation produces inequality, but not discrimination.

In fact, it may even carry positive effects in the long term. The contingency of similar offenders receiving different penitentiary treatment may create pressure for an overall elevation of prison conditions. Likewise, the circumstance of a State that applies the death penalty having to be satisfied with enforcing a penalty of imprisonment with a set duration may create pressure to moderate the sentences applied for equivalent acts to offenders arrested in that State, as well as provide an opportunity for that community to witness successful cases of rehabilitation of individuals who would otherwise be dead.

\section{d) Aut dedere aut judicare}

One idea stated in different moments of this study was that even the perpetrators of the most heinous acts should have their fundamental rights protected. ${ }^{568}$ This section reinforces that view by noting that, as a rule, grounds for refusal based on human rights do not even entail impunity. The fact that a person risks being tortured or executed in the requesting State, or prejudiced at his/her trial due to his/her race, does not mean that this person has not committed a crime, and possibly a very serious one. Thus, the requested State, upon refusing extradition, may conduct a criminal procedure on behalf of the State

\footnotetext{
this must translate into the particular situation of the individual at issue. Both of which carry that the requesting State, albeit unable to accord satisfactory standards to most of its defendants or inmates, may obtain extradition of specific individuals if it is able to ensure that they will be placed under specific conditions which do attain those standards. This differentiates extradited individuals from individuals whose custody was possible to obtain without providing any particular guarantees to another State.

566 See supra, Chap. 1, \3.

567 On the concepts, see JoHAnNEs KeILER / DAvid RoEF, "Forms of Participation”, in Johannes Keiler / David Roef (eds.), op. cit., p. 212 f.

568 See e.g. supra, \2.1.3., and further supra, Chap. 7, \ 1.3
} 
that was denied extradition. ${ }^{569}$ This should constitute an additional argument for the protection of human rights in the field of extradition not to be subdued to security concerns. These are precisely the cases where security concerns should more easily yield.

In some cases, notably in the context of the humanitarian exception, it may be that refusing extraditing would not be absolutely indispensable. Here too is it useful to bear in mind that, as a rule, the requested State may carry out a prosecution, and, therefore, that the application of this ground for refusal need not be limited to absolutely extreme cases.

In only a few cases will vicarious criminal proceedings be proscribed on human or para-human rights grounds. As far as it is possible to see, this will only be the case where the persecution by the requesting State is exclusively motivated by discriminatory reasons or the person is mentally unfit to stand trial. However, in these cases one can hardly speak of 'impunity' anyway, because there is either nothing to punish or no point in punishing.

\subsubsection{Clarifying the intervention of the executive branch}

Earlier in this chapter it was argued that the intervention of the executive branch in extradition proceedings not only need not be seen as problematic for the development of international cooperation, but also it can contribute to loosening the regulation of certain grounds for refusal. ${ }^{570}$ Throughout this chapter, such a proposition was put into practice with respect to several grounds for refusal. ${ }^{571}$

Entrusting the assessment of certain issues to the executive branch is a proposition that can be implemented in two basic manners. One is simply not to set out in writing, in a legal norm, that a given situation constitutes a ground for refusing extradition. This will still allow the executive branch of the requested State to intercede, since this prerogative is based on a general notion of 'political convenience' which applies to an unspecified set of situations (even if many grounds for refusal do show possible to appraise, at the same time, from either a more normative or a more political dimension). ${ }^{572}$ The other approach, followed by some States, ${ }^{573}$ is to provide for certain grounds for refusal and explicitly establish that their application falls within the competence of the executive branch alone. Both approaches entail that, regarding the issues entrusted to executive discretion, there will not be unreasonably wide and meritless litigation, insofar as the exercise of that discretion cannot be appealed. However, the latter approach has the advantage of providing the executive with a reference for the exercise of its discretion. It flags the existence of certain issues that should be pondered when appraising whether extraditing is politically acceptable or, to the contrary, untenable. This would be the desirable approach for appraise, for instance, cardinal quantitative proportionality. ${ }^{574}$

569 This idea already surfaced in the context of the prohibitions to extradite imposed by EU law, where the ruling of the ECJ in Petrubhin, in addition to other, more direct implications, carried a noteworthy reinstatement of the importance of the principle aut dedere aut judicare: see supra, Chap. 6 \$, e.g. 2.4.2.c).

570 See supra, $₫ 2.1$.

571 See esp. $\iint$ 2.1.4., 3.2.1.d), 3.5.1.e), 4.1.2.g)(i), 4.2.1.d), and 4.2.2.c).

572 See supra, $\int 2.1$; and further supra, Chap. 1, \ 5.4.8.

573 Of which the UK, covered in Part III, constitutes an example: see supra, Chap. 5, $\int$ 2.3.1.

574 See supra, \3.2.1.d). 


\subsection{Enhancing the system}

\subsubsection{Increasing State accountability in extradition matters}

As in respect of other aspects of their international relations, States are generally not accountable before an impartial entity for their conduct in extradition matters. The issue of accountability has surfaced in some points of this study in a fragmentary way, namely in respect of the scrutiny to which the executive branch of the State is liable when intervening in these matters, ${ }^{575}$ reciprocity too was acknowledged to form a guarantor of compliance with international commitments, playing a ground-levelling function; ${ }^{.76}$ the creation of judicial entities charged with upholding human rights also signifies a momentous guarantee of State accountability in relation these fundamental guarantees. ${ }^{577}$

However, most aspects of extradition law concerning grounds for refusal which do not protect individual rights are never brought to light before an impartial instance competent for interpreting treaties and general international law. A firm signal of commitment to the development of international cooperation would be the inclusion in extradition treaties of a clause providing for the explicit acceptance of the jurisdiction of the ICJ on conflicts arising from such treaties (Art. 36 (1) Statute of the ICJ), and/or, for States that have subscribed or contemplate subscribing to the mandatory jurisdiction of that Court under Art. 36 (2) to (5) of its Statute, not to exclude from this commitment possible conflicts related to international cooperation in criminal matters. ${ }^{578}$

The author of this study is aware that this is to state the obvious, but this seemed a fitting place do so. He is also aware that this is quite far from current reality. This should therefore be understood more as a proposal de lege desiderata than as a proposal de lege feren$d a^{579}$

\subsubsection{Streamlining the intervention of the judicial branch}

Some grounds for refusal as currently in place are simpler to assess than they would be if the proposals presented in this chapter were adopted. This is notably the case with the replacement of dual criminality for the concept of qualitative relevance. Added complexity is a natural consequence of following a substantially more adequate approach to

575 See supra, \2.1.3.

576 See supra, Chap. 7, \ 3.1.3., and ulterior references.

577 See supra, Chap. 3 in general.

578 Increasing the intervention of supranational judicial entities in extradition matters has been supported by some authors, although usually in relation to specific aspects of extradition law, such as the determination of whether or not certain acts should be considered 'political', or the safeguard of individual rights (but even here the focus is often on political acts): see CHRISTINE VAN DEN WyngaERT, The Political Offence Exception... op. cit.., p. 215 f.; M. CHERIF BASSIOUNI, International Extradition... op. cit., p. 737; KAI I. REBANE, "Extradition and Individual Rights: The Need for an International Criminal Court to Safeguard Individual Rights", FILJ 19 (1995), p. 1636 f. The proposition of van den Wyngaert to involve in domestic extradition proceedings non-judicial international entities that promote human rights, so that they "supply governments with useful information about the legal system of the requesting state", proved nothing short of prescient, as this is precisely the course of action indicated e.g. by the ECJ in Aranyosi \& Căldăraru.

579 To draw on a distinction also used by Christine van DEN WyngaerT, The Political Offence Exception... op. cit.., p. 207. 
extradition law, since this approach requires more indeterminacy. Sufficiently specific criteria are thought to have been proposed in relation to those grounds for refusal: the issue as to how States' core criminal justice concepts can be identified has been addressed in detail; moreover, it was argued that such technical difficulties would exist essentially in an initial stage, until a body of case law began to develop. In any case, a further proposal is hereby made with a view to smoothing a possible reform of grounds for refusal of extradition - one which in fact could benefit extradition systems even as they currently are. The proposal is that the decision of extradition cases in the requested State be concentrated in one court. This is the approach followed in the Netherlands regarding the execution of EAW's, which are concentrated in the District Court of Amsterdam.

Competence for national criminal procedures, even in relatively small States, is usually distributed by different courts depending on the location where the acts were committed and other objective factors. The principle of territoriality is paramount not only at the international level, but also at the national level, and for the same (good) reasons: the place where the crime was committed is the one where it is felt more intensely, and the one that in principle is best placed to ascertain the truth of the facts. Such reasons do not apply to extradition proceedings, since these typically deal with acts which were not even committed in that State, and where the question is not whether a person is criminally liable, but whether assistance should be provided to another State for assessing such liability or for enforcing an already applied penalty. It may of course occur that the requested State also has jurisdiction over the acts for which extradition is being requested. However, the decision as to whether the person should be extradited or, instead, prosecuted is autonomous in relation to the criminal procedure in course or possibly to be initiated in the requested State. If the requested State is to prosecute the acts, then the procedure can run its course in the appropriate legal district within this State. Why not, then, streamline extradition decisions? ${ }^{580}$ A central court for extradition cases could contribute to rationalise the system. It could avoid duplication of efforts, enable specialisation of human resources, and foster jurisprudential consistency. ${ }^{581}$

Pragmatic reasons are often invoked to justify unconvincing theoretical approaches, and sometimes that is understandable. So, in the event that any of the proposals made in this chapter has theoretical value, this could be a possibility to consider before rejecting it outright based on pragmatic reasons.

580 The same may not apply to other forms of international cooperation, such as the delegation of criminal proceedings or the execution of foreign sentences, because these may presuppose the involvement of different local authorities (the court in which the procedure will be delegated, the prison facility where the person will serve the sentence) in carrying out the cooperation act. In any case, there would be no peremptory reason not to contemplate this possibility even in these cases.

581 In States that are very large and/or have significant legal and administrative idiosyncrasies (e.g. some federal States), it would probably be less practical and/or justified to have one central court for the whole country, but the cases can still be streamlined, if that is not already the case, within each administrative region (in the example, within each federated State). 


\section{Chapter 9 \\ Conclusions: \\ Reshaping the Extradition Triangle}

The emergence of what Habermas refers to as "functional systems of world society whose influence permeates national borders" has given rise to problems that States can no longer address singlehandedly. ${ }^{1}$ Crime prevention is an objective that cannot anymore be pursued on a national scale, in a hermetical manner. However, for understandable reasons, the paradigm of criminal justice remains basically unchanged: jurisdiction is still fundamentally State-centric and territorial, and criminal procedure ubiquitous. As a device that enables States to outstretch the limits of their sovereignties (sc. national territories), extradition therefore remains a primary tool at their disposal to respond to those phenomena.

The key factual conditions underpinning modern extradition law have changed drastically: distances have become easier to travel, and human conduct wider in reach; taking refuge abroad has become less intimidating, and social distress at the escape of criminals often more intense. Today's world is a smaller one, where States and their communities are in several ways closer to each other. However, extradition law continues to conceive them as isolated entities. It still displays many of the attributes that were conferred upon it at its inception at the turn of the $19^{\text {th }}$ century. Grounds for refusal, the central elements of extradition law, have not been subjected to a corresponding conceptual reform. This produced a substantial lag between the reality and the law. A mismatch currently exists between the scope and the rationale of numerous grounds for refusal, between the range of situations that receive protection and those that in effect require protection, the latter being significantly narrower. This is chiefly the case of the treaty requirement, dual criminality, the political and military offence exceptions, time-bars and other instances of extinction of criminal liability other than ne bis in idem, and the nationality exception. Some traditional grounds for refusal moreover failed to adjust to the emergence of 'second generation' grounds for refusal brought by the advent of individual and human rights in international law. Thus far, the opportunity has been missed to draw what Lagodny designates as the "positive" impact of human rights towards the increase of international cooperation: ${ }^{2}$ the supervening appearance of grounds for refusal based on human rights, which express a consensus of the international community as to the values whose protection is indispensable in the context of extradition, implies that certain pre-existing grounds for refusal can be reformed; however, such a reform remains largely to be effected, as is again evidenced by the political and military offence exceptions, ${ }^{3}$ as well as by the nationality ex-

\footnotetext{
${ }^{1}$ JÜrgen Habermas, op. cit., p. xi, 55 f.; and supra, Chap. 7.

2 See Otto Lagodny, "Human Rights in the Field of Extradition", op. cit., p. 50 f., and supra, Chap. 2.

3 As noted very early by CHRISTINE VAN DEN WYNGAERT, The Political Offence Exception... op. cit.., p. 207 f.
} 
ception. Image 1, below, recollects the aspect of the mismatch that currently exists between the scope and the rationale of several grounds for refusal.

Image 1

Discrepant Ground for Refusal

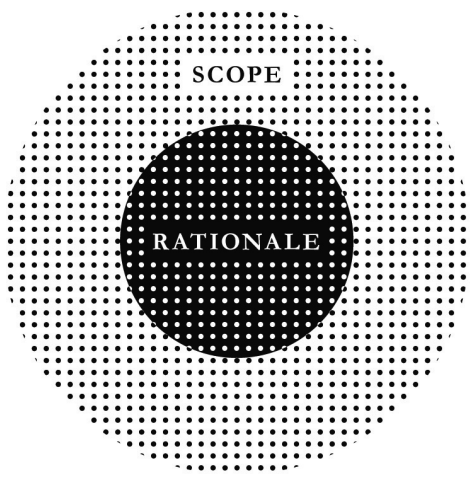

Drawing on this diagnosis, this study posits a set of normative propositions intended to bridge the perceived gap between the reality and the law. Since the factual developments mentioned above occurred at a pace which was not, and arguably cannot be fully accompanied by national (social, cultural, political) structures, adjusting to those developments requires assigning even greater preponderance to territorial and protective jurisdiction (and, thus, to the requesting State) than that which it already, justifiably, receives. Indeed, paradoxical as it may seem, globalisation calls for more territoriality, because it is still States that have the competence to tackle most criminality, even transnational one.

Nevertheless, this study is grounded on the premise that international cooperation cannot be sustainably enhanced in detriment of national 'cultural biotopes'. In literary, political and social discourse, globalisation is often evoked in its static significance (i.e. as a consummated process) and functionalised as a justification for normative commands: individuals are now able to do ' $x$ ' due to globalisation; States must therefore now do ' $y$ ' in response to globalisation. Globalisation, however, is a dynamic, ongoing process; and while few doubts exist that in many regards it did become irreversible, several aspects of social and political reality continue to display attributes and to abide by concepts of an older paradigm, making it more adequate to refer to a 'globalising' than to a 'globalised' world. ${ }^{4}$ As an evolving process, globalisation can to a degree be rationally steered in certain directions rather than others. In particular, it does not inevitably carry the annihilation of local idiosyncrasies. Accordingly, and in line with the view of Beccaria that between impunity and asylum there often is but a "difference of degree", 5 this study seeks to overcome the selfcenteredness that characterises the paradigm of cooperation forged at the end of the $18^{\text {th }}$ century without engaging in the notion that the globalisation processes which took place later require States to relinquish their legal traditions altogether.

\footnotetext{
${ }^{4}$ See Robert O. Keohane, p. 14 f.; and David Held et al., Global Transformations: Politics, Economics and Culture, Stanford: University Press, 1999, p. 16.

${ }^{5}$ Cesare BeCCARIA, op. cit., p. 67, and supra, Chap. 7 in general, abridged at its $\int 4$.
} 
By relying on a markedly formalistic approach to international cooperation, grounds for refusal of extradition currently protect States' essential and unessential values alike. By equating the secondary values that integrate a criminal justice system and its core values or ethos, extradition law weakens the latter at the expense of the former, making them converge onto an intermediate degree of importance. Paradigmatic examples of this are again dual criminality and the time-bars exception, based on which requested States project upon requesting States their own substantive criminal laws as a whole, hindering cooperation even in cases where there are only tenuous differences in perspective as to the criminal relevance of the acts, or indeed merely formal or technical variations in their regulation at national level. This fails to reflect the sense of justice of the community of the requested State, and is hardly understandable in the eyes of the community of the requesting State. Based on the principle attributed to Montesquieu that 'useless laws weaken necessary laws', 6 this study seeks to bring extradition norms into congruence with their spirit. To that end, it proposes to extricate from the scope of grounds for refusal the situations which affect merely secondary values of the requested State, narrowing the scope of such grounds for refusal down to the limit set by its core values. This approach is particularly visible in the proposed reform of the concept of extraditable acts: this study advocates the replacement of the dual criminality rule for a concept of 'qualitative relevance' according to which States could extradite for acts which they do not criminalise, so long as the criminalisation of such acts would be consistent with their essential criminal justice values. ${ }^{7}$ This approach not only allows to preserve the identity of the requested State, but in a way even reiterates it, evincing the paramount character of the latter set of values. At the same time, it expresses deference towards the criminal justice necessities and concepts of other States and their communities, a process which, to borrow Rawls' words, may carry States to "esteem" each other more and to strengthen their affinity.

Consequently, instead of pinpointing that certain grounds for refusal of extradition should be removed and others maintained, this study envisages a transversal optimisation of grounds for refusal. ${ }^{9}$ The method through which this optimisation is pursued is largely inspired in the functioning of private international law, as reformed following the groundbreaking contribution of Savigny. ${ }^{10}$ Traditionally, the scope of application of a given private law norm was determined by reference to its object. In the event of a conflict, the norm that would apply would be the one that carried certain effects deemed preferable in the light of given substantive criteria (e.g. the one that showed more favourable to the individual concerned). This state of affairs changed profoundly in the $19^{\text {th }}$ century. Savigny reasoned that such an approach was both partial and unclear, and developed an alternative theory which relied on a straightforward separation between the content of a norm and its sphere of application. Applicability would no longer be deduced from the content of the norm, but rather from the legal relationship at issue, such that, in the event of a conflict,

\footnotetext{
${ }^{6}$ See Montesquieu, op. cit., p. 606 f., p. 617, and supra, Chap. 7, $\int$ 3.2.3.

7 See supra, Chap. 8, \ 4.1.1.

${ }^{8}$ JOHN RAwLS, op. cit., p. 112 f., and supra, also Chap. 7, \$ 3.2.3.

${ }^{9}$ See supra, Chap. 7, $\int$ 3.2.4., implemented throughout Chap. 8.

${ }^{10}$ See Friedrich Carl von SAvigny, op. cit. p. 6, 15, 370, et passim, and supra, Chap. 7, \$ 3.1.1. f.
} 
the norm that would apply would in line of principle be the one emanating from the legal system to which the situation was more strongly connected. Private international law thus became 'neutral'. Aware of the meaningful differences that exist between private law and criminal law, between private international law and transnational criminal law, this study posits that, at present, the question as to whether or not extradition should be granted which from that neutral perspective should by default be answered in the affirmative (insofar as the legal system of the requesting State is the one with which the crime is more strongly connected) - is dependent on grounds for refusal that are infused with substantive considerations springing from the legal system of the requested State. As if this legal system had any links to the case other than the contingency that after the perpetration of the crime its author entered its territory. That is, under current extradition law, requested States 'internalise' acts with which they have no contact whatsoever. Assigning unambiguous preponderance to the requesting State is to bestow on extradition law the neutrality it is currently lacking.

Nevertheless, considering the repressive nature of extradition, the primacy which from that jurisdictional standpoint is owed to the requesting State does not translate into an absolute entitlement on its part to obtain extradition. By granting extradition, a State not only assists in the possible application of an extreme legal consequence to an individual (a penalty), but also it immediately subjects this individual to a repressive measure (a period of deprivation of liberty coupled with a coercive transfer to another jurisdiction). This inevitably confers some relevance on its own notions of justice, triggering what Bassiouni refers to as specific "law and public policy considerations". ${ }^{11}$ As noted by Swart and other authors before him, ${ }^{12}$ such considerations have similarities with a concept which also has its roots in private international law: ordre public. This concept comes into play subsequently to the neutral determination of the applicable law: as mentioned, in line of principle, a foreign law should apply if its legal system is the one that has the strongest ties to the case; however, such an application will be limited or excluded if, although only if, it is likely to carry effects that would be unbearable to that legal system. That is, ordre public is a 'shock-absorbing device' which allows for avoiding the abnormal effects that could result from a purely neutral system of determination of the applicable law. By definition, it is also an exclusive concept, in that it encompasses but a select cluster of values and purports to avoid but a particular type of results. It does not block the application of foreign norms whenever they may carry results that are different from those that would follow from national norms, but only results that are intolerable to the social consciousness of the community at issue. Regarding criminal justice, the select group of values that form the ethos of a community is to be found in its supra-ordinary law - notably in its constitution -, which is their natural seat. Constitutional and 'para-constitutional' law thus constitute the source of the criteria that enable the distinction between the essential and the unessential criminal justice values of a State, and, consequently, the optimisation of grounds for refusal of extradition.

11 M. Cherif Bassiouni, International Extradition... op. cit., p. 55, and supra, Chap. 7, \3.2.

12 See BERT SWART, "Human Rights...”, op. cit., p. 250 f., and supra, also Chap. 7, \ 3.2. 
In the past extradition proceedings were bilateral, and as such they could be graphically represented through a straight line linking the requesting State to the requested State. With the advent of fundamental and human rights, individuals targeted by extradition requests were given a legal standing, rendering those proceedings triangular, which is the shape that they still display today. ${ }^{13}$ This can be illustrated through the following image, also already presented at an earlier moment of this study.

Image 2

Extradition Currently

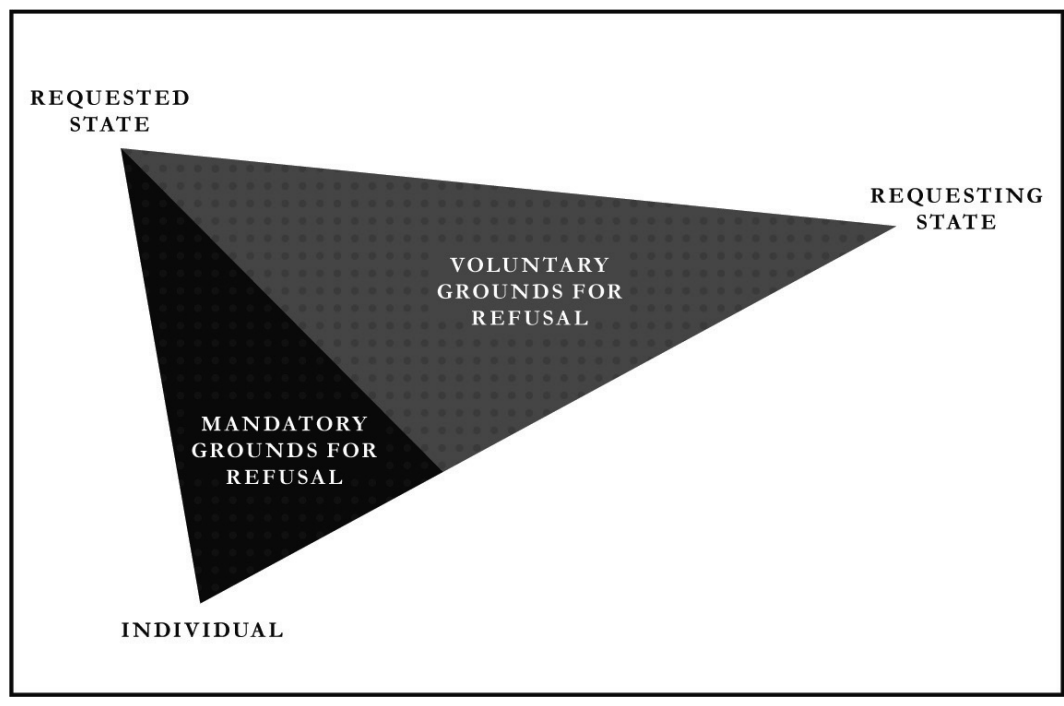

Individuals occupy the lower vertex of this triangle, because they are to a large extent a mere appendix to the original straight line. Indeed, in their basic structure those proceedings remained unchanged: apart from the (important, but) few exogenous constraints imposed by international law (human rights, international immunities) and by norms emanating from regional organisations with legislative competences (e.g. the EU), ${ }^{14}$ it is still States, as holders of authority over acts committed in their territories, that decide whether or not, and if so to what extent, they will persecute a person; and it is still States, as holders of (a different type of) authority over persons located in their territories, that decide whether or not, and if so under what conditions, they will contribute to such a persecution.

In the field of extradition, the duty of non-interference guiding international relations operates almost exclusively in its classic negative dimension (i.e. as a prohibition on States to unilaterally seize individuals located in the territory of other States). Although an alternative view was already implicit in the writings of such authors as Grotius, ${ }^{15}$ non-interference is still not deemed to encompass a positive duty for States to extradite individuals to other States even where this is necessary for these to assert their territorial sovereignty. This

\footnotetext{
13 See Albin EsER, “Basic Issues...”, op. cit., p. 6, 14 f., and supra, Chap. 3, \ 1.2., and Chap. 7, \ 3.3.

14 See supra, Chap. 2, \2.2., and Part II in general.

15 See Hugo Grotius, De Jure Belli ac Pacis... op. cit., p. 368, and supra, Chap. 7, \ 3.1.2.
} 
causes an imbalance between the requested and the requesting States whereby the former has clear primacy. Their bilateral relationship is therefore not horizontal, but diagonal, the upper standing being held by the requested State. The subjects involved in extradition proceedings thus form a triangle in which the requested State is higher up than the requesting State, and the individual farther away from the requesting State than from the requested State, as his/her possible extradition is an event which depends largely on the interests of the requested State and which lies fundamentally within its power. This is also why the two inner triangles into which the extradition triangle is divided ( $s c$. the one representing grounds for refusal imposed upon States, and the one representing grounds for refusal voluntarily enacted by States) have the requested State as their common vertex in the outer triangle: it is this State that applies both sets of grounds for refusal, even though one of them is exogenous in its source and binding in its character.

The model defended in this study sheds new light on the current extradition triangle, as illustrated in image 3 below. To recollect, the theoretical framework posited in this study contains the following propositions: (i) the requesting State shall as a matter of principle be assisted in tackling its domestic criminality, in the name of the principle of territoriality, and of the principle of non-interference (which in this instance carries a positive duty for the requested State); (ii) the requested State shall as a matter of principle provide such an assistance, in the name of those same principles, and with the additional incentive of securing reciprocity; (iii) the foregoing propositions shall, but shall only be departed from where that is imposed upon the requested State or where this State would otherwise sacrifice other fundamental individual guarantees or jeopardise its core values; (iv) individuals targeted by extradition requests shall be acknowledged to face adverse conditions, but (v) this shall not prevent the recognition that they currently benefit from a broad array of guarantees that do not protect any relevant individual rights, but which instead are simply incidental to the protection of ethnocentric interests of the requested State.

Image 3

Theoretical Framework

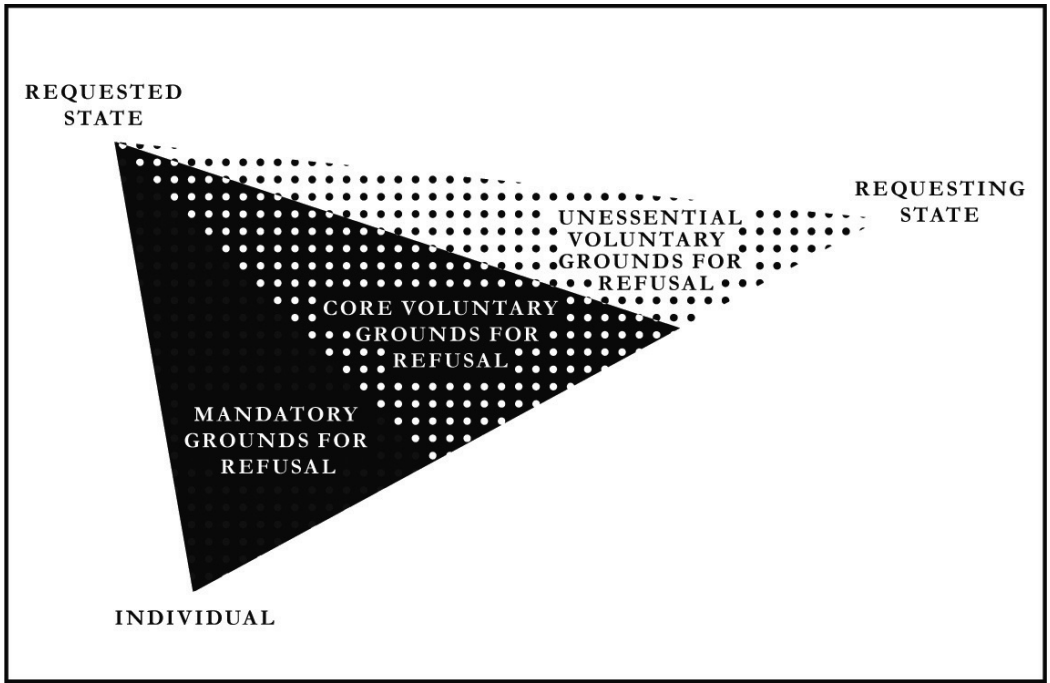


The area of the current extradition triangle formed of unessential values of the requested State does not seek to convey an exact measure: it corresponds to $1 / 3$ of the overall area of the extradition triangle, and to $1 / 2$ of the area of the inner triangle corresponding to voluntary grounds for refusal, because $1 / 2$ is the fraction that was used when illustrating through concentric and overlapping circles the optimisation to which several voluntary grounds for refusal could be subjected. The triangle of unessential voluntary grounds for refusal is, therefore, the macro-analytical equivalent of the mismatch verified at the microanalytical level between the scope and the rationale of several grounds for refusal.

This study relies on an as much as possible objective diagnosis of the state of affairs in international cooperation, and the reform proposed is a direct result of that approach. It does not pursue externally defined criminal policy goals, even though it does show consistent with a widely endorsed view according to which enhancing cooperation is a goal worth pursuing, and even though it was this very view that prompted this study. Evidence of this objectivity is that the study does not limit itself to proposing the compression of grounds for refusal, but also upholds the preservation and occasionally even the expansion of some of them - which runs counter to that criminal policy agenda. This is namely the case of quantitative relevance thresholds, ne bis in idem, absence of valid jurisdiction by the requesting State, the rehabilitation exception, existence of jurisdiction by the requested State, and evidentiary requirements; special mention is due to the specialty rule (and to an extent also to the limitations on re-extradition), which constitutes a true precondition of extradition - i.e. a rule without which this very institution would be immaterial. The study moreover proposes the enactment of one ground for refusal that does not currently exist, namely 'severe disproportionality between the acts and the penalty applicable in the requesting State', as in certain cases it is necessary to protect core values of the requested State.

In any case, even these grounds for refusal can in some aspects be optimised, as they also feature attributes of the conceptually outdated regulatory paradigm within which they were developed. On the other hand, they generally do not constitute peremptory denials of cooperation. Rather, they form conditions which can at any time be fulfilled by the requesting State ${ }^{16}$ and/or elementary guarantees against disproportionality in the restriction of fundamental individual rights. ${ }^{17}$ In the case where the requested State has jurisdiction over the acts, the question is not even a divergence between this State and the requesting State as to whether the acts should be prosecuted, but an intention of the former to exert prosecution instead of assisting the latter to do so. ${ }^{18}$ Thus, the voluntary grounds for refusal which according to this study should remain in force or even be expanded do not in fact qualify as exceptions to the principle according to which States should increase cooperation towards preventing impunity, but much more as embodiments of principles according to which certain cases do not raise major impunity concerns.

${ }^{16}$ As is visibly the case with the gathering of evidence necessary to meet evidentiary requirements, and with the guarantee of return of the person for enforcement, required by the rehabilitation exception.

${ }^{17}$ As is the case with relevance thresholds, ne bis in idem, specialty, re-extradition, disproportionality between the acts and the penalty, absence of valid jurisdiction by the requesting State, and again evidentiary requirements and the rehabilitation exception.

18 See supra, e.g. Chap. $1, \int 5.2$. 
As for the grounds for refusal that protect merely secondary interests of the requested State, and that do thereby open unwarranted spaces for impunity, virtually all are subjected to optimisation efforts. This is why, in an overall assessment, the model proposed probably entails wider room for cooperation than that which presently exists. The old extradition triangle gives way to a smaller one which comprises only: on the one hand, and insofar as regards voluntary grounds for refusal, essential values of the requested State and relevant individual guarantees; on the other hand, grounds for refusal rooted in superseding rules of international law, notably human rights, whose supreme significance justifies the inviolable character they are assigned in this study, and which, as such, maintain the exact same area (in itself already inflated due to the intentionally expansive approach followed in this regard) ${ }^{19}$ in the new extradition triangle.

In the 'new' extradition triangle - represented in image 4, below - the individual is still represented as the lower vertex, and closer to the requested State than to the requesting State. This is because he/she will still be profiting from certain grounds for refusal whose function is to protect interests of the requested State (although these are now reduced to their core), as well as because the requested State is still the subject that will be deciding whether or not any grounds for refusal (including those that are mandatory) are met in any given case. However, the individual is represented much closer to the requesting State than what happened in the old triangle, because he/she is now protected by fewer grounds for refusal set in place in view of the interests of the requested State.

\section{Image 4}

\section{Extradition Reformed}

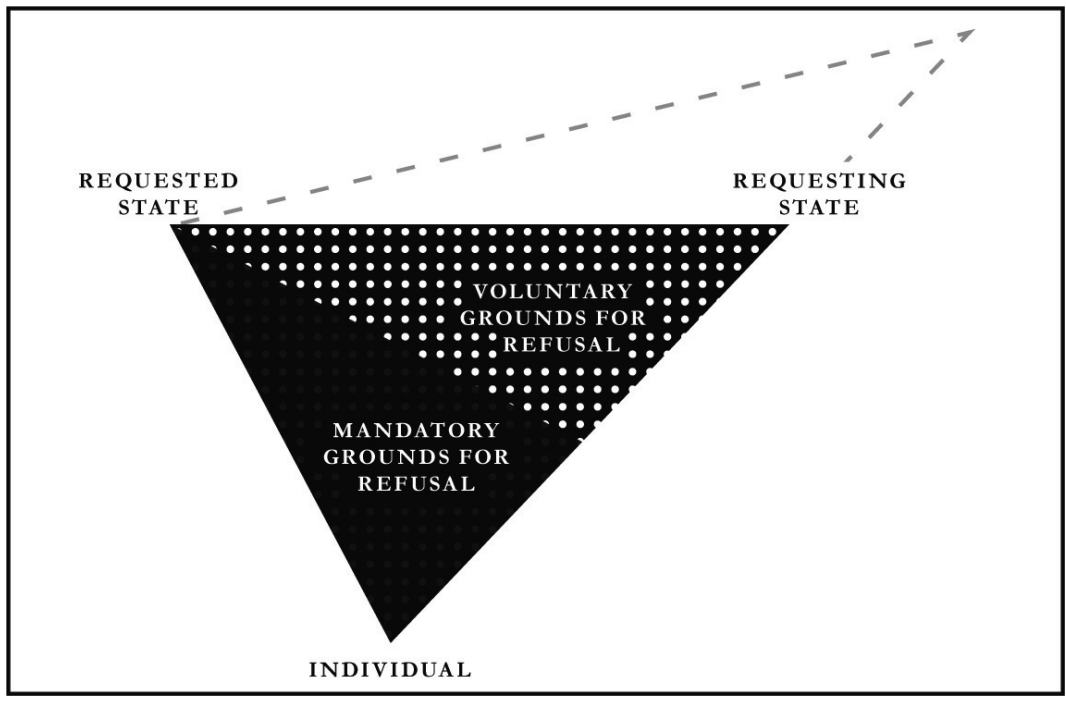

It should be emphasised that the increase in cooperation illustrated by this new extradition triangle is not necessarily concrete or tangible. It is even possible that, at least in the short term, the propositions made in this study would result in quantitatively narrower

${ }^{19}$ See supra, Chap. 3. 
room for extradition, considering the added weight attributed to human rights and other fundamental individual guarantees, notably proportionality requirements. However, then again, many such guarantees do not constitute static impediments to cooperation, but can instead be satisfied by the requesting State, either in the concrete case (e.g. by producing a minimum amount of evidence denoting that there is indeed a situation of impunity worth tackling), or through the longer-termed improvement of its human rights standards (e.g. of prison conditions). Others do constitute static impediments (e.g. quantitative thresholds), but concern trivial cases, which raise minor impunity concerns and for which extradition is already only seldom sought. ${ }^{20}$ This contrasts with the grounds for refusal that this study seeks to reform, which do prevent cooperation in potentially serious cases and to which the requesting State cannot in any way adjust. Thus, even at a practical or numerical level the model proposed does have the potential to increase cooperation.

But the increase in cooperation envisioned here is fundamentally qualitative. Not only because, as noted, it covers cases that raise intense impunity concerns, but also, and especially, because it is symbolic of further solidarity in interstate relations in the field of criminal justice. By stripping extradition law of the elements which express superfluous values of the requested State, the old extradition triangle, in addition to becoming narrower in its area, also rotates in such a manner that, in the new extradition triangle, the requested State and the requesting State bear equal standing. The perfectly horizontal position in which they are now placed is the result of the increased primacy assigned to the principle of territoriality that governs criminal law, and of the positive dimension assigned to the principle of non-interference that governs international law. The requested State will now only refuse to assist the requesting State if that is crucial for safeguarding international law (notably human rights), relevant individual guarantees, or core elements of its own legal identity. Up to these limits, it will recognise the necessities and respect the differences of the requesting State. ${ }^{21}$

\footnotetext{
20 See supra, Chap. 8, \3.2.1.b).

${ }^{21}$ See the Annex immediately below, for a graphic illustration - at the micro-analytical level (A) and at the macro-analytical level (B) - of the reform defended in this study.
} 


\title{
ANNEX
}

\section{Graphic Illustration of the Reform Defended}

\author{
A - Micro-Analytical Level \\ 1 - Ground for Refusal Currently
}

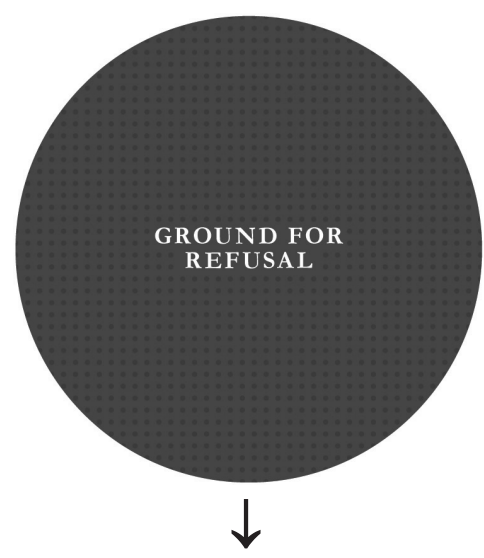

2 - Theoretical Framework

SCOPE

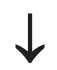

3 - Ground for Refusal Reformed 
B - Macro-Analytical Level

1 - Extradition Currently

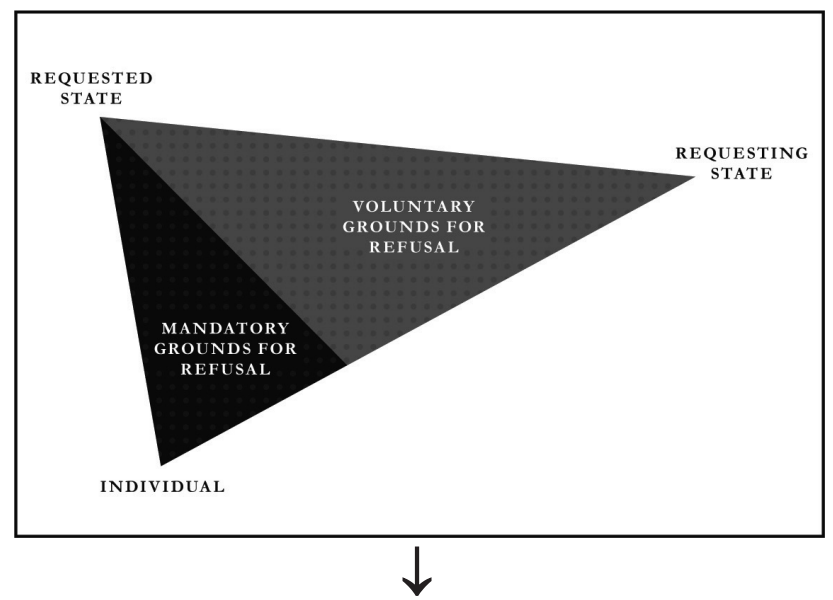

2-Theoretical Framework

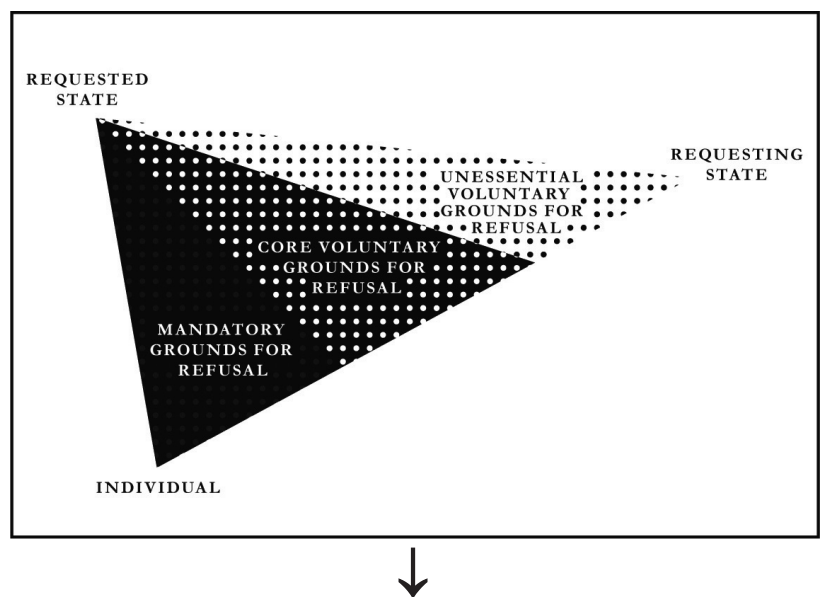

3 - Extradition Reformed

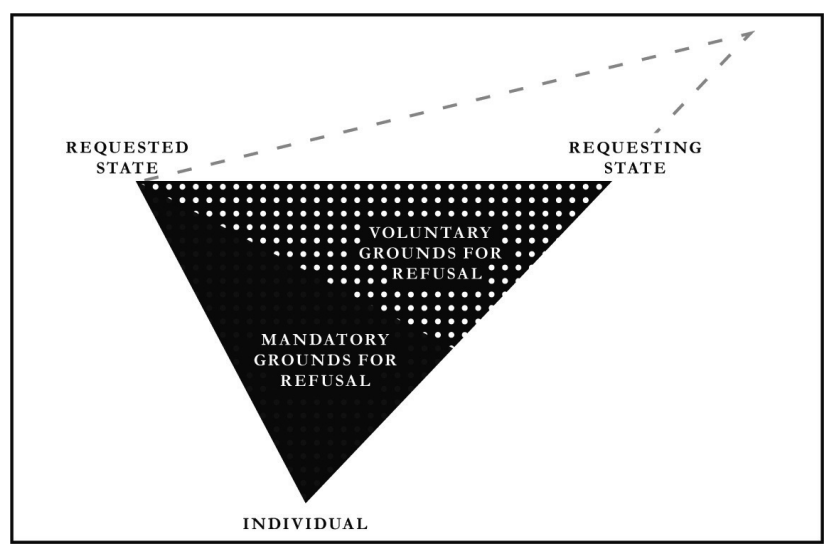




\section{REFERENCES}




\section{I - Bibliography}

- AAs, Katja Franko, “Analysing a world in motion: Global flows meet 'criminology of the other' ", TC 11 (2007) [Chap. 7]

- AAS, Katja Franko, “'Crimmigrant' bodies and bona fide travelers: Surveillance, citizenship and global governance”, TC 15 (2011) [Chap. 10]

- AAs, Katja Franko, “ 'The Earth is one but the world is not': Criminological theory and its geopolitical divisions", TC 16 (2012) [Chap. 7]

- ABBELL, Michael, “Controlling the Abusive Use of Provisional Arrest”, RIDP 62 (1991) [Chap. 8]

- ABbell, Michael, International Prisoner Transfer 2010, Leiden: Brill, 2010 [Chap. 8]

- AkAnde, Dapo, "Ecuador Seeks to Confer Diplomatic Status on Julian Assange: Does this Oblige the UK to Allow Him to Leave the Embassy \& Is the Matter Headed to the ICJ?", EJIL: Talk!, 25 January 2018, in www.ejiltalk.org [Chap. 8]

- AKANDE, Dapo / SHAH, Sangeeta, "Immunities of State Officials, International Crimes, and Foreign Domestic Courts”, EJIL 21 (2011) [Chap. 2]

- ALDEIA, João, “An iron curtain around the continent - Produção e exclusão do 'outro' na 'Fortaleza Europa”, D\&D (12) 2013 [Chap. 4]

- AlmeidA, Carlota Pizarro de, “A Cooperação Judiciária Internacional”, in Maria Fernanda Palma (coord.), Jornadas de Direito Processual Penal e Direitos Fundamentais, Coimbra: Almedina, 2004 [Chap. 6]

- Amвоs, Kai, “The International Criminal Court and the traditional principles of international cooperation in criminal matters", FYIL 9 (1998) [Chap. 7]

- Ambos, Kai, “Remarks on the General Part of International Criminal Law”, JICJ 4 (2006) [Chap. 1]

- AмBos, Kai, "The Overall Function of International Criminal Law: Striking the Right Balance Between the Rechtsgut and the Harm Principles - A Second Contribution Towards a Consistent Theory of ICL", CL\&F 9 (2015) [Chap. 8]

- ANDERson, Benedict, Imagined Communities: Reflections on the Origin and Spread of Nationalism, $3^{\text {rd }}$ ed., London: Verso, 2006 [Chap. 8]

- ANDRADE, Manuel da Costa, “Consenso e oportunidade (reflexões a propósito da suspensão provisória do processo e do processo sumaríssimo)", in CEJ (ed), Jornadas de Direito Processual Penal: O Novo Código de Processo Penal, Coimbra: Almedina, 1988 [Chap. 7]

- Andrade, Manuel da Costa, Sobre as Proibições de Prova em Processo Penal, Coimbra: Coimbra Editora, 1991 [Chap. 8]

- ANDRADE, Manuel da Costa, Liberdade de Imprensa e Inviolabilidade Pessoal: Uma perspectiva juridico-criminal, Coimbra: Coimbra Editora, 1996 [Chap. 8]

- ANDREAS, Peter, "Introduction: The wall after the wall", in Timothy Snyder / Peter Andreas (orgs.), The wall around the West: State borders and immigration controls in Northern America and Europe, Lanham: Rowman \& Littlefield, 2000 [Chap. 4]

- Antunes, Maria João, Consequências Jurídicas do Crime, Coimbra: Coimbra Editora, 2013 [Chap. 7, 8]

- ANTUNES, Maria João, “A problemática penal e o Tribunal Constitucional”, in Estudos em homenagem ao Professor Doutor José Joaquim Gomes Canotilho. Vol. I: Responsabilidade entre passado e futuro, BFDUC: Stvdia Ivridica 102 (2013) [Chap. 8]

- Antunes, Maria João, Direito Processual Penal, Coimbra: Almedina, 2017 [Chap. 1, 8]

- AREndT, Hannah, The Origins of Totalitarianism, New York: Meridian Books, 1962 [Chap. 4] 
- ARNELL, Paul, “The European Human Rights Influence upon UK Extradition - Myth Debunked”, EJCCLECJ 21 (2013) [Chap. 1, 3]

- ARNELL, Paul, “The forum bar to extradition”, SLT 24 (2013) [Chap. 6]

- ARnell, Paul , "Extradition and the right to a fair trial - Case Comment", SLT 36 (2013) [Chap. 6]

- Ashworth, Andrew, Sentencing and Criminal Justice, $4^{\text {th }}$ ed., Cambridge: University Press, 2005 [Chap. 8, 9]

- Asp, Petter, The Substantive Criminal Law Competence of the EU, Stockholm: Juridiska Fakulteten vid Stockholms Universitet, 2012 [Chap. 8]

- Asp, Petter / von HirSCH, Andrew / FräNDE, Dan, "Double Criminality and Transnational Investigative Measures in EU Criminal Proceedings: Some Issues of Principle”, ZIS 11 (2006) [Chap. 7, 8]

- Asp, Petter / Bitzilekis, Nikolaos / Bogdan, Sergiu / Elholm, Thomas / Foffani, Luigi / Frände, Dan / Fuchs, Helmut / Helenius, Dan / Kaiafa-Gbandi, Maria / Leblois-Happe, Jocelyne / Nieto-Martín, Adán / Satzger, Helmut / Suominen, Annika / Symeonidou-Kastanidou, Elisavet / Zerbes, Ingeborg / Zimmermann, Frank (European Criminal Policy Initiative), A Manifesto on European Criminal Procedure Law, ZIS 8 (2013) [Chap. 8]

- BAKER, Estella, "What Price Criminal Justice in the EU?”, EJCCL\& $\&$ CJ 24 (2016), p. 95 f. [Chap. 1]

- BAKer, Scott / Perry, David / Doobay, Anand, “A Review of the United Kingdom's Extradition Arrangements (Following Written Ministerial Statement by the Secretary of State for the Home Department of 8 September 2010) - Presented to the Home Secretary on 30 September 2011", HO_01859_G [Chap. 1, 5, 6, 8]

- BARAK, Aharon, Proportionality: Constitutional Rights and their Limitations, Cambridge: University Press, 2012 [Chap. 8]

- BARENTS, René (Helen E. Breese, ed.), Remedies and Procedures before the EU Courts, Alphen aan de Rijn: Wolters Kluwer, 2016 [Chap. 4]

- Bassiouni, M. Cherif / Wise, Edward M., Aut Dedere Aut Judicare: The Duty to Extradite or Prosecute in International Law, Dordrecht: Kluwer Academic Publishers, 1995 [Chap. 1, 8]

- BAssiouni, M. Cherif, International Extradition and World Public Order, Leiden: Stijhoff, 1974 [Chap. 7 ]

- BAssiouni, M. Cherif, “The Penal Characteristics of Conventional International Criminal Law”, CWRJIL 15 (1983) [Chap. 1]

- BAssiouni, M. Cherif, "International Crimes: jus cogens and obligatio erga omnes", L\& CP 59 (1996) [Chap. 1]

- BAssiouni, M. Cherif, "Reflections on International Extradition”, in Kurt Schmoller (ed.), Festschrift für Otto Trifferer zum 65. Geburtstag, Vienna: Springer, 1998 [Chap. 7]

- Bassiouni, M. Cherif, "Reforming International Extradition: Lessons of the Past for a Radical New Approach", LLAICLR 25 (2003) [Chap. 8]

- Bassiouni, M. Cherif, "Law and Practice of the United States", in M. Cherif Bassiouni (ed.), International Criminal Law, Vol. II: Multilateral and Bilateral Enforcement Mechanisms, 3'd ed., Leiden: Brill, 2008 [Chap. 5, 6]

- Bassiouni, M. Cherif, "United States Policies and Practices on the Execution of Foreign Sentences", in M. Cherif Bassiouni (ed.), International Criminal Law, Vol. II: Multilateral and Bilateral Enforcement Mechanisms, 3 ${ }^{\text {rd }}$ ed., Leiden: Brill, 2008 [Chap. 8]

- BAssiouni, M. Cherif, “The 'Indirect Enforcement System': Modalities of International Cooperation in Penal Matters", in M. Cherif Bassiouni, Introduction to International Criminal Law, $2^{\text {nd }}$ Revised Edition, Brill | Martinus Nijhoff Publishers, 2013 [Chap. 1]

- Bassiouni, M. Cherif, International Extradition: United States Law and Practice, $6^{\text {th }}$ ed., Oxford: University Press, 2014 [Chap. 1, 3, 6, 7, 8, 9]

- Bassiouni, M. Cherif, “Two Hypothetical Prospective Extradition Cause Célebre: the Snowden and Knox cases", in Pia Acconci (ed.), International law and the protection of humanity: Essays in honor of Flavia Lattanri, Leiden: Brill, 2017 [Chap. 8] 
- BÁTORA, Jozef / HyneK, Nik, Fringe Players and the Diplomatic Order: The 'New' Heteronomy, Basingstoke: Palgrave Macmillan, 2014 [Chap. 2]

- Bauman, Zygmunt, Postmodernity and its Discontents, Cambridge: Polity Press, 1997 [Chap. 4]

- BAUman, Zygmunt, "Social Issues of Law and Order", BJC 40 (2000) [Chap. 7]

- Bauman, Zygmunt, Europe (An Unfinished Adventure), Cambridge: Polity Press, 2004 [Chap. 1, 4]

- BECCARIA, Cesare, Crimes and Punishments (trans. James Anson Farrer), London: Chatto \& Windus, 1880 [Chap. 1, 7, 8, 9]

- BeCCARIA, Cesare, On Crimes and Punishments (trans. David Young), Indiana: Hackett, 1986 [Chap. 8]

- BeCKetT, Katherine / Herbert, Steve, "Penal Boundaries: Banishment and the Expansion of Punishment”, LesI 35 (2010) [Chap. 7]

- BeDEll, Zoe, "European Court of Human Rights Takes on Extraditions to the U.S.: Trabelsi v. Belgium”, Lawfare, 5 December 2014, in www.lawfareblog.com [Chap. 3]

- Bederman, David J., International Law in Antiquity, Cambridge: University Press, 2001 [Chap. 3]

- BeDERMAn, David J., The Spirit of International Law, London: The University of Georgia Press, 2002 [Chap. 2]

- Bederman, David J., "International law in the ancient world", in David Armstrong (ed.), Routledge Handbook of International Law, London: Routledge, 2009 [Chap. 3]

- Bell, Christine, On the Law of Peace: Peace Agreements and the Lex Pacificatoria, Oxford: University Press, 2008 [Chap. 3]

- Beltrán de Felipe, Miguel / Nieto Martín, Adán, "Post 9/11 Trends in International Judicial Cooperation - Human Rights as a Constraint on Extradition in Death Penalty Cases”, JICJ 10 (2012) [Chap. 6]

- Bentley, David J., "Procedural Safeguards and Evidentiary Requirements: The Common Law Approach", RIDP 62 (1991) [Chap. 8]

- Bernard, Paul, Traité Théorique et Pratique de l'Extradition. Vol. II, Paris: Arthur Rosseau, Éditeur, 1883 [Chap. 1, 8]

- BERNITZ, Ulf, "The Scope of the Charter and its Impact on the Application of the ECHR The Akerberg Fransson Case on Ne Bis in Idem in Perspective", in Sybe de Vries / Ulf Bernitz / Stephen Weatherill, The EU Charter of Fundamental Rights as a Binding Instrument: Five Years Old and Growing, Oxford: Hart, 2015 [Chap. 4]

- Bhutyan, Jahid Hossain, "Protection of Refugees through the Principle of Non-Refoulement", in Jahid Hossain Bhuiyan / M. Rafiqul Islam (eds.), An Introduction to International Refugee Law, Leiden: Brill | Nijhoff. 2013 [Chap. 3]

- BiLling, Fenella, "The Parallel Between Non-removal of Asylum Seekers and Non-execution of a EAW on Human Rights Grounds: The CJEU Case of N.S. v. Secretary of State for the Home Department', EC$\operatorname{rimLR} 2$ (2012) [Chap. 2]

- BILlot, Albert, Traité de l'Extradition: suivi d'un recueil de documents étrangers et des conventions d'extradition conclues par la France et actuellement en vigueur, Paris: E. Plon et Cie 1874 [Chap. 1, 8]

- BiLtGen, François, “Citizenship of the Union and Purely Internal Situations - Discrimination of One’s Own Citizens?”, NJECL 7 (2016) [Chap. 4]

- BJORGE, Eirik, The Evolutionary Interpretation of Treaties, Oxford: University Press, 2014 [Chap. 2]

- Blackstone, William, Commentaries on the Laws of England. Book the Fourth, Oxford: Clarendon Press, 1769 [Chap. 8, 8]

- Blakesley, Christopher L. / Lagodny, Otto, “Competing National Laws: Network or Jungle?”, in Albin Eser / Otto Lagodny (eds.), Principles and Procedures for a New Transnational Criminal Law: Documenta- 
tion of an international workshop in Freiburg, May 1991, Freiburg im Breisgau: Society for the Reform of Criminal Law / Max-Planck-Institut für Ausländisches und Internationales Strafrecht, 1992 [Chap. 1]

- Blakesley, Christopher L., "The Practice of Extradition from Antiquity to Modern France and the United States: A Brief History", BCICLR 4 (1981) [Chap. 8]

- Blakesley, Christopher L., "The law of international extradition: a comparative study", in John Dugard / Christine van den Wyngaert (eds.), International Criminal Law and Procedure, Aldershot: Dartmouth Pub. Co., 1996 [Chap. 6]

- BlakesLey, Christopher L., "The Autumn of the Patriarch: The Pinochet Extradition Debacle and Beyond - Human Rights Clauses Compared to Traditional Derivative Protections Such as Double Criminality", JCL \& 91 (2000) [Chap. 5, 6, 7, 8]

- BLANCHET, Thérèse, "From Workers to Citizens - The Evolution of European Citizenship", NJECL 7 (2016) [Chap. 4]

- Blondel, Evariste, Monographie Alphabétique de l'Extradition, Paris: Cosse, Marchal et Cie, 1866 [Chap. 8]

- BoAs, Gideon / BISCHOff, James L. / REID, Natalie L. / TAYLOR III, B. Don, International Criminal Law Practitioner Library Series - Vol. III: International Criminal Procedure, Cambridge: University Press, 2011 [Chap. 1]

- BOISTER, Neil, “The trend to 'universal extradition' over subsidiary universal jurisdiction in the suppression of transnational crime: transnational and organized crime”, AJ (2003) [Chap. 1, 4]

- BRABYN, Janice, "Inter-Jurisdictional Co-operation in Criminal Matters: Extradition, Mutual Legal Assistance, Prisoner Transfer to and from the HKSAR", in Raymond Wacks (ed.), The New Legal Order in Hong Kong, Hong Kong University Press, 1999 [Chap. 2]

- Brandão, Nuno, Crimes e Contra-Ordenações: da Cisão à Convergência Material - Ensaio para uma Recompreensão da Relação entre o Direito Penal e o Direito Contra-Ordenacional, Coimbra: Coimbra Editora, 2016 [Chap. 8]

- Breitenmoser, Stephan / Wilms, Gunter E., "Human Rights v. Extradition: The Soering Case”, MJIL 11 (1990) [Chap. 2, 8]

- Bribosia, Emmanuelle / Weyembergh, Anne, "Extradition et Asile: Vers un Espace Judiciaire Européen?”, RBDI 30 (1997) [Chap. 8]

- Brodersen, Kei Hannah, “The ICTY's Conditionality Dilemma: On the Interaction of Influences of the European Union's Conditionality Policy and the International Criminal Tribunal for the Former Yugoslavia on the Development of Rule of Law in Serbia”, EJCCL\&CJ 22 (2014) [Chap. 7]

- Brown, Alastair, Extradition and International Co-operation Act 2003 - A Current Law Statute Guide, London: Sweet \& Maxwell, 2004 [Chap. 5, 6]

- Brown, Bartram S., "Primacy or Complementarity: Reconciling the Jurisdiction of National Courts and International Criminal Tribunals", YJIL 23 (1998) [Chap. 7]

- BRYCE, Trevor, Life and Society in the Hittite World, Oxford: University Press, 2002 [Chap. 3]

- BRYCE, Trevor, Letters of the Great Kings of the Ancient Near East: The Royal Correspondence of the Late Bronze Age, London: Routledge, 2003 [Chap. 8]

- BRYCE, Trevor, “The 'Eternal Treaty’ from the Hittite perspective”, BMSAES 6 (2006) [Chap. 8]

- Bueno ARus, Francisco, “L’Infraction Politique et L'Extradition dans la Legislation Espagnole”, RIDP 62 (1991) [Chap. 7, 8]

- BuRDICK, Charles K. (rep.), "Harvard Research in International Law: Extradition”, AJIL (Sup.) 29 (1935) [Chap. 1, 6, 7, 8]

- Burns, Kai, A Cornerstone of Modern Diplomacy: Britain and the Negotiation of the 1961 Vienna Convention on Diplomatic Relations, London: Bloomsbury, 2014 [Chap. 2]

- BuYsE, Antoine, “The Draft Copenhagen Declaration - What About Civil Society?", Strasbourg Observers, 1 March 2018, in www.strasbourgobservers.com [Chap. 7] 
- Caeiro, Pedro / Fidalgo, Sónia, "The Portuguese experience of mutual recognition in criminal matters: five years of European Arrest Warrant”, in Gisèle Vernimmen-Van Tiggelen / Laura Surano / Anne Weyembergh (eds.), The future of mutual recognition in criminal matters in the European Union / L'avenir de la reconnaissance mutuelle en matière pénale dans l'Union européenne. Bruxelles: Éditions de l’U.L.B., 2009 [Chap. 5, 6]

- CAeIro, Pedro, “Legalidade e oportunidade: a perseguição penal entre o mito da 'justiça absoluta' e o fetiche da 'gestão eficiente' do sistema”, RMP 21 (2000) [Chap. 7]

- CAeIro, Pedro, “Ut Puras Servaret Manus - Alegações contra a assunção, pelo Estado Português, da obrigação de entrega ao Tribunal Penal Internacional de um cidadão que possa ter de cumprir uma pena de prisão perpétua”, RPCC 11 (2001) [Chap. 6, 8]

- CAEIRo, Pedro, “A Decisão-Quadro do Conselho, de 26 de Junho de 2001, e a relação entre a punição do branqueamento e o facto precedente: necessidade e oportunidade de uma reforma legislativa”, in Manuel da Costa Andrade / José de Faria Costa / Anabela Miranda Rodrigues / Maria João Antunes (eds.), Liber Discipulorum para Jorge de Figueiredo Dias, Coimbra: Coimbra Editora, 2003 [Chap. 8]

- CAeIro, Pedro, “O procedimento de entrega previsto no Estatuto de Roma e a sua incorporação no Direito Português”, Coimbra: Coimbra Editora, 2004 [Chap. 6, 7]

- Caeiro, Pedro, Fundamento, Conteúdo e Limites da Jurisdição Penal do Estado. O Caso Português, Coimbra: Coimbra Editora | Wolters Kluwer, 2010 [Chap. 1, 2, 4, 6, 8, 9]

- CAEIRO, Pedro, "A coerência dos sistemas penais nacionais em face do direito europeu”, in Constança Urbano de Sousa (coord.), The area of freedom, security and justice: recent developments, Lisboa: Universidade Autónoma, 2014 [Chap. 4]

- Caeiro, Pedro, "Reconhecimento Mútuo, Harmonização e Confiança Mútua (Primeiro Esboço de uma Revisão), in Margarida Santos / Mário Ferreira Monte / Fernando Conde Monteiro (eds.), Os novos desafios da cooperação judiciária e policial na União Europeia e da implementação da Procuradoria Europeia, Braga: Centro Interdisciplinar em Direitos Humanos da Escola de Direito da Universidade do Minho, 2017 [Chap. 2]

- CALSTER, Geert van, European private international law, 2nd ed., Oxford: Hart, 2016 [Chapter 7]

- Canotilho, J. J. Gomes / Moreira, Vital, Constituição da República Portuguesa Anotada, Vol. I, 4. a ed. revista, Coimbra: Coimbra Editora, 2007 [Chap. 6]

- CAnotilho, J. J. Gomes, “Caso Varizo - Extradição no caso de prisão perpétua”, RLJ 128 (1995) [Chap. 6]

- Canotillo, J. J. Gomes, Direito Constitucional e Teoria da Constituição, 6 ${ }^{\text {th }}$ ed., Coimbra: Almedina, 2002 [Chap. 5, 8]

- CANTrell, Charles L., “The Political Offense Exemption in International Extradition: A Comparison of the United States, Great Britain and the Republic of Ireland”, MarLR 60 (1977) [Chap. 8]

- CARDAiLlac, Fernand de, De l'Extradition: Droit International, Tarbes: Émile Croharé, 1878 [Chap. 1, 8]

- CARLSON, Adam, “The Case of Richard O’Dwyer: Extradition as a Means to the International Enforcement of Copyright Protections", TL\&CP 23 (2014) [Chap. 6, 7]

- Carrara, Francesco, Programma del Corso di Diritto Criminale dettato nella R. Università di Pisa: Parte Speciale ossia Esposizione dei Delitti in Specie con Aggiunta di Note per uso della Pratica Forense - vol. V, 2 ${ }^{\text {nd }}$ ed., Lucca: Tipografia Giusti, 1870 [Chap. 7]

- CAssese, Antonio, "When May Senior State Officials Be Tried for International Crimes? Some Comments on the Congo v. Belgium Case", EJIL 13 (2002) [Chap. 2]

- CAssese, Antonio, International Criminal Law, 2nd ed., Oxford: University Press, 2008 [Chap. 1, 6]

- CAssese, Antonio, The Human Dimension of International Law. Selected Papers, Paola Gaeta / Salvatore Zappalà (eds.), Oxford: University Press, 2008 [Chap. 3, 7]

- CAstor, Bruce L. (ed.), "The Statute of Limitations in Criminal Law: A Penetrable Barrier to Prosecution", UPLR 102 (1954) [Chap. 8] 
- Cavallone, Giulia, "European arrest warrant and fundamental rights in decisions rendered in absentia: the extent of Union law in the case C-399/11 Melloni v. Ministerio Fiscal”, ECrimLR 4 (2014) [Chap. 2]

- CHABert, Susana, "Ordem pública internacional e direito comunitário”, in Nuno Andrade Pissarra / Susana Chabert, Normas de aplicação imediata, ordem pública internacional e direito comunitário, Coimbra: Almedina, 2004 [Chap. 7]

- ChePesiuk, Ron, The War on Drugs: An International Encyclopedia, Santa Barbara: ABC-CLIO, 1999 [Chap. 7]

- Cherviatsova, Alina, "Gravity of the Past: Polish-Ukrainian Memory War and Freedom of Speech", EJIL: Talk!, 22 February 2018, in www.ejiltalk.org [Chap. 8]

- CHryssikos, Demostenes, "Commentary on the United Nations Model Law on Extradition”, in M. Cherif Bassiouni (ed.), International Criminal Law, Vol. II: Multilateral and Bilateral Enforcement Mechanisms, 3rd ed., Leiden: Brill, 2008 [Chap. 2]

- ClaRK, Roger S., The United Nations Crime Prevention and Criminal Justice Program: Formulation of Standards and Efforts at Their Implementation, Philadelphia: University of Pennsylvania Press, 1994 [Chap. 2]

- Clarke, Edward, A Treatise upon the Law of Extradition, London: Stevens \& Haynes, 3rd ed., 1888 [Chap. 7]

- ClosE, Josepha, "Human rights outcasts: seriously-ill migrants as beyond the reach of European protective legal regimes”, International Law Blog, 20 April 2015, in www.aninternationallawblog.wordpress.com [Chap. 3]

- CoCA-VILA, Ivó, "Self-driving Cars in Dilemmatic Situations: An Approach Based on the Theory of Justification in Criminal Law", CL\&Ph. 12 (2018) [Chap. 8]

- CoHEN, Williams M., "Implementing the UN Torture Convention in U.S. Extradition Cases", DJIL \& P 26 (1998) [Chap. 8]

- COLAÇO, António Bernardo, “O Procedimento Extradicional na Óptica do Operador Judiciário”, RPCC 7 (1997) [Chap. 6]

- Collins, Cath, Post-transitional Justice: Human Rights Trials in Chile and El Salvador, Pennsylvania State: University Press, 2010 [Chap. 7]

- Collaço, Isabel de Magalhães, Direito Internacional Privado: Vol. II, Lisboa: AAFDL [Chap. 7]

- CONDORELLI, Luigi, “Le Tribunal Pénal International pour l’ex-Yougoslavie et sa jurisprudence”, CEBDI 1 (1997) [Chap. 1]

- Correia, A. Ferrer, Lições de Direito Internacional Privado I, Coimbra: Almedina, 2000 [Chap. 7]

- CORREIA, Eduardo, Direito Criminal (com a colaboração de Figueiredo Dias), Volume I, Coimbra: Almedina, 1963 [Chap. 7, 8]

- Correia, Eduardo, Actas das sessões da comissão revisora do Código Penal: Parte Especial, Separata BMJ (1979) [Chap. 7]

- Costa, Joana, Joint Criminal Enterprise: O Problema da Imputação Individual do Facto Colectivo na Jurisprudência dos Tribunais Penais Internacionais, Coimbra: Coimbra Editora [Chap. 7]

- CosTa, José de Faria, Globalização e Direito: Reflexões não locais e pouco globais, Coimbra: Coimbra Editora, 2010 [Chap. 6, 7]

- CostA, Miguel João, “Extradição e Administração Supletiva da Justiça Penal”, BFDUM34 (2013) [Chap. 2]

- Costa, Miguel João, Dedere Aut Judicare? A decisão de extraditar ou julgar à luz do direito português, europeu e internacional, Coimbra: IJ, 2014 [Chap. 1, 4, 5, 6, 7, 8]

- Costa, Miguel João, "O princípio da dupla incriminação na extradição”, in Pedro Caeiro (org.), Temas de Extradição e Entrega, Coimbra: Almedina, 2015 [Chap. 6, 8]

- CostA, Miguel João, “Comentário à Proposta de Directiva relativa ao Apoio Judiciário Provisório para Suspeitos ou Arguidos Privados de Liberdade e ao Apoio Judiciário em Processos de Execução de MDE", in Pedro Caeiro (org.), A Agenda da União Europeia sobre os Direitos e Garantias da Defesa em Processo Penal: A 'Segunda Vaga' e o seu Previsível Impacto sobre o Direito Português, Coimbra: IJ, 2015 [Chap. 1] 
- CostA, Miguel João, “The Emerging EU Extradition Law: Petrubbin and Beyond”, NJECL 8 (2017) [Chap. 4]

- CRYER, Robert / Friman, Håkan / RoBInson, Darryl / WiLMShurst, Elizabeth, An Introduction to International Criminal Law and Procedure, Cambridge: University Press, 2014 [Chap. 7]

- CRYER, Robert, "Sudan, Resolution 1593, and International Criminal Justice”, LJIL 19 (2006) [Chap. 1]

- CunHA, Damião da, “Artigo 33.”, in Jorge Miranda / Rui Medeiros, Constituição da República Portuguesa Anotada, Vol. I, $2^{\text {nd }}$ ed. revista, Lisboa: Universidade Católica Editora, 2017 [Chap. 6]

- DALBORA, José Luis Guzmán, “Crímenes internacionales y prescripción”, in Kai Ambos / Ezequiel Malarino / Jan Woischnik (eds.), Temas Actuales del Derecho Penal Internacional: Contribuciones de América Latina, Alemania y España, Montevideo: Fundación Konrad-Adenauer, 2005 [Chap. 8]

- DANNER, Allison Marston / MARTINEZ, Jenny S., "Guilty Associations: Joint Criminal Enterprise, Command Responsibility and the Development of International Criminal Law", CLR 93 (2005) [Chap. 7 ]

- DAVIDSON, Rosemary, "A sledgehammer to crack a nut? Should there be a bar of triviality in European arrest warrant cases?”, CLR (1) 2009 [Chap. 6, 8]

- Davidson, Rosemary, "Extradition Offences", in John R. W. D. Jones (general ed.) / Rosemary Davidson (assistant ed.) / Arvinder Sambei (contributor) / Brian Gibbins (contributor), Extradition and Mutual Legal Assistance Handbook, $2^{\text {nd }}$ ed., Oxford: University Press, 2010 [Chap. 6]

- DAvidSOn, Rosemary, “The Extradition Hearing”, in John R. W. D. Jones (general ed.) / Rosemary Davidson (assistant ed.) / Arvinder Sambei (contributor) / Brian Gibbins (contributor), Extradition and Mutual Legal Assistance Handbook, $2^{\text {nd }}$ ed., Oxford: University Press, 2010 [Chap. 6, 8]

- DAVIDSOn, Rosemary / Lloyd, Ben / PAYTER, Adam, "Recent developments in extradition law some practical implications", CLR 7 (2015) [Chap. 6]

- DAwson, Joanna, "Brexit: implications for policing and criminal justice cooperation", House of Commons Briefing Paper no. 7650, 24 February 2017 [Chap. 5]

- DAwson, Joanna / Lipscombe, Sally / GodEC, Samantha, "The European Arrest Warrant", House of Commons Briefing Paper no. 07016, 18 April 2017 [Chap. 5, 8]

- Decaux, Emmanuel, La Réciprocité en Droit International, Paris: R. Pichon et R. Durant-Auzias, 1980 [Chap. 7]

- Deen-Racsmány, Zsuzsanna, "Modernizing the Nationality Exception: Is the Non-extradition of Residents a Better Rule?”, NJIL 75 (2006) [Chap. 8]

- Deen-Racsmány, Zsuzsanna / BlekXtoon, Rob, “The Decline of the Nationality Exception in European Extradition? The Impact of the Regulation of (Non-)Surrender of Nationals and Dual Criminality under the European Arrest Warrant', EJCCLECJ 13 (2005) [Chap. 1]

- DeEre, Lora L., "Political Offenses in the Law and Practice of Extradition", AJIL 27 (1933) [Chap. 8]

- DeFabo, Vincent, “Terrorist or Revolutionary: The Development of the Political Offender Exception and Its Effects on Defining Terrorism in International Law", AUNSLB 2 (2012) [Chap. 8]

- DEN HeIJER, Maarten, "Whose Rights and Which Rights? The Continuing Story of Non-Refoulement under the European Convention on Human Rights", EJML 10 (2008) [Chap. 3]

- Dias, Jorge de Figueiredo / ANDrade, Manuel da Costa, Direito Penal. Questões Fundamentais, A Doutrina Geral do Crime (fascículos), 1996 [Chap. 6]

- Dias, Jorge de Figueiredo / CAEIRo, Pedro, "Comentário ao Acórdão do Tribunal de Justiça de 3 de Maio de 2007, proc. C-303/05, Advocaten voor de Wereld VZW contra Leden van de Ministerraad", in Eduardo Paz Ferreira / Maria Luísa Duarte / Miguel Sousa Ferro (orgs.), Jurisprudência Cunba Rodrigues - Comentários, Associação Académica da Faculdade de Direito de Lisboa, 2013 [Chap. 6, 8]

- DiAs, Jorge de Figueiredo, "Compétence des jurisdictions pénales portugaises pour les infractions commises à l'étranger", BFDUC 41 (1965) [Chap. 6]

- Dias, Jorge de Figueiredo, Direito Processual Penal: Vol. 1, Coimbra: Coimbra Editora, 1974 [Chap. 8] 
- DiAS, Jorge de Figueiredo, “Algumas questões em tema de extradição e de sede do crime [anotação]”, Revista de Legislação e Jurisprudência 118 (1985) [Chap. 6]

- DiAs, Jorge de Figueiredo, "Extradição e non bis in idem [parecer]", DJ 9 (1995) [Chap. 6]

- DiAs, Jorge de Figueiredo, Temas Básicos da Doutrina Penal, Coimbra: Coimbra Editora, 2001 [Chap. 8]

- DiAs, Jorge de Figueiredo, Direito Penal. Parte Geral. Tomo I: Questões Fundamentais. A Doutrina Geral do Crime, Coimbra: Coimbra Editora, 2004 [Chap. 4, 6]

- DinsteIn, Yoram, "Diplomatic Immunity from Jurisdiction Ratione Materiae", I 2 CLQ 15 (1966) [Chap. 2]

- DinsteIn, Yoram, “General Report”, RIDP 62 (1991) [Chap. 5]

- Donald, Alice / LEACH, Philip, “A Wolf in Sheep's Clothing: Why the Draft Copenhagen Declaration Must be Rewritten”, EJIL: Talk!, 21 February 2018, in www.ejiltalk.org [Chap. 7]

- DraKe, Samantha K., "Dangerous Precedents: Circumventing Extradition to Implement the Death Penalty", STLR 36 (2013) [Chap. 1]

- Drumbl, Mark A., "Prosecution of Genocide v. the Fair Trial Principle Comments on Brown and others v. The Government of Rwanda and the UK Secretary of State for the Home Department', JICJ 8 (2010) [Chap. 6]

- DufFY, Aoife, "Expulsion to Face Torture? Non-refoulement in International Law”, IJRL 20 (2008) [Chap. 3]

- Dugard, John / VAn den Wyngaert, Christine, "Reconciling Extradition with Human Rights", AJIL 92 (1998) [Chap. 3]

- EFRAT, Asif, "Resisting cooperation against crime: Britain's extradition controversy, 2003-2015, IJLCJ 52 (2018) [Chap. 1, 6, 8]

- EsER, Albin, "Common Goals and Different Ways in International Criminal Law: Reflections from a European Perspective”, HILJ 31 (1990) [Chap. 1]

- Eser, Albin, "Basic Issues Concerning Transnational Cooperation in Criminal Cases: A Problem in Outline", in Edward M. Wise (ed.), Criminal Science in a Global Society: Essays in Honor of Gerbard O. W. Mueller, Littleton: Fred B. Rothman \& Co., 1994 [Chap. 1, 7, 9]

- FELLER, S. Z., "The Significance of the Requirement of Double Criminality in the Law of Extradition Steven Ivan Ross v. State of Israel (1973) (II) 27 P.D. 365”, ILR 10 (1975) [Chap. 6, 8]

- FELLER, S. Z., “Concurrent Criminal Jurisdiction in the International Sphere”, ILR 16 (1981) [Chap. 4]

- FERnANDES, Carlos, A extradicão e o respectivo sistema português, Lisboa: Instituto Hispano-Luso-Americano de Derecho Internacional, 1996 [Chap. 5, 6]

- FicherA, Massimo, “The EAW and the Sovereign State: A Marriage of Convenience?”, ELJ 15 (2009) [Chap. 2]

- FINDLAY, Mark, The Globalisation of Crime: Understanding Transitional Relationships in Context, Cambridge: University Press, 1999 [Chap. 7]

- Flore, Daniel, "Reconnaissance mutuelle, double incrimination et territorialité", in Gilles de Kerchove / Anne Weyembergh (eds.) La reconnaissance mutuelle des décisions judiciaires pénales dans l'Union européenne, Bruxelles: Ed. de l'Université, 2001 [Chap. 2]

- FLORE, Daniel, "Le mandat d'arrêt européen: première mise en œuvre d'un nouveau paradigme de la justice pénale européenne", JT 121 (2002) [Chap. 2]

- FLORE, Daniel (with the collaboration of Stéphanie Bosly), Droit Pénal Européen, Bruxelles: Larcier, 2014 [Chap. 4]

- ForsteIn, Carolyn, "Challenging Extradition: The Doctrine of Specialty in Customary International Law", CJTL 53 (2015) [Chap. 8]

- Foster, Steve Harold, "Case Comment - The great review and release swindle: the European Court, whole life sentences and the possibility of review and release, CovLJ 20 (2015) [Chap. 3]

- Foster, Steve Harold, "Whole Life Sentences and Article 3 of the European Convention on Human Rights: Time for Certainty and a Common Approach?", LLR 36 (2015) [Chap. 3] 
- Foucault, Michel, Discipline and Punish - The Birth of the Prison, Alan Sheridan (trans.), New York: Vintage Books, 1977 [Chap. 7]

- Fox, Hazel, “The First Pinochet Case: Immunity of a Former Head of State”, I \& CLQ 48 (1999) [Chap. 2]

- Fox, Hazel "Imputability and Immunity as Separate Concepts: The Removal of Immunity from Civil Proceedings Relating to the Commission of an International Crime", in Kaiyan Homi Kaikobad / Michael Bohlander (eds.), International Law and Power: Perspectives on Legal Order and Justice - Essays in Honour of Colin W arbrick, Leiden: Nijhoff, 2009 [Chap. 2]

- Fox, Hazel / WeBB, Philippa The Law of State Immunity, 3rd ed., Oxford: University Press, 2013 [Chap. 2]

- Freeman, Chris / Louçã, Francisco, As Time Goes By: From the Industrial Revolutions to the Information Revolution, Oxford: University Press [Chap. 7]

- FriAs, Margarida, "Portugal e a Convenção Europeia sobre Extradição de 13 de Dezembro de 1957”, RMP 11 (1990) [Chap. 6]

- Friedland, Martin, Double Jeopardy, Oxford: University Press, 1969 [Chap. 8]

- FrIEDRICHS, Gordon, Smart Security Council? Analyzing the Effectiveness of Targeted Sanctions, Hamburg: Anchor, 2013 [Chap. 7]

- FU, H. L., "The Form and Substance of Legal Interaction Between Hong Kong and Mainland China: Towards Hong Kong's New Legal Sovereignty”, in Raymond Wacks (ed.), The New Legal Order in Hong Kong, Hong Kong University Press, 1999 [Chap. 2]

- GALEOTTI, Mark, “Introduction: Global Crime Today”, GC 6 (2004) [Chap. 7]

- GArcíA-MorA, Manuel R., “The Nature of Political Offences: A Knotty Problem of Extradition Law”, VLR 48 (1962) [Chap. 8]

- GARDOCKI, Lech, "Double Criminality in Extradition Law”, ILR 27 (1993) [Chap. 6, 8]

- GÁSPÁR-SZILÁGY, Szilárd, “Joined Cases Aranyosi and Căldăraru: Converging Human Rights Standards, Mutual Trust and a New Ground for Postponing a European Arrest Warrant”, EJCCLECJ 24 (2016) [Chap. 2]

- GEIST, Michael A., "Is there a there there? Toward Greater Certainty for Internet Jurisdiction”, BTLJ 16 (2001) [Chap. 7]

- GelLner, Ernest, Nations and Nationalism, Oxford: Basil Blackwell, 1983 [Chap. 8]

- GERARDS, Janneke, "The scope of ECHR rights and institutional concerns - The relationship between proliferation of rights and the case load of the ECtHR", in Eva Brems / Janneke Gerards (eds.), Shaping Rights in the ECHR. The Role of the European Court of Human Rights in Determining the Scope of Human Rights, Cambridge: University Press, 2014 [Chap. 3]

- GEYER, Florian, "European Arrest Warrant: Advocaten voor de Wereld VZWv. Leden van de Ministerraad", EConstLR 4 (2008) [Chap. 2]

- GIL, José, Em Busca da Identidade - o desnorte, Lisboa: Relógio D’Água, 2009 [Chap. 8]

- GILBERT, Geoff, Transnational Fugitive Offenders in International Law - Extradition and Other Mechanisms, The Hague: Martinus Nijhoff, 1998 [Chap. 1, 6, 8]

- GILBERT, Geoff, Responding to International Crime, Leiden: Martinus Nijhoff Publishers, 2006 [Chap. 7, 8]

- Glerum, Vincent / Rozemond, Klaas / VAn Sliedregt, Elies, "Lessons of the European Arrest Warrant”, in Larissa van den Herik / Nico Schrijver (eds.), Counter-Terrorism Strategies in a Fragmented International Legal Order: Meeting the Challenges, Cambridge: University Press, 2013 [Chap. 8]

- GLERUM, Vincent, De weigeringsgronden bij uitlevering en overlevering - Een vergelijking en kritische evaluatie in bet licht van het beginsel van wederiijdse erkenning, Nijmegen: Wolf Legal Publishers, 2013 [Chap. 5]

- Gless, Sabine, “Bird's-Eye View and Worm's-Eye View: Towards a Defendant-Based Approach in Transnational Criminal Law", TLT 6 (2015) [Chap. 7, 8] 
- GoDINHO, Inês, “O mandado de detenção europeu e a 'Nova Criminalidade': a definição da definição ou o pleonasmo do sentido", Politeia 2 (2005) [Chap. 6]

- GodinHo, José Magalhães, “O asilo político e o direito de extradição”, ROA 33 (1973) [Chap. 8]

- GoMEs, Henrique Guerra Tavares, “A prescrição do procedimento criminal na extradição e no mandado de detenção europeu em Portugal”, LLM paper: FDUC, 2012 (unpublished) [Chap. 6]

- Gordon, Michael, Parliamentary Sovereignty in the UK Constitution: Process, Politics and Democracy, Oxford: Hart, 2015 [Chap. 8]

- GRAÇA, António Pires Henriques da, A Jurisprudência do Supremo Tribunal de Justiça na execução do regime relativo ao Mandado de Detenção Europeu, based on a communication made at the "Acção de Formação Permanente Cooperação Judiciária Internacional em Matéria Penal”, CEJ (org.), 8 May 2008, in http://www.sti.pt/ficheiros/estudos/piresdagraca-direitoeuropeu.pdf [Chap. 5, 6]

- GRANGE, Edward / NibLOCK, Rebecca, Extradition law: a practitioner's guide, $2^{\text {nd }}$ ed., London: Legal Action Group, 2015 [Chap. 1, 5, 6]

- GrANGE, Edward, “Amendments to the Extradition Act 2003: new opportunities (and new pitfalls) for those defending extradition requests", 7 July 2015, Corker Binning Blog, in http://www.corkerbinning.com/amendments-to-the-extradition-act-2003-new-opportunities-and-newpitfalls-for-those-defending-extradition-requests-2/ [Chap. 6]

- Grassi, Yvonne G., "Federally Sponsored International Kidnapping: An Acceptable Alternative to Extradition?”, WULQ 64 (1986) [Chap. 1]

- Graziano, Thomas Kadner, "Is it Legitimate and Beneficial for Judges to Compare?", in Mads Andenas / Duncan Fairgrieve (eds.), Courts and Comparative Law, Oxford: University Press, 2015 [Chap. 2]

- GreEN, Leslie, "Legal Positivism", in Edward N. Zalta (ed.), in The Stanford Encyclopedia of Philosophy, Spring 2018 ed., in https://plato.stanford.edu/archives/spr2018/entries/legal-positivism [Chap. 7]

- Greenman, Kathryn, "A Castle Built on Sand? Article 3 ECHR and the Source of Risk in NonRefoulement Obligations in International Law”, IJRL 27 (2015) [Chap. 3]

- Greenwald, Glenn, Drug Decriminalisation in Portugal: Lessons for Creating Fair and Successful Drug Policies, Washington: Cato Institute, 2009 [Chap. 8]

- GREENWALD, Glenn, “America's refusal to extradite Bolivia's ex-president to face genocide charges”, The Guardian, 9 September 2012, in https://www.theguardian.com/commentisfree/2012/sep/09/americarefusal-extradite-bolivia [Chap. 7]

- GRIFFITH, Gavan / HARRIS, Claire, "Recent Developments in the Law of Extradition”, Melb.JIL 6 (2005) [Chap. 8]

- Grotius, Hugo, The Rights of War and Peace (trans. A. C. Campbell), London \& New York: M. Walter Dunne Pub., 1901 [Chap. 7]

- Grotius, Hugo, De Jure Belli ac Pacis, Washington D.C.: Carnegie Institution of Washington, 1913 [Chap. $1,7,9]$

- Gully-Hart, Paul, "The Function of State and Diplomatic Privileges and Immunities in International Cooperation in Criminal Matters: The Position in Switzerland", FILJ 23 (2000) [Chap. 2]

- Gully-HART, Paul, “The European Approach to Extradition”, in M. Cherif Bassiouni (ed.), International Criminal Law, Vol. II: Multilateral and Bilateral Enforcement Mechanisms, $3^{\text {rd }}$ ed., Leiden: Brill, 2008 [Chap. $5,6]$

- GuOQIAng, Zhao, "Cooperação judiciária inter-regional no âmbito Penal da China, sob o princípio 'um país, dois sistemas", in Leonel Alves / Paulo Cardinal (coord.), 1.as Jornadas de Direito e Cidadania da Assembleia Legislativa de Macau - Direito Processual Penal, Estado Presente e Perspectivas de Evolução, Coimbra: Coimbra Editora, 2009 [Chap. 2]

- Habermas, Jürgen, The Crisis of the European Union - A Response, Cambridge: Polity, 2012 [Chap. 1, 7, 9] 
- HALL, Stephen, "Researching International Law", in Michael McConville / Wing Hong Chui (eds.), Research Methods for Law, Edinburgh: University Press, 2007 [Chap. 2]

- Hald, William Edward, A Treatise on International Law, A. Pearce Higgins (ed.), Oxford: Oxford University Press, $7^{\text {th }}$ ed., 1917 [Chap. 1]

- Hammel, Andrew, Ending the Death Penalty - The European Experience in Global Perspective, Basingstoke: Palgrave Macmillan, 2010, p. 86 f. [Chap. 3]

- Han, Byung-Chul, A Sociedade do Cansaço, Lisboa: Relógio d’Água, 2014 [Chap. 7]

- HARrington, Johanna, "The Absent Dialogue: Extradition and the International Covenant on Civil and Political Rights”, QLJ 32 (2006) [Chap. 2, 3, 8]

- HARrington, Johanna, "Extradition of Transnational Criminals", in Neil Boister / Robert J. Currie (eds.), Routledge Handbook of Transnational Criminal Law, New York: Routledge, 2015 [Chap. 6]

- HART, Naomi, "Case Comment: Whole-life sentences in the UK: volte-face at the European Court of Human Rights?”, CLJ 74 (2015) [Chap. 3]

- Hathaway, Oona A., "Do Human Rights Treaties Make a Difference? YLJ 111 (2002) [Chap. 2]

- Hathaway, Oona A., “The Cost of Commitment”, SLR 55 (2003) [Chap. 2]

- Held, David / McGrew, Anthony / Goldblatt, David / Perraton, Jonathan, Global Transformations: Politics, Economics and Culture, Stanford: University Press, 1999 [Chap. 9]

- Helenius, Dan, "The If, How, and When of Criminal Jurisdiction - What is Criminal Jurisdiction Anyway?”, BJCL\&CJ 3 (2015) [Chap. 7]

- Henzelin, Marc, Le principe de l'universalité en droit pénal international. Droit et obligation pour les états de poursuivre et juger selon le principe de l'université, Basel: Schulthess Verlag, 2001 [Chap. 1, 6, 7, 8]

- HoffNer, Jr., Harry Angier, The Laws of the Hittites. A Critical Edition, Leiden: Brill, 1997 [Chap. 3]

- Homer, The Iliad, New York: Signet Classics, 2007 [Chap. 7]

- Homrig, Brigette Belton, "Abduction as an Alternative to Extradition: A Dangerous Method to Obtain Jurisdiction over Criminal Defendants, WFLR 28 (1993) [Chap. 1]

- Howse, Tricia, "England", in Katalin Ligeti (ed.), Toward a Prosecutor for the European Union - Volume 1: A Comparative Analysis, Oxford: Hart Pub., 2012 [Chap. 7]

- JaCKson, Miles / AkAnde, Dapo, "Foreign Office Certificates and Diplomatic Immunity in the Assange Affair”, EJIL: Talk!!, 2 March 2018, in www.ejiltalk.org [Chap. 7]

- JACQUES, Hartmann, “The European Convention on Human Rights and Extradition”, in Kaiyan Homi Kaikobad / Michael Bohlander (eds.), International Law and Power Perspectives on Legal Order and JusticeEssays in Honour of Colin Warbrick, Leiden: Martinus Nijhoff, 2009 [Chap. 3]

- JAMneJAD, Maziar / WoOD, Michael, “The Principle of Non-intervention”, LJIL 22 (2009) [Chap. 2, 8]

- JANssEns, Christine, “Case C-303/05, Advocaten voor de Wereld VZW v. Leden van de Ministrraad”, CJEL 14 (2007) [Chap. 2]

- Janssens, Christine, The Principle of Mutual Recognition in EU Law, Oxford: University Press, 2013 [Chap. 2]

- JARDIM, José Vera, "Por fim, podemos extraditar portugueses! - Explicações de um Ministro”, in António José Avelãs Nunes et al., A Inclusão do Outro: BFUDC 9 (2002) [Chap. 6]

- JESCHECK, Hans-Heinrich, "Die internationale Rechtshilfe in Strafsachen in Europa”, ZStW 66 (1954) [Chap. 7, 8]

- JONES, Alun, Jones on Extradition and Mutual Assistance, London: Sweet \& Maxwell, 2001 [Chap. 6]

- JOUTSEN, Matti, "International Instruments on Cooperation in Responding to International Crime”, in Philip Reichel / Jay Albanese (eds.), The Handbook of Transnational Crime and Justice, Los Angeles: SAGE, $2^{\text {nd }}$ ed., 2014 [Chap. 2]

- KeIJZER, Nico, “The Double Criminality Requirement”, in Rob Blekxtoon / Wouter van Ballegooij (eds.), Handbook on the European Arrest Warrant, The Hague: T.M.C. Asser Press, 2005 [Chap. 2, 6] 
- KEILER, Johannes, Actus reus and participation in European criminal law, Antwerp: Intersentia, 2012 [Chap. 7]

- KeILER, Johannes, “Commission versus Omission”, in Johannes Keiler / David Roef (eds.), Comparative Concepts of Criminal Law, Antwerp: Intersentia, 2015 [Chap. 7]

- KeILer, Johannes / RoEF, David, "Forms of Participation”, in Johannes Keiler / David Roef (eds.), Comparative Concepts of Criminal Law, Antwerp: Intersentia, 2015 [Chap. 8]

- KeLSEN, Hans, General Theory of Law and State, Cambridge: Harvard University Press, 1949 [Chap. 7]

- Keohane, Robert O., Power and Governance in a Partially Globalized World, London: Routledge, 2002 [Chap. $1,7,8,9]$

- KESTER, John G., “Some Myths of United States Extradition Law”, GLJ 76 (1988) [Chap. 8]

- KLAmberg, Mark, Evidence in International Criminal Trials: Confronting Legal Gaps and the Reconstruction of Disputed Events, Leiden: Martinus Nijhoff, 2013 [Chap. 1]

- KLIP, André / VAN DER WILt, Harmen, "Non bis in idem: Report for the Netherlands”, RIDP 73 (2002) [Chap. 8]

- KLIP, André, “Complementarity and concurrent jurisdiction”, NEP 19 [special no. "International Criminal Law: Quo Vadis?’] (2004) [Chap. 7]

- KLIP, André, "International criminal law. Information society and penal law", RIDP 85 (2014) [Chap. 1, 7]

- KLIP, André, European Criminal Law. An Integrative Approach, Cambridge: Intersentia, 3 ${ }^{\text {rd }}$ ed., 2016 [Chap. 1, $4,6,8]$

- KLIP, André, “Europeans First!: Petruhhin, an Unexpected Revolution in Extradition Law”, EJCCLECJ 25 (2017), p. 195 f [Chap. 4]

- KLOTH, Matthias, Immunities and the Right of Access to Court Under Article 6 of the European Convention on Human Rights, Leiden: Brill | Nijhoff, 2010 [Chap. 5]

- KNOWLES, Julian B., Blackstone's Guide to the Extradition Act, Oxford: University Press, 2004 [Chap. 8]

- KoHen, Marcelo G., “The Distinction between State Immunity and Diplomatic Immunity”, in Susan Carolyn Breau / Marcelo G. Kohen / Gerhard Hafner (eds.), State Practice Regarding State Immunities, Leiden: Brill, 2006 [Chap. 2]

- Konstadinides, Theodore, “The Perils of the 'Europeanisation' of Extradition Procedures in the EU Mutuality, Fundamental Rights and Constitutional Guarantees”, MJECL 14 (2017) [Chap. 8]

- Kopelman, Frank, "Extradition and Rendition: History - Law - Recommendations", BULR 14 (1934) [Chap. 2]

- Kostić, Milica, "Public Opinion Survey in Serbia Sheds Light on ICTY Legacy", EJIL: Talk!, 22 January 2018, in www.ejiltalk.org [Chap. 7]

- KREß, Claus, "Universal Jurisdiction over International Crimes and the Institut de Droit international', JICJ 4 (2006) [Chap. 7]

- Kuipers, Jan-Jaap, EU Law and Private International Law: The Interrelationship in Contractual Obligations, Leiden: Brill, 2012 [Chap. 7]

- Lagarde, Paul, "Public Policy", in Kurt Lipstein (chief ed.), International Encyclopedia of Comparative LawVol. 3, Chap. 11, Tübingen : J.C.B. Mohr, 1994 [Chap. 7]

- LAGODNY, Otto, "Human Rights in the Field of Extradition”, RIDP 62 (1991) [Chap. 1, 8, 9]

- LAGODNY, Otto, "Possible ways to reduce the double criminality requirement: From double criminality to double prohibition", Report of the CoE Committee of Experts on Transnational Criminal Justice, PC-TJ/Docs 2005/PC-TJ, 2005, in www.coe.int/tcj/ [Chap. 7, 8]

- LANDIS, Kristin T., "The Seizure of Noriega: A Challenge to the Ker-Frisbie Doctrine”, AUJILP 6 (1991) [Chap. 1]

- Langdon, S. / Gardiner, Alan H., "The Treaty of Alliance between Hattušili, King of the Hittites, and the Pharaoh Ramesses II of Egypt”, JEA 3 (1920) [Chap. 3] 
- LARSEN, Lars Bay, "Judicial control within the European penal area", in Stefan Braum / Anne Weyembergh (eds.), Le contrôle juridictionnel dans l'espace pénal européen, Bruxelles: Ed. de l’Université, 2009 [Chap. 4]

- LAUTERPACHT, Hersch, An International Bill of the Rights of Man, Columbia: University Press, 1945 [Chap. $7,8]$

- LAVENEX, Sandra, "Mutual recognition and the monopoly of force: limits of the single market analogy", JEPP 14 (2007) [Chap. 2]

- LAVRYSEN, Laurens, "Belgium violated the ECHR by extraditing a terrorist to the USA despite an interim measure by the Strasbourg Court: Trabelsi v. Belgium", Strasbourg Observers, 12 September 2014, in www.strasbourgobservers.com [Chap. 3]

- Rick Lawson, "Life After Bankovic: on the Extraterritorial Application of the European Convention on Human Rights", in Fons Coomans / Menno Kamminga (eds.), Extraterritorial Application of Human Rights Treaties, Antwerp: Intersentia, 2004 [Chap. 3]

- ŁAZOWSKI, Adam, "Towards the reform of the preliminary ruling procedure in JHA Area", in Stefan Braum / Anne Weyembergh (eds.), Le contrôle juridictionnel dans l'espace pénal européen, Bruxelles: Ed. de l’Université, 2009 [Chap. 4]

- LEEUW, Frans L. / SCHMEET, Hans, Empirical Legal Research - A Guidance Book for Lanyers, Legislators and Regulators, Cheltenham: Edward Elgar, 2016 [Chap. 2]

- LeidenmüHLer, Franz / Grafeneder, Sandra, "Civis europaeus sum! - Current legal issues relating to the extradition of citizens of the Union to third States. Discussion of the Cases C-182/15, Petruhhin; C-473/15, Schotthöfer \& Steiner; C-191/16, Pisciotti”, ELF 3 (2016) [Chap. 4]

- LeItE, Inês Ferreira, O Conflito de Leis Penais. Natureza e Função do Direito Penal Internacional, Coimbra: Coimbra Editora, 2008 [Chap. 4, 7, 8]

- Lemontey, Jacques, Du Rôle de l'Autorité Judiciaire dans la Procédure d'Extradition Passive, Paris: R. Pichon et R. Durant-Auzias, 1966 [Chap. 8]

- LEMOs, Miguel Ângelo, "As of today there is no doubt that terrorism is a crime under international law", 2016, in www.umac.mo/fll/doc/Terrorism $\% 20$ is $\% 20 \mathrm{a} \% 20$ crime $\% 20$ under $\% 20$ international $\% 20$ law.pdf [Chap. 4]

- Lemos, Miguel Ângelo, “Direitos Fundamentais e Processo Penal: o Habeas Corpus, o Direito ao Recurso de Decisão Condenatória e as Funções de Tutela de Direitos Fundamentais do Tribunal de Instrução Criminal", in Leonel Alves / Paulo Cardinal (coord.), Segundas Jornadas de Direito e Cidadania da Assembleia Legislativa da RAEM, Direitos Fundamentais - Consolidação e Perspectivas de Evolução, Macau: Assembleia Legislativa da RAEM, 2016 [Chap. 2]

- LEMOS, Miguel Ângelo, Nullum crimen nulla poena sine lege e o direito internacional - Em defesa de como os tribunais de guerra deram vida ao direito penal internacional, Ph.D Thesis, Coimbra: FDUC, 2017, in http://www.umac.mo/fll/doc/NULLUM\%20CRIMEN\%20NULLA\%20POENA\%20SINE\%20LE GE.pdf [Chap. 7]

- LenAerTs, Koen, “' 'Civis Europaeus Sum': From the Cross-border Link to the Status of Citizen of the Union”, in Pascal Cardonnel / Allan Rosas / Pernilla Lindh (eds.), Constitutionalising the EU judicial system: Essays in honour of Pernilla Lindh, Oxford: Hart, 2012 [Chap. 4]

- Levin, Remy Z. / CHEN, Paul, "Rethinking the Constitution-treaty relationship", IJConstL 10 (2012) [Chap. 8]

- LETSAS, George, “The Truth in Autonomous Concepts: How to Interpret the ECHR”, EJIL 15 (2004) [Chap. 2]

- Ligeti, Katalin / Vervaele, John / KLIP, André (reps.), "Draft Legislative Proposals for the prevention and resolution of conflicts of jurisdiction in criminal matters in the European Union", European Law Institute: Vienna, 2017 [Chap. 4]

- Ligeti, Katalin / Simonato, Michele (eds.), Chasing Criminal Money: Challenges and Perspectives on Asset Recovery in the EU, Oxford: Hart Publishing, 2017 [Chap. 7] 
- Lippman, Matthew, “The Recognition of Conscientious Objection to Military Service as an International Human Right”, CWILJ 21 (1990) [Chap. 3, 6, 8]

- Lubet, Steven / CzAcKes, Morris, “The Role of the American Judiciary in the Extradition of Political Terrorists", JCL \&C 71 (1980) [Chap. 8]

- Machado, Jónatas, Direito Internacional: Do Paradigma Clássico ao Pós-11 de Setembro, Coimbra: Coimbra Editora, 2003 [Chap. 1]

- MACKAREL, Mark, “' 'Surrendering' the fugitive - the European Arrest Warrant and the United Kingdom”, JCL 71 (2007) [Chap. 5, 6]

- MACKAY, R. D., "Unfitness to plead - some observations of the Law Commission's consultation paper", CLR 6 (2011) [Chap. 6]

- Magnuson, William, “The Domestic Politics of International Extradition”, VJIL 52 (2012) [Chap. 1, 3, $7,8]$

- Malcolm, Davies, Davies, Croall and Tyrer's Criminal Justice, Harlow: Pearson, 2015 [Chap. 6]

- Mancano, Leandro, “The Place for Prisoners in European Union Law?”, EPL 22 (2016) [Chap. 2]

- Marcum, Catherine D. / Higgins, George E. (eds.), Social Networking as a Criminal Enterprise, New York: CRC Press, 2014 [Chap. 7]

- Martens, Georg Friedrich, Recueil des Principaux Traités d'Alliance, de Paix, de Trêve, de Neutralité, de commerce, de limites, d'échange etc. conclus par les Puissances de l'Europe tant entre elles qu'avec les Puissances et États dans d'autres parties du Monde : Depuis 1761 jusqu'à présent, Tome VI, Suplémments et continuation jusqu'aux préliminaires de Leoben 1797, Gottingen: Dieterich, 1800 [Chap. 8]

- MARTIN, Richard A., "Dual criminality in organized crime cases", RIDP 62 (1991) [Chap. 6]

- MARTins, Teresa Alves / Roma, Mónica Quintas, "Cooperação internacional no processo penal”, RPCC 5 (1995) [Chap. 6]

- MASSA, Anne-Sophie, "Jurisdiction in England and Wales and the Netherlands: A comparative appraisal with a European touch", in André Klip (ed.), Substantive Criminal Law of the European Union, Antwerp: Maklu, 2011 [Chap. 6]

- Mathisen, Gjermund, "Nordic Cooperation and the European Arrest Warrant: Intra-Nordic Extradition, the Nordic Arrest Warrant and Beyond”, NJIL 79 (2010) [Chap. 2]

- Matos, Ricardo Jorge Bragança de, “O princípio do reconhecimento mútuo e o Mandado de Detenção Europeu”, RPCC 14 (2004) [Chap. 6]

- MatтA, José Caeiro da, Direito Criminal Português - vol. II, Coimbra: F. França Amado Ed., 1911 [Chap. 8]

- MatToso, José, A Identidade Nacional, Lisboa: Gradiva, 1998 [Chap. 8]

- Mavronicola, Natasa, “On Trabelsi v Belgium”, Human Rights in Ireland, 7 October 2014, in www.humanrights.ie [Chap. 3]

- Mazzochi, Sarah / Portmess, Jess / HAney, Alexandra, "Special Coverage of the $140^{\text {th }}$ Period of Sessions of the Inter-American Commission on Human Rights", HRB 18 (2010) [Chap. 2]

- McCorquodale, Robert, "Wikileaks Documents are Admissible in a Domestic Court", EJIL: Talk!, 21 February 2018, in www.ejiltalk.org [Chap. 8]

- McDavitT, Laura, "Unfitness to plead: the Law Commission’s report”, AR 2 (2016) [Chap. 6]

- MCGOLDRICK, Dominic, "Extraterritorial Application of the International Covenant on Civil and Political Rights", in Fons Coomans / Menno Kamminga (eds.), Extraterritorial Application of Human Rights Treaties, Antwerp: Intersentia, 2004 [Chap. 3]

- Mesquita, Maria José Rangel de / MACHAdo, Cristina Sousa, Extradiscão e mandado de detencão europeu enquanto formas de cooperacão internacional em matéria penal e fiscalização da constitucionalidade - Relatório do Tribunal Constitucional de Portugal - XIV Conferencia Trilateral dos Tribunais Constitucionais de Espanha, Itália e Portugal, Lisboa, 2012 [Chap. 5, 6] 
- MEYER, Jürgen, “The Vicarious Administration of Justice: An Overlooked Basis of Jurisdiction”, HILJ 31 (1990) [Chap. 1]

- Milanović, Marko, “Extradition and Life Imprisonment”, CLJ 68 (2009) [Chap. 5]

- Milanović, Marko, Extraterritorial Application of Human Rights Treaties: Law, Principles, and Policy, Oxford: University Press, 2011 [Chap. 3]

- MiLTNER, Barbara, "Revisiting Extraterritoriality after Al-Skeini: The ECHR and its Lessons”, MJIL 33 (2012) [Chap. 3]

- MiN, Bruno, "The Forum Bar: it does exist”, UK Human Rights Blog, 9 February 2018, in www.ukhumanrightsblog.com [Chap. 6]

- Miranda, Jorge / MACHAdo, Miguel Pedrosa, "Processo de extradição e recurso para o Tribunal Constitucional: admissibilidade e tema do recurso - Parecer”, DJ 9 (1995) [Chap. 6]

- Mirandola, Sofia, "European arrest warrant and judicial independence in Poland: where can mutual trust end? (Opinion of the AG in C-216/18 PPU L.M.)”, in European Law Blog, 24 July 2018, in www.europeanlawblog.eu [Chap. 2]

- Mitchell, Claire, Aut Dedere, aut Judicare: The Extradite or Prosecute Clause in International Law, Genève: eCahiers de l'Institute, 2009 [Chap. 1]

- Mitsilegas, Valsamis / Vavoula, Niovi, "Criminal law: institutional rebalancing and judicialisation as drivers of policy change", in Florian Trauner / Ariadna Ripoll Servent (eds.), Policy Change in the Area of Freedom, Security and Justice: How EU institutions matter, London: Routledge, 2015 [Chap. 2]

- MitsiLEgas, Valsamis, "The Transformation of Criminal Law in the 'Area of Freedom, Security and Justice”, YEL 6 (2007) [Chap. 4]

- Mitsilegas, Valsamis, “The Limits of Mutual Trust in Europe’s Area of Freedom, Security and Justice: From Automatic Inter-State Cooperation to the Slow Emergence of the Individual”, YEL 31 (2012) [Chap. 2]

- MitsiLegas, Valsamis, "European criminal law without the United Kingdom? The triple paradox of Brexit”, NJECL 8 (2017) [Chap. 5]

- Monteiro, Cristina Líbano, "Art. 349. (Tirada de presos)" and "Art. 352. (Evasão)", in Jorge de Figueiredo Dias (dir.), Comentário Conimbricense do Código Penal: Parte Especial, Tomo III, Artigos 308. a $386 .^{\circ}$, Coimbra: Coimbra Editora, 2001 [Chap. 7]

- Montesquieu, The Spirit of Laws (1748), Kitchener: Batoche Books, 2001 [Chap. 7, 8, 9]

- MoOrE, John Basset, A Treatise on Extradition and Interstate Rendition, Boston: Boston Book Company, 1891 [Chap. 1, 6, 7]

- Moreira, Vital, "Princípio da maioria e princípio da constitucionalidade", in Legitimidade e Legitimação da Justiça Constitucional: Colóquio no 10. Aniversário do Tribunal Constitucional, Coimbra: Coimbra Editora, 1995 [Chap. 8]

- MOREIRA, Vital, “O Tribunal Penal Internacional e a Constituição”, in O Tribunal Penal Internacional e a Ordem Juridica Portuguesa, Coimbra: Coimbra Editora, 2004 [Chap. 6]

- Moreno-LAx, Violeta, Accessing Asylum in Europe: Extraterritorial Border Controls and Refugee Rights under EU Law, Oxford: University Press, 2017 [Chap. 3]

- MOWBRAY, Alastair, "The Creativity of the European Court of Human Rights”, HRLR 5 (2005) [Chap. 2]

- Murnane, William J., The Road to Kadesh: A Historical Interpretation of the Battle Reliefs of King Sety I at Karnak ( $2^{\text {nd }}$ ed. rev.), Chicago: The Oriental Institute, 1990 [Chap. 8]

- NADELMANN, Ethan A., "The Evolution of United States Involvement in the International Rendition of Fugitive Criminals”, NYUJIL \&P 25 (1993) [Chap. 1]

- NANDA, Ved P., "Bases for Refusing International Extradition Requests - Capital Punishment and Torture”, FILJ 23 (1999) [Chap. 3] 
- NASU, Hitoshi, "Revisiting the Principle of Non-Intervention: A Structural Principle of International Law or a Political Obstacle to Regional Security in Asia?", AsJIL 3 (2013) [Chap. 7]

- Neuman, W. Lawrence, Social Research Methods: Qualitative and Quantitative Approaches, 7th ed., Harlow: Pearson, 2014 [Chap. 2]

- Neves, António Castanheira, O Instituto dos Assentos e a Função Jurídica dos Supremos Tribunais, Coimbra: Coimbra Editora, 1983 [Chap. 8]

- Neves, António Castanheira, Digesta: Escritos Acerca do Direito, do Pensamento Jurídico, da sua Metodologia e Outros - Volume 1.', Coimbra: Coimbra Editora, 1995 [Chap. 7]

- Nichols, Clive / Montgomery, Clare / Knowles, Julian B. / Doobay, Anand / Summers, Mark, Nichols, Montgomery and Knowles on The Law of Extradition and Mutual Assistance, Oxford: University Press, 2013 [Chap. 2, 6]

- NORTON, William J., "United States Obligations under Status of Forces Agreements: A New Method of Extradition?”, GJI\&CL 5 (1975) [Chap. 8]

- Nussbaum, Arthur, A Concise History of The Law of Nations, New York: McMillan, $8^{\text {th }}$ ed., 1954 [Chap. 7]

- O’BoyLE, Michael, “The European Convention on Human Rights and Extraterritorial Jurisdiction: A Comment on 'Life After Bankovic'", in Fons Coomans / Menno Kamminga (eds.), Extraterritorial Application of Human Rights Treaties, Antwerp: Intersentia, 2004 [Chap. 3]

- O’Higgins, Paul, "Disguised Extradition: The Soblen Case”, MLR 27 (1964) [Chap. 1]

- OETER, Stefan, "Effect of Nationality and Dual Nationality on Judicial Cooperation, including Treaty Regimes such as Extradition", David A. Martin / Kay Hailbronner (eds.), Rights and Duties of Dual Nationals: Evolution and Prospects, The Hague: Kluwer Law International, 2003 [Chap. 8]

- OliveIra, Andreia Sofia Pinto, O Direito de Asilo na Constituição Portuguesa - Ambito de Protecção de um Direito Fundamental, Coimbra: Coimbra Editora, 2009 [Chap. 6]

- Oliver Olmo, Pedro, La pena de muerte en España, Madrid: Editorial Sintesis, 2008 [Chap. 3]

- OppenHeIm, Lassa, International Law: A Treatise - Vol. I. Peace, New York: Longmans, Green and Co., 1905 [Chap. 7, 8]

- Ormerod, David / Perry, David (gen. eds.), Blackstone's Criminal Practice 2016, Oxford: University Press, $26^{\text {th }}$ ed., 2015 [Chap. 6]

- Ouwerkerk, Jannemieke, Quid Pro Quo? A comparative law perspective on the mutual recognition of judicial decisions in criminal matters, Antwerp: Intersentia, 2011 [Chap. 2, 4]

- Ouwerkerk, Jannemieke, “All 'bout the Money? On the Division of Costs in the Context of EU Criminal Justice Cooperation and the Potential Impact on the Safeguarding of EU Defence Rights", EJCCL\&CJ 25 (2017) [Chap. 1]

- Paridaens, D. J. M. W., “The Extradition of Nationals According to Dutch Law”, RIDP 62 (1991) [Chap. 8]

- PARRY, John T., “The Lost History of International Extradition Litigation”, VJIL 43 (2002) [Chap. 7]

- PedAin, Antje du-Bois, "The Right to Family Life in Extradition Cases: More Defendant-Friendly than Strasbourg Requires”, CLJ 69 (2010) [Chap. 6]

- PeErs, Steve, EU Justice and Home Affairs Law, $2^{\text {nd }}$ ed., Oxford: University Press, 2006 [Chap. 6] / $3^{\text {rd }}$ ed., 2011 [Chap. 2]

- PeERs, Steve, EU Justice and Home Affairs Law - Volume I: EU Immigration and Asylum Law, Oxford: University Press, 2016 [Chap. 4, 8]

- PEERs, Steve, "Extradition to non-EU countries: the limits imposed by EU citizenship", EU Law Analysis, 7 September 2016, in http://eulawanalysis.blogspot.com [Chap. 2, 4]

- PEERS, Steve, "EU Referendum Brief 5: How would Brexit impact the UK's involvement in EU policing and criminal law?", 21 June 2017, http://eulawanalysis.blogspot.com [Chap. 5] 
- PeErs, Steve, "The Beginning of the End? Citizens' rights in the Brexit 'Sufficient Progress' deal”, 9 December 2017, in http://eulawanalysis.blogspot.com [Chap. 5]

- Pendleton, Michael, "Non-empirical Discovery in Legal Scholarship - Choosing, Researching and Writing a Traditional Scholarly Article", in Michael McConville / Wing Hong Chui (eds.), Research Methods for Law, Edinburgh: University Press, 2007 (2007) [Chap. 2]

- Pereira, Luís Silva / Martins, Teresa Alves, "O princípio ne bis in idem e os conflitos internacionais de jurisdição", RCEJ 7 (2007) [Chap. 6]

- Pereira, Luís Silva, "Alguns aspectos da implementação do regime relativo ao mandado de detenção europeu”, RMP 96 (2003) [Chap. 6]

- Pereira, Luís Silva, "Contributo para uma Interpretação dos Artigos 12 n. 1 al. g) e $13 .^{\circ}$ al. c) da Lei n. ${ }^{\circ}$ 65/2003, de 23 de Agosto", RCEJ 7 (2007) [Chap. 6]

- Peristeridou, Christina, The principle of legality in European criminal law, Antwerp: Intersentia, 2015 [Chap. $4,7]$

- PERRY, Gregory Chadwick, "Comment - The Four Major Western Approaches to the Political Offense Exception to Extradition: From Inception to Modern Terrorism”, MLRev. 40 (1989) [Chap. 8]

- PERSAK, Nina, Criminalising Harmful Conduct: The Harm Principle, its Limits and Continental Counterparts, London: Springer, 2007 [Chap. 8]

- Petersen, Antje C., "Extradition and the Political Offense Exception in the Suppression of Terrorism", ILJ 67 (1992) [Chap. 8]

- Pettigrew, Mark, "A Tale of Two Cities: Whole of Life Prison Sentences in Strasbourg and Westminster”, EJCCL\&CJ 23 (2015) [Chap. 3]

- PetTigrew, Mark, "A Vinter retreat in Europe: Returning to the issue of whole life sentences in Strasbourg”, NJECL 8 (2017) [Chap. 3]

- PiÇARra, Nuno, "As revisões constitucionais em matéria de extradição. A influência da União Europeia”, in Themis - Edição Especial: 30 Anos da Constituição Portuguesa 1976-2006, Lisboa, 2006 [Chap. 6]

- PIÇARRA, Nuno, "A proibição constitucional de extraditar nacionais em face da União Europeia”, RCEJ 7 (2007) [Chap. 1, 4, 6]

- Piggot, Francis Taylor, Extradition. A treatise on the law relating to fugitive offenders, London: Butterworth \& Co., 1910 [Chap. 1]

- PIRIS, Jean-Claude, The Lisbon Treaty - A Legal and Political Analysis, Cambridge: University Press, 2010 [Chap. 2]

- PŁACHTA, Michał, "Human Rights Aspects of the Prisoner Transfer in a Comparative Perspective", LLR 53 (1993) [Chap. 8]

- PŁACHTA, Michał, “(Non-)Extradition of Nationals: A Neverending Story?”, EILR 13 (1999) [Chap. 2]

- PlachtA, Michael, “Aut Dedere Aut Judicare: An Overview of Modes of Implementation and Approaches", MJE\&CL 6 (1999) [Chap. 1]

- PLACHTA, Michael, “European Arrest Warrant: Revolution in Extradition?”, EJCCL\&CJ 11 (2003) [Chap. 2]

- POLLOCK, Joycelyn M., Criminal Law, 11 th ed., New York: Routlegde, 2016 [Chap. 8]

- Posner, Eric A. / Vermeule, Adrian, “Transitional Justice as Ordinary Justice”, HLR 117 (2004) [Chap. 7]

- Pradel, Jean / Cortens, Geert, Droit Pénal Européen, Paris: Éditions Dalloz, 2.e ed., 2002 [Chap. 6]

- Prosperi, Luigi / Terrosi, Jacopo, "Embracing the 'Human Factor': Is There New Impetus at the ICC for Conceiving and Prioritizing Intentional Environmental Harms as Crimes Against Humanity?", JICJ 15 (2017) [Chap. 8] 
- PyLE, Christopher H., Extradition, Politics, and Human Rights, Philadelphia: Temple University Press, 2001 [Chap. 1, 2, 8]

- QueIró, Afonso, “A função administrativa”, RDES 24 (1977) [Chap. 8]

- QuigLEY, John, “The Rule of Non-Inquiry and the Impact of Human Rights on Extradition Law”, NCJIL \&C 15 (1990) [Chap. 8]

- Quintano Ripolés, Antonio, Tratado de Derecho Penal Internacional e Internacional Penal, Tomo II, Madrid: Instituto Francisco de Vitoria, 1955 [Chap. 8]

- RAMOs, Rui Manuel Moura , “L’ordre public international en droit portugais”, in BFDUC 74 (1998) [Chap. 7]

- Ramos, Rui Manuel Moura, Da Lei Aplicável ao Contrato de Trabalbo Internacional, Coimbra: Almedina, 1991 [Chap. 7]

- Ramos, Rui Manuel Moura, Estudos de Direito Internacional Privado e de Direito Processual Civil Internacional-II, Coimbra: Coimbra Editora, 2007 [Chap. 7]

- Ramos, Vânia Costa, "Ne bis in idem e Mandado de Detenção Europeu. Comentário ao Caso Gaetano

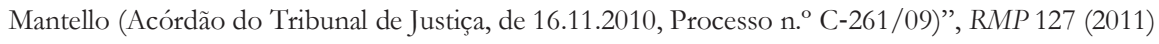
[Chap. 6]

- RAwLs, John, The Law of Peoples; with The Idea of Public Reason Revisited, Harvard: University Press, 1999 [Chap. 7, 9]

- Rebane, Kai I., "Extradition and Individual Rights: The Need for an International Criminal Court to Safeguard Individual Rights”, FILJ 19 (1995) [Chap. 8]

- ReEves, J. S., "Extradition Treaties and the Death Penalty”, in AJIL 18 (1924) [Chap. 3]

- REMPEL, William C., "How Colombia is busting drug cartels", 19 January 2012, in www.edition.cnn.com/2012/01/18/opinion/rempel-colombia-extradite-cartels/ [Chap. 7]

- Richardson, Gregory B., "Double criminality and complex criminal offences", RIDP 62 (1991) [Chap. 6]

- Ritz, Christian / VASCONCELOS, Bernardo, "Extradition discrimination? Pisciotti's legal battle continues as Regional Court of Berlin refers questions of fundamental EU law principles to the CJEU”, ECompLR 37 (2016) [Chap. 4]

- Rizcallah, Cecilia, “The EU and the Spanish Constitutional Crisis”, EU Law Analysis, 6 November 2017, in www.eulawanalysis.blogspot.com [Chap. 8]

- Rocha, Manuel António Lopes / MARTins, Teresa Alves, Cooperação Judiciária Internacional em Matéria Penal: Comentários, Lisboa: Aequitas / Editorial Notícias, 1992 [Chap. 1, 5, 6]

- RochA, Manuel António Lopes, “Aplicação da lei criminal no tempo e no espaço”, in Jornadas de Direito Criminal. O Novo Código Penal Português e Legislação Complementar. Lisboa: Centro de Estudos Judiciários, 1983 [Chap. 6]

- Rodrigues, Anabela Miranda, “O Mandado de Detenção Europeu - Na Via da Construção de um Sistema Penal Europeu: Um Passo ou um Salto?”, RPCC 13 (2003) [Chap. 6]

- Rodrigues, Anabela Miranda, O Direito Penal Europeu Emergente, Coimbra: Coimbra Editora, 2008 [Chap. 2]

- Rodrigues, Joana Amaral, “As Sanções (ou Medidas Restritivas) Internacionais: Enquadramento e Questões Jurídicas Fundamentais”, Themis 24/25 (2013) [Chap. 7]

- RÖHrig, Markus, "Nowhere to Hide? Extradition in Antitrust Cases from a European Perspective", JECL\&P 6 (2015) [Chap. 4]

- Roxin, Claus, Derecho Penal. Parte General. Tomo I: Fundamentos. La Estructura de la Teoria del Delito (1994), Madrid: Civitas, 1997 [Chap. 8]

- Ruggieri, Stefano, Audi Alteram Partem in Criminal Proceedings: Towards a Participatory Understanding of Criminal Justice in Europe and Latin America, Cham: Springer, 2017 [Chap. 1] 
- RUI, Jon Petter / SIEBER, Ulrich (eds.), Non-Conviction-Based Confiscation in Europe: Possibilities and Limitations on Rules Enabling Confiscation without a Criminal Conviction, Berlin: Max-Planck-Institut, 2015 [Chap. 7]

- Rusche, Georg / KirchHeImer, Otto, Punishment and Social Structure, Columbia: University Press, 1939 [Chap. 7]

- RYNGAERT, Cedric / ABDALLA, Abdullahi Abdulrahman, "Extradition of Terrorism Suspects: ECtHR Rules on the Compatibility of Life without Parole with the European Convention. The Case of Nizar Trabelsi v. Belgium", Ucall, 16 January 2015 [Chap. 2, 3]

- RYNGAERT, Cedric, Jurisdiction in International Law. United States and European Perspectives, Katholieke Universiteit Leuven, 2007 [Chap. 1]

- RYNGaERT, Cedric, "Does the European Court of Human Rights read the UCall blog? Court makes Uturn in life imprisonment cases", Ucall Blog, 24 February 2015, in https://unijuris.sites.uu.nl [Chap. 3]

- SADOFF, David A., Bringing International Fugitives to Justice: Extradition and its Alternatives, Cambridge: University Press, 2016 [Chap. 7, 8]

- SAMBEI, Arvinder "The Political Offence Exception”, in John R. W. D. Jones (general ed.) / Rosemary Davidson (assistant ed.) / Arvinder Sambei (contributor) / Brian Gibbins (contributor), Extradition and Mutual Legal Assistance Handbook, $2^{\text {nd }}$ ed., Oxford: University Press, 2010 [Chap. 6]

- SAMuel, Geoffrey, An Introduction to Comparative Law Theory and Method, Oxford: Hart, 2014 [Chap. 2]

- SANDS, Philippe (ed.), From Nuremberg to The Hague: The Future of International Criminal Justice, Cambridge: University Press, 2003 [Chap. 7]

- SANDs, Philippe, East West Street: On the Origins of 'Genocide' and 'Crimes Against Humanity', London: Weidenfeld \& Nicolson, 2016 [Chap. 7]

- SANTOS, Boaventura de Sousa (coord.), The European Arrest Warrant in Law and in Pratice: A Comparative Study for the Consolidation of the European Law-Enforcement Area, Coimbra: Centro de Estudos Sociais, 2010 [Chap. 5]

- SARmiento, Daniel, “The Strange (German) Case of Mr. Puigdemont's European Arrest Warrant”, Verfassungsblog, 11 April 2018, in www.verfassungsblog.de [Chap. 8]

- SARTORI, Daria, "Gap-Filling and Judicial Activism in the Case Law of the European Court of Human Rights”, TE\& CLF 29 (2014) [Chap. 2]

- SATZger, Helmut, “The Future of European Criminal Law Between Harmonization, Mutual Recognition and Alternative Solutions", JECL 1 (2006) [Chap. 2]

- SATZgER, Helmut, International and European Criminal Law, München: Nomos, 2012 [Chap. 4]

- SATZger, Helmut, "Is mutual recognition a viable general path for cooperation?”, in Pedro Caeiro (org.), Proceedings of the Conference 'European Criminal Law In The Global Context: Values, Principles and Policies' (Abstracts), Coimbra: IJ, 2018 [Chap. 2]

- SAvigny, Friedrich Carl von, Private International Law: A Treatise on the Conflict of Laws, and the Limits of Their Operation in Respect of Place and Time (transl. William Guthrie), Edinburgh: T. \& T. Clark, 1869 [Chap. 7, 9]

- SCHABAS, William A., "Soering's Legacy: The Human Rights Committee and the Judicial Committee of the Privy Council Take a Walk Down Death Row”, I E CLQ 43 (1994) [Chap. 2, 4]

- SCHABAS, William A., "International Law and Abolition of the Death Penalty", WéLLR 55 (1998) [Chap. 7]

- SCHABAS, William A., The Abolition of the Death Penalty in International Law, $3^{\text {rd }}$ ed., Cambridge: University Press, 2002 [Chap. 3]

- SCHabas, William A., "The Contribution of the Eichmann Trial to International Law", LJIL 26 (2013) [Chap. 7, 8]

- SCHABAs, William A., The European Convention on Human Rights: A Commentary, Oxford: University Press, 2015 [Chap. 3] 
- Scheffer, Thomas / Hannken-Illjes, Kati / Kozin, Alexander, Criminal Defence and Procedure: Comparative Ethnographies in the United Kingdom, Germany, and the United States, Basingstoke: Palgrave Macmillan, 2010 [Chap. 1]

- SCHEININ, Martin, "European human rights as universal rights - In defence of a holistic understanding of human rights", in Eva Brems / Janneke Gerards (eds.), Shaping Rights in the ECHR. The Role of the European Court of Human Rights in Determining the Scope of Human Rights, Cambridge: University Press, 2014 [Chap. 2, 3]

- SCHLÜTTER, Birgit, “Aspects of human rights interpretation by UN treaty bodies”, in Helen Keller / Geir Ulfstein (eds.), UN Human Rights Treaty Bodies: Law and Legitimacy, Cambridge: University Press, 2012 [Chap. 2]

- SCHÖnenberg, Regine / VON SCHÖnfELD, Annette (orgs.), Transnational Organized Crime: Analyses of a Global Challenge to Democracy, Bielefeld: Transcript, 2013 [Chap. 7]

- SciacchitANO, Giusto, "Doppia incriminazione nelle maxi-istruttorie relative a casi di criminalità organizzata”, RIDP 62 (1991) [Chap. 6]

- Selvaggi, Eugenio, "Dual criminality in abstracto or in concreto?", Discussion Paper of the CoE Committee of Experts on the Operation of European Conventions on Co-operation in Criminal Matters, PCOC/Documents 2011/PC-OC(2011)19E, 2011, in www.coe.int/tcj/ [Chap. 8]

- Semmelman, Jacques, "Federal Courts, the Constitution, and the Rule of Non-Inquiry in International Extradition Proceedings", CorLR 76 (1991) [Chap. 8]

- Semmelman, Jacques, "The Doctrine of Specialty in the Federal Courts: Making Sense of United States v. Rauscher", VJIL 34 (1993) [Chap. 8]

- Serrano, Mário Mendes, "Extradição. Regime e praxis”, in José Manuel da Cruz Bucho et al., Cooperação Internacional Penal, Volume I, Lisboa: CEJ, 2000 [Chap. 5, 6]

- SHAW, Malcolm N., International Law, 6th ed., Cambridge: University Press, 2008 [Chap. 2, 3, 8]

- SHEA, Michael P. Expanding Judicial Scrutiny of Human Rights in Extradition Cases After Soering, YJIL 17 (1992) [Chap. 8]

- SHEARER, Ivan Anthony, "Non-Extradition of Nationals - A Review and Proposal", ALR 2 (1966) [Chap. 3]

- SHEARER, Ivan Anthony, Extradition in International Law, Manchester: University Press, 1971 [Chap. 2, 3, $6,7,8]$

- Silva, Germano Marques da, Direito Penal Português I, Parte Geral: Introdução e Teoria da Lei Penal, Lisboa: Editorial Verbo, 2001 [Chap. 6]

- SILVIS, Johannes, “Human Rights as a 'Living Concept”, EJTN, 29 April 2014, in www.ejtn.eu [Chap. 2]

- SMET, Stijn, 'The 'absolute' prohibition of torture and inhuman or degrading treatment in Article 3 ECHR - Truly a question of scope only?”, in Eva Brems / Janneke Gerards (eds.), Shaping Rights in the ECHR: The Role of the European Court of Human Rights in Determining the Scope of Human Rights, Cambridge: University Press, 2013 [Chap. 3]

- SoAres, Rogério Ehrhardt, “Administração Pública e Controlo Judicial”, RLJ 127 (1994-5) [Chap. 8]

- Somers, Margaret R., Genealogies of Citizenship: Markets, Statelessness, and the Right to Have Rights, Cambridge: University Press, 2008 [Chap. 8]

- Spencer, John R., Hearsay Evidence in Criminal Proceedings, Oxford: Hart, 2008 [Chap. 1]

- SPENCER, John R., "Implementing the European Arrest Warrant: A Tale of How Not to Do it”, StLR 30 (2009) [Chap. 5, 6]

- SpenCER, John R., "Fair trial rights and the European Arrest Warrant", CLJ 69 (2010) [Chap. 6]

- SPENCER, John R., “Extradition, the European Arrest Warrant and Human Rights”, CLJ 72 (2013)

[Chap. 8] 
- Stanbrook, Ivor / Stanbrook, Clive, Extradition: Law and Practice, 2nd ed., Oxford: University Press, 2000 [Chap. 6, 8]

- Stefano, Gianni De, "Meet the First Extradited Businessman on Cartel Charges", JECL\&P 8 (2017) [Chap. 4]

- STEPHEN, Chris, "We want you: extradition in the UK Supreme Court”, EdLR 15 (2011) [Chap. 6]

- Strandbakken, Asbjørn, "Extradition between Nordic countries and the new Nordic Arrest Warrant", in Nico Keijzer / Elies van Sliedregt (eds.), The European Arrest Warrant in Practice, The Hague: T.M.C. Asser Press, 2009 [Chap. 2]

- Stumpf, Juliet P., "The Process is the Punishment in Crimmigration Law", in Katja Franko Aas / Mary Bosworth (eds.), The Borders of Punishment: Migration, Citizenship, and Social Exclusion, Oxford: University Press, 2013 [Chap. 7]

- Sullivan, JR., Frank, “A Separation of Powers perspective on Pinochet”, II\&CLR 14 (2004) [Chap. 6]

- Suominen, Annika, “The Nordic Arrest Warrant finally in force”, ECrimLR, 4 (2014) [Chap. 2]

- SWAAK-Goldman, Olivia, "Recent Developments in International Criminal Law: Trying to Stay Afloat Between Scylla and Charybdis", I\&CLQ 54 (2005) [Chap. 1]

- SWART, Bert, Nederlands Uitleveringsrecht, Zwolle: W.E.J. Tjeenk Willink, 1986 [Chap. 5]

- SWART, Bert, "Human Rights and the Abolition of Traditional Principles", in Albin Eser / Otto Lagodny (eds), Principles and Procedures for a New Transnational Criminal Law, Freiburg: Max Planck Institut, 1992 [Chap. 3, 6, 7, 8, 9]

- SWART, Bert, "Refusal of Extradition and the United Nations Model Treaty on Extradition", NYIL 23 (1992) [Chap. 2, 3, 5, 6, 8]

- SWART, Bert "Extradition", in Bert Swart / André Klip (eds.), International Criminal Law in the Netherlands, Freiburg im Breisgau: Edition Iuscrim, 1997 [Chap. 1, 6, 8]

- TAte, David A., "Draft Evasion and the Problem of Extradition", AlbLR 32 (1968) [Chap. 8]

- Teitel, Ruti G., “Transitional Justice Genealogy”, HHRJ 16 (2003) [Chap. 7]

- THOMAS, Christopher / STEFANO, Gianni de, "Extradition \& antitrust: cautionary tales for global cartel compliance", MLex Ab Extra, 30 September 2016 [Chap. 4]

- TIGAR, Michael E., "The extradition requirement of double criminality in complex cases: illustrating the rationale of extradition", RIDP 62 (1991) [Chap. 6]

- ToltTILA, Karri, “The Nordic Arrest Warrant: What Makes for Even Higher Mutual Trust?, NJECL 2 (2011) [Chap. 2]

- TOP, Sibel, “The European Arrest Warrant against Puigdemont: A feeling of déjà vu?”, EJIL: Talk!, 3 November 2017, in www.ejiltalk.org [Chap. 8]

- Tosato, Gian Luigi, "Some remarks on the limits to mutual recognition of judicial decisions in civil and criminal matters within the European Union, RDIPP 38 (2002) [Chap. 2]

- Townsend, Robert, “The Whistle Blower as Entrepreneur", in Ralph Nader / Peter J. Petkas / Kate Blackwell (eds.), Whistle blowing: the report of the Conference on Professional Responsibility, New York: Grossman Publishers, 1972 [Chap. 8]

- Trechsel, Stefan, Human Rights in Criminal Proceedings, Oxford: University Press, 2006 [Chap. 1]

- Turner, Jenia Iontcheva, "Interstate Conflict and Cooperation in Criminal Cases: An American Perspective", ECrimLR 4 (2014) [Chap. 2, 3]

- TURNs, David, "Pinochet's fallout: jurisdiction and immunity for criminal violations of international law», LS 20 (2000) [Chap. 2, 7]

- Tushnet, Mark V., Weak Courts, Strong Rights: Judicial Review and Social Welfare Rights in Comparative Constitutional Law, Princeton: University Press, 2008 [Chap. 8] 
- Tyler, Katherine / NApley, Kingsley / Sternberg, Daniel, "Extradition: bars to extradition (Insight)", Westlaw, last updated 22 December 2014 [Chap. 6]

- Tyler, Katherine / NApley, Kingsley / Sternberg, Daniel, “Extradition: special cases”, Westlaw, last updated 20 February 2015 [Chap. 6]

- VABres, Henri Donnedieu de, Supplément au Traité élémentaire de droit criminel et de législation pénale comparée: $2 e$ éd., Le Droit pénal du Gouvernement provisoire de la République française, Paris: Librairie du Recueil Sirey, 1946 [Chap. 1]

- Valente, Manuel Monteiro Guedes, Do mandado de detenção europeu, Coimbra: Almedina, 2006 [Chap. 6]

- VAN BALlegooij, Wouter, The Nature of Mutual Recognition in European Law - Re-examining the Notion from an Individual Rights Perspective With a view to Its Further Development in the Criminal Justice Area, Antwerp: Intersentia, 2015 [Chap. 2]

- VAN BOCKEL, Bas, “The 'European' Ne Bis in Idem Principle: Substance, Sources, and Scope”, in Bas van Bockel (ed.), Ne Bis in Idem in EU LAW, Cambridge: University Press, 2016 [Chap. 3, 8]

- VAN DEN Wyngaert, Christine, The Political Offence Exception to Extradition: The Delicate Problem of Balancing the Rights of the Individual and the International Public Order, Deventer: Kluwer, 1980 [Chap. 1, 7, 8, 9]

- VAn Den WyngaerT, Christine, “The Political Offence Exception to Extradition: Defining the Issues and Searching a Feasible Alternative”, RBDI 17 (1983) [Chap. 8]

- VAN DEN WyNGAERT, Christine, “Applying the European Convention on Human Rights to Extradition: Opening Pandora's Box?”, I\& CLQ 39 (1990) [Chap. 3]

- VAN DEN WyngaERT, Christine, “The political offence exception to extradition: How to plug the 'terrorists' loophole' without departing from fundamental human rights", RIDP 62 (1991) [Chap. 8]

- VAN DEN WYNGAERT, Christine, "Rethinking the law of international cooperation: the restrictive function of international human rights through individual-oriented bars", in Albin Eser / Otto Lagodny (eds.), Principles and Procedures for a New Transnational Criminal Law, Freiburg im Breisgau: Society for the Reform of Criminal Law | Max Planck Institute for Foreign and International Criminal Law, 1992 [Chap. 6]

- VAN DEN WYNGAERT, Christine, “Double criminality as a requirement to jurisdiction”, in John Dugard / Christine van den Wyngaert (eds.), International Criminal Law and Procedure, Aldershot: Dartmouth Pub. Co., 1996 [Chap. 1, 4, 6, 7, 8]

- VAN DER MEI, Anne Pieter, "EU external relations and inter-institutional conflicts: the battlefield of Article 218 TFEU”, MJECL 23 (2016) [Chap. 4]

- VAN DER MEI, Anne Pieter, "Flexibility and differentiation: A plea for allowing national differentiation in the fundamental rights domain”, in Bruno De Witte / Andrea Ott / Ellen Vos (eds.), Between Flexibility and Disintegration The Trajectory of Differentiation in EU Law, Cheltenham: Edward Elgar, 2017 [Chap. 2, 3, 7]

- VAN DER WILT, Harmen, “On the Hierarchy between Extradition and Human Rights”, in Erika De Wet / Jure Vidmar (eds.), Hierarchy in International Law: The Place of Human Rights, Oxford: University Press, 2012 [Chap. 2, 3, 4, 7, 8]

- VAN ELST, Richard / VAN DER WILT, Harmen, "Netherlands”, RIDP 79 (2008) [Chap. 1]

- VAN SLIEDREgt, Elies, Individual Criminal Responsibility in International Law, Oxford: University Press, 2012 [Chap. 7]

- VAndekerckhove, Wim / Uys, Tina / Rehg, Michael T. / Brown, A. J., "Understandings of whistleblowing: Dilemmas of societal culture", in A. J. Brown / David Lewis / Richard E. Moberly / Wim Vandekerckhove (eds.), International Handbook on Whistleblowing Research, Cheltenham: Edward Elgar, 2014 [Chap. 8]

- Vasconcelos, Bernardo, “The Pisciotti Saga: A Duel in Karlsruhe as Finale?”, Verfassungsblog, 15 April 2018, in www.verfassungsblog.de [Chap. 4] 
- VAVOULA, Niovi, "The interplay between EU immigration law and national criminal law - The case of the Return Directive", in Valsamis Mitsilegas / Maria Bergström / Theodore Konstadinides (eds.), Research Handbook on EU Criminal Law, Cheltenham: Edward Elgar, 2016 [Chap. 4]

- VEIGA, António Miguel, "Da Relevância da Vontade do Visado na Extradição Passiva e na Execução do Mandado de Detenção Europeu”, RPCC 22 (2012) [Chap. 6]

- Vernimmen-Van Tiggelen, Gisèle / Surano, Laura, Analysis of the future of mutual recognition in criminal matters in the EU, Institute for European Studies, Université Libre de Bruxelles / European Criminal Law Academic Network, 2008 [Chap. 2]

- Vervaele, John, "European Criminal Law and General Principles of Union Law”, RPL 5 (2005) [Chap. 2]

- Vervaele, John, “The European Arrest Warrant and Applicable Standards of Fundamental Rights in the EU” - ECJ Judgment (Grand Chamber) C-399/11 of 26 February 2013”, REAdmL 2 (2013) [Chap. 2]

- Vervaele, John, “Ne Bis In Idem: Towards a Transnational Constitutional Principle in the EU?”, ULR 9 (2013) [Chap. 3, 8]

- VestergaArD, Jørn / AdAmo, Silvia, "Mutual Recognition in Criminal Matters: The Danish Experience", SSL 54 (2009) [Chap. 2]

- VIDmar, Jure, Democratic Statehood in International Law: The Emergence of New States in Post-Cold W ar Practice, Oxford: Hart, 2013 [Chap. 8]

- VIDMAR, Jure, “Catalonia: The Way Forward is Comparative Constitutional Rather than International Legal Argument”, EJIL: Talk!, 24 October 2017, in www.ejiltalk.org [Chap. 8]

- VIEIRA, Manuel Adolfo, “L'évolution récente de l'extradition dans le continent américain”, CCHAIL 185 (1984) [Chap. 7]

- VIEN, Michael, "Provisional Arrest, Release and the Role of Interpol”, RIDP 62 (1991) [Chap. 8]

- Villefort, Alfred, Des Traités d'extradition de la France avec les pays étrangers, Paris: A. Guyot et Scribe, 1851 [Chap. 1]

- VOGLER, Theo, “The rule of speciality in extradition Law”, RIDP 62 (1991) [Chap. 6]

- VON Hirsch, Andrew, "Proportionality in the Philosophy of Punishment", CJ 16 (1992) [Chap. 8]

- VON HiRsCH, Andrew, Censure and Sanctions, Oxford: Oxford University Press, 2003 (rep.) [Chap. 1, 8]

- VON LISZT, Franz, "Die deterministischen Gegner der Zweckstrafe", ZStW 13 (1893) [partly translated into English in JICJ 5 (2007)] [Chap. 7]

- VRanken, Jan, "Methodology of Legal Doctrinal Research”, in Mark van Hoecke (ed.), Methodologies of Legal Research: Which Kind of Method for What Kind of Discipline?, Oxford: Hart, 2011 [Chap. 2]

- VReELAnd, James Raymond, "Political Institutions and Human Rights: Why Dictatorships Enter into the United Nations Convention Against Torture”, IO 62 (2008) [Chap. 2]

- WARBrICK, Colin, "Recent developments in UK extradition law", I\&CLQ 56 (2007) [Chap. 6]

- Warleigh, Alex, Democracy and the European Union: Theory, Practice and Reform, London: Sage, 2003 [Chap. $2,4]$

- Weyembergh, Anne, “L'impact du 11 septembre sur l'équilibre sécurité / liberté dans l'espace pénal européen”, Emmanuelle Bribosia / Anne Weyembergh (eds.), Lutte contre le terrorism et droits fondamentaux, Bruxelles: Bruylant, 2002 [Chap. 2]

- Weyembergh, Anne, "Le rapprochement des législations pénales au sein de l’Union européenne: les difficultés et leurs consequences", in Gilles de Kerchove et al., L'espace pénal européen: Enjeux et perspectives, Bruxelles: Ed. de l’Université, 2002 [Chap. 2]

- Weyembergh, Anne, “L’espace pénal européen”, in Lucette Defalque (coord.), Actualités en droit européen et rappel de quelques principes, Bruxelles: Bruylant, 2006 [Chap. 4, 6] 
- Weyembergh, Anne, “Consequences of Brexit for European Union criminal law”, NJECL 8 (2017) [Chap. 5]

- WieHL, Lis, "Extradition Law at the Crossroads: The Trend toward Extending Greater Constitutional Procedural Protections to Fugitives Fighting Extradition from the United States", MJIL 19 (1998) [Chap. 8]

- WiLKITSKI, Peter, "Defences, Exceptions and Exemption in the Extradition Law and Practice and the Criminal Policy of the Federal Republic of Germany (Excuding the 'Political Offence' Defence", RIDP 62 (1991) [Chap. 8]

- Willems, Auke, "Extradition on the Two Sides of the Atlantic: The U.S. Model as Blueprint for the European Arrest Warrant?", Criminal Law Forum 27 (2016) [Chap. 2, 4]

- WiLliams, Sharon A., “The Double Criminality Rule Revisited”, ILR 27 (1993) [Chap. 6, 8]

- Wilson, John A., The Culture of Ancient Egypt, Chicago: University Press, 1951 [Chap. 3]

- Wilson, John A., "Egyptian Treaty", in James B. Pritchard (ed.), Ancient Near Eastern Texts Related to the Old Testament, Princeton: University Press, 1969 [Chap. 3]

- Wims, Michael D., "Re-examining the Traditional Exceptions to Extradition”, RIDP 62 (1991) [Chap. 8]

- WIRTH, Steffen, “Immunity for core crimes? The ICJ's Judgment in the Congo v. Belgium case”, EJIL 13 (2002) [Chap. 2]

- Wise, Edward M., "Extradition: The Hypothesis of a Civitas Maxima and the Maxim Aut Dedere Aut Judicare", RIDP 62 (1991) [Chap. 7]

- Wise, Edward M., “The Obligation to Extradite or Prosecute", ILR 27 (1993) [Chap. 1]

- WoOD, Michael, "The Principle of Non-intervention in Contemporary International Law: Noninterference in a State's Internal Affairs used to be a Rule of International Law: Is it still?", Summary of the Chatham House International Law discussion group meeting held on 28 February 2007", in www.chathamhouse.org [Chap. 7]

- Wouters, Werner, “Urhi-Tešub and the Ramses-Letters from Boghazköy”, JCS 41 (1989) [Chap. 8]

- ZAÏrI, Anna, Le principe de la spécialité de l'extradition au regard des droits de l'homme, Paris: Librairie Générale de Droit et de Jurisprudence, 1992 [Chap. 8]

- ZANOTTI, Isidoro, Extradition in Multilateral Treaties and Conventions, Leiden: Martinus Nijhoff, 2006 [Chap. 3]

- ZARTNER, Dana / RAMOS, Jennifer, "Human Rights as Reputation Builder: Compliance with the Convention Against Torture", HRR 12 (2012) [Chap. 2]

- Zimmermann, Robert, La Coopération Judiciaire Internationale en Matière Pénale, Bruxelles: Staempfli Editions / Bruylant, 2004 [Chap. 6, 8]

- ZÜHLKE, Susanne / PASTILLE, Jens-Christian, "Extradition and the European Convention - Soering revisited", ZRV 59 (1999) [Chap. 8] 


\section{II - Normative Instruments}

\section{A - United Nations}

- Charter of the UN of 1945

- Convention Against Corruption of 2003

- Convention against Illicit Traffic in Narcotic Drugs and Psychotropic Substances of 1988

- Convention against the Taking of Hostages of 1979

- Convention against Torture and Other Cruel, Inhuman or Degrading Treatment or Punishment of 1984 [UNCAT]

- Convention Against Transnational Organized Crime of 2000

- Convention for the Suppression of Acts of Nuclear Terrorism of 2005

- Convention for the Suppression of Terrorist Bombing of 1997

- Convention for the Suppression of the Financing of Terrorism of 1999

- Convention on Consular Relations of 1963

- Convention on Diplomatic Relations of 1961

- Convention on Special Missions of 1969

- Convention on the Law of Treaties of 1969

- Convention on the Non-Applicability of Statutory Limitations to War Crimes and Crimes against Humanity of 1968

- Convention on the Prevention and Punishment of the Crime of Genocide of 1948

- Convention on the Privileges and Immunities of the Specialized Agencies of 1947

- Convention on the Representation of States in their Relations with International Organisations of a Universal Character of 1975

- Convention relating to the Status of Refugees of 1951; Protocol of 1967

- Declaration on Principles of International Law concerning Friendly Relations and Co-operation among States in accordance with the Charter of the UN of 1970

- Draft Agreement on Legal Assistance (STL)

- Draft Articles on Responsibility of States for Internationally Wrongful Acts of 2001

- General Convention on the Privileges and Immunities of the UN of 1946

- Geneva Conventions of 1949

- Headquarters Convention between the UN and the USA of 1947

- International Covenant on Civil and Political Rights of 1966 [ICCPR]

- Methods of the UNWGAD

- Model Agreement on the Transfer of Foreign Prisoners of 1985

- Model Law on Extradition of 2002 [UN-MLE]

- Model Treaty on Extradition 1997 [UN-MTE]

- Model Treaty on Mutual Assistance in Criminal Matters of 1990

- Model Treaty on the Transfer of Proceedings in Criminal Matters of 1990 
- Model Treaty on the Transfer of Supervision of Offenders Conditionally Sentenced or Conditionally Released of 1990

- Regulation 2000/15 of the UN Transitional Administration in East Timor

- Rules of Procedure and Evidence of the ICC

- Rules of Procedure and Evidence of the ICTR

- Rules of Procedure and Evidence of the ICTY

- Rules of Procedure and Evidence of the STL

- Security Council Resolution 2166 (2014) [on the downing of Malaysia Airlines flight MH17]

- Security Council Resolution 827(1993) [Establishing the ICTY]

- Security Council Resolution 955 (1994) [Establishing the ICTR]

- Standard Minimum Rules for the Treatment of Prisoners of 1955

- Statute of the ICC

- Statute of the ICJ

- Statute of the ICTR

- Statute of the ICTY

- Universal Declaration of Human Rights of 1948 [UDHR]

[All available at www.un.org, www.ohchr.org, www.icc-cpi.int, http://unictr.unmict.org/, www.icty.org/, and www.stl-tsl.org/.]

\section{B - Council of Europe}

- Convention for the Protection of Human Rights and Fundamental Freedoms, of 4 November 1950 [ECHR]; Protocol no. 6, of 18 April 1983; Protocol no. 13, of 3 May 2002

- Convention on Extradition, of 13 December 1957; Additional Protocol, of 15 October 1975

- Convention on Laundering, Search, Seizure and Confiscation of the Proceeds from Crime Strasbourg, of 8 November 1990

- Convention on Mutual Assistance in Criminal Matters, of 17 March 1978; Second Additional Protocol, of 8 November 2001

- Convention on Mutual Assistance in Criminal Matters, of 20 April 1959; Additional Protocol, of 17 March 1978; Second Additional Protocol, of 8 November 2001

- Convention on the International Validity of Criminal Judgments, of 28 May 1970

- Convention on the Transfer of Proceedings in Criminal Matters, of 15 May 1972

- Convention on the Transfer of Sentenced Persons, of 21 March 1983; Additional Protocol, of 18 December 1997

- European Prison Rules - Recommendation Rec(2006)2 of the Committee of Ministers to Member States, of 11 January 2006

- Statute of the CoE, of 5 May 1949

[All available at https://www.coe.int.]

\section{C - European Union}

- Agreement between the EU and the Republic of Iceland and the Kingdom of Norway on the surrender procedure between the Member States of the EU and Iceland and Norway - OJ L 292, 21 October 2006

- Agreement on extradition between the EU and the USA - OJ L 181, 19 July 2003

- Charter of Fundamental Rights of the EU, of 7 December 2000 - OJ C 202, 7 June 2016 [CFREU] 
- Convention implementing the Schengen Agreement of 14 June 1985 between the Governments of the States of the Benelux Economic Union, the Federal Republic of Germany and the French Republic on the gradual abolition of checks at their common borders, of 19 June 1990 - OJ L 239, 22 September 2000 [CISA]

- Convention on Extradition between the Member States of the EU, of 27 September 1996 - OJ C 313, 23 June 1996

- Convention on Mutual Assistance in Criminal matters between the Member States of the EU, of 29 May 2000 - OJ C 197, 12 July 2000; Additional Protocol - OJ C 326, 21 November 2001

- Convention on Simplified Extradition Procedure, of 10 March 1995 - OJ C 78, 30 March 1995

- Cooperation agreement between Eurojust and Ukraine, Brussels on 27 June 2016 http://eurojust.europa.eu

- Directive 2011/95/EU of the European Parliament and of the Council of 13 December 2011, on standards for the qualification of third-country nationals or stateless persons as beneficiaries of international protection, for a uniform status for refugees or for persons eligible for subsidiary protection, and for the content of the protection granted - OJ L 337, 20 December 2011

- Directive 2013/48/EU of the European Parliament and of the Council of 22 October 2013 on the right of access to a lawyer in criminal proceedings and in European arrest warrant proceedings, and on the right to have a third party informed upon deprivation of liberty and to communicate with third persons and with consular authorities while deprived of liberty - OJ L 294, 6 November 2013

- Directive 2014/41/EU of the European Parliament and of the Council of 3 April 2014, regarding the European Investigation Order in criminal matters - OJ L 130, 1 May 2014

- Directive 2016/1919/EU of the European Parliament and of the Council of 26 October 2016 on legal aid for suspects and accused persons in criminal proceedings and for requested persons in European arrest warrant proceedings - OJ L 297, 4 November 2016

- Directive 2017/541 of the European Parliament and of the Council of 15 March 2017 on combating terrorism and replacing Council Framework Decision 2002/475/JHA and amending Council Decision 2005/671/JHA - OJ L 88, 31 March 2017

- European Council, Copenhagen, 21-22 June 1993, Conclusions of the Presidency, SN 180/1/93 REV 1 www.consilium.europa.eu [Copenhagen Criteria for EU Membership]

- FD 2002/584/JHA of 13 June 2002 on the European arrest warrant and the surrender procedures between Member States - OJ L 190, 18 July 2002 [FD-EAW]

- FD 2006/783/JHA, of 6 October 2006 on the application of the principle of mutual recognition to confiscation orders - OJ L 328, 24 November 2006

- FD 2008/909/JHA of 27 November 2008 on the application of the principle of mutual recognition to judgments in criminal matters imposing custodial sentences or measures involving deprivation of liberty for the purpose of their enforcement in the EU - OJ L 327, 5 December 2008

- FD 2008/947/JHA of 27 November 2008 on the application of the principle of mutual recognition to judgments and probation decisions with a view to the supervision of probation measures and alternative sanctions - OJ L 337, 16 December 2008

- FD 2008/978/JHA of 18 December 2008, on the European evidence warrant for the purpose of obtaining objects, documents and data for use in proceedings in criminal matters - OJ L 350/72, 30 December 2008

- FD 2009/299/JHA of 26 February 2009 amending Framework Decisions 2002/584/JHA, 2005/214/JHA, 2006/783/JHA, 2008/909/JHA and 2008/947/JHA, thereby enhancing the procedural rights of persons and fostering the application of the principle of mutual recognition to decisions rendered in the absence of the person concerned at the trial - OJ L 81/24, 27 March 2009 
- FD 2009/829/JHA of 23 October 2009 on the application, between Member States of the European Union, of the principle of mutual recognition to decisions on supervision measures as an alternative to provisional detention - OJ L 294, 11 November 2009

- FD 2009/948/JHA of 30 November 2009 on prevention and settlement of conflicts of exercise of jurisdiction in criminal proceedings - OJ L 328, 15 December 2009

- Operational and strategic cooperation agreement between the European Police Office and Ukraine, The Hague, 14 December 2016 - http://eurojust.europa.eu

- Regulation (EU) no. 1215/2012, of 12 December, on jurisdiction and the recognition and enforcement of judgments in civil and commercial matters

- Roadmap for strengthening procedural rights of suspected or accused persons in criminal proceedings, Resolution of the Council, 30 November 2009 - OJ C 295, 4 December 2009

- Rules of Procedure of the ECJ - OJ L 265, 29 September 2012, as amended in OJ L 173, 26 May 2013

- TCE - OJ C 340, 10 November 1997; OJ C 224, 31 August 1992

- TEU - OJ C 202, 7 June 2016

- TFEU - OJ C 202, 7 June 2016

- TFEU / TEU - Protocol no. 24 to the on asylum for nationals of Member States of the EU - OJ C 202, 7 June 2016

- Treaty on the Establishment of the European Community on 1 January 1958 - https://eur-lex.europa.eu

\section{D - Portugal}

- Code of Criminal Procedure - Decree-Law no. 78/87 of 17 de February

- Code of Military Justice - Law no. 100/2003 of 15 November

- Constitution of the Portuguese Republic - Decree of 10 April 1976

- Decree-Law no. 15/93 of 22 January, on Combat on Drugs

- Decree-Law no. 43/91 of 22 January, on International Cooperation in Criminal Matters (no longer in force)

- Decree-Law no. 437/75 of 16 August, on Extradition (no longer in force)

- Law no. 102/2001 of 25 August, Implementing the Rome Statute of the ICC

- Law no. 144/99 of 31 August, on International Cooperation in Criminal Matters [PT-L]

- Law no. 30/2000 of 29 November, Decriminalising Drug Use and other acts related to Personal Use

- Law no. 35/2015 of 4 May, Revising PT-EAW

- Law no. 65/2003 of 23 August, Implementing the FD-EAW [PT-EAW]

- Law no. 93/99 of 14 July, on Protection of Witnesses

- Law of 1 July 1867, Abolishing the Death Penalty and Reforming the Penitentiary System http://legislacaoregia.parlamento.pt (no longer in force)

- Penal and Disciplinary Code of the Portuguese Merchant Navy - Decree-Law no. 33252/43 of 20 November

- Penal Code - Decree-Law no. 48/95 of 15 March

[All available at www.pgdlisboa.pt/, unless otherwise stated.]

\section{E - United Kingdom}

- Anti-social Behaviour, Crime and Policing Act 2014

- Children and Young Persons Act 1933 
- Code for Crown Prosecutors

- Crime (Sentences) Act 1997

- Crimes and Courts Act 2013

- Criminal Justice Act 1967

- Criminal Justice Act 2003

- Criminal Justice Order 1998 [Northern Ireland]

- Criminal Procedure (Insanity and Unfitness to Plead) Act 1991

- Criminal Procedure Act 1995 [Scotland]

- Diplomatic Privileges Act 1964

- Emergency Provisions (abolishing the death penalty for common offences) Act 1973 [Northern Ireland]

- Extradition Act 1870

- Extradition Act 1989

- Extradition Act 2003 [UK-EA]

- Fugitive Offenders Act 1881

- Fugitive Offenders Act 1967

- Human Rights Act 1998

- Magistrates' Court Act 1980

- Murder (Abolition of Death Penalty) Act 1965

- Nationality, Immigration and Asylum Act 2002

- Police and Justice Act 2006

- Proceeds of Crime Act 2002

- Prosecution of Offences Act 1985

- State Immunity Act 1978

- Suppression of Terrorism Act 1978

- Taking of Hostages Act 1982

- Youth Justice and Criminal Evidence Act 1999

[All available at www.legislation.gov.uk $/$.]

\section{F - Other}

- (America) American Convention against Terrorism of 2002, in www.oas.org

- (America) American Convention on Human Rights (ACHR), of 1969, in www.cidh.oas.org

- (Ancient Egypt \& Hatti) Treaty of Qadesh, 13 ${ }^{\text {th }}$ century BCE, in S. Langdon and Alan H. Gardiner: supra, bibliography

- (Ancient Rome) Corpus Juris Civilis, 6 ${ }^{\text {th }}$ century; Justinian's Novel XVII, in https://archive.org/details/corpusjuriscivil00krueuoft

- (Argentina, Bolivia, Chile, Costa Rica, Ecuador, Guatemala, Peru, Uruguay \& Venezuela) South American Treaty on International Penal Law of 1889, in http://www.refworld.org/docid/3ae6b3781c.html

- (Bavaria \& USA) Extradition Treaty of 1853, in http://avalon.law.yale.edu/

- (Bavaria) Penal Code of 1813, in http://ghdi.ghi-dc.org/sub document.cfm?document id=3531

- (Belgium) Law no. 1195, of 1 October 1833 on Extradition, in Pasinomie: Collection complète des lois, décrets, arrêtes, et règlements généraux qui peuvent être invoqués en Belgique, Troisième Série, Tome Troisième, Règne de Léopold 1 er - Année 1833, Bruxelles: Librairie de Jurisprudence de H. Tarlier, 1834 
- (Belgium \& France) Extradition Treaty of 1834, in Georg Friedrich Martens / Frédéric Murhard, Nonvean Recueil des Traités d'Alliance, de Paix, de Trêve, de Neutralité, de Commerce, de Limites, d'Échange etc. et de plusieurs autres actes servant à la connoissaince des rélations étrangères des Puissances et Etats dans d'autres parties du globe: Depuis 1808 jusqu'à présent, Tome XII, 1827-1833, Gottingen: Dieterich, 1837, p. 1834 f.

- (Brazil \& Portugal) Treaty of Friendship, Cooperation and Consultation, of 22 April 2000, in https://www.dgae.mec.pt/?wpfb $\mathrm{dl}=1023$

- (Brazil \& Spain) Extradition Treaty of 1872, in Collecção de Leis do Império do Brasil de 1872 - Tomo XXXV, Parte II, Rio de Janeiro: Typographia Nacional, 1872, p. 473 f., in http://bd.camara.gov.br

- (Brazil) Federal Constitution of 1988, in http://www.planalto.gov.br/ccivil 03/constituicao/constituicao.htm

- (Canada \& USA) Extradition Treaty of 1971, https://www.oas.org/juridico/mla/en/traites/en traitesext-can-usa4.html

- (Canada) Charter of Rights and Freedoms of 1982, in http://laws-lois.justice.gc.ca/eng/Const/page$\underline{15 . h t m l}$

- (Community of Portuguese Language Countries) Extradition Treaty of 2005, in http://www.pgdlisboa.pt/leis/lei mostra articulado.php?nid=1565\&tabela=leis

- (Denmark \& USA) Extradition Treaty of 1972, as amended by the Extradition Agreement of 2005, in https://www.state.gov/documents/organization/182843.pdf

- (Duchy of Württemberg \& France) Extradition Treaty of 1765, in Georg Friedrich Martens: supra, bibliography

- (England, France \& Spain) Peace Treaty of Amiens of 1802, in https://en.wikisource.org/wiki/Treaty of Amiens

- (France \& Savoy) Treaty of 1376, apud BLAKESLEY, Christopher L., "The Practice of Extradition from Antiquity...": supra, bibliography

- (France \& Spain) Treaty of 1765, apud SERRANO, Mário Mendes: supra, bibliography

- (France \& States of the Helvetic Confederation) Extradition Treaty of 1828, in Georg Friedrich Martens / Frédéric Saalfeld, Nonvean Recueil des Traités d'Alliance, de Paix, de Trêve, de Neutralité, de Commerce, de Limites, d'Échange etc. et de plusieurs autres actes servant à la connoissaince des rélations étrangères des Puissances de l'Europe et Etats dans d'autres parties du globe: Depuis 1808 jusqu'à présent, Tome VII - Seconde Partie, 18241827 incl., Gottingen: Dieterich, 1830, p. 665 f.

- (France \& USA) Consular Convention of 1788, in http://avalon.law.yale.edu/18th century/fr-1788.asp

- (France, Holy Roman Empire, Netherlands, Spain \& Sweden) Treaties of Münster and Osnabrück of 1648, in http://opil.ouplaw.com/view/10.1093/law:oht/law-oht-1-CTS-271.regGroup.1/law-oht-1CTS-271

- (France, UK, USA \& USSR) Charter of the International Military Tribunal of Nuremberg of 1945, in http://avalon.law.yale.edu/imt/imtconst.asp

- (France) Constitution of 1793, in http://www.conseil-constitutionnel.fr/conseilconstitutionnel/francais/la-constitution/les-constitutions-de-la-france/constitution-du-24-juin$\underline{1793.5084 . h t m l}$

- (France) Decree of 19 February 1791, in Collection générale des lois, décrets, arrêtes, sénatus-consultes, avis du Conseil d'État et réglemens d'administration, publiés depuis 1789 jusqu'au I. er Avril 1814, et insérés dans la Collection du Louvre in $4 .{ }^{\circ}$, dans la Collection in-8. de l'Imprimerie nationale, et dans les quatre premières Séries du Bulletin des lois, recueillie et mise en ordre par L. Rondonneau - Tome Premier, II.e Partie : Assemblée Constituante, Octobre 1790 Février 1791 (1817), Paris: L'Imprimerie Royale, p. 931 f.

- (Germany) Act on International Cooperation in Criminal Matters of 1982, in http://www.gesetze-iminternet.de/englisch irg/

- (Germany) Constitution of 1949, in https://www.gesetze-im-internet.de/englisch_gg/englisch_gg.html 
- (Germany) Criminal Code of 1871, in https://de.wikisource.org/wiki/Strafgesetzbuch_f\%C3\%BCr_das_Deutsche_Reich_(1871)

- (Gibraltar) EAW Act 2004, in http://www.gibraltarlaws.gov.gi/articles/2004-04o.pdf

- (Great Britain \& Portugal) Extradition Treaty of 1892, in Treaty Series no. 7, London: Harrison and Sons, 1894

- (Great Britain \& USA) Webster-Ashburton Treaty of 1842, in http://avalon.law.yale.edu/19th century/br-1842.asp

- (Hong Kong) Fugitive Offenders Ordinance (Chapter 503 of the Laws of Hong Kong) of 1997, in https://www.elegislation.gov.hk/hk/cap503

- (India) Extradition Act 1962, in https://indiacode.nic.in/bitstream/123456789/1440/1/196234.pdf

- (International Conference of American States) Montevideo Convention on the Rights and Duties of States of 1933, in http://avalon.law.yale.edu/20th century/intam03.asp

- (Japan) Law no. 68 of 1953 - Extradition Act, in http://www.oecd.org/site/adboecdanticorruptioninitiative/39360681.pdf

- (Latvia, Estonia \& Lithuania) 1992 Agreement, apud ECJ, Petrubbin: infra, case law

- (League of Arab States) Arab Convention for the Suppression of Terrorism of 1998, in http://www.unodc.org/images/tldb-f/conv_arab_terrorism.en.pdf

- (League of Nations) Covenant of the League of Nations of 1919, in http://avalon.law.yale.edu/20th_century/leagcov.asp

- (Macau \& HK) Agreement on the Transfer of Prisoners, HK, 20 May 2005, in https://www.doj.gov.hk/eng/mainland/pdf/macao/tsp.pdf

- (Macau) Law no. 6 of 2006, on International Cooperation in Criminal Matters, in http://bo.io.gov.mo/bo/i/2006/30/lei06.asp

- (Mercosur) Agreement on Extradition between the States Parties of the Mercosur, of 1998 [MAW], in http://www.oas.org/juridico/spanish/tratados/sp_acuer_sobre_extra_ent_esta_part_mercosur.pdf

- (NATO) Agreement between the Parties to the North Atlantic Treaty regarding the Status of their Forces, of 1951, in https://www.nato.int/cps/en/natohq/official_texts 17265.htm

- (Netherlands \& Ukraine) Agreement on International Legal Cooperation regarding Crimes connected with the Downing of Malaysia Airlines Flight MH17 on 17 July 2014, of 2017, in https://zoek.officielebekendmakingen.nl/

- (Netherlands) Charter for the Kingdom of the Netherlands of 1954, in http://www.palatauruscentrostudi.eu/doc/Kingdon of the Netherlands Charter 1954 EN.pdf

- (Netherlands) Constitution of 1815, in http://www.wipo.int/wipolex/en/text.jsp?file_id=468353

- (Netherlands) Extradition Act of 1967, in http://wetten.overheid.nl/BWBR0002559/2017-03-01

- (Denmark, Finland, Iceland, Norway \& Sweden) Convention on Surrender Between the Nordic States, of 2005 [NAW]

- (Organization of the Islamic Conference) Convention of the Organization of the Islamic Conference on Combating International Terrorism of 1999, in http://ww1.oicoci.org/english/convenion/terrorism_convention.htm

- (Portugal \& Spain) Treaty of 1360, apud VIEIRA, Manuel Adolfo: supra, bibliography

- (Denmark \& England) Treaty of 1661, apud VIEIRA, Manuel Adolfo: supra, bibliography

- (England \& Netherlands) Treaty of 1662, apud VIEIRA, Manuel Adolfo: supra, bibliography

- (Portugal \& States of the Helvetic Confederation) Extradition Treaty of 1873, in http://www.lexfind.ch/dtah/51758/3/0.353.965.4.fr.pdf

- (Portugal \& USA) Extradition Treaty of 1908, in http://www.pgdlisboa.pt/leis/lei_mostra articulado.php?nid=1580\&tabela=leis; and 
https://internationalextraditionblog.com/2011/06/02/portugal-extradition-treaty-with-the-unitedstates/

- (Republic of Ireland) EAW Act 2003, in http://www.irishstatutebook.ie/eli/2003/act/45/enacted/en/html

- (Spain) Constitution of 1978, in https://www.boe.es/buscar/doc.php?id=BOE-A-1978-31229

- (USA \& UK) Extradition Treaty of 1972, in https://www.state.gov/documents/organization/187784.pdf

- (USA \& UK) Treaty of Amity, Commerce, and Navigation [Jay Treaty] of 1794, in http://avalon.law.yale.edu/18th century/jav.asp

- (USA) Constitution of 1787, in http://avalon.law.yale.edu/18th_century/usconst.asp

- (USA) Espionage Act of 1917, in

http://www.digitalhistory.uh.edu/disp_textbook.cfm?smtid=3\&psid=3904 


\section{III - Parliamentary Debates}

\section{A - Portugal}

- Assembleia Constituinte, Diário da Assembleia Constituinte, n. o 14, of 8 July 1975

- Assembleia Constituinte, Diário da Assembleia Constituinte, n. ${ }^{\circ}$ 36, of 23 August 1975

- Assembleia da República, Diário da Assembleia da República, II Série, RC, n. 6 (Suplemento), of 20 October 1981

- Assembleia da República, Diário da Assembleia da República, II Série, RC, n. ${ }^{\circ}$ 11, of 12 May 1988

- Assembleia da República, Diário da Assembleia da República, II Série, RC, n. ${ }^{\circ}$ 65, of 10 January 1989

- Assembleia da República, Diário da Assembleia da República, II Série, RC, n. ${ }^{\circ}$ 68, of 25 January 1989

- Assembleia da República, Diário da Assembleia da República, II Série, RC, n. ${ }^{\circ}$ 20, of 12 September 1996

- Assembleia da República, Diário da Assembleia da República, II Série, RC, n. ${ }^{\circ}$ 82, of 30 April 1997

- Assembleia da República, Diário da Assembleia da República, II Série, RC, n. ${ }^{\circ} 84$, of 6 May 1997

- Assembleia da República, Diário da Assembleia da República, II Série, RC, n. ${ }^{\circ}$ 11, of 4 July 2001

[All available at www.debates.parlamento.pt/.]

\section{B - United Kingdom}

- House of Commons, 25 March 2003, column 181

- House of Commons, 9 December 2002, columns 64, 67, 114-118

- House of Lords, 10 July 2003, column GC108

- Speech of Secretary of State for the Home Affairs Theresa May before Parliament, on 16 October 2012, in www.youtube.com/watch?v=5MEQVo8ENC8

[All available at www.publications.parliament.uk, unless otherwise stated.] 


\section{IV - Case Law}

\section{A - United Nations}

- ICJ, Case Concerning United States Diplomatic and Consular Staff in Tehran (United States of America v. Iran), Judgment of 24 May 1980

- ICJ, Questions of Interpretation and Application of the 1971 Montreal Convention arising from the Aerial Incident at Lockerbie (Libya v. United Kingdom) [Lockerbie] - Dissenting Opinion of Judge Weeramantry, 14 April 1992; Joint Declaration of Judges Evensen, Tarassov, Guillaume and Aguilar Mawdsley, 14 April 1992

- ICJ, Arrest W arrant of 11 April 2000 (Democratic Republic of the Congo v. Belgium) [Yerodia], Judgment of 14 February 2002; Separate Opinion of President Guilhaume; Dissenting Opinion of Judge van den Wyngaert; Dissenting Opinion of Judge Al-Khasawneh; Joint Separate Opinion of Judges Higgins, Kooijmans and Buergenthal

- ICJ, Questions Relating to the Obligation to Prosecute or Extradite (Belgium v. Senegal) [Habre], Judgment of 20 July 2012

- ICTY, Prosecutor v. Nikolic, Decision on Defence Motion Challenging the Exercise of Jurisdiction by the Tribunal, Case No. IT-94-2-PT, 9 October 2002

- ICTY, Prosecutor v. Nikolic, Decision on Interlocutory Appeal Concerning Legality of Arrest, Case No. IT94-2-AR73, 5 June 2003

- PCIJ, S.S. Lotus (France v. Turkey) [Lotus], Judgment of 7 September 1927

- STL, Interlocutory Decision on the Applicable Law: Terrorism, Conspiracy, Homicide, Perpetration, Cumulative Charging, STL-11-01/I/AC/R176bis, 16 February 2011

- UN Commission on Human Rights, Resolution 1991/42, E/CN.4/RES/1991/42, 5 March 1991

- UN Commission on Human Rights, Resolution 1997/50, E/CN.4/RES/1997/50, 15 April 1997

- UN Committee Against Torture, Alan v. Switzerland, no. 21/1995, UN Doc. CAT/C/16/D/21/1995 (1996), 31 January 1995

- UN Human Rights Council, Resolution 24/7, A/HRC/RES/24/7, 26 September 2013

- UN Security Council Resolution 138 (1960), S/RES/138 (1960), 23 June 1960

- UNHRC, A.P. v. Italy, no. 204/1986, CCPR/C/31/D/204/1986, 2 November 1987

- UNHRC, Torres v. Finland, no. 291/1988, CCPR/C/38/D/291/1988, 2 April 1990

- UNHRC, Giry v. Dominican Republic, no. 193/1985, 40 (A/45/40), 20 July 1990

- UNHRC, Kindler v. Canada, no. 470/1991, CCPR/C/48/D/470/1991, 11 November 1993

- UNHRC, Ng v. Canada, no. 469/1991, CCPR/C/49/D/469/1991, 7 January 1994

- UNHRC, Cox v. Canada, no. 539/1993, CCPR/C/52/D/539/19930, 9 December 1994

- UNHRC, A.R.J. v. Australia, no. 692/1996, CCPR/C/60/D/692/1996, 28 July 1997

- UNHRC, Judge v. Canada, no. 829/1998, CCPR/C/78/D/829/1998, 20 October 2003

- UNWGAD, Opinion 54/2015 concerning Julian Assange (Sweden and the United Kingdom of Great Britain and Northern Ireland), A/HRC/WGAD/2015, of 4 December

[All available at www.ici-cii.org/, http://unictr.unmict.org/, www.icty.org/, www.stl-tsl.org/, and www.refworld.org/.] 


\section{B - European Court of Human Rights}

- (European Commission of Human Rights), no. 4212/69, 13 July 1970

- (European Commission of Human Rights), no. 9433/81, 12 December 1981

- A.A. and Others v. Sweden, no. 14499/09, 28 June 2012

- A.L. (X.W.) v. Russia, no. 44095/14, 29 October 2015

- A.S. v. Finland, no. 40156/07, 28 September 2010

- A.T. v. Luxembourg, no. 30460/13, 9 April 2015

- Abdolkhani \& Karimnia v. Turkey, no. 30471/08, 22 September 2009

- Abu Zubaydah [Husayn] v. Litbuania, no. 46454/11, 31 May 2018

- Aborugeze v. Sweden, no. 37075/09, 27 October 2011

- AlNasbiri v. Poland, no. 28761/11, 24 July 2014

- AlNasbiri v. Romania, no. 33234/12, 31 May 2018

- Al Skeini \& Others v. UK, no. 55721/07, 7 July 2011

- Al-Adsani v. UK, no. 35763/97, 21 November 2001

- Al-Moayad v. Germany, no. 35868/03, 20 February 2007

- Al-Saadoon \& Mufdhi v. UK, no. 61498, 2 February 2010

- Aleksanyan v. Russia, no. 46468/06, 22 December 2008

- Aoulmi v. France, no. 50278/99, 17 January 2006

- Aswat v. UK, no. 17299/12,16 April 2013

- Babar Abmad \& Others v. UK, no. 24027/07, no. 11949/08 and no. 36742/08, 6 July 2010

- Bader \& Kanbor v. Sweden, no. 13284/04, 8 November 2005

- Baysakov \& Others v. Ukraine, no. 54131/08, 18 February 2010

- Borcea v. Romania, no. 55959/14, 22 September 2015

- Catan \& Others v. Moldova \& Russia, no. 43370/04, no. 8252/05 and no. 18454/06, 19 October 2012 Partly Dissenting Opinion of Judge Kovler

- Chabal v. UK, no. 22414/93, 15 November 1996

- Charabili v. Turkey, no. 46605/07, 13 July 2010

- Collins \& Akariebie v. Sweden, no. 23944/05, 8 March 2007

- Cruz Varas \& Others v. Sweden, no. 46/1990/237/307, 20 March 1991

- D. \& Others v. Turkey, no. 24245/03, 22 June 2006

- D. v. UK, no. 30240/96, 2 May 1997

- D.N.M. v. Sweden and S.A. v. Sweden, no. 28379/11 and no. 66523/10, 27 June 2013

- Daoudi v. France, no. 19576/08, 3 December 2009

- Denmark, Norway, Sweden \& the Netherlands v. Greece, no. 3321/67, 5 November 1969

- Dickson v. UK, no. 44362/04, 4 December 2007

- Dougoz. v. Greece, no. 40907/98, 6 March 2001

- Drozd \& Janousek. v. France \& Spain, no. 12747/87, 26 June 1992

- Einhorn v. France, no. 71555/01, 16 October 2001

- El Haski v. Belgium, no. 649/08, 25 September 2012

- El-Masri v. the former Yugoslav Republic of Macedonia, no. 39630/09, 13 December 2012

- Elorza v. Spain, no. 30614/15, 12 December 2017

- Findikoglu v. Germany (2016), no. 20672/15, 7 June 2016 
- Guja v. Moldova, no. 1427724, 12 February 2008

- Harkins \& Edwards v. UK, no. 9146/07 and no. 32650/07, 17 January 2012

- Harkins v. UK (2017), no. 71537/14, 15 June 2017

- Husayn (Abu Zubaydah) v. Poland, no. 7511/13, 24 July 2014

- Hutchinson v. UK, no. 57592/08, 3 February 2015; Dissenting Opinion of Judge López Guerra; Dissenting

Opinion of Judge Pinto de Albuquerque

- Ilascu \& Others v. Moldova \& Russia, no. 48787/99, 8 July 2004

- Izevbekhai \& Others v. Ireland, no. 43408/08, 17 May 2011

- Ireland v. UK, no. 5310/71, 18 January 1978

- Jabari v. Turkey, no. 40035/98, 11 July 2000

- Kafkaris v. Cyprus, no. 21906/04, 12 February 2008

- Kalashnikov v. Russia, no. 47095/99, 15 July 2002

- Khaydarov v. Russia, no. 21055/09, 20 May 2010

- Klein v. Russia, no. 24268/08, 1 April 2010

- Kolk \& Kishyiy v. Estonia, no. 23052/04 and no. 24018/04, 17 January 2006

- Kononov v. Latvia, no. 36376/04, 17 May 2010

- Kordian v. Turkey, no. 6575/06, 4 July 2006

- M.E. v. France, no. 50094/10, 6 June 2013

- M.S. v. Belgium, no. 50012/08, 31 January 2012

- M.S.S. v. Belgium \& Greece, no. 30696/09, 21 January 2011

- Makhmud乏han Ergashev v. Russia, no. 49747/11, 16 October 2012

- Mamatkulov \& Askarov v. Turkey, no. 46827/99 and no. 46951/99, 4 February 2005

- Matiošaitis \& Others v. Lithuania, no. 22662/13, no. 51059/13, no. 58823/13, et al., 23 May 2017

- Mbunzu v. Netherlands, no. 17878/91, 10 May 1992

- Monedero Angora v. Spain, no. 41138/05, 7 October 2008

- Muminov v. Russia, no. 42502/06, 11 December 2008

- Murray v. the Netherlands, no. 10511/10, 26 April 2016

- N. v. Sweden, no. 23505/09, 20 July 2010

- N. v. UK, no. 26565/05, 27 May 2008

- Nivette v. France, Nivette v. France, no. 44190/98, 14 December 2000 / 3 July 2001

- Öcalan v. Turkey, no. 46221/99, 12 May 2005

- Omeredo v. Austria, no. 8969/10, 20 September 2011

- Othman v. UK, no. 8139/09, 17 January 2012

- Öztürk v. Germany, no. 8544/79, 21 February 1984

- Peers v. Greece, no. 28524/95, 19 April 2001

- Peñafiel Salgado v. Spain, no. 65964/01, 16 April 2002

- Penart v. Estonia, no. 14685/04, 24 January 2006

- Poltoratskiy v. Ukraine, no. 38812/97, 29 April 2003

- Pretty v. UK, no. 2346/02, 29 April 2002

- Previti v. Italy, no. 1845/08, 12 February 2013

- Razaghi v. Sweden, no. 64599/01, 11 March 2005

- Romagnoli v. Montenegro, no. 11200/15 (pending application) 
- S.J. v. Belgium, no. 70055/10, 27 February 2014

- Saadi v. Italy, no. 37201/06, 28 February 2008

- Sejdovic v. Italy, no. 56581/00, 1 March 2006

- Shakurov v. Russia, no. 55822/10, 5 June 2012

- Shamayev \& Others v. Georgia \& Russia, no. 36378/02, 12 April 2005

- Soering v. UK, no. 14038/88, 7 July 1989

- Stamose v. Bulgaria, no. 29713/05, 27 November 2012

- Stanford v. UK, no. 73299/01, 12 December 2002

- Stapleton v. Ireland, no. 56588/07, 4 May 2010

- Stoichkov v. Bulgaria, no. 9808/02, 24 March 2005

- Sufi \& Elmi v. UK, no. 8319/07 and no. 11449/07, 28 June 2011

- Tomic v. UK, no. 17837/03, 14 October 2003

- Trabelsi v. Belgium, no. 140/10, 7 October 2014; concurring opinion of Judge Yudkivska

- Tyrer $v$. UK, no. 5856/72, 25 April 1978

- V.v. UK, no. 294888/94, 16 December 1999

- Vinter \& Others v. UK, no. 66069/09, no. 130/10 and no. 3896/10, 9 July 2013; Concurring Opinion of Judge Power-Forde

- Weeks v. UK, no. 9787/82, 2 March 1987

- Wynne v. UK, no. 67385/01, 22 May 2003

- Z. \& T. v. UK, no. 27034/05, 28 February 2006

- Zhu v. UK, no. 36790/97, 12 August 2001

[All available at https://hudoc.echr.coe.int/.]

\section{C - Court of Justice of the EU}

- Advocaten voor de Wereld VZW v. Leden van de Ministrraad (C-303/05) - Opinion of AG Ruiz-Jarabo Colomer of 12 September 2006; Judgment of 3 May 2007

- Akerberg Fransson (C-617/10), Judgment of 26 February 2013

- Aranyosi \& Căldăraru (C-404/15 \& C-659/15): Opinion of AG Yves Bot, 3 March 2016; Judgement of 5 April 2016

- Aranyosi [Aranyosi II] (C-496/16), Request for a preliminary ruling from the Hanseatisches Oberlandesgericht in Bremen (Germany), 16 September 2016; Order of the Court of 15 November 2017

- Bickel \& Franz,(C-274/96), Judgment of 24 November 1998

- Casati (C-203/80), Judgment of 11 November 1981

- Cowan v. Trésor public (C-186/87), Judgment of 2 February 1989

- Dorobantu (C-128-18), Request for a preliminary ruling lodged on 16 February 2018

- Elliniki Radiophonia Tiléorassi AE \& Panellinia Omospondia Syllogon Prossopikou v. Dimotiki Etairia Pliroforissis \& others (C-260/89), Judgment of 18 June 1991

- Generalstaatsanwaltschaft [Aranyosi III] (C-220/18), Judgment of 25 July 2018

- Göæütok \& Brügge (C-187/01 \& C-385/01), Judgment of 11 February 2003

- Hubert Wachauf v. Bundesamt für Ernährung und Forstwirtschaft (C-5/88), Judgment of 13 July 1989

- I.B. (C-306/09), Judgment of 21 October 2010

- Kozlowski (C-66/08), Judgment of 17 July 2008

- LM [Celmer] (C-216/18 PPU): Opinion of AG Evgeni Tanchev, 28 June 2018; Judgment of 25 July 2018 
- Melloni (C-399/11), Judgment of 26 February 2013

- N.S. \& others (C-411/10 \& C-493/10), Judgment of 21 December 2011

- Oebel (C-155/80), Judgment of 14 July 1981

- Opinion 2/13, of 18 December 2014

- Peralta (C-379/92), Judgment of 14 July 1994

- Petrubbin (C-182/15): Opinion of AG Yves Bot of 10 May 2016; Judgment of 6 September 2016

- Piotrowski (C-367/16), Judgment of 23 January 2018

- Pisciotti, (C-191/16): Opinion of AG Yves Bot of 21 November 2017; Judgment of 10 April 2018

- Pupino (C-105/03), Judgment of 16 June 2005

- Radu (C-396/11), Judgment of 29 January 2013

- Rangevicius (C-247/17), Request for a Preliminary Ruling of 7 July 2017

- Rottmann v. Freistaat Bayern (C-135/08), Judgment of 2 March 2010

- Schotthöfer \& Steiner (C-473/15), Order of 6 September 2017

- Spasic (C-129/14), Judgment of 27 May 2014

- van Dam en Zonen \& Others (C-185 to 204/78), Judgment of 3 July 1979

- Wilhelm \& Others $v$. Bundeskartellamt (C-14/68), Judgment of 13 February 1969

- Zambrano (C-34/09), Judgment of 8 March 2011

[All available at http://curia.europa.eu/.]

\section{D - Portuguese Courts}

- Constitutional Court, 4 July 1995, no. 417/95

- Constitutional Court, 6 July 1995, no. 430/95

- Constitutional Court, 6 July 1995, no. 449/95

- Constitutional Court, 4 October 1995, no. 527/95

- Constitutional Court, 17 November 1995, no. 474/95

- Constitutional Court, 12 November 1996, no. 1146/96

- Constitutional Court, 10 January 2001, no. 1/2001

- Constitutional Court, 12/13? July 2005, no. 384/2005

- Constitutional Court, 9 October 2007, no. 501/07

- Constitutional Court, 5 July 2012, no. 360/12

- Constitutional Court, 27 August 2015, no. 403/2015

- Court of Appeal of Coimbra, 14 May 2014, process no. 1721/11.8PBCBR-A.C1

- Court of Appeal of Évora, 3 May 2005, process no. 29/05-1

- Court of Appeal of Évora, 31 January 2012, process no. 179/11.6YREVR

- Court of Appeal of Lisbon, 4 February 2004, process no. 3880/2003-3

- Court of Appeal of Lisbon, 14 December 2004, process no. 6293/04.

- Court of Appeal of Lisbon, 9 April 2008, process no. 4076/2005-3

- Court of Appeal of Lisbon, 9 August 2008, process no. 4076/2005-3

- Court of Appeal of Lisbon, 17 November 2011, process no. 759/11.0YRLSB-3

- Court of Appeal of Porto, 14 February 1990, process no. 0123625

- Court of Appeal of Porto, 18 January 2006, process no. 0516310

- Court of Appeal of Porto, 31 October 2007, process no. 0715689 
- Court of Appeal of Porto, 7 March 2012, process no. 32/12.6YRPRT

- Supreme Court, 11 July 1996, process no. 96P684

- Supreme Court, 30 September 1999, process no. 99P885

- Supreme Court, 13 March 2003, process no. 03P1646

- Supreme Court, 29 April 2003, process no. 03P1646

- Supreme Court, 13 January 2005, process no. 04P4738

- Supreme Court, 15 March 2006, process no. 06P782

- Supreme Court, 27 April 2006, process no. 06P1429

- Supreme Court, 22 June 2006, process no. 06P2326

- Supreme Court, 7 August 2007, process no. 48/12.2YREVR.S1

- Supreme Court, 9 January 2008, process no. 07P4855

- Supreme Court, 2 February 2008, process no. 07P4850

- Supreme Court, 6 February, 2008, process no. 369/06

- Supreme Court, 24 April 2008, process no. 08P1422

- Supreme Court, 12 November 2008, process no. 08P3709

- Supreme Court, 7 January 2009, process no. 08P4144

- Supreme Court, 4 March 2009, process no. 09P0685

- Supreme Court, 25 June 2009, process no. 1087/09.6YRLSB.S

- Supreme Court, 10 September 2009, process no. 134/09.6YREVR

- Supreme Court, 25 February 2010, process no. 42/10.8YFLSB

- Supreme Court, 25 March 2010, process no. 76/10.2YRLSB.S1

- Supreme Court, 23 June 2010, process no. 2113/09.4YRLSB.S1

- Supreme Court, 21 July 2010, process no. 586/10.1YRLSB.S1

- Supreme Court, 29 September 2010, process no. 143/10.2YRCBR.S1

- Supreme Court, 9 February 2011, process no. 1215-10.9YRLSB.S1

- Supreme Court, 5 May 2011, process no. 22/11.6YREVR.S1

- Supreme Court, 21 October 2011, process no. 130/11.3YFLSB

- Supreme Court, 15 November 2011, process no. 92/11.7YRPRT.S1

- Supreme Court, 13 December 2011, process no. 130/11.3YFLSB

- Supreme Court, 11 January 2012, process no. 111/11.7YFLSB

- Supreme Court, 30 May 2012, process no. 290/11.3YRCBR1.S1

- Supreme Court, 9 August 2013, process no. 750/13.1YRLSB.S1

- Supreme Court, 30 October 2013, process no. 86/13.8YREVR.S1

- Supreme Court, 21 November 2013, process no. 753/13.6YRLSB.S1

- Supreme Court, 22 January 2014, process no. 144/13.9YRLSB.S1

- Supreme Court, 21 May 2015, process no. 16/13.7YREVR.E1.S3

[All available at www.dgsi.pt and www.tribunalconstitucional.pt.]

\section{E - Courts of the United Kingdom}

- Agius v. Court of Magistrates, Malta [2011] EWHC 759 (Admin)

- Assange v. The Swedish Prosecution Authority [2012] UKSC 22; 2012 WL 1854507

- Asztaslos v. Szeekszard City Court Hungary [2010] EWHC 237 (Admin); [2011] 1 W.L.R. 252 
- Atkinson v. United States Government [1971] AC 197

- Badre v. Court of Florence, Italy [2014] EWHC 614 (Admin)

- Boudhiba v. Central Examining Court No 5 of the National Court of Justice Madrid [2006] EWHC 167 (Admin); [2006] 3 All ER 547 (DC); [2007] 1 WLR 124 (Part III)

- Cheng v. Governor of Pentonville Prison [1973] AC 931

- Dabas v. High Court of Justice in Madrid, Spain [2007] 2 AC 31; [2007] UKHL 6

- Dabkoowski v. Poland [2010] EWHC 1712 (Admin)

- Dibden v. Tribunal de Grande Instance de Lille France [2014] EWHC 3074 (Admin)

- Domminich Shaw v. Government of the United States of America [2014] EWHC 4654 (Admin)

- Gomes v. Government of the Republic of Trinidad and Tobago [2009] 1 WLR 1038

- Gözütok and Brïgge [2003] ECR 1-1345

- Hamza v. Secretary of State for the Home Department [2012] EWHC 2736 (Admin)

- Hashmi v. Government of the United States of America [2007] EWHC 564 (Admin)

- HH v. Deputy Prosecutor of the Italian Republic, Genoa; PH v. Deputy Prosecutor of the Italian Republic, Genoa, F-K (FC) v. Polish Judicial Authority, [2011] EWHC 1145 (Admin); [2012] UKSC 25; 2012 WL 2191316;

[2012] 3 WLR 90

- Hilali v. National Court of Madrid [2006] EWHC 1239 (Admin)

- Jansons v. Riga District Court, Latvia [2009] EWHC 1845 (Admin)

- Jaroslav Atraskevic v. Prosecutor General's Office, Republic of Lithuania [2015] EWHC 131 (Admin)

- Kakis v. Government of the Republic of Cyprus [1978] 1 WLR 779

- Klimas v. Prosecutors General Office of Lithuania [2010] EWHC 2076 (Admin)

- Loncar v. County Court in Vukovar Croatia [2015] EWHC 548 (Admin)

- Love v. US A [2018] EWHC 172 (Admin)

- Maclean v. High Court, Dublin [2008] EWCA 547 (Admin)

- Matuszenskivi v. Regional Court in Radom [2014] EWHC 357 (Admin)

- McKinnon v. Secretary of State for the Home Department [2009] EWHC 2021 (Admin)

- Miraszenskei v. Poland [2014] EWHC 4261 (Admin)

- Nikolics v. The City Court of Szekszard (A Judicial Authority in Hungary) [2013] EWHC 2377 (Admin)

- Norris v. Government of United States of America [2010] UKSC 9; 2010 WL 605760

- Office of the King's Prosecutor (Brussels) v. Cando Armas [2004] EWHC 2019 (Admin); [2005] 1 WLR 1389;

[2005] UKHL 67; [2006] 2 AC 1; [2006] 2 AC 9

- Phillip Harkins v. The Secretary of State for the Home Department v. Government of the United States of America

[2014] EWHC 3609 (Admin); 2014 WL 5599581

- Piotrowicz, v. Regional Court In Gdansk. Poland [2014] EWHC 3884 (Admin)

- Prancs v. Rezelkne Court of Latvia [2006] All ER (D) 28

- R (Absan) v. Government of the United States [2008] EWHC 66 (Admin)

- $R$ (Bermingham and other) v. Government of the United States of America and another [2006] EWHC 200 (Admin)

- R (Bermingham) v. Director of the Serious Frand Office [2006] EWHC 200; [2007] QB 727

- $\mathrm{R}$ (Kashamu) v. Governor of Brixton Prison (No 2) [2002] QB 887

- $\mathrm{R}$ (on the application of Wellington) (FC) v. Secretary of State for the Home Department [2008] UKHL 72

- R (Rot) v. District Court of Lublin, Poland [2010] EWHC 1820 (Admin)

- R (St John) v. Governor of Brixton Prison [2002] QB 613

- R (Warren) v. Secretary of State for the Home Department [2003] EWHC 1177 (Admin) 
- R v. (Bermingham) and others v. Director of the Serious Fraud Office [2007] QB 727; R. (Government of the United States of America v. Bow Street Magistrates' Court [2007] 1 WLR 1157; Re Campbell's Applicant [2009] NIQB 82

- R v. Bermingham and others [2006] EWHC 200 (Admin)

- R v. Bow Street Metropolitan Magistrate and others, ex parte Pinochet Ugarte (No. 3) [1999] 2 WLR 827

- R v. Governor of Brixton Prison, Ex parte Schtraks [1964] AC 556

- R v. Jogee [2016] UKSC 8

- R v. Newell (Lee William) / R. v. McLoughlin (Ian) [2014] EWCA Crim 188; [2014] 1 W.L.R. 3964

- R v. Secretary of State for the Home Department exp Johnson [1999] QB 1174

- R v. Wilson [1877] 3 QBD 42

- Sandru v. Government of Romania [2009] EWHC 2879 (Admin)

- Sbar v. The Court of Bologna [2010] EWHC 1184 (Admin)

- Shrien Dewani v. Government of the Republic of South Africa [2012] EWHC 842 (Admin)

- Spanovic v. Government of Croatia and another [2009] EWHC 723 (Admin)

- Sukhdev Singh Kandola, Lenuta Droma, Naweed Ijaz.v. Generalstaatwaltschaft Frankfurt, Germany, State Prosecutor Nurnburg-Furth, Bavaria, Germany, The Court of Milan (An Italian Judicial Authority) [2015] EWHC 619

(Admin)

- Symeou v. Public Prosecutor's Office Patras Greece [2009] EWHC 897 (Admin)

- The Queen on the Application of Stephen Williams, Geoffrey Williams v. Public Prosecutor of Lille Court of First Instance, France [2012] EWHC 2128 (Admin)

- VB, CU, CM, ENv. Westminster Magistrates' Court, The Government of Rwanda, The Crown Prosecution Service v. CMK [2014] UKSC 59

- Vincent Brown aka Vincent Bajinja, Charles Munyaneza, Emmanuel Nteziryayo, Celestin Ugirashebuja v. The Government of Rwanda, The Secretary of State for the Home Department [2009] EWHC 770 (Admin)

- Wrobel v. Judicial Authority of Poland [2011] EWHC 374 (Admin)

[All available at www.westlaw.co.uk, unless otherwise stated.]

\section{F - Other Courts}

- (Canada) Supreme Court, Kindler v. Canada (Minister of Justice), [1991] 2 SCR 779, in http://www.refworld.org/cases,CAN_SC,3ae6b6ed0.html

- (Canada) Supreme Court, United States v. Burns [2001] 1 SCR 283, 2001 SCC 7, in http://www.refworld.org/cases,CAN_SC,3ae6b74e0.html

- (IAtCHR) Wong Ho Wing - Order of 28 May 2010; Order of 29 January 2014, in http://www.corteidh.or.cr/

- (Macau) Court of Final Instance, 20 March 2007, process no. 12/2007, in http://www.court.gov.mo/pt/subpage/researchjudgments?court=tui

- (Netherlands) District Court of The Hague, 2 November 2017, no. KG ZA 17-857, in https://uitspraken.rechtspraak.nl/inziendocument?id=ECLI:NL:RBDHA:2017:12708

- (Spain) Supreme Court, ruling of 5 December 2017, appeal no. 20907/2017, in http://www.poderjudicial.es/search/contenidos.action?action=contentpdf\&databasematch=TS\&refer ence $=8230925 \&$ links $=$ \&optimize $=20171212$ \&publicinterface $=$ true 


\section{V - Other References}

- (Canada) Immigration and Refugee Board of Canada, "EU: Application of the Protocol on Asylum for Nationals of Member States of the European Union (2013 - June 2015)”, 9 July 2015, ZZZ105193.E, in http://www.refworld.org/docid/55bf55094.html

- (CoE) "Draft Copenhagen Declaration", 5 February 2018, adopted at the High Level Conference meeting of 12-13 April 2018 at the initiative of the Danish Chairmanship of the Committee of Ministers of the $\mathrm{CoE}$, in

https://menneskeret.dk/sites/menneskeret.dk/files/media/dokumenter/nyheder/draft copenhagen declaration 05.02.18.pdf

- (CoE) "Explanatory Report to the European Convention on Extradition", European Treaty Series, no. 24, 13 December 1957, in https://rm.coe.int/16800c92bc

- (CoE) ECtHR Directorate of the Jurisconsult, "Guide on Article 6 of the European Convention on Human Rights Right to a fair trial (criminal limb)", 31 December 2013, in https://www.echr.coe.int/Documents/Guide Art 6 criminal ENG.pdf

- (CoE) ECtHR Directorate of the Jurisconsult, "Guide on Article 8 of the European Convention on Human Rights: Right to respect for private and family life", 31 December 2016, as last updated on 30 April 2017, in https://www.echr.coe.int/Documents/Guide Art 8 ENG.pdf

- (CoE) ECtHR Press Unit, “Expulsions and extraditions”, July 2013, in http://www.refworld.org/pdfid/539eb4094.pdf

- (CoE) ECtHR Press Unit, “Terrorism and the European Convention on Human Rights”, May 2018, in https://www.echr.coe.int/Documents/FS Terrorism_ENG.pdf

- (CoE) ECtHR, “Opinion on the draft Copenhagen Declaration”, adopted by the Bureau in light of the discussion in the Plenary Court on 19 February 2018, in https://www.echr.coe.int/Documents/Opinion_draft_Declaration_Copenhague\%20ENG.pdf

- (EU \& UK) 'Joint Report from the Negotiators of the European Union and the United Kingdom Government on Progress During Phase 1 of Negotiations under Article 50 TEU on the United Kingdom's Orderly Withdrawal from the European Union", TF50 (2017) 19 - Commission to EU 27, 8 December 2017, in https://ec.europa.eu/commission/publications/joint-report-negotiators-european-unionand-united-kingdom-government-progress-during-phase-1-negotiations-under-article-50-teu-unitedkingdoms-orderly-withdrawal-european-union en

- (EU) Council of the EU, "Evaluation Report on the Fourth Round of Mutual Evaluations 'The Practical Application of the European Arrest Warrant and Corresponding Surrender Procedures Between Member States' - Report on Portugal" - Doc. 7593/2/07 REV 2, 27 July 2007, in https://www.consilium.europa.eu/ueDocs/cms_Data/docs/polju/FR/EJN725.pdf

- (EU) Council of the EU, "Revised version of the European handbook on how to issue a European Arrest Warrant", 17195/1/10, REV 1, 17 December 2010, in http://register.consilium.europa.eu/doc/srv?l=en\&f=ST $\% 2017195 \% 202010 \% 20 \mathrm{REV} \% 201$

- (EU) Council of the EU, "Roadmap for strengthening procedural rights of suspected or accused persons in criminal proceedings", Resolution of the Council, of 30 November 2009 - OJ 2009/C 295/01

- (EU) Eurojust, “Guidelines for Deciding 'Which Jurisdiction Should Prosecute?’ ”, 2016, in http://www.eurojust.europa.eu/doclibrary/Eurojustframe- 
work/Casework/Guidelines $\% 20$ for $\% 20$ deciding $\% 20$ which $\% 20$ jurisdiction $\% 20$ should $\% 20$ prosecute $\%$ 20(2016)/2016_Jurisdiction-Guidelines_EN.pdf

- (EU) European Commission Task Force for the Preparation and Conduct of the Negotiations with the United Kingdom under Article 50 TEU and the UK, Joint Technical Note "Comparison of EU/UK Positions on Citizens' Rights"; "Joint technical note expressing the detailed consensus of the UK and EU positions on Citizens' Rights”, 8 December 2017, in https://ec.europa.eu/commission/sites/betapolitical/files/citizens_rights_-_comparison_table.pdf

- (EU) European Commission, "Commission Staff Working Document Annex to the Report from the Commission based on Article 34 of the Council Framework Decision of 13 June 2002 on the European arrest warrant and the surrender procedures between Member States", (revised version) COM(2006)8 final, SEC (2006)79, 24 January 2006, in http://ec.europa.eu/justice/criminal/files/annex_eaw_implementation_report_2005_en.pdf

- (EU) European Commission, "Commission Staff Working Document”, SEC(2011) 430 final, 11 April 2011, in http://ec.europa.eu/justice/criminal/files/annex eaw implementation report 2011 en.pdf

- (EU) European Commission, "Communication from the Commission to the European Council (Article 50 ) on the state of progress of the negotiations with the United Kingdom under Article 50 of the Treaty on European Union", COM(2017) 784 final, 8 December 2017 in https://ec.europa.eu/commission/publications/communication-commission-european-council-article50-state-progress-negotiations-united-kingdom-under-article-50-treaty-european-union en

- (EU) European Commission, "Communication from the Commission to the European Parliament, the Council, the European Economic and Social Committee and the Committee of the Regions, Making Progress on the European Union Agenda on Procedural Safeguards for Suspects or Accused Persons, Strengthening the Foundation of the European Area of Criminal Justice", COM(2013) 820 final, 27 November 2013, in http://ec.europa.eu/transparency/regdoc/rep/1/2013/EN/1-2013-820-EN-F1$\underline{1 . P d f}$

- (EU) European Commission, "Proposal for a Directive on the protection of persons reporting on breaches of Union law: European Commission, Brussels, 23 April 2018, COM(2018) 218 final 2018/0106 (COD), in https://eur-lex.europa.eu/resource.html?uri=cellar:a4e61a49-46d2-11e8-be1d01aa75ed71a1.0001.02/DOC 1\&format $=$ PDF

- (EU) European Commission, "Proposal for a Regulation of the European Parliament and of the Council on the mutual recognition of freezing and confiscation orders", $\operatorname{COM}(2016) 819$ final - 2016/0412 (COD), 21 December 2016, in https://eur-lex.europa.eu/legalcontent/EN/TXT/HTML/?uri=CELEX:52016PC0819\&from=EN

- (EU) European Commission, "Report from the Commission to the European Parliament and the Council on the implementation since 2007 of the Council FD of 13 June 2002 on the EAW and the surrender procedures between Member States", $\operatorname{COM(2011)~} 175$ final, 11 April 2011, in https://eurlex.europa.eu/legal-content/EN/TXT/HTML/?uri=CELEX:52011DC0175\&from=EN

- (FATF) "International Standards on Combating Money Laundering and the Financing of Terrorism \& Proliferation" [FATF Recomendations], adopted by the FAFT Plenary in February 2012, as updated in November 2017, in www.fatf-gafi.org/

- (Macau) 1 $1^{\text {st }}$ Permanent Commission of the Legislative Assembly of Macau, "Opinion no. 2/III/2006", in www.al.gov.mo

- (Portugal) Attorney-General's Office, “Opinion on the Law Proposal no. 271/XII” [leading to Law no. $35 / 2015]$, in http://app.parlamento.pt/webutils/docs/doc.pdf?path=6148523063446f764c3246795a5868774d546f3 34e7a67774c336470626d6c7561574e7059585270646d467a4c31684a535339305a58683062334d7663484 2734d6a63784c56684a535638304c6e426b5a673d3d\&fich=ppl271-XII 4.pdf\&Inline=true

- (Portugal) Ministry of Justice, "Actas das sessões da comissão revisora do Código Penal: Parte Especial”, Lisboa - Separata do BMJ, 1979 
- (Portuguese-speaking African Countries [PALOP]) "Quadro Jurídico sobre o Branqueamento de Capitais, Combate à Corrupção e ao Tráfico de Droga nos PALOP”, Cidade da Praia: Imprensa Nacional de Cabo Verde, July 2015, p. 203, in www.legis-palop.org/bd

- (UK) “The United Kingdom's exit from and new partnership with the European Union”, Cm 9417, February 2017 , in

https://assets.publishing.service.gov.uk/government/uploads/system/uploads/attachment data/file/ 589191/The_United_Kingdoms exit_from_and partnership_with the_EU_Web.pdf

- (UK) CPS, "Director's guidance on the handling of cases where the jurisdiction to prosecute is shared with prosecuting authorities overseas", 17 July 2013, in

http://www.cps.gov.uk/publications/directors guidance/director_s_guidance_on_concurrent_jurisdic tion.html

- (UK) "Draft Extradition Bill", published on 27 June 2002, introduced in the House of Commons on 14 November 2002, in http://www.publications.parliament.uk/pa/cm200203/cmbills/002/en/0300002x- .html

- (UK) "Explanatory Notes of the Anti-Social Behaviour, Crime and Policing Act 2014", in http://www.legislation.gov.uk/ukpga/2014/12/pdfs/ukpgaen_20140012 en.pdf

- (UK) "Explanatory Notes of the EA 2003", in http://www.legislation.gov.uk/ukpga/2003/41/notes

- (UK) Government, “The Government Response to Sir Scott Baker's Review of the United Kingdom's Extradition Arrangements", Presented to Parliament by the Secretary of State for the Home Department by Command of Her Majesty, October 2012, Cm 8458, in https://www.gov.uk/government/uploads/system/uploads/attachment_data/file/228566/8458.pdf

- (UK) Government, "The Government Response to the Second Report from the Select Committee on Extradition Law Session 2014-15 HL Paper 126: Extradition: UK law and practice" - Presented to Parliament by the Secretary of State for the Home Department by Command of Her Majesty, July 2015, Cm 9106, in http://www.parliament.uk/documents/lords-committees/extradition-law/2015-0716\%20-Cm9106-ExtraditionEMBARGOED.PDF

- (UK) Home Office, "The Law on Extradition: A Review”, March 2001, in http://webarchive.nationalarchives.gov.uk/20070506113601/http://www.homeoffice.gov.uk/docume nts/cons-2001-extradition?view=Binary

- (UK) House of Lords Select Committee on Extradition Law, "2nd Report of Session 2014-15 - Extradition: UK law and practice", ordered to be printed 25 February 2015 and published 10 March 2015, in http://www.publications.parliament.uk/pa/ld201415/ldselect/ldextradition/126/126.pdf

- (UK) Law Commission (LAW COM no. 267), "Double Jeopardy and Prosecution Appeals: Report on two references under section 3 (1) (e) of the Law Commissions Act 1965", Presented to the Parliament of the UK by the Lord High Chancellor by Command of Her Majesty, Cm 5048, March 2001, in http://www.lawcom.gov.uk/app/uploads/2015/03/lc267 Double Jeopardy Report.pdf

- (UK) Liberty, "The Law on Extradition: A Review - Submissions of Liberty in response to the Home Office Consultation Document of March 2001", in https://www.liberty-humanrights.org.uk/sites/default/files/jun-extradition.pdf

- (UK) Lord Chief Justice, "Criminal Practice Directions Amendment No 2", [2014] EWCA Crim 1569, 23 July 2014, in https://www.judiciary.gov.uk/wp-content/uploads/2014/07/Criminal-PracticeDirections-Amendment-No-2.pdf

- (UK) Select Committee on Home Affairs, "First Report - Ordered by the House of Commons to be printed 28 November 2002", in http://www.publications.parliament.uk/pa/cm200203/cmselect/cmhaff/138/13802.htm

- (UN) International Law Commission, "The obligation to extradite or prosecute (aut dedere aut judicare) Final Report", 2014, in http://legal.un.org/ilc/texts/instruments/english/reports/7 6 2014.pdf 
- (UN) "Draft articles on Responsibility of States for Internationally Wrongful Acts, with commentaries", 2001, in http://legal.un.org/ilc/texts/instruments/english/commentaries/9 6_2001.pdf

- (UN) UNCHR, “Torture and Other Cruel, Inhuman or Degrading Treatment or Punishment - Report by the Special Rapporteur, Mr. P. Kooijmans, appointed pursuant to Commission on Human Rights Resolution 1985/33”, E/CN 4/1986/15, in http://ap.ohchr.org

- (UN) UNHRC, “General Comment no. 21 - Article 10: Humane treatment of persons deprived of their liberty", HRI/GEN/1/Rev.9 (Vol. I), 10 April 1997, in http://www.refworld.org/docid/453883fb11.html

- (UN) UNHRC, "General Comment no. 32 - Article 14: Right to equality before courts and tribunals and to a fair trial", CCPR/C/GC/32, 23 August 2007, in http://hrlibrary.umn.edu/gencomm/hrcom32.html

- (UN) UNODC, "Handbook on the International Transfer of Sentenced Persons", Vienna, 2012, in https://www.unodc.org/documents/organizedcrime/Publications/Transfer_of Sentenced_Persons_Ebook_E.pdf

- (UN) UNODC, "Manual on Mutual Legal Assistance and Extradition", Vienna, 2012, in https://www.unodc.org/documents/organizedcrime/Publications/Mutual Legal Assistance Ebook E.pdf

- (UN) UNODC, "Revised Manuals on the Model Treaty on Extradition and on the Model Treaty on Mutual Assistance in Criminal Matters", Siracusa, 2002, in https://www.unodc.org/pdf/model treaty extradition revised manual.pdf

- (UN) UNODC, "The Globalization of Crime: A Transnational Organized Crime Threat Assessment", Vienna, 2010, in http://www.unodc.org/res/cld/bibliography/the-globalization-of-crime-atransnational-organized-crime-threat-assessment_html/TOCTA_Report_2010_low_res.pdf

- (UN) UNWGAD, "Report of the Working Group on Arbitrary Detention: Civil and Political Rights, Including Questions of Torture and Detention", 9 November 1998, in https://documents-ddsny.un.org/doc/UNDOC/GEN/G98/145/43/PDF/G9814543.pdf?OpenElement

- (USA) United States Department of State - Office of Foreign Missions, Diplomatic and Consular Immunity: Guidance for Law Enforcement and Judicial Authorities, Washington, 2015, in https://www.state.gov/documents/organization/150546.pdf

- Boynton, Rachel, "Our Brand is Crisis" (documentary film), produced by Boynton Films Production, in association with British Broadcasting Corporation / Films Transit / Slough Pond / Urban Empire, 2005

- GALEANO, Eduardo, "El Derecho al Delirio", in https://www.youtube.com/watch?v=Z3A9NybYZj8

- Loudenberg, Kelly, “The Confession Tapes” (documentary series): “True East Part I" and "True East Part II” (episodes), produced by Netflix, 2017

- SAUL, Ben, "International Convention against the Taking of Hostages", UN Audiovisual Library of International Law, in http://legal.un.org/avl/pdf/ha/icath/icath e.pdf

- TAYLOR, Ken / Perry, John (featuring KenNEDy, David) “The Military: What is it Good For?”, in Philosophy Talk (podcast produced by KALW [San Francisco local public radio - 91.7 FM] on behalf of Stanford University as part of its Humanities Outreach Initiative), 26 November 2011, in https://www.philosophytalk.org/shows/military-what-it-good

- VetTer, Marcus / Steinberger, Karin, "Killing for Love", also known as "The Promise" or "Das Versprechen" (documentary film), produced by Filmperspektive GmbH / Bukera Pictures / Sundance Selects (USA), co-produced by Südwestrundfunk / Arte / Bayerischer Rundfunk / Danmarks Radio / British Broadcasting Corporation / SVT / Vrijzinnig Protestantse Radio Omroep, 2016 


\section{Summary}

\section{The Purpose of the Study}

The initial drive of the study was to assess whether extradition should be rendered swifter by reducing its traditional grounds for refusal. The reason to consider enhancing extradition in the present historical moment is intuitive. To quote from a prominent textbook (John B. Moore): "In modern times the importance of the subject has vastly increased. The improved facilities of communication which modern invention has afforded (...) have rendered it essential to the order of society that flight should not secure immunity from punishment." The statement is dated from 1891...

Since then, mobility of people has not only continued to increase, but also reached exponential levels. It has also become easier to commit from a distance crimes that produce their effects predominantly in other territories, which led States to expand their extraterritorial jurisdiction. Some offences, notably those that are generally encompassed by protective jurisdiction, even tend to damage exclusively States and communities other than those within which they were committed, meaning that they are usually not punishable in the latter, and, consequently, that the only possibility to avoid impunity may be for the former to obtain the extradition of the offender. Nevertheless, several obstacles to effective cooperation endure. Some of them have their origins in the distant and very diverse world of the $18^{\text {th }}$ century, and others can be traced to even more ancient times. Whether all such grounds for refusal are still necessary is the key issue addressed here.

\section{Fundamental Concepts}

The study commences by laying down its conceptual foundations and establishing its key working definitions. This is performed in Chapter 1, where extradition law is defined and characterised, as well as contrasted with substantive criminal law and with criminal procedure, on the one hand, and with other forms of international cooperation in criminal matters, on the other hand. This chapter also ascertains why and to what extent States need to obtain extradition and to extradite, and concludes that the fundamental force compelling extradition relations between States is their interest in enforcing their own penal laws: this interest manifests itself in a direct manner when a State requests extradition to another State (as it thereby expresses its desire to obtain custody of a person), and in a merely reflexive manner when a State grants extradition to another State (as it thereby secures the reciprocity of the latter State in symmetrical cases that may come to occur in the future), but it manifests itself in both instances.

This chapter then elaborates on the concept of grounds for refusal or obstacles to extradition. Based on the conclusion that States have a self-interest in extraditing, it is submitted that the norms which establish grounds for refusal of extradition can only be conceived of as embodiments of other interests that conflict with, and supersede (or at least are thought to supersede) States' interest in ensuring the efficacy of their own penal systems. 
In turn, this definition provides the basis for delineating the scope of the study. For instance, it entails that limited attention should be paid to the grounds for refusal (such as that according to which extradition is to be rejected if the offence was committed, at least in part, in the territory of the requested State) which concern mainly interstate allocation of jurisdiction: in these cases, the crime caused an injury not only to the requesting State, but to the requested State itself, which, therefore, is also the holder of a direct punitive interest thereupon. This means that both States involved in the extradition proceedings have primary jurisdiction, and impunity is not a possibility. The main issue here is to determine which of those two States shall carry out the prosecution or the enforcement. Conversely, enhanced focus is placed on the grounds for refusal (such as the dual criminality rule and the time-bars exception) which necessarily entail impunity, in the sense that they preclude even the eventuality of the requested State carrying out a vicarious criminal procedure - that is, a criminal procedure on the behalf of the requesting State after refusing extradition.

This chapter is also the place where the study initiates a dialogue between classic extradition and surrender, its more recent counterpart of which the European Arrest Warrant (EAW) is the most noteworthy concretisation. In this regard, it is underscored that the main focus of the study is extradition proper - i.e. the transfer of persons, for penal purposes, between States which are not necessarily linked by ties of political, legal, cultural or historical affinity. Nevertheless, to that end, the study does dedicate significant attention to mechanisms that fall within the concept of mutual recognition - especially to the EAW, but occasionally also to the Nordic Arrest Warrant and the Mercosur Arrest Warrant -, using them as a reference for a possible reform of classic extradition.

Very importantly, in Chapter 1 a distinction is drawn which impacts profoundly on the structure of the study (although, admittedly, it is a more notional than precise distinction): a distinction between 'voluntary' and 'mandatory' grounds for refusal. The former is comprised of grounds for refusal that are considered necessary by specific States to protect specific interests; the latter, of grounds for refusal that protect values which the international community as a whole considers worthy of being protected. Mandatory grounds for refusal stem largely from human rights, and they produce not only (direct) obstructive effects, in that they block extradition even if the specific State to which extradition is requested would not find it necessary to refuse it, but also (indirect) permissive effects, in that they suggest that the grounds for refusal that were set in place in order mainly to protect specific State interests are open to be reformed. Mandatory grounds for refusal thus play both an exclusionary and a habilitating role in the study: they constitute an unyielding set of principles and guarantees below which extradition law cannot under any circumstances fall, and above which it can be called into question.

\section{Research Design}

With the fundamental concepts of the study laid down, Chapter 2 formulates its research question in the following terms: which grounds for refusal of extradition voluntarily enacted by States are necessary to preserve the interests which are at stake in extradition law? It then provides and articulates the sub-questions into which that core question unfolds, together with an explanation of the research methods deployed with a view to answering them. 


\subsection{Mandatory Grounds for Refusal - Deductive Analysis}

Since the purpose of addressing mandatory grounds for refusal is not to challenge their existence, but to determine their scope (with a view precisely to exempting them from such a challenge), the method used here is a top-down analysis which consists of deducing from specified sources of law what that scope is.

\subsubsection{Human Rights}

As stated, mandatory grounds for refusal derive largely from human rights. This body of law is analysed in Chapter 3. The main unit of analysis here is the ECHR. The option for a regional instrument in a study that strives for wider validity is explained by the fact that the ECHR is, by far, the human rights instrument that has given rise to more generous case law imposing constraints on extradition: if the purpose of this chapter is to identify paramount values that must stay untouched, then what is important is not so much that the object of analysis is representative, but rather that it is extensive, since this provides increased assurance that such paramount values are not put at risk in the theoretical exercise performed later in the study. For the same reason, the study moreover makes an intentionally expansive interpretation of that case law, such that several fundamental individual guarantees are brought into the category of human rights or 'para-human rights' grounds for refusal.

\subsubsection{European Union Law}

Another set of mandatory grounds for refusal analysed in the study - in Chapter 4 - is that which EU law came recently to impose on Member States in their extradition relations with third States. Although these limitations on extradition apply only to the Member States of that specific organisation and are unique in their legal structure, they are illustrative of an approach which may be replicated (and which in fact can already, in a way, be found) among other constellations of States. The main normative references are the EU Treaties, where the primary law of the Union is contained, but attention is also paid to extradition agreements concluded by the EU pursuant to its competence for external action, particularly to that concluded with the USA in 2003. Heavy focus is placed on the case law initiated by the ECJ in 2016 with Petrubbin, which devised a 'EU citizenship exception to extradition' and paved the way for the emergence of a 'EU extradition law', as confirmed by the subsequent rulings in Schotthöfer \& Steiner, Pisciotti, and Rangevicius.

\subsection{Voluntary Grounds for Refusal - Two-tiered Approach}

Voluntary grounds for refusal are the ones that are brought into question in this study. Early in the study it is posited that States have an interest in maintaining extradition relations so as to ensure the effectiveness of their own criminal laws, and that consequently the existence of grounds for refusal that prevent this interest from being more extensively achieved must be due to other, conflicting interests. With mandatory grounds for refusal already identified in Chapters 3 and 4, the research question then requires two further operations: first, that those conflicting interests are identified; second, that they are weighed against that overarching interest in maintaining extradition rela- 
tions. The first operation is carried out in Part III (Chapters 5 and 6), again through deductive analysis; the second in Part IV (Chapters 7 and 8), in this instance through inductive analysis.

\subsubsection{Deductive Analysis}

A deductive analysis is carried out in Chapter $\mathbf{5}$ and Chapter $\mathbf{6}$ with a view to determining the voluntary grounds for refusal which are currently in place, their scope and their rationales. This analysis is similar to that effected with regard to mandatory grounds for refusal, with the particularity that the sample here is more difficult to select, because there are 'voluntary grounds for refusal' in each and every international (bilateral and multilateral) and national legal instrument on extradition. Evidently, it would be impossible to assess all those elements, or even a decent fraction of them. The adopted solution consists of the composite sample described subsequently.

\section{a) United Nations Model Instruments}

Providentially, extradition has been the object of model normative instruments elaborated by the UN with a view to providing States with a useful framework when concluding extradition treaties: the Model Treaty on Extradition (1990, updated in 1997) and the Model Law on Extradition (2006). Developed under the aegis of the UN, these instruments reflect the specificities of different legal traditions, and thus they possess virtually global reach. They condense the state of affairs in this legal area, such that their analysis ensures the representativeness of this part of the study.

However, they are not fully-fledged legal instruments: they are not in force as such, nor are they applied by any judicial instance. Therefore, they would be insufficient: they ensure representativeness, but lack tangibility.

\section{b) National Legislation - Portugal and United Kingdom}

Tangibility is ensured by the assessment of self-sufficient legal instruments that were enacted in view of the interests of specific States and that are applied in concrete cases. A key criterion for determining the sample was that, in combination, the instruments to be assessed would contain all the grounds for refusal found in the UN model instruments. The analysis focuses on national statutes rather than on international treaties, because the former are conceived for regulating extradition between a given State and an unspecified pool of requesting States, such that the grounds for refusal contained therein constitute a 'default parameter': they embody the interests that a given State deems necessary to protect in the abstract (i.e. without knowing beforehand the characteristics of the requesting State). The selected States are also parties to the EAW scheme (the main reference of the study with regard to enhanced models of cooperation), as well as to the ECHR (the main reference of the study with regard to human rights).

Based on yet other criteria, the sample that is ultimately reached consists of the legal systems of Portugal and of the UK. Combined, these two extradition systems not only match in full the catalogue of the UN model instruments, but also they stand in open divergence on all contentious issues (nationality exception, treaty requirement, evidentiary requirements, life imprisonment exception), conferring on this combination the advantage 
of allowing for a contrast, already at this point of the study, between opposing views on traditional rules of extradition law. These legal systems moreover stand as representatives of two different legal traditions: common law and civil law.

\subsubsection{Inductive Analysis}

After establishing the interests protected by voluntary grounds for refusal, such grounds for refusal are subjected to an essentially inductive exercise through which the research question is finally answered. Put in inductive terms, this question may at this point be worded as follows: in a hypothetical scenario where no grounds for refusal of extradition existed other than those which are imposed by international law, which ones would be necessary in order for those interests to be attained?

Chapters 7 and 8 (outlined subsequently) seek to answer this question through an innovative approach to extradition law (described in more detail further below, $\int 4$ ).

\section{a) Theoretical Framework}

In Chapter 7, the key normative concept of the research question - 'necessary' - is defined. To that end, a theoretical framework is developed drawing on findings and insights arisen in the previous parts of the study. This exercise is not fully self-referential, but rather it also explores elements that only marginally or implicitly arose earlier. Since it sets the parameters within which the research question is ultimately answered, this exercise plays a pivotal role in this study.

\section{b) Application of the Theoretical Framework}

In Chapter 8, the theoretical framework is applied to all voluntary grounds for refusal, so that a clear-cut picture emerges reflecting what extradition law could become if the views defended in that framework were implemented. In the process of applying the framework to the object of analysis, a dialogue is established between the two. Such a process is mainly unidirectional, with the theoretical framework determining the 'new' scope to be assigned to the several voluntary grounds for refusal. However, new insights emerged during the application of the framework which enabled its improvement, such that the theoretical framework ultimately presented in Chapter 7 constitutes a fine-tuned version of an earlier one elaborated before the exercise carried out in Chapter 8.

\section{c) Sources of Inspiration}

Both the elaboration of the framework and its application to the grounds for refusal are influenced by another dialogue: the interchange established earlier in the study between classic cooperation and mutual recognition is intensified at this point. Some studies have taken cooperation between federated States as a reference for the possible furthering of cooperation between EU Member States. This study takes cooperation between EU Member States as a reference for cooperation between potentially any States.

Since classic extradition and the EAW share the same foundation, and since the theoretical framework developed in this study is inspired by elements other than legal instruments on mutual recognition, namely an analysis of the evolution of private international law (see again below, $\mathbb{S}$ ), the dialogue between classic extradition and mutual 
recognition is also not strictly unidirectional. Rather, the views developed in this study, albeit primarily concerned with classic extradition, might apply to the very instruments of mutual recognition it uses for inspiration, and in this sense this study also constitutes a reflection about the EAW system.

\subsubsection{The Character of this Study}

This study is normative. It employs deductive as well as inductive methods, and it is composite also in its goals. This leads to a final result which features elements of different archetypes of legal research, namely: (i) doctrinal, in that it attempts to offer a systematic account of the rules governing a given legal area and to expose their interactions (especially in Part II [Chapters 3 and 4], and Part III [Chapters 5 and 6], where, respectively, mandatory and voluntary grounds for refusal are analysed through deductive methods); (ii) theoretical, in that it seeks to obtain a more comprehensive understanding of the conceptual bases underpinning that legal area (especially in Part IV [Chapter 7], where the theoretical framework is developed); and (iii) reform-oriented, in that it evaluates the adequacy of existing rules, with a view ultimately to proposing solutions for their improvement (especially in Part IV [Chapter 8], where voluntary grounds for refusal are analysed through inductive methods).

\section{The Core Ideas of this Study}

This study tries to offer a new vision on extradition law, and, thereby, to some extent, on transnational criminal law more broadly. Its most innovative element is arguably the parallel established between transnational criminal law and private international law. While the latter area of the law is already often called into consideration in respect of certain aspects of the former, this consideration tends to be scant, superficial and unstructured: it is limited to the concept of ordre public, it does not seek to understand the role and the functioning of such a concept within its own natural environment, and it does not explore to their full extent the structural implications of this concept when applied in criminal law. Consequently, it fails to grasp the potential of such an application.

Another central idea of this study which arguably possesses some originality concerns the duty of non-interference that governs international law: in the field of extradition, this duty is generally honoured in its negative dimension only, as a prohibition to unilaterally seize individuals located in the territory of other States; this study propounds that such a duty should be acknowledged to also play a positive role, as a duty to grant extradition where this is necessary for another State to assert its sovereignty over acts that injured it. The subsequent paragraphs summarise the conclusions of the study, which are provided in more detail, as well as graphically illustrated, in its Chapter 9.

The key factual conditions underpinning modern extradition law have changed drastically: distances became easier to travel, human conduct wider in reach; taking refuge abroad less intimidating, and social distress at the escape of criminals often more intense. Today's world is a smaller one, where States and their communities are in many regards closer to each other. However, extradition law continues to conceive them as isolated entities, displaying many of the attributes it was conferred on upon its inception at the turn of the $19^{\text {th }}$ century. Grounds for refusal - the central elements of extradition law - have 
not been subjected to a corresponding reform, producing a substantial lag between the reality and the law. There currently exists a mismatch between the scope and the rationale of numerous grounds for refusal - i.e. between the range of situations which receive protection and those which in effect require protection -, the latter being significantly narrower.

Drawing on this diagnosis, this study posits a set of normative propositions intended to bridge the perceived gap. Since those factual developments befell at a pace which was not, and arguably cannot, be fully accompanied by national (social, cultural, political) structures, adjusting to such developments requires assigning even greater preponderance to territorial jurisdiction (and hence to the requesting State) than that which it already, justifiably, receives. Indeed, paradoxical as it may seem, at present globalisation calls for 'more' territoriality, because it is still States that bear the responsibility to tackle most criminality, even transnational one. Notwithstanding, this study is grounded on the premise that international cooperation cannot be sustainably enhanced in detriment of national cultural identities. Instead, it seeks to overcome the self-centeredness that characterises the paradigm of cooperation forged at the end of the $18^{\text {th }}$ century without succumbing to the view that the globalisation processes that took place subsequently require States to relinquish their legal traditions altogether.

By relying on a markedly formalistic approach to international cooperation, grounds for refusal of extradition currently protect States' essential and unessential values alike. By equating them, extradition law weakens the former at the expense of the latter, making them converge onto an intermediate, homogeneous, degree of importance. This is clearly illustrated, for instance, by dual criminality and the time-bars exception, based on which requested States project their own substantive criminal laws, as a whole, upon requesting States, hindering cooperation even in cases where there are only tenuous disparities in perspective as to the criminal relevance of the acts. This does not mirror the sense of justice of the requested State, and is hardly understandable in the eyes of the requesting State. In order for extradition law to be brought into congruence with its spirit, this study proposes to extricate from the scope of grounds for refusal the hypotheses that affect merely secondary values of the requested State, narrowing the scope of such grounds for refusal down to the limits given by its essential values - its ethos. This approach is particularly visible in the suggested reform of the concept of extraditable acts, from a principle of dual criminality into a principle of qualitative relevance according to which States can extradite for acts that they do not criminalise, so long as criminalisation would be consistent with their essential criminal justice values.

Thus, rather than pinpointing that certain grounds for refusal should be removed and others maintained, this study conceives of a transversal optimisation of grounds for refusal. As noted above, the manner in which such an optimisation is envisaged is largely inspired in the functioning of private international law. Traditionally, the applicability of a private norm was determined by reference to its content. In the event of a conflict, the norm that would apply was the one carrying the effects that were deemed preferable according to given substantive criteria (e.g. the one that was more favourable to the person concerned). In the $19^{\text {th }}$ century, Savigny reasoned that such an approach was both partial as well as unclear, and he developed an alternative theory which relied on a straightforward separation between the content of a norm and its sphere of application. Applicability would no longer be deduced from the content of the norm, but from the legal relation- 
ship at issue, such that, in the event of a conflict, the norm that would apply would, in line of principle, be the one in force in the legal system to which the situation was more strongly linked. Private international law thus became neutral.

Aware of the pointed differences that exist between private law and criminal law, between private international law and transnational criminal law, this study posits that, at present, the question as to whether extradition should be granted - a question which, from such a neutral perspective, should in principle be answered in the affirmative (because, and insofar as, the legal system of the requesting State is the one to which the crime is more closely connected) - is dependent on norms (grounds for refusal) which are infused with substantive considerations springing from the legal system of the requested State (to whose legal system the acts are not in any way connected). That is, under current extradition law the requested State 'internalises' acts with which it has no connection. To assign unambiguous primacy to the requesting State is to confer extradition law the neutrality it is currently lacking.

Nevertheless, considering the repressive nature of extradition, the primacy that from that jurisdictional standpoint is owed to the requesting State does not translate into an absolute entitlement on its part to obtain extradition. By granting extradition, a State not only assists in the possible application of an extreme legal consequence to a person (a penalty), but also it immediately subjects this person to a repressive measure (a period of deprivation of liberty coupled with a coercive transfer to another jurisdiction). This inevitably confers some relevance on its own notions of justice. As already defended by many authors, such notions can be reflected about based on a concept which also has its roots in private international law: ordre public. This concept comes into play subsequently to the neutral determination of the applicable law: as stated, a foreign law should in principle apply if the respective legal system is the one that has the strongest link to the acts; however, such an application will be limited or excluded if, though only if it is likely to carry effects that would be unbearable to such legal system. Ordre public is, therefore, a 'shock-absorbing device' which allows to avoid the abnormal effects that could result from a purely neutral determination of the applicable law. By definition, it is also an exclusive concept, in that it encompasses but a select cluster of values and purports to avoid but a particular type of results: it does not block the application of foreign norms whenever these may carry results which are different from the ones that would result from an application of national norms, but only results which are intolerable to the social consciousness of the community at issue. As far as criminal justice is concerned, the select set of values which form the 'ethos' of a community is to be found in its supra-ordinary law, notably in its Constitution. Constitutional and para-constitutional law constitute the source of the criteria which enable the distinction between the essential and the unessential values of a State, and, consequently, the optimisation of grounds for refusal of extradition.

On the other hand, the fact that in the field of extradition the duty of non-interference operates exclusively in its classic negative dimension causes an imbalance between the requested and the requesting States whereby the former has preponderance over the latter. The subjects involved in extradition proceedings therefore form a triangle in which the requested State has higher standing than the requesting State. Their relation is not horizontal, but diagonal instead. 


\section{The Model Defended in this Study}

The model defended with a view to rectifying that imbalance consists of the following propositions: (i) the requesting State shall be assisted in tackling its domestic criminality, in the name of the principles of territoriality and of non-interference (in its positive dimension); (ii) the requested State shall provide such an assistance, in the name of those same principles, and with the additional incentive of securing reciprocity; (iii) the foregoing propositions shall, but shall only be departed from where this is required by international law or where the requested State would otherwise sacrifice other fundamental individual guarantees or core values of its legal system; (iv) individuals targeted by extradition requests shall be acknowledged to face adverse conditions, but (v) this shall not prevent the recognition that they currently benefit from a wide array of guarantees which do not protect relevant individual rights, but which instead are merely incidental to the protection of ethnocentric interests of the requested State.

This study relies as much as possible on an objective diagnosis of the state of affairs in international cooperation, and the reform defended here is a direct result of that approach. It does not pursue externally defined criminal policy goals, even though it does show consistent with a widely supported view according to which cooperation should be enhanced, and even though this was this view that triggered this research. Evidence of this objectivity is that the study defends the preservation and even the expansion of certain grounds for refusal - which runs counter to such an agenda. This is namely the case of quantitative relevance thresholds, ne bis in idem, absence of valid jurisdiction by the requesting State, rehabilitation exception, existence of jurisdiction by the requested State, evidentiary requirements, and the specialty rule. The study moreover proposes the enactment of a ground for refusal which does not currently exist, namely the severe disproportionality between the acts and the penalty applicable in the requesting State.

As for those grounds for refusal that protect secondary interests of the requested State, and that thereby open unwarranted spaces for impunity - such as dual criminality, time-bars and other cases of extinction of criminal liability other than ne bis in idem, the political and the military offence exceptions, and the nationality exception - virtually all are subjected to an unequivocal optimisation effort. This is why, in a final balance, the model defended here probably entails wider room for cooperation than that which presently exists. As noted, refusal of extradition will now be limited: on the one hand, and insofar as voluntary grounds for refusal are concerned, to core values of the requested State and relevant individual guarantees; and, on the other, to grounds for refusal rooted in superseding rules of international law, notably human rights, which are inviolable.

But the increase in cooperation envisaged in this study is fundamentally qualitative, in that it embodies a more solidary approach to interstate relations in the field of criminal justice. By stripping extradition law of the elements which express merely superfluous values of the requested State, grounds for refusal not only become narrower in their scope, but also the requested State and the requesting State will now bear equal standing vis-à-vis each other. The perfectly horizontal position in which they are now placed is the result of the increased preponderance assigned to the principle of territoriality that governs criminal law and of the positive dimension assigned to the duty of non-interference that governs international law. The requested State would now only refuse to assist the 
requesting State in exceptional cases. In all other cases, it would recognise the necessities and respect the differences of the requesting State. The model envisaged here is based on a principle, not of mutual trust, but of mutual understanding; not of mutual recognition, but of mutual respect. 


\section{Valorisation Addendum}

\section{Relevance}

The factual conditions underpinning modern extradition law have changed drastically: distances became easier to travel, human conduct wider in reach; taking refuge abroad less intimidating, social distress at the escape of criminals often more intense. Today's world is a smaller one, where States and their communities are in many regards closer to each other and interdependent. Extradition is central for addressing these phenomena, since it empowers the State where the harm materialised to reach out to States where the authors of the acts are located. In a sense, extradition constitutes the nemesis of remote criminality, as it is itself remote: a remote criminal law tool through which national legal systems outreach their ordinary (territorial) area of influence; a long-armed tool against long-armed criminality.

However, extradition law persists to conceive them as isolated entities, displaying many of the attributes it was conferred on upon its inception at the end of the $18^{\text {th }}$ century. Grounds for refusal - the key elements of extradition law - have not been subjected to a corresponding reform, producing a substantial lag between the reality and the law. Consequently, a mismatch currently exists between the scope and the rationale of several grounds for refusal - i.e. between the range of situations in which extradition is refused and those in which it should in effect be refused -, the latter being significantly narrower.

Drawing on this diagnosis, this study posits a set of normative propositions aimed at bridging the perceived gap. This is the aspect of this research which has more societal relevance: bridging that gap means creating the conditions for a more secure world. On the other hand, the manner in which this study seeks to do so does not involve the sacrifice to fundamental individual guarantees, nor does it conceive of a homogenisation of criminal justice among States. On the contrary, it seeks to safeguard and in fact to promote those guarantees, as well as to devise ways for national cultural biotopes to be preserved. In sum, this research attempts to strike a balance between the increased security concerns that characterise today's world, the imperative to remain faithful to paramount principles of justice and of protection of individuals against the potential abusiveness of States, and the preservation of local idiosyncrasies.

\section{Target Groups}

In addition to the academic community, this research can, in my view, be of interest to mainly two sets of entities. On the one hand, governmental and intergovernmental agencies with competence for enacting legislation or concluding international treaties and other types of normative instruments on extradition matters. This thesis is heavily reform-oriented and contains several initiatives to improve legislation in this field, both at the national and at the international levels. Therefore, this is would be my main target group. It would be particularly impactful if this research were to resonate with the Unit- 
ed Nations agencies that develop the model instruments on international cooperation, as this in turn influences States' legislative and treaty-making activity in this field.

The other target group consists of practitioners in the legal area, including lawyers and judges. Indeed, although as noted this research is essentially reform-oriented, in that it advocates for the law as is currently in force to be modified, it can also guide in the interpretation and application of these norms within the present state of affairs. Although this research (necessarily) focuses on specified legal instruments, these have been selected as a sample of a broader normative paradigm, the goal of the study being to have virtually global applicability. Thus, the target groups indicated above are not limited to specific jurisdictions, but rather they might belong in any jurisdiction.

Within the ambit of international cooperation, the usefulness of this research is not necessarily limited to extradition, but rather it may extend to other forms of cooperation (such as the transfer of proceedings), because extradition has a paradigm-setting status in that ambit. However, its value is not necessarily limited to this ambit either. Extradition law constitutes an intersection of numerous sets and types of norms. As far as its sources are concerned, it involves: national norms, of both ordinary and constitutional rank, and of both the requested and the requesting States; international norms, of both general (customary and imperative) and conventional (bilateral and multilateral) character; in States included in legally and politically integrated regional organisations such as the EU, peculiar normative instruments such as Framework Decisions also apply. Thematically, these norms refer, inter alia, to: extradition law in a stricter sense, substantive criminal law (prescriptive and adjudicative), criminal procedure, rules on remand, human rights, diplomatic law, nationality and refugee law, and private international law. At the organic level, such norms are applied by multiple judicial bodies (national, regional and international) whose jurisprudence also constitutes a source of law and, in any case, codetermines the real scope of norms stemming from other sources. Moreover, extradition cases involve not only legal, but also political assessments, making them sensitive cases from the perspective of international relations.

Consequently, while this study ultimately intends to inspire legislative entities into shifting the current regulatory paradigm, it is quite comprehensive and may attract a much wider readership. For instance: (i) It provides a detailed analysis of human rights law and respective case law in removal cases (extradition, expulsion, deportation, asylum): mainly under the European Convention on Human Rights, but to some extent also the International Covenant on Civil and Political Rights and the American Convention on Human Rights. (ii) It contains a detailed analysis of EU law and of the case law of the Court of Justice of the EU (which erupted during the elaboration of the study) on extradition from Member States to third States. (iii) It addresses classic extradition as well as mutual recognition: mainly the European Arrest Warrant and respective case law (by the Court of Justice as well as by national courts), but to some extent also the Nordic Arrest Warrant and the Mercosur Arrest Warrant. (iv) Very importantly, it offers a complete analysis of the United Nations' model instruments on extradition (with additional references also to the model instruments on other forms of cooperation), which may be of interest for virtually any State. But it also provides information on numerous bilateral and multilateral treaties. (v) It offers a complete and comparative analysis of two national extradition systems (that of Portugal and that of the United Kingdom) which abide by two dis- 
tinct paradigms and belong within two different legal families. But, again, it also conveys information on other extradition systems (e.g. that of the Netherlands). (vi) While it does not feature a historical chapter, it contains profuse information, dispersed by its different sections, on the history of this topic. (vii) Another relevant feature is that is looks at extradition law as a whole, rather than focusing on specific points: it looks into all grounds for refusal; mainly into its legal, but also into its political dimension; mainly into theoretical, but also into practical aspects; into extradition proper, but also into its interplay with substantive criminal law and criminal procedure. This research seeks to provide the reader with a wide field-of-view while attempting never to neglect detail.

In sum, this book can be of interest to different types of readers: scholars or students, practitioners or policy makers; to readers interested in the specific normative systems of the United Nations, the United Kingdom or Portugal, but also to any reader interested in extradition, international cooperation or transnational criminal law; to readers more interested in traditional extradition, but definitely also to readers focused on mutual recognition and EU law; to readers more interested in human rights, other fundamental guarantees in transnational criminal proceedings, or refugee law, but also to readers more keen on systemic perspectives concerned with tackling emerging threats. It may be of interest to someone researching these matters, but it may also serve as a textbook to be consulted.

\section{Activities/Products}

First and foremost, this research will be published as a monograph (Brill|Nijhoff, 2019). The book has been peer-reviewed by this publisher and accepted unconditionally - that is, without any modifications of substance being considered required. This means that this research will be published with virtually the exact same content as that which will be brought to public defence at Maastricht University.

This book is a thesis in the proper sense of the term, in that it attempts to answer a given research question, it is structured in such a way as to accomplish that goal, and it seeks at all times to avoid unnecessary digressions. Nevertheless, as mentioned above, in the process the book came to organise and review the fundamental concepts of the legal area where it belongs, and it became quite comprehensive. This may confer on it the potential to be used as a textbook type of read for possibly any lawyer. It is my intention to continue to update and further develop this book in the future, should it indeed be able to attract such a readership.

In the shorter term, I will be looking to promoting the book next to the identified target groups, through conferences and publications (articles as well as blogs) summarising and expanding further on certain aspects covered therein, or addressing new developments related to it. I intend to bring forward these presentations and publications in different fora and in different languages, to different individuals and entities within the broader target group.

I will also try to draw attention to this research in university courses and training programs for professionals, whenever such opportunities arise. I will moreover seek to put into practice the knowledge I acquired by conducting this research, to channel it onto my professional activities and to pass it on to my colleagues. Although such an impact is extremely difficult to measure, I think this intensive research experience will influence 
me throughout my entire life, especially if - as I hope - I have more opportunities to conduct research, in this or in another area.

\section{Innovation}

This study tries to offer new insights on extradition law, and, thereby, to some extent, on transnational criminal law more broadly. One of its innovative traits should be the parallel established between transnational criminal law and private international law. The latter area of the law is already frequently called into consideration in this context, but generally in a rather scant and unstructured manner: attention is generally limited to the concept of ordre public, and even so it does not in effect look into the role and functioning of the concept within its own natural environment; it does not explore either, to their full extent, the structural implications of this concept when applied in criminal law. Consequently, it prevents this application from achieving its full potential.

Another central idea of this study which arguably possesses some originality concerns the duty of non-interference reigning in international law: in the field of extradition, this duty tends to be honoured in its negative dimension only, as a prohibition to unilaterally seize individuals located in the territory of other States; this study argues that it should also be credited a positive role, as a duty to grant extradition where this is necessary for another State to assert its sovereignty over acts of which it is the main injured party.

Yet another key view posited in this study is that, since the globalisation processes that took place after the birth of the classic paradigm of international cooperation befell at a pace which was not entirely accompanied by national (social, cultural, political) structures, at present, even greater primacy should be given to territorial jurisdiction. Indeed, paradoxical as it may seem, at present globalisation calls for more territoriality, because it is still States that bear the responsibility to tackle most criminality, even transnational one.

Notwithstanding, this study is grounded on the premise that international cooperation cannot be sustainably enhanced in detriment of national cultural identities - and this view separates this study from many scholarly and legislative efforts to enhance international cooperation. Instead, this study aims to overcome the obsolete classic cooperation paradigm without succumbing to the view that globalisation requires States to abandon their legal traditions almost entirely.

The increase in international cooperation envisaged in this study is more qualitative than quantitative, which also contrasts with several such scholarly and legislative efforts. The goal was to develop conceptual bases for a more solidary approach to cooperation in the field of criminal justice. The model defended here translates into a principle, not of mutual trust, but of mutual understanding; not of mutual recognition, but of mutual respect.

\section{Schedule \& Implementation}

I intend to make a strong promotion of this research with the first few years following the defence (e.g. until 2023), through the activities and products indicated supra, $\mathbb{S}$ 3. The objective is to draw attention to my research results and as much feedback thereon as possible, with a view to revisiting and improving my own ideas.

Drawing on that feedback, I plan to continuously develop this very book throughout my career (e.g. as of 2025), although this will naturally depend on its success next to 
the envisaged target groups and other editorial considerations, as well as on my professional availability, since at this point it is uncertain whether I will follow an academic, or a different career instead.

Should I have other opportunities to conduct in-depth research (e.g. post-doctoral), I will be looking into moving on to new topics within the ambit of criminal justice, while bringing into this context the experience gathered during my doctoral research. The plan is not to engage in radically different topics, but rather to build on acquired knowledge, so as to develop solid areas of expertise. This may consist either of narrowing my focus to specific areas involved in my doctoral research (e.g. EU criminal law, foundational issues of substantive criminal law or procedure); or, instead, of taking on an even more general research topic (e.g. conceptual structures in transnational criminal justice [possibly by exploring further the reference to private international law and/or to constitutional law], classic theory of punishment). I would like to engage in one such large research project as of 2027 , at most. 


\section{Curriculum Vitae}

Miguel João Costa (Coimbra, 1985) has a Law Degree (2003-2008) from the University of Coimbra (magna cum laude) and a Master's Degree in Criminal Law (2008-2011) from the same University (summa cum laude). He was an Erasmus student at the University of Bologna, Italy (2006-2007). In 2013 he became a Ph.D. researcher at Maastricht University and submitted his dissertation in the summer of 2018.

He currently works as an advisor at the Portuguese Constitutional Court (2018-). In the past, he worked, among other, as a teaching assistant at the University of Coimbra (2010), as a legal advisor at the Law Reform and International Law Bureau of the Government of Macau, China, where he was a member of the Working-Group for the Revision of the Code of Criminal Procedure (2010-2013). In this period he also taught at the University of Macau the courses of Criminal Law and Procedure, Administrative Law and Business Law (2011-2013). During his doctoral research he taught the course of European Criminal Justice Area at Maastricht University (2015), and completed an internship at the Portuguese Desk of Eurojust (2016).

He is a member of the European Criminal Law Academic Network, and has taken part in numerous research projects and conferences. He has published work, including a monograph on the interplay between extradition and jurisdiction in criminal matters ( $D e-$ dere Aut Judicare?, 2014). His areas of expertise and/or interest include: substantive criminal law, criminal procedure and drug policy; disciplinary and punitive (other than criminal) law; European and international criminal law, jurisdiction and cooperation in criminal matters; international law, human rights and refugee law; private international law; and constitutional law. 



\section{Extradition Law \\ Reviewing Grounds for Refusal from the \\ Classic Paradigm to Mutual Recognition \\ and Beyond}

Miguel João Costa

\section{Propositions*}

1. Objectivity is hard to be attained in normative research, but carefully devised methods can reduce meaningfully the room for subjectivity.

2. As important as objectivity is transparency: it enables the reader to uncover possible biases or flaws on the part of the researcher and, therefore, to position $\mathrm{him} /$ herself straightforwardly in respect of the merits of the research.

3. At least insofar as ordinary criminality is concerned, supranational criminal law oscillates between an outdated paradigm which continues to place excessive emphasis on national conceptions of criminal justice, and a new approach which excessively disregards national perspectives; it may however be possible to strike a balance, pursuant to a notion, not of mutual recognition, but of mutual respect among States.

4. Extradition law should be conceived of, not simply as a part of international law nor simply as a prolongation of national criminal law, but as a composite discipline where those legal areas (and yet other disciplines) converge in such a manner as to produce a qualitatively specific result.

5. Paradoxical as it may seem, at present, globalisation requires even more emphasis on territorial jurisdiction, which for extradition law means conferring more preponderance on the State that requests extradition.

6. While in the field of extradition the duty of non-interference is generally honoured in its negative dimension only, as a prohibition to unilaterally seize individuals located in other States, it should be accredited a positive role, as a duty to grant extradition where this is necessary for another State to assert its sovereignty over acts of which it was the main injured party.

7. The two foregoing propositions should, but should only, be disregarded where required by international law (notably, by human rights), or where they would carry a sacrifice of other fundamental guarantees or core values of the requested State's legal system.

8. Although individuals targeted by extradition requests face adverse conditions which justify specific protections, many of the grounds for refusal currently in place do not in fact protect relevant individual rights, but rather ethnocentric interests of the requested State.

9. A distinction should therefore be drawn between the secondary values of a legal system and its core values (or 'ethos'), such that the former cease to prevent cooperation; this distinction can be effected based on concepts developed in private international law and on the axiological framework provided by the constitutional law of that legal system.

10. The views defended in this thesis could be considered by States when enacting or reviewing legislation or treaties on extradition; it would be particularly impactful if they were considered in a future update of the UN model legal instruments on extradition.

11. It can be quite hard to write a thesis, however fragile, and quite easy to depreciate it, however solid; think well before doing either.

\footnotetext{
* In compliance with the Regulation Governing the Attainment of Doctoral Degrees at Maastricht University (resolution of the Board of Deans from 12 May 2003, as last amended in 24 January 2018: Arts. 7 (1) (d), 22 (6) and 23 (1)): propositions 1 to 3 are related to the field of science of the doctoral candidate, but not directly to the topic of the dissertation; propositions 4 to 9 are directly related to the topic of the dissertation; proposition 10 is related to the valorisation opportunities for the topic of the dissertation; proposition 11 is related to none of the above.
} 